Ten Journeys to Cameron's Farm An Australian Tragedy 



\title{
Ten Journeys to Cameron's Farm An Australian Tragedy
}

\author{
Cameron Hazlehurst
}

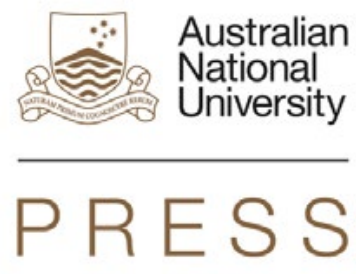




\section{ANU \\ PRESS}

Published by ANU Press

The Australian National University

Acton ACT 2601, Australia

Email: anupress@anu.edu.au

This title is also available online at http://press.anu.edu.au

National Library of Australia Cataloguing-in-Publication entry

Author:

Hazlehurst, Cameron, 1941- author.

Title:

Ten Journeys to Cameron's Farm /

Cameron Hazlehurst.

ISBN:

9781925021004 (paperback) 9781925021011 (ebook)

Subjects:

Menzies, Robert, Sir, 1894-1978.

Aircraft accidents--Australian Capital Territory--Canberra.

World War, 1939-1945--Australia--History.

Australia--Politics and government--1901-1945.

Australia--Biography.

Australia--History--1901-1945.

Dewey Number:

320.994

All rights reserved. No part of this publication may be reproduced, stored in a retrieval system or transmitted in any form or by any means, electronic, mechanical, photocopying or otherwise, without the prior permission of the publisher.

Cover design and layout by ANU Press

Printed by Griffin Press

(C) Flaxton Mill House Pty Ltd 2013 and 2015

Cover design and layout (C) 2013 ANU E Press

Cover design and layout (C) 2015 ANU Press 


\section{Contents}

\section{Part 1 Prologue}

13 August $1940 \ldots \ldots \ldots \ldots \ldots$. . . . . . . . . . . ix

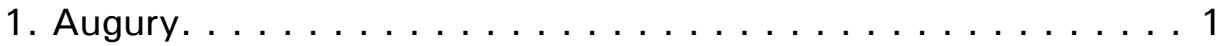

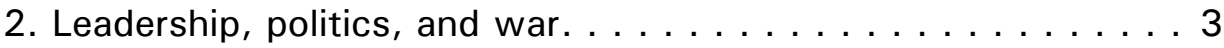

\section{Part 2 The Journeys}

3. A crew assembles: Charlie Crosdale and Jack Palmer. . . . . 29

4. Second seat: Dick Wiesener . . . . . . . . . . . . 53

5. His father's son: Bob Hitchcock . . . . . . . . . . 71

6. 'A very sound pilot'?: Bob Hitchcock (II) . . . . . . . . . . . 99

7. Passenger complement $\ldots \ldots \ldots \ldots \ldots \ldots \ldots$

8. The General: Brudenell White (I) . . . . . . . . . . . . 139

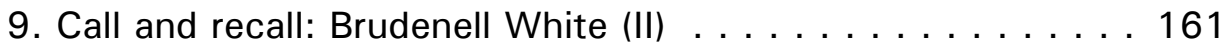

10. The Brigadier: Geoff Street . . . . . . . . . . . . . . 187

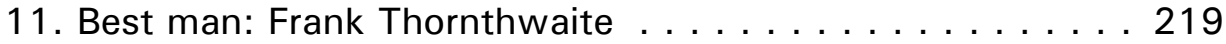

12. Patriot: Harry Gullett . . . . . . . . . . . . . . . . . . 239

13. 'A charming boy who would do big things': Dick Elford . . 271

14. A passion for the air: James Fairbairn (I) . . . . . . . . 307

15. 'A minister or a clerk?': Jim Fairbairn (II) . . . . . . . . 337

\section{Part 3 'The most devastating tragedy'}

16. 'Not a machine for the careless or the ham fisted' . . . . . 369

17. 'A leaf falling off a tree' . . . . . . . . . . . . . . 385

18. Extinguishers . . . . . . . . . . . . . . 419

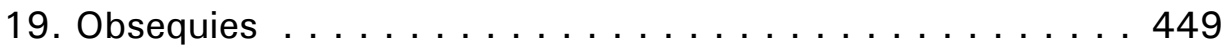




\section{Part 4 Understanding}

20. Inquiry and investigation. . . . . . . . . . 461

21. Expert witnesses? . . . . . . . . . . . . . . . 487

22. Lowe's last word. . . . . . . . . . . . . . . . . . 515

23. Mr Storey's story . . . . . . . . . . . . . . . . 525

24. Cockpit secrets . . . . . . . . . . . . . . . . 551

25. Diagnosis and remedies . . . . . . . . . . . . 585

\section{Part 5 Reflection}

26. 'That terrible hour' . . . . . . . . . . . . . . . . 619

27. Aftermath. . . . . . . . . . . . . . . . . 637

Sources and acknowledgements . . . . . . . . . . 661 
Part 1 Prologue 



\section{August 1940}

Melbourne in August. Another chill mid-winter day in prospect. An 'energetic depression' moving across the Great Australian Bight. The weather forecast: 'cold and cloudy with some further showers, but improving to chiefly fine' if you could believe it. With influenza and bronchitis rampant, not the kind of morning to choose for a flight to Canberra. But the newspapers on 13 August 1940 made it clear why Australia's Army Minister Geoffrey Street, the Minister for Air James Fairbairn, and their Cabinet colleague Sir Harry Gullett had no choice. 'ELECTION PLANS CABINET TO MEET MANY RUMOURS', The Argus said on page one. Prime Minister Robert Menzies, in office for barely 16 months since the death of the United Australia Party (UAP) leader Joe Lyons, was conspicuously evasive about when he would face the electorate. An election was due in not more than two months and a decision could not be long delayed.

To Sir Brudenell White, Chief of the General Staff, and his liaison officer, Lieutenant Colonel Frank Thornthwaite, there was also a summons to brief the Prime Minister. Not about politics, but about the war raging over the British Isles and Australia's own preparations to assist the beleaguered heartland of the Empire and meet threats nearer home. For White, the more arresting news of the day was streamed across the front page of The Argus: 'Some of the most terrific and spectacular fighting that has occurred since the outbreak of war.' Far away though it was, the second successive day of a German aerial offensive that would soon be known as the Battle of Britain was an alarming portent. Headlines about 'THIRD SUCCESSIVE VICTORY GAINED BY R.A.F.' and 'attacks repulsed' would not mask the peril understood by the General Staff and the War Cabinet.

There was a more worrying story for Dick Elford, the Minister for Air's private secretary, and even more for the crew of the RAAF Lockheed Hudson aircraft on which the very important passengers were to be flown to Canberra. Since 5.00 p.m. the previous day, six of their comrades had been missing in a 'twin-engined aircraft' off the coast near Brisbane. As Flight Lieutenant Bob Hitchcock and Pilot Officer Dick Wiesener of No. 2 Squadron knew, the lost plane was a Hudson, just like the one they were to be flying that morning. To the pilots and the airmen chosen to accompany them, fitter Charlie Crosdale and wireless operator Jack Palmer, there were disturbingly unanswered questions. Was there something they should know about the construction or maintenance of a frontline aeroplane that had disappeared without warning or explanation?

To each of these 10 men, vastly differing in their status and responsibilities, the realities of a world at war were inescapable. A patriotically optimistic editorial writer had asked that morning: 'Is the much-vaunted German blitzkrieg yet to begin, or is it already in progress?' The threat of invasion to the British Isles, 
the presence of German raiders in local waters, Australia's vulnerability if Japan were to enter the conflict, the urgent need to train manpower and enhance the nation's defences - these were the daily preoccupations of government and Service life. For Army Minister Geoff Street, there had been announcements the day before about the internment and guarding of enemy aliens, a large number of them being sent from the United Kingdom. With his advisers, Brudenell White and Frank Thornthwaite, Street had also taken note of the preparations for 'the greatest AIF march in Australian history' from Ingleburn to Bathurst. There was publicity too for the call-up, on Monday, August 12, of the first 1400 men - those with surnames beginning with A and B - for universal homedefence training. Some employers, under an obligation to allow men time off to enrol but not to pay them while they were absent, had docked their men half a day's pay. The Cs and Ds were due on Tuesday morning and afternoon. The Army Minister, hopeful though not confident, said he did not believe that employers would continue to penalise men who were called up in the service of their country.

Deeply perturbing as the war was to those privy to secret cables and Service briefings, for many Australians it was still little more than a disruptive influence on what would otherwise have been business or pleasure as usual. It was arguably not Australia's concern at all. Melbourne University's Professor A. R. Chisholm detected a resurgence of the old theory of 'cutting the painter'. Dismayed also by the persistent pursuit of sectional interest, the poisonous bargaining and compromise of party politics, Chisholm had a message for readers of his Argus column on August 13:

In peaceful times one could agree that if Australia is to develop a national personality she must not slavishly imitate Britain. She does not want an Oxford accent or a secondhand literature. But such independence is not incompatible with Imperial unity; and, above all, it should not be antagonistic to the Imperial instinct of self-preservation.

Yet, directly or by implication, people are proclaiming that our interests lie purely in the Pacific; that Britain's quarrels are not ours.

To Chisholm and other alarmed observers, parochialism, persistence in peacetime work and leisure habits, and political disunity - the Labor Party had spurned overtures from the Prime Minister to create a national government - were jeopardising Australia's safety. In Sydney, where Pilot Officer Dick Wiesener's wife and young child remained close to Dick's parents and her own wealthy family, plans were being made for a public demonstration in Martin Place on September 3, the first anniversary of the outbreak of hostilities with 
Germany. The Governor of New South Wales and the Premier would be there to affirm the country's determination to prosecute the war to a victorious conclusion.

It said something about a nation still secure and prosperous that men whose duty it was to understand Australia's strategic position found it necessary to warn their seven million fellow citizens that they would soon be asked to make heavy sacrifices. As Professor Douglas Copland, the Commonwealth Prices Commissioner and economic adviser to the Prime Minister, had put it in a 'Pleasant Sunday Afternoon' talk at the Melbourne Central Mission, the sacrifice would not just be financial. This alone would be unwelcome news to thousands of families still suffering from the impoverishment of the Depression. Yet what had to be faced, Copland said, would be the sacrifice of 'ideals of life, which would disturb the whole economic and social structure of the community'. It would not be long before about a quarter of Australia's manpower would be in military uniforms or employed in munitions work. When that stage was reached, about a quarter of the national income would be devoted to the war effort. Copland did not mention the Australian Army Nursing Service on active duty; nor hint at the thousands of women now training in volunteer organisations as drivers and mechanics, signallers, despatch riders, clerks, and aerodrome ground staff.

Meanwhile newspaper and magazine social pages reported on proliferating charity concerts, funds launched to buy war planes and ambulances, appeals for tinned food, and clothing for evacuee and refugee children, and 'comforts' for the troops. 'Women also Serve' the Australian Women's Weekly proclaimed regularly. In Sunshine, a few miles away from the RAAF base at Laverton, a week of 'festivities to aid patriotic funds' had just begun. There was to be a dance, a picture night, a concert, a euchre party, a massed band performance, and a debutantes' ball. Hostesses in Melbourne and country districts had already arranged 525 house parties to raise money for Blamey House, a hostel for men on leave from the $2^{\text {nd }}$ AIF. The Mothercraft Association was conducting a refreshment room at the Air Force Recruiting Depot in Brisbane. But amid the flowering of voluntary effort, the elimination of waste at home, and fundraising entertainment, there was a hint of different contributions that might be expected in future. Mrs R. G. Menzies' appealed on radio for support for the British YWCA: 'Women in England are working long hours at all sorts of jobs, some big, some little, but all important.' The Prime Minister himself announced that the Commonwealth Government was setting up a special section of the Department of Defence Co-ordination to co-ordinate voluntary offers of help in the nation's war effort.

A nation struggling to define its proper role in a war that threatened to engulf the Pacific as it had Europe, a public increasingly bewildered by party discord when 
Ten Journeys to Cameron's Farm

national unity seemed an imperative...this was a time for political leadership of the highest order. In Canberra, on 13 August 1940, Robert Menzies and his ministers would assemble to try once more to determine a way forward. 


\section{Augury}

Jim Fairbairn loved flying. When still only 18, freshly released from Geelong Grammar School, he had sailed to Britain from Australia in 1916 to enlist for service in the Royal Flying Corps. He had been an instructor in England, a combat pilot in France, and a prisoner of war in Germany. Shot down and wounded, he carried the memory of his two months at the front in a crippled right arm. Three thousand flying hours later, his last 200000 miles had been without an accident. Unusually for one so experienced, he had only once damaged an aeroplane. Today, 1 June 1940, in the Spirit of Flinders, the twinengine de Havilland Dragonfly (VH-ADG) that he cherished, there was to be a blemish on a happily undramatic logbook.

It began as a routine Saturday afternoon flight, one he had taken often with his neighbour and political colleague, the Minister for the Army, Geoff Street. Home to the Fairbairn property at Mount Elephant in the Western District of Victoria, where one of the first tasks of the new owner 16 years earlier had been to create an airstrip. After an exhausting month of attendance to Cabinet, departmental and parliamentary duties, the Minister for Air and his old friend would enjoy a short break together.

The two men had left Essendon airport at 3.30 p.m. Approaching Rokewood, 60 kilometres west of Geelong and some 50 kilometres from their destination, they ran into a rain squall. With severely reduced visibility, an emergency landing was prudent. Fairbairn guided his aircraft towards a field at the Walton family's Wurrook South sheep property. As his wheels touched the ground it was obvious that the plane was landing in the wrong paddock and running downhill. The prescribed action, instinctive for an experienced aviator, was to take off again. The attempt almost succeeded. But a wheel clipped a fence. After straddling a creek, the aircraft came to rest in a ditch. One of the wheel fairings was bent, the press reported; a propeller had lost a tip, and there was a slit in the cabin three-ply.

The sturdy Dragonfly was quickly repaired and flown back to Melbourne on Monday morning. The pilot and passenger also returned to work, shaken but otherwise none the worse for wear apart from Fairbairn's lacerated finger. There was a war on. And men who were young enough to have experienced the ghastly realities of an earlier European conflict were not likely to be kept from their duties by a few cuts or bruises. ${ }^{1}$

1 Sydney Morning Herald, Sun News Pictorial, 4 June 1940. I am grateful to Shane Finch and Rene Pompe for assistance in locating the scene of the crash. 



\section{Leadership, politics, and war}

The political world to which Jim Fairbairn and Geoff Street returned in June 1940 had been transformed in the last 15 months. In April 1939 the Prime Minister, Joe Lyons, had died suddenly, precipitating the United Australia Party into an extraordinary leadership contest. The former Deputy Leader of the UAP, Robert Menzies, self-exiled to the backbenches only weeks before, emerged narrowly victorious. A frantic but futile move by the Treasurer Dick Casey and Country Party leader Sir Earle Page to persuade the ex-Prime Minister Stanley Bruce to declare himself a candidate had fizzled out.

The Melbourne and Sydney power brokers of the UAP - the National Union and the Consultative Council - had come to believe that Bob Menzies was too independent for their taste. Even Errol Knox, managing editor of The Argus, hitherto a strong Menzies supporter, had urged the return of Bruce. But, in Los Angeles en route to Washington and London where he was High Commissioner, Bruce had no desire to return to Australia; he set conditions that he was sure were unacceptable. ${ }^{1}$ If Bruce could not be persuaded, then his protégé Casey was the next best thing. Casey belatedly threw his own hat into the ring but, never a mingler with the rank and file, he had little support. His best hope had been to succeed Bruce some years into the future. Billy Hughes, Prime Minister a quarter of a century earlier, but at 76 still driven by self-belief and determination not to be bested by a man who mimicked and mocked him, was the last man for Menzies to beat.

Although the leadership ballots had been conducted in secret, informed observers thought that Hughes garnered most of his support from Queensland and New South Wales. There had been a last-minute bid to get all the NSW members to swing behind him. At least three men were reportedly offered the Defence Ministry in return for their vote. At the funeral service for Lyons at St Mary's Cathedral in Sydney, Hughes had men placed at each of the entrances to lobby UAP members on his behalf. The 31-year-old member for Martin, Bill McCall, was Hughes' 'hatchet man in the party room'. ${ }^{2}$ The former independent Percy Spender, who sat next to Sir Harry Gullett in the House of Representatives and owed his place in the parliamentary UAP to Menzies, identified some of

\footnotetext{
1 Bruce told the journalist Irvine Douglas, Joe Lyons' former private secretary, of the impossible terms he had set (interview, Irvine Douglas, 15 June 1972, transcript, National Library of Australia, TRC 121/36). 2 Harold Cox, interview, 27 Sept. 1978; interview with Mel Pratt, 6 April 1973, transcript, NLA TRC 121/43/12; Alan Reid, interview with Mel Pratt, 9 Oct. 1972, transcript, NLA TRC 121/40, p.36.
} 
'Hughes's boys'. They included J. A. Perkins and the highly decorated soldier and former minister Sir Charles Marr (who would have preferred Bruce if he had been prepared to stand). ${ }^{3}$

A handful of other New South Welshmen, including Sir Frederick Stewart (MHR for Parramatta and ex-Minister for Commerce), and John Lawson, whose lack of tact and discretion were outweighed for Menzies by his 'cutting edge' mind, held out for Menzies. ${ }^{4}$ But Menzies' strength was in Victoria and South Australia. Among them were ambitious backbenchers with an eye to advancement, like the 30-year-old Melbourne solicitor Harold Holt and the millionaire grazier Senator Philip McBride. In the final ballot the men of the Victorian Western District were almost certainly behind Menzies. But there are good reasons for supposing that their conspicuously ambitious colleague might not have been their first choice.

Some heart searching had been caused by Menzies' resignation after Cabinet decided in March not to proceed with the national insurance scheme with which both he and Casey, as Treasurer, were strongly identified. The decision had deeply distressed Joe Lyons: 'It's gone, it's wrecked, it's finished', a tearful Prime Minister told two Sun journalists. ${ }^{5}$ Casey, who had repeatedly said 'if the scheme goes out, I go out', had acquiesced in its abandonment and remained in the Cabinet. Politically embarrassed that the Treasurer 'suddenly sponsored the idea to repeal it', Jim Fairbairn poured scorn on those members who had gone 'jelly-spined' in the face of orchestrated letter writing. ${ }^{6}$ Alarmed by the apparent unpopularity of national insurance in his electorate, Casey might also have feared that the restless star of NSW politics, B. S. B. Stevens, would come to Canberra and succeed him as Treasurer. Menzies, proclaiming that he was pledged to support the scheme, had left the ministry, alluding as well to other policy differences. This, recalled Sir Cecil ('Peter') Looker who was private secretary to both Casey and Menzies in succession, was the beginning of a 'great hatred' between them. Menzies was angry at a retreat brought on in large part by Country Party recalcitrance and the belatedly awakened opposition of the

\footnotetext{
3 Sir Percy Spender, interview, 16 Aug. 1977; Sydney Morning Herald, 18 April 1939. Spender, standing as an Independent, defeated the sitting UAP member, Sir Archdale Parkhill, in the 1937 general election. Happily rid of a possible rival for party leadership, Menzies had invited Spender to join the UAP, welcoming him into the fold in October 1938. (M. R. McNarn, 'Sir Robert Archdale Parkhill and Defence Policy 1934-1937', BA Hons thesis, Department of History, Faculty of Military Studies, University of New South Wales, Royal Military College, Duntroon, 1979, pp.66-7). Perkins, dropped from Cabinet at Menzies' behest, had been re-instated later by Lyons (Dame Enid Lyons, Among the Carrion Crows, Rigby, Adelaide, 1972, p.56). He recorded his vote for Hughes, his appointment as an hon. minister by Menzies, and withdrawal, in his diary, 18, 24 April 1939, 13 March 1940, Perkins MSS, NLA MS 936/3/37-8.

4 Lawson, Menzies' parliamentary secretary, had pledged his support 'to the last ditch' when his chief resigned (Lawson to Menzies, telegram, 15 March 1939, Menzies MSS NLA MS 4936/579/3). Menzies to Casey, 8 Dec. 1940, copy, Menzies MSS, NLA MS 4936/582/31.

5 Alan Reid, interview with Mel Pratt, 4 Oct. 1972, transcript, NLA TRC 121/40, p.27.

6 The Argus, 23 March 1939.
} 
Melbourne finance and business interests known as the Temple Court group. ${ }^{7}$ Casey felt betrayed by Menzies' grandstanding, sensing that the time had arrived when his colleague was going to make a long-expected bid for the party leadership. The anticipated move was soon signalled when Menzies broached with him the idea of a coup against Lyons. Casey's refusal to 'have a bar of it' was fatal to their relationship. ${ }^{8}$

\section{'...how feeble and futile our leadership is'}

For weeks after the national insurance debacle and the rejected coup proposal, Casey and Menzies did not speak to each other, even if they met in the parliamentary lobby. Loyalties were now being put to the test. Harold Holt expressed his support for the former deputy leader. Fairbairn, growing impatient with the Lyons government's tardy defence preparations, also went on the public record affirming how refreshing it was that Menzies had given a lead 'to those who put personal integrity before political advancement'. This was a gesture of solidarity with someone who was about to join voluntarily those whose presence on the backbenches was not of their own choosing. It perhaps also signalled Fairbairn's genuine surprise that the ambitious 'coming man' was prepared to defer his coming on a point of principle.

Since their earliest days together in Victorian politics, as leaders in what became the Young Nationalist movement, Geoff Street and Jim Fairbairn had watched the evolution of Robert Gordon Menzies from precocious celebrity barrister and vibrant street-corner orator to self-esteeming state and federal minister. They respected his persuasive ingenuity in the courts, his masterful dexterity in parliamentary debate, his withering ripostes on the platform. Bob Menzies was an awesome political force. But he was not one of them. He was a scholarship boy from a dusty country town. Not born to inherit great wealth or vast estates. Not a returned serviceman. Not a man of the land. Not a sportsman. True, his father and uncle had been parliamentarians. And he had made his own way, rising through state politics to Cabinet rank before making the transition to Canberra. For such application and political talent there was admiration. But there was little empathy, still less affection.

7 Frank C. Green, Servant of The House, Heinemann, Melbourne, 1969 p.114. Rob Watts, The Foundations of the National Welfare State, Allen \& Unwin, Sydney, 1987, pp.1-24 is a valuable account of the national insurance debacle. Watts, accepting the thrust of Philip Hart's argument ('The Piper and the Tune', in Cameron Hazlehurst ed., Australian Conservatism: Essays in Twentieth Century Political History, pp.111-48), doubts Green's view of the influence of the Temple Court group.

8 Sir Cecil 'Peter' Looker, interview, 25 March 1976; Allan W. Dawes diary, 8 Nov.-15 Dec. 1938, Frances McNicoll MSS, NLA MS 9246, Box 12; Diane Langmore, Glittering Surfaces: A Life of Maie Casey, Allen \& Unwin, Sydney, 1997, pp.61-2. On 17 Feb. 1947, Sir Owen Dixon recorded in his diary Casey's version of a similar incident that had supposedly, and improbably, occurred 'abt 1935' (Philip Ayres, Owen Dixon, Miegunyah Press, Melbourne, 2003, p.342, fn. 4). 
Like all their colleagues, Fairbairn and Street were always in danger of being the butt of Menzies' cruel wit. They could not be unaware, as Percy Joske, his Wesley College, university, and courtroom contemporary remembered, that in his early days in Parliament Menzies ingratiated himself with the squattocracy, while forming a poor opinion of the intellectual capacity of their wives, whom he caustically described as sleeping partners'. ${ }^{9}$ The Western District gentry endured his moods, the days, one in seven, as one of his private secretaries put it, when he was 'touchy and difficult... different from his normal ebullient self'. ${ }^{10}$ They did not often go out of their way to be in his company.

Geoff Street was observed to be friendly with Menzies early in his federal political career. But Street had in fact been closer to Casey, whom he had known since Gallipoli, being frequently in and out of his office in Canberra. ${ }^{11} \mathrm{Jim}$ Fairbairn's fiercest loyalties were with men who had placed themselves in harm's way when the nation was at war. His dearest friend, the grievously wounded Charles Hawker, killed in an aircraft crash late in 1938, had been his hope for the political future. He had written to Hawker's mother that for those 'who know what Charles could have done for Australia during the difficult dangerous years ahead, and who realise how feeble and futile our leadership is, it is hard not to give way to a feeling of bitterness against Fate'. Street wrote of Hawker: 'I always looked upon him as my guide, philosopher, and friend in all political matters.' ${ }^{12}$ As the erstwhile Cabinet minister Tommy White observed, Hawker was "the spiritual leader of the "squatter" group in the House - McBride, Fairbairn, and others following him always slavishly' ${ }^{13}$ Sir Harry Gullett, too, himself a former senior minister, had 'always admired and applauded' Hawker in spite of Hawker's sustained opposition to his trade policy. After an 'irritable and unpardonable outburst' in Canberra one vexing day in 1936, Gullett had told Hawker: 'This House has very little attraction for me and I could not face any disturbance in a friendship which I value more than I can put into words. ${ }^{\prime 4}$

With Hawker dead, the 'squatters' had more in common with Casey, who had served in Gallipoli and France albeit in staff posts, than with the notorious

9 Sir Percy Joske, Sir Robert Menzies 1894-1978 - a new, informal memoir, Angus \& Robertson, Sydney, 1978 , p.96.

10 Sir Peter Heydon, interview with Mel Pratt, Nov. 1970, NLA TRC121/2.

11 Alfred Stirling, interview, 14 May 1976, for Street and Menzies; Colin Moodie, interview, 28 Sept. 1977, and Lt Gen. E. K. Squires diary, 30 Aug. 1938, Australian Defence Force Academy (UNSW@ADFA) Library, MS 184 folder 1; on Street and Casey, Sir Peter Looker, interview, 25 March 1976, and Casey diary, 8 June 1915, Casey MSS NLA MS 6150.

12 Lilias Needham, Charles Hawker: Soldier - Pastoralist - Statesman, privately published, Adelaide, 1970 (1st ed. 1969), pp.160, 168.

13 White diary, 25 Oct. 1938, by courtesy of the late Lady White, in Cameron Hazlehurst, Menzies Observed, George Allen \& Unwin, Sydney, 1979, p.152. Allan Martin (A. W. Martin assisted by Patsy Hardy, Robert Menzies A Life, vol. 1 1894-1943, Melbourne UP, 1993, p.245), makes Hawker a 'spirited' leader, which he was; but White was making a different point.

14 Gullett to Hawker, 1 April 1936, typescript copy from Hawker MSS, Gullett MSS, NLA MS 3078/3/16. For Gullett's fondness for Hawker: H. B. 'Jo' Gullett, interview, 7 Aug. 1978. 
'stay at home' Menzies. Those who knew Casey well recognised his vitality and diligence; they appreciated, too, a side of him that was rarely revealed. As Harry Gullett's son Jo put it, 'he really didn't mind making a fool of himself a bit'. He was not a good horseman and would try to get out of riding. But 'if you were cleaning out, off would come his trousers and he would get in up to his knees in mud and laugh'. To the young Gulletts he was 'a terribly outgoing vigorous slightly non-conforming chap, forward looking, unorthodox' ${ }^{15}$ In the days after Lyons' death there was 'a very strong movement' in Melbourne UAP circles to elevate Casey. One alarmed Menzies supporter detected 'much underground work' going on. ${ }^{16}$

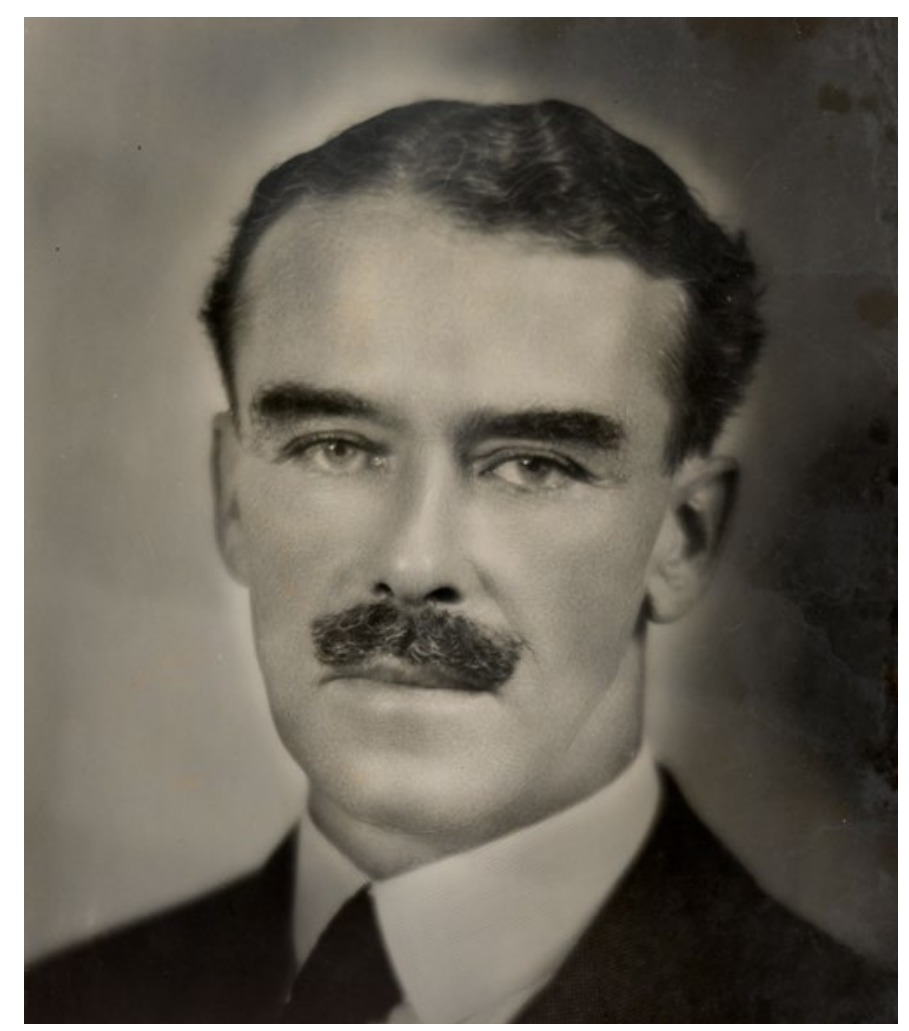

R. G. Casey 1938 by Gordon Furlee Brown: ‘he really didn't mind making a fool of himself'

(Courtesy of the National Portrait Gallery, Canberra)

Casey survived the first leadership ballot when the lightweight former Minister for Trade and Customs, Tommy White, an Australian Flying Corps pilot and famous escapee from Turkish captivity, was easily eliminated. But Casey's

15 H. B. 'Jo' Gullett, interview, 7 Aug. 1978.

16 F. H. Wright to W. D. Gillespie, 14 April 1939, Wright MSS, NLA MS 8119 Series 2, Box 15. 
supporters could not get him past the next round. Only when he was clearly out of the running did the even less palatable prospect of a Billy Hughes government persuade not only the squatters but others, like Senator Hattil 'Harry' Foll, into the Menzies camp. ${ }^{17}$ Their switch of allegiance was crucial.

Hughes's 19 votes reflected a continuing public regard for the wartime 'little Digger' as well as the widespread unpopularity of Menzies in the parliamentary party. A few days later Menzies was to try to laugh off publicly the 'fantastic ideas' that circulated in current gossip, accusations of 'grave defects, aloofness, superiority and what not'. ${ }^{18}$ Yet apart from those of his family who idolised him - his loyal brother Frank, his elderly parents, and his devoted wife - there were few believers. Nothing much had changed since Casey had told his mentor Bruce after the 1937 election that 'People have the idea that he has a contempt for the average man, and they don't like it.' ${ }^{19}$ As the astute Governor-General, Lord Gowrie, had observed only days before Menzies had resigned in March, 'Mr. Menzies with his great ability lacks the art of keeping his colleagues together and extracting loyal service from them.' ${ }^{20}$

In the final ballot, there were 23 votes for Menzies - among the earliest of them almost certainly the South Australian Senator George McLeay, the social reformer and national insurance advocate Sir Frederick Stewart, and Harry Gullett, long disenchanted with the Country Party in general and Sir Earle Page in particular. The majority reflected a rush of last-minute threats, promises, and second-best choices. Some NSW party insiders, including the chairman of the powerful Consultative Council, Telford Simpson, and the UAP NSW secretary, Bert Horsfield, were to say a year later that when the vote was taken Hughes had a majority of two among members of the House of Representatives. Menzies had risen to power on the votes of senators. ${ }^{21}$ The scorn of the thwarted wire-pullers was undisguised and enduring.

After the leadership ballot there had followed the most extraordinary personal attack on a major political figure in Australian history. Earle Page, enraged by what he saw as Menzies' blatant undermining of Lyons in the preceding year, blamed him for the Prime Minister's death. As Lyons lay dying, Page was observed sitting in the hospital reception room in the early hours of the morning with a group of ministers, local MPs, and newspaper men 'in the most

\footnotetext{
17 Hattil S. Foll to $\mathrm{CH}, 27$ Feb. 1976.

18 R. G. Menzies, 'To the Australian People', broadcast talk, 26 April 1939, transcript, NAA: A981, Australia 94.

19 Casey to Bruce, 17 Nov. 1937, Bruce Papers, NAA: A1421, (4).

20 Lord Gowrie to the King, 9 March 1939, copy, Gowrie MSS, NLA MS 2852/8/2.

21 'Notes Relative to Lobbying Preceding Conference, May 25th, 1940', Menzies MSS, NLA MS 4936/581/25. The notes were evidently compiled by Stanley Perry and J. J. Simons from Perth who were reporting the continuing hostility to Menzies of Simpson and Horsfield. For Simons' allegations in 1943 against the National Union, 'working under cover': L. F. Crisp, Australian National Government, Longman Cheshire, Melbourne, 4th ed. 1978, p.242.
} 
objective, unemotional, coldblooded way possible...tracing the course of Lyons' heart condition as a doctor and linking its development to the attacks which he alleged Menzies had made on Lyons' ${ }^{22}$ Menzies' resignation from the ministry - ostensibly over national insurance, yet with enigmatic reference to finding himself repeatedly at variance with the majority of the Cabinet on 'matters of great moment and in particular upon important aspects of our Defence preparedness $^{23}$ — was construed as a stroke of opportunistic destabilisation. The departed minister was not going to be credited with adherence to principle. A pointed public speech about deficiencies in national leadership, and his poorly concealed clandestine negotiations with the press and party financiers, made it seem obvious that Menzies had intended to strike. His ambition was the worstkept secret in Canberra. As one of his private secretaries would remember: 'He thought he would be a good Prime Minister of Australia, he wanted to be Prime Minister of Australia, and all his political actions were largely tested against that particular framework of reference.' In the succinct judgement of his former Cabinet colleague Jack McEwen, 'he was rather a man in a hurry' ${ }^{24}$

In the days after Lyons' death, Page was wooed by Billy Hughes into a pact of mutual support. 'Doc, you know I have always admired you...'; the blandishing was overheard by the minister's private secretary. ${ }^{25}$ At Hughes' suggestion the Governor-General appointed Page as Prime Minister pending the UAP's election of a new leader. The Country Party leader was determined to prevent Menzies from securing the highest prize. He made it known that he would not serve in a Menzies ministry. Anonymous Country Party MPs floated the idea that a joint party meeting should elect the new Prime Minister. The field of candidates would consist only of UAP members, several of whom, including one minister, were said to strongly support the suggestion. ${ }^{26}$ Both Page and Hughes had been victims of Menzies' indiscriminate condescension. Neither could expect a position of real power in a Menzies government. After Menzies had won the UAP ballot their last best hope was to discredit him sufficiently to make it impossible for him to form a viable Cabinet. Thus Page rose in Parliament to excoriate the man of naked ambition, disloyal to his dead chief. Menzies, an officer in the Melbourne University Regiment, Page reminded the House, did not volunteer throughout 1914-18, instead advancing his university and legal career while fellow students, lawyers, young men of all professions and of none, were shedding blood at Gallipoli and on the Somme.

\footnotetext{
22 Harold Cox, interview, 27 Sept. 1978; with Mel Pratt, 6 April 1973, NLA TRC 121/43.

23 R. G. Menzies to Prime Minister, 14 March 1939, copy, Gowrie MSS, NLA MS 2852/5/10.

24 Sir Peter Heydon, interview with Mel Pratt, 2 Dec. 1970, NLA TRC 121/2; Sir John McEwen, interview, 14 May 1976.

25 Sir Keith Waller, interview, 21 June 1977. Waller heard the critical meeting via an accidentally open intercom.

26 The Argus, 19 April 1939.
} 


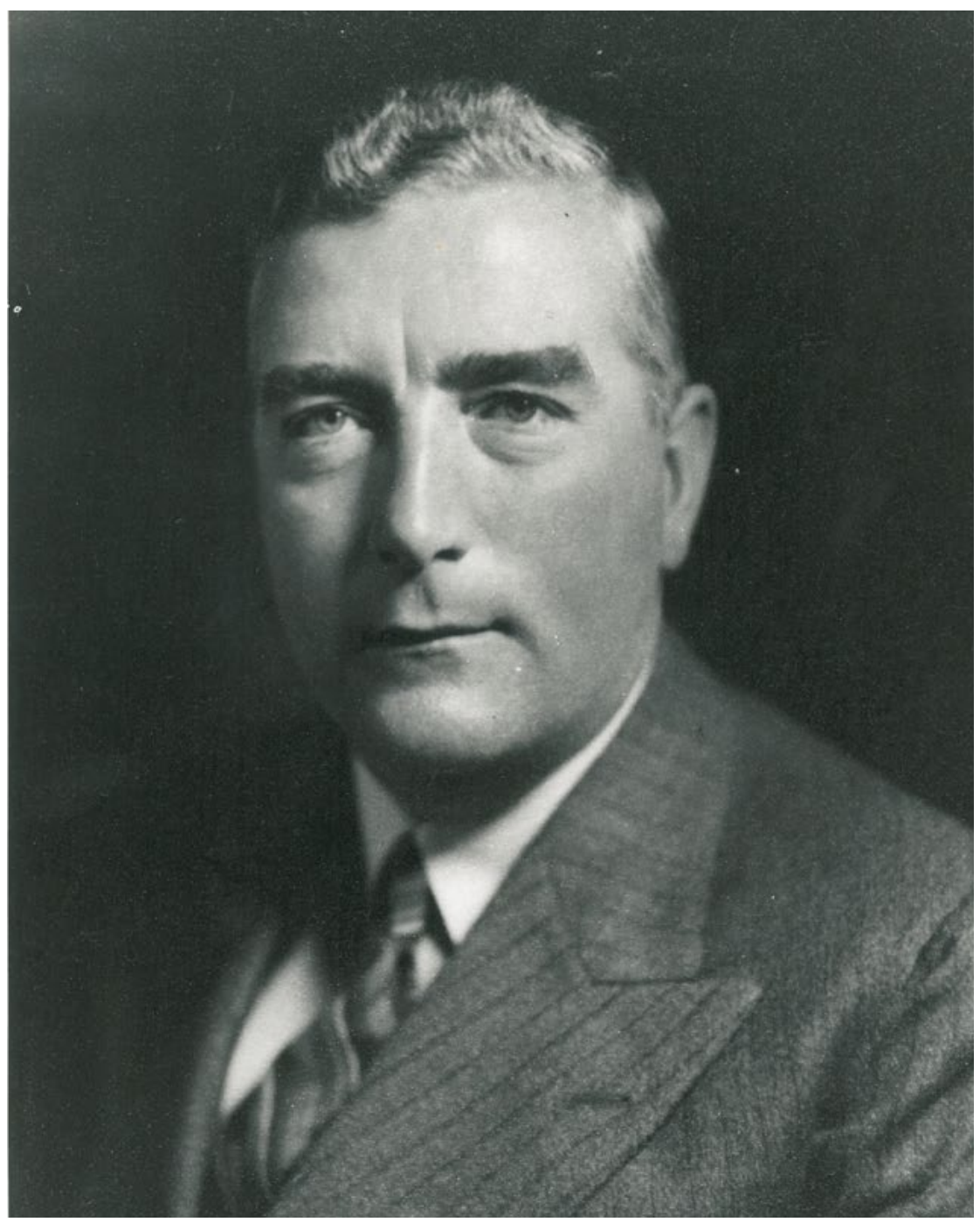

Robert Menzies: more than 'the slightest desire to be Prime Minister' (Courtesy of the National Library of Australia)

Page's attack was unprecedented in destructively personal intent but, as Menzies responded with dignity, inaccurate in detail. Though even some of Page's own party colleagues were offended by his vehemence - Arthur Fadden and three others distanced themselves from the personal assault - the Country Party followed their leader in refusing to serve with Menzies. Undeterred, Menzies therefore formed a ministry solely of United Australia Party members. (With two additional men in the Cabinet, skilled tradesmen had to work over a weekend to widen the massive maple Cabinet table by two feet, and adjust electrical wiring linked via push buttons on each seat to telephones, radio, an 
overseas radiotelephone, and an amplifier installed to assist Billy Hughes). ${ }^{27}$ Ironically Page had achieved by his ill-judged invective what Menzies might not have contrived for himself; a united UAP front bench. It was, as Menzies was soon to boast, a ministry 'unique in Australia because it contained an amazing proportion of young and what might be called untried men'. (In later years he would confide that the absence of veterans like Sir George Pearce, defeated in 1937, was 'the greatest defect of his Cabinet'. $)^{28}$ 'There is no doubt,' Stanley Bruce wrote later from London, 'that Page was your fairy godfather, if you had the slightest desire to be Prime Minister.' ${ }^{29}$

Menzies would never be thought 'warm and likeable' like the departed Lyons. His arrogance and self-belief were in sharp contrast to the 'mild infusion of ambition and egoism' which Lyons so adeptly cloaked beneath 'unbearable amiability' ${ }^{30}$ But he had put himself through the leadership challenge, defended his honour, and earned a grudging respect. Jim Fairbairn, for one, was disgusted by the attack on his elected chief. It was known that Fairbairn had been working for some months on getting Stanley Bruce to come back to Australia; and he had publicly offered to give up his seat of Flinders if Bruce should return to take up the party leadership. He had even made the mischievous suggestion that the High Commissioner's job in London could be capably carried out by 'such men as Mr Casey and Mr Menzies'. ${ }^{31}$ So he was certainly not in the Menzies camp. Yet five years earlier he had said in Parliament that it was not right for those without intimate knowledge of particular circumstances to criticise those who had not served in 1914-18. 'Some were too young, some were too old, and some others physically or mentally unfit for service. ${ }^{32}$ Menzies was not encompassed by any of these categories but that did not diminish the egregiousness of the calumny. Realising the distress it must have caused his colleague's wife, Fairbairn followed Pattie Menzies out of the House and walked consolingly with her in the parliamentary rose gardens. ${ }^{33}$

The eight United Australia Party ministers from the Lyons Cabinet, including Hughes, then gathered in Casey's room and agreed on a letter dissociating themselves from Page. The man whom Harry Gullett had once dubbed 'the most tragic Treasurer' that Australia had ever known had become a political pariah. ${ }^{34}$

\footnotetext{
27 The Mail (Adelaide), 13 May 1939.

28 Peter Heydon, Quiet Decision: A Study of George Foster Pearce, Melbourne UP, 1965, p.211.

29 Sydney Morning Herald, 16 May 1939; Bruce to Menzies, 4 Oct. 1939, Menzies MSS, NLA MS 4936 in Hazlehurst, Menzies Observed, p.166.

30 Don Whitington, Twelfth Man?, Jacaranda Press, Milton, 1972, pp.74-5; Frank. C. Browne, They Called Him Billy: A Biography of the Rt. Hon. W. M. Hughes PC MP, Peter Huston, Sydney, [1948?], p.191.

31 Sydney Morning Herald, 18 April 1939.

32 CPD, House of Representatives, 1 Aug. 1934, p.1047.

33 Dame Pattie Menzies, interview with Allan Martin, 1 Oct. 1987, in Martin, Robert Menzies A Life, vol. 1 1894-1943, p.300.

34 S. Encel, Cabinet Government in Australia, Melbourne UP, 2nd ed. 1974, pp.74-5; K. R. Ingram (journalist and Parliamentary reporter), interview, 1978.
} 
The location of the meeting was significant. Casey's hopes of leadership had been dashed. He admired Page, his regular tennis partner, as a man of energy and ideas. In supporting the bid to bring back Bruce, Page was by implication recognising Casey as next after Bruce in line of succession as Prime Minister. But the assault on Menzies was a step too far. Typed by Casey's secretary, Jean Francis, the document repudiating Page was brought in for signature by Casey's private secretary, Colin Moodie, who delivered it to the new leader. ${ }^{35}$ Menzies was able to assure the Governor-General of sufficient support both from the UAP and from the Country Party to carry on. Lord Gowrie was conscious of 'treading on rather delicate Constitution [sic] grounds' as Labor had a majority of two over the UAP. But he believed that no party wanted an election so that 'although they may harass Menzies they would take very good care that he should not be defeated on a major question'. ${ }^{36}$ And so it proved.

\section{War government}

Barely five months later Menzies had the 'melancholy duty' of announcing that Australia was at war with Germany. At a hastily convened Federal Executive Council meeting in the rarely used Governor-General's room in Melbourne's Treasury Place, the Prime Minister had been joined to authorise the formalities by Fairbairn (now in the Cabinet as Minister for Civil Aviation), Holt (Minister without Portfolio assisting the Minister for Supply), Gullett, and Casey. There they advised Sir Winston Dugan, acting as Deputy for Lord Gowrie, that a proclamation of 'the existence of danger of war' was to be issued. ${ }^{37} \mathrm{~A}$ War Cabinet had been formed a few weeks after the declaration of war. Its initial members were Hughes (Deputy Leader of the UAP, Attorney General, and Minister for Industry), Casey (Minister for Supply and Development), Street (Minister for Defence), Gullett (Minister for External Affairs and Minister for Information), and McLeay (Minister for Commerce).

Menzies' vanquished rival Dick Casey, spurred on by his wife Maie, had soon accepted the post of inaugural Ambassador to Washington. He was attracted to the job, and vulnerable to a Prime Minister who shamelessly kept him on tenterhooks about the appointment. Casey, with Bruce concurring, had considered that his own departure from the political arena would leave no one suitable to act as Prime Minister if Menzies were to go to London or 'came to

35 Moodie, interview, 28 Sept. 1977. For Page and Casey as tennis partners, see Sir Alan Watt, Australian Diplomat, Memoirs, Angus \& Robertson in association with Australian Institute of International Affairs, Sydney, 1972, p.21. On Menzies' military service and the background to Page's attack see Cameron Hazlehurst, 'Young Menzies', in Hazlehurst (ed.), Australian Conservatism, pp.10-20.

36 Lord Gowrie to Walter Hore-Ruthven, 22 May 1939, copy, Gowrie MSS, NLA MS2852/5/10.

37 N. C. Tritton, interview, 7 June 1977. 
grief'. Casey's reservations, spoken and unspoken, were swept aside. 'I hope no one here underestimates the importance of the appointment,' the Prime Minister told Casey's Corio Young Nationalist constituents, 'for it was with some reluctance that I abandoned the idea of asking for the appointment myself.' There was less humbug and even less charity in a later private account of the circumstances. 'If ever a man had his tongue hanging out to go to America it was Casey,' Menzies was to recall, his colleague's clearly expressed desire to stay in Canberra conveniently erased from the story. ${ }^{38}$

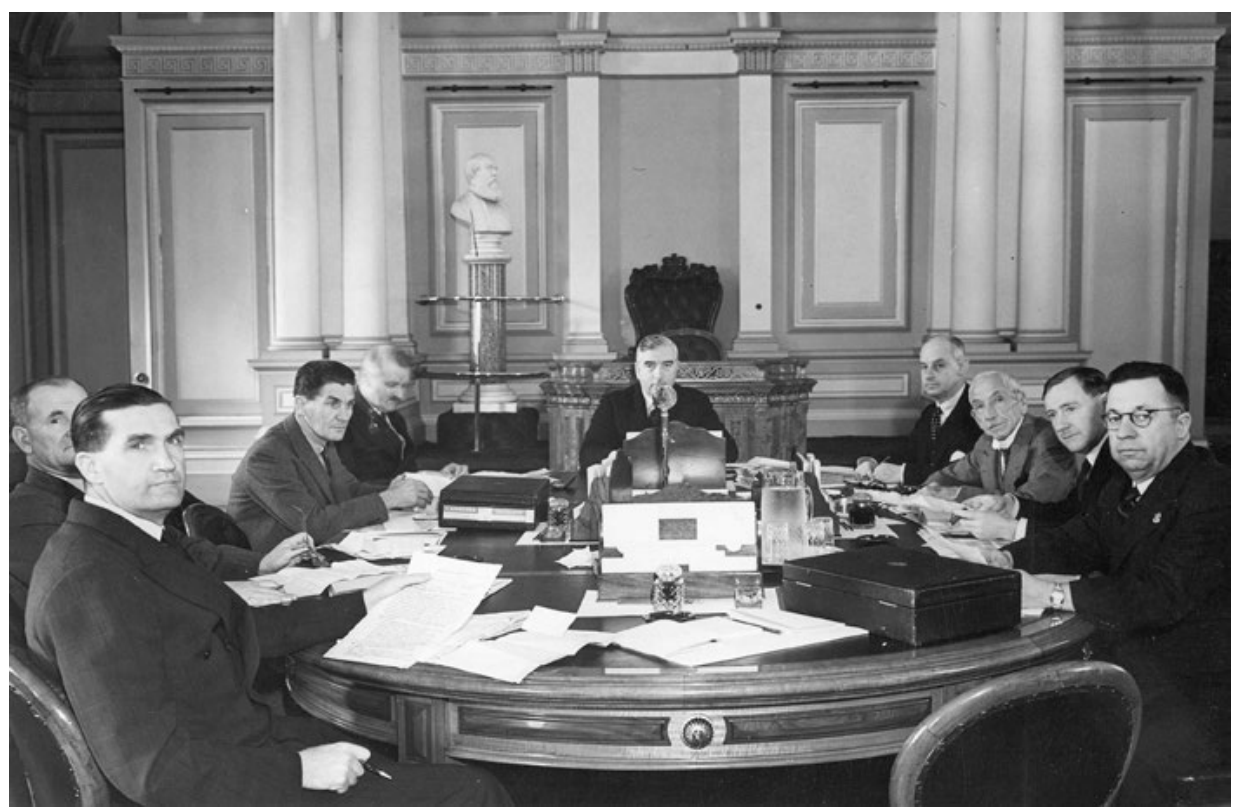

The coalition War Cabinet in the old Legislative Council Chamber,

Parliament House, Victoria. Left to right around the table: J. McEwen, External Affairs; Sir F. Stewart, Supply and Development; G. A. Street, Army; A. G. Cameron, Navy; R. G. Menzies, Prime Minister; the Secretary to the War Cabinet, F. G. Shedden; W. M. Hughes, Attorney General; P. C. Spender, Treasurer and Senator H. S. Foll, Minister for the Interior; (J. V. Fairbairn, Minister for Air, absent)

(Argus Collection of Newspaper Photographs, State Library of Victoria, H99.201/2584)

As the war progressed, with little but bad news from the European theatre, amid growing discontent and criticism, Menzies had come to rely increasingly on the Victorian duo of Fairbairn and Street. Their responsibilities for military

38 Sir Cecil Looker, interview with Alan Hodgart, 1975, NLA Oral TRC 370, p.20; The Argus, 15 Jan. 1940; David McNicoll, Luck's A Fortune, Wildcat Press, Sydney, 1979, p.219; W. J. Hudson, Casey, Oxford UP, Melbourne, pp.115-6; Casey to Menzies, 1 Nov. 1939, NAA: CP 290/6, item 1, in R. G. Neale (ed.), Documents on Australian Foreign Policy [DAFP], vol. II, Canberra, 1976, p.366; Note by S. M. Bruce of conversation with Casey, 8 Nov, 1939, DAFP, vol. I, 1975, p.381. 
and Air Force affairs were expanded. Fairbairn was promoted from Minister for Civil Aviation to Minister for Air in November 1939, joining the War Cabinet along with Harry Foll and Sir Frederick Stewart in a re-organisation that saw Street become Minister for the Army and Menzies assume greater control as Minister for Defence Co-ordination as well as Prime Minister. In March 1940, the Country Party, now under the leadership of Archie Cameron, accepted a proposal to form a new coalition. It was a lifeline for a Prime Minister who was privately admitting that his difficulties 'on all war matters are great and growing and defeat of Government by no means improbable' ${ }^{39}$

In the ministerial re-shuffle some of Menzies' party colleagues had to stand down. While their friend Harry Gullett was dropped from the inner group to make way for Country Party representatives, Fairbairn and Street kept their places. They were now in almost daily contact with the Prime Minister. If their influence was less than the ubiquitous and secretive Secretary of the War Cabinet, Frederick Shedden, they were clearly now in the first rank of the nation's political leadership.

\section{Defending the Empire}

In the early days of the war, the government realised that a great national effort would be required if Australia was to be a help to the British homeland. As Street had put it in a Cabinet paper on 11 September 1939:

Each part of the Empire accepts responsibility for its own local defence and the adequacy of these preparations is important lest any Dominion should become a burden on the United Kingdom strength in the event of a crisis. ${ }^{40}$

Recognising the priority to defend the heart of the Empire, and accepting assurances of British readiness to come to Australia's aid should she be threatened, the Australian commitment soon entailed the deployment of naval forces far from their home bases under Royal Navy command, and the development of the RAAF as an incubator of crew for the RAF.

The Australian Chiefs of Staff had no choice but to acknowledge the limited operational capability of the chronically under-funded RAAF. The Air Force was

39 Menzies to Bruce, 21 Feb. 1940, NAA: A3196, O. 1038. In March the UAP lost the seat of Corio vacated by Dick Casey (Mal Harrop, 'Corio 1940: Triumph for John Curtin but Stillbirth for an Australian Motor Car', Labour History, No. 91, Nov. 2006, pp.131-49).

40 Cabinet agendum 6/1939, 11 Sept. 1939, NAA: A2697, 146/1939, quoted in John McCarthy, A last call of empire: Australian aircrew, Britain and the Empire Air Training Scheme, Australian War Memorial, Canberra, 1988 , p.2. 
only half way through a three-year expansion plan, with about two-thirds of its aircraft already obsolete. Japan's declaration of neutrality relieved immediate anxieties - and encouraged the quixotic thought that perhaps training aircraft could be acquired from the Japanese. While they awaited the delivery of modern aircraft, the RAAF would be fully stretched in meeting the threat posed by armed German merchant vessels, submarines, and a lone cruiser in the Pacific. Australian Air Force squadrons were in due course to operate in Britain and the Middle East; and infantry divisions, a second Australian Imperial Force (AIF), would also eventually be despatched to North Africa and the Mediterranean.

Initially it had been thought that Australia would send an air expeditionary force to augment the RAF. But British planners had long mooted the idea that the Dominions would better serve the imperial cause by training the vast numbers of air crew that would be needed to fly against the Luftwaffe. In spite of naïve pronouncements to the contrary, Australia did not have the resources for an expeditionary force as well as a massive training undertaking. Negotiations to establish such a scheme - approved in principle by the War Cabinet on 5 October 1939 without reference to their professional advisers, the Air Board began at long range. South Africa declined to participate, and both Australia and Canada resisted British ambit requests. New Zealand also had reservations. If basic agreement was to be reached, and arrangements made for what would be an immensely complex and costly program, face-to-face talks were essential. The venue was to be Ottawa.

While still only Minister for Civil Aviation and Minister assisting the Minister for Defence, Jim Fairbairn was sent to Canada with a small delegation to represent Australia in developing the Empire Air Training Scheme. Recognising the fragility of the government's parliamentary majority both Fairbairn and Dick Casey, who had left earlier for London, had taken the precaution of leaving signed nomination papers for their electorates in case an election was called in their absence. ${ }^{41}$ On the way to the Canadian capital, Fairbairn took the opportunity to call in to the Lockheed Aircraft Corporation factory at Burbank to check on the progress of Australia's recent order for 100 Hudson bombers. The aircraft were to form the RAAF's principal reconnaissance and home defence units. Their speedy acquisition was vital. But Fairbairn's main focus was on Ottawa. The stakes there were high and this was his first international mission. The British had sent a large and powerful team; and the Canadians, on their home soil, had all of their defence and departmental advisers at hand. Menzies clearly had doubts about Fairbairn's ability to achieve a favourable result against the imperial ministers and mandarins with whom he was matched. The minister had told reporters before he left that no limit had been set on the extent to 
which he was authorised to commit Australia 'except our ability to fulfil that commitment' ${ }^{42}$ However, War Cabinet's prior decisions, surviving cables, and transcripts of telephone conversations reveal a representative on a short leash. ${ }^{43}$

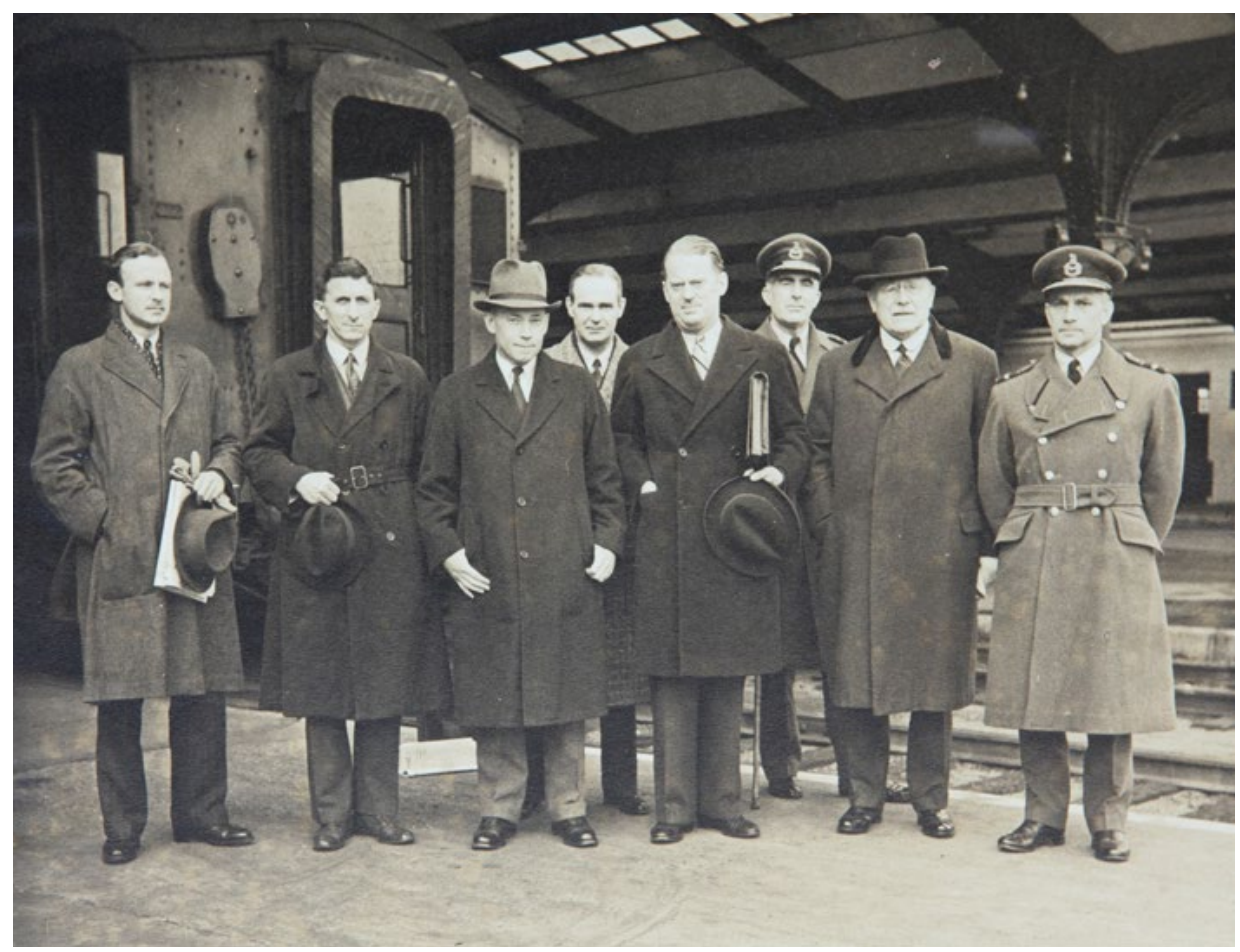

The Australian Air Mission greeted at Ottawa Railway Station by British and Canadian representatives, 1 November 1939. Left to right R. E. Elford (Secretary, Australian Air Mission), WCdr G. Jones (Asst Chief of Staff RAAF), Norman McL. Rogers (Canadian Minister of National Defence), C. V. Kellway (A/g Asst Trade Commissioner, New York), AM Sir C. L. Courtney (UK Air Mission), AVM G. M. Croll (Chief of Air Staff, Canadian Department of National Defence)

(Courtesy of Hugh Elford)

Fairbairn himself was confident. He took the initiative in saying that Australia would train half of the local recruits rather than bear the cost of training them all in Canada. Stiffened by instruction from Menzies not to commit Australia in any way, he pressed the argument that the quotas of men to be delivered should be based on population rather than the arbitrary and excessive numbers presented by Britain. Realising that neither the Canadians nor the British delegation could

42 'National Defence [Fairbairn and air recruits]', Movietone News, vol. 10, no. 44, 21 Oct. 1939, AWM: F01912.

43 'Report of the Australian Air Mission...November 1939', War Cabinet Agendum No. 20/1940 (6/2/40), Secret, NAA: A5954, 235/9. 
afford to have the whole plan founder, he gave them the impression that he was prepared to leave if the negotiations drifted inconclusively. Speaking on the radio on November 24 he surprised the Canadian Prime Minister with a 'voice and delivery [that] was remarkably good'. But it was the content more than the performance that caught Mackenzie King's attention:

Substance good but I was horrified to hear him say that Australia had adopted plan suggested at outset and was prepared to exceed it. As a matter of fact the whole scheme has had to be revised twice because of Australia's unwillingness to adopt plan suggested and agreed to by others. $^{44}$

When the British conceded the fundamental quota principle and agreed that seven of nine service training schools be set up in Australia, Fairbairn seized the moment to sign an agreement with them on 27 November 1939. It was another three days before the Australian Cabinet was briefed on what had been decided. Their representative had done well. Eighty-three staff officers in every branch of the RAAF had been asked whether Australia could do what the scheme required. None of them, the then RAAF liaison officer to the secretary of the Department of Defence, John McCauley, remembered, said they could. All said 'Let's try it. $^{45}$ While the Canadians were especially cautious, and there were details still to be settled between all the parties including New Zealand, Fairbairn moved on to London where he was to assist in finding a new Chief of the Air Staff before returning to Australia. ${ }^{46}$ The Prime Minister announced the signing of the 'vast Empire Scheme of Air Training' with Britain on December 15.

On the role to be played by the graduates of the Empire Air Training Scheme (EATS), Fairbairn and Street shared a wish to preserve the national identity of the Australians in the United Kingdom. Street, a fervent nationalist, had put it to Cabinet when recommending an air expeditionary force in September 1939 that a unified Australian force would 'appeal to the national spirit of the country and accord with those tendencies towards independence inherent in the Australian character'. Menzies had given public assurances that fears of the loss of Australian identity were groundless. Fairbairn, with the growing status of Minister for Air, was to remind Menzies in March 1940 that he had always had in mind that 'the personnel would remain RAAF, wearing RAAF uniforms or a distinguishing badge, and be grouped in squadrons which would bear the name Australia'. But the British refused to contemplate the formation of more than the limited number of 'Australian' squadrons agreed under Article XV of the

44 W. L. Mackenzie King diary, 24 Nov. 1939, William Lyon Mackenzie King Papers, Library and Archives Canada, www.collectionscanada.gc.ca.

45 AM Sir John McCauley, interview, 6 Jan. 1978.

46 Kent Fedorowich, 'Sir Gerald Campbell and the British High Commission in Wartime Ottawa, 1938-1940', War in History, vol. 18, no. 3, 2011, pp.357-85, for the Canadian and British record of the negotiations. 
EATS agreement. They routinely appointed RAF officers to command positions over Australians. And the vast majority of EATS graduates were eventually to be dispersed into RAF units. Fairbairn had not foreseen the extent to which the connivance and compliance of his British Chief of the Air Staff, Sir Charles Burnett, would ensure that RAF, not RAAF, wishes would prevail. ${ }^{47}$

In the War Cabinet as the war continued, the two Victorian ministers with defence portfolios found themselves in continual discussion over strategy, manpower, recruitment, command, and organisation of military forces, and industrial mobilisation issues. When Treasury tried in March 1940 to solve a RAAF trades recruiting problem that was accentuated by differential rates of pay being offered to pre-war and current recruits, Street, Fairbairn, and Harry Gullett were as one in rejecting a Treasury Finance Committee formula (endorsed by Menzies) that would have increased separation allowances rather than the basic pay rates. Fairbairn argued that peacetime rates of pay should be restored. He agreed with the Chief of Air Staff and the Air Board who warned of the discontent that will arise from having men on every station doing similar work at different rates of pay'. Street forecast that a complete reversion to RAAF rates could bring demands from the Army for similar treatment. Gullett, a former journalist and war historian, was alert to public opinion. He urged 'an immediate strong appeal to the patriotism of those who are wanted for this class of home service'. No such appeal had yet been made. Gullett articulated his agreement with the view that the Prime Minister had 'many times expressed that when the war actually commences on a grand scale in Europe the response to all kinds of our recruiting effort will be incomparably more satisfactory than it is now' ${ }^{48}$

In many ways there was an air of unreality about 'the war' for Australians well into the first half of 1940. It was largely a distant conflict, the stuff of censored news stories, tales of heroism, and reassuring domestic propaganda about surging growth in munitions production and military expansion. In a speech early in March Menzies found himself talking of 'a struggle which at present is but a faint rumble on the horizon... we have been able to continue to go about our ordinary business, having a look at the races, and talking about the crops. This is possible only because the world is still ruled by the British Navy.' ${ }^{49}$ Prime Ministerial encomiums about Australians appreciating 'the magnificent response which the British people can make to any challenge that threatens

47 Douglas Gillison, Royal Australian Air Force 1939-1942, Australian War Memorial, Canberra, 1962, pp.79-89 is a good guide to the establishment of the EATS. See also McCarthy, A last call, pp.15-23; Air Marshal Sir Richard Williams, These Are Facts, The Autobiography, Australian War Memorial and AGPS, Canberra, 1977, pp.248-9, 267-9; Chris Clark, 'The Empire Air Training Scheme', Australian War Memorial 2003 History Conference - Air War Europe, http://www.awm.gov.au/events/conference/2003/clark.asp.

48 The Herald, 3 March 1940. Melanie Oppenheimer persuasively rebuts the view that apathy was widespread during the first year of the war (All Work No Pay: Australian Civilian Volunteers in War, Ohio Productions, Walcha, 2002, pp.76-122).

49 The Herald, 3 March 1940. 
their future' struck the wrong note. After the Cabinet had attended a special Canberra screening of Alexander Korda's simplistic drama documentary The Lion Has Wings, Menzies would say that it showed 'the Empire moving irresistibly towards supremacy in the air'. But a schoolboy knowledge of recent history, geography, and aviation would have been enough to expose the film's errors, lies, and half-truths. Many adults who saw it in the coming months would echo the bemusement of British audiences at the patronising propaganda. ${ }^{50}$

Strident adversarial politics was unmuted. Unions were fractious. The press showed little patriotic restraint. A concerned Chief of the General Staff, Lieutenant General Ernest Squires, captured the mood from his minister early in December 1939 when the government was on the verge of a decision about pay rates and conditions of service for the Australian Imperial Force and the Militia:

A long talk with Street - the Govt are very anxious about their own position, which is precarious owing to the very unfair attack by the other two parties - in unholy alliance - over the question of the soldier's pay. They are also sore because they feel that their hands have been unduly forced by Casey, in consultation with the Home Govt. ${ }^{51}$

Such economic controls as were imposed brought no great hardships to most of the population. At a time of burgeoning expenditure, interest rates had actually fallen. 'All the really difficult things are unspectacular, and could not produce a cheer from anybody,' the Prime Minister told a sympathetic Commonwealth Institute of Accountants 'smoke social' early in March. He had announced on the same day the expansion of the AIF with a seventh division and 16000 extra troops to make up an army corps. A few weeks later he asked rhetorically: 'What did the people of Australia know of food rationing, of import reductions in any real sense, of reduced standards of living, or of reduced standards of industrial progress?'

A prolonged coal strike from March to May 1940 was a major distraction for the government. And the prospect of petrol rationing was beginning to alarm the minority who owned their own cars. 'The rationing of petrol', a defiant Menzies told a hostile audience in Camberwell, 'is as inevitable as the rising and setting of the sun. ${ }^{52}$ The collapse of France, the entry of Italy into the war, and the evacuation of British forces from Dunkirk in May and June 1940 brought the beginning of an understanding that this was to be a war 'on a grand scale'. Germany had invaded Holland, Belgium, and Luxembourg. Surely she must now

\footnotetext{
50 Notes from the Mass Observation Report, No. 15, Dec 1939, (www.powell-pressburger.org/Reviews/39_ Lion/Lion01.html); Sydney Morning Herald, 5 Dec. 1939; The Lion Has Wings, adapted by John Ware from the film written by Ian Dalrymple, Collins, London, 1940.

51 Squires diary, 2 Dec. 1939, Australian Defence Force Academy (UNSW@ADFA) Library, MS 184 folder 3; Sun News Pictorial, 6 Dec. 1939.

52 The Age, 6 March 1940; Sydney Morning Herald, 21 March, 25 July 1940.
} 
be preparing to invade Britain. The Army Minister held a long Saturday morning conference with Sir Brudenell White, recalled as Chief of the General Staff on the death of Lieutenant General Squires in March, to consider the implications of the German invasion of the Low Countries (which they had learned about from the press). Street then joined Menzies and Air Minister Fairbairn - to all intents and purposes now an inner war cabinet - for a discussion of the disturbing position before the full War Cabinet met..$^{53}$

\section{'A full participation in the war'}

With the Empire in peril, Australia's contribution to the war effort was overdue for re-assessment. The Treasurer, Percy Spender, was expressing frustration with his colleagues at 'piecemeal submissions' and the absence of a 'comprehensive statement of requirements for defence expenditure'. On 3 June 1940 Service departments were instructed to provide the Prime Minister 'within the next 48 hours and in the most concentrated form' information that would 'enable him to answer the statement which is now being given great currency - "that nothing has been done to get Australia ready for a full participation in the war"'".54 Outraged by rumours that he had sent his children to safe haven in the United States, an angry Prime Minister used a speech to the NSW Commercial Travellers' Association to condemn the 'false, miserable allegation' that Australia was not playing her part: 'there must be a silence of the dogs that bark' ${ }^{55}$ War Cabinet discussed a counter-propaganda campaign against false rumour and criticism of war organisation. Menzies asked for a list of instances to cite to editors: 'Failing response will have to put censors into offices. ${ }^{.56}$

By July 1940 the prospect of hostilities with Japan was also real and alarming. As Menzies said in a cable to Stanley Bruce, Australia's High Commissioner in London:

...the necessity to reconstitute our ideas in the light of what we are now told is the inability of Great Britain to send Naval forces to Singapore has occasioned a degree of anxiety among the Members of the Cabinet which can only be increased by any approach to Japan which stops short of being realistic and comprehensive. ${ }^{57}$

\footnotetext{
53 The Mail (Adelaide), 11 May 1940.

54 War Cabinet Minutes, 2 July 1940, NAA: A2673, 373; A1196, 36/501/92.

55 Sydney Morning Herald, 8 July 1940.

56 The full War Cabinet discussed 'spreading of dangerous rumours' including 'PM's children sent to USA', (War Cabinet Notes, vol. 2, 10, 16 July 1940, NAA: A5954, 729/2). Charles Bean had been appointed early in July as liaison officer, by authority of the Prime Minister, to 'keep the editorial staffs of press and broadcasting services prudently informed as to the strategical background of the war' (NAA: A705, 168/1/170). 57 Cablegram, unnumbered, 9 July 1940, Most Secret, NAA: A3196, 1940, 0.4583; cablegram Prime Minister to High Commissioner London, 8 Aug. 1940, NAA: A981, Far East 20b, 1.
} 
The closure of the Burma Road, potential wool sales to Japan, and a decision about the ultimate destination of the Australian seventh division were on a cascading War Cabinet agenda. War with an increasingly bellicose Japan seemed more and more likely. As late as early June general staff officers were expressing alarm at the absence of 'a satisfactory plan for the defence of Australia'. Army Headquarters 'have been somewhat handicapped in planning as Government policy in the past would not permit arrangements to be made against invasion on any scale'.$^{58}$ The United States could not be relied upon to come to Australia's aid. Dick Casey's first personal message from Washington to the Minister for External Affairs, Harry Gullett, had reported a conversation with Franklin Roosevelt in which the President reminded Casey of advice given to Joe Lyons some years earlier. The United States Cabinet, when asked to consider what the US attitude should be to hypothetical attacks on Canada, the South American republics, and Australia and New Zealand, 'believed that the element of distance denoted a declining interest' in Australia. ${ }^{59}$ Casey repeatedly warned from Washington that no appeal other than self-interest would move the Americans. Menzies' entreaty to Roosevelt for a 'magnificent and immortal gesture' of making available all of America's 'financial and material resources' welding the whole English-speaking world at one stroke 'into a brotherhood of world salvation' was plainly an embarrassment. ${ }^{60}$

As war anxieties increased, there were growing calls for greater national unity. Broadcasting to the nation on June 15 Menzies announced new defence plans and appealed to the union movement for co-operation in industrial and manpower mobilisation. A home defence force of 250000 would be trained; government would take unlimited powers to tax, acquire property, direct employers and labour; but there would be no conscription for overseas service. ${ }^{61}$ At a special conference of the Labor Party in Melbourne on June 18 and 19 it was resolved that a National War Council should be established. Menzies seized on this suggestion to propose the formation of a genuine national government. He offered five or possibly six seats in the Cabinet to Labor, including a new Labour ministry. Although he professed not to believe that his own continuation as Prime Minister was an obstacle, he would not, he said, let his occupation of the post stand in the way of agreement. The formal offer was made in a letter on 12 July 1940. It was not until August 6 that John Curtin was able to inform the Prime Minister that a meeting of the Federal Parliamentary Labor Party had

\footnotetext{
58 'Memorandum on employment of A.M.F. for defence of Australia in event of Japanese attack April May 1940', 'Most secret'. AWM: 54 243/6/160.

59 Casey to Sir Henry Gullett, 9 March 1940, copy, Casey MSS, NLA MS 6150/1.

60 Menzies to Casey, cablegram, 14 June 1940, NAA: A3196, O.3829. For the 'ambivalent relationship' between Australia and the USA: Augustine Meaher IV, The Australian Road to Singapore: The Myth of British Betrayal, Australian Scholarly Publishing, North Melbourne, 2010, pp.75-83.

61 Sydney Morning Herald, 16 June 1940.
} 
rejected the proposal. ${ }^{62}$ The Labor leader had already emphatically rejected the notion, floated by Menzies, that the life of Parliament might be extended should 'exigencies' warrant it. Curtin saw no reason why the government should not face the electorate as they were due to do later in the year.

There being no prospect of a national unity government, a fact that Menzies publicly deplored, an election was now clearly in view; or as the Prime Minister put it 'not entirely absent from the government's mind'. There was speculation that he planned 'a lightning aerial tour' of the country. ${ }^{63}$ Frustrated by his isolation from the centre of imperial power, Menzies' mind was actually turning to the idea of taking himself to London where the 'whole conduct' of the war should, he argued, receive 'early consideration by appropriate Empire body so that we may make our plans, intelligently and not merely day by day'. ${ }^{64}$ This had been his ambition since the beginning of the war. In October 1939 he had been forced to deny as a misunderstanding a report in morning papers that he expected to attend a special meeting of the British War Cabinet early in the New Year. The Melbourne Herald stood by the story: there had been "no misunderstanding on the part of the two Herald representatives who saw $\mathrm{Mr}$ Menzies yesterday as to what he said'. No one in the inner circles of government - certainly not the key ministers, Street and Fairbairn - could doubt that the Prime Minister yearned for a bigger stage. ${ }^{65}$

Aware of Australian political developments and concerns about the progress of the war, Winston Churchill sent an eloquent 'IMMEDIATE PERSONAL AND MOST SECRET' message to Menzies on August 11. It followed by a few hours a lengthy 'appreciation' of the situation in the Far East by the British Chiefs of Staff. Point by point Churchill addressed the anxieties he knew were weighing on the Australian government. Britain was trying to avoid war with Japan. Japan was unlikely to declare war unless Germany successfully invaded Britain. If Japan did declare war, Britain would defend Singapore which 'ought to stand a long siege'. The Eastern Mediterranean fleet could be sent to relieve Singapore if it was vital to Australia's safety. If, 'contrary to prudence and self-interest Japan set about invading Australia or New Zealand on a large scale...[Britain would] proceed to your aid sacrificing every interest except only defence position of this island on which all depends'. And so it went on - the RAF was showing 'individual superiority over the enemy', Lord Beaverbrook was making 'astounding' progress in aircraft manufacture, the Navy was getting stronger. If Hitler were to fail to invade and conquer Britain 'before the weather breaks' he

62 Menzies MSS, NLA MS 4936/581/27.

63 Canberra Times, 8 Aug. 1940, p.2.

64 Prime Minister to High Commissioner, London, Cypher Cablegram, 22 July 1940, Secret and Personal, NAA: A3196, 1940, 0.5030; Bruce Papers NAA: M100, July 1940; War Cabinet Minutes, 10 July 1940, NAA: A2673, 401.

65 The Age, The Herald, 6 Oct. 1939. 
would have received his 'first and probably his fatal check... We therefore feel a sober and growing conviction of our power to persevere through the year or two that may be necessary to gain victory.' ${ }^{66}$

What credence could be given to the British Prime Minister's forecasts and personal assurances? Menzies and his colleagues had minuted doubts as early as June about the likelihood that a British 'squadron', let alone a fleet, of capital ships would proceed to Singapore if hostilities began in the Pacific. It was scarcely coincidental that they had decided shortly afterwards to increase the home defence forces to 250 000, a somewhat rag-tag combination of Militia and AIF in training, and Militia reserves, including returned soldiers. ${ }^{67}$ In mid-July the Chiefs of Staff had concluded that the 'strategical situation' had changed considerably for the worse and that defensive plans should assume the 'heaviest scale of attack'. A Joint Planning Committee of the deputy chiefs of each Service had prepared its first report on August 6. Recommending that the Chiefs of Staff should make plans against invasion, they also proposed the establishment of a Central War Room containing a 'combined operation intelligence centre'. ${ }^{68}$ War Cabinet had secretly agreed on 'the desirability of expanding local air defence to greatest degree prac. from whatever sources are available, any adjustment being made in Empire Air Scheme'. The matter was left to the Prime Minister and Service Ministers. ${ }^{69}$

Newspapers were headlining German preparations for an invasion of Britain. With early signs that Germany was mounting a massive aerial offensive on Britain it was imperative that the Australian War Cabinet undertake a comprehensive review. When last asked to consider the 'basis of defence policy' on July 10, the full War Cabinet had concluded that the Navy had all the ships it could obtain or build; the Army had authority to grow to 200 000; any further expansion of the Air Force depended on the supply of aircraft, 'regarding which enquiries are being made'; and the Director-General of Munitions had been told 'the sky is the limit'. Summing up, as the minutes rather tepidly put it, the government decided that:

\footnotetext{
66 Lord Caldecote, U.K. Secretary of State for Dominion Affairs, to Sir Geoffrey Whiskard, U.K. High Commissioner in Australia, Cablegram 262 LONDON, 11 August 1940, 6.48 p.m. rec'd Aug. 12, NAA: A1608, A41/1/1, xii; also in 'Assurance of Assistance to Australia by Mr Churchill. 11/8/40-29/11/42', NAA: A5954, 581/2.

67 NAA: A2671, 133/1940. 12 June 1940; 'Notes of Discussion in War Cabinet Room, Melbourne, Evening of 12th June 1940, Secret', [Present: the PM; Sir Brudenell White, Sir Keith Murdoch, Sir Carl Jess, Essington Lewis, J. B. Brigden, F. G. Shedden], Menzies MSS, NLA MS 4936/40/21; Paul Hasluck, The Government and the People, 1939-1941, Australian War Memorial, Canberra, 1952, p.221.

68 Joint Planning Committee, First Report, 6 Aug. 1940, NAA: A816, 31/301/121.

69 'Ag[endum] 151/1940 Expansion of R.A.F.[sic]', War Cabinet Notes, vol. 2, NAA: A5954, 729/2.
} 
defence preparations...are not to be limited by formula but are to be governed by the most practicable form of defence in each arm of the Services that can be provided from the nature and extent of the resources available. ${ }^{70}$

Briefed with this knowledge, and soon to be informed by qualified Churchillian pledges and optimistic conjectures, ministers and the Chiefs of Staff were to reassemble in Canberra on Tuesday August 13 to discuss once again where and how Australian men and resources should be deployed. For a month they had been deferring a decision on the British request for a division to be sent to Malaya pending the new appreciation of the Far East. The Prime Minister now had the document. Meanwhile, a fresh and relevant issue was the fear of Japanese action against the Netherlands East Indies. In answer to an enquiry from the British, the Dutch government had indicated that it would resist the Japanese. But the British had failed to respond to an understandable Dutch question about whether they could expect British assistance if they were defending themselves against Japanese aggression. The reply was obviously important for Australia. Menzies wanted to bring the matter before the Cabinet at its next meeting and on August 8 sought urgent advice about British intentions. The answer was enveloped in equivocation. ${ }^{71}$

Parliament had sat in the second week of August. It would be sitting again on Wednesday August 14. Since the beginning of the war the Cabinet and War Cabinet had been on a relentless schedule of meetings - once every two-anda-half days, the Canberra Times reported on August 5. From its formation in September 1939 to the end of July 1940, a government spokesman said, the War Cabinet alone had sat 70 times - 46 in Melbourne, 20 in Canberra, and four in Sydney. (He could have added that they had met in Brisbane three days earlier and that there was to be a two-day Cabinet meeting in Melbourne on August 6-7). Now once again members of the House of Representatives, senators, ministers, and their staffs, senior public servants, and defence chiefs would converge on the national capital from around the country. Cabinet would meet on August 13 before facing the Opposition in Parliament the next day. The morning papers on August 12 carried the news that, following 'a searching survey by legal officers of the constitutional position', ministerial plans for a federal election had been 'maturing'. An election was predicted for September 14. If the international situation made it necessary to postpone polling day after Parliament had been dissolved, legal authorities had advised that government could continue by executive authority during an emergency. ${ }^{72}$

70 War Cabinet Minutes, Agendum 403, 10 July 1940, NAA: A2673, 291.

71 War Cabinet Minutes, Agenda 426, 442, 23 July, 2 Aug. 1940, NAA: A2673; Prime Minister to High Commissioner, secret cable (recyphered) 8 Aug. 1940, Bruce Papers, NAA: M100, Aug. 1940; Sec. of State for Dominion Affairs to High Commissioner in Australia, 11 Aug. 1940 (rec'd Aug 12), NAA: A1608, A41/1/1, xii. 72 The Argus, 12 Aug. 2012. 
From Melbourne, the nerve centre of the military establishment, the RAAF would provide a designated aircraft to convey the Minister for Air, Jim Fairbairn, and five other colleagues or associates of his choice to Canberra: Army Minister and close friend Geoff Street; senior Cabinet member Sir Harry Gullett; the Chief of the General Staff, Sir Brudenell White; White's right-hand man, Lieutenant Colonel Frank Thornthwaite; and Fairbairn's private secretary, Dick Elford. One specially fitted Lockheed Hudson light bomber, two pilots, two airmen, and six important passengers. A simple flight from Essendon aerodrome to Canberra. This is their story. 



\section{Part 2 The Journeys}





\section{A crew assembles: Charlie Crosdale and Jack Palmer}

It was Squadron Leader A. D. Carey's job. The Station Administrative Officer at RAAF Station Laverton initiated preparations on Friday, 9 August 1940 for a flight on Tuesday, August 13 to 'Convey Minister for Air and five other passengers to Canberra A.C.T.' Alfred Carey's Flying Operation Instruction No. 111 advised that the aircraft would be one of No. 2 Squadron's latest acquisitions, a Lockheed Hudson bomber, A16-97. The captain and crew for the flight to Canberra were to be detailed by No. 2 Squadron's commanding officer. When their delivery of important people to the capital was completed the intention was that, in the absence of alternative orders, A16-97 should return to Laverton, empty save for ballast and its crew of four. ${ }^{1}$

A16-97 was one of the second batch of 50 Hudsons delivered to the RAAF from the Lockheed plant in California. Of the 100 Hudsons in the country at the end of July 1940 two had already been 'written off by conversion' as a result of crashes. One was undergoing 'major repair owing to crash', and another two had been 'robbed of various parts'. The last four machines in the second group were fitted with seven passenger seats as well as dual controls. These specially fitted Hudsons were to be dispersed to bases around the country. They would form part of a Hudson squadron reserve at Richmond, Pearce, Darwin, and Laverton, and be available to transport 'essential maintenance stores and personnel to advanced operational bases'. The Air Board was also hopeful that the modified machines might provide the 'much-felt need' for wireless telegraphy school aircraft. When required, and the Minister for Air saw this as an essential function, they would take members of the Cabinet and their entourages wherever and whenever they were needed. Ministerial traffic between Melbourne and Canberra was expected to be greatest. A16-97, the first of the four Hudsons to be furnished with passenger accommodation, was therefore allocated to No. 2 Squadron at Laverton. Received at 1 Aircraft Depot on 20 June 1940 along with eight others, A16-97 was assembled and tested over the next six weeks. It was a sound machine. There was plenty of room for the six passengers in what was the fastest and most comfortable aeroplane the RAAF could then offer. ${ }^{2}$

\footnotetext{
1 NAA: Al1094, 5/6/Air Part B; copy attached to 'Report No. 4 of August 1940: Report of Accident to Lockheed Hudson Aircraft A16-97, Reference Air Accident Report No. 39 of 1940/41', NAA: A705, 32/10/2729. 2 'Re-arming with Hudson Aircraft (Policy)', NAA A1196, 1/501/317. Much of the information in this paragraph is conveniently assembled and documented in David Vincent, The RAAF Hudson Story, Book Two, 2010, Vincent Aviation Publications, Highbury, 2010, pp.246-7.
} 
No. 2 Squadron was one of the original Australian Flying Corps and RAAF squadrons. Its distinguished past remembered through the lean depression years, it was re-formed as a Citizen Air Force (CAF) squadron at Laverton in May 1937 under the command of Squadron Leader J. H. Summers. Two Hawker Demon aircraft, three officers, and 38 airmen were its starting complement. ${ }^{3}$ Johnny Summers was promoted Wing Commander in February 1938 and was succeeded in March 1939 by Wing Commander Alan Charlesworth. The unit had been designated a general reconnaissance squadron in which extended courses in navigation training could be given. By then there were seven officers, three sergeant pilots, and 70 other ranks. The squadron was being re-equipped with the new British maritime reconnaissance aircraft, the Avro Anson. A twinengine monoplane, the first in RAAF service, with an enclosed cockpit, also a first, the Anson had several unique features. Some had dual controls. All had a cumbersome hand-wound retractable undercarriage. And, as operations over Bass Strait soon established, its range was limited - not least because of maintenance shortcomings resulting from administrative parsimony. ${ }^{4}$

\section{Fred Thomas's squadron}

Three months after war broke out Alan Charlesworth was replaced by Squadron Leader Fred Thomas, a 33-year-old former CAF and Reserve officer. Thomas had been a Melbourne University accountancy student who had served two years in the Melbourne University Regiment when he enlisted as an Air Force cadet in 1926. Taking readily to flying, Thomas topped the course, just beating another bright student, Ray Garrett, whom he was delighted to find at No. 2 Squadron as a flight lieutenant recalled to active duty from his own successful photographic business at the outbreak of war. Thomas's steady advance in the Service had been matched in his civilian life as he assumed managerial roles in a flourishing family company, W. C. Thomas \& Sons Pty Ltd, grain merchants and flour millers. The Thomases had been prominent in Melbourne commercial and social life for several generations. Fred, smart and well-connected, standing over five feet ten inches tall and with what one of his seniors, Harry Cobby, was later to call 'regimental bearing', was appointed in 1934 honorary ADC to the recently arrived Governor of Victoria, Lord Huntingfield. Two years later, the link with Huntingfield was extended when the Governor became Honorary Commodore

\footnotetext{
3 Operations Record Book, No. 2 (General Reconnaissance) Squadron, NAA: A9186/5; Richard S. Gunter, 'No. 2 (General Reconnaissance) Squadron Royal Australian Air Force: A Brief History', RAAF War History Section Albert Park Barracks, Jan. 1950 (cyclostyled document furnished by the RAAF Historical Branch, Nov. 1979); 'History of No. 2 Squadron Royal Australian Air Force 1916-1952', RAAF Historical Section, n.d. 4 Stewart Wilson, Anson, Hudson and Sunderland in Australian Service, Aerospace Publications, Weston Creek ACT, 1992, pp.25-7; ACdre Sir Raymond Garrett, taped reminiscences, transcribed and edited by Anne Kelly, Garrett MSS; A. J. Jackson, Avro Aircraft Since 1908, Putnam, London, 1965, pp.319-23.
} 
of the new No. 21 Squadron to which Thomas, a flight lieutenant since 1932, was posted. Thomas was then the most senior flight lieutenant in the CAF; but the Air Board baulked at the Air Member for Personnel's recommendation that he be promoted to squadron leader. Officers of equal rank, but higher seniority in the Permanent Force, were awaiting promotion. As a compromise he was granted honorary rank as squadron leader, with no extra pay. In what appears to have been a transient enthusiasm, Thomas applied to join the newly formed $2^{\text {nd }}$ Light Tank Company of the Australian Tank Corps in March 1939 three weeks after transferring to the RAAF Reserve and being promoted temporary squadron leader. ${ }^{5}$

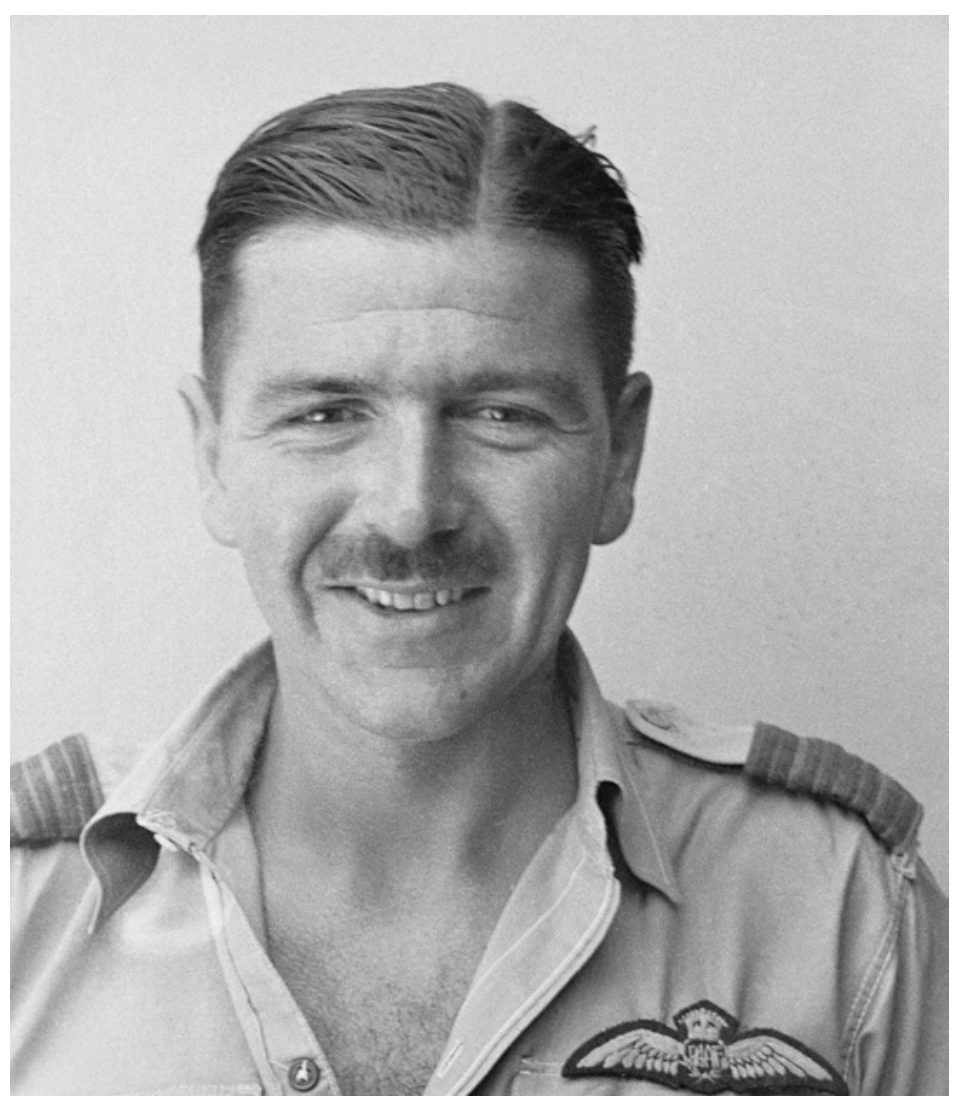

\section{Fred Thomas, confident in command}

(From National Archives of Australia, A9300 Thomas FW)

By mid-1940, under Fred Thomas's leadership, No. 2 Squadron's 10 already obsolescent Ansons were mainly engaged in reconnaissance, navigation training, searches for enemy raiders, and exercises in co-operation with the Navy,

5 NAA: A9300, THOMAS FW. 
operations which were being taken over by the superior Lockheed Hudsons as they were progressively delivered. Like other similarly equipped units No. 2 Squadron was receiving its allotment of Hudsons at intervals to allow for the maintenance of operational efficiency with Ansons while pilots were being converted to the new type. ${ }^{6}$ Dispersing the new aircraft around the country, together with at least one instructor for each unit, using the limited number of trained pilots without simultaneously crippling the pilot conversion program, had challenged headquarters logistical ingenuity. ${ }^{7}$

By the time A16-97 was assigned to them on 2 August 1940 Fred Thomas's squadron had 11 Hudsons, seven of them delivered within the last month. ${ }^{8}$ A secret 'Warstand' report on August 1 had noted that one of the Hudsons was 'unserviceable'. If required as reinforcements, five aircraft could 'move at short notice' with second pilots, W/T operator, and two air gunners. But lack of armament equipment and spares would render them 'operationally unserviceable'. ${ }^{9}$ Most of the squadron's Ansons had been returned for use in training establishments. One instructor, Flight Lieutenant John P. Ryland, had been assigned to lead the squadron's conversion, starting with the $\mathrm{CO}$ and the flight commanders. As other Hudson squadrons were being sent for duty in Darwin and Sembawang, Singapore, Fred Thomas could reasonably aspire to lead his men into more hazardous zones. For the time being, however, as the Director of Operations and Intelligence had pointed out to a staff conference at the end of April, Hudsons lacking guns and bomb racks could be regarded only as general reconnaissance aircraft, not bombers. ${ }^{10}$ But the unpleasant inoculations for typhoid, smallpox, and tetanus that No. 2 Squadron personnel were all receiving were the promise of action to come. Meanwhile, it was a life of routine operations and training at home.

During the May sittings of Parliament, No. 8 Squadron in Canberra had used DC-3s to provide a weekly shuttle to and from Melbourne, leaving Laverton at 8.15 a.m. each Tuesday morning and returning on Fridays. These arrangements had been requested by the Minister for Air, who evidently expected that a similar service would be provided when Parliament resumed in August. As No. 8 Squadron was preparing to move to Singapore, and the chartered DC3s it had been using had been returned to their owners, the only operational squadron with a suitable aircraft for a passenger flight to Canberra was No. 2 . With a gathering of dignitaries to be carried, the Service would want to ensure a smoothly professional trip. In the previous two months, No. 2 Squadron had

6 DOI (GpCpt. T. A. Swinbourne) for CAS to HQ Southern and Central Areas and RAAF Stations Darwin and Pearce, 'Rearming with Hudsons - Operational Efficiency', 15 June 1940, NAA: A1196, 1/501/317.

7 NAA: A1196,1/501/317.

8 Ron Cuskelly to $\mathrm{CH}, 15$ July 1978.

9 'Service Training Report Southern Area', NAA: A1196, 37/501/20 Pt 1.

10 'Report of Staff Conference No. 32...', 30 April 1940, NAA: AA1977/635. 
transported the Chief of the Air Staff to Sydney, Cambridge in Tasmania, and Archerfield in Queensland; and the Air Officer Commanding had been flown to Parafield in South Australia. On June 13 and 14 the Air Minister and the Chief of the Air Staff, Sir Charles Burnett, had been flown from Laverton to and from Mascot. In the first week of August, the new Hudson A16-97 had been taken to Canberra by Flying Officer W. P. Heath with five passengers, one of them the Air Minister. ${ }^{11}$ Bill Heath was an experienced commercial flyer. Before the war he had served five years in the CAF as an airman pilot (sergeant) while flying for Australian National Airways. Appointed a temporary flying officer at the outbreak of war, he had been mustered for General Duties with No. 1 Squadron before joining No. 2 Squadron on 1 June $1940 .{ }^{12}$ Heath would have seemed a natural choice for the next flight to Canberra. But there were other possibilities.

At the end of July there were, according to the No. 2 Squadron Operations Record Book monthly report, 'five captains fully operational' on the recently arrived Hudson aircraft. ${ }^{13}$ Ensuring that senior pilots could handle the new aircraft was a high priority. The $\mathrm{CO}$ and the three flight commanders, Flight Lieutenants Bob Hitchcock, Ray Garrett, and Jack Ryland, had all been converted. Ryland was the first, instructed at Richmond in February and March by Lockheed's field service representative, L. D. 'Swede' Parker. Garrett had also spent several eventful weeks with the respected company test pilot Parker at Richmond and had just completed his training under Ryland at Laverton, passing his final 'crew' and 'full load' tests on August 3. On August 6, Garrett had flown Air Commodore Harry Wrigley and a crew of five to Adelaide, returning on August 8. Although he had less than 57 hours as a Hudson first pilot, Garrett's ability and long commercial flying record made him a suitable man to take the flight to Canberra. But his expertise as a Hudson instructor was of more value. Almost every day since July 16 he had been taking a group of pilots up for training in airmanship and emergency procedures. ${ }^{14}$

Bill Heath was a more likely choice for the Canberra assignment. He had a great deal of experience as an airline captain. In 1939 he had been detailed to teach RAAF pilots to fly DC-2s. Though relatively junior in rank, Heath was mature (approaching his thirty-first birthday) and had ferried the group including the Minister for Air to Canberra the previous week. ${ }^{15}$ He had accompanied Ryland in A16-32 when the Chief of the Air Staff was taken to Tasmania on July 17. But, even more than Garrett, he had been occupied since his arrival at No. 2 Squadron in

11 Flying Operation Instruction, [106], 5 Aug. 1940, signed by S/Ldr Thomas, NAA: A11094, 5/6/AIR PART B.

12 NAA: A9300, HEATH WP.

13 No. 2 Squadron Operations Record Book, 1 Aug. 1940, NAA: A1980, 599. In fact four were fully trained as captains; the fifth, 90 per cent trained, was expected to complete conversion on Aug. 4. ('Service Training Report — Southern Area Pt 1', NAA: A1196, 37/501/20 Pt 1).

14 W. R. Garrett, Flying Log Book, courtesy of Anne Kelly.

15 Vincent, The RAAF Hudson Story, Book Two, p.248, referring to an unnamed 'junior officer', overlooks Heath's extensive experience as a commercial airline pilot. 
putting new pilots through their paces. And since August 3, when he too completed his Hudson conversion with Ryland on the dual-control A16-6 (the first Hudson to be assembled in Australia), he had spent almost every day in second-pilot training in Hudsons working through the airmanship syllabus and occasionally testing engines, instructing on full load flying and use of wireless telegraphy.

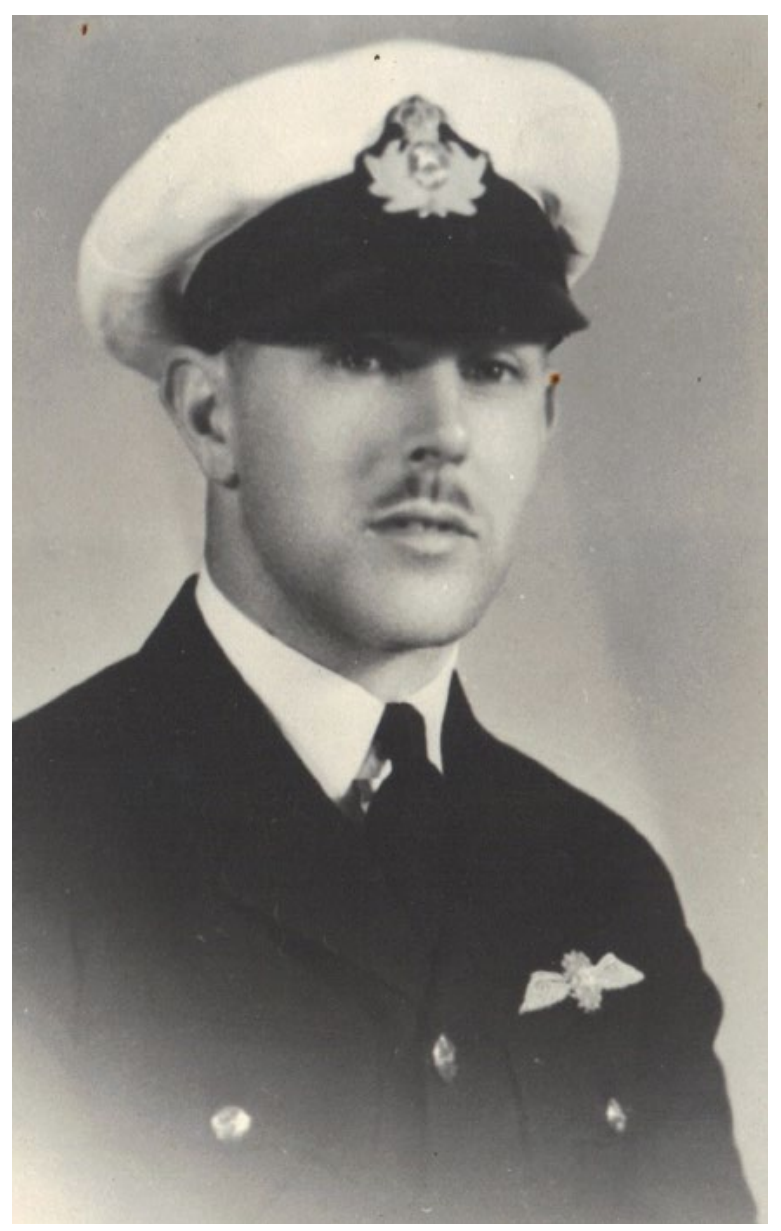

\section{Bill Heath in Australian National Airways uniform}

(Courtesy of Daryl Heath)

'A very able pilot was detailed... but he went sick at the last moment,' Sir George Jones recalled. ${ }^{16}$ Jones, then Director of Training, knew that the Laverton base was in the grip of an outbreak of a debilitating illness - described as a cross between influenza and bronchitis - that was frazzling doctors. Flight Lieutenant Peter Delamothe, commanding the recently opened 200-bed RAAF

16 AM Sir George Jones, interview, 14 Sept. 1977. 
hospital, with only four nurses to assist, had his hands full. ${ }^{17}$ Heath's absence on 'special leave' without pay 'in hospital or sick quarters or sick at home' for 82 days between mid-March and the end of May could indicate fragile health. He is recorded as relinquishing his commission, only to have it re-instated a couple of months later. ${ }^{18}$ But if anyone was too ill to fly that day it was not Heath. ${ }^{19}$ His log book records that he flew to Mount Gambier with Pilot Officer Bill White and a crew of four, returning the next day. Garrett, Heath's flight commander, was also detailed to fly to Mount Gambier and Adelaide on August $13 .{ }^{20}$ Ryland was not ill. And he was the senior man, apart from the commanding officer, Fred Thomas, who had less Hudson flying experience. Ryland had flown the Chief of the Air Staff Sir Charles Burnett around the country several times in recent months. He had taken both Burnett and Jim Fairbairn to Mascot on June 13 in A16-20 and returned with the Air Minister the next day in another Hudson, A16-21. Nevertheless, for Ryland the conversion of recently arrived pilots was his primary role, a far more effective use of his time than a routine transport assignment. In fact, since spending a day with Burnett flying to Archerfield and Mascot and back on August 2, Ryland had spent most of the next 10 days with a very young and venturesome Pilot Officer, Wilbur Wackett, son of the head of the Commonwealth Aircraft Corporation Lawrence Wackett, taking him through his conversion course. On August 13 he and Wackett were on a threehour 'seaward patrol' to Mount Gambier, returning the following day. ${ }^{21}$

Whoever was actually available, on the afternoon of Monday, August 12 the task was assigned to Bob Hitchcock, commander of No. 2 Squadron's A Flight. Though he would only have learned it after the event, George Jones might have been right in remembering that 'the only other man available was Hitchcock' ${ }^{22}$ The selection, forced though it may have been, was the responsibility of Fred Thomas. Thomas, when an honorary squadron leader, had first known the then Flying Officer Hitchcock in 1938 as his flight commander in No. 21 Squadron. Hitchcock had completed his own conversion course on the Hudson under the instruction of Ryland three weeks earlier. Thomas had been in the group with him along with Bill Heath, Jack Sharp, and Phil Howson who had just been

17 Joan Delamothe and Brian Stevenson (ed. Tony Delamothe), The Delamothe Story, Boolarong Publications, Brisbane, 1989, p.40; Gay Halstead, Story of the RAAF Nursing Service 1940-1990, Nungurner Press, Metung, 1994, pp.3-4. Sir Hubert Opperman recalled arriving at 'cold wet Laverton' that August, and encountering 'a wide spectrum of human behaviour' among the drill instructors; while many strict but just applicants were trained and appointed, there also slipped through unwanted flotsam and jetsam from guard house and kitchen'. Humiliation and hazing, 'diabolical perversity' by swaggering bullies, was not uncommon. (H. F. Opperman, Pedals, Politics and People, Haldane Publishing Co, Sydney, 1977, Ch. XIII).

18 For Heath's background: NAA: A9300, HEATH WP.

19 By Sept. 1, one of the squadron's captains had been 'placed medically unfit'. (NAA: A1196, 37/501/20 Pt 1).

20 W. P. Heath, Flying Log Book, Aug. 1940, Heath Papers, courtesy of Daryl Heath; Garrett's Flying Log Book, Aug 1940.

21 J. P. Ryland, Flying Log Book, Aug. 1940, Ryland Papers, NLA MS 5020 Box 1.

22 Thomas, Service Court of Inquiry, p.14, 13 Aug. 1940, NAA: A705, 3210/2729; AM Sir George Jones, interview, 14 Sept. 1977. 
promoted to temporary flight lieutenant at the age of 21 and was scheduled to leave No. 2 Squadron for No. 6 Squadron in the first week of July. The last member of the cohort was A. B. 'Tich' McFarlane who had graduated as a CAF pilot officer in No. 21 Squadron in December 1937 and was now completing a law degree. During the conversion course Hitchcock had nearly 70 hours experience in the type, 49 of them solo practice, before taking the crew test on July $21 .^{23}$ Since then he had flown Hudsons almost every day, seven different aircraft, passing on what he knew, and testing equipment. He was, 'Tich' McFarlane remembered, 'an average pilot who flew by the book' ${ }^{24}$

\section{The chosen}

With Hitchcock detailed by his $\mathrm{CO}$ as first pilot, and no passengers to bring back to Melbourne, another return path was suggested. Next to his fellow flight commander Ray Garrett, a pioneer of aerial photography, Hitchcock was now the squadron's senior photographic expert (the former squadron commander Alan Charlesworth, with whom neither Garrett nor Hitchcock had ever been close, had been trained in the RAF aerial photography school). Hitchcock and his crew could go on patrol for two days and undertake a photographic survey of Woodside, South Australia. Such a survey would no doubt have been welcomed by the General Reconnaissance School at Laverton where, according to one of their instructors, they 'had to use a map of South Australia made on some strange projection for the agriculture department, which showed stock routes and suitable waterholes for cattle'.$^{25}$

An extended period in the air would also give whoever was chosen to sit in the second pilot's seat of the Hudson an excellent opportunity to become familiar with the aeroplane. So, early on Monday, August 12, a place was reserved for LAC Frank Jefferies, the squadron photographer. Jefferies had flown with Hitchcock several times in Hudsons on similar missions in recent weeks. On August 1 they had been up twice in A16-34 doing oblique and vertical photography. They went up together again on the next two days in A16-9 and A16-80 as well as A16-34. On August 7 they went up twice. But Jefferies, whose twentyeighth birthday was just three days away, learned later on August 12 that the

23 Ryland, Service Court of Inquiry, p.37, NAA: A705, 32/10/2739; NAA: A9845, 318/123.

24 GpCpt. A. B. McFarlane, interview, 18 April 1978.

25 Brett Hilder, Navigator in the South Seas, Percival Marshall \& Co., London, 1961, p. 85. 
photographic task for the next day had been re-assigned. He was to yield his berth to Dick Elford, James Fairbairn's private secretary. ${ }^{26}$ The minister wanted his principal assistant close by on the trip to Canberra.

In the normal course, Hitchcock's crew would be a second pilot and a wireless operator; a fitter might be added. For the airmen, being rostered to fly was usually a welcome duty; it brought them an additional two shillings a day in crew pay and the chance to get away from the routine of the squadron. The choice of wireless operator and fitter was straightforward, especially the latter, as each new aircraft became part of a particular ground crew's family. Among No. 2 Squadron's other ranks were experienced airmen with pre-war service, like Jack Palmer as well as recently enlisted men like Charles Crosdale. The wireless operator, Corporal John Frederick Palmer (Service number 2130), was born in Maryborough in Victoria, where his father was a farmer. Frederick and Mabel Palmer had moved to the Melbourne suburb of Malvern by the time Jack's two younger brothers, Max and Laurie, were born in 1914 and 1915. Jack was in his mid-20s, and had previously spent 18 months as a private in the AMF, when he enlisted in the RAAF for six years in April 1936 as an ACl aircraft hand general. He had been encouraged to join by a friend already in the Service. Ron Curtain, a radio telegraphist, urged Palmer to apply for the wireless telegraphy operators' course. By coincidence, Curtain was a good friend of Bob Hitchcock, having known him since his early days in the ranks. ${ }^{27}$

Jack Palmer had been educated at Coburg Primary and Coburg High School. For eight years he had been employed as a 'letter carrier' in the Postmaster General's Department. Striving to improve his prospects he became a salesman, first with the clothing manufacturers Thompson F. Davies of Flinders Lane and, in the year before he enlisted, with the Standard Insurance Company of Market Street. Having decided to join up, for 12 months he attended night classes in wireless at Melbourne Technical College. Privately he was practising Morse and studying the standard textbook, The Admiralty Handbook of Wireless Telegraphy 1931. He impressed the recruiters and was set on the path he had chosen. In July 1937, having obtained a 76 per cent pass in No. $3 \mathrm{~W} / \mathrm{T}$ course, he was re-mustered and posted to No. 21 Squadron at Laverton depot as a freshly minted wireless operator. 'Average, should make a good operator,' his commanding officer's report remarked, concluding that he was not suitable to be an instructor. Tradetested for the rank of LAC the following month, he scored an 82 per cent pass. 'Appears to have studied the work,' was the bemusing assessment signed by Wing Commander A. W. 'Spud' Murphy, President of the Trade Test Board.

26 John Bennett, Highest Traditions: The History of No 2 Squadron, RAAF, Australian Government Publishing Service [AGPS], Canberra, 1995, p.112, citing Jefferies' written memoir. It had been known since Aug. 9 that there were to be six passengers but it seems to have been hoped until late on Aug. 12 that there would be a vacant seat for Jefferies.

27 Sqn Ldr Ron Curtain to CH, 1 Dec. 1982. 
Palmer had married Ron Curtain's sister Sheila at St Margaret Mary's Roman Catholic Church, Brunswick North, in May 1939. Jack and Sheila, now living in Gardiner Parade, Glen Iris, had first met four years earlier when he was the local postman and friendly with Ron and her other brothers. Sheila was the eighth of nine surviving children of John and Ellen Curtain. Jack Curtain, a nononsense stolid senior police constable in Donald in the Wimmera at the time of Sheila's birth, had retired on health grounds in 1915. His last posting had been as the sergeant in Coburg and there the family stayed. Jack's oldest son, William Basil 'Bas', after defying his anti-British parents and volunteering for the Royal Australian Navy as soon as he turned twenty-one, had continued to serve in the fleet reserve after the war as an engine room artificer. When his time expired he had followed his father into the Victoria Police. Like many of their co-religionists, Jack and Bas Curtain found the police force a congenial employer for Roman Catholics.

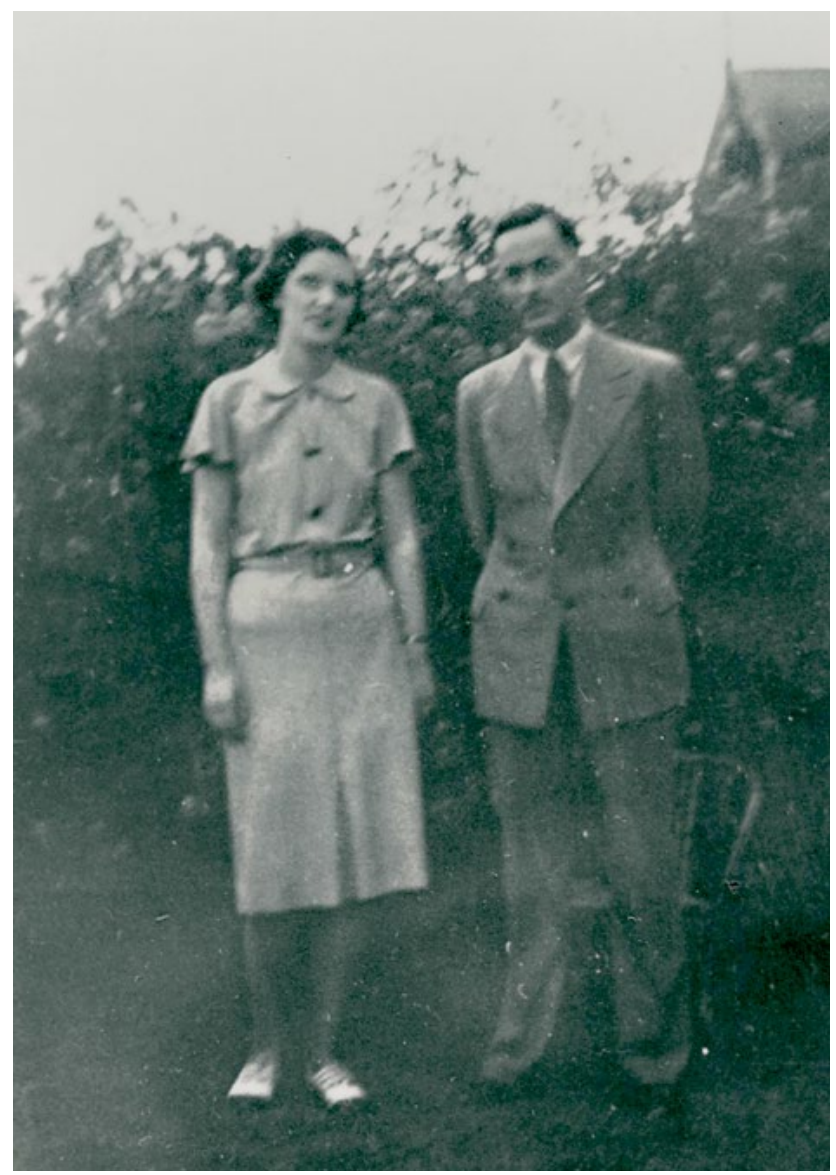

Jack Palmer and Sheila Curtain, December 1938

(Courtesy of John Foley and S/Ldr J. R Curtain) 
In a family that traced its history from the Irish famine in Limerick to the Ballarat goldfields and the Eureka rebellion, Sheila Curtain and her siblings were enveloped in fiercely anti-monarchist sentiment at home. Their father, though Australian born, had an unmistakeable brogue. Her brother Bas seemed destined to be caught up in the 1923 Melbourne police strike. Though he stayed home in bed during the most violent confrontations, he was one of the hundreds expelled from the force. ${ }^{28} \mathrm{~A}$ marked man, there was a note on his file that he was never to be re-employed. As Jack Curtain's health continued to deteriorate, the younger children, especially Sheila, increasingly looked to their older brothers for guidance and support. The second son, Cyril, had become a successful country solicitor, and eventually a partner in the Melbourne legal firm of McInerny, Williams, and Curtain. But respectable as his professional life was, Cyril had married a committed Irish republican, Helen Butler. His wife's brothers had been in the famous St Patrick's Day march in 1920 when Archbishop Mannix was escorted by 14 Victoria Cross winners mounted on grey chargers. ${ }^{29}$ Cyril and Helen Curtain's house at 17 Howard Street, Kew, a stone's throw from Robert and Pattie Menzies, was a salon for visiting Irish celebrities, Catholic luminaries, and clergy.

It would not have taken long for Jack Palmer to be immersed in the republican passions of the family that was embracing him. The Christian names of two of Sheila's brothers, Daniel Mannix Curtain, born in 1917, and Robert Emmet (who died as an infant the year before), bespoke their parents' fervent Irish nationalism. Helen Curtain and her sister Rita $\mathrm{O}^{\prime}$ Brien thought nothing of embarrassing their lawyer husbands and less resolute cousins and nieces by remaining firmly seated in cinemas when the national anthem was played. Sheila Curtain herself, known as 'Bub' even after younger children arrived, was tall, attractive, and sociable. She had passed the Merit Certificate and at thirteen began work as a junior shop assistant at the Mutual Store in Flinders Street. Later she moved to the lingerie department of Buckley and Nunn, the fashionable emporium next to Myers in Bourke Street. By 1940 she had found a job with the Air Force in Collins St as a comptometer operator preparing RAAF wages and pay records.

Sheila was an independent young woman, especially popular with her nieces who vowed to emulate her elegant smoking as soon as they were old enough to be seen with cigarettes. Protected though she was by a phalanx of brothers, Sheila somehow contrived to see Jack at church dances and weekend trysts in the city. Romance blossomed. It was a love match. Fortunately, the tall, rangy,

28 Gavin Brown \& Robert Haldane, Days of Violence: The 1923 police strike in Melbourne, Hybrid Publishers, Melbourne, 1998, p.175.

29 AWM: POI383.018 for a composite photograph of the VC winners, the Archbishop, and John Wren, the reputed organiser of the ride. 
quietly spoken Palmer impressed all of the Curtains with his sincerity. If their sister loved Jack Palmer, that was good enough for the Curtain brothers. But his willingness to 'take instruction' and convert from the Anglican faith to his fiancée's Catholicism undoubtedly helped his cause. Sheila and Jack would marry proudly in front of the altar, not as a mixed-marriage couple at the side or behind the altar, or even more ignominiously in the sacristy or an adjacent presbytery. ${ }^{30}$

Jack Palmer's prospective brother-in-law, Bas Curtain, a fitter and turner whose skills were at a premium, had joined the Air Force in 1924. He had previously been sacked from two jobs when his 'striking' past as a plain-clothes policeman had been discovered. Afraid that the same thing would happen with the RAAF, he was assured by Squadron Leader Frank McNamara VC, his new CO, that his involuntary severance from the police force would not be held against him. 'Dilb' McNamara was well aware of Curtain's record. He shared the Curtains' Irish Catholic heritage but as a serving officer he had refused to take part in the VCs' escort to Dr Mannix in 1920. A notoriously bad pilot, McNamara had his own reasons for encouraging the young man. It was said that when he appeared on the tarmac with a set of flying goggles 'mechanics disappeared like snowflakes in the Sahara'. ${ }^{31}$ A mechanic who owed him a favour was more than welcome. Ron Curtain had followed his older brother into the RAAF four years later, accepted into the first wireless operators' course.

The Curtain brothers were close to their sister's fiancé. They could well have known of the single blip on Jack Palmer's General Conduct Sheet - five days confined to barracks, awarded by Squadron Leader Charles Eaton for 'conduct to the prejudice of good order \& Air Force discipline'. Evidently, Palmer had not appeared one morning in April 1938 'at his place of parade appointed by his $\mathrm{CO}^{\prime}$ and 'failed to open W/T watch with Richmond' ${ }^{32}$ As a W/T operator Palmer's duties were not confined to operating and maintaining aircraft radio equipment. He was required to run signals office watches on ground point-topoint links and watches with aircraft, and maintaining and tuning transmitters at transmitting stations. He could even be asked to work on a telephone switchboard at weekends. ${ }^{33}$ There were still a very small number of qualified

\footnotetext{
30 Siobhan McHugh, 'Not in front of the altar: Mixed marriages and sectarian tensions between Catholics and Protestants in pre-multicultural Australia', History Australia, vol. 6, no. 2, Aug. 2009, DOI: 10.2104/ ha090042.

31 C. D. Coulthard-Clark, McNamara VC: a hero's dilemma, Air Power Studies Centre, Fairbairn ACT, 1997, pp.60, 66 .

32 Palmer's Service record, NAA: A9301, 2130/30,32,45,48; The Argus, 14 Aug. 1940; H. J. Manning, 'Air Disaster at Canberra', Stand-To, Jan.-Feb. 1962, pp.6-22; Coronial papers, NAA: A1378, P8903; biographical notes about his mother and the Curtain family kindly furnished by John Foley, 23 and 27 July 2009; reminiscences of WCdr W. 'Bas' Curtain, 1977: and Curtain's memories on www.shermanjungle.com/_curtain_ website/williambasil/index.htm.

33 GpCpt E. R. Hall (Retd.), A Saga of Achievement, Bonall Publishing, Box Hill North, 1978, pp.45-56.
} 
operators; so a failure to turn up on time could have significant consequences. ${ }^{34}$ Apart from this one episode, the result perhaps of an entirely understandable boisterous night out away from home, his sheet was clean. By the time of his marriage Palmer was assimilated into the Curtain family; they were all what Father Ken Morrison, then the Roman Catholic chaplain at Laverton, called 'practical Catholics'. ${ }^{35}$

Finding Jack Palmer on the same plane as Bob Hitchcock was no surprise. They had served together in No. 21 Squadron, with Palmer frequently accompanying Hitchcock as junior pilots were put through their 'airmanship' paces on Ansons. In October and November 1938 they had both been part of a team that flew to Richmond, Brisbane, Charleville, Cloncurry, and Darwin to meet the much publicised RAF long-range development flight. In the 'sociable seating arrangement' of the front end of an Anson, the pilot's seat was not separated from the rest of the crew; and the fuel gauges were positioned closer to the wireless operator than the pilot. As the historian of the aircraft cockpit puts it:

The pilot could check these gauges only by craning round to the right. Near the end of a long flight, when fuel was at a premium, the fuel gauge selector button would be surreptitiously pressed by the anxious wireless operator or even by the navigator. Peripheral vision being very acute, the pilot was usually made aware of his crew's concerns. ${ }^{36}$

Hitchcock and his wireless operator saw eye to eye. In October the following year, Palmer was promoted LAC (W/T Op) and attached to Station HQ at Laverton. There he was one of a team responsible for manning the recently installed Marconi-Adcock direction-finding station. In addition to guiding Air Force machines, the Laverton DF station passed bearings to the civil airliners flying into Essendon at night from Adelaide and Sydney. They assisted the RAAF aircraft carrying out reconnaissance and, as fears of German raiders grew, convoy protection over Bass Strait. Five months after war was declared - and now a corporal - Palmer was posted to No. 2 Squadron. On 22 July 1940 he was one of 11 men who went up with Hitchcock to practise full-load flying in Hudson A16-32. Two days later he flew with Hitchcock to Richmond and Canberra. They returned from Canberra to Laverton via Wagga on the same day. On August 10, Jack Palmer celebrated his twenty-ninth birthday.

\footnotetext{
34 At the beginning of Aug. 1940, No. 2 Squadron reported 11 fully trained W/T operators available for crew work; a month later they admitted that after work on operations three required more experience (NAA: A1196, 37/501/20 Pt 1).

35 Msgnr K. R. Morrison to CH, 6 June 1983. I am grateful to John Foley for information about the Curtain family; and to the family history website www.shermanjungle.com/_curtain_website.

36 L. F. E. Coombs, The Aircraft Cockpit: from stick-and-string to fly-by-wire, Patrick Stephens Ltd, Wellingborough, 1990, pp.122-3.
} 


\section{'We were moving Mum'}

Joining Palmer on the morning of 13 August 1940 was another 29-year-old, Aircraftman Charles Joseph Crosdale (Service number 6673), mustered as aircraft hand mechanic. Vital parts of the nearly pristine A16-97 were in Crosdale's care, although on this trip he was as likely to spend time loading and unloading ballast, emptying the Elsan dry chemical toilet, perhaps serving coffee and sandwiches and collecting sick bags, as assisting with re-fuelling, servicing, and minor repairs. Born in Merriwa, in the Upper Hunter Valley of New South Wales, in November 1910, Charlie Crosdale was the second-oldest in a Catholic family of 17 children. He was to grow up sturdily amid a forest of relatives. His paternal grandfather, twice married, had 15 children, Charlie's father George being the eldest. George Crosdale had been a coal miner at the Maitland Main Colliery until his retirement. Charlie and his older brother Sidney both followed their father into the mine when they turned 16.

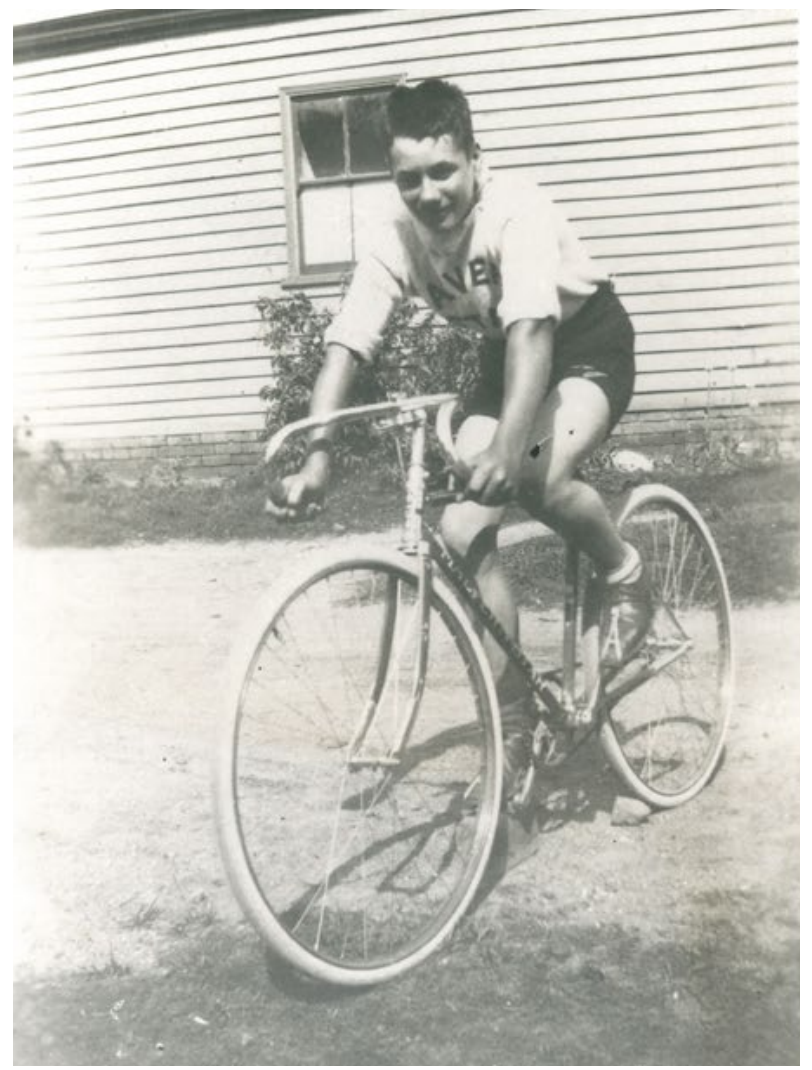

Charlie Crosdale, cycling medallist

(Courtesy of Alice McDonald) 


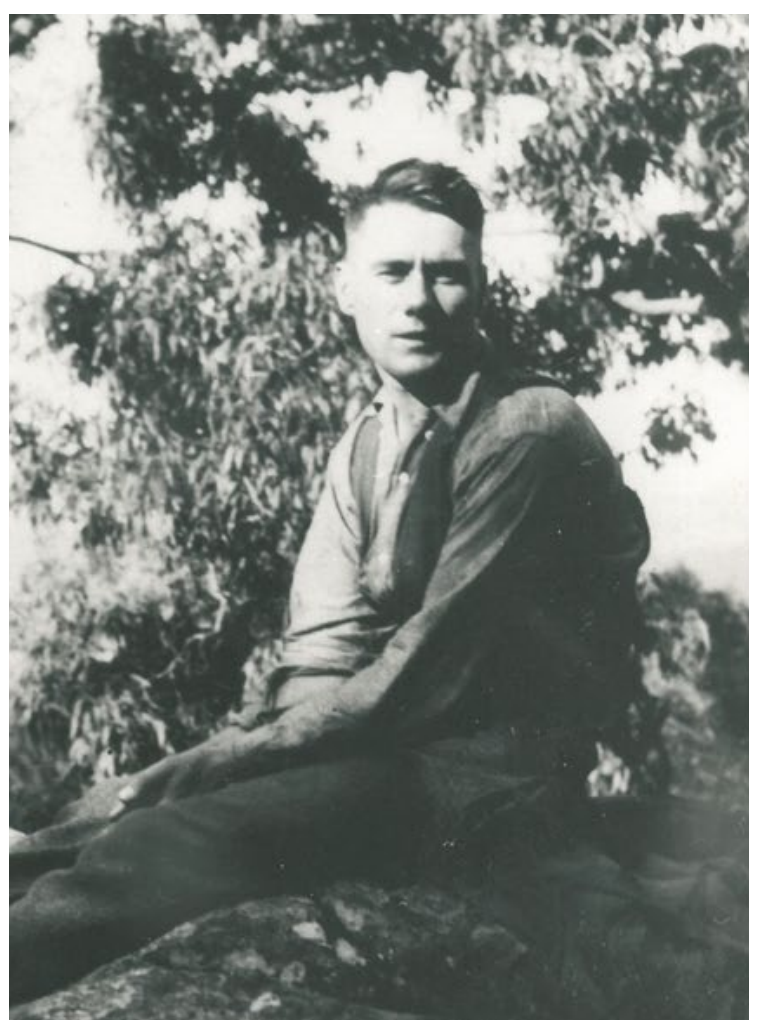

\section{Charlie Crosdale, local explorer}

(Courtesy of Alice McDonald)

When George opened a garage in Congewai, about 18 kilometres southwest of Cessnock, Charlie joined him and had his earliest experience of motor repairs. He was later to describe his six months there as an apprenticeship. When George Crosdale was bankrupted in 1925, Charlie had to look elsewhere for work. A job as a conductor with Rover Motors, a private bus company, followed until he was laid off and replaced by a younger man. Mostly unemployed thereafter, he could truthfully tell the RAAF recruiters that he had been running his own business. He had work a couple of days a fortnight as a lorry driver, and as a mechanic based in Paxton, a private village sub-divided in the 1920s by the East Greta Coal Mining Company, seven kilometres closer to Cessnock. With his spare cash he bought books, moving on from the study of motor mechanics to the theory of aircraft construction. He was fascinated as well with Aboriginal art, and explored the Watagan Mountains by the Congewai Valley, finding a number of cave paintings. For fun, he also swam in local creeks, paddling down them when they were flooded in a canoe he had made himself. He was a competitive cyclist. For a faster and noisier thrill he raced motor bikes at the speedway track in Newcastle. 
From the mid-1930s, Charlie Crosdale's gaze had been firmly on the RAAF. He repeatedly sought to enlist, but his qualifications never matched the vacancies. Finally an open door was glimpsed early in 1939. He had undertaken a trade test and, at 5'6" and 10 stone, with a 36" chest and three inches of expansion, he was certified as medically fit in June 1939. To his disappointment, however, he failed to meet the standard required for mustering as a 'fitter driver motor transport'. The president of the RAAF Selection Board at Victoria Barracks did nothing to alleviate the sense of failure. He wrote: '...it is not possible to give any detailed information as to the reasons for your being unsuccessful.' The applicant was not to know that he had failed the practical test as a fitter and scored only 10 per cent in the theory test.

It seemed that the RAAF was an impossible dream. Charlie Crosdale had previously enquired about the possibility of joining in the photography section, then as a draughtsman or even as a sign writer, if such posts existed. There were 62 separate mustering categories but he could find no advertised vacancies for which his qualifications were compelling. If he could not get into the Air Force, he contemplated seeking employment with the new Commonwealth Aircraft Factory at Fisherman's Bend. Failing that, he wondered about the transport bus service. But, just as all looked lost, hope was revived by a letter from the Secretary of the Air Board on 2 August 1939 advising that he would be placed on the waiting list of applicants considered suitable for entry to the Air Force as an aircraft hand. With RAAF recruitment in New South Wales suspended but due to be resumed in September, he looked forward to an early change of fortune. Frustratingly, it was not till December, and the nation was at war, that Charlie was called again for interview. Like many thousands of applicants, he simply had to wait while the RAAF Directorate of Manning developed the machinery to cope with a massive influx of ground crew recruits. ${ }^{37}$ In the interim the conditions of service had changed and he was obliged to indicate his acceptance of the revised terms. Instead of a weekly wage of £3.19.4 he would be entitled only to five shillings a day, with an extra three shillings a day if he were married and another shilling per child. Charlie did not hesitate.

There was one last hurdle. Unlike the Royal Australian Navy which offered free dental treatment to recruits to render them fit for service, the RAAF obliged them to become dentally fit at their own expense. Nearly 17 per cent of recruits in Melbourne, thought to be typical of all centres, had been rejected on dental grounds in the first two months of the war. Very few of them were willing to pay for or could afford the required treatment. ${ }^{38}$ Thus, having also furnished certification from a Newcastle dental surgeon that he had 'all necessary fillings

37 Gillison, Royal Australian Air Force 1939-1942, pp.68-9.

38 Air Board Agenda 2634, [Nov. 1939], NAA: A4181, 17. Dental health requirements for RAAF applicants were eliminated in May 1940. 
and prophylactic treatment' and was 'dentally fit for enlistment', Charlie Crosdale entered the Richmond (NSW) depot as an 'aircraft hand mechanic', enlisted just before Christmas 'for the duration of the war \& up to 12 months thereafter'. His older brother Sidney was to enlist seven months later.

What Charlie Crosdale knew, though probably most of his fellow mechanics did not, was the extent to which his presence among them was a result of political influence. By early 1940 RAAF recruitment literature carried a warning that representations from members of Parliament or 'influential citizens' would be regarded as 'an indication that the candidate lacks confidence in his own merits'.$^{39}$ Yet, had it not been for two of the ministerial passengers about to board his Hudson on 13 August 1940, the frustrated volunteer might still have been waiting to be called to service. For two-and-a-half years he had sought entry to the RAAF. Letter after letter in his own hand found a home on Department of Defence files. He had been aided in his quest by a man who had known him since he was a boy, Rowley James, the ALP MHR for the federal seat of Hunter. James had concluded that the only way for constituents - even one as 'honest, sober and industrious' as he averred Charlie Crosdale was - to be called up to the glamorous Air Force from his severely depressed coal mining region was to use their political connections. At Crosdale's request, James had repeatedly approached Geoff Street, the Minister for Defence. Charlie's local state MP, the union leader and deputy leader of the New South Wales Labor Party, the bulletheaded Jack Baddeley, added his voice.

There was enormous inertia to overcome. Street's officials ensured that the courtesies were observed; the minister kept James, a pugnacious political opponent, abreast of developments in his constituent's case. Minutes passed back and forth between the Secretaries of the Air Department and the Air Board. The Air Member for Personnel's initials were spattered across an ever-growing file. Eventually when Street's friend Jim Fairbairn became Air Minister he referred the matter to him. It was all that was necessary. Fairbairn had actually flown Street, with James and another Labor MP, to Cessnock, Singleton, and Newcastle in May 1939..$^{40}$ Ever the optimist, James had hoped to persuade ministers of the strategic value of developing Cessnock aerodrome. He did not help his cause by appointing himself navigator so that he could hunt for his own chimney pots at Kurri Kurri. Over-shooting Cessnock by seven miles compounded the merriment of the mission. Happily, James's advocacy for his eager constituent was more successful than his aerial navigation. As was noted on Crosdale's file, he was 'Enlisted under instructions from Air Board'. The Director of Recruiting, Harry Cobby, had personally signed the 'important' cypher message on 19 December 1939 directing his enlistment. Australia had been at war for three months.

39 'Royal Australian Air Force, Conditions of Service in the Ranks - Airmen, Ground Personnel', revised April 1940, p.7.

40 The Argus, 24 May, 3 June 1939; Sydney Morning Herald, 31 May 1939. 
Like many others entering as ground crew, Charlie Crosdale had aspired to fly with the RAAF. In fact since leaving school he had been ambitious to work in aviation in any capacity. He had approached both the famed Charles Ulm and the Qantas company without success. While picking up such work as he could in and around Paxton as a motor mechanic and lorry driver delivering logs to a sawmill near Newcastle, he had two main diversions. He had passed the Leaving Certificate at school - the only one of his family to do so - and studied mechanical engineering for a year with the International Correspondence School. With an aptitude for drawing, he had earned 16 commercial art diplomas at the Art Training Institute in Melbourne as well as two certificates from the Australian Sketching School in Sydney. He was a talented amateur artist whose pictures, mostly pencil sketches, won him awards in art shows as far afield as Wollongong, Newcastle, Bega, Tamworth, and even the Sydney Royal Show. His works adorned his parents' walls. His drawing of a magpie won a prize from the Gould League of Bird Lovers and was featured on one of the League's membership cards. He was proud as well of his caricatures of Sir Charles Kingsford-Smith and Australia's courageous cricket captain, W. M. Woodfull.

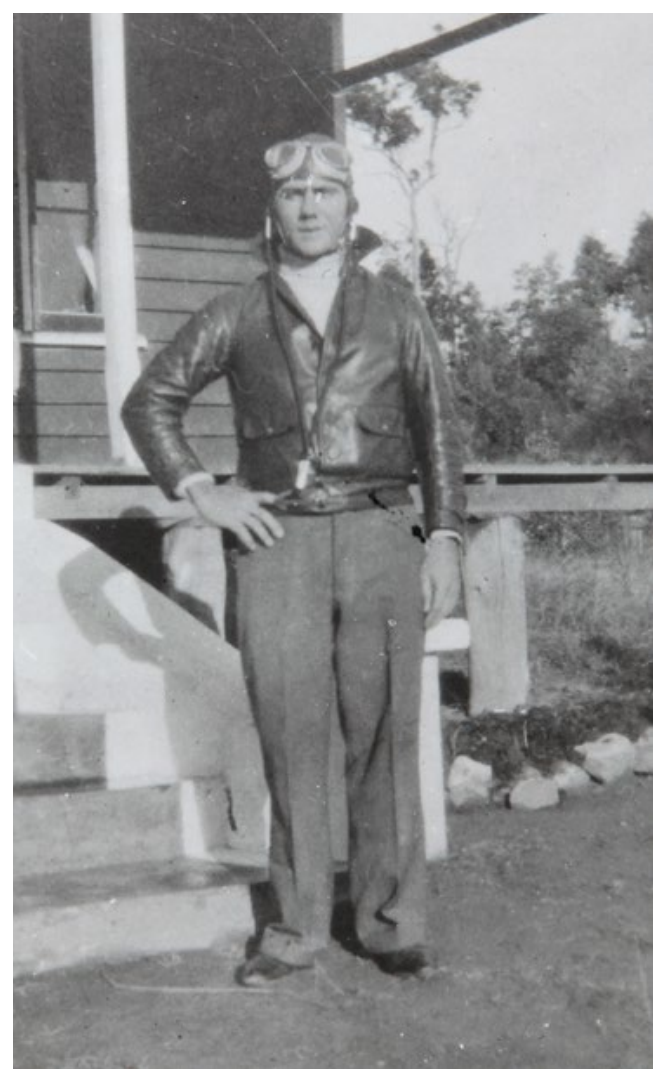

Charlie Crosdale, yearning to go solo

(Courtesy of Alice McDonald) 
As soon as he could afford it Charlie had begun learning to fly. An aero club had been formed in Newcastle in 1934 and from 1936 had assumed responsibility for flying training in country towns to the north and northwest. The RAAF did its bit to encourage the local enthusiasts. In May 1937, No. 3 Squadron at Richmond sent three Hawker Demons to the Cessnock Aero Club to put on a display of formation flying, 'message picking up', and aerobatics. Exciting as the thought of emulating the daring Air Force pilots was, the costs of flying lessons were a dispiriting hurdle. Jack Palmer had also started flying lessons in Melbourne but had to give up as his funds ran out. As Jim Fairbairn, the MP for Flinders, was to tell the House of Representatives in June 1937: 'It is most disconcerting to me every week or two to be asked by some young man if I know of a cheap way of learning to fly. I am unable to give him any advice.' The fact was that the government's subsidies to the aero clubs were spread thinly and, in Fairbairn's estimation, some 75 per cent of the pupils were learning 'for the sport of it, just as they join golf or tennis clubs' ${ }^{41}$

Over four years Charlie Crosdale had managed only 20 hours and 50 minutes dual flying time with the Newcastle Aero Club. As Rowley James pointed out to the Minister for Defence, because of conditions prevailing at Cessnock Aerodrome he had been unable to undertake training there. Nevertheless he had been close to going solo when he ran out of cash. With some help from his mother he had spent $£ 200$, more than he could expect to earn in most years. ${ }^{42}$

Interviewed at RAAF Station Richmond in 1938, Charlie had been assessed by the 'Staff Officer Administrative' as a 'very good type of applicant - exceptionally keen to become a member of this Service'. He ticked all the boxes. He played tennis and cricket, was a cyclist and swimmer. He would serve anywhere and, in the language of the interview form, would 'sleep in barrack room' and 'rough it'. He had no police record and needed only a week's notice to present himself for duty. It was, he said, his life's ambition to join the Air Force. All of which earned him a score of 75 per cent.

On 16 September 1939, the RAAF Recruiting Centre in Melbourne forwarded C. J. Crosdale's file to their Sydney counterparts. Impressed by his keenness and his partial training as a pilot, they had placed him on a waiting list for enlistment as a mechanic six weeks earlier. Charlie Crosdale's flying aspirations necessarily were on hold. But he could reasonably expect that his time had come when war was declared. He had not allowed for the congestion and memory lapses of bureaucracy. It was to take another political intervention, and another interstate transfer of files, before he was called up a week before Christmas.

$41 C P D$, House of Representatives, 14 Aug. 1940, p.377; minutes, forms, and correspondence in Crosdale's RAAF Record of Service, NAA: A9301/2.

42 Instruction at the Victorian Flying School was $£ 8$ an hour (J. D. Balfe, War Without Glory: Australians in the air war with Japan 1941-45, Macmillan, South Melbourne, 1984, p.15). 
Many others were still waiting to be summoned. A few days later, Jim Fairbairn was to appeal to young men not to be disheartened if they were not called up immediately. The war would go on, the Air Minister assured them. It was 'only tripe' to suggest that Germany would 'crack up' before long. ${ }^{43}$

After a brief period at Richmond, Crosdale went to the Engineering School at Ascot Vale Showgrounds in Melbourne for four months. Then, after passing yet another trade test with a score of 68 per cent, he was sent to No. 21 Squadron at Laverton, re-mustered as a flight mechanic in May 1940. Finally he was posted as aircraftman 1 to No. 2 Squadron on 4 July $1940 .{ }^{44}$ In that month the Minister for Air announced that the number of men serving or being trained as fitters in the RAAF had increased four-fold since September 1939. There were now 2048 fitters on duty and another 2828 at the Engineering School or technical schools. The total was greater than the entire strength of the Air Force, including officers, cadets, and airmen, when war began. ${ }^{45}$

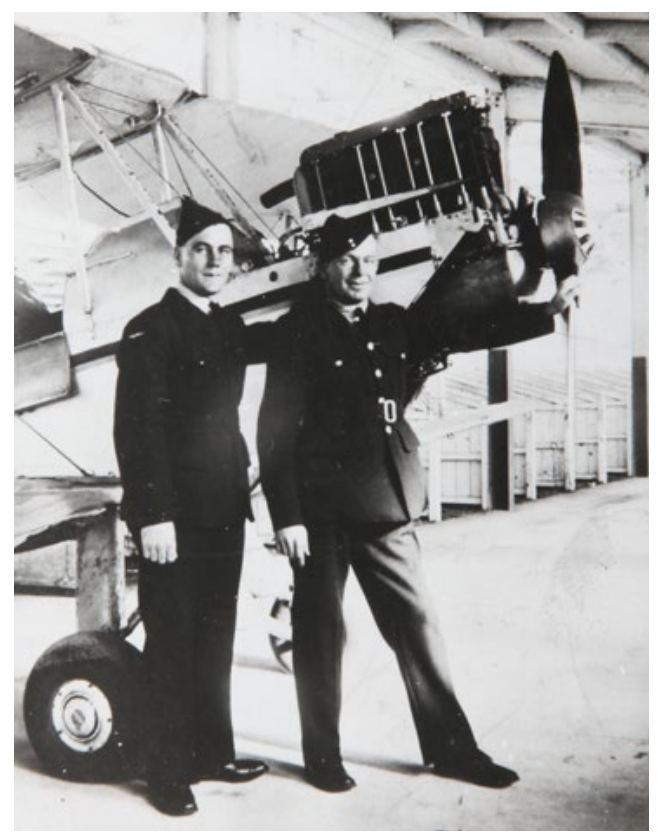

\section{A/C Crosdale under instruction, with S. Graham and Gipsy Major at the Nicholas Building, Melbourne Showground, April 1940}

(Courtesy of Alice McDonald)

\footnotetext{
43 Canberra Times, 3 Jan. 1940.

44 Biographical information about Palmer and Crosdale, The Argus, 14 Aug. 1940; Manning, 'Air Disaster at Canberra', Stand-To, Jan.-Feb. 1962, pp.6-22; Coronial papers, NAA: A1378, P8903; RAAF Record of Service, Charles Joseph Crosdale, NAA: A9301/2; Cessnock Eagle, 16 Aug. 1940.

45 Jane's All the World's Aircraft 1940, p.28a.
} 
Three days before starting in Melbourne in January 1940 Charlie Crosdale had married Rita Pearl Ling. Rita was from the tiny township of Ellalong, a few kilometres down the road from Paxton. She was one of six children of Benjamin and Mary Ling. 'Everyone seemed to know each other from one village to another,' as one of Charlie's younger brothers, Norman, and his wife Jan remembered. Rita's brother Mervyn had married Charlie's sister Cecilia (known as May) in 1932. Her own honeymoon was short; nothing could impede Charlie's progress now that he had at last achieved his ambition. The Air Force made no provision for the travel of airmen's families or the removal of their furniture and effects. ${ }^{46}$ So the new bride had initially remained behind in Paxton, staying with her parents-in-law. But soon a happily pregnant Rita had found accommodation in Princes Street, Newmarket. By the end of April, with no relatives in Melbourne and his wife experiencing ill health, Charlie was granted permission to live 'off station'.

At last the obstacles that had delayed Charlie Crosdale's enlistment and impeded his progress seemed to be surmounted. He had been determined to wear his country's uniform and his mechanical talent was now finding expression in servicing the RAAF's most formidable new aircraft. His wife was receiving $£ 4.4 .0$ a fortnight, with another $£ 1.0 .0$ per fortnight due to be paid for the child on the way. Charlie's service record was impeccable. There was not a single blemish on his general conduct sheet, on which 'Cases of drunkenness (in red ink)' and punishments awarded were routinely entered in the columns provided. He was fit, well behaved, and chirpily in his element. 'He was like a boy who got a toy he really wanted,' a fond sister recalled. To another sister and brother-in-law, May and Merv Ling, he had written on Sunday, 28 July 1940: 'I am in No 2 Squadron now working on those big Lockheed Hudson bombers. They have 14 cylinders twin bank radial each motor. They have 2 motors 28 cylinders and boy say do them [sic] hum and go.'

He had felt the 'hum and go' of the Hudson's Pratt \& Whitney Twin Wasp 1050 hp SC-3G engines in the air. 'I went to Geelong on Tuesday in mine. We went down the bay Port Philip and then flew across the bay to Geelong back down the coast home' through heavy clouds. 'Hell the scene was wonderful up above them.' Flying at 3500 feet most of the way at 180 miles an hour, as he told his mother two weeks later, they could see the Ford manufacturing plant at Geelong where the British Fairey Battle light bombers were being assembled. He had flown over Melbourne: 'small from the air I know every inch of it Mum'. The new Hudsons were being put through their paces and Charlie delighted in telling the family of his flights in A16-97, which had arrived at Laverton on August 2:

46 'Conditions Governing Enlistment, Promotion, Re-Muster, Transfer and Discharge', RAAF Form P/P. 30, revised Nov. 1939. 
I was up photographing with the photographers in my plane on Monday [August 5]. ${ }^{47}$ We were taking photos of all the petrol dumps from 6000 $\mathrm{ft}$ to $2000 \mathrm{ft}$. Clouds were fairly troublesome but they secured them all I think...

When we were coming down from photographing the pilot said hang on I am going into a vertical dive and hell we were moving. He pulled out at $300 \mathrm{~m}$. p. hour. We were moving Mum.

With Bob Hitchcock at the controls of A16-34, they really were moving. Not as fast as Alec Barlow and his crew who had 'swooped down on Ceduna at over $330 \mathrm{mph}$ at about 300 feet and scared the devil out of the town' ${ }^{48}$ But definitely pushing the aircraft. At 6500 feet the Mark I Hudson's recommended cruising speed was $220 \mathrm{mph}$; maximum speed was supposed to be $246 \mathrm{mph}$. The air speed indicator was calibrated to 300 knots $(345 \mathrm{mph}$ ) but the highest diving speed to which the aircraft had been tested in Lockheed and official trials was 295 knots (339 mph). The Mark II Hudsons, those numbered from 51 to 100, already had enhanced performance; they were faster, carried more weight; had a higher service ceiling, and a greater range.$^{49}$ When Crosdale was not being exhilarated in the air or undertaking his normal duties on the ground he was exercising some of his other talents. 'I am doing all the jobs of signing and drawings and draughtsman here when they want them.' The squadron leader had discovered his artistic ability. In the intervals between official tasks he found time to do a drawing for his father of a miner with a gas mask. He took photos of the planes he was tending but was cautious about sending them to his younger brother Douglas, known to all as 'Tiger', who wanted to show them to his Air League friends. If caught, Charlie said, he could be court-martialled and imprisoned for five years. 'Tell him if I send them not to say where he got them but do you think Mum it's worth the risk?'

No such fear inhibited him from sending up a lamp to his parents, He had intended to use it for photography but realised that it would make a good reading light if his father rigged it up on the bedroom wall. 'I will draw up a little plan how it works. You will not need to get up out of bed to switch the lamp off when it's fixed up.' Best though that no-one mentioned where the lamp came from: 'It's off a Hudson Mum. Don't let on.' His mother could also look forward to receiving a chromeplated butter knife made from a .303 bullet shell. It awaited only engraving. 'It's wonderful all the machines to work with. I have made myself a nice kit of tools for my plane. You would think they were bought.'

47 Hitchcock's log shows a series of photography sessions in August with Crosdale aboard on the seventh, not Monday the fifth.

48 Charles Learmonth diary, quoted in Charles Page, Wings of Destiny: Wing Commander Charles Learmonth DFC and Bar and the Air War in New Guinea, Rosenberg, Dural, 2008, p.64.

49 Information from Rich Stadler, Office of Public Information, Lockheed-California Company; 'Diving 
On August 13, Charlie Crosdale was about to take to the air again, this time with some of the most famous and powerful men in the country. He had been laid low for five weeks with the new strain of influenza and bronchitis that had swept through the Laverton base defying medical remedies. He was clearly suffering, as he told May and Merv Ling, from exposure to the 'cold bleak wind howling in...straight into our hangars from the direction of Ballarat and by hell we know it'. But he was determined to take his place that day. On Monday night he finished a long letter to his mother, 'it's 8.30 and I have to work in the morning'. If he was lucky, his cough would not keep him awake and he would travel down to Laverton refreshed to begin the preparations for the trip to Canberra. But he had not counted on the premature arrival of his first child. In the early hours of Tuesday morning, Rita's labour began. He took her to Queen Victoria Memorial Hospital in the city, the hospital established by women and run by women. Should he leave his wife there with no family to support her? Would he in any case be able to make it to the base in time?

Rita Crosdale had no doubt what her husband's priority should be. As she later told her sister-in-law, she said: 'Look, you are so intent on going on this important flight with all those ministers, you go. I'll be alright.' With mixed feelings the anxious father-to-be rushed to Laverton. There his best friend offered to take his place. But there was no time for the necessary change of clothes, approval, and paperwork. Joining Jack Palmer, the wireless operator, in a greatcoat over his Air Force blues to keep out the chill morning wind, Charlie was to climb aboard and complete the final checks before confirming that his aircraft, A16-97, was ready for the flight. ${ }^{50}$

\footnotetext{
50 Biographical information about Crosdale, The Argus, 14 Aug. 1940; Manning, 'Air Disaster at Canberra', Stand-To, Jan.-Feb. 1962, pp.6-22; Coronial papers, NAA: A1378 P8903; RAAF Record of Service, Charles Joseph Crosdale, NAA: A9301/2. C. Crosdale to Mrs G. Crosdale, 12 Aug. 1940, Crosdale MSS. I have silently inserted punctuation where its absence would be distracting. Mrs R. McDonald to CH, 6 Sept., 14 Oct. 1977, 24 May, 7 June, 27 June 1978. I am particularly grateful to Charlie Crosdale's brother and sister-in-law Norman and Jan Crosdale for compiling genealogical information, and to his sister, Alice McDonald, for allowing me to see and copy family letters and photographs, and for her recollections of her brother's employment history.
} 



\section{Second seat: Dick Wiesener}

The clutch of new pilot officers who presented themselves for duty at No. 2 Squadron on Monday, 12 August 1940 exemplified the varied backgrounds and destinies of the RAAF's wartime officer recruits. All but one appeared to meet the threshold criterion of being under 28 years of age when he enlisted - before war broke out they would need to have been under 26 and unmarried. All must have been found by an examining medical officer to be free of scrofula, phthisis, syphilis, defective intelligence, defects of vision, voice or hearing, traces of corporal punishment, marked varicocele 'with unusually pendent testicle', 'or any other disease or physical defect calculated to unfit him for the duties of a soldier [sic]'. All would be deemed to be of 'pure European descent'. All would have survived a discreet enquiry to their local constabulary as to their good character, criminal record, or 'blameless life' after any serious offences 'many years ago'. ${ }^{1}$ Their seniority would be based on the date of their appointment as an officer. If graduated from a course of flying training they would be ranked on the results obtained in the practical tests during the course and the final graduation examination. They would be on probation for six months, after which - if their copy books were clean - they could expect promotion to flying officer. ${ }^{2}$

The first of the group parading themselves before Squadron Leader Fred Thomas at Laverton was Peter Fowler, of the Sydney earthenware, pottery, and stoneware family. Almost 23 years old, a quiet, slightly prickly character, as his contemporary Bob Dalkin recalled, his reserve was perhaps a reaction to years of ragging about wash basins, toilets, and urinals. After being posted to No. 1 Squadron in Malaya, 'Chook' Fowler was to be captured by the Japanese and spend much of the war in a Thai prison camp. William Vyner Duckett White, a hard-drinking company manager, Inverell born, had farmed and been engaged in mining in Kenya, learned to fly in Sydney, and served in Shanghai with the

1 Air Board Agenda 2714, 5 Feb. 1940, NAA: A4181, 17. Pre-war 'candidates for entry' were screened by the Fingerprint Office and the City Watchhouse as well as their local police station; for example, R. L. Peverell (NAA: A9301). The Secretary of the Air Board was appalled at the suggestion by the Air Member for Personnel that men with recent convictions might be recruited: ‘Can't we get enough without resorting to these types?' Within weeks, the War Cabinet had decided that 'in view of the heavy personnel commitments under the Empire Air Scheme, aliens and British subjects of non-European origin or descent should be permitted, at the discretion of the Air Board, to serve in the RAAF during the war' (Minutes of War Cabinet Meeting, 29 Feb. 1940, NAA: A2673). Confidential enquiries (Form P/P 35) were made as to whether candidates were 'sober, honest and respectable', or were recorded by the Special Branch as members of 'any Communist organization' (W. E. Belfield, NAA: A9301, 13041).

2 'Conditions of Entry to Commissioned Rank in the RAAF', RAAF Publication No. 3, revised July 1939. Bizarre as the list of disqualifying conditions might seem, the American authority H. G. Armstrong's standard treatise, Principles and Practice of Aviation Medicine (1939), stated that candidates for pilot training should be rejected if they had elephantiasis, Hodgkin's disease, or hydrocephalus. 'Why', the Medical Journal of Australia reviewer asked, 'did he not add leprosy and yaws while he was at it?' (MJA, I, 25, 22 June 1940, p.868). 
British militia force and Chiang Kai-shek, before returning finally to Sydney. Determined to fly with the RAAF, he put his age down by four years. 'Dark, handsome and tough, with a shining personality', as Bob Dalkin recorded after his death, Bill 'VD' White was to be the first in his squadron to be awarded the DFC; he too was captured, and executed by the Japanese in February 1942. ${ }^{3}$ David Campbell, thinking himself only 15 months White's junior, arrived at No. 2 Squadron later in the month and remembered a man apparently 'quite a lot older than the rest'. He especially remembered White's daily bottle of whisky that may have contributed to the prematurely aged appearance of a man with a colourful past. Campbell himself was a Cambridge graduate and rugby international with a NSW grazing background. He had learned to fly in Cambridge. Joining the RAAF as a cadet in November 1939, he was commissioned in February 1940, and was to end the war as a temporary Wing Commander with a DFC and bar of which he rarely spoke, and to become one of Australia's most admired poets. ${ }^{4}$ The third man was a professional pilot. Robert Nixon 'Bob' Dalkin, who had just earned his unrestricted commercial pilot's licence with the W. R. Carpenter company in New Guinea before joining the RAAF aged 26 at the beginning of 1940, was to serve with distinction north of Australia and in RAF Bomber Command, eventually retiring as an RAAF Air Commodore. ${ }^{5}$

Dalkin, White, and Fowler were accompanied by Dick Wiesener, a 29-year-old accountant from Sydney, enlisted by special authority nine days after the birthday that in ordinary circumstances would have disqualified him. ${ }^{6}$ Making friends with the even older Bill White during intermediate flying training at No. 26 Flying Training School, Wiesener had done his share of carousing and stunting, and waving the wings of small aircraft over family in Edgecliff and Strathfield. He and the others, as well as Noel Quinn and Paul Metzler, had all - to their

3 James Affleck (ed.), Geelong Grammarians at World War Two, Old Geelong Grammarians Inc., 2002, pp.91-2, evidently confusing him with someone else, states that White returned to Australia in Nov. 1940 to join the RAAF. Cf. R. N. Dalkin diary, Feb. 1942, RAAF Hudson Squadrons Association Newsletter, 49, May 2002, p.5. Dalkin and the Ambon Memorial Roll of Honour described William Vyner Duckett White as 32 at the time of his death but his RAAF personnel record shows his date of birth as Oct. 1913. On White's hard drinking and appearing hale and hearty after 90 minutes' sleep: Kym Bonython, Ladies' Legs \& Lemonade, Rigby, Adelaide, 1979, p.44. I am grateful to Geoffrey White (interview, 29 Jan. 2010) for information about his uncle. White, Dalkin, and John Ryland appear in the Department of Information film, 'Keeping our Sea Lanes Open'. White's active service is recounted in Balfe, War Without Glory, passim.

4 David Campbell, telephone interview, 24 May 1978; Leonie Kramer, 'Campbell, David Watt Ian (19151979)', John Ritchie and Christopher Cunneen (eds.), Australian Dictionary of Biography, vol. 13, Melbourne UP, 1993, pp.356-7.

5 J. C. Waters, Valiant Youth: The Men of the R.A.A.F., F. H. Johnston Publishing Co., Sydney, 1945, pp.5860; for Dalkin's experiences as a Hudson pilot see Vincent, The RAAF Hudson Story, Book Two, passim.

6 ACdre R. N. Dalkin, interview, 18 April 1978, recalled the arrival of the four new pilot officers whose postings are shown in Station Routine Orders No. 98, 2 Sept. 1940, NAA: A10605/8 Box 503, vol. 7/HQ Laverton. Dalkin erred in his later recollection (quoted in David Vincent, The RAAF Hudson Story, Book One, Highbury, 1999, p.152) that Campbell was one of the group arriving on 12 Aug. 1940. Campbell himself recalled arriving 'a week or two later' (telephone interview, 24 May 1978). Campbell does not appear in the Aug. 1940 group photograph of officers in Bennett, Highest Traditions, pp.108, 112. R. A. Dunne and N. G. Hemsworth, who are in the photo, were posted as flying officers on 26 Aug. 1940. 
disappointment — been posted to the navigation reconnaissance school at Point Cook. Navigational skills, more than ever essential for the RAAF's newer bomber aircraft, larger and with longer ranges, were increasingly understood to require special training. The days of a lone pilot, sometimes with a jack-ofall-trades observer, were passing. In the United Kingdom in April 1938 it had been calculated that in the previous two years Bomber Command pilots had lost their way and made forced landings on 478 occasions. Just over a year later a senior RAF officer reported that even in daylight flying, above clouds, deadreckoning navigation could not be relied upon to get an aircraft closer than 50 miles from its destination. ${ }^{7}$ The establishment of the General Reconnaissance School as a separate unit on 29 April 1940, initially at Point Cook, was a step towards meeting the need for specialist navigation officers as well as enhancing the skills of all of the RAAF's general duty pilots. ${ }^{8}$

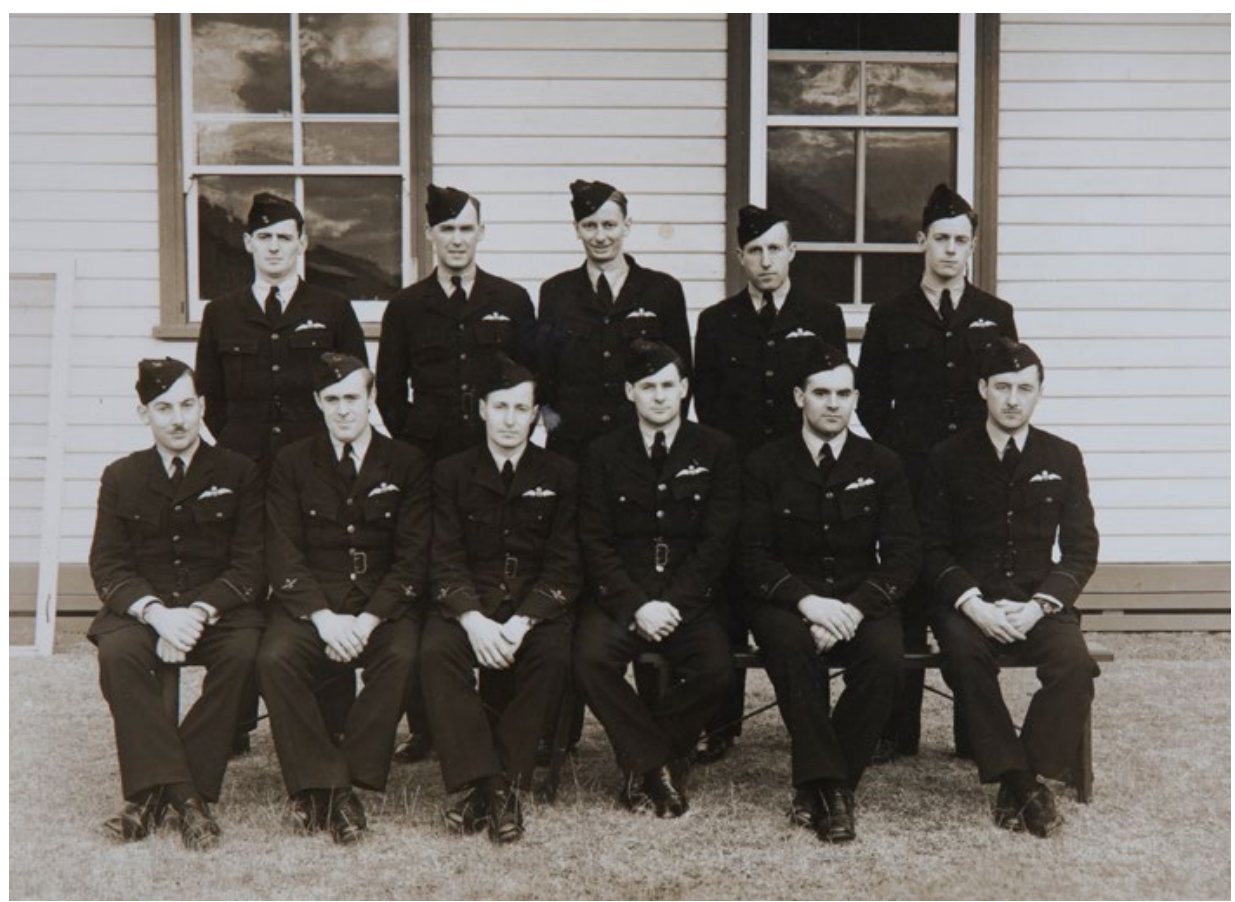

No. 8 Navigation Reconnaissance Course, RAAF. From left: back row: Pilot Officers Bill White, Dick Wiesener, Bob Dalkin, Tom Skillman, Ron Cornfort; front row: Peter Fowler, Barry Hack, Harold Croker, Noel Quinn, Lin Hurt, Paul Metzler

(Courtesy of Geoffrey White and the Australian War Memorial, No. P00946.004)

7 Sir Charles Webster and Noble Frankland, The Strategic Air Offensive Against Germany 1939-1945, vol. 1: Preparation Parts 1, 2, and 3, HMSO, 1961, pp.110-2.

8 Tim Coyle, 'Track Made Good: A history of air navigation in the Royal Australian Air Force and its predecessor, the Australian Flying Corps 1914 to 1945', PhD thesis, University of New South Wales, Australian Defence Force Academy, 2006, Ch. 2 is a comprehensive account of developments 1938-40. 


\section{Demand for Hudson pilots}

Although later they were to appreciate the value of their work on astro navigation and spherical trigonometry, maps, charts, sextants, and compasses, the navigation reconnaissance group envied their peers who had been posted direct to flying duties. Some, like Bill White and his wealthy friend Ron Cornfoot, 'took our flying seriously but the academic side bored us, so we drank beer and played billiards in the mess every night instead of studying' ${ }^{9}$ Like his other drinking companion, Wiesener, White had qualified in accountancy and worked as an auditor. They also had the celebrated swashbuckling miscreant Errol Flynn in common - briefly, before he was expelled, a pupil with Wiesener at Shore (Sydney Church of England Grammar School); and in White's case as a fellow junior at Dalgety's headquarters in Sydney whence Flynn had been dismissed after trying to shift blame to the innocent White for the disappearance of $£ 50$ from petty cash. ${ }^{10}$

What the happy bunch graduating from the navigation reconnaissance school were probably only dimly aware of was the dilemma that their superiors at Central Area in Point Piper and Air Force headquarters in Toorak were struggling with. The RAAF had to balance the urgent need for qualified pilots to captain and navigate the newly arrived Hudsons as well as meet the demand for general flying instruction. The Air Minister himself had been quoted at the end of 1939 as saying that flying had changed so much since he earned his wings that he was amazed that competent pilots could be trained to fly such complicated modern machines in six months. ${ }^{11}$ Jim Fairbairn's observation had a concerning undertone. On July 2, in the very week Dalkin, Wiesener, and the others began their navigation course at Laverton, the commanding officer of Central Area, Air Commodore Adrian 'King' Cole, wrote personally to Group Captain George Jones, Director of Training:

Mr Parker, of the Lockheed Aircraft Factory, tells me, after observing the training and general flying in conversion course at RICHMOND, that it is his opinion that the pilots for Lockheed aircraft should be seeded in such a way as to provide for those whose records show that they

9 R. G. Cornfoot to Anthony White, 13 July 1984, courtesy of Geoffrey White. Cornfoot, son of a dairy products manufacturer, Geelong Grammar educated, became an outstanding Hudson squadron leader (Balfe, War Without Glory, passim).

10 Note by Geoffrey D. White, enclosed with letter to Bob Dalkin, 4 May 1988, copy, courtesy Geoffrey White; John Hammond Moore, The Young Errol: Flynn Before Hollywood, Angus and Robertson, Sydney, 1975, pp.23-8. According to the boy whose bed was next to Flynn's, the expulsion from Shore was a result of repeated stealing, not the boasted dalliances with a maid in the coal heap (Kate Riseley [Shore School archivist] to $\mathrm{CH}, 24 \mathrm{Jan} .2012$ ).

11 The Argus, 20 Dec. 1939. 
are above the average. In this connection, it has come to notice that some of the pilots posted to Lockheed squadrons have the following endorsements on their passing-out report:

"Weak at instrument flying"

"Generally slow, mentally" \&c \&c

Cole then alluded to another sensitive issue:

In view of the extreme necessity of saving equipment, it would seem better to employ this type on instructing, where, during the six months they would be so employed, there would be a chance of their picking up leeway in the aspects in which they are weak.

To make up for a reduced flow of Hudson pilots Cole suggested that a number of first-class pilots, particularly those from civil life who had been posted to instructing, would be better able to successfully fly the more challenging machines. Such experienced men could be relied upon, 'observing the economy necessary in equipment...to take the extreme care which is necessary on the controls to save petrol consumption and protect the engine'.

Knowingly or not, Cole was about to touch off a paper war at headquarters. He announced that, pending further instructions, he had already 'arranged' with Wing Commander Alan Charlesworth to 'seed the Hudson squadrons' in his Area and was recommending to Melbourne the alterations in postings that would give effect to his recommendations. Two days later, Cole wrote formally to the Secretary of the Air Board: '... it is considered that unless Hudson squadrons are given better material from which to train Captains, the accident rate will increase out of all proportion, or else the squadron will spend an indefinite period on training, in an attempt to produce a qualified pilot.'

Speaking specifically to his own Area's concern, he said that too many experienced pilots had been posted away, leaving his No. 6 Squadron with only three officers, including the CO, qualified to captain Hudsons. There were three more partly trained, and a cluster of 15 young pilot officers or air cadets with some 100 flying hours each on Demons and Wirraways. Cole accepted the conventional view that the Service should not be producing a cadre of 'specialised' pilots. But Hudson pilots should, he argued, be capable and experienced, not young men who had only just finished their flying course. 'Fundamentally the flying of one type is the same as any other, but it is in the temperament, reliability, and ability to handle modern engines that experience plays such an important part.'

What followed in Cole's submission was that a number of the men currently employed in flying training were potential Hudson pilots and should be reassigned for this priority role without delay. Five of them should be replaced by 
the inexperienced second pilots who 'after a period on flying training, would be infinitely better material for training on Hudsons'. By taking action as well as minuting his ideas, Cole was displaying the inherent tension in the RAAF's devolved command structure. If his recommendations were to be followed they would entail closer co-operation not only between Area commands and headquarters but between the Training and Personal Services branches. George Jones, Director of Training, bluntly disagreed 'that ex civil pilots should be posted to Hudson squadrons and that those who have recently graduated from our own schools should be employed on instructing. One cannot generalise in this way.' The policy should be that the posting of individuals must depend on their qualifications. In fact, Jones went on in a minute to the Director of Personal Services, sensing an opportunity to expand the influence of his training domain, 'there should be closer liaison between us in...selecting pilots for different units. I suggest that the proposed posting of pilots might be passed to this branch for comment before issue of Orders.'

A battle for organisational territory was under way. Jones, an introvert, trusting no-one, was not going to have his carefully drawn plans subverted. ${ }^{12}$ The Sydney démarche had to be crushed. With a file created, and views invited, branch heads scrambled. Group Captain F. M. 'Dad' Bladin, Director of Operations and Intelligence, mischievously pointed out that the Deputy Director of Postings had 'always shown him his intentions' about postings from units, and he in turn left postings to units to the good sense of the DPS 'hoping that pilots were posted in accordance with recommendations from their S. F. T. S.[Service Flying Training School]'. Bladin was confident that if the right people were chosen for the navigation reconnaissance course, from which all first pilots would now be coming, 'we should automatically get the better class pilots for 1st pilot in Hudsons'. One of Jones's staff, Squadron Leader Joshua McDonald, head of flying training (and contemporary of Bob Hitchcock at No. 21 Squadron in 1936), dutifully opposed the idea of sending below-average pilots from Service flying training schools to be instructors. The result, he sensibly concluded, would be 'their poor standard being reflected throughout the service'. McDonald noted that pilots who were selected for the navigation reconnaissance school would not normally get more than 15 hours as a pilot during the course. They would be 'scarcely more experienced in the handling of an aircraft as pilot, than one who goes to a Squadron direct from the S. F. T. S.'.

Determined not to concede, Jones reiterated on July 26 that no general rule should determine postings. He reminded colleagues that he had asked the Director of Recruiting to appoint as many experienced civil pilots as possible. He agreed that comparatively inexperienced pilots, whatever their background,

12 Peter Helson, The Private Air Marshal: A Biography of Air Marshal Sir George Jones, Air Power Development Centre, Canberra, 2010, passim. 
should be sent to bombing and gunnery schools, air observers' schools, and wireless air gunners' schools before posting to service units, particularly those equipped with Hudsons. But he did not agree that a pilot who had reached 'a satisfactory standard' on the locally built Wirraways could not be converted in a 'reasonable period' to fly Hudsons. Jones's conclusion was emphatic:

There is definitely a tendency to over state the difficulties and standard required for piloting this type of aircraft. The only general principle that I can agree to is that our more experienced pilots should be posted to service units, particularly Hudsons, on account of the heavy responsibility involved. It will be necessary, however, to make exceptions to even this rule, and I feel that we must endeavour to hold the balance by giving careful consideration to each individual's qualifications.

Reviewing all the documented information about accidents, Jones did not need to be reminded of the dangers of inexperience and lack of vigilance by young junior officers. He knew too that even a seasoned Hudson instructor like Alec Barlow, an ex-Australian National Airways captain and Lockheed 14 pilot with over 7000 hours flying time, might not always anticipate a lapse of judgment by a pupil. ${ }^{13}$ And Jones had the ear of his chief. Overseeing these exchanges, and privy to the internal reports on accidents, had been Air Commodore W. H. Anderson, the Air Member for Personnel. One of his subordinates was to write of Anderson, an outstanding Melbourne Grammar student, artillery officer, AFC and RAAF veteran, that 'he was slow and so immersed in the minutiae of administration that some important policy matters languished' ${ }^{14}$ The languishing was now over. Anderson concurred with Jones and called for a reply to Cole to be drafted. There was to be no recall of men already posted. ${ }^{15}$

For pilots like Dalkin, Fowler, and White - experienced civil flyers of modern aircraft - and even Wiesener, who was a licensed pilot before enlistment, posting to a Hudson squadron was likely under whatever policy was adopted. Having moved to Laverton on July 4 and completed their navigation assignment with the brilliant 24-year-old Flight Lieutenant Deryck Kingwell and Squadron Leader Dallas Charlton on Friday August 9, they transferred into No. 2 Squadron that weekend and prepared to present themselves on Monday to their commanding officer Fred Thomas. They were all excited about the prospect of getting to know the Hudsons after spending three months in Ansons and previously converting at Richmond in New South Wales on Hawker Demons. None of them had as much as been up in a Hudson. As soon as they arrived, Dalkin said, 'we all sort of crawled over the aeroplane'.

13 Barlow: Examiner (Launceston), 8 August 1935.

14 J. E. Hewitt, Adversity in Success, Langate Publishing, South Yarra, 1980, p.3.

15 The lively exchange is documented in 'Policy of training First Pilots - Lockheed Hudson aircraft Posting of inexperienced pilots to Units equipped with', NAA: A705, 208/1/1533/1-19. 
Later, while Dalkin, White, and Fowler were poring over manuals, Wiesener stole a march on his friends. Someone, probably Wilbur Wackett, gave him a ride behind the pilots during an instruction flight. ${ }^{16}$ Nothing he had experienced before had prepared him for the sensation. 'God, you've never seen anything like it,' he told the other three; 'the belt in the back when you open the throttles.' Dalkin later elaborated on Wiesener's report: 'He commented on the "tremendous power" available to the pilot on take-off from the two 900 [sic] horsepower twin-row Pratt and Whitney engines; the mass of instruments and ancillaries, the modern layout, the effectiveness of the hydraulic undercarriage, bomb doors and Fowler flaps...' ${ }^{\prime 7}$

\section{'One of you chaps has got to come with me to Canberra tomorrow.'}

After lunch on Monday afternoon, although they had been dispersed into different flights, the four newcomers were together listening to Wiesener recount the joy of the Hudson he had been in that morning, when Bob Hitchcock came into the room. It was time to nominate from among the new arrivals someone to sit in the second pilot's seat on the flight to Canberra and begin to learn about the Air Force's front line machine. Bob Dalkin recalled the scene:

I don't remember ever seeing Hitchcock before that moment... And he came in very smartly. He was a small man. He said 'One of you chaps has got to come with me to Canberra tomorrow.' And we all, you know, thought 'this is big stuff, this is really getting close to things.' Bear in mind none of us were qualified in any way. But I have always thought that when he said that he knew who he was going to take.

16 Wiesener's presence is not recorded in the log books of Ryland, Garrett, Heath, Thomas or Hitchcock. I have not traced the log book of Wilbur Wackett.

17 ACdre Bob Dalkin, typescript 'The 13th August 1940', July 1991, courtesy Peter Dalkin, quoted in Vincent, The RAAF Hudson Story, Book Two, p.249. The Hudson provided over $1000 \mathrm{hp}$ on take-off; $900 \mathrm{hp}$ at 12000 feet. 
Whatever the impulse - perhaps Thomas had made the suggestion to his $\mathrm{C}$ Flight Commander - there was no hesitation: 'Wiesener, you'd better come. Get your gear.' Whereupon Wiesener 'scurried round, got his gear and went off, not with Hitchcock but after him'. ${ }^{18}$

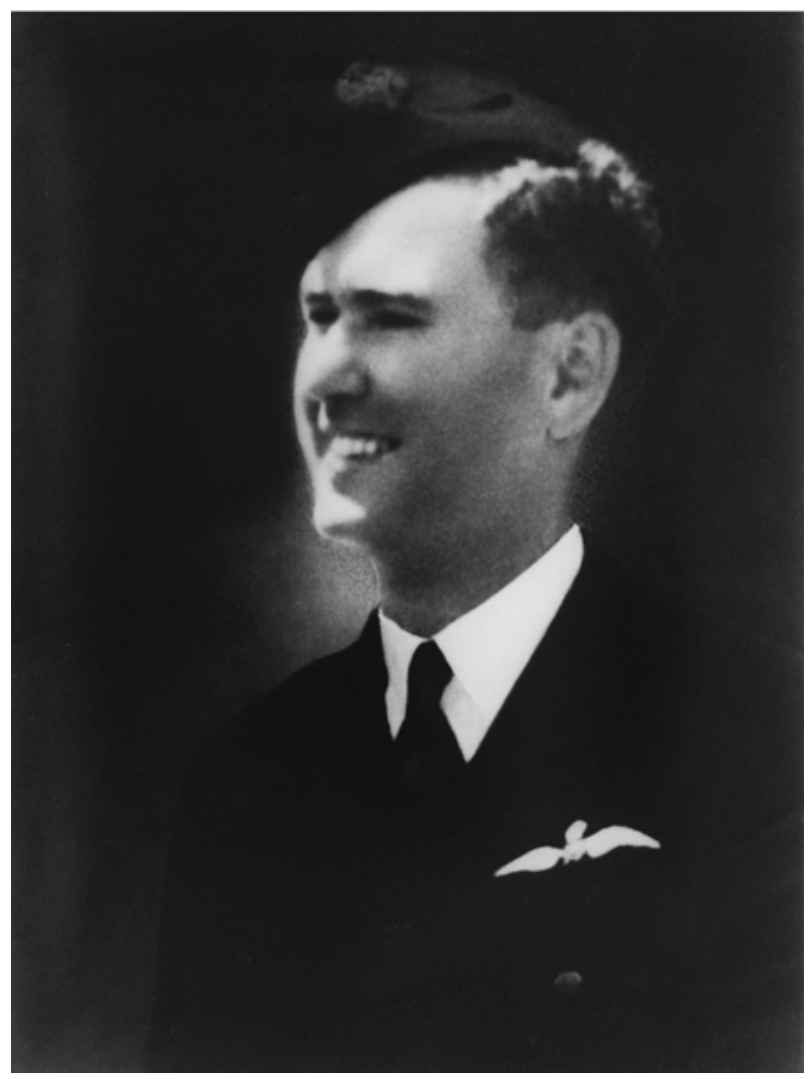

\section{Pilot Officer Dick Wiesener, the only surviving portrait}

(Courtesy of Margot Buttrose)

It seems Wiesener's glowing reputation as the head of the order of merit in No. 27 Flying Training Course had preceded him. Appearing perhaps a little more polished than the other newcomers, there was more to his background

18 I quote here from Dalkin's 1978 interview with me rather than the more polished 1991 typescript. Andrew Tink (Air Disaster Canberra: the plane crash that destroyed a government, Newsouth, Sydney, 2013, pp.152-3) says that S/Ldr Thomas directed who the crew should be. The copy of Carey's flying operation instruction given to the president of the Service Court (WCdr Lachal) on Aug. 13 contains a list of the crew and other notes about the route, ballast, parachutes, etc., in Thomas's hand (Service Court, Appendix E). Thomas told the Air Court of Inquiry that he had added 'remarks, with my instructions'; but the crew list might have been a record of what had been discussed and agreed with Hitchcock rather than a decision given to the pilot. There is some confusion here: Thomas also tendered a copy of the flying operation instruction to the Air Court (Exhibit No. 1) stating that it was the one, with his additions, 'handed to the captain of the aircraft' on Aug. 12. It would appear therefore that Hitchcock did not carry 'his' copy with him the next day. 
than his personnel file would have revealed. He was formerly an accountant with the Sydney office of Sorenson, Purves, and Co. He was married with a son and daughter, and his wife was carrying a third child. Grandson of a German emigrant clockmaker who became a prominent optical, mathematical, and surveying instrument maker; son of a prosperous Macquarie Street eye specialist, Richard Frederick Wiesener was born on the last day of $1910 .{ }^{19}$ He was educated initially at a small local private school, Strathfield Grammar. Founded in 1917 by a group of Congregationalists with just 19 boys, Strathfield Grammar proudly proclaimed its aim to 'establish strong Christian character' and 'develop a sound physique and a healthy interest in games', while preparing boys for the Intermediate Certificate examination 'or for the Intermediate Classes of the Great Public Schools'.

Dick Wiesener and his fellow students - 100 were enrolled along with him by 1919 - enjoyed the environs of the splendid mansion 'Llandilo', built in 1878 by the eminent consulting physician Sir Philip Sydney Jones. Jones had died in 1918; his property was sub-divided, and the new school bought his house on one of the highest points in what were then Sydney's western suburbs. As the school prospectus shamelessly confided, 'Many cultured and wealthy people' had followed Jones, son of the founder of the Sydney retail emporium, to Strathfield. Seven miles from the 'enervating moist sea-air' of central Sydney, 'Strathfield became, and remains, one of the leading residential suburbs.' The school was just 12 minutes' walk to the junction of four suburban railway lines, and a stopping place for country trains. Trams from surrounding areas passed close by. Thus it was convenient and safe for boarders, and day boys could 'avoid the dangers of changing trains or of passing through the City'.

Offering tuition in English Grammar and Literature, Latin, French, Arithmetic, Algebra, Geometry, History, Geography and Elementary Science, at eight levels, and meeting the extra-curricular expectations of the city's mercantile elite, must have demanded a great deal of the five teachers who assisted Strathfield's principal proprietor and headmaster. F. F. Wheaton, who had earned his B.A. (Syd.) as an evening student, began each day with prayers and scripture readings. His school provided for football, cricket, tennis and swimming, as well as a physical culture class with Robert Rae Turner, a partner in the rapidly growing Bjelke-Petersen Bros School of Physical Culture. A music tutor was available. All pupils had 15 minutes of exercise and drill every morning; and older boys like Dick fulfilled their compulsory military training requirements as junior cadets. At $£ 5.15 .6$ per term for tuition for students over 12 , and six

19 Bennett, Highest Traditions, p.108 has Wiesener born in 1920. For Wiesener's education and employment: Annex to Department of Air Press Release, 13 Aug. 1940, NAA: A98451, 318/43. 
guineas for the Intermediate candidates, it was a barely viable enterprise. The boarding option was terminated after three years and the school was bought by nearby Trinity Grammar in 1926, losing its separate identity six years later.

Strathfield Grammar's records have not survived. All we know of Dick's brief time there is that he competed in heat three of the under-14 100 yards handicap in the fifth annual sports meeting in 1923. More auspiciously, at the same meeting, competing in the under-14 220 yards championship, was a young member of the neighbouring Beale family, a son of Ronald Matthew Beale, scion of the Sydney piano and sewing machine manufacturing firm. ${ }^{20}$ Dick was soon to meet and be smitten by his school friend's sister, Elizabeth Joan, a pupil at Meriden, Strathfield's private school for girls. Betty Beale, as she was then known, was tall and fair-haired with two long plaits. Always full of fun, her friend Betty Kessell remembered, and a good tennis player, she knew Dick's own sisters, Mollie and Betty. They too were Meriden girls, and their youngest sister Patricia would follow. By 1924 there were so many Bettys in one of the Meriden senior classes that it was agreed that some of them would change their names. Betty Kessell became Bettina. Betty Beale became Joan. As they grew older, past and present Bettys, their friends, brothers and brothers' friends enjoyed weekend tennis parties on family courts, afternoon teas, and dancing to gramophone records.

Agreeable as the after-hours and weekend company was, Dick outgrew the Rev. Wheaton's establishment. To complete his schooling he moved in 1924 to the more prestigious Sydney Church of England Grammar School on the North Shore. Mysteriously, his new school's register records that at that time he was a 'ward of E. C. Mackay Westhoven Bancroft Ave Roseville'. Both his parents were alive and Edward Mackay's identity has proved elusive. Neither school archives nor family memory provide an explanation for the wardship. But it was not uncommon for boys at Shore, as the school was familiarly known, to live out. As Bancroft Avenue is just around the corner from Roseville railway station it would have been a convenient place to board and travel to North Sydney station. Conceivably, Dick's parents had left him with a guardian while travelling overseas, his father having completed his medical course in 1923 and been appointed to an honorary post as an ophthalmic surgeon at St Vincent's Hospital.

At Shore, Dick encountered some of the brightest boys in Sydney. The school had recently appointed Leonard Robson, a 28-year-old mathematics master from Geelong Grammar, as its headmaster; and the young broom, a Rhodes Scholar with an MC earned as an AIF lieutenant, was sweeping out moribund

20 I am grateful to Alison Field, Trinity College archivist, for information about Strathfield Grammar School; to Diana Tilley-Winyard (archivist), Bettina Gowing, and Anne Cooke, Visions of Parnassus: Meriden's first 100 years, Meriden School, 1997, for details of Meriden in the 1920s; and to Welwyn Petersen and Kate Riseley for material from Shore Archives. 
masters and himself taking the senior maths classes. ${ }^{21}$ Under the guidance of enthusiastic new staff, Dick was to compete with the gifted classics scholar Tom Dunbabin, who would become Reader in Classical Archaeology in Oxford, a Fellow of All Souls, and a decorated wartime intelligence officer and resistance leader in Crete; ${ }^{22}$ Laurie Fitzhardinge, a historian and versifier whose heart was to be in ancient Sparta but who was chosen by ex-Prime Minister Billy Hughes to write his biography; and the brilliant mathematician and physics student David Myers, whose glittering career in electrical engineering would culminate in his appointment as the first Vice-Chancellor of Latrobe University. Between them these four carried off most of the school prizes in their final year, with Fitzhardinge and Dunbabin scooping the major state awards in the Leaving Certificate examinations.

When he left Shore at the end of 1927, shortly after his libidinous rascal contemporary Errol Flynn was expelled, Wiesener had topped Form VIb and had passed seven Leaving Certificate subjects, with first-class honours in English and second-class honours in Physics. ${ }^{23}$ Having beaten David Myers for the school Physics prize, the second-class honour would have been a disappointment. Yet it may have been that Dick's competitive motivation was diminished as he had already determined on a non-academic future. Unlike his clever peers he did not go on to Sydney University. Instead, in a step that might have puzzled those who did not know his family connections, at the age of 18 he took up a fiveyear apprenticeship in Wollongong as an electrical fitter. In this step he would have enjoyed the support of his headmaster who had declared that 'the national prosperity depends more than ever before upon a high level of efficiency and endeavour in productive industrial and commercial life' ${ }^{24}$

Transferring after three years to special electrical welding work, Dick was employed at Australian Iron and Steel's Port Kembla steelworks. His introduction to AI\&S was through his mother, Wilmot, daughter of Charles and Emily Hoskins. His maternal grandfather was the founder of AI\&S. His uncles, Cecil and Sid, were joint managing directors of the AI\&S enterprise, owner of mines, quarries, and foundries as well as the iron and steel works, and employer of over 3000 people. The company, possibly the largest private company in the

\footnotetext{
21 G. E. Sherington, 'Robson, Leonard Charles (1894-1964)', John Ritchie and Di Langmore (eds), Australian Dictionary of Biography, vol. 16, MUP, 2002, pp.115-7; Peter Taylor, A Celebration of Shore, Sydney Church of England Grammar School in assoc. with Allen \& Unwin, Sydney, 1988, pp.31-3.

22 For Dunbabin's wartime exploits with SOE see Wes Davis, The Ariadne Objective: The Underground War to Rescue Crete from the Nazis, Crown Publishers, NY, 2013; Artemis Cooper, Patrick Leigh Fermor: An Adventure, John Murray, 2012; and N. A. Kokonas, The Cretan Resistance 1941-1945: The Official British Report of 1945 together with comments by British Officers who took part in the Resistance, Iraklion, Crete, 2004.

23 When Wiesener filled in his application for the RAAF he remembered only six Leaving Certificate subjects but doubled his number of first-class honours.

24 Geoffrey Sherington, Shore: A History of Sydney Church of England Grammar School, Allen \& Unwin, Sydney, 1983, p.114.
} 
nation until it went public in 1928, was hurt by the Depression. Its reliance on government contracts made it especially vulnerable to the collapsing economy of New South Wales. Yet even when fortunes were low there was always a place for a talented nephew in the family business. ${ }^{25}$

Dick had worked his way up from the shop floor but was evidently on the fast track to promotion. He was sent away for two periods of six months in the United States investigating steel pipe plants and new processes in the steel industry. But he had other ambitions. Port Kembla's grim environment and industrial strife held little appeal. By the time the family company was acquired by BHP in 1935 his heart was set on marriage, moving back to Sydney, and becoming a chartered accountant. He and his childhood sweetheart Joan, who had been born a day before him, were engaged late in 1933 and married in March 1935. Their first son, Richard Antony, was born in July 1937. Margot Abbey followed in November 1938.

Dick soon passed the intermediate examination and final law examination of the Chartered Institute of Accountants, and joined the firm of Halberg, Parsons, and Anderson as an audit clerk. After further experience with Smith, Johnson and Co., he moved as a fully-fledged cost accountant to become an audit clerk with Sorenson, Purves. There he became close to Ray Purves, the head of the Sydney office of the firm, who was only six months older than his new recruit. Meanwhile Dick had served three years in the Militia (19th and 34th battalions), reaching the rank of corporal. But like so many of his generation of independently wealthy professional men he also caught the flying bug. He was one of the earliest applicants under the pre-war civil air reserve plan. He had earned a civil 'A' pilot's licence a few months before joining the RAAF as an Air Cadet in January 1940 (Service number 607). Beginning at Mascot in No. 28 Flying Training Course A with C Flight, No. 4 Elementary Flying Training School, he completed his Service flying training with No. 22 Squadron at Richmond and was awarded a Distinguished Pass with a score of 85.14 per cent. ${ }^{26} \mathrm{He}$ was granted a commission as a pilot officer on probation in the Citizen Air Force on 4 May 1940.

The generally available record of Wiesener's training told a story that culminated in brilliant achievement. But before passing out at the top of No. 28 Flying Training Course A he had some inglorious moments. On his arrival at Mascot on

\footnotetext{
25 George Parsons, 'Hoskins, Charles Henry (1851-1926)', Nairn and Serle (eds), Australian Dictionary of Biography, vol. 9, pp.371-3; Sir Cecil Hoskins, The Hoskins Saga, Halstead Press, Sydney, 1969, p.119; Jim Hagan \& Henry Lee (eds), A History of Work and Community in Wollongong, Halstead Press in assoc. with Wollongong UP, Sydney, 2001, p.82; Donald G. Hoskins, The Ironmaster: The Life of Charles Hoskins 18511926, University of Wollongong Press, 1995; E. M. Johnston-Liik, George Liik, R. G. Ward, A Measure of Greatness: The Origins of the Australian Iron and Steel Industry, Melbourne UP, 1998.

26 AOC Laverton to Secretary Air Board, 9 May 1940, NAA: A705, 208/17/44. Wiesener's name is consistently misspelled in the course reports. The score is given elsewhere as 81 per cent.
} 
9 January 1940, he was taken into the care of W. E. Clarke, an instructor with Airflite (Training) Pty Ltd. Sixteen cadets under the command of Squadron Leader Alfred Ellis had been distributed between the Royal Aero Club, the Kingsford Smith Air Services Co., and Airflite. Six more went to Newcastle Aero Club. Subsidies to aero clubs having been abolished, cadets were being trained (unprofitably it was claimed) for £2.12.6 an hour. Clarke noted that his new pupil already had 25 hours solo but had not previously been in a DH82 (Tiger Moth). It was soon apparent that Dick's skills were only 'fair' at best. And he was suffering from air-sickness, for which the remedy was more spins. Allowed to go solo after seven hours, he was given a progress test after 11 days. Flight Lieutenant George Coleman, the chief flying instructor, was unflattering:

Thinks very slowly and not very deeply. Generally an erratic and inconsistent pupil who will have to be watched carefully \& prevented from developing wrong conclusions in his rather unusual train of thought. Reactions slow. Progress to be watched carefully.

Three hours and 40 minutes solo flying later, Airflite's chief flying instructor found the pupil's 'Judgement in landing not too good. Turns uncertain. Sideslips ditto. Unless improvement very soon, recommend cease flying Solo Practice.' The instructor persevered, recording slow improvement and indications of absorbing previous lessons'. But he adjudged the cadet 'Generally erratic...will fly well one day \& bad the next.'

Flight Lieutenant Coleman did not mince words. He judged that Wiesener's 'airmanship is bad', recording that he had always been 'a difficult subject' for his instructors. As a pilot, Dick was awarded 67 out of 100: 'a free \& easy outlook... prevented him from being higher than below average'. It was not that he did not try. But he was 'adversely affected by possessing what he considered more than average ability at other pursuits'. Elaborating, Coleman commented that Dick was a 'good type' inclined to be overconfident. Possessing an 'uncanny, retentive memory', he had secured the highest points in the 'progressive paper'. But to the evident irritation of the instructors he did not 'apply the same attentiveness' on the parade ground as he did in the lecture room.

While highlighting his faults, the final assessment from the flying training course acknowledged that with discipline Dick would 'probably make a good officer'. Attention needed to be paid to 'improvement of general bearing and outlook' ${ }^{27}$ There was perhaps a hint of resentment in the character assessments of the self-confident scion of a prosperous upper-middle class family. Dick's service pay of 21/- a day (including 2/- 'flying margin' and 5/- dependants' allowance)

27 Inexplicably, the record of Wiesener's flying training course is attached to a file of the Committee of Adjustment 'for the purpose of dealing with the public and private effects' of the personnel who died on 13 Aug. 1940 (NAA: A705, 53/1/739, viewed on 12 Dec. 2012). 
was a welcome income supplement. But he and Joan had other financial resources. Dick's grandfather, Theodore Frederick Wiesener, had left Goslar in Lower Saxony with his brother in 1869. He made a great name in Sydney as an entrepreneurial master craftsman, most renowned for the design of the internal workings of the Sydney Town Hall clock. ${ }^{28}$ Wiesener's instrument-making business in George Street was across the street from Gowings, the drapers, and next door to W. Abbey \& Co., boot and shoemakers. T. F. Wiesener had married his neighbour's daughter, Annie.

Dick's father, Frederick Abbey Wiesener, had stood aside when the world war ended to allow his younger brother George, discharged from the AIF, to take over the family firm. Frederick established himself instead in an optometry practice. Successful as he was, he was not satisfied by the professional limitations constraining optometrists. With medical qualifications finally achieved at the age of 46 he became a fashionable ophthalmologist and ophthalmic surgeon. It was perhaps a tribute to his mother's Abbey ancestry that he appeared in university calendars as 'Abbey-Wiesener, Frederick'. Sometimes there was a comma rather than a hyphen. In either case it might have deflected some of the lingering wartime 'lies \& calumnies disseminated by competitors' that the family had suffered. (Rumours that their proprietary company, registered in 1910, was an enemy business, flew in the face of the fact that its co-director, Frederick's 35-year-old widower brother, had enlisted in the Field Ambulance, contributing a fully equipped motor ambulance; and had served in motor transport and supply columns in Gallipoli, France, and Flanders for four years, earning a mention in despatches, promotion to sergeant, and a Meritorious Service Medal). ${ }^{29}$ It certainly did Frederick no disservice commercially to be listed in Knox's Medical Directory for Australia as the first name in the book. Neither he nor his son seems to have used a hyphenated form in official documents.

If Dick was only a hyphen removed from a craft and merchant background, the Beales were also 'in trade'. With a business employing over 500 people, theirs too was a recent urban fortune rather than a landed inheritance. However, following the triumphant showing of their wares at the Wembley Exhibition in London in 1924, Queen Mary had bought a Beale piano. This was a coup, commercially valuable, but also conferring a social cachet that could not be ignored in the outer reaches of the Empire. By the mid-1920s, although Joan's grandfather Octavius could be an embarrassment with his extreme views on racial and eugenic themes, the Beale family had scaled the heights of Sydney society. Joan's parents, Ronald and Gertrude Beale, were the object of local

28 Julian Holland, 'T. F. Wiesener', in Chris Pratten (ed.), Summer Hill, Ashfield and District Historical Society, 1999, pp.83-9.

29 NAA: A1 1917/17660; NAA: B2455 WIESENER WG. 
curiosity and envy as the owners of a croquet green, though it was no match for the miniature zoo with a peacock, monkeys, and other exotic denizens on parade with Dick's grandfather, Charles Hoskins.

Royal patronage of the Beale company, a priceless business advantage and a feature of their newspaper advertising, could not fail to be noticed in fashionable circles. Politically, more discretion was called for. Through both of their families Dick and Joan were connected to the smoke-filled rooms of conservative politics. Dick's uncle, Cecil Hoskins, had been an executive member of the All for Australia League, the movement that in 1931 had brought together Joe Lyons and other ALP defectors and dissident Nationalists. Membership of the League by their employees was strongly supported by the AMP Society on whose prestigious board Hoskins was an influential member. Hoskins was chairman of the Consultative Council, controlling conservative political pursestrings in New South Wales, and was an early member of the United Australia Party into which the All for Australia League merged along with the National Party. Critical 'unity conference' meetings were held in the AI\&S boardroom. ${ }^{30}$ Octavius Beale had been a vocal advocate of conscription in 1916, a pillar of right-wing politics and Masonic affairs in New South Wales. ${ }^{31}$ Joan Beale's uncle Rupert was also active in the All for Australia League. Although there were radical suspicions of Hoskins family involvement in the leadership of the anticommunist paramilitary New Guard in Wollongong, no such activities have been documented..$^{32}$

Ronald Beale, one of 10 children who survived their father, was fully occupied in the offices of the Beale family business. He succeeded as head of the company on his father's death in 1930. In a little-known collaboration in Sydney with the Marks Motor Construction Company, the Beale piano workshops had produced in 1933 a prototype car body of Queensland pine and walnut, glued under pressure with aircraft casein glue. The chassis was integral to a venture to produce an Australian car, largely financed by the recently knighted Sir Charles Kingsford-Smith, to be called after his famous aircraft, the 'Southern Cross'. Like many of Smithy's business schemes, notwithstanding the initial support of well-known Sydney business and political figures like Sir Charles

\footnotetext{
30 Strictly speaking, the AFA and the National Association ceased to exist after their members joined together in the new party in April 1932 (C. L. A. Abbott to J. A. Lyons, 19 Nov. 1931; J. P. McDonald to M. M. Threlfall, 24 Jan. 1933, Lyons MSS, NLA MS4851, Box 1, folder 8).

31 Andrew Moore, The Secret Army and the Premier: Conservative Paramilitary Organisations in New South Wales 1930-32, NSWU Press, Sydney, 1989, pp.133-4. For the AMP's attitude to the All for Australia League, see Michael Cathcart, Defending the National Tuckshop: Australia's Secret Army Intrigue of 1931, McPhee Gribble/Penguin, Fitzroy and Ringwood, 1988, p.47; Geoffrey Blainey, A History of the AMP 1848-1998, Allen \& Unwin, Sydney, 1999, pp.189-90, 238.

32 Len Richardson, The Bitter Years: Wollongong during the Great Depression, Hale \& Iremonger, Sydney, 1984, p.91. Charles Hoskins, on whom Richardson speculates, had died in 1926. Sid Hoskins, who managed the steel works, is a more likely candidate (Jim Hagan \& Henry Lee eds, A History of Work and Community in Wollongong, Halstead Press in assoc. with Wollongong UP, Sydney, 2001, p.82).
} 
Marr and Richard Windeyer KC, it struggled for lack of capital. Dick Wiesener did not need the connection with his fiancée's family to be fascinated by the celebrated aviator whose disappearance and presumed death in 1935 ended the motor vehicle project. ${ }^{33}$ But it is easy to believe that he would have seized any opportunity to be in the great man's presence. For an eager young flyer there could be no more desirable company.

\section{Pilot officer}

When Dick went down to Melbourne in May 1940 in his new uniform as a pilot officer, Joan stayed back in Sydney in 'Endymion', their rented Ethel Street, Burwood home, awaiting the birth of their third child.$^{34}$ Her parents lived just across the road. It would be time to decide where the growing young family might live when Dick had completed his training and the baby was born. Anticipating some leisure, Dick had taken his golf clubs and his Zeiss camera. But now the Service adventure was gathering momentum.

Making his first serious flight in a Hudson with a cabin full of brass hats and Cabinet ministers was the beginning of what promised to be the RAAF experience Dick Wiesener had been hoping for. He had seen the Hudsons being put through their paces at Richmond and for the last month or so in the air above Laverton. He had felt their power in a short flight and had regaled his friends with the thrill of it. Dalkin, White, and Fowler already knew him as the best mind among them. They all had a lot more serious flying time than his 87 hours 40 minutes (less than half of them solo). But when they needed guidance with mathematics and trigonometry, it was the former engineer and accountant they turned to. When the class passed out together from the navigation course on Friday August 9, he was the only one of 11 graduates awarded a 'special distinction'. ${ }^{35}$ Bob Dalkin was to recall Dick Wiesener, only a few years older than some of the others in the group, as almost a father figure to the unruly knockabout types on the course with him. 'Although,' Dalkin admitted, 'we were a bit hard to control.'

Perhaps feeling that it would be sensible to spend some more time with the manual and charts, and get a good night's sleep, Wiesener did not show up in the mess on Monday evening. Anticipating some navigational chores when he sat next to Hitchcock in the morning, he borrowed Dalkin's brass divider before turning in. He did not join the others for a drink. Peter Fowler, who

33 Pedr Davis, Charles Kingsford Smith, The World's Greatest Aviator, Lansdowne Press, Sydney, 1985 (1st ed. Summit Press 1977), p.115; The Argus, 5 Jan. 1934.

34 E. Joan Wiesener to $\mathrm{CH}, 19$ Sept. 1977.

35 No. 8 NR course, NAA: A705, 208/14/58. 
had been told he was to fly the next day to Mount Gambier and Adelaide in another Hudson with Ray Garrett and the photographer Frank Jefferies, had also retreated to prepare himself for taking the second seat. 'We always had a couple of beers, we always had dinner, and it was the custom if you went flying,' said Dalkin. 'I talked to Hitchcock that night, I think with White, over a cup of coffee, and I remember we were quizzing Hitchcock about the aeroplane and this sort of thing. ${ }^{36}$

Next morning, as Dalkin and the others were wandering down to morning parade, A16-97 was already in the air. Charlie Crosdale was perched in the cabin, with Jack Palmer attending to the wireless apparatus in his cramped niche immediately behind the pilot's seat, and Dick Wiesener alongside the pilot in the cockpit. Bob Hitchcock was in command and about to display for the most distinguished passengers he had ever flown just what his powerful new aircraft could do. 


\section{His father's son: Bob Hitchcock}

In August 1940 anyone familiar with Australia's recent aviation history would probably recognise the name Bob Hitchcock. Not the 28-year-old Flight Lieutenant Hitchcock who was trained to take the controls of the latest Hudson bombers to be delivered to the RAAF's No. 2 Squadron. But his father, the tragedy of whose death while searching for Charles Kingsford-Smith's missing Southern Cross had been on every Australian front page and silent cinema newsreel in 1929, and in books and countless articles in the years that followed. Henry Smith 'Bob' Hitchcock had perished with Keith Anderson in a futile attempt to find the aviation heroes Charles Kingsford-Smith and Charles Ulm. His name was perpetually inscribed alongside those of some of Australia's most celebrated aviators. ${ }^{1}$

Bob Hitchcock senior was born in Broken Hill in 1891. With his mother and 12 siblings he followed his father Harry in search of work to Adelaide and further west to Kalgoorlie, Perth, and Fremantle. Little is recorded of his childhood. He attended South Kalgoorlie Primary School until he was 12 or 13. His sister Pretoria remembered him about this time occasionally disappearing into his father's workshop and reappearing with a tiny wooden aeroplane fashioned from a clothes peg. Other accounts suggest a continuing fascination with building model aircraft. Apprenticed as a bricklayer (his father's trade), Bob - as he preferred to be known - did not complete the apprenticeship. By the time he married Violet Bourne in 1911 his parents had separated and his mother had settled in Perth with the younger children. Bobbie, as many people were wont to call him then, had worked briefly as a barber while hankering after a job that would use his mechanical talent. He found a position as a buggy driver for a mine manager's family in Kalgoorlie and, when his employer, Ralph Nichols of the Great Boulder Perseverance, bought the town's first motor car, he took the chauffeur's seat. Later, according to Army records, he was a 'labourer' and a 'blacksmith's striker'.

When war came, Bob left Violet and two boys behind in Boulder City and enlisted early in 1915 for service abroad. Posted to C Company, the $28^{\text {th }}$ Battalion, $7^{\text {th }}$ Brigade, he was with the ANZACs at Gallipoli in the autumn. But within a few months he was stricken with bouts of fever, jaundice, and endocarditis. Several hospital stays brought no relief from 'valvular heart disease'. He had suffered a minor wound but his condition was described as 'Constitutional. Aggravated by Active Service.' Poor nutrition and pneumonia from prolonged exposure had severely weakened him. He had hopes of being accepted for the Royal

1 I am persuaded by Keith Raymond Meggs, Australian-Built Aircraft and the Industry, Vol. One: 1884 to 1939 Book 1, Finger-Four Publishing, Seymour, Vic., 2009, pp.161-3, that Kingsford-Smith should be hyphenated. 
Flying Corps but allegedly 'owing to his weight' that was not to be. Pronounced 'permanently unfit for service' and totally incapacitated from earning 'a full livelihood in the general labour market', he was shipped home from Egypt in April 1916. His luck was in. By war's end the $28^{\text {th }}$ Battalion had the fifth-highest casualty rate in the AIF. ${ }^{2}$ Further medical examination in Fremantle confirmed the Cairo diagnosis but concluded that Hitchcock was now fit for less-strenuous occupations. He was discharged in May 1916 and awarded a pension of 16 shillings a fortnight. Eventually Bob found work at the Ivanhoe Gold Mine in Kalgoorlie then drove trucks for the Salvation Army Hope Service in Perth. Building on some experience he had enjoyed with the Atlas Engineering Company in Fremantle and occasional workshop repairs in Kalgoorlie, he was to become a largely self-taught but exceptionally skilled and creative mechanic. ${ }^{3}$

\section{Records, recriminations, and rescues}

In 1922 Hitchcock found employment as a ground engineer in Major Norman Brearley's Western Australian Airways, a 'small \& economical' venture according to Lieutenant General Sir Brudenell White who visited the workshops in April 1923. ${ }^{4}$ There Bob would meet two young war flyers in search of work and fortune, Keith Anderson and Charles Kingsford-Smith. His destiny was inextricably linked thereafter with the two men whose record-seeking adventures were to fascinate Australia in the years that followed. Caught up in the enthusiasms of Smithy and Anderson, in 1926 he drew on his slender savings to join them in attempting to start a new air service from Port Moresby further into the New Guinea highlands where gold had been discovered. The New Guinea venture was Bob's idea. While his two associates were vainly attempting to break the Perth to Sydney flying record, he had done much of the organising and had even secured his miner's right. Sadly it came to nothing. Smithy, at first keen, was deterred by photographs of the unfriendly terrain. ${ }^{5}$ Moving across the country

\footnotetext{
2 Neville Browning, The Blue \& White Diamond: The History of the 28th Battalion 1915-1919, Advance Press, Ballajura W. A., 2002, p.589.

3 Bob Hitchcock's life and his role in the search for Kingsford-Smith's party is outlined in Dick Smith and Pedr Davis, Kookaburra: the most compelling story in Australia's aviation history, Lansdowne Press, Sydney, 1980. Additional details from war service records (NAA: B2455 HITCHCOCK H 441), Harry Hitchcock to GpCpt Eric Douglas, 28 Aug. 1957 (courtesy Dr Charles Eaton), and interviews with his nephews Barley and Lyle Hitchcock (sons of Bob's brother Stan), 22 Sept. 1992, and niece Gwen Bliss (daughter of Pretoria Hitchcock), 19 Sept. 1992, transcripts courtesy of Ian Mackersey. Peter Fitzsimons has Hitchcock born in Kalgoorlie and 'badly wounded' at Gallipoli (Charles Kingsford Smith and Those Magnificent Men, Harper Collins, Sydney, 2009, p.240).

4 White diary, 20 April 1923, White MSS, NLA MS 5172/9.

5 Norman Ellison, Flying Matilda: Early Days in Australian Aviation, Angus and Robertson, Sydney, 1957, pp.302-3. Ellison MSS NLA MS 1882 3/31 for Kingsford-Smith's sister Elsie recalling 'Bobby simply bursting with a splendid project'.
} 
to Sydney with two superseded Bristol Tourers bought from Norman Brearley in January 1927, the three men had thoughts of running a transcontinental air service.

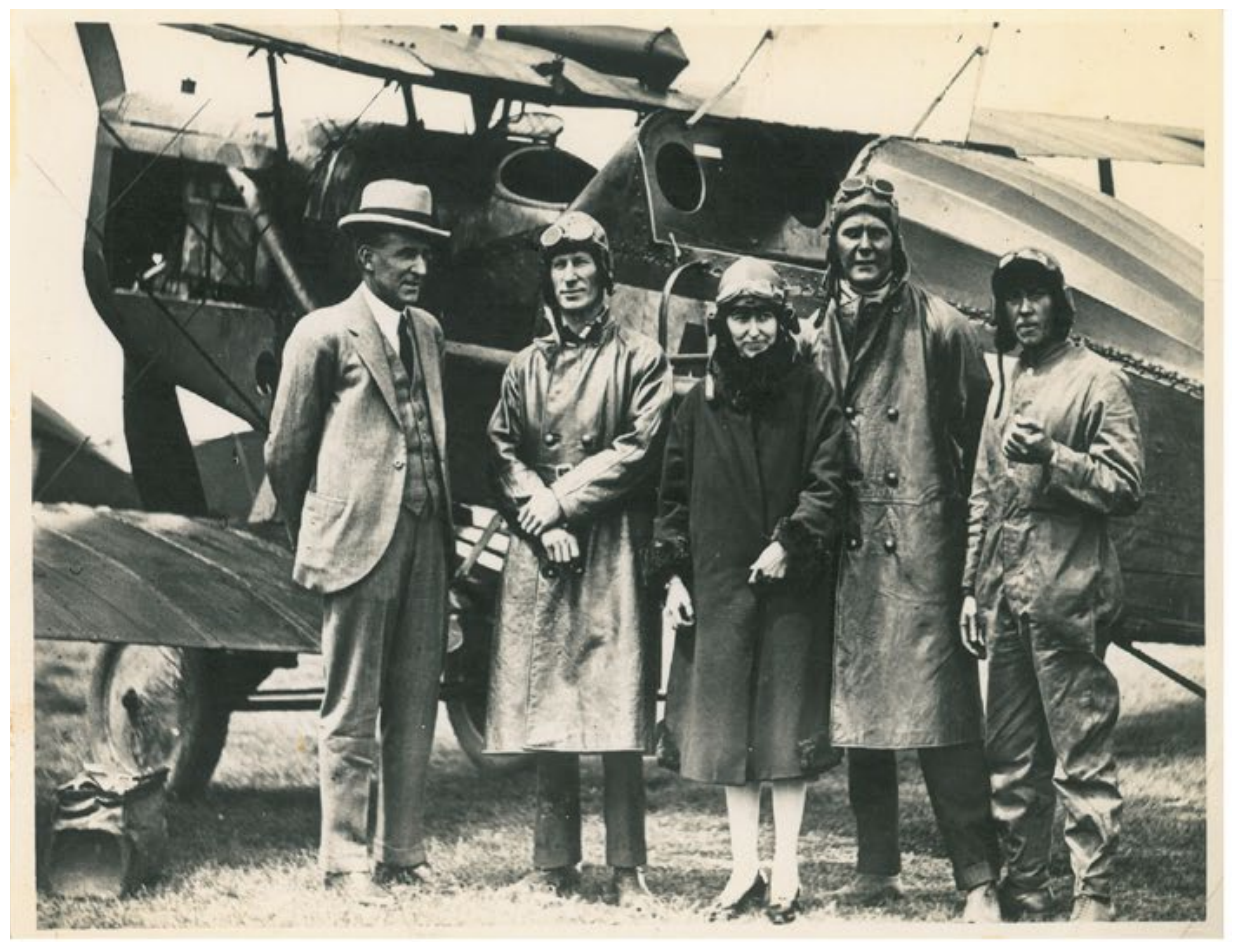

\section{Smithy, Anderson and Bobby Hitchcock with the Marshalls of Smith's Weekly, Maylands Aerodrome, Perth}

(Courtesy of Ian Hitchcock)

Later that year Kingsford-Smith flew around the country in a record-making attempt with a new associate, Charles Ulm, who had displaced Anderson. Hitchcock happily accompanied a disgruntled Anderson and an observer, Charles Vivian, in the second Bristol. Their passenger was the representative of George A. Bond \& Co., hosiery manufacturers, with whom Ulm had secured a sponsorship deal.

In the days that followed, Bob was to have a devastating shock. He had given up his job on the understanding that he was to take part in the world's first east-west trans-Pacific flight. But when it came time to depart for the United States he was dropped from the team to make room for Ulm. Anderson too was eventually dumped. Believing themselves to have been the victims of broken promises, depriving them of places in the epic 1928 flight and the fame and financial reward that followed, both Hitchcock and Anderson had a bitter falling out with 'Smithy' and Ulm, now Smithy's business partner. After prolonged 
recrimination and litigation the fractured relations remained unhealed. A 'gentlemen's agreement' and a cheque for £1000 - repayment of what he had invested in the enterprise - had helped soften Anderson's pain. Hitchcock was not so fortunate, eventually in March 1929 losing a costly and humiliating court battle over Smithy's alleged and subsequently denied pledge that 'on our return to Sydney we'll pay you a thousand pounds for dropping you out'. The two teams went their separate ways. ${ }^{6}$ Bob scratched a living in Sydney with casual work as a mechanic. He boarded in a room at the Customs House Hotel in Macquarie Place. Whenever he could, he sent money back to support the family in Western Australia. In 1928 he and Anderson had set out on their own attempt to fly to Britain in record-breaking time. They got as far as Darwin, where they crash landed their Bristol. Hitchcock's left leg was badly gashed and the wound, slow to heal, became infected. ${ }^{7}$

On 30 March 1929, Kingsford-Smith, Ulm, and two companions took off from Sydney in their famous aircraft, the Southern Cross, to fly across the continent on the first leg of a round-the-world flight. Meanwhile Anderson, with Hitchcock's aid, had been secretly planning a record-breaking 24-hour solo endurance flight in his own small aircraft, a Westland Widgeon III, which he had christened the Kookaburra. At the RAAF base at Richmond in New South Wales they were ready to set off when news came that the Southern Cross had disappeared somewhere in northwest Australia. Whatever their differences had been, Anderson - 'the Dreamer' as he was known at Mascot - had an abiding affection for Smithy. ${ }^{8}$ While others dithered over the organisation of a search he was sure he could find his old friends. After a whip-around, Jack Cantor, publican of the Customs House Hotel and former business associate of Smithy's, made up an offer of $£ 500$ to defray the cost of a search. ${ }^{9}$

\footnotetext{
6 The falling out between Kingsford-Smith and Ulm, Anderson and Hitchcock, is best recounted in Ian Mackersey, Smithy: The Life of Sir Charles Kingsford Smith, Little Brown \& Company, London, 1998, pp.81101,179-82.

7 According to Dick Smith, nurses at Alice Springs hospital had told Charles Eaton, the RAAF officer heading the search for the lost flyers, of a blood-poisoned arm. Fitzsimons, citing no authority, refers to a bandaged right arm. But Nurse Annie Inglis deposed that she treated and bandaged Hitchcock's leg; and Sgt Eric Douglas, second in command of F/Lt Charles Eaton's RAAF search party, referred to a bandaged left leg. ('Report on Operations in Connection with Search for, and Burial of, Lieutenant Anderson and Mr. Hitchcock', Apps VIII and IX, NAA: A705, 21/1/84 Pt 3; 'Final Version of the Search 1958', unpublished MS, courtesy of Sally Douglas).

8 Milton Kent to Eric Douglas, 19 June 1958, courtesy Dr Charles Eaton.

9 A $£ 500$ contract between Anderson and Cantor, requiring private progress reports, was found among Anderson's papers (The Mercury, 28 May 1929).
} 


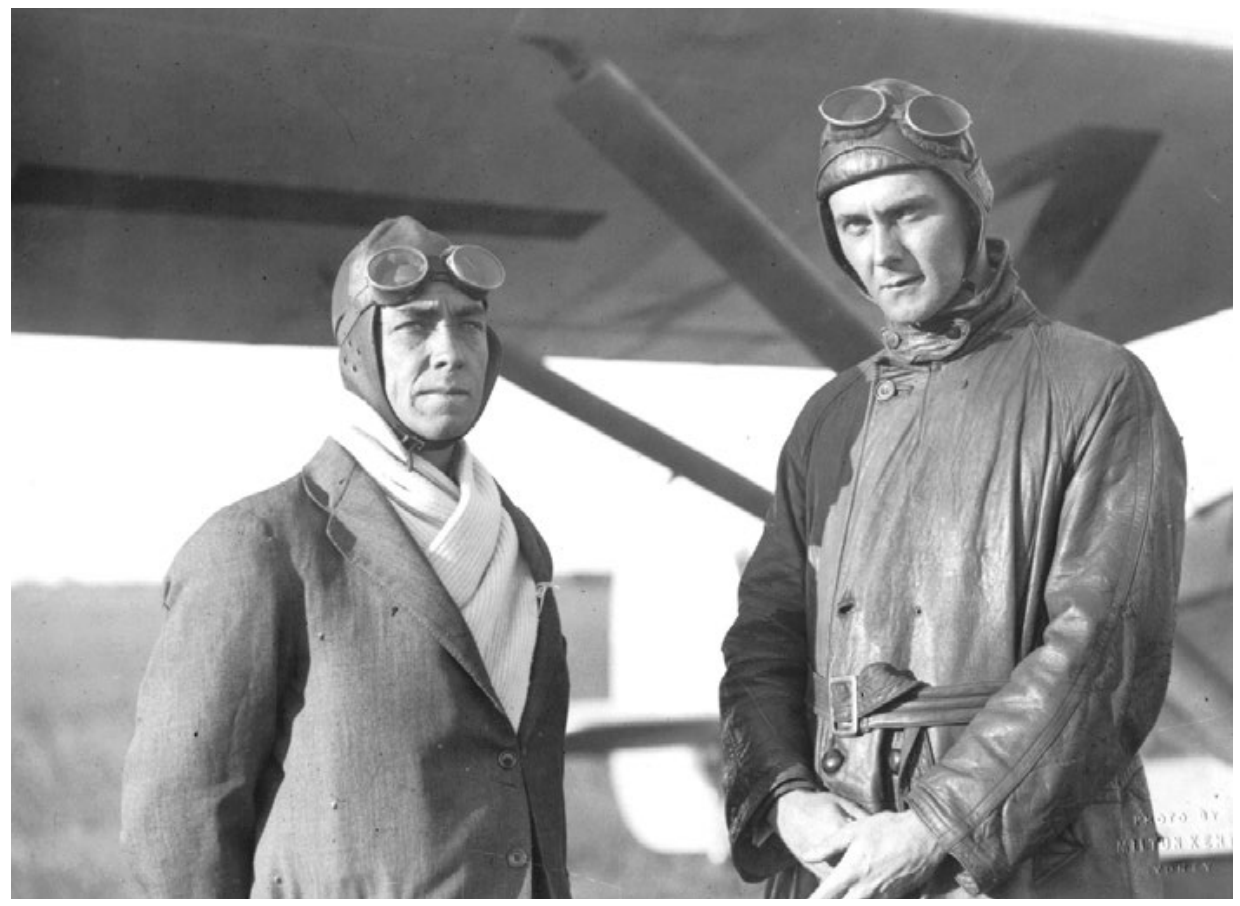

\section{Bobby Hitchcock, Keith Anderson, and the Kookaburra}

(Photo by Milton Kent, Sydney, courtesy of Sally E. Douglas)

Anderson was on the verge of launching a new career with Hitchcock as a roving promotional team for a suit of flying gear designed and manufactured by George Bond. There was another sponsorship agreement with Smith's Weekly. For Hitchcock the job with the American businessman meant the chance of some financial security for the first time in his life. But a quick telephone call from Anderson and the offer of a fee of $£ 100$ changed his priorities. Though still nursing his injured leg, and weakened by blood poisoning, he did not hesitate. They would search for the men they still thought of, in spite of their acrimonious recent history, as friends. Bond, the managing director of a firm soon to be nationally renowned for its 'Chesty' Bond brand, had given Kingsford-Smith and Ulm athletic singlets and woollen underwear the previous year for their Pacific flight. Bond had used the endorsements of the famous flyers in his advertising. He was happy to give Hitchcock and Anderson, who had made the first 'commercial' flight with his advertising manager in 1927, leave to defer taking up their appointment as company ambassadors. Perhaps unwilling to let it be known how desperately poor he was, on March 13 Bobby had already pawned his only valuable possession, a gold watch and chain 
with a small nugget pendant, for $£ 2.10 .0 .^{10}$ Jack Cantor had paid $£ 100$, to be treated as a loan, covering Hitchcock's arrears at the Customs House Hotel. The loan probably would have been discharged had Bobby forgone his fee for accompanying Anderson on the rescue mission. Still he could not afford a warm coat; he left Richmond in a shabby woollen suit, scarf, and flying helmet.

The extra fuel tank Anderson had installed in the front cockpit of the Kookaburra meant that they could cover the long distances. But to reduce the time it would take to reach the supposed location of the Southern Cross, Anderson departed from the safe overland telegraph route and took a shorter course over the Tanami Desert. He could not foresee the navigational error in seven hours flying from Alice Springs with Hitchcock's second-hand compass - the instrument, poorly adjusted, further affected by the theft of spare parts and tools that had been stowed close to it. Perhaps he should have planned for a mechanical failure, such as a faulty push-rod coming loose, and a forced landing in the desert. Ultimately, not carrying a radio or enough water, or an axe or shovel, sealed the would-be rescuers' fate. Unable to clear the scrub that surrounded them, they could not take off again or tell anyone of their plight.

The Southern Cross and its crew were eventually found, relatively unharmed, though allegations that their disappearance had been a publicity stunt persisted in spite of a subsequent inquiry into the 'Coffee Royal' affair that cleared Smithy and Ulm. Anderson and Hitchcock were lost somewhere in the spinifex and termite mounds of the Tanami Desert where they had made an emergency landing on April 10. Hitchcock had repaired the engine, but they could not get the aircraft back into the air. An unsuccessful RAAF search for the missing men led by Flight Lieutenant Charles Eaton resulted in the loss of three out of five obsolete World War 1 D.H.9a aircraft. Eaton's own plane, A1-1, the RAAF's first, had caught fire in the air and crash landed at Tennant Creek. Not till April 21 did Lester Brain, an RAAF reserve pilot working for the fledgling outback airline QANTAS, locate the tiny Kookaburra. The Sydney Citizens Relief Committee had raised $£ 7000$ with which to compensate a reluctant Hudson Fysh of Qantas for the use of an aircraft and Brain's services. Brain had met Hitchcock and Anderson in Townsville on their round-Australia flight. He could scarcely believe the recklessness of their rescue mission. He knew the Tanami area well, having flown an American gold hunter there a few years earlier. With the benefit of his directions, a group on horseback guided by RAAF aircraft and Aboriginal trackers reached the scene over a week later. ${ }^{11}$

10 Believing the watch to have been stolen, the Commonwealth Investigation Department located it three months later in a Paddington pawnshop (Barrier Miner, 2 Aug. 1929, The Mercury, 3 Aug. 1929).

11 For Brain's remarkable career, see Cameron Hazlehurst, 'Brain, Lester Joseph (1903-1980)', in Ritchie and Cunneen (eds), Australian Dictionary of Biography, vol. 13, pp.247-8 and Neil Cadigan, A Man Among Mavericks. Lester Brain: Australia's Greatest Aviator, ABC Books, Sydney 2008. Dr Charles Eaton's forthcoming biography of his father, The Cross in the Sky, is the most authoritative account of the RAAF searches. 
Eaton's party, who had themselves been fortunate to survive an appalling journey, buried the two men where they found them. The harrowing final days of Anderson and Hitchcock were partly recorded by Anderson in a diary scrawled on the aircraft's rudder. Hitchcock's Bible, found on the starboard wing under which he lay in his underpants and singlet, gave some hope that, as a devout member of the Church of Christ, he had not perished without consolation.

The 37-year-old 'Air Mechanic H. S. Hitchcock', as the newspapers described Lieutenant Anderson's companion, left a widow, Violet, living in Victoria Park, Perth with three sons: Robert Edward (almost seventeen), Albert Leslie (fifteen), and Henry Smith (fourteen, named after his father).

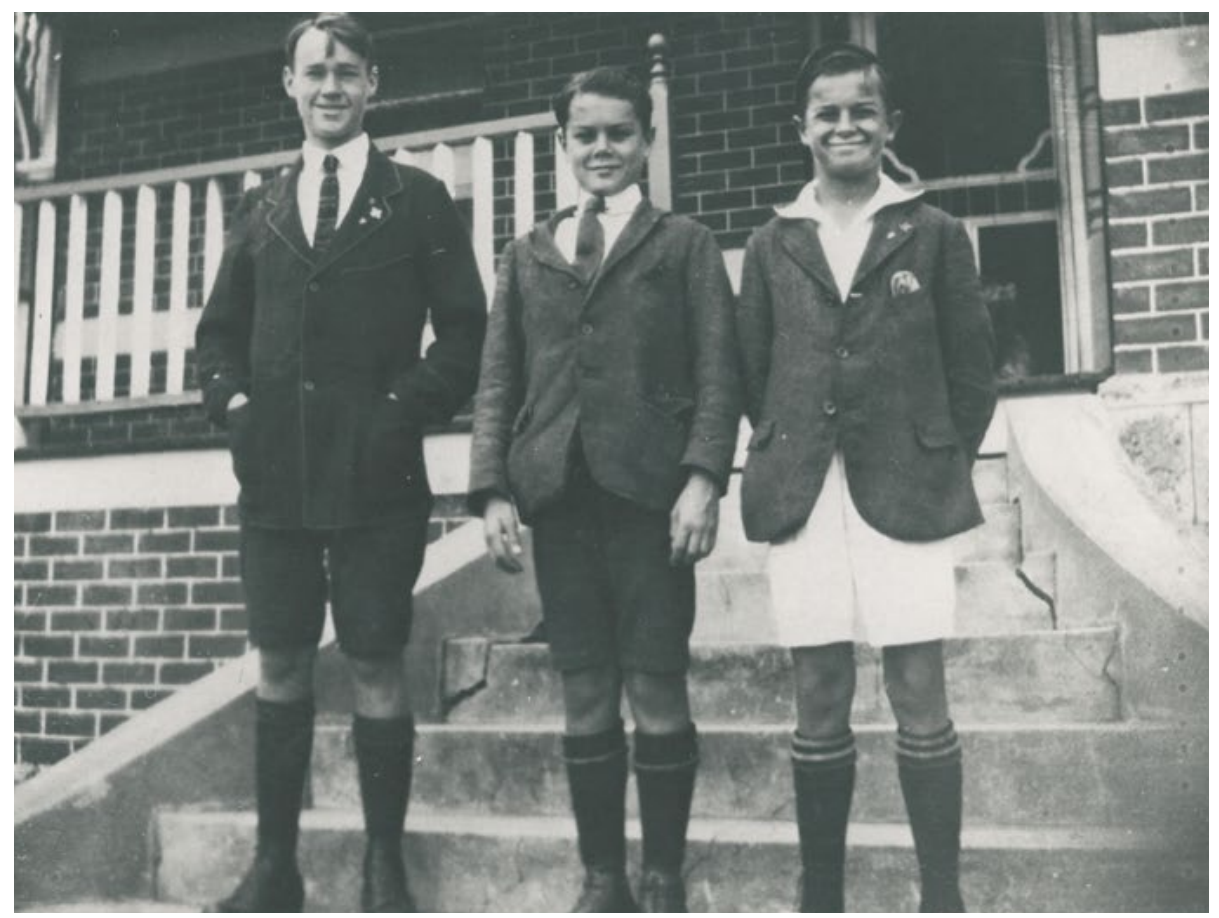

The Hitchcock boys: Bob, Les, and Harry, 1928

(Courtesy of Les Hitchcock)

In the words of the Register News Pictorial, Bob Hitchcock's widow and children were 'not in good circumstances'. There were also two surviving brothers and five married sisters to mourn Bob. Although there were tensions between Violet and her in-laws, they were united in rejecting the idea of erecting a memorial to the two Kookaburra heroes in central Australia. If there were to be a memorial, they said, far better that it be in Perth, where both men had relatives and friends. 
But first the families understandably wished that the bodies should be brought home for re-burial. While arrangements were made for Anderson, it was not at first clear who would bear the cost of repatriating Hitchcock's body or, indeed, whether it might not be necessary initially for an inquest to be held, perhaps in Alice Springs. From Canberra came the insensitive news that no action had been taken by the Commonwealth government which was awaiting information about the financial position of the families. Nothing would be promised 'unless it is informed they are in necessitous circumstances'. ${ }^{12}$ The Perth Aero Club promptly sent a telegram to the Prime Minister, Stanley Bruce, affirming that the Hitchcock family was in need of assistance. Bob's brother Stan had already written on behalf of his siblings and parents asking that 'our hero brother and son's body' be brought back to Perth as soon as possible 'so that we will be able to pay our dear one last respects'.

After a week of deliberation, the Prime Minister's public service advisers concluded on 2 May 1929 that there was nothing to distinguish this case from many similar ones in which lives had been lost in an attempt to save others. The Commonwealth had not granted assistance previously. To do so now would be to establish a precedent that 'might be attended by embarrassing consequences in the future'. Government indifference to the plight of the widow and her three sons presumably would be attended only by tolerable embarrassment. If help were to be given from Canberra it would have to be without publicity. These were the same advisers who had earlier issued a press release over the Prime Minister's name announcing that the government would, if funds from private subscription were insufficient, provide assistance for a search for Lieutenant Anderson 'and his mechanic' ${ }^{13}$ Eventually, pressed by MPs, especially John Curtin from Fremantle, and shamed by public reaction, the government sent an expedition to exhume the bodies and return them to their families. Anderson was in due course given a magnificent state funeral in Sydney with military honours and an aerial salute. Bob Hitchcock, at his widow's request, was buried quietly and privately at Karrakatta Cemetery in Perth. Kingsford-Smith had already left for England the day after the Committee of Inquiry had cleared him, his absence never to be forgotten by the Hitchcock family. ${ }^{14}$

Unbeknown to the government and to the public at large, Violet Hitchcock had long been estranged from her husband. Although she had let it be thought by relatives that Bob had deserted her and left her destitute, the truth was that she had formed another relationship while he was pursuing business ventures in eastern Australia. News of his wife's changed circumstances had come to Bob in a shocking way. He received a letter from her doctor asking for his permission

12 Register News Pictorial, 25 April 1929 (courtesy of Ian Hitchcock).

13 NAA: A461, H 344/1/13; A458, AH314/4.

14 Joyce Batty, unpublished memoirs, Been There Done That, Ch. 15, p.45, courtesy of Bob Landt. 
for her to have a hysterectomy. Realising the seriousness of the operation he travelled back to Perth by train only to discover Violet at the hospital in the company of another man. A distressed Bob, mindful of his church's teachings on the sanctity of marriage, would not agree to a divorce. He went back to Sydney.

A photograph of an unidentified dark-haired young woman, found with his Bible near his body, suggests that Bob might have found happiness there. ${ }^{15}$ Nevertheless he continued, whenever he could, to send remittances to Violet to support the boys. Les would say in later years that money from his father came 'seldom'. But, although his income was unpredictable and never substantial, Bob had always done his best to provide for his family. When he filled in his Army enlistment form in 1915, he had struck out the required standard threefifths allocation of his pay to wife and children and inserted four-fifths. ${ }^{16}$ After the war and until his death, Violet had drawn Bob's partial Service pension of about a guinea a week, as well as the seventeen shillings she was entitled to for herself and the children. Now she faced the prospect of caring for her children with the primary source of funds from an honourable husband greatly reduced.

\section{The will to succeed}

Violet Hitchcock could not rely on government to meet her needs. On seeking to collect her family's pension a week after Bob disappeared, she had been refused his money because she declined to certify that to the best of her belief he was alive. The Repatriation Commissioner had intervened to insist that she receive the money until her husband's death was proved. It was a short reprieve. ${ }^{17}$ And for a widow in Perth there would be no other pension. In New South Wales a widows' pension scheme (restricted to widowed mothers of children under fourteen) had been introduced in 1926. Western Australia had not followed suit; and it was not until 1942 that the Commonwealth legislated for the nation as a whole. ${ }^{18}$ In time Violet found work with the Perth Electric Tramways Office. But a way in which the family's circumstances could be improved immediately

\footnotetext{
15 Eaton's inventory of items found in and around the Kookaburra records these words on the back of the photograph in the Bible: 'No 233. Madigans Pharmacy, Bondi Junction.' A second photograph found at the scene was of a child, taken in Hill St, Blayney in March 1929, and inscribed 'Wishing you the best of luck.' Bob Muir, the Blayney garage proprietor, had refuelled the Kookaburra free of charge; Dick Jackson, one of Muir's salesmen, lent Anderson and Hitchcock a leather coat ('Royal Australian Air Force - Report on operations in connection with search for, and burial of, Lieutenant Anderson and Mr Hitchcock', NAA: A9376, 48; and see http://www.janesoceania.com/australia_historical_truestories, accessed 31 March 2012). 16 Attestation Paper, 4 March 1915, NAA: B2455 HITCHCOCK H 441. The background to the Hitchcocks' separation was provided to Ian Mackersey by Bobby's nephews.

17 The Advocate, 29 April 1929.

18 Joy Damousi, 'The State and the Widow: Pension Debates in Inter-War Australia', in Lynne Haney and Lisa Pollard (eds), Families of a New World: Gender, Politics, and State Development in a Global Context, Routledge, New York, 2003, pp.99-118.
} 
was by securing the employment and prospects of the boys. Norman Brearley, Hitchcock's unashamedly parsimonious former employer, was to recall that Bob was, like many other employees in the company, 'reliable and efficient, but I knew nothing of their family affairs' ${ }^{19}$ Brearley, sensitive to public opinion, had sent up a number of his own aircraft in the search for Bob and Keith Anderson. However, the surviving widow and her sons, none of whom he had met, were not his problem.

Fortunately friends and neighbours rallied to support the bereaved family. The local baker instructed his bread carter to leave loaves at the Hitchcock house every day whether Mrs Hitchcock said she needed them or not. And there was to be no charge. Bob, the oldest boy, born on 19 June 1912, had earlier been taken under the wing of Bob Pritchard, a meat-carting contractor who lived several doors away in Victoria Park. Pritchard had three school-age sons of his own but sympathised with the Hitchcocks' precarious financial situation. 'The job was a sinecure,' Bob's brother Les, 15 months younger and the inheritor of the seat on the cart, recalled, 'because all Bob had to do was sit on the contractor's truck and keep the contractor company and listen to his amateur singing while they travelled between the abattoir and Perth's butcher shops.'

The diminutive Les ( 5 feet $6 \frac{1}{2}$ inches and $8 \frac{1}{2}$ stone), incapable of lifting, let alone carrying, a 150 to 200 pound quarter of beef, was being paid £2 a week for accompanying the meat truck. It was time for Bob to move on.

Employment as a delivery boy with Perth's Bon Marché department store came first. Then the manager of the Yellow Cab company took him on as a messenger. Harry too was working for Yellow Cabs. The boys quickly showed their mettle in declining to accept their workmates' proposal to launch a memorial fund in honour of their father: '...dad left us mum to look after. We will work and do what he wanted' ${ }^{20}$ Happily for Bob, within a short time he was given the chance to exchange his office clothes for overalls. He could therefore properly be described as a garage hand (greaser) when, the day before his eighteenth birthday, he enlisted for six years in the RAAF. ${ }^{21}$

With his father's technical prowess as example, and the encouragement of his mother, herself once a keen passenger on flights to the northwest with her husband, he had set his sights on joining the Air Force. Shortly after his father's death he had asked his local MP, John Curtin, for help. Curtin's friendship with the Scullin government's Minister for Defence, A. E. 'Texas' Green, MP for Kalgoorlie, may have been crucial. Green had been instrumental in securing

19 Sir Norman Brearley to $\mathrm{CH}, 30$ March, 9 April 1982.

20 Barrier Miner, 2 May 1929.

21 NAA: A9300, HITCHCOCK RE Unless otherwise indicated, details of Hitchcock's service record are from this file. 
a training scheme for RAAF pilots and in adding to the Air Force's exiguous complement of aircraft. More important, he earned the gratitude of Air Commodore Richard 'Dicky' Williams, the Chief of the Air Staff, for resisting the push, led by the influential former Chief of the General Staff Sir Brudenell White, to end the RAAF's autonomous existence and amalgamate separate elements with the Navy and the Army. ${ }^{22}$

Bob Hitchcock was later to tell fellow airmen that his mother had been assured that he and his brothers, who were both to follow him, would be taken into the RAAF when they were old enough. Initially he applied for a cadetship but he was informed that he did not possess the necessary educational qualifications. It was not for want of effort. He had already been motivated to learn carpentry, blacksmithing, tin-smithing, and mechanical drawing. Then at Perth Technical College he had passed a day engineering apprenticeship course. In his free time he was an active member of the Perth Rover Crew. In January 1929, with his friend Les Lingwood he attended an All Australian Scout Corroboree celebrating the centenary of the settlement of Western Australia, including a four-day camp and hike at Dwellingup in the state's southwest.

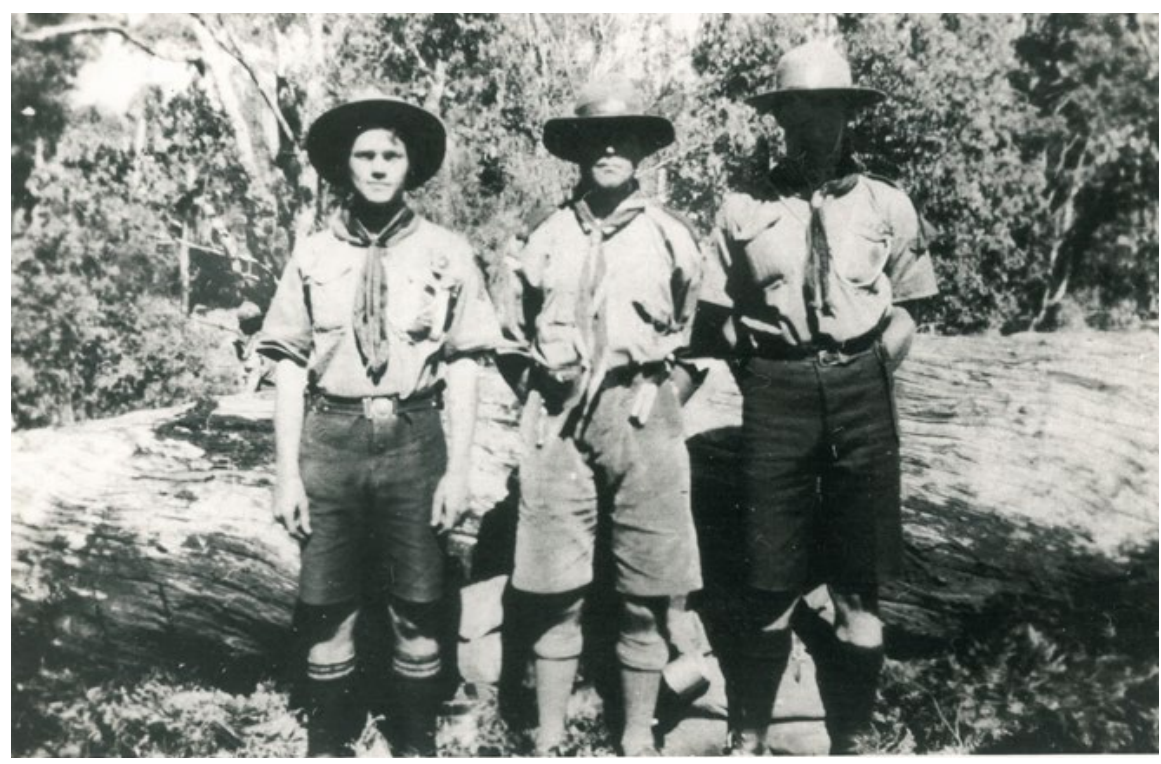

The practised photographer Bob Hitchcock ensures the sun is on his face, with friends at Scout Jamboretta, Dwellingup, January 1929

(Courtesy of Les Lingwood)

22 G. C. Bolton, 'Green, Albert Ernest (1869-1940)', Nairn and Serle (eds), Australian Dictionary of Biography, vol. 9, pp.89-90; C. D. Coulthard-Clark, The Third Brother: The Royal Australian Air Force 1921-39, Allen \& Unwin in association with The Royal Australian Air Force, Sydney, 1991, pp.72-4. 
This was a youth determined to better himself. Finally he augmented his credentials for a Service career during a year as a senior cadet in the Citizen Military Force, $28^{\text {th }}$ (infantry) Battalion, his father's old unit. John Curtin, who continued to take a close interest in young Bob's progress, had no hesitation in pulling the strings necessary to ensure that his application to the Air Force was successful. ${ }^{23}$ The recruit's attestation form noted that he was enlisted by 'special authority' number AS. 9139 on 18 June $1930 .^{24}$

Past the doorstep of the service at last, like all new recruits Bob Hitchcock was numbered (115), then measured and medically scrutinised in Perth by a military doctor, Colonel Douglas McWhae. Fair complexion, light brown hair, blue eyes, and a small mole right of the lower end of the spine were noted. At 5' 53/4" and 120 lbs, with a 32" chest, he was shorter and no heavier than his puny younger brother. But a five-inch chest expansion suggested vigorous good health. ${ }^{25}$ In fact it was testimony to a regime of jogging, press-ups, knee bends, and other exercises prescribed by the American mail-order body-building expert Earle E. Liederman. The results were achieved by adherence to the philosophy and techniques embodied in Liederman's best-selling illustrated booklet, Muscular Development, assisted by repetitive use of a chest expander. Whatever else he would become, Bob was not going to be a despised weakling.

Starting as an aircraft hand 1 labourer, recruit Hitchcock completed his initial training and obtained a trade certificate. He was awarded a special distinction pass in the storekeepers' ammunition course in February 1932. Then, with acceptance as an officer cadet in mind, he embarked on the long academic journey to achieve the requisite mathematical and language qualifications. Harry and then Les Hitchcock, who enlisted in June 1938 and July 1940 respectively, heard of Bob's progress during the next three years. Officers and men at Laverton:

used to take bets and run sweepstakes on just when Hitchcock would crack up or, if not, which of his three major activities he would relinquish. They were (a) his HEAVY job as an AHG [aircraft hand general], stacking bombs, unloading tenders, etc.; and (b) his university studies; or (c) his personal campaign for physical fitness.

There were no sweepstake winners. After three years of part-time study, Bob earned an intermediate certificate at the examination conducted by Melbourne

$23 C P D$, House of Representatives, 14 Aug. 1940.

24 The 'magic words': 'Son of late "Bobby" Hitchcock who lost his life with Lieutenant Anderson whilst searching for Sir Charles Kingsford-Smith' which Tink (Air Disaster, p.133) suggests would have explained Hitchcock's successful passage through the cadet course to his supposedly puzzled contemporaries were not 'endorsed' on his personnel file. They were remarks added in a posthumously compiled record of service (NAA: A9300, HITCHCOCK RE).

25 NAA: A9300, HITCHCOCK RE, A1979, 337/1544. 
University, passing in mathematics and French, and was advanced to a general classification in February 1933. He had worked hard with the aid of the RAAF education officer. ${ }^{26}$ Eighteen months later he was promoted to corporal and mustered as an AC 1 storekeeper in the tool store at No. 1 Aircraft Depot, Technical Squadron. ${ }^{27}$ It was there that Bob met Rex Taylor who was to become for a while his room-mate and his closest friend for the next five years. Rex was himself a fitter destined for a stellar Air Force career. When he arrived in early 1934 he found that because 'the majority of the other airmen were much older, Bob and I and a few others tended to seek each other's company'. Bob was 'a likeable and pleasant fellow but extremely quiet and reserved...even within this relatively small group these characteristics were noticeable. Nevertheless, he remained popular because his inherent honesty and integrity far outweighed any minor shortcomings.'

Among the Melbourne circle were Len Bacon (later a Squadron Leader and armaments specialist), Ben Kennedy whose 10/12 Harley-Davidson was greatly envied, and Les Lingwood, the friend of Bob's brother Les, who had attended the Scout Corroboree with Bob in 1929. Lingwood's brothers-in-law, the Hirons brothers, also welcomed the new recruit. Jack Hirons, sharing Bob's enthusiasm for photography, would himself soon enlist as an RAAF airman. When Bob had come to Victoria, his mother had asked family friends in Perth who had relatives in the Brunswick district (now part of Moreland), John and Olive Darlison, to look out for her son. He became a frequent weekend visitor at the Darlisons, befriending their two sons and two daughters. When his roommate Rex Taylor joined him there one day he was smitten by the Darlisons' younger daughter, Nancy. Rex also came to meet Bob's mother, 'a kindly and affectionate person', who was staying with the Darlisons while visiting Melbourne for a national conference of a 'ladies' fraternal order'. He was struck by the evident 'warm and caring' bond between Violet and Bob. ${ }^{28}$ Never having known his itinerant father well, Bob had drawn even closer to his widowed mother. He would travel back to Western Australia whenever he could. And as a permanent reminder of how much he cared for her, he would fashion the framework for a clock from the airscrew of an unserviceable Tiger Moth. ${ }^{29}$

\footnotetext{
26 Dr Richard Hosking, then the RAAF's only education officer, was attached to No. 1 FTS at Point Cook (Air Board Agenda 1880, [April 1936] NAA: A4181, 13); Chris Clark, 'Hosking, Richard (1877-1971)', John Ritchie and Christopher Cunneen (eds), Australian Dictionary of Biography, vol. 14. MUP, 1996, p.501.

27 For much information about the Hitchcock family and Bob Hitchcock's youth I have benefited from the guidance of the late Les Hitchcock (A. L. Hitchcock to CH, 20 Oct., 10 Nov., 24 Nov., 1977).

28 ACdre C. R. Taylor to CH, 25 Sept. 1983.

29 Joyce Batty to $\mathrm{CH}, 7$ April 1982. The clock was passed on to Les Hitchcock and eventually the treasured keepsake was presented to Joyce Batty's son Christopher, who had flown a 50th anniversary flight of the Kookaburra.
} 


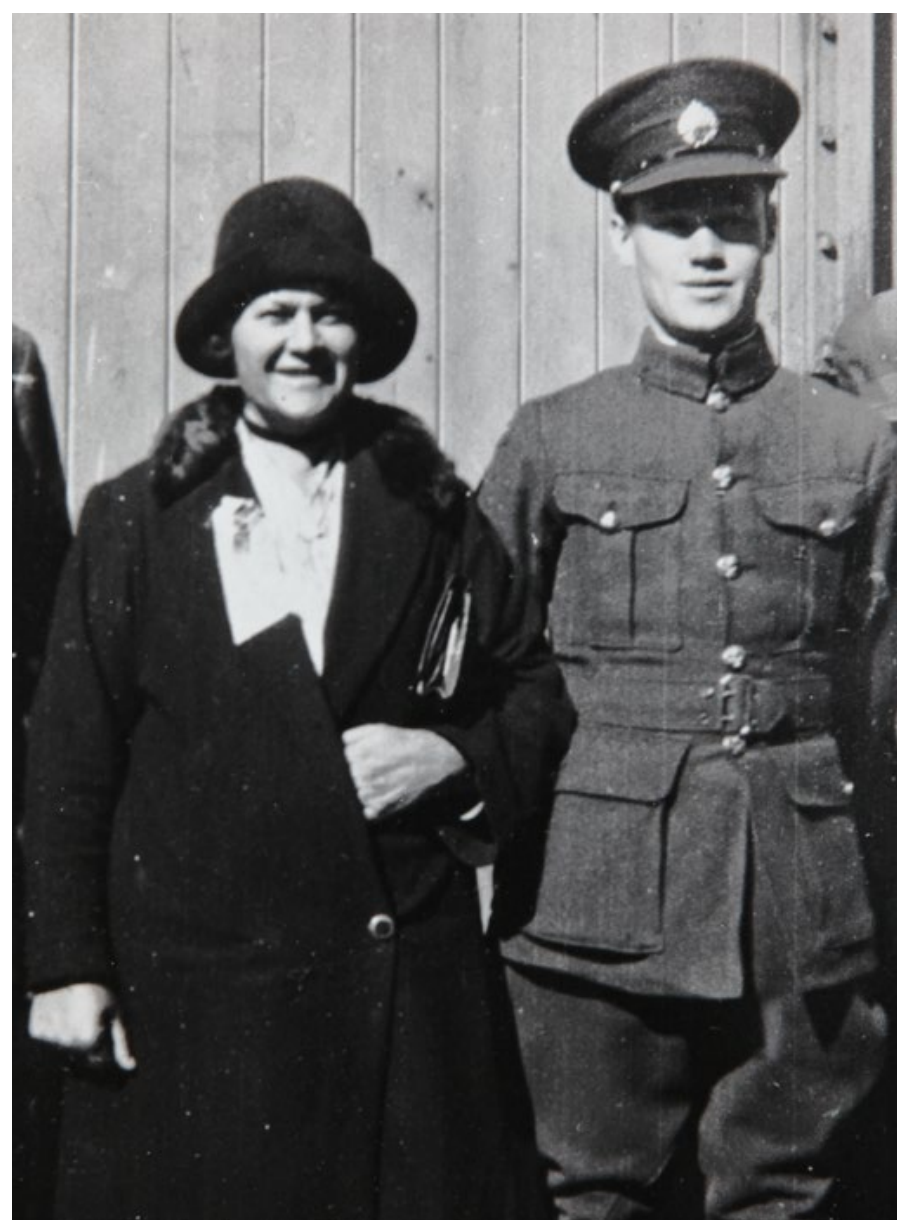

\section{Violet Hitchcock and her airman son, Victoria Quay 1931}

(Courtesy of Les Hitchcock)

While Rex was courting Nancy, Bob met and fell in love with the Darlisons' friend Olive Blanche Beecroft. He was soon to learn of a family history very different from his own. Olive's father Wilfred Beecroft, an emigrant from a coastal village in east Yorkshire, ran a small dairy farm at Koonwarra in South Gippsland. 'It is rare to find a dairy farmer of any kind who is not prosperous', the journalist and propagandist of emigration Harry Gullett had written in $1914 .{ }^{30}$ The son of a farm labourer and a domestic servant, Wilfred had certainly bettered himself in Australia. He had arrived in Australia as an infant in 1887 with his parents, a brother and a sister. Among the youngest of 17 children, one of whom died on the voyage, he moved with his father (also Wilfred) from

30 H. S. Gullett, The Opportunity in Australia, The Field \& Queen (Horace Cox), London, 1914, p.81. 
Maryborough in Queensland, to Colac in Victoria, until they eventually settled at Koonwarra in 1899. On a small selection, the Beecroft family built a log house, extended it many times, grew onions, peas, and potatoes, and milked 100 cows.

It was to the tiny township of Koonwarra in 1909 that young Wilfred brought his 20-yearold bride, Olive Blanche Hoskings, the oldest of 12 children from Grantville, the tiny port town on Westernport Bay. Wilfred had also bought a farm and would follow his father in growing onions and milking a small dairy herd. A granddaughter, Joan Richardson, tells their story:

My grandfather was a very short small framed man, very quietly spoken. Aunt Mavis [Olive Hitchcock's younger sister] once said she had never heard her father swear even having had 5 sons or amongst the roughest of men. I think my grandmother was a strong woman...My father would tell stories of how she rode horses side saddle or bare back, of attending the local women in childbirth, even swimming the horse through flooded rivers to do so (they were unsure when they would see their mother next). I gather being the eldest of a large family my grandmother had practical childbirth and mothercraft skills. (All of us were born at home on the kitchen floor my father would say).

All the children rode horses as soon as they could walk (which was the only way really for them to go to the local store, school, church) although grandma did have a horse and jinker.

Dad [Olive Beecroft's brother Don] and his brother shared a pair of good boots, so only one could go to a dance/church at a time (although one never wore the boots the whole way for fear they would wear out too soon - you walked barefoot until you could see the building through the trees) - after all there were 3 pairs of feet to still grow into them.

Wilfred and Olive Blanche had seven children, five of them boys. The third child, named after her remarkable mother, was born in Leongatha in 1912. She had moved to Melbourne in search of work, probably boarding with an aunt, Emily Musicka. Olive was a regular visitor to the Taylor household. Tall and beautiful, as a young cousin remembered her, she was Bob Hitchcock's first serious girlfriend, and his last. 'We were not playboys by any means', Rex Taylor recalled. ${ }^{31}$

31 Beryl Noske to $\mathrm{CH}, 25$ Aug. 2009; Joan Richardson to $\mathrm{CH}$, (email), 5 Oct. 2009; interview, ACdre C. R. Taylor, with Chris Clark, 21 Jan. 1988, transcript courtesy of Dr Clark. I am indebted to the late ACdre Taylor for extensive written recollections, 25 Sept. 1983; and to Peter Rickard and Graeme and Carol Bancroft for information about the Darlison and Taylor families. 


\section{Air cadet}

Barely a month after his twenty-third birthday, six months after he re-applied for a cadetship, Bob Hitchcock was enlisted on 15 July 1935 as an Air Force Cadet, No. 1544. He had been passed fit by Squadron Leader E. A. Daley in March, and attested his willingness to serve for two years in the presence of the commanding officer of No. 1 Flight Training School, Point Cook, Wing Commander H. F. ('Kanga') De La Rue. ${ }^{32}$ He had confided in Rex Taylor his ambition to 'endeavour to justify his father's sacrifice, and untimely death, by aiming to qualify as a pilot through a flying cadetship'. His mother had spoken to the press about how he had 'abstained from parties and smoking and drinking lest they unfit him for flying' ${ }^{33}$ To have got so far was a notable achievement. He was among 22 candidates originally chosen from more than 800 applicants. There were other men with a trade background who were accepted for flying training but most remained in the ranks and in due course would graduate as sergeant pilots. There was one other conspicuous exception in this intake, Charles Houston, who had also come from Perth. As The Argus reported delicately, 'Messrs Hitchcock and Houston are employed at present in junior positions at Laverton.' Bob himself, exempted from the normal education test apart from map reading, had been passed for promotion to sergeant. But his ambition had always been commissioned rank. And if all went well in due course, after successfully completing a short service commission, possibly with the RAF, appointment to a permanent commission. In September 1935 there were just 88 men in the General Duties (aircrew) branch of the Permanent Air Force. ${ }^{34}$ As he began his training to join the branch, Bob Hitchcock was on the way with 27 fellow cadets to becoming one of a tiny elite. ${ }^{35}$

Hitchcock's personal file does not contain the cyclostyled 'R.A.A.F. Interview Form (for cadetships)' on which he would have been marked on 'appearance and manners', 'intelligence, accuracy, general alertness, quickness observation,' and 'general promise of fitness for service'. Nor are the customary references on file. However, thanks to the 'Flying Pupil's Record of Progress' (RAAF Form $\mathrm{P} / \mathrm{T}$ 3), which has been retained, we have valuable information about the trainee's year of instruction. After five years in the Service, with more practical

32 'Proceedings of Court of Inquiry-Flying Accidents, Master Copy, Vol. 1', NAA: A98451, 318/42.

33 Sunday Times, 2 June 1935.

34 Alan Stephens, Power Plus Attitude: Ideas, Strategy and Doctrine in the Royal Australian Air Force 19211991, AGPS, Canberra, 1992, p.40.

35 Sources differ on the number of cadets in this course. Of the 22 first selected, several appear to have withdrawn before the course began (The Argus, 14 May 1935). Others were added. The Daily Routine Orders of No. 1 Flying Training school list 24 being posted to the Training Squadron 17 July 1935 (NAA: A10605, 521/2). I rely on Air Board Agenda 1901 which records 26 plus two, including Colin Hannah who had been hospitalised and had not completed the previous course. There are 33 in the course photograph, five of whom are NCOs (NAA: A4181, 13; A12372, R/338/P). Twenty-seven Air Cadets and five airmen graduated from the course (Aircraft, 1 July 1936, p.26). 
experience and local knowledge than many of the younger recruits, Hitchcock evidently had some difficulty adjusting to his new status. Class snobbery was rampant in the Air Force. As a former Cabinet minister was told two years later: 'young pilots of 20 are being taught to look down upon mechanics as belonging to an inferior social caste' ${ }^{36} \mathrm{~A}$ month after he embarked on No. 18 Flying Training Course 'A', the former aircraftman's 'Record of Progress' notes under the heading 'Qualities as Officer': 'Inclined to be of the "old soldier" type, who might be inclined to lead the remainder of the cadets astray. Keeps to himself.' ${ }^{37}$ Possibly a little perplexed by the internal inconsistency in these comments the commanding officer concluded: 'Must be interviewed in view of these remarks.' The interview had more than the desired effect. A definite improvement was noted a month later: 'has lost the "troop" complex...' But now he was adjudged 'timid'. By October, though he was 'improving slowly' and 'reliable', he showed 'no outward signs of taking responsibility'. It was about this time that a mischievous Bob sent his mother a photograph of himself in the bush in an Earle Liederman body-building pose, wearing only a jockstrap and a smile. 'Mum thought this unfunny but forgave him as he was the firstborn', the second-born son recorded.

Hitchcock's instructors and lecturers found him an average pupil, attentive, hardworking, but slow to learn. 'Thinks slowly', his instructor, Flying Officer Ernie Hey, commented in March 1936. The contrast with some others in the group could not have been more marked. Robbie Watson from Adelaide, for example, six foot three and over 14 stone, a wrestler, apprenticed as a motor fitter: 'an above average pilot...of above average intelligence with a fine intellect', but 'too many ideas of his own which do not fit into Service life...Has developed a know-all complex. Has been checked.' Still, the bumptious Watson went solo on August 20. ${ }^{38}$ Hitchcock was nearly three weeks behind, going solo on 9 September 1935, and passing the landing test on October 15. Before then his flying was assessed as slightly below average, then average. He was 'timid' it was again recorded. 'Approaching \& landing is his trouble' but then 'consistent improvement' was noted. 'Has good hands \& feet. Lacks judgment of distance \& height during a forced landing approach.'

The official language described a young man straining to keep up with the expectations of those who were responsible for his training. Gipsy Moths and then Westland Wapitis, obsolete light bombers that were being replaced as frontline aircraft by Hawker Demons, submitted reluctantly to his touch. Some

\footnotetext{
36 F. S. Alford to Charles Hawker, 9 Dec. 1937, Hawker MSS, NLA MS 4848/2/4.

37 Hitchcock (b.1912) was several years older than most of the cadets: eg. T. H. Davies (b. 1917), R. F. Wiley and E. V. Read (b.1915).

38 Watson and fellow South Australian Phil Ford were flown home on leave when a group of Point Cook flight instructors took seven Moths to Adelaide in Dec. 1935 (The Advertiser, 16 Dec. 1935; www.sealikeglass. com/the-mystery/38-who-is-robbie/164-robert-arthur-mclister-watson, accessed on 1 Oct. 2011).
} 
of his class, like Bill Keenan and Don Ashton-Shorter, were lucky enough to learn about the Wapiti with Eric Douglas. Sergeant Douglas, who had buried Bob's father in the Tanami seven years earlier, was now an AI instructor who had taught some of the RAAF's best young pupils like Dixie Chapman, Tony Carr, Sam Balmer, and Brian Walker. ${ }^{39}$

In his own struggle for mastery Hitchcock was not alone. Hughie Edwards, a 20-year-old former office boy and Army private from Fremantle, had the minimum necessary educational qualifications. He too found Point Cook a challenge. 'Chemistry I had never touched, theory of heat, theory of flight, engineering, signals - all this was black magic to me.' Edwards had never before seen an aeroplane at close quarters; they were, he would recollect, 'contraptions beyond my comprehension'. ${ }^{40}$ But his clumsy landings were far outweighed in RAAF evaluations by his prowess at cricket and Australian Rules football. And perhaps there was a glimpse of the dash and valour that was to make him a decade later Australia's most decorated airman. ${ }^{41}$

Another fellow cadet, 19-year-old Julius 'Dick' Cohen, remembered that Bob Hitchcock was very tentative, not careless, but cautious:

Half way through the first half of the course, that is about three or four months in, he told me that his instructor was not very happy with him, and was considering scrubbing him from the course. And I said: 'Why was that?' And he said he can't apparently co-ordinate well enough for my $[s i c]$ very demanding instructor.

Cohen asked for an example. The answer was his 'aerobatic insufficiency'. Hoping to help, and with the advantage of all he had learned at Randwick Public School, the selective Sydney boys' high school, and many nights and weekends in the NSW Public Library, Cohen tried to teach Hitchcock what he knew. Cohen himself had been slow to master the elements of flying and, sensing that he too might be scrubbed off the course, had begun to scrutinise civilian job advertisements. It was 'the blind leading the blind', as he was to admit 62 years later, 'teaching him the mechanics of a slow roll where the surfaces of the aeroplane rudder change function...To see me instructing him on the floor of my room, trying to explain how these change their function as we roll, I think would have won an Oscar these days. ${ }^{42}$

39 Eric Douglas, 'Pupils' 1929-37, Douglas MSS courtesy Sally E. Douglas.

40 Hughie Edwards, typescript memoir, AWM: PR82/193.

41 Peter Firkins, The Golden Eagles, St George Books, Perth, 1980, pp.133-5.

42 Sir Richard Kingsland, interview, 19 April 2007, transcript courtesy Geoff Crane; Into the Midst of Things: The Autobiography of Sir Richard Kingsland, Air Power Development Centre, Canberra. 2010, pp.17-23. Cohen changed his name by deed poll in 1947 taking his mother's new married name of Kingsland. For his wartime exploits see Gerald Pynt (ed.), Australian Jewry's Book of Honour World War II, Australian Federation of Jewish Ex-Servicemen \& Women, Netley (S.A.), [1974], pp.7-14. 
Dramatically diverting though this assistance may have been, it seems to have made a difference, or at least coincided with improved performance. By February 1936, believing that he 'is now a cadet whom it would be wise to polish up', the instructing staff found Bob 'considerably smarter'. He was trying to understand and overcome his faults, a lack of common sense, they said, and little initiative. What was manifest in the record of progress was that this was a working-class youngster with a simple Christian faith struggling to be comfortable in an environment that was both intellectually challenging and socially unfamiliar.

As an officer cadet Hitchcock was separated from the 10 airmen cadets on his course, many of them former workmates, LACs and one temporary corporal, Reginald Peverell, who were quartered together while undergoing training. Surrounded by the polished products of Wesley College, Scotch College, or Melbourne Grammar, he could scarcely have been at ease in the dinner jacket, starched dress shirt, and bow tie at the Thursday night mess dinners described by cadet Geoff Hartnell to his mother: after dinner, wine, a toast to the King, and fruit, all adjourned to the ante room 'where black coffee is served \& no one is supposed to talk shop, women or politics'. Cadets were expected to stay for at least three-quarters of an hour, and the talk was in practice mostly 'shop' ${ }^{43}$ And that was the expurgated version for parents. No hint of what Hughie Edwards would describe as 'unloosed inhibitions' at Guest Nights when the throng 'prompted by Bacchus became real aces'. What went on, and was so challenging to an abstemious church-goer who could not afford to supplement his clothing allowance, is vividly depicted by Sir Richard Kingsland (as Dickie Cohen would become):

On Mess nights we cadets all felt under pressure to excel in boisterous behaviour, in order to demonstrate to each other, and to the staff and instructors, that none of us was a sissy. We used to engage in the usual silly games, 'cock-fighting' and so on. Worse than that, we'd risk life and limb by climbing up on the ceiling and over the rafters, at midnight, after we had consumed quite a few beers. There were other dangerous practices, such as having motorcycle races around the block or the oval in the early hours of the morning, at high speed, and all without helmets or protective clothing. Inevitably there were some casualties - never deaths, but certainly injuries. ${ }^{44}$

43 G. C. Hartnell to his mother, 23 Jan. 1936, Hartnell MSS, courtesy of AVM Hartnell. For the Point Cook regime as experienced by one of the immediately following intake, see Gordon Olive and Dennis Newton, The Devil at 6 O'Clock: An Australian Ace in the Battle of Britain, Australian Military History Publications, Loftus 2001, pp.1-12. For the wardrobe and other requisites ('including evening dress if in your possession') to be brought by a cadet when reporting to commence duty, see Secretary, Air Board to N. Ford Jr, 29 May 1935 (Ford, Norman Philip 0339 NAA A12372, R/339/P). On the cadets' mess in 1938: Rollo Kingsford-Smith, I Wouldn't Have Missed it for Quids, self-published, Exeter (NSW), 1999, p.17; R. Kingsford-Smith, telephone interview, 15 March 2009.

44 Edwards memoir, AWM: PR82/193; Kingsland, Into the Midst, p.19. 
Amid all this roistering Hitchcock was, it was observed, 'very quiet and reserved. Keeps apart from other cadets.' His practical instructors had reported at the beginning that he worked very well but was 'inclined to be shy'. If aeronautical theory was taxing his brain, and solo flying was testing his skill and courage, staying awake during Wing Commander Fred Knight's Friday afternoon class on 'Discipline and Law' was another big challenge. What the instructing staff, including the redoubtable Sergeant R. J. Parker, observed in class and in the air, Bob's peers experienced in the mess. Their language was identical. Colin Hannah, another contemporary, found him 'very quiet reserved and studious' ${ }^{45}$ By contrast Hughie Edwards, who had arrived from Western Australia as a gangling loner, would shrug off his Methodist inhibitions and forge strong friendships with fellow cadets Joe Godsell and Dick Cohen. Edwards was soon enjoying weekends in their company, even 'holding up the bar' at the Hotel London in Elizabeth Street. On one unforgettable occasion Edwards, Godsell, and three other miscreants (Tom Harvey, R. K. Hedrick, and B. G. Braithwaite), transgressed by carousing in a bedroom after a guest night and earned themselves seven days confinement to barracks. For their mess mate Bob Hitchcock, a communicant member of the Church of Christ, both the crime and the penalty were nigh unthinkable. ${ }^{46}$

\section{Graduate blues}

Hitchcock's personal file does not contain the 'Report on a Pupil Pilot on Passing out from an "ab initio" Flying Training Course' which would have provided full details of his examination performance and his evaluation by the commander of the Cadet Squadron, 'Dad' Bladin. We know, however, that he was awarded his flying badge on 16 June 1936, discarded the cadet's white band around his cap, and was posted along with seven of his fellow graduates to No. 3 (Army Co-operation) Squadron at Richmond in New South Wales. There he emerged as a pilot officer on 11 July 1936. Others in the class of 1936 at No. 3 Squadron were Pilot Officers Gerry Buscombe, Don Ashton-Shorter, Phil Ford, Bill Allshorn, Thomas Davies, and Geoff Quinan. Seven of their cohort: Wally Williams, Harry Daish, Robbie Watson, Alan Sisley, Alan Pitfield, Tom Harvey,

45 F. F. Knight, These Things Happened: Unrecorded History 1895-1946, Hawthorn Press, Melbourne, 1975, p.314; AM Sir Colin Hannah to CH, 31 Mar. 1978.

46 Edwards's memoir suggests that the group forfeited Christmas leave. No.1 FTS...Daily Routine Orders Part 2 Personnel 1/1936 -65/1936 shows that it was seven days CB (NAA A10605, 521/3), served from Dec. 12 (NAA: A9300, BRAITHWAITE BG); Arthur Hoyle, Sir Hughie Edwards VC DSO DFC: The Fortunate Airman, A. R. Hoyle, Canberra, 1999, pp.3-8. 
and Hughie Edwards embarked for the United Kingdom for a two-year spell in the RAF. ${ }^{47}$ Colin Hannah, assessed as above the average 'particularly in powers of leadership and command', went to No. 22 Squadron. ${ }^{48}$

At No. 3 Squadron the new pilots would in theory be learning dive-bombing and gunnery, assisting with anti-aircraft gun co-operation, and undertaking photographic reconnaissance and survey, mostly the latter. ${ }^{49}$ As the neophytes began their lives as operational flyers it was not long before Hitchcock came to notice. Rex Taylor told the story that his friend 'celebrated his graduation by putting an aircraft across the Geelong Road fence on his first flight on his first posting'. Unfortunately Taylor appears to have conflated an accident eight weeks after Bob's arrival at Richmond with another rather later incident. The official records show that on 10 September 1936 Pilot Officer Hitchcock was at the controls of a Demon (A1-10) that came to grief on landing. Hitchcock emerged unscathed but his companion ACl E. S. Banks suffered abrasions and shock as the aircraft swung to port and turned over, landing on its nose and causing extensive damage to the airframe and tearing the reduction gear from the engine. ${ }^{50}$

It seems that there was real concern about the new pilot's flying. As Dick Cohen remembered hearing from friends in No. 3 Squadron:

...it was common knowledge that Hitchcock had been taken off flying and it was recommended by his flight commander and squadron commander and Group Captain Cole that he should go off flying... And I thought that this would probably save his life, because he was apparently so appallingly bad. ${ }^{51}$

47 ACdre (Sir) H. I. Edwards VC etc., Australia's most decorated airman, retired from the RAF in 1963. H. C. Daish also stayed with the RAF, becoming a key member of the Photographic Development Unit flying reconnaissance Spitfires, then CO 27 (Beaufighter) Squadron in India, retiring as a Group Captain in 1954 (Dennis Newton, A Few of 'The Few', Australians and the Battle of Britain, Australian War Memorial, Canberra, 1990, pp.22-3, 117-8). A/g S/Ldr W. C. Williams relinquished his RAF commission in March 1943 and rejoined the RAAF until discharged in 1946. F/O T. F. Harvey (Sch. of Air Nav., No. 23 Trg Grp) relinquished his commission because of ill-health. F/Lt A. L. Pitfield, in a Fairey Battle of 88 Squadron attacking the pontoon bridges at St Valery in June 1940, was shot down from the ground and killed. P/O R. A. McL. Watson crashed and died on a night training flight in bad weather in Jan. 1937. WCdr A. F. M. Sisley was killed in Aug. 1944 in the crash of an RAF No. 550 Squadron Lancaster, on a mission to bomb a V-2 rocket store (www. ww2 chat.com/biographies/5833-raf-australians-wing-commander-alan-francis-moir-sisley.html). Much of this information is drawn from Ann Brech's splendid website www.sealikeglass.com (accessed 1 Oct. 2011).

48 Hannah, Colin Thomas: Service Number 0338, NAA: A12372, R/338/P,H.

49 John Bennett, 'Flexibility in Air Power: No. 3 Squadron AFC/RAAF: The Direct and Effective Operational Application of Air Power', MA (Hons) thesis, [Australian Defence Force Academy], 2001, p.87; RAAF Unit History sheets (Form A50) [Operations Record Book — Forms A50 and A51] Number 3 Squadron Jul 25-Aug 43, NAA: A9186, 8.

50 NAA: MP187/3, Box 1, reference courtesy Dr Chris Clark. A search by Leslie Weatherall reveals no reference to E. S. Banks in the control records for casualty reports (A2408, 32/3, subject registration booklets for the Department of Air correspondence files [CRS A705, 1922-1960]: Casualties Airmen, 32/3/1 to 32/3/815). Banks, like Hitchcock a member of the Church of Christ, appears to have been discharged from the RAAF and re-enlisted in June 1935 (NAA: A9301, 205436; A10605, 78/1). Al-10 was damaged beyond repair on 19 Dec. 1936 when the engine failed at 8000 feet (www.adf-serials.com/2al.shtml).

51 Kingsland, interview, 3 April 2007, transcript courtesy Geoff Crane. 
Wilfred Compagnoni, then a flight lieutenant in No. 3 Squadron and acknowledged as 'a highly qualified flight instructor', would recount how serious matters were. 'After spending quite a few hours with him I realised that he would not make a pilot. It would have taken many hours and patience to make him even reasonably safe in an aeroplane.' Although the exact circumstances are unclear, Compagnoni was to recall that Flight Lieutenant Bertie Simms, temporarily in command of No. 3 Squadron, had told him to do what he could with Hitchcock. It was an unwanted brief from an officer not known for his patience. ${ }^{52}$

With the squadron reduced to one flight as a result of reorganisation of the Richmond base, Compagnoni had been the station signals officer for a year while nominally commanding the inactive B flight. Given the command of A flight in April 1936, he was charged with Hitchcock's further training. 'After spending many sessions with him trying to get him to approach and land,' Compagnoni said, 'he came in downwind one day and about 30 miles too fast and tried to put the aircraft down.' The result, summarised in a table of accidents prepared for the Director of Training, was a 'slightly injured' aircraftman and an 'extensively damaged' aircraft that had swung and overturned. ${ }^{53}$ It was too much for the flight commander, himself a talented and exacting flyer who had just won the annual bombing competition at Laverton on behalf of the squadron as well as the NSW aerial derby in a Demon the previous year. ${ }^{54} \mathrm{He}$ reported that he was not prepared to continue. 'We were paraded to the Station Commander and he said that he would report the matter.'

On 10 September 1936 Pilot Officer Robert Edward Hitchcock was charged with 'Neglecting to obey an order in that he did land Demon Al-10 contrary to orders'. Notwithstanding the vagueness of the charge - was he acting contrary to a specific order or a standing order by landing downwind and too fast, or to a signal from the ground to go around again? - he was reprimanded by the Station Commander, Group Captain Adrian Cole MC DFC, and forfeited one day's pay. Hitchcock was badly shaken by the whole experience. Found wanting by 'King' Cole, a wartime ace and one of the RAAF's founding fathers, his confidence in himself as a pilot was shattered. Cole had been the $\mathrm{CO}$ at No. 1 Aircraft Depot when the fatherless recruit joined the Air Force five years earlier. Perhaps Cole had never been happy about the way in which the young tradesman had been foisted upon him. Was this a problem that he had long predicted, and an opportunity to rid the Service of someone whom he believed should never have been admitted in the first place? Someone who certainly should not have been allowed to advance into the ranks of the cadets.

52 Jeffrey Watson, Killer Caldwell: Australia's Greatest Fighter Pilot, Hodder, Sydney, 2005, p.227.

53 F/Lt I. D. McLachlan, 'Demon aircraft accidents involving injury to personnel', [Dec. 1937], NAA: A705, 32/101915.

54 Compagnoni's activities are documented in No. 3 Squadron Operations Record Book, NAA: A9186, 1; his personnel file in the A9300 series; Air Board Agenda 1898 [June 1936], NAA: A4181, 13; and Derek Roylance, Air Base Richmond: The Story of the RAAF base on the Hawkesbury, RAAF Base Richmond, 1991, p.47. His foresight as Director of Signals in 1938 in preparing specifications for Australian production of radio equipment is documented in Hall, A Saga of Achievement, p.285. 


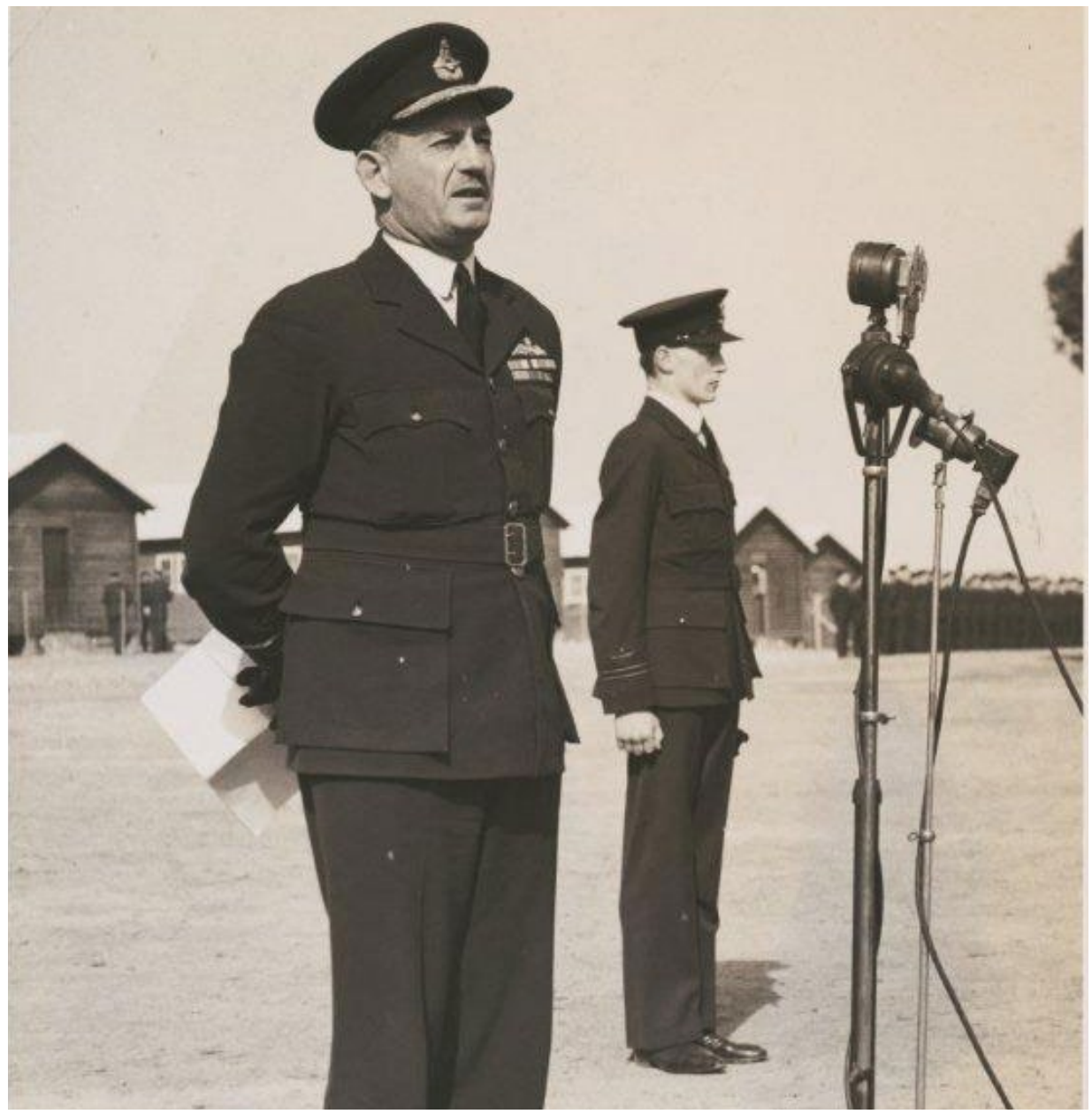

'King' Cole reprimanded Hitchcock and recommended his termination

(Ellison MSS, National Library of Australia MS1882/7/216)

Whatever Cole's motives, Hitchcock felt that he had been unfairly treated. Intimidated as he must have been in the authoritative and assured presence of Cole, towering over him at 6' 41/2", it was Compagnoni whom he held directly responsible for his misfortune. His flight commander, whom he could look directly in the eye, was just two years older but five years his senior in the Service. From an Italian-Danish immigrant farming family settled at Wondai, 150 miles west of Brisbane, Compagnoni had moved to the city to complete his high school education before enlisting in 1930. He had done well in the RAAF and had recently been granted a permanent commission. Twice in the past few months he had been temporary $\mathrm{CO}$ of the squadron, and he was soon to begin a succession of staff and command appointments. 
As retired Group Captain Compagnoni was later to admit, Hitchcock 'pointed the bone at me. I was on his back.' But there was no hint that Compagnoni might bear some of the responsibility for the novice pilot officer's poor performance when the commanding officer at Richmond forwarded an adverse report to the Air Member for Personnel. Air Commodore Hazleton Nicholl, an RAF officer on exchange with the RAAF's Air Commodore S. J. Goble, recommended to the Air Board that Hitchcock's probationary appointment be terminated with effect from 9 October 1936. Nicholl's submission was terse and damning. Hitchcock, he wrote:

...is reported to have stated that he knows himself to be incapable of piloting Demon aircraft successfully, in spite of the fact that he was warned that such a statement might affect his future employment in the Royal Australian Air Force. He has had 15 hours flying on this type.

The Station Commander, Richmond, recommends that he is temperamentally unsuited to become an efficient pilot. After examination of this officer's training reports, I accept this view, and concur with the recommendation.

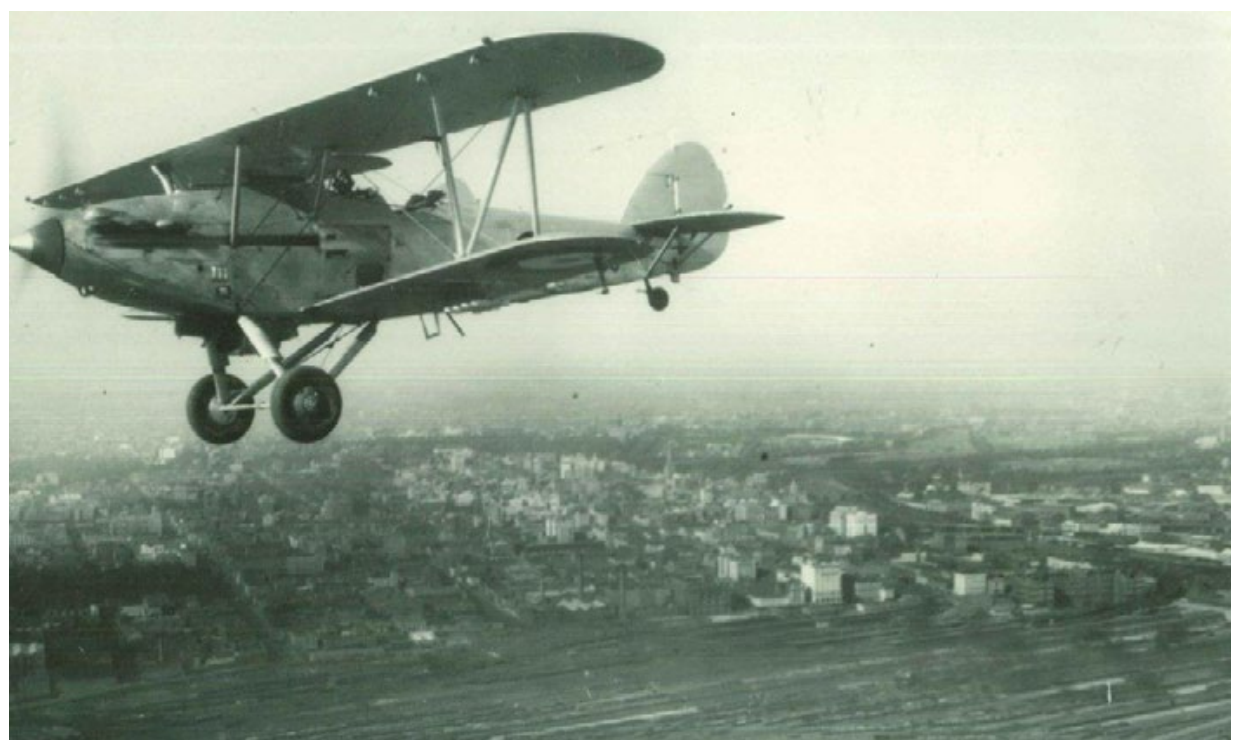

A Hawker Demon over Port Melbourne: an aircraft Bob Hitchcock thought himself incapable of piloting

(The Jack McNally collection, courtesy of Wendy Coultas)

Normally, the Air Board might be expected to endorse such an unequivocal recommendation about the fate of an individual officer. It came from a respected and responsible Board member. 'Daddy' Nicholl was an RAF veteran. Allowed into the Royal Flying Corps at the late age of 33 through the influence of the 
GOC, his relative Sir David Henderson, he had served in a series of post-war senior training and personnel posts. ${ }^{55}$ Yet when the Board met on 29 September 1936 they were not of a mind to agree with their British colleague. With Dicky Williams, now an Air Vice Marshal, in the chair, supported by Air Commodore W. H. 'Mucker' Anderson, it was decided 'to defer consideration of the A. M. P's recommendation for the present'. The deferment formula was in character for the 'nice' but habitually indecisive Anderson who was seen by one of his senior staff as generally 'loath to take disciplinary action' ${ }^{56}$ It was no doubt a surprise for 'King' Cole, who would have expected his old friend and fellow Naval and Military Club member Anderson to endorse his judgment. It was a face saver for Nicholl. But the CAS would have had the decisive voice. Williams knew very well who Hitchcock was and had made some enquiries of his own. He might well have caught a whiff of concoction about a disciplinary charge being brought against a young pilot whose accident was by no means unique. He was not persuaded that Hitchcock was a lost cause. If he could not be saved, then he would at least be allowed a more dignified exit than an involuntary termination.

In a minute paper prepared nearly six months later, P. E. 'Johnnie' Coleman, the long-serving Secretary of the Air Board, recorded the thinking underlying the decisions that were taken:

The Board noted that P/O HITCHCOCK obtained better than an average pass at No. 1 F. T. S., and in qualities as a pilot was awarded $68 \%$, also that the crash in question, due to a bad landing, was his first in the service. In ordinary circumstances, an officer with a similar record would be given another chance before considering the serious step of terminating his appointment. Pilot Officer HITCHCOCK has stated, however, that he does not wish to fly Demon aircraft, and it is contrary to the policy of the Air Board to force an officer to continue flying if he has lost his nerve. ${ }^{57}$

Visible in this preamble was a wordless rebuke to those who had recommended termination: the unforgiving Compagnoni and Simms, and their too readily acquiescent if not complicit superior, 'King' Cole. Cole should have known better. As a member of the Air Board until May 1936, Cole would have been aware of the Board's rejection of a recommendation by the Air Accidents Investigation Committee, following the death of Air Cadet N. L. Chaplin in April 1936, that

\footnotetext{
55 For AVM Sir H. R. Nicholl's career see 'Air of Authority - A History of RAF Organisation', http://www. rafweb.org/Biographies/Nicholl.htm.

56 Hewitt, Adversity in Success, p.3.

57 Air Board Agenda 1945, NAA: A4181, 13. Coleman is often referred to as 'Johnny' but he is 'Johnnie' in a letter from his senior colleague Mel Langslow to Sir Frederick Shedden, 27 March 1944, copy, NAA: A5954, $1568 / 6$.
} 
consideration be given to abolishing aerobatics for pupils early in their flying courses. Perhaps he had been influenced by testimony that Chaplin had thought he was losing his nerve, although it was a structural failure that led to his death. Chaplin's parachute had failed to open, or possibly become entangled in his machine when he lost control and attempted to bail out. Within days, another cadet, Leslie Clisby, had parachuted from his own Moth, abandoning it in flight, evidently not appreciating that his loss of control was occurring because he was in the slipstream of the aircraft ahead of him in formation. ${ }^{58}$ Certainly Cole had seen recent evidence that the flying training course for Air Cadets which Hitchcock had passed was fraught with obstacles and stumbles that could lead to discharge from the Service.

In the immediately preceding course to Hitchcock's, four cadets had indeed been discharged, one was killed, and two had deferred because of illness or injury. Brian Walker, better known in later years as 'Black Jack', hospitalised after a major crash at Echuca in October 1935, missed his final exams and was not awarded his Pilot's Flying Badge until February 1936. Court-martialled the following year, he lost six months' seniority. ${ }^{59}$ One of Hitchcock's immediate predecessors was appointed with one day's loss of seniority as a disciplinary measure for low flying endangering the public, and another was discharged from the Permanent Air Force for two similar offences and 'most undesirable tendencies', with a recommendation that he be appointed to the reserve as a sergeant. ${ }^{60}$ From his own class, a cadet with several years military experience was released at the end of the course, 'services no longer required', having spent twelve days confined to barracks for, 'to the prejudice of good order and discipline', obtaining bottles of beer from an officers' mess steward and consuming them, contrary to orders, in a bedroom. ${ }^{61}$ By implication Hitchcock, with a 'better than average pass', was someone worth persevering with. He could be given another chance. ${ }^{62}$ It was agreed that he should be interviewed in Melbourne by the Air Member for Personnel. If the AMP thought it necessary,

\footnotetext{
58 NAA: MP187/4, 160, 161. 'The accident was due to structural failure in the port lower front spar on the out board side of the interplane strut...reasonably attributed to faulty technique in the execution of a loop.' S/Ldr F. M. Bladin of the Cadet Squadron had testified to the Coroner that Chaplin's crash was due to mishandling of the aircraft by the pupil doing the loop rather than to a structural defect. Re Clisby's 'completely wrecked' Moth: NAA: MP187/3; MP116/1 vol. 6. By May 1940, when he was shot down and killed, RAF F/O Clisby DFC was credited with bringing down at least 14 enemy aircraft (Lex McAulay, 'Clisby, Leslie Redford (1914-1940)', Ritchie and Cunneen, eds, Australian Dictionary of Biography, vol. 13, pp.445-6). 59 NAA: A9300, WALKER BR; NAA: A10605, 521/3.

60 Air Member for Personnel, 'Appointments to Short Service Commissions', [17 Dec. 1935], Air Board Agenda 1827, NAA: A4181, 13.

61 After becoming a Lieutenant in the Militia and rejoining the RAAF in July 1941, the former cadet's probationary appointment was terminated a year later (NAA: A9300, HEDRICK RK).

62 NAA: MP187/3 RAAF 1936. I am indebted to Dr Chris Clark for sending me a copy of the late GpCpt John McKenzie's compelling analysis of the 10 Sept. 1936 incident and its aftermath.
} 
medical advice would be sought. Following this, Nicholl would make 'a further recommendation as to whether Pilot Officer Hitchcock should be given a further trial with another unit or be allowed to resign his commission' ${ }^{63}$

The message that came back to Richmond about the Air Board's decision was relayed to Compagnoni by Cole. Recalled by Compagnoni many years after the event, the story showed signs of subtle editing. The impression Cole seems to have created was that his advice would have been followed by the Board were it not that there was 'a political direction that Hitchcock was to be taught to fly...The Minister had directed that we were to persist with him.' ${ }^{\prime 64}$ The inherent improbability of this self-serving explanation does not seem to have troubled Compagnoni. ${ }^{65}$ The UAP Defence Minister in 1936, Sir Archdale Parkhill, had not been a minister at the time of Hitchcock's father's death in 1929. He might not even have known of the assurances given to the Hitchcocks by his Labor predecessor. True he had been deep in negotiations over Kingsford-Smith's trans-Tasman commercial ambitions during 1935; and when Kingsford-Smith disappeared in November, this time forever, the events of 1929 were once again resonant in the headlines. Moreover, Parkhill had visited No. 3 Squadron during Hitchcock's first week at Richmond to view the Squadron's 'normal routine'. But there is no evidence to suggest that he knew anything of Hitchcock or that a junior officer's possible severance from the Service was brought to his attention a few months later.

Nor is there any reason to suppose that the Chief of the Air Staff would have needed a reminder of the special circumstances surrounding Hitchcock's presence in the RAAF. 'King' Cole, too, almost certainly knew Hitchcock's background, having known of him since he arrived at Laverton from Western Australia in 1930 under the protection of Dicky Williams. No renewed ministerial direction was necessary to ensure that Bob Hitchcock would get a second chance. He was not one of Cole's private school, golfing, and clubland chums. But, whether Cole

63 'Pilot Officer R. E. Hitchcock', minute by Secretary, Air Board, 25 March 1937, RAAF 59/1/585, copy courtesy Chris Clark.

64 GpCpt W. G. Compagnoni, taped memoir, cited in Coulthard-Clark, The Third Brother, p.206; Clark interview, 6 Jan. 2008, courtesy G. Crane. Compagnoni's recollection that Allan Walters, as his flight commander, recommended Hitchcock's termination cannot be correct as Walters was at the RAF Staff College and Navigation Reconnaissance courses between Nov. 1935 and June 1937, and then CO of 22 Squadron. Walters became Director of Staff Duties at Air Force HQ in June 1939. Compagnoni had been temporary CO of No. 3 Squadron for five days in June 1936 and a week in Aug. 1936; he was posted as Director of Signals at HQ at the end of May 1937. (NAA: A9300, COMPAGNONI WG; Ray Funnell, 'Walters, Allan Leslie (1905-1968)', Ritchie and Langmore (eds), Australian Dictionary of Biography, vol. 16, pp.482-3; http://en.wikipedia.org/ wiki/Allan_Walters).

65 In June 1937, the Chief of the Air Staff rejected as 'dangerous' the finding of a Court of Inquiry into the death of Donald Ashton-Shorter presided over by Cole. The court had concluded that by disregarding standing orders the pilot had placed himself 'not on duty' ('Pilot Officer D. Ashton-Shorter. Criticisms by Brother', NAA: A705, 32/10/1785). 
liked it or not, the Scullin government's commitment to the Hitchcock family endured because it was entrusted to a decent and compassionate Chief of the Air Staff. ${ }^{66}$

66 Cole's career is well summarised in a Wikipedia article, 'Adrian Cole (RAAF officer)', and more blandly in Brian Eaton, 'Cole, Adrian Lindley Trevor (1895-1966)', Ritchie and Cunneen (eds), Australian Dictionary of Biography, vol. 13, pp.459-60. His reputation, embarrassing behaviour ('irregular conduct') at a RAAF officers' mess general meeting, and consequent removal as Air Member for Personnel in Dec. 1944 are documented in a top-secret file (NAA: M2740, 259). For AVM J. E. Hewitt's report of USAAF General Kenney's comment, 'that man is a fool', see Hewitt's 'Diary for my daughter Part II Sept 1939-December 1948', p.97, Hewitt MSS, AWM: 3DRL/4141; this passage is omitted from Hewitt's Adversity in Success. 


\section{6. 'A very sound pilot'?: Bob Hitchcock (II)}

Pilot Officer Robert Hitchcock, protected by an honoured pledge, was transferred to the recently formed Citizen Air Force No. 21 (City of Melbourne) Squadron in October 1936. At his interview with the Air Member for Personnel, Hitchcock had 'agreed voluntarily to have another try'. Away from the harshly judgmental atmosphere of Richmond he grasped at the chance to redeem himself. With the voluntary nature of the arrangement on the record, Air Commodore Nicholl had satisfied himself that a 'further trial' was in everyone's interests. Initially Hitchcock would be under the supervision of No. 21 Squadron's CO, Squadron Leader Johnny Summers. But Summers left the squadron at the end of the month and was replaced by Flight Lieutenant Robert Dalton. A former fitter, the 29-year-old Dalton - known to his friends as 'Dorothy', after the American silent film actress - had risen rapidly from the ranks. Only temporarily in command and preoccupied with providing continuity of flying opportunities on alternate weekends for demanding citizen flyers, he was not the man to restore Hitchcock's confidence. ${ }^{1}$ The sensitive assignment was taken on by Group Captain H. N. Wrigley, the most senior officer at Laverton. Informed of the reports from Richmond and the decision to allow Hitchcock time to overcome his fears, Harry Wrigley sensed there was something that was not being said. Someone, he thought, had been giving an unsettled probationer the 'thick end of the stick'.

If Wrigley had been curious enough to acquaint himself with Hitchcock's performance at the Initial Flying Training School he might have wondered what had happened in the next few months. Twenty-seven men had passed out from the course. The average mark for the graduates was 71.3 per cent. Twenty-one-year-old Colin Hannah, later an Air Marshal and Chief of the Air Staff, had been eighth in the class. Hughie Edwards, later Air Commodore with a VC, DSO, and DFC, was seventeenth, closely followed by Dick Cohen, who would finish the coming war as an Air Commodore with a DFC attesting to his outstanding service. These distinctions of course lay in the future. But Wrigley, a school teacher before he was a pilot, could see there and then that Hitchcock had finished in the upper half of the course, in thirteenth place with a score of 73.5 per cent, comfortably ahead of Edwards on 69.7 per cent and

1 A decade later, as a WCdr temporarily commanding Northern Area HQ, Dalton was assessed by his CO, GpCpt. C. W. Pearce, as needing 'constant direction and frequent reminders of his duties'. After a general court-martial under Section 4 AFA in December 1944 he lost two years' seniority as a temporary GpCpt (NAA: A9300, DALTON RFM). 
Cohen on 69.2 per cent. $^{2}$ Of the young men who went from Point Cook to No. 3 Squadron, Hitchcock had been third on the list. His student tutor Cohen, who later recounted his friend's difficulties, had failed the final Gipsy Moth test at the end of the basic phase. In the advanced phase he received more pre-solo dual instruction in the Wapiti than the cadet who finished at the bottom of the course. After he successfully went solo, Cohen became overconfident, taking upon himself 'the task of demonstrating to his fellow cadets that he could be as dashing as they declared they were'. He blotted his copybook by getting caught low flying as a cadet - or rather by being falsely charged and convicted after the one exercise when, tipped off by fellow cadet Joe Godsell that he was going to be watched, he was punctiliously following regulations; and then on one later occasion terrorising the residents of Corowa by diving and barnstorming a few feet above the main street. While Hitchcock was managing to keep his nose clean, Cohen would barely survive the course with, by his own account, the lowest mark ever recorded for 'Qualities as an Officer'. ${ }^{3}$

Perhaps, too, Wrigley knew that two weeks after Hitchcock's accident at Richmond his former course-mate Hannah, now with No. 22 Squadron at Richmond, had written off a Demon in a crash officially attributed to 'Pilot's error of judgment'. Hannah had incurred no disciplinary action as a result of his error. He was it seems already marked for higher things as he had been appointed senior under-officer during his cadet course and was soon to become No. 22 Squadron adjutant. ${ }^{4}$ The official preliminary report on Hitchcock's accident had actually been less critical. It referred not to pilot error but to 'inexperience of pilot'. The Air Accidents Investigation Committee had made a similar finding. The treatment of Hitchcock looked all the more disproportionate when set against an accident which everyone at RAAF headquarters would have known about. The man who had escaped retribution after what he characterised in his own log book as a 'major crash' in a Demon in August 1935 was the Director of Training, Squadron Leader George Jones. If a man with 989 hours' flying could overturn a Demon in the middle of the Laverton airfield, was it not understandable that a tyro like Hitchcock might find it hard to quickly master the new type? ${ }^{5}$

\footnotetext{
2 Hoyle, Sir Hughie Edwards, p.8 places Edwards thirteenth of 33. Phil Ford, ex St Peter's College, and Bank of Adelaide clerk, who scored 77.1 per cent, would soon be chastised for 'low flying whilst on detached duty' but within a year appeared to 'realise his responsibilities and is considered to be reliable' (Ford, Norman Philip 0339 NAA: A12372, R/339/H).

3 Kingsland, Into the Midst, pp.23-6.

4 NAA: A12372, R/338/P.

5 I was alerted to information about the course and flying records of Hitchcock and his contemporaries by the invaluable research of the late GpCpt. John J. McKenzie summarised in a letter to Chris Coulthard-Clark, 28 Sept. 1999, generously made available by Dr Clark. Preliminary reports of 1936 flying accidents and forced landings are at NAA: MP187/3.
} 
In any event, Wrigley made it his business to see for himself what was going on with the young man over whose future there was a large question mark.

Shortly after he came to me at Laverton, I got him into the office one day. I said to him 'you seem to be very timid about some aspects of flying,' and...had a sort of homely chat with him. 'You want to tell me anything...,' I said, 'this is perfectly confidential between you and I.' And he said there had been occasions when he had been a bit scared of flying but he said it had mainly been when he had moved from one type of aircraft to another he had not known about.

Wrigley was a legendary decorated wartime pilot and record-breaking aviator. With A. W. 'Spud' Murphy in 1919 he had made the first crossing of Australia from Point Cook to Darwin. They had surveyed the route for the first England to Australia air race. He was also a student of RAAF history and a thinker about strategy and policy. ${ }^{6}$ This was the time for the avuncular assurance that only someone of his experience could give. If, Wrigley noted, Hitchcock had:

...timid tendencies...he just wanted a little bit of sympathetic handling to grow out of - he got it. I said 'well now you are on the station here' - we had some Demons there at the time - I said 'What don't you like?' And he said 'Well they are a bit bigger than what I have been used to, and I don't know that I know as much about them as I ought to.'

If Hitchcock felt under-trained on the two-seater single-engine biplane he was not alone. When the Demon had been introduced in May 1935 the RAAF had declared a policy that no-one could go solo in them unless they first had dual instruction. Policy was one thing, practice another. At No. 3 Squadron there was a shortage of qualified pilots to usher the new charges in. It seems that a single sortie in an aircraft with dual controls was not unusual. Donald AshtonShorter, the pilot who topped Hitchcock's cadet course, and was among those who went with him to No. 3 Squadron, was sent solo after only 35 minutes' dual instruction. A confident and well-regarded young flyer like AshtonShorter could safely be waved through. More experienced pilots like the then Flying Officer Val Hancock, irked by the conversion requirement, might also have got away with a quick circuit of the aerodrome sitting in the back seat of

6 WCdr H. N. Wrigley, 'History of the Royal Australian Air Force', Royal Air Force Quarterly, vol. VI, no. 3, July 1935, pp.301-11; WCdr H. N. Wrigley, The Battle Below: being the history of No. 3 Squadron, Australian Flying Corps, Errol G. Knox, Sydney, 1935. ACdre Brendan O'Loghlin and WCdr Alan Stephens, 'The Air Power Notebooks of Air Vice-Marshal H. N. Wrigley', Australian Defence Force Journal, no. 86 Jan./Feb. 1991, pp.43-50. Alan Stephens and Brendan O'Loghlin, The Decisive Factor: Air Power Doctrine by Air Vice-Marshal H. N. Wrigley, AGPS, 1990. AM Sir Valston Hancock lamented that Wrigley, 'a really inspired and a gifted airman', kept his thinking to himself (interview with Ken Llewellyn, 30 June 1993, AWM: S01657). 
the aircraft listening to an explanation from the instructor. ${ }^{7}$ But others needed more guidance. And records show that both Ashton-Shorter and at least one more of those who arrived in July 1936 were checked out in a flight that lasted a barely credible five minutes. Their log books were signed by 22 -year-old Ronald Hubert Cox, himself a graduate of the immediately preceding course whose promotion to flying officer coincided with their arrival. Cox had emerged from Point Cook nineteenth out of 21 in his class. It was hardly to be wondered that there was some shakiness among the most recent graduates at No. 3 Squadron.

Wrigley, astute and aware of training deficiencies, seized the moment and took Hitchcock down to the aircraft. 'I just want you to get into the aircraft and sit in it and fiddle around with everything until you get to know where this is and where that is...don't hesitate...do anything you like in the cockpit. Get used to it.' Wrigley recalled doing the same thing with the Anson, a larger, heavier aircraft when the first batch was delivered to No. 21 Squadron at the end of 1936. And he believed Hitchcock had again used the same drill when the new Lockheed Hudsons arrived in mid-1940. Certainly the junior officer responded well to Wrigley's advice. When he had finished 'fiddling around', he was encouraged to start the engines, 'get the hang of it', do a taxi around the airfield a couple of times; and then 'when you are right, you can go off and do a few circuits and landings'.

The practical therapy worked. On 22 December 1936, Wrigley reported that:

Pilot Officer R. E. Hitchcock has shown steady progress and improved flying ability since joining this command.

He has developed greater confidence in himself and now handles Demon aircraft with average ability. Pilot Officer HITCHCOCK shows considerable keenness in his Air Service duties, and it is considered that he will develop into a useful officer. ${ }^{8}$

It was a cheering Christmas present. Perhaps it was influenced by the outcome of the just completed flying training course. Nine cadets had been discharged as 'not likely to become efficient Air Force pilots', another had 'claimed a free discharge within three months of attestation', one had been killed, and 25 of the remaining 31 graduates were proceeding to the United Kingdom in accordance with an agreement that Australia would supply 50 pilots a year to the RAF.

7 Sir Valston Hancock, Challenge, Access Press, Northbridge, Western Australia, 1990, p.48; AVM Ernie Hey spoke of a similar experience (Coulthard-Clark, The Third Brother, pp.348, 510).

8 AVM H. N. Wrigley, interview, [1978]; Air Board Agenda 1945, NAA: A4181, 13. Hitchcock had been one of six pilots accompanying F/Lt Dalton for an Aerial Pageant with four Demons at Bordertown in October 1936 (Kevin O'Reilly, Flyers of Time: Pioneer Aviation in Country Victoria, 2012, pp.232-3). 
In this context, with the number of pilots 'considerably below Establishment', Hitchcock's performance looked strong enough to warrant patience and remedial attention. ${ }^{9}$

Hitchcock's rehabilitation was well under way. At No. 21 Squadron, he is recorded as participating in the full range of the squadron's activities. He is first noted taking up a Moth in December 1936 to join the search for a Bulldog from No. 1 Squadron, a single-seater all-metal biplane, lost on a meteorological flight over the Brisbane Ranges, southwest of Bacchus Marsh. On New Year's Day 1937 he was again up in a Moth searching unsuccessfully with CAF Flying Officer John Ryland in another Moth for four men who had disappeared in hilly and heavily wooded terrain near Gisborne. Over the next three weeks he had two attempts at photographing the Barwon Heads golf course from a Demon flying at 3000 and 4000 feet. The resulting mosaic, required by Station Headquarters, proved 'an excellent job', the squadron commander reported. It was as close as Bob Hitchcock would get to the club that was the playground of the Fairbairns, Manifolds, Russells, and Curries of the Western District and his wealthy Citizen Air Force contemporaries, the weekend and holiday flyers who constituted twothirds of No. 21 Squadron's officer complement. ${ }^{10}$

Although detached observers might correctly assess the RAAF as a negligible fighting force in the mid-1930s, it was, as Bob Hitchcock's mentor Harry Wrigley had written, 'most profitably employed for the benefit of the Commonwealth' in its aerial survey and forest fire-fighting roles. In February 1937 at the Forests Commission in Melbourne, Hitchcock accompanied his CO, Flight Lieutenant 'Dorothy' Dalton, on behalf of the RAAF Air Patrol at a Fire Patrol Conference with representatives of the Forestry Commission and Australian Paper Manufacturers. They were there to discuss substitution of 'a substance called "bitterns" for water for fire fighting purposes, various methods of distributing same and the provision of operational bases nearer the bush fire area'. Further experiments were to be undertaken with bitterns - concentrated seawater with approximately 70 per cent of the sodium chloride removed, high in magnesium and potassium salts. The squadron itself received a visit from the Forest Fire Commission Conference a few weeks later and two of Hitchcock's colleagues, Pilot Officers Bill Keenan and John Eagerty, gave an exhibition of air-to-ground communication with borrowed portable radio equipment. ${ }^{11}$

\footnotetext{
9 Air Board Agenda 1974, 1979, NAA: A4181, 13; No.1 FTS Daily Routine Orders...Personnel, 6 March 1936, NAA: A10605, 521/3. Only 24 of Deryck Kingwell's 1935 class volunteered for the RAF; the bottom two graduates drew straws to make up the number (ACdre D. Kingwell, interview, 31 Oct 1981, NLA TRC 1108 Tape 1). It would not have escaped Wrigley's notice early in Dec. 1936 that the well-regarded cadet squadron adjutant and flying instructor F/Lt Doug Candy had written off a Moth and extensively damaged his own Avro Cadet by an 'error of judgment' in a collision while approaching to land (NAA: A12372 R/327/P).

10 Weston Bate, Heads, You Win! A History of the Barwon Heads Golf Club, Barwon Heads, 2007.

11 No. 21 Squadron Operations Record Book, Jan. 1937, NAA: A9186, 42/16.
} 


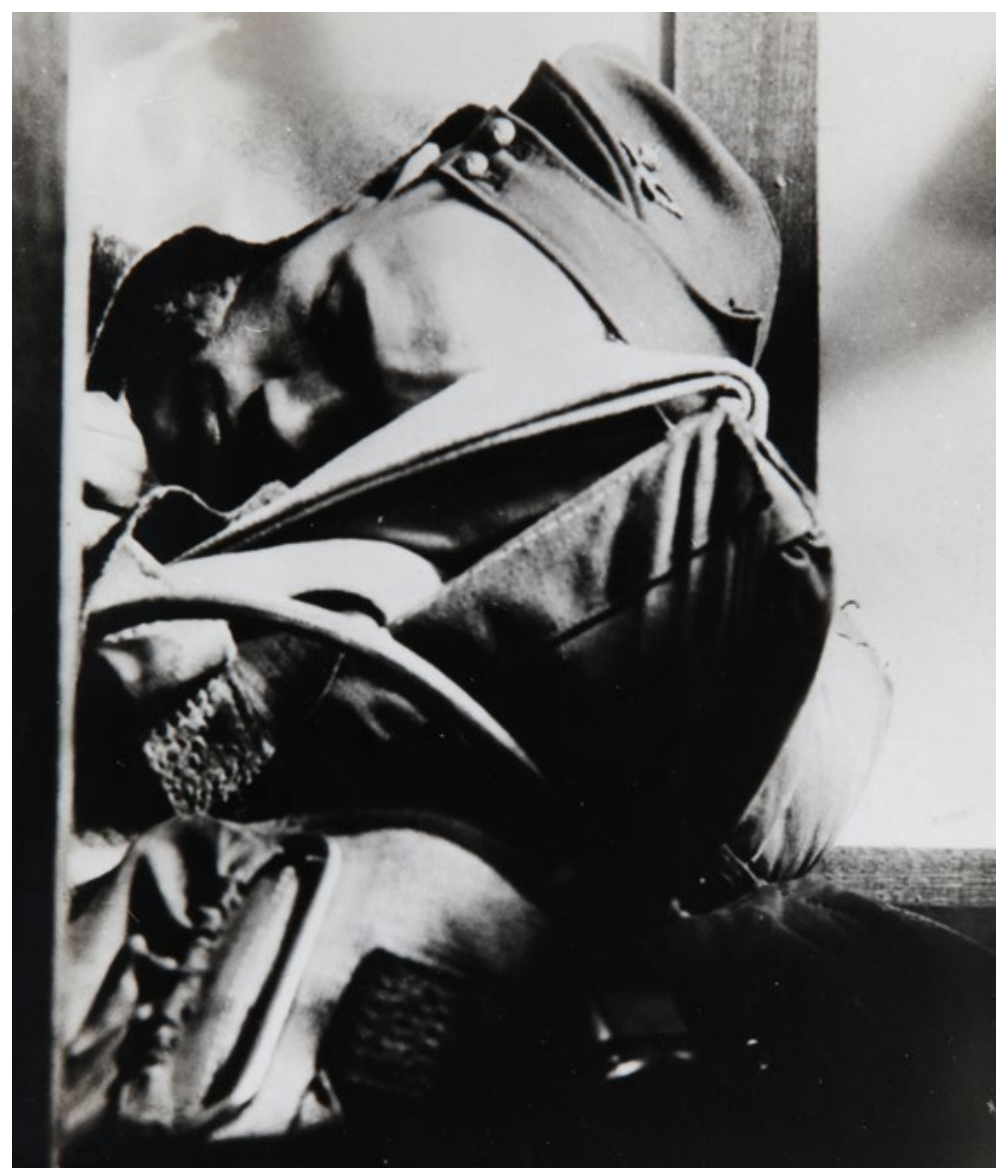

Exhausted on manoeuvres, Yanakie, 1937

(Courtesy of Les Hitchcock)

Several months elapsed before the Air Board reviewed the Hitchcock case. On 25 March 1937, in the light of the recommendation from the Laverton Station Commander, 'it was decided to take no further action on this Agenda'. ${ }^{12}$ In December 1937 Hitchcock flew Wrigley from Laverton to Essendon where the Laverton base commander was to officiate at the opening of the Royal Victorian Aero Club clubhouse enclosure followed by a 'smoke night' at the Drill Hall in North Melbourne with the Governor in attendance. He caught the attention of a photographer for Aircraft magazine.

12 'Pilot Officer R. E. Hitchcock', minute by Secretary, Air Board (P. E. Coleman), 25 Mar. 1937, RAAF 59/1/585, courtesy Dr Chris Clark. 


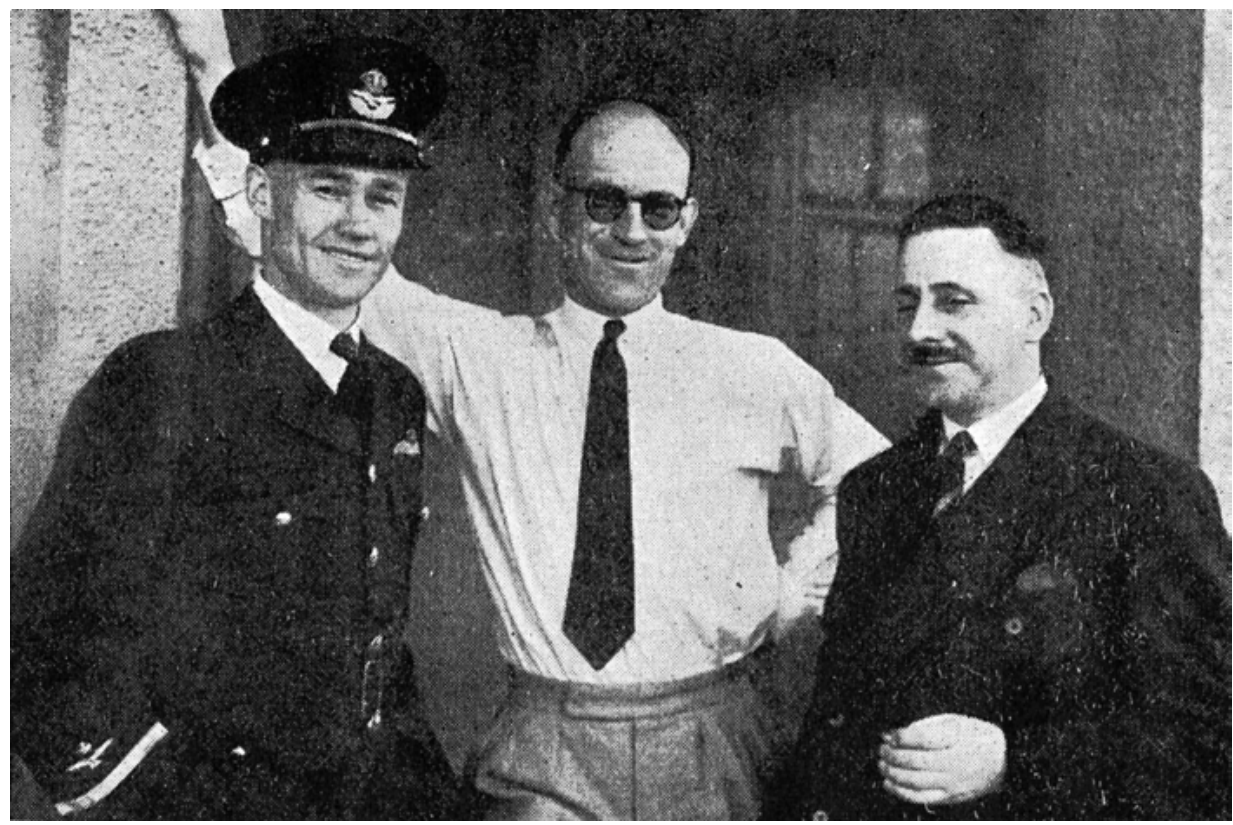

\section{F/O Hitchcock with Hubert Boss-Walker (Chief Instructor) and James Bell (committeeman) at the Royal Victorian Aero Club, December 1937}

(Aircraft, January 1938, p.17, courtesy of David Vincent)

His confidence substantially restored, Hitchcock became, in Wrigley's words, 'a very sound pilot'. ${ }^{13}$ Wrigley's conclusion was justified. Given the number of accidents reported in the next couple of years, Hitchcock's record appears to have been different more in degree than essential character from that of most of his contemporaries.

The late Group Captain John McKenzie, a former Staff Officer Air Training, made a detailed study of the archives. He concluded:

Within fourteen months after Hitchcock's course finished at 1FTS, three of the graduates had been killed in flying accidents together with a pilot from the following course who was in one of the aircraft. Accidents caused by pilots from Hitchcock's course within this fourteen month period resulted in Air Board formally writing off nine (9) aircraft; Hitchcock's accident to the Demon is not on this list.

What McKenzie's research points to is a very different story from the one that later gained credence about the supposedly singular inadequacy of Hitchcock. Slips, scrapes, and minor accidents, usually characterised as errors of judgment but sometimes found to be the result of ignoring instructions, were

13 AVM H. N. Wrigley, interview, [1977]. 
commonplace. Pilot Officer Cohen, for example, marred a display of aerobatics and formation flying at Somers Camp when the port wing tip flare bracket on his Bulldog struck the starboard elevator of the accompanying Bulldog. The damage was minor and only pride was hurt. Ironically Cohen had been brought in from No. 1 Squadron as it was thought that only one pilot available in No. 21 Squadron was experienced enough to take part in the display. More seriously, Cohen was held responsible by the Air Accidents Investigation Committee for one of a series of Demon accidents occurring within a week late in 1937 that provoked a press and parliamentary clamour. Prior to take-off at Archerfield his 'faulty operation of the aircraft brakes' swung him across the path of another Demon that braked violently to avoid a collision, tilted on to its nose, and broke its airscrew. That Cohen, along with Eric Read and Brian Eaton, was one of the RAAF's aerobatic display team that went on show in Bulldogs around Victoria, Tasmania, and South Australia, puts the performance of Hitchcock's contemporaries into perspective. ${ }^{14}$

Among the most notable of the casualties in the year and a half after the class of 1936 passed out was a university graduate and the star of the course, Donald Ashton-Shorter. Awarded a 'pass with special distinction' with a score of 85 per cent, Ashton-Shorter received the sword of honour. Within eighteen days of joining No. 3 Squadron he 'crashed [Major]' (sic) in a Wapiti while practising for a display for Royal Military College cadets. In February 1937, inadvisedly pushing through bad weather between Laverton and Tasmania, he and Gerry Buscombe wrote off their Demons in forced landings in 'strange and difficult country.' The Air Accidents Investigation Committee had pronounced the incident 'an error of judgment... attributed to lack of experience'. By May that year Ashton-Shorter had a total of 190 hours at No. 3 (Army Co-operation) Squadron. Recognised as an officer of great promise - he had won the Mannock Cup for best pilot 10 months earlier - he was probably allowed greater latitude than some of his contemporaries. He had dazzled troops of the $31^{\text {st }}$ Battalion on exercises around Townsville, manoeuvring between trees and a telephone pole to pick up message bags suspended between two sticks six feet high and 10 feet apart. But his skill could not save him when a farewell aerobatic display - at an angle and height contrary to instructions - put a strain on his aircraft that it was not able to take. Pulling out of a dive-bombing demonstration at

14 NAA: A5954, 869/8; MP187/4/173, 184A; Kingsland, Into the Midst, p.36. The Special Technical Committee that examined this incident could not see 'any reason for the failure of F/O. Cohen's brakes...other than their misuse by the pilot, or that they were inoperative at the time, owing to failure of the pilot to release the parking cock before taxying out'. For minor accidents involving others from Hitchcock's cadet cohort, A. N. Hick (fined $£ 10$ for damages to his Seagull), N. P. Ford, D. J. Macpherson, B. G. Braithwaite, W. F. Allshorn, T. H. Davies, R. F. Wiley, and W. J. Keenan, see NAA: MP187/3 and MP116/1. For Eric Read's mangling of a Bulldog and himself in December 1936, see A705, 32/10/1704 and Dick Kingsland, 'Weather on my mind', Canberra Times, 14 Aug. 1981. 
250 feet the Demon's upper port wing and then the lower wing sheared off. ${ }^{15}$ Pilot Officer Ashton-Shorter, already signing his own log book as 'OC B Flight 3 Squadron', would not live to fulfil the hopes of those who rated him so highly. Six days after his death his log book was signed by the acting commander of the squadron, Flight Lieutenant Wilfred Compagnoni.

\section{A nice young man with a good future}

Uncertain though his beginning had been, Bob Hitchcock survived his own year as a pilot officer unscathed. Almost a year after he had received his wings, having passed the requisite examination and with routine promotion to flying officer imminent, Bob was married to his first and only sweetheart, Olive Beecroft. It was just six weeks since he had taken part in a Coronation ceremonial fly-past of 36 aircraft and a spectacular formation dive over the Victorian Governor's saluting base. The occasion was capped when he joined a select group of pilots including Flying Officers Jack Ryland and Jack Graham, and Squadron Leader Fred Thomas at a levee at Parliament House and was presented to the Governor, Lord Huntingfield. Memorable as these ceremonies were, they were no more than a prologue to the transformation of his personal life. The wedding on Saturday 26 June 1937 was a big event at the Swanston Street Church of Christ conducted by the church's celebrated minister, Thomas Henry Scambler. The bride, attended by her 14-year-old sister Mavis, was 'charmingly gowned in deep creamy satin cut on unusual lines with a deep pleated panel on either side falling gracefully into a train at the hips'. A veil of lace lined with creamy satin was surmounted by a coronet of tiny magnolias. As the couple left the church they passed through a guard of honour of RAAF officers. The bride was handed a model aeroplane as a mascot. The bride's mother received guests at the afternoon reception held at The Green Door, 229 Collins Street. ${ }^{16}$

\footnotetext{
15 'Biplane pilot sees an old friend restored', Sydney Morning Herald, 4 Feb. 1987; NAA: MP187/3; MP187/4/176B; Henry Darwen, 'The Kissing Point Camp - 1937', The Whispering Boomerang: News Bulletin of the 31st Infantry Battalion Association, vol. 4, no. 8, March 1988, pp.5-7, courtesy Loftus Dun; CoulthardClark, The Third Brother, pp.327-8.

16 Unidentified press cutting courtesy of Joan Richardson.
} 


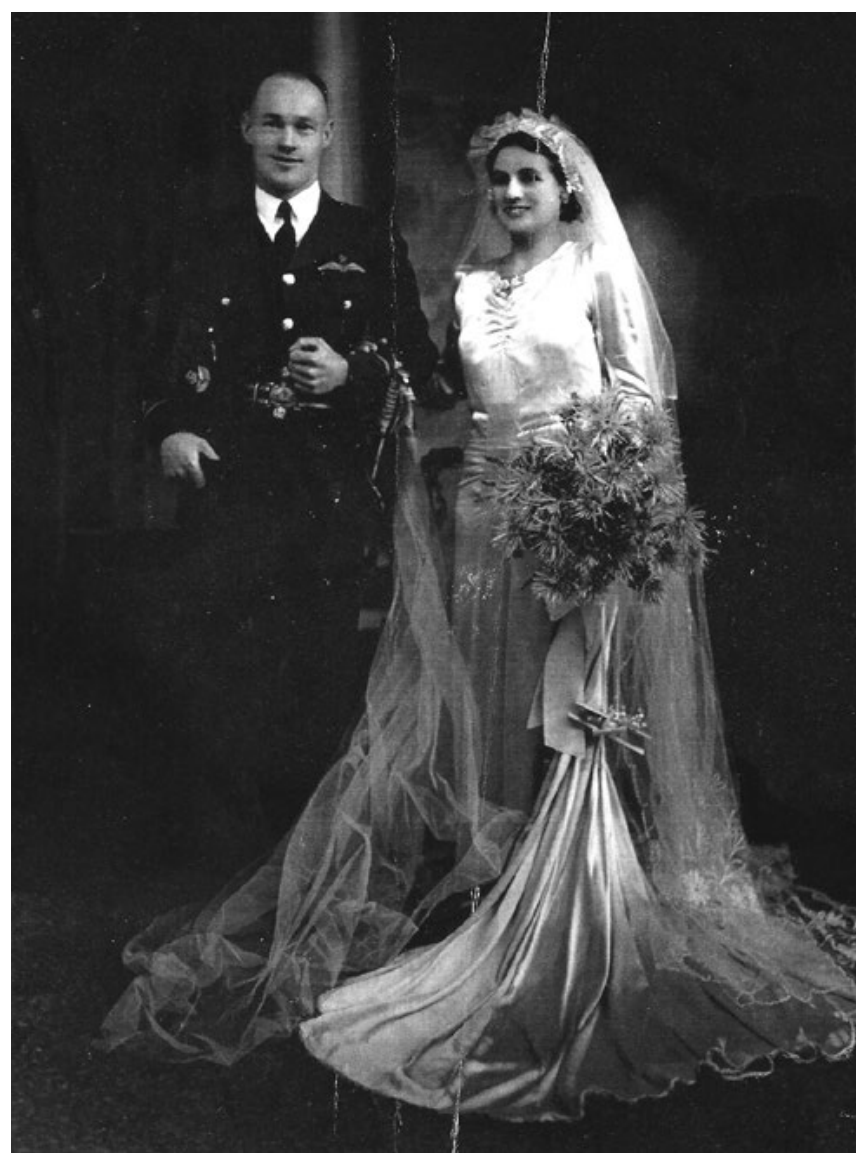

\section{Bob and Olive Hitchcock}

(Courtesy of Joan Richardson and Helen Gregg)

Along with Hitchcock family and friends, a flotilla of Olive's Beecroft and Hoskings relations from Gippsland was in attendance. Bob's friend Rex Taylor was there with Nancy Darlison (they were to be married in the same church in April 1939). There were other RAAF comrades as well, including Bill Keenan and notably Bob's new commanding officer, Charles Eaton, who had taken over No. 21 Squadron in May. Ever since he had led the ground party that found and buried the bodies of Keith Anderson and Bob's father in 1929, 'Moth' Eaton had taken a kindly interest in Bob's affairs. He spoke of him to his own son as a 'nice young man' with a 'good future' ${ }^{17}$ In a squadron photograph of Permanent Air Force members Hitchcock sits comfortably in the front row at his CO's left. ${ }^{18}$

17 ACdre C.R. Taylor to CH, 25 Sept 1983; Dr Charles Eaton to CH, (email), 6 April 2008.

18 SLdr W. H. Brook RAAFAR, Demon to Vampire: The Story of No. 21 (City of Melbourne) Squadron, DemonVamp Publications, Glen Waverly, 1986, p.27. 


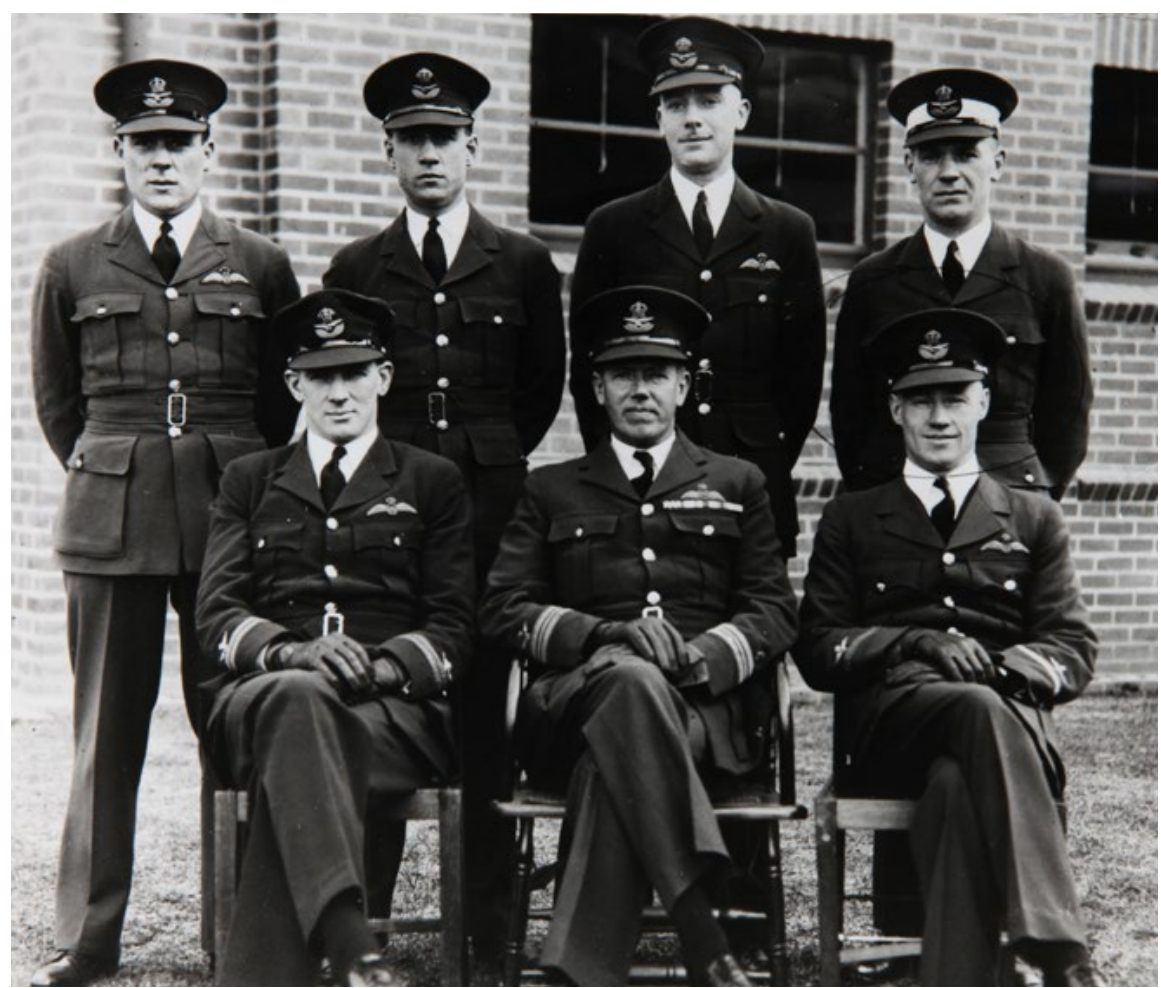

No. 21 Squadron $\mathrm{CO}$ and Permanent Air Force officers. Back row left to right: F/O D. T. Forsyth, F/O W. J. Candler, F/O W. J. Keenan

(Adjutant), Cadet Campbell; front row left to right: F/Lt Dallas Scott, S/Ldr Charles Eaton, CO, F/O R. E. Hitchcock

(Courtesy of Dr Charles Eaton)

Among the 'absent friends' from No. 21 Squadron not present at the wedding was a fellow graduate from the July 1936 Point Cook Flying Training School. John Eagerty, a Xavier College boy, had completed a diploma of agriculture at Dookie College before he joined at Point Cook. He had lived just nine months after gaining his wings. At the controls of a Bulldog undertaking camera gun practice against a drogue target in March, Eagerty had inexplicably failed to pull out of a dive and crashed to his death in Port Philip Bay. It was the same aircraft (A12-8), supposedly undamaged, in which Dick Cohen had clipped another Bulldog during the display of formation flying at Somers Camp six months earlier. ${ }^{19}$ Hitchcock might not have known that Eagerty, who had been transferred to No. 21 Squadron at the same time as himself, had been moved for similar reasons. Classed 'below average' as a pilot in his 'A' course, Eagerty had no recorded accidents. He had subsequently been 'very erratic in his flying, very heavy on controls, and dangerous in landings' of his Seagull V aircraft.

19 NAA: MP187/4/176; No. 21 Squadron Operations Record Book, Jan. 1937, NAA: A9186, 42/18. 
In submitting the adverse report from the Richmond CO to the Air Board, the Air Member for Personnel had expressed the opinion that, 'although slow in learning', Eagerty would eventually become a satisfactory pilot. A further trial in a landplane squadron, 'preferably at Laverton', had been approved. ${ }^{20}$ In his case, though not in Hitchcock's, the Air Board had made a fatal misjudgement.

On the day of the wedding Bob moved out of single quarters and began to draw full married rates of allowances. Following a honeymoon at Healesville the couple were to set up house in Williamstown. After a year together, Olive became pregnant. A son, Robert Gordon (named in honour of his grandfather, not the headline-making parliamentarian), was born in March 1939. The growth of the infant provided Bob with an ideal subject for his main hobby of photography. Now a family man, taking the customary steps in his profession, his career was settling into a predictable pattern and trajectory.

Over the next few years at Laverton, Hitchcock flew regularly in shadowing patrols and exercises in naval co-operation, bombing practice, searches for lost 'overlanders', displays - all the normal duties of a peacetime Air Force preparing for an apprehended war. He spent two months in 1938 with No. 2 Squadron undergoing a navigation reconnaissance course. In Eaton's No. 21 Squadron he undertook a variety of appointments: member of the fire committee, armaments officer, signals officer, photographic officer, officer in charge of the bar in the officers' mess (perhaps a little embarrassing for a tee-total Church of Christ communicant though Eaton himself drank sparingly). He was even acting commander of the squadron for a week before Christmas 1937.

Eaton thought well of Hitchcock, assessing him in February 1939 as average in navigation, bombing, and air gunnery but 'above average' in flying ability. In the language of RAAF form A.18A there was nothing in his flying or airmanship that 'should be watched'. ${ }^{21}$ No-one knew of the incident he mentioned to his younger brother Les when he just missed flying into a freshly erected radio mast in southwest Victoria. If he had been 'involved', as the RAAF historian Dr Chris Clark thought, in the collision of two Ansons on take-off from Curry Aerodrome at King Island on 23 August 1938, Eaton's opinion might have been thought excessively kind. But, as it happened, Bob Hitchcock and his friend Bill 'Dilly' Keenan had captained the aircraft on the way to King Island and

20 Air Board Agenda 1944, NAA: A4181, 13. The Air Board presumably had not been told of the incident in May 1936 when Eagerty lost his way on a cross-country flight in a Wapiti and made a forced landing in Wodonga (NAA: A9300, EAGERTY EJ).

21 R. E. Hitchcock Flying Log Book, NAA: A705, 32/10/2729 Attachment 1. 
then handed them over to two recently graduated pilot officers. Hitchcock was not mentioned in the official accident investigation files or the reports to the Secretary of the Defence Department and the minister. ${ }^{22}$

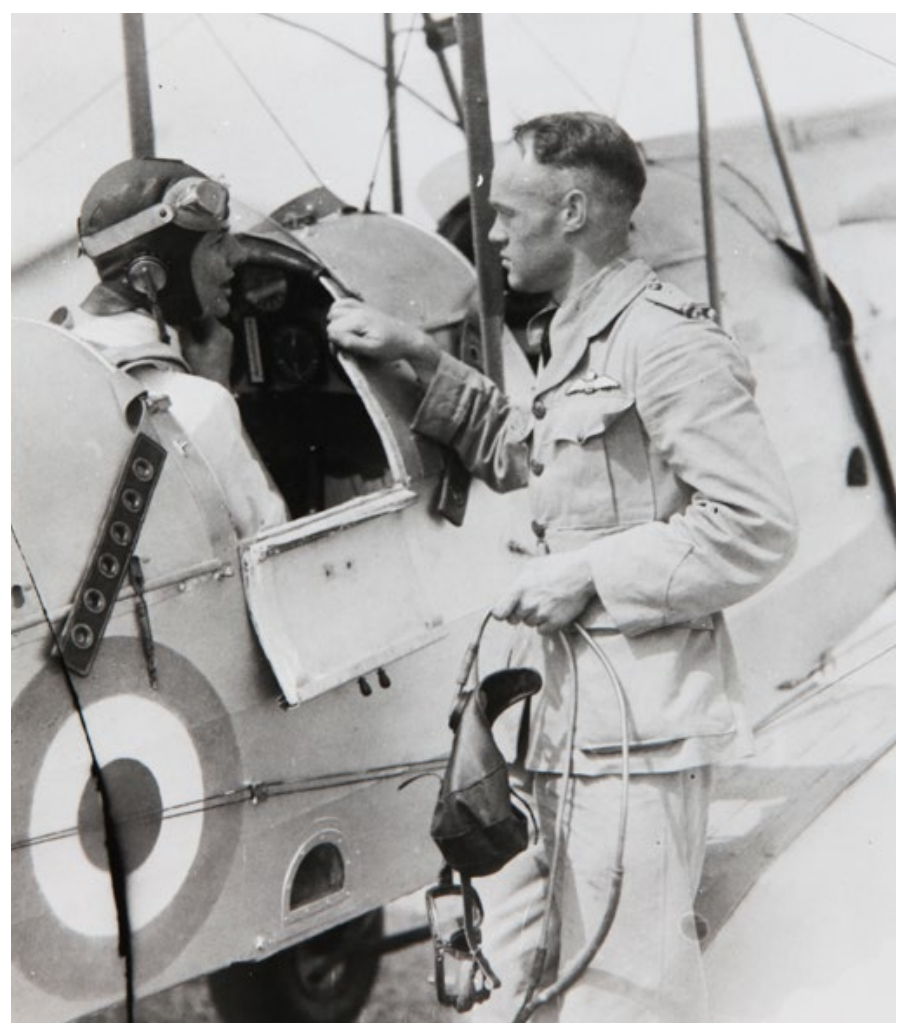

Flying Officer Hitchcock, helmet, goggles, and intercom lead in hand, with DH 60 Gipsy Moth trainer and trainee, March 1938

(Courtesy of Les Hitchcock)

In February 1939 Hitchcock was transferred to No. 1 (Bomber) Squadron and promoted to officer in charge of $\mathrm{C}$ flight and $\mathrm{O} / \mathrm{C}$ photographic section. For six weeks he was temporary commander of the squadron pending the arrival of $\mathrm{P}$. G. 'Paddy' Heffernan from the United Kingdom. The promotions of Heffernan to squadron leader and Hitchcock to flight lieutenant were gazetted on the same day, 27 April 1939. They were two of the 10 (sometimes only eight or nine) officers in the unit, with 109 airmen, in charge of 12 Demons, an NA-16 and an NA-33. In mid-1939 No. 1 Squadron won the AFC Memorial Trophy for the best Victorian Service squadron. Only 20 per cent of the marks were for flying and operational efficiency; but in this category, in which Hitchcock's contribution

22 A. L. Hitchcock to CH, 10 Nov. 1977; NAA: MP187/3 RAAF 1937/1938, reference courtesy Dr Chris Clark; Coulthard-Clark, The Third Brother, p.206; GpCpt. J. J. McKenzie to Dr C. Coulthard-Clark, 28 Sept. 1999. 
would have been important, they scored 166 out of a possible 200 . Heffernan had assessed him at the end of June as above the average for both flying ability and bombing. Intermittently since April the increasingly assured flying officer had been engaged in testing of the two American NA-16 and NA-33 aircraft brought in as construction examples by the Commonwealth Aircraft Corporation.

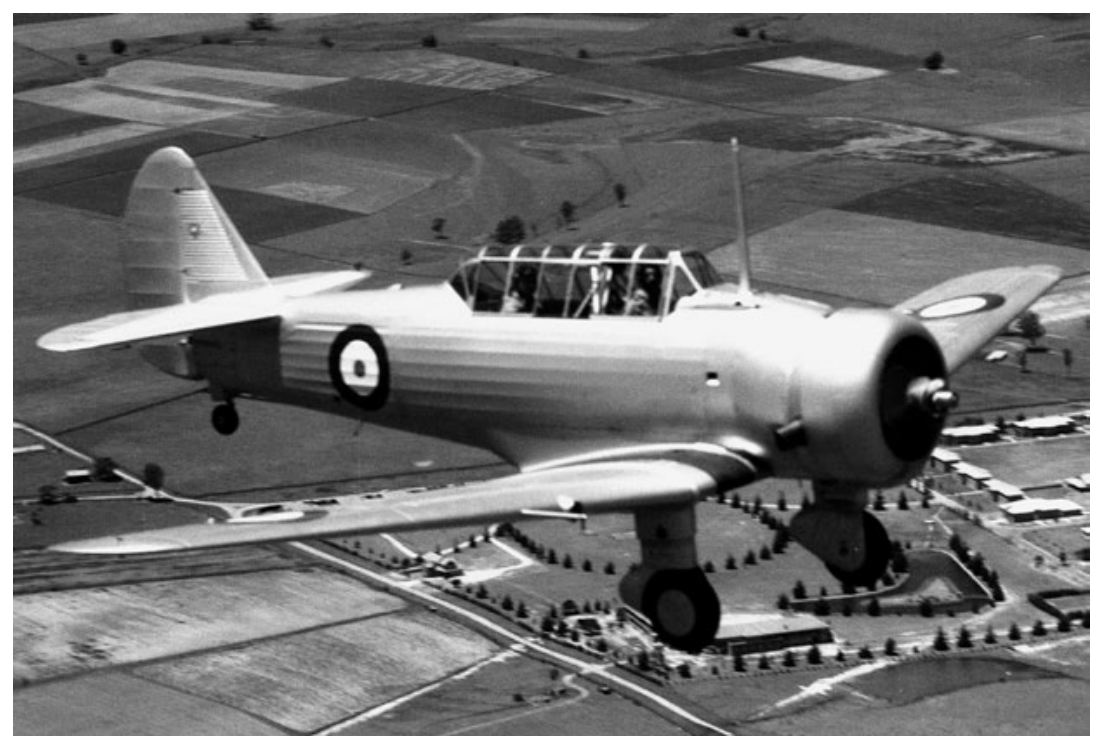

The North American Aviation NA-16-1A (A20-1), flown by Bob Hitchcock seven times between May and August 1939

(RAAF Photograph, courtesy of Gordon Birkett)

When the first three of the new CAC Wirraways, developed under licence from the NA16, were ready for acceptance in July 1939 it was Hitchcock together with Heffernan and one of the RAAF's top pilots, Squadron Leader Fred Scherger, who joined the CAC's test pilot Flight Lieutenant Hubert Boss-Walker to show off the new machines to the press and celebrating ministers. ${ }^{23}$ The RAAF needed good publicity after a year in which five Avro Ansons had crashed with the loss of 15 men. No publicity was given to Heffernan's opinion that Lawrence Wackett had taken 'the worst design features' of the two American NA-16s 'and called the result the Wirraway'. ${ }^{24}$

23 Hitchcock had 'completed successfully a conversion course' on Wirraways on 3 July 1939. (Air Force Court of Inquiry...', attachment forms A 18A, AFO 10/A/9, NAA: A705, 32/10/2729); Brian L. Hill, Wirraway to Hornet: A History of the Commonwealth Aircraft Corporation Pty Ltd 1936 to 1985, Southern Cross Publications, 1998, pp.28-9.

24 Heffernan in conversation recalled by John Hopton, email message to Aviation Historical Society of Australia, 12 May 2012. 


\section{Officers and gentlemen}

The normally spare language of No. 1 Squadron's operations record book suddenly took a new tone in the spring of 1939. Paddy Heffernan noted that his unit was converted to a bomber reconnaissance squadron on August 28 and 29. Their Hawker Demons were transferred to No. 21 Squadron, the Wirraways to No. 12 Squadron. They were replaced by nine Ansons, gathered from No. 22 Squadron, 1 Aircraft Depot, and No. 21 Squadron. 'This change over,' Heffernan said, 'took place during the war crisis and this Squadron was placed in a very precarious position.' In a frank declaration, Heffernan was to report the next month that the outbreak of war 'found this unit unprepared for the role it would have to fulfil if called upon' ${ }^{25}$ It was not just the change of equipment that left his squadron so vulnerable but the departure of fully trained captains, leaving only three who had completed the navigation reconnaissance course. On August 28, five days before war broke out, Hitchcock had left No. 1 Squadron, assigned to No. 2 Squadron as $\mathrm{O} / \mathrm{C}$ of A flight.

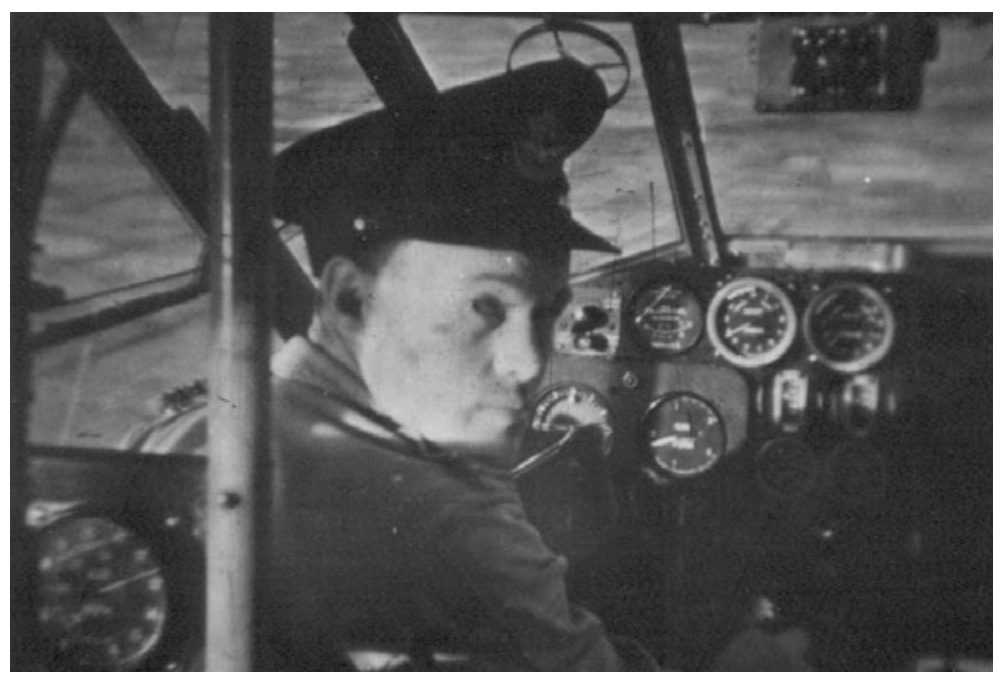

\section{Bob Hitchcock ready for take-off in an Anson}

(Photograph by Frank Jefferies, courtesy of Paul and Helen Struc]

When Bob Hitchcock arrived at No. 2 Squadron, war fears gripped Laverton. Aircraft were grounded amid an intense period of equipment checking and maintenance. Wing Commander Charlesworth reported at the end of August that the preparation of mobilisation orders had been completed and the squadron was 'being maintained in a state of readiness for any eventuality'. With 11 officers and 130 airmen, the squadron had 10 Ansons 'fully equipped

25 No. 1 Squadron Operations Record Book, NAA: A9186. 
for War Operations'. They began immediately diverging searches to seaward. As no enemy vessels had been sighted after two days, the patrols were suspended. For several weeks two aircraft and crews were placed on standby every second day. Then a system of duty flights in conjunction with No. 1 Squadron and No. 21 Squadron began. Occasional patrols up to 150 miles eastward from refuelling bases established at Yanakie on Wilson's Promontory and Pat's River aerodrome on Flinders Island followed in October and November. Under a new CO, Fred Thomas, the squadron also undertook parallel track searches from Mount Gambier to Parafield under instructions from the Central Operations Room. As the months wore on, the search for enemy submarines, raiders, and mine-layers continued, with occasional interruptions to protect 2 nd AIF troop convoys. ${ }^{26}$

The bare formalities of Hitchcock's service progress are on record. Some, though by no means all, of the evaluations of those whose job it was to judge him and measure him against his peers are preserved. The report on a pupil pilot passing out from an ' $a b$ initio' flying training course (Form F/T.4), for example, is missing from his file. So too are some of the annual confidential reports on officers. Thus we are more than usually reliant less on contemporary official judgements than on the later private observations and impressions of those who saw him at work and in the mess. One of the young pilot officers in his flight at No. 1 Squadron was Lindsay Trewren, who made the following observations:

From my lowly position he was regarded as quite a good pilot, having survived the Bulldog, Demon, Anson eras of the Sqdn then finally Hudsons.

He was of smallish stature, quite efficient and had a bright \& very likeable personality and very popular with all ranks in the Sqdn, although a little reserved at times.

Never flamboyant or over-confident - in fact quite the opposite more retiring and quite modest. ${ }^{27}$

Father Ken Morrison, a popular Roman Catholic priest, knew Hitchcock in the mess at Laverton. Morrison had been commissioned to the RAAF in 1936 to act as part-time chaplain to No. 21 Squadron. When war came, he was called to fulltime duty and lived on the base until the beginning of September 1940 (initially, in order to keep him more fully occupied, he was made a cypher officer). ${ }^{28}$ Morrison recalled Hitchcock as:

\footnotetext{
26 No. 2 (General Reconnaissance) Squadron Operations Record Book, NAA: A9186.

27 L. R. Trewren to CH, 3 June 1978. Trewren recalled landing a badly damaged Hudson in June 1942 (Sid Grantham, The 13 Squadron Story, Dee Why, 1991, pp.68-9).

28 Msgnr K. Morrison to CH, 14 Oct. 1982; Fr John McNamara, 'The Role of the R.A.A.F. Chaplains in the Middle East', in Peter Alexander, We Find and Destroy: History of 458 Squadron, The 458 Squadron Council, 1979, p. 275.
} 
...a somewhat rugged person, not big but solidly made, slightly russet in colouring, balding or suggesting that he was going that way. He was by no means a recessive or negative character though could have been something of a loner and not socially successful type. ${ }^{29}$

David Colquhoun, who was to leave Australia for Singapore as a Hudson captain with No. 1 Squadron in June 1940, remembered a 'short stockily built pleasant chap who seemed to have a somewhat shy and retiring disposition'. Though he did not know him well, Colquhoun had 'a vague recollection that Bob was not terribly keen about flying but was following in his father's footsteps'. ${ }^{30}$ Clarence 'Spud' Spurgeon, a young pilot officer in No. 21 Squadron, noted that Hitchcock 'didn't booze much'. Not that, as a very junior 20-year-old, Spurgeon would himself have mixed much socially with a flight commander. 'I probably would never have spoken to him except on the stairs... hierarchy was maintained strictly. ${ }^{31}$ Another colleague who knew Hitchcock better was Deryck Kingwell. Kingwell had arrived as a 20-year-old cadet at Point Cook just as Hitchcock graduated. He was to win the sword of honour in July 1937 and the Mannock Cup as best pilot. Later at Laverton, then a flight lieutenant, Kingwell was chief instructor at the General Reconnaissance School. The Hitchcock he remembered was 'a quiet good looking chap who mixed well with his fellow officers'. ${ }^{32}$ As a cadet and young officer, 'Tich' McFarlane, later to rise to Secretary of the Air Department and Public Service Board Commissioner, found him 'not the typical aristocratic Air Force type, the superior type'. McFarlane, a self-improver educated at Scotch College and Melbourne University, remembered a man who was 'courteous, very generous with his time'. Hitchcock's good relations with his fellows were perceptively noted by Kingwell, a natural leader who was soon to become the youngest Group Captain in the Air Force.

Whatever was beneath the mask of reserve, maybe lingering uneasiness about his own ability, Bob Hitchcock was making a success of his Service life. He was an accepted member of the flying fraternity. None of those who testified in later years about his personality, vague as their memories might be, connected his shyness and reserve to his past. If they knew, they did not relate his behaviour to the feelings of a boy who might have thought - contrary to the evidence known to his uncles, aunts, and cousins - that his father had abandoned his beloved mother years before he died. They did not speculate on the effect of being thrust into national spotlights as the son of a tragic hero about whom an important truth was never publicly disclosed. The fact was that young Bob, from

29 Msgnr K. Morrison to CH, 14 Oct. 1982.

30 ACdre D. W. Colquhoun to $\mathrm{CH}, 7$ June 1978.

31 ACdre C. H. Spurgeon, telephone interview, 16 Nov. 1982.

32 ACdre D. W. Kingwell to CH, 18 April, 31 May 1978; interview with Fred Morton, 31 Oct. 1981, NLA TRC 1108. Kingwell spoke of being a flying instructor at Point Cook when he knew cadet Hitchcock; but Hitchcock had graduated a year earlier. 
the age of 16, was labelled as his father's son. The Argus, presumably primed by an Air Force press release, had singled him out when his name appeared in the list of successful applicants for the cadet course. He knew, as he must have suspected all those who commanded him knew, that he owed his continuing place in the Air Force to compassion, with perhaps a tincture of guilt, over his father's fate.

Unwisely, he had told some fellow recruits that his mother had been promised that the Service would look after him and his brothers. They knew that his father had died in 1929 because he followed the lead of Keith Anderson, a man of repute but poor judgment, trying to save their friend Charles KingsfordSmith, a charismatic, courageous but feckless and reckless glory-seeker. It had seemed like the least the Air Force could do. Contemporary trainees recalled hearing that when he arrived in Melbourne by train from Western Australia Bob Hitchcock had spent his first night in the home of the Chief of the Air Staff. Dicky Williams did not routinely provide shelter for recruits. But as the son of a copper miner in Moonta, South Australia, and former telegraph messenger, the abstemious Williams knew what it meant to make the journey from a working man's world to the officers' mess.

At Laverton in the early days of the war, Bob remained very much a private man. His fellow flight commander Ray Garrett saw him as 'a very good type of young man and very popular in the Squadron though of a very shy and retiring disposition. ${ }^{33}$ Garrett, also a flight lieutenant though some 12 years older than Hitchcock, had been a Citizen Air Force instructor - the only certified CAF instructor in the 1930s - and a commercial pilot. He, like Bob, had lost his father at an early age. As his daughter recounts, Garrett left school at 14 to work at Watson's and Son, pioneers in X-ray and optical equipment. He studied parttime with Professor T. H. Laby, the dean of the science faculty at Melbourne University:

He was involved in various projects from importing cars to installing lifts which weren't very successful so when the Depression came and he was engaged to mum her brothers finally asked him what his intentions were. This is when he decided to fly the Airmail Route in Northern Aust. for Jimmy Larkin to try and earn enough money to get married. 


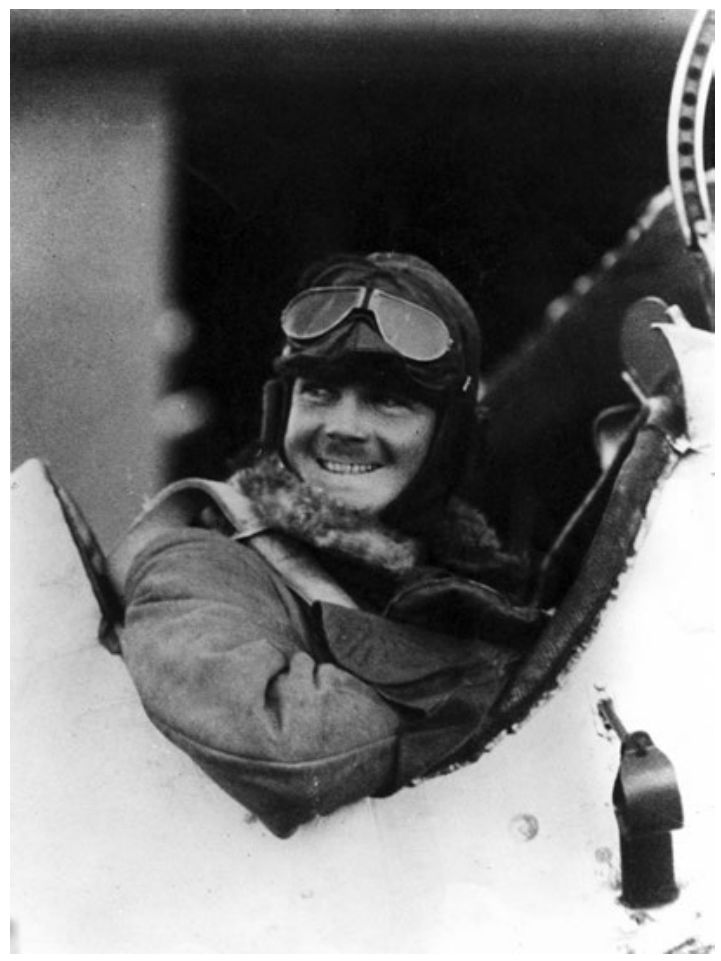

\section{Ray Garrett in an SE5a, 1926}

(Courtesy of Anne Kelly)

After their marriage the Garretts lived in his mother's home in East Kew, where Ray set up a photographic business in the laundry. ${ }^{34}$ While running the business Garrett had continued in the active Reserve and was called up at the outbreak of war. Like Bob, Ray lived off the base with his wife and young family. Both Ray and Vera Garrett were Methodists. Like Bob and other Church of Christ parishioners, they were teetotallers and non-smokers. Yet, for all that he made his own way in the world, and friendly as he was with Hitchcock, there was some social distance between the Garretts and the Hitchcocks. Affluent East Kew was a world away from the inner south-western working class suburb of Newport where Bob, Olive, and their little boy Robert had settled.

Bob was probably more at ease with his other fellow flight commander Jack Ryland. Ryland, a year older than Hitchcock, was the son of a Mallee farmer. A Roman Catholic, educated in the country, and then at Xavier College where he was captain of boats and the Australian Rules football team, he had earned a degree in agricultural science while learning to fly and serving in the Citizen

34 Anne Kelly to $\mathrm{CH}$, (email), 29 April 2009. 


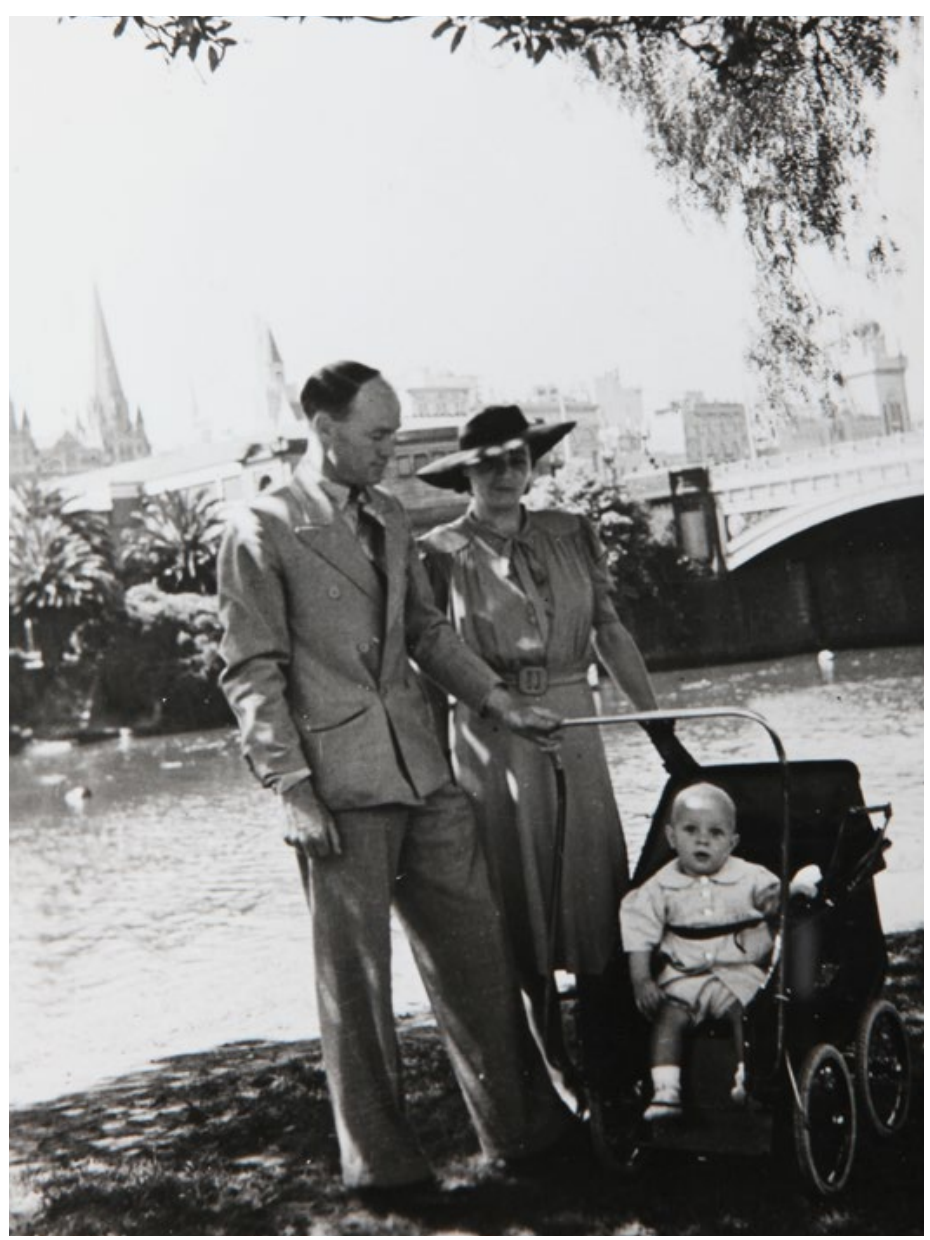

\section{Bob and Olive Hitchcock with baby Robert: a stroll by the Yarra}

(Courtesy of Les Hitchcock)

Air Force. He worked briefly in the Victorian Department of Agriculture before joining Ansett Airways in 1937. Ryland had been in the Air Force Reserve from 1938. Called up in October 1939, he was the most experienced of the three flight commanders on Hudsons. He converted both Garrett and Hitchcock in July 1940. Ryland, as David Campbell testified, 'had no side to him...he didn't pretend to belong to the Toorak lot'. 'Tich' McFarlane, who liked him, would say: 'nothing terribly brilliant about John, nothing terribly imaginative... but a very solid, sound fellow'. ${ }^{35}$ In 19 hours dual and check-dual flying as Ryland's pupil, and a subsequent crew test, learning the particularities and peculiarities of the new aircraft, Hitchcock had come to know the 'very solid, sound fellow' well.

35 A. B. McFarlane, interview, 18 April 1978. 
Wing Commander J. H. Glasscock, then a Flying Officer in No. 1 Squadron, remembered Hitchcock early in the war as a popular officer with 'a pleasing personality'. Ivon Black, later Wing Commander, DFC and CO of No. 21 Squadron, but then another flying officer in No. 1 Squadron, found Hitchcock a 'likeable fellow'. Professionally, he thought him 'quite a safe pilot...definitely a cautious type'. But as a single man living on the base Black did not mix much with Hitchcock. ${ }^{36}$

If Hitchcock kept to himself it was understandable that he wanted to be with his family each evening or at weekends. Reliant on his service pay of £1.7.6 a day he certainly could not afford the entertainment and leisure pursuits that so many of his contemporaries took for granted..$^{37}$ But there was in any case another element in his life that seems to have eluded his peers and superiors: his church affiliation.

\section{‘I don't want to seem a snob...'}

From his earliest enlistment documents Bob Hitchcock acknowledged that he was a member of the Church of Christ. It was the faith of his parents. But it identified him among an austere religious minority that deplored the 'tendencies of modern life'. A census of religions in the RAAF conducted in July 1940 found 223 airmen in the Church of Christ and just five air crew. When the RAAF began to appoint full-time chaplains at the beginning of the war it recognised only the four largest groups: Anglicans (49 per cent), Roman Catholics (17 per cent), Methodists (14.5 per cent), and Presbyterians (12.5 per cent). The Church of Christ was one of an undifferentiated aggregation of 'Other Protestant Denominations' (7.5 per cent). ${ }^{38}$ Closest in doctrine and practice to the Welsh Baptists, though with early nineteenth century American roots in Methodism and Presbyterianism as well, the Church of Christ proclaimed 'no creed but Christ'. Membership of the church followed a public confession of faith. Penitent believers were baptised by full immersion. Congregations were autonomous. There was no priesthood, though those who hoped to serve as ministers were trained in Bible colleges and ordained. Individual churches

\footnotetext{
36 J. H. Glasscock to CH, 5 June 1978; Ivon O. Black to CH, 24 June 1978.

37 Standard rate of pay for married RAAF flying officers, inclusive of allowances, in April 1936 was £533570 a year (Air Board Agenda 1860, NAA: A4181, 13).

38 Peter A. Davidson, Sky Pilot: A History of Chaplaincy in the RAAF 1926-1990, Dept of Defence, Canberra, 1990, p.1/9. The census figures for 18 July 1940 were: Anglican (51 per cent) 7215 airmen, 467 air crew; Roman Catholic (17 per cent) 2642 airmen, 92 air crew; Methodist (14 per cent) 2016 airmen, 101 air crew; Presbyterian (10 per cent) 1438 airmen, 119 air crew; Baptist 289 airmen, four air crew; Congregational 207 airmen, 17 air crew. There were 51 Salvation Army in the ranks, 38 Jewish and four Jewish air crew. Of the other faiths, only Christian Science had more than 25 adherents. There were three Mormons, one Mahomedan, three agnostics and two atheists (NAA: A705, 36/1/99).
} 
'called' their own 'preachers'. Their principal belief was a passion for church unity. Each congregation celebrated the 'breaking of bread' every Sunday. Through the rest of the week members were enjoined to temperance; card play and gambling were discouraged; smoking was frowned upon; and they were frequently reminded of the moral dangers of dancing.

When Bob was 12 years old, a Church of Christ had begun in Victoria Park, Perth. A handful of adherents met at first in a rented library hall. Two years later, evangelists from eastern Australia, the Hinrichson-Brooker tent 'mission', had elicited 75 'decisions' and a 'thank offering' sum of £300. Bobby Hitchcock, a Wesleyan when he enlisted in 1915, and Violet were baptised by the minister F. A. Youens early in 1926. With the funds raised by the mission a chapel was erected in 1928 and the congregation flourished. ${ }^{39}$ In Western Australia as a whole the church had nearly 3000 members in 1930. By 1939 it had fallen to 2600. In Victoria, where the church was strongest, there were over 13000 members in 1939, a figure virtually unchanged since $1930 .{ }^{40}$ Membership was not a matter of nominal adherence. Regular attendance at worship services and participation in family 'socials' were expected. It is hard to imagine the young RAAF officer, rugged and fit as he was, not being drawn into local church tennis teams or youth activities, especially the Boys' Explorer Club, which combined moral instruction and calisthenics. We know that Bob often spent weekends out of barracks in Moreland with the 'lovely lady' who knew his mother. It was there that his fellow trainee and pal Rex Taylor had met his future wife. And Olive Beecroft was a constant visitor to the Taylor household.

In 1940, Bob and Olive with their infant son Robert were living in Newport. Although he had previously been a member of the Hampton Church of Christ, Bob now seems to have drifted away from the church. Without a building of its own, the Newport congregation was reporting 'splendid meetings' in the Scouts' Hall. But Bob, having left Hampton to be 'nearer his place of work', as the church journal would put it, was not among those present. ${ }^{41}$ The Hitchcocks'

39 Information from the Silver Jubilee Souvenir History of Churches of Christ in Western Australia 1890-1940 and Gordon A. Ewers, A Century of Worship and Witness 1890-1990: Churches of Christ in Western Australia, supplied by Don Parker; Australian Christian, 1925-26. See also Roy Raymond, A Preacher's Progress: An Autobiography, Perth, 2002; Australian Christian, 25 April 1929. The preacher, E. C. Hinrichson, and song leader, Les Brooker, had recently completed a six-month mission in country Queensland, where a youthful future Premier had been a convert (Cameron Hazlehurst, Gordon Chalk, A Political Life, Darling Downs Institute Press, Toowoomba, 1987, p.25).

40 Graeme Chapman, One Lord, One Faith, One Baptism: A History of Churches of Christ in Australia, Vital Publications, Melbourne, 2nd ed. 1989, pp.111ff; A. W. Stephenson, Pioneering for Christian Unity In Australia and New Zealand, Being an Outline of the History of Churches of Christ in Australia and New Zealand and a Brief Study of their Teachings and Ideals, Austral Printing and Publishing Co. Ltd, Melbourne, 1940, p.91.

41 Australian Christian, 24 Jan., 12 June, 21 Aug. 1940. In July 1940 the church in Victoria counted 23 Explorer Clubs for some 2000 boys aged between 11 and 15. As a young teenager in the mid-1950s, I attended the Church of Christ in Footscray, an adjoining suburb to Newport, where Newport members then worshipped. The Boys' Explorer Club met weekly in the church hall, making good use of a vaulting horse and roman rings suspended from the ceiling. 
two-bedroom weatherboard worker's cottage at 43 Agg Street, was five minutes' walk to the Newport railway station through which trains went to Laverton, Aircraft Siding, and Geelong. ${ }^{42}$ Not that most of Hitchcock's colleagues were patrons of the Victorian railways. Not for them the weekend rail concession fares granted to men in uniform from mid-June $1940 .{ }^{43}$ 'The flying people were a coterie somewhat removed from all other sections of the personnel,' Monsignor Ken Morrison recalled, more likely to be seen in a jaunty sports car than a railway carriage. If they did use the train for return journeys between Melbourne and Laverton or Point Cook, for an extra threepence they could travel first class. Someone who had risen from the ranks with a trade background might be able to afford the first-class fare; but he could rarely hide his origins. If he was a Roman Catholic he had overcome a double handicap in the selection process, thanks to the presence among the selectors of 'Dad' Bladin (who was married to a Catholic and was received into the faith after his retirement) and John Joseph Swift, a medical administration officer with honorary commissioned rank, specifically chosen to ensure Catholic representation. Those affiliated with the smaller dissenting Christian churches faced less obvious but no less real discrimination. According to Monsignor Morrison, Bladin 'expounded his theory of selection \& made no apology for it':

...there was a super-abundance of applications and the responsibility was on the candidates to present themselves in a manner that was known and accepted by the selectors. Consequently if a lad was in the cricket XI or the 100 yards at Scotch or Xavier it was to his credit but if he had the same achievements at one of the lesser known colleges...it did not mark him so highly.

Within the coterie, 'the Toorak lot', as David Campbell recalled them, were a class apart. These were men with pastoral backgrounds, men from the legal and medical professions, a handful of commercial pilots, men of business, whose families had known little of the privations of the Depression. At their head in No. 2 Squadron was Fred (Freddie to his intimates) Thomas, the affluent businessman, committee member of the Naval and Military Club, honorary ADC to Victoria's Governor, Lord Huntingfield, himself a flying enthusiast. The squadron's popular adjutant was a young man about town, well off and well liked. A few brother officers at Laverton came from the two leading Catholic private schools, Xavier and Riverview. But more were educated at Geelong Grammar, St Peter's (Adelaide), Wesley, Scotch, Melbourne Grammar, Sydney Grammar, Brisbane Grammar, or perhaps at Fort Street in Sydney or Melbourne High, Victoria's premier selective high school.

42 I am grateful to Brian Haynes and Jane Ridley of the Williamstown Historical Society for information about Agg Street, and to my former Monash University colleague Sid Ingham for his recollections of Newport. 43 NAA: AA1966/5/226. 
There were rare exceptions. Bill Heath, whose father was a Collins Street doctor, was unusual in having earned a diploma of agriculture at Longerenong College in the Wimmera, a qualification for farmers' sons. But even he grew up in South Yarra as well as the family farm at Freshwater Creek near Torquay. What Heath really wanted to be, as his RAAF enlistment form described his 'civil trade or profession', was an 'aviator'. He was to learn to fly in Geelong, his ambition undiminished by his father's Depression misfortunes. As another contemporary with similar status put it, hesitating to express his opinion of Hitchcock to me, 'I don't want to seem a snob...' The unspoken words said it all. If the 'otherness' was ever articulated it was in the snooty shorthand of a senior officer's wife remembered by Paddy Heffernan: 'N.O.C.' (Not Our Class). ${ }^{44}$ He would not rub shoulders at the Naval and Military Club with his superiors like Anderson, Thomas, and the Laverton base commander and club president, Frank Lukis. Nor was Hitchcock ever completely comfortable with many of his flying peers, or they with him. Although he needed no reminder of the social distance between them, he could see it any morning on the way to work as his train pulled out of Newport station - a four-storey brick flour mill bearing the name 'W. C. Thomas \& Sons Pty Ltd', his CO's family firm. ${ }^{45}$

That said, whatever Hitchcock may have felt, Father Morrison who was familiar with the Laverton milieu, 'never saw anything in the attitudes of his fellow officers, snobbishness, caste, scorn for inferior ability'. While the social barriers may have been barely perceptible to the young priest, he was impressed with a strong professional bond discernible in the mess. 'The flying course with its attendant training in discipline and intercourse with other people, always put a stamp on those who went through it. ${ }^{46}$ What Father Morrison had not seen before the war was the subtle condescension, and occasional irritation, of some of the Citizen Air Force weekend flyers. These were the part-timers, driving down for a Saturday night sleep-over, who were learning about reconnaissance, naval co-operation, and bombing. The exercises were instructive but there was more fun to be had in pageants, air displays, and excursions to the Bass Strait islands, often with family friends clandestinely on board.

Until the middle of 1939, as Rollo Kingsford-Smith, nephew of Sir Charles, put it, 'for officers the RAAF was a combination of a gentleman's country club associated with a flying club for enthusiastic amateurs' ${ }^{47}$ There was no exact counterpart of the RAF's No. 601 (County of London) Auxiliary Squadron,

44 P. G. Heffernan, 'TOC and Cork', The Duntroon Society Newsletter, 2/1990, p.12.

45 Major Warren Perry, The Naval and Military Club Melbourne: A History of its First Hundred years, 18811981, Lothian Publishing, Melbourne, 1981, pp.178, 190, 387-8; Lewis and Peggy Jones, The Flour Mills of Victoria 1840-1990: An Historical Record, Flour Millers' Council of Victoria, 1990, pp.137-8.

46 Msgnr K. R. Morrison to CH, 6 June 1983.

47 Kingsford-Smith, I Wouldn't Have Missed it for Quids, p.24; Michael Molkentin, “'Unconscious of any distinction"? Social and vocational quality in the Australian Flying Corps, 1914-18', Journal of the Australian War Memorial, no. 40, Feb. 2007 (http://www.awm.gov.au/journal/j40/molkentin.htm). 
the 'Millionaires Squadron' created in 1925 at White's Club by Lord Edward Grosvenor who selected members to serve under him after assuring himself that copious quantities of gin and port would not incapacitate them. London's aristocratic clubmen lined their uniform tunics with red silk and played polo on Brough Superior motor cycles. ${ }^{48}$ But Australia's elite flyers, though a tad less flamboyant, unashamedly indulged the perquisites of their wealth and status. Thus the hard-drinking Bertie Simms, CO of No. 6 Squadron at Richmond in 1939, would occasionally summon Pilot Officer John Murphy for a 'few holes this afternoon' taking him to the golf course in his staff car. ${ }^{49}$ 'Moth' Eaton was widely believed to have told his pilots to keep their eyes open for trout streams which he could share with his fishing companions Frank Lukis, Sir Tom Blamey, and Blamey's friend, the businessman Major (later Brigadier) Lionel Lemaire. Eaton's son Peter remembered how one of his father's young pilots, 'Johnny' Lerew, a Scotch college old boy, sportsman, racing motorist, and civil engineering graduate, told him to 'jump in the old Wapiti'. They proceeded on 'a hedge-hopping joy ride, buzzing farm houses at tree height as they flew en route to Geelong where Lerew dive-bombed his girl-friend's home'.50 Many a young woman, like Dick Cohen's acquaintance holidaying in the path of one of his meteorological flights, was the recipient of a message from on high with a streamer attached. 'There was a bombing range on a property at Cressy,' the meteorologist Allen Cornish recalled, 'and sometimes Dick would land and taxi to the homestead where we would have morning tea in the Demon. ${ }^{51}$

In all the recollections of Bob Hitchcock's character and behaviour, frivolity, spontaneity, and exuberant leisure pursuits are rarely part of the story. Witness Jack Graham, a Cambridge law graduate, who had been put through a complete flying training course at Point Cook in 1932 in spite of his three years with the Cambridge University Air Squadron. Graham joined the new No. 21 City of Melbourne Squadron in 1936. There, where Hitchcock was one of the nucleus of permanent officers, he encountered someone he recalled was considered to be 'a very over-confident pilot'. Not a man looking for fun but thought by some to be flirting with danger. Flying in formation with Hitchcock, Graham found him 'taking the most awful risks...very easy to collide in formation especially in the aircraft we were flying then, the Anson which was like a flying cow, sloppy sort of aircraft'.

\footnotetext{
48 Tom Moulson, The Flying Sword: The Story of 601 Squadron, Macdonald, London, 1964. As Commodore of No. 21 Squadron, Lord Huntingfield arranged an affiliation with the RAuxAF 600 (City of London) Squadron (Lord Lloyd to Huntingfield, 2 Jan. 1938, Huntingfield MSS, NLA AJCP M2821).

49 Steve Eather, Blue Lightning: The Story of 6 Squadron 1917-2005, Australian Military History Publications, Loftus [NSW], 2007, p.17; A. B. McFarlane, interview, 18 April 1978.

50 Charles Eaton, The Cross in the Air, Ch. XIII (draft courtesy of Dr Eaton). Blamey's son F/O Charles Blamey had been killed when his Moth stalled and crashed in Dec. 1932 (Coulthard-Clark, The Third Brother, p.323). 51 Allan Cornish, Memories of the Bureau of Meteorology 1929-1946, pp.512-3; http://wark.austehc. unimelb.edu.au/fam/0512.html.
} 
Graham's personal experience of this risk taking was only one isolated incident. It could hardly have been otherwise:

We were a very friendly happy mob in the mess at 21 and I don't recall any sort of people being left out of our activities there. In fact, at weekends - we used to go down every second weekend - arrived down there midday Saturday... and we stayed down to late Sunday and we had a whale of a time...

Quite often we would go down there and find that the permanent people had flown the guts out of the aircraft and they were all unserviceable, and that used to make us mad, naturally. ${ }^{52}$

Bob's contribution to wear and tear on the aircraft included an occasional unadvertised diversion to south Gippsland. He would drop parcels into a Koonwarra paddock where Olive's younger brother, Don Beecroft, was working. On one surprise run he swooped over a group of men weeding an onion field. Flying low over the pine trees straight toward them he was unaware that one of the older workers was a shell-shocked Flanders veteran. As he learned later, the terrified man threw himself on the ground screaming, 'The Bastard's got us!' ${ }^{3}$

This was not the kind of tale to be shared with CAF officers who might take umbrage or seek retribution. Later, when at No. I Squadron, his CO Paddy Heffernan was impressed by a quite different side of Hitchcock's personality. He was not an overconfident pilot Heffernan thought - rather 'he may not have been a confident pilot'. 'Although he flew satisfactorily, I never really felt happy about him.' Heffernan would recall 'a silly thing' he did while flying in formation:

I was leading and had my aerial out, some 200 feet of wire trailing below the aircraft. For some reason known only to himself, he decided to change from port to starboard and ended up with the aerial wrapped round his aircraft. He could not give any satisfactory reason for this stupid antic when I took him to task later.

Apart from this, according to Heffernan, his flight commander never did anything wrong: 'BUT I was always waiting for him to do something wrong.' ${ }^{54}$ It was this kind of incident, uncommon as it may have been, that could have reinforced Jack Graham's perception of Hitchcock as a risk taker. Graham, law

52 GpCpt. J. E. Graham, interview, 11 May 1978. Graham might have been recalling a 'most awful risk' during a display by a flight of five Ansons at a graduation parade for No 1 Flying Training School in December 1937 (No. 21 Squadron Operations Record Book, NAA: A9186/42/46). Philip Russell (comp.), Old Geelong Grammarians at War, Ocean Grove, 1996, pp.190-1.

53 Joan Richardson to CH, (email), 5 Oct. 2009. Hitchcock's flying log book records a flight in an Anson to Koonwarra on 13 July 1938.

54 ACdre P. G. Heffernan to CH, 20 July 1978. 
partner of the recently elected youthful federal MP Harold Holt, and secretary of the Cinematograph Exhibitors Association, may not have noticed or more likely had just forgotten that Hitchcock was not actually at Laverton on many a Sunday. Paddy Heffernan on the other hand did notice:

I knew Bob Hitchcock quite well, he was a pilot with me when I was commanding No. 1 Squadron at Laverton in 1939 and I found him to be a good average type of lad. Not particularly outstanding in any field, but generally reliable and did what tasks were allotted to him. Generally in a Squadron, there are always some lads...coming forward with bright ideas to improve either the technical aspects or flying standard of the unit, but Bob did not appear to be one of this type, maybe because of his somewhat reticent nature. He married early in his career and consequently 'lived out' and by so doing I think he missed out on what I would call 'mess life'. Usually after the day's flying, we would get together over a beer and have a 'hate session' on some aspect of the day's work, but Bob always appeared to want to get home to his family.

Heffernan gave an illustration. In October and November 1938, while still Chief Flying Instructor at No. 1 Flying Training School, he led a flight of four Ansons from No. 21 Squadron to Darwin to act as the supporting aircraft to three RAF Wellesleys which were about to take part in the $150^{\text {th }}$ Anniversary of the 'founding' of Australia after completing an attempt to break the world long-distance record. While they waited at Darwin for the Wellesleys of the British Long Range Development Unit to be serviced, the other pilots (including Flight Lieutenant Peter Lavarack, the son of the Chief of the General Staff, Major General J. D. Lavarack), were untroubled by having to sit around. They enjoyed the free time. But Hitchcock was restless. He approached Heffernan several times with the question: 'When are we likely to get away?'55

\section{'A serious business'}

As early as the end of February 1940, when he was taken for a return flight to Sydney in a Lockheed 12 for 'Lockheed experience', it was clear that Flight Lieutenant Hitchcock was going to be one of the early pilots converted to fly the newly acquired Hudsons. This was an acknowledgement of proficiency and aptitude different from some of his peers. Phil Ford, for example, who had been posted as a flying instructor at No. 1 FTS, originally graded by Fred Scherger as an instructor 'of fair ability', was about to become Chief Flying Instructor at the

55 ACdre P. G. Heffernan to CH, 7 April 1978; Brook, Demon to Vampire, pp.38-9. 
Central Flying School. Considered well above average in flying in January 1940 , he would spend less than two hours in a Hudson as a second pilot. ${ }^{56}$ On June 26 Hitchcock began dual instruction with Jack Ryland in A16-6.

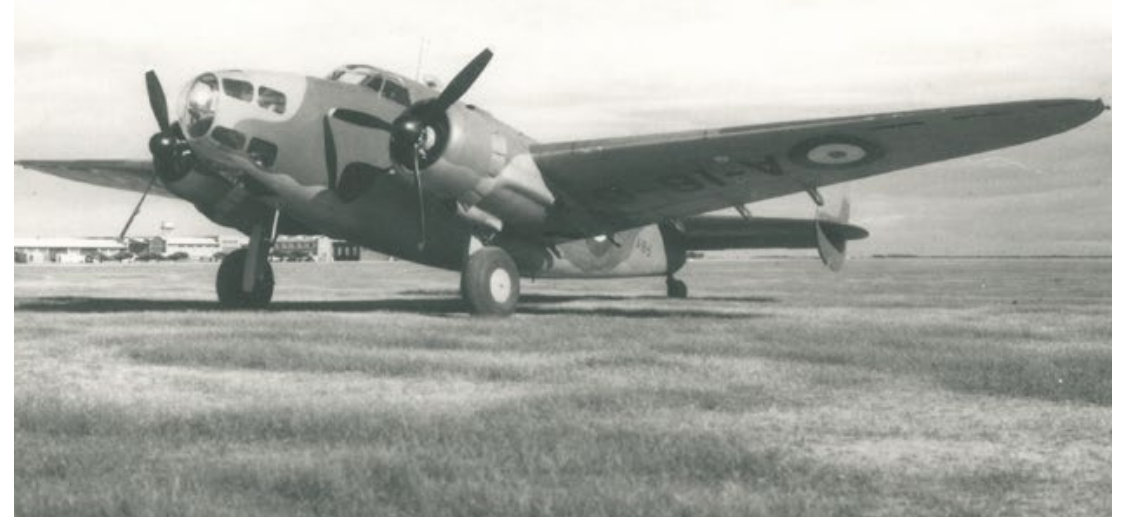

\section{A16-6, the first RAAF dual control Hudson}

(Courtesy of ACdre Bob Dalkin)

He went solo a week later. Over the next six weeks Hitchcock gathered confidence in the new Hudsons, going up in eight different machines, practising everything from landings to emergency gear operation. For much of July and early August he put a succession of young second pilots through the routines of landing, re-take-offs, instrument and engine flying, gyro-pilot, single and cloud flying, and flight formation. ${ }^{57}$ Among those who went up with him were Pilot Officer Jim Shackell, a member of the Toorak and Collins House 'ShackellBaillieu clan', and Pilot Officer Stanley Prowd, educated at Scotch College and a pharmacist before joining the RAAF in January 1940. Prowd would be killed almost exactly a year later when he failed to bring a training aircraft out of a spin..$^{58}$ Another of those under instruction was the gregarious 6' $3^{\prime \prime}$ Canberran Keith Eddison, son of a soldier-settler but with a small farm of his own, styling himself a 'grazier'. Eddison had been entranced by the Hudsons, 'beautiful machines, all green upholstery inside with a nice little bunk' and enjoyed the company of Hitchcock, 'a hell of a nice chap'. ${ }^{59}$ Eventually flying Beaufighters with No. 30 Squadron, Eddison would die in battle at sea off Lae in May 1943.

56 Ford, Norman Philip 0339 NAA A12372, R/339/H.

57 WCdr Sam Wood recalled that as a second pilot he really knew more about Hudsons than his 'skipper' Hitchcock but his name does not appear in Hitchcock's log book (Mike Hayes, Angry Skies: Recollections of Australian Combat Fliers, ABC Books, Sydney, 2003, p.70).

58 NAA: A9300, SHACKELL JB; The Argus, 4 Aug. 1941.

59 E. K. Eddison to M. L. Eddison, 1 April, 16 Aug., 1940, ACT Heritage Library, Eddison MSS 19400, 194016. 
Herb Plenty, previously put through his paces in Ansons, would later say that he sensed that Hitchcock was not relaxed in the cockpit. But Plenty acknowledged that unlike some instructors he was not an arrogant person: 'he was a gentle type of bloke...he'd coax people along' ${ }^{60}$ If Hitchcock was a little on edge it might have had something to do with his mounting realisation that he was one of a diminishing few. His brother Les would recall a letter around this time saying that 'there were only a couple of the boys left and that he now regarded flying as a serious business especially as another of his mates had just "bought it $^{\prime \prime \prime} .{ }^{61}$ What made for an even more serious attitude were missives about flying discipline emanating from on high. 'An unsatisfactorily high accident rate' was disclosed by the analyses demanded by the Chief of the Air Staff. Burnett let it be known that the loss of an aircraft was serious because it meant 'the loss of six or more pilots who might otherwise have been trained'. Moreover accidents undermined public confidence in the Air Force. Concern at headquarters was being communicated to every unit of the Service. 'An atmosphere must be created by all grades of commanders,' the Air Member for Personnel had enjoined, 'in which any departure from orders, no matter how slight, is regarded as an indication of inefficiency and entirely reprehensible.' 'Mucker' Anderson ruminated a few weeks before No. 2 Squadron began to receive its Hudsons:

It has also been noticed that practically all pilots are still under the impression that their flying ability is centred in and judged by their landing of the aircraft. Modern technique for landing does not demand constant special practice and after the completion of a conversion course, there should be no need for pilots to spend complete periods on practising landings or forced landings unless the Squadron Commander is of the opinion that a particular pilot requires landing practice, and in such cases the particular practices should be specially ordered by the Squadron and not the Flight Commander unless the Squadron Commander is of the opinion that the Flight Commander is sufficiently experienced to assume the responsibility. ${ }^{62}$

Bob Hitchcock's own flying may not have been flawless. He did not hide his fears as well as some. He had no old school tie. He was never the life and soul of the mess. But in 1940 Hitchcock was a maturing and respected flight commander, trusted with the training of able young men on the most challenging of the RAAF's aircraft, and happy in his work. Though still showing the benefit of his youthful exercise regime he could not completely hide the ageing signs of

60 GpCpt. H. C. Plenty, interview, 19 April 2007, transcript courtesy Geoff Crane. For Plenty's DFC earned by gallantry and resourcefulness: These Eagles: Story of the R.A.A.F. at War, R.A.A.F Directorate of Public Relations, Australian War Memorial, Canberra, 1942, p.141.

61 A. L. Hitchcock to $\mathrm{CH}, 10$ Nov. 1977.

62 Chief of the Air Staff, 'Prevention of Flying Accidents', confidential, 7 June 1940; Air Member for Personnel, 'Flying Discipline', confidential, 11, 29 May 1940, NAA: A705, 231/8/7 Pt 1. 
baldness under his peaked cap. The cheeky if occasionally wistful curiosity of his first days in uniform had long since given way to an earnest dedication to the profession in which he was determined to succeed. Never afflicted by the devil-may-care disposition so common in the Citizen Air Force he would take seriously the AMP's advice that 'the cost of each hour's flying in a modern type of aircraft is very high (in a Hudson it is approximately $£ 25$ inclusive of depreciation, fuel, etc) ${ }^{\prime}{ }^{63}$ He was an officer moulded in a modernising Air Force that was growing bigger and faster than any of its senior leaders had imagined it could.

If all went well in the coming months of Air Force expansion it might not be long before Hitchcock had his own squadron. ${ }^{64}$ Although the Air Board had decreed otherwise, he might still harbour the ambition along with other short-service officers that he might join the shrinking group of General Duties permanent officers. ${ }^{65}$ In the meantime he had taken a crucial step towards bridging the social distance that separated him from too many of his colleagues and superiors. There was a new bond, transcending rank, with Ray Garrett, Harry Wrigley, Charles Eaton, Alan Charlesworth, and others. In December 1939 he was initiated as a Freemason in Verdon Lodge No. 395 in Williamstown. The Lodge, in Electra Street near the Beach railway station, was now the place he would be found on the second Thursday evening of the month. Brother Hitchcock, demonstrating sufficient merit in his oral examination, passed to $2^{\text {nd }}$ Degree in February and was raised to $3^{\text {rd }}$ Degree on 4 March 1940.

\footnotetext{
63 Inexplicably I have lost this reference.

64 Eric Lansell, from the immediately preceding cadet course, had been promoted temporary S/Ldr at the beginning of June, a fatal accident in Tasmania evidently long since forgiven (see Chapter 24, 'Cockpit Secrets', particularly footnote 52). Hitchcock's own contemporary Donald Macpherson had also been acting S/Ldr from June.

65 The Air Member for Personnel's recommendation 9 Nov. 1939 that around 50 officers appointed to short service commissions before May 1938 should join the 78 permanent officers among the 436 General Duties officers was rejected by the Air Board. The Board decided, evidently without reference to the Air Minister, to defer granting permanent commissions for the duration of the war (Air Board Agenda 2620, NAA: A4181, 17). ABO N.98/40, 8 March 1940: 'It has been decided for the time being not to effect transfers of members from the Citizen Air Force or from members appointed or enlisted for the duration of the war to the Permanent Air Force.' (NAA: A705, 163/1/177).
} 


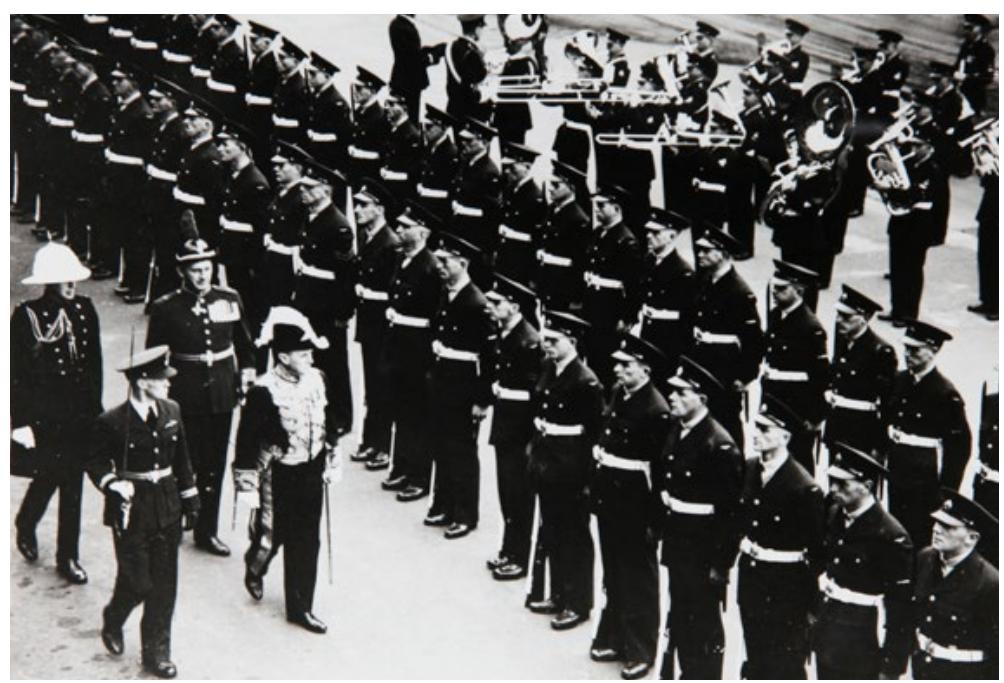

\section{F/Lt Hitchcock commands a RAAF guard of honour, GpCpt 'King' Cole in attendance}

(Courtesy of Les Hitchcock)

On the evening of 12 August 1940, the home-loving Bob Hitchcock was sleeping on the base at Laverton. Before retiring, he took time over a cup of coffee to talk to two of the new arrivals at No. 2 Squadron, Bob Dalkin and Bill White, about the Hudsons they were due to climb into the next morning. For these pilot officers, junior in rank but with years of flying experience, it would be familiarisation flights at first, prior to a decision being made about whether or not they were suitable for conversion. At first they were to go up in the second seat but without dual controls.

So stretched was the squadron for converted Hudson pilots that Bob Dalkin was assigned to fly with 19-year-old Pilot Officer Wilbur Wackett, who himself had only about five hours since going solo in a Hudson. ${ }^{66}$ Dalkin, who went on to be an outstanding Hudson pilot, would never forget his first time on August 13. Wackett, son of Wing Commander Lawrence Wackett, manager of the Commonwealth Aircraft Factory, had been told by his own instructor Jack Ryland that he was to practise stalls and recovery 'under the hood':

66 Wilbur Wackett's personal file indicates that by the time of his death in 1944 he had acquired over 400 hours as a Hudson captain although his form P/P 64 omits to mention that he had flown Hudsons at all (NAA: A9300, WACKETT WL); Lawrence James Wackett, Aircraft Pioneer: an autobiography, Angus and Robertson, Sydney, 1972, pp.206-9. For Wackett's intrepid survival after crash-landing at sea, swimming for nine hours, and crossing the Papuan Peninsula from north to south, see Mark Johnston, Whispering Death, Allen \& Unwin, Sydney, 2011, p.164. Leon Kane-Maguire, Lost Without Trace. Squadron Leader Wilbur Wackett RAAF. A Story of Bravery and Tragedy in the Pacific, Air Power Development Centre, Canberra, 2011, was published after this book was drafted. 
He handled the aircraft competently enough. He was a very young and brash young man. Anyway he'd done his homework as you sometimes do especially on instruments...He got to the stage where the aircraft wasn't completely in a stall. He'd done about 20 minutes of this and was a bit fed up with it, and he suddenly said 'Oh I'll make the damn thing stall' and with one hand he swept the curtain to one side and with the other pulled the stick right back...the next thing we were in a spin.

Dalkin was pitched forward out of his jump seat and 'disappeared down the front'. By the time he managed to claw himself back, the aeroplane was still spinning. Wackett had been thrown forward and was still trying to sort himself out. Dalkin took the initiative and put on one-third throttle, then half throttle. They came out of the spin at about 2000 feet and 'went back very white faced, and landed' ${ }^{67}$ It was a chastening experience: something to enliven an afterdinner session in the mess with his friend Dick Wiesener after he returned more sedately from Canberra with Flight Lieutenant Bob Hitchcock later that day.

67 Dalkin, interview, 18 April 1978. 


\section{Passenger complement}

When the new Parliament House opened in Canberra in 1927 many departmental offices remained in Melbourne. Ministers and their staffs had quarters in both cities. They trekked up and down for parliamentary sittings, changing trains at the Victoria/New South Wales border or Goulburn, regularly reminded of the colonial folly of non-standard rail gauges as they transferred four to six steel cases of classified papers from one train to the other. ${ }^{1}$ As commercial air services improved in reliability, the journey would sometimes be made by air. Regular schedules with DH-86s were inaugurated by Ivan Holyman's Australian National Airways in 1936. In 1940 there was one flight daily. Douglas airliners left Melbourne at 3.00 p.m., arriving in Canberra two hours later. An 11.45 a.m. flight from Canberra reached Melbourne at 1.50 p.m. Ministers living in Melbourne increasingly patronised these services: Dick Casey, Jim Fairbairn, Harold Holt, even the Prime Minister would be caught by photographers at Essendon airport striding across the tarmac, brief cases and portmanteaux in hand. As The Argus had commented in May 1939: 'If the new Cabinet is not airminded it will not be the fault of the Victorian members.'

Passionate private airmen like Jim Fairbairn and Dick Casey would, when they could, fly themselves. Colin Moodie, Dick Casey's private secretary, recalled several occasions late in 1938 and early 1939 when the Treasurer asked if he would like to fly down to Melbourne with him. Moodie, who much preferred the train, was relieved when bad weather kept them on the ground. Casey had disturbed Moodie by the casual revelation that on a previous trip he had almost hit a hill. 'He told me he was a bit shaken. He said "I almost did it."'3 Early in March 1939 Dick and Maie Casey had twice been forced down on a trip from Canberra to Melbourne, reportedly rather enjoying 'the thrill'. Casey's interest in flying and aviation safety was long standing. He had flown before 1914 and as a passenger during the European war. After an Imperial Airways Handley Page W10 had come down in the English Channel in June 1929, leading to the drowning of seven men, he had told the Prime Minister Stanley Bruce that he had refused for two years to fly in the old two-engined Handley Pages. Casey had by then flown across the Channel about 20 times and confessed that he had been 'considerably scared at times', mostly by low flying. ${ }^{4} \mathrm{~A}$ decade later, after

\footnotetext{
1 Agnes Hannan, Victoria Barracks Melbourne: A Social History, Australian Defence Force Journal Publication, 1995, pp.111-2.

2 The Argus, 2 May 1939.

3 C. T. Moodie, interview, 28 Sept. 1977.

4 Casey to Bruce, 20 June 1929, W. J. Hudson and Jane North (eds), My Dear P.M.: R. G. Casey's Letters to S. M. Bruce 1924-1929, AGPS, Canberra, 1980, p.528; Langmore, Glittering Surfaces, pp.56-7. Casey's thinking on aviation policy and prospects in the 1920s is reported in My Dear P.M., pp.68, 95, 171, 208-11, 426, 431-2, $516,520,532,534-5$.
} 
successfully completing flying training, he and his wife had flown to central Australia in mid-1938, prudently accompanied by P. G. 'Bill' Taylor of transPacific fame. ${ }^{5}$ In later years he had taken a keen interest in aviation policy. As Minister for Supply and Development his portfolio included the Department of Aircraft Production; it was he who had given the belated go-ahead to Lawrence Wackett to expand production of the Wirraway after war began. In September 1939, he had consulted Fred Scherger secretly about the proposed Empire Air Training Scheme and was drawn by Scherger into a desperate bid to stop the planned air expeditionary force. ${ }^{6}$ In the USA he was featuring in cinema newsreels as 'the flying diplomat', and had made headlines by having his wife and children come by air to join him in Washington a few weeks after his own arrival. $^{7}$

If there were more convenient commercial flights even the most dedicated of private flyers would take them. But there was no doubting their preference for the air. An emphatic reminder of Jim Fairbairn's commitment to flying had found its way into the newspapers in August 1939 when he publicly apologised for having taken a train to get to a morning meeting in Sydney with the Prime Minister and senior colleagues. 'I personally do not use the railways,' he had once averred. ${ }^{8}$ But on this occasion there was no scheduled flight that would get there in time. A picture in next morning's Sun of Defence Minister Geoff Street posed on the steps of the afternoon mail plane explained Fairbairn's sensitivity. His friend had made a 900-mile round trip to the conference - eight hours in the air - by Avro Anson 'bomber' and Douglas airliner. The story in the Herald later in the day rubbed it in: 'Snow in the cockpit and blind flying in bad weather', swooping low to pick up the railway line to Cootamundra, had made the flight from Melbourne one of the most exciting in Street's experience. ${ }^{9}$

There were good reasons to be worried about the danger of air travel. Newspapers were frequently telling of hazardous bad weather, abandoned flights, fatal accidents, and of the inquiries that followed. The RAAF was just emerging from a distressing phase of fatal crashes and a severely critical report on their training and procedures by a British Air Marshal. The death of the MP and former minister Charles Hawker late in 1938 had occasioned a shake-up of civil aviation. Ministers had frightening experiences of their own to tell: in Geoff Street's case, not only persevering through zero visibility, but the forced landing of an Anson in northern New South Wales. He had also been with Jim Fairbairn over rugged mountains in May 1938 when a plug in one of the engines of Fairbairn's

5 W. J. Hudson, Casey, Oxford UP, Melbourne, 1986, p.97.

ACM Sir Frederick Scherger, interview, 2 Sept. 1978.

Carl Bridge, 'R. G. Casey, Australia's First Washington Legation, and the Origins of the Pacific War, 1940-

42', Australian Journal of Politics and History, vol. 28 (2) Aug. 1982, pp.181-9.

$8 C P D$, House of Representatives, 2 Oct. 1935, p.452.

9 Sydney Morning Herald, 18 Aug. 1939; The Sun, 19 Aug. 1939; The Herald, 19 Aug. 1939. 
Dragonfly blew out and they had been forced to return to Canberra on one motor. Six weeks later, this time on the way back from Melbourne, Fairbairn was forced to detour far to the west to dodge electrical storms, and fly through hail in sight of the ground to avoid collision with the hills around Canberra. ${ }^{10}$ In 1936 Billy Hughes, Minister for Health in the Lyons government, had been a passenger in an airliner that crash-landed near Beaudesert en route to Brisbane. Unfazed by the experience and the consequential broken collar bone, Hughes continued to fly around the country when speed was essential. ${ }^{11}$ At least one of Hughes's colleagues owed his life to the skill of an RAAF pilot. Vic Thorby, then Minister for Defence, en route from Canberra to Melbourne on 9 May 1938 had the courageous 23-year-old Flying Officer Harry Durant to thank for his. Durant, less than 18 months from earning his wings, had managed to bring their Anson down safely near Albury when disaster threatened. He was soon a flying instructor and was awarded the AFC in the 1939 New Year's Honours List.

If it was not an Australian story of tragedy or providential escapes it was one involving friends or colleagues overseas. In June 1940, Norman Rogers, Canadian Minister of National Defence, had been killed in a crash of a Defence Department aircraft on a flight from Ottawa to Toronto. Jim Fairbairn, who had met Rogers just six months before, had cabled the Canadian Prime Minister, William Lyon Mackenzie King, expressing his shock and sympathy. Mackenzie King, who had never flown, had long been apprehensive about air travel and had advised his ministers against it. ${ }^{12}$ In Europe there were no such inhibitions. Newsreels of the 1930s memorably showed Adolf Hitler campaigning and the British Prime Minister Neville Chamberlain embarking on successive peace missions by air.

Australian cinema audiences too had seen Joe Lyons becoming a regular aircraft passenger. 'Without the assistance of air travel I would not have been able to cover so much ground or to have kept so fit,' he told an Adelaide audience in 1937. ${ }^{13} \mathrm{He}$ had flown several times during the 1931 election campaign. Facing his first election as Prime Minister in 1934 he travelled extensively in a private plane provided and co-piloted by Charles Ulm. Irvine Douglas, then Commonwealth Government Publicity Officer accompanying the Prime Minister's party, recorded that there was a leaflet drop over Lyons' electorate. A sofa had been installed in the aircraft for Lyons' comfort. The Prime Minister had insisted that Ulm fly the plane. Unwilling to admit that he was a little

10 John McCarthy, Australia and Imperial Defence 1918-39: A Study in Air and Sea Power, UQP, St Lucia, 1976, p.85; Sydney Morning Herald, 6 May, 29 June 1938.

11 The Argus, 12 June 1936; L. F. Fitzhardinge, The Little Digger 1914-1952: William Morris Hughes A Political Biography, vol. II, Angus \& Robertson, Sydney, 1979, p.640.

12 Fairbairn to W. L. Mackenzie King, 12 June 1940, Mackenzie King Papers, MG26-J1 vol. 287, p.242971; Mackenzie King diary, 10 June 1940, Library and Archives Canada; Sholto Watt, I'll Take the High Road: A History of the Beginning of the Atlantic Air Ferry Service in Wartime, Brunswick Press, Fredericton, 1960, p.136. 13 The Advertiser, 15 Oct. 1937, quoted in C. J. Lloyd, 'The Formation and Development of the United Australia Party, 1929-37', PhD thesis, ANU, July 1984, p.357. 
unreliable on landings and take-offs, Ulm had brought along another pilot. ${ }^{14}$ The following year, in Britain for the King's Silver Jubilee, Lyons and his wife flew from London to Brussels. It was Enid Lyons' first flight. Thereafter the couple would frequently take to the air as they made their way around Australia to public functions. Six of his family flew around Tasmania in 1935.

By the beginning of the 1937 federal election campaign Lyons was described as a 'thoroughly seasoned air traveller' with almost as many flying hours as a qualified pilot. 'Of course,' electors were reassured, 'he does not handle the controls himself.' ${ }^{15}$ Seventeen-year-old Sheila Lyons was soon announcing her ambition to be an air hostess; and her brother Desmond was to join the Air Force in October 1939. ${ }^{16}$ On the Sydney to Melbourne route, the Lyons entourage would fly in an Australian National Airways DH-86. A regular pilot of these 12-seater fabric-covered bi-planes was Harry Purvis. Purvis, whose expertise the RAAF was to call upon in March 1940 as a Hudson instructor, was always uneasy in a DH-86. So too were other pilots. Lawrence Wackett believed the machines had structural flaws. But after a series of crashes and disappearances, the temporary grounding of all of them, and exhaustive flight tests, they were declared airworthy by the Department of Civil Aviation. Dick Casey and Harry Gullett, as well as Lyons, continued to use them until they were superseded by DC-2s. ${ }^{17}$

Joe Lyons had said at the beginning of July 1936 that an aeroplane for the exclusive use of Cabinet ministers was inevitable but not imminent. Such an exclusive machine might have been even less imminent if the Prime Minister or his colleagues had taken seriously the announcement of a Mr Penny of Auckland that he had developed a ray that could stop aeroplane engines. ${ }^{18}$ When controversy erupted following a Demon accident in which the son of a Labor MP was killed, various ministers had made a show of travelling in Service aircraft. The Chief of the Air Staff expressed his gratitude to the newly licensed Dick Casey: 'however confident one is in one's organization, these incidents have their moral effect on all members of the Service.' ${ }^{19}$ Frequent patronage of ANA's Melbourne-Sydney route demonstrated the 'air-mindedness' of the Victorian members of the government. On at least one occasion the flight made

\footnotetext{
14 Irvine Douglas, interview, 15-19 June 1972, NLA 766383 ORAL TRC 121/36. Lyons would secure unanimous Cabinet approval to guarantee an $£ 8000$ bank overdraft for Ulm's final flight (John Ulm with Bill Bunbury, ABC Radio, 27 Oct. 1987).

15 Sunday Times (Perth), 19 Sept. 1937.

16 Alan Fewster (ed.), Capital Correspondent: The Canberra letters of Edwin Charles 1936-37, Ginninderra Press, Charnwood ACT, 2002, p.32.

17 Kate White, A Political Love Story: Joe and Enid Lyons, Penguin Books, Melbourne, 1987, pp.164, 173-4, 178; Harry Purvis with Joan Priest, Outback Airman, Rigby, Adelaide, 1979, pp.75-6; Peter Yule, The Forgotten Giant of Australian Aviation: Australian National Airways, Hyland House, Melbourne, 2001, pp.66-106; J. L. Kepert, Aircraft Accident Investigation at ARL: The First 50 Years, DSTO Australia, 1993, pp.7-10.

18 Canberra Times, 2 July, 20 Mar. 1936.

19 AVM R. Williams to Major R. G. Casey, 24 Jan. 1938, copy, Williams MSS, RAAF Museum.
} 
a special stop at Canberra to disembark Menzies, Casey, Fairbairn, Street, Holt and several secretarial staff. By August 1940 ANA's 3.00 p.m. weekday service to Sydney was via Canberra. ${ }^{20}$

No dedicated aircraft had been allocated for ministerial use by 1940 . When Geoff Street had to be in Sydney on January 18 for a conference with the New Zealand Defence Minister he was forced to borrow BHP's Lockheed 12A, Silver City, for the day. Repeated requests had been made unavailingly by Jim Fairbairn while still a backbencher, for the creation of a travel allowance 'to enable Ministers and members to travel by air, or to utilize other forms of transport which may suit them better than the railways'. Even an appeal to the ' 100 per cent airminded' Treasurer Dick Casey - he had flown his dog, reportedly yawning with boredom, to Canberra in November 1938 - had brought no joy. There were reports in mid-1939 that the government had ordered an aeroplane with a seating capacity of six for ministers travelling to and from Canberra. The Civil Aviation Board had recommended the purchase of a Lockheed machine in 1938 but the government insisted on a British plane. ${ }^{21}$ Shortly before the outbreak of war, Geoff Street as Defence Minister had foreshadowed that for 'transport of Ministers and senior officials between Canberra and Melbourne, special flying arrangements might be necessary for urgent movements which do not fit in with the timetable of the air services. This could be decided by the demands of experience. ${ }^{22}$

The demands of experience, confirming his own predilections, soon convinced Jim Fairbairn that 'special flying arrangements' were necessary. The Civil Aviation Board's Percival Q6, operational from August 1939, was inadequate for the purpose, too small and under-powered. ${ }^{23} \mathrm{He}$ had determined that some of the RAAF's new Hudsons would be fitted out and reserved for use as required for ministerial transport. In its original civil configuration the Lockheed 14 offered a comfortable insulated cabin with five rows of reclining and swivelling passenger chairs, reading lights, 'ash receptacles', and safety belts. An attractive interior trim with the promise of a low sound level was important. With Seapak flame-proofed sound absorption, and air introduced and exhausted from the cabin through sound traps, Lockheed boasted that the noise level with full open throttle was maintained 'lower than that of a railway sleeping coach'. ${ }^{24}$ It was as well that it should be so.

\footnotetext{
20 The Argus, 2 May 1939; The Age, 6 Aug. 1940.

21 The Argus, 23 Nov. 1938; Sydney Morning Herald, 19 Jan. 1940; CPD, House of Representatives, 9 Oct. 1935, p.452; 10 Nov. 1938, p.1443; The Sun, 3 May 1939.

22 G. A. Street (Minister for Defence), 'Machinery for Higher Direction of War', Cabinet Submission, 28 Aug. 1939, considered by Cabinet 26 Sept. 1939, NAA: A2671, 12/1939.

23 http://www.airwaysmuseum.com/Percival\%20Q6\%20VH-ABY.htm accessed 21 Sept. 2012.

24 'Aviation: Purchase of Lockheed Bombers Part 1', NAA: A1608, F17/1/2/249-77.
} 
For it was not fear alone - Mr Penny's death ray, or just understandable anxiety about heavier-than-air machines staying in the sky - that kept people out of the air. For MPs, cost was a consideration. A proposal to allow airline travel concessions had been rejected in December 1938 'in view of the state of Commonwealth finances'; revived on a more modest scale by the Minister of the Interior in April 1940 it was still undecided. ${ }^{25}$ For the public servants whose job it was to ensure that the War Cabinet was able to function away from the Melbourne defence headquarters there was the regular chore of loading and accompanying secure containers of files by rail or road. For those less burdened, the railway had long been a preferred alternative to flying. Harry Gullett's son Jo, who had made the journey with his father, and was to enter the House of Representatives in 1946, would say: 'air services in those days were unreliable, often uncomfortable and every now and then unpleasantly rough' ${ }^{26}$ By contrast, bad weather would rarely deflect a locomotive on Australian tracks. Noise and smells were at a more acceptable level. Since the launch in November 1937 of the streamlined and air-conditioned Art Deco express, the 'Spirit of Progress', there was a new level of comfort, a tinge of glamour. In mid-winter even the most passionate flyers like Jim Fairbairn, Geoff Street, Dick Casey, and Harry Holt might be happy to take the night train together. ${ }^{27}$

The overnight journey to Canberra had become a kind of rolling social club, 'the old train dining car network' as one regular described it. ${ }^{28}$ Over dinner, between Melbourne and Albury, ministers, public servants, private office staff, and occasionally wives would while away the hours convivially. Drinks were available with the meal, and there was access to an observation or 'parlor' car by ministerial gold pass or a premium for others who were prepared to pay. For senior public servants, the capacity to pay was enhanced by a travel allowance of 10 pence an hour. (Colonel Harry Jones of the Intelligence Bureau, claiming at the rate of 20/- a day, could pocket over $13 /-$ when the train ran late). ${ }^{29}$ Labor MPs and government supporters would suspend hostilities for the duration of the trip. Cards might be brought out. A War Cabinet minister might hand round cigars, more than likely 'Admiral' or 'Cubanola Principes' purloined from the box provided at meetings in the Defence Committee room at Victoria Barracks. ${ }^{30}$ The powerful War Cabinet Secretary and head of the Department of Defence Co-ordination, Frederick Shedden, might unbend a little with his assistant Sam

\footnotetext{
25 Hattil S. Foll, 'Air Transport for Senators and Members', Cabinet Agenda 27, NAA: A2697, roll 2.

26 Henry 'Jo' Gullett, Good Company: Horseman, soldier, politician, University of Queensland Press, St Lucia, 1992, p.221.

27 The Argus, 14, 21, 27 June 1939.

28 Sir Keith Waller, interview, 21 June 1977.

29 C. T. Moodie, interview, 28 Sept. 1977; Travel expenses claim, July 1940, Lieutenant Colonel H. E. Jones [Personal file], NAA: A367, C17200.

30 Sam Landau, interview, 27 May 1977; Agnes Hannan, Victoria Barracks Melbourne: A Social History, Australian Defence Force Journal Publication, 1995, p.132.
} 
Landau. The reserved Shedden knew this was the not the time or place for business. Billy Hughes, a frequent traveller with his wife Dame Mary, would entertain with a stream of anecdotes.

Often Robert Menzies would also be there, not in Hughes's orbit but exchanging mildly malicious banter with his private secretary, the brilliant but troubled Anglophile Catholic Theo Mathew, or later the bright, witty, eccentric Corby Tritton. ${ }^{31}$ A journey of up to 18 hours gave Menzies respite from the plague of advisers and supplicants that gathered outside the Prime Minister's office. Distant from domestic cares as well, Menzies enjoyed train travel. The normally omnipresent Shedden, who had no small talk and who couldn't take a ribbing, would retreat to avoid being teased. His chief would linger, the centre of an admiring circle of acolytes and ambitious colleagues, eager to please and exhibit their talent to amuse. The Monday night service from Melbourne departing at 6.24 p.m. was scheduled to arrive in Canberra conveniently just before nine the next morning. After alighting at Albury around 10.24 p.m. there was a halfhour wait to change trains. Then the possibility of retreat to a sleeping berth, sometimes shared with a colleague, in a through carriage on the Melbourne Express, time to digest the papers for meetings ahead, perhaps a soothing pipe or another cigar. The carriage would be detached at Goulburn to join a train from Sydney and complete the winding rattle to Canberra on the narrower gauge. ${ }^{32}$ The return journey could be just as diverting. Coming home to Melbourne as Prime Minister-designate in April 1939, Menzies was heard in earnest conversation with the Minister for Defence debating whether Ironmonger or Blackie was the better bowler. ${ }^{33}$

Not everyone spent the trip so agreeably. The Country Party's John McEwen, intermittently Minister for the Interior from late 1937 to March 1940 when he became External Affairs Minister, used the journey to catch up on accumulated work with his staff. It was not that McEwen had anything in principle against air travel. He had taken it up enthusiastically when he became a minister. Around a campfire in the Northern Territory in 1938 he had 'sold' Eddie Connellan on the notion of connecting remote outback stations by air. In July 1939 Connellan Airways had begun a subsidised airmail service between Alice Springs, Mount Doreen, Tanami, Victoria River Downs, and Wyndham with two Percival Gull

\footnotetext{
31 Moodie recalled that 'things went wrong' in Mathew's private life; intemperance led to his departure from the External Affairs Department. Menzies had been rebuffed by Colonel Hodgson, the punctiliously tactless head of External Affairs, when seeking Mathew's services in 1938. When Hodgson discharged Mathew on medical grounds Menzies did not hesitate to offer him employment (Moodie, interview, 28 Sept. 1977; Peter Heydon's recollections in Hazlehurst, Menzies Observed, p.135). Sir Laurence McIntyre, interview, 28 Feb. 1978. For Tritton's personality I rely in part on the recollections of Sam Landau and my own conversations with Tritton, 7 June and 5 July 1977.

32 I am grateful to Victor Isaacs and Geoff Lambert of the Australian Association of Time Table Collectors for details of the train services from Melbourne to Canberra.

33 The Argus, 22 April 1939.
} 
VIs. McEwen had been supported in encouraging Connellan by Jim Fairbairn whose influence as a director of the Commercial Banking Company of Sydney ensured the vital bank overdraft. ${ }^{34}$ Yet on the regular journeys between Canberra and Melbourne the train was McEwen's chosen mode. With his two private secretaries, Roy Rowe and Fred Hill, and a stenographer in tow, he always ensured they had a compartment to themselves. 'We carried a portable typewriter and virtually a portable filing system, set up an office in the compartment and worked all the way. ${ }^{35}$ The ambitious Jack McEwen, a self-made soldier-settler, who had been acting Minister for Air while Fairbairn was overseas, was a harder task master than the Western District gentleman graziers.

Whatever personal preferences or official priorities determined who was to fly to Canberra on August 13, by late on the previous day six men had been chosen to make the trip. The Minister for Air of course was at the top of the list. Jim Fairbairn's friend Geoff Street, as Minister for the Army, was his almost inevitable companion. The government's principal military adviser, General Sir Brudenell White, accompanied by his staff officer Lieutenant Colonel Frank Thornthwaite, was required along with the other Chiefs of Staff. Sir Harry Gullett, Vice-President of the Executive Council, his Cabinet experience stretching back to the late 1920s, had ministerial seniority. And the last seat would go to the man upon whom Fairbairn relied perhaps more than anyone else; his private secretary, Dick Elford. Together they would join the aircraft at Essendon when it arrived from Laverton after breakfast.

34 Stanley Brogden, The History of Australian Aviation, Hawthorn Press, Melbourne, 1960, p.127; Purvis with Priest, Outback Airman, pp.92-3; E. J. Connellan, Failure of Triumph: the story of Connellan Airways, Paradigm Investments, [NT], 1992, pp.110, 157.

35 F. T. Hill, interview, 20 June 1978. 


\section{The General: Brudenell White (I)}

Silver-haired, lean, and erect, shielded from the chill air by a Service greatcoat, the figure striding across to the waiting aircraft was Australia's most distinguished living soldier. Garlanded with military decorations and imperial honours - DSO, CB, CMG, KCMG, KCVO, KCB, as well as a quiver of foreign awards - General Sir Cyril Brudenell Bingham White's reputation was made as the nation's most senior and accomplished wartime staff officer. So valuable had he been to the Allied cause as a tactician and organiser that he was denied the commands that would have tested his capacity for operational leadership at the very highest level. His praise as the genius of the evacuation from Gallipoli had been sung in official histories, biographies, and memoirs. After the war he had served in Australia as the Chief of the General Staff and then, applying his gifts to civilian administration, as chairman of the Commonwealth Public Service Board.

Although his military and administrative background qualified him uniquely for further public service posts, Brudenell White had been a businessman and grazier for more than a decade before war broke out in 1939. Declining the offer of a second term as the chairman of the Public Service Board, he had settled in 1928 on a 2000-acre property, 'Woodnaggerak' near Buangor, 20 kilometres west of Beaufort, on the edge of the Western District and the Wimmera. Staying with the Board would have meant working in the nascent national capital in Canberra. Nurturing fine wool merinos far from the clatter and clamour of politics held more appeal. Thus, when still in his early 50s, White had opted for the life of a company director and pastoralist not far from the country he had known as a child. As he gradually improved his financial position, he added another 500 acres to his holding and bought a second farm nearby. As supervisor for Australia and chairman of the New Zealand Loan and Mercantile Agency Co. Ltd, and vice-chairman of the National Mutual Life Association of Australasia Ltd, and of the Trustees, Executors, and Agency Co. Ltd, he was closely connected to some of the nation's leading businessmen. He was selective in responding to invitations to other appointments. With commitments to the Alfred Hospital, the AIF Trust, the Rhodes Trust, several other trusts, as well as the committee of the Australian War Memorial, he had a full diary; he declined the stockbroker Staniforth Ricketson's offer of a seat on the board of the reconstructed Argus and Australasian company. Believing himself to be out of touch with contemporary military affairs, he had not sought a return to active service in 1939. But in March 1940 the death of Lieutenant General E. K. Squires, the British officer who had been made Chief of the General Staff in September 1939, brought an invitation he could not refuse. He was to take up once again the post he had held immediately after the First World War. 
Born in September 1876 in St Arnaud, a gold mining town 132 kilometres northwest of Ballarat, White had moved to Queensland at the age of five with his Anglo-Irish emigrant parents and six siblings. His father having failed as a pastoralist, his business interests in a parlous state, Brudenell (the name by which he was always known) left school at 15. He worked as a clerk in the Australian Joint Stock Bank in Brisbane, Gympie, Gladstone, and Charters Towers. His ambition was to follow his paternal grandfather into the law but after several years of private study and saving he turned in a different direction. His friend Thomas 'Bill' Glasgow was soldiering with the Queensland Mounted Infantry. His older brother Dudley had been serving in the Queensland Land Forces since 1889. Brudenell was provisionally commissioned in the $2^{\text {nd }}$ Queensland Regiment in 1896 and joined the Queensland Permanent Artillery in 1899. It seemed clear from very early days that he was an outstanding young officer. Diligent and disciplined, his rise in the military was rapid. After an unhappy posting to Thursday Island, he served briefly with the Commonwealth Horse in the South African War and in 1904 was appointed aide-de-camp to Major General Sir Edward Hutton, the head of the Australian Military Forces. He was the first Australian officer to go to the Staff College at Camberley in England, in 1906. By the outbreak of war in 1914 only six Australians had attended the College, among them Tom Blamey and John Lavarack whose careers would march forward a few steps behind his own.

Late in 1905 at the age of 29, shortly before travelling to take up his Staff College course, White married Ethel Davidson, the eldest of nine children of W. H. Davidson of the historic Coliban Park, a 5000-acre sheep station at Elphinstone in north-eastern Victoria. He had first delicately extricated himself from an engagement to the daughter of a senior officer. Ethel, tall, slender, and elegant, belonged, her daughter Rosemary would say, 'to a world of wide acres and prosperity which Brudenell's father had always sought and always lost'. It was a powerful love match. Three children followed at four-year intervals: Margaret Clamina, James Edward, and Patrick Fitzmaurice. After his return to Australia from the European war came a fourth, Rosemary Joan. All of them carried forward Brudenell as their third forename. By all accounts, the deeply religious Anglican White was a devoted family man. He knew about the loneliness of separation. Never happier than when in the company of his wife and children, he was especially fond of the youngest, Rosemary. On the verge of womanhood, Rosemary White shared her father's love of riding, and was a cheerful distraction from business preoccupations and in due course the sombre news of another world war.

From his earliest days in the Army, Brudenell White's progress was tracked by the Australian press. When still a lieutenant in 1901 his departure for Melbourne with his brother, Police Inspector J. Warren White, was recorded 
in The Queenslander's 'Personal Notes'. The Brisbane Courier reported on his social engagements in Ireland in 1906. In April 1908 he was shown in the Adelaide Observer acting as 'classification officer' at the Nairne encampment where the local field artillery were undergoing training and assessment of their proficiency. A cable message from London told of his passing of the Staff College examination. He had impressed Brigadier General Henry Wilson, the commandant, who noted not only his ability but his popularity. Though 'modest and unassuming' his opinions carried weight with the other students. He is reported in 1909 lecturing in Ireland on 'The Military Forces of the Dominions'. These and many other references testify to a family's shrewd appreciation of the social and professional value of publicity. ${ }^{1}$

After two years at Camberley, White returned to Australia to an intelligence staff appointment at Army headquarters working under Colonel W. T. Bridges. Like Bridges, and unlike other senior officers whose cast of mind was local and national, he was a proponent of closer co-operation with an Imperial General Staff. At the request of the War Office, late in 1908 he was posted to London, where he served until 1912. ${ }^{2}$ Serving in Henry Wilson's Directorate of Military Operations he was involved in the development of the new Territorial Force. Sitting alongside Britain's war planners provided incidental strategic and administrative insights on a daily basis. The young Australian saw and was seen. He worked hard but also found time for other activities. The local Buckinghamshire newspaper reported in July 1910 that Captain White was among the leading citizens organising the establishment of a Boy Scout brigade in Beaconsfield. He was to have a lifelong commitment to scouting, carrying with him in later years a presentation swastika in a silver matchbox. ${ }^{3}$

Perhaps the most important element of White's War Office assignment was the perceptions he gleaned of the attitudes, prejudices, and personal relations of the Empire's most senior military officers, and of the interplay between the Service and departmental officials and ministers. He attended the 1911 Imperial Conference as military secretary to the Commonwealth Minister for Defence, George Pearce; and at meetings with the Chief of the General Staff, Sir William Nicholson, became privy to the most secret planning for an expected war against Germany. Back in Australia as Director of Military Operations at Army

\footnotetext{
1 Guy Verney, 'General Sir Brudenell White; The Staff Officer as Commander', in D. M. Horner (ed.), The Commanders: Australian military leadership in the twentieth century, George Allen \& Unwin, Sydney, 1984, p.29. 2 For extended accounts of White's family background and early career: Rosemary Derham, The Silence Ruse: Escape from Gallipoli, Oryx Publishing, 1998; John Bentley, 'Champion of Anzac: General Sir Brudenell White, the First Australian Imperial Force and the emergence of the Australian military culture 1914-18', PhD thesis, University of Wollongong, 2003, pp.47ff. Jeffrey Grey, 'White, Sir Cyril Brudenell Bingham (1876-1940)', John Ritchie and Christopher Cunneen (eds), Australian Dictionary of Biography, vol. 12, MUP, 1990, pp.460-3, is a comprehensive and authoritative summary. Mark Derham's unpublished essay on his grandfather, kindly made available by the author, is informed and judicious.

3 The swastika symbol was abandoned by the Boy Scout movement in 1940.
} 
Headquarters from the beginning of 1912 Major White, as he had become the previous year, was entrusted with the task of planning to raise and organise an expeditionary force of volunteers ready to embark within six weeks. Ostensibly the role of such a force would be to co-operate with New Zealand if Australia's neighbour should be invaded. But the real purpose of the plan, agreed to secretly by Pearce at the Imperial Conference, was to ensure that Australia was able to respond promptly if Britain were involved in a European war. Such an objective, at odds with the limitations placed by the Defence Act on the employment of Australian troops overseas, would have to be undertaken quietly if it were not to arouse nationalist opposition. White had nailed his colours to the mast of imperial military consolidation. ${ }^{4}$

When not engaged in the desk work at which he was recognised as the most competent of Australia's staff officers, Major White of the Royal Australian Garrison Artillery attended the final day of the annual camps of most battalions. It was at the camp of the $73^{\text {rd }}$ Battalion, Victorian Rangers, at Burrumbeet in the summer of 1913 that he first met Richard Williams, the future head of the RAAF. Then the battalion adjutant and assistant brigade major of the $18^{\text {th }}$ Brigade, Williams was to become little more than a year later one of the first four officers, the only member of the permanent forces, to begin flying instruction at Point Cook. ${ }^{5}$ In the meantime White, as Director of Military Operations, had been one of the small inspection party which had travelled to George Chirnside's Werribee Park Estate in July 1913 and there decided to purchase a sub-division of 734 acres on which to establish a central flying school.

Although he was still a major, White's time in England had given him unique knowledge and authority on current military thinking. He was acting Chief of the General Staff when war was declared in 1914. By then his work in preparing Australia's defence plans, including the secret scheme for a mixed Australian/ New Zealand expeditionary force, was well in hand. Within six weeks of the outbreak of war, the nation was in a position to send a substantial contingent overseas. ${ }^{6}$ Defying the British preference for smaller units that could be absorbed

4 John Mordike, An Army for a Nation: A history of Australian military developments 1880-1914, Allen \& Unwin in assoc. with the Directorate of Army Studies, Department of Defence, Sydney, 1992, pp.196-8, 244-5; 'We Should Do This Thing Quietly', Japan and the great deception in Australian defence policy 1911-1914, Aerospace Centre, RAAF Base Fairbairn ACT, 2002, Part IV; Bentley, 'Champion of Anzac', pp.134-6. For a different perspective on Pearce's insistence on secrecy, see John Connor, Anzac and Empire: George Foster Pearce and the Foundations of Australian Defence, Cambridge UP, Melbourne 2011, p.37.

5 Williams' fellow trainees were Lt David Manwell of the Light Horse, Capt. Tommy White of the 60th (Princes Hill) Battalion, and Lt George Merz, a medical graduate and brother officer of Robert Gordon Menzies in the Melbourne University Rifles, who in 1915 was the first Australian military pilot killed in action, by hostile Bedouin after a forced landing near Basra (T. L. Smart. 'Remembering Lieutenant Merz: Australia's military aviation medical officer pioneer', Journal of the Australasian Society of Aerospace Medicine, 2 [1], 2005. pp.9-15).

6 Bruce Douglas Faraday, 'Half the battle: the administration and higher organisation of the AIF 1914-1918', PhD thesis, University of New South Wales - Australian Defence Force Academy, 1997, pp.29-30. 
into larger British formations, the Australian Imperial Force would comprise an infantry division and a light horse brigade. White was appointed Chief of Staff to the commander of the AIF, Major General William Bridges. With Bridges he selected the senior officers for the division and was, with Bridges, one of the first of those to leave with Australian forces for the developing European conflict. When the ANZAC contingent was diverted to Egypt, in due course to attack the Dardanelles, White would be among those who landed at Gallipoli early on the first day of the campaign. Wherever Australian troops were to be found over the next four years he was to be one of the most significant guiding hands. Less well known at home during the war than his celebrated contemporary John Monash, he was nonetheless one of the nation's most admired soldiers, and was to emerge to even greater prominence soon afterwards.

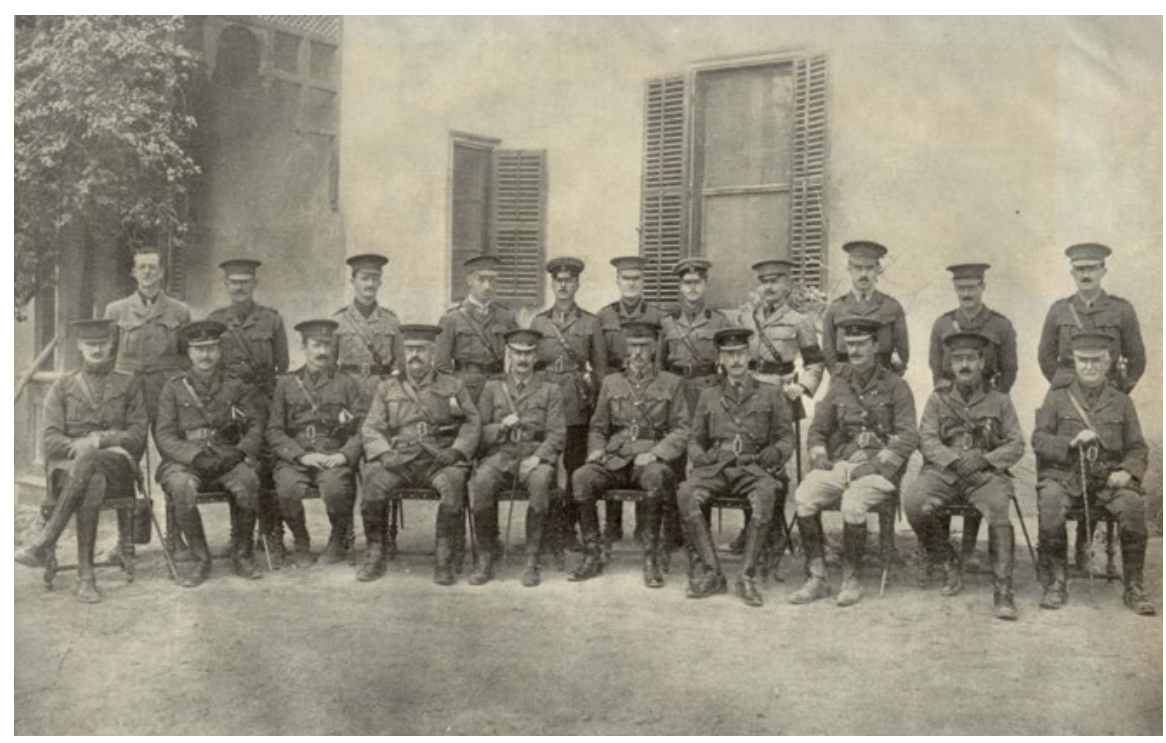

Staff, 1st Australian Division, Mena House, Egypt, February 1915

(The Australasian, 3 April 1915, from Ethel White's scrapbook, courtesy of Mark Derham)

\section{Reputation}

When the first volume of Charles Bean's official history of Australia in the war of 1914-1918 appeared in 1921, White's reputation soared. ${ }^{7}$ Bean could find no fault in the Chief of Staff to Lieutenant General William Birdwood, the

\footnotetext{
7 In 1936 the Professor of History at Melbourne University, Ernest Scott, would embellish the portrait of 'one of the most brilliant officers in the British forces... Beneath a gentle mien and imperturbable politeness... maintained a soldier's keenness and firmness; the sword in the velvet scabbard...gifted with a swift and comprehensive intelligence...' (Australia During the War, Angus and Robertson, Sydney, 1936, p.200).
} 
commander of the ANZACs from September 1915 to the end of the war. As one newspaper reviewer wrote: 'The great staff-officer appears throughout a far more lovable character than Birdwood. The impression is that Birdwood was self-consciously pleasant while White was kind; that Birdwood had personal ambitions whereas White's whole effort was centred on the army with which he was serving.' Whatever the justice of this observation, Birdwood's high esteem for White was evidenced by his recommendation to Sir Douglas Haig that White should be his Chief of Staff and his own appointment of White as Major General, General Staff of the $5^{\text {th }}$ Army. Personally, Birdwood was to write: 'He was the most delightful of companions - always so cheery, so full of life and of real human sympathy...He was not only a great man, but a God-fearing man: indeed he was great because he trusted in God. ${ }^{8}$

Charles Bean's admiration for White can be traced in his private diaries long before the official volumes on the war were to inscribe his hero's name indelibly in Australia's history. While still waiting in Egypt, seeking permission to travel with the Mediterranean Expeditionary Force, Bean noted that White 'has more genuine sense in his little finger than many War Officials have in their small minds'. White's advocacy on Bean's behalf prevailed over War Office obscurantism. Bean was not a mere newspaper correspondent but the accredited representative of the Australian government. He would be attached to General Bridges' $1^{\text {st }}$ Division staff, liaising with Major Tom Blamey of intelligence. On 10 April 1915 Bean recorded a 'yarn with Colonel White':

He tells me he thinks it is an extraordinary compliment the Australian troops being chosen to make the present attempt on the Dardanelles. They have got the very best British regular troops they could - the $29^{\text {th }}$ Division....and here are the first Australian Division and the New Zealand and Australian Division chosen to start the ball. 'They wouldn't send us unless they thought we were competent,' he said.

To Bean we owe a glimpse of White as he was about to embark on April 23 'with his pistol in its case on his belt, his haversack packed, and a little blue enamelled pannikin tied onto the end of his swag'. A few days after the landing Bean was there when White was hit 'by a shrapnel pellet pretty hard and laughed as he was hit'. The Age correspondent Phil Schuler noticed White at this time 'indefatigable, never perturbed, always ready to remedy a defect' ${ }^{9}$ But the most revealing of conversations came with Bean on 2 November 1915 as the Gallipoli campaign was drawing to a close:

8 Field Marshal Lord Birdwood, Khaki and Gown, An Autobiography, Ward, Lock, London, 1941, pp.325, 437. 9 Phillip F. E. Schuler, Australia in Arms: A Narrative of the Australasian Imperial Force and their Achievement at ANZAC, T. Fisher Unwin, London, 1916, p.136. 
Had a yarn with White last night over matters in general. He was charming as usual. We both notice that the Australians here can be picked out on the instant by their faces - a little hard, but the strong, lined, individual faces which men get who stand and think by themselves. The Australian discipline is for orderliness - to get an operation through in an organised manner. The British discipline has a different reason - to make men go forward because they are told to do so. Our men we have to send forward trusting to quite a different principle - we rely on the strong, independent willed men carrying on the weak ones...

White evidently wanted to give me the benefit of an idea which had been strongly impressed on him. 'What I had seen since Suvla,' I had said, 'is making me a Socialist.'

'It's not making me that,' he said, 'but I'll tell what I should like to tell the people of Australia - what, if I get the chance, I shall tell them some day - and that is that they are right in the main thing: they may be wrong in the details - I'm no politician as you know, but I'm sure they're right in this - in giving every man a chance, a good, equal chance.'

White's character was shown not only in his willingness to speak truth to his chiefs but in his readiness to listen attentively and deal sympathetically with those he commanded. In Cairo early in 1915 John Treloar, his confidential clerk, had confided to his diary that Colonel White 'looks after us boys like a father'. On Gallipoli he was to write that 'one could never serve a more gentlemanly and considerate officer' ${ }^{10}$ A junior officer who was with White at 5.00 a.m. on 25 April 1915 as they approached land just north of Gaba Tepe recorded a conversation with him a month later:

I asked Colonel White today what wd happen to me if (\& when) the new General (if he came) brought an ADC with him \& whether I wd be allowed to go as O. O. to the $7^{\text {th }}$ Bgd with General Walker. He was kind enough to say that if I moved he had a better job for me than that, \& that the $\mathrm{G}$ had been good enough to say that he thought I had a pretty good grip of things here. ${ }^{11}$

Thus did Lieutenant Richard G. Casey also learn to appreciate the wisdom and sympathy of an extraordinary commander in embryo. White allowed Casey to photograph him sitting in his shirt sleeves at his collapsible table at the front

10 J. L. Treloar diary, 8 Jan. 1915, J. L. Treloar, An ANZAC Diary, Armidale, 1993, pp.72, 142; for an appreciation in the memoirs of a young field-ambulance unit private of 'one of our few favourites among the top brass', see Roy Ramsay, Hell, Hope and Heroes, Rosenberg, Dural, 2005, p.109.

11 R. G. Casey diary, 29 May 1915, Casey MSS, NAA: M1141/0/2a. 
of his dugout. Files were stacked on adjacent sandbags. With tie in place, boots brilliantly shined, jacket neatly folded at his feet, White was calmly going about his business, his pipe held slackly between his lips. ${ }^{12}$ Casey, always attracted to, and at times in awe of, older men of influence, would often recall White's lines: 'After this war a lot of old maids will die wondering' and 'Eating veal is like kissing one's sister - insipid. ${ }^{13}$

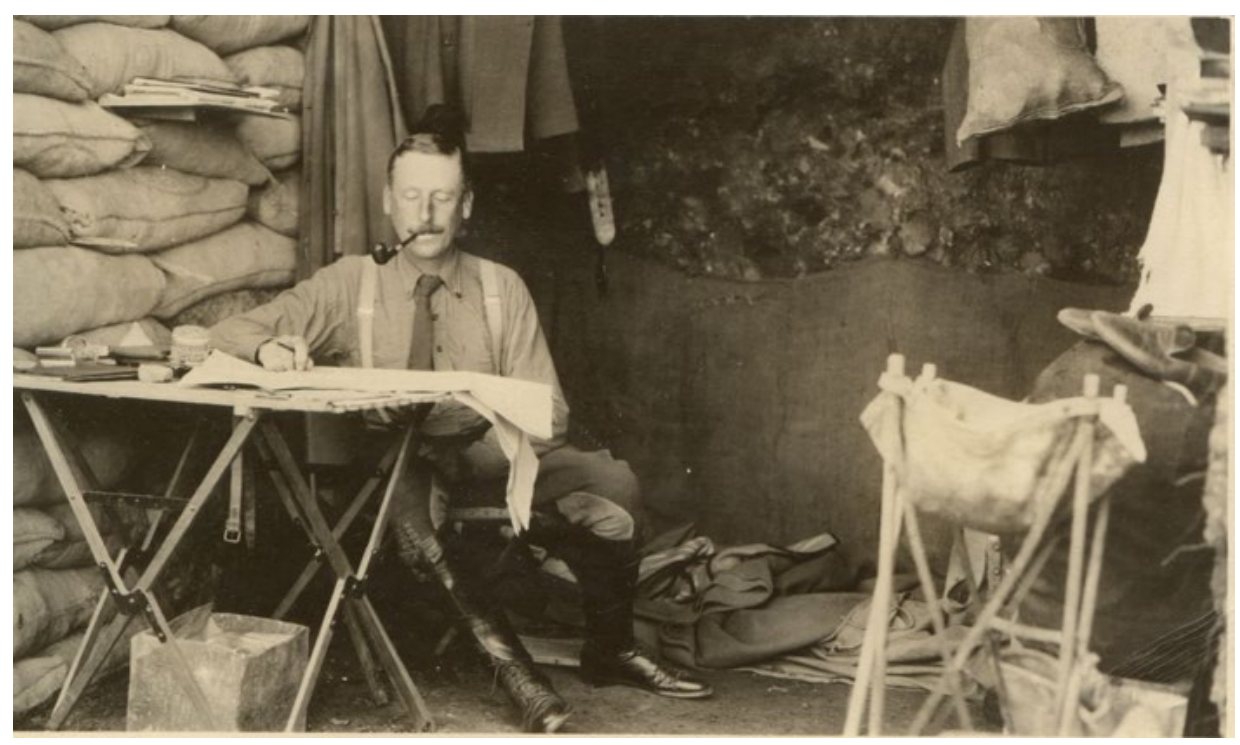

\section{Colonel C. B. B. White at Gallipoli May 1915}

(Courtesy of the Australian War Memorial PO4340.001)

It had not taken long for White to impress the senior commanders. As his chief General Bridges lay dying, after once too often exposing himself to enemy snipers, General Birdwood had taken comfort in the fact that he had in White, senior General Staff Officer of the Division, 'a man who is worth anything, and one of the best and most capable soldiers I have met for a long time...full of common sense and has much detailed knowledge and sound judgment'. ${ }^{14}$ It was not so much the fighting at Gallipoli that made White's reputation - in the larger force there his influence was reduced at least until July 1915 - but the detailed planning of the evacuation in December 1915. The logistics and

12 Kevin Fewster (ed.), Bean's Gallipoli: The diaries of Australia's official war correspondent, 3rd ed. (1st ed. 1983), Allen \& Unwin, Sydney, 2007, pp.52, 59, 66, 96, 221-2. I have followed the original diary where Fewster's transcription errs (AWM38, 3DRL606/3/1,5/1 19/1).

13 W. J. Hudson, 'A Foreign Minister's Qualifications', seminar paper, Dept of International Relations, Research School of Pacific Studies, ANU, 29 March [1984?].

14 Birdwood to Sir Ronald Munro-Ferguson, 17 May 1915, copy, Birdwood MSS, AWM: 3DRL 3376/31, quoted in John Dermot Millar, 'A study in the limitations of command: General Sir William Birdwood and the A.I.F., 1914-1918', PhD thesis, University of New South Wales - Australian Defence Force Academy, 1993, p.60. 
timetables, and the concealment of the thinning of the Australian forces from the Turks, were devised with imagination and precision. This was staff work of the highest order. The story of the 'silent ruse' was to be told and retold wherever ANZACs foregathered in the years to come. When the second volume of Charles Bean's war history was published late in 1924 White was disappointed at being given only 'subdued credit for the evacuation'. Truth to tell, however, Bean's version of White's role diminished the responsibility of Birdwood and of the acting GOC ANZAC, Alexander Godley, who commended 'the thoroughness and excellence of his Staff work, which resulted in the success of the operation'. If the operation had not been successful it was their reputations more than White's that were in jeopardy. But they were big men who were happy to give credit to a remarkably able subordinate. ${ }^{15}$ In retrospect it should also be observed that White had recognised that being a confidant of a well-connected and influential publicist was a vital element in shaping perceptions at the highest levels. It was all the more valuable for someone who was believed to eschew publicity.

John Monash, himself understanding the value of 'advertisement', was appreciative of White's ability. He wrote to his wife in April 1916: 'He is far and away the ablest soldier Australia has ever turned out...He is also a charming good fellow.' ${ }^{16}$ In the innermost thoughts that he shared with his own wife, White had said after three weeks at Gallipoli 'I am obviously not a soldier that is to say a war soldier. I confess to any quantity of obsolete notions of peacetime soldiering of which I am no longer proud or boastful!' At root the trouble was, he said, that he just did not like war, at any rate 'modern war' ${ }^{17}$ There was no escaping the fact, however, that notwithstanding illness, bouts of depression, and occasional tension with his superiors, he was exceptionally good at it. As an anonymous newspaper correspondent wrote in April 1916:

...saw General Brudenell White, of the Australian army, looking as young and boyish as ever. He is regarded as the man of the war, as far as this part of the world is concerned. They say that if he had been in supreme command the Suvla Bay tragedy would never have happened. ${ }^{18}$

If the extraordinary success of the Dardanelles withdrawal had not made his name, his next remarkable achievement - the organisation and transfer to France of an Australian force twice its former size - demonstrated his unmatched administrative capacity. As modern military historians, no less than

\footnotetext{
15 Derham, The Silence Ruse, p.215; Millar, 'A study in the limitations of command: General Sir William Birdwood and the A.I.F., 1914-1918', p.112; Robin Prior, Gallipoli: The End of the Myth, UNSW Press, Sydney, 2009, p.227; David W. Cameron, Gallipoli: The Final Battles and Evacuation of Anzac, Big Sky Publishing, Newport (NSW), 2011.

16 F. M. Cutlack, War Letters of General Monash, Angus \& Robertson, Sydney, 1934, pp.xii, 112.

17 Bentley, 'Champion of Anzac', p.215. Bentley's excellent thesis provides the material that refutes White's self-deprecation.

18 The West Australian, 24 April 1916.
} 
Bean, have shown, it is impossible to write the story of Australia's role in the European theatre without White's role being at its heart. His offensive planning was not faultless. He could be chastised by his superiors for being too optimistic about the prospects of success for certain operations. His own chief Birdwood would express irritation that subordinates would take matters to White that should have come to him. But White's reputation with the high command continued to rise. After the failure of the Australian attack at Pozières, Sir Douglas Haig visited the Australian Corps HQ at Contay on 29 July 1916 where he saw Birdwood and White. White remembered the occasion in an interview 24 years later:

This failure drew upon the Anzac Corps Staff an informal but emphatic reprimand from Haig who thought it due to over-confidence engendered by success at Gallipoli [sic].

'You are not fighting Bashi-Bazouks now,' he said to Birdwood and me in our office at Contay. 'This is serious scientific war, and you are up against the most scientific and military nation in Europe.' And pointing to a map on the wall he explained a number of alleged omissions in artillery and other arrangements and said that he would have no such rough-and-ready methods in France.

But as a matter of fact, any errors that were made were not of the crude nature indicated by Haig, who had made many mis-statements. I felt myself getting hot all over until at last I could stand it no longer. In spite of Birdie's protest I dragged Haig back to the map and said: 'Look here, Sir, I may be a damned interfering colonial, but you were wrong!' And I took him back over his accusations and showed him that it was not all Birdie's fault at all. I was in such a state I really didn't care, but Haig was splendid. He just looked at me with kindly blue eyes and said: 'Perhaps you're right, young fellow.' ${ }^{19}$

The eruption did White no harm. 'The latter seems a very sound capable fellow,' Haig noted that day in his diary of Birdwood's Chief of Staff, 'and assured me that they had learned a lesson, and would be more thorough in future.' Charles Bean reflected privately in November 1916: 'This chronicle seems to contain a great deal more of White than of anyone else. But really he is the AIF \& has been since Bridges died \& even before. ${ }^{20}$

19 The Mercury, 26 March 1940.

20 Martin Gilbert, The Somme: the Heroism and Horror of War, John Murray, London, 2006, p.136; Bean diary, 8 Nov. 1916, Bean MSS, AWM: 38, 3DRL606/66/1. White's contribution is set authoritatively in context in Peter Pedersen, The Anzacs: Gallipoli to the Western Front, Penguin Books, Camberwell, 2007. 


\section{Sent from Heaven}

With $1^{\text {st }}$ ANZAC in September 1917 was another Australian war correspondent, the Sydney journalist Harry Gullett. After the 'great show' on September 20, Gullett wrote to his wife Penelope about the work behind the scenes:

The genius of the Australian Army is a man of our own - Major General White a Queenslander — once a bank clerk who took to soldiering before the war as a profession, did brilliantly in the military colleges in England, \& left Australia for Gallipoli at the outset as a staff captain. His fame is all thro France: many count him as possibly the master of them all. His work goes far beyond our force. Certainly he has not nearly finished. He is now Chief of our Staff. Isn't it good to have produced him? And he is the most modest \& charming man alive: a delightful easy manner, \& he radiates light \& intelligence. He is one of those rare big personalities that always have a lot in hand. He always has a minute to spare for everybody. In the midst of the show today he greeted me with a cordiality that was a revelation of his size. I believe he comes from a good old squatting family which lost its cash \& he is practically selfeducated. He has very fine kindly blue eyes $\&$ a long fair face runs to a huge strong Roman nose. He rides a horse in a curious way with a hump in his back \& at the Haig review he sat away behind the smaller fry an aloof, shy \& intensely interesting figure. I enthuse about him because if he is not the man we think he is sent from heaven. ${ }^{21}$

Not every Australian in France thought White sent from heaven. As the historian Ross Mallett points out, Brigadiers Harold 'Pompey' Elliott and John Gellibrand ignored his tactical caution in the advance to the Hindenburg Line. His misgivings about the first Bullecourt attack were not heeded; and his scheme for the second Bullecourt battle was flawed. His planning was generally more successful. ${ }^{22}$ But that did nothing to mollify the particularly aggrieved brigade commander, 'Pompey' Elliott. Revered by the troops, who knew him as a fearless leader whose tactical decisions were informed by frontline observation, Elliott was frequently at odds with headquarters. Overruled by White on the appointment of his own battalion commanders, he was even more chagrined at being passed over for promotion when Thomas Glasgow and John Gellibrand were given divisions in May 1918. Foreshadowing an appeal to the Australian Minister of Defence about being unjustifiably overlooked, Elliott provoked a masterly response from White:

21 Gullett to Penelope Gullett, 20 Sept. 1917, Gullett MSS, NLA MS 3078/5/13. Decades later, Gullett's son would write that his father admired White — was 'in some awe of him' — but did not much like him (J. Gullett, notes for Lord Casey, 7 Oct. 1972, NAA: M1129 WHITE/C B).

22 www.aif.adfa.edu.au:8888/Generals/index.html accessed 26 June 2011. 
Do you think anyone doubts your courage? No one in the AIF, I assure you. Or yr ability? It is well known; but - you mar it by not keeping your judgment under complete control...Finally you actually threaten me with political influence. You have obviously written hurriedly and I am therefore not going to regard yr letter as written. But let me say this: if the decision rested with me I should send you off to Australia without the least hesitation if calmly and deliberately you repeated yr assertion to seek political aid - and if you managed to raise a dozen 'politicomilitary' enquiries I wd fight you to a standstill on them!

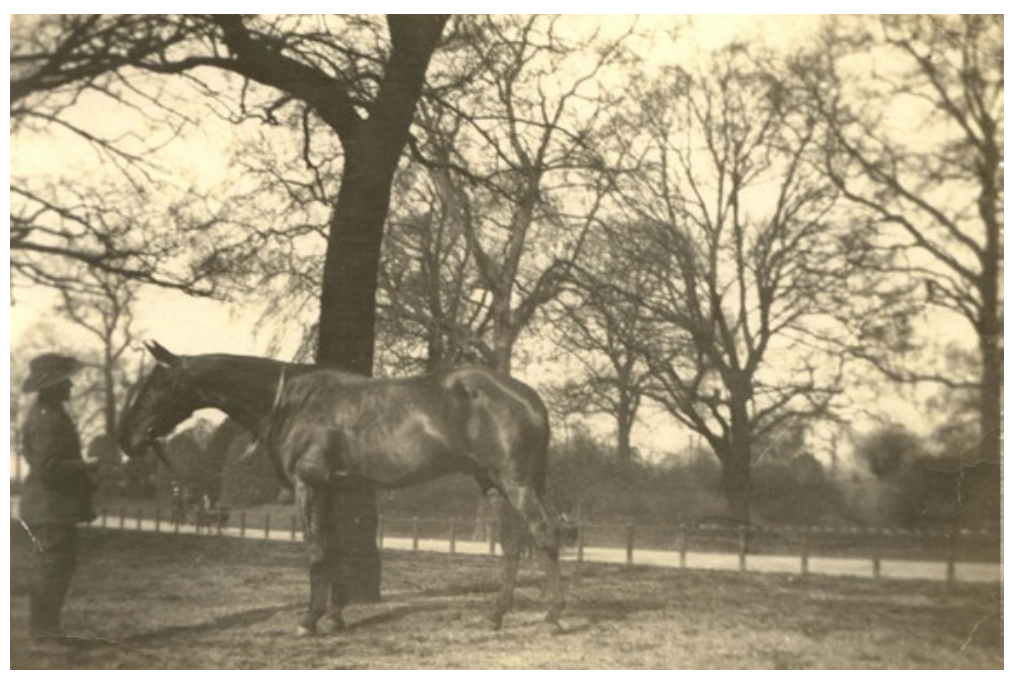

'Traveller', the horse White rode 'in a curious way' throughout the war, sold for 86 guineas, May 1919

(Ethel White's scrapbook, courtesy of Mark Derham)

What Elliott's biographer describes as an 'astute blend of intimidation and inducement' - a hint that he was next in line for a divisional command subdued the unbalanced brigadier. When it was known that White was to follow Birdwood from the Australian Corps to the Fifth Army, Elliott's judgment was that White:

...is undoubtedly a very able man but he is now completely under General Birdwood's thumb, as he sees his future being made by sticking close to him and this is natural under the circumstances. But I cannot help thinking that it has more than once led to the betrayal of Australian interests. $^{23}$

23 White to Brig. H. Elliott, 22 May 1918, Elliott diary, 29 May 1918, Elliott Papers, quoted in Ross McMullin, Pompey Elliott, Scribe Publications, Melbourne, 2002, pp.427, 437; Elliott to his wife, 24 May 1918, Elliott Papers, AWM: 2DRL/0513. Series 3 Wallet 10. 


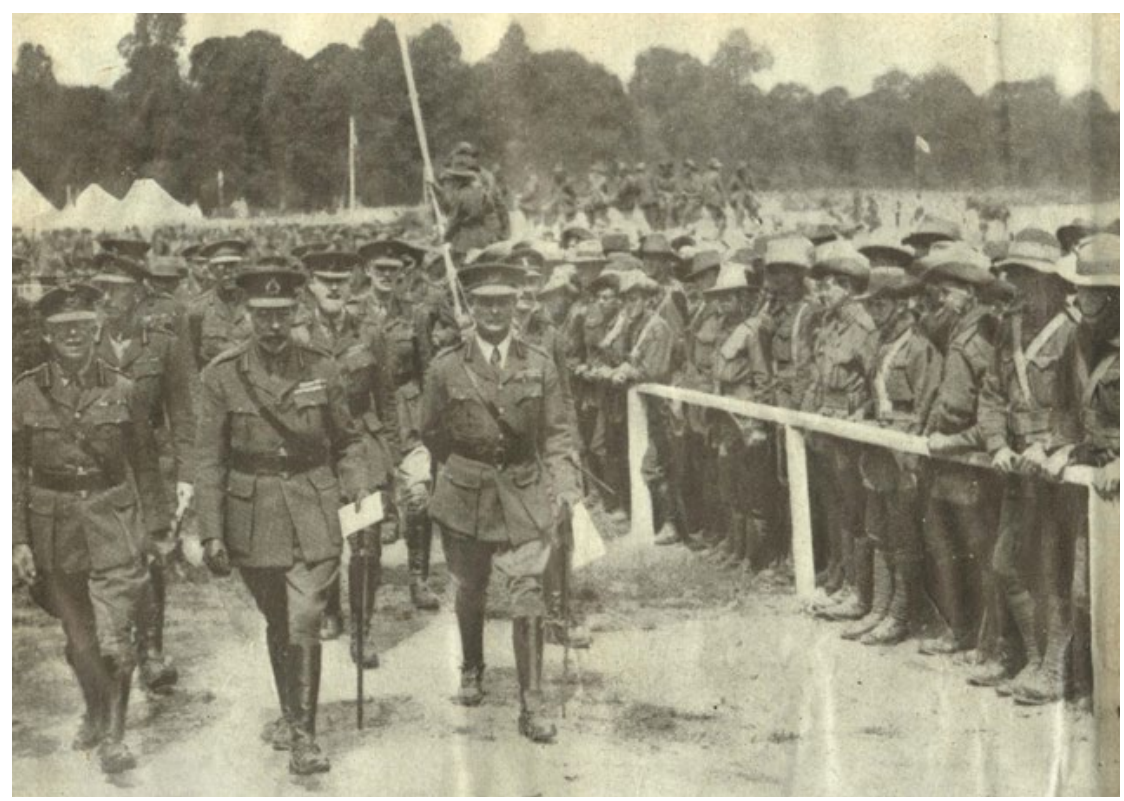

\section{King George V, flanked by Sir William Birdwood, visits Australian troops at play, White in close attendance}

(Ethel White's scrapbook, courtesy of Mark Derham)

In France, White was indeed at Birdwood's right hand throughout. Some scholars were later to suggest that he was in fact doing much of the work more properly done by his chief. Certainly, as his own daily diary shows, he was organisational architect, planner, trouble shooter, adviser, and emissary. If Bean exaggerated his role and achievements, diminishing those of Sir John Monash and others like Robert McCheyne Anderson, the Sydney businessman sent to England to manage the AIF's supplies and finances, White was undoubtedly one of the outstanding successes of the war. Whether some of the spectacular victories attributed to Monash in 1918 would have been his if he had been given the command of the Australian Corps in succession to Birdwood or to Monash can never be known. Bean and Keith Murdoch conspired unsuccessfully to thwart and then overturn the Monash appointment; but White himself, though never an uncritical admirer of Monash, had doubts that he was himself the right man for the post. ${ }^{24}$

The war provided White with unrivalled experience, not simply of the thinking and performance of the Australian and imperial high command, but of the labyrinthine intrigues of generals and politicians. He was privy to, and

24 Roland Perry, Monash: The Outsider Who Won A War, Random House Australia, Sydney, 2004, pp.32939, 385-6; Geoffrey Serle, John Monash: A Biography, MUP, 1982, pp.318-28, 375. Bean's laudatory character sketch of White, datelined 4 March 1918, was published in Murdoch's Herald, 23 May 1918, and quoted again at length in the Herald ('A Wonderful Record....Brilliance Manifested'), 18 June 1918. 
unimpressed by, much of the ambition for promotion and honours that animated many of his peers. However, he was not above manoeuvring to influence the organisational and command choices of his superiors. His hand had been evident in the undermining of Major General J. G. Legge's appointment to lead the AIF in 1915 and the transfer of the GOC's powers to Birdwood. In subsequent years he had developed considerable distaste for the propensity of government leaders to subordinate military priorities to political interests. Decisions about the deployment of the Australian third division in late 1916, for example, were, he thought, contrived to influence the soldiers' vote in the conscription campaign. Though he deprecated this he was unabashed in urging Bean to persuade Birdwood to come out publicly in favour of conscription. Whispering campaigns for and against candidates for corps and divisional commands swirled around him. Rumours of negotiated peace and of rifts between the high command and the War Cabinet were an intermittent distraction. When news came late in 1918 that Germany had accepted President Wilson's peace terms, his profound scepticism about all things political found expression: 'Great discussions on Peace. Army a little mistrustful. ${ }^{25}$

Although as the war progressed he was largely detached from the trench and training worlds, White had thought deeply about problems of command in the field, and the difference between British and Australian forces: 'the moment you get inexperienced British commanding officers administering Australian troops you find the differences'. He was a strong supporter of promoting officers from the ranks and ensuring that they remained close to the regiment or at least the brigade in which they had served. As he told Bean: 'You want them with the CO who knew them and often with the men they knew. That is a concrete difference that the British don't realise.' ${ }^{26}$

That the war took its toll on White, as for all of his contemporaries, scarcely needs to be acknowledged. Perhaps only Bean, in whom he regularly confided, sensed how fragile was his temperament. An ounce of enmity worries him more than a ton of work. ${ }^{27}$ Sent to spend time in the London General Hospital late in 1917 he was enjoined by his good friend Neville Howse, Director of Medical Services, to keep his bed and sitting rooms well ventilated. 'Walking or riding exercise every day (weather is no bar to a healthy man), five minutes exercise before first meal, preferably in the open air. ${ }^{28}$ It was a sensible regimen if not a cure-all. In a letter of commiseration to the then troubled brigade commander John Gellibrand in

\footnotetext{
25 Bean diary, 15 Oct. 1916, Bean MSS, AWM: 38, 3DRL606/61/1; White diary, 12, 13 Oct. 1918, White MSS, NLA MS 5172/7.

26 Bean diary, 2 March 1916, Bean MSS, AWM: 38, 3DRL606/40/1, quoted in Faraday, 'Half the battle...', pp.156-7.

27 Bean diary, 17 Feb. 1917, Bean MSS, AWM: 38, 3DRL606/70/1.

28 Michael B. Tyquin, Neville Howse: Australia's First Victoria Cross Winner, Oxford UP, South Melbourne, 1999, p.109.
} 
June 1917, White had spoken of demands that were 'wearing \& for how long it is possible is a doubtful business... We both suffer from a certain lack of those Apollo like qualities which make hard physical work, \& privation \& discomfort of small account.' More serious was the emotional and psychological strain 'a certain amount of rest and freedom from responsibility' would be necessary before it was possible to 'see the world in correct perspective again'. ${ }^{29}$

One thing White did see in a particular perspective that even his greatest advocate did not appreciate was the need for the hard-pressed British Army to take credit for some successes in the autumn of 1918. He had previously been unenthusiastic about an idea of Bean's 'to write something wh. wd force the British to treat Australia as a separate distinct (tho' kindred) nation'. With the British Commander in Chief failing to acknowledge the role of Australian and Canadian troops, White told Bean that in Haig's position he would have done the same. The value to British morale of the victory that freed Amiens would have been lost if it had been attributed to Dominion forces. To Bean, this was to miss the larger strategic picture: that one day Australia's future might depend on the perception of the Americans of 'how far we had put the civilised world under an obligation to us in this war. Our existence may depend on it.. ${ }^{30}$ But then and later White remained an admirer of Haig. It was to Haig more than any other commander, he affirmed on the Field Marshal's death in 1928, that victory was owed. It was Haig's character, 'a character without a flaw', that saved the British Army in March 1918: 'The belief that the men had in him undoubtedly kept them from rout.' ${ }^{31}$

White had ended the war as a Lieutenant General, Chief of Staff of the Australian Imperial Force and Chief of Staff of the British Fifth Army. When the shooting stopped he was tasked with establishing a repatriation and demobilisation branch of the AIF in London. Four days after the Armistice, White saw Billy Hughes in London. Realising that he lacked sufficient knowledge of education and industrial employment he recommended that John Monash should be given the industrial responsibility or, almost certainly his less-preferred option, put in charge of the whole organisation. The Prime Minister, he discovered, 'evidently wants Monash for Demob job'. Within days Monash had taken over. White it seemed had been out-manoeuvred. To White's astonishment, when he offered his services to Monash he was turned down. Emerging from a private

29 Peter S. Sadler, The Paladin: A Life of Major-General Sir John Gellibrand, Oxford UP, Melbourne, 2000, p.139.

30 Bean diary, 22, 29 Feb. 1917, 18 Aug. 1918, AWM: 38 3DRL606/70/1;116/1; John F. Williams, Anzacs, The Media and The Great War, UNSW Press, Sydney, 1999, p.246.

31 The Argus, 23 Nov. 1936; Brisbane Courier, 1 Feb. 1928. 
meeting with Monash, he stunned Bean with an uncharacteristic expletive. ${ }^{32}$ On Monday, December 16 the now-unemployed general recorded: 'Drove a car for a couple of hours for practice. ${ }^{33}$

While he spoke warmly of Monash publicly, White for the most part kept his own counsel about his real feelings. But a private letter in 1937 revealed his lukewarm appreciation of a man whom he said had 'an easier war on the whole than many of the other higher Commanders'. The unpopular J. W. McCay, he said, was an abler soldier. Monash 'like so many of his race was quick to grasp and quick to learn; even if the knowledge was without depth'. White professed to be quite certain that if Monash, like Birdwood, had 'been subject to the test of a 4 years command he would have failed'. ${ }^{34}$ 'Brudenell did not discuss the war with his family,' his daughter wrote, 'and it is doubtful if he ever mentioned his feelings about it to them...It had been a time of such agony for him and for Ethel that they tried to forget it. ${ }^{35}$

\section{Finding a new role}

Sir Cyril Brudenell White KCMG, as he had been since the beginning of 1919, returned home in HMAS Australia at the end of May 1919. He was elated at seeing the Southern Cross for the first time in five years. Acclaimed as a hero, he was given a civic reception at Melbourne Town Hall and fêted wherever he went in the next few weeks. In a warm pen-portrait in The Argus, the acting Minister of Defence was quoted as saying that White was considered 'the greatest and most capable soldier that Australia has produced'.$^{36}$ Before setting sail he had represented Australia on a War Office Reorganisation Committee considering the future of cavalry. His return to Australia saw him immediately engaged in defence planning as a member of a committee chaired by George Swinburne. The committee reported in August 1919 in favour of the creation of an air force and of maintaining a citizen army with the capability of putting 180000 men into the field if war were to come. Early the next year he participated with

\footnotetext{
32 Clem Lloyd and Jacqui Rees, The Last Shilling: A History of Repatriation in Australia, MUP, 1994, p.115. C. E. W. Bean evidently did not know that the job had first been offered to White (Two Men I Knew, William Bridges and Brudenell White Founders of the A.I.F., Angus and Robertson, Sydney, 1957, p.181). The announced demobilisation and repatriation arrangements entailed the creation of a mixed civilian and military board and a department headed by a minister, initially Hughes and then Senator Pearce; Monash would be director-general and White would sit ex-officio as the connecting link with General Birdwood (The Argus, 25 Nov., 24 Dec. 1918; The Herald, 26 Dec. 1918 for objections to demobilisation delays and to sending Pearce to London).

33 White diary, 14-20 Nov., 16 Dec. 1918, White MSS, NLA MS 5172/7.

34 White to J. Black RSSILA (Vic), 7 April 1937, AWM: 38 DRL606, item 276 (1), in Williams, Anzacs, The Media and The Great War, p.235.

35 Derham, The Silence Ruse, p. 213.

36 The Argus, 5 June 1919.
} 
Generals Monash, McCay, and Hobbs in a Senior Officers' conference chaired by Sir Harry Chauvel. In a two-volume Report on the Military Defence of Australia, the nation's military elite concluded that the safety of Australia depended on her ability to thwart an invading enemy long enough for help to arrive from other parts of the British Empire. The only enemy in mind, then and in the next two decades, was Japan. ${ }^{37}$

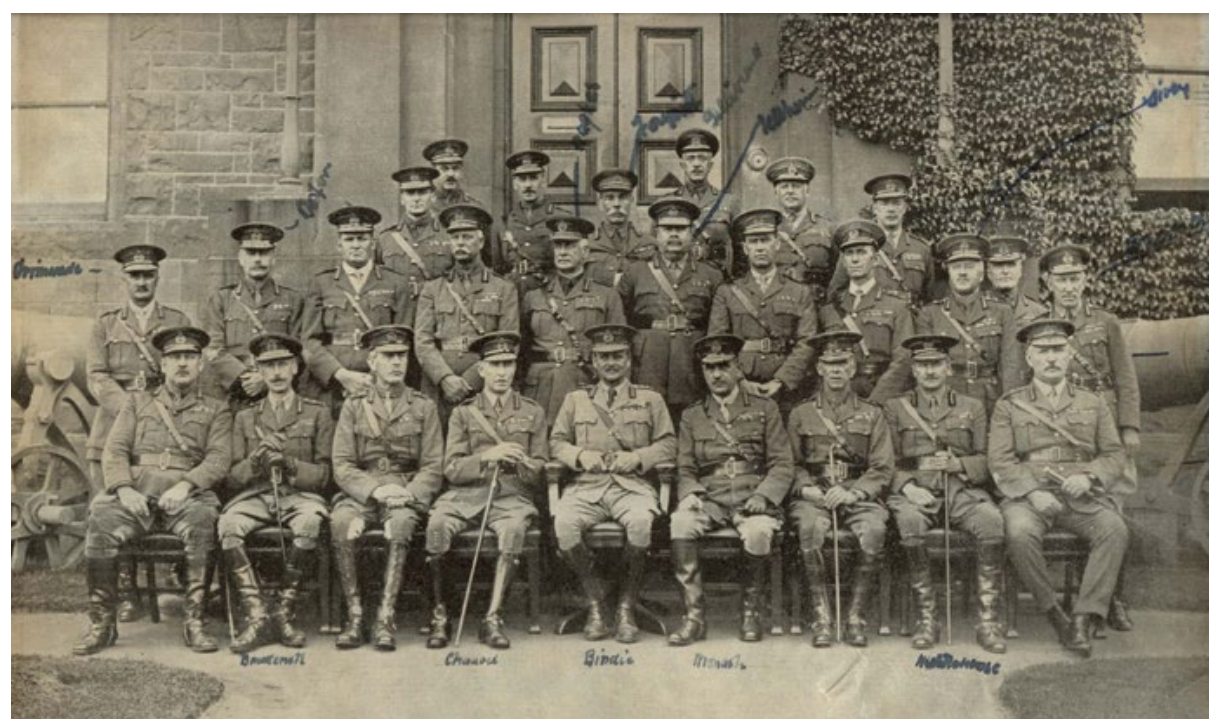

\section{A gathering of generals to meet Lord Birdwood}

(Photograph by T. Humphrey, The Australasian, 21 Jan. 1920, from Ethel White's scrapbook, courtesy of Mark Derham)

Appointed Chief of the General Staff in April 1920 in succession to Major General J. G. Legge, White took responsibility for developing the structure, recruitment, and training of the Militia. It was a task for which his meticulous mind was well suited. And his fervent belief in the value of a citizen army had only been confirmed by his wartime experience. Speaking at a farewell dinner as his period as CGS ended, White averred that he had refused to act as a propagandist. The Army realised that its strength was a matter for 'statesmen' after careful review by a foreign office and a military department. He was to note then and again that the absence of a foreign office was 'somewhat of a handicap to Australia' ${ }^{38}$ White's great admirer, Bean, was to write of him that 'the war swung him to a belief in democracy which, though at first almost reluctant, became firmer as his experience of it increased'. He was no natural democrat. But he believed it to be 'right in principle'. And when it seemed that Australia's democracy was

37 Claude Neumann, 'Australia's Citizen Soldiers, 1919-1939: A Study of Organization, Command, Recruiting, Training and Equipment', MA thesis, University of New South Wales at Duntroon, 1978, pp.37-9. 38 'General Sir Brudenell White: Notes', Official Historian's Misc. Research Notes, AWM: 3 DRL 419/45/13. 
threatened by Bolshevism he would not be a mere spectator. Democrat though he was, White was also a monarchist and, after successfully organising the visit of the Prince of Wales in 1920, he was made KCVO - Knight of the Royal Victorian Order - an honour in the gift of the sovereign. It was no secret that in 1921 he was elected a member of the general council of the League of Nations Union of which J. G. Latham was president. Eighteen months later, while still CGS, he revealed his political sympathies by appearing on the platform with other 'representative men' when Prime Minister Hughes delivered his policy speech at Chatswood Town Hall. Patriotism and Christianity were inseparable, White would tell an audience at St Paul's Cathedral in 1925, as long as patriotism was subordinate. ${ }^{39}$

In May 1923, Stanley Bruce prevailed upon White to become Chairman of the newly established Board of Commonwealth Public Service Commissioners. He had not been an applicant. He was still considering an offer to become secretary of the Victoria Racing Club, where his brother Jack (John Warren White) had been appointed chairman of the stipendiary stewards in 1920. Nor it seems, notwithstanding a substantial salary of $£ 2500$ a year, did he find the Public Service Board a particularly congenial task. He had necessarily resigned his appointment in the Permanent Force and was transferred to the unattached list of the Citizen Forces. He would retain his seat on the Council of Defence but in an honorary capacity.

Many officers who had not long since been urged by White to show loyalty to the Army while it went through the difficulties of retrenchment were unimpressed by his departure: 'there was a common phrase about Victoria Barracks that "the penny was mightier than the sword"'. There were comparisons with General Chauvel's steadfastness, much to White's disadvantage, Sir Sydney Rowell would remember. ${ }^{40}$ If there was a loss of esteem among old colleagues and subordinates, a growing intimacy with the Prime Minister was some compensation - he was consulted on 'probable new Govr Genls (??Allenby; recomdd Plumer)' in $1925 .{ }^{41}$ But the Public Service Board proved a wearying chore. The public service was practised and purposeful in resisting change. And nothing in his military life had prepared the general for dealing with recalcitrant staff associations, arbitrated

39 Carolyn Rasmussen, The Lesser Evil? Opposition to War and Fascism in Australia, 1920-1941, History Dept, University of Melbourne, 1992, p.12; Brisbane Courier, 25 Oct. 1922; The Argus, 11 April 1925.

40 Rowell to Lord Casey, 25 Oct. 1972, NAA: M1129 WHITE/C B.

41 White diary, 6 April 1925, White MSS, NLA MS 5172/10; Derham, The Silence Ruse, p.215 quotes an earlier diary entry which does not disclose White's queries about Allenby and support for Plumer. Sir John Baird Bt, a former Conservative Cabinet minister, was appointed and created Lord Stonehaven. 
wage settlements, formal appeals over promotions, calculated defiance that fell short of sanctionable transgression, or abusive character assessments under parliamentary privilege. ${ }^{42}$

White understood well enough that the Prime Minister's objectives of economy and efficiency could not be achieved simply by careful planning and command decisions. He sought co-operation and was willing to negotiate. Promotion purely by seniority having been abolished, his remit was to smooth the path for the new criteria of efficiency, merit, and good and diligent conduct. A revised position classification scheme was achieved after prolonged wrangling. Unhappily, there was a poor response to his attempts to engage departments in initiatives to identify and reward officers whose skill or inventive capacity brought savings or efficiencies. ${ }^{43}$ As his term came to an end there was nothing to attract him to continue in a job which would have entailed moving his family from the comfort of the grazing property near Beaufort they had bought in 1925 , to the unappealing environment of the nascent national capital.

It was a frustrating time at the Public Service Board, interrupted by illness, confrontation with Prime Minister Bruce over economies that threatened the viability of the defence forces, and the long distraction in 1926-27 of arranging the visit of the Duke and Duchess of York and the opening of the new Parliament House. Unfulfilling as the five years as Commissioner had been, they had been preceded by a more consequential disappointment. White had failed to ensure the succession he wished in his place at the head of the Army. On stepping down as Chief of the General Staff in 1923 he was succeeded by Harry Gullett's friend Sir Harry Chauvel, characterised that year in Gullett's history of the exploits of the Light Horse in the Middle East as 'a sound administrator and a wise and far-seeing commander', and 'a leader of broad Imperial sympathies and infinite tact' ${ }^{44}$ White had hoped that Brigadier General Tom Blamey would be appointed; but the best he could achieve was a splitting of the CGS's role into two, with Blamey designated to assume a new position as second CGS in charge of peace organisation, peace establishments, and training. A disappointed Blamey was enticed by Monash and encouraged by Chauvel to accept an offer from the Victorian government to become its Chief Commissioner of Police. ${ }^{45}$

\footnotetext{
42 The Bulletin, 29 Jan. 1925, quoting a Labor MP: 'an old conservative, dust-laden, brainless idiot...a troglodyte whose principal characteristics are ignorance, arrogance and egotism...pitchforked into a high position by social influence and patronage'.

43 Gerald E. Caiden, Career Service: An Introduction to the History of Personnel Administration in the Commonwealth Public Service of Australia, MUP, 1965, pp.14-15, 173-7, 199.

44 H. S. Gullett, The Australian Imperial Force in Sinai and Palestine 1914-1918, Angus \& Robertson, Sydney, 1923, pp.59, 61.

45 David Horner, Blamey: The Commander-in-Chief, Allen \& Unwin, Sydney, 1998, pp.70-3; A. J. Hill, Chauvel of the Light Horse: A Biography of General Sir Harry Chauvel, G.C.M.G., K.C.B., MUP, 1979, pp.207-9.
} 
White was more successful in arranging the transition to his favoured successor at the Public Service Board. His term over in June 1928, White was ready to make home, family, and a limited portfolio of business and voluntary service interests his priorities. In 1925 he had turned down an offer from Sir John Grice of $£ 2500$ a year to become general manager of the Trustees Executors and Agency Company Ltd. Two years later he declined the Prime Minister's proposal of a safe seat in the House of Representatives. Then, forewarned of an approach about the High Commissionership in London - widely canvassed in the press - he made sure that Stanley Bruce knew he was not interested. Now he accepted an offer from Grice of $£ 3000-4000$ a year to become chairman of the local board and superintendent of the Australian business of the New Zealand Loan and Mercantile Agency Company Ltd. ${ }^{46}$ He sat on the boards of the Alfred Hospital and the Australian War Memorial, the Rhodes Scholarship selection committee, and the council of Trinity College at the University of Melbourne, where his 'very long, very slow' first meeting was an uninspiring introduction to the contrasting decision-making conventions of the university, military, and commercial worlds. But at various times he was brought into counsel by the federal government. ${ }^{47}$ His generally laconic diary occasionally gives a glimpse of a man unafraid to speak his mind. A three-hour Council for Defence meeting in November 1929 was one such occasion 'whereat I definitely stated some views'. The matters were rehashed at a lunch with newly promoted fellow Generals Chauvel and Monash; and followed the next day after further consultation with Monash by a telegram to the Prime Minister 'demurring at terms of his press notification'. ${ }^{48}$ It was not coincidental that there were no further Council of Defence meetings for five years. ${ }^{49}$

Military matters and echoes of the war were never far away. In early August 1927 he dined with Monash — ' a jolly party' — and found himself sitting next to Pompey Elliott. 'We had a reconciliation - but not before I had told him what I thought of him.' On 2 June 1930 there was an 'extraordinary letter from Genl Elliott'. 'Another strange letter' from Elliott, a Nationalist Senator since 1919, arrived on June $10 .^{50}$ Elliott's resentment at his wartime 'supersession' by Generals Glasgow and Gellibrand had been re-ignited after the war when White was CGS. He had imprudently taken his personal grievances against White and Birdwood into public arenas. Never appeased in spite of being promoted Major

\footnotetext{
46 Derham, The Silence Ruse, pp.215, 254-5; Sydney Morning Herald, 2 Feb. 1927; White diary, 1 March 1928, White MSS, NLA MS 5172/11.

47 For some of the Council of Defence meetings he attended and his sharp comments on secret documents, see White Papers, AWM: 3DRL?1400, Series 5 Wallet 5.

48 White diary, 12-13 Nov. 1929, 25 June 1930 (re Trinity College) White MSS, NLA MS 5172/12.

49 Neumann, 'Australia's Citizen Soldiers', p.107.

50 White diary, 8 Aug. 1927, 2, 10, June 1930, White MSS, NLA MS 5172/11.
} 
General and given a divisional command in 1928, and still seeking vindication even from White, Elliott fell ill a few months later, and took his own life in March 1931.

Since Elliott had 'ventilated his supersession' in the Senate in 1921 and 'apparently condemned no one but himself', he had been a nuisance. ${ }^{51}$ But for White, his own reputation secured in the imposing volumes of Charles Bean's history of Australia in the war, there were more compelling contemporary concerns. 



\section{Call and recall: Brudenell White (II)}

Brudenell White was on the verge of being drawn into the vortex of politics. On 12 February 1930 he records 'Visit 12/15 from a Mr Armstrong with a new code book.' On March 17 'C. R. Murphy called on behalf of Pastl Vigilance Cttee \& wanted me to go to Canberra re Fed Land Tax Bill. Lobbying!!' C. R. Murphy, an influential grazier who made no secret of his Nationalist associations, was a fellow director of the Trustees, Executors, \& Agency Co. along with Sir John Grice. The Graziers' Vigilance Committee, as Murphy's group was properly called, was campaigning against the federal land tax that burdened many graziers who were not even making working expenses. This 'iniquitous capital tax', as the Victorian grazier MP, James Fairbairn, was to dub it, was to remain in place until a more sympathetic Lyons government eventually reduced it by half in 'one of its most progressive steps towards creating employment'.

Economic conditions and the political temper of the times now began to interrupt White's placid journal entries on theatre outings, AIF Trust meetings, quiet dinners at the Melbourne Club or the Naval and Military. He was angered by the rising tide of anti-war literature, 'the works of degenerates, whose war experiences, if put to the test, would be found to be mainly imaginative; and they have been made the tools of profit-seeking publishers' ${ }^{2}$ 'Who, with a clean mind,' he asked the NSW RSL Reveille's readers in March 1930, 'from so much pure gold, would wish to throw the light upon the inevitable dross?' There was dross looming ahead as well - base contaminants in the body politic. The mood in conservative circles was sombre. Thus at a National Mutual board meeting on 27 May 1930 he found fellow director Sir Robert Gibson, the powerful chairman of the Commonwealth Bank Board, 'very gloomy'. The day before, the private secretary to the New South Wales Governor Sir Philip Game had tried to arrange a dinner; but a 'troublesome' cold meant a telephone conversation instead.

By July 16 White was attending a 'most impressive meeting of Citizens in protest of budget at Melbourne Town Hall. A wonderful gathering.' August 14 was another cheerful day when he presided at the $75^{\text {th }}$ anniversary meeting of the Melbourne City Mission and heard a good speech by the rising Victorian politician R. G. Menzies. There was another 'excellent \& interesting speech' four days later, this time by the British Treasury official Sir Otto Niemeyer. White had met Niemeyer at dinner at the Melbourne Club with Sir John Higgins, the former chairman and now liquidator of the British-Australian Wool Realisation

1 CPD, House of Representatives, 25 Sept. 1935, p.165.

2 The federal executive of the RSSILA urged in March 1930 that the official war historian should be authorised to censor all war books (Peter Coleman, Obscenity Blasphemy Sedition: Censorship in Australia, Jacaranda Press, Brisbane, 1974, pp.37-8). 
Association. Higgins was shortly to be one of the key members of a small group that eased the passage of Joe Lyons from the Labor Party into the leadership of a new political force, the United Australia Party.

Another of those whose minds were turning towards a fundamental political re-alignment, with Robert Menzies as one of the moving spirits, was the chief executive of the National Mutual, Charles Norris. At the National Mutual on September 9, Sir Robert Gibson was 'very pessimistic re amendt present adverse conditions'. As chairman of the Commonwealth Bank, Gibson had joined Niemeyer in pressing the Commonwealth government and state premiers to reduce government borrowing and spending in an attempt to improve Australia's economic position. Without pronouncing directly on the programs and policies of political parties, White did find occasion to declare his belief that Australia needed 'a lot less cant in our political, business, and social life'. The 'greatest wrong' in contemporary Australia he asserted was the fostering of a class spirit which encouraged envy, hatred, and malice towards those who possessed what others coveted. It was to be this class spirit that would deter him from advocating the formation of an Officer Training Corps for young men who had the benefit of a higher education - because it might be thought undemocratic. ${ }^{3}$

\section{Secret leagues}

Uninterested in party politics, White played no discernible part in the secret conversations of Menzies, Norris, and Higgins, and their associates, Staniforth Ricketson, the journalist Ambrose Pratt, the prominent architect Kingsley Henderson, and later, Keith Murdoch. He would rub shoulders with Menzies and some of the others at the Savage Club. And an occasional discreet dinner with R. W. Knox, and confabulations with bankers and economists, kept him au fait with political and financial developments. ${ }^{4}$ But he could not easily remain unmoved by the actions that many of his former Army friends were taking during the turbulent Depression years. Whether he knew it or not, he came incidentally, and maybe purposely, to the notice of intelligence agencies. ${ }^{5}$

Informants reported that White was involved with a group of Victorian Militia officers in a League of National Security loosely linked with the secretive citizens' groups in New South Wales, often referred to as the Old Guard. The League was perhaps a re-incarnation of the White Army of the early 1920s. It was known to many as the White Guard. This was not apparently an acknowledgement

3 Brisbane Courier, 6 Dec. 1930; F. H. Wright to General D. Wynter, 30 Dec. 1941, copy, White MSS, NLA MS 8119 Series 2 Box 15.

4 White diary, 13, 26 May 1931, White MSS, NLA MS 5172/13.

5 Richard Hall, The Secret State: Australia's Spy Industry, Cassell Australia, Stanmore, 1978, pp.20-2. 
of White's leadership. Indeed there are good reasons for believing that Major General Tom Blamey was more actively involved in the shadowy Victorian League. As head of the Victoria Police, Blamey took the threat of Communist subversion more seriously than the Commonwealth Investigation Branch. Although contemporaries were unequivocal that Blamey 'was the boss', the precise nature of Blamey's and White's roles has never been conclusively established. ${ }^{6}$

Both British and American intelligence sources reported the formation of a secret army 'X Force' sometime between October and December 1930. ${ }^{7}$ Around this period there are suggestive entries in White's diary. A Sunday morning (9 November 1930) visit by 'Frank De Crespigny, Richardson, McKay \& Bastin' might well have been merely a friendly gathering of neighbours. But the shared backgrounds and military associations of the men suggest the possibility of another purpose. Dr Frank Champion de Crespigny had been a captain in the Australian Army Medical Corps in England and France in the last year of the war; practising in nearby Ararat he was serving in the Army Reserve. Colonel J. D. Richardson had led the $7^{\text {th }}$ Light Horse regiment $1918-19$ with success against the Turks in the final battles of the war. Now a grazier, he commanded the 2nd Cavalry Brigade, AMF. ${ }^{8}$ Charles McKay, from Beaufort, was a former Light Horseman and AIF officer promoted from the ranks, a stalwart of Ararat local government and the RSSILA. ${ }^{9}$ Lieutenant Colonel Hector Bastin had risen from sergeant to major in the war, serving in Egypt, Gallipoli, and France, was awarded the MC and was then commissioned into the Indian Army. In India he had commanded the Viceroy's bodyguard of the Bengal Lancers and served as a staff officer. Since late 1924 he had been in the Australian Army Reserve. ${ }^{10} \mathrm{He}$ was now farming 3800 acres near the White property at Woodnaggarak.

Did White and these local friends usher in the birth of a league of national security? The evidence, nothing but their Sunday morning meeting, permits no more than conjecture. We do know, however, that among White's key associates at this time were the solicitor and citizen soldier Colonel Francis P. Derham, who brought 'Colonel' Roach with him to a meeting in February 1931. On 2 July 1931, White noted in his diary: 'Saw Col. Derham re Secret League.' ${ }^{11}$ It was the only reference he made to the organisation, by now active, and penetrated by the Secret Service. But other scholars have established that, in addition to Frank

6 Cathcart, Defending the National Tuckshop, pp.56-7.

7 'Evidence of secret army uncovered', Canberra Times, 8 May 1980; Keith Amos, ABC Radio AM, 9 May 1980.

8 Richardson's The History of the 7th Light Horse Regiment A.I.F. was published in 1923.

9 McKay, Charles Holly NAA: B2455.

10 Bastin, Hector Ernest VX29296, NAA: B883; Ronald J. Austin, Our Dear Old Battalion: The Story of the 7th Battalion, AIF, 1914-1919, Slouch Hat Publications, McCrae, 2004, pp.27, 179, 208.

11 Rosemary Derham, The Silence Ruse: Escape from Gallipoli, A record and memories of the life of General Sir Brudenell White,Oryx Publishing, Melbourne, 1998, p.258. 
Derham, a decorated wartime artillery officer, the leaders of the 'Secret League' included several Militia officers - the barrister, Lieutenant Colonel E. F. 'Ned' Herring, who had been active in the White Guard which crystallised after the Victorian police strike in 1923, and the pharmacist, Lieutenant Colonel Colin Simpson, soon to found Allied Master Chemists of Australia Ltd (AMCAL), a confidant of Tom Blamey. Major General Harold Grimwade, related by marriage to the Fairbairns and Manifolds of Victoria's Western District, was also of the group. ${ }^{12}$

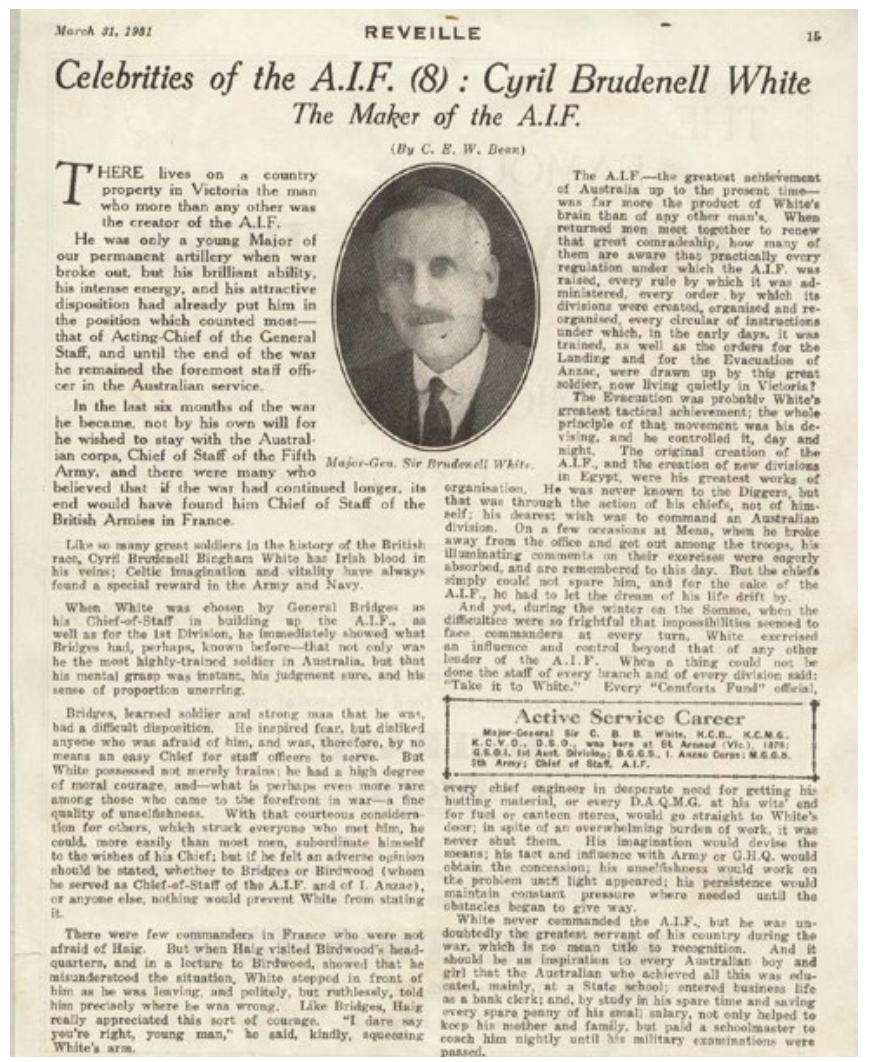

\section{Charles Bean's reminder about 'The maker of the A.I.F.'}

(Reveille, 31 March 1931, Ethel White's scrapbook, courtesy of Mark Derham)

12 Andrew Moore, 'Guns across the Yarra: Secret armies and the 1923 Melbourne Police Strike', Sydney Labour History Group, What Rough Beast: The State and Social Order in Australian History, George Allen \& Unwin, Sydney, 1982, pp.220-33, 265-9; Moore, The Secret Army and the Premier, pp.89, 135, and sources cited in p.260 fn 53; Stuart Sayers, Ned Herring: A Life of Lieutenant-General the Honourable Sir Edmund Herring, Hyland House Melbourne in association with Australian War Memorial, Canberra, 1980, pp.91-2; David Horner, Blamey: The Commander-in-Chief, Allen \& Unwin, Sydney, 1998, pp.94-8; Paul de Serville, The Australian Club Melbourne 1878-1998, Australian Club, Melbourne, 1998, p.126. 
There appears to be little doubt that the League of National Security in Victoria, and the Old Guard groups in New South Wales, like the Country Defence Organisations and the metropolitan Citizens Reserve Corps, were looked upon officially as potential auxiliaries if government were to be faced with revolutionary disorder. White's diaries give only fragmentary clues: a telegram from NSW Governor Sir Philip Game on 21 July 1931 and a conversation with the Governor's ADC two days later, then a National Mutual board meeting on August 11 at which Sir Robert Gibson was 'very overwrought' look innocent enough. So too on 25 November 1931: 'A. S. Rogers in to see me re politics.' Yet there is something about the casual crypticness of these entries that suggests they conceal more than they reveal. Arthur Rogers, for example, was a former Minister for Trade and Customs, now moving away from his Liberal and Nationalist origins towards the Country Party; soon he would co-found the Primary Producers' Restoration League to pursue debt adjustment for farmers and graziers. In January 1932, a fortnight after the Lyons ministry was sworn in, we find White invited by Sir George Fairbairn of the National Union to dine with Latham and Stanley Bruce who spoke, and the new Prime Minister 'who spoke well, \& impressed me'. Early in April White himself spoke - 'did very badly' - against the federal land tax at a town hall meeting organised by the Taxpayers' Association. Later that month, he dined with Sir John Higgins in a large party to meet Lyons, who spoke 'admirably'. But by September he was railing against a 'stupid meeting re Communism in Gibson's office' ${ }^{13}$

Eric Roberts, who had flown with the AFC in the war, and served later in the Citizen Force Army, was told by a friend in early 1931 of 'a secret organisation being formed by World War I officers, with the objective of countering any moves which might be made by subversive forces to exploit the unemployment situation'. Roberts' friend, a wartime staff captain in France, said that he and a major had been asked by 'some leading businessmen' to lead the volunteers. They were told, Roberts recalled, that the Chief Commissioner of Police, the Army Commander, the Director of Civil Aviation, and the President of the Royal Victorian Aero Club all knew of the organisation. The group, which Roberts offered to assist, was charged with liaising with CMF Militia commanders to ensure that arms and ammunition stores were secure. They were only to be called into action if the police were overwhelmed. 'No publicity could be given to building an organisation of this nature and everything had to be done by personal contact.' ${ }^{14}$

13 White diary, 21 Jan., 7, 14 April, 6 Sept. 1932, White MSS, NLA MS 5172/13; Geoff Browne, 'Rodgers, Arthur Stanislaus (1876-1936),' Geoffrey Serle and Christopher Cunneen (eds), Australian Dictionary of Biography, vol. 11, MUP, 1988, pp.435-6.

14 E. G. Roberts, RAAF (Retd), Box Kites and Beyond, Hawthorn Press, Melbourne, 1976, pp.63-4. 
One of those entrusted with crucial personal contacts was a 41-year-old Warrant Officer (honorary lieutenant), H. H. Downey MC, a master gunner attached to the Ordnance Department, $2^{\text {nd }}$ District, at Victoria Barracks in Sydney. Herbert Hamilton Downey was a professional soldier, with two years in the Victorian Rangers and five years in the Royal Australian Garrison Artillery before enlisting in the AIF in 1916. He had been granted a commission, and had served latterly in the $36^{\text {th }}$ Australian Brigade, Royal Australian Artillery, $2^{\text {nd }}$ Siege Battery. He earned his MC for conspicuous gallantry and devotion to duty in the field in mid-1918. After advanced ordnance training in England in 1919 and termination of his AIF commission in March 1920, he was repeatedly re-engaged in the Instructional Corps through the next decade as a warrant officer. ${ }^{15}$

In a confidential statement to his superiors on 6 February 1933 Downey said:

Having been a student of International Politics for many years and alive to menace of Communistic Activity in British Empire and actuated by sentiments of loyalty to my King and Constitutional Govt. I, in company with several others in 1930 concerned ourselves in the formation of a body for the purpose of maintaining Constitutional Govt. against the attack of Communism or other disloyal elements.

Downey, then in Melbourne, had taken an oath of loyalty to the King and was sworn to secrecy - never to mention the existence of the organisation or to discuss its members or affairs with anyone other than proven members. In July 1932 Downey had been appointed Quartermaster and honorary Lieutenant (on probation). ${ }^{16}$ In December he met Lieutenant Colonel Eric Campbell with whom he had served in the war, and subsequently held a meeting with leaders of the proto-fascist New Guard. As early as October the previous year, intelligence sources had believed that the 'virile and youthful' New Guard had a 'working agreement' with the 'White Guard' in Victoria. No evidence was adduced in support of this belief. If indeed there had been such a working agreement, Downey's mission seems to have been a response to rapidly changing conditions. At the meeting Downey reportedly claimed to represent a Melbourne-based organisation over which Sir Brudenell White 'presided' with a 'Major' Roach as his chief of intelligence. Len Roach - the 'Colonel' Roach who had accompanied Frank Derham on his visit to White in July 1931 - was indeed the League of National Security's intelligence chief, a role he somehow combined with his duties on secondment as a staff captain at 10th Brigade headquarters. Roach had served in Gallipoli and France where he earned an MC.

15 For the character and role of the Instructional Corps: Roland Millbank, 'Out of Empire: an introduction to the story of the Australian Instructional Corps, 1921-1955', Sabretache, 1 Dec. 2004.

16 NAA: B883/VX13547 for Downey's Army career. 
Commonwealth and NSW police officers in Sydney knew that Downey had found and exploited divisions among the leadership of the New Guard. Captain Frank De Groot, notorious for his ribbon-slashing at the opening of the Sydney Harbour Bridge six months earlier, had been at odds with the founder Eric Campbell. There are discrepancies in various accounts but it appears that De Groot resigned from the New Guard late in November 1932 and with Brigadier General H. W. Lloyd reached out to Downey. Downey had therefore taken the initiative - or had been given the task - of setting up a new organisation separate from the New Guard, with De Groot as its chief of intelligence. (Another account makes Downey De Groot's right-hand man). As the Commonwealth Intelligence Bureau knew, Downey had subsequently approached an unnamed Sydney businessman allegedly seeking 'interest and assistance in forming three brigades of private individuals, these formations to be classified as (a) Mobile Brigade; (b) Police Brigade; and (c) Reserve Brigade'.

So secretive were the Melbourne and Sydney conservative coteries that Downey appears to have been led unwittingly into indiscretion. Thinking to link De Groot with the existing organisation in Sydney which he understood to be allied to the 'Melbourne organisation', he approached first Major Blair Wark VC DSO. Wark he knew as a member of the organisation in Sydney which he believed operated under the 'aegis' of the Commonwealth government. At Wark's suggestion he then saw Major W. J. R. Scott DSO, a militia officer who was, Wark said, the leader. Jack Scott was a man whose influence outstripped his nominal rank. An insurance broker by profession, son of a director of the Commercial Banking Company of Sydney, cousin of the aspiring Victorian politician Geoffrey Street, he had long been close to very senior military figures, especially Major General Sir Charles Rosenthal, who was re-appointed to command the $2^{\text {nd }}$ Division, Australian Military Force, in 1932. In 1918-19 Scott had been deputy to Rosenthal in organising the repatriation of Australian troops from France and England. Rosenthal had led the $2^{\text {nd }}$ Division from 1921 to 1926 and with Scott at his side had been active in organising resistance to 'bolshevism' in the immediate post-war years. He had a long-standing interest in aviation, dating from his pioneering use of an aeroplane in military manoeuvres in 1912. Twice in the 1920s he had been associated with companies bidding unsuccessfully for airmail service contracts, latterly with Charles Ulm, Smithy, and Keith Anderson. Rosenthal's wartime rise from artillery commands to Major General 
at the head of the AIF $2^{\text {nd }}$ Division, and his post-war appointments, reflected White's respect for a bold and intelligent leader. An unabashed Nationalist, he had sat in the New South Wales Parliament and would do so again. ${ }^{17}$

Scott had worked with Eric Campbell in 1925 in assembling 500 ex-servicemen to support the Commonwealth government in breaking the shipping strike. He already knew Major Roach; and both he and Wark understood that 'General White presided over' the Melbourne organisation. But before the talks with Scott could take shape, reports from the Commonwealth Intelligence Bureau and the NSW CIB about Downey's contacts with the New Guard reached Army headquarters. The reaction was immediate. Military Intelligence had noted in August 1932 that branches of the League of National Security were dormant. ${ }^{18}$ The Minister for Defence, on the advice of the Chief of the General Staff, had not long since denied that members of the Defence forces were involved with private 'defensive - or offensive' — organisations. Downey's activities therefore constituted a serious breach of discipline. They had the potential for huge embarrassment to the government. They had even greater possible consequences for Downey.

The Military Board had promulgated a direction in March 1931 that members of the Staff Corps and Instructional Corps were 'in no manner...to associate themselves' with any organisation enrolling members for the purpose of assisting police in an emergency' ${ }^{\prime}$. Any member of the Permanent Forces who was 'inadvertently' associated with such an association was to rescind his association or membership immediately. As recently as May 1932, the Prime Minister had been obliged to rebut charges of collusion between the Defence Department and the New Guard. ${ }^{19}$ When questioned at Victoria Barracks, Downey at first denied but then admitted his activities. In a written response demanded by the military authorities, Downey trod delicately around the question of whether he had breached the signed undertaking not to participate in organisations that were to be avoided. He had not claimed to act as an emissary for Brudenell White's Victorian group, he said. But he had undertaken to find out whether it was permissible for him to pass on information about its structure to interested parties in New South Wales. He had not said that the Victorians were anxious about the lack of a similar organisation in New South Wales.

17 A. J. Hill, 'Rosenthal, Sir Charles (1875-1954)', Serle and Cunneen (eds), Australian Dictionary of Biography, vol. 11, pp.451-3; Ellison, Flying Matilda, p.303; C. E. W. Bean, The Australian Imperial Force in France During the Main German Offensive, 1918, [The Official History of Australia in the War of 1914-1918, vol. V, The A. I. F. in France December 1917-May 1918], Angus \& Robertson, Sydney, 1937, pp.300-1.

18 Keith Amos, The New Guard Movement 1931-1935, MUP, 1976, p.16; Cathcart, Defending the National Tuckshop, p.203.

19 Richard Hall, 'The Secret Army', National Times, 23-28 Jan. 1978, pp.12-3, quoting unreferenced documents from the Australian Archives. For the Defence Minister's proposed response to a parliamentary question from Jack Beasley, NAA: A5954, 973/6. 
The documentation reeked of hair splitting and backside covering. Conceivably, there had been some coaching from sympathisers, possibly Major Bertrand 'Boz' Combes, head of military intelligence, later a senior member of White's staff, who would bring Scott in to head military intelligence in the $2^{\text {nd }}$ Military District in 1935. ${ }^{20}$ Colonel H. E. Jones, the head of the CIB, had reported these developments to the Attorney-General who in turn informed the Prime Minister. As long as Labor was in power in Canberra, Jones had been sparing in the information he provided to his minister. But he was increasingly frustrated by the inaction of the Military Board. Now he forwarded a secret memorandum from his associate in Sydney, Major Longfield Lloyd, on Downey's attempt to form an organisation in New South Wales; his covering letter advised the Attorney that there was no need for any further organisation as the one that had been in readiness early in 1931 could be brought into operation at short notice if necessary. At Latham's request Jones sent the memorandum to the Prime Minister. Having digested all this, Lyons instructed that the relevant papers be copied to the Minister for Defence 'with an intimation that I suggest action be taken by him to deal with the officer concerned'. ${ }^{21}$ Downey, whose activities had been reported to the Chief of the General Staff, evidently escaped with a reprimand and a delay of six months in gazetting his promotion to honorary lieutenant. As no other action seems to have been taken against him it appears that this was a man who enjoyed protection at high levels.

How deeply involved in the Melbourne League White had become is impossible to say. Frank De Groot himself, in a handwritten draft of his unpublished memoirs, refers to a meeting with White in Melbourne in 1932. But, as Andrew Moore, the foremost scholar in this field, established, the passage is omitted from a later typescript version. Was White a leading figure in a clandestine organisation known and welcomed by the federal government? The evidence is slender. But in all of the discussions of the credibility of Downey's denials and evasions one thing stands out. Not one of the military intelligence officers or base commanders questioned the references to Brudenell White as the leader of the Victorian group. White's daughter, Rosemary Derham, in a valuable work on her father published in 1998, concluded after consulting several scholars that 'it would be entirely out of character for Brudenell White to lead a secret and illicit organisation' ${ }^{22}$ Major Harold Jones had written to the Attorney General:

20 Desmond Ball and David Horner, Breaking the Codes: Australia's KGB network, 1944-1950, Allen \& Unwin, Sydney, 1998, p.16.

21 NAA: A367, C94121; Lyons MSS, NLA MS4851 Box 1, folder 4.

22 Derham, The Silence Ruse, p.297. 
It is actions like those of Downey that brings Commonwealth Administration under very adverse criticism and makes for misunderstandings with those loyal and highly influential citizens upon whom we have to rely in emergency, and at times the position becomes very embarrassing to those upon whom responsibility is vested. ${ }^{23}$

That White was one of the 'loyal and highly influential citizens' who could be relied upon in an emergency is hard to doubt. He was informed of the plans that were made in Victoria. It seems unlikely that they could have proceeded as effectively as they did had he withheld his blessing.

What may be safely assumed is that White was known to have countenanced the work of others who were creating the framework for an emergency mobilisation in support of the civil power. In doing so he filled a role that had been rejected by his great contemporary John Monash. In November and December 1930, approached by Kingsley Henderson, Robert Knox, and Len Roach, closely followed by Harold Grimwade, Monash had dismissed their fears. He was unwilling to take a lead privately, still less publicly, and insisted that 'the only hope for Australia is the ballot-box and an educated electorate' ${ }^{24}$ White, evidently sought out as the default choice of figurehead, was cautious but not dismissive. He had less confidence in popular sovereignty: 'Democracy as a machine,' he told the Carey Baptist Grammar School speech night in December 1932, 'is entirely out of control.' ${ }^{25}$ The fact that the Secret League's activities could be legitimised under the Commonwealth Peace Officers Act of 1925 would remove any taint of illegality. And, as one police investigator noted, the 'High Council' of the 'White Army' had taken steps to minimise any overt association between themselves and such inordinately robust anti-communist activities as might attract unwelcome official attention to their rank and file. ${ }^{26}$

It would have been natural for patriots in Melbourne to put out feelers to their supposed counterparts in Sydney. White could not have been unconcerned about indications that elements of the New Guard might themselves have

23 H. E. Jones to J. G. Latham, 22 Dec. 1932, enclosing 'a secret report from Sydney,' NAA: A367, C94121. I have drawn information about the New and Old Guards and related groups from 'Para-military groups of the 1920s and 1930s: Documents copied from ASIO files', NAA: A12393, 7/99; 'The Association (Post War) and the New Guard (Pre War), Vol. 1 1931-1949', NAA: A6122, 40; 'The New Guard and "The Association"', NAA: A367, C94121; 'The New Guard 1931-48', A432, 1931/1871; 'Activities of Hon. Lieutenant HH Downey, MC, AIC, in regards to disloyalty due to association with New Guard and Communism 1933', NAA: SP1141/1, S33/1/30. Andrew Moore's The Secret Army and the Premier is valuable and complemented by his subsequent work (which unfortunately I saw only after I had completed my own research on Downey) including Francis de Groot Irish Fascist Australian Legend, Federation Press, Sydney, 2005 and 'Loyal lieutenant or spy? Frank De Groot and the intelligence services', Journal of the Royal Australian Historical Society, vol. 96, Pt 2, Dec. 2010, pp.201-20, and 'Superintendent MacKay and the curious case of the vanishing secret army: A response to Richard Evans', History Australia, vol. 6, (3), Dec. 2009. DOI: 10.2104/ha090072.

24 Serle, John Monash, pp.518-20.

25 The Argus, 14 Dec. 1932.

26 'Extract from Memorandum from Inspector R. S. Browne 17/11/31', NAA: A367, C94121. 
contemplated a coup d'état. As the threat of civil disorder receded, Eric Campbell became more engaged with European fascism, alienating many of his followers. He launched his own 'Centre Party' but threw his weight behind the United Australia Party in the 1934 federal election. White's role - whatever it had been, it was always spoken in a whisper behind a veil of discretion - was in diminuendo. With secure conservative governments in the Commonwealth, New South Wales, and Victoria, he settled into an essentially private life.

However much he might eschew the limelight, White was too respected and connected a figure to avoid participation in public affairs altogether. As a leading figure in the pastoral industry he would return from time to time to warnings about the impact of heavy taxation on struggling wool growers. Appearing as a witness before the Royal Commission on Banking he renewed his lamentation about 'oppressive taxation', musing that creating an open market for Treasury Bills might lead to a reduction in government expenditure. ${ }^{27}$ Defending the interests of the international wool-broking and quasi-banking business he led was unavoidable. His faith brought him often to church platforms where he would affirm the virtue of family prayers, more responsible parenting, and the example of 'cheerful and useful labour' ${ }^{28}$ He had more choice about invitations to speak to Service and voluntary organisations. Many of these he accepted as a duty, revealing on occasion his views on the contemporary world. In the year Hitler came to power, for example, he reflected for a Legacy Armistice Day meeting on the Versailles peace settlement, 'in which lay the germ of future revenge' ${ }^{29}$ An enterprising journalist would occasionally elicit a quotable comment as did a Courier-Mail reporter who caught him on a visit to Brisbane in August 1936 and asked for his thoughts on the possibility that the 'Spanish revolution' would turn into a wider conflict. 'There is no chance of another big war developing,' White said, 'because the will of the people of France, and of England, is entirely opposed to war.' Without endorsing either the Popular Front government or the 'rebels', he concluded enigmatically: 'This revolution is most unfortunate, and it is to be hoped that other nations will be wise in their attitude towards it. ${ }^{30}$

But the public stage, especially page 17 of a Brisbane newspaper, was not where White's real influence was felt. The Northcote Children's Emigration Trust, the Alfred Hospital, the Fourth Victoria Permanent Building Society, and the Melbourne Sunday Christian Observance Council all sought his counsel. He had sat on the board of the National Mutual Life Association since 1928 and became vicechairman in 1935. When Sir John Latham stepped down as leader of the federal

\footnotetext{
27 The Argus, 24 June 1932; Morning Bulletin (Rockhampton), 15 July 1937; The West Australian, 26 Feb. 1936.

28 The Argus, 30 Oct. 1930.

29 The Argus, 15 Nov. 1933.

30 Courier-Mail, 18 Aug. 1936.
} 
conservative parliamentary forces, White was one of a select group invited by Sir George Fairbairn to a farewell lunch. ${ }^{31}$ He was quietly consulted from time to time by successive Defence ministers. When the Council of Defence was reconstructed in 1935, Archdale Parkhill asked him to act in an advisory capacity in accordance with its new constitution; the invitation might have seemed more gracious had White not already learned from the press that his previous formal connection with the Council had ended..$^{32}$ In March 1938 we find him at the Melbourne Club, of which he had been president in 1934, in conversation with James Darling of Geelong Grammar School and Raymond Priestley about possible candidates to succeed Priestley as Vice-Chancellor of Melbourne University. ${ }^{33}$ Seven months later, when the future of the Chief of the Air Staff, Richard Williams, was in the balance, Williams had suspicions of subterranean influence by 'Chauvel, White and the G-G - but I expect I am hardly likely to know'. What Williams did know was that the RAF's Sir Edward Ellington, sent to report on the RAAF, had discussed with White the proposal that the Australian CAS should be posted to the UK on exchange with a senior British officer. ${ }^{34}$ The fact was that White, without really trying, was an eminence grise.

\section{War clouds}

As an anxious sense of impending war in Europe took hold of the Australian government in 1939, White was summoned once again to the Council of Defence in July. The increasingly influential Acting Chief of the General Staff, Ernest Squires, was pushing for national service and the raising of a force of 7500 regulars. White it appears was not opposed to this, much to the disgust of his old comrade John Gellibrand. For Harry Gullett, like Gellibrand a champion of the Militia, the only remedy was prayer. To Gullett, the true nemesis was the British General: Squires, he told Gellibrand, was 'entirely unscrupulous \& a bad swine', but he could have been stopped if it were not for the fact that 'Chauvel, White \& Street are nincompoops \& Squires' "Yes men"". The truth was rather that the retired generals were yesterday's men; and Geoff Street, now Defence Minister, actually saw merit in his principal advisor's argument. Nevertheless, by early August the balance of opinion had swung again. Menzies announced

\footnotetext{
31 White diary, 14 March 1934, White MSS, NLA MS 5172/14.

32 CPD, House of Representatives, 11 April 1935, p.1273.

33 Priestley diary, 7 March 1938, Ronald Ridley (ed.), The Diary of a Vice-Chancellor University of Melbourne 1935-1938 Raymond Priestley, MUP, 2002, p.428.

34 GpCpt. F. H McNamara to AVM R. Williams, 7 Oct. 1938, Williams to McNamara, 26 Oct. 1938, copy, Williams MSS, RAAF Museum.
} 
that a permanent mobile force would not be created, and that the nation must make the voluntary system work, 'training and equipping ordinary citizens to defend Australia'. ${ }^{35}$

As if to signify that, no matter what might issue from the deepening troubles in Europe, White's military service had come to an end, he was placed on the retired list on 17 August 1939, with the honorary rank of Lieutenant General. Not long after war was declared he also stepped down as superintendent of the New Zealand Loan and Mercantile Agency, remaining as chairman of the company. As his friend Charles Bean later wrote, 'he came as near to a retirement from public life as ever since $1914^{\prime} \cdot{ }^{36} \mathrm{He}$ would now spend less time in the city and more on the farm. The rhythm of his life had perceptibly changed. He was largely a spectator on great events. His wartime comrade, Major General (now UAP Senator) Charles Brand, had urged his appointment as Commanderin-Chief to relieve the Military Board of its responsibilities for training and administration. The call had gone unheeded. At 63, as Brand admitted, White was a year over the regulation retirement age. ${ }^{37}$ On September 18, White recorded: 'War news is most disturbing...Dick Casey rang me in the aftn — but only to say that had I been in town he wanted to have a talk to me.' Casey, once a junior officer on White's staff in wartime France and as a part-time soldier in post-war Melbourne, had abiding admiration for White. Evidently he did not chase his old mentor. ${ }^{38}$

In retirement, and with no expectation of a recall to service, the marginalised general had been co-opted to the Australian Comforts Fund committee. Now a commentator rather than a participant, he responded to a request from the editor of Reveille to provide a short piece on the ascendant Tom Blamey. 'A man of the world.... leader as well as a staff officer; he likes his fellow man and gets on with him...If called upon for war service, the 6th Division under Blamey's command will render a good account of itself.' ${ }^{39}$ A fortnight later The Argus sought his opinion on what the as yet 'unnamed war' should be called. Humourists abroad had already dubbed it the 'Confetti War', because of the R.A.F. 'pamphlet raids' over Germany. The Americans were using the 'scientific' label 'World War II'. Other titles were the 'War for Decency', the 'War for World Freedom', the 'War for Liberty', 'The War of the Air', 'The Totalitarian War', 'The Machine War', and 'The War of Words'.

35 John and Elsie Gellibrand's diaries, 8 July 1939; Sydney Morning Herald, 3 Aug. 1939 quoted in Sadler, The Paladin, p.247.

36 Bean, Two Men I Knew, p.201.

37 The West Australian, 14 Sept. 1939.

38 White diary, 18 Sept. 1939, White MSS, NLA MS 5172/16. Casey would tell Sir Sydney Rowell in 1972 he had developed 'almost a passion' for White in the first war (NAA: M1129 WHITE/C B).

39 The Argus, 4 Oct. 1939; Reveille, 5 Oct. 1939, in Derham, The Silence Ruse, p. 264. 
Since the last war was called the 'Great War,' that appellation is barred. 'The Greater War,' military leaders say is too cumbersome for an age that demands snappy titles.

'Hitler's War' is rejected as a possible title on the ground that nothing should be done to perpetuate the name of one who is a menace to civilisation.

White was cautious: 'Names for wars just grow. Time must pass before we find a name for this one. It must be a name that is simple and with world-wide appeal.'

So distant was White from the levers of power that he was to learn from the newspapers on 29 November 1939 of the decision to send the AIF 6th Division overseas. Although he could not escape awareness of the long-running and unresolved debate about whether the Army should be configured to repel a Japanese invasion or mere 'raids', he would have been hard pressed to deny that Australian troops were needed to augment the British forces facing formidable German threats. As 1940 began, White's regime of a morning ride in the city, office work, board meetings in Collins Street, lunch at the Melbourne Club (where he was a trustee and still kept a bedroom), seemed undisturbed. ${ }^{40}$ Early in January, with Australian troops now embarking for service abroad, the Chief of the General Staff sought to draw on his unique experience. 'Brudenell White very kindly came in during the afternoon,' Ernest Squires wrote, 'to advise about the control of the A. I. F. when overseas - most helpful, as one might expect. ${ }^{\prime 11}$ On January 23 White dined at the club with Keith Murdoch, Squires and others to farewell Dick Casey, who was about to leave for Washington. On February 7 he and Ethel dined at Government House in honour of Lieutenant General Sir Thomas Blamey, designated since late September to command the $6^{\text {th }}$ Division $2^{\text {nd }}$ AIF. Before Christmas the previous year Blamey had sent a car to bring him to his Headquarters for what turned out to be a 'pleasant \& useful conversation' ${ }^{42}$ He had prepared a memorandum for Blamey which after further consultation with Squires, an intervention by Charles Bean, and final revision, was to be promulgated by the Army Minister Geoff Street as the AIF commander's charter.

On February 13, White talked to Street after dinner and was 'grieved to hear that Genl Squires is very very ill'. He called on the Squires family the next day. It was a week later that a letter from Blamey brought an idea to the Prime Minister that was to change the course of White's life. Acknowledging that it

40 Ronald McNicoll, Number 36 Collins Street: Melbourne Club 1838-1988, Allen \& Unwin/Haynes in conjunction with the Melbourne Club, Sydney, 1988, p.180.

41 Squires diary, 10 Jan. 1940, UNSW@ADFA Library, MS 184 folder 3.

42 White diary, 13 Dec. 1939, White MSS, NLA MS 5172/16. 
was 'right outside my line of suggestion', Blamey wrote that if had the personal opportunity to ask the Prime Minister to consider it he would not hesitate to do so:

And that is, if you think it desirable for someone else to take up General Squires work, to give very earnest consideration to Lt.-Gen. Sir Cyril White. He is the only man in Australia who has handled war on a big scale. His military knowledge is wide, and his experience has been greatly deepened by the last few years in his business life. It would give a sense of satisfaction to the Army that no other appointment could give. Personally, on going away I would feel the utmost confidence in the support that I would receive, because I am quite certain that even if my views do not always co-incide with his, his would be entirely disinterested and in the best interests of the country.

Such a ringing endorsement from the chosen commander of Australian forces in the field could not be ignored. 'I am grateful to you for your suggestion of Brudenell White,' Menzies replied, 'which I will follow up vigorously.' ${ }^{43}$ Menzies needed little encouragement to recruit the one general whom he believed had any brains. ${ }^{44}$ Army Minister Geoffrey Street sent the Deputy Chief of the General Staff, John Northcott, to sound White out. Northcott reported White's misgivings: he had been out of the Army for the best part of two decades; he was not in robust health, and he had doubts about his own capacity. In the interim, Menzies had spoken on February 21 at a lunch of the Carry on Club in Melbourne, a meeting attended by White who earlier that day had a conversation with the Chief of the Air Staff Sir Charles Burnett.

A week passed. At the Melbourne Club on Wednesday night February 28, White dined with the financier W. S. Robinson to 'meet Sir Charles Burnett'. As the head of the RAAF, Air Chief Marshal Burnett was now the government's principal defence advisor. An 'interesting evening' became even more interesting: 'P.M. approached me as to whether my services wd be available if required.' Three days later the question was no longer hypothetical. Squires died on March 3. Consultation with the Army Minister was now imperative. They could meet discreetly at the Melbourne Club. 'Discussed problem of CGS with him' on Monday, March 4, and had a further talk after dinner. White attended the funeral of General Squires on the fifth. The next day there was another long talk with Street after dinner. By the seventh the press were beginning to speculate on White's appointment as CGS. On Sunday, March 10 Geoff Street announced the appointment of the 63-year-old general 'to act for a time'. It was reported

43 Blamey to Menzies, 20 Feb. 1940, Menzies to Blamey, 'Private and Unofficial', copy, 22 Feb. 1940, Menzies MSS, NLA MS 4936/579/4.

44 Jon Chittleborough to CH, 24 March 2013, (email), reporting an interview with Menzies in 1975. 
the next morning that White had been given indefinite leave of absence from New Zealand Loan \& Mercantile by his chairman in London; and the letters of congratulation began to arrive as he called at Victoria Barracks for a formal meeting with the Army Minister and the Military Board. ${ }^{45}$

Street was happy to report to the Prime Minister on March 11 that the 'reaction to Sir Brudenell White's appointment is very good'. Apart from Communist reminders that the 'New Brass Hat has fingers in Capitalism' being 'one of the privileged members of the financial oligarchy', there was little that anyone in the press could find to say against him. ${ }^{46}$ The Herald in Melbourne had raced to Beaufort that morning and obtained a statement:

...may I say that I much prefer being Cincinnatus at the plough, though I do appreciate the honour paid to me...I do want it to be fully realized, however, that I am not taking up any appointment for a fixed term but only to fill a gap. I do not want to act to the detriment of any permanent staff officer, and as soon as my services are unnecessary I want to return to the farm. ${ }^{47}$

The following day Menzies advised Street that the recommendation of the Military Board and the Army Minister that Honorary Lieutenant General White be promoted to full General was approved. He was to be restored to the Active List. The promotion was necessary 'owing to the legal difficulties' that might arise if he was not superior in rank to the commander in the field. ${ }^{48}$

\section{Cincinnatus leaves his plough}

That White took up the appointment as a matter of duty is plain from his testimony to those who knew him best. 'The return to soldiering involved me in very mixed feelings. I had planned a much more peaceful autumn of my days,' he told an old comrade. ${ }^{49}$ His attitude was summed up in a brief note to Chief Justice Sir John Latham who had written to congratulate him: 'I could wish to have been spared the task - \& can only pray for the necessary strength \& wisdom.' It was symbolic of the deep tensions already placing strains on the relationship between Britain and Australia that this message was on notepaper headed 'Imperial General Staff (Australian Section).' He had in fact been

45 White diary, Feb.-March 1940, White MSS, NLA MS 5172/16; Sydney Morning Herald, 11 March 1940.

46 M. H. Ellis, 'The Garden Path: The Story of the saturation of the Labour Movement by Communism', The Land Newspaper, Sydney, 1949, p.390.

47 Lucius Quinctius Cincinnatus, answering Rome's call in 458 BC, routed the besieging Aequians and returned to his farm after 15 days as 'Dictator'.

48 Street to Menzies, 11 March 1940; Menzies to Street, 12 March 1940, copy, Menzies MSS, NLA MS 4936/579/5.

49 Maj.-Gen. S. S. Butler to Editor, The Argus, 5 Sept. 1940. 
gazetted as from March 18 not only Chief of the General Staff but also 'First Military Member of the Military Board and Chief of the Australian Section of the Imperial General Staff'.$^{50}$ As the Governor-General would write privately to the British Secretary of State for War: 'while Squires was here one knew that he kept in close touch with the War Office as most of those holding important posts there were old colleagues and friends... and of course Brudenell White will not have quite the same contacts'.$^{51}$
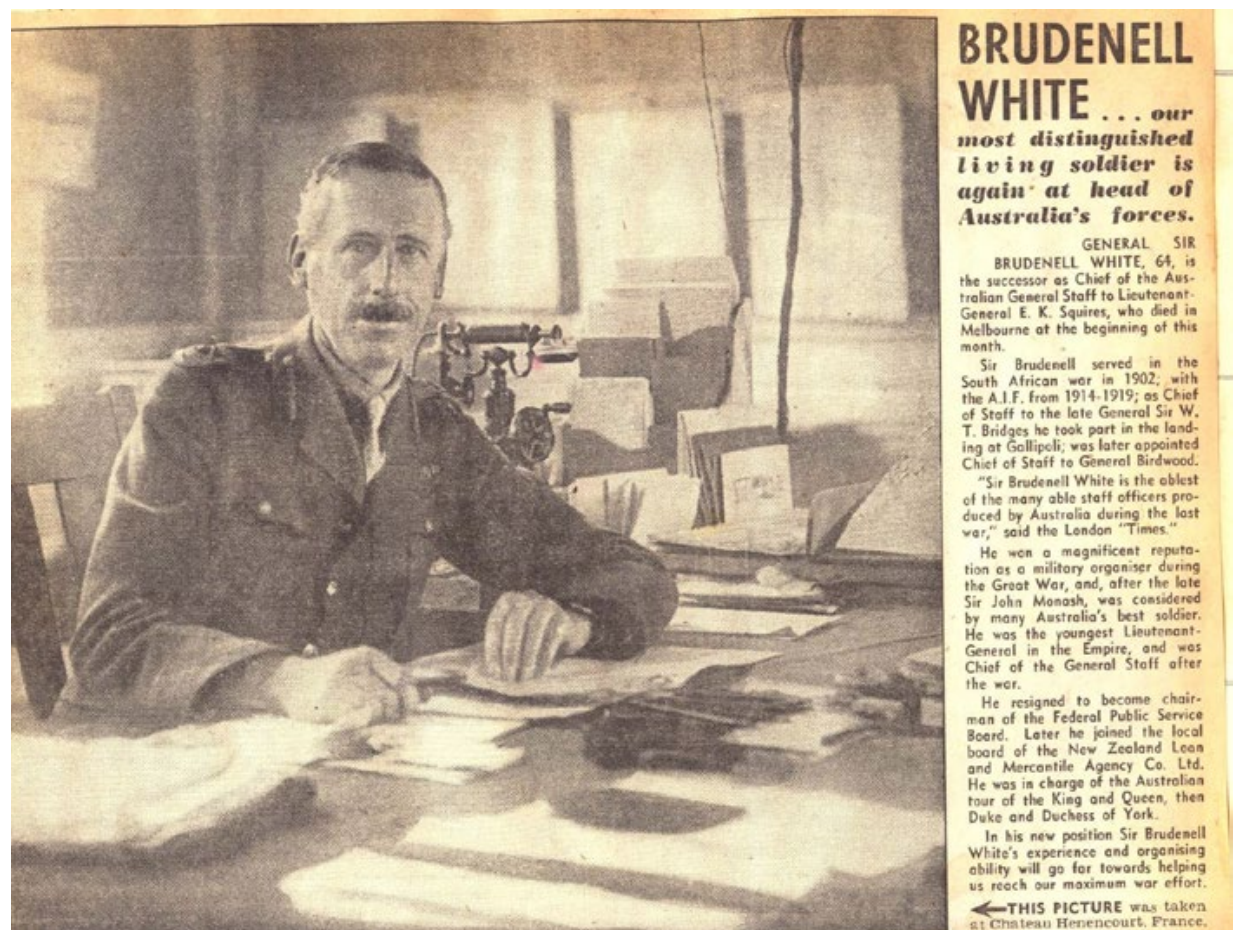

\section{A general out of retirement, a photograph from the archives}

(The Australian Women's Weekly, 30 March 1940, from Ethel White's scrapbook, courtesy of Mark Derham)

It was true that there had been a generational change in Whitehall and the British high command. In Australia as well, as Menzies was advised by his friend Henry ('Ferdie') Wright, a Lieutenant Colonel in the Militia, 'it will take him some time to work back a knowledge of personnel'. ${ }^{52}$ With the Deputy Chief of the General Staff, Major General Northcott, at his side the new Australian Chief of the General Staff stepped smoothly into the routines established by his predecessor and ordained by the Army Minister and Prime

\footnotetext{
50 J. F. Ramsbotham to R. G. Menzies, 16 Aug. 1940, NAA: A461, 700/1/391; White to Latham, 29 March 1940, Latham MSS, NLA MS 1009/1/5424.

51 Gowrie to Lord Stanley, 18 March 1940, Gowrie MSS NLA MS2852/5/11.

52 [F. H. Wright notes for Prime Minister], 'Confidential: Proposed Divisional Command', [March 1940], Wright MSS, NLA MS 8119, Series 5/8.
} 
Minister. Each week, the Chiefs of Staff submitted a progress report to the War Cabinet and spent an hour or two most Monday mornings briefing the Prime Minister. White would soon discover that the man who was closest to the Prime Minister on all military matters was the Secretary of the War Cabinet, Frederick Shedden. Defence planning and operations were on a vastly different scale from the Army-dominated world White had known intimately two decades earlier. Fred Shedden had designed much of the administrative machinery for war and sat at the centre of a network of handpicked subordinates. White had neither the aptitude nor the appetite to engage in the kind of bureaucratic finessing and finagling at which Shedden excelled. ${ }^{53}$ However, a weekly meeting with Shedden would diminish opportunities and excuses for miscommunication.

In his own domain, White was vested with very considerable authority and he was prepared to use it. A significant early decision was to affirm his support for the promotion of Blamey to command the AIF. Another was to exercise a quiet veto over an AIF post for the unattached senior Major General Gordon Bennett whose outspoken criticism of the Military Board and the Staff Corps had ensured he had no friends at the top. ${ }^{54}$ At less exalted heights there was a queue of applicants and posts to be filled. Within a month or so of his appointment, White had been approached by Menzies' friend Henry Wright asking that he be transferred from the Reserve to A. H. Q. 'and attached for duty to the P.M.':

The appointment would be in the nature of honorary Military Secretary carrying out the duties, say, of an A. D. C...Personally and confidentially, I know that the P.M. desires to use me in a very general manner, and my liaison duty with you, is not the major point in his mind. ${ }^{55}$

Wright's attachment to the Prime Minister was not difficult to arrange, notwithstanding his role as honorary consul for the Netherlands in Victoria. He was a fellow club man, a Freemason, with a record of service at Gallipoli.

Nor was there any problem for White in securing the services as his own liaison officer of Lieutenant Colonel Frank Thornthwaite. This was a critically sensitive role, perfect for a friend who was related by marriage to the Minister for the Army, and was already at Victoria Barracks, recalled to service as a General Staff officer. Others with past connections also found billets. The trusted Herbert

53 A. T. Ross, Armed \& Ready: The Industrial Development \& Defence of Australia, 1900-1945, Turton \& Armstrong, Wahroonga N.S.W. [1995?], Chapter 8.

54 Frank Legg, The Gordon Bennett Story, Angus \& Robertson, Sydney, 1965, pp.160-1. 'I was senior to Blamey, Laverack, Sturdee, and the rest when this war started and was penalized because I was foolish enough to draw attention to our unpreparedness, especially on the industrial side' (Bennett to S. Ricketson, 11 Aug. 1941, copy from Ricketson to F. H. Wright and Menzies, 23 Oct. 1941, Wright MSS, NLA MS 8119, Series 5/8). 55 F. H. Wright to White, 18 April 1940, copy, Menzies MSS, NLA MS 4936/579/5. Wright would later state to Central Army Records that he had been a confidential liaison officer with every CGS from 8 Nov. 1939 to 15 April 1947 (Wright MSS, NLA MS 8119 Series 8/5). 
Downey, now a captain and soon to be a major, gave the required 'voluntary undertaking to serve beyond the limits of the Commonwealth' six weeks after White arrived at Victoria Barracks. Downey was assigned to staff duties before being sent to the Middle East and Greece where he died of wounds in April 1941. Colonel Colin Simpson became chief signals officer when the $1^{\text {st }}$ Australian Corps was formed in April 1940.

It did Jack Playfair's prospects no detriment to have been one of the founders of the UAP and its state president (1932-39), as well as a member of the NSW Legislative Council. Wounded at Gallipoli, an artillery brigade major in France, and more recently an influential politician, he was just the man to command the $21^{\text {st }}$ Field Brigade, Royal Australian Artillery (militia) and to be appointed artillery commander of the 2nd Division as a temporary colonel in August. ${ }^{56}$ In May 1940 Bertie Lloyd, former deputy commander of the New Guard and since 1932 NSW state MP for Mosman, was appointed to the civilian post (unpaid) of Director-General of Army Recruiting. At the beginning of August, Lloyd became Deputy Adjutant General at Army Headquarters with the rank of brigadier (he was still an honorary brigadier general). Francis Derham was promoted temporary major general on 2 May 1940, and given command of the 4th Division. Blair Wark, a prosperous quantity surveyor, re-enlisted in April and was soon promoted lieutenant colonel and given command of 1st Battalion, City of Sydney's Own. White's grazier neighbour at Buangor, Hec Bastin, who had resumed active service at the end of 1936 and was now commanding the 4/19th Light Horse Regiment, was 'taken on strength' of the AIF and arrived in mid-July 1940 as lieutenant colonel commanding the $8^{\text {th }}$ Division Cavalry Regiment. ${ }^{57}$

Among the others whose fortunes rose with White was Major Jack Scott, sometime chief of staff of the Old Guard and since 1935 a military counterintelligence officer working in collaboration with the NSW police. Through his uncle the late Sir Philip Street, previously Chief Justice of New South Wales, Scott was related to the Army Minister, Geoff Street. In the early 1930s he wrote articles in the Sydney Morning Herald that were supportive of Japanese expansionism and he was active in the Australia-Japan Society. In April 1939 he was appointed to head the NSW section of Military Police Intelligence. To this day, some of what he was assigned to do both in the peacetime militia and security service and on the wartime intelligence staff remains mysterious. In any event, an inveterate gambler and ladies' man was fortunate to have friends in high places. ${ }^{58} \mathrm{He}$ joined his former commanding officer, Colonel 'Boz' Combes, now

56 G. P. Walsh, 'Playfair, Thomas Alfred John (Jack) (1890-1966)', Serle and Cunneen (eds), Australian Dictionary of Biography, vol. 11, pp.244-5.

57 R. Clark, 'Lieutenant-Colonel Hector Ernest Bastin, M.C., M.I.D.', Sabretache, vol. XVIII, No. 3, July 1977, pp.182-3.

58 Ball and Horner, Breaking the Codes, p.17. 
Director of Military Operations and Intelligence in Melbourne, at the centre of action at Victoria Barracks. Len Roach, too, White's principal conduit a decade ago to the League of National Security, found his career prospering. Joining the second AIF, promoted to temporary lieutenant colonel, Roach was given command successively of the $14^{\text {th }}$ Battalion and from July 1940 the $2 / 21^{\text {st }} .{ }^{59}$ And it did not escape notice that Combes had 'surrounded himself by henchmen' some of whom 'openly or under cover, were at one time active members of the New Guard' ${ }^{60}$

As CGS, White struggled to define his own role. None of the functions in which he had made his military reputation were his. Logistics and planning for battle were in other hands. The deployment of new divisions was an essentially political domain. It seemed sometimes as though he was rambling around the periphery of the defence establishment seeking meaningful work. Thus he was drawn into discussion with Essington Lewis and Sir John Latham to consider a proposal prepared by Latham to mobilise universities for the war effort. ${ }^{61}$ In May he sat down with Geoff Street to meet a delegation from the Returned Servicemen's League to begin the process of setting up the RSL Volunteer Defence Corps. 'Happily,' he had told, Sir Gilbert Dyett, 'Australia is not threatened on land.'

In consequence, there is no need for an organized citizen force capable of expansion...There is no need therefore for national guards, legions, or such like organizations. But...even after such an explanation, the pent up feelings of the community will not be satisfied and this, perhaps, applies particularly to returned soldiers. If their desires are not harnessed, they may be given voice which would be embarrassing both to the Government and those charged with advising them. ${ }^{62}$

In this matter White knew of what he spoke. It was just 10 years since exservicemen with pent up feelings in 'national guards, legions, or such like organizations' had looked to him for leadership in responding to the threat of communist subversion and civil disorder.

59 Roach and Scott are now best remembered for their roles as successive commanders of the ill-fated Gull Force (Joan Beaumont, Gull Force: Survival and Leadership in Captivity 1941-1945, Allen \& Unwin, Sydney, 1988, pp.97-100 and passim; Courtney T. Harrison, Ambon Island of Mist: 2/21st Battalion AIF [Gull Force] Prisoners of War 1941-45, T. W. \& C. T. Harrison, Geelong, 1988; Andrew Moore, 'Scott, William John Rendell (1888-1956)', Serle and Cunneen (eds), Australian Dictionary of Biography, vol. 11, pp.550-2). Drew Cottle, The Brisbane Line: A Reappraisal, Upfront, Leicestershire, 2002, contends that Scott might have been a Japanese spy and prospective collaborator. Others imply that his friendliness to Japan was a pose (Jacqui Murray, Watching the Sun Rise: Australian Reporting of Japan, 1931 to the Fall of Singapore, Lexington Books, Lanham MD, 2004, pp.109, 218).

60 Lt Col. J. Mawhood to Solicitor General (Sir G. Knowles), 18 Oct. 1941, NAA: A432, 15 55/4432, cited Ball and Horner, Breaking the Codes, pp.22-3.

61 'Universities and War Effort (University of Melbourne)', 19 June 1940, Menzies MSS, NLA MS $4936 / 579 / 26$.

62 G. L. Kristianson, The Politics of Persuasion: The Pressure Group Activities of the Returned Servicemen's League, ANU Press, Canberra, 1966, pp.73-4. 
Irrespective of rank or status, the CGS could impress with a serene humanity. To some he seemed 'cold though courteous...one who never under any circumstances unbends...often mistaken for an Englishman'. Others caught glimpses of a 'modest, gentlemanly, and distinguished' leader. ${ }^{63}$ Before the war, the young architect Balcombe Griffiths saw him regularly "on a "family friend" basis, perhaps a chat in Collins Street or at other meetings. He was always so generous of time, and thought for a young chap 30 years his junior. ${ }^{64}$ Frederick Howard, a much-travelled Melbourne Herald journalist serving as an AIF captain, 'had one brief appearance in the presence of Sir Brudenell White at Victoria Barracks, and remember him as a twinkling-eyed quiet spoken man who showed more courtesy than the normal military brusqueness in addressing a low form of life' ${ }^{6}{ }^{65}$

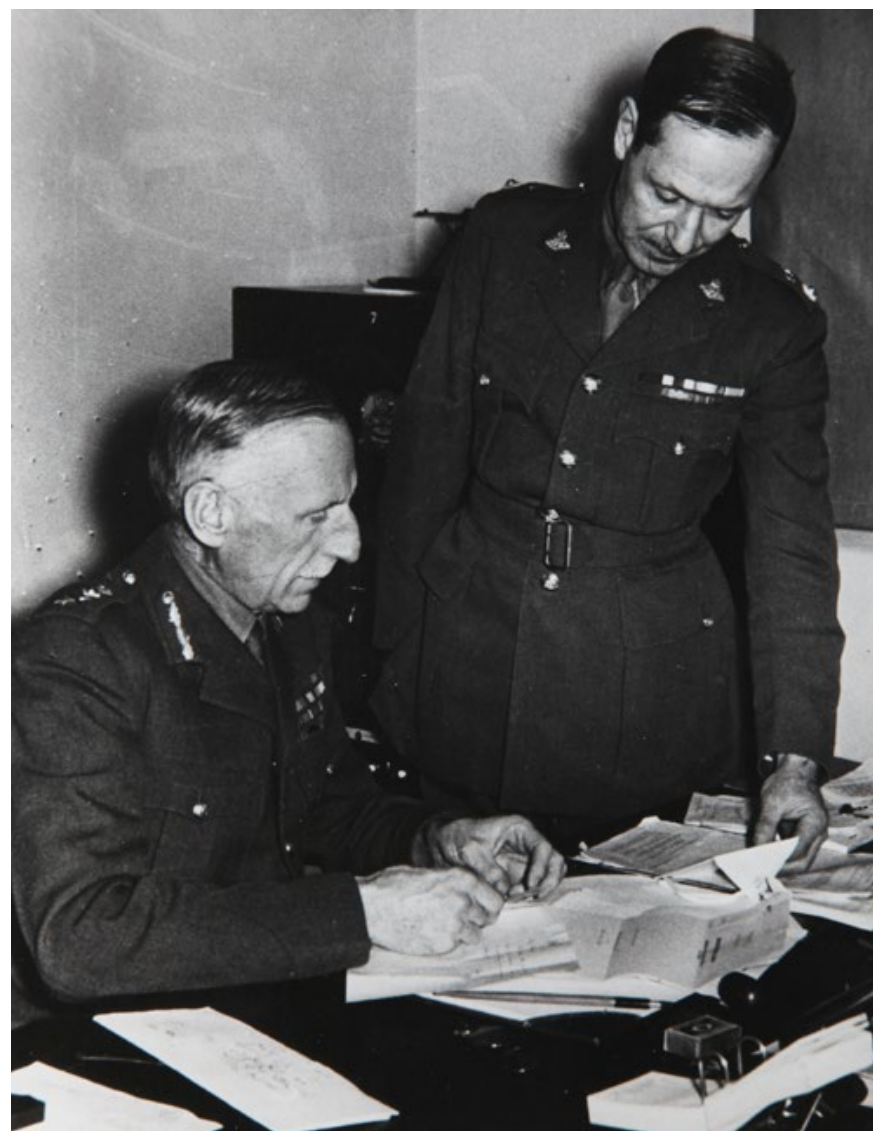

The CGS and his liaison officer, Lt Col. Frank Thornthwaite, posed for Pix July 1940

(Cover photo, Pix, 17 Aug. 1940, courtesy Inez Thornthwaite)

63 Australian Women's Weekly, 23 March 1940; The Register (Adelaide), 12 Jul 1923.

64 Balcombe Griffiths to $\mathrm{CH}, 8$ May 1982.

65 F. J. Howard to CH, 25 May 1982. 
After a quarter of a century of dealing with the nation's political leaders White was not afraid to give frank advice privately. Discussing senior Army appointments one day there was what Sir Robert Menzies recalled as a 'spirited argument', with one nominee being criticised as too young. After the meeting White walked back into the city from Victoria Barracks with Menzies who later paraphrased the general's remarks:

You know, Prime Minister, compared to me you are a young man. And I want to say to you, never dispose of anybody, otherwise qualified, by the argument that he is too young. I was a very young man when the AIF was operating in France...very young indeed, and yet, I was made the Chief of Staff to the whole AIF. And there have been those sufficiently charitably minded to think that I didn't do a bad job. Now the moral of this is that I couldn't have succeeded unless I had qualifications of mind and imagination, and age had nothing to do with it. My advice to you is never reject the best qualified man because somebody thinks he is too young.

Confident as he was in giving advice to a Prime Minister nearly 20 years his junior, White had genuine misgivings about his own capacity to lead in a very different military environment from the one in which he had once flourished. There had been major changes in the nature of warfare, in weapons technology, and battlefield tactics. At the strategic level it was not long before his judgment was being called into question. Early in June he had told the War Cabinet that a German offensive could not occur without another six to nine months' preparation. When the Germans crossed the Somme in force the next day his credibility understandably plunged. His assessment a short time later that Japan could 'bring the Commonwealth to terms without the need for invasion' if it had naval superiority was the kind of gloomy realism that some ministers found distinctly uncomfortable.

White was not alone in having to face challenging questions. Billy Hughes, no pessimist, was enjoying the licence to quiz the military chiefs. His direct question to Charles Burnett on June 5 about the adequacy of the Commonwealth's air defences had the Air Marshal struggling for a form of words that would justify his barely reassuring conclusion that 'a sufficient striking force would be available to make an aggressor think seriously before attacking...if we obtained the aircraft proposed we would be safe'. Burnett had hastened to add when he saw the draft War Cabinet minutes that he had meant in a safe position to implement Australia's obligations under the training plan, "not "safe" from attack by a powerful enemy nation'. On hearing from the CGS that Australia's 
strategy was based on Japan not entering the war, Billy Hughes confided to his neighbour at the Cabinet table: 'Look at that man's profile. Did you see it? He may have many things, but he has not got guts. ${ }^{66}$

Hughes was wrong. White did not lack courage. He had been appalled at the June 5 meeting, 'much of it', as he wrote in his diary that night, 'a shocking waste of time'. But he was clearly struggling for understanding and inspiration about how to lift Australia out of its enfeebled vulnerability. He had been ill at ease at a high-level conclave on munitions and manpower questions in midJune. He seemed out of touch and bereft of new ideas. Some things, however, were obvious. His admission to the War Cabinet in June, under persistent questioning from Sir Keith Murdoch, that Australia could not rely on Britain and would last barely a month if invaded produced the blunt response from the new Director-General of Information that these were not predictions to be shared with the public. He was happy to accept Murdoch's proposal that Charles Bean become the link between the Chiefs of Staff and the press - what the Deputy Chief of the Air Staff would sceptically call 'a rather nebulous commission... to act as liaison, and philosopher and guide to editors' ${ }^{67}$ Yet no matter how professionally war news was managed, there were more fundamental questions to be answered. As the months wore on White found himself wrestling as well with a range of unresolved conflicts over what was called for the War Cabinet 'the higher direction of the Army'. Should there be a Commander-in-Chief? Should there be one C-in-C for Home Defence and another for command and training of the Militia Forces? Should there be direct Militia representation on the Military Board or at Army Headquarters? At least he and Geoff Street were at one on these questions when they were raised for 'discussion without agendum' on July 11. But both could hardly have been happy with the Cabinet's failure to reach a decision on any of them.

It was becoming obvious that White was finding the War Cabinet an uncongenial forum. A concerned Menzies had taken him aside on July 2: 'PM dined with me and very tactfully criticised my methods at War Cabinet meetings — insufficient strength!! This is a hard blow.' The blow might have been harder if Menzies had added that some of the CGS's views were bemusing ministers. He had first recommended sending troops to bolster the French when they were already on the point of capitulation. Then he 'emphasised the desirability of the despatch

\footnotetext{
66 'Notes of Discussion in War Cabinet Room...', 12 June 1940, secret, Menzies MSS NLA MS 4936/40/21; War Cabinet Minutes, 5, 18 June 1940, NAA: A2673, 218,253; Bean, Two Men I Knew, pp.24-5; Horner, High Command, p.36.

67 Murray, Watching the Sun Rise:, p.210; Day, The Politics of War, pp.58-9; Bean, Two Men I Knew, p.217; Bill Bostock to Norman Ellison, 16 Aug. 1940, Ellison MSS NLA MS 1882,2/22.
} 
of forces raised for service overseas', not for strategic reasons but because the Australian 'was a much more manageable soldier when separated from his family and political and other influences' ${ }^{68}$

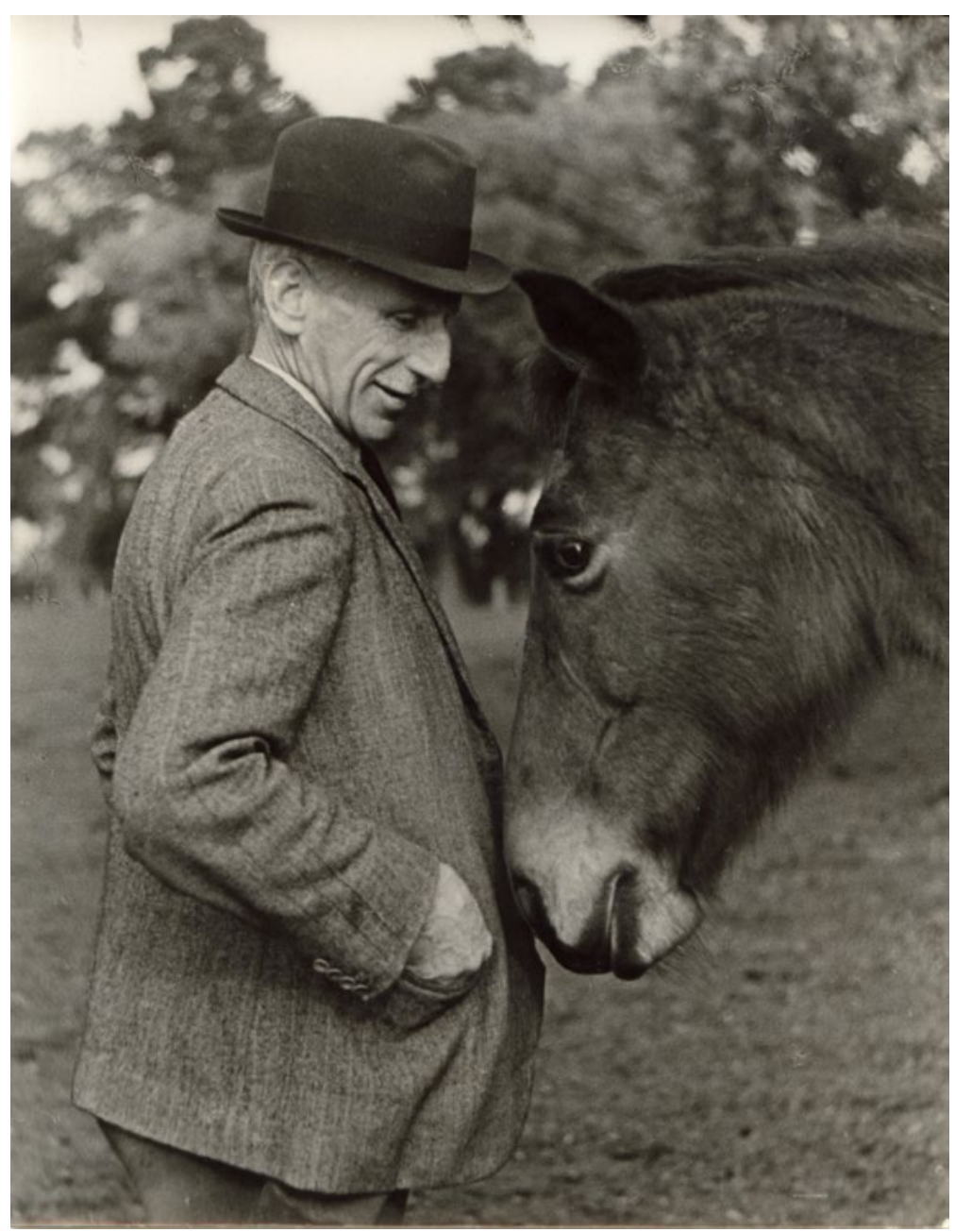

\section{The CGS with his mare 'Jenny', July 1940}

(Courtesy of Mark Derham)

When Cabinet was called to meet in Canberra on Tuesday, 13 August 1940, White had to be there. He had thought of taking the deputy CGS with him but decided it was better that Northcott should stay at headquarters. In wet and windy Melbourne on Monday, he shuttled between Victoria Barracks and the Melbourne Club for lunch, returning late to the club to dine, sleep,

68 Record of Decisions of War Cabinet, 13 June 1940, Annex A, NAA: A2673, 247. 
and write a letter home. ${ }^{69}$ He had intended to travel overnight by train but he and his right-hand man Lieutenant Colonel Frank Thornthwaite had been delayed in conference. In characteristically unassuming manner - though well aware that his wish would be close to a command - the nation's most senior soldier telephoned the man he knew disposed of places on the Air Minister's transport aircraft. Jim Fairbairn's assistant private secretary Murray Tyrrell, then 26-years-old and fourteen months in the position, remembered:

I had a call from Brudenell White, who said he had been summoned to Canberra to be there the following morning for a Cabinet meeting with Prime Minister Menzies. Could he have a seat in the aircraft? Well I'd filled the aircraft by then but in the circumstances I said 'Of course you can sir. You can have my seat.' So I gave him my seat and I arranged there and then...to travel to Canberra that same night by train. ${ }^{70}$

Prepared as he had learned to be for an uncertain number of days away from home, White carried with him in his suitcase a Travalarm clock that folded into a steel case, a fine set of hairbrushes, and a miniature bar of medals that he always kept at hand. ${ }^{71}$ As he stepped out of his staff car at Essendon, a greatcoat protected his spare frame from the searching wind. Perennially suffering from respiratory distress and digestive troubles, he was 'thin as a wisp' from months of stress and frugality - having taken a large pay cut shortly before he became CGS, he had been saving money by going without lunch. With his uniform and insignia covered, his rank was concealed as he walked past onlookers to the waiting aircraft. His red-banded cap, of course, signified that he was a staff officer. To those who knew his face, the soft eyes, the noble Roman nose made even more prominent by a long-forgotten car accident, the neatly trimmed moustache and matching silver sideburns, the Chief of the General Staff was instantly recognisable. ${ }^{72}$

\footnotetext{
69 Bean, Two Men I Knew, p.221; Derham, The Silence Ruse, p.269.

70 Sir M. Tyrrell, interview with Mel Pratt, 27 May 1974, NLA Oral TRC 121/54, p.6.

71 'Aeroplane Crash at Canberra on 13th August, 1940', Commonwealth Police file P8903, NAA: A1378, ff. 185-6, 177.

72 Derham, The Silence Ruse, p.232. White had overturned his T Model Ford en route to Duntroon from Yass in Dec. 1913 (Rowell to Casey, 25 Oct. 1972, NAA: M1129 WHITE/C B).
} 



\section{The Brigadier: Geoff Street}

No one in Australian federal politics in 1940 was more deeply rooted in the land than the Army Minister, Geoffrey Austin Street. His great-grandfather John Street, of Birtley in Surrey, had emigrated in 1822, bringing with him merino sheep from Thomas Henty's flock at West Tarring in Sussex. Taking up property at Woodlands, Bathurst, John Street corresponded with Henty over several years as he worked to improve the breed. A century later Major Geoff Street, back in Australia after five years at war, maintained his forebear's pastoral tradition, breeding prize Polwarths at his own Victorian property 'Eildon' in Lismore.

Born in Sydney on 21 January 1894, Geoff Street was the second of four children of John William Street, a prosperous city solicitor, and Mary Veronica Austin, daughter of Henry Austin, chairman of directors of the Perpetual Trustee Company. Henry Austin's brother, Alfred, had been appointed by Lord Salisbury in 1896 to succeed Lord Tennyson as Britain's Poet Laureate - a distinction of which the Australian family were unashamedly proud. They were happy too to acknowledge that John W. Street was for a decade in partnership with Australia's own popular writer and poet A. B. 'Banjo' Patterson. Geoff had an older brother, John Austin, born in 1891 and a younger, Anthony Austin, four years his junior. A sister, Mary Veronica, was born in August 1902. John Street, probably assisted by his father's business connections with shipping companies, went to sea at an early age, earned his master's certificate, and joined P. \& O. He served at sea throughout the 1914-18 war. After the war he joined BHP in Newcastle which had created its own small shipping fleet. With both John and Geoff in uniform, Anthony had enlisted at the age of 19 only to succumb to the influenza epidemic that swept England in the autumn of $1918 .{ }^{1}$

Like his father and cousins, Geoff Street attended Sydney Grammar School. He was captain of the cricket $1^{\text {st }}$ XI and a prefect in 1912, also representing the school at rugby 'football', athletics, and swimming. Among his contemporaries were Len Robson, who was to become headmaster of Shore in 1922 after a 'good' war and a Rhodes Scholarship; and Robert Rainy Harper, who would go on with him to university, interrupt his studies, and earn a DSO at Pozières. Street scraped through his senior examinations in December 1912 with a $\mathrm{C}$ in Ancient History, English, French, and Greek and a B in Latin. ${ }^{2}$ Enrolled in law at Sydney University, he was more likely to be found on a sports field than in a library. He played representative cricket and hockey and competed in athletics.

1 Kenneth Whistler Street, Annals of the Street Family of Birtley, Fine Arts Press, Sydney, 1988 (1st ed. 1941), pp.126-9: Cameron Hazlehurst, 'Street, Geoffrey Austin (1894-1940)', Ritchie and Cunneen (eds), Australian Dictionary of Biography, vol. 12, pp.117-8.

2 The Sydneian, vol. CCXV, March 1913, p.5. 
His multiple office-holding in sporting clubs was an indicator of his priorities: the committee of the sports union and athletics club, treasurer of the hockey club, cricket $2^{\text {nd }}$ XI selection committee. An undistinguished academic record did not reflect the exceptionally accurate memory, rapid grasp of detail, ability to marshal masses of facts, and fluency in French, admired by those who knew him well in later years. However, it was a fair return for the limited time he spent immersed in books. Compelled like all law students to take a Bachelor of Arts degree, he passed English I in December 1913, Geology, Latin and Greek I in March 1914. But when war was declared six months later he did not hesitate to abandon his studies.

Street was among a number of Sydney University law students who enlisted immediately in August 1914. ${ }^{3}$ His Sydney Grammar contemporary Wilfred Robert Dovey joined the Australian Naval and Military Expeditionary Force to fight in New Guinea, sailing away a fortnight after war was declared. Street had joined the same force on August 5. But just before embarkation, the realisation came to him, prompted by his father, that the real war was going to be fought in Europe. The first New South Wales Infantry Brigade had been formed under Colonel Henry MacLaurin, a 36-year-old Sydney lawyer. Together with Major Charles Macnaghten, a city solicitor, MacLaurin had considerable influence over the selection of company and platoon officers. The first of the brigade's four battalions was led by Colonel Leonard Dobbin, another Sydney solicitor. Legal connections and militia experience made law graduates, and even students, prime candidates for commissions. Thus, after four days as a private in the Australian Imperial Force, 20-year-old Geoffrey Street of 'Enniskillin', Ithaca Road, Elizabeth Bay, was commissioned $2^{\text {nd }}$ Lieutenant in Dobbin's battalion and sailed with F Company from Sydney in the Afric on October $18 .{ }^{4} \mathrm{He}$ had, if there was no mistake on the form, attested as a Roman Catholic. ${ }^{5}$

\footnotetext{
3 The absence of Street's name from an official Honour Roll of law graduates and undergraduates who served overseas suggests that, as he had not actually begun his law studies, he was not technically a law student although he was always so described in the press during his lifetime (Vernon Treatt, 'The Law School and the War', Sir Thomas Bavin [ed.], The Jubilee Book of the Law School of the University of Sydney 1890-1940, Sydney, 1940, p.137).

4 The 1st Battalion's story was chronicled in The History of the First Battalion, A.I.F., 1914-1919, 1st Battalion, A.I.F., History Committee, Sydney, 1931.

5 Street had filled in the attestation form himself; and was embarked as 'RC' (www.awm.gov.au/collection/ records/awm8/23/18/awm8-23-18-1-4.pdf).
} 


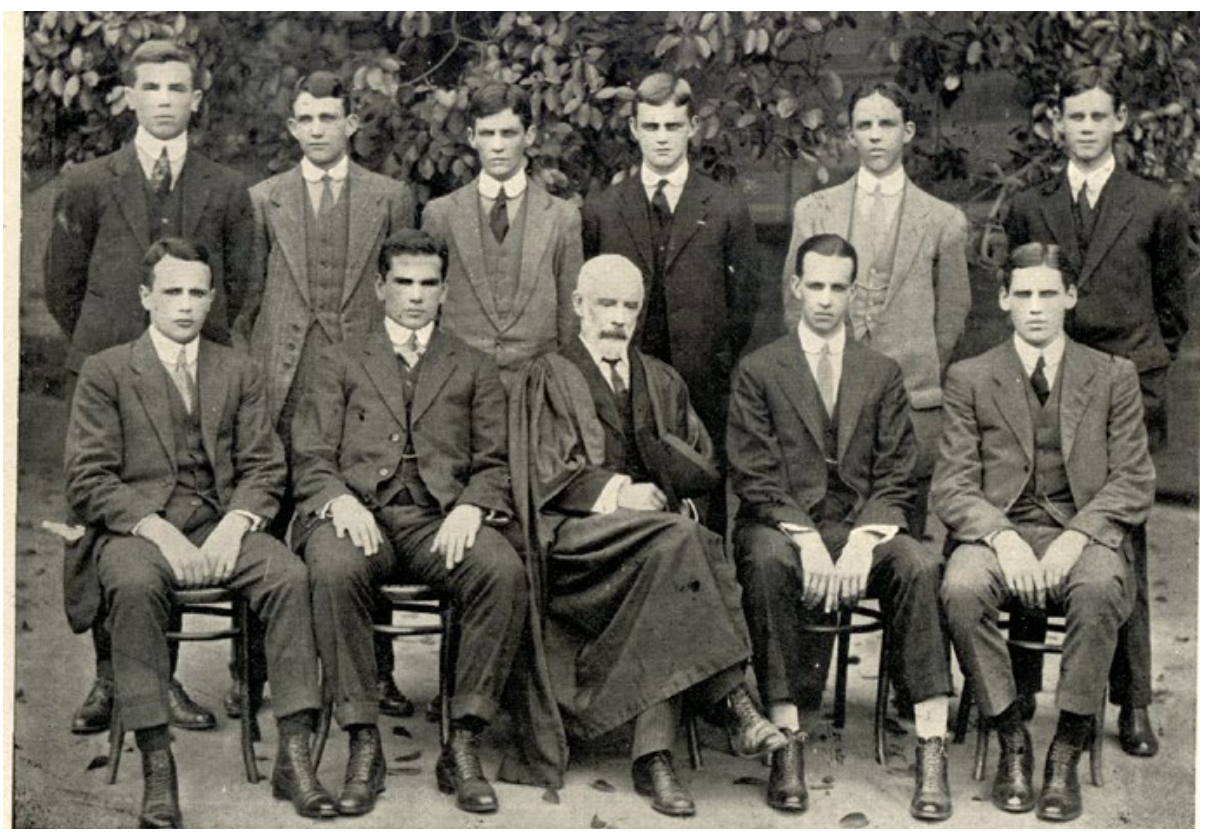

\section{Sydney Grammar School Prefects 1913}

(The Sydneian, CCXV, March 1913, p.15, Courtesy of Sydney Grammar School)

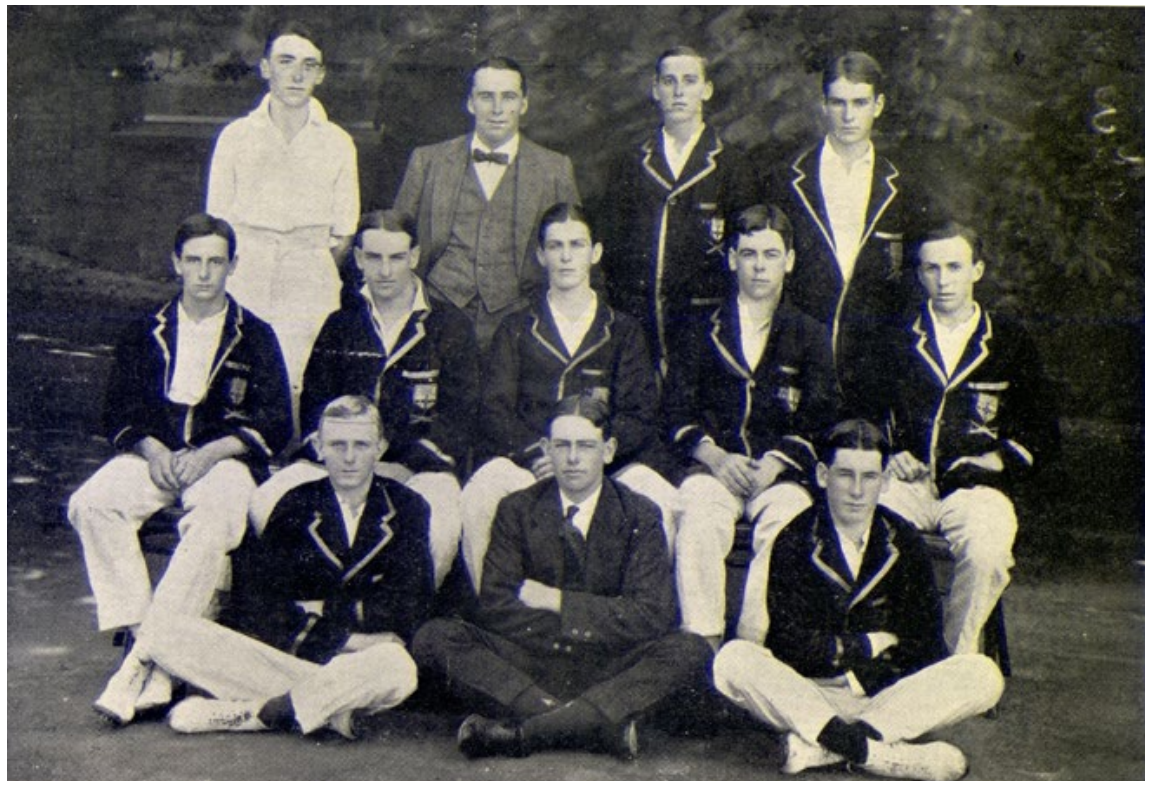

\section{Sydney Grammar School $1^{\text {st }}$ XI 1913}

(The Sydneian, CCXV, March 1913, p.14, courtesy of Sydney Grammar School) 
Arriving at Alexandria early in December, Street went with his men via Cairo to Mena for training. The $1^{\text {st }}$ Battalion was reorganised on a four-company basis and he became platoon commander of D company. The battalion, part of the Middle East Expeditionary Force, embarked on the transport Minnewaska on April 5 en route for Gallipoli via Lemnos. Street would recount 25 years later his vivid recollection of the extraordinary gallantry of the young Royal Navy midshipmen who were in command of the boats from which they landed. He had gone ashore at Gallipoli with his company on the morning of April 25. 'These youngsters,' he said, 'showed an entire absence of fear. ${ }^{6}$ Discarding their packs, Street and his men went up Russell's Top to a hill named Baby 700. The Australians they found already on the hill at 11.00 a.m. were barely holding their own against encircling Turks. Street's company charged the enemy, driving them back over the top of the hill. For days they held the position. Street was wounded in the head and, 'slight' as the wound was, he was evacuated to Alexandria. His cousin, Laurence Street, reported home that a Major Millard whom he had met in the trenches had seen Geoff in Alexandria 'well and cheerful' ${ }^{7} \mathrm{He}$ was back leading his men a month later. Charles Bean records that the youthful lieutenant - he had been promoted with effect from April 26 - took a party of eight men from Steele's Post on June 4 to try to silence an enemy machine-gun position. Unexpectedly stumbling into Turkish troops in a supposedly unoccupied 'sniper's trench' he had to turn back. His sergeant, the flamboyant scout Harry Freame, remained to hold off the enemy. The two men would become lifelong friends. ${ }^{8}$

Before long, Street had been made acting adjutant of the $1^{\text {st }}$ Battalion, with which he was to spend a rest period on Lemnos in September and October. It was perhaps at this time that he committed to memory the regimental number of every man in the battalion, a feat reported in awe many years later by Smith's Weekly. ${ }^{9}$ At the beginning of November he wrote to his mother that he had just heard that 'all our letters have been sunk accidentally!' But there were some good tidings:

I think I told you in my last letter that my appointment as adjutant had been confirmed in Divisional Orders and further news is that I am a Captain!

Unfortunately the present GOC Aust/Div has not the same power that General Bridges had so that one has to wait until the promotion is approved in Melbourne. Still I wear the three stars \& draw Captain's pay

6 The Herald, [25] April 1940.

7 L. W. Street to Mrs P. W. Street, 16 May 1915, Sir David Gilbert Ferguson MSS, NSW State Library, ML MSS 2858.

8 Information from the Hon. Tony Street.

9 Smith's Weekly, 30 July 1938. 
and have every privilege of the rank but although it is in Orders one has to wait till it is confirmed by letter. The only unfortunate, and really rather hard, part of it is that if one is wounded or goes sick then the rank lapses if it is not confirmed. So, as long as I am safe, I am a Captain. Nuff sed. I am sure you will be as pleased as I am and I will try hard to dodge shells \& bullets. ${ }^{10}$

Successfully dodging enemy fire for the next month, Street was evacuated to Egypt with the $1^{\text {st }}$ Battalion on December 20. After a brief spell at Tel-elKebir and the Canal Zone, the battalion embarked for France where, after a few months, Captain Street resumed regimental duty. Within weeks he had been seconded to the $14^{\text {th }}$ Infantry Brigade. During the Battle of Fromelles he was, as Staff Captain, in charge of the Brigade's report centre. In February 1917 he was sent to Cambridge to No. 7 Staff Course. From late July 1917 to April 1918 he was seconded by Major General Talbot Hobbs for duty as brigade major to Brigadier General H. E. 'Pompey' Elliot's $15^{\text {th }}$ Infantry Brigade. Gallant and willing as the young officer was, Elliott found him utterly unsuitable.

There is little doubt that the volatile Elliott, careless of appearances and unguarded in speech, resented having the charming and well-connected staff officer foisted upon him. Four years later, without naming him, Elliott was to describe Street as 'a wealthy man, who was able to shout car trips for some of the senior officers in Paris...His thoughts were always with his best girl, and he could not sleep in anything rougher than silk pyjamas at ten guineas a suit.' Frustrated by not being permitted to appoint his own man, a socially inferior but better qualified officer, Elliott acknowledged that Street was 'a very decent boy' and 'a very lovable lad'. But the 'social butterfly' as he would later call him, just did not seem to measure up to the job:

I have to think of every mortal thing and suggest every single thing he does. In his spare time instead of...thinking of next day's or next week's work - unless he is actually doing a job of work I have set him - he goes playing bridge with the rest of my staff causing them to waste their time also...I cannot sack him and it is no use rowing with him all the time. He is only a boy after all, but I feel it very much.

By asking to be sacked himself, Elliott had in fact obtained from Brudenell White an agreement that Street could be transferred if it proved necessary. The unhappy arrangement lasted for nearly nine months. Street's promotion as Major in the AIF and Honorary Major in the Australian Military Force came simultaneously at the beginning of October. It was April 1918, when the $15^{\text {th }}$

10 G. A. Street to Mary Veronica Street, 19 Nov. 1915, Street MSS, courtesy the Hon. Tony Street. 
Brigade had just secured the village of Bouzencourt, north of Hamel, that his chief's patience finally ran out. The denouement is best told in the words of Elliott's biographer:

To enable the reserve battalion, the $57^{\text {th }}$, to be less exposed to enemy shellfire, Elliott decided to move it back across the Somme to more secure billets; he directed his brigade major to arrange it and to let all the battalions know. In an aberration, however, Street's order to the other three front-line battalions was worded as if each of them was to withdraw across the Somme as well. Fortunately they queried it, and the error was corrected. Pompey was livid: 'trying to retreat in broad daylight over narrow pontoon bridges almost in full view of the enemy' would have produced 'a tremendous disaster, if not a massacre of the Brigade', as well as creating 'a break in the line almost 3 miles long.' Pompey felt that his longstanding misgivings about Street's capacity had been vindicated. Hobbs agreed that, after a mistake of such magnitude, he would have to be replaced. ${ }^{11}$

\section{Something definite in life}

After more than three years of soldiering, and having just turned 24, Street was contemplating possible futures. He had fallen in love with Evora Frances 'Gyp' Currie, daughter of Edwin Currie of 'Gala', Lismore, one of the Victorian properties in the extensive holdings accumulated by John Lang Currie. ${ }^{12}$ Evora Currie - known always as Gyp because of her free spirited gypsy childhood - had arrived in England in 1916 with her friend Esther Fairbairn and Esther's brother Jim (bound for the Royal Flying Corps). She had been working at the Australian headquarters in Horseferry Road, at railway station canteens and, from mid-1917, as a member of a Voluntary Aid Detachment. She stayed in a hotel with her mother, who had also come in the hope of seeing her son Clive when he was on leave from the Army in France. ${ }^{13}$ Among the thousands of men warmed by Gyp's smile there were other serious suitors, none more so than Major Jack Scott, Geoff's distant cousin, a Sydney insurance company manager in civil life. But it was Geoff, blue-eyed, tall, and trim, who won Gyp's heart. Keen to marry 'his best girl' on his next leave in May 1918, he told his mother of the uncertainty he was facing:

11 Elliott's comments on Street in letters to his wife are quoted in Ross McMullin, Pompey Elliott, Scribe, Melbourne, 2008 (1st ed. 2000), pp.335-6, 379, 544.

12 Alexander Henderson, Henderson's Australian Families: A Genealogical and Biographical Record, vol. I, Melbourne, 1941 pp.171-4.

13 Tim Gillespie to $\mathrm{CH}$, (email), 4 Feb. 2010. Australian women travelling to England to train as VADs are briefly noticed in Melanie Oppenheimer, 'Gifts for France: Australian Red Cross Nurses in France, 1916-1919', Journal of Australian Studies, vol.17. no.39, 1993, pp.66-7. 
I only wish I had something definite though in life. The authorities over here refuse point blank to tell me anything about the permanent Australian Forces though I believe something can be done in Australia. Dad once said that he thought he might be able to help \& I wish he would try. I want to get on the A and I staff of the Australian Forces. It was very hard to write to Mr Currie for although as long as the war lasts I am alright as soon as it is over then I'm more or less stranded and without a job so to speak and no income at all. It is very hard isn't it? ${ }^{14}$

By April 1918, with the Passchendaele offensive and the Messines sector behind him, Street returned to the $1^{\text {st }}$ Battalion. He understood the reasons for his transfer but they were not something he would confide to his parents. For them the important news was the award of a Military Cross in the New Year's Honours. ${ }^{15}$ 'I am keeping very fit indeed,' he would tell his mother, 'and though a little "war worn" am still in love with soldiering and in fact find it hard to believe that there was a time that I did anything else' ${ }^{16}$ In love with soldiering he may have been, but a different future beckoned. On June 29 in London, with his best friend Major Frank Thornthwaite at his side, he would marry Gyp Currie at St Columba's Church of Scotland. The newly-wed couple had first met in 1912 when Gyp's brother, Clive, was playing cricket for Melbourne Grammar against Street's Sydney Grammar. The young 'leg theory' bowler, captain of the Sydney side, had left a vivid impression, taking 10 wickets in a match which Melbourne lost by an innings and 111 runs. His vivacious bride was herself a cricket devotee, her father having played for St Kilda and been president of the Victorian Country Cricket League. She was also a fine golfer, an accomplished horsewoman, and a remarkably good shot. Her sporting prowess mirrored that of her husband. Geoff Street himself, broad-shouldered, lean, arrestingly handsome in build and carriage, radiated energy and good humour. ${ }^{17}$ It was an ideal match.

Geoff Street would survive the war, wounded twice - the second time in September 1918 - but intact. After his marriage he had returned to France as OC of the 1st Battalion A Company in operations against the Hindenburg Outpost Line. In a brief biography published 44 years later, H. J. Manning summarised the ensuing months:

Rejoining the $1^{\text {st }}$ Battalion at Pradelles, in Flanders, shortly after the $1^{\text {st }}$ Division's sudden turnabout from Amiens to help meet the new

14 Street to Mary Street, 27 Jan. 1918, Street MSS.

15 Brig.-Gen. C. J. Hobkirk's recommendation spoke of his 'excellent and capable work' with the 14th Infantry Brigade in 1916-17: 'The cheerful way in which he carried out his work was very helpful' (NAA: B2455 Street Geoffrey Austin).

16 Street to Mary Street, 16 May 1918, Street MSS.

17 The Referee, 10 Nov. 1938; Daily Telegraph (Sydney), 22 Nov. 1938. 
German threat, through Hazebrouck, to the Channel ports, Street was given command of 'A' Company. Four months later, after holding the line at Meteren and Strazeele, the $1^{\text {st }}$ Division came south again to join the Australian Corps on the Somme to take part in the victorious offensive that began on $8^{\text {th }}$ August. Street led his company in the fighting at Chuignolles on $23^{\text {rd }}$ August, and also in the battalion's last battle of the war at Hargicourt, on September $18^{\text {th }}$. Later that day he was wounded in the right wrist by a machine-gun bullet. ${ }^{18}$

He did not dwell on it in later years but Street had received a 'mild' gunshot wound that threatened to close his cricket career. The bullet passed through the middle of his right wrist. It put an immediate end to the fun he had been having with Captain Charles Kelleway, the Test all-rounder with whom he had been playing behind the lines on 'matting' wickets spread with hessian. Asked 20 years later by the editor of Reveille to recall 'the circumstances of both your woundings' he replied laconically: 'Just happened to be in the wrong place. ${ }^{\prime 19}$

Friends and relatives also in the wrong place were less fortunate. Of the 1796 Sydney Grammar men who would appear on the 1914-18 Honour Board in the 'Big School', 313 did not return. ${ }^{20}$ Geoff's cousin, Laurence Whistler Street, two years ahead of him at school, and associate to his father, Justice Philip Whistler Street, when he enlisted, had been posted to the $3^{\text {rd }}$ Battalion. He was shot and died at Gallipoli on 19 May 1915. Frederick Muir, a fellow law student who had joined as a private, was evacuated from the Peninsula in late November 1915 with wounds in the head and face; he died and was buried at sea three days later. At Pozières in July 1916, another cousin twice Geoff's age, John Rendell Street, was severely wounded. Rather than be taken prisoner, the immobilised Street took his rifle and shot himself under the chin. It was months before his family confirmed their suspicions that the Red Cross report of a 'fatal wound' concealed the manner of his death. ${ }^{21}$ Humphrey Scott, yet another cousin, and a 27-year-old Lieutenant Colonel when he died in October 1917, fell to a sniper's bullet near Polygon Wood. There was nothing unusual about these losses. Many families could tell of similar suffering. But they signified that young Geoff Street had shared to the full the war experiences and grief of his generation.

\footnotetext{
18 Manning, 'Air Disaster at Canberra', Stand-To, Jan.-Feb. 1962, p.7; C. E. W. Bean, The Australian Imperial Force in France: During the Allied Offensive, 1918, Angus and Robertson, Sydney, 1942, pp.751-2.

19 Street to Mary Street, 21, 28 Sept 1918, Street MSS; Street to J. Black, 17 Dec. 1938, AWM: 43 A843.

20 Gordon Cooper (Sydney Grammar School Archivist) to CH, 12 Oct. 2011.

21 The context of Street's service, 1914-16, is illuminated by Tony Cunneen in his unpublished papers at www.forbessociety.org.au/documents/law_war.pdf (downloaded 7 May 2009): 'A Social History of the New South Wales Supreme Court Judges in the First World War', and 'Engaged to Act on Another Front: A Working Paper describing the actions of Members of the New South Wales Legal Profession on Gallipoli', and 'The Law at War (1916): A Social History of the New South Wales Legal Profession in 1916'.
} 


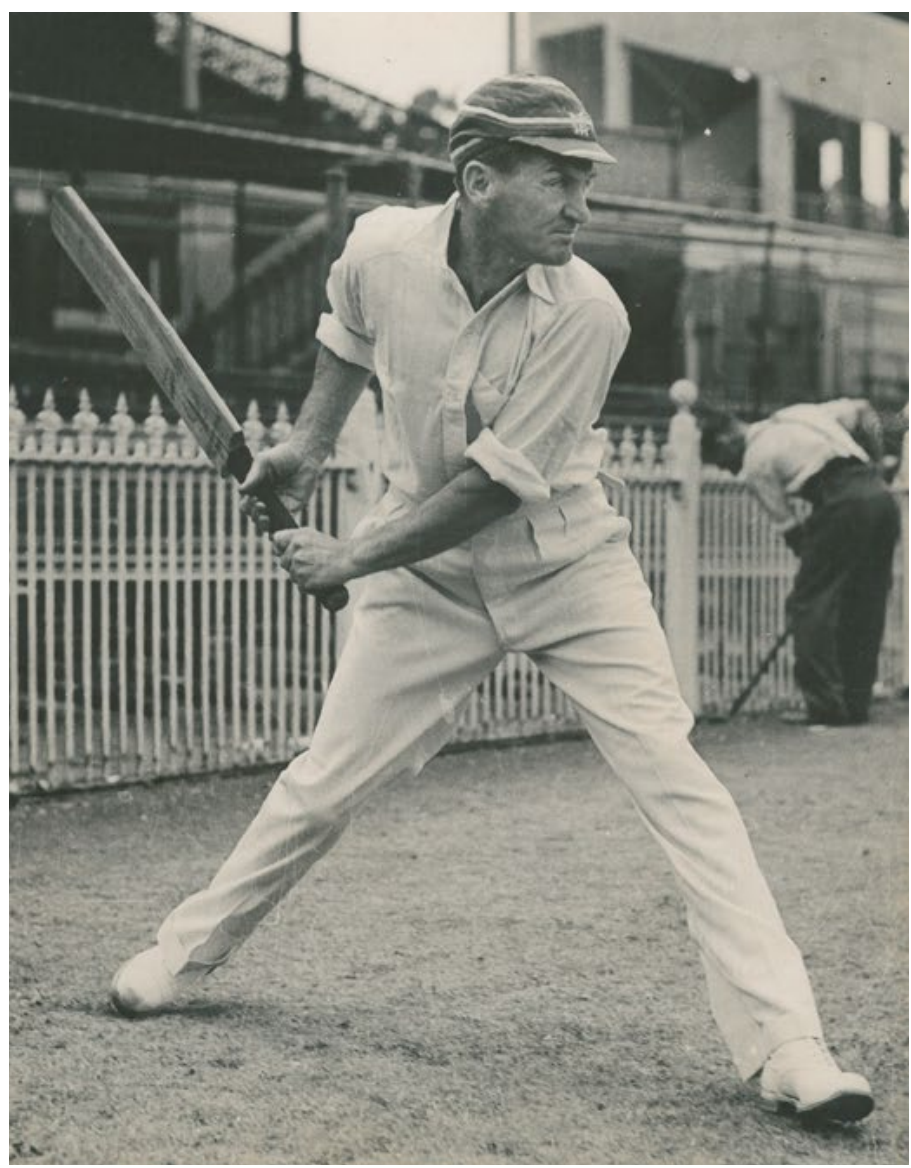

\section{In Victor Trumper's image}

(Courtesy of the Hon. Tony Street)

Street's AIF appointment was terminated on 2 August 1919. He had spent four months after the end of the war on furlough (75 days' sick leave) but attached to General Monash's Demobilisation and Repatriation depot in Horseferry Road. Returning from Europe, he bought a portion of his father-in-law's Western District estate and in January 1920 settled near Lismore at a property he called 'Eildon'. There he bred and successfully exhibited Polwarth sheep. But the life of a pastoralist was not enough to contain him. He was soon to be seen contributing to the work of local organisations such as the Lismore Agricultural and Pastoral Society and the Australian Sheep Breeders' Association. And there was an undeniable sense that he ought to be playing a part on a bigger stage. Sport was, as it had always been, an outlet for his surplus energies. If he had any passion outside the Army, family, the land, and eventually politics, it was 
cricket. He came late to golf, challenged by the fact that his wife and her brother played it so well. Eventually he got his handicap down to seven; but to those more adept he never really looked like a golfer.

Cricket was the sport Street loved. Gyp's own interest - she even took an umpire's course - made for a joyful bond with her husband. ${ }^{22}$ Unlike the portly Bob Menzies, whose appreciation of the game was from beyond the boundary, preferably in the Members' Pavilion, Street was to play in the middle against some of the best. His wounded wrist had been substantially restored by massage and exercise. Though he could never bend it back as far as in his youth, he could still bowl the googlies that he had made his own. For six years he was in the Melbourne Cricket Club first XI playing on occasion under the great Test captain Warwick Armstrong.

In the country he turned out whenever he could with other devotees like 'Ford' Guthrie and Henry Bolte in the Lismore and Western Plains teams. Friends and neighbours were also likely to be caught up in his military enthusiasms. On the Reserve of Officers from 1920, he joined the AMF $4^{\text {th }}$ Light Horse Regiment in 1931. Late in 1932, as Guthrie remembered, 'he persuaded me and others to join the $4^{\text {th }}$ Light Horse, which he was commanding at the time before being promoted to Brigadier' in the $3^{\text {rd }}$ Cavalry Brigade. ${ }^{23}$

When still in his twenties, Major Street MC was drawn into public life, first as a member of the Hampden Shire Council on which he eventually served for 16 years. Together with his friend Frank Thornthwaite he had rallied to the side of his old chief Pompey Elliott when special constables were being enlisted to patrol the streets during the Victorian police strike in 1923. Although he was close to Ned Herring and other militia leaders associated with the League of National Security, he seems to have held aloof from the secret army organisations of those years. ${ }^{24} \mathrm{He}$ was, however, an early member of the Young Nationalist Organisation that was reviving conservative political morale and fortunes. In 1929, assisted by Bob and Pattie Menzies, he had been campaign secretary for Chester Manifold in Manifold's run for the Legislative Assembly seat of Hampden. ${ }^{25}$ A competent administrator, approachable, free from prejudice and snobbery, Street was president of the Hampden council in 1931-32. A reporter who first heard him in 1934 was immediately struck by the councillor's 'freelyflowing and flawless English'. Wherever he was called upon, at civic receptions for visiting dignitaries, at council meetings, at smoke nights, Street spoke

22 In a novel charity game in 1927, Gyp Street opened the batting for a ladies' team, top scoring with 25 before being bowled by her husband who went on to take 6 for 3 for the losing men's team, who wore women's clothes and batted wrong-handed (Camperdown Chronicle, 19 Feb. 1927).

23 The Hon. A. A. (Tony) Street, interview, 24 May 1983; Sir Rutherford Guthrie to CH, 15 June 1983.

24 Smith's Weekly, 30 July 1938; Gavin Brown \& Robert Haldane, Days of Violence: The 1923 police strike in Melbourne, p.211; Sayers, Ned Herring, pp.112-3.

25 J. Marjorie Butler, Talindert and the Chester Manifolds, privately printed, Mount Eliza, 1983, p.20. 
impromptu, easily, humorous, and polished.$^{26}$ This was a man made for politics. In 1933 he was appointed a member of the Victorian Transport Regulation Board by his friend Bob Menzies. As Minister for Railways, Menzies acknowledged that Street was 'largely responsible' for the Board's 'masterly report' into transport regulation. A year later, at the 1934 federal general election, Street took the seat of Corangamite for the United Australia Party. He had displayed reluctance and diffidence before agreeing to stand in the electorate held by the Country Party; but once elected he never looked back. Like Menzies, who moved from the state to the national political arena in the same year, he retained his seat at the next election.

There were threats before the 1937 election that the Corangamite electorate would be abolished. However, a boundary redistribution in the end favoured the sitting member. Sensitive to the concerns of his constituents, Street was diligent in attendance to his parliamentary duties, tireless in visiting local communities. He covered 60000 miles in three years. He was quickly on record pressing for half-yearly telephone directories and more frequent mail deliveries and, with his neighbour Jim Fairbairn, for action on rural rehabilitation. He was heard too on matters of national as well as parochial importance. Taking a keen interest in the treatment of infantile paralysis victims, he was an advocate of support for the controversial Sister Elizabeth Kenny. From his earliest days in Parliament, he also put down his marker on defence matters. In a triple-barrelled question bristling with innuendo, he asked Archdale Parkhill in November 1934 whether the Minister for Defence dealt directly with members of the Military Board on matters affecting their departments: how many times since 1919 had the Council of Defence met and when was the last time; and how was the allocation of the defence vote amongst the various services determined? He returned to the subject six months later, expressing his incredulity that the Council of Defence, whose statutory powers were extensive, had not met since November 1929. ${ }^{27}$ An embarrassed minister announced the reconstruction of the Council a few days later.

In answer to what looked very much like an invited question, Street was told late in November 1935 by the Attorney-General Robert Menzies, representing the Minister for External Affairs, that the government was looking into ways in which the staff of the Department of External Affairs might be increased to 'adequate proportions'.$^{28}$ These and other queries and pinpricks showed the member for Corangamite to be an adroit parliamentary performer. He trod carefully around the trade diversion minefield, making plain in an unplanned intervention in praise of the hard-pressed Trade Negotiations Minister, Harry

26 Terang Express, 16 Aug. 1940.

27 CPD, House of Representatives, 14 Nov. 1934, p.249; 9 April 1935, p.1088; Sydney Morning Herald, 2 Sept. 1937.

28 Canberra Times, 21 Nov. 1935. 
Gullett, that he and other wool growers had loyally obeyed the request of the Prime Minister to refrain from taking part in the dispute. He was careful to distance himself from Labor's schemes for banking reform and rural rehabilitation, but argued that defence should be above party politics. On set-piece occasions he was accomplished, authoritative, and courteous, seen to particular advantage for example in the 1936-37 Budget debate; then he advanced the case for a strong Air Force and an increase in the Army's Permanent Forces to two cavalry regiments and a brigade of infantry. He would reiterate this theme the following year, urging the addition of a brigade of field artillery, and the expansion of the Royal Military College at Duntroon. ${ }^{29}$ Many observers were convinced that he would have made his way into the Cabinet after the 1937 election had the Prime Minister not been obliged to find places for representatives of the smaller states.

\section{Into the inner circle}

In July 1938 Lyons attempted to lighten the load of two of his most overburdened ministers, the Treasurer and the Defence Minister. J. N. Lawson was added to R. G. Casey's Treasury team in the innovative capacity of Parliamentary Secretary. At Defence, whose role was growing rapidly as the government began to realise its unpreparedness in the face of the worsening European situation, H. V. Thorby, deputy leader of the Country Party, was increasingly weighed down with responsibility for all three services as well as Civil Aviation; but he was unwilling to delegate. More seriously, as General Squires told the New South Wales Governor, Lord Wakehurst, a few months later, Thorby 'has no ideas on defence of much wider scope than the W.C.s he began life by building' ${ }^{30}$ Lyons, prompted by Fred Shedden, appointed Geoff Street to the same novel role as Jack Lawson. Neither man would be permitted to answer parliamentary questions. They were to be unpaid assistant ministers, a position unknown to the constitution. ${ }^{31}$ The case for creating a separate ministry of civil aviation, also a transport department, was strong. ${ }^{32}$ Soon to be embarking on an even larger role, 'terrifying at first', Street would tell Charles Hawker: 'My one regret is Jim. I feel that he is being wasted and I don't know why.' ${ }^{33}$

Jim Fairbairn's turn was still to come. Meanwhile, pending a major reshuffle, which was widely believed to await the return of Sir Earle Page, Robert Menzies, and Tommy White from a mission to London, the promotion of Street

$29 C P D$, House of Representatives, 30 Sept., 26 Nov. 1936, pp.708-11, 2438-9.

30 Wakehurst diary, 17 Nov. 1938, in Lord Wakehurst, ts memoirs, n.d. (ca 1966-71), John de Vere Wakehurst Papers, NSW State Library ML MSS 1788 Add-on 1043.

31 Crisp, Australian National Government, pp.383-6.

32 David Horner, Defence Supremo: Sir Frederick Shedden and the making of Australian defence policy, Allen \& Unwin, Sydney, 2000, pp.61-5; Sydney Morning Herald, editorial, 15 July 1938.

33 Street to Hawker, n.d., Hawker MSS, NLA MS 4848/2/4. 
brought into the government someone whom the Sydney Morning Herald called 'a discerning advocate of the strengthening of the national defence'. His support for a small, well-trained, permanent Army was well known. His military background and current post as colonel commanding the $3^{\text {rd }}$ Cavalry Brigade would give credibility to his views. Privately he had made clear his support for the idea of appointing a commander-in-chief, and it was not long before Tom Blamey was being sounded out. ${ }^{34}$

In late October and early November, following the Munich crisis, Street was on the periphery as a divided Cabinet debated and rejected the introduction of universal training, announcing instead that the Militia would be increased to 70000 men, 'if possible' by voluntary enlistment. A well-publicised threat of resignation by Menzies came to nothing. He had support in Cabinet from Casey and Tommy White and probably two others. ${ }^{35}$ From outside, the Young Nationalist Organisation president, Ned Herring, was pressing the Prime Minister for a separate Army minister and the appointment of a commanderin-chief as well as 'universal physical and military training for home defence' ${ }^{36}$ But it was not enough. The principal stumbling block was Lyons, who was pledged not to introduce 'conscription'. Lieutenant General Ernest Squires, the distinguished British officer recently installed as 'Inspector-General' of the Australian Army, was a close observer of the political aftermath:

A secret session this morning [7 November 1938] with Shedden, the Chiefs of Staff, \& Munitions people, to consider possible re-organization of the Defence Dept - what the upshot will be, we don't yet know but we fear that a new \& forceful Defence Minister will probably not be the P. M.'s solution of the difficulty.

The next day brought a surprise:

Street has been made Minister for Defence - with Civil Aviation removed — \& Thorby Minister for Works \& Civil Aviation: a sheer piece of face-saving as far as Thorby is concerned, \& Street's appointment has largely been stultified by his non-inclusion in the newly-invented 'Inner

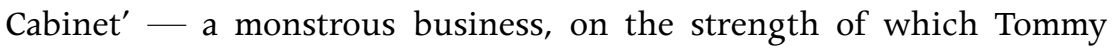
White has resigned the Ministry of Customs.

The 'monstrous business' of an 'inner Cabinet' did not in fact materialise, although Street's name was hastily added to the senior Cabinet group. His appointment was widely commended, even by those like Sir Harry Gullett

34 Gavin Keating, The Right Man for the Right Job: Lieutenant General Sir Stanley Savige as a Military Commander, Oxford UP, Melbourne, 2006, pp.31-2.

35 The Sun, 31 Oct. 1938.

36 'Young Nationalist Conference - Correspondence - PM \& Minister', Shedden MSS, NAA: A5954, 895/5. 
who thought Tommy White had been badly treated. As Gullett put it in a character sketch of Street for Sir Keith Murdoch's Herald on November 8: 'He has advanced himself neither by intrigue nor by making himself a conspicuous nuisance to the administration of the day. His speeches have been relatively few and have been marked by earnestness rather than by any dramatic quality.' Wishing the new minister well, Gullett warned that with responsibility for all three of the fighting services he faced 'a task of a heartbreaking and almost impossible kind' ${ }^{37}$

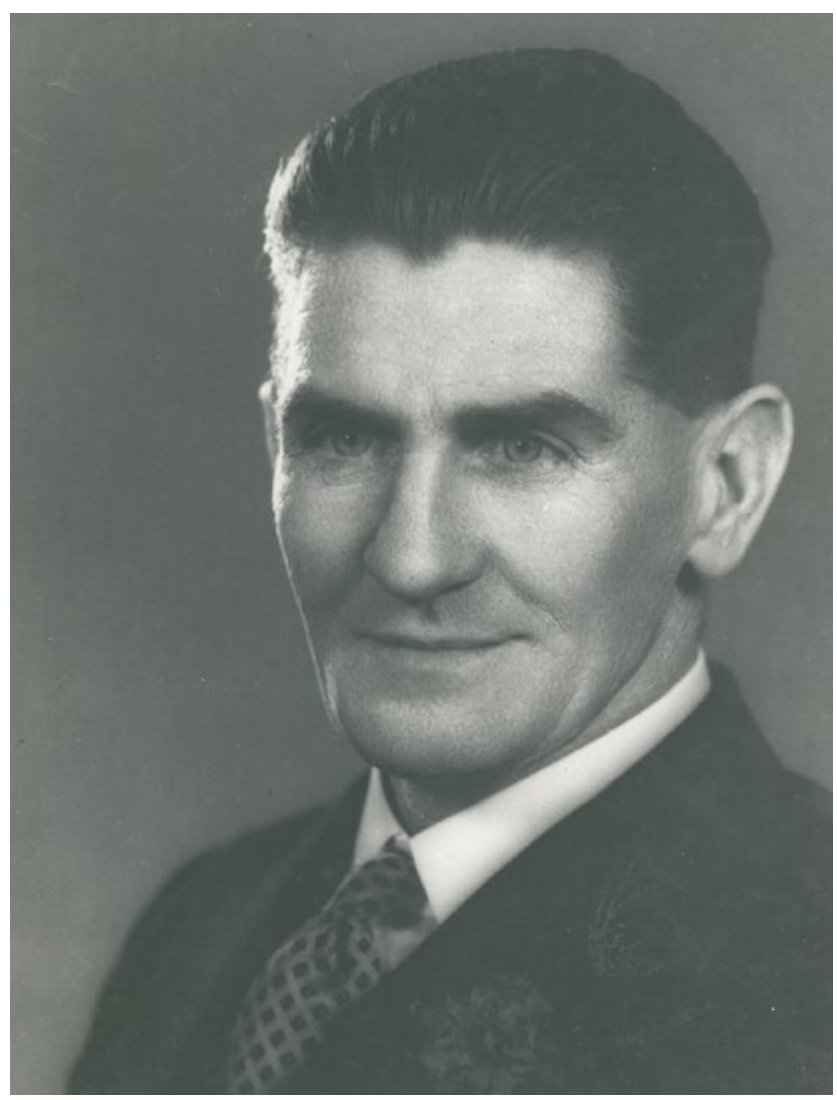

\section{A popular appointment: advanced neither by intrigue nor by making himself a conspicuous nuisance}

(Courtesy of the Hon. Tony Street)

37 Squires diary, 7, 8, 11 Nov. 1938, UNSW@ADFA Library, MS 184 folder 1; Wakehurst diary, 17 Nov. 1938, in Lord Wakehurst, ts memoirs [ca 1966-71], John de Vere Wakehurst Papers, NSW State Library ML MSS 1788 Add-on 1043. Noting Street's lack of ministerial experience and alleged lack of 'standing', Eric Andrews says that Street's appointment, like that of Thorby, rather than Menzies or Casey, 'reveals Lyons's pre-occupation with internal politics and an amazing failure to realise the overriding importance of the Defence portfolio at the time' (The Department of Defence: The Australian Centenary History of Defence, vol. 5, Oxford UP, 2001, pp.88-9, 106). Andrews appears to have followed Paul Hasluck's condescending assessment of Street's 'enthusiasm and a knowledge of soldiering...together with the frank and agreeable manners of an honest and manly character' (The Government and the People 1939-1941, p.107). 
General Squires already knew the heartbreak. But he quickly found himself cheered by the new minister. Whereas under Thorby, he told Lord Wakehurst, there had been 'a lack of thinking things out and too many piece-meal announcements...made without consulting the soldiers', Squires had hopes that 'things will be better co-ordinated under Street who has commanded a militia brigade and knows what's what'. 'I have great hopes that, under him, we shall really be able to get a move on $-\&$, I gather, he's prepared to go large in putting the A. M. F. on a proper footing.' Street did indeed 'go large' and, after 'a tremendous battle' in Cabinet, got his defence program through with only a very small cut. ${ }^{38}$ Eight days after his appointment, Street brought to Cabinet proposals for an expanded defence program. Increased funding, from $£ 43$ million to $£ 62.5$ million, was announced in December. In the week before Street's promotion Lyons had stated the government's intention to order 50 of the Lockheed company's new Hudson bombers. This was a precaution in case an order for British Beaufort torpedo bombers - which a misleadingly-advised Cabinet was in effect foisting on an unwilling Air Board - failed to materialise. The British had initially urged the Australian government to set up its own manufacturing plant to build Beauforts; they finally decided to allow Australian production only of components. Anxious to protect the Commonwealth Aircraft Corporation (CAC), but under pressure from the British, Geoff Street took an implausible compromise proposal to Cabinet: the CAC should produce as the power plant for the Hudsons the unproven British Taurus engines as well as the Pratt and Whitney Twin Wasps for which the CAC was already tooling up. This was the beginning rather than the end of a process of indecision and policy reversal that would beset the Beaufort project for the next two years. ${ }^{39}$

Barely a month after he came into office Street moved to remedy what he saw as one of the defects of peacetime military organisation - the lack of opportunity for Citizen Force officers to gain the experience of staff duties that would be expected of future senior commanders. He approved the creation of over a dozen staff appointments for Militia officers. But, while he could ensure the existence of posts for the Militia, what he could not do was quell the rampant jealousies between permanent and citizen officers, Staff Corps and Militia. Many regular Army officers who had endured long hours and low pay through the 1930s were not pleased to see changes benefiting what they considered to be an already favoured Militia. For Staff Corps officers who had felt excluded from operational commands this was in fact a backward step. The rifts were too deep, affecting too many individuals with accumulated resentments and suspicions of unfair treatment. ${ }^{40}$

\footnotetext{
38 Squires diary, 3 Dec. 1938, UNSW@ADFA Library, MS 184 folder 1.

39 Peter Ewer, Wounded Eagle: The bombing of Darwin and Australia's air defence scandal, New Holland Publishing, Sydney, 2009, pp.122-58; Hill, Wirraway to Hornet, pp.45-6.

40 Claude Neumann, 'Australia's Citizen Soldiers, 1919-1939: A Study of Organization, Command, Recruiting, Training and Equipment', MA thesis, University of New South Wales at Duntroon, 1978, pp.111ff; Peter J. Dean, “'The Making of a General: Lost Years, Forgotten Battles," Lieutenant General Frank Berryman 1894-1941', PhD thesis, University of NSW, 2007, pp.171-3.
} 


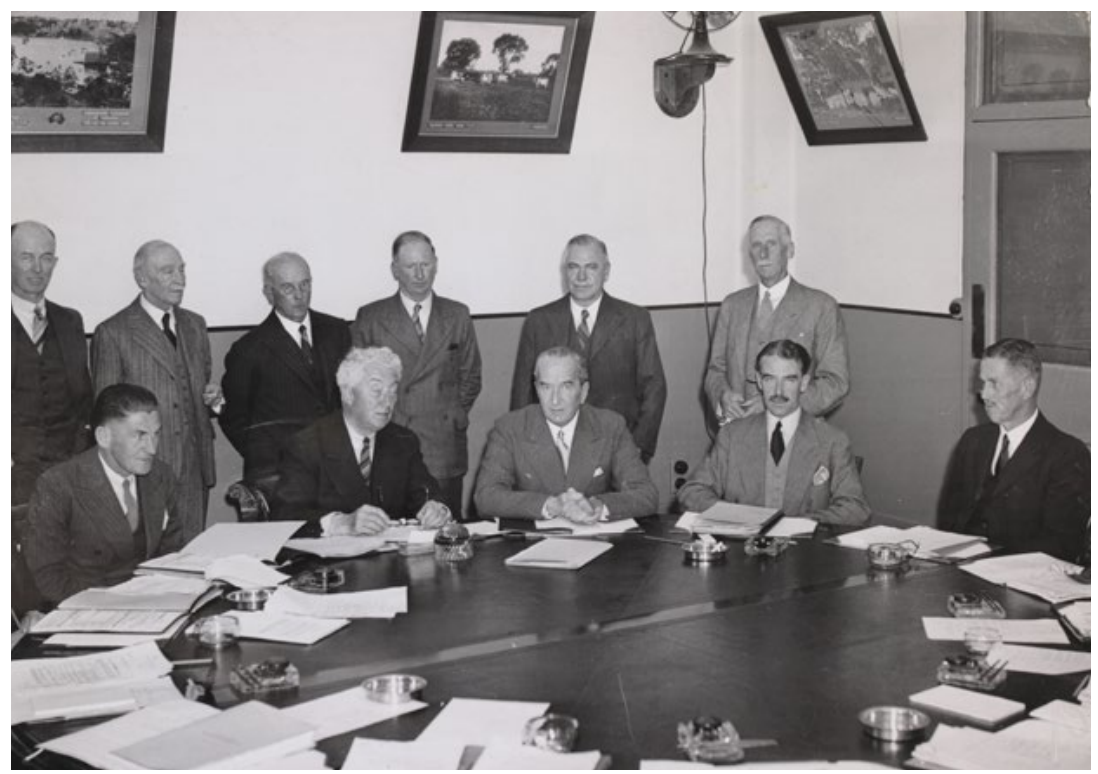

The Defence Council poses, 25 January 1939. From left: Sir Ragnar Colvin, (1st member Naval Board), F. G. Shedden (Secretary of Defence Dept.),

Brig. Street (Minister of Defence), J. A. Lyons (Prime Minister), S. M. Bruce, R. G. Casey (Federal Treasurer), Lt. Gen. Squires (Insp. Gen. of Australian Military Services); standing from left: Maj. Gen. Lavarack (Chief of General Staff), Air Vice Marshal Williams (Chief of Air Staff), Sir Harry Chauvel, A. E. Leighton, N. K. S. Brodribb (Controller of Munitions Supply), Sir Thomas Blamey (Director of Recruiting) and Sir Brudenell White

(Argus Newspaper Collection of Photographs, State Library of Victoria)

On 30 January 1939, refreshed from a game of cricket in which he took four for 56 for the Melbourne Cricket Club against a Southern Peninsula XI, Street sat down with the Chiefs of the Naval Staff, the Air Staff, and the Army's General Staff, and the Chairman of the Principal Supply Officers' Committee (also representing the Controller General of Munitions Supply), to discuss 'The International Situation, Emergency Measures'. The Chiefs had been presented with information that the British had decided to 'accelerate as far as possible the preparation with every defensive and counter-offensive measure'. Now Street made it clear to them that he required an urgent review of the state of preparedness, recommendations for immediate action, and steps that should be taken before the issue of the warning telegram if the situation continued to deteriorate. There was no room for complacency; and if anyone was tempted to 
advance claims at the expense of the other Services they were forestalled by the instruction of Street's departmental secretary, Fred Shedden, to exchange their statements and confer on the 'joint Service relation of measures'.$^{41}$

It was not long before Street was relying heavily on advice from General Squires. When Cabinet met in Hobart early in February 1939 the Inspector-General was asked to telephone and comment on what he called a 'fantastic' decision that no-one presenting to a recruiting centre was to be turned away whether they were needed or not. The requested comments were not complimentary. The British Inspector-General was not afraid to turn away willing volunteers. He was equally ready to dispense with redundant senior officers. The Defence Minister secured the Prime Minister's support to act on a 'most secret' report from Squires urging a 'drastic purge of senior S[taff]. C[orps]. officers.' An unfortunate 12 were eventually told they were to be removed in August, only to be reprieved a week after war broke out, and then in some cases advised shortly afterwards that it had only been a stay of execution after all. Squires' more far-reaching recommendations on Army re-organisation, including creation of a permanent mobile force were for the most part adopted in mid-March. However, it was not until the eve of war that Cabinet approved proposals for the extended training of about 15000 Militia and improved training for the Militia as a whole. ${ }^{42}$

Brought more closely into the orbit of the senior members of the party, Street found himself attracted to the coming men rather than the older figures whose great days belonged to a cobwebbed past. Menzies and Casey were of his own generation. And it was a severe blow when Menzies chose to resign in March 1939, leaving Casey behind to bear the responsibility for the government's abandonment of much of the scheme of national insurance to which they had both been strongly committed. At the Melbourne Club on Thursday night, March 16, two days after Menzies had left Canberra, Street sat down to write a letter that looked beyond the present severance:

Dear Bob

This is just a note to say how sorry I am about the position that has arisen.

I have been afraid for some time that it might arise but have always hoped against hope.

41 Minute by Secretary Department of Defence, approved by Minister, 31 Jan. 1939, 'Emergency JanuaryFebruary 1939. Emergency Measures \& Plans', NAA: A1196, 35/501/68.

42 Squires diary, 7, 13, 17 Feb., 16-17 March, 12, 17 Aug., 11, 28 Sept. 1939, UNSW@ADFA Library, MS 184 folder 2 . 
You will forgive me if I say that I believe that the country cannot spare one who has such gifts. You have a very clear thinking mind, you have exceptional gifts of expression, logic and concentration on essentials. These are too rare to be missed.

May I just say that during my short association with you I have learnt a lot from you; I had hoped to learn more.

...all I can say is that I hope that events will soon make it possible for Australia to have the enormous benefits of your gifts.

\section{Yours}

\section{Geoff}

The sudden death of Joe Lyons barely a month later was the tragic event that enabled Menzies to return to power, before he had time to launch the 'constructive and objective' criticism of the government that he promised Street in his reply. ${ }^{43}$ Though not without misgivings, Street would have shared the opinion of the Governor-General that Menzies was 'brilliantly clever, full of energy and will, I think, make a far better head of a government than a subordinate' ${ }^{44}$ With Menzies at the head of the party and the government, and the Country Party refusing to join a Menzies Cabinet, Street found himself one of the inner circle. His popularity in the country - enhanced by his twice having refused to accept an increase in his parliamentary salary - was now matched by his position in the government. He was ranked fourth in the ministry behind only Billy Hughes and Dick Casey, neither of whom Menzies could afford to slight. It had been an exceptionally rapid rise.

Advanced in status, Street did not wait long before requesting the Chiefs of Staff to review defence policy. He now also had the opportunity to arrange the succession to Major General Lavarack as Chief of the General Staff. One of the moody Lavarack's last significant moves was to endorse a proposal from the Military Board that Australia initiate preparations for defensive use of mustard gas 'as spray or bombs'. This 'Most Secret' minute was not approved by Street until Lavarack had departed and his successor had been in place for over a month. ${ }^{45}$ In spite of fears that the appointment might turn out to be illegal, Lieutenant General Squires was gazetted as acting CGS on May $18 .{ }^{46}$ Almost his

\footnotetext{
43 Street to Menzies, 16 March 1939; Menzies to Street, 18 March 1939, copy, Menzies MSS, NLA MS 4936/579/6.

44 Lord Gowrie to Walter Hore-Ruthven, 22 May 1939, copy, Gowrie MSS, NLA MS 2852/5/10.

45 Secretary, Military Board to Secretary, Department of Defence, 5 April 1939, initialled by Lavarack, 4 April 1939 and Street, 25 June 1939, NAA: A816, 9/301/89. The proposal did not gather momentum until the war was well advanced.

46 For the conflicting advice on the legality of Squires' appointment as Inspector-General of the Army, and by implication his subsequent appointment as CGS, see Ronald J. Austin, 'The appointment of LieutenantGeneral Squires: the role of Major General Sir Carl Jess in the conflict between the military board and the government', Sabretache (1 March 2003).
} 
first major task was writing a paper for the minister on 'the undesirability of introducing universal training at this time, when we have got an amply large enough, \& very promising Militia (now over 75000 ) \& when we want to put every penny we can get into arms \& equipment ${ }^{\prime}{ }^{47}$ The government's war preparations advanced with the creation of a national register of manpower accompanied without enthusiasm by a census of wealth, the latter - a concession negotiated by Street - appeasing Labor critics of a census of males that could facilitate industrial conscription.

In a brief interruption to the demands of office, the Streets and their friends had a reminder of the success of a partnership that had lasted more than two decades. On 29 June 1939, Geoff and Gyp celebrated their twenty-first wedding anniversary at a dinner at Menzies Hotel. The years had treated them well. They had been blessed with a son and a daughter. Gyp cut a striking figure, always elegant and vital in any company. Some observers thought Geoff had aged since he joined the Cabinet. But he was not merely the fittest minister, he had also gained a reputation as the best-dressed one. Bob Menzies was overheard remarking: 'By heaven, Geoff, you make me look more like a gentleman's gentleman every day.' True, his principal sartorial rival Dick Casey was deemed the most handsome. But Geoff's deeply furrowed forehead and cheeks were, as the Daily Telegraph had described this 'typical Digger', the frequently observed 'characteristic of the Australian who has worked hard and long under hot suns on the land'. ${ }^{48}$

The Minister's new British friend, Ernest Squires, noted that the anniversary guests were 'mostly Western District' ${ }^{49}$ Among them was the man who had stood with Street at the altar 21 years before. Lieutenant Colonel Frank Thornthwaite, Street's best man in 1918, was to report to Squires' staff just two days later. Thornthwaite would have enjoyed the story of how the Defence Minister had just faced down a deputation in Newcastle representing 500 businessmen, bank employees and 'men from the industries' who were demanding the creation of a kilted regiment. Official policy was that there should be one Highland regiment in each capital city. 'It is not considered desirable to encourage different types of national units, when after all this is Australia.' ${ }^{50}$

At a Defence Council meeting on 6 July 1939 the CGS recorded:

Backed by the 'co-opted' Generals, Street \& I managed...to scotch a fantastic scheme of Gullett's; \& we've got permission to work out a new programme for raising 2 $\frac{1}{2}$ quotas of the Permanent Force (about 3600

47 Squires diary, 28 May 1939, UNSW@ADFA Library, MS 184 folder 2.

48 Daily Telegraph (Sydney), 22 Nov. 1938; Courier-Mail, 22 Feb. 1940; The Argus, 2 Dec. 1939.

49 Squires diary, 29 June 1939, UNSW@ADFA Library, MS 184 folder 2.

50 Unidentified press cutting, [June/July 1939], Street MSS. 
men) as quickly as possible, \& as cheaply as possible. There seems to be no chance of our getting any substantial increase in the total money allotted to us... ${ }^{51}$

The news became increasingly gloomy from Squires' point of view:

A rather depressing talk with Street, about the chances of getting the revised Permanent force scheme through the Cabinet: what with uncertainty about this, the delays in introducing the Supplementary List \& the 'Command' organization, the failure to do anything about new conditions of service for the Staff Corps. \& to spend any more money in essential munitions - in spite of the Chiefs of Staff review - I don't know whether I'm really justified in staying on here.

So dispirited was Street's chief advisor with the government's procrastination and misleading public statements about the progress of the defence program that he was 'left with the unpleasant feeling of betraying the Army's confidence, \& letting them down' ${ }^{52}$ As for Street himself, he was rapidly coming to the same conclusion. After a 'heart to heart talk' on the afternoon of July 28 Squires recorded:

The Cabinet are, we believe, going to take a number of Defence questions next week - many of them very important — \& we're both feeling very anxious, \& wondering whether we'd be justified in staying on in our jobs if the Cabinet were to turn down the things which we consider to be necessary. He's going to have a very difficult time, I'm afraid. ${ }^{53}$

Street's anxieties suggest either that he was not enjoying the full support of the Prime Minister or that Menzies himself was not strong enough to compel acquiescence in his Defence Minister's plans. Whatever Menzies' true position, the worst fears of Street and Squires were realised. The Permanent Force scheme approved by the Lyons Cabinet was now turned down. Street had summoned the CGS urgently to Canberra on Tuesday afternoon, August 1: 'I knew it must be an S. O. S., so didn't feel optimistic.' Luckily for Squires it was the one night of the week when there was a quick train connection from Albury, enabling him to arrive two hours before he was due to appear before the Cabinet at $11.00 \mathrm{a} . \mathrm{m}$.

Cross-examined with 'surprisingly unintelligent questions', Squires realised that the real reason the scheme was rejected was financial. There was some consolation in that ministers had been logical enough to decide to rely on training the Militia to a higher standard. And, after a talk with Menzies, the Prime Minister agreed to hold meetings of the Defence Council monthly.

51 Squires diary, 6 July 1939, UNSW@ADFA Library, MS 184 folder 2.

52 Squires diary, 24 July 1939, UNSW@ADFA Library, MS 184 folder 2.

53 Squires diary, 28 July 1939, UNSW@ADFA Library, MS 184 folder 2. 
However, it was not until the eve of war that Cabinet approved proposals for the extended training of about 15000 Militia and improved training for the Militia as a whole. What they were not prepared to do as late as August 30, when the Prime Minister 'harangued' all the Service Boards together, was spend any more money than had already been allotted. ${ }^{54}$

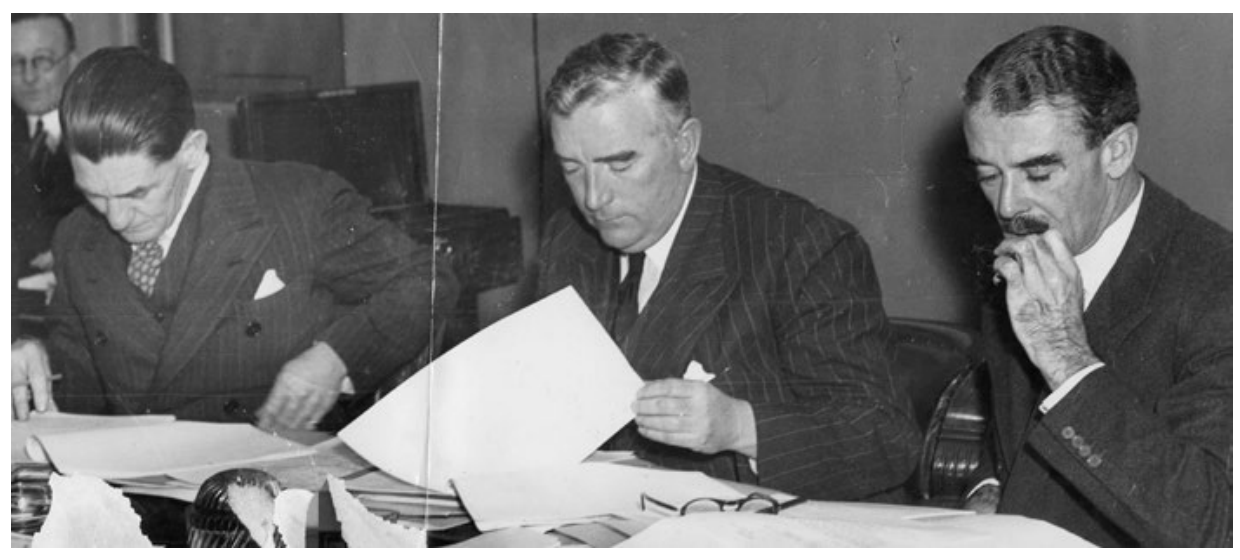

\section{Defence Councillors: Street, Menzies, and Casey}

(Argus Newspaper Collection of Photographs, State Library of Victoria, H99. 201/20589)

\section{War Minister}

On Friday, 1 September 1939, Councillor Street was making one of his now rare appearances at a Hampden shire council meeting. Called from a committee room late in the afternoon he bounded down two flights of stairs, ran to his car, and sped to Melbourne. It was the last time he was to be seen at a council meeting. ${ }^{55}$ The next day a Federal Executive Council meeting, with the Governor of Victoria, Sir Winston Dugan, acting for the Governor-General, concluded that it was time to 'proclaim the existence of danger of war'. The proclamation was signed by the Minister for Defence 'G. A. Street'. In the terms of the Defence Act, ministers had in effect declared that they were now in 'a time of war'. When ministers emerged from a long Cabinet meeting on Sunday, September 3, alerted to the British government's intention to set Germany a deadline for assurances that it would withdraw its forces from Poland, it was Street as Minister for Defence who communicated a simple message: the fighting services were ready; the public were calm. ${ }^{56}$ Later that night the Director of Military

54 Squires diary, 1, 2, 3, 23, 30 Aug. 1939, UNSW@ADFA Library, MS 184 folder 2.

55 The Lismore Advertiser, 21 Aug. 1940.

56 Canberra Times, 4 Sept. 1939, p.2. 
Intelligence, Colonel 'Boz' Combes, arrived outside the minister's office where Street's assistant private secretary, Garry Armstrong, was awaiting news from London of the declaration of war:

'Can I see the minister?' I opened the door and hesitated there, and Combes said to him, 'well it's on sir.' With twinkling eyes the minister jumped up and said 'Oh grand Boz. Have you got the signal from the War Office?' 'No sir,' he said 'I heard it on 3DB. ${ }^{.57}$

Meanwhile, in Treasury Place the group called to constitute the Federal Executive Council had heard the announcement from the BBC. With war declared, the Prime Minister's 'melancholy duty' to inform the nation performed, Menzies suggested that there should be a toast to peace. Neither glasses nor anything to drink could be found at the Commonwealth offices, so the Prime Minister's assistant private secretary, was dispatched to Jim Fairbairn's nearby flat at Alcaston House on the corner of Spring Street and Collins Street. Within half an hour the assembled ministers, Sir Winston Dugan acting for the GovernorGeneral, and several private secretaries, had toasted peace. The Army Minister, at his desk in Victoria Barracks, was already prosecuting the war. ${ }^{58}$ At 10.25 p.m. the Defence Department Secretary Fred Shedden sent a copy of the 'War' telegram received from the Dominions Office to the Secretary of the Military Board. Stamped 'Most Immediate', it was initialled by the Acting Chief of the General Staff 10 minutes later. In his excitement Shedden had signed and dated the covering minute ' $3 / 9 / 38^{\prime}$. It could not have been more immediate. ${ }^{59}$

The first few weeks of war brought rapid changes of organisation. As Defence Minister, Street brought to Cabinet a paper prepared by Fred Shedden on 'Machinery for Higher Direction of War' ${ }^{60}$ As a member of the resulting War Cabinet, Street was an inevitable leading participant in conclaves with the Service chiefs and the Prime Minister. There was much hesitation and uncertainty about the way in which a manifestly ill-equipped and under-resourced Army, desperately short of trained officers, could best be put on a war footing. On September 15 Menzies announced a scheme for raising an expeditionary force of 20000 and the call up of the Militia in two groups for a month's continuous training. ${ }^{61}$ Three days later, after two hours with Squires who went with him

\footnotetext{
57 Garry Armstrong, taped reminiscences, Nov.-Dec. 1982; Gavin Long, To Benghazi, Australian War Memorial, Canberra, 1961 (1st ed. 1952), pp.33-4.

58 Sir Cecil Looker, interview with Alan Hodgart, 1975, (NLA Oral TRC 370; nla.gov.au/nla.cat-vn87421). Realising it was a historic moment, Looker souvenired one of the glasses.

59 'Record of Government decisions just prior to and after the outbreak of War 3rd September 1939', AWM: $54243 / 6 / 153$.

60 G. A. Street, 'Machinery for Higher Direction of War', Most Secret, 28 Aug. 1939, and Cabinet decision, 26 Sept. 1939, NAA: A2671,12/1939.

61 Jeffrey Grey, The Australian Army, The Australian Centenary History of Defence, vol. I, Oxford UP, South Melbourne, 2001, pp.107-22.
} 
to a conference with the Prime Minister, Shedden, and the other two Service chiefs, Street kept Squires back for a further talk with Menzies. Street intimated to the CGS that the government wanted him to stay on in Australia rather than return to Britain.

The next day in Canberra Street publicly explained the plans for the Militia and the proposed 'Special force'. It was a good speech, Squires noted, 'but that hasn't \& probably won't silence the storm of abuse in certain papers, nor their fantastic suggestions, made quite regardless of facts' ${ }^{62}$ The storm of abuse went to the fundamental policy of the maintenance of two armies. It was hoped that half of the volunteer army would be former militiamen, another quarter would have previous Militia service, and the rest would be from country areas where Militia training had been largely in abeyance since the early 1920s. They would be eligible for overseas service in the $6^{\text {th }}$ Division. The residual Militia would not. The ensuing recruitment drive was lacklustre, and some Militia commanders openly discouraged their men from volunteering for the AIF. ${ }^{63}$

It would have been strange had the government, and the Defence Minister in particular, not been the focus of press criticism and discontent in the early months of the war. Although the announcement that Sir Thomas Blamey would command the troops being gathered to send overseas was popular, subsequent general officer appointments had a mixed reception. And alleged deficiencies and dilatoriness in mobilising resources made Street and Squires, who had moved his belongings into the room of the Chief of the General Staff on October 14 , easy targets. Late in October the government announced that compulsory military training - three months for 20-year-olds - would be introduced in January. The numbers called up, the CGS noted, would be those required 'to fill gaps in the Militia caused by transfers to the $2^{\text {nd }}$ AIF \& the withdrawal (to a Militia reserve) of married \& "key" men'. Street had discussed it with Squires several times. But the Military Board had not been consulted. 'Strange people, these politicians,' Squires commented. ${ }^{64}$

Stranger still were the political masters of the armed services as the months wore on. As Squires confided to his diary, 'the position of the Chiefs of Staff vis-à vis the Cabinet is becoming quite impossible; \& it's becoming equally impossible to plan for the future without knowing what we are planning for ${ }^{6}{ }^{65}$ Most vexing was the continuing delay in settling on the despatch of the $6^{\text {th }}$ Division. For this, and many other frustrations, Squires realised that Street was not to blame. In a 'personal and confidential' letter to his predecessor John Lavarack he had explained a few weeks after the war began:

62 Squires diary, 18, 19, 23 Sept. 1939, UNSW@ADFA Library, MS 184 folder 2.

63 Jeffrey Grey, A Military History of Australia, Cambridge UP, Melbourne, 2008 (1st ed. 1990), pp.146-8.

64 Squires diary, 21 Oct. 1939, UNSW@ADFA Library, MS 184 folder 2.

65 Squires diary, 28 Nov. [wrongly dated by Squires ‘Dec.'], 1939 UNSW@ADFA Library, MS 184 folder 3. 
I'm terribly sorry for Street, he's having an awfully difficult time, as he says the Cabinet contains 15 Defence Ministers, \& their interference with what are purely domestic Army matters is becoming intolerable. They apparently regard themselves as entitled to decide everything for us - including appointments! Luckily Menzies is realizing at last the futility of the present method of conducting business, \& the War Cabinet is to start functioning next week. ${ }^{66}$

A multiplicity of Defence ministers had its frustrations but it also had some benefits. In the early months of the war Street's portfolio still embraced the RAAF. There were big decisions to be taken about the role of the Air Force and it quickly became obvious that the burden had to be shared.

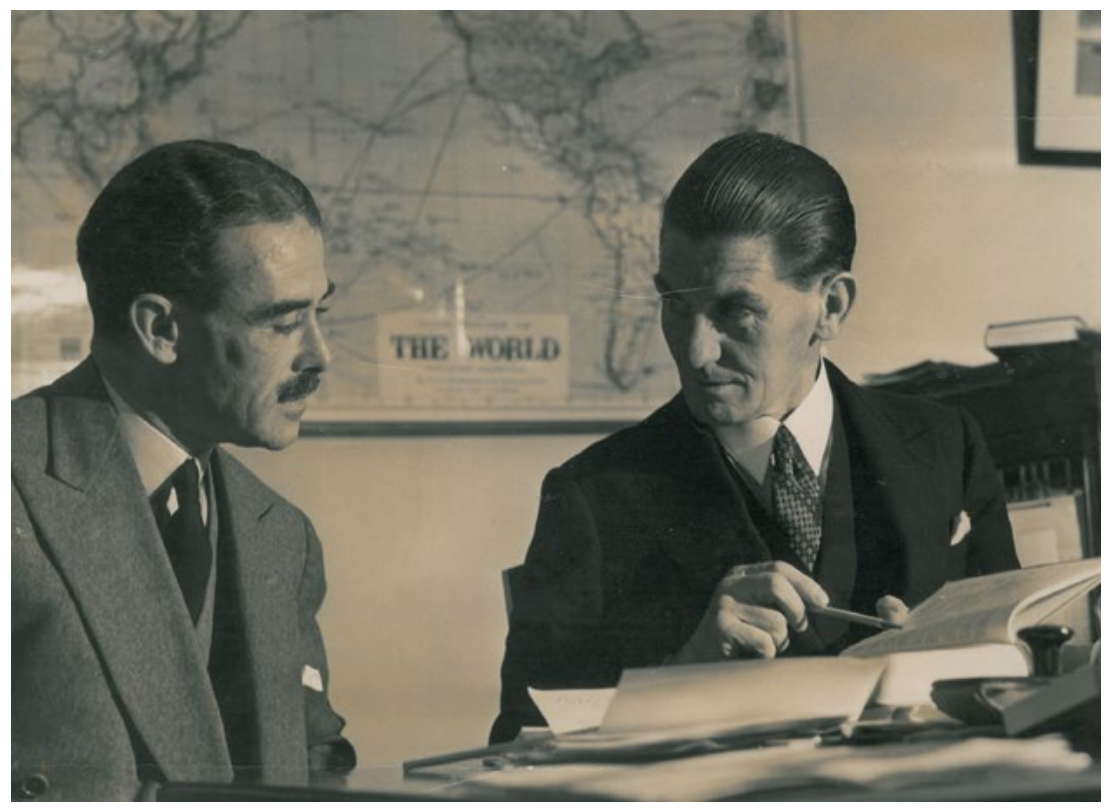

\section{Getting down to war: the Ministers of Supply and Development and Defence, 30 September 1939}

(Courtesy of the Hon. Tony Street)

Dick Casey, as Minister for Supply and Development, took up procurement and production, and Civil Aviation Minister Jim Fairbairn picked up questions of facilities and training. From mid-November all aviation issues would come within the purview of the new Air Ministry. But, in the meantime, some matters were unavoidably the responsibility of the Defence Minister. Street was thus embroiled in the conflict between the Chief of the Air Staff, Air Vice Marshal S. J. Goble, and the Air Member for Personnel, Air Commodore J. C. Russell,

66 Squires to Lavarack, 22-24 Sept. 1939, Lavarack Papers, UNSW@ADFA Library, MS 164 Box 4, folder 13. 
who was on secondment from the RAF. When taxed by Street on 11 November 1939 with the Cabinet's concern over a 'reported lack of co-operation' between members of the Air Staff and other branches, Goble had responded that Russell had been 'a great hindrance to progress' and had 'stubbornly refused to adjust himself to local conditions and regulations and has shown marked inconsistency and unreliability in his opinions and statements on service matters'. Goble made the mistake of concluding that: 'I find it impossible to carry on unless there is stability in the direction of the Branch of the Air Member for Personnel.' His private and confidential letter was passed by Street to the Prime Minister. ${ }^{67}$

By the end of the year, Goble's fate was sealed. The appointment as Chief of the Air Staff of 58-year-old Air Chief Marshal Sir Charles Burnett, nominally one of two Inspector-Generals of the RAF, was announced by the Prime Minister on 5 January 1940. Russell, who had blotted his copybook with Menzies as well, was shortly to return to the United Kingdom. ${ }^{68}$ After a period of leave, the hapless Goble was sent to Canada to look after the Empire Air Training Scheme there. As if to epitomise his propensity to make seriously poor choices, Goble and his wife were passengers on the ill-fated Niagara en route to Vancouver in June 1940. They were lucky to be rescued when the ship, carrying a fortune in gold and a large quantity of small arms and ammunition, struck a mine and sank in the Hauraki Gulf, north of Auckland. ${ }^{69}$

\section{'One of the most deceptive men in the Federal Cabinet'}

Street, like the Prime Minister, as well as Fairbairn, Gullett, and the Country Party's John McEwen, had homes in Victoria. Melbourne was the preferred venue for War Cabinet meetings. There were strong practical reasons for this since Canberra meetings, usually confined to periods when Parliament was sitting, entailed the transfer and accommodation of staff and the transport of voluminous files. ${ }^{70}$ Menzies had been determined that Canberra should not be a deserted village when Parliament was not in session. But the gravitational pull of Melbourne remained powerful. From mid-November 1939 the Defence ministry was split into separate Navy, Air, and Army departments. This 'drastic re-arrangement', as the Prime Minister described it, was 'in no sense a reflection

67 AVM S. J. Goble (CAS) to Minister for Defence (Street), 12 Nov. 1939, Menzies MSS, NLA MS 4936/579/4.

68 The Russell-Goble affair is summarised in Coulthard-Clark, The Third Brother, pp.460-63.

69 A rumour sweeping the Niagara's 1st class breakfast tables that Goble wore a corset had been confirmed when some enterprising young women disrobed him at a party in the captain's cabin the night before the disaster (Keith Gordon, Deep Water Gold: The story of RMS Niagara - the quest for New Zealand's greatest shipwreck treasure, SeaROV Technologies Ltd, Whangarei, 2005, pp.34-5).

70 Horner, Defence Supremo, pp.81-2. 
on my colleague...the best tribute I can pay to my colleague's labours is implicit in the fact from now on there will be three Ministers busily employed in doing what he has been doing alone for some time past $^{\prime} .^{71}$

His labours now focused on Army matters, Street's office at Victoria Barracks was on the first floor of the northern wing, across the corridor from Fred Shedden, now the Secretary of the Department of Defence Co-ordination and Secretary of the War Cabinet. The minister was close to the Chief of the General Staff. And to the evident approval of Squires he attended a meeting of the Military Board for the first time on 23 January 1940. ${ }^{72}$ It had been an auspicious day as 5000 Victorian members of the $2^{\text {nd }}$ AIF marched through a throng estimated at 500 000, the largest crowd ever seen in the city streets. The 'noble bearing' of the men 'has touched our hearts', Street said. 'Today's great march was more than symbolical: it was proof that the spirit of the old A.I.F. has survived.' There was something also more than symbolical in the Army Minister's conclusion. The Prime Minister had praised the demeanour of men and onlookers for their 'quiet seriousness and determination which have really been the characteristics of the British people in this war'. Street, knowing his audience better, struck a different note, national not imperial: the men of the $6^{\text {th }}$ Division were leading 'Australia's crusade for justice and permanent peace' ${ }^{73}$

'Mr Street is one of the most deceptive men in the Federal Cabinet,' the Sydney Morning Herald's Canberra correspondent had written just before the outbreak of war. 'He is almost invariably underestimated on first acquaintance, because of his restraint, courtesy, and unassuming manner.' He was, recalled Frank Green who, as Clerk of the House of Representatives, observed him at close quarters, 'a quiet man, but of the kind in whom ordinary people have confidence'.$^{74}$ Owing much to unaffected geniality, Street's public popularity also reflected skilful use of the press. 'An unheard-of innovation', the appointment of a press officer to the Defence Department, embodied the new minister's belief that 'as far as possible the people of Australia should be told what we are doing and how their money is being spent' ${ }^{75}$ The 'press and information officer', Allan Dawes, made sure that editors were served with lively biographical material on his chief. Not that Street seemed to need much coaching on press relations. He instinctively knew what reporters and photographers needed. His cricket library, 'a result of the activities of dealers and collectors all over the world', made good copy as it grew from 500 to 600 volumes. He would happily pause in open-necked shirt

$71 C P D$, vol.162, 15 Nov. 1939, p.1131.

72 Squires diary, 23 Jan. 1940, UNSW@ADFA Library, MS 184 folder 3.

73 Sydney Morning Herald, 24 Jan. 1940. In an Australia Day broadcast for England, Menzies made some amends: 'the major element in the British genius' was that it had been able to 'reconcile the unity of an Empire with the independent development of the individuality and character of each of its parts' (The Age, 26 Jan. 1940).

74 Sydney Morning Herald, 26 Aug. 1939; Green, Servant of The House, p.118.

75 The Sun, 22 Nov. 1938. 
and shorts when caught on the Canberra golf course in hot weather. He would strike a Victor Trumper-like pose while getting some batting practice before going out to play for the MCC with the great Bill Ponsford and the brilliant Victorian batsman Percy Beames against a Fremantle XI.

The Minister's cricket exploits were a source of endless fascination, whether it was his multi-wicket hauls with 'vicious' leg spin or bamboozling Arthur Mailey, Herbie Collins, his wartime friend Charles Kelleway, and others with his prodigious memory of their statistics and performances. Or simply the fact that he was chosen to play alongside Bill Woodfull and Jack Ryder in an Australia v. England night match organised for charity at the Exhibition Building by the Australasian Electric Light Cricket Association. Street's comfort with the press contrasted with the Prime Minister's indifference. Touring naval dockyards in Sydney in January 1940, the Defence Minister fretted as Menzies turned his back and covered his face with his hands when reporters saw him taking an interest in the chart room. The Prime Minister was 'a nightmare to his publicity man'. Reporters noticed that Street persuaded Menzies to pose later in front of a gyro compass aboard a cruiser exercising with live shells outside Sydney Heads. $^{76}$

As Army Minister it was Street's responsibility and prerogative to recommend the officers to hold the most senior military appointments. Probably no minister before or since was so intimately acquainted with the candidates for promotion. He had served with many of them. Just over a year before war broke out, he had spent a week enrolled with 28 major generals, brigadiers, and colonels at the new Command and Staff School in Sydney. ${ }^{77}$ Resigning his commission on entering the Cabinet had been a sad moment. But it would not do to be his own superior yet junior to those whose futures were in his hands. With the expansion of the $2^{\text {nd }}$ AIF into a Corps, and Blamey's elevation as Corps Commander, there were two divisional commands to fill in March 1940. Conscious of the rivalries between Staff Corps and Militia officers, and personally acquainted with all those who were qualified, he opted for the former CGS, Lieutenant General John Lavarack, for the $6^{\text {th }}$ Division and Major General Iven Mackay (under whom he served in 1918) for the $7^{\text {th }}$. The proposal of the volatile Lavarack for the $6^{\text {th }}$ Division appalled Blamey, who catalogued Laverack's 'temperamental disqualifications' both for the Army Minister and the Minister for Defence Co-ordination. (Writing to the Prime Minister in his capacity as Minister for Defence Co-ordination was a fig leaf of protocol to cover the inappropriateness

\footnotetext{
76 C. J. Lloyd, Parliament and the Press: The Federal Parliamentary Press Gallery 1901-1988, MUP, 1988, p.127 citing The Journalist, Feb. 1940; Sun Pictorial, 31 Jan. 1940; The Herald, 4 Jan. 1939. For Menzies' relations with the press at this time, see Warren Edward Denning, 'Robert Gordon Menzies', n.d. (1945?), Denning MSS, NLA MS5129; Allan Dawes' 'biographical sketch' of the Defence Minister, Street MSS, courtesy the Hon. Tony Street.

77 Sydney Morning Herald, 9 Aug. 1938.
} 
of going over Street's head). 'Uncontrolled outbreaks,' he wrote, 'have been all too frequent in his work, in the presence of junior officers, in private places, and in the sporting field.' Blamey asked for the opportunity to discuss the matter with Street, Menzies, and 'if you think fit, General White'.

Obviously afraid that Street would ignore his plea, Blamey sent a copy of his letter to Menzies with a covering letter damning Lavarack as not appearing to have 'the necessary amount of stability and wisdom in his make-up to be entrusted with this responsibility practically away from all control'. Friction was inevitable, Blamey warned. The friction Menzies apprehended in the first instance was Street's reaction if he read Blamey's excuse for writing direct to the Prime Minister. Blamey explained that he was not sure that his letter, sent three days earlier, would have reached Street. In a pencilled note to his private secretary, Menzies instructed 'Do not pass on!' Blamey was firmly put in his place. Menzies would discuss the matter with his colleagues, and would treat his correspondence as confidential. Not content to rely on the ordinary mail to reach the Prime Minister in time, and having received no reply from Street, Blamey sent copies of the previous correspondence together with a second protest at an appointment that would be 'terribly unwise'. Probably suspecting as well the malign hand of Fred Shedden, no friend of Lavarack, Street had already written to the Prime Minister in his own hand before Blamey's second letter was despatched:

Both Squires \& White agreed that Lavarack was the man for the job. The Military Board recommended Lavarack. I know his failings but I also recommend him.

Blamey does not like him \& says 'I fear greatly the cool judgment necessary in war will be lacking particularly when things are going wrong and the pressure is on.'

I have given very careful consideration to General Blamey's viewpoint. Notwithstanding all he says I stick to my recommendation which is I am sure sound.

Both Sturdee and Wynter would do the job well — in fact there are others who could doubtless do the job well — but I think Laverack is the best. It will be well received in the Service \& I think the only person who will not be satisfied will be Blamey (\& perhaps Jess!).

Street rang Corby Tritton, the Prime Minister's private secretary, urging him to ensure that the matter was dealt with promptly. Ministers needed to be consulted. Until the divisional commanders were named, no action could be taken on appointing the staffs to the Corps and divisional commands. 'I also want to beat the press to any announcement that may be made!' It was two 
weeks before the appointments were confirmed by the War Cabinet, the minutes discreetly recording that 'The Chief of the General Staff and the G. O. C. of the Australian Army Corps were consulted separately. ${ }^{78}$ Blamey, apparently with Brudenell White's support, succeeded in thwarting Laverack's appointment to the $6^{\text {th }}$ Division which went instead to Iven Mackay. Laverack, taking a step down in rank, went to the $7^{\text {th }}$ Division.

Much as he was absorbed in the work of the Army and War Cabinet, Street chafed at the limits of his authority, attenuated by an unbounded Prime Ministerial ego and Fred Shedden's unsleeping drive for control. He yearned to be closer to the battle front. When the British government indicated that it would like to have a Light Horse Brigade and attendant troops he made it clear to Menzies that he wanted to take his place at its head. His desire to escape and serve in uniform had clouded his judgment. As the Governor-General Lord Gowrie confided to the Prime Minister:

As regards the Command of the Brigade, you mention that Street was very anxious to obtain it, but do you think that would be altogether wise an appointment? I am sure he would make an excellent Commander in every way, but I am rather afraid his appointment might cause a good deal of heart-burning in Light Horse ranks. There are a splendid lot of men to choose from and don't you think they might be a little bit annoyed if the Minister for the Army was instrumental in appointing himself to what may be the only Light Horse Command for foreign service? I know, of course, that the appointment would be made by the War Cabinet and not by Street himself, but he would always be accused of having influenced his own appointment. ${ }^{79}$

As it turned out, the idea of forming a Cavalry Brigade was dropped a few weeks later at almost exactly the same time as an article that looked like a job application - 'a vigorous vindication of the cavalry arm' - appeared under Street's name in the Sydney Morning Herald.$^{80}$ Two days later it became clear that destiny still had plans for him. Stopping on his way home to talk to an officer outside Victoria Barracks he stepped a few paces backwards just as a large pane of glass crashed to the ground from a third storey window. 'It might have killed $\mathrm{me}^{\prime}$, he told a reporter. ${ }^{81}$

78 Street to Prime Minister, 8 March 1940, 'Most Confidential'; Blamey to Menzies, 11 March 1940, with enclosed copy Blamey to Street, 8 March 1940; Menzies to Blamey, 12 March 1940, copy, Blamey to Menzies, 12 March 1940; Street to Menzies, 11 March 1940, Menzies MSS, NLA MS 4936/579/5; Minutes of War Cabinet Meeting, 21 March 1940, NAA: A2673.

79 Lord Gowrie to Prime Minister, 25 March 1940, Menzies MSS, NLA MS 4936/579/5.

80 Telegram, Prime Minister's Dept to Sec. of State for Dominion Affairs, 6 April 1940, copy, Menzies MSS, NLA MS 4936/581/23; 'The Light Horse in War', Sydney Morning Herald, 3 April 1940. The Military Board and senior officers had been debating the utility of various possible mounted infantry and mechanised cavalry units (Captain James C. Morrison, Mechanising an Army: Mechanisation Policy and the Conversion of the Light Horse 1920-1943, Study Paper No. 307, Land Warfare Studies Centre, June 2006, pp.57-68). 


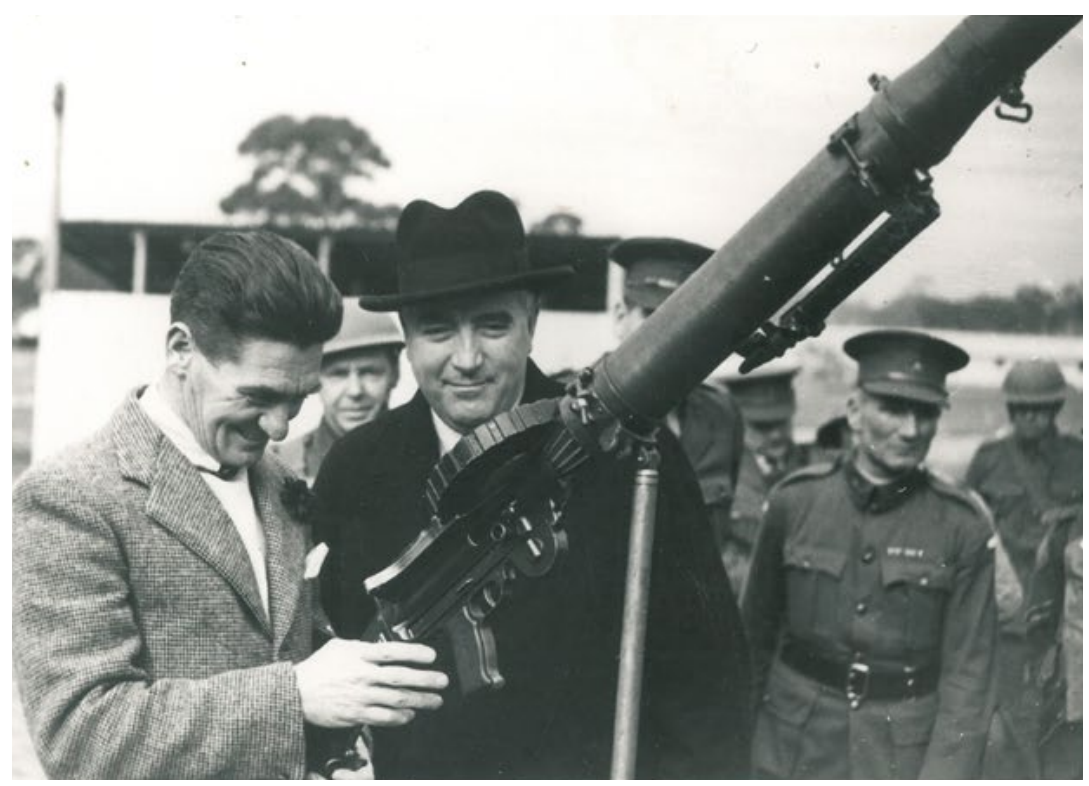

\section{Geoff Street and a 'slightly de trop' Prime Minister}

(Courtesy of the Australian War Memorial)

Talking to Australian newspapermen in New York, Dick Casey heard of 'a good remark of Geoff Street's - Australia to Britain - "We remain, Yours faithfully"'. ${ }^{82}$ The phrase was in fact the end of a robust speech Street had delivered at Avoca on 3 August 1940. He condemned rumour mongering and destructive criticism, 'not merely useless, it is noxious and even dangerous'. Contrary to German propaganda that Australia had declined to send more men abroad to aid the British cause: 'We have refused nothing, and will refuse nothing, not a man, not a machine, not a shilling, not a shell, to Great Britain.' Like everyone in the upper reaches of the Australian government, the Army Minister was attuned to the delicate balance of imperial and national interests. He also understood the need not only to maintain the morale of the population at large but also among the troops in training.

No one at the Puckapunyal camp would ever forget the day the minister turned up for an inspection, asked if a horse could be made available, and cantered around the installations in jodhpurs and a canary yellow shirt. Street's jodhpurs, open necked shirts, and sports jackets served him well on visits to other camps, earning him press plaudits when the Prime Minister was thought to be 'slightly de trop' in a Homburg hat and 'a great black overcoat worthy of the Archbishop of Canterbury'. 
Reporting in detail on Street's tireless visits to Service units around the country, his note-taking and recording of details on a miniature camera, the regional press and afternoon tabloids displayed unquenchable interest in the Army Minister. Their enthusiastic stories about 'A.M.', as the troops called him because of his early morning inspections, more than compensated for the occasional policy grumblings and chidings of the metropolitan broadsheets. ${ }^{83}$

Obliged to travel up and down to Canberra regularly, Street was one of the first ministers to experience the RAAF's new Lockheed Hudsons. On April 29 he joined Sir Charles Burnett in a Hudson of No 1 Squadron to fly to Canberra and back in one day. ${ }^{84} \mathrm{He}$ was happy enough to take the train when there was no rush. If the Prime Minister was on board, they might swap cricket stories and statistics over dinner. Then he would retire to the compartment he shared with Garry Armstrong, the young officer, law graduate, and family friend of Brudenell White whose appointment to the minister's office had been forced on Fred Shedden in April 1939. Armstrong knew he could expect to be woken early wherever they were and put through a set of exercises. When Street stayed in Canberra, Armstrong would be called out from his bed on the balcony of the Hotel Canberra at 6.00 a.m. for a three or four-mile run around the Royal Canberra golf links. Percy Spender and Bill McCall, the baby of the House of Representatives, would occasionally join them. To Armstrong, 20 years Street's junior, his chief's relentless physical fitness regime was balanced by 'a lightning mind, a grand sense of humour'. In his mid-40s, at the height of his powers, Geoff Street was 'a lean, virile, subtle man' of boundless energy. In Melbourne, he lunched frugally at his Victoria Barracks desk, sometimes foregoing lunch altogether to go ice-skating. He rarely drank, and never smoked. Admired by public servants, he was trusted by senior military men who could rely on him to understand their point of view, tell them plainly if he disagreed, and fight their cause in the War Cabinet. 'Soft voiced, and with a delightful boyish smile', he was liked and respected on both sides of the House. ${ }^{85}$

Next to the Prime Minister, Street was by mid-1940 the most prominent member of the government. With the AIF $6^{\text {th }}$ Division raised, the $7^{\text {th }}$ Division and the Corps Troops being recruited, the decision to form an eighth division announced by the Prime Minister late in May, and Bertie Lloyd freshly installed as DirectorGeneral of Recruiting, Street knew the time had come for a major appeal for men: 'As Minister for the Army it is I who should make his voice ring clearly.' Newspapers in his electorate and around the nation published his speeches and radio broadcasts verbatim. They were replete with exhortations to the manhood

83 The Argus, 28 Oct. 1939; The Herald, 29 June 1940; The Sun, 19 July 1940; The Stawell News, 20 July 1940.

84 No. 1 Squadron Operations Record Book, NAA: A9186, 1/176.

85 Garry Armstrong, taped reminiscences, Nov.-Dec. 1982; A. A. Street to CH, 31 March 2010; Sydney Morning Herald, 22 March, 14 Aug. 1940. 
of Australia to join the forces and resist the 'mailed fist of the marauder thrust into our very faces... The march of the horde of the Huns must be stopped...We are fighting savages.' ${ }^{\prime 86}$

Uncomfortable as he might be with such rhetorical excess, Street was ever alert to opportunities to promote the ministry's more prosaic activities. He announced on August 6 that the government was going to purchase 2000 Australian-made bicycles. The machines did not herald the formation of a cyclists' corps. Rather, they were to be available for signallers and battalion runners in AIF and Citizen Force units. ${ }^{87}$ In the great scheme of things for which he was responsible, the 2000 bicycles were a trivial diversion. More serious were the hospital matters brought to him in the evening of August 12 by Major General Rupert Downes, Director-General of Medical Services, who was pressing for membership of the Military Board. Discussion with Downes would continue late into the night over the vexed question of the Red Cross being the sole agent for gifts for medical services. But when Street excused himself to dine at the Melbourne Club with the Rutherford Guthries, the bicycles were at least something he could talk about without revealing too much of the strategic dilemmas that he and the Chief of the General Staff would be confronting in Canberra the next day. ${ }^{88}$

\footnotetext{
86 Colac Reformer, 25 May 1940.

87 Canberra Times, 7 Aug. 1940, p.4.

88 'Report of the DGMS 13/11/39 to 10/4/42 in the form of War Diary', 12 Aug. 1940, AWM: 54 481/1/27 PART1; Ian Howie-Willis, Surgeon and General: A Life of Major-General Rupert Downes 1885-1945, Australian Military History Publications, Loftus, 2008, pp.359-61 for Downes' death in the crash of Hudson A16-118 in 1945; Sir Rutherford Guthrie to CH, 15 June 1983.
} 


\section{Best man: Frank Thornthwaite}

As he crossed the Essendon tarmac to take his place in the waiting Hudson, Geoff Street was accompanied by another old friend. A very dear friend. A neighbouring pastoralist at Derrinallum. A wartime comrade in arms. The man who had stood at his side on his wedding day in London in 1918. The man for whom he himself was best man at St Columba's Pont Street, London, on 23 November 1918. The man married to his wife's cousin and closest friend, Lorna Maud Inez Currie, always known as Inez.

Lieutenant Colonel Francis Thornthwaite, who had driven out to the aerodrome with the Army Minister, had been a career artillery officer with a distinguished record in the Great War. ${ }^{1}$ Recalled to service just before the German invasion of Poland, he was now a General Staff Officer I in the Department of the Army, assigned as Army Liaison Officer attached to the Department of Defence Coordination. In practice he was the Chief of the General Staff's right-hand man. Born in Launceston in February $1890,{ }^{2}$ Francis Thornthwaite was the son of William Wright Thornthwaite, an immigrant from Manchester who had married Frances (Fanny) Stackhouse, only daughter of the rector of Longford, the Rev. Alfred Stackhouse of the Tasmanian early-settler family, in 1885. William Thornthwaite, almost blind from a childhood accident, was a leading light in Tasmanian musical circles. After training in London in piano, organ, and singing he had arrived in Hobart in 1880 and began at once advertising his services as a music teacher. Soon appointed organist at Hobart's St Andrew's Presbyterian Church he moved to Launceston in 1884 as organist at St John's, then to Paterson Street Methodist Church, eventually becoming Launceston City Organist, conductor of the Launceston Philharmonic Society, and founder of the local branch of the Trinity College of Music. ${ }^{3}$

\footnotetext{
1 For Thornthwaite's life and military career I rely, unless otherwise noted, on his service records (NAA: B884, V159753), the Australian War Records Section Biographical Details form he completed on 24 Feb. 1919 (AWM: 181.11), notes in AWM: 43 A872, the Army List of officers of the Australian Military Force 1940, and newspaper reports. I have also drawn on information in an undated typescript 'Canberra Air Disaster Recalled', in the Thornthwaite MSS, apparently a draft of H. J. Manning's article, 'Air Disaster at Canberra', Stand-To, Jan.-Feb. 1962, pp.6-22; and letters and recorded memoirs by the late Inez Thornthwaite.

2 Date of birth is given as 1891 on some Army records but is corrected on several to 1890, the year given in the ADFA AIF project. His school enrolment entry also shows 1890. I am grateful to Thomas Gunn, Archivist of Launceston Grammar School, for details of Thornthwaite's school years.

3 The Examiner, 8 Jan. 1940. The ACT Coroner's report on Francis Thornthwaite described the father of the deceased as a grazier but I have found no evidence to confirm this. At the time of his son Ralph's enlistment in 1915 he was living in Kew in Melbourne (NAA: A1378, P8903; B2455). 'The Rev. W. W. Thornthwaite' was later minister in charge at the Catholic Apostolic Church in Redfern (Canberra Times, 21 Oct. 1927, The Argus, 27 Sept. 1937). He died after being run over in a Sydney street in Dec. 1939, his wife having predeceased him in 1933.
} 
William, still in his twenties, and Fanny (10 years his senior) already had two children when Francis was born; and a fourth soon followed. Educated at Launceston High School - a small independent establishment soon to hit hard times and merge with Launceston Grammar School - Francis had dropped out of the Bachelor of Arts course at the University of Tasmania and enlisted in the Army a few months before his twentieth birthday. ${ }^{4}$ Commissioned as a lieutenant in the Royal Australian Garrison Artillery in December 1910, he completed a short course in gunnery and then a master gunner's course, and transferred to No. 2 Battery, Royal Australian Field Artillery a year later. ${ }^{5}$

Within two weeks of the outbreak of war in August 1914 Frank Thornthwaite, as he came to be known, enlisted in the Australian Imperial Force. Army records noted that he was 5' 10" tall and weighed 12 stone; he had 'good' eyesight and a 36/38" chest. In October 1914 he left Australia on the Argyllshire with the AIF's First Division Artillery. He was among the earliest to reach Gallipoli on 25 April 1915 with the first Australian battery. But, in the ensuing chaos in finding suitable emplacements for the ANZAC Corps guns, all four Australian batteries spent the next two weeks watching the action from troopships. They were then sent to Cape Helles, attached to the British $29^{\text {th }}$ Division. Hospitalised briefly in Malta, Thornthwaite returned as adjutant of the Australian First Division Artillery from October to December 1915. For six weeks, on flimsy sheets of graph paper, he kept diary notes of the daily routine of enemy shelling, 'retaliation rounds' on Turkish trenches, preparation of new gun pits, repositioning of guns, and construction of 'funk pits'. The faithfully-listed names of sick, wounded, and killed, were punctuated by a rare 'casualties nil'. From late November the gathering momentum of evacuation is recorded:

November 20:

Guns and limbers of 2nd Battery and all ammunition wagons less two of the 1st Battery moved from Shrapnel Valley to Reserve Gully ready to be embarked. All vehicles stripped and ammunition removed. Fatigue party manhandled vehicles from Rest Gully to bottom of Reserve Gully.

Vehicles were not embarked but were parked ready to be embarked at short notice.

\footnotetext{
4 Launceston High School, not to be confused with the later state school of the same name, amalgamated with Launceston Grammar in 1913 (Alison Alexander, Blue, Black and White: The history of Launceston Church Grammar School 1846-1996, Launceston, 1996, p.77).

5 For the context of Thornthwaite's military career, David Horner, The Gunners: A History of Australian Artillery, Allen \& Unwin, St Leonards NSW, 1995, and David Coombes, The Lionheart: A Life of LieutenantGeneral Sir Talbot Hobbs, Australian Military History Publications, Loftus, 2007, are invaluable.
} 


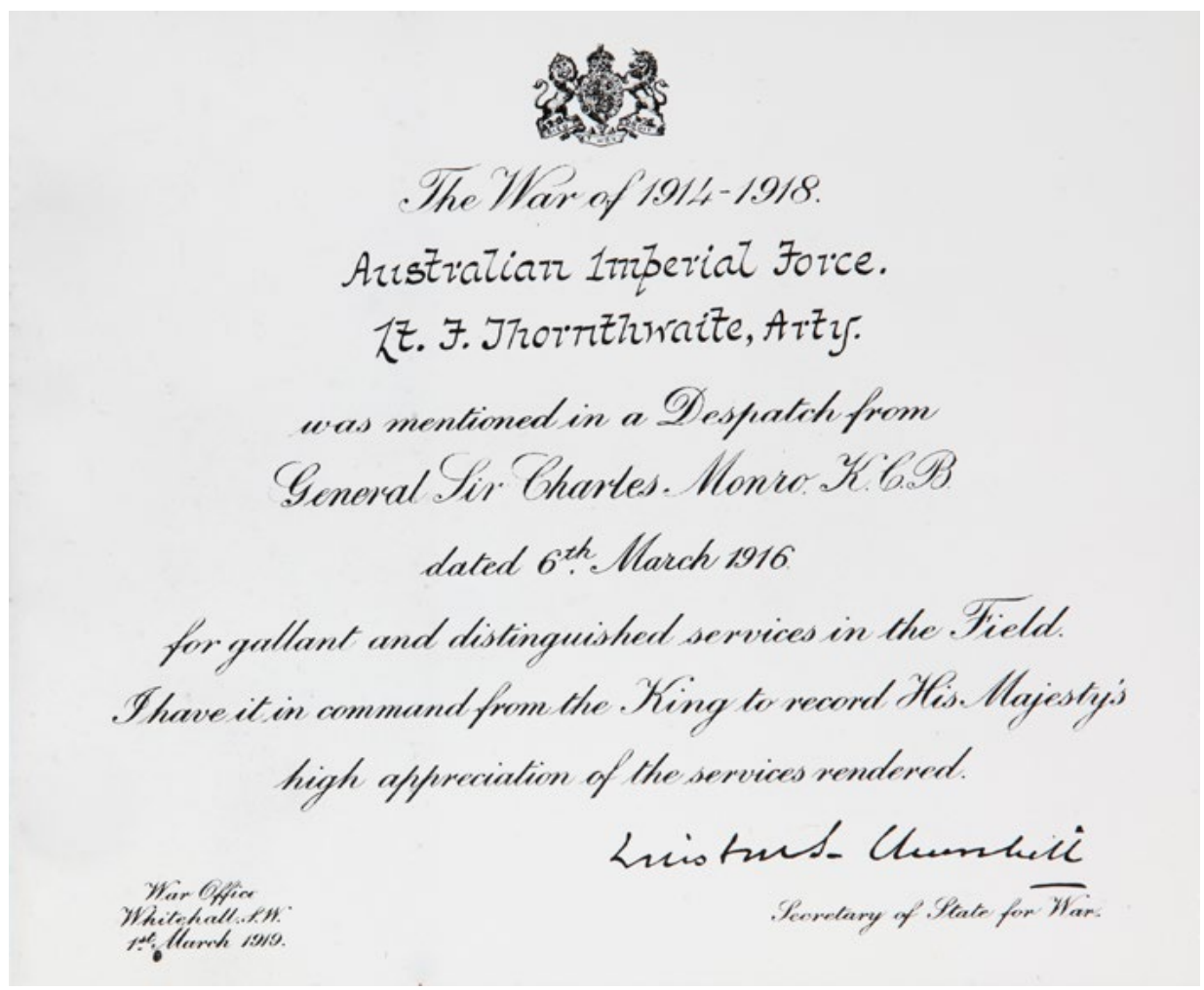

\section{Mentioned in Despatches, a belated appreciation}

(Courtesy of Inez Thornthwaite)

The next day, 92 reinforcements arrived and were posted to units. Bad weather prevented the loading of the guns and wagons until the $23^{\text {rd }}$ when they were embarked on lighters and placed on board H.T. Queen Louise. Then on November 24 begins the laconic record of the operation that was to be synonymous with the name of Brudenell White: 'a conference of Brigade commanders was held at Div. Arty Hd Qrs. It was decided that fire would be withheld from the artillery for the next three (3) days.' After three days, with the batteries not firing:

Report received that the Turks were massing in their trenches at six (6) different points along the line. All precautions taken in case of attack. Nothing eventuated however. Owing to inclement weather embarkation of the remaining vehicles of the brigade was further postponed.

Then the final diary entry:

The silent ruse on the part of the artillery agreed to on the $24^{\text {th }}$ inst. Ended at $24.0027^{\text {th }} / 28^{\text {th }}$ inst. Normal conditions now prevail. 
Heavy fall of snow during the night — and today, making roads impassable for mule traffic. Reserve supply of rations brought into use.

Batteries did not fire.

After departing from the Gallipoli peninsula at the end of 1915, Thornthwaite was to serve in Egypt, France, and Flanders. He was adjutant of the First Field Brigade and Brigade Major of the Fifth Australian Divisional Artillery in Egypt. As the AIF was being vastly expanded, the artillery staffs of the Fourth and Fifth Divisions had the monumental task of increasing the number of batteries from 18 to 60 . Thornthwaite was among a nucleus of experienced artillery men who would gather and train volunteers from the infantry and the Light Horse.

Promoted Major on 26 May 1916, he sailed from Alexandria for France a month later. News of his Military Cross - 'for distinguished service in the field' had come through at the beginning of June. Among those who noticed and wrote personally to congratulate him on the MC 'which your good service has so thoroughly well earned for you', was General Birdwood with the $1^{\text {st }}$ ANZAC Corps. 'We shall be very glad to see the artillery of your division with us here,' Birdwood wrote, 'and I am quite sure it will do just as well as the old artillery we had with us on the Peninsula.' ${ }^{6}$

In France, Thornthwaite could reasonably hope for rather better outcomes than were possible on Gallipoli, where guns and ammunition were in short supply and the terrain frustrated the siting of the howitzers and the flat-trajectory 18-pounder batteries. The gunners had learned valuable lessons summarised by a thoughtful modern scholar:

...the importance of camouflage; the value of counterbattery fire; the use of aerial observation; the relative merits of high explosive and shrapnel; and, most important of all, the need for centralised command and control of the guns. ${ }^{7}$

Soon in action at the battle of Fromelles, Thornthwaite endured the bitter winter of 1916-17 on the Somme, successively in the $15^{\text {th }}$ and $13^{\text {th }}$ Field Artillery Brigades, and the $5^{\text {th }}$ Divisional Artillery Headquarters. He was evacuated sick to England at the end of February 1917. Transferred first to Fort Pitt Hospital at Chatham, he was soon moved to the Earl and Countess of Darnley's Cobham Hall at Gravesend. A South Australian officer who arrived at Cobham Hall a few weeks earlier described the scene for his parents:

6 Sir W. R. Birdwood to Thornthwaite, 4 June 1916, Thornthwaite MSS.

7 Ross Mallett, 'The Interplay between Technology, Tactics and Organisation in the First AIF', MA thesis, University of New South Wales Australian Defence Force Academy, 1999, pp.44-8. 
It is a fine old country house, and the owner, Lord Darnley, has handed over to the Australian Imperial Forces one wing of the building and the use of grounds as a convalescent home. You may remember, although it was before my time, that the Hon. Ivo Bligh took over a famous English cricket team to Australia, which I believe wiped the floor with the Australians. He married an Australian girl. They are the present Earl and Countess of Darnley. The ground floor of the wing the officers are in is the banqueting-room, and the floor above the ballroom. I am in the ballroom, where there are about 30 beds. The whole place is hung with valuable old paintings. I am sitting under a picture now which was painted by Rubens and is insured for $£ 10,000$. This portion of the building is the newest and was built I think in 1801, the oldest portion, having been built in the 15th century. Lord and Lady Darnley are still using the house, but are at present in London, so I have not met them yet. The district also is historical, inasmuch as Charles Dickens lived in and wrote much about this part of Kent. There is a little hotel in the village of Cobham called the Leather Bottle Inn, which figures prominently in Pickwick Papers. If Dickens were still alive he would, no doubt, write a book about the old chap who keeps it now.

The Darnleys had made space for 50 officers in their state rooms to be administered as an AIF hospital. The Countess, formerly Florence Morphy, daughter of the Beechworth Police Magistrate, helped in the nursing of the wounded, and bore a large share of the expenses. 'Lord Darnley and I help in every way we can by giving comforts - vegetables, fruit, milk, tobacco, etc. to these brave fellows', she would tell an Australian correspondent. ${ }^{8}$ It was no hardship to return there after being gassed in November 1917 and again in August 1918. Still less for Thornthwaite to be able to tell his cricket-loving friend Geoff Street that he had stayed in the luxurious company of the aristocratic couple whose mantelpiece was adorned by the already legendary Ashes urn. It was the beautiful music teacher, Florence Morphy, who had won Ivo Bligh's heart when the English cricketers sailed to Australia in 1892 intent on winning back the recently lamented 'ashes' of English cricket; she had been present when he was jestingly presented with an ash-filled urn at a Christmas Eve party, and the couple were married just over a year later. ${ }^{9}$

8 The Argus, 1 March 1917.

9 For Florence Morphy: Joy Munns, Beyond reasonable Doubt: The Birthplace of the Ashes, 1994. The Ashes story is distilled, with variations, in Rex Harcourt, The Origin of the Ashes: Which came first-The urn or the velvet bag? (www.mcc.org.au) and RIC (Richard Cashman), 'Ashes', Richard Cashman et al., The Oxford Companion to Australian Cricket, OUP, Melbourne, 1996, pp.33-5. 


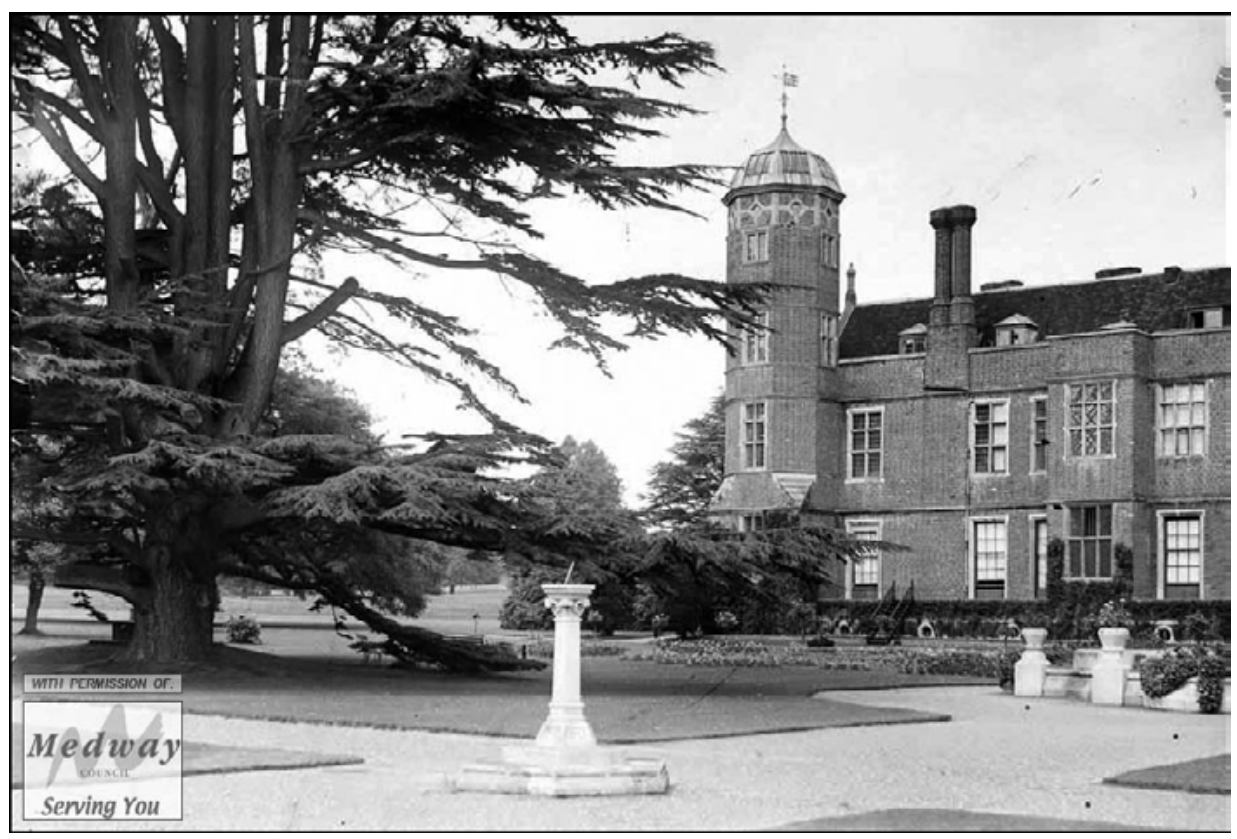

Cobham Hall, seat of the Earl of Darnley, who had dedicated a wing as a hospital for Australian officers. Thornthwaite was admitted 'suffering from mild illness (not yet diagnosed)' in March 1917; and again after being gassed in November 1917 and August 1918

(Courtesy Kent Photo Archive, Medway Council)

After a recuperative spell, Major Thornthwaite was back in France in May, commanding the $50^{\text {th }}$ Battery, $5^{\text {th }}$ Division, AIF. As H. J. Manning records, he served with the $50^{\text {th }}$ Battery at Morchies, facing the Hindenburg Line until the beginning of July.

Then, while the Australian infantry was completing its training in the back areas as a prelude to participation in the Third Battle of Ypres, the $1^{\text {st }}, 2^{\text {nd }}, 4^{\text {th }}$ and $5^{\text {th }}$ Australian Divisional Artilleries were moved up to the Ypres Salient to help support British divisions in the opening phases of this great offensive... The British and Australian batteries, crowded on to the Ypres flats, had to fire from almost naked positions, and the sufferings of the drivers and the gunners were, in general, beyond any in their previous experience, and their casualties such as they had never before suffered...

Thornthwaite's battery was emplaced 1,000 yards forward from the Menin Gate, covering the right of the $15^{\text {th }}$ (Scottish) Division. The initial 
attack was fairly successful, but then the rain started and it continued to pour...turning the churned up battlefield into a morass into which men and animals simply floundered. ${ }^{10}$

Charlie Gatliff, a 35-year-old Lieutenant with the $50^{\text {th }}$ Battery, provides an admiring glimpse of Major Thornthwaite and his environment in letters to his parents on 16 and 19 September 1917:

We have a very strong combination of officers in this battery now Major Thornthwaite MC, who was Brigade Major for our Div. Arty for a long time \& for a little while was B.C. for the $51^{\text {st }}$, is our B.C. \& it would be hard to find a better one - he belongs to our permanent forces, is a good gunner $\&$ administrator $\&$ has a nice personality.

In a brief interval out of the line in France, Thornthwaite's men were:

Situated right on the banks of a canal - billets \& horse lines close together — with a large wood on a hill close behind us. The country is all green $\&$ is very picturesque $\&$ the view from the window of our officers' mess is rather typical of Australia.

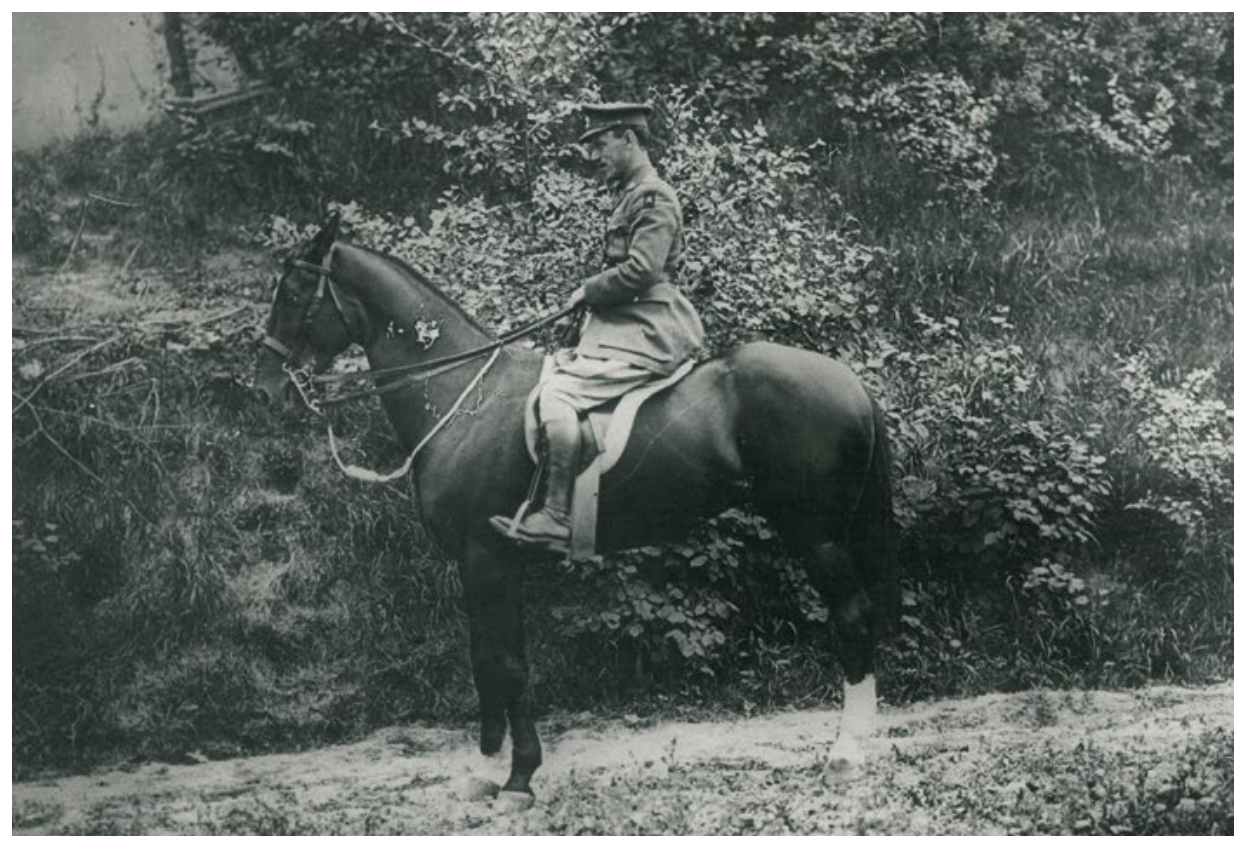

Frank Thornthwaite, away from the guns

(Courtesy of Inez Thornthwaite)

10 Manning, 'Air Disaster at Canberra', Stand-To, Jan.-Feb. 1962, p.17. 
A month later it was very different world in Belgium — worse, Gatliff said, than the Somme: "'no bon pour soldat" \& winter hasn't started.'11

Thornthwaite was slightly wounded in August 1917 but remained on duty until caught (for the second time) in a German gas attack in November. After 10 days he returned to the line. Ypres - Frezenberg Ridge, Westhoer Ridge, Passchendaele, Broodseine, Messines - the names he recorded in the form he was later asked to complete for the Australian War Records Section, would resonate a century later. It was an unremittingly exhausting and nerve-wracking regime. Rare meetings with Geoff Street on Pompey Elliot's $15^{\text {th }}$ Victorian Brigade staff were among the few pleasant diversions.

The young artillery officer had impressed his superiors. In November 1917 he was mentioned in despatches for the third time, on this occasion by Sir Douglas Haig. He was given temporary command of an artillery brigade for six weeks before being sent to England to a senior artillery officers' school at Shoeburyness. Back in France at the end of January 1918, he was with the 50th battery again for a few weeks before being transferred to command the $5^{\text {th }}$ Divisional Ammunition Column.

Periodically his parents, who moved from Sydney to Melbourne in 1916 and back to Sydney again in 1918, were relieved and gratified to receive official letters telling them of Frank's latest awards and mentions of his 'distinguished and gallant services' in despatches. Captain Thornthwaite had appeared alongside Colonels John Monash and Brudenell White, Captain Bean, the war correspondent, and others in General Monro's April 1916 despatch about service on Gallipoli. Monro's ANZAC list was not published till July 1916 because, as the press reports enigmatically noted, of the 'miscarriage of the Australian portion which had been abroad for verification' ${ }^{12}$

By mid-1916 Frank Thornthwaite had a brother in uniform. The Thornthwaites' second son, Ralph, had left his job as a foreman in an explosives factory in July 1915 to enlist as a bombardier. Ralph sailed from Australia in May 1916 and, after six months at Larkhill Camp, proceeded with the $8^{\text {th }}$ Field Artillery Brigade to France. He was soon transferred to the $3^{\text {rd }}$ Divisional Ammunition Column, and came through the war unscathed. Late in 1918 he had reverted to gunner at his own request in order to gain experience of gunnery in a battery. ${ }^{13}$ News of Ralph, who like his father now professed to be a member of the Catholic Apostolic church, was good. Less happily, in March 1918, the Thornthwaites at home read Frank's name in a list of wounded published in the Sydney Evening News. They had not received any official notification. It was, the Army's base

11 Gatliff MSS, AWM: 1 DRL 309 Pt 2, 12/11/952.

12 The Argus, 14 July 1916, p.7.

13 NAA: B2455, B884 S68525 THORNTHWAITE RALPH. 
records office, said, 'a Press error for which this Department is not responsible'. As friends had been telephoning to find out about their son, they made enquiries and discovered that the Army was right. The newspaper was publishing lists that were months old.

\section{Life changes}

As the war reached its climax, Major Thornthwaite was in the final Somme offensives including Villers-Bretonneux, the attack and capture of Peronne, and the advance to the Hindenburg Line. By then, more prayers than ever before were being offered for his safety. He had met, courted, and was engaged to Inez Currie who had been working as a ward VAD in a Red Cross hospital in Mayfair. Inez was a daughter of the Western District aristocracy. In 1898 her father, John Lang Currie Jr, had inherited the homestead portion of his father's 'Larra' property near Camperdown which the pioneer family had been farming for over 50 years. With the associated properties, 'Gala' (leased and then bought by Edwin Currie) and 'Titanga', the Currie holdings were among the most valuable in western Victoria. ${ }^{14}$ Inez, John's only child, had come to Europe and England with her mother in May 1914. Aged 17, she revelled in a summer of sight-seeing, visits to friends in Oxford and Cambridge, and theatre, parties, and dances in London. The 'ripping' times recorded in her diary included Ascot for the Gold Cup, Hendon for flying displays, and the trooping of the colours. A golfing and bathing holiday with family friends at Cruden Bay in Scotland was enlivened by a fascinating new acquaintance, Tryggve Gran, the young Norwegian polar explorer and ski instructor to the Antarctic expedition led by Robert Falcon Scott. Now an aviator, Gran was about to attempt the first flight across the North Sea. When cinema-photographers arrived to record Gran's preparations and test flights in his Blériot XI-2 monoplane, Inez and another girl were enlisted to present him with British and Norwegian flags. She would look forward to seeing herself in 'the halls' at the side of the intrepid airman. A few weeks later she and her mother would know for themselves the elation of the air as they were flown up and down Lake Windermere.

Inez Currie had been struck by how many people she knew had been in Britain for the summer. Alice Ryan and her 22-year-old daughter Maie were much in evidence. Alex Russell became a frequent companion. In Edinburgh she bumped into Peggy Forrester 'in great form'. The Curries, mother and daughter, would see almost every play and musical comedy of the season, and Inez

14 Henderson, Henderson's Australian Families: vol. I, p.171; Mary Turner Shaw, 'Currie, Sir (Henry) Alan (1868-1942), and John Lang (1856-1935)', Bede Nairn and Geoffrey Serle (eds), Australian Dictionary of Biography, vol. 8, MUP, 1981, pp.180-1; Leslie Gordon Lomax, 'The Western District Farmer, 1914-1927', 2 vols, PhD thesis, Monash University, 1979. 
particularly admired performances of Pygmalion with Mrs Patrick Campbell and Sir Herbert Beerbohm Tree; La Bohème with Melba and Caruso; and the Russian Ballet at Drury Lane. The Futurist paintings at the Doré Gallery had to be seen but were 'mad, quite mad'. Apart from the portraits and water colours, the Royal Academy paintings were 'rotten'. But she loved the Turners and Corots at the National Gallery, and lots of 'old friends' at the Tait, 'ones I have seen copies of from earliest infancy.' An endless succession of social engagements and sophisticated entertainment was increasingly bemusing for the pastoralist's daughter. 'What is it I want, oh, I don't know,' Inez confessed to her diary, 'life is an awful puzzle \& I don't quite know how to start \& work it all out.' Exactly a month later the German invasion of Belgium would supply an answer to the bad attacks of 'discontents' and the 'blues'. 'Mother says I do nothing but buy papers and read her awful things.' ${ }^{\prime 5}$

Within weeks of the outbreak of war, all Inez's male Australian friends were volunteering. Alex Russell was soon in uniform. Ivo Whitton, the brilliant young golfer, was returning to Australia to enlist in the AIF. Although there were fears about the safety of sea travel, and it took some time to secure passages, Alice Currie and Inez, urged by her cousin Gyp, set sail for home on R. M. S. Orontes on October 9. Somewhere in the Indian Ocean, as Orontes steamed on towards Australia, the AIF's First Division Artillery with Lieutenant Frank Thornthwaite, was en route to Egypt in the Argyllshire. Among her relatives, friends, and neighbours no family was untouched by the war. Sons and brothers, cousins, uncles, even fathers, were rushing to the colours. No sooner had she reached home than Inez was in conversation with Esther Fairbairn, whose brother Jim at Geelong Grammar was determined to get to England to join his older brother Osborne in the Royal Flying Corps. Anxious to 'do their bit', the young Currie girls, with Esther Fairbairn and Catherine Austin, raised over $£ 1000$ by subscription early in 1915 for the purchase in London for the Red Cross of two 'Western District Motor Ambulances'. Inez herself was a whirlwind of charitable endeavour, organising a concert and auction for the Belgian Relief Fund, donating personally and publicly to the British Red Cross Society Australian branch and the Victorian Red Cross Fund for Sick and Wounded Soldiers. ${ }^{16}$ By the second year of hostilities, both Inez and Gyp Currie were in London with Esther Fairbairn making their own contribution to the war effort.

Inez had enrolled with the Red Cross in April 1916 for training in first aid and home nursing, hygiene, and cookery. She spent a week in August 1916 at the Red Cross's Marylebone Auxiliary Hospital, a small private home in Weymouth Street, before finding a more congenial berth in the 'Australian room' at the Coulter

15 Inez Currie's diary, 3, 11, 12 July, 3 Aug. 1914, courtesy the Hon. Tony Street.

16 Camperdown Chronicle, 27 Mar., 1 May 1915; The Argus, 18 Feb., 29 July 1915. 
Hospital in Grosvenor Square. Founded by an American psychic, Mrs Charlotte Herbine, and run by titled socialites, the Coulter's 85 or 90 beds were filled with seriously wounded men. ${ }^{17}$ Praise for its open-air ward, 'where wounded men get full benefit of the air', tapered off as patients began to complain about cold and exposure. The Australian connection of the hospital was nourished by the assistant commandant, the Hon. Mrs Cyril Ward, the wealthy Dutchborn sister-in-law of the pre-war Governor-General, Lord Dudley. Before her marriage Irene, better known as 'Daisy', Ward, was the Baroness de Brienen. She had accompanied her husband, a career naval officer, during his Australian posting as ADC to his brother. Daisy's other life as a lover of The Times military correspondent Colonel Charles À Court Repington, and informal intelligence gatherer in the Netherlands, was a world apart from the circles of the young Australian VAD. So, too, was the political and literary domain of the honorary secretary of the hospital, Lady Juliet Duff. 'Juliet', Charles Repington recorded in January 1917, 'said everything went back to love, even in her conversations with Cabinet Ministers.' A year later she would confide: 'that she cannot fall in love with anybody while she has hospital accounts to do' ${ }^{18}$ Inez could glimpse the social stratosphere if not the romantic challenges of her superiors; but her head was not in the clouds and, when at last the carnage ended, she had every intention of returning home to Australia.

\section{Towards home}

It was not long before Inez was introduced by her cousin Gyp's fiancé, Geoff Street, to his friend Frank Thornthwaite, then attending a senior officers' school at Shoeburyness at the mouth of the river Thames. When Gyp Currie married Street in mid-1918, Frank and Inez, now his fiancée, were best man and bridesmaid. Frank's respite in London was brief. In October 1918 he was supporting the Americans at Bohain, Le Cateau, and along the Sambre Canal. After commanding the $14^{\text {th }}$ Field Brigade, he was in command of the $12^{\text {th }}$ Field Brigade (in the place of Brigadier General H. W. 'Bertie' Lloyd) when the war ended, and was promoted Lieutenant Colonel five days after the armistice.

\footnotetext{
17 British Red Cross Museum and Archives (Sarah Cox) to CH, (email), 30 Sept., 4 Oct. 2011 (Inez Currie's Red Cross VAD enrolment); hospital details at New York Times, 4 May 1916, www.redcross.org.uk/ museumandarchives, and www.scarletfinders.co.uk; Ana Carden-Coyne, The Politics of Wounds: Military Patients and Medical Power in the First World War, Oxford UP, 2014, pp.134-5.

18 Maurice Baring (with an introduction by Margaret Fitzherbert), Dear Animated Bust: Letters to Lady Juliet Duff France 1915-1918, Michael Russell, Salisbury, 1981; Lady Cynthia Asquith, Diaries 1915-1918, Hutchinson of London, 1968, pp.223, 260, 263, 279, 282, 431, 455; C. À Court Repington, The First World War 1914-1918, 2 vols, Constable, 1920, vol. I, pp.199, 314-5, 402, 447, vol. II, pp.237, 295.
} 


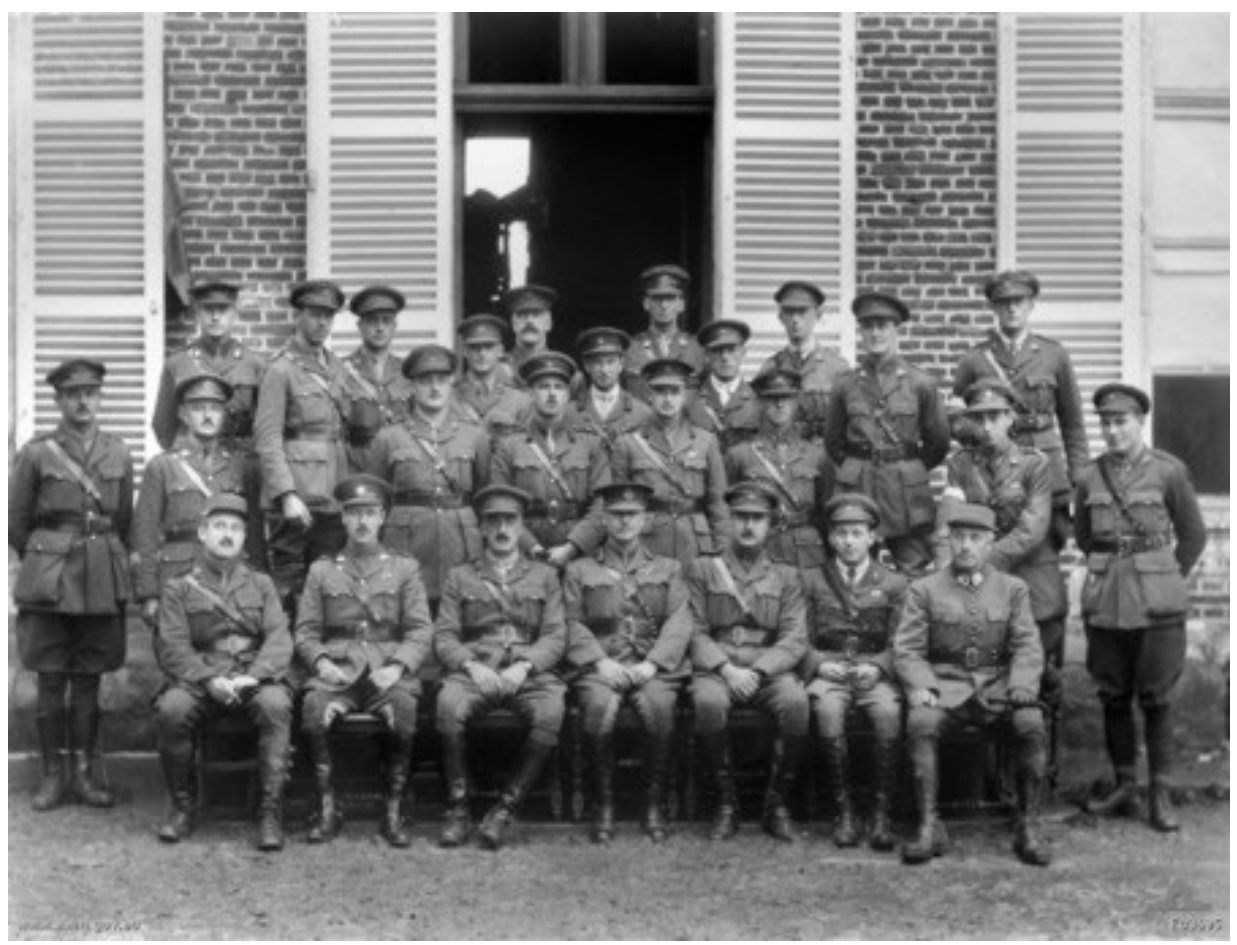

\section{Brigadier General H. J. Bessell-Browne, Commander Royal Artillery,} and officers of the 13th Brigade, Australian Field Artillery, Boutillerie, 5 November 1918: Maj. F. Thornthwaite MC, 5th DAC, front row second from left

(Courtesy of the Australian War Memorial, Photo ID no. E03695)

In the closing weeks of the war Thornthwaite had been working once again with Brudenell White. On his own staff during the last phase of hostilities was Major Eric Campbell who, with Bertie Lloyd, was later to achieve notoriety as the founder and deputy commander respectively of the Sydney-based patriotic anti-communist group, the New Guard.

The first order of business in London when the guns were silenced was marriage. With Geoff and Gyp Street at their side, Frank and Inez were married on 23 November 1918. They had just a week together before Frank returned to France. It was to be another four months before they were reunited for the voyage back to Australia. Inez would travel with her husband in a troopship, together with what she was to describe as 'a boat-load of married and single diggers' wives'. 


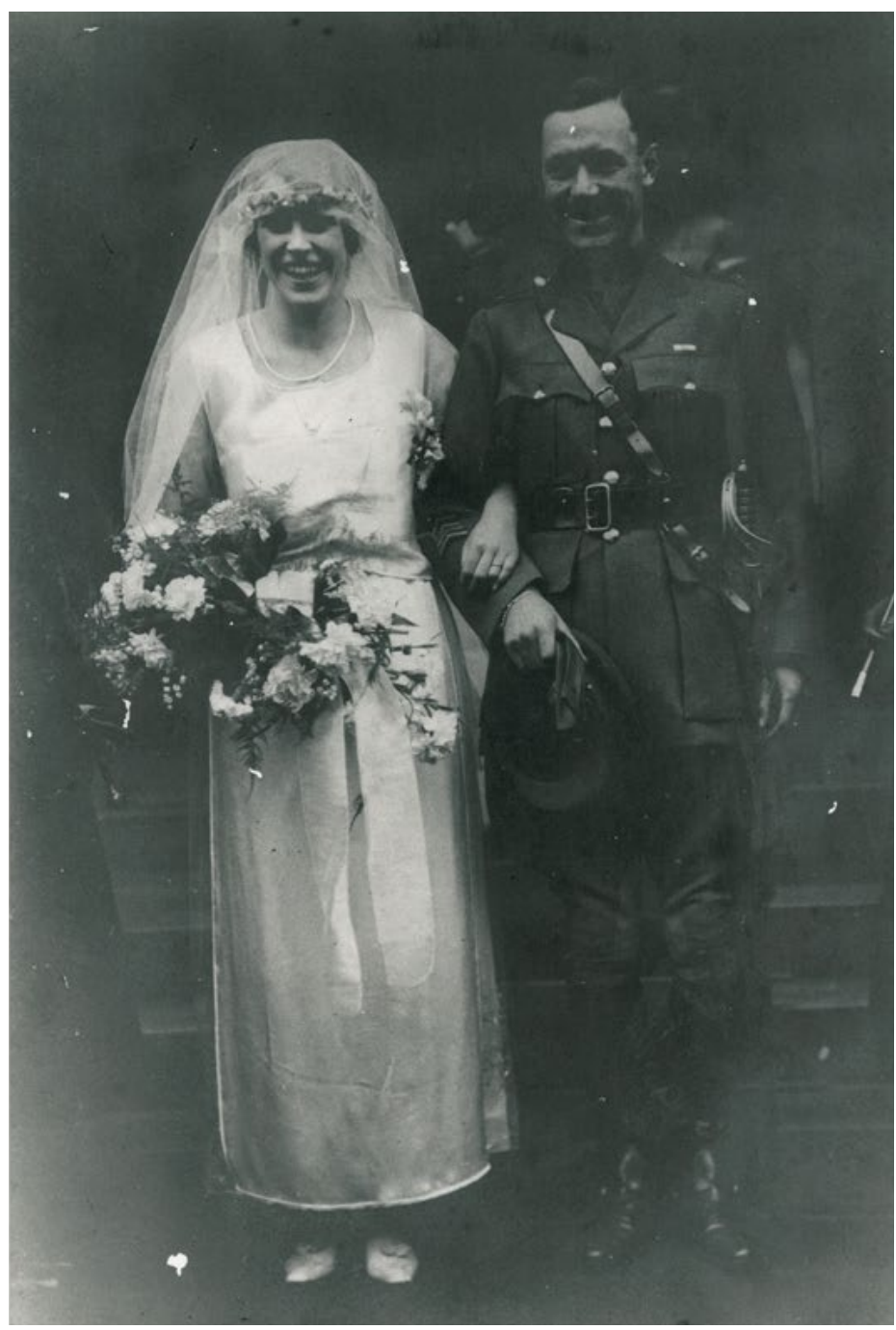

\section{Inez and Frank Thornthwaite}

(Courtesy of Inez Thornthwaite)

The problem of how to ship home the spouses and children of the 'colonial contingents', some 20000 of them Australian, had been exercising the Ministry of Shipping for months before the end of the war. One of the ministry's senior men, Archibald Elford, had calculated the number of ships and voyages required to get all the Dominion troops and their dependents home. ${ }^{19}$ It was up to General Monash's demobilisation team to determine the priorities for release and arrangements for discipline on board. For the Thornthwaites' passage, Frank

19 'Dependents [sic] of officers \& men serving in Colonial Contingents', undated note by A. S. Elford, Elford MSS, courtesy of Hugh Elford. 
was to be the $\mathrm{CO}$, and his adjutant was the former journalist and stockbroker, Captain Stan Ricketson DSM, soon to be in business partnership with the young Melbourne barrister Robert Menzies.

Nothing in France or Flanders could have prepared Thornthwaite and Ricketson for the extraordinary social dislocations and distinctions of the seven-week voyage to Sydney across the Atlantic and the Pacific in a surrendered German liner renamed H.M.A.T. Wahehe. Inez Thornthwaite, leaving the elegant environs of a Knightsbridge apartment opposite Hyde Park, would never forget the distraught wives detached at the last moment from their husbands, childless couples allocated separate accommodation in different classes, segregation of shell-shocked troops and victims of venereal disease (discreetly housed behind a sign 'which does not indicate its purpose'), alternating blankets of listlessness and frenetic gambling and drinking on pay-days. ${ }^{20}$ Shortly after they departed from Tilbury for Torquay, Teneriffe, and points south and west on May 10, Lieutenant Colonel Thornthwaite, as OC Troops, wrote the first editorial for The Wahehe Times. The 'Ship's general Nuisance' as its sub-title advertised, was priced threepence with proceeds to go to the Soldiers' Widows and Orphans Fund. Readers were reminded that it was the first paper on a ship making its maiden voyage 'and which the Hun intended using as a transport to convey troops for his projected invasion of England and at the end of the War as one of his means of capturing the world trade'.

'Of course,' Inez wrote many years later, 'most of the troops got drunk in Capetown and it took days to get them all rounded up again. ${ }^{21}$ In addition to the demands of morale and discipline for the OC troops, a full program of entertainment and sport would keep both of the Thornthwaites on duty every day: dances on the promenade deck, performances by the Wahehe Pierrots, cricket matches (engineers $\mathrm{v}$ machine gunners, officers $\mathrm{v}$ sergeants, officers $\mathrm{v}$ engineers, First Saloon Ladies v Second Saloon ladies, officers v First Saloon Ladies), tug-o'-war (the engineers and machine gunners fought out the 'pull off'). They took in good part the occasional jibe in the gossip column, 'They Say'. The OC Troops had, it was said, 'graciously allowed the Ladies an issue of Guinness every day. Is it true??' the columnist mused. 'That the Ladies who do not require same may pass it on to their husbands. I wonder $-?^{\prime 22}$

For the Thornthwaites it was a relief to be home, disembarking in Sydney on 1 July 1919 along with 86 men and 64 women. ${ }^{23}$ Inez had become pregnant

\footnotetext{
20 Peter Plowman, Australian Migrant Ships 1946-1977, Rosenberg Publishing, Dural, 2006, p.91; Clem Lloyd and Jacqui Rees, The Last Shilling, pp.128-32; Sydney Morning Herald, 2 July 1919.

21 Inez Thornthwaite, biographical notes on Lt Col. Thornthwaite, [22] April 1979.

22 The Wahehe Times, 1st ed. n.d., AWM: Troopship and Unit Serials, Folder 224.

23 I follow here the list published in the Sydney press, noting that it is inconsistent with Thornthwaite's Army personnel file that has him disembarking in Melbourne on June 28 at ' 3 MD' (the Australian Military Forces Third Military District).
} 
on the honeymoon and the baby was expected two months after the couple reached Australia. Alas, there were complications; tragedy not joy awaited them. On July 25 a little boy arrived, some six weeks prematurely. William Currie Thornthwaite lived just four days. He was buried in Lismore cemetery close by the Currie family home. Frank and Inez would never again have children.

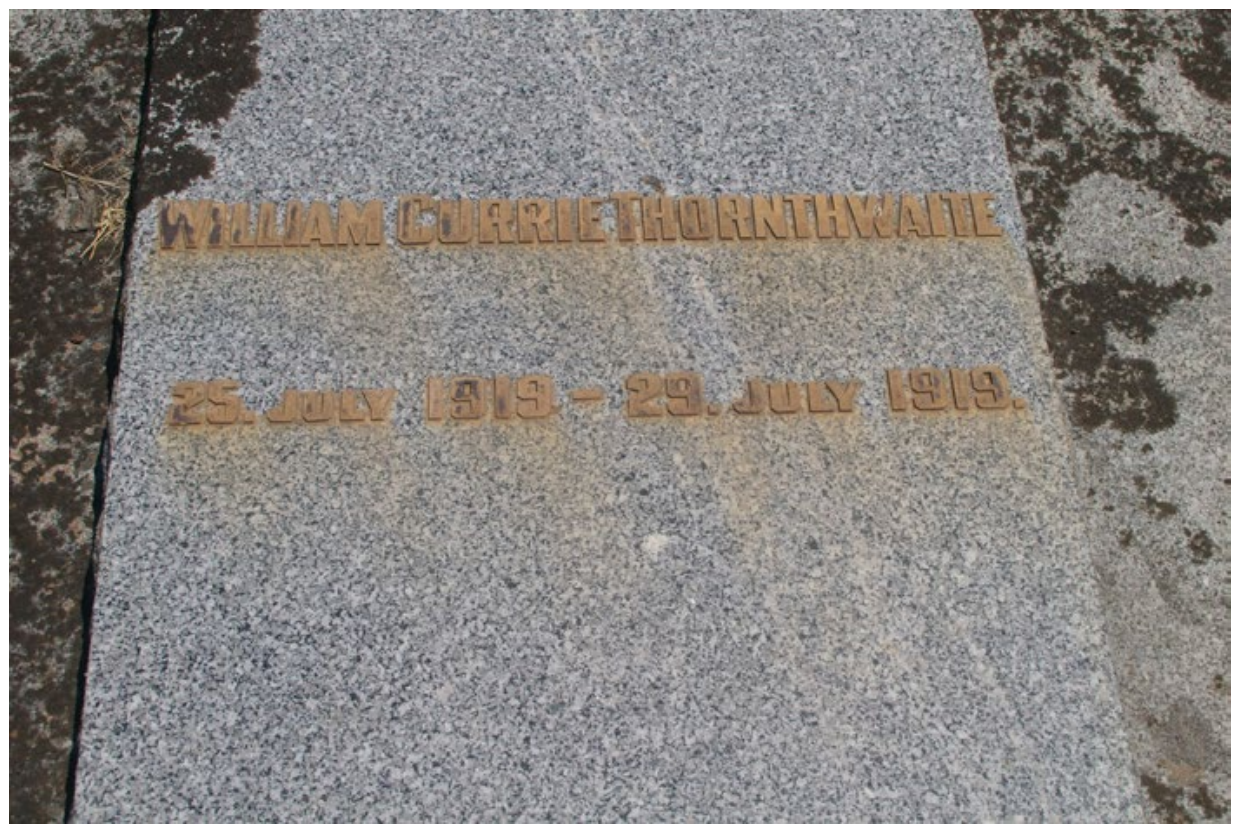

\section{William Currie Thornthwaite, Lismore cemetery}

(Courtesy of Carol Judkins)

Returning to Australia with his wife, decorated with the DSO and Croix de Guerre, as well as the MC earned on Gallipoli, and four mentions in despatches, Thornthwaite was discharged from the AIF in September 1919. Like many of his contemporaries who had survived the war, he had been the beneficiary of the enormous expansion of the Australian military forces. He had seized the opportunities created by the massive growth of the artillery arm and served with distinction. Many of his contemporaries could not wait to get out of uniform and enjoy a civilian existence. But he was a soldier and wanted a soldier's life. He re-joined the permanent Army. He was posted to the First Battery, RAFA, in Sydney. Then came an unforeseen interruption to the career he had chosen. Following the Washington Disarmament Conference in 1922 and the Commonwealth government's decision to reduce the permanent staff of the Army, he joined 71 of his rather more reluctant contemporaries on the half-pay 
list, and shortly afterwards on the unattached list. It gave some small hope of recall to active service that he was placed on the reserve of officers on 1 July 1927. ${ }^{24}$

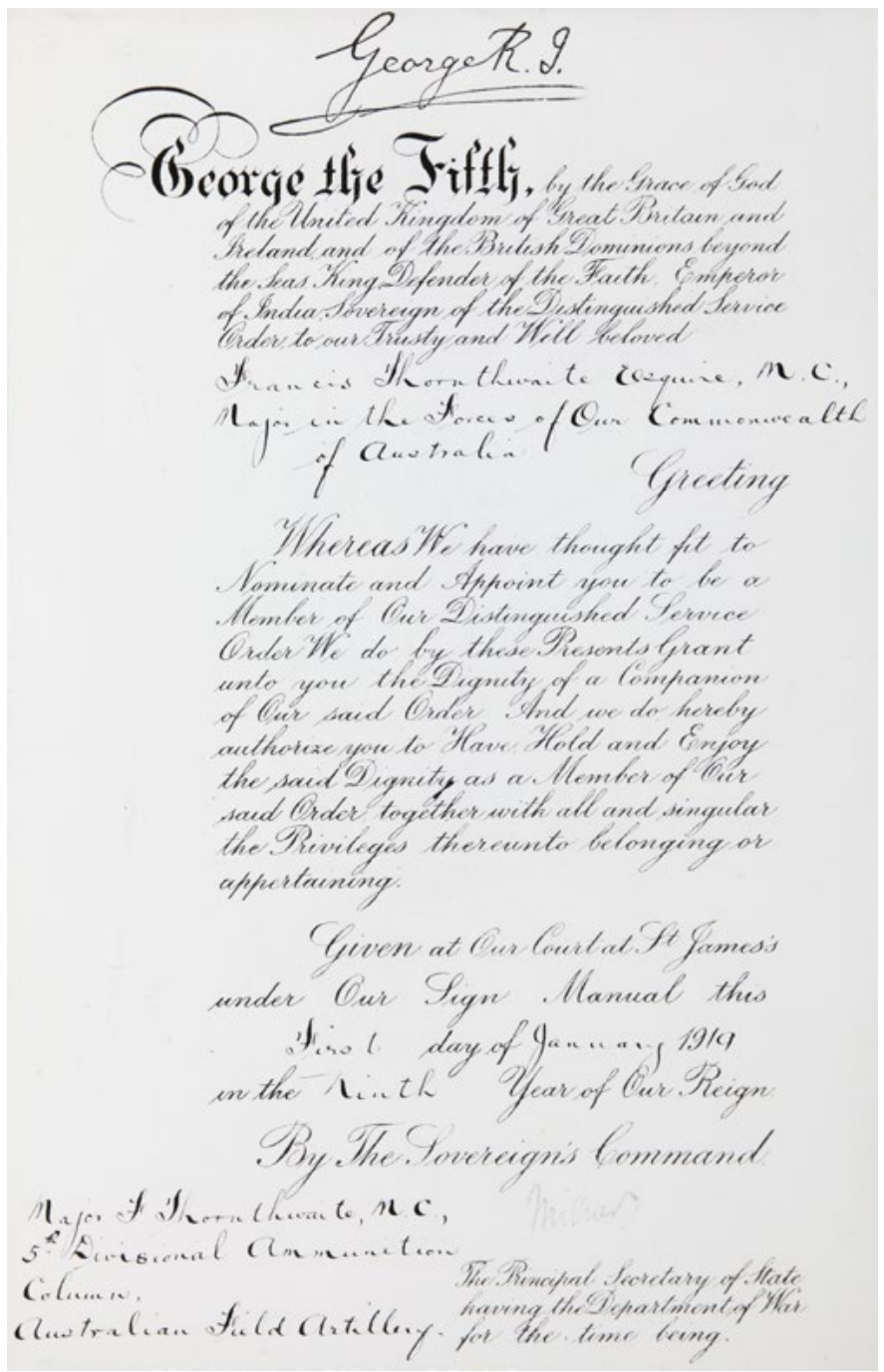

\section{Major Thornthwaite's appointment to the DSO}

(Courtesy of Inez Thornthwaite)

Still in his early 30s, Thornthwaite now had to make a new life. Though he had little experience of the land he felt he could learn what he needed to know to succeed as a grazier. He was not, as was suggested by H. J. Manning many years

24 On the post-war retrenchment see Gavin Long, To Benghazi, Australian War Memorial, Canberra, 1961 (1st ed. 1952), pp.2-5; Grey, A Military History of Australia, pp.125-6. 
later, distressed by having to leave the Army. Inez was undeniably happy to be returning to the station life of her youth. And there was never going to be any financial hardship. Frank went as a jackeroo to the famous Riverina merino stud Wanganella Station, where he enjoyed the tutelage of the redoubtable Otway Falkiner. A year later he bought a 9800-acre property, 'Marong', at nearby Conargo, some 30 kilometres north of Deniliquin, and over 700 kilometres southwest of Sydney. He and Inez ran the property, with the aid of a married couple and one boundary rider. They 'loved the district and the life', Inez said, having 'a lot of fun' with their horses and successfully entering picnic race meetings.

Frank had never taken any part in RSL activities and eschewed local government. Approached late in 1930 by the Country Party to consider standing for Riverina in the House of Representatives, he wrote to Inez's friend Charles Hawker for advice. He did not feel 'at all fitted for such a job'. Could he manage the property as well as fulfil parliamentary duties? To do the job well, how much more than the salary might it cost? More seriously, although all his interests were in the country, he doubted if he 'agreed altogether with the tenets of the Country Party'. He wondered if the National Party might again contest the seat.

Hawker's response confirmed him in the belief he had already been coming to: that he would not be able to cope with the constant travelling. 'I am not a particularly strong man - the knocking about of the war seems to have left its mark on me and both Inez and I think that I should never stand it. ${ }^{25}$ There were other ways in which a gentleman farmer could contribute to community affairs. He took an active interest in the Southern Riverina Graziers' Association, joined the council in 1935, and was re-elected in 1936 with Brudenell White. ${ }^{26}$ After the death in 1935 of Inez's father John Lang Currie, the Thornthwaites sold their farm and 4700 merino ewes and moved to Victoria, to the Currie family's 'Larra' at Derrinallum. There they were neighbours of Jim and Peggy Fairbairn across the lake at Mount Elephant.

Frank had been elected a member of the Melbourne Club on his return from the war; and Sydney's Union Club had welcomed him as well. He was nominated for the Melbourne Club by the recently knighted Sir Charles Ryan, who had been on Birdwood's staff at Gallipoli before becoming consulting surgeon to the medical headquarters staff in London and then honorary surgeon-general of the Australian Military Forces. The father of Inez's friend Maie, still seven years from marrying Dick Casey, Ryan was an influential sponsor. But no more so than Frank's seconder, Frederick Fairbairn, Jim Fairbairn's uncle, who had

25 Thornthwaite to Hawker, 7 and 22 Nov. 1930, Hawker MSS, NLA MS 4848/2/4.

26 Albury Banner and Wodonga Express, 29 March 1935; J. O Randell, Teamwork: A History of the Graziers' Associations of Victoria and Riverina, (1983?), p.76. 
headed the Australian Red Cross in London while Inez was serving there. Frank's appearance in the new edition of Who's Who in Australia, published in 1935 after an interval of seven years, acknowledged the position in society he had acquired.

The polo-playing colonel and his wife, a tireless supporter of local charities and services like baby-health centres, as well as special occasions like a Flemington Oaks Day luncheon with her friend Mrs Neville Fairbairn Armytage, regularly made the social pages. In town for Cup Week in 1938, The Argus reported many of the Western District set stayed at the Hotel Windsor. But the Thornthwaites, endowed with the inexhaustible wealth of the Curries, had their own flat in the Melbourne Mansions, 99 Collins Street. Admittedly, a house-warming party in November 1938 at 'Gala', Lismore, which boasted a private links golf course, sounded a little more glamorous than it was. The Gala Golf club course, on which Frank competed for the H. O. Nevett Cup in June 1939, wound its way through paddocks on Inez's uncle's property; the club house was an old tin shed with a stone fireplace, a gravel floor, and rough wooden tables and benches. Nevertheless, regularly reported events like this, and a farewell to the Alex Russells and the Ford Guthries who were about to sail to England, saw an assemblage of Fairbairns, Streets, Curries, Chirnsides, and others that confirmed Frank and Inez Thornthwaite's place at the heart of the Victorian aristocracy. ${ }^{27}$

\section{Intimations of war}

Though he made a success of farming, Frank Thornthwaite's heart was never divorced from the military life. He weathered the years of Depression and low wool prices and could be optimistic about the future. But the resurgent menace of Germany troubled him. Seeing Hitler's world first hand in 1936, after a pilgrimage to the European cemeteries and battlefields he had known so well 20 years earlier, his concern was heightened. Touring the Rhineland by car shortly after it had been re-occupied, he saw hundreds of young Germans marching with shovels on their shoulders, 'quite obviously drilling'. Inez would remember that he remarked almost every day that he felt certain war would come again in two or three years. Unhappy that his service training and knowledge had been so long neglected, he turned his mind to national defence. He wrote 'arresting and practical' articles on Australian military needs.

When his dearest friend Geoff Street ascended to Cabinet as Minister for Defence in the Lyons government late in 1938, it could only be a matter of time before a way was found to bring Frank Thornthwaite back into the Army fold. Seven

27 The Argus, 19 Feb., 29 Oct., 3 Dec. 1938; Camperdown Chronicle, 22 Sept. 1938; Virginia 'Bardie' Mercer, telephone interview, 19 Oct. 2009 and 'Memories of J. V. Fairbairn', [Dec. 2009]. 
months later, on 1 July 1939, he reported for duty as a General Staff Officer, $3^{\text {rd }}$ grade in the Chief of the General Staff's branch. He was raised to $2^{\text {nd }}$ grade and a major's pay on September 2. On November 1, he completed a mobilisation attestation form at Sturt Street, South Melbourne, a short walk from Victoria Barracks. In April 1940 he was appointed GSO to the Deputy Chief of the General Staff, Major General John Northcott. Northcott had been invalided out of action for most of the previous war but the two men had spent weeks in each other's company in 1937 when they sailed across the Pacific together with their wives on the Aorangi.

Within months, Frank had been poached by the new Chief of the General Staff Sir Brudenell White. White was well acquainted with Thornthwaite's ability and record of achievement. The fact that his friend was connected by marriage to the Minister for Defence, and was close to Rutherford Guthrie, and to others like Jim and Osborne Fairbairn, the Alex Russells, and the Chester Manifolds, in the interlocking family networks of the Western District, gave assurance to those who mattered that he was a sound man. Moreover, White knew that Frank Thornthwaite was more than sound. He had ideas and could express them. His own connections, too, were useful. A fellow wartime artillery commander, Bertie Lloyd, was recalled to active duty as Deputy Adjutant General at Army Headquarters on 1 August 1940.

In a very short time Thornthwaite himself had been noticed by the Prime Minister. Newspapers had reported on his attachment to Army intelligence and his attendance as an adviser at War Cabinet meetings. ${ }^{28}$ When the Cabinet was due to meet again in Canberra on August 13 he would as always accompany his chief, Brudenell White. Fairbairn's assistant private secretary, Murray Tyrrell, was thought to be arranging the final allocation of seats for the flight to Canberra. When Pip Hayter, Geoff Street's private secretary, was told on the afternoon of August 12 that he had to get White on to the plane, he telephoned Tyrrell at his office in Victoria Barracks. Tyrrell takes up the story:

Pip...said 'Look Murray, I know it's late but I want a seat on your aircraft in the morning' ... And I said I hadn't got one. He said 'Well Menzies has called a Cabinet meeting for ten [sic] o'clock tomorrow. He wants the Chief of the General Staff there.' And I said 'Well, if it's that important, it's immaterial to me. I'll go in the train tonight.' My bag was alongside my desk, you see. 'And Brudenell White can have my seat.' And Pip said 'Well, thank you very much. I'm sure the minister will appreciate that.'

28 According to the Courier-Mail and Townsville Bulletin, 30 April 1940, Thornthwaite of 'the army intelligence section' was among senior officers present as advisors at a War Cabinet meeting on 29 April 1940, which discussed defence measures in light of European and Middle Eastern developments, and received a report on communist penetration of the AIF and militia. 
With that, Tyrrell rang his wife, Nell, and told her he would not be home as he was going to catch the train to Canberra. An hour later, Hayter rang again:

'Menzies wants the chief of intelligence, Thornthwaite. ${ }^{29}$ Can you give him a seat in the aircraft?' I said 'I've told you, Pip, the bloody thing's full. I've given up my seat.' And I said 'If he's got to go you're the next junior on the sheet. You give him your seat.' Pip said 'Oh, come off it.' I said 'All right, you're the most junior left, off you go.' He said 'Well, when you're booking your passage on the train tonight will you book me too?' So Pip and I came to Canberra on the train, and I put Thornthwaite on. ${ }^{30}$

Bearing a briefcase with the papers that the CGS needed to assimilate before the next day's meetings in Canberra with the other Service chiefs and the War Cabinet, Frank Thornthwaite was driven from his Melbourne Mansions apartment to join the group at Essendon waiting for Lockheed Hudson A16-97. Cheery as always, and recognisable by his uniform to RAAF personnel on the tarmac as a colonel on the staff, he boarded the aircraft and looked for a seat near his chief.

29 Thornthwaite had been 'required' at 'AHQ M. I.' in Oct. 1939 (NAA: B884, V159753). Tyrrell to Lord Casey, 24 Oct. 1972, shows him guessing that Thornthwaite was chief of intelligence (NAA: M1129 WHITE/C B). 30 Sir Murray Tyrrell, interview, 5 April 1977. The Examiner (14 Aug. 1940) reported Hayter's 'protest' at being bumped from the flight. 


\section{Patriot: Harry Gullett}

First of the passengers to arrive at Essendon aerodrome, a man whose chronicles of battle made him second only to Charles Bean as a historian of the war that Street, Fairbairn, Brudenell White, and Thornthwaite had fought, was Sir Henry Gullett. At 62, silver-haired, bespectacled, stooped a little below his measured five feet eleven, with years of stress, chain-smoking, and illness etched on his face, Gullett was in the twilight of a chequered political career. He had risen rapidly in the conservative ranks in the 1920s after making his name as a war historian and journalist. He was the son of Rose Somer and Charles Gullett, a farmer, his paternal grandfather having emigrated from Devon to Melbourne in 1853.

Born in Harston in central Victoria in 1878 Harry, as he was known to his friends, started his working life on the family farm, leaving school at 12 to help his widowed mother. He was a keen reader and began to be attracted to a career in journalism. With the right connections it was not hard to get a foot in the door. (His sister Isabel would follow the same path.) He wrote articles on agricultural themes for the Geelong Advertiser until eventually in 1900 the call came to join his uncle Henry and brother-in-law, T. W. Heney, in Sydney. Henry Gullett had edited the Sydney Daily Telegraph, and now at the Sydney Morning Herald, he invited his nephew to join him. Young Harry learned quickly, and was well established by the time his uncle was given a comfortable retirement berth in the NSW Legislative Council in 1908.

Although his namesake and patron had been succeeded at the helm of the Herald by his brother-in-law, Gullett decided it was time to move on. For the next six years he made his base in London, working as a freelance journalist, sending articles back to the Sydney Daily Telegraph and The Sun. With a growing interest in emigration and development, he lectured and wrote pamphlets in association with Australia House. He travelled to the Continent and to the western hemisphere where he investigated innovations in irrigation. In 1914 he published The Opportunity in Australia, a 150-page tract extolling his native land as a destination for British emigrants. A year earlier, at 35, he had married Penelope Frater in a London registry office. ${ }^{1}$ The autobiographical opening chapter of The Opportunity would help Harry's bride - 'small, dark and full of enchantment' as her grand-daughter would describe her - to understand the elemental forces that had helped shape her husband. ${ }^{2}$ He was not the match

1 A. J. Hill, 'Gullett, Sir Henry Somer (Harry) (1878-1940)', Nairn and Serle (eds), Australian Dictionary of Biography, vol. 9, MUP, 1983, pp.137-9; Ken Stewart, 'Heney, Thomas William (1862-1928)', Nairn and Serle (eds), Australian Dictionary of Biography, vol. 9, pp.258-9.

2 Penne Hackforth-Jones, Barbara Baynton: Between Two Worlds, MUP, 1995 (1st ed. 1989), p.105. 
Penelope's socially ambitious mother, the widowed writer of Bush Studies, Barbara Baynton, had hoped for her daughter. He had grown up in a world far removed from the society pages and the Parisian ballet school to which a 20-year-old Penelope had been despatched. Barbara Baynton had drawn a fictional veil over her own youthful rural poverty. Not so Harry. As a child, he said, he had thought his life on the half-cleared 320-acre selection in Victoria's Goulburn Valley quite rough and hard: 'Only in after years, when I had taken to the soft life of the cities, did I realise what it was not to have worked with the pioneers.' Now he urged the virtues of Australia's paternal state, the land on offer, the possibilities for the man without capital: 'Australia is the happiest of hunting grounds for the poor man.'3

\section{War chronicler}

Within months of the outbreak of war, Harry Gullett was accredited to the British and French armies as an Australian Official Correspondent. For the next two years he covered the conflict on the Western Front. He was seeing war at close quarters but was not happy to be a mere observer. A spell as an ambulance driver left him frustrated. Spurning an offered commission in the Grenadier Guards, he returned to Australia with Penelope and their infant son Joe (the 'e' would later be dropped) to enlist in the AIF. On 29 July 1916, aged 38 years and two months, he went to the Royal Agricultural Showgrounds at Moore Park in Sydney and attested. Already known as a propagandist, he was before long engaged by Billy Hughes as a speaker in the Prime Minister's conscription campaign. Then, drafted into the artillery, he was sent to England, accompanied by his family, on the troopship Osterley. ${ }^{4}$ Afflicted with pleurisy, and plainly not well enough to endure life at the front, his past caught up with him. His friend Charlie Bean sought him out to assist with the expanding task of collecting war records and preparing for the future creation of a war museum. As a Warrant Officer class 1 and Temporary Lieutenant, he was posted to the Audit Section, AIF HQ, in August 1917. There, with Bean, and occasionally in company with Will Dyson, Hubert Wilkins, Frank Hurley, and Keith Murdoch, he saw at first hand the Flanders terrain that was so familiar to the Australian infantry: Hill 60, Zonnebeek, Sanctuary Wood, Polygon Wood, the Menin Road, and Broodseinde. ${ }^{5}$

\footnotetext{
H. S. Gullett, The Opportunity in Australia, The Field \& Queen (Horace Cox), 1914, pp.1-2, 37.

Hackforth-Jones, Barbara Baynton, pp.125-7.

Manning, 'Air Disaster at Canberra,' Stand-To, Jan.-Feb. 1962, p.8.
} 
12. Patriot: Harry Gullett

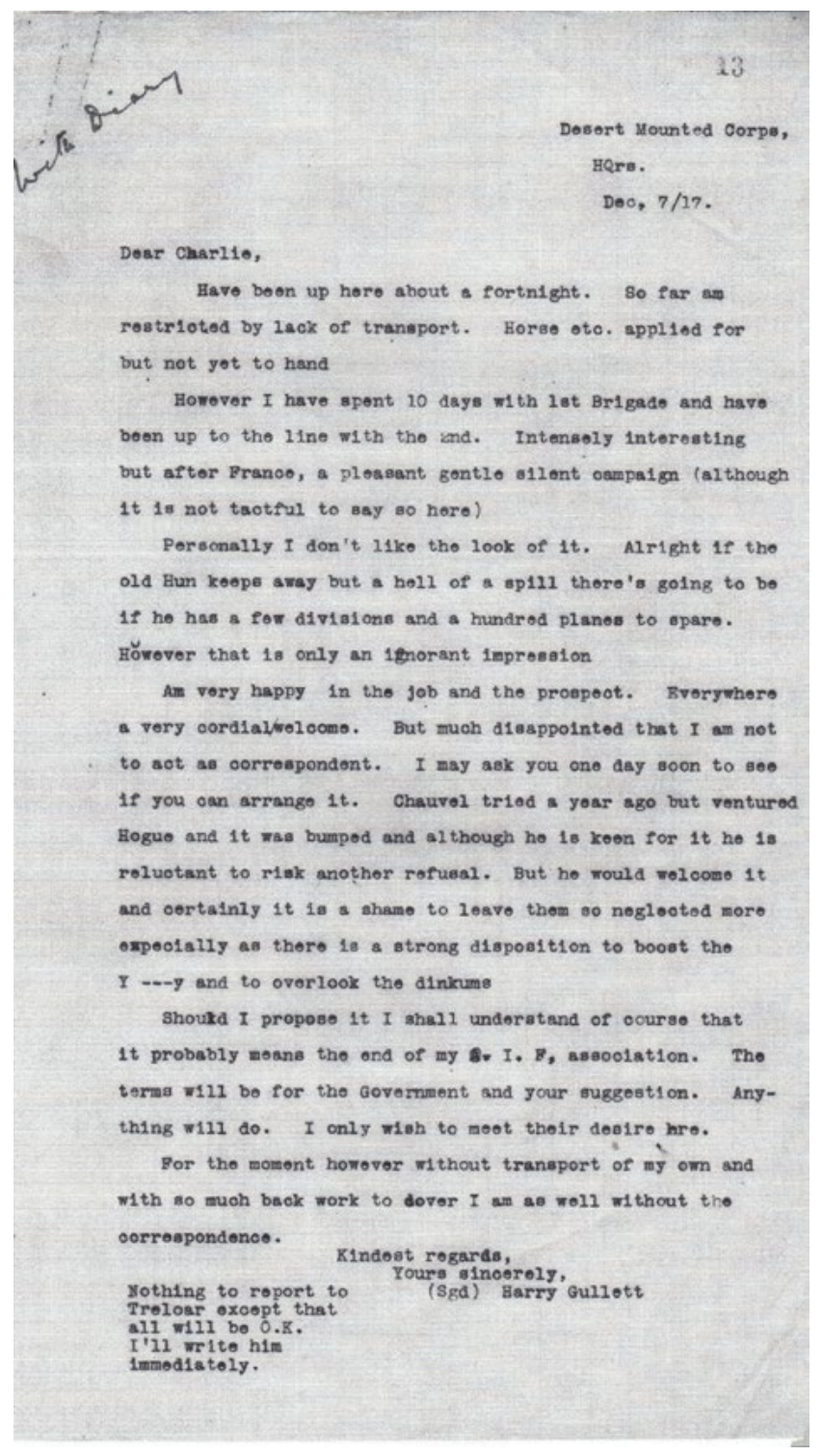

\section{Harry Gullett expresses his frustration to Charlie Bean, December 1917}

(Bean MSS, AWM38 3DRL606/97/1)

Seven weeks later, Gullett was detached and sent to AIF War Records Section in London. At Bean's behest, in November 1917 he was attached 'for administrative purposes' to Australian HQ in Cairo. Belatedly, Bean had realised the need for an Australian war correspondent in Palestine. But there was a thicket of protocol to negotiate. The historian Alec Hill explained: 
Brudenell White, the Chief of Staff, refused to put the idea up to Birdwood, insisting that such a proposal must come from the Australian Government through the High Commissioner in London. It was agreed that it should be left for Gullett himself to decide after he had tested the feelings of the A.I.F. in Palestine. If he favoured it, Bean was to arrange the appointment through the High Commission who would ask the Australian Government to seek the approval of the War Office in London. ${ }^{6}$

Successive attachments saw him at the Desert Mounted Corps HQ in December 1917 and early January 1918 - 'after France, a pleasant gentle silent campaign (although it is not tactful to say so here)' - then 10 days with the $67^{\text {th }}$ Squadron Australian Flying Corps, and another 10 days each with the $3^{\text {rd }}$ and $4^{\text {th }}$ Light Horse Brigades. He then had a month detached to ICC Brigade, followed by two months at the $2^{\text {nd }}$ Light Horse Brigade HQ before being appointed OIC, subsection Australian War Records, in May 1918.

His peripatetic existence in the new role Bean had envisaged was to continue for what turned out to be the last four months of the war. Relinquishing his war records post and the temporary rank of Lieutenant, Gullett was attached initially to the Desert Mounted Corps, and finally designated Assistant Official Correspondent, AIF in Egypt. His appointment was terminated late in September 1919. ${ }^{7}$

While based in Cairo, taking notes and drafting historical chapters, Harry kept up a stream of informative letters to Penelope. His pen pictures, written in great haste, were vivid and warm in their appreciation of Australian endeavours. He had told of his admiration of Brudenell White in France in September 1917. In Palestine in November 1917 he wrote of a morning meeting with Major General Sir Harry Chauvel:

He gave me an hour \& was most cordial \& frank. A slight almost elegant man of scarcely average height: dried \& wrinkled; a typical little horseman from Queensland, with a quiet confident manner; speech slow \& diffident \& occasionally a flashing smile of extraordinary charm. He is not as direct \& humorous as White perhaps but there is capacity all over him \& a gentleman of the rare kind. Queensland has been strangely rich in leadership. Nine of our generals come from there \& this man \& White are big fellows. ${ }^{8}$

6 A. J. Hill, 'Introduction', The Australian Imperial Force in Sinai and Palestine, 1914-1918: Official History of Australia in the War of 1914-1918, vol. VII, University of Queensland Press, St Lucia, 1984 [1st ed. 1923]. 7 Gullett to Bean, 7 Dec. 1917, Bean MSS, AWM: 38, 3DRL606/97/1; Notes compiled 1933, AWM: 43 A327. 8 Gullett to Penelope Gullett, 27 Nov. 1917, Gullett MSS, NLA MS 3078/5/31. 
12. Patriot: Harry Gullett

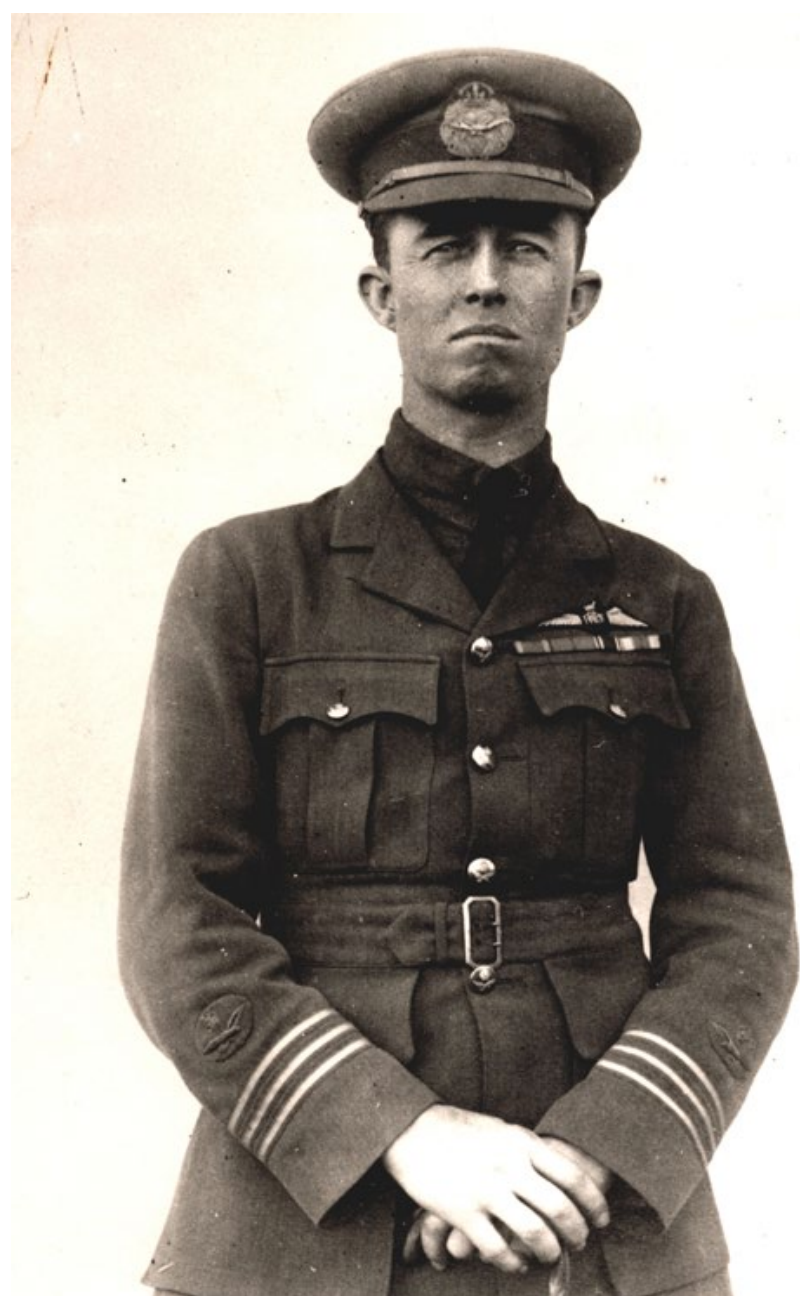

WCdr Dicky Williams: still a 'fearsome disciplinarian' ca 1925

(Courtesy of the RAAF Museum)

It was not only the senior officers who caught Gullett's eye. He wrote from Jerusalem in July 1918 of a twilight visit to No. 1 Squadron AFC, where he pulled up outside the flight commander's big tent:

You would have been gratified at the affectionate greeting. Of the three 'flyers' one grabbed my baggage, another left for the mess for a large bottle of Bass \& the third laid out his bath \& filled it with water. Such charming boys. Ross Smith the star among them got two Huns in very brilliant fashion yesterday. They dived as he attacked \& flew very low among some wadies [sic]. He downed them when they were within 50 feet of the ground by sheer pugnacious pursuit within a few yards of the ground. Then he photographed them...He is the South Australian I once 
said had the manners of a prince: he would stand very close to top in our gallery of young Australians...He is an inspiration to every man in the squadron both as a great airman \& a personality.

Gullett's status as historian in uniform enabled him to move freely among all ranks. It helped that his friend Major A. B. 'Banjo' Patterson, commanding the Australian Remount Squadron, entrusted him with good horses. Shortly after the memorable interlude with the former Light Horseman Ross Smith and his companions, he had tea with 'Colonel Williams', now commanding the wing, whom he described as: 'Just a well grown goody goody schoolboy... A fearsome disciplinarian. He has made a great Australian squadron of this...Williams is capable of almost anything. ${ }^{9}$ Richard 'Dicky' Williams didn't drink, smoke, or swear but was 'not only popular, but he was also deeply respected throughout his squadron'.$^{10} \mathrm{He}$ was to be a towering presence in Australian military aviation for another 25 years.

A week later, Gullett completed two articles on 'the flying people'. ${ }^{11}$ When he came to write the official history of the Australians in Sinai and Palestine four years later, Gullett was to refer in passing to No. 1 Squadron and its commanding officer, 'a young Australian of marked capacity' and the reputation of Williams' unit 'recognised as a great battle-squadron, and... at the same time conspicuous as a model of efficiency in all mechanical work and administration' ${ }^{12}$

By mid-1918 there were hopes that a way might be found to escape to London to join Penelope and their three-year-old son for a break from duty. He had been awarded a C. B.: not the decorations and mentions of his cousin Sid, nor the distinction in battle of Sid's younger brother who was killed in action; but it was welcome recognition of the earnest and sometimes dangerous duties to which he had been summoned. He was already beginning to look forward to a post-war world. As he told his friend Jack Latham, who was 'fully and usefully employed' in naval intelligence in Melbourne, whatever they had done in the past few years would 'be nothing to the employment that will lie before everybody at the conclusion of the War'. Looking back he lamented: 'the pity of the business is that so much splendid work in 1915 was interrupted by irresponsible criticism, which can only be described as crazy. I have never yet been able to understand why Australian people swallowed such stuff, however that cannot be helped.'13

9 Gullett to Penelope Gullett, 21-24 July 1918, Gullett MSS, NLA MS 3078/5/190.

10 L. W. Sutherland in collaboration with Norman Ellison, Aces and Kings, Angus \& Robertson, Sydney, 1935, p.57.

11 Gullett to Penelope Gullett, 31 July 1918, Gullett MSS, NLA MS 3078/5/364.

12 H. S. Gullett, The Australian Imperial Force in Sinai and Palestine 1914-1918, Angus \& Robertson, Sydney, 1923, p.658.

13 Gullett to Latham, 17 June 1918, Latham MSS, NLA MS 1009/20/651A. 
The opportunity to better inform the Australian people about their 'forgotten army' in Palestine had been thrust upon Gullett in the closing stages of the war. As he explained to Penelope about the thwarting of their plans for a reunion in London: 'There was nothing to stop it until they sprang the job as correspondent... The position is this. The whole force has resented having no publicity \& there has been the strongest desire that I should do it.' Badly as he felt, 'it would be very questionable to go off for three months...there are some 15000 to 20000 men here \& most of them have been away for years. They $\&$ their people at home will be greatly pleased to see the Light Horse written about.' $^{14}$

A cataract of articles came from his typewriter over the next few months. Yet there was always time for a long bulletin of news for Penelope. At the end of August he once again visited the fighter squadron:

Young McGinness who already had two certain and one probable German to his credit this week yesterday got two more in a very brilliant fight over our lines. A more unlikely looking coot you never saw: very fair with wild straight fair hair hanging nearly to his eyes: hatchet faced round shouldered with upper teeth always showing. But such a nice modest boy. I congratulated him \& he said 'O I only steered the old bus while Fysh shot them.' Fysh was the observer, a long innocuous pleasantfaced Tasmanian not yet done growing. McGinty as the squadron call him gave me the compass from one of the Hun machines, or what was left of it after a fall of 12000 feet. I said I would hand it in to Trophies. 'In that case,' he said, 'I'll keep it. I want you to have it yourself.' So I have it for Joe. ${ }^{15}$

The correspondent's life was replete with surprises and excitements. None revealed more of his character than the aftermath of the Surafend incident, when some 200 men of the Anzac Mounted Division 'cleaned up' a village in which a New Zealand sergeant had been killed by an Arab caught in the act of stealing a rifle. The Anzacs had waited in vain for some action from GHQ before angrily taking the matter into their own hands. A rum-fuelled rampage left scores of dead Bedouin and a village in embers. The Commander-in-Chief, Sir Edmund Allenby, had the troops assembled and rebuked them as cowards and murderers. No culprits were identified or charged. But the entire division was sent to Rafa, a desolate semi-desert post, with all leave cancelled and those on leave recalled. As a further mark of displeasure, the forthcoming honours list contained no names from the offending division. When the Australian and New

14 Gullett to Penelope Gullett, 26-28 July 1918, Gullett MSS, NLA MS 3078/5/205.

15 Gullett to Penelope Gullett, 1-4 Sept. 1918, Gullett MSS, NLA MS 3078/5/259. Hudson Fysh and 'Young McGinnis' would become two of the founders of Qantas. 
Zealand troops were about to return home in June 1919, Gullett took it upon himself to warn Allenby of the unwisdom of allowing their deep resentment to fester. The general attempted to order Gullett to withdraw. But, no longer a mere lieutenant, and now in civilian clothes and holding an appointment from the Australian government, he stood his ground. Allenby at last saw the point. This was no time to hazard Imperial ill-will. The Anzacs had after all been instrumental in bringing him some considerable victories. A hastily concocted order of the day was printed and distributed throughout the departing division and to every Australian and New Zealander in Egypt, Palestine, and Syria. It was typical of Gullett that when he wrote of this incident in his official history of the war he did not identify himself as the man who had confronted the Commander-in- Chief. ${ }^{16}$

\section{Politics or nothing}

When the war was almost over it was time for a fundamental decision. Before returning to England, Gullett had sent a long letter from Cairo to his 'darling Penelope' setting out his thoughts:

Have some writing to do. Hard to work: now the long strain is over I am panting to get back to work - this time constructive work I pray that you will be interested in.

The Labour people at home will be hard to swallow. And they must be swallowed whole: if I start there I must burn my boats \& curb my restlessness \& temper \& go in for better or worse. It is that or no politics or ambition at all. I have flirted with the idea of the Other Side but it's no use: I can't see myself as the champion of Fat. Had I myself attained to Fatness it might have been different. But that I should spend the rest of my life working to make Fat still fatter is unthinkable. Even with riches I have I think been politically for Labour. Without riches the decision is easier. It will be hard to take sides against many good friends in the AIF who are uncompromising. But all in all we have few we care about as far as that. We are so independent \& complete in our happiness.

\footnotetext{
16 Lieut.-Col. G. F. Langley DSO, 'Sir Henry Gullett, A Tribute', Reveille, Dec. 1940, p.8. Langley dined with Gullett immediately after the meeting with Allenby. The story is repeated in George F. and Edmée M. Langley, Sand, Sweat and Camels, Seal Books Sydney, 1980 (1st ed. Rigby 1976), pp.174-5; Gullett, The Australian Imperial Force in Sinai and Palestine, pp.790-1. Paul Daley, Beersheba: A journey through Australia's forgotten war, MUP, 2009, pp.251-304, Terry Kinloch, Devils on Horses: in the words of the Anzacs in the Middle East 1916-19, Exisle Publishers, Auckland, 2007, pp.329-34, and Peter Rees, Desert Boys: Australians at war from Beersheba to Tobruk and El Alamein, Allen \& Unwin, Sydney, 2011, pp.285-90 examine the Surafend 'massacre'.
} 
12. Patriot: Harry Gullett

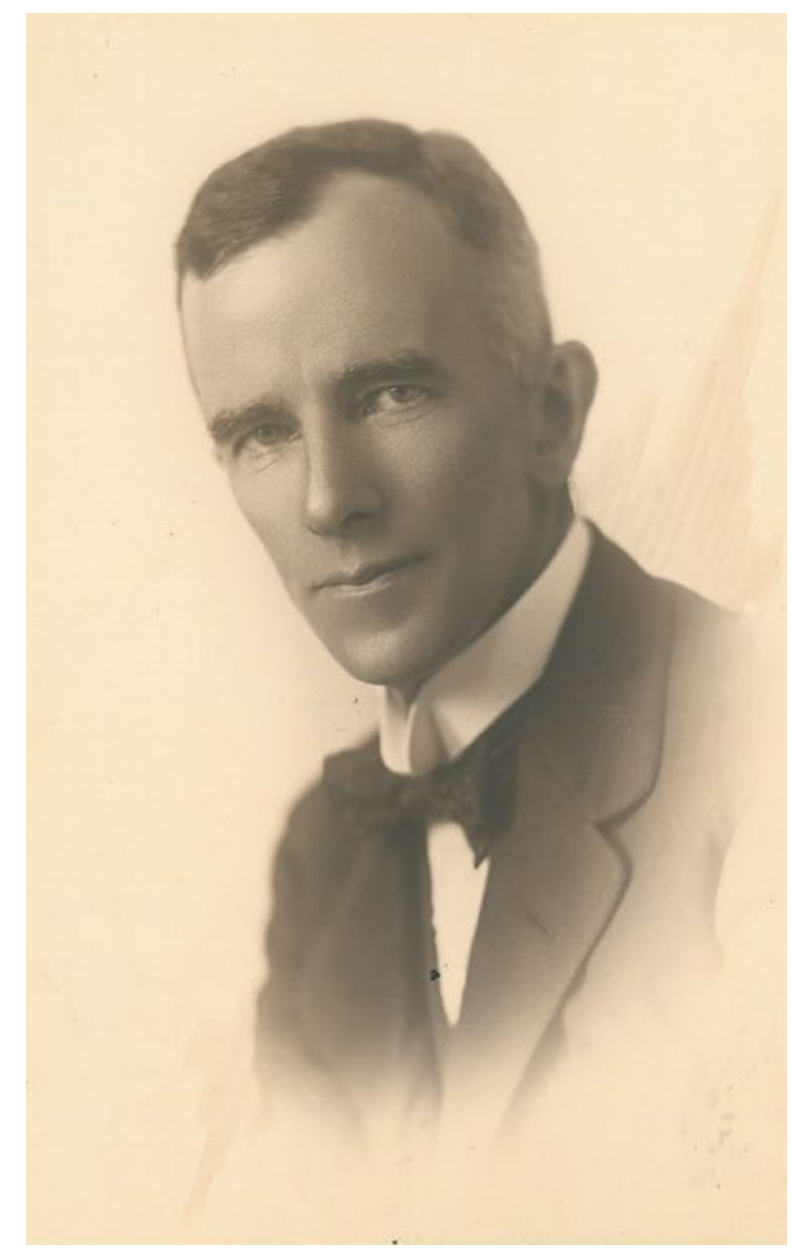

Boats burned and heading towards politics

(Courtesy of Peter and Kate Gullett)

The way ahead, as Harry saw it, was if possible to join a new Labor newspaper, The World, in Sydney which would serve as a 'good platform for my political apprenticeship'. Convinced in his bones that he could make a unique contribution to Labor, he knew that he needed to work on his public speaking. It might take three years before he could get into federal Parliament but, once in, he was sure his progress would not be slow. The only alternative was London:

I have no ambitions in journalism in Australia: it is politics or nothing for me \& also I think for you. London would be a surrender - pleasant 
but a surrender. Our lives would go gaily enough \& we should live in a House Beautiful \& rejoice in Joe. But feeling as I do today more confident \& full of fight than I have ever been, London is not satisfying. ${ }^{17}$

While still in London he told Penelope: 'I should give a fortune to be out on the Labour ticket next elections in Australia. With a good propagandist on their side they will sweep $\mathrm{H} \&$ Co into the sea. The present administration is a hopeless thing \& is not improving. ${ }^{18}$ As Press Liaison Officer to the Prime Minister at the Paris Peace Conference, he had seen enough of Hughes to form a definite judgement. But needing to work and earn an income, and with a second child on the way, he did not vex his chief with unnecessary dissent. He was aware that if he were to start expressing political views on the platform or in the press his government work must cease. It had to be all government work or none. And the choice could not be long delayed.

Not yet swept into the sea, and oblivious to Gullett's true sentiments, Billy Hughes invited Gullett to become director of the proposed Australian War Museum, relieving the over-burdened Bean. It was a creative job enlivened by good company, as his son remembered:

My father used to rise very early and work a couple of hours on his history. Then he set off to the Exhibition Building on the old cable tram. On Sunday mornings artists and soldiers would come to our house with notes, sketches, maps and battle pictures. General Chauvel and General White rode up on horses, while Generals Gellibrand and Glasgow came by taxi, because there were no trams on Sunday morning. Albert Jacka, the most famous of all Australian fighting soldiers with his VC, MC and Bar, rode a bicycle. Bill Dyson and George Lambert walked the mile or so from the railway station. Only our cousin Sid Gullett drove his own car. ${ }^{19}$

Enjoyable as his post at the War Museum was, Gullett still had a career in public life in mind. In 1920, he accepted an offer from Hughes to become director of the Australian Immigration Bureau, a role he seems to have devised for himself. Soon falling out with the Prime Minister over immigration policy ('a wretched quarrel' as he told his lawyer friend Jack Latham), he 'left the work - officially - with very deep regret, not impulsively but only after long consideration \& when I was convinced that things must get worse before they could improve'.$^{20}$ A day after his resignation, a cable from Lord Northcliffe in London offered

17 Gullett to Penelope Gullett, 3 Nov. 1918, Gullett MSS, NLA MS 3078/5/301.

18 Gullett to Penelope Gullett, [n.d. ?1919], Gullett Family MSS.

19 Gullett, Good Company, pp.2-3.

20 Gullett to Latham, 5 March 1922, Latham MSS, NLA MS 1009/1/995. 
him a senior post on The Times. It was the kind of appointment few journalists would have resisted. His Army friend George Langley was with him when the message arrived:

...he quickly made up his mind to decline the offer - giving two reasons for so doing — he thought it would look like funking it if he left Australia then. He preferred to stay and resolved at once to try politics, entering the lists as a critic of the P.M. His second reason was that he wanted his son Joe...to 'grow up an Australian'. ${ }^{21}$

There was a third reason. After prolonged editorial battles, his Official History volume was close to publication. His narrative of the Australian Light Horsemen at war in the Middle East was imbued with respect and admiration for 'the very flower of their race'. In a book of almost 800 pages, he told a story of courage and achievement by 'a remarkable band of brothers in arms...drawn from a wide and fragrant countryside, animated by a noble cause, thrilled and expectant with the sense of a grand adventure in foreign lands, and knit together by the common interest of their peace-time callings and the still closer ties of personal friendship and affection'. The lyrical portrait of the 'Light Horseman and his Horse', preceded a lengthy exposition of tactical insight, generous character assessment, and vivid action.

Some British experts in particular would find fault with what they thought 'fierce and unfair criticism'. But the book was an impressive effort, nearly 300000 words long, comparable in scope, if not quite in authority, with the works of Bean on the more popular themes of the Western Front and Gallipoli. Unlike Bean, however, Gullett did not invest his Desert Mounted Corps heroes with too grand a moral mission. Downplaying the indiscipline of the troops in the Holy Places that so troubled their superiors, he told Bean, 'their campaign was to a remarkable extent one with a casual sporting purpose to which they bent all their high intelligence and endeavour'. His aim was to provide a 'clear honest narrative' that would serve both as a military textbook and a book for the general reader. Intentionally or not, it was to have the effect of making reputations for the commanders whose praises he sang. Much as he admired Sir Harry Chauvel, however, he resisted some of Chauvel's strongly pressed suggestions. As Gullett himself noted, the usually un-self-congratulatory Chauvel saw the potential for 'a good deal of self-advertisement' in the book. ${ }^{22}$

21 Langley, 'Sir Henry Gullett...', p.8.

22 Daley, Beersheba, p.298; The Times, 14 Aug. 1940; Christopher Lee, "War is not a Christian Mission": Racial Invasion and Religious Crusade' in H. S. Gullett's Official History of the Australian Imperial Force in Sinai and Palestine', Journal of the Association for the Study of Australian Literature, vol. 7, 2007, pp.85-96; Hill, 'Introduction', The Australian Imperial Force in Sinai and Palestine, 1914-1918. 
In ill-health, and incensed at the criticism of his text from Angus and Robertson's editors, Gullett had threatened to withdraw the manuscript, pay back his fee to the Defence Department, and publish the book himself. Dissuaded by Bean from extreme measures, he would soon enjoy public acclaim and qualified professional commendation. In what was generally regarded as an engaging if 'over coloured' journalistic account, clichés and banalities were noted by discerning reviewers, though there was little reaction to the assumption of racial inferiority implicit in passages about the peoples of Palestine and the Sinai. It would be many years before shifting cultural values and a new generation of military historians brought significant revision of a work that the author himself was glad to put behind him. ${ }^{23}$

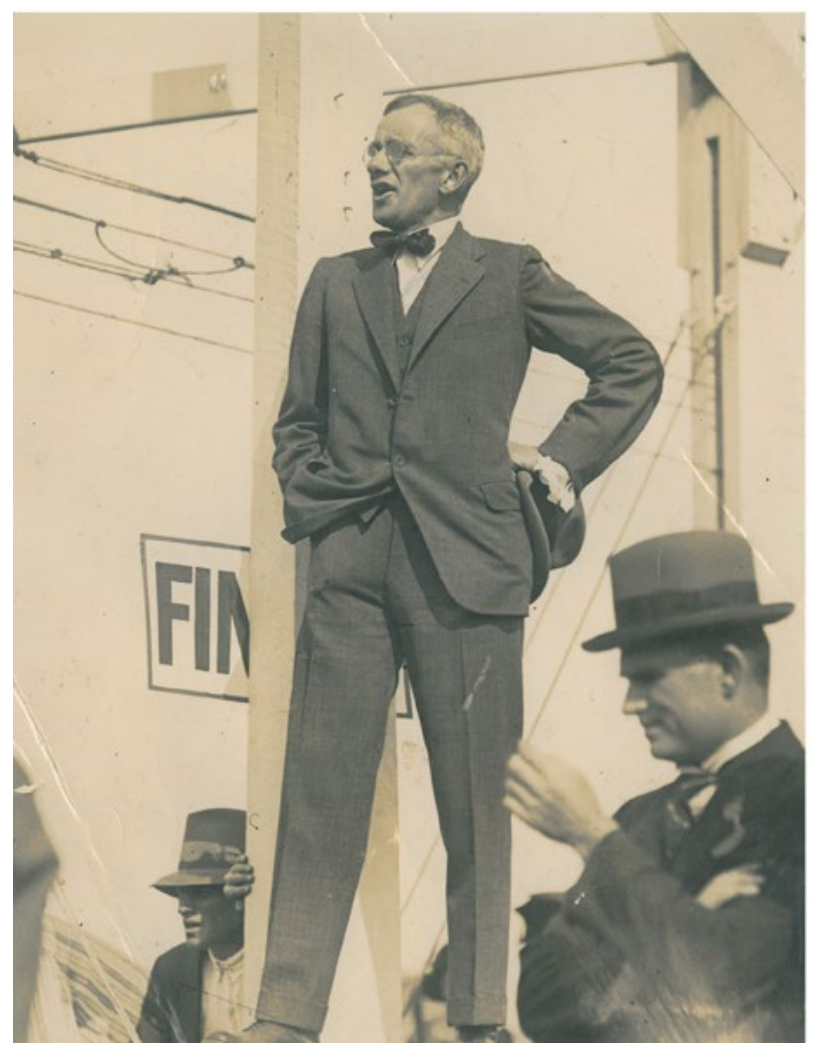

\section{On the hustings, with trade-mark bow tie}

(Courtesy of Peter and Kate Gullett)

23 Suzanne Brugger, Australians and Egypt 1914-1919, MUP, 1980, pp.72-5; Graham Wilson, Bully Beef \& Balderdash: Some Myths of the AIF Examined and Debunked, Big Sky Publishing, Newport NSW, 2012, pp.211-3 for Gullett's failure to correct false stories of the fate of the horses of the Light Horse. 


\section{Political intent}

As his historical task was coming to an end, both Gullett and his friend Jack Latham stood for the House of Representatives. Latham succeeded as an antiHughes candidate in 1922. It took Gullett, who had been working as news editor of the Melbourne Herald, a second attempt before he was elected in 1925 as an Independent Nationalist for Henty, centred on the Melbourne bayside suburb of Brighton. Independent of Hughes, independent of Labor, Gullett cast himself into the fray as a Nationalist who would accept no party whip. George Langley, formerly of the Camel Corps and the $5^{\text {th }}$ Light Horse Regiment and now back teaching in country Victoria, was at his side during the electioneering. ${ }^{24}$ In the meantime, Gullett had foreshadowed something of his own future political spirit and instincts in letters to Latham. Commending Latham on an independent vote, he wrote, 'The rigid party line is an accursed thing. ${ }^{25}$ While working at the Herald he confessed: 'I find it extremely difficult to abstain from rebellion against the prolonged idleness of the men of big personality and ability... And I cannot escape the conviction that the Country Party fellows are playing a very selfish game.' Gullett had seen a good deal of Stanley Bruce, 'in a personal way', and formed the opinion that the Prime Minister would have:

...broken the show up but for his difficulty in forming an all-Nationalist team which would have been in the least impressive. He has had an exceedingly trying time and is very anxious lest the continuation of the Composite Government should weaken Nationalists now holding rural seats. ${ }^{26}$

Almost from the beginning of his parliamentary career, Gullett found much about the life disagreeable. 'God knows I am no saint,' he told his wife in February 1928, 'but I feel at least a little too decent to remain long in this dirty game.' He felt as though he was 'in the gun' and would never get to the front bench in the absence of drastic change. Riding for a while with a small group of independent Nationalist backbenchers, he certainly did not advance his cause by characterising the Country Party leader Earle Page in November 1927 as 'the most tragic Treasurer' Australia had ever had. ${ }^{27}$ The defeat of Bruce and the loss of half a dozen of his supporters might, he thought, produce a different story after the next election. ${ }^{28} \mathrm{He}$ had made up his mind to go his own way, 'careless

24 George F. and Edmée M. Langley, Sand, Sweat and Camels, pp. xv, 144.

25 Gullett to Latham, 16 Aug. 1923, Latham MSS, NLA MS 1009/1/1112.

26 Gullett to Latham, 11 Aug. 1924, Latham MSS, NLA MS 1009/1/1270.

27 C. J. Lloyd, 'The Formation and Development of the United Australia Party', Ph.D. thesis, Australian

National University, 1984, p.24, courtesy of the late Professor Clem Lloyd.

28 Gullett to Penelope Gullett, 22 Feb. 1928, Gullett MSS, NLA MS 3078/5/595-7. 
of consequences', in the next House. But it was not long before Bruce took him aside for the kind of heart to heart conversation that party leaders bestow on promising but recalcitrant backbenchers:

He had me marked for early inclusion in Ministry. He dwelt on my many qualities; pressed the point that outside the Ministry I could do nothing along the lines I believed in, while inside I could use my influence. He was a reasonable man, always prepared to listen \&c \&c.

He said nothing as to future \& I can only guess at what he was driving at...I gave no assurances, but admitted frankly that our repeated disagreements were a keen disappointment to me \& that I regarded the future without much personal satisfaction. ${ }^{29}$

Gullett would not have to wait for Bruce's misfortune before making the longedfor advance. In November 1928 he was appointed Minister for Trade and Customs. Among his first social engagements as a member of the Cabinet was a dinner he gave for Sir Hugo Hirst, chairman and managing director of the General Electric Company, who was visiting Australia with three other British industrialists and their wives. The delegation had come at the invitation of the Prime Minister to give advice on economic development. Hirst recorded his impressions of the new minister as 'a most cultured man' who 'seems to have been a journalist at one time'. Hirst was struck by the decorations in the Gullett house that 'show in good taste' records of his travels in Japan and the East, Canada, and Europe. Like almost everyone, he found Penny Gullett charming. ${ }^{30}$

There was real work to do as a minister; but less than a year later Gullett was out of office when the Bruce-Page government was defeated at the polls. With a Labor government in power, and his former leader Bruce departed, Gullett felt 'without much direction politically'. Yet his career advanced. As Deputy Leader of the Opposition under Latham there was some relief to be felt that it was James Scullin and his Labor colleagues who were at the helm at a time of world economic crisis. It was Labor that would have to bear the opprobrium for some years of 'increasing expenditure \& falling revenues - and more direct taxes'. ${ }^{31}$ As Jack Lang remembered, Gullett was 'the gad-fly who harassed the Scullin Government incessantly' ${ }^{32}$ Gradually, from a vantage point in the inner circle, he was becoming more comfortable with the moneyed interests he had once disdained. The lack of direction was perhaps further mitigated by the news that the National Union, the Collins Street powerbrokers, had granted him up

29 Gullett to Penelope Gullett, [n.d. 1928], Gullett MSS, NLA MS 3078/5/600.

30 Sir Hugo Hirst's diary, 25 Nov. 1928, 6 Jan. 1929, MS Marconi 3174, Bodleian Library, Oxford.

31 Gullett to Latham, 3 Feb. 1930, Latham MSS, NLA MS 1009/1/1956.

32 J. T. Lang, The Great Bust: The Depression of the Thirties, McNamara's Books, Katoomba, 1980 (1st ed. Angus \& Robertson 1962), p.311. 
to $\$ 400$ a year to pay for a secretary. ${ }^{33}$ Direction was certainly found when the departure of Joe Lyons from the Labor ranks and the formation of the United Australia Party soon brought an end to Labor rule. Gullett, working closely with Menzies, had been privy to the manoeuvrings with Lyons, his friend and fellow Athenaeum Club man Keith Murdoch, and others that led to the new party. He was present when Menzies vetoed Earle Page as 'No. 2', thereby determining that the conservative forces were to go ahead without the Country Party. ${ }^{34}$ In the new configuration Latham, having deferred to Lyons as leader, assumed Gullett's role of Deputy Leader of the Opposition. After the UAP's landslide victory in the general election of December 1931, Gullett entered the Lyons Cabinet, once again as Minister for Trade and Customs. ${ }^{35}$

The political ferment of the next few months, with 'secret' and not so secret armies competing in alarms and excursions, left few political leaders completely untouched. Unfounded fears of communist revolution and well-founded concern about the intentions of the New South Wales government under Jack Lang, brought many prominent businessmen, pastoralists, and retired military officers into anxious conclave. Among the first to congratulate Gullett on his new appointment was Captain L. W. Sutherland, secretary of the militant and highly visible anti-communist group, the New Guard. Leslie 'Woodie' Sutherland was a former Australian Flying Corps observer whose service in Palestine had brought him a DCM and an MC as well as several mentions in Fred Cutlack's official history of the AFC at war. ${ }^{36}$ Cutlack, now a leader writer for the Sydney Morning Herald, remained an ally in advancing patriotic causes. ${ }^{37}$ In the late 1920s, having been invalided out of the RAAF after an accident, Sutherland was aviation representative for the Vacuum Oil Company; in that capacity he was closely involved with Charles Kingsford-Smith, Charles Ulm, and Keith Anderson. He had testified to the 'Coffee Royal' Inquiry that Anderson had not followed regulation procedure in 'swinging' of the Kookaburra's compass at Richmond before the fatal flight with Bobby Hitchcock. 'Highly intelligent and of adventurous disposition', as a secret naval intelligence division report described him, Sutherland now wrote to 'Harry' Gullett introducing 'a close personal friend of mine Capt De Groot'.

\footnotetext{
33 E. H. Willis to Latham, 25 Feb. 1930, Latham MSS, NLA MS 1009/1/1961.

34 Anne Henderson, Enid Lyons: Leading Lady to a Nation, Pluto Press Australia, North Melbourne, 2008, p.161; Anne Henderson, Joseph Lyons: The People's Prime Minister, Newsouth, Sydney, 2011, p.290.

35 'The Rise and Fall of the United Australia Party', is authoritatively distilled by Clem Lloyd in J. R. Nethercote (ed.), Liberalism and the Australian Federation, The Federation Press, Sydney, 2001, pp.134-62; for 'The Politics of the Depression' Allan W. Martin's essay in Robert Manne (ed.), The Australian Century, Text Publishing Melbourne, 1999, pp.80-118, remains unsurpassed.

36 Sutherland to Gullett, 28 Jan. 1932, NAA A367/1, C94121; F. M. Cutlack, The Australian Flying Corps in the Western and Eastern Theatres of War 1914-1918, Angus \& Robertson, Sydney, 1935 (1st ed. 1923). Sutherland's own war stories, written in collaboration with Norman Ellison, are in Aces and Kings, published in 1935.

37 Moore, The Secret Army and the Premier, pp.123, 131.
} 
According to Sutherland, Attorney-General Jack Latham had been anxious to contact Eric Campbell, the New Guard leader, 're some departmental matter'. Campbell was a decorated artillery officer, and now a well-connected solicitor with command experience in the Militia. He had been retained for some time by Vacuum Oil where he came into close contact with the former post-war Director of Artillery, Brigadier-General Herbert Lloyd, who punctuated his military and business career with spells as a Nationalist, and later UAP MP in the NSW Parliament. Campbell had achieved considerable publicity in 1929 representing Kingsford-Smith and Ulm as they defended themselves against allegations that their disappearance in the Kimberley was a stunt arranged with Keith Anderson. He had been intimately connected with the shadowy groups of businessmen, graziers, and ex-officers gathered together in 1930 amid fears of revolutionary anarchy. By 1932, having broken away in February 1931 from what came to be known as the Old Guard, he had recruited his own New Guard with as many as 36000 adherents. Herbert Lloyd initially occupied the deputy leadership role. Kingsford-Smith was, it seems, designated by Campbell as the head of an air wing if the New Guard were ever to be mobilised to keep order. Both Campbell and Gullett's parliamentary colleague Frederick Stewart were directors of Kingsford-Smith's company, Australian National Airways.

Meanwhile, Captain Frank De Groot had been detailed to see the AttorneyGeneral. It was 28 January 1932 and the NSW Premier J. T. Lang's populist economic policies were causing increasing alarm in conservative financial and political circles. Evidently Gullett acted promptly on the request that he assist De Groot to contact Latham. If Gullett did not know Campbell, he certainly would have known of him. Campbell had been associated in a para-military venture with Major Jack Scott, at the instigation of former Prime Minister Stanley Bruce in 1925. Scott was now chief of staff of the Old Guard, with whom the New South Wales police had a quiet understanding. Sutherland's letter bears a handwritten note from Latham to the Director of the Intelligence Bureau: 'Brought to me by Capt de Groot to whom I explained that I had not sought contact with Col. Campbell but that, as A. G., I wd be glad to receive any authentic information which might prove of value. ${ }^{\prime 38}$

Latham, long enmeshed with the intelligence community and forces arrayed against communism, appears to have been economical with the truth about his contact with Campbell..$^{39}$ On the same day, from his office in the Sydney Morning

38 NAA: A367/1, C94121. The connection between De Groot, Campbell, and Latham is acknowledged in Andrew Moore, 'De Groot, Francis Edward (Frank) (1888-1969)', Christopher Cunneen et al (eds), Australian Dictionary of Biography, Supplementary Volume, MUP, 2005, pp.97-9, and explored more fully in Moore's Francis De Groot: Irish Fascist Australian Legend, Federation Press, Sydney, 2005, and 'Loyal lieutenant or spy? Frank De Groot and the intelligence services', Journal of the Royal Australian Historical Society, vol. 96, Pt 2, Dec. 2010, pp.201-20, the latter of which came to hand after these paragraphs were written.

39 For Latham as legal officer for Monash's special constables during the 1923 Victorian police strike, and the support of the anti-Bolshevik Australian Legion for his early parliamentary candidacies, see Andrew 
Herald building, Campbell wrote direct to Latham introducing De Groot who was, he said, 'known to Mr Gullett'. It appears that Gullett's old colleague and 'very close friend' Fred Cutlack had acted as an intermediary, and Campbell acknowledged that it might be embarrassing for Latham to see him personally. ${ }^{40}$ Campbell did not need to add that De Groot was well-known as a former reproduction furniture manufacturer, shop-fitter, and antique dealer, as well as a prominent supporter of the Red Cross Limbless Soldiers' Association. Latham met De Groot but was careful to put on record for the director of the Investigation Bureau that he had given no undertaking, agreement, or understanding about future government action. He would, however, 'be glad to receive at any time useful information - rather than hearsay accounts - from any source'.

Whatever authentic information Latham received directly from Campbell's camp, the government was well-informed about the New Guard, especially its wilder elements, and soon recognised, along with the New South Wales police, that it was better treated with caution, as more a threat to 'constituted authority' than an ally in the cause of social harmony. De Groot's spectacular intervention at the opening of the Sydney Harbour Bridge caught the public imagination. But more-sinister plans were germinating. When Campbell cabled the Prime Minister in April 1932 offering to place the New Guard at the government's disposal in the event of an emergency, he was politely rebuffed. 'We deprecate the suggestion that an emergency is likely to arise that will require intervention by the Commonwealth and the use of organised force,' Lyons wrote. ${ }^{41}$

Gullett, as Minister for Customs, was too cautious to have allied himself with Campbell's quasi-fascist and fractious movement. He was neither attractive to, nor attracted by, secret armies. But some of his parliamentary colleagues were not bashful about their New Guard links. It was evident that there was considerable overlap between those in the community who looked to the New Guard as a guarantor of public safety and those who saw in the United Australia Party the answer to the nation's political troubles. The newly-elected UAP MP for Parramatta, Frederick Stewart, was most conspicuous. A director of Associated Newspapers, as well as chairman of Kingsford-Smith and Ulm's airline, ANA, Stewart openly assisted the Guard by making part of his Sydney bus fleet available to convey a bizarre fire-fighting expedition to Cobar. ${ }^{42} \mathrm{He}$ was soon to become Minister for Commerce and to take over trade negotiations from an exhausted Gullett.

\footnotetext{
40 Re Cutlack as a very close friend: Gullett to A.R. Wiggins, 3 Jan. 1933, Gullett Family MSS.

41 Campbell to Attorney-General, 28 Jan. 1932; Maj. H. E. Jones to A/g Attorney-General, 1 March 1932, 'The New Guard and "The Association"', NAA: A367/1, C94121; Cables Campbell to Lyons and reply 6,7 April 1932, Lyons MSS, NLA MS 4851 Box 1, folder 4; Moore, Francis De Groot, pp.48-51,56-81; Richard Evans, "'A menace to this realm" The New Guard and the New South Wales police, 1931-32', History Australia, 5(3), Dec. 2008, DOI: 10.2104/ha080076.

42 Moore, The Secret Army and the Premier, p.149; Mackersey, Smithy, pp.204-5, 253.
} 
It was only 10 months later, after playing a key role in defending Australian trade interests at the Ottawa imperial economic conference - his 'fiery temper was useful' Stanley Bruce would recall - that Gullett's health broke down. ${ }^{43}$ After four months of convalescence he felt compelled to resign his office. As Charles Bean was to summarise this phase of his life, he 'rounded off his work at the Ottawa Conference with one of the greatest speeches ever delivered in our Parliament, and with the permanent loss of his health' ${ }^{44}$ Consoled with a knighthood, 'like all the political ones, purely an accident but...a pleasant souvenir of the happy, if somewhat hazardous, Ottawa enterprise', he might have supposed that he would spend the rest of his political career on the UAP back benches. ${ }^{45}$

\section{'A fanatical Australian'}

'The main purpose of the United Australia Party', a young Sydney scholar had pronounced in 1935, was to keep the ALP out of office. 'It is not bound together by any principle that it can claim as peculiarly its own.' If anything held together 'the chequered and speckled complicated piece of cabinet-making known as the United Australia Party', it was 'a determination to defend the rights of property' ${ }^{46}$ It was to be expected therefore that men like Geoff Street and Jim Fairbairn would be found among the UAP's most active figures. Nor was it strange that the announced policy of what was left of the New Guard in August 1934 was to give whole-hearted support to the UAP at the next federal general election. But Harry Gullett? During a decade and a half of political turmoil and re-alignment he had found a home outside the Labor Party to which he had at first been attracted. For all his instinctual revulsion from fat capitalists, his vision was of development and immigration, an Australia of prosperous farms and pasture but also of burgeoning towns providing work for builders, carpenters, plumbers. He saw too a future for secondary industry. As early as 1914 he had written: 'For nearly a century the squatters produced the bulk of Australia's wealth; but the second century is to belong not to the squatter but to the farmer and the industrialist. ${ }^{\prime 7}$ 'He was,' remembered Sir Larry Hartnett, 'a fanatical Australian, absolutely crazy to get a motor car manufactured.' ${ }^{48}$

\footnotetext{
43 Cecil Edwards, Bruce of Melbourne: Man of Two Worlds, Heinemann, London, 1965, p.211.

44 Reveille, Sept. 1940, p.8. Kosmas Tsokhas, 'Australia and the Ottawa Conference', Working Papers in Economic History, No. 122, Jan. 1989, Research School of Social Sciences, ANU.

45 Gullett to Sir Hugo Hirst Bt, 11 March 1933, Gullett MSS, NLA MS ANU 3078/3/468.

46 J. A. McCallum, 'The Economic Bases of Australian Politics', W. G. K. Duncan (ed.), Trends in Australian Politics, Angus \& Robertson in conjunction with the Australian Institute of Political Science, Sydney, 1935, pp.62-4.

47 Gullett, The Opportunity in Australia, p.114.

48 Recollections of Sir Laurence Hartnett, 16 Sept. 1977: Joe Rich, Hartnett: Portrait of a Technocratic Brigand, Turton \& Armstrong, Sydney, 1996, pp.102-7.
} 
Gullett was a man of enthusiasms, with a deep belief in the potential of government to make the nation a better place. For such a man, thoughts of retirement were premature. Lyons brought him back after the 1934 general election as Minister without Portfolio with responsibility for trade treaties. When he returned to the government he had not foreseen the difficulties ahead, not least his own ill-health. Jim Fairbairn would tell Charles Hawker in February 1935 that their friend 'looked like death (or a candidate for the mad house)'. In London in October 1935, he was contemplating but rejecting the idea of resigning: 'There is nobody else for the job \& it must be done. ${ }^{49}$ Reflecting on the experience when in due course he did resign, he told one of his old wartime heroes, the 'serene and unpretentious little man' Sir Harry Chauvel, 'I had rather an awful $2 \frac{1}{2}$ years because of the fact that after my illness I joined in a junior capacity, and yet was called upon to handle so much important work. ${ }^{50}$

The important work to which Gullett had to turn his hand was the government's policy of 'trade diversion'. In May 1936 he was to announce the new policy designed to increase export of primary produce, expand secondary industry, and generate rural and industrial employment. A key element of the plan entailed preference for 'great customers' like Britain and correspondingly higher tariffs on Japanese textiles. When the pastoral industry, particularly the NSW graziers, mounted a campaign against the government's policy, Gullett was staunch with Lyons and the Country Party leader, Earle Page, in standing firm against pressure from wool growers and brokers to accede to Japanese demands. Restrictions on Japanese rayon and cotton exports to Australia looked to some like a capitulation to British cotton manufacturers. Gullett explained the policy privately to the Governor-General: 'If we cannot keep within definite bounds the import and competition of goods produced by Eastern standards (not only in textiles but in all manufactures) there is no safe future for British Australia. ${ }^{51}$

Unimpressed graziers, abetted initially by Gullett's erstwhile Cabinet colleague Charles Hawker, saw the minister with responsibility for trade treaties as the author of their prospective misfortunes. Bob Menzies, Deputy Leader of the UAP, was quietly letting it be known that he had misgivings about the way negotiations were being conducted. ${ }^{52}$ But there was an 'inwardness' about the policy. Hawker, understanding the political danger of a stalemate and public conflict between pastoral interests and the UAP, eventually came round to support a compromise government position. Gullett and Lyons were edging

\footnotetext{
49 Fairbairn to Hawker, 28 Feb. 1935, Hawker MSS, NLA MS 4848/1/1; Gullett to Lady Gullett, 17 Oct. 1935, Gullett MSS, NLA MS 3078/5/626.

50 Gullett to Chauvel, 22 March 1937, copy, Gullett MSS, NLA MS 3078/3/40; Gullett, The Australian Imperial Force in Sinai and Palestine, p.698.

51 Gullett to Lord Gowrie, 10 Jan. 1937, Gowrie MSS NLA MS 2852/5/9.

52 J. P. Moffat's diary, 11-12 Feb. 1937, microfilm copy, NLA G7251.
} 
their way towards a balance between the wool industry and the interests of beef producers, dairy men, and other primary-goods exporters who needed access to the British market. ${ }^{53}$

Less controversial treaties were negotiated with France, Czechoslovakia, and Belgium. On the North American dimension of trade diversion Australia was less successful. With the Americans unwilling to do anything to ease the large trade imbalance with Australia, it fell to Gullett to introduce measures to restrict imports of American goods. A licensing system and prohibitive duties were imposed in the hope of persuading the United States to lower barriers to Australian primary produce while simultaneously boosting Australian manufacturing, and increasing both rural and urban employment. A visionary element of the policy was the notion that it would smooth the way for an Australian automobile manufacturing industry. ${ }^{54}$ When the Americans retaliated in November 1936, Gullett had the task of putting the Australian position to J. P. Moffat, the U.S. Consul-General. Moffat's diary records the Trade Treaties Minister's heartfelt argument:

We are not out of the woods; we are fighting for national solvency. We have had six good moist years in a row, thank God! But Australia is a country of ups and downs; you have never seen it withered and parched and thirty or forty million sheep dying in a year. But we have. And the vision haunts us. We cannot rest until we have reserves enough to ride us over such a period. That is our first consideration. If not, we might have to default, and non-payment might gradually weaken the bonds of Empire and then God help us. No, our financial solvency is not only a matter of honour but of self-preservation.

And now you come along, oblivious of the fact that buying from North America is Australia; it is not only you but Canada. That is our next problem.

Five months later, the 'next problem' was to bring about Gullett's downfall. As Moffat summarised it on 10 March 1937, Gullett had resigned after encountering almost total opposition when seeking Cabinet agreement to impose further limits on Canadian imports and encourage trade with nations outside the Empire:

\footnotetext{
53 Kosmas Tsokhas, 'Business, Empire and the United Australia Party', Politics, 24 (2), Nov. 1989, pp.39-52; Kosmas Tsokhas, Markets, Money and Empire: The Political Economy of the Australian Wool Industry, MUP, 1990, pp.105-18; D. C. S. Sissons, 'Private Diplomacy in the 1936 Trade Dispute with Japan', Australian Journal of Politics and History, 27 (2), Aug. 1981, pp.143-59; D. C. S. Sissons, 'Pitfalls on the Road to N.A.R.A. - Sir Henry Gullett's Treaty Negotiations with Japan 1935-36', paper presented at 46th ANZAAS Congress, Canberra, 23 Jan. 1975.

54 Ross, Armed \& Ready, pp.85, 96-7.
} 
The rest of the Cabinet apparently pointed out that his trade diversion policy was getting nowhere, that this would cut across inter-Empire trade, etc. Finding himself virtually alone, with only the Prime Minister supporting him, and with his colleagues almost a unit in censuring him, he walked out of Cabinet meeting, resigned then and there and is leaving Canberra today. ${ }^{55}$

What Moffat knew, as a result of the disloyal indiscretion of J. F. Murphy, Secretary of the Department of Commerce, was that not even Gullett's department supported the trade diversion policy. Murphy explained at a private lunch that, had it not been for the absence overseas of Page and Menzies when the policy was being formulated, the measures decided upon would not have given 'such immense offence'. ${ }^{56}$ Gullett pointed the finger firmly at Earle Page: 'He and his tribe deliberately worked behind my back in direct consultation with the Canadians.' ${ }^{57}$ Gullett resigned for 'personal reasons' but insiders knew better. He had made it clear that he had not left because of his health. To a journalist invited to his hotel on the evening of his dramatic departure he went on the record: 'I have not felt so fit for many years.'

There were the usual commiserations from former colleagues. But, of all the valedictions, that from Attorney-General Menzies to 'My dear Harry' showed the most effort:

Although I was, unfortunately, not able to agree with you on the particular point we were discussing before your resignation, I feel I must write to tell you how distressed I feel about the whole matter. In a way, I have mixed feelings. On the one hand, any Cabinet must be the poorer when it loses a man of patriotism, ability and courage. On the other hand I have felt for a long time that you were over-exhausting yourself, both nervously and physically, and that only your indomitable spirit kept you to a task which most men would have long since abandoned. On the whole, I suspect that you will be a happier man from now on, and I certainly know that there will be many occasions during the next twelve months when I will envy you mightily.

Thank you for all your friendliness and companionship of the last few years... ${ }^{58}$

Menzies' distress was no doubt tempered by the fact that he had himself been given responsibility for trade treaties, co-ordinating the work of the Ministers

55 Moffat diary, 10 March 1937, Nancy Harvison Hooker (ed.), The Moffat Papers: Selections from the Diplomatic Journals of Jay Pierrepont Moffat 1919-1943, Harvard UP, Cambridge Mass, 1956, p.144.

56 Moffat diary, 26 Jan. 1937, microfilm copy, NLA G7251.

57 Gullett to Latham, 24 March 1937, Latham MSS, NLA MS 1009/1/5117.

58 Menzies to Gullett, 12 March 1937, Gullett MSS, NLA MS 3078/3/37. 
for Customs and Commerce and their departments. If Gullett felt any resentment he did not show it. He would later confide to a former parliamentary colleague: 'I was rather the "pigeon" of the piece, as trade diversion really had its origin in the Treasury. ${ }^{59}$ He would stay in the House of Representatives as a private member, he had said, a role that offered 'a great field of usefulness'.

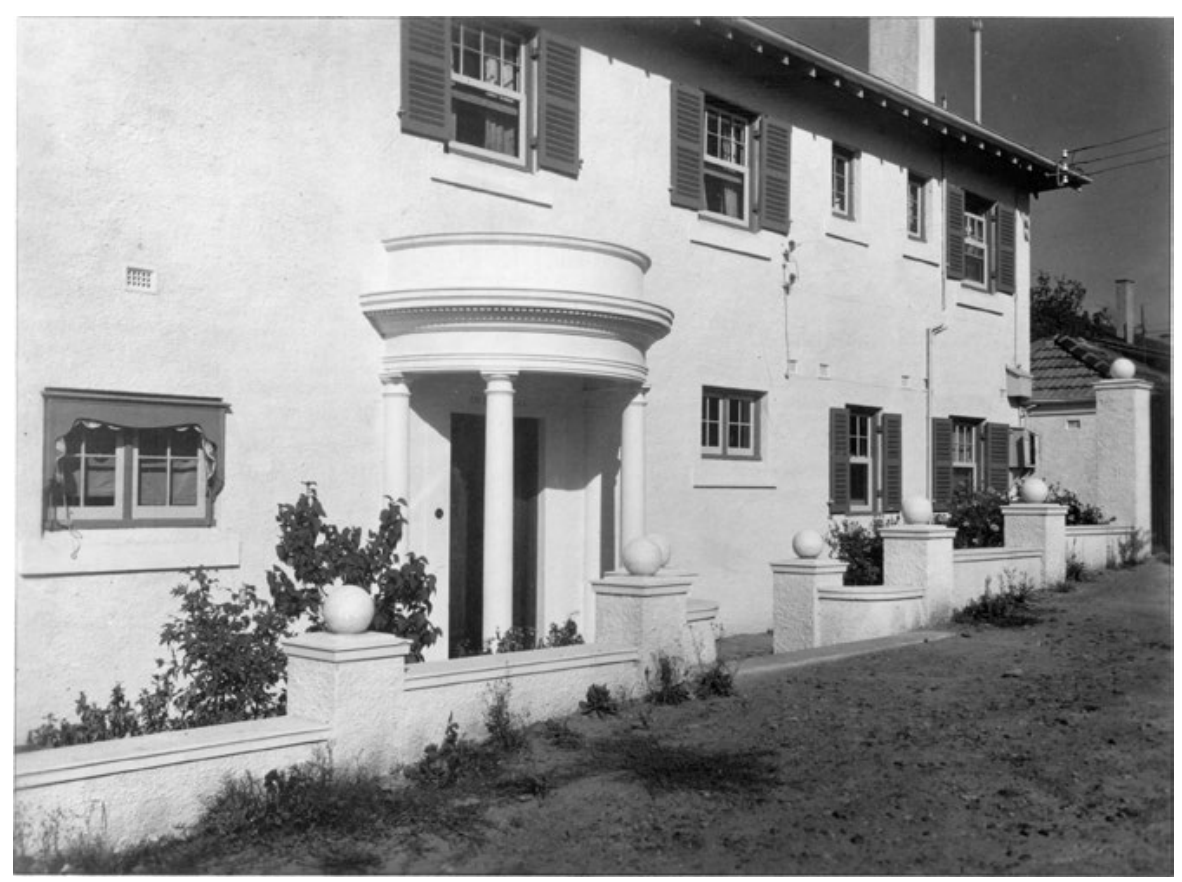

The Gulletts' Orchard Cottage, photograph by Nash-Boothby Studios, 1924

(Courtesy of Malvern Historical Society and Stonnington History Centre)

With a homestead and 2500 acres six miles from the capital, the Gulletts had assumed a leading role in Canberra social life. They were welcome visitors at Yarralumla, where the Governor-General found discussions with Harry on 'various subjects, local, Imperial, world wide...most helpful and instructive'. ${ }^{60}$ Charles Hawker would spend weekends and go out riding; the Fairbairns and others would drive out to dine or for a picnic. But, for a backbencher without the obligations of the political inner circle, the Hill Station property, remote from the nation's metropolises, become more a burden than an asset. In Melbourne, at Orchard Cottage in Moonga Road, Toorak, the Gulletts were closer to the heart of society. Extended as a result of a generous settlement from Penny Gullett's mother, Lady Headley (an astute businesswoman, principal shareholder of the profitable Law Book Company, but still more widely known

59 Gullett to Sir Donald Cameron, 11 May 1939, copy, Gullett Family MSS.

60 Lord Gowrie to Lady Gullett, 16 Aug. 1940, copy, Gowrie MSS NLA MS 2852/5/12. 
as the writer Barbara Baynton), the house and a tennis court sat on an acre and a half. It was big enough to accommodate a cook, a housemaid, and a parlour maid, with a governess for the children when they were young, and a gardener and part-time laundress. A chauffeur was shared with Lady Headley, who built and occupied a house next door until her death in 1929. There was one large room for entertaining.

Penny Gullett was a popular hostess, 'devastatingly funny' as Elisabeth Murdoch remembered, celebrated for amusing stories about her friends, whose voices she effortlessly mimicked. She had befriended Enid Lyons and cleverly brought together personalities from politics, the press, especially the Murdochs, and wider society. She had been 'a loving friend and encourager' of Elisabeth Murdoch since taking the 19-year-old under her wing when she was being courted by the 42-year-old bachelor editor of The Herald.$^{61}$ Bob Menzies too had often enjoyed the Gulletts' hospitality and befriended their son Jo. During his first visit to the United Kingdom in May 1935, the Attorney-General went up to Oxford to take Jo, Bill Baillieu, and some other young Australian friends to dinner at the Mitre Tavern. ${ }^{62}$ It was the kind of gesture that counted with a colleague who was a proud father. Gullett and Menzies were not confidantes. They disagreed publicly on modern art. But they had mutual respect and their easy communication survived breaches over policy as well as their differences over Matisse, Picasso, and Van Gogh. ${ }^{63}$ Whatever their quarrels, Gullett would tell his son, he admired Menzies as 'the least greedy man you can imagine' giving up a most lucrative legal practice for a life of public service with all its political savagery and personal slurs. ${ }^{64}$

After the election of 1937, discontent simmered in the Cabinet. For some, the issue was what seemed like a dilatory approach to defence preparations. Writing 35 years later, Enid Lyons described the malcontents as men who thought her husband lacked vigour and drive. Gullett, she said, was one of them. 'He resigned his portfolio and openly opposed Joe's leadership. ${ }^{65}$ In fact, the Prime Minister's wife had been informed privately that Gullett was secretly contributing critical articles to the Murdoch press. ${ }^{66}$ Briefed by the restless retired Major General Sir John Gellibrand, a former parliamentary colleague, Gullett was openly calling for the creation of an effective infantry and infantry mobilisation plan, a national register of men from 18 to 50, and 'sounder training'. By the end of 1938, as the Cabinet itself was increasingly divided on the best way to respond

61 Gullett, Good Company, passim; John Monks, Elisabeth Murdoch: two lives, Sun, Sydney, 1995 (1st ed. Pan Macmillan 1994), p.139.

62 Menzies' draft typescript diary, 17 May 1935, Menzies MSS, NLA MS 4936/579/7. Gullett recalled a breakfast with other friends in his rooms at Oriel College (Gullett, Good Company, pp.96-7).

63 June Helmer, George Bell: The Art of Influence, Greenhouse Publications, Richmond, 1985, p.86.

64 H. B. 'Jo' Gullett, interview, 7 Aug 1978.

65 Lyons, Among the Carrion Crows, p.61.

66 Henderson, Enid Lyons, p.242. 
to growing international tensions, Gullett had nailed his colours to the mast of a stronger commitment to defence and compulsory military training. He was understood to be colloguing with Menzies and Sir Keith Murdoch (who had taken on Gullett's son as a reporter), all of them impatient for a change at the top of the government. In a speech laced with inflammatory language, he spoke on a Labor confidence motion on 3 November 1938 of the 'farcical training' of the citizen force which, if it were to encounter any 'real invading trouble', would be 'a mere suicide club'.

Two days later, Gullett raised concerns in the party room about leadership, suggesting that Lyons should make way for someone else. There was 'a little wordy by-play' between him and the Prime Minister. But he received little support and was openly derided by Tommy White, the Minister for Trade and Customs. ${ }^{67}$ Within a few months Murdoch and the money men of the UAP had lost their confidence in Menzies. They were convinced that he was so unpopular with the electorate that Lyons, although exhausted and desperate to retire, was essential to the survival of the government. Lyons had reshuffled the ministry immediately after the November party room meeting, promoting Geoff Street to be Minister of Defence, and creating a 'policy committee', in effect an inner Cabinet, prompting an excluded and piqued Tommy White to resign. Recognising that matters of substance remained unresolved, Gullett did not waver. In the manoeuvrings that followed Menzies' resignation and the death of Lyons in April 1939, he was unequivocally in Menzies' camp. ${ }^{68}$

Support for Menzies brought its reward. It did not hurt that he had publicly praised the increasingly influential Fred Shedden, Secretary of the Defence Department. Gullett had kept in touch with other key figures - hosting a dinner for Jim Fairbairn and General Squires on March 7 after which the latter recorded 'much talk... about Defence matters - I hope not indiscreet on my part' ${ }^{69}$ Squires may not have known how close Gullett was also to Sir Tom Blamey, appointed chairman of the Manpower Committee by a hesitant Joe Lyons, who had heard 'funny things' about the Victorian Police Commissioner. ${ }^{70}$ Initially expressing reluctance to take up office again, Gullett had two meetings with the new Prime Minister. The disclosure by Menzies that he was offering the External Affairs portfolio brought him into the fold. Writing to Jack Latham, now Chief Justice of Australia, he commented on the new ministry:

A fair team. All depends on Bob. He has it in him, if it can be extracted \& applied.

67 White diary, 5 Nov. 1938, in Hazlehurst, Menzies Observed, p.154.

$68 C P D$, House of Representatives, 3, 8 Nov. 1938, pp.1231, 1323-6; White, A Political Love Story, pp.201, $206-16$.

69 The Herald, 24 Feb. 1939; Lt Gen. E. K. Squires diary, 7 March 1939, UNSW@ADFA Library, MS 184 folder 2.

70 Frank Legg, The Gordon Bennett Story, Angus \& Robertson, Sydney, 1965, p.158. 
Alas I am one of the few survivors - the only one of the old B-P team.

I was reluctant to begin again but Bob put it almost as a duty. And he has treated me handsomely. I think Coalition will come quickly, but only if Page is discarded. When it does I am out. ${ }^{71}$

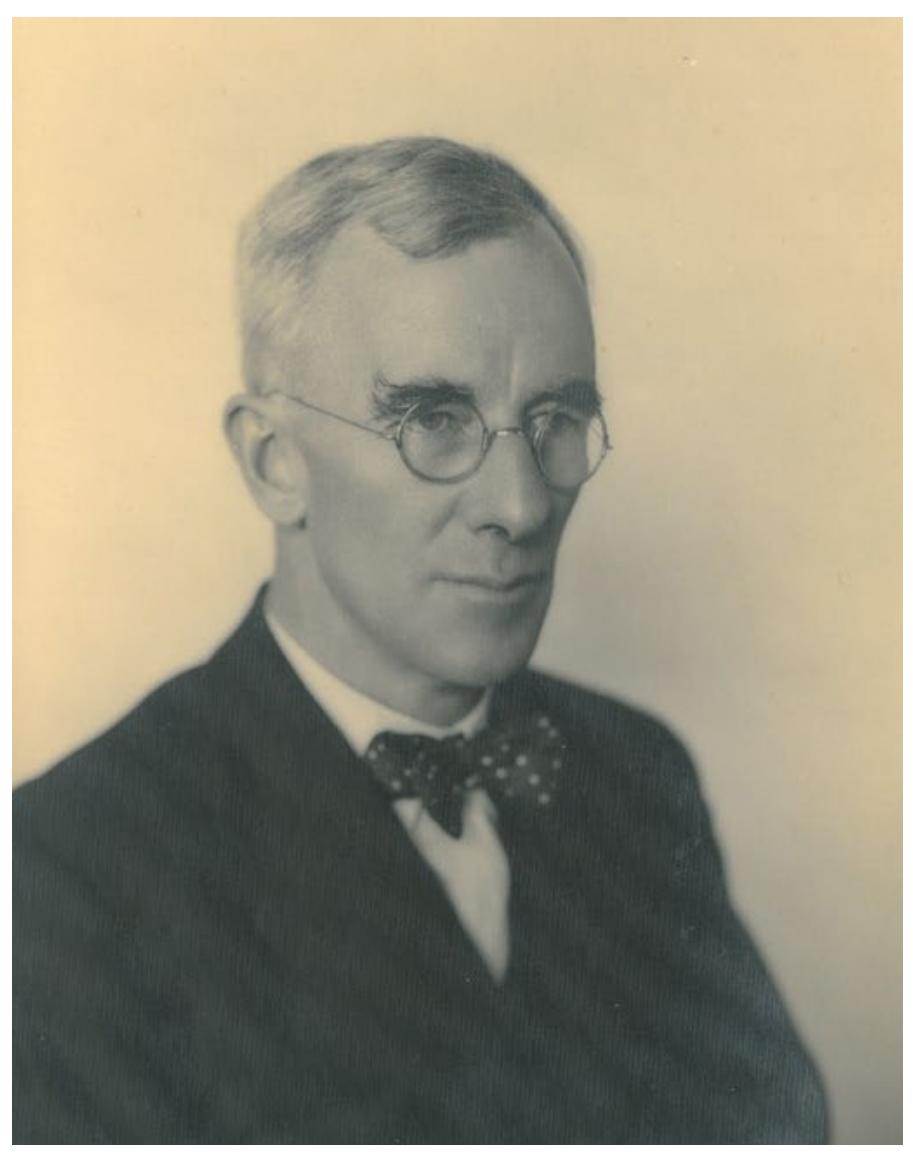

\section{A minister again, reluctant but persuaded}

(Courtesy of Peter and Kate Gullett)

Writing more expansively to an Australian pastoralist living in London, Gullett explained a fortnight later:

The new Menzies team which is solely U. A. P. is of course at the mercy of the Country Party. The C. P. after Page's loathsome attack on Menzies has split, and I think now that five members do not attend its meetings. So long as Page remains the C. P. leader a coalition is impossible and

71 Gullett to Latham, 3 May 1939, Latham MSS, NLA MS 1009/1/5312; Gullett to Sir Archdale Parkhill, 11 May 1939, copy, Gullett MSS, NLA MS 3078/3/519. 
with the general unhappiness of the party I think it likely that we will carry on through this year and possibly up to the eve of the elections. However this is all surmise, and the P. M. probably has his own views about it.

We have a sound team and Menzies is shaping phenomenally well. $\mathrm{He}$ is striking a deeper, wider note and certainly has a grand public throughout Australia after only three weeks of office. Page's attack on him did him the world of good and, strangely enough, particularly with the returned soldiers. ${ }^{72}$

As External Affairs Minister, Gullett was a member of the Council of Defence. He took a variety of issues to Cabinet, but it was soon obvious that both foreign and defence policy were firmly in the Prime Minister's hands. Menzies left Gullett to handle the delicate diplomatic contacts with Japan. In dialogue with the Japanese Ambassador, the External Affairs Minister faithfully presented the Australian official position that 'there was not the least hostility in this country towards Japan, apart from some feeling over the Sino-Japanese war'. He oversaw negotiation of oil concessions in Timor, and endeavours to thwart Dutch ambitions to secure the commercial air route from Dilli [sic] to Darwin both in pursuance of establishing Australian interests in Portuguese Timor and 'to forestall Japanese activities as part of their southward advance policy'. The Australian government had proposed to the Portuguese government a weekly air service as long ago as April 1939. The effort gained impetus following a survey visit to the colony in July 1939 by Jim Fairbairn, the Minister for Civil Aviation, in company with his principal public service advisor, Edgar Johnston. A draft agreement had been sent to Lisbon. ${ }^{73}$

Like all of the Cabinet, by early July 1939, Gullett had to contemplate the imminent outbreak of war with the Axis Powers in Europe. With Menzies' concurrence he had earlier danced gingerly around the contentious question of the extent to which Australia was free to make its own decisions. The Prime Minister had said in a broadcast that 'the British countries of the world must stand or fall together'. But these words, Gullett said:

...were not to be interpreted to mean that in any and every set of circumstances the foreign policy of a United Kingdom Government, if it led to war, should or would, automatically, commit Australia to participation in that war. Nor did they mean that action taken by a

72 Gullett to D. Russell Ferguson, 18 May 1939, Gullett MSS, NLA MS 3078/3/497.

73 Sir Henry Gullett, Minister for External Affairs, to R. G. Menzies, Prime Minister, Memorandum, 7 June 1939, Secret, NAA: A981, Japan 101, ii; H. S. Gullett, 'Portuguese Timor-Oil Concessions and Air Service', Cabinet submission, 13 March 1940, NAA: A981, Timor (Portuguese) 22, v; Hudson Fysh, Qantas at War, Angus and Robertson, Sydney, 1968, p.112. 
Government of the Commonwealth in any and every set of circumstances, and leading to war, should or would automatically commit the United Kingdom to participation in that war.

It is conceivable that upon either side a policy might be adopted which met with strong disapproval, or condemnation, by the other Government...But in the circumstances in which the Governments of the United Kingdom and of the Commonwealth find themselves today there is no sort of disagreement. On the contrary there is complete unanimity on the policy being followed, and on any action which may arise out of that policy. ${ }^{74}$

As the record of a discussion of a defence policy review by the Chiefs of Staff makes clear, Gullett was profoundly pessimistic about the prospects in the next few months:

If in that period war should come, we would be in a very unsatisfactory position. Singapore was devoid of assistance from an effective Navy and would remain so until the position was cleared up in the North Sea by the British and French Navies. Within that period...anything might happen. Japan would, in his opinion, undoubtedly come south and have the capacity to entirely destroy the small Australian Navy, some portion of which, unfortunately, at the present time, was in the unhappy position of undergoing modernisation. Our Air Force had not a single frontline aircraft in Australia, although of course, it soon would have.

He said that the outline conveyed by the Chief of the General Staff as to the ineffectiveness of our coastal defences was most depressing and, in addition, many of our 6" guns appeared to be not fully effective. He particularly stressed the fact that he did not wish to reflect on anyone in authority for he stated that, when the present position was surveyed in the light of the situation three or four years ago, our position now was undoubtedly good, but nevertheless was not good enough. To his mind the Army was of first importance in view of the relative ineffectiveness of the Navy without the support of a squadron at Singapore and the deficiencies in the Air Force, but when he considered the Army strength it appeared that we had at present no military force outside of the Fixed Defences. $^{75}$

The Chiefs of Staff might have protested that this was an unduly gloomy assessment. But there was too much truth in it for anyone's comfort. After

74 Sydney Morning Herald, 10 May 1939; Hasluck, The Government and the People 1939-1941, p.119.

75 Summary of Proceedings of Council of Defence Meeting, 5 July 1939, NAA: AA 1971/216 in Documents on Australian Foreign Policy, vol. 2, 1939, No. 117. 
a Council of Defence meeting, Gullett confided to his Army friend, John Gellibrand, his disillusion with the makers of defence policy. General Squires he thought was 'unscrupulous \& a bad swine'. Generals Chauvel and Brudenell White, and the Defence Minister Geoff Street were 'nincompoops \& Squires' Yes men' ${ }^{76}$ Being noticeably sensitive, Gullett could be impetuous in debate.

An entertaining conversationalist, he could occasionally be a little too free with his opinions. Yet much was forgiven of a man of ideals and intellectual rigour, a fine host, and above all someone who did not spare himself in the pursuit of the government's goals. ${ }^{77}$

\section{Weary propagandist}

The coming of war dissolved many old quarrels and brought new responsibilities. Jo Gullett, awaiting his medical examination before joining the AIF, would sense his father's frustration: 'Menzies puts a dam side [sic] too much work on him because the Cabinet is pretty full of dumbells [sic]. Dad is working up for a frightful row with Street who lacks drive but he holds back with impatience. ${ }^{78}$

When a Department of Information was created in September 1939, the portfolio was assigned to Gullett. ${ }^{79}$ As Secretary of the department he brought in his old friend and successor at the Australian War Memorial John Treloar. A punctilious and disinterested classical public servant, Treloar had served as a staff sergeant during the war on Gallipoli, as a lieutenant in No. 1 Squadron Australian Flying Corps in Egypt, as confidential clerk to General Brudenell White in France, and finally as officer in charge of war records in London. Treloar made it clear to his subordinates that they were on no account to be drawn into defending the government or the Minister. In October, Gullett explained to the Cabinet the tasks of the department. First was maintenance of domestic morale and distribution of information. Next was overseas propaganda (a logical link with the External Affairs department's role) mainly disseminated by means of a shortwave radio service. And third was censorship. In elaborating his mandate for Cabinet, he articulated a grand aspiration to 'constantly increase and sustain the faith of the Australian people in the cause for which we are engaged in war'. Specifically, they were 'to promote the interest and thought calculated

\footnotetext{
76 Edith Gellibrand diary, 8 July 1939, in Peter S. Sadler, The Paladin: A Life of Major-General Sir John Gellibrand, Oxford UP, Melbourne, 2000, p.247.

77 Watt, Australian Diplomat, p.21; Irvine Douglas, 'Australian Air Disaster: Careers of Three Ministers', Sunday Times (London), 18 Aug. 1940.

78 Jo Gullett to 'Weed', 25 Sept. [1939], Gullett Family MSS.

79 For much of what follows on the Department of Information I have drawn on Edward Louis Vickery, 'Telling Australia's story to the world: The Department of Information 1939-1950', PhD thesis, Australian National University, Aug. 2003, pp.15-79 and John Hilvert, Blue Pencil Warriors: Censorship and Propaganda in World War II, UQP, St Lucia, 1984, pp.17-65.
} 
to support the government in the necessary recruiting, the raising of money, the acceptance of the inevitable taxation and its activities generally'. Then, in case anything important had been omitted, they were 'to distribute sound facts upon all phases of the war direct and indirect through every kind of available channel'.

Gullett's mission might have been easier if there had been greater clarity about the 'cause' for which Australia was fighting. But the government was notably quiet about its war aims. He was astute enough to realise that whatever the volume of 'sound facts' despatched throughout the country, increasing and sustaining the 'faith' of the people was going to be an elusive goal. At least, without any regular attempt to gauge public opinion, no one could say with certainty that they were failing. What could be said, albeit with little foundation, was that the department was in effect a government-financed propaganda machine for the United Australia Party. A Labor Party standing aloof from government could make the charge but could not give it substance. And of course, in its international role, dissemination of propaganda was precisely what Gullett's team was meant to be doing.

If his statement to Parliament on 21 November 1939 was a reflection of his real feelings, Harry Gullett had little enthusiasm for the Information role. The ministry was not his creation, he said. 'It was passed over to me for administration. It is a very heavy task.' The weight of the task owed something to the jealousies and resistance of established departments. Relations with Defence and the Army especially had to be constantly finessed. He was happy in January 1940 to join the Service Chiefs in putting the representatives of the Sydney press right about what could and could not be said about the movements of the AIF, happily assisting as General Squires and Admiral Colvin 'refuted their arguments' ${ }^{80}$ But a few weeks later, after a bungle over the release of information about the landing of the $2^{\text {nd }}$ AIF in Egypt, he had to get Cabinet backing to secure 'paramount authority' for himself and the Chief Publicity Censor. Service representatives were henceforth to be advisors only. ${ }^{81}$

By March 1940 Gullett was showing signs of weariness. He, along with the Prime Minister, had been rebuked in letters to newspaper editors for suggesting that Army recruiting figures showed that Australians were apathetic about the war. He was perhaps less in touch with popular sentiment than once he had been. ${ }^{82} \mathrm{He}$ wrote to his old comrade Latham that he had 'not been in much physical shape'. With relations between the UAP and the Country Party once again proving difficult, he reflected:

80 Squires diary, 12 Jan. 1940, UNSW@ADFA, MS 184, folder 3.

81 Submissions, Cabinet decisions and minutes, 16 Oct. 1939, Jan.-Feb. 1940, NAA: A A2676, 36.

82 The Argus, 20 Jan. 1940; Sydney Morning Herald, 27 Feb. 1940. 
A lovely political kettle of fish. A counter attack is I think overdue \& between ourselves I am advising Bob to object to Cameron, but to offer to deal generously with a C. P. led by McEwen. (The going between Cameron \& McEwen is I think about equal, if it does not actually favour McEwen). Whatever the government's frailties it has had no chance with a press so hostile...

I find myself strangely disinterested. Perhaps I am too old to worry now. I do my job with what strength \& brains I have — \& leave the rest to fate. Meanwhile I dream of the day when I may be able to go for the rest of my days to 'Tawstock' - my farm. ${ }^{83}$

Gullett got part of his retirement wish when coalition came shortly afterwards. He was dropped from the War Cabinet, making way for McEwen at External Affairs, when the ministry was reconstructed in March 1940. Within External Affairs he had been increasingly seen by his officials as 'a dilettante, rather indolent, very agreeable, very civilised, good company - but the sort of man who never bestirred himself very much'. He had the reputation, one recalled, of being 'an able but somewhat vain and pernickety man' ${ }^{84}$ Whatever the truth of that, Menzies was at pains to keep him in the government as Vice President of the Executive Council, minister in charge of industrial and scientific research, and minister assisting the Minister for Information, the second post he had himself just vacated.

The appointment of Sir Keith Murdoch as Director-General of Information in May might have been thought by some a recipe for friction. Menzies had not hidden from the War Cabinet his belief that the Information Department was 'poor' ${ }^{85}$ Murdoch was given unprecedented powers and reported directly to the Prime Minister, who had 'nominally appointed' himself Minister for Information. But Murdoch was an old friend and shooting companion, and Gullett was not minded to make difficulties. He turned his attention to censorship, leaving the rest of the domain to Murdoch. It was just as well. Menzies soon began to lose patience with the Director-General and the antagonism which the appointment of a business rival eventually provoked from the Sydney Morning Herald's Rupert Henderson. Rationing of newsprint aroused the wrath of press proprietors convinced that Murdoch had disclosed commercially sensitive information to the government. In July 1940 other media interests also found themselves in conflict with the Director-General over proposed national security regulations requiring newspapers, cinemas, and broadcasters to publish statements deemed essential to the prosecution of the war. Forced into embarrassing amendments

83 Gullett to Latham, [?] March 1940, Latham MSS, NLA MS 1009/1.

84 Sir Keith Waller, interview, 21 June 1977; Watt, Australian Diplomat, p.21.

85 War Cabinet Notes, 21 May 1940, Shedden Papers, NAA: A5954, 729/1. 
by a storm of protest over the proposed 'dictatorial' powers and an openly disgruntled Postmaster-General, Vic Thorby, and other unconsulted Cabinet members, Menzies instructed his private secretary Peter Looker to keep Murdoch at arm's length. ${ }^{86}$

As early as April 1940, with a general election looming, Gullett had admitted:

I am somewhat feeble on the physical side. My capacity for night engagements really is most limited. As a general rule I take to my bed immediately after dinner and there read papers. The social side of my life has been almost entirely abandoned which at my age is perhaps not unbecoming. ${ }^{87}$

What was unbecoming was a needless row with John Curtin over arrangements to distribute the Leader of the Opposition's shortwave address to South Africa, which was in Gullett's view 'merely a rehash of a great many speeches he has made on Labor's defence policy'. 'Mr Menzies, it is believed,' the Sun News Pictorial reported on April 10, 'prevailed upon Sir Henry Gullett to modify his attitude.' Recurring bouts of ill-health, silently accentuated by decades of tobacco smoking, had taken their toll. He was still able to make a good speech, as he did at the University of Melbourne on July 20 commending newspaper scrutiny of the ministry: 'A government leading its people into war should have the worst known about it at the outset.' Yet, unless they were intent on changing the leadership or removing a government, newspapers should be careful in the national interest not to bring a ministry into 'disrepute with soldiers or citizens' $^{\prime}{ }^{88}$

A plea for co-operation between journalism and government might have been Gullett's political swan-song. Had his electorate seemed safe he would have preferred to stand down and not fight the next election. He had bought a block of grazing land about 50 miles north of Melbourne, fenced off five acres, and built a weekend cottage flanked by a stream and surrounded by ash, oak, and other English trees he planted himself. 'Tawstock', an evocation of the Somerset of his grandfather's youth, was an increasingly enticing retreat. However, there were signs that a fresh candidate might have difficulties in the Henty electorate; and he was already beginning to think that he might have to saddle up again. Perhaps he would be relieved of ministerial responsibilities. But for now, on another crisp August morning, with the quick smile that flickered for Prime Minister and chauffeur alike, Harry Gullett embarked dutifully on the familiar drive from Toorak to Essendon.

\footnotetext{
86 Hilvert, Blue Pencil Warriors, pp.56-65; Sir Cecil (Peter) Looker, interview, 25 March 1976; Sydney Morning Herald, 18, 19, 20 July 1940.

87 Gullett to A. Bishop, 4 April 1940, Gullett MSS, NLA MS 3078/3/66.

88 The Argus, 30 July 1940.
} 



\section{3. 'A charming boy who would do big things': Dick Elford}

The youngest of the civilians walking across the tarmac on the morning of August 13 was Dick Elford, the private secretary to the Minister for Air. Stricken with influenza, Elford had risen from his sickbed at 508 Punt Road, in fashionable South Yarra, very early that day to be driven to Essendon. Since joining Jim Fairbairn the previous year, Elford had become accustomed to flying with him and his assistant, Murray Tyrrell, in the Minister's own sleek DH90 Dragonfly. But now the arrangements for travel to Canberra were different. Along with many other private flyers, Fairbairn had handed in his own aircraft for use as the government saw fit. The Dragonfly had been impressed by the Air Force, the Minister deciding it was politically inexpedient to insist on giving it to his friend Eddie Connellan. ${ }^{1}$ The machine he had used on a flight around the nation a few weeks earlier, a Percival Q6 Petrel, had been returned to its owners, the Civil Aviation Department. Like other ministers he must now rely on the newly allocated Lockheed Hudsons for transport to Canberra.

The 30-year-old Richard Edwin Elford was embarrassed to be in his well-cut three-piece lounge suit rather than in an Air Force blue tunic or battle dress and cloth-visored peak cap. He was eligible. He was fit. He wanted to serve in the armed forces. He had taken flying lessons to prepare for enlistment in the RAAF. But since he had joined Fairbairn at the beginning of 1939 the Minister had come to rely upon him.

When Fairbairn was sent overseas to negotiate the terms of the proposed Empire Air Training Scheme soon after the outbreak of war, Elford's duty was to accompany his chief. He knew then that he could not travel as a serviceman as that would render him liable to internment in any neutral countries through which they might have to pass. On their return to Australia, the demands of office were unremitting. So Elford's personal desire for service in uniform was on hold, indefinitely. In his pocket as he stepped across to the waiting aircraft was the jangling reminder of his servitude, a ring holding 10 keys including those that opened the ministerial safes in Melbourne and Canberra, for whose custody he had sole responsibility.

1 Connellan, Failure of Triumph, p.283. 


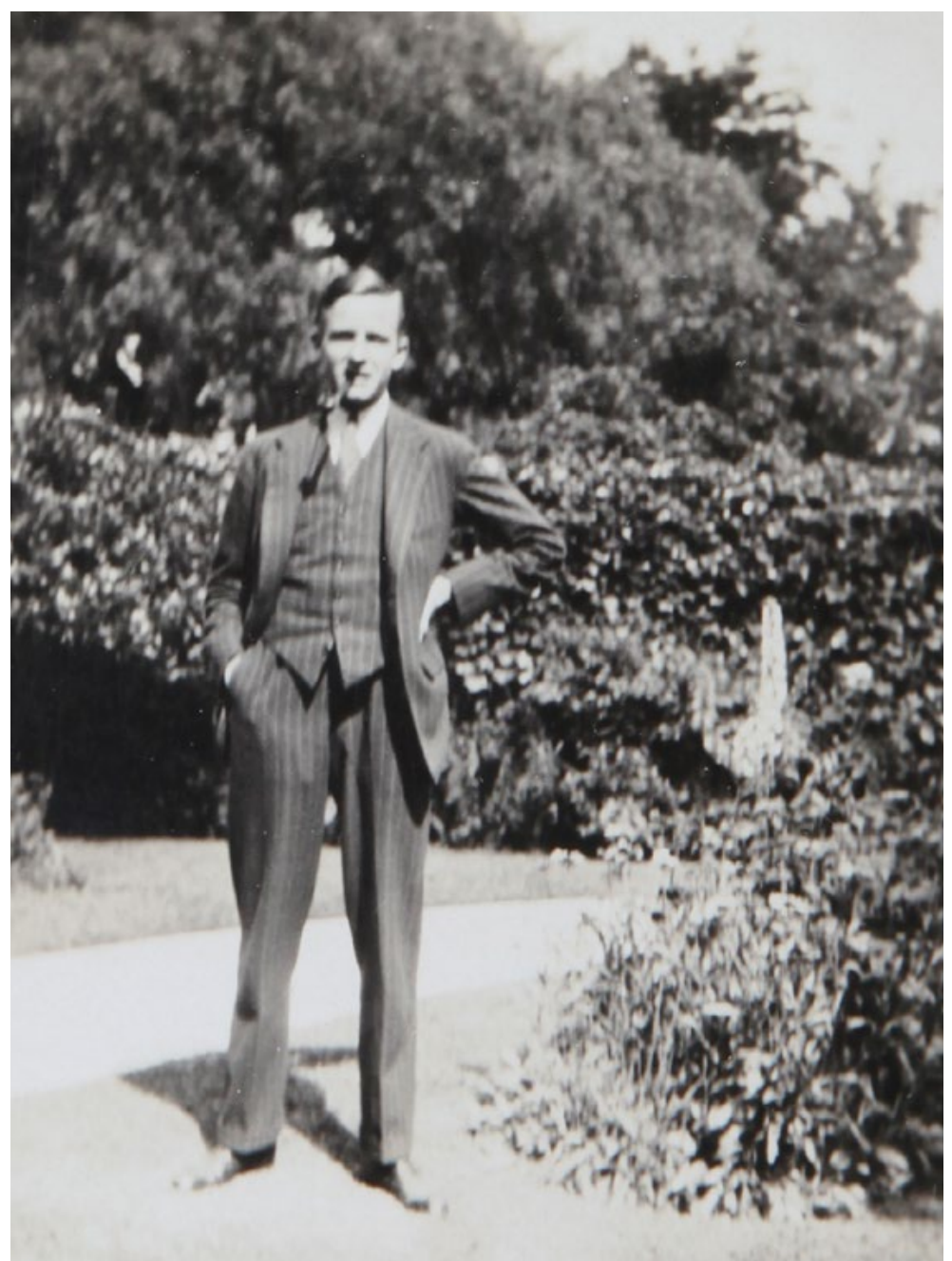

Dick Elford, who would rather have been in uniform, 1939

(Courtesy of Hugh Elford)

\section{New lives}

Dick Elford was an immigrant. Born in Chelmsford, Essex, in 1910, he arrived in Australia from England with his parents 10 years later. His father Archibald Sefton Elford, born near Exeter into a prosperous merchant family in 1878, was the last of a remarkable cluster of Elfords who studied chemistry at St John's College in Oxford. Percy Elford, Archibald's oldest brother, had won an open scholarship to Christ Church, was awarded first-class honours in Natural Sciences (Chemistry) in 1889, was President of the Oxford Junior Scientific 
Club, and after a brief spell at University College, Reading, and lecturing for the Shropshire County Council, became a Fellow of St John's in 1892. ${ }^{2}$ After their father, Edwin Elford, died in a railway accident at the age of 47, Percy assumed a special place in the lives of his six surviving siblings (three others had died in infancy). Their mother, born Ann Louisa Fell, had been bequeathed £5514 on Edwin's death. With income from the Etna Fire Light Company founded by her husband, Ann Elford had sufficient means to move to Oxford. But there would no longer be a governess, cook, housemaid, and nurse to assist her.

To relieve the family's burdens, oldest daughter Constance had become a governess, and Percy abandoned his chance of a rowing 'Blue', cutting short his studies in mathematics to work in the Christ Church chemistry laboratory as a demonstrator under the ingenious experimenter, Dr A. G. Vernon Harcourt, FRS. ${ }^{3}$ In an unprecedented record, Percy taught a succession of his brothers, Stanley, Bertram, and Archie, each of whom took additional classes at Magdalen College's Daubeny Laboratory in the Oxford Botanical Gardens. Early in the new century, after a long association with local technical education, Percy was appointed Secretary to the Oxfordshire Education Committee. He was soon playing a part in national education policy discussions as president of the Association of Directors and Secretaries for Education. He would hold the Oxfordshire post until retiring in 1920 following a nervous breakdown, his condition partly attributable to an exhausting schedule of school visitations and compilation of a vast 'Domesday' card index of information about every elementary school in the county, with 3000 annexed photographs.

While Percy Elford was consolidating his authority over Oxford education, Stanley Elford had, at 31, already earned a glowing reputation as headmaster of Cirencester Grammar. He had then topped a field of 70 candidates to become head of the Coopers' Company and Coborn School, a sixteenth-century foundation in London's East End that had merged with an eighteenth-century co-educational school in 1891. Stanley had taken early steps in his older brother's professional domain as an Oxford science master, then as Inspector of Science and Art Schools for Oxford County Council. The Elfords were close and not embarrassed to offer or to accept each other's helping hand. Undeterred by the misgivings of the Cooper's school governors, Stanley almost immediately appointed younger brother Bertram to the vacant science mastership at Cooper's. Undeniable ability, as well as nepotism having taken them so far, the brothers contrived for Bertram to move to Bath School in $1906 .{ }^{4}$ Their older sister Constance, like Percy living with their widowed mother, was already a high school teacher in

2 Daily News, 14 Oct.1892.

3 Percy Elford to David and Hugh Elford, 8 Dec. 1949, (transcripts), Elford MSS, courtesy Hugh Elford.

4 John Ireland (compiled and illustrated by Edwin Cuss), The History of Cirencester Grammar School, 1993, pp.68-70, courtesy of Peter Rowe; Colin Churchett, Coopers' and Coborn School Anniversary History, Coopers' Company and Coborn Educational Foundation, Upminster, 1986, p.80, extract courtesy of Dorothy Gorsuch. 
Oxford. Another sister, Mary, was a nurse. She also soon moved back to live with her mother. Although Stanley had been in business briefly before taking up teaching, only one of Edwin Elford's sons, John Farley, had followed his father into trade, joining a wholesale velvet house in London as a clerk. By 1914 John was managing a rubber plantation in Ceylon, where he distinguished himself by building over nine years a magnificent mountain-top mansion for his Scottish bride, only to be sacked for the 'colossal waste of time, money and labor' ${ }^{5}$

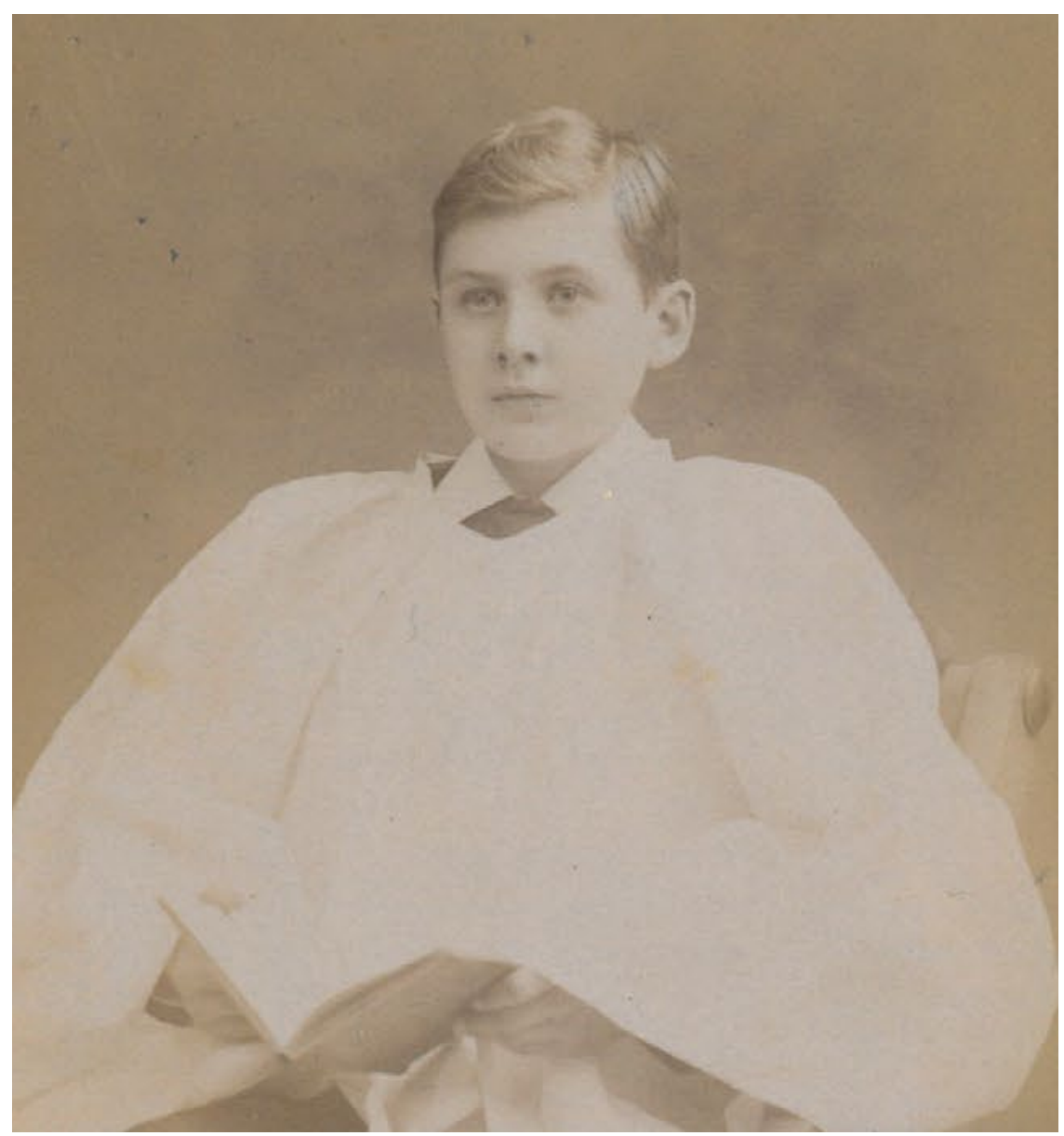

Archie Elford, chorister, 1888

(Courtesy of Hugh Elford)

5 'Ayr' became a luxury hotel (http://www.estatebungalows.com/ayr.htm). 


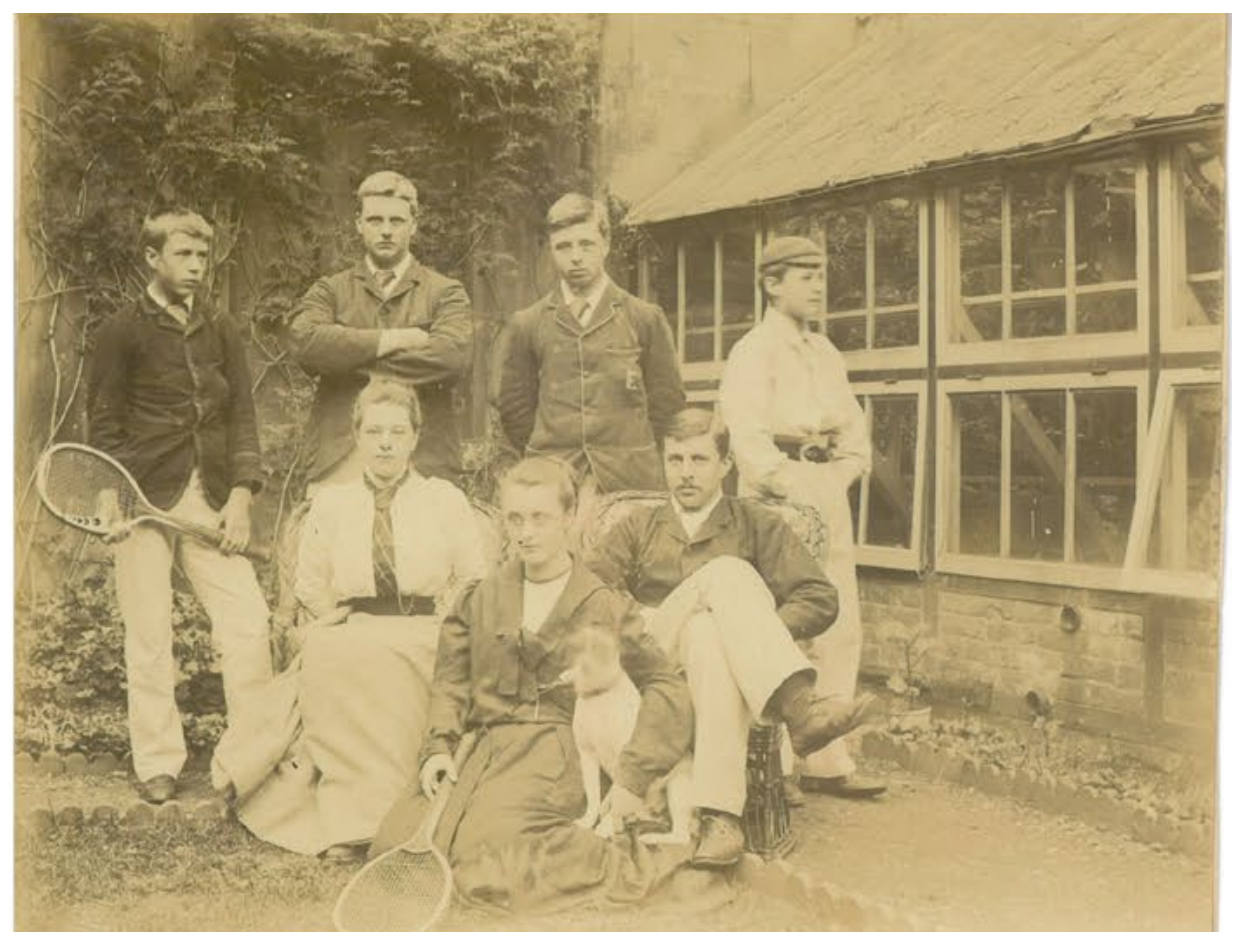

\section{Archie and his six siblings}

(Courtesy of Hugh Elford)

Archie Elford, the youngest of the children, had been educated as a chorister at Christ Church school in Oxford until his voice broke at 15, then at Magdalen College Grammar School. Moving to London, he lived with an uncle and worked for five years as a messenger at the Stock Exchange. Then, with Percy's encouragement, he successfully sat the entrance exam at St John's and graduated in 1902 with a third-class degree. With the example and assistance of his three brothers putting wind in his sails, he also embarked on a career in education. While still an undergraduate he had been assistant organising secretary to the Oxfordshire Technical Instruction Committee. Posts with the Surrey and Essex education committees led late in 1914 to a divisional school inspectorship with the London County Council. It was not a job for the faint-hearted. In the slums of London, he was told to wear the oldest clothes he possessed, not to take a watch, and only carry enough money for his travelling expenses.

When war came, Archie Elford was rejected four times for active service; poor eyesight and a hernia could not be disguised. Eventually, in March 1916, he was 'borrowed' by the Admiralty, finding a niche in the Military Sea Transport Branch and then in the new Ministry of Shipping which took over his department. There he worked on the senior staff of the Director of Transports and Shipping, Graeme Thomson, a precociously gifted civilian administrator 
promoted by Winston Churchill over the opposition of the Sea Lords, and dubbed 'the greatest transport officer since Noah'. ${ }^{6}$ Graeme Thomson was an inspiring leader and valuable patron. In April 1918, Archie accompanied Thomson to the USA to assist in organising the embarkation and transport of American troops across the Atlantic to Europe. In his first four months, over half a million men were embarked on British vessels. ${ }^{7}$ As the war drew to an end he was entrusted with the task of determining the compensation that should be paid to American and Canadian shipowners whose vessels had been lost or damaged after being requisitioned for war service. A colleague on the North American mission was a young maritime communications expert and managing director of Amalgamated Wireless (Australasia), Ernest Fisk. Elford's final task, in consultation with the War Office, was drawing up a complete shipping scheme for the repatriation of demobilised British and Dominion troops from the various theatres of war. ${ }^{8}$ His work was recognised with an OBE at the end of hostilities.

With temporary staff being shed in Whitehall, it was time for Elford to return to his former career path. He found an unexpected opening in the midlands. After a financial scandal and a purge of incompetent council authorities who had not noticed the disappearance of $£ 84000$ over 12 years, he was appointed Director of Education for the County Borough of Wolverhampton in February 1919. This was a challenging appointment for a man of integrity with a reputation for administrative acumen. Graeme Thomson's reference attested that he had 'shown very great ability and energy together with organising capacity of a very high order...great tact and adaptability'. ${ }^{9}$ He won the post against 110 applicants, five of whom were interviewed. It had taken the casting vote of the chairman to break a tied committee. After passing a medical examination Elford quickly set about re-organising schools, developing curricula, and determining salaries and conditions of service for teachers. But within five months, to the regret of the council, he had tendered his resignation. He left the $£ 800$-a-year job 'for family reasons' at the end of October. The Wolverhampton education committee wished him 'happiness and success in the new work he is called upon to undertake'. ${ }^{10}$ But family tradition suggests that no 'new work' was in prospect. He was leaving for his health. On medical advice, the smoke and grime of the industrial heartland of England could not be endured. He was worn out from the pressures of war work. Perhaps too he was vulnerable to the influenza

6 Time, 9 Oct. 1933.

7 J. A. Salter, Allied Shipping Control: An Experiment in International Administration, Clarendon Press, Oxford, 1921, p.193. I am grateful to Dr Nick Lambert for assistance in tracing details of Elford's wartime work.

8 'Memorandum on General Proposals for Shipping Programme for Repatriation of Troops, Labour, and Prisoners of War', 15 Sept. 1918, Elford MSS.

9 Thomson undated reference, ts copy, Elford MSS.

10 Wolverhampton Education Committee Minutes 1918-19, Wolverhampton Archives \& Local Studies, CMB-WOL-C-EDU-16; G. W. Jones, Borough Politics: A Study of the Wolverhampton Town Council 18881964, Macmillan, 1969, pp.234-6, 272. 
pandemic that had taken thousands of lives on Atlantic transport ships as well as millions on land. Whatever the cause, Archie Elford had to seek a change of climate.

While assistant secretary of the Surrey education committee Archie had met and successfully courted Sybil Audrey West, daughter of a hop merchant and champion rose-grower. The couple married in Reigate in 1907. A daughter, Barbara, was born the next year. Richard Edwin (named for the paternal grandfather he had never known) followed in 1910 when his father was working for the Essex County Council. Barbara and Dick, as he was soon known, would surmount several disruptions in their childhood, making and losing friends as their father's successive appointments took them to new homes. After a bomb crashed through the roof of grandmother Ann Elford's nearby house in Sydenham, bouncing down the stairs but failing to explode, their own house was packed up, and they were sent to live with their mother's parents in Reigate. Dick would lose his playmate, Peter Scott, the son of the Antarctic hero whose widow, the sculptress Kathleen Scott, lived a few houses away. Dick's sister would never forget the excitement before their move:

One day the air raid warning sounded but Mother said we should go upstairs so that if there was a hit we wouldn't be buried under tons of rubble! We watched the raid over London... We should have felt much worse if we'd realised they were bombing the Admiralty. Father and all the other staff had grabbed the most secret documents and fled to the basement. After it was over it was discovered a bomb had gone right through my father's office and the one below, exploding on the next floor down.

Both Barbara and her brother went to boarding schools on Reigate Hill. Sevenyear-old Dick and his prep school classmates - dressed up in long pin-striped trousers and short Eton jackets, wide Eton collars, and top hats - would join the girls at church on Sunday. His family transplanted to Wolverhampton at war's end, Dick continued at the prep school. Inured as he had become to new homes and new friends, nothing had prepared him for the adventure that would now take him away not only from friends but from the extended networks of indulgent relatives who could be relied upon at least to make holidays a treat. His parents were drawn to a new life in Australia. 'Mother had a brother orcharding in Tasmania,' Barbara recalled, 'so they decided to try that and through agents in London bought what was described as a 54 acre apple orchard in full production.' Thus Archibald and Sybil Elford set sail for Melbourne on the Orient liner Osterley, with 'Master Richard' and 'Miss Barbara' in tow, on 23 January 1920. 


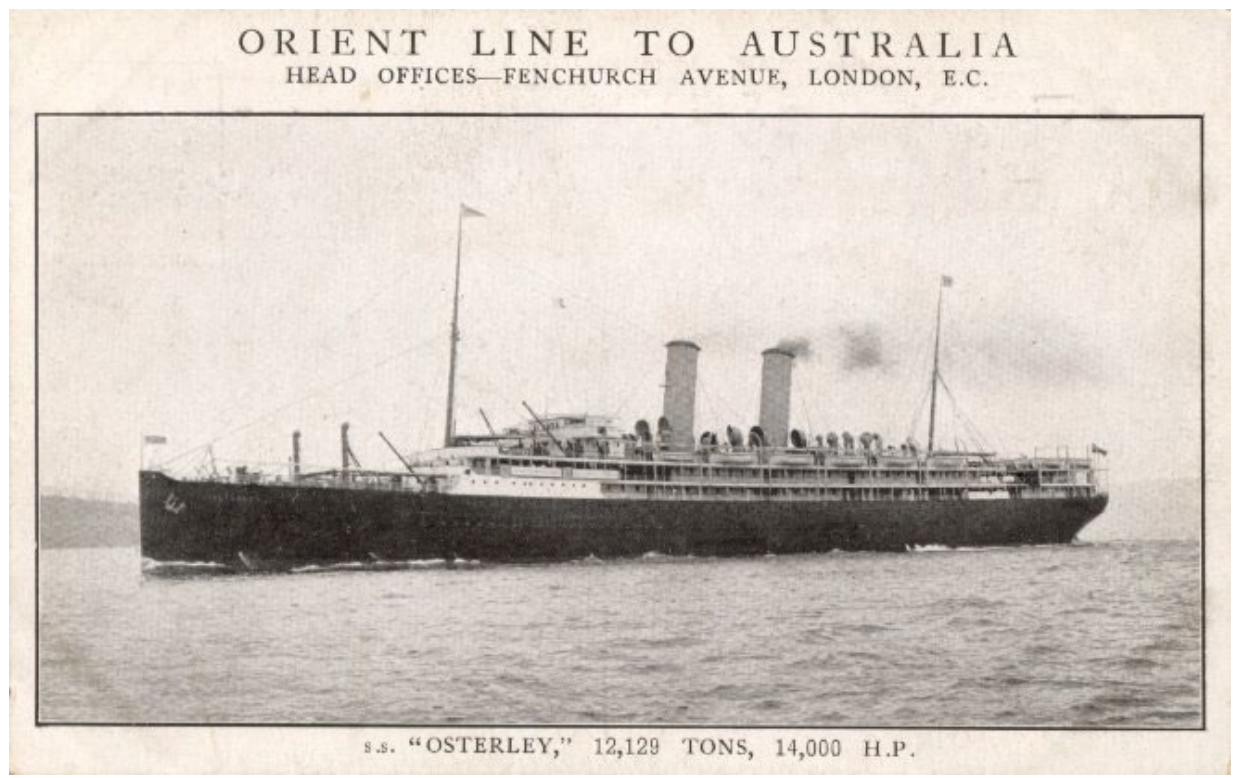

\section{S. S. Osterley took Harry Gullett to England in 1916 and brought the Elfords to Australia}

(Courtesy of Bernard Malloy)

Archie knew all about the Osterley, which had been requisitioned as a troop hospital ship during the last 18 months of the war. To the ANZAC soldiers it was known familiarly as 'The Osteralia'. Returned to service as a migrant ship, she was now refitted with accommodation for up to 1000 passengers, 200 in first class. With Archie's maritime connections they could expect more comfort and consideration on the 45-day journey than most of those on board. Barbara Elford described the departure and the trip:

Only a very small amount of cargo space was allotted to each passenger so most of the furniture had to be sold. This was done in a large hall in Reigate only a week before we sailed. There were a ring of dealers who wouldn't bid against each other, but one would buy and then they bid among themselves afterwards. It was heartbreaking, the furniture went for almost nothing but had to be sold before we left England. We left two days after my 12th birthday for Australia. In the Indian Ocean near the Cocos Is we struck a cyclone and counted seven water spouts dangerously close. The Captain ordered the hatches closed and all passengers below. Even in 1st class the crowd and heat was bad...We were carrying a cargo of chemicals whose smell began to permeate the ship...just like rotten fruit. How thankful we were when the ship was opened up again...We arrived in Melbourne just before the Autumn race meeting and all good accommodation was booked out...Father finally 
found rooms at the old Federal Hotel at the Spencer St end of Collins St. In those days it was described as a family hotel and was a temperance one. A huge building and good sized rooms but we discovered there were bed bugs and had to sit up all night. Next morning Father managed to get accommodation at what is now the Windsor Hotel, a booking had been cancelled. Thankfully we moved and spent a comfortable week there. ${ }^{11}$

There had been a long shipping strike which ended at the end of our week in Melbourne. They didn't want to load cargo but filled the boat with impatient passengers. We had the worst crossing of Bass Strait there had been for years, luckily we still had our sea legs but the luggage shifted from one side of the cabin to the other all night and we had to cling to our bunks for dear life otherwise we should have rolled on the floor with the luggage. All our boots and shoes were in a kit bag which a wharfie missthrew on to the deck and it landed in the water never to be seen again. Father was so furious he tongue lashed the careless man. Wharfies weren't used to being talked to like that but he was so stunned he gave Father a murderous look and backed away. A man in the crowd just near said 'Well done Mister but you're lucky you aren't in the water too.'

Worse was soon to come. Archie Elford, with visions of being a gentleman farmer, had described himself as a property owner on the emigrant ship's passenger list. For advice on his rural venture, his oldest brother was the person to turn to. Unfortunately, although Percy Elford had published reassuring handbooks on 'practical school gardening' and a best-selling guide to the cultivation of allotments, what Percy could not do was guarantee what awaited Archie and his family 12000 miles from home.

Arriving in Launceston we drove the 16 miles to Exeter in a horsedrawn cab and next day Father went with his brother-in-law to see his new orchard. He had never had any farming experience and was unfitted for physical labour by his bad hernia, so imagine his horror and despair when he found only five acres of the land planted with apple trees which looked in bad shape as the drainage system was blocked, the rest of the property was bush. He realised he would have to sell as quickly as possible and find some office job, cutting his losses. He took his family to Hobart where they rented what had once been a golf club house. The golf club had given up. This was at Sandy Bay which was then a very sparsely settled bit of bush... The children were sent to schools in Hobart and my father looked for work...

11 The Grand Hotel, remodelled, refurnished, and extended, became the Windsor late in 1923 (Chrystopher J. Spicer, Duchess: The Story of the Windsor Hotel, Loch Haven Books, Main Ridge [Vic.],1993, pp.38-43). 
The Elfords were not the first hopeful emigrants who bought land in the Tamar Valley unseen, only to be deceived about what awaited them. With a wife and two young children to support, the 42-year-old head of the family had to seek employment urgently. He was offered the headmastership of the recently reestablished junior school at The Hutchins School, Hobart's leading Anglican boys' school; but, as his daughter remembered, 'turned it down as the pay was so bad he said he couldn't bring up a family on it'. ${ }^{12}$ Within three months he found a better paid position in Adelaide as manager and secretary of Standard Salt \& Alkali Ltd, overseeing the amalgamation and public share offering of two salt mines. ${ }^{13}$ But the saga of misfortune had not yet ended. After renting a house at Walkerville and placing the children once again in new schools, Archie realised, in the words of his daughter, that the salt company was 'run by crooks'.

Elford had the background for better things. A return to public service or education was possible. However, his experience in shipping and transport opened up more remunerative prospects. At the Admiralty and Ministry of Shipping, Archie had come under the notice not only of Cabinet ministers and top civil servants but of prominent shipowners and executives serving on advisory bodies and negotiating contracts with the government. He could count on the good offices of the former Shipping Controller, Lord Maclay, as well as Sir Thomas Royden, the chairman of Cunard, Sir Kenneth Anderson of the Orient Line, and Sir Graeme Thomson. By fateful coincidence, in late March 1920 the directors of the Australasian Steamship Owners' Federation had begun to discuss the need for a salaried chairman. Since the federation was launched in 1899 its chairman, who served on an honorary basis, had been elected annually from among its leading figures. The federation founder, W. T. Appleton, chairman and managing director of the dominant coastal steamship company Huddart Parker, had been chairman or president for 11 of the organisation's first 21 years. During the war, Appleton had been president of the Melbourne Chamber of Commerce and the Associated Chambers of Commerce of Australia. His company had extensive coal interests. Fortuitously for Elford, Appleton was also on the board of Amalgamated Wireless Australasia Ltd (AWA) whose managing director, Ernest Fisk, had haunted the corridors of Whitehall in the recent past pursuing the merged interests of AWA and Marconi. ${ }^{14}$ Fisk's principal wartime and post-war role had been in maritime communications, crucial for the troop convoys from the United States evading submarine attacks. But he had spent time with Elford in North America dealing with claims for payment for loss or damage to ships that had been requisitioned. They had come to know each other

12 The Hutchins School has no record of the offer, which came exactly a year after an assistant master was promoted into the position on $£ 200$ p.a. plus a house, then given a Christmas bonus of $£ 20$ (Margaret MasonCox to $\mathrm{CH}, 13$ Jan. 2011, email).

13 The Advertiser, 1 June 1920 (prospectus).

14 G. R. Henning, 'Appleton, William Thomas (1859-1930)', Bede Nairn and Geoffrey Serle (eds), Australian Dictionary of Biography, vol. 7, MUP, 1979, pp.84-5. 
well. It did Archie's career no harm either that he had been acquainted with the Nobel Prize-winning Guglielmo Marconi since living in Chelmsford within sight of the first wireless station.

There is no evidence that the idea of a salaried position to relieve the Steamship Owners' Federation chairman was a response to Fisk's advice about Archie Elford's availability. If family tradition is to be believed, their luck changed when Archie saw a newspaper advertisement for a job that seemed to have his name on it. His then 12-year-old daughter remembered: 'The applications were due to close the following day. He rang them explaining his difficulty and sat up all night writing out his qualifications and posting them.' The real impulse for the appointment of a full-time chief executive was the urgent need to organise a scheme that would meet the Commonwealth government's desire to rationalise coastal shipping arrangements without transgressing the antimonopoly provisions of the Industries Preservation Act.

Having rejected the idea of a new amalgamated company, the immediate task for the steamship owners was therefore to devise and manage a workable interstate shipping pool. This was a job for which Elford was uniquely qualified. He was in Australia. He was available. And there were men locally as well as overseas who could vouch for him. In Adelaide he had assisted Thomas McGlew, a ship broker and coal merchant, in a company reconstruction. At least one other prominent shipping executive, John Langley Webb of Huddart Parker, had an interest in AWA's affairs. ${ }^{15}$ Langley Webb was a close associate of Fisk, having taken a large shareholding and joined the AWA board at Fisk's invitation in 1917. Other Australian shipping interests, including Burns Philp, and the Adelaide, Melbourne, and Union Steamship companies had shares in AWA. ${ }^{16}$ Fisk's endorsement therefore, together with compelling references from Britain, could well explain the exceptionally short time between the decision to advertise the post of 'Vice-President' of the federation in June 1920 and Elford's appointment as 'Deputy Chairman' of the interstate shipping combine at $£ 1000$ a year five weeks later. ${ }^{17}$ At last, in what Sir Kenneth Anderson called a 'distinguished billet' at the head of a major industry group, with a handsome salary, and growing links with some of the nation's most influential businessmen, Elford could look to the future with confidence. ${ }^{18}$

\footnotetext{
15 H. J. Gibbney and Anne G. Smith (eds), A Biographical Register 1788-1939; Notes from the name index of the Australian Dictionary of Biography, 2 vols, ADB, Canberra, 1987, vol. 2, p.334.

16 Jock Given, 'Transit of Empires: Ernest Fisk and the World Wide Wireless', PhD thesis, University of Melbourne, 1997, pp.99-100, 119.

17 Decisions leading to the appointment of Elford as the Steamship Owners' Federation Deputy Chairman can be traced in the Minutes of the Federation board, Noel Butlin Archives Centre, ANU, NBAC E217. On Australian interstate shipping interests, see John Bach, A Maritime History of Australia, Nelson, West Melbourne, 1976, pp.308-26.

18 Sir Kenneth Anderson to A. E. Elford, 20 Sept. 1920, Elford MSS.
} 


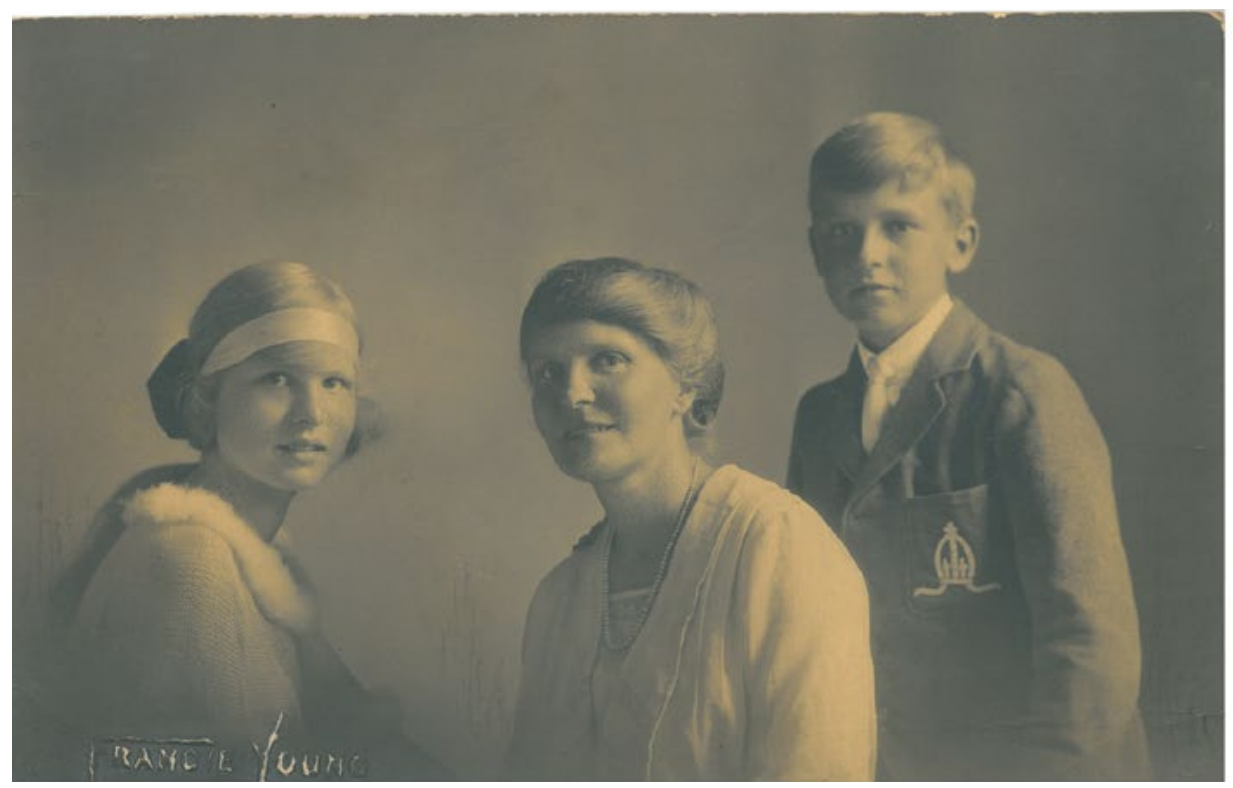

The new boy with mother and sister

(Courtesy of Hugh Elford)

\section{Class rooms}

For the Elfords' children, a decision about their schooling was critical. The family had rented a small house in Middle Brighton, and Barbara was enrolled as a day girl at nearby Firbank. While they were in Adelaide, Dick had attended St Peter's preparatory school. As a former educational administrator, Archie was well qualified to compare the merits of local Australian public schools like Melbourne Grammar, Wesley College, and Scotch College. Nevertheless, there was a serious false start. Dick was sent, once again as a boarder, to Melbourne Grammar's Grimwade House (the junior school). Discovering that the Matron was incompetent, neither making the small boys wash properly nor administering their prescribed medication, the Elfords complained and withdrew their son. Urgently seeking an alternative, they lit upon a resurgent boarding institution southwest of Melbourne.

Geelong Grammar School had long been the school of choice for the graziers of Victoria's Western District, like the Fairbairn dynasty. Since 1914, when it had opened a splendid building at Corio on a new 262-acre site with its own railway station, Geelong Grammar had become a fashionable boarding option for the 
sons of Melbourne's business and professional elite. ${ }^{19}$ Thus in 1921, at the age of 11, Dick Elford was despatched to Geelong. There, initially in Junior House and then in Perry House, he was seen at first as 'a rather timid or hesitant boy'. This was perhaps unsurprising for an English child, a 'pom' detached from all his friends, and now embedded with a company of robust colonial youth, including two Mackinnons and John Grey Gorton.

The Corio atmosphere was 'philistine and hearty', a junior contemporary found in 1926. 'Scorching heat beat down in spring and summer; piercing winds swept across in winter when the place was not petrified in frost.' Naked dashes to cold showers after a bugle call awakening, unheated dormitories, scorn for dressing gowns, uncompromising emphasis on games, weekly military instruction, would toughen or crush the nervous boy. No wonder, as Balcombe Griffiths, a couple of years Elford's senior, remembered, the English lad had largely overcome his shyness by the time he left school. ${ }^{20}$

Though undistinguished academically or on the sporting field, Dick was a notable performer in school drama, appearing in a fund-raising production of Frank Anstey's fantasy farce Vice Versa following a devastating fire in 1925. Dick seems to have contracted the acting bug at the same time as his sister. Barbara would progress from understudying in amateur productions to walk-on and bit parts with the Sybil Thorndike and Lewis Casson touring company. In Brisbane, with cast member and private pilot Norman Shelley at the controls of a rented Moth, Barbara would become the first member of her family to loop the loop. ${ }^{21}$ Dick's interest in theatricals led to an unusual friendship with Tom Judd, the school porter. The stage-struck Judd, whose Cockney father was the school laundryman, had been allowed to sit in on play rehearsals, and even to assist with make-up. The first play he ever saw was Beauty and the Beast with Elford and Noel Newman, a prefect three years older than his co-lead and better known as an athlete and superb Australian Rules footballer, playing the young lovers. Judd was to write many years later:

Dick and I were nearly the same age. I was a little older in years but not in any other way. He had been in Perry House and because of my help with the Pastime Club we discovered, that although poles apart as regards class and upbringing, we had something in common: our love

\footnotetext{
19 Peter Gronn, 'Schooling for Ruling: The Social Composition of Admissions to Geelong Grammar School, 1930-1939', Australian Historical Studies, vol.25, no.98, April 1992, pp.72-89.

20 Francis Stuart, Towards coming of age: a foreign service odyssey, Griffith University, Division of Asian and International Studies, Centre for the Study of Australian-Asian Relations, Nathan, 1989, p.14; Balcombe Griffiths to CH, 10 Nov. 1981, 8 May 1982.

21 Norman Shelley, falsely rumoured to have voiced some of Winston Churchill's wartime broadcasts, flew as a ferry pilot in the Air Transport Auxiliary and became a much-loved radio actor. (For an authoritative review of the impersonation myth, see www.winstonchurchill.org.)
} 
of the theatre, drawing and art and we had read the same books, in fact there are a number of books I would never have read if Dick had not lent them to me and insist that we discuss them later. ${ }^{22}$

Dick had also made a lasting impression on his first house master R. G. Jennings. 'Jenno', housemaster of Junior House, was 'a middle aged bachelor with a mission in life', recalled Jo Gullett, Harry Gullett's son, who entered the school in the year Elford left. 'The mission was to turn the schoolboys under his authority into Christian gentlemen, perhaps rather self-conscious Christian gentlemen, as he was himself.' For Reginald Jennings it mattered less that one might be an outstanding scholar or sportsman. What was important was the moulding of character. ${ }^{23}$ If Tom Judd's testimony is to be believed, Dick Elford was a natural gentleman. Judd's friend had 'a good sense of what was right and wrong. He also had an earnestness of purpose and when combined with a very pleasant personality it made him a boy to remember.' As for Jennings, author of stories of school life, who had also published a three act play, Snappy, in 1919, he was to remember Elford as 'a boy of whom I held a very high opinion', especially 'preparing him for the leading part in a play at school and how really well he did it...I learned to regard him as a charming boy who would do big things.' ${ }^{24}$ This was perhaps a conventional posthumous tribute, though 'charming' has a ring of authenticity.

What we know for certain is that Dick's time at Geelong meant that his life touched that of many boys and their families whose path he was likely to cross again: Pat, younger brother of Jim Fairbairn; Jim and Pat White, sons of General Sir Brudenell White; as well as Balcombe Griffiths, whose mother had been a bridesmaid at the Whites' wedding. ${ }^{25}$ In class, dormitory, and sports field close friendships were forged. Hampers were shared: Heinze [sic] Baked Beans 'done up in tomato sauce gravy (not too strong)' might have only 'one bit of bacon (not pork) just big enough to cover a florin, but the beans were glorious. They make one big meal for two people or a fairly large one for three, you try them', he urged his mother.

\footnotetext{
22 Tom Judd, Fifty Years Will Be Long Enough! a school porter's story, National Press, Melbourne, 1971, pp.39-40. Newman, later a long-serving master at the school, was the father of the AFL footballer and television personality Sam Newman.

23 Gullett, Good Company, p.30. For other views of Jennings: Geoffrey Dutton, Out in the Open An Autobiography, UQP, St Lucia, 1994, pp.37-55; David Osborne Hay, From Collendina to Boomanoomana: An Unfinished Autobiography, Hyland House Publishing, Melbourne, 2009, pp.28-32.

24 Judd, Fifty Years, p.112; R. G. Jennings to Audrey Elford, 2 Sept. 1940, Elford MSS. For Jennings' influence, see Weston Bate, Light Blue Down Under: The History of Geelong Grammar School, Oxford UP, Melbourne, 1990, pp.147-50.

25 W. B. Griffiths to $\mathrm{CH}, 10$ Nov. 1981.
} 


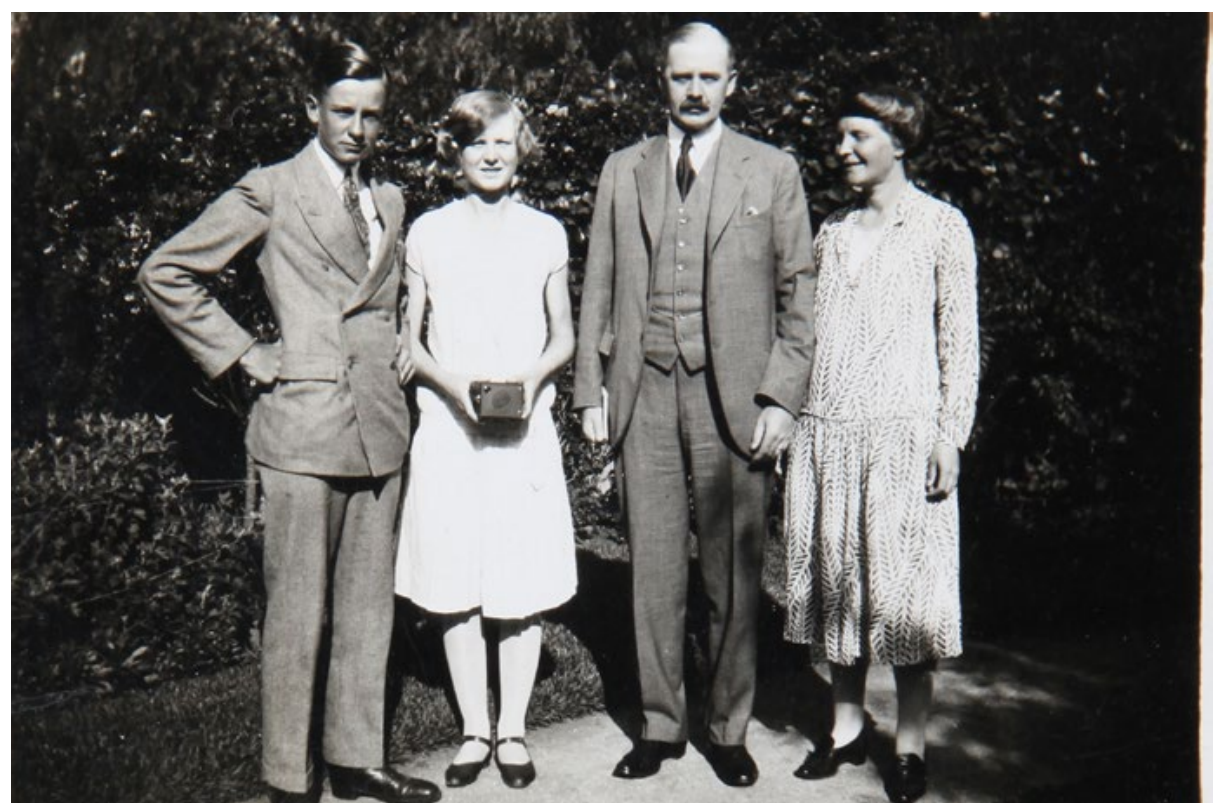

Archie and Sybil Elford, and children home from school

(Courtesy Hugh Elford)

Dick matriculated in 1927, with first-class honours in drawing in the School Leaving Examination, and entered Melbourne University in 1928. Enrolled in architecture, he managed to pass only two subjects, graphics and drawing, in his first year. Pure mathematics, natural philosophy, and chemistry proved beyond him. He tried them all again without success in March and December 1929, and finally in March 1930. The triple failure in chemistry must have been a barely fathomable disappointment to his father and uncles, in particular Percy Elford, who claimed that he had been a month away from discovering Argon in 1890 when he was forced to end his research to take up a teaching appointment in Shropshire. ${ }^{26}$ Dick's lecturers had lost patience. In the terse language of the university's student record, he was 'reported for repeated failure'. He told the authorities that he did not desire to proceed with the architecture course. But this evidently was not enough. Presumably to guarantee that he could not change his mind and come back, he was formally excluded from the course in May $1930 .^{27}$

What had happened? Lack of application rather more than lack of ability seems the likeliest explanation. There had been distractions. In September 1929 he was elected the architecture faculty representative on the Students' Representative

26 Percy Elford's research is summarised in a letter to David Elford, 8 Dec. 1949, Elford MSS.

27 I am indebted to Michael Collins Persse for information about Elford's schooling and to the Melbourne University Archives for his later academic record. 
Council, and became honorary treasurer. Richard Latham, the federal AttorneyGeneral's son, was SRC president. The brilliant Latham, a dedicated practical joker, was soon on his way to Oxford as a Rhodes Scholar. Others prominent on the council were the Test cricketer Ted A'Beckett, succeeding Harry Winneke as representative of the law faculty; the medical student, William Fenton-Bowen, who was to become notorious as an abortionist; and the engineer C. N. Edgerton, who made his name on campus as a boxer. Engaging as student politics and innocent undergraduate romps were, the most significant diversion for Elford was the vivacious girl he met at the architects' ball in his first year. Audrey Edith Basham had just arrived in Melbourne on a holiday trip from Perth. A friend persuaded her to go to the ball. Before the night was out she and Dick were unofficially engaged.

Apart from the understandable hesitations of their parents about such a meteoric courtship, there was another consideration: Audrey was three years older than the 18-year-old university student she had just met. In deference to parental counsel, the couple were to wait until Dick was 21 before they were to marry. Audrey's father George Basham, a retired bank manager, was ill and would die aged 64 in February 1930. By then it was obvious that Dick had to find employment. In a depressed economy, with construction and house building languishing, prospects for advancement in the architectural profession, even for a graduate, were few. His slightly older school chum and fellow architecture student Balcombe Griffiths was secure for the moment in the fashionable firm of A. and K. Henderson, biding his time before quitting with his friends John and Tom Freeman and Rob Yuncken to start their own practice. ${ }^{28}$

For Dick a junior drafting position, at the going pittance of five shillings a week, was out of the question. An opening for a cadet reporter on The Argus, Melbourne's conservative morning newspaper, was more promising. As if to demonstrate the intimate interlocking of the Melbourne elites, Balcombe Griffiths' boss Kingsley Henderson, along with W. T. Appleton and Sir George Fairbairn, had been among the principal money-men supporting Stanley Bruce before his electoral defeat in 1929. ${ }^{29}$ Henderson was one of the small group behind the transition of Joe Lyons from the ALP to lead the United Australia Party in 1931, and in a few

28 'William Balcombe Griffiths, O.B.E., M.C., E.D.', The Corian, July 1991, pp.197-8; Roy Simpson, 'W. Balcombe Griffiths', Architect, July 1991, pp.4-5. For Latham, see 'Geoffrey Hutton', in Hume Dow (ed.), More Memories of Melbourne University: Undergraduate Life in the Years Since 1919, Hutchinson of Australia, Melbourne, 1985, pp.24-5. For Elford's reflections on 'The Training of an Architect', The Argus, 19 Aug. 1937. 29 The Argus, 2 Nov. 1929, p.18. 
years was to become one of the financial angels of The Argus. ${ }^{30}$ The Argus was unashamedly the paper of the right in politics: 'Conservative, free trade; very dignified, stands for everything constitutional, strongly Imperial; circulates amongst society people, commercial leaders, pastoralists, bankers, etc.', was how a brief for the new Victorian governor characterised it in January $1934 .{ }^{31}$ George Johnston, who also started as a cadet in the 1930s, thinly disguised it as the Morning Post in his novel My Brother Jack: 'Everything... was deliberately and publicly arranged to suggest dignity, grandeur, omniscience, infallibility and a privileged standing in the community.' ${ }^{32}$ A staid broadsheet appealing to the status-conscious, it sold less than its morning rival, The Age. Between them, the two rather self-satisfied morning papers barely exceeded the circulation of Keith Murdoch's brash tabloid the Sun News-Pictorial. But The Argus had strong connections with the federal government, and was the favoured recipient of information from Melbourne financial circles.

So Dick Elford began there at the bottom of the journalists' ladder, the most junior member of the 'literary staff', assigned to the motoring section, on the lowest circulation daily paper in the city. Advancement within the business had to be the first objective. His cadetship was a four-year apprenticeship. The Argus cadets were subjected to a rigorous regime of training that enriched their general knowledge while it polished their grammar and syntax. Another way forward was a recently launched Diploma of Journalism course at Melbourne University. The diploma could lead eventually to a Bachelor of Arts degree. Still maybe hoping to satisfy waning family aspirations that he would obtain university qualifications, he enrolled in the course. It proved a struggle. He scraped through Economics I and Law affecting Journalism at the end of 1932. But that was to be the end of his studies. Clearly Dick had no appetite for the higher education that his father, uncles, and aunts had enjoyed. Nor, if truth were acknowledged, was he dedicated to journalism. He had talent as a reporter and feature writer; but the newspaper was a means to an end not a vocation.

\footnotetext{
30 According to Dame Enid Lyons, Henderson was one of her husband's two closest friends from 1931 onwards (Dame Enid Lyons, So We Take Comfort, Heinemann, London, 1965, p.275). The other members of the group that persuaded Lyons to join the new political grouping were the stockbroker Staniforth Ricketson (head of J. B. Were), C. A. Norris (secretary of the National Mutual Life Association), Ambrose Pratt (former journalist, novelist, and tariff reform advocate, with mining interests in Malaya and Siam), Sir John Higgins (head of the British Australian Wool Realisation Association Pty Ltd, the largest public company in Australia), and Robert Menzies, a leading Opposition figure in the Victorian Parliament (Philip Hart, 'The Piper and the Tune', in Cameron Hazlehurst (ed.), Australian Conservatism, p.115).

31 P. M. G. Bayley (London News Editor, Australian Press Association), ‘The Australian Press', Huntingfield MSS, NLA AJCP M2821.

32 George Johnston, My Brother Jack, Collins, Melbourne, 1964, p.206.
} 
Ten Journeys to Cameron's Farm

\section{Ambition}

Dick Elford's real ambition was a life in politics. What led him in this direction is unknown. An eighteenth-century ancestor, Sir William Elford, first and last Baronet, was a friend of William Pitt the Younger and had been an ally of William Wilberforce in the anti-slavery movement in the House of Commons. And Dick's grandfather, Edwin, was related by marriage to the famous Welsh reforming MP, Henry Richard. But all that was in the distant past, and the Elford name - in spite of a lineage traceable back to the thirteenth century - meant nothing in the Australia of the 1930s. If a political career were to be undertaken, some strategic planning was needed. So too was maturity. Dick was no longer a 'rather timid or hesitant boy'. A prolonged engagement and some career success had changed him. Balcombe Griffiths remembered a transformation into 'an active and positive personality'. Exposure as a young adult to the banter of the newsroom and the raffish after-hours haunts of Melbourne's literary luminaries, as well as his father's more decorous social world, had melted his residual shyness. On his wedding day in November 1931, followed by Griffiths as his groomsman, and best man Dick Latreille of the pastoral company Dennys Lascelles, all in white tie and tails, Dick Elford looked as though he belonged on the steps of the Reverend Dr Archibald Law's fashionable St John's Church, Toorak.

Dick's bride, Audrey Basham, and her two younger brothers Geoffrey and Maxwell had a colourful heritage. Their father had moved from the family's mixed farming property at Port Elliot in South Australia for a career as an accountant with the Western Australia Bank, first in the goldfields boom town of Menzies, then as manager in the burgeoning Laverton, 150 miles to the northeast. At Laverton he met Alice Byfield, formerly of Hobart, a nurse at the local hospital. Married in 1905 in St George's Cathedral by the Bishop of Perth, the couple moved to the more established port town of Geraldton, and then in 1920 to Katanning, in the farm belt southwest of Perth.

George Basham traced his ancestry from Xenophon Basham, a Hammersmith butcher transported to Tasmania in 1814 after being found with a forged £5 note in his possession, serving time in the hulks, escaping, and having a death sentence commuted. Xenophon was clearly a man of some resource, as he was followed to Hobart shortly afterwards by his wife and four children. By the 1840s there were Basham children and grandchildren in South Australia. Audrey's grandfather, Charles Abraham Basham, purchased the broad acres of Pleasant Banks stretching from Port Elliot to Middleton in 1856 on his return from the Bendigo goldfields, where he and his brother had made money crafting cedar gold boxes. George, the second son and sixth of Charles' eight children, had cash if not gold dust running in his veins. He had bought an interest in the 
Hotel Australia in Laverton as well as making his own way as a successful and well-connected bank manager. With his uncle and cousins running a Guernsey stud, his father the creator of the 'Basham Black Mammoth' grape, and a Basham history of dairy production, flour milling, and farming around Port Elliot, the convict stain had been well and truly erased. ${ }^{33}$

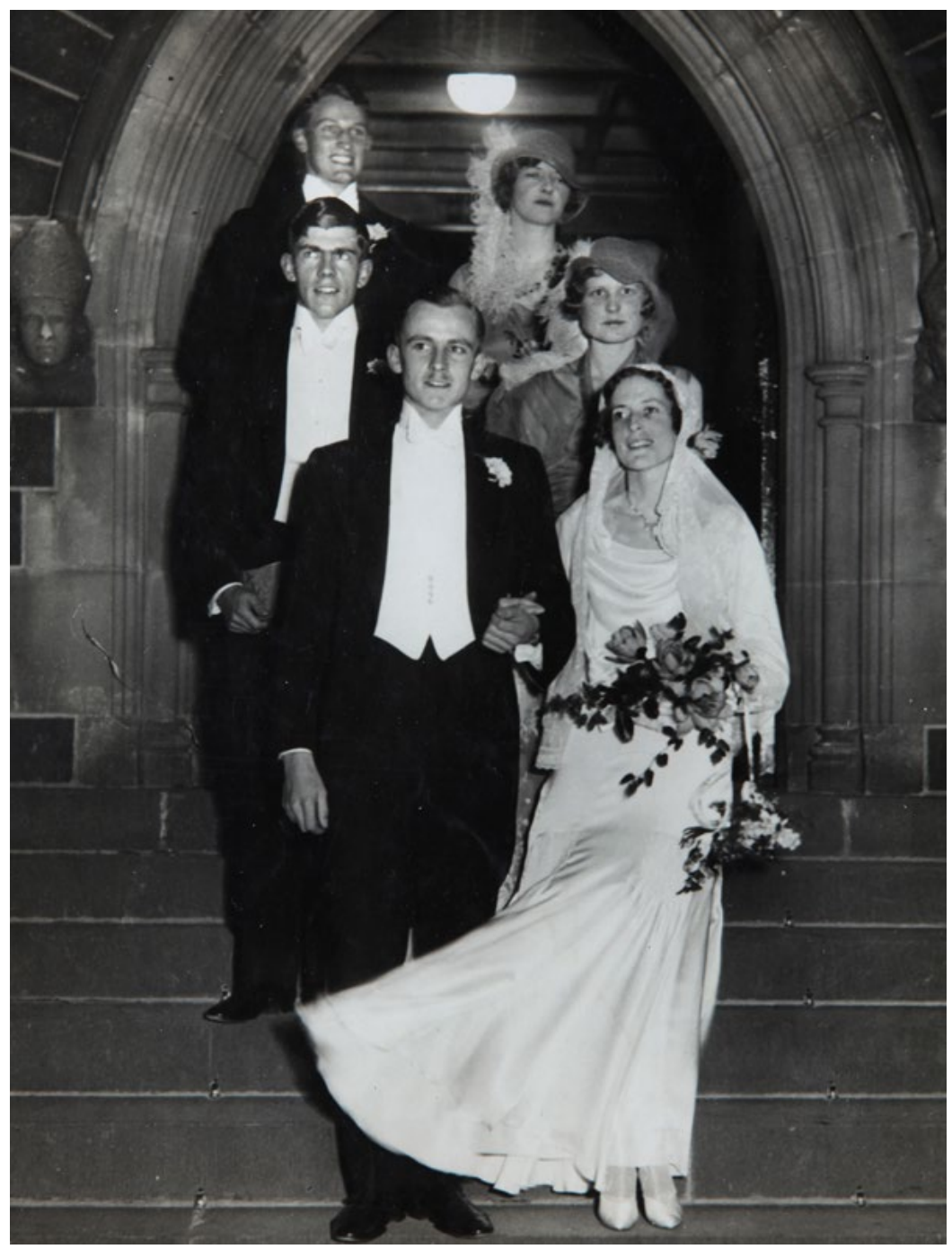

\section{Audrey and Dick, wed at last}

(Courtesy of Hugh Elford)

33 Annie Basham and Melody Cartwright have generously instructed me on Audrey Basham's ancestry. 'A family history of Xenophon Basham and descendants', an essay by Judy Johnson, is held in the library of the Society of Australian Genealogists, Sydney. 
If the Bashams had risen from convict forger to bank manager (sleeping with a revolver under his pillow) in three generations, the Elfords, twentieth-century immigrants, had long-established claims to gentility. Descended from the Elfords of the hamlet of Sheepstor on Dartmoor, the family traced their ancestors back to the late thirteenth century and beyond. ${ }^{34}$ They had the right to bear arms. Sir William Elford Bt, MP for Plymouth, a banker, was a Fellow of the Royal Society and a talented amateur artist, one of whose paintings graced the royal apartments at Windsor. Although his company crashed spectacularly in the 1820s his descendants were proud of their name. Dick Elford wore a signet ring bearing the crest with a demi lion rampant over the family motto adopted by Sir William: Difficilia qua pulchra, variously translated as 'To be honourable is difficult' and 'Things that are honourable [or beautiful or excellent] are difficult to attain. ${ }^{35}$ Now established in a smart South Yarra apartment, a member of the Australian Club and the exclusive residential Peninsula Country Golf Club in Frankston, Archie Elford moved in the same circles as the Grimwades, Harold Clapp, G. J. Coles, Herbert Brookes, and the conservative party leaders Stanley Bruce, John Latham, and the coming man, R. G. Menzies, and their financial backers. As chief executive of a shipping cartel that operated with official blessing, A. S. Elford was frequently in the news for his negotiations with the Waterside Workers and the government. But it was evidence of his family's aspiration if not their arrival in Melbourne society when The Argus social notes on 6 January 1930 recorded the return of the Elfords to their Toorak Road home after spending a few days at the 'millionaires' golf course' in Frankston. ${ }^{36}$

Archie Elford had briefed the young barrister Robert Menzies, and first appeared with him in the Commonwealth Arbitration Court in 1925 when they attempted to get the unruly Seamen's Union deregistered. ${ }^{37}$ Menzies, though possibly blackballed in previous years because of his lack of a war record, had been elected to the Australian Club in 1931. ${ }^{38}$ This was a connection that could in time be useful for the Elfords. But Dick's more immediate need was financial independence. Through the City directors who sat on the Steamship Owners' board - men like James Kelso of McIlwraith, McEacharn; David York Syme of the Melbourne Steamship Co., a director of the National Bank of Australasia, and a fellow member of the Australian Club; and J. Langley Webb of Huddart Parker and chairman of the Commercial Bank of Australia - Archie could help his son

\footnotetext{
34 'A Brief History of the Elford Family of Sheepstor', St Leonard's Church, Sheepstor, n.d., Elford MSS.

35 A. E. Elford to Col. H. E. Jones, 23 Oct. 1940, NAA: A1378, P8903 refers to a 'golf ring'. For the Elford family background, see www.one-name.org/profiles/elford.html; and a family tree and other records in the Elford MSS; Felicity Owen, 'Elford, Sir William, baronet (1749-1837)', Oxford Dictionary of National Biography, Oxford University Press, 2004 [http://www.oxforddnb.com/view/article/8624, accessed 3 April 2010].

36 John Pacini, It's Your Honour: An Account of the First Fifty Years of the Peninsula Golf Club, [1975], p.17; for the 'so-called millionaires golf course', Lord Wakehurst's diary, 31 Oct. 1937, Wakehurst Papers, NSW State Library ML MSS 63471 (5).

37 The Argus, 20 Jan. 1925.

38 Paul de Serville, The Australian Club Melbourne 1878-1998, Australian Club, Melbourne, 1998, p.87.
} 
to embark on a lucrative course in commerce or finance. With his friends on the Court of Directors of the Royal Humane Society, and associates in the 1928-29 Industrial Peace Conference, friends of the Prime Minister like the flour miller W. C. F. Thomas and the Collins House powerbroker R. W. Knox, he could open many other doors. Archie Elford made no secret of his political views, notably his hope in mid-1932 that the New South Wales governor would intervene and end the premiership of Jack Lang. ${ }^{39}$

The path for Dick might not be rapid but it would be steady. He and his adoring wife Audrey would be a team, sharing the burdens and rewards of a modestly prosperous middle-class family life. In due course, with a secure home base, a sound business reputation, and carefully cultivated connections, they would be ready to move forward if and when a political opening presented itself. A cautious approach had much to recommend it, especially as The Argus, respectable newspaper though it was, was going through troubled times. The company lost money in 1932 and, with classified advertising shrinking, there was no revival in sight. With this in mind it seems that an attempt was made to mobilise friendly forces on Dick's behalf. Foremost among them, and as respected as a referee could possibly be, was the Commonwealth Deputy Prime Minister, AttorneyGeneral, Minister for External Affairs, and Minister for Industry, John Latham. Latham had come into the orbit of Dick's father as retained legal counsel to several shipping companies, and then as the Bruce-Page government's moving spirit in industrial relations disputes and legislation affecting the maritime industries. A courteous formal relationship with the minister was deepened by the furnishing of private information on waterfront conditions, and warmed by assurances that the shipowners had no wish to embarrass the government, even when they were alarmed about the impending Maritime Industries Bill in 1929. After the formation of the Lyons government, Elford sought Latham's private guidance on contentious issues such as the Queensland government's move late in 1932 to force volunteers off the waterfront, an action that Elford hoped was 'ultra vires the Constitution'. ${ }^{40}$

As a young barrister, John Latham had contributed articles to The Argus at a penny a line, and had been a correspondent for the London Standard. He knew newspapers, and had almost certainly authorised the provision of intelligence information that underpinned a series of Argus articles on communism in May 1933. ${ }^{41}$ Now, in March 1934, he recorded that he had known 'Mr R. E. Elford'

\footnotetext{
39 Sir Kenneth S. Anderson to A. S. Elford, 1 May 1932, Elford MSS.

40 Elford to Latham, 3 Jan. 1933, Latham MSS, NLA MS 1009/1/2958. Elford's correspondence with Latham in 1929, including 'personal and confidential' exchanges about the "'red" and highly undesirable element', is in Latham MSS NLA 1009/36 and 39.

41 Sybil Nolan, 'Manifest editorial differences: The Age and The Argus in the 1920's and 30's' and David Dunstan, 'The Argus: The Life, Death and Remembering of a Great Australian Newspaper', in Muriel Porter (ed.), The Argus: The life and death of a great Melbourne newspaper 1846-1957, RMIT UP, Melbourne, 2003, pp.9-41, 79-113.
} 
for seven years, since Elford's university days in fact, when his own son had been President of the Students' Representative Council. Elford was a man 'of attractive personality and he has displayed great energy and ability in his work as a journalist'. Moreover, Latham attested:

I know he is entrusted by his newspaper with assignments usually reserved for men of much longer experience, and I am assured from a well informed and independent source that his progress in the journalistic profession has been unusually rapid, whether judged from a standpoint of the work with which he has been entrusted or of the salary which he is now paid.

Latham had 'no hesitation in recommending Mr Elford as an intelligent, well informed and energetic young man' ${ }^{42}$ With this sort of support, a new arena was probably only a few interviews away. But an unexpected turn of events a few months later brought another option.

In December 1934, following the sudden death of Lauchlan Mackinnon, principal proprietor and general manager of The Argus, Archie Elford was entrusted with responsibility for managing the newspaper interests of the Mackinnon estate. As a member of the council of management he became, in effect, a director of The Argus and Australasian company. The unforeseen assignment lasted for the next three years until new owners led by Robert Menzies' business partner, Staniforth Ricketson of the stockbrokers J. B. Were, took over what was a commercially ailing property. ${ }^{43}$ His father's position affording him some protection, if not patronage, Dick could adopt a more audacious strategy. He presented Audrey with a choice. If they were to put all their resources into developing his career, staying with The Argus and riding out its financial uncertainties would give him flexible hours to widen his circle of useful acquaintances, and pursue other interests and opportunities. The polo, racing, and riding to hounds of the Mackinnons, the Fairbairns, and their Western District pastoralist neighbours might be beyond his reach. But he would have enough money for smart clothes, entertainment, perhaps tennis and squash, and even occasional hospitality. Meanwhile Audrey would stay in the background, thrifty and frugal, taking care of the children - twins Hugh and David born in February 1933 - until her husband 'came good'.

42 Latham testimonial, 6 March 1934, Elford MSS (copy, Latham MSS, NLA MS 1009/1/3561). Seven months later Archie Elford was a member of the organising committee led by Prime Minister Lyons for a dinner honouring Latham on his retirement from politics - 'one of the greatest tributes ever paid to a public man in Australia' (The Argus, 11 Oct. 1934).

43 For Lauchlan Mackinnon and The Argus, see Geoffrey Serle, 'Mackinnon, Lauchlan Kenneth Scobie (1861-1935)', Bede Nairn and Geoffrey Serle (eds), Australian Dictionary of Biography, vol. 10, MUP, 1986, p.316. For the business links between Ricketson, Henderson, and Menzies, see 'The House of Were' 1839 1954, privately printed, Melbourne, 1954, pp.300-1, 326, 329-31. 


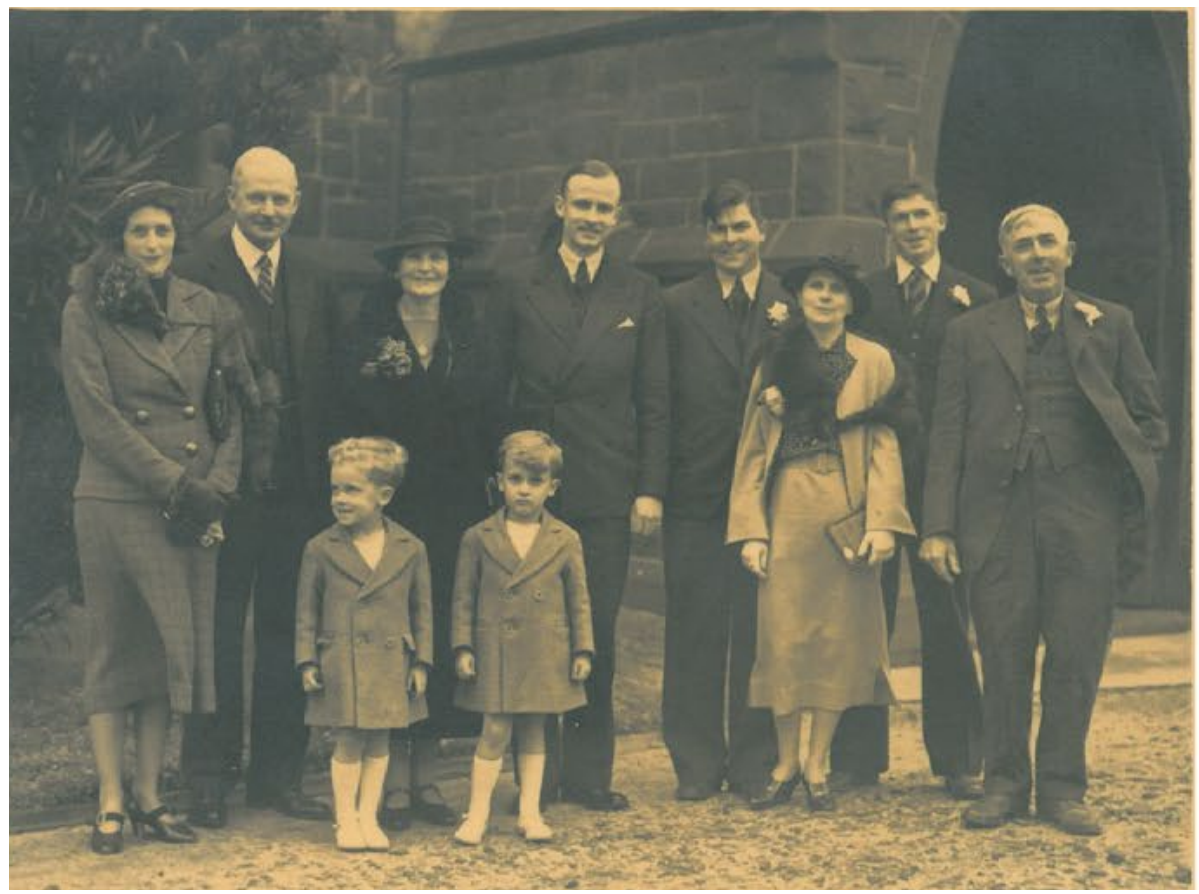

The Elfords at Roy Pearce and Barbara's wedding 1937; left to right: Audrey, Archie, Sybil, Dick, Roy, Barbara, the best man, groom's father, with twins David and Hugh

(Courtesy of Hugh Elford)

Dick's preference was obvious; and Audrey acquiesced. So this was the plan, 'an arrangement', as Audrey described it with a tinge of embarrassment 40 years later. To the extent that their carefully rationed means would allow, Dick would live something akin to a playboy life. His social circle would embrace old school chums, the junior members of the Mackinnon clan, his architect friends like Balcombe Griffiths and their wealthy clients, Dick Latreille of Dennys Lascelles, journalists like Archer Thomas of The Herald and the flamboyant leftwinger Rupert Lockwood, the rising society solicitor Max Ham, the ex-Geelong Grammarian and aspiring artist Russell Drysdale, and the dashing bachelor MP for Fawkner, Harold Holt. ${ }^{44}$ On rare occasions, noticed in The Argus 'Life in Melbourne' columns, Audrey would also come into her own - acting as a ticket secretary and then committee president, for example, when Dick and a group of old boys from public and grammar schools' associations organised an 'Alma Mater' ball and other functions to raise funds for a boys' ward at Prince Henry's Hospital. ${ }^{45}$

44 Harold Holt to John Buchan, 16 June 1961, Holt MSS, NAA: M2606/1/23 recalls Holt's friendship with Elford.

45 The Argus, 6 Nov., 16 Dec. 1935. 
The Elford plan also included taking work seriously. At The Argus Dick was at first taken under the wing of Edgar Holt, one of the younger men already making their mark on the paper, along with the Deputy Chief of Staff W. Shelton Smith, and Clive Turnbull. A poet, and a major presence in the literary pages, Holt was assigned to 'keep an amiable eye on him' by the editor, Roy Curthoys. ${ }^{46}$ Within a short time of joining the paper, 'Richard Elford' had stories appearing over his own by-line. Initiation pranks for college freshmen, the prospect for the Victorian ski-ing season - he could turn his hand with a light touch to whatever was required..$^{47}$ By the time Curthoys, opinionated and volatile, fell out with the owners and left in 1935, Dick was securely established.

From late 1937, Argus staff came under the supervision of the dynamic Sydney journalist Errol Knox, who had enlisted as a private in the AIF, was commissioned and served with No. 3 Squadron, Australian Flying Corps, and ended the war as a temporary major attached to the Royal Flying Corps staff. Appointed as managing editor to turn around the paper's faltering fortunes, 'Knocker' Knox had edited Who's Who in Australia 1933-34 and another edition in 1935 in which Archibald Elford now appeared among his more famous friends. Other contemporaries of Dick at The Argus included Bob Menzies' sister, Belle Green, working for the board of directors in 'a public relations capacity'; and in the newsroom the senior feature writer, film reviewer, and novelist Erle Cox; Bill Brennan the veteran chief leader writer (whose brother Tom was a junior United Australia Party minister); and Erle Cox's son Harry, deputy chief of staff, who went on to assist in the paper's Canberra parliamentary gallery from 1933, and would share tales of the turmoil and conflict in the national capital before moving on to be news editor at the Sydney Daily Telegraph. Elford himself brought along the talented Melbourne University student journalist Geoffrey Hutton to work for $£ 2$ a week under the stern tutelage of Roy Curthoys. ${ }^{48}$ It was a good school. And, as the paper was revamped in the late 1930s, with news on the front page, rising circulation and advertising revenue, Dick Elford settled into a comfortable routine. ${ }^{49}$

\footnotetext{
46 Edgar Holt to $\mathrm{CH}$, [May 1983]; Bridget Griffen-Foley, 'A “Civilised Amateur": Edgar Holt and His Life in Letters and Politics', Australian Journal of Politics and History, 49 (1), 2003, pp.33-6.

47 The Argus, 14 March 1931, 4 June 1932.

48 'Isabel Alice Green née Menzies', Latrobe Library MS 10741 Box 957/4; Dow (ed.), More Memories of Melbourne University, p.36.

49 For The Argus's revival, see Bob Murray, 'All a matter of finance', in Jim Usher (ed.), The Argus: Life and Death of a Newspaper, Melbourne, 1999, p.15 and Matthew Ricketson, 'Staniforth Ricketson and the Rejuvenation of The Argus', in Muriel Porter (ed.), The Argus..., pp.159-73. Also Sally O'Neill, 'Knox, Sir Errol Galbraith (1889-1949)', Australian Dictionary of Biography, vol. 9, MUP, 1983, pp.628-9.
} 


\section{An auspicious embrace}

At last, his spurs earned, Dick was beckoned towards one of the political doors he was hoping would open. One of the people into whose orbit he had inserted himself was James Fairbairn, the flying MP for Flinders. He had perhaps first met Fairbairn through Fairbairn's younger brother Pat, one of his contemporaries at Geelong Grammar. Allan 'Jiggie' Spowers, an Argus director, was a prefect and captain of boats at Geelong when Fairbairn was there. Spowers and Fairbairn and their wives moved in the same social circles: polo tea parties, vice-regal balls, racing carnivals. Spowers, Osborne Fairbairn, and Jim Fairbairn himself had seen something of the young journalist on the committee of the old Geelong Grammarians' Association which Elford had joined two years after leaving school and remained on ever since. He was, it was said, a keen and useful committee man. In mid-1938, Fairbairn invited him on an adventure. They were to fly to New Guinea together in August, ostensibly to undertake an aerial survey of the Salamua-Wau road but with another agenda that emerged on return: to challenge the choice of Salamua over Lae as the capital of the mandated territory. ${ }^{50}$

The Argus gave Elford leave of absence. It was to be a determining event in the young journalist's life. A more intimate environment than the cockpit of a small plane is hard to imagine. Sharing the dangers of the air through rough sea crossings and blinding storms, navigating with official maps that did not show many ranges and peaks of over 1000 feet, the two men learned that they really liked each other. ${ }^{51}$ Great excitement followed when Fairbairn's arguments against Salamua led to Cabinet repudiating the decision of the Minister for Territories, Billy Hughes, and considering Fairbairn's proposal that the administration of Papua be merged with New Guinea. So it was not a great surprise when early in 1939 Fairbairn, raised to the Cabinet in the Menzies ministry as Minister for Civil Aviation and Minister assisting the Minister for Defence, asked Elford to become his private secretary. Dick did not hesitate.

The appointment as private secretary to the new minister reflected both professional and social acceptance. The Fairbairns, Victorian Western District aristocracy, were socially exclusive. Mere public servants and business acquaintances did not readily get past the ex-RAN petty officer manning the lobby of Alcaston House at the top of Collins Street, the seven-storey apartment building designed by A. and K. Henderson, where the Caseys and the Streets also had flats. Still less were invitations proffered to the Fairbairn estate at Mount Elephant. The gregarious Fred Scherger, for example, then a 35-year-old Wing

50 Sydney Morning Herald, 8, 23 Aug. 1938.

51 The Mercury, 13 Aug. 1938. 
Commander and RAAF Director of Training, whose ability their father greatly admired, was never seen at home by the Fairbairn children. ${ }^{52}$ A career officer, graduate of the Royal Military College, Duntroon, too young to have flown in the Great War, the diminutive Scherger was ambitious and well-connected. One of the RAAF's most respected pilots, he was Chief Flying Instructor at No 1 Flying Training School, Point Cook, when the Minister for Defence Vic Thorby (prompted by the Prime Minister Joe Lyons) authorised the school being placed at Dick Casey's disposal to enable him to qualify for his pilot's licence.

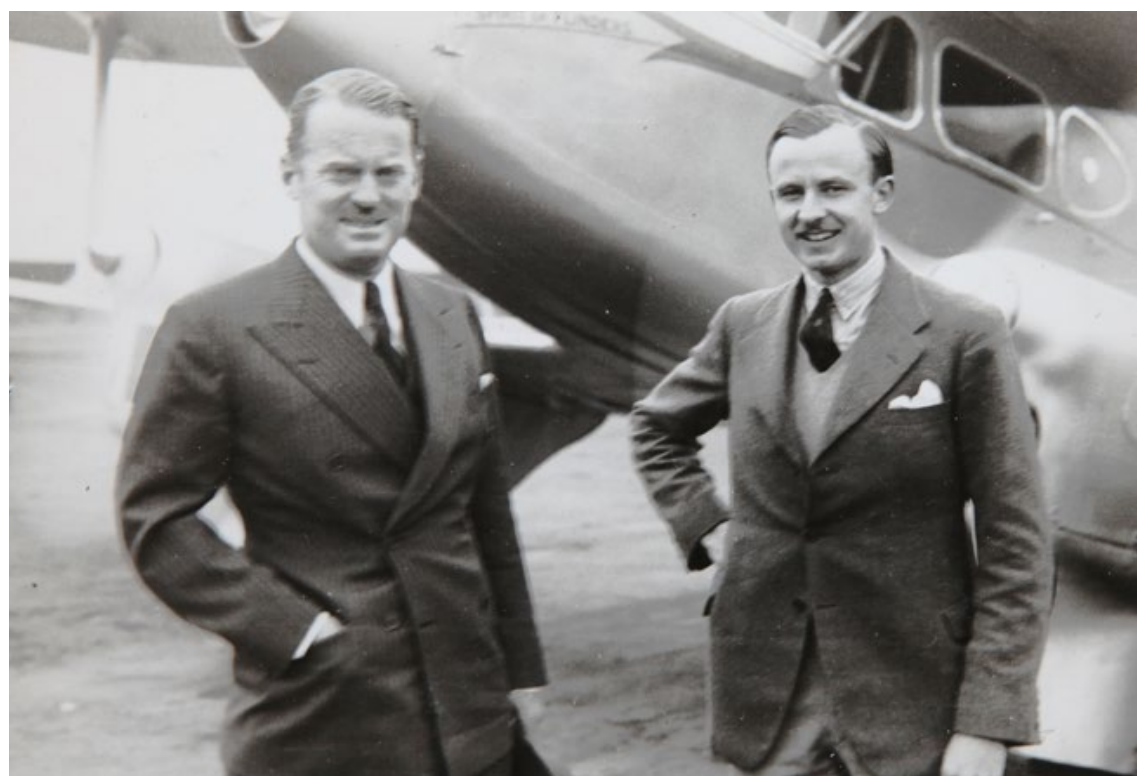

\section{Fairbairn and Elford take flight together, August 1938}

(Courtesy of Audrey Elford)

The Chief of the Air Staff gave Scherger the task of instructing the Treasurer. In the 1937-38 Christmas holidays the instruction that had begun at Laverton was continued at the Caseys' Berwick property in southeast Victoria; there Maie Casey, now an enthusiast after early misgivings, joined the class. Scherger remained friendly with the appreciative Caseys. ${ }^{53}$ He played golf with Fairbairn whenever they met at the Barwon Heads Golf Club. The minister later confided to his teenage son Geoffrey that he would have promoted Scherger to the top of

52 Geoffrey Fairbairn, interview, 10 Oct. 1978.

53 Williams, These are Facts, p.229; Harry Rayner, Scherger: A biography of Air Chief Marshal Sir Frederick Scherger KBE CB DSO AFC, Australian War Memorial, Canberra, 1984, pp.24-5; Maie Casey, Tides and Eddies, Penguin, Harmondsworth, 1969 (1st ed. Michael Joseph, 1966), pp.65-6. 
the RAAF if he could. But he had to tell a crestfallen Scherger in 1940 that he must yield his position to a more senior man, one of the Great War generation, because he lacked 'weight in the top councils of the service'. ${ }^{54}$

Relative youth was not a handicap for a ministerial private secretary. The right old-school tie and social graces in any case compensated for much that might otherwise be deficient. Dick Elford's journalistic colleagues had appreciated his 'quiet courtesy and unfailing bonhomie'. As the Geelong Grammar magazine, The Corian, was to put it 16 months later, Elford had qualities to impress an older man: 'a keen sense and acute mind, good judgment, and a strong sense of right and wrong, together with a real though not oppressive earnestness of purpose...a natural pleasantness of manner'.$^{55}$ Perhaps, too, Jim Fairbairn was able to confirm his assessment of Elford's character and ability from his uncle Sir George, a former Senator and Victorian Agent General in London, who was a director of The Argus and Australasian Ltd. George Fairbairn, as trustee for the Wilson family, The Argus's original owners, of course knew Dick's father from his days as the Mackinnons' trustee. As President of the Victorian National Union in the early 1930s, the main financial backer of the United Australia Organisation, George Fairbairn's influence reached into the deepest recesses of the conservative political heartland. ${ }^{56}$ Scattered through the network of relatives and business associates, the Melbourne and Australian Club establishment, the Collins Street mining and financial magnates, there would be many people who could vouch for the sociable Dick Elford.

Dick was in fact in demand. Sir Keith Murdoch was contemplating offering him a post on the Melbourne Herald. And just two days after he had accepted Fairbairn's offer, Dick Casey, appointed as Minister for Supply and Development, made a similar proposal. Casey had just relinquished the Treasury portfolio and, by mutual agreement, his private secretary, Colin Moodie, a graduate clerk from External Affairs, had returned to a better-paid departmental post. Moodie had not enjoyed the demands of the private secretary's post: hours lingering around Parliament House, Sunday summonses to the minister's home, an ambience of political intrigue from which as a career public servant he felt he should be detached. Elford's pedigree and commitment were different. He had known Casey's wife, Maie, for several years. She, and their mutual friend Russell Drysdale were fellow students at George Bell's Melbourne art school. Ethel Spowers, sister of The Argus director, Allan Spowers, was another of Bell's Contemporary Group circle. Maie, as well as her husband, and her brother Rupert were avid flyers, with a newly built airstrip on their 'Edrington' property near Berwick. Much as he welcomed the chance to work with Fairbairn, Elford regretted the

54 ACM Sir Frederick Scherger, interview, 2 Sept. 1978.

55 The Argus, 14 Aug. 1940, editorial; 'Richard Edwin Elford', The Corian, Aug. 1940, p.122.

56 Lex Watson, 'The United Australia Party and its Sponsors', in Hazlehurst (ed.), Australian Conservatism, pp.73-4. 
missed opportunity to join the entourage of the more senior party figure. It was more than a co-incidence that Elford's bosses at The Argus had backed the campaign for Stanley Bruce to succeed Joe Lyons, a bid led by Casey, whose ill-judged support for Bruce and subsequent lame candidature of his own, cost him whatever confidence the successful Bob Menzies might have retained for a declared leadership rival.

Irrespective of the immediate political consequences, there was a lesson to be learned from a particular enthusiasm Fairbairn and Casey shared. The two ministers had a unique bond. Elford could not fail to be impressed by the passion for the air displayed by both his new chief and the 'figure of glamour', the immaculate 'Ronald Colmanesque' Casey. As Casey was to write some 18 months later: 'Australia is one of nature's flying countries. ${ }^{\text {.57 }}$ If Fairbairn was the betterknown aviator, Casey had his own early flying stories. His first was paying $£ 5$ to spend 10 minutes aloft near Paris in 1911. In 1917 he was attached as an observer to an Australian squadron in France and went up in several military machines. ${ }^{58}$ He had started flying lessons in England as long ago as 1929. But, after a few months, his instructor 'killed himself by running into another machine in the air, so that I am at present subject to certain domestic pressure to give it up' ${ }^{59}$ The domestic pressure had abated by January 1938 when Casey bought Simple Flying for Simple People: notes for the use of A-licence pilots by one of them, Nancy Lyle, who happened to be the first woman to fly across Bass Strait. ${ }^{60}$ Although Audrey Elford did not know it, Dick himself was soon to begin flying lessons. But first, traditionally farewelled by his Argus colleagues with a wrist watch suitably engraved in recognition of nearly a decade of service, he had fresh realms on land to make his own.

\section{The political world}

People in political and public service circles quickly warmed to Dick Elford. On the new stage, with her boys at school, and an additional allowance supplementing her husband's salary, Audrey could begin to entertain more expansively in their Punt Road home. Cocktail parties for visiting friends on successive evenings in late August 1939 found their way into The Argus social page. 'The rooms

\footnotetext{
57 'Notes to assist in the preparation of scenario for "March of Time" of Australia', attachment to Casey to Sir Keith Murdoch, 5 Sept. 1940, Casey MSS, NLA MS 6150/2.

58 Lord Casey, 'Foreword', Sir Norman Brearley (with Ted Mayman), Australian Aviator, Seal Books, 1974 (1st ed. Rigby 1971).

59 R. G. Casey to S. M. Bruce, 23 May, 18 July, 1 Aug. 1929, W. J. Hudson and Jane North, My Dear P. M.: R. G. Casey's Letters to S. M. Bruce 1924-1929, AGPS, Canberra, 1980, pp.515, 542, 553.

60 Casey bought the book, published by Angus \& Robertson in 1937, in Sydney on 24 Jan. 1938; it now forms part of the Casey Collection in the Berwick Mechanics' Institute \& Free Library (Judith Dwyer to $\mathrm{CH}$, email, 31 Aug. 2009).
} 
were decked with hyacinths, violets, daffodils, and blossom. The hostess wore a frock of misty blue woollen striped with red and white, with a wide belt and buttons of white patent leather. ${ }^{61}$ Many in Melbourne and Canberra of course knew Dick's father as the principal representative of the employers in the shipping and waterfront conflicts of the last decade and recently as a member of a Commonwealth government defence co-ordination committee advising on the requisitioning of mercantile vessels in time of war. Dick soon became a popular member of the coterie of younger ministerial private secretaries. Cecil ('Peter') Looker was friendly. Looker had come from the Prime Minister's department as Casey's third choice when Moodie departed and Corby Tritton declined. ${ }^{62}$ Keith Waller, a Melbourne University history graduate and career External Affairs officer seconded to Billy Hughes' staff, was among those who introduced him into the close world of Canberra society. Dick made friends wherever he went, Waller said, 'one couldn't help liking him'. Though his university career had been brief and unremarkable, Elford was embraced by the clique of graduates recently recruited to the Department of External Affairs. The group included Waller's Scotch College contemporary Pat Shaw, Colin Moodie, Tom Eckersley, and Peter Heydon who had been at Fort Street High School in Sydney with Looker. Heydon's Sydney law background, joviality, and quick intelligence had impressed Bob and Pattie Menzies on a five-and-a-half-month overseas trip in 1938. As External Affairs liaison officer with the Defence Department in Melbourne in the first few months of war, he was to see much of Elford, along with Geoff Street's Toorakite assistant, CMF Captain Garry Armstrong, in the ante-rooms of the War Cabinet. ${ }^{63}$

'He was a most attractive fellow', Keith Waller recalled of Fairbairn's private secretary. 'I don't think there was any great profundity but he was tremendous fun and a splendid person to spend an evening with — bit of a womaniser but that's forgivable in youth I suppose. ${ }^{64}$ Waller's verdict was echoed by the distinguished RAAF officer Air Marshal Sir George Jones, then a Wing Commander and Assistant Chief of the Air Staff. Jones saw Elford at close quarters for many weeks crossing the Pacific aboard the Matson liner Monterey, then travelling across the United States, and in Ottawa for a month from mid-October 1939. Temporarily gazetted out of the RAAF and travelling in mufti so that the neutral Americans would not be obliged to intern him, Jones accompanied the

\footnotetext{
61 The Argus, 21 Aug. 1939; 1 Nov. 1938.

62 N.C. Tritton, interview, 7 June 1977.

63 Keith Waller to Audrey Elford, 13 Aug. 1940, Elford MSS; David Lee, 'Shaw, Sir Patrick (1913-1975)', Ritchie and Langmore (eds), Australian Dictionary of Biography, vol. 16, pp.220-1; J. R. Nethercote, 'Heydon, Sir Peter Richard (1913-1971)', Ritchie and Cunneen (eds), Australian Dictionary of Biography, vol. 14, pp.445-6; Hazlehurst, Menzies Observed, pp.135-7.

64 Sir Keith Waller, interview, 21 June 1977.
} 
Minister to assist in negotiating the Empire Air Training Scheme. Fairbairn's private secretary, he remembered with a twinkle, 'was a nice sort of a fellow. He got on well with people, particularly with the girls. ${ }^{\prime 65}$

Elford was indeed attractive to women. Nor was he afraid to pitch his cap in dangerous territory. The Minister's wife, Peggy Fairbairn, encouraged his attention, pursued him, according to Audrey Elford. What especially irked Audrey was the way in which Peggy's 15-year-old son Geoffrey, home from school, was charged with delivering messages from his mother. For his part, Geoffrey was at pains 39 years later to affirm that the initiative came from the other direction. Elford wrote poems and sent them to his mother. She was 'charmed' by Elford's attentions. His father, he said, was not worried about the relationship. In answer to a question that had not been asked, he volunteered that there had been no affair. ${ }^{66}$

Whatever the truth about the young Dick Elford and Peggy Fairbairn, known in her family for sensitivity about her age, it clearly did not bother her husband. Scarcely a day passed when Fairbairn and Elford were not in each other's company. The friendship that had been forged in the air over New Guinea and strengthened as the uneasy months of peace in 1939 turned to 'phony' war, was to be tested by another extended period of travelling intimacy. When the Menzies government decided to join with the United Kingdom and the other Dominions in launching an Empire Air Training Scheme it was natural that the Civil Aviation Minister and Minister assisting the Minister for Defence, Fairbairn, should be sent overseas to negotiate the terms. The small team accompanying the Minister was just his private secretary, Wing Commander George Jones (Assistant Chief of the Air Staff), and C. V. Kellway, Finance Member of the Air Board, who joined the mission in New York where he was Acting Assistant Trade Commissioner. For Elford it was an eye-opening trip, 'one to remember for the rest of my life', as he told his mother on his return. ${ }^{67}$

On the long sea voyage across the Pacific, the Minister and his private secretary had weeks to relax and restore their bodies and spirits. There was good company, and they enjoyed it. The journey was broken to collect the New Zealand delegates. Then in Fiji, on October 19, the Monterey paused long enough for a party of 28 to be entertained by the Governor, Sir Harry Luke, at lunch followed by a vocal concert in aid of Red Cross. The highlight, according to the host, was the 'admirable rendering' of the 'Song of the Flea' by the Australian baritone Alfredo Luizzi, the 1938 Sun Aria winner and a protégé of Marjorie Lawrence, en route to the USA to further his studies. ${ }^{68}$ 'There were also a lot of parties in

65 AM Sir George Jones, interview, 14 Sept. 1977.

66 Geoffrey Fairbairn, interview, 10 Oct. 1978; telephone conversation, 8 March 1979.

67 R. E. Elford to Sybil Elford, 31 Jan. 1940, Elford MSS.

68 Sir Harry Luke, From a South Seas Diary 1938-1942, Nicholson \& Watson, London, 1945, p.130. 
various cabins', Elford and Fairbairn's travelling companion Jones remembered. The Prime Minister's friend F. B. 'Tim' Clapp and his wife, Jane, were also on board. Clapp, who headed General Electric in Australia, was going to New York to supervise the 'expediting of orders for defence requirements' in association with a proposed British Purchasing Mission. Although his appointment had been kept confidential - he was travelling incognito as were the Air Minister's party - Clapp's identity was no secret. And it soon became apparent to Fairbairn and his group that there would be much to be gained if Clapp could join them in Ottawa to meet the various British, French, and Canadian representatives at the air conference. ${ }^{69}$

For Elford, more than his well-travelled companions, landfall brought both delights and disagreeable surprises. 'After the luxuriant growth and colour of the tropics,' he reported to his mother, 'Los Angeles with its timber frame houses and apparent lack of civic pride which allowed much dirt and many eyesores to disfigure the landscape rather appalled me.' Even Hollywood was a disappointment. But the trip was, after all, official business. As Australia had placed an order for 100 of the Lockheed Corporation's latest Hudson bombers, the Lockheed factory at Burbank and several other big manufacturing plants on the west coast were on the official itinerary. Francis Clapp, as 'Special Business Consultant, Commonwealth Government', reported to Menzies that he had accompanied Fairbairn's party to the Lockheed works where the president of the company had shown them all that was to be seen. They found that the last machines for the initial British order of Hudsons were being cleaned up and that production of the Australian order was about to begin at the rate of two a day.

As Fairbairn and his team were aware, final negotiations were in train for Australia's payment to Lockheed. Under America's recent neutrality legislation, title to the aircraft had to pass to the buyers on American soil. This entailed that final transfer of funds must occur on delivery at the factory or warehouse not on the ship, a technicality that occasioned considerable teleprinter traffic between Defence and Treasury officials, the Air Board, the Commonwealth Bank, and the Prime Minister's department. ${ }^{70}$ Clapp had told his brother Harold, general manager of the Aircraft Construction Branch of the Commonwealth Department of Supply and Development, that Lockheed had 6800 employees, of whom 600 were draughtsmen; 'he can figure out for himself what he is up against'. Harold had been given the task of supervising the assembly of the Bristol Beaufort

69 F. Clapp to Menzies, 16 Oct. 1940, NAA: A5954, 713/1. Neither the Clapps nor the Fairbairn party appear on the ship's passenger list.

70 'Purchase of Lockheed Aircraft in U.S.A.', NAA: A705, 9/19/95. Hudsons purchased for delivery in Canada were flown to a specially purchased airstrip in North Dakota and dragged over the border by mule teams (Wayne Biddle, Barons of the Sky: From Early Flight to Strategic Warfare: The Story of the American Aerospace Industry, Henry Holt, New York, 1991, p.263). 
bombers the government had agreed to build. When the delivery of Beauforts was delayed because of British needs, he was soon to be a key player in the Hudson program. ${ }^{71}$

From the west coast there followed an overnight trans-continental flight to New York, a train journey to Ottawa, and a month ensconced in the turreted magnificence of the Château Laurier hotel with offices next door in the Canadian House of Commons. Elford and his colleagues worked hard but managed some recreational escapades as well, including trips across the river to Hull, the French quarter. In spare moments, at the suggestion of Harry Gullett, Dick despatched a series of 12 cables and collected photographs for use in Department of Information publicity. Out of pocket - 'the Lockheed pictures alone cost him two very expensive lunches' - he had to wait until June before receiving what a departmental official described as a 'meagre and long overdue' 10 guineas honorarium. An ever-miserly Commonwealth Public Service Board had sought 'further particulars' of the material supplied. Dilatory (nine weeks from provision of the information requested) and circumlocutory (the Victorian Public Service Inspector referred the matter to Canberra for decision), the Board finally had 'no objection' to the proposed special payment. ${ }^{72}$

When an agreement on imperial air training collaboration was finally sealed, there was time for the Minister and his private secretary to explore New York. Then an island-hopping flight to Lisbon by Pan American Airways transAtlantic clipper with an initial unplanned five days in Bermuda, 'where there are no motor-cars and people take life very calmly'. The delay was supposedly caused by inclement weather at Horta in the Azores. When they finally arrived at Horta after flying all night, they picked up 18 Germans. Refuelled, they flew on towards Lisbon only to encounter a severe electrical storm. By what Elford admiringly described as 'a fine piece of navigation' they managed to find the Azores again before retracing their path to Lisbon the following day.

Four days in Lisbon were enjoyable but for the ubiquitous 'German intrigue', a reminder of why Elford - like George Jones, who had temporarily gazetted himself out of the Air Force - was not allowed to be in uniform. There had been earlier evidence of German intrigue. While in New York, Fairbairn was informed that a Nazi agent under surveillance had received a clumsily coded cable from London advising him of the date of the Air Minister's departure. The cable was traced to a waiter in a London restaurant who had overheard a British minister talking indiscreetly. ${ }^{73}$ The original 'inclement weather' it seems may have been the excuse for a cautious change of flight plan. From Lisbon there

71 F. Clapp to Menzies, 5 Nov. 1939, Menzies MSS, NLA MS 4936/579/4.

72 'Missions from Australia - Mr Fairbairn to (Canadian) [sic]', NAA: SP112/1, 353/3/1.

73 Irvine Douglas, 'Australia Air Disaster: Careers of Three Ministers', Sunday Times (London), [18] Aug. 1940. 
was one more stop, at Biscarosse in France, before arrival at last in England at Southampton. The contrast between perpetually damp, wintry London and the springtime Melbourne Elford had left could hardly have been greater. At the heart of the Empire he found a city of sandbags, blackouts, rationing, gas masks, and a pervasive sense that there was to be a very long war. There was much to see in a short time - the War Office, the headquarters of Fighter, Bomber, and Coastal commands. Crossing the Channel through pelting rain in a fast French steamer with a destroyer escort, there was a visit to advanced units, conversations with Australian pilots, and a day in 'the biggest fort in the Maginot line'. Back to Paris, thence to Marseilles to join an Imperial Airways flying boat for the journey home. To complete the tour, there were brief inspections of war preparations in Egypt, Palestine, Iran, and Iraq. Siam and the Dutch East Indies were the last ports of call before Australian landfall.

Back in Canberra and Melbourne early in the New Year, Dick Elford was now a connected and effective insider. He was well liked by Air Board and departmental chiefs, Fred Mulrooney and Mel Langslow. He would liaise and gossip with friends in uniform at RAAF HQ, such as the lawyer, Jack Graham. After a long day in Parliament, he would carouse in the company of Artie Fadden, who had led a group of Country Party dissidents appalled at Sir Earle Page's attack on Menzies' war record and was to become Minister without Portfolio in March 1940. Among the ministerial staff, Dick had become especially friendly with 'Peter' Looker who, since the departure of Casey to Washington, had been assistant private secretary to the Prime Minister. 'We were all bearing the heat and burden of the day', Looker reflected 36 years later. He himself was enjoying the company of a stenographer in Fairbairn's office, Jean Withington, whom he was later to marry. Another sharing the heat and burden, and Elford's companionship, was J. R. (Bob) Willoughby, a political organiser who had come from Adelaide as private secretary to one of the Prime Minister's key political associates, George McLeay, leader of the government in the Senate and successively Minister for Commerce and Minister for Trade and Customs.

Like Elford, many of the younger men in the Cabinet entourage chafed at being prevented from joining the armed services. Fred Shedden vetoed his assistant Sam Landau's attempt to get into uniform. Dick Randall, a Treasury research officer attached to Percy Spender, had undertaken flight training but a defect in his left eye was keeping him out of the RAAF. ${ }^{74}$ Also determined to get away was W. S. Bengtsson, secretary to the Minister for the Interior. Dick's friend Bill Bengtsson, formerly a Victorian public servant and draughtsman with militia experience, presented himself to the RAAF's No. 1 Recruiting Centre in Melbourne in June 1940. ${ }^{75}$ He was soon on his way. Garry Armstrong, briefly a

74 Sir Richard Randall, interview, 20 June 1977.

75 W. S. Bengtsson, Attestation Form, Personal File, NAA: A9300. 
colleague at The Argus, who had been assigned to Geoff Street's staff from the Department of Defence, was gone in July. Armstrong, a law graduate and CMF captain, had been despatched to the minister's office on the day he was about to be interviewed for a short service staff course at Duntroon. Street, who knew of him socially, wanted the bright young officer to take on the tasks for which the 'precise and accurate writer of minor letters', his private secretary Percy Hayter, had little aptitude. When war came Armstrong was told he could join the AIF if he produced a suitable replacement as assistant private secretary. It took nine months but he finally found Hugh Bathurst whose ability, and status as an AIF volunteer who had been medically discharged, made him acceptable to Street. ${ }^{76}$

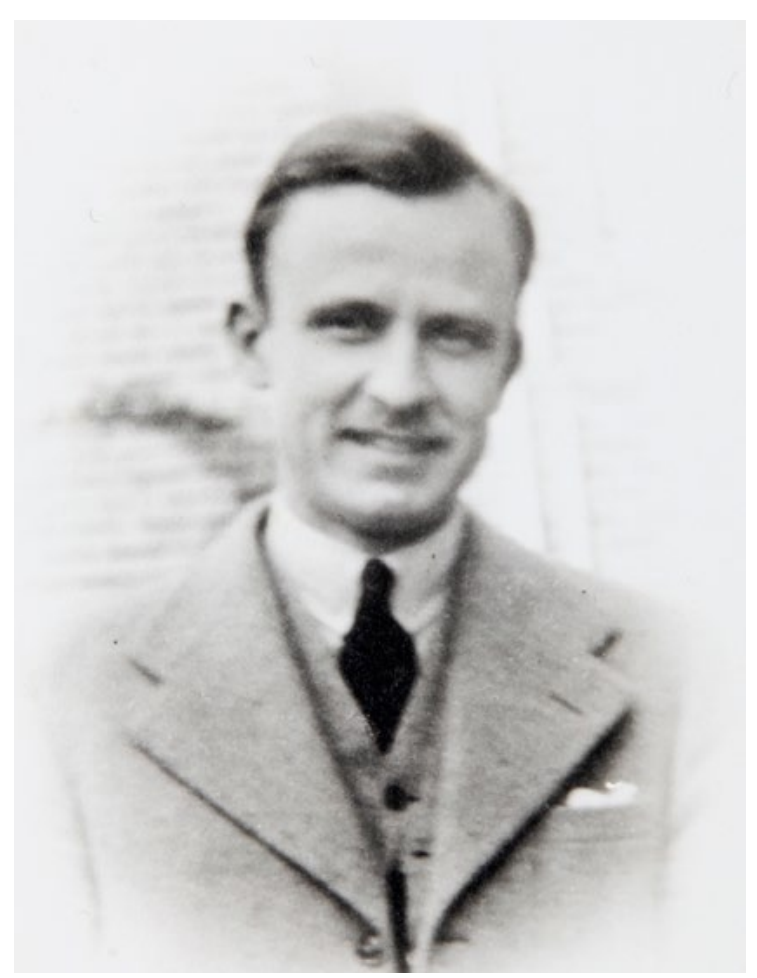

\section{Charming, but still hoping for a uniform rather than tweeds}

(Courtesy of Hugh Elford)

For Dick Elford there was no release from the Minister's staff. Where Fairbairn went, so must he. With the House of Representatives sitting in August 1940, it was once again a schedule of shuttling between Melbourne and Canberra. There were shoals of constituency correspondence to attend to, requests for autographs and souvenirs, appointments to arrange, untimely callers to meet, unwanted callers to deflect, research for speeches to be gathered, official files 
to be digested, catnaps for the Minister to be organised during late night parliamentary sittings, instructions to be transmitted to the Chief of the Air Staff and the Secretary of the Department of Air. And on Monday evening, August 12, at 8.25 p.m., just before he left Century House after a 'friendly pee' in the men's room with John Harrison of the public relations staff, a telephone call conveying another disturbing accident report to be followed up. This time it was about the disappearance of one of the new Hudson bombers, apparently crashed into the sea off the Queensland coast. ${ }^{77}$

It was less than a fortnight since news of the death of two young pilots in a training accident in the Blue Mountains had greeted the Air Minister on his arrival in Melbourne at the end of his trip around Australia. Two more airmen had been killed, one of them an instructor, when their machine crashed near the Narromine flying training school on August $8 .^{78}$ Tragic as they were, such deaths had become almost routine as the RAAF strained to produce the new generation of flyers the war demanded. However, a Hudson vanishing without trace was something Dick's chief would want to know about as soon as possible the next day. 'John,' he told Harrison, 'I'm sorry, I've done you out of a trip. I'm going with the boss tomorrow.' ${ }^{79}$

On a bleak morning, when he would rather have been in a warm bed nursing his influenza-racked body, it was therefore an early call for Dick Elford, a drive out to Essendon, and the prospect of an hour and a half in the air to be endured before work would begin again in earnest at Parliament House. 



\section{A passion for the air: James Fairbairn (I)}

James Valentine Fairbairn, grazier, politician, flyer, was a man whose adult life had been shaped by war, the Great War. Fairbairn, born in Wadhurst, England, in 1897, grew up in Victoria's Western District. His grandfather George Fairbairn, who died before he was born, was a pioneer pastoralist whose holdings in Victoria and Queensland totalled millions of acres. His father, Charles, the third of six brothers, had been joint general manager with his brother, George, of the Fairbairns' Queensland properties. At one time, as another brother, the legendary Cambridge rowing coach Steve Fairbairn, recalled, they were running 300000 sheep 'the finest big flock...in the world, but they were travelling all over Australia for food'. ${ }^{1}$ Charles Fairbairn married Elizabeth, daughter of Sir James Osborne of Yackendandah. He acquired Banongill near Skipton and moved there with his family in the year of his second son James's birth.

On his eleventh birthday Jim, or Jimmy as some of his friends called him, was despatched with 11 cakes to be a boarder at Geelong Church of England Grammar Preparatory School. In 1909 he moved to the Geelong Grammar senior school, where he had been preceded by his father, five uncles, and his older brother, Charles Osborne, known as Osborne. ${ }^{2}$ The Fairbairns were a Grammar dynasty, captains of the cricket team, senior prefects and then, spurning the fledgling Melbourne University, undergraduates at Jesus College, Cambridge. Like most of his forebears, Jim's six years at Geelong were remembered principally for his sporting achievements. He was a member of the running team, played in the tennis four, and rowed in the first eight. Scholastically, he distinguished himself in Classics, winning the prize for Greek in his final year. ${ }^{3}$

For many of Jim Fairbairn's generation, their final years of schooling were an unwelcome impediment to joining their older brothers, cousins, and uncles in the great conflict that had engulfed Europe since August 1914. Compulsory military training only added tedium to frustration. 'I looked forward with hatred to eight years without free Saturday afternoons,' the mature Fairbairn would testify. ${ }^{4}$ When he was at last free to pledge his service, the 18-year-old James V. Fairbairn sailed to England, his mind set on entering the Royal Flying Corps. Ten of his Geelong Grammar contemporaries had made the decision to enlist at Christmas 1915.

\footnotetext{
1 Steve Fairbairn, Fairbairn of Jesus, John Lane The Bodley Head, London, 1931, p.208.

2 In later life he was 'popularly known' as John (Australian Women's Weekly, 17 Aug. 1940).

3 I thank Michael D. de B. Collins Persse for material from the Geelong Grammar School archives and for a draft of his contribution, 'Fairbairn, James Valentine (1897-1940)', Bede Nairn and Geoffrey Serle (eds), Australian Dictionary of Biography, vol. 8, MUP, 1981, pp.458-9.

4 The Argus, 18 Nov. 1938.
} 


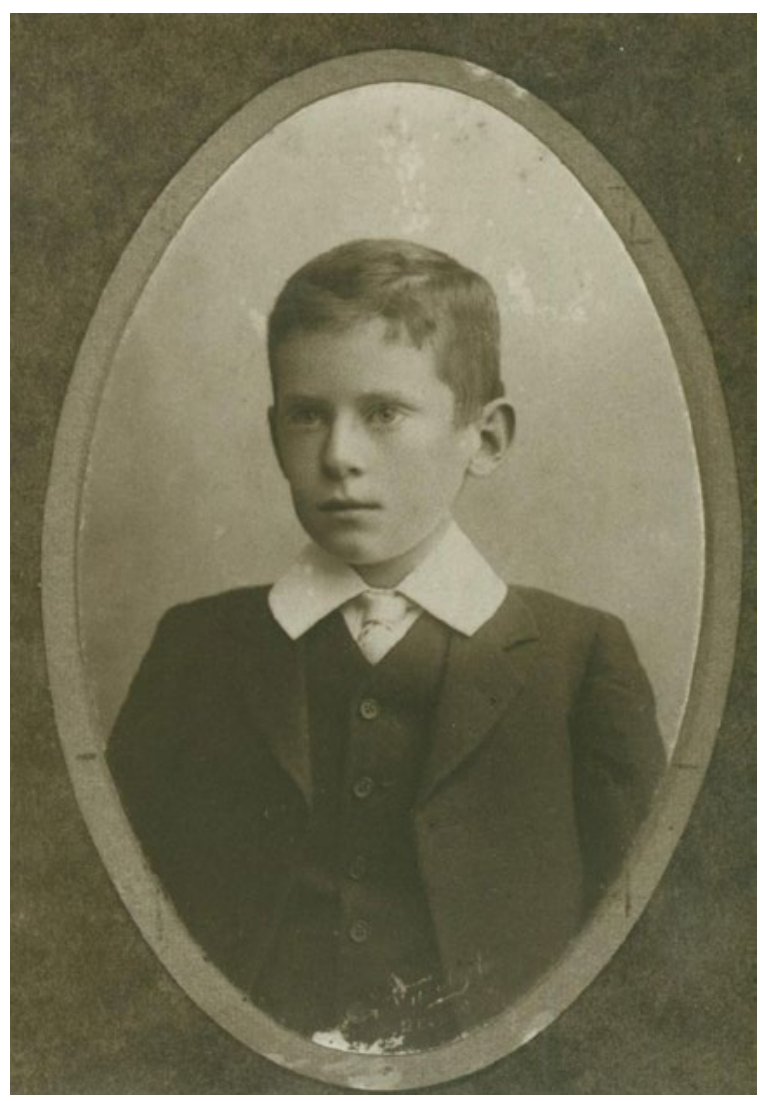

\section{The new boarder}

(Courtesy of Geelong Grammar School)

Accompanying Jim on the journey on the P \& O liner RMS Medina were his older sister Esther and her friend Inez 'Gyp' Currie from the neighbouring 'Larra' station at Derrinallum. ${ }^{5}$ The young women, too, with no professional training, were intent on finding opportunities to serve. Jim's older brother Osborne had been at Jesus College, Cambridge, when the war broke out. After a short spell in the $3^{\text {rd }}$ Battalion, Loyal North Lancashire Regiment, Osborne had transferred to the RFC. Shot down and wounded in December 1915, he was undergoing a series of operations on what was to remain a disabled left arm. ${ }^{6}$

\footnotetext{
5 The Argus, 23 Feb. 1916.

6 I. Alethea Russell, 'Fairbairn, Charles Osborne, O.B.E., A.F.C., (1893-1959)', Gordon Forth, with Jan Critchett and Peter Yule (eds), The Biographical Dictionary of the Western District of Victoria, Hyland House, South Melbourne, 1998, p.42. Charles Osborne Fairbairn was promoted to flight commander (captain) in 1916, and appointed an instructor at No. 5 School in August 1917. Acting as a major in the RAF by October 1918, he returned to Australia as a squadron leader.
} 


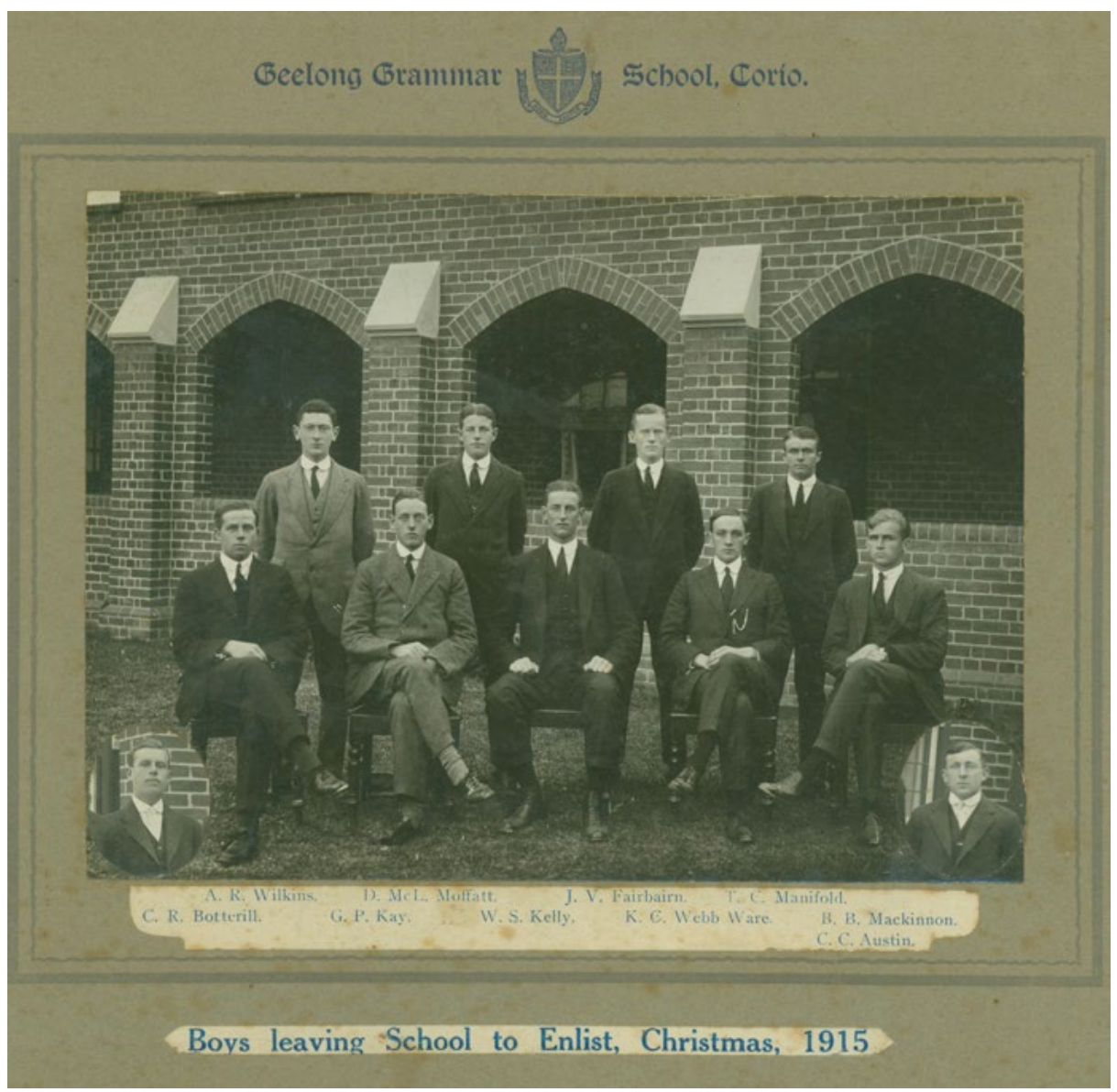

\section{Eleven Geelong Grammar boys about to enlist}

(Courtesy of Geelong Grammar School)

Admitted to officer training, Jim was sent to Scotland for flying instruction in June 1916. In letters home he told of flights from Turnhouse over the Forth, where he could soar over the navy's battle cruiser squadron, but he missed Admiral Beatty's return from the battle of Jutland because of bad weather. Moved to Stirling, he made 'nerve-racking' take-offs and landings from an aerodrome 'bounded at one end by Stirling castle on a cliff 400 feet high, at the other end by a hangar on one side of the cliff and on the other a thickly wooded hill'. The hills deflected the wind upwards, making violent air bumps that gave the trainees a 'terrible shock' at first but 'soon you hardly take any notice of them'. Hoping no doubt to reassure anxious parents, Jim reported that one of the 'most extraordinary things about flying is the way people have terrific smashes and don't get hurt': 
At Stirling I saw a man, who was up by himself for the first time, gliding down into the aerodrome at about 75 miles an hour. He was doing turns just [sic] one way then another in order to judge his distance and when he went to make his final turn into the aerodrome by some temporary lapse he banked his machine the wrong way, and still travelling at 75 and side slipping violently he crashed into the ground on one wing. The machine was entirely destroyed and when the ambulance dashed up they found him strolling around the machine, quite unhurt except for a scratch on the ear. And the first day I was here a man stalled his machine three hundred feet from the ground and dived vertically nose first. He would also have come off unhurt only he got his chin over the glass wind screen and had his throat nearly cut, but was otherwise unhurt.

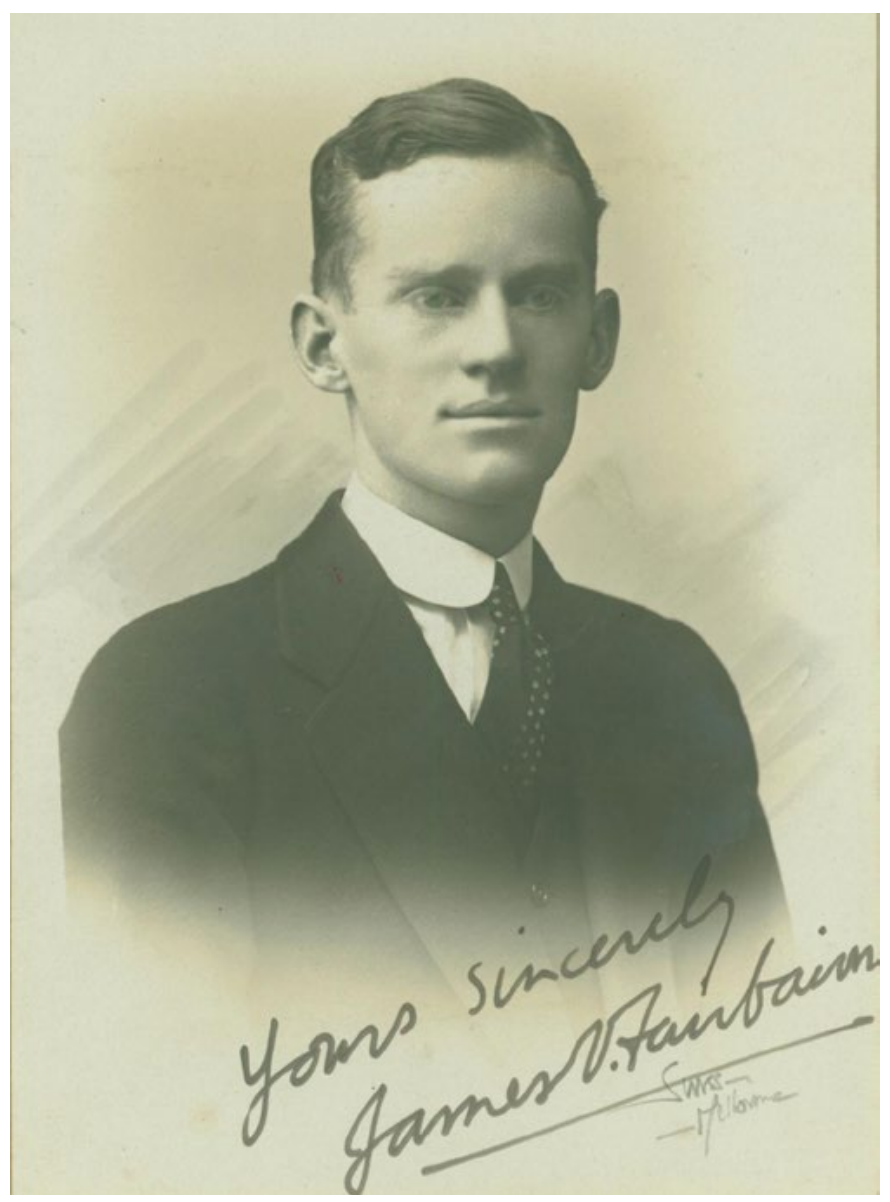

\section{A portrait before leaving Melbourne}

(Courtesy of Geelong Grammar School) 
The truth was often harsher. The word 'crash', applied to aviation accidents, had been coined in England in 1914. When Paymaster Lieutenant Lidderdale first used it to describe an accident on landing it was thought amusing. ${ }^{7}$ The humour was short-lived. As Jim Fairbairn and his wartime colleagues were to learn, heavier-than-air machines were unforgiving vehicles. While the youngsters were learning the perils of flight they were also learning the attitudes and habits of the flying elite. 'Discipline was casual,' W. E. 'Bill' Johns recalled, 'for the senior officers of the R.F.C. had not had time to grow old.' 'Flying and everything to do with it is an extravagant matter,' admitted Maurice Baring who served at RFC headquarters throughout the war. As Baring elaborated: 'The pilot is extravagant, the squadron is extravagant, even the Equipment Officer, even the Technical Sergeant-Major was sometimes found to be extravagant.' But extraordinary efforts were made to curb 'useless' extravagance: 'even superfluous magneto boxes and an unnecessary indent for lorry cushions were noted'. ${ }^{9}$ To the extravagance few denied, Baring might have added exhibitionism, more sympathetically described perhaps as an understandable youthful propensity for high jinks. Fairbairn was quick to report his impressions of the revelry that was to become more frenetic in the evening intervals between rehearsals for confrontation with the enemy:

The Flying Corps is very unpopular in a great number of Scotch [sic] towns, because they always try to wake up the inhabitants a bit. At Montrose the Mayor was continually complaining about the way the R.F.C. officers drove their cars and motor bikes about the town. The O.C. was so annoyed that he threatened to fly an aeroplane through the town, and when there was another complaint he went up in a small Bristol Scout and flew it right down the main street below the level of the house tops. After that they decided that it was preferable to have cars scorching through the town than an aeroplane.

After only a week in Stirling, Fairbairn was moved again, this time further south to Croydon. Taking advantage of the long summer evening twilight, flying practice continued until 9.30 p.m. when weather permitted. Happily the base was close enough to London for occasional late-night or Sunday afternoon recreational sorties. Expecting to get his wings in about three weeks or a month, Fairbairn wrote on 29 June 1916 of his latest exploits. 'A few days ago I was taken up by my flight commander to do "stunts." It... showed me that you can do whatever you like provided you are high enough and the machine will recover itself.' For the benefit of earthbound Geelong Grammar boys he explained:

7 Hector Bolitho, War in the Strand: A Notebook of the First Two and a Half Years in London, Eyre and Spottiswoode, 1942, p.3.

8 Capt. W. E. Johns, Biggles of the Camel Squadron, Dean \& Son, [1961, 1st ed. 1934], p.7. Johns actually left the post-war RAF as a flying officer.

9 Maurice Baring, Flying Corps Headquarters 1914-1918, William Heinemann, 1920, p.192. 
First he climbed up to 400 feet and then stalled the machine a few times. To stall a machine is to lose flying speed so that the machine is no longer under control and dives at the ground for a few hundred feet till flying speed is regained and then it flattens out. When intentionally stalling... you pull the control back till the nose is pointing straight up in the air, then it slowly stops and falls backwards and suddenly nose dives. We did this several times and then tried to loop the loop, but he did not get up sufficient speed and when we got upside down there was not enough pace to take us right over, and we began to fall upside down for nearly a thousand feet, till the machine slowly turned over sideways and righted itself.

Wasn't this dangerous? Should friends and family be worried? 'It was a rather horrible sensation while it lasted,' he admitted, 'especially as I had no safety belt and had to hold on for all I was worth. Of course,' he hastened to add, 'if you loop properly you could not fall out if you tried with all your strength, as the centrifugal force is very great and forces you down into your seat.' He was perhaps unaware of the fate of several pilots whose seat belts had failed to take the strain. He would certainly have known that parachutes were only issued to the crews of airships and balloons.

Loops, stalls, landings, and take-offs mastered; instruction received in photography, gunnery, aerial observation, and bomb dropping; Jim Fairbairn emerged with his commission as a flying officer in the $17^{\text {th }}$ Reserve Squadron in July 1916. At various flying schools around the country, there had been 178 officers and 15 men in training at the beginning of June. Three months later there were 909 officers and 54 men needing instruction. ${ }^{10}$ This vast and rapid expansion meant that many just-qualified pilots almost immediately became instructors. So, for two weeks after he graduated, Jim stayed at Croydon as an instructor with No. 43 Squadron, one of 'a bunch of raw pilots' as their CO, Major Sholto Douglas, described them, who would endeavour to escape to London each night at 19.00 and return for duty at 09.00 the next morning. ${ }^{11}$ Then it was to Netheravon in Wiltshire to practise on Bristol Scouts while 54 Squadron waited to take out 'Sopwith fighting machines' to France.

10 Statistics of the Military Effort of the British Empire During the Great War 1914-20, The War Office, 1922, p.497.

11 Sholto Douglas, Years of Combat, Quality Book Club, London, 1963, p.134. 


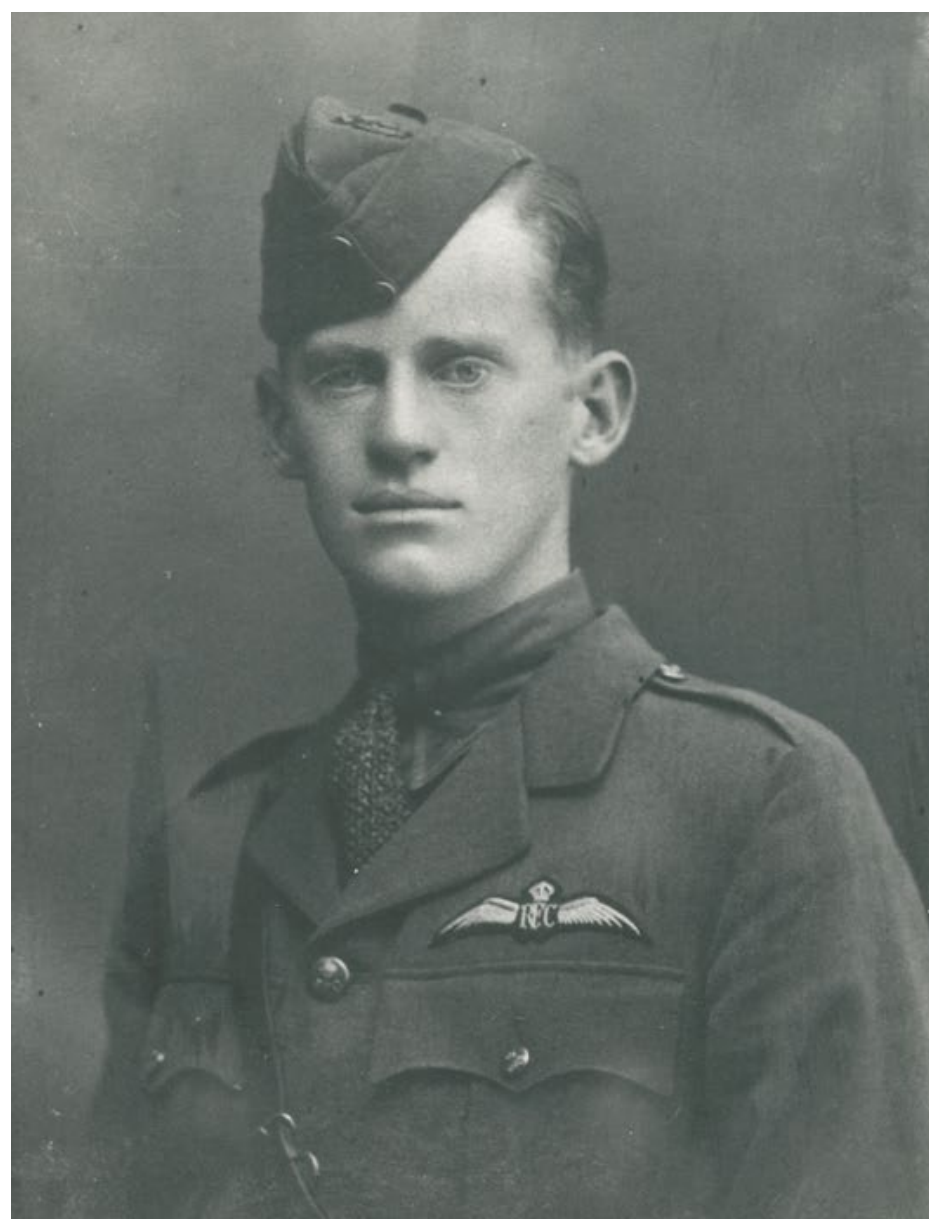

\section{Flying Officer Fairbairn RFC}

(Courtesy of Angela Mercer)

Netheravon, as another young Australian trainee flyer reported six months later, 'is situated in a most drearisome place on Salisbury Plain, miles from any town...However it is an ideal place for an aerodrome with plenty of good fields for landing.' ${ }^{12}$ Jim proudly explained that the new Sopwiths, highly manoeuvrable at great heights, were 'about the best machines that we have, only one squadron of them has gone out before, and they did marvels, and strafed every Hun machine that they met'. Arthur Gould Lee, who had to wait three months after getting his wings before being allowed into the cockpit of a Pup in April 1917, was to describe it as 'a dream to fly, so light on the control,

12 R. W. Howard to 'Father', 20 Feb. 1917, 'The Personal Letters of Captain R. W. Howard. MC, Australian Flying Corps, Part One', The '14-'18 Journal, 1997, Australian Society of World War 1 Aero Historians, p.69. 
so effortless to handle, so sweet and amenable, and so eagerly manoeuvrable that you found yourself doing every kind of stunt without a thought - loops, sideslip landings, tail slides, rolls, spins' ${ }^{13}$

In London, Fairbairn had seen old boys from Geelong Grammar, some of them resting or recuperating from wounds. A star among them, Alex Russell Osborne Fairbairn's friend, and four years Jim's senior, a prefect, captain of the $1^{\text {st }}$ XI, member of the $1^{\text {st }}$ XVIII football team and the shooting team - his Cambridge engineering studies abandoned, was now an artillery lieutenant. He was recovering after being buried by a shell burst. Russell, soon to be engaged and married to Fairbairn's cousin Jess, elder daughter of Frederick W. Fairbairn, had been 14 months at the front. By the end of the war he would be Major Russell MC. John Webster, a younger and close companion from schooldays, recently awarded the Military Cross, 'was very badly knocked about and has nearly 70 scars on his body'. On Salisbury Plain, Australians were everywhere, including 'Chettie' Manifold (a lieutenant in the Royal Field Artillery), Les Chomley on the staff of 'General' (temporary Brigadier-General commanding the $3^{\text {rd }}$ Division Artillery) Harold Grimwade, and others from Geelong. The lucky ones were taken up for a short flight; all were treated to an exhibition of loops each day over the Larkhill camp.

Fairbairn's squadron had been told they were to be 'used exclusively for fighting and long reconnaissances'. Writing on 26 September 1916 he could scarcely contain his joy that they were not to be required for bombing or artillery spotting: 'Fighting is much the best fun in France especially on a really good machine.' Such was the 'fun' that in the previous week 20 RFC aircraft had been lost. The German ace Oswald Boelcke had been responsible for one of them; and a new pilot, Lieutenant Manfred Freiherr von Richthofen, for a second. The British press was more interested in the latest four combat victories of Captain Albert Ball DSO MC. But those who understood the growing German dominance of the air were increasingly alarmed. On September 30, Major General Hugh Trenchard, GOC of the Flying Corps, wrote to the Chief of the Imperial General Staff, Sir William Robertson, at the War Office urging the accelerated supply of fighters capable of competing with the best German machines. British losses in the air were unsustainable. At the beginning of July 1916 there had been 426 pilots available for duty. By November 17 there were 585 with their squadrons. In the meantime, 308 had been killed, wounded or were missing, and another 268 had been removed from active duty from other causes. In the same period, 191 observers had been lost. ${ }^{14}$ These were not statistics to be shared with the young men on their way to the front.

13 Arthur Gould Lee, Open Cockpit: A Pilot of the Royal Flying Corps, Jarrolds, 1969, p.24.

14 Hilary St, George Saunders, Per Ardua: The Rise of British Air Power 1911-1939, Oxford UP, 1944, pp.212-13. 


\section{Real stunts}

It was not until Christmas Day 1916 that Fairbairn's No. 54 Squadron, with their 18 Sopwith Scouts, arrived in France. Until then the only squadron equipped with the Pups, as they were called unofficially, was No. 8 Royal Naval Air Service, whose B Flight was commanded by the Australian ace, Flight Lieutenant S. J. Goble. Naval Eight, as it was known, had become operational on November 3. The RFC had one squadron of Nieuport 17s for its fighter pilots, Frenchdesigned, proven, and popular. 'A little daisy of a machine,' the Canadian Billy Bishop called it, 'with all the daintiness of a Parisienne.' ${ }^{15}$ The rest were condemned to go up day after day in obsolescent two-seater pusher DH 2 s and FE 8s. Fairbairn was lucky. He had filled in the last two months assisting in the air defence of London. Scores of other freshly qualified pilots had been sent to France with an average of about 17 hours of solo flight. He had more time to gain knowledge and confidence in a safe environment, to learn a little about formation flying, so crucial for survival against superior German forces.

Flying a Pup, 'smooth and stable, mellow like old wine', as a contemporary fighter pilot described them, Fairbairn imbibed the new trade of aerial reconnaissance and combat over the next six weeks. Under Major K. K. Horn MC, No. 54 Squadron began operations on January 11. Before coming out to France Fairbairn had learned of how a novice pilot had shot down the German ace, Immelman. 'It shows that there is a considerable element of luck in air fighting.' ${ }^{16}$ And, as his squadron motto said, 'Audax omnia perpeti' (Boldness to endure anything). If luck was with him at first, on 14 February 1917 his fortune changed. Perhaps by now he realised as Alec Little, another Australian with Naval 8, reported on December 30, the deficiencies of the outclassed Pup on escort duty: relatively poor manoeuvring powers and a slow-firing gun, in particular. ${ }^{17}$

Ten scouts of No. 54 Squadron were assigned to escort 10 planes of the reconnaissance squadron that shared their aerodrome. They were charged with taking photographs of the sector between Cambrai and St. Quentin, some 20 miles across the lines. With his $80 \mathrm{hp}$ Rhone engine failing as they reached the target, Fairbairn was forced to break off from the formation and head back to the lines. Swarmed over by a superior force of 'Hun scouts', he and several of his friends did not make it back. His own machine shredded by the German guns and barely controllable, and with one arm shattered, Fairbairn was eventually brought down. After some months of suspense following reports that he was

15 William A. 'Billy' Bishop V. C., Winged Peace: The Story of the Air Age, McGraw-Hill Ryerson, Montreal, 1990 (1st ed. Macmillan 1944), p.37.

16 'J. V. F.' , 20 June 1916, The Corian, Aug. 1916, pp.55-6.

17 Mike Rosel, Unknown Warrior: The search for Australia's greatest Ace, Arcadia, North Melbourne, 2012, pp.50-5. 
missing in action, relieved family and friends heard that he was a prisoner of war. Informed only that he had a broken leg, they were unaware of the extent of his injuries. ${ }^{18}$

The downed pilot's dramatic narrative account of his experience, written from internment in June, revealed how lucky he was to survive. Noticing that his engine was spluttering and dropping revs, he had signalled to his flight commander that he could not continue and must turn for home:

Then the fun began. Immediately the Huns started to dive on my tail and flanks from all directions. I held straight on till they got to close range and opened fire; at once I turned and attacked the nearest machine which dived vertically, then began to spin and was still spinning when I lost sight of it.

Fairbairn turned and fought five or six times and then, a mile from home, at 2000 feet, he tried to turn and fire at the last four of his pursuers but the machine did not respond:

I looked to see what had happened, and noticed that my hand had fallen off the control stick whereupon I concluded that I was wounded, so took the stick in my left hand. Then I did an Immelmann turn, but when I tried to get my machine off the bank I found that my lateral control was broken and there was no means of getting the bus level again.

Forced to descend in a vertical spiral, he crashed as gently as he could, turned a catherine wheel on the ground, and came to rest, 'my nose sticking into the ground and my tail in the air'.

Some Huns came running up from every direction, swords drawn and bayonets fixed as though they had half the British Army to deal with. I tried to get my revolver out but found I could not reach it with my left hand, so I decided there was nothing to be done but burn my machine and 'wait and see', so I threw a match into a pool of petrol that was dripping from my engine and tried to clamber out, but found to my consternation that I could not get my belt undone, as it was clasped under my left armpit and could only be got at with the right hand, which was not taking much interest in life at the moment. However a

18 J. V. Fairbairn, Royal Air Force Casualty Cards, RAF Museum, courtesy Peter Elliott; International Committee of the Red Cross Archives record: James V. Fairbairn, 2nd Lt, Royal Flying Corps, captured in Péronne 14 Feb. 1917; wounded. Present in Reslz. [Reserve Lazarett] Hann[oversch] Münden, coming from Krgslz [Kriegslazarett $=$ War Dept Hospital] I Western (list dated 9 May 1917). Interned military (no place indicated). Arrived on 14 April 1918, coming from Hanover (list dated 7 May 1918); Trevor Henshaw, The Sky Their Battlefield: Air Fighting and the Complete List of Allied Air Casualties from Enemy Action in the First War, Grub Street, 1995, p.137 describes Fairbairn as the first Sopwith Pup pilot lost in action by the RFC and notes the claim of Lt George Schlenker of Jasta 3 to this, the second of his 14 victories. 
Hun cut my belt with his clasp knife, and hauled me out of the fire, but not until I had given a very life-like imitation of Guy Fawkes for the space of about a minute.

Press reports in later years echoed the Commonwealth Parliamentary Handbook in saying that Jim Fairbairn had been 'Credited in official communiques with destroying two hostile aircraft. ${ }^{19}$ He said that he had seen one enemy plane go down; and a German flieger officer, congratulating him on the fight he had put up, told him that two of the 10 pilots who attacked him had been killed. These stories were not denied but there was no confirmation in official records. ${ }^{20}$ What was undoubtedly true was that badly wounded, scorched, but alive, Jim Fairbairn had beaten the odds. If a new pilot in France had survived incompetent teaching, poorly constructed training aircraft, and foolhardy stunting over his base, he had an 80 per cent chance of becoming a casualty before he flew 20 missions. Rationalising the loss of lives in 'stunting' during training earlier in the war, the commander of the British Air Mission in Washington told an Academy of Sciences audience a year after Fairbairn was shot down that the danger was not in stunting but in not being able to stunt: 'The man who is going to come out alive is the one who can outdo his opponent in flying...unless you are trained to do real stunts (which are really not at all dangerous), you are not going to be able to down him. ${ }^{21}$

In fact, though it was not known precisely at the time, about seven in 10 of the casualties among first-year pilots were victims of their own errors rather than the combat skill of the enemy. ${ }^{22}$ As P. G. Taylor recalled: 'It was said... that any pilot who destroyed more German aircraft than British had justified his existence. This did not always happen. A friend of mine in the RFC crashed five British aircraft, and was therefore said to be a German ace!'23 Of the youthful survivors, the Australian war records historian Harry Gullett was to write to his

19 Parliamentary Handbook and Record of Elections for the Commonwealth of Australia, Ninth Issue, 1931 to 1938, Canberra 1938, p.74.

20 Sydney Morning Herald, 25 April 1939, The Argus, 13 Oct. 1939, 19 Feb. 1941; John D. R. Rawlings, Fighter Squadrons of the R.A.F. and their aircraft, Macdonald and Janes, revised ed., 1976, p.132 says 54 Squadron's 'first victory' went to Captain W. V. Strugnell in April 1917. According to Norman Franks (Sopwith Pup Aces of World War 1, Osprey Publishing, Oxford, 2005, pp.15-6), the Squadron claimed at least three victories by the end of January.

21 C. F. Lee, 'Aviation and the War', Journal of the Washington Academy of Sciences, vol. VIII, no. 8, 19 April 1918, pp.225-6.

22 For the RFC I have drawn principally on Christopher Cole (ed.), Royal Flying Corps 1915-1916, William Kimber, 1969; Denis Winter, The First of the Few: Fighter Pilots of the First World War, Allen Lane, 1982; Peter H. Liddle, The Airman's War 1914-18, Blandford Press, Poole, 1987; John H. Morrow, The Great War in the Air: Military Aviation from 1909 to 1921, Smithsonian Institution Press, Washington, 1993; S. F. Wise, Canadian Airmen and the First World War: The Official History of the Royal Canadian Air Force, vol. I, University of Toronto Press, 1981; and Richard Townshend Bickers, The First Great Air War, Hodder \& Stoughton, 1988. E. R. Hooton's important study, War over the Trenches: Air Power and Western Front Campaigns 1916-1918, Midland, Hersham, Surrey, 2010, did not come to hand until after this book was published.

23 John Hetherington, Uncommon Men, F. W. Cheshire, Melbourne, 1965, p.180. 
wife a few months later: 'it is hard to believe such schoolboys can be captains with wonderful records'.$^{24}$ It was true that, before appalling attrition rates led to selection of many from the 'lower middle classes and some from the artisan class', most pilots were likely to have been previously 'the public schoolboy, the cavalry officer, or the athlete'. Whatever their background, by their own testimony 'it appears necessary for the well-being of the average pilot that he should indulge in a really riotous evening at least once or twice a month' ${ }^{25}$

For Jim Fairbairn, public schoolboy, horseman, and athlete, fortnightly indulgences came to an abrupt halt. His fate is best told in his own words, writing from an officers' prison in Germany on 3 March 1917:

When I was at the French town where I was kept for three days after coming down, I met some of the officers who had claimed to have brought me down. They were very nice, and obviously gentlemen and sportsmen, and laughed heartily when I told them that it was my engine that brought me down really though I could have glided home if I had not had to turn and drive them away every few yards...

Some German stretcher-bearers took me to a neighbouring dressing station. The worst part of the whole show was being shelled by our own guns; one of the bearers was hit but they behaved splendidly.

Taken to Germany in an evil-smelling 'hospital train', accompanied by Russian prisoners wounded by British shelling while digging trenches for the Germans, the young flyer got his 'first glimpse of the true German spirit':

Whenever I wanted anything the Huns simply tumbled over themselves to do it; when the Russians asked anything they were answered as though they were dogs, German dogs, of course, as no civilised person could ever speak or act to a dog as the Huns did to these poor helpless prisoners.

The journey took two days and nights:

If it had lasted much longer I believe I would have gone quite mad. The Russians, on the other hand, although very badly wounded, considered themselves in clover, being able to lie and rest for once, the first real rest for three years, even if it was in a bumpy goods van. ${ }^{26}$

24 Gullett to Penelope Gullett, [n.d. ? Aug. 1917], Gullett MSS, NLA MS 3078/5/319.

25 'The Temperament of Aviators', Flight, vol. 10, 3 Oct. 1918, pp.1117-8 being extracts from Capt. T. S. Rippon and Lieut. E. G. Manuel, 'The Essential Characteristics of Successful and Unsuccessful Aviators, with Special Reference to Temperament', The Lancet, 28 Sept. 1918.

26 'J. V. F.', 28 June 1918, Letters from the War', The Corian, Dec. 1918, pp.86-92. 
A prisoner of war in Holland and then a convalescent in neutral Switzerland for a total of 14 months, Fairbairn carried with him thereafter a permanent reminder of his war service in a burnt face and a crippled right arm, shattered at the elbow by a bullet from a German Spandau. Doctors in the prison hospital had been reluctant to operate as the broken bones set slowly and grew together, and fragments of bone were expelled from the dressed wounds. Captivity was a time of boredom punctuated by pain. There was some relief in the company of a French priest, the only other prisoner who could walk. 'In apologising to the Frenchman for not understanding his language better I said "At school I spent so much time learning Latin and Greek languages that I rather neglected French."' The priest promptly offered to speak Latin instead but the embarrassed young flyer had the presence of mind to say that he would prefer to practise his French. ${ }^{27}$ Fairbairn was eventually exchanged for a wounded German airman, and entered the Prince of Wales Hospital in Marylebone in April 1918.

By war's end, 417 Geelong Grammarians had enlisted; 87 did not return. ${ }^{28}$ For many of the survivors like Jim Fairbairn, in London after the Armistice and back home in Australia, there was to be recurring medical treatment. Jim Fairbairn would submit in all to 20 operations. Now the recipient of a small RAF war pension, he sailed home on the P \& O's Orvieto, converted from its wartime mine-laying and armed merchant-cruiser roles. He arrived in Melbourne in December 1919. Though he may not have been aware of it, Fairbairn's return to Australia was in the same vessel on which the AIF's first 91 officers and 1347 men had left Sydney in 1914, including the chief of staff, Lieutenant Colonel C. B. B. White, Major J. Gellibrand, Lieutenant R. G. Casey, and the official correspondent, C. E. W. Bean. ${ }^{29}$

Chettie Manifold, a lifelong friend and neighbour, recalled:

After the War he spent several years in the hands of doctors in an endeavour to regain the use of his right arm without success. This wound greatly restricted his activities in after life. He was a keen tennis \& squash player \& learnt to play left handed. As a result of a circular saw accident he lost two fingers on his left hand. He then through sheer determination learnt to play right handed with considerable success.

In fact, as Fairbairn's niece Alethea Russell remembered, after losing one finger in the circular saw incident, her uncle accidentally discharged a gun while he

27 'J. V. F.', 29 July 1917, 'Letters from the War', The Corian, Dec. 1917, pp.82-3.

28 I. V. Hansen, Nor Secular Nor Free: Six independent schools in Victoria: a first sample, Oxford UP, Melbourne, 1971, p.49.

29 For details of the wartime service of the P \& O ship Orvieto, see http://petermanchester.me.uk/index. php?page=rmsorvietol and post-war history in http://flotilla-australia.com/hmat.htm (accessed l Oct. 2011). 
had a finger in the barrel. Thus, having taught himself to play tennis left-handed after the war, he had to learn to throw up the ball with his right hand and revert to playing right-handed..$^{30}$

Keen-eyed readers of The Herald on 15 February 1940 would have noticed in a photograph that the third finger of the Air Minister's left hand was severed at the knuckle, and the ring finger was completely absent. In spite of these afflictions 'you would have to watch him pretty carefully to realise that he had quite a disability in one of his arms', George Jones remembered as a senior RAAF advisor to the minister. 'It wasn't very conspicuous. ${ }^{31}$ As John Manifold, Fairbairn's colleague on the Geelong Grammar School Council, testified: 'Disability that would have handicapped most men, he simply disregarded.'32

What was conspicuous if you visited Fairbairn at Mount Elephant, the onetime Chirnside and Currie property near Derrinallum he acquired in 1924, were the pictorial reminders of aerial warfare and post-war aviation development - cartoons on the wall, and magazines in the billiard room. Jim Fairbairn's own airstrip and private plane, 176 kilometres west of Melbourne, completed the picture of a dedicated aviator. On his desk, a decade after the war ended, there were photographs of two men. John Webster, his school friend, killed in Palestine, had run out of money while on leave in 1918, and returned to active service when multiple wounds should have kept him at home. Close by was Charles Hawker, another Geelong Old Grammarian, the great friend of his later years in Parliament, grievously wounded, crippled, disfigured, and enduring never-ending pain. Hawker's death in an aircraft accident in 1938 would stun Jim Fairbairn and the many colleagues who had looked to him as the man who should lead the United Australia Party when the Prime Minister, Joe Lyons, eventually retired. ${ }^{33}$

Fairbairn, flanked by Chettie Manifold, had married Daisy Olive 'Peggy' Forrester, daughter of Charles and Alice Forrester of Toorak, in March 1923. It was, said The Argus, 'a wedding that attracted wide interest'. The bride's father was an estate and commission agent, and a stalwart of the Australian Club; she had two surviving brothers, one of whom, Charles Lamont Forrester, was to set up in the city as an auctioneer a few years later. ${ }^{34}$ Among Peggy's bridesmaids was Jim's younger sister, Betty Fairbairn. During the previous Easter, Jim and Betty had reached the semi-finals of the mixed doubles at the Geelong Lawn Tennis Club's Annual Tournament. Had they won they would have met Miss Forrester and her partner in the final. By November, Jim Fairbairn and

\footnotetext{
30 Sir Chester Manifold to CH, [1976]; Alethea Russell to CH, (email), 20 Jan. 2009.

31 AM Sir George Jones, interview, 14 Sept. 1977.

32 'The Acting Chairman's (Mr. John Manifold) Address, Speech Day 1940', The Corian, Dec. 1940, p.214.

33 Geoffrey Fairbairn, interview, 10 Oct. 1978; Fairbairn, 'Personal History', p.10.

34 The Argus, 28 June 1935 (Charles Forrester obituary).
} 
Peggy Forrester were paired in the mixed doubles handicap at the Victorian championship. With the new partnership confirmed for life at St John's Church, Toorak, two children, Geoffrey and Angela, quickly followed.

Jim Fairbairn and Peg (as her husband and close friends called her) embraced the opportunities their privileged life offered. They thrived in the company of the younger generation. Jim enjoyed taking Peter and John Mercer, sons of a neighbour, on flights to Melbourne, returning with a copy of The Herald 4.00 p.m. edition for the boys' father. When there were no youngsters to disembark, he would drop the folded paper from the air, usually managing to avoid the big dam just outside the garden fence. ${ }^{35}$ On weekends and school holidays there was a parade of family visitors at Mount Elephant.

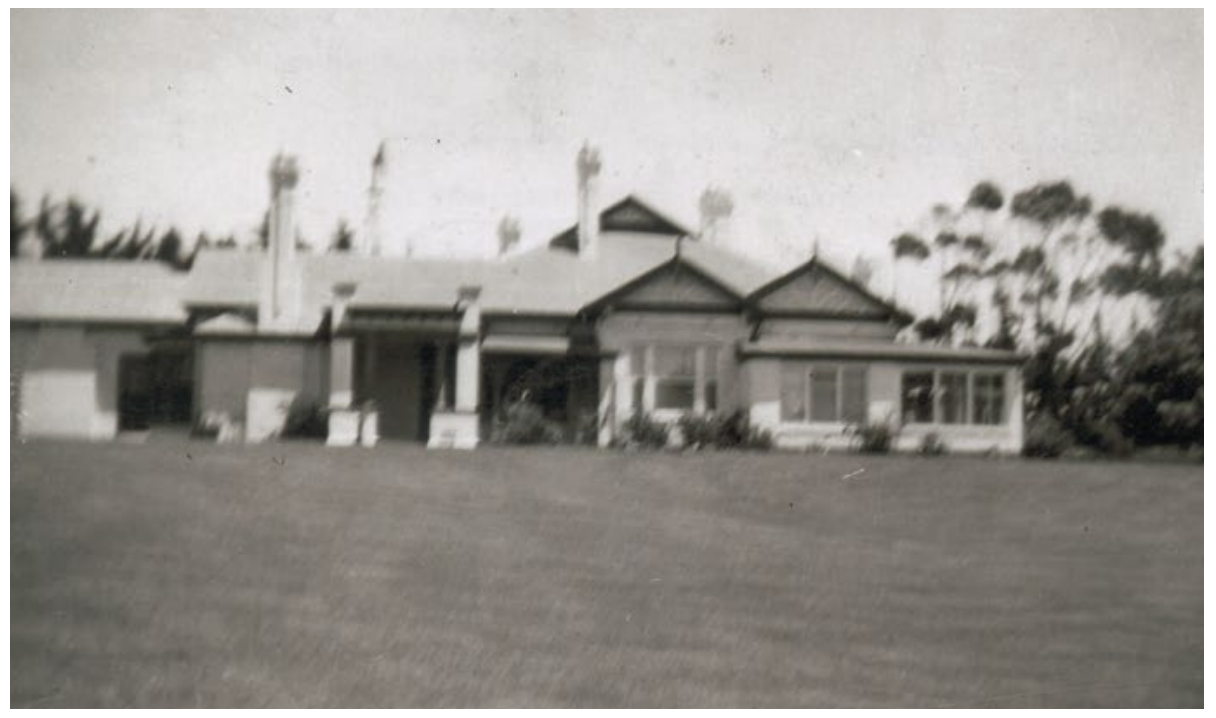

\section{Mount Elephant estate homestead}

(Courtesy of Fay Stokie-Ryan and Virginia 'Bardie' Mercer)

It was a fine homestead on the banks of Lake Logan, known throughout the Western District as the 'swagman's lighthouse'. ${ }^{36}$ To Gillian Gubbins, Peggy Fairbairn's niece, there was an unforgettable aura about that 'elegant, spacious home...Geoffrey and Angela having their own quarters, surrounded by a magnificent well-manicured garden, two tennis courts (one grass, one hard court), a squash court (quite rare in the 1930s), a lake complete with boat and fishing gear'. For Geoffrey there were memorable older visitors: 
...a hairy and beloved uncle who had landed at Gallipoli; another, equally loved, who had been decorated for rescuing a man who fell overboard from a Dover-Calais troop transport; yet another who had won the A.F.C. for restoring the depleted morale of his air squadron by stunting in the face of the enemy... ${ }^{37}$

Successful on the land, Jim had run the family's Peak Downs station in central Queensland for five years before buying Mount Elephant for himself. He was a progressive farmer, one of the first, his daughter said, to have Southdown rams cover Corriedales. He represented his district in the Graziers' Association of Victoria. ${ }^{38}$ Raised as a Presbyterian, he became active in Anglican diocesan affairs, and in the Old Geelong Grammarians Association and School Council. He had dipped his toe in local politics late in 1924, losing by 288 votes to 171 to his friend and neighbour Geoff Street in an extraordinary election for a vacancy in the North Riding of the Shire of Hampden. But it was an invitation to attend a private meeting at the recently launched Constitutional Club in Melbourne on 29 April 1926 that was to transform his life. It was a remarkable gathering. His friend Alex Russell was there, now both a national golf champion and budding course designer, and lately companion and private secretary to the Prime Minister, Stanley Bruce. ${ }^{39}$ So also were two of the Manifolds (a third sent apologies); Fairbairn's cousin George; the young city commercial lawyer Trevor Oldham; Lionel Grimwade of the Melbourne pharmaceutical and chemicals family, a former Royal Navy and Royal Australian Navy officer and now a stockbroker with William Noall \& Sons; Harold Oscar Nevett, a Camperdown solicitor and friend of the Manifolds and Geoff Street; Billy Kent Hughes, gallant Light Horseman and Olympic athlete; and the man who organised the meeting, Keith Officer. Among those who sent apologies were Geoff Street and Alex Russell's cousin Max Bell, of Golf Hill, chairman of the pastoral company Dennys Lascelles and a council member and benefactor of Geelong Grammar. ${ }^{40}$

What had brought these young men together? Keith Officer, from the Western District and Melbourne Grammar, trained as a lawyer, a decorated AIF staff officer, had returned to Australia in 1924 after three years in Nigeria with the British Colonial Service and an interval in London. He was ostensibly working

37 Gillian Gubbins to CH, 8 Feb. 2009; Geoffrey Fairbairn, 'Personal History', Nation, No. 150, 8 Aug. 1964, p.10.

38 Angela Mercer, interview, 8 Nov. 1978; J. O Randell, Teamwork: A History of the Graziers' Associations of Victoria and Riverina, (1983?), p.63.

39 William I. Whitton, 'Russell, Alex (1892-1961)', Ritchie and Langmore (eds), Australian Dictionary of Biography, vol. 16, pp.151-2; Tony Hirst and Neil Crafter, 'Great Australian Golf Course Architects: Alex Russell (1892-1961)', Golf Architecture: The Journal of the Society of Australian Golf Course Architects, Issue 6, 2003, pp.20-8.

40 I am grateful to Veronica Filmer, Registrar, Geelong Gallery, for information about Max Bell. Diane Langmore, 'Biddlecombe, Janet (1866-1954)', Ritchie and Cunneen (eds), Australian Dictionary of Biography, vol. 13, p.179, records the Bell family's financing of a music school at Geelong Grammar in association with Janet Biddlecombe (née Russell). 
in his father's accountancy firm but had begun the clandestine development of an integrated conservative organisation to compete more effectively against the Australian Labor Party. Officer and his associates, including the ambitious young barrister Robert Gordon Menzies, were creating a political action movement. Nationalist fortunes in Victoria were at a low ebb with a Country Party government in power. Officer saw the need both to revive the Nationalists' urban appeal and to reconnect the party to rural voters. ${ }^{41}$ Their evolving plan was to diminish control of party finances by the recently unmasked National Union powerbrokers, infiltrate party branches, nominate candidates, and eventually install a new party leader. Fairbairn, present at the creation, was to be an active participant in the unfolding of the strategy that led to the creation of the Young Nationalist Movement three years later with Menzies soon at its head. Fairbairn's own Hampden district was the first with its own finance committee. ${ }^{42}$ He himself with Chester Manifold (now married to Gwenda Grimwade, his old CO's daughter), assisted by H. O. Nevett, was soon drawn into local government as a member of Hampden Shire Council along with Geoff Street. ${ }^{43}$ With Trevor Oldham, Manifold, and Bob Menzies, Jim was elected to the executive of the Young Nationalists, Menzies becoming president in February 1931. The 'fighting platform' of the organisation declared that the 'restoration' of government finance through balanced budgets was the key to a return to national prosperity.

In May 1932 Jim Fairbairn became Member of the Legislative Assembly for Warrnambool. For some two years as an endorsed Nationalist he had cultivated the former Country Party seat now held by Henry Bailey, Minister for Lands in the Hogan Labor government, but standing as a Premier's Plan candidate. Proclaiming his faith in free enterprise, and supported by the Australian Women's National League as well as the National Federation, Fairbairn said his principal aim in standing was to defend the interests of primary producers. Harry Gullett's friend Colonel George Langley, headmaster of the local high school, acted as his campaign manager. Fairbairn would lend Langley his Buick from time to time to assist the campaign as well as making it possible for Langley to enjoy occasional family outings. Robert Menzies came down to speak for the candidate at a well-attended Town Hall meeting in the week before the election. The friendly Camperdown Chronicle and Terang Express had previously

\footnotetext{
41 Leslie Gordon Lomax, 'The Western District Farmer, 1914-1927', PhD thesis, Monash University, 1979, vol. 2, provides valuable background on post-war Western District politics.

42 Keith Officer's hitherto unnoticed role in organising a Nationalist revival in Victoria in the 1920s is described in Alan Fewster, Trusty and Well Beloved: A Life of Keith Officer Australia's First Diplomat, Miegunyah Press, Melbourne, 2009, pp.90-102, 107-8. For details of H. O. Nevett's professional and political interests I am grateful to his son, Guy Nevett (telephone interview, 2 Aug. 2007). Phylia Keble-Johnston kindly provided information about her father, Lionel Grimwade (telephone interview, 4 Dec. 2007).

43 Manifold, Street, and Fairbairn look thoughtfully into the camera in a 1930 council photograph (R. A. McAlpine, The Shire of Hampden 1863-1963, Terang Express, 1963, p.20). The photograph has now been lost.
} 
lauded 'Three Virile Politicians' - Menzies, Manifold, and Fairbairn — but the blatant bias of the Warrnambool Standard probably did more to contribute to a resounding victory over the 'effete generation' ${ }^{44}$ The next year Fairbairn retired from the Hampden council on the expiration of his term. His sights were set higher.

After only 17 months in the Victorian Parliament with Chettie Manifold, Billy Kent Hughes, and Bob Menzies, Fairbairn resigned to contest a by-election in the federal seat of Flinders, vacated by Stanley Bruce. It was a path from state to national politics that had been trodden by his uncle Sir George Fairbairn. Flinders, running around the southeast edge of Port Phillip Bay, included the southern Mornington Peninsula, and reached the shores of Western Port Bay, embracing Phillip and French Islands as well as the holiday resorts of Portsea, Sorrento, and Rosebud. Normally it was a safe conservative seat for a favoured candidate whose presence in Canberra was desired by party chieftains. Bruce, who had a 16-room mansion in Frankston, had regained the seat in 1931 after being ejected in 1929 because of what his Labor opponent E. J. Holloway called 'the wilfulness and overbearing class bias of his policies' ${ }^{45}$ Fairbairn, who would never live in the electorate, had all the class but none of the overbearing bias of the former Prime Minister. The 'flying $\mathrm{MP}^{\prime}$, as he was soon dubbed, caught the eye of the press at once by piloting his own plane to Canberra for his parliamentary debut. The train would have taken him 16 to 19 hours, he said. Even the five-hour flight itself was too long, so he was contemplating buying a faster machine. ${ }^{46}$

\section{The flying MP}

Tanned, fit, firm-jawed, blue-eyed, his fair reddish hair and moustache neatly clipped, the young backbencher was soon noticed on the national stage. Everyone knew his flying credentials. Personally disappointed by being rejected as medically unfit for the Citizen Air Force, he was on record as a critic of government aviation policy. He served on the executive of an evanescent lobby group of ex-wartime flyers calling itself the Air Convention. Eric Roberts (who was simultaneously embroiled in the shadowy League of National Security), the aero club pioneer Major Harry Turner Shaw, and the struggling airline operator Jimmy Larkin had been alleging malpractice in the subsidised

44 Camperdown Chronicle, 28 Aug. 1930. I am indebted here to Ian Hancock for exploring the Warrnambool Standard and to Alan Gregory for information not included in his The sentimental soldier: A life of George Furner Langley, Langley, Courtis, Thompson Library Trust, South Yarra, 2008, pp.96-7.

45 E. J. Holloway, 'From Labour Council to Privy Council', unpublished autobiography, Holloway Papers, NLA MS 2098.

46 Sydney Morning Herald, 29 Nov. 1933. 
monopoly airlines and favouritism in the administration of civil aviation. Larkin and Shaw were the spokesmen. ${ }^{47}$ Fairbairn, 'slightly out of place with legalities and formalities', as a young public servant was to observe, was never a fluent speaker. ${ }^{48}$ Reserved, some people thought, with a quiet, deliberate manner of speaking. But he was at home with graziers and club men as well as those with experience of war and 'wind in the wires'; and his pastoral background allowed him to speak with authority on rural production and marketing. In 1932 he had made a hurried trip to England to study the quality and marketing of Australian butter. Irregular supplies and competition from higher-grade Danish butter were handicapping Australian exports. Flying to Denmark in the company of a Warrnambool dairyman, he spent two days investigating Danish farming practices, concluding that their pasturing and dairying methods are 'far from ultra modern'. Where the Danes excelled was in the high average standard of their herds and their marketing. With immediate prospects for the Australian dairy industry gloomy, he advocated methodical herd testing, culling of all but the truly profitable cows and, where feasible, converting to mixed farming. ${ }^{49}$ In London, in May 1933, he spoke to the committee of the Empire Parliamentary Association on the practical working and future possibilities of closer settlement in Victoria.

Fairbairn had ideas about world affairs. He had enjoyed a private audience with Benito Mussolini in April 1933. 'In the Duce', he enthused, 'the Italian people have an asset worth more than all the golden hoards of America.' Agreeing with Il Duce that there was little prospect that any international monetary or credit scheme would raise wholesale price levels and stimulate world trade, he pointed out the great difficulties attending tariff reduction. ${ }^{50}$ Understandably, the new member's principal focus in the House of Representatives was rural. He spoke in defence of dairy producers, the preservation of large-scale sheep studs, the adjustment of farmers' debt and, drawing on personal knowledge, he forecast the future value of Corriedales, and the present benefits of the restored fertiliser bounty:

...nine years ago a property of 4,000 acres of which I have the direction, in Victoria, carried 3,000 sheep indifferently, although the season was good. This year the same property will shear over 10,000 sheep, almost entirely owing to the use of superphosphate on its pastures...The production of wool...has increased from 54 bales to over 220 bales...

\footnotetext{
47 Leigh Edmonds, 'Jealousy and Death, War and Politics: Reasons for Creating the Department of Civil Aviation in November 1938', History '86, Papers Presented to Civil Aviation Sessions, Adelaide, 25/26 Aug. 1986, pp.5, 6, 17.

48 Garry Armstrong, taped reminiscenses, 30 Jan. 1983.

49 J. V. Fairbairn, 'The Position of Australian Dairying: The Present Situation', The Australian Quarterly, No. 21, 14 March 1934, pp.41-8.

50 J. V. Fairbairn, 'Impressions of a Short Visit to Rome', reproduced from The Standard (Warrnambool), 19 April 1933, copy courtesy of Mary Browne.
} 
When those 3,000 sheep were carried...it was not possible to carry any cattle, except a few milkers, yet it is now carrying 350 head of cattle. The 3,000 sheep were looked after by one station hand with very occasional assistance in the way of casual labour, whereas at present five men are permanently employed..$^{51}$

For all that he was recognised as someone who spoke authoritatively on behalf of graziers, Fairbairn was also welcomed into the city corporate world with invitations to sit on the board of the Union Trustee Company of Australia (replacing Sir George Fairbairn who had served for 40 years) and the Victorian board of the Commercial Banking Company of Sydney, the domain of Sir Robert Knox, the leading conservative powerbroker.

No one who knew 'JV' doubted that his flying was much more than a hobby. His deep belief in the future of aviation was exemplified annually through the early 1930s to generations of teenage boys who were brought together in Lord Somers' camps.

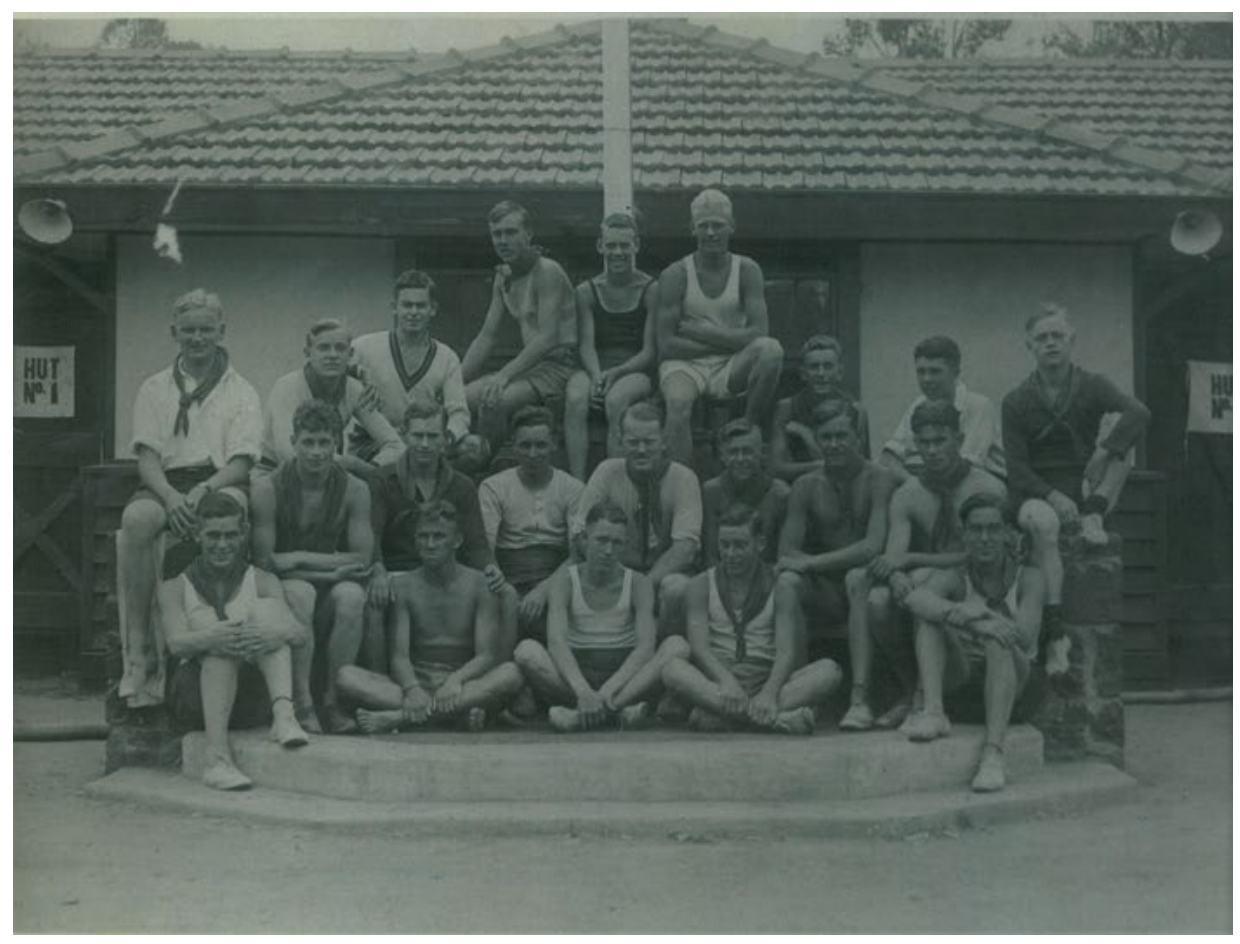

Yellow Group and its leader, Lord Somers' Camp, January 1932

(Courtesy of Pat Lesslie and Alan Gregory)

$51 C P D$, House of Representatives, 26 July 1934, p.794. 
As a camp group leader, Fairbairn would fly in every January and land in a nearby playing field to take his place with Wilfrid 'Billy' Kent Hughes, Squadron Leader Ray Brownell, Gilbert Castieau (Assistant Solicitor-General), and other civic leaders. ${ }^{52}$ He would take the Somers boys up in the air, imagining for them a future in which as men they would commute 150 miles to work, meet their wives after they had a day's shopping in the city, and fly them home to the country 'in time to cook dinner'. It was a vision that his own wife did not share with him. 'Peg you will be pleased to hear is getting air minded at last', he told Charles Hawker in February 1935. But it was a false dawn. Although 'she thinks nothing of flying to Melbourne \& back for a day's shopping', Peggy Fairbairn was not a light plane enthusiast. ${ }^{53}$ Fast cars - even for a journey from Sydney to Melbourne - were always more to her taste.

In Parliament, Fairbairn was cautious about predictions and silent on spousal preferences. But he raised questions about subsidies to aero clubs, the desirability of creating a new airport at Fishermen's Bend to replace Essendon, the poor condition of Canberra aerodrome, the improbability of any increase in efficiency resulting from the establishment of a Civil Aviation Board, and the resentment of the airline industry at the practice of holding secret inquiries into aircraft accidents. After the loss of a DH86 in Bass Strait in October 1935, the third DH86 to crash, he rose to the defence of the British aircraft before a court of inquiry had reported:

A little while ago I had an opportunity to hold a lengthy conversation with one of the chief pilots of Qantas, during which we discussed frankly the eccentricities of various aeroplanes, and I asked him whether he had any misgivings at all about the DH86 machines. The pilot assured me they were the finest machines he had ever flown...

...I consider that as much publicity as possible should be given to the findings of the court...the publication of the causes or possible causes of these accidents will have the effect of restoring confidence, rather than of causing uneasiness.

On one point he was emphatic. There was, he said, a certain reluctance by many people to testify at an inquiry 'because they feel that they may seem to be maligning the dead pilot of the ill-fated aeroplane'. But it was the duty of those with relevant knowledge to appear as witnesses and tell of what they knew. ${ }^{54}$

52 Alan Gregory, It's only the Game that counts: A History of Lord Somers' Camp and Power House 1929 1989, [1994], pp.48, 56, 61 .

53 Fairbairn to Hawker, 28 Feb. 1935, Hawker MSS, NLA MS 4848/1/1.

54 Sydney Morning Herald, 4 July 1935, 1 Dec. 1939; CPD, House of Representatives, 17 Oct. 1935, p.835. For anxieties, investigations, and confidential consultations on the safety of the DH86, see NAA: MP187, 3, and T. W. White to Vera White 15 Mar. 1936, T. W. White MSS, NAA MS9148, 2/2: 'The machines have a bad reputation and I have been warned not to travel in them.' A pilot recalled that quite a few words would be said 'if an air hostess walked too quickly fore or aft... because down would go the nose'. (Willis Reeve, 'A talk to the AHSA meeting 24 May 1978', Aviation Heritage, vol. 43, no.1, March 2012, p.41). 
When he began to travel regularly between Canberra and Melbourne, Fairbairn soon attracted attention by flying himself in the second-hand Metal Moth he had bought in April 1931. Sometimes it was unwanted attention. The 'grazier pilot' had already made headlines in March 1932 when he smashed up the nose of his Moth, crash-landing in a field half a mile from Camperdown on the way home from a Hampden Shire Council meeting. Belatedly adjusting his goggles, he inadvertently touched the controls and flew into the only tree in the paddock. Apart from a scratch over his right eye, only his pride was injured. But it was a sharp reminder of the need to be careful in the cockpit. In July 1934, at Duntroon aerodrome, there was trouble of a different kind. Someone took a knife to the fabric of his recently acquired DH85 Leopard Moth's wings, slashing them so severely that it was too dangerous to fly. Even without malicious damage, Fairbairn family flying could have tragic consequences. As Betty Fairbairn told the press, when asked if she intended to try to lower Amy Johnson's time for a flight from England to Darwin, 'It's then that people crash. ${ }^{.55}$

Without chasing records, Jim's youngest brother, George Patrick 'Pat', was to die with his wife Mary at the controls when their Spartan Arrow ran out of fuel and crashed soon after take-off from Essendon in May 1935. Pat had made headlines in 1931 while still a 22-year-old undergraduate at Jesus College, Cambridge, when he flew in a deliberately leisurely fashion from England to Australia in an overloaded Gipsy I Moth. ${ }^{56}$ The risk of the flight was reduced by the presence of a passenger, a fellow undergraduate and previous flight companion, Kenneth Shenstone, soon to become managing director of a family firm supplying leading aircraft companies with machine tools. It was sobering for Jim Fairbairn to learn from a private briefing how his 26-year-old brother and sister-in-law may have died, leaving a 14-month old orphan daughter, Frances Mary. They had simply failed to fill their petrol tank before leaving Wooloomanata, their home at Lara. The deficiency might have been remedied had Pat not declined, as he usually did, to refuel at Essendon the next day. Although the Air Accidents Investigation Committee had no choice but to disclose that Mrs Fairbairn was not authorised to carry a passenger in Spartan aircraft, they softened their finding by concluding that there was no reason to doubt her competency to fly the aircraft. Evidence from the proprietor of the Hart Aircraft Company that Pat Fairbairn was very casual about the maintenance of his aircraft - 'the way he used to keep the machine was a disgrace' - was not mentioned in the Investigation Committee's report. ${ }^{57}$

\footnotetext{
55 The Argus, 5 March, 17 April 1932.

56 Edward P. Wixted, The North-West Aerial Frontier 1919-1934, Boolarong Publications, 1985, p.94 has Fairbairn and Shenstone flying the Spartan Arrow to Australia. Contemporary Northern Territory newspapers do not identify the aircraft type.

57 NAA: MP187, 4/144. Much of the archival material on which this paragraph was based was subsequently published in Neil Follett, 'An Accident Investigation: George Patrick Fairbairn', Aviation Heritage, vol. 42, no. 4, Dec. 2011, pp.174-9. A coronial inquest had concluded that it was impossible to determine the 'actual cause' of the crash (Camperdown Chronicle, 29 June 1935). There is no substance to the theory that 'the plane's controls had been jammed by a large suitcase' (Tink, Air Disaster, p.108). Frances Mary's maternal grandparents became her guardians. With the concurrence of her trustee, Osborne Fairbairn, she was given the adopted name of Murray-Fairbairn (The Argus, 22 June 1939).
} 


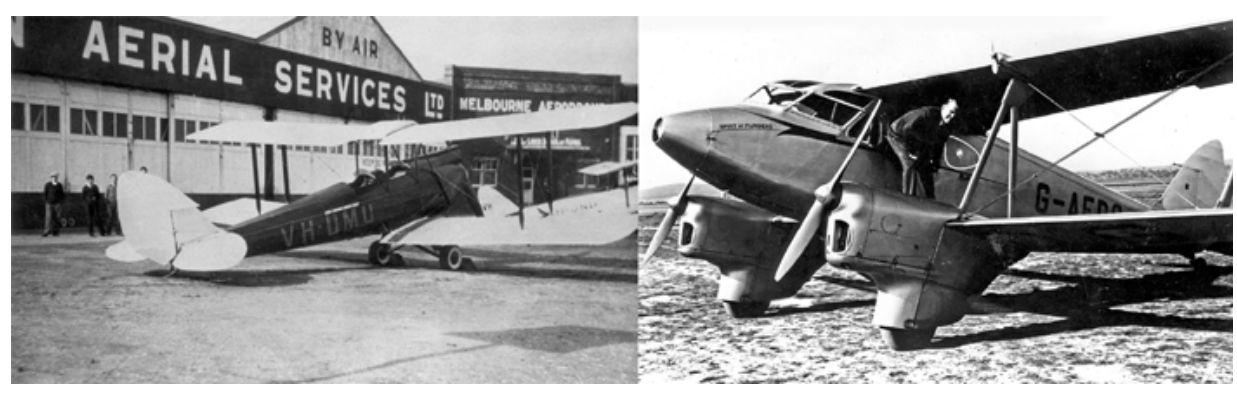

Moth (left) and Dragonfly (right): the progress of a private flyer

(Courtesy of the Civil Aviation Historical Society, Phil Vabre, and Geoff Goodall)

Amid his other responsibilities, Jim had found time to fly his Leopard Moth cabin tourer (VH-UUL) 7075 miles around northern Australia in 1935 with his other brother, Osborne, to whom he had sold his Gipsy Moth the previous year. The 'Flying Fairbairns' the press called them. Reflecting on the trip, he suggested that it would be helpful to aviators if every post office and railway station in the country should have the name of the town painted on its roof in as big letters as possible. He then left on a Qantas mail plane to England, where Peggy had taken a flat for six months, returning the following year in his own brand-new de Havilland Dragonfly. Osborne Fairbairn, unfazed by the deaths of his other brother and sister-in-law whose estate he was now managing, was again the buyer of Jim's redundant aircraft, this time (September 1936) the Leopard Moth, VH-URK. ${ }^{58}$ The dual-control DH90, a streamlined twin-engine biplane, had a plywood fuselage skin and high aspect ratio wings. Its list price was $£ 2650$ sterling. Normally accommodating up to five passengers and crew, Jim Fairbairn's craft had one passenger seat removed and an extra fuel tank installed. It had a cruising speed of $127 \mathrm{mph}$ though he usually kept to around $115 \mathrm{mph}$ on the long trip home.

With a young Sydney pilot, Frank Thomas, navigating and sharing the flying, Fairbairn had set off from Lympne on 14 September 1936 intending to reach Vienna in one hop. Fog made them set down in Brussels before flying along the Rhine through bad weather to Budapest. He attended a parliamentary congress in Bucharest, flew across Turkey and thence via Basra and Karachi to Delhi, Calcutta, Rangoon, Bangkok, Penang, Singapore, Surabaya, and Koepang. They reached Darwin, clad in khaki shorts, coats and topees, on October 3. At about the same time, Peggy Fairbairn was about to board ship for an unhurried voyage home from Naples. When the Orontes docked in Adelaide, Jim was there to meet her and fly her to Mount Elephant in the new Dragonfly which, he proudly said, was the first of its type seen east of Karachi.

58 For a history and photographs of VH-URK: http://www.goodall.com.au/australian-aviation/dh85/ dh85leopardmoth.htm. 
Having registered the 'baby airliner' in Australia in September 1937, Fairbairn made it known that he intended to use it to fly between Melbourne and Canberra. Like his brother Osborne, Jim was one of the 'old men' of aviation, the flyers of the Great War, the pioneers and record breakers, the founders of airlines. Men who could scarcely imagine life without flying. Of his generation of RFC flyers, a British official had written in July 1916 that 'the Australian temperament is specially suited to the flying service' ${ }^{59}$ For them, accidents were vivid threads in the tapestry of flying life. And, of course, the veterans of the 1930s were not old men. Most - like Norman Brearley in Western Australia, Horrie Miller in Victoria, Hudson Fysh of Qantas, Murray Jones of de Havilland Australia, and Jim Fairbairn himself - were in their 40s. They had accepted, some might say embraced or even sought, the danger of the air all their adult lives. As Horrie Miller put it of the time he and a band of ex-AFC men launched a barnstorming business in Glenelg in 1919: 'The general public still associated aircraft with death and disaster. ${ }^{\prime 60}$ The general public were not wrong. But the flyers were undaunted. Oliver La Farge, a wartime staff officer in the U.S. Air Transport Command was to write of their American contemporaries: 'The progress of their craft had been such that they had never lost the habit of doing things which until recently had been known to be impossible... They were ready for new conquests and strange developments, not in the far future, but tomorrow. ${ }^{61}$

Jim Fairbairn never forgot the good fortune of his survival in 1917. His feelings were revealed in a brief intervention on the Repatriation Bill in 1934:

Those of us who, after a month or two at the front, and a comparatively brief share of the strain imposed on the fighting forces, found our services terminated by injury, did not suffer the same nervous strain as those who, month after month, and year after year, escaped injury... the unfortunate individual who, though apparently bodily sound, has frayed nerves, and perhaps finds it necessary to take stimulants to steady them, experiences great difficulty in getting work, and is not regarded with understanding or sympathy. ${ }^{62}$

The speech might have referred to many of his flying contemporaries, not least to those with unrecognised afflictions, like that hero of the hour, Sir Charles Kingsford-Smith.

Fairbairn was not obsessed by the air. Nor did he depend on aviation for a living. Yet if flying was not his vocation it was certainly the passion of a man whose wealth, pastoral interests, business connections, and family traditions directed

59 Firkins, The Golden Eagles, p.14.

60 H. C. Miller, Early Birds, Rigby, 1968, p.71.

61 Oliver La Farge, The Eagle in the Egg, Houghton Mifflin, Boston, 1949, pp.7-8.

$62 C P D$, House of Representatives, 1 Aug. 1934, p.1047. 
him to a career of public service. It was a passion he shared not only with his brothers but with his sister Betty and brother-in-law and horse racing partner Ross Grey-Smith. The one person close to Fairbairn who was nervous about flying was his wife. As her niece Gillian Gubbins remembered, Peggy declined to accompany Jim on his regular trips from Mount Elephant to Essendon, preferring to be driven. ${ }^{63}$ But his interest was not merely that of an avid private flyer. 'Jimmy' Fairbairn, as Qantas's Hudson Fysh - a slightly older Geelong Grammar contemporary - called him in correspondence with Imperial Airways associates, was acknowledged as an authority on aviation policy, both domestic and international. On his return from England in 1936, The Age had reported that he had seen the new flying boats to be used on the proposed imperial air mail service. Seizing the opportunity to offer his thoughts on policy, he had told the journalist that he favoured a five-year agreement, renewable for five years, rather than the 10-year agreement being mooted. ${ }^{64}$

In a letter to his old school magazine, written while he was away, the young MP professed to have been shocked at the state of the meteorological station in Darwin - safety was being compromised by the government's cheeseparing economies. ${ }^{65}$ In his public utterances it was rare for Fairbairn to venture beyond rural and aviation matters, where his expertise gave him some latitude to probe weaknesses and gaps in government policy. A notable exception was his adjournment motion in April 1936 on 'the alarming growth of imports' from the USA and the consequent 'growing menace' to trade with the United Kingdom and other 'good customer nations'. The speech earned him the plaudits of Charles Hawker, who mocked the ministerial responses of Harry Gullett (Trade Negotiations) and Tommy White (Trade and Customs) who gave Fairbairn's critique their blessing 'with a sickly kind of sentiment designed to rob it of its vitality'. The exercise was a revelation that parliamentary badinage and byplay were not Fairbairn's strong suit. This would not have surprised his former Hampden Council colleagues who had observed that he was capable and courteous but never had much to say. It was eight months before he returned to the fray. In a mild remonstrance at the trade diversion policy, he criticised the 'unnecessary curtailment' of trade with Japan compared with the far gentler treatment of the USA, 'our most unsatisfactory customer'. This time, however, his touch was lighter. He had not noticed until May 22, he admitted, that he had moved his motion on April 1. And, following a slashing attack on Harry Gullett by the Country Party's Archie Cameron, he confessed his disinclination to put pinches of salt in the minister's claymore wounds. ${ }^{66}$

63 Gillian Gubbins to CH, 8 Feb. 2009.

64 The Age, 5 Oct. 1936

65 The Corian, Aug. 1936, p.175.

66 Camperdown Chronicle, 15 Aug. 1933; CPD, House of Representatives, 1 April, 25 Nov. 1936, pp.741-53, 1322-5. 
Gathering confidence session by session, year by year, Fairbairn was sufficiently satisfied with his performances in the House of Representatives to arrange for a friend, Eddie Connellan, to sit behind him any time when Parliament was in session. ${ }^{67}$ Never a polished speaker, and noted for a degree of personal reserve, the member for Flinders commanded respect as someone who seldom got to his feet unless he had something worthwhile to say. Such an occasion was his attempt to head off an Opposition attack on the government in December 1937 for its handling of a series of 'Air Force Disasters'. In view of the damage being done to Australian aviation by the 'extravagant publicity given in the press and in this House to aviation accidents and minor mishaps', Fairbairn asked the Minister for Defence to make an appeal to 'keep such publicity to something approaching proportion to that given to accidents associated with other forms of transport'. And, because of Labor attacks on the government's Air Accidents Investigation Committee, would the Minister make a statement 'explaining the very great difficulties that confront any committee that inquires into major air accidents'.

Unhappily the Minister's statement provoked an adjournment motion in which the 'black record' of the RAAF — eight accidents in nine days - was contrasted unfavourably with civil aviation and motor accident rates. After listening to an hour of unrestrained criticism, Fairbairn rose to defend the government. It was 'fantastic' to call several of the accidents 'serious'. Secret inquiries, to which Labor speakers objected, were more likely to yield candid answers. The latest modifications or servicing changes resulting from advice given in secret inquiries were promulgated in air regulations. Admitting that there was considerable controversy in air circles about whether inquiries should be open to the public, he was emphatic that 'aviation would benefit to the greatest extent if the evidence were given in camera'. To the complaint that the interests of the public were not represented, he asserted that the rights of the public were protected by coronial investigations: 'a coroner is as capable of carrying out an inquiry into an aircraft accident as any other'. A statement issued by Defence Minister H. C. Thorby two days later regarding 'serious Air Force flying mishaps' quoted 'Mr. Fairbairn, M.P. (himself an airman)' on 'A Question of Proportion'. ${ }^{68}$ Proportionality was to be encouraged by officially characterising even fatal crashes as 'mishaps'.

Useful as he had been to Thorby, unbeknown to many Fairbairn's influence in aviation had been increased by the appointment of Geoff Street as Assistant Minister of Defence. The role he could play was evidenced late in October 1938 after the appalling crash into Mount Dandenong of the ANA DC-2 Kyeema in which his dear friend Charles Hawker perished with four crew and 13 other passengers,

67 Connellan, Failure of Triumph, p.84.

$68 C P D$, House of Representatives, 8 Dec. 1937, proof copy, NAA: A461, V314/1/1. 
including the winemakers Tom Hardy, Hugo Gramp, and Sidney Hill Smith of Yalumba. ${ }^{69}$ Writing to Hudson Fysh, Hawker's friend since their schooldays at Geelong Grammar, he sweetened an earlier feeler on behalf of the government:

This tragedy has certainly put the press and the public into a frame of mind to demand a clean-up of Civil Aviation which has been due for a long time. Things may happen, I think quickly. You will, of course, have realised when we were discussing the post of chairman of the Civil Aviation Board the other evening that I was pumping you to see whether there was any possibility of your being persuaded to take this job should a change be made.

I feel that I would like to know whether you would consider accepting the position if it should become vacant and be offered to you, and what conditions you would consider adequate. I think many senior members of Cabinet feel that this position should be very greatly increased in status.

Fysh was happy where he was. To the managing director of Qantas's annoyance, the government then secretly sounded out his lieutenant, the Qantas flying operations manager, Lester Brain, who indicated without reference to his boss that he would accept the position should it be offered. It wasn't. ${ }^{70}$ In due course the senior post in the reformed civil aviation regime went to Arthur B. Corbett, an engineer who was close to retirement as Deputy Director-General of Posts and Telegraphs in Queensland. Unencumbered by knowledge of aviation, ABC or 'the Alphabetical Old Bastard' as Corbett was known by staff, was to stay at the helm under successive ministers long enough to accumulate a litany of offences in the eyes of frustrated subordinates. Released in 1944 from the public service obligation to mute his political opinions, he became chairman of the provisional executive that formed the Liberal Party in Queensland. ${ }^{71}$

When the Ministry of Civil Aviation was created late in November 1938 the Country Party's H. C. Thorby, demoted from Defence where he was replaced by Geoff Street, was appointed as the first Minister. Fairbairn was not completely at one with his old friend on defence matters, believing that the government

69 The Canberra Times reported on 14 Aug. 1940 that Fairbairn escaped death on this occasion because the Kyeema was delayed by fog and he therefore flew himself to Canberra. The story was repeated elsewhere (e.g. Lismore Advertiser, 21 Aug. 1940). But, as the crash occurred before the plane reached Melbourne, Fairbairn could not have been on board.

70 Hudson Fysh, Qantas at War, Angus and Robertson, Sydney, 1968, pp.75-6; John Gunn, The Defeat of Distance: Qantas 1919-1939, UQP, St Lucia, 1985, pp.280-1, 334, 338, 343. Brain, perennially irritated at being under-appreciated by Fysh, had made clear his willingness to join Edgar Johnston, Controller-General of Civil Aviation, as his deputy as early as 1935. (Cameron Hazlehurst, 'Brain, Lester Joseph [1903-1980]', Ritchie and Cunneen (eds), Australian Dictionary of Biography, vol. 13, pp.247-8).

71 S. A. Prentice, 'Corbett, Arthur Brownlow (1877-1970)', Ritchie and Cunneen (eds), Australian Dictionary of Biography, vol. 13, pp.500-1; Arthur H. Affleck, The Wandering Years, Longmans, Croydon, Victoria, 1964, pp.157-60, 165; C. Arthur Butler, Flying Start: The history of the first five decades of Civil Aviation in Australia, Edwards \& Shaw, Sydney, 1971, p.46. 
had over-emphasised home defence over Imperial needs. ${ }^{72}$ But he was at pains to publicly congratulate Street on his appointment, 'something for which I have hoped for many years'. Nor was he uncritical of British influence on Australian affairs. He lambasted the government for its 'monstrously unfair' public gloss on a report by Marshal of the RAF Sir Edward Ellington that purported to demonstrate poor training and discipline in the RAAF.

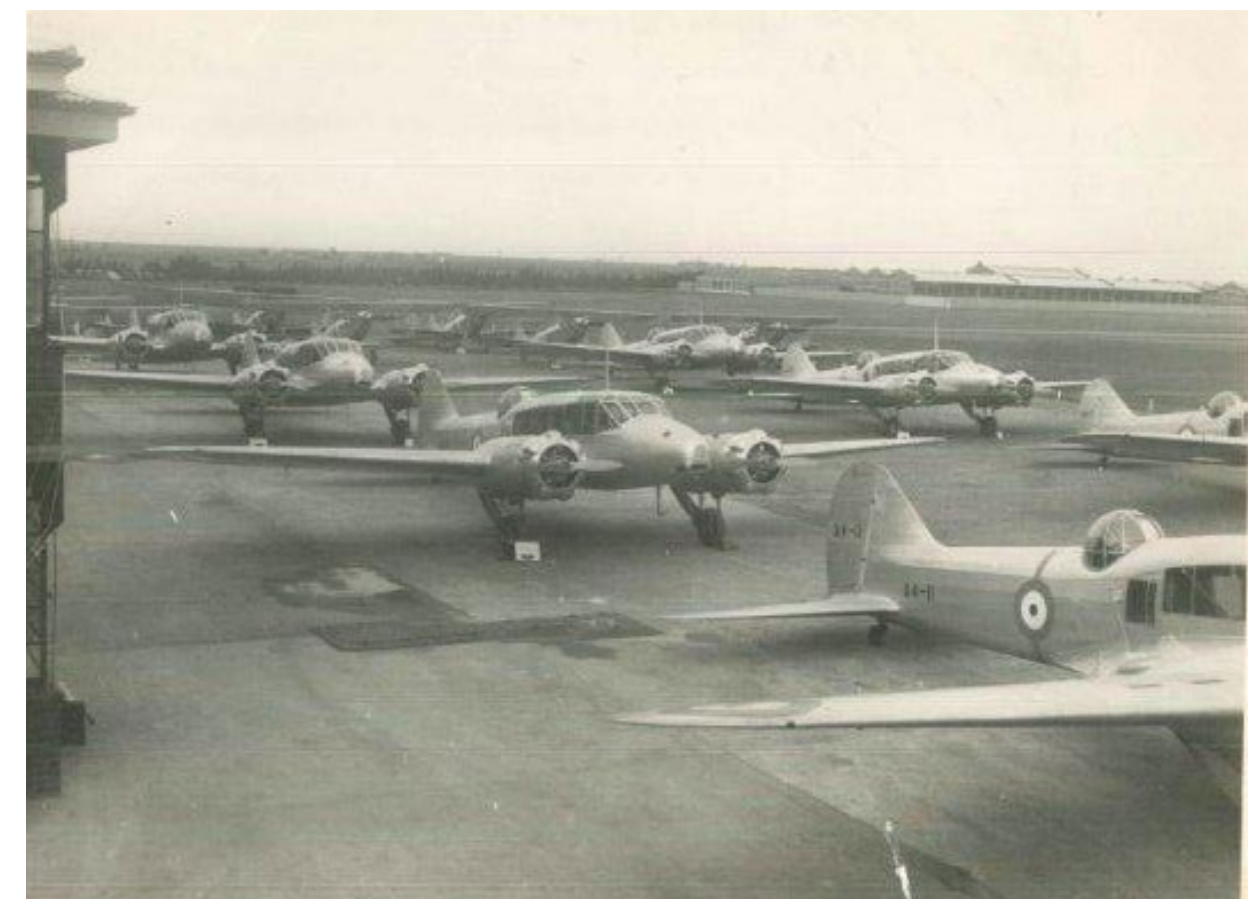

Ansons and Demons on parade for Sir Edward Ellington: A4-11, at the head of the line, would crash in controversial circumstances in 1939

(The Jack McNally Collection courtesy of Wendy Coultas and Peter Dunn)

Although he was speaking at 3.30 a.m. to a sparse and somnolent House, his defence of the RAAF made headlines. Were it not for his reputation as an aviator, his customary loyalty to the government, and the presence of friends in high places, such an attack might have seriously damaged his political prospects. He was an advocate of national service - that was an issue still to be resolved and of a commitment to reinforce Singapore in an emergency. He warned how easy it would be for an enemy to invade Western Australia or land a powerful force in Newcastle. And he was fertile with ideas about the training of Air Force pilots: if the RAAF could not manage enough cross-country flights then their pilots should be allowed to fly as assistant pilots on commercial airliners.

72 David S. Bird, J. A. Lyons - the 'Tame Tasmanian': Appeasement and Rearmament in Australia, 1932-39, Australian Scholarly Publishing, North Melbourne, 2008, p.294. 
As it was, within months, following the death of Joe Lyons and the refusal of the Country Party to serve with the new Prime Minister, Bob Menzies, Jim Fairbairn's moment came. The position of Civil Aviation Minister was vacant. No one in the UAP was better fitted to occupy the post. Harry Gullett had proposed him as 'obviously the man for the job' back in October $1938 .{ }^{73}$ Fairbairn did not have to ask.

73 Sydney Morning Herald, 29 April, 28 Oct., 8 Nov 1938; The Argus, 8, 14 Dec. 1938; 25 Nov., 8 Dec. 1938. 



\section{5. 'A minister or a clerk?': Jim Fairbairn (II)}

At last Jim Fairbairn was in a position to apply all he knew and believed about aviation. There was wide appreciation of the Minister's appointment, not least at Geelong Grammar where the boys were awarded a celebratory half-holiday on 6 May 1939 in honour of the chairman of the school council's attainment of Cabinet rank. ${ }^{1}$ A proud Geoffrey Fairbairn enjoyed universal gratitude at Corio, but his mother was not at home to share her husband's delight. In midMarch she had left for six months abroad, farewelled at a party for 400 guests. Peggy Fairbairn was now in England and, as one of Bob Menzies' British friends reported, she was 'in the seventh heaven' about Jim's elevation. ${ }^{2}$

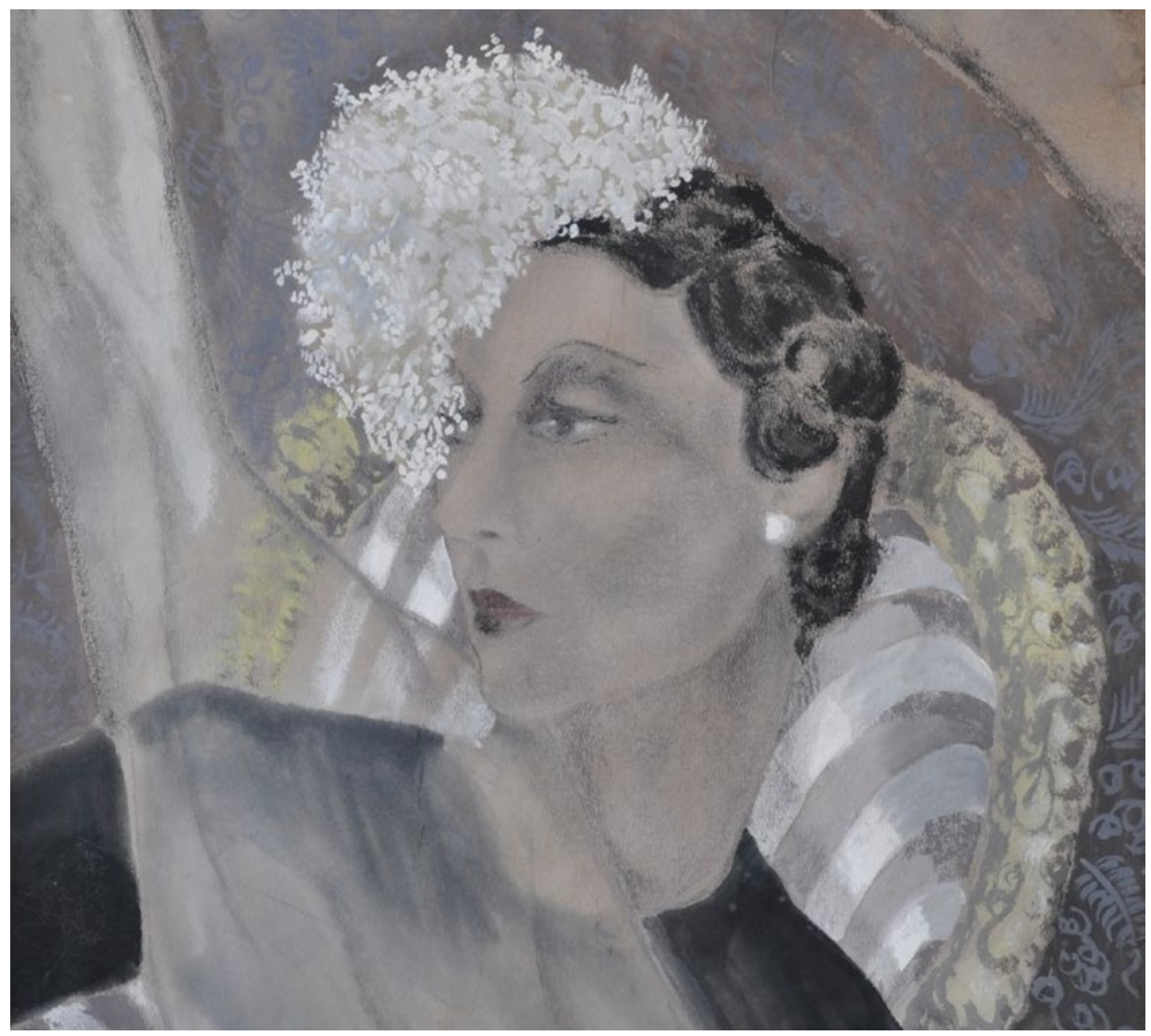

Peggy Fairbairn in pastel and gouche by Loudon Sainthill, 1939

(Courtesy of the Bridget McDonnell Gallery) 
Fairbairn's new Air Ministry would soon move into offices in the recently constructed Century Building at the corner of Swanston Street and Little Collins Street, opposite the Melbourne Town Hall. Blonde plywood panelling, flush jointed, with matching joinery, cushioned rubber-sheet flooring, terrazzo, and stainless steel were more suggestive of a passenger liner than flying machines. But it was a sparkling Art Deco structure reaching 14 vertically ribbed storeys to the sky. Melbourne's first fully air-conditioned building, it was a symbolic contrast to the grim earth-clasping nineteenth-century bluestone of the Army's Victoria Barracks, a brief tram ride away in St Kilda Road, where Geoff Street presided over the Defence ministry. The 100 or so officers of the Department of Civil Aviation central administration were also re-located from Victoria Barracks to two floors of Almora House, at the other end of Little Collins Street. ${ }^{3}$ Plans made by the former Defence minister, Vic Thorby, to shift Civil Aviation to a new building in Canberra had been shelved by Menzies amid Country Party remonstrances at the dominance of Victorian ministers in the Cabinet, and the alleged 'evacuation' of public servants from the capital to Melbourne. Air Vice Marshal Williams, by contrast, could hardly conceal his joy at the arrival of an informed and enthusiastic aviation minister and the departure of the uncommunicative Thorby, a builder who 'paid particular attention to building plans to ensure that plumbing costs were kept to a minimum by having kitchens, bathrooms and toilets close to one another'. ${ }^{4}$

The new minister was soon in the news. He was, it was reported, going to meet weekly with his senior staff. There was going to be 'frank talk'. A cascade of policy announcements followed. He signalled his support for the introduction of night-flying services by Australian airlines. He recommended stop-gap measures to ensure stability of domestic airmail and passenger services pending new agreements and rationalisation. He announced that all aircraft operating on routes supplied with beam radio beacons would be equipped with receiving apparatus by the end of May. He pronounced that there was no limit to the amount of money that could be spent on aviation in Australia, without one penny being wasted. Rising temperatures at the Treasury were mildly subdued when he said that the three aerodromes needed in every capital city would not all have to be paid for by the government. He was also quickly on record attesting his pleasure at finding that:

the old idea that a pilot should be a reckless devil-may-care individual has passed - at any rate as far as the professional pilot is concerned - and that displays of fool-hardiness by the inexperienced are greeted with all the emphasis on the 'fool' and none on the 'hardiness'...

3 Butler, Flying Start, pp.45-7.

4 Williams, These are Facts, p.229. 
Not only must air transport be safe, but it must convince the public of its safety...[and] the subsidy requirements of existing lines are reduced by greater public patronage.

Belatedly displaying sensitivity to the cost of aviation to the public purse, Fairbairn took opportunities to underline the contribution made by the civil aviation industry to the nation's defence preparedness.

Although he was only assisting the Defence Minister in relation to military aviation, Fairbairn's knowledge and popular acceptance as an authority on all aviation matters were a political advantage to Geoff Street and the Prime Minister. As war came closer, it was he who issued a reassuring statement about the organisation of Australia's reserve flying forces. In an emergency, he said, Australia could provide 373 highly trained pilots and 121 transport machines capable of carrying a force of 1000 men. Commercial pilots provided a reserve of skilled men for the RAAF, capable of making long-distance flights under any weather conditions. In what some might have thought an implicit admission of inadequate and vulnerable air capability, he described the reserve forces as a second line of defence in the air. In addition to these pilots, he said, aero clubs and other organisations had trained 2500 pilots, giving Australia an additional reserve of about 1500 . With little expansion of present civil training facilities, he suggested, 1000 pilots a year could be trained 'at a moderate expense to taxpayers'. Fortunately for the government these rather fanciful figures escaped serious criticism. ${ }^{5}$

Among the earliest tasks for the new Minister for Civil Aviation had been some delicate matters of personnel. None was of more concern to Fairbairn than the fate of Wing Commander A. H. Cobby. Writing about him to the Prime Minister, Fairbairn noted that 'Cobby was the greatest single seater fighter pilot in the Australian Flying Corps during the War' (No. 4 Squadron's 'most successful Hun-getter' as the squadron history had put it in 1919). ${ }^{6}$ Unfortunately, in the reorganisation of the Civil Aviation Department, Harry Cobby's position of Controller of Operations had become redundant. Cobby had retired from the RAAF to become a member of the Civil Aviation Board in the Department of Defence. The Board having been abolished with the creation of the department, he was neither a public servant nor an Air Force officer. 'It is unthinkable that Wing Commander Cobby's appointment should be terminated without some other position being found for him.' Thus matters stood at the beginning of August 1939. Menzies referred the problem to the Defence Minister. A month

5 Sydney Morning Herald, 2, 11, 13, 19 May 1939; The Argus, 13, 16 May 1939; Flight, 3 Aug. 1939, p.113.

6 E. J. Richards, Australian Airmen: History of the 4th Squadron Australian Flying Corps, Melbourne, 1919, p.17. For a modern account of Cobby's exploits, see Michael Molkentin, Fire in the Sky: The Australian Flying Corps in the First World War, Allen \& Unwin, Sydney, 2010, passim. 
later, with war declared, an obvious solution presented itself. The famous Harry Cobby DSO DFC and two bars would be welcomed back into the RAAF. As it turned out this was not one of Geoff Street's best decisions. ${ }^{7}$

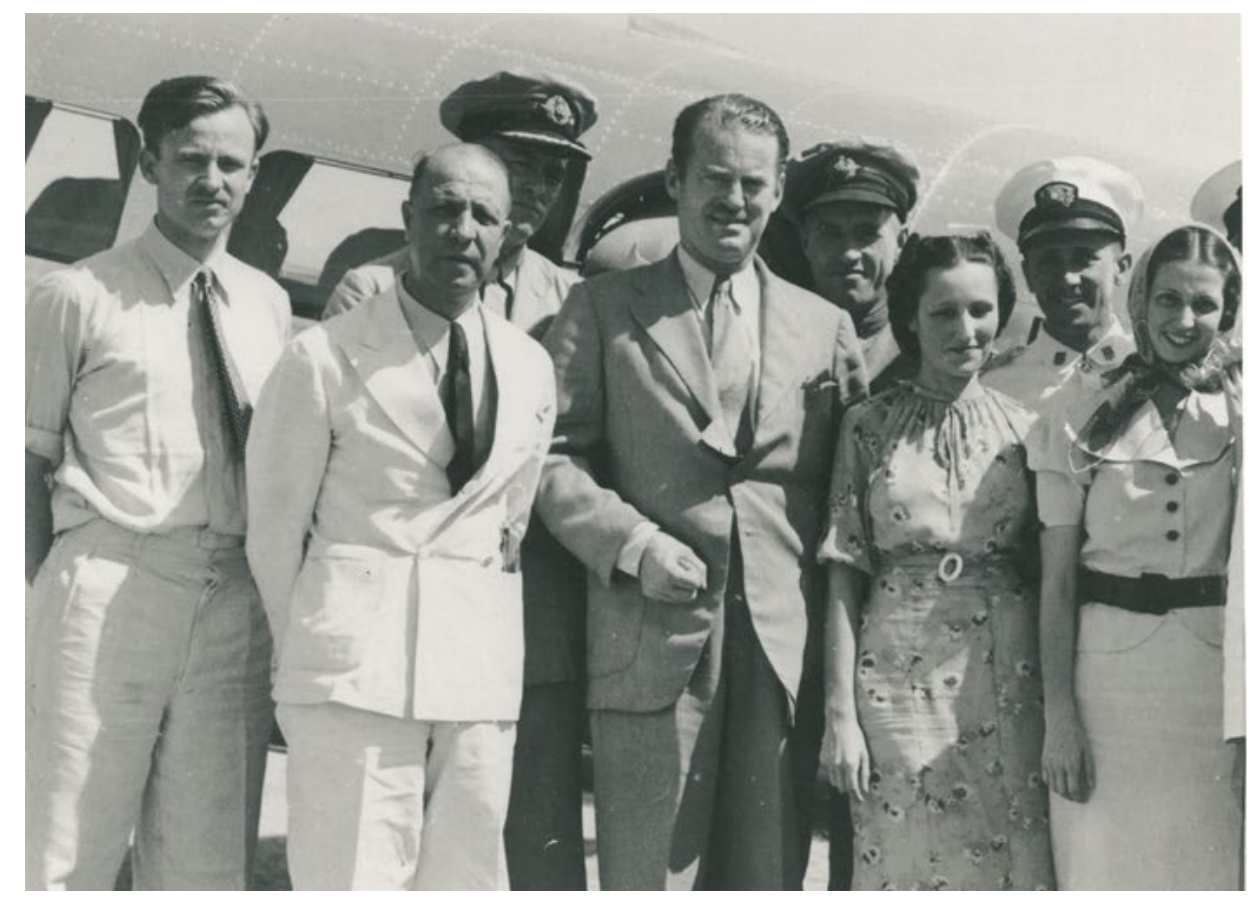

The Dili Mission: 'Fraternisation 22/7/39 J. V. Fairbairn'

(Courtesy of Audrey Elford)

Shortly before he had taken up Cobby's case, on 22 July 1939, Fairbairn had flown to Dili with his private secretary, Dick Elford, to explore the possibility of an air service between Portuguese Timor and Australia. The mission itself was productive in spite of Fairbairn having no facility in Portuguese and being unable to understand the Acting Governor's French. Fairbairn's English was equally unintelligible to his host. Negotiations were therefore carried out in both English (the Governor) and French, in which the Australian minister, like his friend Geoff Street, was proficient. Proceedings were accompanied by numerous 'rounds of port wine on an empty stomach' followed by a breakfast of more port, fried eggs, roast mutton, boiled pork, sweet cakes, preserved fruits, and cocoa. Earlier, a full dress parade of 100 barefooted native troops had turned into farce when they approached the saluting stand only to find the Governor's car stalled in their path. Urgently hand-cranked into life, the vehicle showered the front rank with gravel as it pulled away just in time to reveal a gaping hole

7 Fairbairn to Menzies, 28 July 1939, and N. C. Tritton to P. Hayter, 7 Aug. 1939, Menzies MSS, NLA MS 4936/2/3; NAA: MP288, 2/22. 
in the ground, dug to accommodate a new flagpole. Bravely the troops marched into the chasm, three feet deep and six feet wide, emerging, according to Dick Elford's account, undismayed 'with scarcely a kink in the ranks' ${ }^{8}$

Diverting as the ceremonial formalities were, the mission was most notable for being the first time anyone had left the country, landed on foreign soil, and returned to Australia in a single day. The original itinerary had the Minister making the trip in a Qantas flying boat; but urgent repairs to the landing strip made it possible to use a Guinea Airways Lockheed 10A Electra airliner chartered by the Commonwealth government in the previous year. ${ }^{9}$ Although it was now available to carry ministers, the primary role of the plane was to assist in calibrating the radio navigation aids that were being brought into service to avoid the kind of accident in bad weather that befell the Kyeema. It was not Fairbairn's first time in the aircraft. He had taken the controls 'nearly all the way' in a flight from Canberra to Sydney two months earlier. This, as the Sydney Morning Herald reported, was 'the first time he had flown such a large plane'. ${ }^{10}$ The Dili trip also had a special personal significance for the Air Minister. His was only the third machine to land in Portuguese Timor. Dave Ross, who accompanied him, had flown the second. His late brother Pat had been the first.

On the evening of his return from Dili to Darwin, the Minister for Civil Aviation gleaned a shaft of spotlight at a 'smoke social' gathering of the Returned Soldiers' and Sailors' League at which the Minister for Supply and Development, Dick Casey, was the principal speaker. 'Darwin,' Casey had declared, 'is the front door of Australia...the front line of Australia's defence.' Yes, Jim Fairbairn concurred, and it was his department that had made it so. ${ }^{11}$ It was not long before Fairbairn's status was further enhanced. When war brought an imperative to build up the RAAF into a genuine fighting force, he was the obvious man to lead the new Air Ministry. Nor was there any doubting that he would retain the dual civil and military aviation responsibilities when some of his UAP colleagues had to make way for Country Party representatives in the reconstructed coalition government of March 1940. No-one was going to displace Jim Fairbairn.

\footnotetext{
8 'Visit to a little known land', The Corian, Aug. 1939, pp.168-70.

9 Sydney Morning Herald, 24 July 1939; NAA: A461, 748/1/539.

10 Sydney Morning Herald, 19 May 1939. The Lockheed Electra (Model 10A), with a crew of two, carried 10

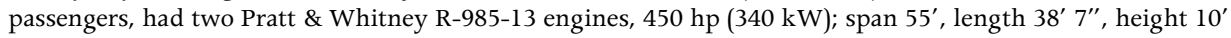
1"; maximum speed $202 \mathrm{mph}$; range 713 miles.

11 Northern Standard, 25 July 1939. For the development of Darwin's defences, Alan Powell, The Shadow's Edge: Australia's Northern War, Charles Darwin University Press, Darwin, 2007, pp.1-33.
} 


\section{A minister in full flight}

'Victory in this war will depend upon mastery in the air,' the Minister for Civil Aviation told radio listeners at the beginning of October 1939. Two weeks earlier he had transferred his office to Victoria Barracks where he could be closer to the nation's principal defence officials. He was vocal in informing the nation of plans to manufacture aircraft, recruit civil pilots as instructors, and train pilots and aircrew. ${ }^{12}$ The government had underestimated the desire of qualified private and commercial pilots to be posted to operational squadrons rather than be sidelined in training establishments. But the faltering expansion plans were about to be overtaken by the ambitious Empire Air Training Scheme. Naturally it fell to Fairbairn to travel to Ottawa to negotiate the details of the plan. As George Jones, who accompanied him, recalled:

There were some very interesting people on the ship, including a little movie actress. She played the poker machines in the cocktail bar twothirds of the way across and then went to bed until the last day. And somebody came to her aid. I'm not going to say who, and she came up as large as life again, for more fun. ${ }^{13}$

There were in fact several companies of actors and show people returning to North America from Australian tours. Fairbairn, long since cured of the shyness that school contemporaries had remarked on, was always ready for fun.

The conferences and private parleys to settle the Empire Air Training Scheme in a form acceptable to Menzies and the Cabinet were to test Fairbairn's political mettle. ${ }^{14}$ While he was away, his authority grew with the announcement that he was to be Minister for Air - all of the air not just civil aviation. Conscious of the growing burden on Street as Minister for Defence, on 13 November 1939 the Prime Minister had split the portfolio into four elements. He created for himself the overarching role of Minister for Defence Co-ordination. ${ }^{15}$ Street was Minister for the Army, and Sir Frederick Stewart was Navy Minister. Fairbairn's appointment was unique in Australian constitutional history. He was the first minister to be sworn in outside the country, the Canadian Governor General, Lord Tweedsmuir (better known as the popular novelist John Buchan), performing the task in Ottawa, to the delighted curiosity of the press.

After finalising the terms of the Empire Air Training Scheme in London and making a quick trip to France late in 1939, Fairbairn flew back to Australia to take

\footnotetext{
12 Sydney Morning Herald, 9, 13 Sept., 2 Oct., 29 Nov. 1939; Canberra Times, 19 Sept. 1939.

13 AM Sir George Jones, interview, 14 Sept. 1977.

14 Empire Air Training Scheme, War Cabinet paper, [ca. 30 Nov. 1939], NAA: A2671 43/1939.

15 Robert G. Menzies, 'Department of Defence Co-ordination Functions, Machinery and Procedure', 23 Dec. 1939, AWM: 54 243/6/157.
} 
up the challenge of overseeing the development of recruiting depots, training schools, and new establishments to receive the thousands of men who were responding to the nation's call to arms. He had hoped to return in the company of Air Vice Marshal Richard Williams, expecting that Dicky Williams, currently exiled on secondment to RAF Coastal Command, would be re-appointed as Chief of the Air Staff. Williams and Fairbairn were old confidants. The then CAS had secretly briefed the backbencher Fairbairn to take up the Air Board's case against the Ellington Report during the 1938-39 Budget debates. Brought from Britain by the government in response to community consternation over a series of fatal accidents, Sir Edward Ellington had concluded that the training of RAAF flying instructors was 'not altogether satisfactory', and 'a high proportion' of accidents (the rate of which was allegedly worse than the RAF) were due to 'disobedience of orders or bad flying discipline'. ${ }^{16}$ The Air Board had been outraged by what they saw as a superficial and inaccurate assessment of their performance by a 'very shy and reserved' man who had not faced them personally. ${ }^{17}$

Fairbairn, necessarily attacking his friend, Defence Minister Geoff Street, had carelessly used information in Parliament that could only have come from Williams. By so doing he seems, unwittingly, to have firmed the government's resolve to replace the CAS. Behind the scenes, Williams was informed, there were at least three ministers (one of them almost certainly Dick Casey) keen to exchange him with an RAF man. Two senior Army figures, Sir Harry Chauvel and Sir Brudenell White, also had 'a finger in the pie'. Whatever the origins of the advice, the government was determined to insist on accountability. As an embarrassed Geoff Street was to admit: 'It is politically expedient for the Government to send you to England at the present time.' Williams, celebrated in print as a man with no 'pals or chums' and with no known vices, had been made a scapegoat. With no satisfactory British officer available, he was replaced as CAS by his rival, Air Commodore S. J. 'Jimmy' Goble. ${ }^{18}$ Dissension and conflict in the senior ranks did not end there. Goble in turn was undermined, and lost the confidence of Fairbairn and, more importantly, the Prime Minister. He resigned amidst controversy within 10 months, misguidedly expecting that the government would accept his demand that a disloyal RAF officer on the Air Board would be removed.

Now, as Minister, Fairbairn wanted a man he knew and could trust by his side. By bringing Williams back as CAS he would be putting right the damage he had carelessly done to the RAAF leader's career the previous year. But Menzies had

\footnotetext{
16 'Report by Marshall [sic] of the Royal Air Force Sir Edward L. Ellington...', 16 July 1938, courtesy of Parliamentary Library, Canberra. The situation in the U.K. was, if anything, worse than in Australia (Wg Cdr Jeff Jefford, 'Accidents Investigation, Institutions and Attitudes 1919-1945', Royal Air Force Historical Society Journal, 37, 2006, pp.35-55). Lord Gowrie to Capt. L. S. Bracegirdle, 25 May 1938, Gowrie MSS NLA MS2852/5/10.

17 Lord Gowrie to Capt. L. S. Bracegirdle, 25 May 1938, Gowrie MSS NLA MS2852/5/10.

18 Williams, These Are Facts, p.244; 'Dicky was completely and absolutely "pure"' (Sutherland with Ellison, Aces and Kings, pp.56-7).
} 
other ideas. He was aware that Williams had divulged confidential information to Fairbairn to be used against the government, and that he had also stirred up agitation in the flying community. Menzies, believing with justification that there was no obvious Australian candidate apart from the unacceptable Williams, wanted an RAF officer to head the RAAF. He had briefed Stanley Bruce and Dick Casey, who was in London before Fairbairn, to begin the search for a suitable senior man. To Fairbairn's chagrin, Menzies proved determined. Williams would not get the job. The British officer on offer, 62-year-old Air Chief Marshal Sir John Steel, had been recalled from retirement to become AOC Reserve Command just before war broke out. There was one other possibility, Air Marshal Sir Charles Burnett, an Inspector General of the RAF. Burnett was 57, had served in France and Palestine during the 1914-18 war, held senior Air Ministry appointments, commanded the RAF in Iraq, led the Training Command from 1936 to 1939, and was a member of the British Mission to Moscow in August 1939. He was a plausible appointee.

When he got back to Australia, Fairbairn allegedly told his old friend Group Captain Adrian 'King' Cole — Bob Hitchcock's nemesis - a somewhat whimsical story:

After negotiating with the Air Ministry he was sent to Portsmouth to interview the officer they had selected, and Sir Charles was sent with him to act as guide and make the necessary introduction. On the way down by car they got on so well together that Jimmy decided to have Burnett and not go with the ministry's selection. ${ }^{19}$

If it was not true, it should have been. Fairbairn had not wanted a British officer at all. He was prepared to consider Australian-born Air Chief Marshals Sir William Mitchell and Sir Arthur Longmore. Unless someone of their 'standing, tact and energy' was found, he told Menzies, he was convinced it was more advisable to recall Williams. As he told Harry Wrigley, rather less whimsically, he had quickly concluded that if Steel were appointed 'he'd have been telling Cabinet what to do instead of Cabinet telling him' ${ }^{20}$ He might have been influenced against Steel by the RAF representatives he had spoken to in Canada (ACM Brooke-Popham and AM Courtney). Something about Burnett, his forthrightness and sense of humour perhaps, an aura of authority and willingness to use it, made him the least worst option. Whatever the attraction, not only did Fairbairn reject the RAF nominee endorsed by Casey and approved by Menzies, he made sure that the British government and the chosen man understood that he saw the appointment as being for a term of just one year. Then, in a conscious act of defiance of the Prime Minister and the Cabinet, he told Williams, whom he intended to promote to Air Marshal, that he would be recalled to Australia as second member of the Air Board, with the implied succession to Burnett. 


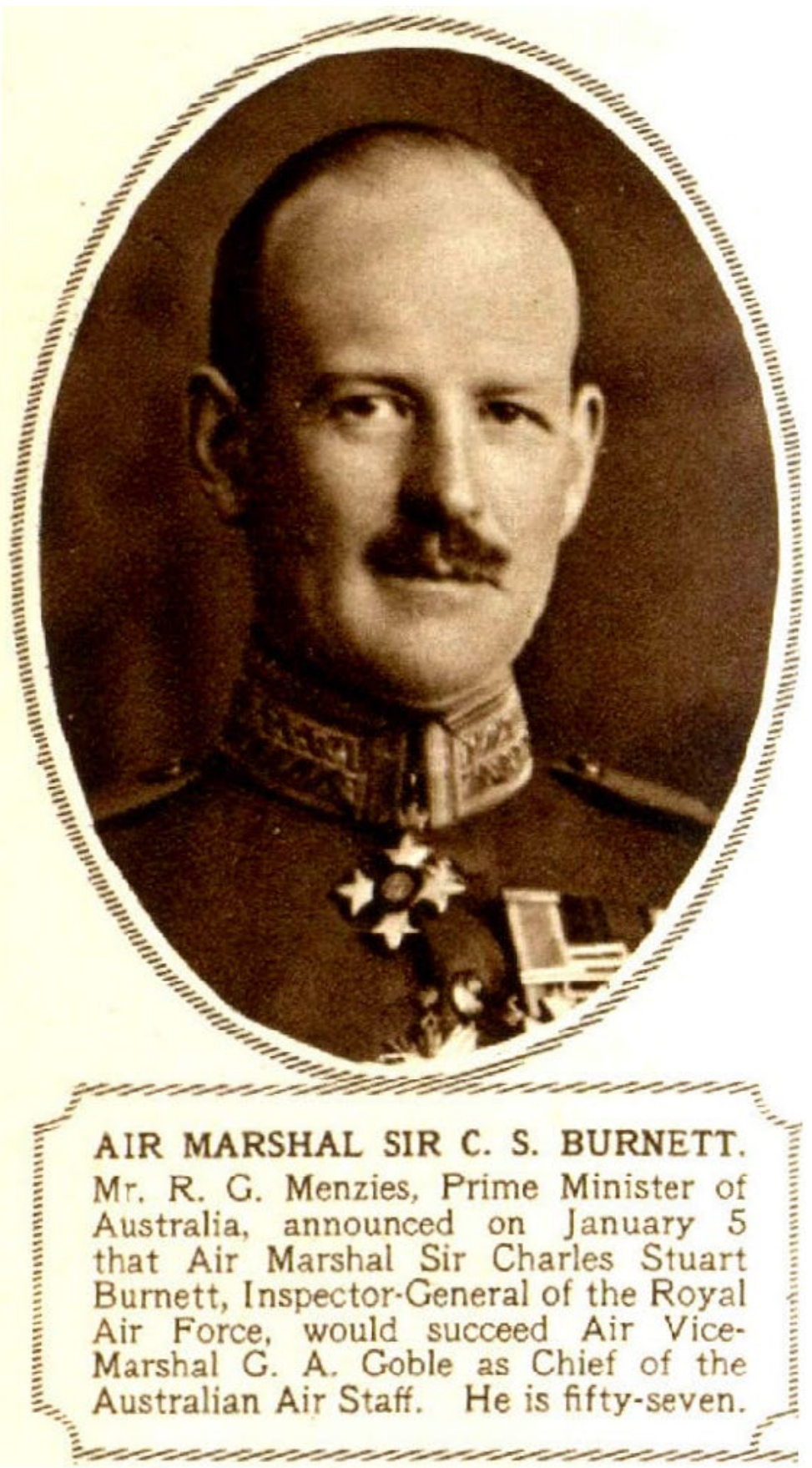

Sir Charles Burnett: an outstanding personality at home, soon to be abroad (Illustrated London News, 13 January 1940, Issue 5256, p. 55, courtesy of the National Library of Australia) 
It was impossible for Menzies to deny Williams the higher rank, but the War Cabinet gave a clear signal to Fairbairn that he had overstepped the mark: they made the promotion temporary with no increase in pay, and decided explicitly that whatever post Acting Air Marshal Williams did take up would 'not imply any right of reversion to the post of Chief of the Air Staff'.$^{21}$ A baffled and annoyed Fairbairn had told Williams: 'While I am to be politically responsible for the Air Force others are making arrangements which tie my hands so far as control of the efficiency of the Service is concerned.' As Williams would put it in his memoirs: 'By now Fairbairn was wondering whether he was a Minister or a clerk. ${ }^{22}$

On Fairbairn's return to Australia, he explained to the War Cabinet that he was 'under the erroneous impression that he had full authority to make an appointment to the post of Chief of the Air Staff'. ${ }^{23}$ Stanley Bruce had warned Menzies that 'Fairbairn might feel impelled to resign if the commitment he entered into believing he was authorised to do so, was repudiated'. Disingenuous as Fairbairn's apology was, it sufficed. When the new appointments were announced, the Prime Minister let it be known that henceforth there was to be closer ministerial direction of the Air Force, to which end the Minister for Air would preside at all important meetings of the Air Board. ${ }^{24}$ The government was saved the embarrassment of having to explain the supersession of Goble while letting it be seen that when Service chiefs disagreed with them, as Goble was understood to have done, the Cabinet would prevail. The message of firm ministerial control was reinforced by allowing photographers into Sir Charles Burnett's first meeting of the Air Board on 20 February 1940. At the head of the table sat the Minister for Air, flanked on his left by Burnett but on his right by the civilian Secretary of the Board, F. J. Mulrooney. The Secretary of the Department of Air, Melville C. Langslow, who had been commissioned in the AIF Pay Corps and liked to be addressed as 'Major', was the only other member not in uniform. ${ }^{25}$

The advent of a new regime was signalled that day by Fairbairn's approval of a request to modify his own pre-war decision that no hardwood floors should be covered with linoleum. Henceforth RAAF Sick Quarters, Link Trainer rooms, bedrooms and passages for officers, cadets and NCOs, and passages in airmen's quarters would all be quieter, cleaner, safer. Mel Langslow, installed as

\footnotetext{
21 The story of Fairbairn's resistance to the pressure to appoint a British Chief of the Air Staff was well told in Gillison, Royal Australian Air Force 1939-1942, pp.74-8. See also Coulthard-Clark, The Third Brother, p.163 and the same author's valuable article, "A Damnable Thing": The 1938 Ellington Report and the Sacking of Australia's Chief of the Air Staff', Journal of Military History, 54 (3), July 1990, pp.307-23.

22 Williams, These Are Facts, pp.252-6.

23 War Cabinet Agendum and Minutes, 4 Jan. 1940, NAA: A2673 80, A2670, 8/1940.

24 The Age, 5 Jan. 1940.

25 Richard Kingsland, 'Langslow, Melville Cecil (1889-1972)', John Ritchie (ed.), Australian Dictionary of Biography, vol. 15, MUP, 2000, pp.58-9.
} 
Secretary of the Air Department in the hope that his uncompromising frugality would contain any ministerial or CAS extravagance, might well have choked. The Air Minister himself had played no part in the selection of his departmental head. Like the heads of all the Service departments, each of them previously the Finance Members of their respective Boards, Langslow was the choice of the Prime Minister, guided by his close advisor Fred Shedden. Exhausted by the travel and travail of the last two months, Fairbairn was rushed to hospital, ordered to rest for several days. It was the second time in a month. To the irritation of his doctors he had risen from his bed to attend the War Cabinet on January 25. In conformity with the Prime Minister's directive that he should chair significant Air Board meetings, he had previously summoned the Board to his hospital bedside to discuss the criteria for aircrew to be sought in a forthcoming recruitment drive. ${ }^{26}$

The press needed little prompting to sense the discontent within the upper ranks of the RAAF at the appointment as their Chief of a modestly regarded British officer nearing retirement, a man who had never been in Australia. Sir Earle Page, suffering the back-bench irrelevance of a discarded Country Party leader, had called the decision to appoint a non-Australian 'staggering' - a comment that might have been taken more seriously had he not been Deputy Prime Minister when Sir Ragnar Colvin and Ernest Squires were appointed from Britain to lead the Navy and Army. The government responded with selective briefing of its own, and crisp statements through gritted teeth by Fairbairn about Burnett's 'exceptional ability with the whole problem of training at his finger tips'. The Prime Minister won no friends in the RAAF by the tactless and contestable statement that Air Chief Marshal Burnett is being brought to Australia so that we will not have to ask our very limited number of relatively senior officers to undertake a task far beyond their experience.' The demonstrated dispensability of Goble and Williams, and the evident determination of Menzies, were chastening. Within days the Sydney Morning Herald's aviation correspondent retracted, saying that a 'careful check of opinion' showed that a majority of RAAF officers supported the appointment. Not knowing whether they would be winners or losers under the new regime, those in the upper echelons were naturally divided. But the initial wounded pride of some top commanders was as nothing to their dismaying realisation that Burnett had little knowledge of the RAAF, little concern for the home defence of Australia, little regard for the men who were to sit around the Air Board table with him, and no intention of being in thrall to inherited arrangements and expectations. Like him or not, he

26 Air Board Agenda 2651, approved by Minister for Air, 20 Jan. 1940, NAA: A4181, 17; Sydney Morning Herald, 22-26 Jan. 1940. For the irascible Burnett's general attitude to wartime expenditure, see John McEwen: His Story, n.d. p.40. 
was their leader. Autocratic and abrupt as some senior colleagues would find him, he was to exhibit a 'tremendous initiative and mental energy' they had never previously encountered. ${ }^{27}$

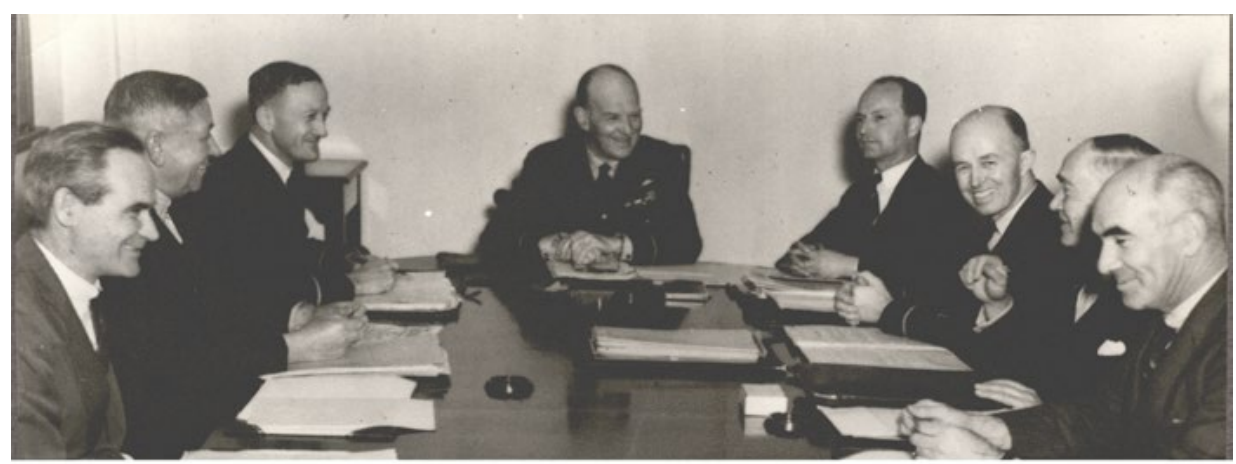

AIR BOARD - Jaly 1940

Air Chief Marahal Sir CHARLes S. BURNeTt KCB, CBE, DSO, RAF, (CAS)

\begin{tabular}{|c|c|}
\hline Air Vico Marahal H. N. WRIGLEY CBE, DFC, AFC, (AMP) & F. J. MULROONEY EAY, (SAB) \\
\hline R. LAWSON Esq., OBE, (DGSP) & Air Marnhal R. wILLIAMS CB, CBE, DSO, (AMOE) \\
\hline C. V. KELLWAY E\&q, (FM) & W. SYDNEY JONES E\&q., (BM) \\
\hline & M. C, LANGSLOW Eaq., MBE, (SDA) \\
\hline
\end{tabular}

The Air Board: happy at their work, July 1940

(Courtesy of the RAAF Museum)

\section{A minister and his friends}

At the outbreak of war there were 310 officers and 3179 airmen in the RAAF; there were an additional 194 Citizen Force and Reserve officers. ${ }^{28}$ Harry Cobby, rescued by Fairbairn, was an eminent representative of the oldest of several

27 Daily Telegraph, 9 Jan. 1940; undated note on Burnett, RAAF Historical Branch, in John Robertson and John McCarthy (eds), Australian War Strategy 1939-1945: A Documentary History, UQP St Lucia, 1985, pp.55-7; Canberra Times, 8, 9 Jan. 1940; F. M. Bladin, typescript memoir, 1953, AWM: MSS 886. See NAA: A705, 163/1/296, A2908, A28, and M2740/ 65 for Burnett's appointment on a salary of £3000 sterling, partially paid in the UK, and other benefits. Jim Fairbairn vetoed his request to bring his personal servant who, in any case as Fairbairn pointed out, could not have stayed at the Melbourne Club where the CAS proposed to reside. Press reports on the reception of Burnett are usefully distilled in Neil Kendall Quarmby, 'Regrettable at Best? A Reappraisal of Sir Charles Burnett's Effect on the Royal Australian Air Force 1939-1942', BA Hons thesis, Department of History, Faculty of Military Studies, Royal Military College of Australia, University of New South Wales, 1985, p.13. For a senior colleague's testimony that Burnett 'could not tolerate opposition of any kind', see 'Wrigley, Henry Neilson CBE DFC AFC (Air Vice Marshal)', Interviewer/Recordist Frank Marshall, ACCNUM S00416, 3 Squadron AWM Collection.

28 Alan Stephens, 'An Analysis of the Development of Doctrine in the Royal Australian Air Force 19211991', PhD thesis, University College, University of New South Wales, 1992, p.188. 
identifiable cadres of RAAF officers. ${ }^{29}$ Most recently there had been an influx of commercial pilots and aero club members. The latter in particular were a concern for George Jones and others at HQ who thought that the aero clubs had been inclined to cut corners to get their paying customers through. ${ }^{30}$ The alleged failure of the government to use the schools to full capacity in the early months of the war would be the leading charge in a litany of criticisms published by the Sydney Morning Herald in May 1940. The resumption of Citizen Air Force flying training in 1932 had opened a door for young men of means who liked to fly while pursuing a civilian career. Wilfred Brookes, for example, then a trainee with the family firm of Australasian Paper and Pulp Co. Ltd, had come through this door in a group of 30 in 1926. Before them in the 1920s and through the middle 1930s there had been a steady trickle of men who enlisted as cadets, some of them like Alan Charlesworth, Val Hancock, and Fred Scherger with previous Army experience, perhaps even Duntroon graduates. A small number of them had also enjoyed four-year commissions in the RAF. The Duntrooners, embraced by Dicky Williams for their supposed administrative competence, were regarded as a select race, resented by both younger and older men for 'getting all the good posts'. ${ }^{31}$ The originals, survivors of the Great War in Europe and the Middle East, and of another two decades of flying in Australia and around the globe, had special bonds and memories. Cobby could recall with wonder and gratitude the training he received from Major Norman Brearley in the Gosport Instructors' course. What Brearley did with an Avro 'seemed to be, to me, impossible, and I thought I could fly'.$^{32}$

Cobby, Dicky Williams, George Jones, Arthur 'Spud' Murphy, 'King' Cole, 'Mucker' Anderson, Lawrence Wackett, Frank Lukis, and others were uniquely connected. And Jim Fairbairn was one of them. Made a Wing Commander, and shortly afterwards promoted Group Captain, Cobby was appointed on 25 July 1940 as Director of Air Force Recruiting. On the same day Wing Commander Carn 'Stiffy' Wiggins arrived from the Department of Civil Aviation, where he had been Chief Electrical Engineer, to resume his old role as Director of Signals. Wiggins was the only member of the civil aviation administration who had emerged with his reputation intact if not enhanced by his appearances in the inquiries into the Kyeema disaster. ${ }^{33}$ Cobby soon found ex-colleagues everywhere: 'the old team is back in harness...for the duration and whatever

\footnotetext{
29 GpCpt D. J. Lancaster, 'The Social Dimension 1921-1939', in Barry Sutherland (ed.), Command and Leadership in War and Peace 1914-1975, Proceedings of the 1999 RAAF History Conference, Canberra 29 Oct. 1999, Air Power Studies Centre, Canberra, 2000, pp.71-82. The data underlying this analysis can no longer be found.

30 AM Sir George Jones, interview, 14 Sept. 1977; AVM G. C. Hartnell, interview, 11 April 1978.

31 ACM Sir Frederick Scherger, interview, 2 Sept. 1978.

32 A. H. Cobby, High Adventure, Robertson \& Mullens, Melbourne, 1942, p.181.

33 Department of Defence Air Accidents Investigation Committee, 'Report...on Kyeema...', 5 Dec. 1938, p.20, NAA: MP 1353/3; Affleck, The Wandering Years, pp.156-7.
} 
period we are wanted for afterwards' ${ }^{34}$ But not everyone was happy about the recall of the old team. Among the many unimpressed officers, Squadron Leader Stuart Campbell, himself summoned to service after 10 years in business and Antarctic exploration, would tell the war correspondent Gavin Long's wife tales of appalling ineptitude and disorganisation. Four decades later Sir Frederick Scherger was still scornful of the appointment of Cobby and other 'World War I chaps that persisted in spite of the certain knowledge that they lacked the necessary attributes to do the jobs they were posted to' ${ }^{35}$

Getting the administration of the burgeoning RAAF to settle down into efficient routine was a taxing assignment for Jim Fairbairn. Constrained initially as he had been by a seniority system in which at the outbreak of war 16 of the top 56 officers were World War I veterans, he was gradually able to take advantage of the demands of an expanding organisation to bring in able men of business. ${ }^{36}$ For all his knowledge of the aviation world, finding the right men for new jobs was not easy. For the key role of Director-General of Supply and Production, devised by Burnett to replace the old Air Member for Supply, he was guided to one of A. B. Corbett's former colleagues in the Postmaster General's Department, the Chief Engineer Robert Lawson. As chairman of an interdepartmental committee investigating the administration of the Civil Aviation Board late in 1938, Lawson had quietly shifted to the Director-General and the Secretary of the Board as a whole much of the blame for the Kyeema disaster initially laid personally on the Finance Member Mel Langslow for his 'insistence on the limitation of expenditure'. Langslow had found a sympathetic ally and Fairbairn recognised the value of an effective and fearless administrator. It turned out to be an outstandingly successful appointment; and Lawson stayed at the centre of RAAF business and technical affairs for the rest of the war.

Sometimes well-meant choices proved mistaken. For all his years in the civil aviation administration, for example, Harry Cobby was not cut out to direct a critical element of a complex, restructured, and rapidly growing wartime Service. He was popular with subordinates who were given latitude. Val Hancock thought him a 'lazy bloke' but a good leader with a gift for talking people into doing things for him. ${ }^{37}$ But he was uncomfortable in dealing with colleagues and superiors, some of whom were unimpressed by his cheery detachment. He was later to do good work in the field, perform heroically when a Catalina in which

34 Cobby, High Adventure, p.196.

35 Mary Jocelyn Long MSS, NSW State Library, ML MSS 7191; Scherger, interview, 2 Sept. 1978. Scherger did not mention, but doubtless had in mind, the debacle in 1945 when Cobby was found to have failed to maintain 'a proper control over his command' when eight of his officers submitted identical letters resigning their commissions in protest against the alleged futility of the operations in which they were engaged. Wiggins, a Duntroon graduate who transferred to the RAAF in 1925, was probably exempted from Scherger's condemnation. 36 Norman Ashworth, How Not to Run an Air Force! The Higher Command of the Royal Australian Air Force During the Second World War, vol. One - Narrative, Air Power Studies Centre, Canberra, 2000, pp.3-32.

37 AM Sir Valston Hancock, interview with Ken Llewellyn, 30 June 1993, AWM: S01657. 
he was travelling crashed at Townsville, but was to come to grief towards the end of the war when unwisely posted to a senior appointment at Morotai by George Jones, then the CAS. Like Lord Kitchener in 1914, however, if not a great man he was certainly a great poster. ${ }^{38}$

It was not all Cobby's fault of course. But, with recruitment in an embarrassing state, Fairbairn had to confront his critics. The Sydney Morning Herald and Daily Telegraph had launched a scathing attack on the 'scandal of air bungling' late in May 1940 alleging, in addition to recruiting chaos, training delays and a shortage of machines for the EATS scheme. An incensed Minister responded unwisely: 'One or two aviation correspondents in Sydney are doing the work of the fifth column... The articles could only have been written in three ways, because of stupidity, because of bitterness against myself, and officers of the Air Force generally, or subversively in the interest of the enemy.' ${ }^{39}$

Predictably, the editor of the Sydney Morning Herald rejected the charges 'as so patently absurd and unworthy of any responsible Minister that it is charitable to dismiss them as the product of temporarily uncontrolled emotions'. Unsubtle he may have been, but Fairbairn did not lack political courage. In the House of Representatives he hit back. The progress of the air training scheme was, he pointed out, dependent on the provision of aircraft. That, he said, was partly out of the government's control. But, he admitted:

Certain mistakes are bound to be made in an undertaking of this size...I would like to remind the House and outside critics that the R.A.A.F. is endeavouring to set up a bigger organisation than the Broken Hill Pty Ltd in less than 18 months.

Our recruiting staff, which now numbers 397, is comprised almost entirely of men who have offered their services from civilian life.

It would be ridiculous to expect that an organisation of this size, staffed by men with great enthusiasm but little experience would make no mistakes in the big and intricate job of dealing with more than 80,000 applications from young men wishing to be pilots, observers, air gunners, educationists, electricians, fitters, air riggers, flight mechanics, cooks and a dozen other occupations. ${ }^{40}$

Fortunately for Fairbairn his friend Sir Harold Luxton, ex-RFC, shot down in August 1917, ex Lord Mayor of Melbourne, ex-UAP MLA, and racehorse breeder, had already provided the answer. Luxton was chairman of directors

38 J. D. Walker, 'Red Tape or Red Blood: Civil Aviation Administration in 1938', Tempus Aerianus: Australian Civil Aviation in 1938, Department of Aviation Historical Society, 1988, p.8; Hayes, Angry Skies, p.108.

39 Aircraft, 18 (9), 1 June 1940.

40 Sydney Morning Herald, 24 May 1940; The Herald, 29 May 1940. 
of the National Mutual Life Association where his vice-chairman, Sir Brudenell White, had just been recalled to service as Chief of the General Staff. Very early in the war Luxton, who also chaired the board of the Metropolitan Gas Company, had released his assistant manager at the gas company, Albert Chadwick, to help with equipping the proposed six-squadron air expeditionary force. Now Luxton himself would take a lead as Victorian director of the Empire Air Recruiting Committee. More important, when listening to Fairbairn's woes over a drink at the Melbourne Club in April 1940, he had suggested that Chadwick, his key executive and sales controller, a wartime air mechanic with Dicky Williams's No. 1 Squadron Australian Flying Corps and now a pilot officer in the Reserve, was the man to sort out the paralysing organisational muddle and inundation of letters from potential recruits. As Recruiting Liaison Officer, appointed 'by special arrangement' and rapidly advanced in rank to squadron leader, Bert Chadwick had set about reorganising the recruiting program. Initially confronted with 12 wheat sacks of mail - there had been 68000 applications by March 1940 - he brought in other men he could trust, and conquered the chaos. ${ }^{41}$

As long as his position was not slighted Cobby was content to be an affable figurehead. With direct access to the Minister, Chadwick, effectively supported by Dick Elford in turning oral briefings into appropriate documentation, created a network of over 500 local committees, each headed by the town or shire clerk or some other 'worthy', and including people like headmasters and RSL subbranch presidents. When regular public servants resisted allocating funds to recruiting committees flushed with devolved authority to spend, Fairbairn successfully took the issue to Cabinet. It was not long before Chadwick also ended the cosy, inefficient, and inequitable practice by which RAAF officers and airmen were directing friends seeking to enlist to amenable staff officers in the Directorate of Recruiting. Henceforth all enquiries were to be passed to the recruiting centre in Queen Street. ${ }^{42}$

As for the Air Minister himself, not only friends, and friends of friends, but relatives as well, all of them able and eminently qualified, were being drawn into positions where they could be useful. There was no disguising the influence that had brought Osborne Fairbairn into the RAAF in April 1940, 'persuaded' by his brother, as his daughter ruefully recalled, to lead No. 1 Wireless and Air Gunnery School (EATS 1 WAGS) at the Ballarat Showgrounds. ${ }^{43}$ The Minister

\footnotetext{
41 Gavin Long, The Six Years War: A Concise History of Australia in the 1939-45 War, Australian War Memorial and AGPS, Canberra, 1973, p.27. RAAF aspirants outnumbered AIF and RAN applicants three to one and nearly 10 to one respectively. So congested was the RAAF recruiting organisation that 25 per cent of those who signed applications did not respond when eventually called up.

42 GpCpt. A. E. Chadwick (Director of Manning) to Air Member for Personnel, May 1945, copy, Chadwick MSS, courtesy of Sir Albert Chadwick; Chadwick, interview, 14 June 1978; Charles Fahey, 'Chadwick, Sir Albert Edward (Bert) (1897-1983)', Di Langmore (ed.), Australian Dictionary of Biography, vol. 17, MUP, 2009, pp.198-9. 43 Alethea Russell to $\mathrm{CH}$, (email), 20 Jan. 2009. At the time, in addition to his property responsibilities, Osborne Fairbairn had in his charge four children of his own, his orphan niece, and two British evacuees.
} 
may not have played a direct part in bringing his brother-in-law Ross GreySmith into the RAAF's Administrative and Special Services Branch, but the wellknown connection could not have been a hindrance. Grey-Smith, a solicitor, was a former committee member of the Royal Victorian Aero Club. Commissioned on 2 July 1940, he became chief instructor at the School of Administration, which opened at Laverton on August 6.

Three weeks later, Fairbairn was confronted with a dilemma which could not be resolved by anyone else, friend or relative, and for which none of his previous experience had prepared him. To make an intrinsically sensitive problem worse he was required to reject the wishes of the Chief of the Air Staff. It was the delicate matter of precedence among the RAAF chaplaincy. Burnett, briefed by Williams, had thought it sensible to follow the British practice of giving chaplains rank and designating a Chaplain-in-Chief. Given that 45 per cent of RAAF personnel were Anglican it seemed to them natural that a chaplains' branch should be headed by an Anglican. But they had not counted on the combined resistance of Roman Catholic, Presbyterian, and Methodist representatives who gathered at a conference with Burnett and the Director of Personal Services, Group Captain Joe Hewitt, on 19 July 1940. In unison the churchmen pointed out that there was no Established Church in Australia and the idea of Anglican primacy was unacceptable. To consolidate their position, Monsignor P. F. Lyons, instructed by Archbishop Daniel Mannix, called on Fairbairn the next day, a Saturday, and elicited from him a signed confirmation that Burnett had been right to accept their argument: the Australian Constitution knew nothing of an Established Church; therefore the four most senior Staff Chaplains would have authority only within their own denominations. ${ }^{44}$

Whatever the tribulations behind the scenes, in public as well as private, the Minister for Air did not disguise his pride in the potential achievement of the Empire Air Training Scheme. For the first time in Australian history, he had told a meeting at Wesley Church in Sydney on 4 February 1940, the nation had embarked on an enterprise in which failure could mean complete disaster for the British peoples throughout the world and in which success can make victory and security against aggression certain'. He had already told the Prime Minister much the same thing: 'The only activity that we have undertaken which could lead to the winning or losing of the war by our failure or success in carrying out our undertaking is the Empire Air Training Scheme. ${ }^{45}$ It was a large claim that carried with it a huge burden of responsibility.

44 Davidson, Sky Pilot: a History of chaplaincy in the RAAF 1926-1990, pp.2/2, 3; Hewitt, Adversity in Success, p.4; NAA: A705, 36/1/99 ('Chaplains - policy file').

45 John Malcolm McCarthy, "The "surrender" of aircrew to Britain 1939-45', Journal of the Australian War Memorial, vol. 5, Oct. 1984, p.4; McCarthy, A last call of empire, p.16; J. V. Fairbairn to Prime Minister, 16 Jan. 1940, NAA: A5954, 235/7. 
When Menzies had outlined the scheme in Sydney on 15 December 1939 he had foreshadowed that a total of 26000 men would be trained, of whom 10400 were to be pilots and 15600 observers, radio operators and air gunners. Most were to be trained in Australia, except for a few thousand in Canada. Australia, Menzies said, would establish and pay for 34 new training schools, supply all aircraft for elementary training, and bear the estimated cost over three years of A£50 000 000. In return, Great Britain was to supply or pay for all engines required for elementary trainers, a proportion of the cost of the intermediate trainers (Wirraways), and all the aircraft for advanced training (Fairey Battles and Avro Ansons). Great Britain would also supply wastage replacements and spare parts for maintenance. Australian instructors were to be supplemented by instructors lent by the Royal Air Force. ${ }^{46}$ It was early February 1940 before the report of the Australian Air Mission at the Empire Air Conference in Ottawa was 'noted by the War Cabinet'. ${ }^{47}$ By March, the scheme had expanded way beyond the original forecasts. The RAAF had enrolled 68000 volunteers, 11500 as aircrew. The first EATS course was inducted on April 29 at Somers in Victoria where the former Cabinet minister and heroic AFC escapee from Turkish captivity Tommy White, one of the first four graduates from Point Cook in 1914 and now back in uniform as a flight lieutenant (temporary squadron leader), was the commanding officer. But by July, in spite of stringent educational standards being applied, the flood of recruits for the RAAF itself was overwhelming the Air Force's capacity to absorb them. Fairbairn had to tell the War Cabinet that training units could not be organised because of the difficulty in devising a syllabus and providing the necessary instructors. ${ }^{48}$

\section{Command and control}

To cope with the massive growth of the Air Force at home, as well as the huge demands of the EATS, a new command system was announced in March 1940. It was designed, according to minutes for ministers as well as in the formal statement published on Anzac Day, to decentralise administration and allow headquarters staff to concentrate on major policy. In fact the new structure was not greatly different from what had preceded it. A great deal of authority remained at the centre, reflecting Burnett's advice on how functions should be allocated. Fairbairn appears to have been content to let the irascible and

\footnotetext{
46 Flight, 31 Dec. 1939, p.516.

47 War Cabinet Minute, 6 Feb. 1940, NAA: A5954, 803/1, cited in Helson, The Private Air Marshal, p.134.

48 War Cabinet Minutes, 2, 9 July 1940, NAA: A2673, 283, 286. One reason why instructors were in short supply was the determination of qualified pilots to gain operational postings. Fairbairn himself tipped off Clive Caldwell during a chance meeting at the Australian Club that his course graduates were to become EATS instructors. Caldwell contrived to resign from the RAAF and re-apply for a later course (Kristen Alexander, Clive Caldwell, Air Ace, Allen \& Unwin, Sydney, 2006, pp.9-10).
} 
indefatigable Burnett have his way on most professional matters. If the Minister did not put his own stamp on the structure of the Air Force nor did he make radical changes to the personnel who were to deliver on the ambitious program for which he was responsible. With both Williams and Goble sidelined, their pre-war rivalry no longer a source of tension for their subordinates, he could hope for a more harmonious higher command group. But the men on whom he was to rely were confirmed or assigned on the customary seniority principle that had prevailed since the RAAF was created.

The Cabinet had endorsed a regionalised operational structure and a reorganised Air Board. ${ }^{49}$ Though press releases and public relations briefings made it look like a whole new regime, the truth was that the new regional commands were in effect the same as the previous No. 1 (Melbourne) and No. 2 (Sydney) Groups that had been created at the beginning of the war. The same men led them. Thus a Southern Area command based in Melbourne was announced under No. 1 Group's Group Captain Harry Wrigley, with Senior Air Staff Officer Wing Commander Leon V. Lachal and Senior Administrative Staff Officer Group Captain Joe Hewitt, who would shortly become Director of Personal Services. A Central Area command with headquarters in Sydney was still to have Air Commodore A. T. 'King' Cole as Air Officer Commanding. Cole's Senior Air Staff Officer was to be Wing Commander Alan Charlesworth; the Senior Administrative Staff Officer was Wing Commander D. E. L. Wilson. The man on whom Sir Charles Burnett had come to rely more than anyone else, Group Captain W. D. 'Bill' Bostock, remained Deputy Chief of Air Staff with Wing Commander (promoted to Group Captain in June) F. M. 'Dad' Bladin as Director of Operations and Intelligence.

At least one of the appointments Fairbairn initiated personally was that of his EATS travelling companion and advisor, temporary Group Captain George Jones, formerly Assistant Chief of Air Staff, to become Director of Training in the branch of the Air Member for Personnel, Air Commodore W. H. Anderson. Fred Scherger, who then held the post was in effect demoted to Assistant Director. 'I think it is better that we have a World War I man there', Fairbairn told Scherger after the younger officer returned from Perth to find Jones sitting in his office. 'Oh boy, you swallow hard when that happens.' Scherger bore no grudge. Fairbairn, he said, was 'a remarkable man, a ton of guts, by jove he was a courageous bloke and a damn good pilot' ${ }^{50}$ Although he did not know all of these senior men well, Fairbairn knew most by reputation. Some were indeed very old friends. Adrian 'King' Cole, like George Jones a wartime AFC ace, had been in the same house at Geelong Grammar School. Cole, two years older than 'Jimmy', had taught the youngster to ride his bicycle in 1908 'in order to gain

49 'Expansion of R.A.A.F. Organisation and Administration Part I, Higher Organisation and Command', Narrator F/O G. E. Mayman, AWM: 54 81/4/143; The Herald, 4 March 1940.

50 ACM Sir Frederick Scherger, interview, 2 Sept. 1978. 
permission to ride it myself'. Meeting up again after the war, Cole recalled, 'At a Picnic Racecourse in Queensland, where I had landed in the course of an air survey in 1919 in exchange for a spectacular "Joy Ride", he had helped me to "pick the card" for the only time in my life. ${ }^{.51}$

Men at the top whom the Minister could trust were a start. But critical also to the rapid expansion of the Air Force was securing candidates for flying training who conformed to the RAAF's desiderata. By March 1940, Fairbairn had been briefed on the difficulty in recruiting young men with sufficient knowledge of mathematics and physics. To his dismay he learned from the officer in charge of the recruiting depot in Melbourne that the six associated public schools together were sending fewer applicants for training as air crew than the Melbourne Technical School. His blood, he said, ran cold at the news. But there was some comfort from his own school. He was delighted to learn that James Darling, the headmaster of Geelong Grammar, was signing an average of two applications for the Air Force every day. Darling admitted he was uneasy about signing testimonials for boys who did not have intermediate maths and physics: 'I am afraid I have been rather reckless about their educational qualifications and hope that this will not be a trouble for somebody else.' Fairbairn hastened to re-assure him:

Not only is the Air Training Scheme the most important part of the Commonwealth's war effort, but air crew trainees will have much greater opportunities of having their capacity utilised to the full than those who join the A.I.F. in view of the fact that 50 per cent of pilots and observers will receive commissions upon the completion of their training. As a great number of the trainees will be young men who have had barely the required education, any boy with reasonable personality and initiative who has had a public school education should be almost certain to receive a commission. ${ }^{52}$

In April 1940, having seen the senior postings in the RAAF settled, Fairbairn was at last completing the reorganisation of the Civil Aviation Department. But there was a stumbling block. The Director-General wanted as his Assistant Director-General, Captain E. C. Johnston DFC, the former Controller-General of Civil Aviation. The Public Service Commissioner, Frank Thorpe, queried the appointment, noting the adverse findings of the Kyeema inquiry which reflected badly on Edgar Johnston. Fairbairn had no reason to favour an official whose department had been denounced for the shortcomings that he held responsible for the death of his friend Charles Hawker. Johnston had been passed over when

51 A. T. Cole, Merry Old Souls, pp.125-6, Cole MSS, AWM: PR88/154.

52 Fairbairn to Darling, 20 Feb and 19 March 1940, Darling to Fairbairn, 14 March 1940, Geelong Grammar School archives, Headmaster's correspondence 1940, A-F, partly quoted in Janet McCalman, Journeyings: The Biography of a Middle-Class Generation 1920-1990, MUP, 1993, p.167. 
Corbett was brought in. But the Minister had come to appreciate his formidable knowledge of Australian aviation. Perhaps too he had a lingering regard for Johnston's outstanding war record as an RFC ace with 20 victories. Seeking to break the deadlock, Fairbairn wrote to Menzies asking him to intervene on Johnston's behalf. Menzies' private secretary Corby Tritton, assuming that the Prime Minister would comply with the request, drafted a personal letter to the Public Service Commissioner for his chief to sign. But Menzies baulked. Tritton was instructed to advise Fairbairn's private secretary, Elford: 'In the light of the evidence of the Kyeema report the Prime Minister feels it would be improper for him to take action as Mr. Fairbairn suggests.'

Undeterred, Fairbairn wrote again to Menzies. Ignoring the undisguised rebuke, he began by saying that he understood from Tritton that the Prime Minister wanted 'further advice'. He admitted that he had at first himself been 'somewhat prejudiced against Johnston'. But he had found him 'most efficient' and he had done excellent work in negotiations with airline companies and in connection with the soon to be inaugurated trans-Tasman service. The failure to confirm Johnston and other senior officers of the department was creating a state of uncertainty that was not only unfair but impairing efficiency. Menzies was unmoved. While he was not going to comment on the merits of individual officers, he would not seek to influence the decision of the Public Service Commissioner. ${ }^{53}$ Fairbairn might well have suspected that Menzies' lack of enthusiasm for Edgar Johnston stemmed from his opposition to ceding control of the Empire Air Mail Scheme route from Singapore to the British. Johnston's preference for all-metal American aircraft over the British flying boats favoured by Menzies compounded his offence. ${ }^{54}$ Had Fairbairn been privy to Menzies' diary of his trip to Britain in 1935 he would have realised that the Prime Minister thought Johnston 'dull' and a 'man of limited vision'. ${ }^{55}$

In the end Fairbairn prevailed. But the Johnston appointment, like the appointment of Sir Charles Burnett at the beginning of the year, was evidence of a certain uneasiness in his relations with the Prime Minister. There had been early signs just before the war. A rambling submission by the Civil Aviation Minister on prospective British trans-Pacific air services and their possible impact on relations with the United States had left the Cabinet floundering. Menzies assumed principal responsibility with Gullett for preparing replies on the subject to the British and New Zealand governments, Fairbairn himself being effectively superseded. ${ }^{56}$ All of this was of course concealed from public view.

\footnotetext{
53 Menzies MSS, NLA MS 4936/581/22.

54 Leigh Edmonds, 'The Ultimate Imperial Air Service: The Empire Air Mail Scheme', Tempus Aerianus: Australian Civil Aviation in 1938, Department of Aviation Historical Society, Sydney, 1988, pp.22-4.

55 Ewer, Wounded Eagle, pp.58-68.

56 Agenda 121, 3 August 1939, NAA: A2697, vol. 2.
} 


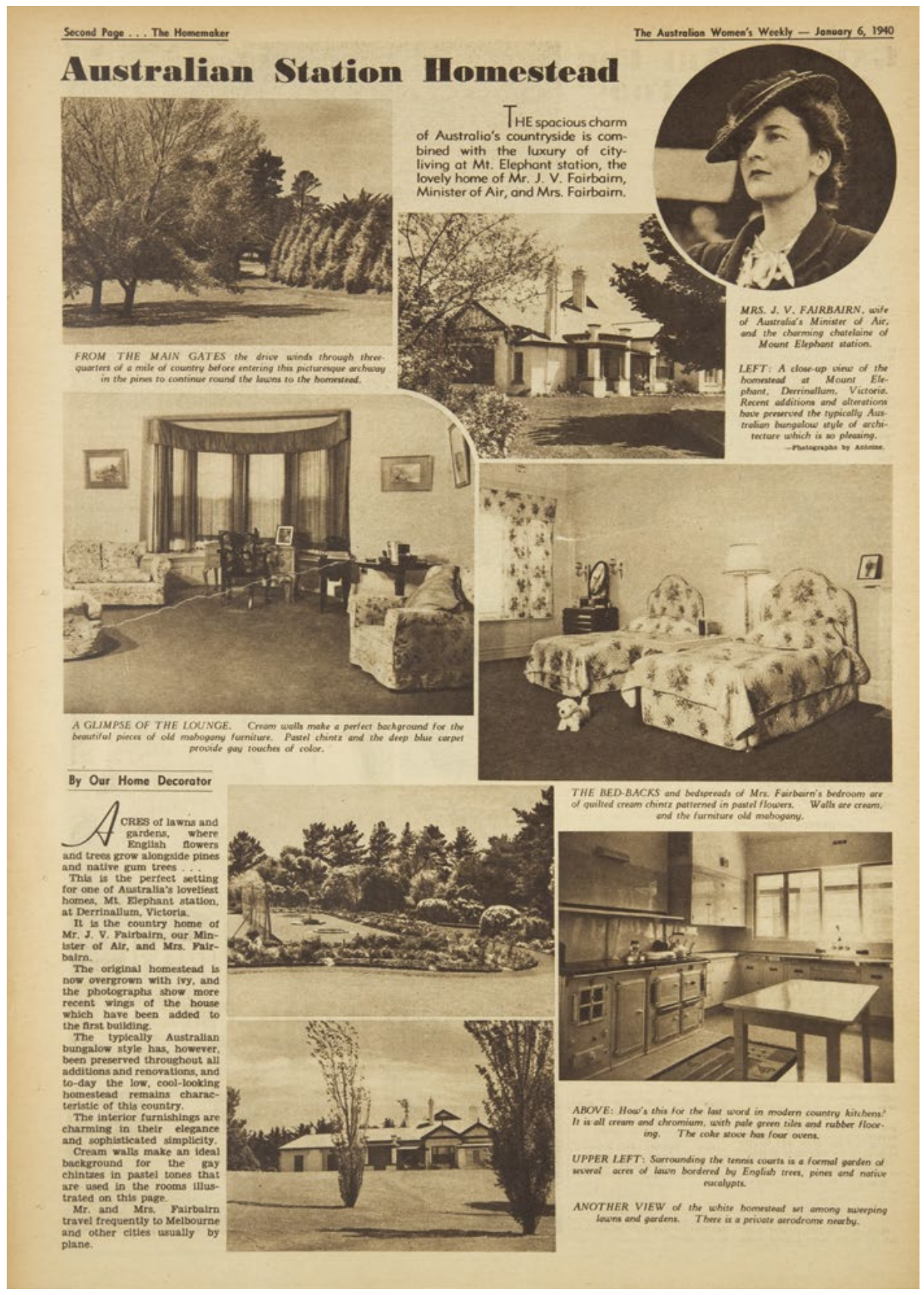

\section{Mount Elephant homestead and its châtelaine}

(The Australian Women's Weekly, 6 January 1940, p.42, courtesy of the National Library of Australia). 
Nor did the public get wind of the conflict underlying Fairbairn's announcement on 18 April 1940 of the War Cabinet's decision to place an order for 49 additional Hudson 'reconnaissance bombers' with spare engines and parts. The truth was that a significant doctrinal shift had occurred in Australian defence thinking. Relying on Burnett's advice of 'a continuous lessening of the probability' of a Japanese attack on Australia, Fairbairn had advised his colleagues to cancel an order for Beaufighters for a proposed fighter squadron. The Defence Committee had come round to the RAAF's view that it was essential to have a sea reconnaissance and bomber capability with which to find and destroy the enemy rather than rely upon intercepting hostile aircraft in the air. ${ }^{57}$ Fairbairn had announced the arrival of the first batch of Hudsons in Sydney on January 26. The new machines were to replace the Avro Ansons that were being phased out of service for home defence, with 18 set aside to equip a new squadron. The Hudsons, 86 of which were already in the country though many were still in crates awaiting construction, were, the Minister said, a great acquisition because of their reliability, power, and endurance. What he naturally did not disclose was that the recommendations of the Air Board which he had taken to the War Cabinet had been questioned by the Treasury Finance Committee, undermined by the Secretary of the Department of Defence Co-ordination, and barely secured the acquiescence of the Chief of the Naval Staff and the Chief of the General Staff. In the end, a reluctant Menzies had tipped the balance in favour of the Defence Committee's advice. Menzies had been cautioned by an unenthusiastic Shedden that it would be risky, as public opinion began to focus more on local than Imperial defence measures, to take the responsibility of not adopting the decision of the defence chiefs 'unless financial considerations absolutely preclude such a course'.$^{58}$

Finally, with the Prime Minister's concurrence, Fairbairn was to all intents and purposes admonished in a War Cabinet decision in which 'grave disapproval' was expressed of negotiations that had begun in Australia with Brown and Dureau, local agents of the Lockheed Corporation, instead of with the Commonwealth representative in the United States who was charged with making all purchases. The point was driven home by the 'instruction' that all future aircraft purchases should be made through the recently created Aircraft Production Commission

57 Stephens, 'An Analysis of the Development of Doctrine in the Royal Australian Air Force', p.189. Ewer (Wounded Eagle, pp.163-4), overlooking the reservations of the other defence chiefs, characterises this decision as based on 'a strategic appreciation of striking ineptitude'. For earlier RAAF thinking on the need for flexible deployment of resources, see David M. Stevens, 'The Impact of the Submarine Threat on Australia's Maritime Defence 1915-1954', PhD thesis, School of History, University College, University of New South Wales Australian Defence Force Academy, Nov. 2000, pp.109-10; and on the equipment implications of strategic thinking in the 1930s David Joseph Wilson, 'The eagle and the albatross: Australian aerial maritime operations 1921-1971', PhD thesis, Humanities \& Social Sciences, Australian Defence Force Academy, UNSW, 2003, Chs 2 and 3.

58 David Day, The Politics of War, Harper Collins, Sydney, 2003, pp.50-1. 
run by Menzies' appointee Harold Clapp. ${ }^{59}$ After so much tension it was something of an anti-climax when a month later Winston Churchill's Minister of Aircraft Production, Lord Beaverbrook, let it be known that the embattled British wanted the next batch of Hudsons, and Menzies agreed to their diversion to England. ${ }^{60}$ By late June, however, the War Cabinet was ready to accept the RAAF's expansion plan entailing an increase in the Home Defence Force from 19 (nominal) to 32 squadrons: seven would be reconnaissance bomber squadrons, another three would be 'general purpose', one was to be flying boats, with two fighter squadrons to be acquired later. ${ }^{61}$

There were legitimate differences of view between the Service chiefs about the priority to be given to the acquisition of extra Hudsons. Yet more than once on matters in which a minister might well feel that his judgment and preference should be accepted, Fairbairn had to fight hard to carry the day. With the Air Minister bearing the liability for decisions on the Empire Air Training Scheme that sometimes were forced upon him, the Prime Minister could allude jocularly to seeing placards insisting 'Fairbairn must go'. It was small comfort to read that Menzies had reminded the public that:

At the moment the question of whether or not Mr Fairbairn gets the sack is for me and he is not getting the sack because I happen to think that he is a pretty good minister and I know that no-one in Australia could have worked harder to make the scheme a success. ${ }^{62}$

If, as a result of some of this faint praise and of other dissonances, there was a slight coolness between the Air Minister and the Prime Minister it was barely perceptible to outsiders. But Fairbairn had reason to feel that Menzies did not accord him the respect appropriate to his role. Menzies was clever but not clever enough to hide his lack of appreciation for minds less agile than his own. Fairbairn was no intellectual. Audrey Elford, his private secretary's widow, remembered that he seemed to rely very heavily on her husband and departmental officials. ${ }^{63}$ Lady White, daughter of Alfred Deakin and wife of Sir

\footnotetext{
59 War Cabinet Minutes, 17 April 1940, NAA: A2673, 165. The background to the decision to order 31 Hudsons and 16 spare engines (not the 49 announced the next day) is in NAA: A5954, 232/10 and A705, 9/19/177. Brown \& Dureau, who advised Lockheed about long-term prospects for US aircraft sales in Australia, were receiving a commission of $\$ 2000$ per plane on the first 100 Hudsons (Lockheed Archives: Brown \& Dureau, file 092-0-5, Box 77761; Box A5189).

60 'Transfer of Lockheed Hudsons to Britain (together with Twin Row Wasp Engines for Hudsons)', NAA: A1608, G17/1/2; War Cabinet Minutes, 28 May 1940, NAA: A2673, Agendum 114/1940. 'Before an intended programme can be proceeded with, changes in the International situation throw it in the melting pot, and discussions from a new beginning are necessary' (D. H. Dureau to S. W. Voorhes, 11 June 1940, Lockheed Archives: Box A5189).

61 NAA: War Cabinet Agendum No. 151/40, 28 June 1940, cited in Stephens, 'An Analysis of the Development of Doctrine in the Royal Australian Air Force', p.191.

62 Sydney Morning Herald, 8 June 1940.

63 Audrey Elford, interview, 27 July 1977.
} 
Thomas White, a minister in the Lyons Cabinet, recalled her husband's friend as a pleasant man, but 'not brainy' ${ }^{64}$ On the other hand, Percy Spender, who sat with him in Cabinet, rated him a 'most competent man undaunted dedicated to the performance of any task allotted to him'. As a minister, Spender placed him with 'Doc' Page and John McEwen, and above the efficient but obtrusively dignified Dick Casey. ${ }^{65}$

What Jim Fairbairn had was an understanding of character gained under fire and in perilous flight. It was something that Menzies' cerebral superiority would never match. Fairbairn had experienced the drudgery of backbench life. He had an acute awareness of the impact on the reputation of a minister and his department of failures to respond promptly and courteously to inquiries and requests from fellow MPs. In April and again in June 1940, he signed remonstrances prepared by Dick Elford at the 'lack of proper organisation and supervision' that was causing him embarrassment with his parliamentary colleagues. ${ }^{66}$ What he understood about men was politically important. What he knew about aircraft and aviation made him a uniquely informed minister. As a discomfited RAAF senior hierarchy learned, he took seriously the criticisms that reached him from units about administration and equipment. An approachable minister, trusted and detached from the chain of command, could be better informed about the state of morale than headquarters staff. ${ }^{67}$

George Jones, who had risen from the ranks and was not given to indiscriminate praise, worked closely with his Minister on their trip to Canada in 1939: 'I thought he was pretty bright', was Jones's later judgement. ${ }^{68}$ Bright or not, the vastly experienced flyer Scotty Allan testified, Fairbairn had:

a lively interest in all factors connected with aviation. We therefore talked about those affairs - general training of pilots which was rather sketchy at that time, civil aviation regulations, air navigation - even meteorology as applied to aircraft movements and how much pilots ought to know or be taught. ${ }^{69}$

Fairbairn's was no academic interest. When the opportunity presented, he would find out for himself what his RAAF flyers were encountering. Thus, on 6 July 1940, the Argus reported that the previous day he had 'thoroughly tested' one of the RAAF's new Fairey Battles, Britain's fastest bomber. Strapping on a parachute, he had taken to the air at Laverton with the station commander, Group Captain Frank Lukis. Five days later he was to fly without a parachute in

64 Lady White, interview, 3 June 1977.

65 Percy Spender, Politics and a Man, Collins, Sydney, 1972, pp.29, 33.

66 NAA: A1 196, 36/501/92.

67 Report of Staff Conference No. 35..., 25 May 1940, NAA: AA1977/635.

68 AM Sir George Jones, interview, 14 Sept. 1977.

69 G. U. Allan to CH, 16 Aug. 1982. 
a War Cabinet meeting. As an unusually detailed minute recorded, the Minister for Air 'raised without Agendum' his alarm about the possibility of Pan American Airways being given landing rights in Australia. To do so would be to give away an important 'bargaining counter' for landings in Hawaii by a British trans-Pacific service. The American company's 'methods of achieving their ends' were, according to Australia's ambassador in Washington, 'circuitous and notably lacking in frankness and honesty'. And, after having been sidelined when he had raised the issue a year earlier, Fairbairn was gratified by the War Cabinet's decision to insist on government-to-government negotiations on the question of reciprocal rights. ${ }^{70}$

As the massive effort of recruiting, training, testing of new equipment and machines, and deployment of squadrons gathered speed, Fairbairn decided to fly on a morale-building tour of inspection around the nation. War Cabinet had contemplated that the Director-General of Information might use his regulatory powers to counter a barrage of press criticism, from the Daily Telegraph in particular. ${ }^{71}$ Fairbairn affected disdain: 'Splenetic outbursts against me are of no consequence..$^{72}$ The Air Minister would admit publicly on July 23 that the response to the recruiting drive had exceeded all expectations. There were 2000 RAAF recruits waiting to be called up. Many prospective pilots would have to wait until the resources were available for intermediate training. Arriving at Darwin after a 1200-mile flight from Brisbane via Rockhampton, Cloncurry, and Daly Waters, he was met by an escort of four Wirraways from No. 12 Squadron. 'I would not like to fly over this country all day long like those fellows with single engine machines,' he told reporters. 'It is tough enough with a twinengined machine.' On the ground there was a frank discussion with the Station Commander, Group Captain Charles Eaton, whose 14-point agenda included delays in construction of the base, inadequate defences, a shortage of spares and equipment, and promotions. Fairbairn was impressed with what he saw. On his return he sent a message to Eaton that he 'was particularly pleased with the keen-ness and efficiency of all ranks of the station'. The very high morale was, the Minister added, 'particularly praiseworthy in view of the definitely difficult conditions under which all have been living and working since the establishment of the station'. For their part Eaton and his team found 'his cheerful presence and vigorous optimism were an encouragement and inspiration to all' ${ }^{73}$

70 'Air Service in the Pacific - Pan American Airways', War Cabinet Decision, 11 July 1940, NAA: A5954,

344/15; John Gunn, Challenging Horizons: Qantas 1939-1954, UQP, St Lucia, 1987, pp.18-22.

71 War Cabinet Notes, vol. 2, 16 July 1940, NAA: A5954, 729/2.

72 'Air Training Scheme: Irresponsible Criticism Deprecated'. Press release, 19 July 1940, NAA: A5954, 235/1.

73 Charles Eaton, The Cross in the Sky, 'Episode XIV'. 


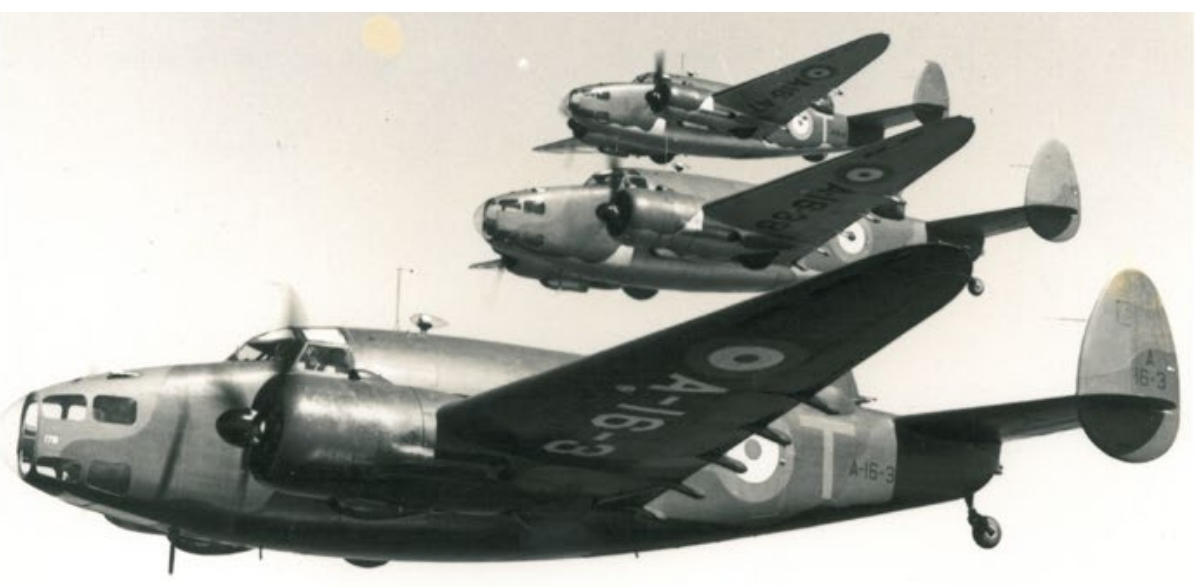

Three Hudsons on display for the Minister, Darwin July 1940

(Courtesy of John Harrison)

The flying Minister for Air arrived back in Melbourne in record time after long hops from Perth and Adelaide. In Perth he had paused long enough to assure a 'national party luncheon' audience that there was method in the government's 'dalliance' over airframe production (engine production was lagging and recruitment had already overtaken the 'ambitious' Ottawa program). And, if they were worried about enemy raids, they should know that bombers could be assembled anywhere between Perth and Cape York within five hours. ${ }^{74}$ When Fairbairn reached Melbourne, he had been away 12 days and covered 6700 miles in 46 hours and 47 minutes' flying time. ${ }^{75}$ In his absence he had missed a twoday War Cabinet meeting in Melbourne during which the Chief of the Air Staff was grilled by the Prime Minister. What was the schedule for aircraft deliveries from Britain? Why were so many recruits being rejected in Victoria (a question that Fairbairn had dodged a fortnight earlier by reference to Air Force insistence on high educational standards)? What was the situation with Hudson aircraft which were rumoured to be crashing? What was the status of the proposal to increase the size of the RAAF to 32 squadrons? What prospect was there of obtaining aircraft from the United States if previously expected British Ansons and Battles did not arrive? For Burnett to be subjected to such an inquisition when his Minister was not there might have been justified if the matters raised were urgent. They were not. It could be seen as another example of Menzies' disrespect for a senior ministerial colleague. ${ }^{76}$

74 The Argus, 30 July 1940

75 The Argus, 2 Aug. 1940.

76 War Cabinet Minutes, Agenda Nos 163, 169, 23 July 1940, NAA: A2673, 308; Extract from War Cabinet Minutes, 9 July 1940, 'RAAF Development and Empire Air Training: Recruiting Organisation', NAA: A5954, 236/3. 
In May, the Minister for Air had made known a Cabinet decision that much of the repair and overhaul work on the 1700 aircraft required for the Empire Air Training Scheme would be carried out by civilian contractors. ${ }^{77}$ On Sunday, August 4, Fairbairn announced a new plan to use every suitable aeroplane, private or commercial, from September onwards to maintain the momentum of training under the Empire Scheme. At the same time, he rejected an offer of a civilian committee to train a home defence force of 1000 airmen. In the unadorned speech for which he was known, he pointed out that there was no shortage of elementary training. It was advanced training that was the problem. It would be 'a waste of time for instructors, men and petrol to give elementary training to hundreds of more men than we could train further ${ }^{\prime}{ }^{78}$ He said nothing of the vexing issue of how best to deploy the existing pool of experienced senior captains. If he knew the extent to which this very real dilemma had been rippling through RAAF headquarters he gave no hint of it. Nor was there any mention of the decision of the Chief of the Air Staff four days earlier to begin planning for a large number of training aircraft to be 'operationally equipped and manned to form a potential second line reserve home defence force'.$^{79}$

Determined to put his stewardship in a better light, the following weekend Fairbairn had his department release comprehensive statistics on recruitment. The RAAF had accepted 22000 ground personnel in addition to 7894 air crew personnel accepted under the Empire Air Training Scheme. These figures did not include cadets in training, calling up of reservists on mobilisation, selection of civil pilots as instructors, and administrative, medical, and equipment officers. Of the ground personnel, 15631 were already serving and 6969 were on the waiting list. Air crew personnel under training totalled 1416 and 6278 were waiting to be called up. ${ }^{80}$ It was a good story.

When Parliament had resumed on August 6, Fairbairn flew up from Melbourne the day before in the new Hudson A16-97, fitted out at his request for important passengers. Flying Officer Bill Heath of No. 2 Squadron was at the controls. It was the Minister's second recorded flight in one of the RAAF's latest machines. A week later, on August 13, he was to fly up to Canberra in the air-conditioned and sound-proofed special aircraft for the second time. As well as War Cabinet business he would be meeting with aviation pioneer, P. G. 'Bill' Taylor, to discuss a proposal of Taylor's - previously rejected by the Chiefs of the Naval and Air Staffs - to roam around the Pacific in a P.B.Y. (Catalina) flying boat surveying for future air bases and watching for German raiders. ${ }^{81}$ Take-off on August 13

77 The Advertiser, 16 May 1940.

78 Canberra Times, 5 Aug. 1940. p.3.

79 Al196, 1/501/355 Pt 1; Wilson, 'The eagle and the albatross', pp.71-2.

80 More detailed figures were released over the next two weeks (The Argus, 12, 24, 26 Aug. 1940).

81 War Cabinet Minutes, 29 April 1940, NAA: A2673, 169; Stuart Swinton, P. G. Taylor, The Last of the Great Air Pioneers, Australian Military History Publications, Loftus 2006, p.67. 
was to be at a gentlemanly hour. An RAAF sergeant driver would collect the Minister in good time. So there was no reason why he could not do his regular exercises. Since he had hung in his dressing room a vibrant study of the touring dancers Baranova and Petroff in full flight in Swan Lake, he said, 'a grace which wasn't apparent before has made itself apparent in my early morning exercises'. 'There is grace and vigour in every line of the picture', he had confided to The Argus at a showing by the 21-year-old artist Loudon Sainthill in April 1939. What he thought of the portrait of Peggy done by Sainthill in her Berkeley Square apartment a year or so later is not recorded. Sainthill's work seems to have been a rare enthusiasm the Air Minister shared with Bob Menzies, who had opened the artist's exhibition at the Hotel Australia. ${ }^{82}$ There would be no opportunity to talk to the Prime Minister on this trip. But Fairbairn could look forward on the flight to another instructive conversation with an experienced Hudson pilot. There was a lot to learn about the new aircraft. 

Part 3 'The most devastating tragedy' 



\section{6. 'Not a machine for the careless or the ham fisted'}

Settling into the cockpit of Hudson A16-97, Bob Hitchcock, his small suitcase stowed, was secure in a dual-purpose harness. His 'QC (quick connection) seat type' parachute allowed for interchangeability with the second pilot or navigator. The Irving parachute pack attached to his harness served as a cushion. Hitchcock faced an array of controls that were now familiar. He could see around him the dials and instruments he had learned to read - the levers, buttons, and switches he knew would respond to his touch, the engine control pedestal with its three cranks for ailerons, rudder and, closest to him, the elevator. In his mind and muscle memory there was recently acquired experience. He had come to know the subtleties of the brakes, operated by pulling a car-type ratchet lever set in the central pedestal to his right. He had been instructed on the Hudson's tendency to swing during the landing run and the consequent importance of a three-point landing, touching down with the main and tail wheels at the same time. He had been warned of the danger if braking became necessary during a landing run and he was forced to lean to one side and pull - the rudder bar's effectiveness could be compromised, the differential brake could be applied unwittingly, resulting in a ground loop. If that were to happen he had the further concern that the fuel tanks, directly above the undercarriage struts, might rupture and be set ablaze. ${ }^{1}$ He had probably heard as well of the story told by Pat Hall to pilots undergoing conversion courses with him at Richmond. An unexplained Hudson crash in England, Hall had said, was attributed to the accidental shifting of the flap lever downwards when the aircraft was flying at high speed. Something to be particularly careful about. ${ }^{2}$

Yet, for all the rumination about Hudson peculiarities and potential dangers, with assiduously acquired knowledge and over 100 hours practice to subdue any lurking apprehension, Bob Hitchcock was in command. To Dick Wiesener, in the right-hand seat, every inch of the machine's $44^{\prime} 37 / 8$ " (13.51m) fuselage and 65' 6" (19.96m) wing span was new. ${ }^{3}$ The previous day's brief observation

\footnotetext{
1 NAA: A705, 919/50 on parachutes; Lettice Curtis, The Forgotten Pilots: A Story of the Air Transport Auxiliary 1939-45, G T Foulis \& Co., Henley-on-Thames, 1971, pp.126-7. An instructor and RAF Hudson squadron commander Geoffrey Bartlett's recollections of the Hudson Mark I: Andrew Hendrie, Lockheed Hudson in World War II, Airlife, Shrewsbury, 1999, pp.17-9. Crashes and 'formidable' blazes were soon experienced by the RAF Hudson conversion training flight at Leuchars in Scotland under an Australian, S/ Ldr Rankin (Gron Edwards, Norwegian Patrol, Airlife, Shrewsbury, 1985, pp.5, 9-10).

2 The Court of Inquiry into the crash of A16-27 on 12 Aug. 1940 would conclude that there was no evidence of what the effect of lowering the flaps at high speed would be; but it was possible, and pilots and crew should be warned that it might cause an accident (NAA: A705, 32/10/2830).

3 There are slight discrepancies in the quoted measurements in different sources. Measurements here are manufacturer's specifications. See also http://airforce.gov.au/raafmuseum/research/aircraft/series2/A16.htm.
} 
from behind the pilot had made a deep impression. In his mind, too, as in the captain's, was knowledge of what they had read and been told by others about this powerful new aircraft. He could not fail to notice the distinctive smell, unlike anything he would previously have encountered: 'something to do with fresh cellulose, upholstery fabrics, floor coverings, and a beautifully clean Elsan', a British Hudson pilot and student of the aircraft would say, 'mingling with the faint whiffs of hydraulic and de-icer fluids, aviation fuel, several different kinds of oil, synthetic rubbers and who-knows-what' ${ }^{4}$

Wiesener knew that the Hudson's Pratt \& Whitney G-3-5 twin-row engines gave it superior performance to the Hudsons delivered to the RAF. He understood that it was faster than the Dutch Lockheed 14s because of less radial resistance and extra horsepower. He knew that its payload would be less than the British machines. There was assurance though in knowing that the Hydromatic (full feathering) propellers fitted to Hudsons 51 to 100 could be stopped from revolving in a few seconds if an engine failed, reducing vibration and making it easier to fly on one engine. Now, in one of the first 17 Hudsons delivered to the RAAF with dual controls, Wiesener could begin his formal conversion. ${ }^{5}$ First he would see, as the British Hudson instructor Geoffrey Bartlett recalled, the help that was necessary in starting the engines from the cockpit:

...it required dexterity single-handed. What with working the handpump (the 'wobble' pump), priming via an electric push-button, pushing the separate starter and booster buttons simultaneously, and turning on the ignition switch after one full revolution of the propeller. ${ }^{6}$

For the men who would fly them, there was much to admire as well as to learn about the Hudson. They would be quick to notice its comfort and sound-proofing. Those who were on the alert to the rapid and remarkable developments in aircraft technology from the mid-1930s onwards would know that the Lockheed company was in the forefront. The first fully pressurised plane, Lockheed's XC35, had taken to the air in May 1937. Feathering airscrews - which cut the drag of a failed engine on multi-engined aircraft - had been introduced for the first time on Lockheed 14 transports. ${ }^{7}$ A brilliant young Lockheed engineer, Clarence 'Kelly' Johnson, had also developed the Fowler wing flap for the model

4 Andrew Hendrie, Seek and Strike: The Lockheed Hudson in World War II, William Kimber, London, 1983, p.33.

5 'Supply of Lockheed Hudson aircraft', NAA: A705, 2 9/1/350. On the delivery of Lockheed Hudsons, see 'Aviation-Purchase of Lockheed Bombers', Prime Minister's Dept Correspondence, NAA: A1608, F17/1/12; War Cabinet Agendum No 28/1939 'Delivery of Lockheed "Hudson" aircraft from USA', NAA: A2671, 28/1939; War Cabinet Agendum No 84/1940 'Supply of 31 Lockheed Hudson aircraft and 16 spare engines', NAA: A2671, 84/1940. For training of maintenance crews and ferrying of Hudsons to squadrons: NAA: A1196, 1/501/317.

6 Hendrie, Lockheed Hudson in World War II, p.17.

7 Peter W. Brooks in C. H. Gibbs-Smith, Flight Through the Ages: A Complete Illustrated Chronology from the dreams of early history to the age of space exploration, Hart-Davis McGibbon, London, 1974, p.156. 
14, designed to improve braking safety and enhance speed when retracted in flight. As the manual for the Model 14 medium-range bomber supplied to the Australian authorities explained:

Trailing edge Fowler type wing flaps on the under surface of the Lockheed Model 14 wing are operated hydraulically and controlled by the pilot...The principal effect of these flaps is to increase the maximum lift coefficient without increasing the vertical sinking speed. The flaps also permit shorter take-offs with steeper climb after takeoff for clearance of obstacles. This increase in lift is not accompanied, as in the case of the split flap, with so large an increase in drag. This further facilitates their use for take-offs...it is possible to carry a much larger load for a given wing area than with the split type of flap. With present day low power loadings, take-off distance, not flight, becomes the critical factor governing wing loading.

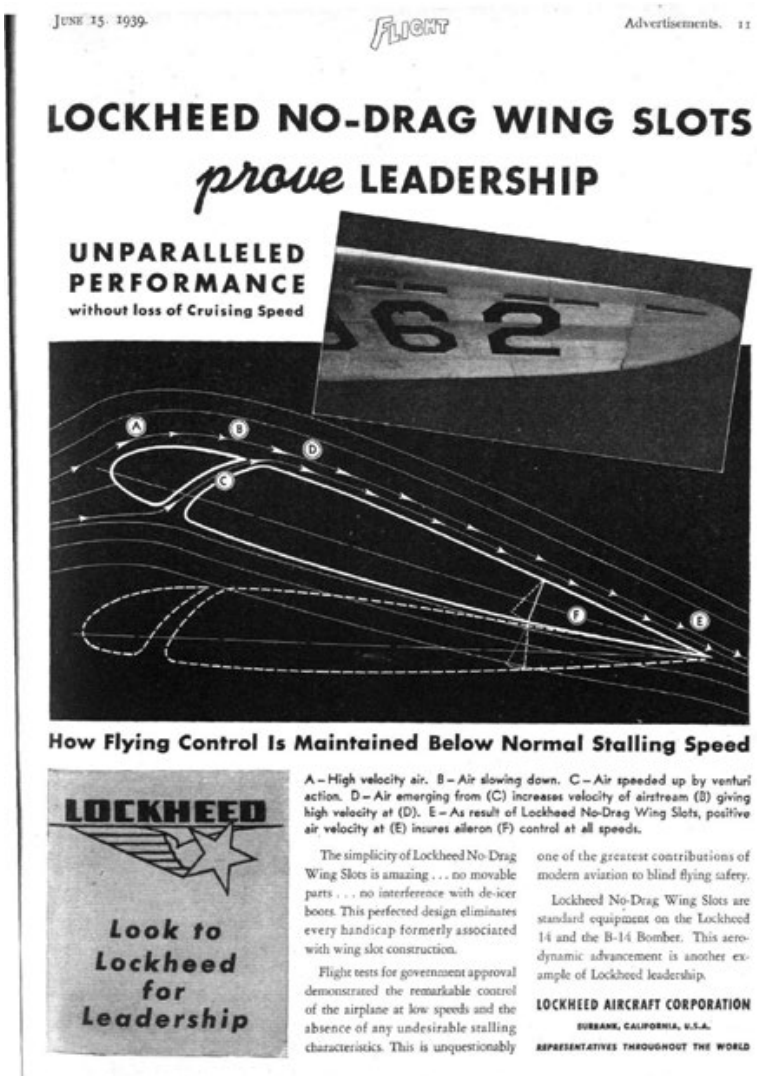

Lockheed's assurance: 'the absence of any undesirable stalling characteristics'

(Flight, 15 June 1939) 
The Lockheed engineers, Hall Hibbard and Kelly Johnson, had settled on a highly loaded wing of relatively small span and area to enable a faster cruising speed. The Fowler flaps were necessary to reduce the otherwise excessive approach and take-off speeds. Drag was increased to lower approach speed, and the wing area was augmented to assist take-off.

The Hudson, with its fuselage constructed of 24ST Alclad aluminum alloy sheet, was still in some ways an unproven aeroplane. This could have been expected for a civil airliner that had been mocked up as a coastal reconnaissance bomber in five days in April 1938 to capture the imagination of a British Purchasing Mission. By the time Lockheed had completed the 250th Hudson in November 1939 the company had more than doubled its staff, pioneered mass-production methods, and started apprenticeship and retraining programs for desperately needed aircraft engineers. ${ }^{8}$

As the aircraft was tested and brought into service, there had been accidents in America and in Britain whose causes were still being studied. The Lockheed 14 was in service with several Norwegian, Dutch, Polish, and Swiss airlines. Japan's GJAL owned some, as did Trans Canada Airlines. The company representative in Europe had given a 'frank exposition' to the leading aeronautical magazine of what was known about the early failures of the Lockheed 14. But doubts persisted about an aircraft that was 'delicate to handle...stalls suddenly, at a rather high speed, and so ought only to be committed to the care of thoroughly competent pilots. It is not a machine for the careless or the ham fisted.' There was talk of the RAF following the lead of British Airways and cutting slit-slots into the wing-tips in front of the ailerons to further improve control of the aircraft at below normal stalling speeds. ${ }^{9}$ It was not only Service pilots unfamiliar with its peculiarities who lost control. In a crash on a test flight near Birkenhead, Cheshire, late in July 1939, a Lockheed pilot, factory inspector, and mechanic who were employed at the assembly plant at Speke Airport, were killed. ${ }^{10}$

Lockheed's own development work was ongoing. In due course Australian pilots like 'Spud' Spurgeon, flying in Singapore with No. 8 Squadron, were to discover that the aircraft 'had about four-and-a-half hours' range in it, I suppose, five if you squeezed it. The books used to say it had seven hours, but I think that must have been in the minds of the advertiser. ${ }^{11}$ This was the performance with the Mark I aircraft with Pratt \& Whitney Twin Wasp engines. The first Mark III Hudsons with Wright Cyclone engines were no better. When Donald Bennett

8 Walter J. Boyne, Beyond the Horizons: The Lockheed Story, St Martin's Press, New York, 1998, pp.88-105.

9 The Aeroplane, 4 Jan. 1939, pp.9-10; 12, 19 Oct. 1939; 11 Jan. 1940, p.32; 5 April 1940, p.418.

10 R. E. G Davies, A History of the World's Airlines, Oxford UP, London, 1964, pp.120-1, 192, 212, 231; Flight, 3 Aug. 1939, p.112.

11 ACdre C. H. Spurgeon, interview, The Australians at War Film Archive, Dept of Veterans Affairs, Archive No. 0937. Strictly, Spurgeon was speaking of endurance (a measure of time) not range (a measure of distance). 
inaugurated the trans-Atlantic ferry service for the RAF, he was charged with testing the aircraft as well as selecting and preparing crews for long-range delivery flights. Bennett's first trial flight, over five hours at the Lockheed plant in Burbank in mid-September 1940, indicated that the performance figures supplied by Lockheed were inaccurate. He was right. ${ }^{12}$

In May 1940 it had been acknowledged that in certain Hudsons the pilot's compass was subject to 'variable magnetic disturbance due to (a) control column (b) undercarriage'. Flight Lieutenant Geoff Hartnell, the navigation officer attached to the Directorate of Operations and Intelligence, had reported on the problem. No-one was sure how many aircraft were affected. Pending further investigation, a confidential order was promulgated that the pilot's compass was not to be relied on for navigation unless it had definitely been established that it was not adversely affected by either cause. By early July the undercarriage had been identified as the culprit, the major cause of the difference between the compass deviation on the ground and in the air. A new order on July 5 pointed out the obvious, that it was impracticable to swing the compass on the ground with the undercarriage retracted. Therefore, until further notice, all pilots' compasses were to be swung in the air by bearings taken on the sun. The entry in both the airframe and compass logbooks had to be endorsed to that effect. Commanding officers were to make arrangements for instructional lectures on the required compass-swinging method. ${ }^{13}$ Bob Hitchcock's logbook for July and August shows that this quickly became a priority. For someone whose father's death was officially attributed to a faulty compass, this was hardly surprising. ${ }^{14}$

In the first few months of Hudson operational flying in Australia there had been a number of accidents. Mishandling of controls and a poor standard of night flying and instrument flying were diagnosed when Pilot Officer Val Morehouse of No. 1 Squadron lost height on take-off and struck a tree with Al6-1's port wing tip on May 13. Morehouse would have another mishap on July 17, overshooting on landing and damaging the undercarriage and bomb chamber of A16-1. ${ }^{15}$ Two days later, A16-31 in No. 14 Squadron at Pearce was damaged in a landing accident and sent for conversion to components. According to the Directorate of

\footnotetext{
12 Major R. H. Mayo, 'Report on Technical Aspects of Scheme for Delivery of Aircraft by Air to Great Britain', 8 Oct. 1940, PRO (now National Archives) AIR 38/1 XCB55K1; Alan Bramson, Master Airman: A Biography of Air Vice-Marshal Donald Bennett...', Airlife, Shrewsbury, 1985, p.40; Firkins, The Golden Eagles, pp.201-2. Seven hours maximum endurance was quoted when A16-32 failed to return from an exercise to seaward from East Sale in July 1943 (NAA: A9845, 134).

13 'CAS [Chief of Air Staff] — Navigation facilities Hudson Aircraft', NAA: A705 9/19/144; 'Compasses, Hudson Aircraft', A.F.C.O. 54,67, and 72; instructions on compass swinging were issued on 29 Aug. 1940 (NAA: A7674, 1/89,112,140-3).

14 'The Committee consider that the primary cause of the tragedy was the inaccuracy of the compass through which Lieutenant Anderson lost his direction and bore to the north of his intended course.' Report of Air Inquiry Committee in Connexion with the Flights of Aeroplanes "Southern Cross" and "Kookaburra", March-April 1929, Victorian Govt Printer for Commonwealth Govt, p.12.

15 NAA: A9845, 134 Lockheed Hudson A16 [Accidents Part 1].
} 
Training the accident was caused by 'inexperience on the type of aircraft'. On May 23, Flying Officer J. F. Murphy of No. 6 Squadron had crashed on take-off in Canberra and was disciplined for negligence in not removing early-morning hoar frost. ${ }^{16}$ A week later both engines failed in a Hudson from No. 2 Aircraft Depot and Flying Officer Lloyd Douglas landed the aircraft 15 miles north of Junee with its wheels up. Another Hudson, A16-58 of No. 6 Squadron, had stalled at 300 feet, crashed, and burned five miles north of Windsor on July 17, killing the pilot, Flight Lieutenant Jim Hamilton, and Cadet Wallace Stewart who was with him. Hamilton had 15 hours of dual instruction and eight hours solo. Squadron Leader Bertie Simms would tell a Coroner's court two months later that the pilot would have needed another nine or 10 hours before being allowed to take a full crew into the air. ${ }^{17}$

Commenting on the unexplained accident in which Jim Hamilton was gaining solo practice, the Training Directorate urged: 'Whenever possible, whilst a pilot is gaining experience as $1^{\text {st }}$ pilot in Hudson aircraft during the early stages after a conversion course, an experienced Hudson pilot should be carried in the aircraft.' As 'Dad' Bladin had minuted in a handwritten note to Jones: 'There may be arguments against this but Hudsons are too valuable to take any chances with them these days.' ${ }^{18}$ Bladin may not have heard that Lockheed's 'Swede' Parker had been showing his own prowess and the aircraft's unadvertised aerobatic capability by doing rolls when no official eyes were on him. Or that the irrepressible Flight Lieutenant Brian 'Black Jack' Walker, who had survived critical injuries as a cadet when his Wapiti was totally wrecked in a 1935 crash at Echuca, was ignoring Parker's warning that 'this Hudson is strictly not aerobatic' ${ }^{19}$

16 RNZAF tradesmen sent to Laverton to learn about the Hudson evidently were not told of the need to remove hoar frost; they worked it out for themselves after a failed take-off at Whenuapai in mid-1941 (Geoffrey Ellis, Tool Box on the Wing: My Life in the Air Force, Mallinson Rendel, Wellington, 1983, pp.181-2). 17 Canberra Times, 3 Sept. 1940.

18 'Lockheed Hudson A16 [Accidents Part 1]', NAA: A9845 134; 'Flying Accidents Analysis of 1940', NAA: A705, 32/10/2478; 'Fatal Accident to A16-58...', NAA: A705, 32/10/2602. For the fate of A16-31, see Vincent, The RAAF Hudson Story, Book One, p.297.

19 A. B. McFarlane, interview, 18 April 1978. Adelaide-born Brian Walker, aged 27 in 1940, ended the war as a Group Captain and became De Havilland's chief test pilot in Australia. The American demonstration pilot had told him: 'I've heard about you and your flying attitudes...' (Canberra Times, 31 Oct. 1935; Brian Walker, Black Jack, Banner Books, Belconnen, 1994, pp.34-5). 


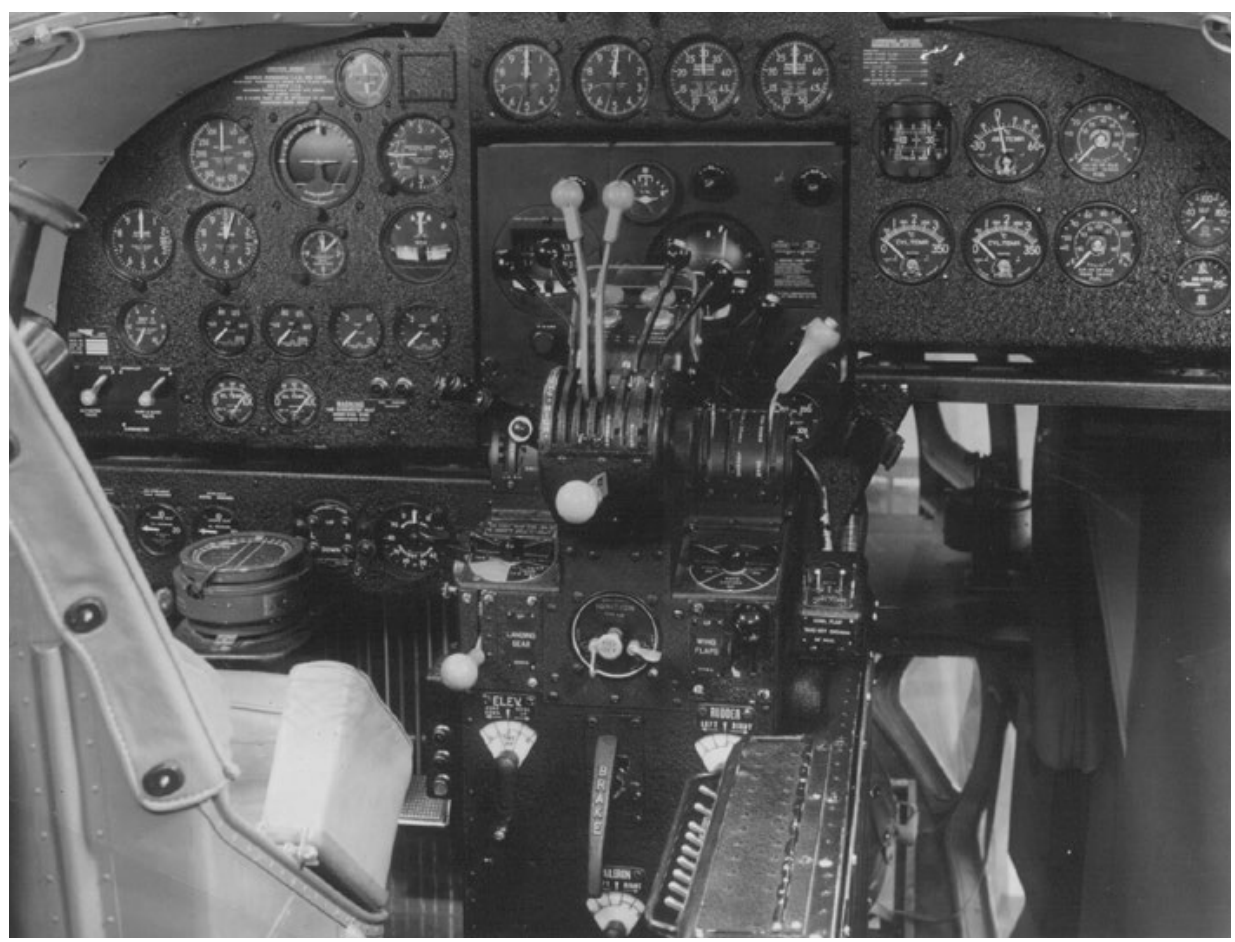

\section{Inside the Hudson cockpit at Laverton}

(Photo by Frank Jefferies, courtesy of Paul and Helen Struc)

The word was out that the Hudson was not without its perversities. Paddy Heffernan had been given a sobering surprise while under instruction from Alec Barlow in Canberra. Preparing to 'land' in cloud at 6000 feet, he was told at the last moment to go round. When power was applied the aircraft snap-rolled into an inverted dive. ${ }^{20}$ Val Hancock, then CO No. 1 Bombing and Gunnery School, also knew 'that the Hudson had some unpredictable tendencies when the flaps were set for various configurations as I got this information in conversation with Flt./Lt. Simms who did the first conversion on the aircraft'. Bertie Simms, one of the RAAF hierarchy's favourite pilots, had been sent to Burbank in April 1939 for instruction. He had seen the efforts Lockheed were making to overcome the dangerous stalling proclivities of the first generation of Hudsons. If Simms, knowing of the modifications that had been made to the original model, commented on it, there was a reason to be cautious. At least one of those under his command in August 1940 would later testify that Simms was not a very good pilot, and those who were proficient Hudson pilots were not popular with

20 ACdre P. G. Heffernan to CH, 7 April 1978; Heffernan, interview, 16 May 1993, quoted in ‘Douglas DC-3's and No. 8 Squadron R.A.A.F.', Man and Aerial Machines, no. 39. Nov-Dec 1993, p.90; Heffernan, 'Singapore 1940', Stand-To, Jan-Feb. 1964, p.13. There are slight variations in the story as told at different times. 
him. Still, as a Squadron Leader in February and March 1940, with the 'control and direction' of the six teams at Richmond responsible for the first Hudson conversion courses, no one spoke with more authority. ${ }^{21}$

\section{A16-97}

Much of this Bob Hitchcock could not fail to know. He knew too that, with the exception of his second pilot, he had a seasoned crew. Notwithstanding the Hudson's temperament there was no reason to suppose that the journey would be anything but uneventful. As he prepared to leave, Hitchcock discussed the weather with his CO: 'he informed me that weather conditions were clear sky all the way', Freddie Thomas remembered..$^{22}$ The six additional parachutes taken aboard at Laverton were hardly likely to see service, even if any of the passengers knew how to use them. ${ }^{23}$ Before being handed over for operational duty, A16-97 had been flown without mishap for two hours and 35 minutes by the Lockheed test pilot. Whatever the aircraft's challenges in the air, on the ground it had been thoroughly prepared for the flight. Received at 1 Aircraft Depot on 20 June 1940 along with eight others, A16-97 was allotted to No. 2 Squadron on 2 August 1940. ${ }^{24}$ By then the squadron had 11 Hudsons, seven of them delivered within the last month. ${ }^{25}$

On the morning of August 13, a four-man team at Laverton had serviced A1697, carrying out what was officially known as a 'tradesmen's daily inspection'. The machine, which had been assigned to A Flight for the first time, had been given a major check the previous afternoon when it was known that it was to be used to carry the Air Minister and his companions. The work on Tuesday morning was done according to the Aircraft Maintenance Schedule for the Hudson-Wasp, S.C.3G. The schedule, issued on August 1, was meant to be used 'in connection with unit maintenance orders, part II, in accordance with

\footnotetext{
21 Air Marshal Sir Valston Hancock to CH, 7 April 1978; Deputy Director, Training (WCdr F. Scherger) to D[irector] O[rganisation] (through D[irector], T[raining]), 18 March 1940, NAA: A1196, 1/501/317; A. B. McFarlane, interview, 18 April 1978.

22 Service Court of Inquiry, 13 Aug. 1940, p.14, NAA: A705, 32/10/2729.

23 RAAF aircrew had been required to wear parachutes since 1927, happily for Sam Balmer who fell out of the Wapiti in which he was instructing a trainee in Aug. 1937 (Chris Clark, 90 Years of the RAAF: A Snapshot History, Airpower Development Centre, Canberra, 2011, p.50); and for F/Lt Sturt de Burgh Griffith and two companions, lost in cloud and out of fuel en route to Canberra from the coast, who had to bail out of their Anson just before midnight on 10 Jan. 1940 (No. 1 Squadron Operations Record Book, NAA: A9186 1; The Argus, 12 Jan. 1940).

24 Ron Cuskelly to CH, 15 July 1978; Air Force Court of Inquiry, report of His Honour Mr Justice Lowe, NAA: A705, 32/10/2729/19; Aircraft status card: Lockheed Hudson A16-97, NAA: A10297, BLOCK 84/180.

25 No. 2 Squadron Operations Record Book, 1 Aug. 1940, NAA: A1980 599. The normal establishment would have been 18, with six in reserve. But because of 'commitments entered into with the United Kingdom government' squadrons were operating on reduced numbers. ('Service Squadron Establishments', A.F.C.O. 71, 1 July 1940, NAA: A7674, 1/116).
} 
aeroplane maintenance instructions, RAAF publication No. 42'. Fitter Corporal James W. Davey assisted by two mechanics, Rigger ACl Les Roffey (Corporal J. Morrow had been detailed the previous day), the electrician, W.O. Mechanic ACl Graham Bardwell, and Instrument Maker Corporal Paul Dines all carried out their designated checks. Instruments, engines, propellers, flap mechanism and the flap indicator, petrol and oil, pressure gauges, hydraulics, gyro pilot all were in good order. The altimeter and rate-of-climb indicator were corrected. Wireless operator Corporal Jack Palmer looked over his own equipment, the AT5/AR8 radio installation. In flight, Palmer would be responsible for the electrical systems as well as the radio. In recent months he had spent a lot of time in the air and was at ease with the routine. As the aircraft was unarmed there was nothing for the Armourer ACl Moore to do. The NCO in charge of A Flight, Flight Sergeant Fitter William S. McGowan (one of the first of the ground staff to be instructed by the Lockheed team at Richmond), signed off the work before Hitchcock did so at about 8.35 a.m. Like all pilots Bob Hitchcock had seen the homily from the Chief of the Air Staff promulgated two months earlier:

Aircraft maintenance, although primarily the duty of the fitters, riggers and technical non-commissioned officers, must also be a matter of deep concern to all pilots no matter whether they are serving as flying instructors or in operational units. The service now contains large numbers of new airmen whose experience is very limited, and these men must be assisted and encouraged to progress rapidly in their training. Routine inspections must be adhered to strictly, and it is to be the duty of all pilots to exercise general supervision over this work on the aircraft for which they are responsible. They must be required to spend as much time as possible with their aircraft so that they may be acquainted with the maintenance staff and with all work performed, do cockpit drill, study the petrol system, and generally take a keen interest in all matters relating to their safe and efficient performance. ${ }^{26}$

As Hitchcock's logbook shows, he had been working closely with the team of Roffey, Davey, Morrow, Dines, Crosdale, and McGowan in the previous month. They had all been in the air with him on several occasions. Before the flight, Hitchcock had discussed with another pilot who had flown A16-97 (probably his No. 2 Squadron colleague Bill Heath) the trim of the aircraft in relation to the stowing of a load. He knew it was necessary to distribute the luggage carefully around the cabin. So far as fuel was concerned the 'Daily Inspection Certificate' showed that there was a full load of 536 gallons and 24 gallons of oil; the 'responsible airman' (JW) had confirmed this. At 2000 r.p.m., fuel usage was estimated at 73 gallons an hour. In its seven hours and 10 minutes' flying

26 I confess to having lost this reference, which was transcribed directly from a document in the National Archives. 
time A16-97 had been run at 1500 r.p.m. ${ }^{27}$ Hitchcock had also discussed with Jack Ryland which petrol tanks it was advisable to empty first, and the two rear tanks were suggested. With the load stowed correctly and the two rear petrol tanks emptied, he would be sure that the aircraft would be within its centre of gravity limits when it arrived for landing in Canberra. ${ }^{28}$

Coughing tentatively, as the starter prompted them, the Pratt \& Whitney engines would soon settle to a steady rhythm, flaring to a deep roar as they were put through their full throttle tests. Hitchcock could expect 1050 hp on take-off and $900 \mathrm{hp}$ in level flight at 12000 feet/3660 metres. The Hudson would need some 650 yards for its take-off run. As late as 1938 a runway of 600 yards was the standard for civil aerodromes but by 1940 the standard for multi-engined aircraft had been extended to 1500 yards. ${ }^{29}$ 'Until its wheels are up,' David Campbell reminisced, a Hudson 'seems to be pulled off the ground by sheer brute force. You can hear the horses straining. Then the wheels tuck themselves up in three slow jerks and the aircraft begins to fly. ${ }^{30}$

\section{Uplift at Essendon}

It was a short hop from Laverton to Essendon where the passengers were to be collected. Hitchcock had been instructed to leave Laverton in time to depart with his passengers at 9.15 a.m. He took off at 8.47 a.m. As he came into Essendon aerodrome from the west around 13 minutes later, the air was filled with training aircraft of No. 3 Elementary Flying Training School. In the control tower, the CO of 3 EFTS, Squadron Leader Roy 'Beau' King DSO DFC, was watching the circuits and landings. King, a Great War ace was credited,

\footnotetext{
27 Aeroplane maintenance form, 'Lockheed Hudson A16 Accidents Part 8 [Air Force Court of Inquiry Lockheed Hudson A16-97 crash on 13th August 1940] - Master Copy [Volume 3]', NAA: A9845, 320/48-9; 'Court of Inquiry....Exhibits', NAA: A705, 32/10/2729 Attachment 1.

28 'Confidential: Informative Circular Relative to the Accident to Hudson A. 16-97 at Canberra on 13th August, 1940', NAA: A705, 32/10/2733.

29 After five Hudson engine failures due to piston trouble in No. 3 Squadron in Nov. 1940, Pratt \& Whitney's expert adviser suggested that RAAF pilots were over boosting engines for take-off. Engines were averaging only 300 hours. It was not until December 1940 that the Director of Technical Services, noting that the makers' advice had been followed, told his colleagues that Hudson engines had been running at wrong ratings comparatively low revs and high boost - giving a weak mixture (Report of Staff Conference Nos 61, 62, 63, 28 Nov., 3, 10 Dec. 1940, NAA: AA1977/635). For the novelty of the Hudson carburettors and superchargers, see Ellis, Tool Box on the Wing, p.179. For airport runway standards: Civil Aviation Department Annual Report 1939-40 in Sydney Morning Herald, 27 Dec. 1940.

30 David Campbell, Flame and Shadow, UQP, St Lucia, 1976, p.165; for the recollections of Geoffrey Bartlett, one of the first RAF Hudson pilots: Hendrie, Seek and Strike, pp.27-33.
} 
somewhat generously, with 26 victories. ${ }^{31}$ An AFC 4th Squadron colleague of Harry Cobby and George Jones, he had seen everything in subsequent years as a pioneer flyer in the Northern Territory. Now he was doing his bit to be useful in preparing a new generation to fight. He asked the civil operator to put the red light on several of the training aircraft, indicating that they were to take another circuit to make way for the Hudson to land. One pupil did not see the signal and completed his landing. The Hudson, already turned into the wind with its undercarriage and flaps down, was at about 100 feet when it pulled up to make a second circuit. Hitchcock may have seen the obstruction on the ground. Or possibly received a 'do not land' light intended for another aircraft. King observed that the undercarriage was retracted and the flaps were pulled up as the motors were put on. To clear the way for the Hudson, two more elementary aircraft were given red lights by the Assistant Control Officer, J. J. Williams. The signals from the control tower reflected the delicate demarcation of authority between the civilian controller of a civil aerodrome and the RAAF users who shared it. Although the RAAF aircraft were not under civil control they would normally obey signals from the control tower and use the civil aeradio service.

'Beau' King had heard the Hudson's engines as it came in a mile or so away at about 1000 feet. Evidently he was not expecting it. After making his second circuit, Hitchcock landed and taxied up to within 25 yards of the control tower, turned into the wind, and shut off the engines. It was 9.05 a.m. King thought the landing 'a particularly good one' and remarked on it to the control tower officer. Hitchcock went over to the tower and reported to King who, no doubt conscious of his own nine-inch height advantage, had come down the steps to meet him. Hitchcock began to apologise for interrupting the flying training, but King told him it was unnecessary to do so. What King wanted to know was what Hitchcock's duty was. Hitchcock explained that he was to pick up 'Federal Ministers and others' to convey them to Canberra. King asked him if he knew who his passengers were. He did not but was 'under the impression there were to be six'. King asked Hitchcock for the names of his crew.

Before Hitchcock could complete writing a list, his first passenger arrived. Sir Harry Gullett emerged from his chauffeur-driven car and joined the two officers. After a few minutes conversation, Hitchcock excused himself to report to the meteorologist's office. Before he left Laverton he had received a summary weather report with a 'route forecast' from the duty pilot. But he was to collect

\footnotetext{
31 King's record was four balloons, 13 aircraft destroyed and three shared, and six out of control (Christopher Shores, Norman Franks, and Russell Guest, Above the Trenches: A Complete Record of the Fighter Aces and Units of the British Empire Air Forces 1915-1920, Grub Street, London, 1990, pp.224-5); Christopher Shores and Mark Rolfe, British and Empire Aces of World War 1, Osprey Publishing, 2001, p.90, say 20 (three shared) for claims of aircraft and balloons 'destroyed or captured'.
} 
at Essendon the more detailed 'Aviation Meteorological Report' that would give him the latest wind and cloud observations, visibility, and any necessary warnings. The forecast, based on a chart drawn up at 6.00 a.m., was:

Scattered to broken cloud - base 2000/3000 feet south of ranges. Broken to overcast on the ranges with snow. Icing risk in cloud above 3000 feet. Cloudless or scattered cloud north of ranges, with morning fog or low stratus in valleys.

They would fly via Benalla, Hotham (where dense fog was likely), Albury, Wagga, and Cootamundra. At Canberra as they came in to land they could expect a northwest wind at 20 miles an hour. Nothing to be concerned about, as the aerodrome Weather Officer, John Nance, told him.

Meanwhile, as Harry Gullett and his bag-carrying chauffeur headed for the aircraft, Squadron Leader King decided to assert himself. A little irritated perhaps by the lack of warning about the interruption to his morning routine and the vagueness about the Hudson's passengers, King immediately instructed the duty pilot of the EFTS to get the names of the crew, 'the passengers who actually got into the aircraft, its time of arrival, departure and destination'. Pilot Officer J. B. Wilson walked over to the aircraft and took details of the crew mingling with the Air Minister's RAAF sergeant chauffeur and Gullett's civilian chauffeur before asking Hitchcock for the names of the passengers and the flight plan. As Al6-97 began manoeuvring for take-off, Wilson followed King back to the control tower. At 9.40 a.m., some 10 minutes after the aircraft left the ground, Wilson delivered the information his chief required. King thereupon telephoned Southern Area HQ to advise Wing Commander Lachal. ${ }^{32}$ Being the authority for the flight as SASO Southern Area HQ, Lachal was due for a polite remonstrance. Of the nine copies of the flying operation instruction form distributed from Laverton, none had been sent to Essendon.

When it left Laverton, the aircraft had four 50lb sandbags loaded as ballast. The sand was to compensate for the dorsal gun turret that had not yet been fitted to the Hudsons, and for the gunner and ammunition that the plane was also designed to carry. (It was illegal for the neutral United States to supply armed aircraft.) $)^{33}$ With six passengers joining at Essendon, the four sandbags were removed to ensure the correct centre of gravity was maintained. ${ }^{34}$ Although

\footnotetext{
32 The sequence of events at Laverton and Essendon and in the air thereafter is reconstructed from documents and oral evidence tendered to the Air Court of Inquiry, NAA: A705 32/10/2729 and the Service Court.

33 For Menzies' perturbation at the American Neutrality Proclamation cutting off Australian access to military aircraft and 'civil aircraft for civil training', see Menzies, Personal Cablegram to President Roosevelt, 7 Sept. 1939, NAA: A1608, F 17/1/2.

34 Inspector of Aircraft Accidents, 'Report on Accident to Lockheed Hudson Aircraft A16-97', 16 Aug. 1940, (Most Secret), para. 5, NAA: A705 32/10/2733.
} 
it was not his responsibility to identify the passengers, the tarmac officer I. Smith recognised four men among the crew and drivers: Sir Harry Gullett, Jim Fairbairn, Dick Elford, and Geoff Street. He noticed two others near the plane but did not see them get aboard. One, he thought, was a colonel in uniform. ${ }^{35}$ Having got all of the passengers seated, Hitchcock started the engines. The last man into the aircraft was Fairbairn, who had been in conversation with King about the Empire Air Training Scheme before excusing himself as he was in a hurry. ${ }^{36}$ Assistant Control Officer Williams noticed that it took two minutes for the starboard engine to start. Then the aircraft taxied to the east boundary of the aerodrome where it remained out of wind for about 10 minutes. Turning into wind, the aircraft paused, Williams thought, for about four minutes.

Taking seriously his obligation to instruct his neophyte second pilot, now would have been a sensible time for Hitchcock to give Wiesener another rundown on the instruments, draw his attention to the need to ensure that weight was properly distributed when there was a full load of passengers, and remind him of the effect of the flaps. Perhaps too the Minister for Air might ease himself forward to get a good look at the cockpit and listen to the briefing. From the control tower, A16-97 was seen to take off perfectly at around 9.30 a.m., make a left-hand circuit, and head for Canberra. Thirteen minutes later, Jack Palmer signalled Essendon confirming that VMZAY — to give it the civil call sign it had been allotted — had 'left Essendon at 0930'. ${ }^{37}$ Palmer knew from the 'Flying Operation Instruction' issued on August 9 that he was to make scheduled calls at 10 and 40 minutes past the hour. The Essendon aeradio station confirmed 'OK schedules 10 and 40'. At 10.12 a.m. Essendon was told that VMZAY was communicating with Canberra. The secondary aeradio station at Holbrook noted that Canberra was the next 'schedule'. Palmer signalled Holbrook 'QTR', meaning 'What is the time?' and was told it was ' $1014 \frac{1}{2}{ }^{\prime} .{ }^{38}$ At 10.41 a.m. he sent 'QRK? QRU' ('How are you receiving? I have nothing for you.'). Three minutes later he repeated 'QRU' and received 'QRU' in return. The aircraft and the Canberra station had nothing to tell each other. It was an uneventful flight.

\section{'The modern technique'}

Having spent much of the last few months teaching others to fly Hudsons, Bob Hitchcock was well equipped to guide his second pilot through a safe approach

\footnotetext{
35 Director General of Civil Aviation to Secretary, Attorney General's Dept, teleprinter message, 23 Aug. 1940, NAA: MO625 CP169/4 (Crown Solicitor's Office Inquest file which appears to be NAA: A6079 MO625). 36 Tink, Air Disaster, p.213, asks: 'Why was the air minister in a hurry? Was it to get a pre-flight briefing from Hitchcock?' That was likely, although the most obvious reason was that everyone else was on board, waiting to go.

37 The DG Civil Aviation advised Sec. AG's Dept that A16-97 took off at '0923' (ibid.).

38 Palmer's querying of the time has led to unfounded speculation that some sort of record attempt was being made (R. A. Fisher [Air Force Office, Dept of Defence] minute, 20 July 1990, courtesy Bronwyn and John Myrtle).
} 
and landing. Dick Wiesener would have been familiar with the RAAF's latest thinking promulgated in an Air Board Order just as he was completing his initial training. In a preamble, the Board explained why it was essential to issue fresh guidance on flying instruction:

The introduction of modern high wing-loaded, flapped monoplanes has rendered the old accepted methods of approaching and landing both difficult and unnecessary. Steep gliding turns with engine throttled back at low altitudes in the modern high wing-loaded monoplanes are necessarily difficult with more than a little danger involved in their performance, due to the rapid increase of the wing-loading to danger point resulting from a change of direction of the aircraft at comparatively low speeds.

For flyers of Jim Fairbairn's vintage, this amounted to a warning that they would have to discard the habits of a lifetime if they were to fly the RAAF's modern aircraft. The Air Board Order had set out the requirements for instructing pupils in 'the modern technique' at all stages of training. A normal powered approach or engine-assisted approach entailed a descent across wind from approximately 1000 feet to about 500 feet at a moderate angle, followed by a turn into wind and a straight descent at the same 'moderate' angle. In the vicinity of the aerodrome, air speed should not exceed 120 m.p.h. (the precise speed to depend on the actual aircraft type being flown). Noting the direction of the circuit and the wind, the pilot should then fly around the aerodrome in a wide circuit at approximately 1000 feet, keeping 'a sharp look-out for other aircraft'. Turning across wind when to leeward, the best landing path could be chosen.

All this was second nature to Hitchcock. He could probably recite how to start a normal approach:

Throttle back, lower the flaps, and assume the correct approach speed. Trim the aeroplane for landing. Keep the throttle open sufficiently to achieve a moderate angle approach. When almost opposite the selected landing path, turn gently into wind and continue the approach at the same moderate angle. The approach should be arranged so that this turn is made at approximately 500 feet.

Hitchcock could talk those he was converting to the Hudson through the next stage. Much of it would sound simple and familiar to any pilot:

Maintaining the correct air speed with the elevators, regulate the angle of approach and the rate of descent with the throttle. If overshooting, throttle back. If under-shooting, open the throttle. During the approach towards the aerodrome, correct any drift and look well ahead and to each side. 
Having reached about 20 feet, the control column would be moved back until the aircraft was flying just above the ground. As the throttle was gradually closed, the control column would be moved further back to prevent the aeroplane sinking until it was in the landing attitude when, all being well, 'it will sink gently to the ground'.

This was fairly conventional advice. It was the effect of the flaps that needed special attention. When they were lowered, there 'may be' a large change of attitude. A steep nose-down attitude might be necessary to maintain an adequate approach speed to overcome the additional drag of the flaps. 'Fortunately,' the novice was assured, 'the aeroplane tends to assume a nose-down attitude of its own accord immediately the flaps are lowered and no attempt must be made to hold the nose up.'

What then was the likely trouble? A steep attitude would result in a greater angle through which the aeroplane must be moved before the landing. The angle could, 'if practicable', be lessened by increased use of the engine. But owing to the drag of the flaps, a decrease in the steepness of the attitude would result in a loss of flying speed. 'Since the lowering of the flaps increases the lift co-efficient of a wing, any reduction of the flap angle during an approach may result in the stalling speed being increased above the approach speed, and therefore the flaps must not be raised during the descent.' ${ }^{39}$

As Canberra came into sight it was time to keep these cautions in mind. Below, east of the airport, were low, sparsely timbered hills, strewn with rocks and dotted with dead trees, stumps, and decaying logs where the ground had been cleared. As observant journalists described it, the hills - all of them a little over 2100 feet high - were scarred by deep gutters etched by cascading rain. That same rain, if it were heavy or persistent, could render the clay surface of the Canberra airfield hazardous for heavy aircraft. This morning the sky was clear, and a medium westerly wind caressed a spur of the range bordering the aerodrome. 'Watchers on the aerodrome saw the plane approach shortly before 11 a.m.,' the Sydney Morning Herald reported, 'make the usual circuit and come in to land':

It appeared as though the pilot had misjudged his height and decided not to land. The machine was trimmed for landing with the wheels lowered in position and the flaps down. The machine gained height and commenced a second circuit.

The hills on the western side of the aerodrome were known to possibly give a false horizon on the instrument panel. Hitchcock might have felt it necessary

39 Air Board Order N.196, ‘Flying Instruction - Approaching and Landing', 26 April 1940, NAA: AA $1977 / 635$. I have followed the wording of the order closely in this summary. 
to go round again. Or perhaps he was just taking the opportunity to show his second pilot or the Air Minister some of the aircraft's characteristics. From the ground near Queanbeyan, Hudson A16-97 was seen to begin another circuit, lower and slower, it seemed, than was customary. What at first looked merely unusual was about to be catastrophic. 


\section{7. 'A leaf falling off a tree'}

Camouflaged though it was with aluminium-doped under-surfaces and regulation RAF dark earth-and-foliage green on the upper surfaces, the Hudson was easily seen by scores of people going about their business in Canberra, Queanbeyan, and the surrounding countryside. ${ }^{1}$ One of the first to catch sight of it was Corporal Mortimer G. Ewing, an RAAF fitter with 2A Survey Flight, who heard the motors at about 10.40, he said, and went outside the Officer Commanding's former office at the aerodrome to see where it was coming from. He could see the aircraft arriving from the southeast at about 6000 feet. Moments later, Pilot Officer Raymond Winter, duty officer of the Survey Flight, saw the aircraft turn left - through approximately 110 degrees to port, he would tell a Service Court of Inquiry two days later - and complete a full circuit of the aerodrome, losing height gradually before continuing in another circuit.

Winter was an experienced civil pilot who had completed an RAAF flying course in May. Two weeks earlier he had successfully landed a twin-engined Wackett Gannet (Al4-6), steering by motors after losing rudder control at 9000 feet and ordering his accompanying photographer to bail out. ${ }^{2}$ When asked by RAAF investigators about his observation of A16-97, Winter said he thought the pilot of the Hudson displayed above-average airmanship as he executed the circuits. Standing on the control tower veranda, Winter could see the machine turn into the wind about 500 feet above the hills and continue in 'an apparently normal approach' with undercarriage down. Having gathered his message pad to write out the message that the Hudson had arrived, he watched as the aircraft approached from the east then turned about 100 degrees to the left, losing height rapidly before disappearing behind the hills. The left wing appeared to be dropping: 'the aircraft flicked down and the port wing continued to drop at an angle of 45 degrees'. The nose, he was sure, when asked later, had not dropped; nor had it gone up. ${ }^{3}$

A less authoritative observer, Flight Sergeant Clifford Linton Smith, a storekeeper, had been standing at the permanent site of the 'new' aerodrome where hangars being erected for the RAAF were almost complete. Smith saw the aircraft approaching from the south, but took no more notice as it did a left-hand circuit until it was flying in an easterly direction 'from where I was standing'. He had noticed that the landing gear was down but it did not seem as though the plane was likely to land. ACl Henry House, a mess steward at No. 2

1 Geoffrey Pentland, Aircraft and Markings of the R.A.A.F. 1939-1945, Lansdown Press, Melbourne, 1970, pp.44-5; Vincent, The RAAF Hudson Story Book One, p.388.

2 NAA: A705, 32/10/2696.

3 NAA: A705, 32/10/2729. 
School of Technical Training, near the Kingston railway station some three miles southwest of the aerodrome, was sitting on the doorstep of the officers' quarters at the school when he heard the aeroplane. He saw it, 'very high', heading in a northerly direction: 'The engines were throttled back over the 'drome. It made a complete circuit of the 'drome and came back heading south. I did not see much because I was cleaning my shoes.'

Flying Officer Ronald Campbell Wilson, the 31-year-old station equipment officer, was walking towards his tent from the ante-room of the Officers' Mess when he heard the noise of aircraft engines. Looking up, he too saw a Hudson about a mile south of the aerodrome going down wind in an easterly direction at the 'usual height he had seen Lockheeds preparatory to landing'. He watched it for a moment or so, he told the Service Court of Inquiry on August 15. He was certain at the time that he noticed that 'the machine wobbled but immediately became, what appeared to me, normal again'. A fortnight later, having looked at other Hudsons approaching in an almost identical fashion, he thought that 'it might have been a trick of the sun'. Wilson was called, and the call took his attention away from the aircraft.

\section{'Is he doing aerobatics?'}

At Parliament House, watching from a window in the office of the Minister for the Army, the minister's staff also saw the aircraft in the eastern sky. Later that day someone remembered Geoff Street's private secretary, Percy 'Pip' Hayter, saying 'The Brigadier will soon be here.' The plane circled and disappeared from sight. ${ }^{4}$ At 10.49, wireless operator Jack Palmer sent the signal 'QAL' — 'I am landing.' 'Ground wind west 10 to 15', was the response from Leonard de Leuil, the wireless operator at Canberra aerodrome. The message was repeated. Then, with a hint of concern that there was no acknowledgement, de Leuil asked: 'Did you want wind?' Half a minute later VMZAY responded but the signal was in de Leuil's words, 'jammed out'. De Leuil tried again at 10.50: 'Did you get the wind OK? ${ }^{5}$

Elsewhere, at Canberra aerodrome most civilian workers, and airmen like Flight Sergeant Smith, were paying little heed to the sound of another incoming aircraft. The RAAF's No. 8 Squadron had been established at Canberra in August 1939. A year later, plans to transfer the aerodrome from civil to military

4 The Herald, 13 Aug. 1940.

5 Feature articles by ill-informed writers 30 or 40 years later sometimes assumed that radio contact was actually by voice. 'The pilot's voice was almost blasé as he reported "I am landing,"' (The Observer [Gladstone], 21 Dec. 1972). 
control had yet to come into force. ${ }^{6}$ An RAAF station had been opened formally at the beginning of April 1940 under the temporary command of Squadron Leader Paddy Heffernan. But for the first few months the Air Force had to make do with an orderly room in the civil aerodrome administrative building. The protracted coal strike and consequent shortage of steel meant that buildings and hangars took longer to finish. Airmen and junior officers required to sleep on the base were accommodated in tents. The Chief of the Air Staff had personally intervened to order the provision of five blankets per man, covering the issue with a medical certificate to the effect that it was essential.

A civilian, Sydney Rhodes, was the senior attendant in charge of the aerodrome. It was customary for him to watch approaching aircraft and to have the only 'crash equipment truck ready for any emergency'. Rhodes was standing outside the original hangar — a large structure, diagonally opposite the RAAF hangars, completed in 1936 - and watching the Hudson approach now from the northwest; it was about 10 miles away, he thought, at 3000 feet or 4800 feet above sea level. Asked 13 days later by counsel assisting the Coroner if he was competent to judge the height of the aircraft, Rhodes said he had been connected with flying for some time. 'We sometimes have competitions at the aerodrome to gauge the height of planes. ${ }^{\prime 7}$ To lend further authority to his testimony, he prefaced his evidence by stating that his employer was 'Mr C. S. Daley', Assistant Secretary of the Department of Interior, the most senior Canberra administrator and colleague of the Coroner on the Federal Capital Territory Advisory Council. Fortunately, he had nothing to lose; he may have been unaware that the Coroner blamed Charles Daley for a severe professional humiliation earlier in their careers. ${ }^{8}$

On August 14 Rhodes described what he had seen to Commonwealth Police Sergeant Ivan Perriman of the Acton Police Station:

The plane made one complete circle of the aerodrome, and the half-circle which brought the plane from a south-easterly direction preparatory to landing into a north-westerly breeze. I saw the plane approaching the hill closest to the drome, and it appeared to me to have then lost unusual height for landing, but I thought it would clear the hill. The next thing I saw was the plane appearing to make what I thought was a right hand turn. It then disappeared from my view behind the hill.

6 T. H. Cooke, 'Aviation', Canberra's Engineering Heritage, Canberra Division. The Institution of Engineers, (2nd ed.), 1990, Ch. 11; Ginette Snow, Canberra Airport:A Pictorial History, Capital Airport Group, 2009, pp.7-12; 'Report of [CAS] Staff Conference No. 32...30th April, 1940', NAA: AA1977 635.

7 Sydney Morning Herald, 27 Aug. 1940.

8 Charles Daley (ed. Shirley Purchase), As I Recall: Reminiscences of Early Canberra, Mulini Press in assoc. with Canberra \& District Historical Society, Cook ACT, 1994, pp.124-5. Rhodes became a stipendiary magistrate, president of the Trades \& Labour Council, and Labor candidate for the ACT in 1949. 
Pilot Officer Winter, seeing the Hudson again, had noticed its left wing down for a second or two. The aircraft appeared to be straightening for approach when the left wing dropped, rapidly at first and then more slowly until it reached an angle of 45 degrees before he lost sight of it. Winter observed that the undercarriage was down but could not say if the flaps were down - he would say later that from that distance it would be hard to judge if the flaps were down. Sydney Rhodes was sure they were not. But Corporal Ewing, recalling the aircraft as he saw it about two-thirds of the way around its second circuit with its engines running normally and wheels coming down, thought he remembered seeing the flaps down. At that time the Hudson was about 500 feet above ground, by his estimate, 200 feet above the hill. Winter had by then gone inside to get a pad to write out the routine arrival message.

About a mile and a half from Queanbeyan on a high point of the road some 300 yards east of the railway station, with a clear view of the Sutton Valley and surrounding hills, F. A. Tetley, a garage proprietor, and his assistant, Lawrence $\mathrm{O}^{\prime}$ Brien, were pushing a truck into the garage when they heard aircraft engines. ${ }^{9}$ A few hours later, they told journalists that they looked up and were struck with how low the aircraft appeared to be. 'Ah boss,' Fred Tetley's assistant said, 'look at this fellow - he's stunting low.' They watched as it flew on north of them towards the hills across the Sutton Valley about two miles away. O'Brien estimated that it turned about 200 degrees before it 'slipped sideways to the right' while at the same time the left wing went down. 'Young' $\mathrm{O}$ 'Brien, as The Examiner called him on August 14, was under the impression that the aircraft had just taken off and was circling to gain height. It appeared to be making a circuit to the left when 'the left wing dipped suddenly and the machine dropped height rapidly'. It dropped nose first into a stall, making two 'corkscrew-like spirals'. The two men gazed in horror as the machine went into the ground among trees. They heard no noise but saw it at once burst into flame. As a column of black smoke then began to rise - it went to 100 feet, they thought Tetley telephoned the Queanbeyan police and gave them directions to the site.

Meanwhile, mess steward Henry House, his shoe cleaning completed, had looked up again and saw the plane heading north, 'just a little over the height of the hills from where I was, almost directly in front of me'. House would say later that he thought 'it was too low if it were going to land'. He noticed the aircraft nose dip 'and it gave a couple of spins' before passing from his view. James Mathews, leading cook at the Royal Australian Navy's Harman Naval Wireless Station, was looking out of his window to the east when he saw 'a large aeroplane falling straight to the ground'. ${ }^{10}$ Speaking to Senior Constable R.

9 In at least one account they were pushing a car out of the garage.

10 Unless otherwise indicated the eye-witness accounts are derived from statements to the Commonwealth Police (NAA: A1378, P8903) and subsequent testimony to the Coronial Inquest, the Service Court of Inquiry, or the Air Court of Inquiry. 
S. Brodribb the next day, he estimated that he was some three or four miles from the crash site. He had not seen the aircraft before he noticed it falling. He could not hear its engines; but he saw it burst into flames. There had been no smoke or flames visible before the impact. Closer to the scene than Mathews were Dudley Lalor, a carpenter by trade and Canberra manager of Victorian construction contractors, J. L. Simmie \& Co., and his foreman plasterer, Jack Tilyard. The Simmie company was working on erecting the hangars at the aerodrome as well as on the construction of the Australian War Memorial, having completed several important Canberra projects including the Albert Hall and Manuka's Capitol Theatre. ${ }^{11}$ Lalor and Tilyard were driving to the aerodrome from a job in Queanbeyan. As they came down the hill approaching the bridge crossing the Molonglo River on the Sutton Road - not the main Canberra-Queanbeyan road - they noticed the aircraft about three-quarters of a mile ahead. It flew easterly across the Canberra-Queanbeyan road about a mile and a quarter from the aerodrome. They could see that the wheels were down but could not hear the engines. They said the aircraft turned to the left 'at a steep angle and went into a spiral dive'. The Age 'special representative' reported next day that 'Mr Lalor involuntarily shouted a warning'. 'I pulled up the car with a jerk,' he told other journalists, 'and yelled, "Look Tilyard! He'll never make it." Tilyard replied, "My God, no. He's got no chance."”12

Speaking to Sergeant Perriman on August 14 Lalor described the plane hitting the ground 'as though it were landing'. Thinking about it a day later, Lalor reiterated that he saw the machine turning left in a northerly direction and the left wing dropping. The aircraft then turned completely over, he said, in a rolling movement with the nose down. The aircraft was at an angle of about 45 degrees when it hit the ground. That was how he remembered it 13 days later for the Coroner. Launceston and Perth readers had seen a more graphic account in The Examiner and the Western Mail on August 14:

The whole ghastly business happened right before my eyes. A few feet from the ground the plane appeared to pull slightly out of the stall and, instead of nosing into the ground, it struck at a shallow angle. The machine caught fire immediately, but Mr Lalor was emphatic that there was no explosion.

As Lalor and Tilyard ran up the hill across the paddock to see if they could help 'there was a sudden burst of intense flame, and a dull explosion was apparent from one of the petrol tanks'. By then, RAAF men who had passed them in a 'lorry' were at the scene. Lalor got as close as he could to the plane but the

11 Simmie \& Co. were about to discover that they had been operating in Canberra without fulfilling the registration requirements as a 'foreign company' and were liable to a fine of $£ 5$ a day since October 1935. After apologies, no fine was imposed (NAA: A432, 1940/651).

12 The Examiner, The Western Mail, The Age, 14 Aug. 1940. 
servicemen declined his offer of assistance; and he and Tilyard were soon ushered behind a cordon of NCOs and lower ranks that Corporal Ewing and Flight Sergeant Smith, under Flying Officer Wilson's orders, had established 150 yards away from the burning wreckage.

Unbeknown to the Simmie managers, one of their employees had a different vantage point. A young bricklayer, Bob McJannett, working on the hangar roof at the aerodrome, would recall 67 years later:

I always liken it to a leaf falling off a tree...

I think there was a wee bit of pilot error inasmuch as he possibly misjudged the speed of the wind for a start and then he banked too sharply which meant that he had more wind force up against him when he put the nose [down]...He actually didn't get right around. He got about halfway round you see, that's when the wind hit him...it just sort of spiralled down.

McJannett had the same reaction as Lawrence O'Brien: 'I said to myself what a stupid height to be stunting. And it was only when he disappeared I thought God, he's crashing and next thing this huge big cloud of black smoke came up. ${ }^{\prime 3}$

John Power, a railway goods clerk, was standing at the door of the office at Queanbeyan railway station when he saw the Hudson flying from Canberra 'fairly low in a normal fashion'. There was nothing about it to hold his attention, he told the Service Court on August 15. The engines sounded normal. It turned west towards the aerodrome just as he moved inside to answer the telephone. D. R. Vest, 42-year-old managing agent of the Texas Oil Company, was at the goods shed at the station. He told the Coroner that he saw the plane heading towards 'heavily timbered country' on course for the aerodrome. Then, he thought, it made two turns to the left, apparently getting into trouble on the second turn. Earlier he had told newspaper reporters and the Service Court that there was a large piece of cleared ground between the plane and Queanbeyan; and he thought the pilot was making for this ground for a forced landing. But before getting there the pilot suddenly took a turn to the left. He seemed to lose control. 'The wing dipped first to the right and then to the left and the whole plane zigzagged until it hit the ground in a pancake landing. It struck the ground heavily and immediately afterwards burst into flames. ${ }^{14}$ In a signed statement for the Coroner Vest said: 'I did see it hit the ground.'

Darcy Vest, like several of the eye-witnesses, would have to tell his story at least three times over the next two weeks as the Coroner, the RAAF, and the

13 McJannett interview with Philip Williams, Stateline Canberra, ABC Canberra, 29 June 2007, http://www. abc.net.au/stateline/act/content/2006/s1967294.htm, transcript accessed 20 Nov. 2010.

14 Canberra Times, 27 Aug. 1940; Vest statement 26 Aug.1940, Coronial Inquiry, NAA: A432, 1940/764. 
government all urgently mounted inquiries. Speaking to the Service Court of Inquiry, he said that when he saw the aircraft it was about a mile and a half from the aerodrome and 400 to 500 feet up. He visualised that if it continued it would crash into the thickly timbered hill between it and the aerodrome. Interviewed by reporters only hours after the crash, Vest had given a more detailed narrative of what he saw and heard:

I heard the motors running perfectly, and watched the machine for about a mile as it glided over the hills 400 or 500 feet up and heading for the aerodrome... when I first saw the machine it was under perfect control, and the motors were running. The pilot throttled them back, and just after he did I noticed that although still gliding stably the aeroplane was losing height much more rapidly than is usual when machines approach the landing ground from that quarter. As I watched, I realised that although still headed for the aerodrome the machine would not clear the last of the hills in its path if it continued its quick descent. The pilot must have realised this simultaneously. To his left, on the timbered hillside, there was a big bare patch of ground.

Suddenly, as the machine continued to sink rapidly, it made a quarterturn to the left, flying towards me and still dropping steadily. It made another quarter-turn to the left, and seemed to head for the bare patch.

Vest kept the aircraft in view and, as the turn was completed, 'it seemed to waver and wobble, when the nose fell and the machine drove in a corkscrew spiral into the ground, striking it', one journalist quoted him as saying, 'almost vertically'. That was one version. ${ }^{15}$ To RAAF officers convened on August 15, Vest was recorded as testifying: 'The plane did not then dive spirally into the ground but went in on a more or less flat turn. The plane hit the ground at an angle of 30 to 40 degrees.' A few minutes later he spoke of a 'spiral dive to the ground'. In fact, Vest had lost sight of the aircraft before it hit the ground though he saw immediately afterwards 'a bright flame flash above the hilltops and then dense clouds of smoke billowed up from the wreck'. ${ }^{16}$ Vest had seen enough to know that urgent action was necessary if there was to be any hope for whoever was in the aircraft. John Power 'heard Mr Vest call out something about the plane'. Vest went inside the goods shed office and asked the clerk to ring the aerodrome, ambulance, and fire brigade. Some seconds later, with a small group congregated on the railway platform staring at the dense column of black smoke, Vest heard 'a loud report'. The same 'explosion...much fiercer' than the first noise he noted, was heard as far away as Harman naval base by

15 The Daily Telegraph report (14 Aug. 1940), in nearly identical words, does not include the phrase 'almost vertically'.

16 The Mercury, 14 Aug. 1940. 
James Mathews. Vest did not immediately go out to the site although he would tell Queanbeyan Police Constable Harold Sheldrick later in the day that when the plane hit the ground it stopped where it crashed. ${ }^{17}$

Much closer to the aircraft, as it did a left turn northwards towards the aerodrome, was 55-year-old Harry Southwell. Working in his pioneer family's Queanbeyan market garden within view of the aerodrome, Southwell saw the left wing drop 'and the aircraft appeared to roll over on to its back and the nose went down'. He lost sight of it as it dived towards the ground about threequarters of a mile away. 'Instantaneously there was a loud explosion and a sheet of flame went up.' 'Did the engines of the aircraft appear to you to be functioning normally?' he was asked soon afterwards at the Service Court. 'Yes up to the time the aircraft rolled over, then as the nose went down the engines appeared to roar.' Dairy farmer Hilton Clothier, out in a paddock fencing with his 16-yearold son Geoffrey, looked up to see an aircraft coming from the west. Clothier's observation from his Queanbeyan River property 'Hazelbrook' on the Oaks estate was similar to Southwell's. He watched the plane flying east about two miles away until it came at about 800 feet to within 800 yards of where he was. As it reached 'the junction of the Queanbeyan, Yass, and Queanbeyan Sutton road' it turned to the north covering a radius of about a mile. Clothier noted that as the plane lost height, the left wing dipped to an angle of 45 degrees. Then, he thought, it seemed to right itself and go about 30 degrees the other way. There was a fairly stiff westerly breeze blowing, he told the Service Court, and 'just at that point I heard the noise of an engine crackle as though it was trying to pick up. Simultaneously the nose went down and then I saw the plane dive towards the ground.' Correcting himself Clothier went on:

It was not really a dive but it was a sort of skid with the nose down and half slipping around to the left at the same time...

It went from my view behind a clump of trees. When the crackle started as those engines were trying to pick up I saw flames coming from the right wing. ${ }^{18}$

Clothier alone reported seeing flames while the plane was in the air. Two other witnesses, John Castle and his 10-year-old son, saw the final seconds. Castle, a Sydney real estate agent and auctioneer, had been driving close to Queanbeyan and was about to return to Sydney. In the next day's Daily Telegraph, alongside photographs of 'Mr John Castle' and 'John Castle Jr', their story was prominent:

17 NAA: A1378, P8903.

18 Hilton Clothier had been a wool classer with New Zealand Loan and Mercantile, then a wool and skin buyer, before starting a five-pen dairy after bankruptcy in 1937 (Karen Williams, Oaks Estate: No Man's Land, 1997, p.151). I am grateful to Raphael Clothier, Hilton Clothier's eldest son, and Max Hill, who as a youth on his father's commercial vegetable garden saw Al6-97 making a circuit over the aerodrome, for information about the Clothier family and Harry Southwell (telephone interviews, 5 Feb., 21 Jan. 2011). 
The plane was pulled out of three slips before it made a final half-roll and crashed.

John asked, 'Is he doing aerobatics?' and I replied, 'No, he's too low; he's in trouble.'

The big plane slipped to one side, and the pilot pulled it out - only to slip to the other.

That happened three times, and it then did a half-roll.

John called out, 'Look you can see the cabin windows,' as it did.

It slid from sight just behind the low hills in front of us, and there was an immediate sheet of flame.

It must have been an inferno. Black smoke followed when the flames got to the oil tanks.

It was no use my rushing to it. Nobody could have lived in that flame.

What impressed me were the desperate attempts the pilot made to get out of trouble.

He was like a car driver trying to pull a car out of a bad skid.

\section{The race to the site}

When the aircraft disappeared from the sight of those at the aerodrome and billowing dark smoke appeared, Flying Officer Winter asked Flying Officer Stanley Willmott, a special-duties officer, to get in touch with the Air Board. Winter ordered the despatch of the fire tender and ambulance and two crash parties before following in an official car. Flight Sergeant Smith went out to the 'main Air Force road and procured a tender', the station's crash-emergency vehicle that was passing, and set off for the site. He would reach the burning wreckage - about one and three-quarter miles southeast from the landing ground - in about five or six minutes, a few seconds after the RAAF ambulance. 
Ten Journeys to Cameron's Farm

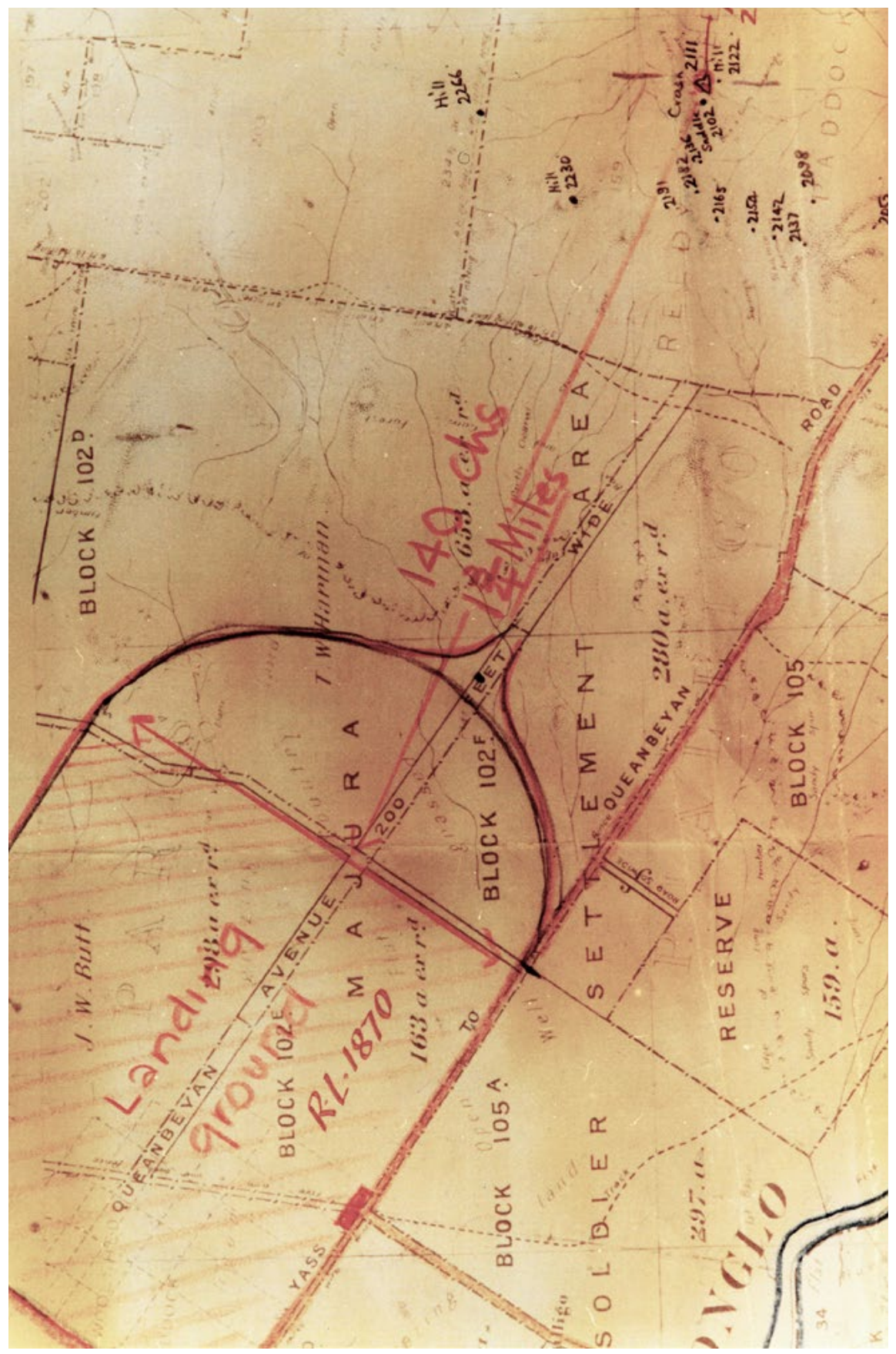

The crash location marked for the Coroner on a 'Federal Territory feature map' published by the Department of Home Affairs

(Courtesy of the ACT Coroner's Office) 
Flying Officer Ronald Wilson heard somebody cry 'Ambulance, fire tender, the Lockheed has nosed in.' Wilson rushed over and jumped into the ambulance with Sergeant W. H. Galvin, the medical orderly sergeant, who had gathered his first-aid kit and already started the engine. Galvin drove along the Queanbeyan road and turned into a paddock to get closer to the aircraft which had come down in Duncan Cameron's 'Dundee', an 888-acre hilly grazing property about two miles north of Queanbeyan on the ACT border. ${ }^{19}$

The RAAF rescuers had to proceed on foot, running through the scrubbed hillside paddocks, dotted with stumps, to reach the smoking wreckage. Winter got there 'immediately after the fire ambulance and ahead of the crash party' he had despatched. Just ahead of him, Wilson claimed to be the first man on the scene, noting that his time of arrival was three minutes past eleven (he checked his watch with 'wireless time' at 1.00 p.m.). Wilson would tell the ACT Coroner 13 days later:

When I arrived the machine was on fire. One part far more than the other. The fuselage had practically finished burning. The starboard wing was only just burning. It was burning very quietly. It wasn't a big blaze at all. The tail fin and rudder were not burning. The port wing and the nose were burning very fiercely.

The aircraft, evidently coaxed into a trajectory of 40 to 45 degrees for a crash landing, had come to a sudden halt on impact with a log — described in some reports as a stunted tree - some two and a half feet in diameter and 15 feet long. Rather than travelling forward, the plane had bounced back about two or three feet, and the engines were embedded in the ground. Sparks had ignited vapour and fuel from a ruptured tank. The wind blowing from the west was pushing the flames toward the nose of the plane, which was oriented north of east. So fierce was the blaze that the young Daily Telegraph journalist, Alan Reid, who went out to the scene, saw that grass was burned and the earth scorched for a radius of 50 feet around the wreckage. A tree 100 feet ahead of the nose was also scorched. Flight Sergeant Smith realised that there was little he could do with the extinguisher he had taken from the ambulance. He told the Coroner the next day that he had 'played it on the bodies mostly. It was not very successful.' Another day later, talking in camera to the Service Court, both he and his superior, Ronald Wilson, were more emphatic: the RAAF extinguishers were 'hopeless'. There was no alternative but to wait for the fire brigade.

19 Block 60 Gungahlin District, Crown lease granted to D. A. Cameron in 1936, was subsequently disposed of to W. A. Taylor (Sharon Priestly, ACT Place Names Officer, to CH, 8 Sept. 2011). 


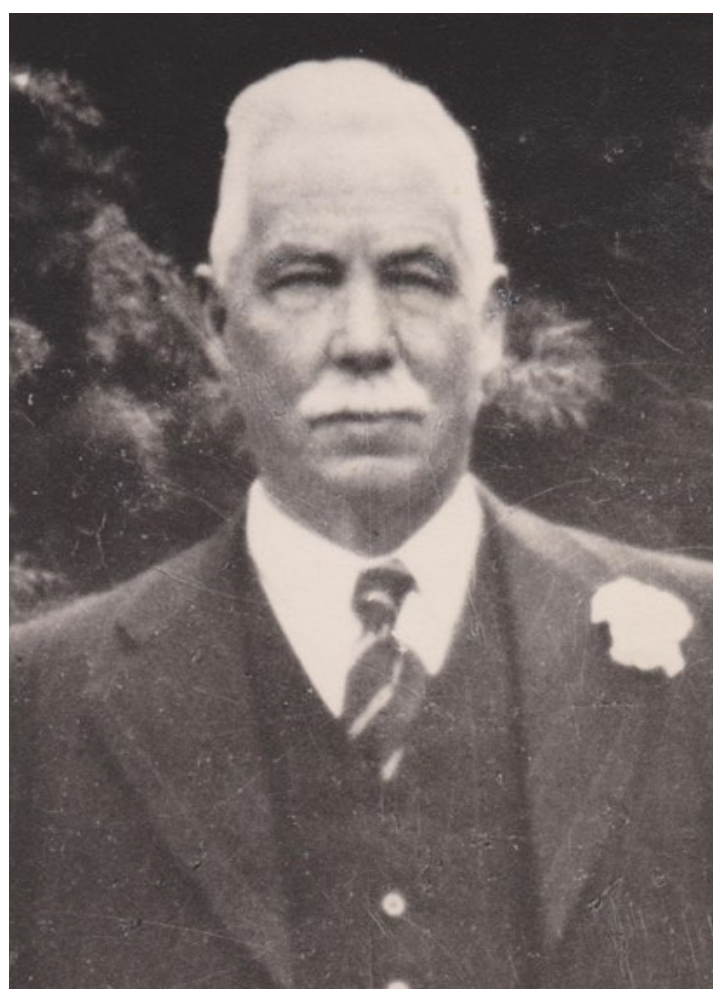

'Old' Jack Butt, perpetually haunted by the lives he could not save (Courtesy of Edna Byrne)

Neither Smith nor Wilson made mention of arriving to see a white-haired local farmer, Jack Butt, and his 15-year-old son Bill, 'attacking the aircraft with axes', and ordering them away. Butt, who lived in Queanbeyan, had leased a 298acre soldier settlement block (102C), much of which had been reclaimed by the Department of the Interior in 1936 to expand Canberra's landing ground; he had been given in exchange a site on the edge of the nearby hills on which he ran sheep. ${ }^{20} \mathrm{He}$ also share-farmed with Duncan Cameron, about a mile closer to Queanbeyan. He was ploughing in Cameron's paddock when he heard an aircraft in trouble. As he would tell his family, when he saw the flames and smoke he rushed to the scene in his truck. He would later tell Jo Gullett of his distress at being prevented from trying to save several men whom he believed were still alive. He had pleaded with an RAAF officer to try to pull away the lightly burning starboard wing, but was told nothing could be done. As his

20 Agistment of sheep on the aerodrome was permitted, a drover being required when mail planes were due, as late as 1938 when the Canberra Aero Club plane struck a stray on landing (Canberra Times, 1 Aug. 1938). 
youngest daughter, Edna Byrne, would recall 73 years later, the sight of men 'panicking at the windows' as they were engulfed by flames would haunt her father for life. ${ }^{21}$

Butt's name appears nowhere in contemporary press accounts or official records of the crash investigations. The story remembered by his family and by Jo Gullett, who wrote of it privately in 1972, is dramatically at odds with the sworn testimony of the RAAF officers and men at the scene. Jo Gullett told the story to Lord Casey in 1972 and apparently to no-one else. ${ }^{22}$ Did Butt or his son tell anyone other than Jo Gullett that they had seen men alive in the crashed aircraft? Were they disbelieved, purposely ignored by the authorities, encouraged to keep silent? Or had they just convinced themselves that no good would come of talking about it? There are no answers to these puzzling questions. Jack Butt, an AIF returned serviceman, a stalwart of the pastoral and agricultural association, was a respected figure in the local community. Perhaps, when it was obvious there was nothing they could do, he and his son simply went back down the hill and returned to their ploughing, somehow escaping the notice of the police.

Jack Butt and his son were not the only men to reach the scene moments after the crash. A young truck driver and well-known local rugby league player, Les McIntyre, on his way from collecting brickies sand, had also been close by. He had run to the aircraft, too late to do anything other than gaze at the burning wreckage. It was a sight that haunted Les McIntyre. His son, John McIntyre, would recall his father's memories of helplessness, often waking in the night long afterwards. ${ }^{23}$

It was no puzzle that the plane had burned so quickly. There were two fuel tanks in each wing centre section of the Hudson. They were directly above the undercarriage struts, rendering them liable to rupture with a heavy landing or broken undercarriage. The tanks were integral tanks - the actual wing structure was sealed to contain the fuel. The capacity of the front tanks was 125 imperial gallons; those in the rear each held 143 gallons. $\mathrm{CO}^{2}$ extinguishers were fitted on the firewall behind the engine accessory section (between the engine and the fuel tank). ${ }^{24}$ With a full fuel load of 536 gallons on take-off from Laverton it is likely that there would have been well over 400 gallons remaining when the plane hit the ground. It was bad enough that the tanks had been only minimally depleted by the trip. Worse was that the Hudson, like all Australian military aircraft, did

\footnotetext{
21 Edna Byrne, telephone interview, 26 March 2013; interview with Alex Sloan, 666 ABC Canberra, 25 March 2013. Mrs Byrne recalled being taken to the crash site a day or two later, walking though white ash, and discovering a clump of coins melted together.

22 Jo Gullett to Lord Casey, 7 Oct. 1972, NAA: M1129, WHITE/C B.

23 Megan Doherty, 'McIntyre recalls crash', Canberra Times, 18 May 2013.

24 Ron Cuskelly to $\mathrm{CH}, 14$ Nov. 1978.
} 
not have self-sealing tanks. Both the British Air Ministry and the RAAF had been unhappy to learn in January 1940 that no satisfactory way had been found to modify the Lockheed aircraft's integral tanks. Jim Fairbairn, who had been intrigued by the self-sealing tanks of a downed German Dornier bomber on an RAF station in France, had called for a report on them just two months earlier. What further accentuated the conflagration was the high magnesium content in the metal skin of the plane. ${ }^{25}$

As the senior Air Force officer present at the wreckage, Flying Officer Wilson took charge and told men to search in front of the plane in case anyone had been thrown clear. One unnamed 'rescuer' was quoted the next day in the Daily Telegraph as saying: 'From the position of the bodies it appeared that they knew the crash was inevitable. They were grouped together, as though the victims had risen from their seats and made for the door of the plane.' This was not the testimony of any of the witnesses who went on the record that day and later. Wilson said he had seen four bodies in the wreckage 'already not recognisable' but knew there must be more. None had been found at the front. Smith had seen three bodies at first. One was at the rear on the ground near a gap where the exit door should have been; the door itself, detached and lying 10 to 15 yards behind the tail, was severely dented. Smith thought that the door might have been released from the inside. Two bodies were on the port side, two yards closer to the nose. The fuselage had been consumed by the fire and the bodies had just fallen through. Following a mild explosion, another body fell out near the port engine. As Wilson, Smith, and the others took in the horror of the scene, the RAAF tender and ambulance were rapidly joined by the airport crash-emergency vehicle. Flight Lieutenant Lloyd Law of the Survey Flight at the aerodrome reached them at 11.10 a.m. and departed almost immediately, leaving Wilson in charge.

Arriving in his own car shortly after the fire tender, ambulance, and two tenders which he had despatched, Pilot Officer Richard Winter, the duty pilot of the Survey Flight, ordered the airmen to empty their extinguishers on the bodies. Winter put on an asbestos helmet and gloves - there were no asbestos suits available - and moved the port wheel and undercarriage leg away from the bodies. There was nothing more they could do, he would tell the Service Court of Inquiry, until the Canberra Fire Brigade arrived. The Queanbeyan police were even less able to help. Alerted by the garage proprietor Fred Tetley, Sergeant

25 Lettice Curtis, The Forgotten Pilots: A Story of The Air Transport Auxiliary 1939-45, G. T. Foulis, Henleyon-Thames, 1971, pp.126-7; 'Lockheed Hudson (B14) - Policy Equipment', NAA: A705, 9/19/50; 'Aircraft Fuel and Oil Tanks — Fire and Bullet Proofing — Processes', NAA: A705, 9/1/598 Pt 1. Mark III and IV Hudsons had self-sealing petrol and oil tanks ('New Features noted on Hudson Aircraft during Erection 1942', NAA: A705, 9/19/69). 'The Hudsons were unpopular in some quarters because of their tendency to burn after a crash landing...it was a standing joke after a heavy landing to shout "Out quick they burn."” (C. L. Hawkes to $\mathrm{CH}, 27$ April 1977). 
L. J. Warburton drove a motor truck with Constable Harold Sheldrick to the crash site, finding the aircraft enveloped in flames. The two policemen said they could see men hunched forward in their seats but could not reach them because of the heat. Outside the machine, scorched but neatly folded parachutes lay among 'charred and smouldering clothing... mixed up with tools, the remains of seats and fixtures, twisted pieces of metal', burnt cameras, suitcases, and other personal belongings. ${ }^{26}$

Although smoke was visible almost immediately after the aircraft itself vanished from view, there was no way of knowing from the airport control tower whether there were survivors. While Sydney Rhodes was racing from the civil aviation hangar in the aerodrome's 'crash equipment car' in the direction of the burning aircraft a call was made to the Canberra Community Hospital for medical staff to be alerted. Nurses were told to prepare 10 beds, only to learn soon afterwards that they would not be needed. Dr Lew Nott had been collected by police from his nearby property but quickly realised that there was nothing he could do for the victims. ${ }^{27}$ Others whose duty called them were converging on 'Dundee', Duncan Cameron's Majura farm. Monsignor Patrick Haydon, Canberra's first parish priest and confidant of ministers and officials, was hurrying to offer or administer the last rites. Police too were on the way. Senior Sergeant Bailey of the Commonwealth Police was despatched to the scene, followed an hour or so afterwards by his chief, Colonel H. E. Jones. Bailey arranged to return with the 'Deputy Coroner' to view the crash site and inspect the bodies. ${ }^{28}$

Whatever the fate of the men on the aircraft, ambulances and fire-fighting equipment would still be required. Since 1935 the Canberra ambulance service had been co-located with the fire brigade though it was soon under the administrative control of the newly formed hospital board. There had never been an exercise to test systems for co-ordinating RAAF and civilian emergency responses. There was no direct telephone line from the sprinkler installations at the aerodrome to the fire brigade headquarters. But the delay this day was minimal. The hospital telephoned the fire brigade. As the brigade 'daily occurrence register' records, the phone message at 10.58 on the morning of August 13 advised of an aeroplane crash on Queanbeyan Rd near Harman wireless station. A fire appliance and an ambulance were requested.

The Canberra Fire and Ambulance Service had one fire appliance and six officers who were on a 24-hour, seven-days-a-week roster. Fire officers with first-aid certificates could be rostered alternately for ambulance duties. For this they would wear white dust-coats and special caps and would earn an extra allowance

\footnotetext{
26 Daily Telegraph, The Examiner, 14 Aug. 1940.

27 Tink, Air Disaster, p.178; Canberra Times, 6 May 2013.

28 Commonwealth Police File, NAA: A1378, 4 P8903. The 'deputy coroner' is not identified but presumably this was a reference to 'Colonel' John Goodwin described elsewhere as Acting Coroner.
} 
of five shillings. Station Officer Bill Maloney was in charge at the new Forrest fire station in Empire Circuit when the telephone call came from Canberra Hospital. As it happened, the No. 1 ambulance, a Buick bought 16 months previously, with officers Harold Stephenson and Tom Hynes on board, was already on its way to the hospital after a call received about 20 minutes earlier. So a message was left for them to drive to the aeroplane accident at 'Pialligo aerodrome' as soon as they could. The station fire-alarm bell was sounded by watch officer C. Lomax. Billy Stewart, the rostered driver, and Lomax's son-in-law Jim Kearney, a professional rugby league player recently added to the crew, jumped on board the Dennis fire engine with Maloney. Extra chemical extinguishers were stowed; and the fire crew headed off through the Royal Military College to the Queanbeyan-Yass road, then turned up the Sutton road.

Almost as soon as they left the station the firemen saw smoke and realised that they had been given the wrong directions. Knowing the area well, they lost no time, and about a mile and a half along a gravel section of the Sutton road - deemed by the Department of the Interior to be in 'trafficable order' - they decided to divert through the bush. Using wire cutters they forced their way through a fence. 'We just followed the smoke', Maloney remembered. Meanwhile, Officer M. O'Brien was called in from leave and told to take the station's reserve ambulance, its superseded 'Austin appliance', to the scene of the accident. He did not make it, returning after 40 minutes with gearbox trouble. The Austin had been prone to breakdown for years, and could manage only 15 miles an hour when climbing Canberra's 'mild slopes' in third gear. ${ }^{29}$

When they arrived at what Maloney described in a police statement next day as 'Cameron's paddock', the fire crew found the nose of the aircraft in the ground, the left wing completely burnt, the right wing and tail in the air, the small wheel on the ground partly burnt. They approached the plane at once with five soda/acid and two pyrofoam extinguishers as well as water. Watching as the firemen moved forward, Flying Officer Wilson made a note of the time they arrived, and instructed Sergeant Charles Oscar Bueno, a storekeeper at No. 2 School of Technical Training, who was with him, to do the same. Police Sergeant Ivan Perriman took Bueno's statement the next day, when he said it was 11.24 a.m. The Queanbeyan brigade reached them at 11.33, three minutes after the first four bodies had been placed in the RAAF ambulance. It was another halfhour before the remaining bodies were taken from the wreckage.

29 Interviews W. Maloney, 15 July 1977; J. Kearney, 23 July 1977; Canberra Fire Station, Canberra Fire Brigade Daily Occurrence Register, Canberra Fire and Emergency Services Museum, formerly held in Australian Archives at CRS A3328; 'Inquisition before a Coroner Sitting Alone', 26 Aug. 1940, Canberra Coroners' Court Papers; Sec. \& Exec. Officer, Bd of Fire Commissioners of NSW to Sec., Dept of Interior, 16 April 1941, NAA: A659, 41/1/151; 'Queanbeyan-Sutton Road...', NAA: A292, C8738; Arthur Ide, Royal Canberra Hospital: An account of its origins and development; The first forty years, 1914 to 1954, Arthur Ide, Canberra, 1994, pp.209-10. 
Report of Stetion Officer W.lialoney.

To Chief Ofloer, Guberza Fire Brigade.

Relative to Aeroplenee orsah on 13.8 .40 .

S12,

I have to report that in reaponse to a telephone call from the Conberre Hospltal st $17.58 \mathrm{gm}$. on 13.8 .40 for an aeroplence cresh on "Queanbejan Road near Harmen Wireless Stetion" I immodetely atowed the "Donnig" applisnce with extro chemicsi extinguisherr and turned out.

Shortiy after lesvine the station smoke from the oragh could be seer and it wes notod thet tho wrong dicretion hed been given. However, eg the logelity 1.8 woll known to the brigede, no tine was lost throngh this cause. The route taken wes through Foyal ililttaxy College to Queanbejan/Yase Rosd. thence elong the Sutton Rosd. Aproxinately one and one half miles along this foad fenolng wiro was polled down and the eppliance travelled across country about one mile to the scene.

Upon arrival the Ilre was attacked with sode/ecid and pyrofoam extinguishers and at the seme time the work of removing the bodies was commenced, the liret body being taken out in about one minute of commenoine operations. Working from the rear, 02 tall, of the plane osch boay was removed ss the fire wes being extinguighed. then seven extinguishers had been used, six bodies hac boen recovered. The Queanbejon Fire Brigade then arrived with two chemicals and with these we were enabled to reoover ono more body. $\Delta 11$ avallable extinguishers were then used up and the empty cylinders were taken by R.A.A.F.tender to ereek for refilling with water to enable thom to be recharged. Before these returned, however, the three remsining bodies, in the nose of the plane, hed been rocorered.

I pergonally took comend of tho situetion and airected all operatione which included the flie, recovery of bodies, covering of soms and their gubsequent romovel to the mortuary. Our work being completied I advised the R.A.A.B. offleers present that we would retum to tho Station. A military suerd was then put over the crash.

Brom obaervet1ong 1 wes noted thet unt1l errelval of the Brigade no attemot was made to elther fight the fire or remove the ocoupants of the plane, it would spnesr that sdequate equipment, for dealing with such a situation was not ara1lable by the R.A.A.J, or, 1t it wes avaliable, no attempt was made to use it either beforo or after the arrival of the Brigede.

The eall to the Brl gade was not a direct one, it having come via the Cenberre Hospital.

The $3 r i g k$ de zeturned to the station st 28.37 pra.

Station officer

Canberra Bire Brigade.

Fire Brigade Station Officer Maloney reports to his chief, 14 August 1940

(ACT Fire Brigade archives, courtesy of Drew McLean) 
Wilson observed that the firemen applied extinguishers where bodies could be seen between the nose and the port engine. Maloney's testimony to the Coroner 13 days later summarised the desperate but unavailing efforts that followed:

The bodies were lying in the debris with the debris of the fuselage on the ground. I took one body out from the tail of the plane. We worked along the tail and removed the bodies as we worked along towards the nose of the plane. The first body was removed a minute or so after commencing operations. We continued to work extinguishing the fire. There were two bodies lying side by side held in by the framework of the seats. We pulled the wire work off the cushions and removed two bodies from there. We worked further forward extinguishing the fire and more bodies were removed. In the nose of the plane there were three bodies. They were removed last. ${ }^{30}$

Bill Maloney had reported on August 14 to the Chief Officer Percy Douglas:

When seven extinguishers had been used, six bodies had been recovered. The Queanbeyan Fire Brigade then arrived with two chemical extinguishers and with these we were enabled to recover one more body. All available extinguishers were then used up and the empty cylinders were taken by R.A.A.F. tender to [a nearby] creek for refilling with water to enable them to be recharged.

Before these returned, however, the three remaining bodies, in the nose of the plane, had been recovered.

Maloney's reiterated reference to three bodies in the nose of the plane appears to be inconsistent with the second of two drawings made the same day by Flying Officer Wilson for Police Sergeant Perriman. The Wilson drawing has marks representing two bodies in the nose and a third on the ground between the nose and the port engine. It also shows three more marks on the port wing. Curiously, in none of Wilson's statements - to the Coroner, to two policemen, to the Service Court or the Air Court - did he say explicitly that he saw two bodies in the nose. To the Service Court, for example, he said: 'When the blaze in the nose and along the port wing had subsided somewhat I saw more bodies, and as soon as it was possible these were taken from the crash. They totalled six...The six mentioned were all taken from the position between the nose and the port engine.'

30 Tink (Air Disaster, p.10), quoting from the Canberra Times report, 27 Aug. 1940, has Maloney accounting for one body in the tail, three in the nose, 'with the remaining six "in pairs on the coiled springs of the burnt seats"'. The newspaper paraphrase of Maloney's testimony said 'the others', not 'six'. The Inquest verbatim transcript, however, refers only to two bodies being removed from the framework of the seats. 


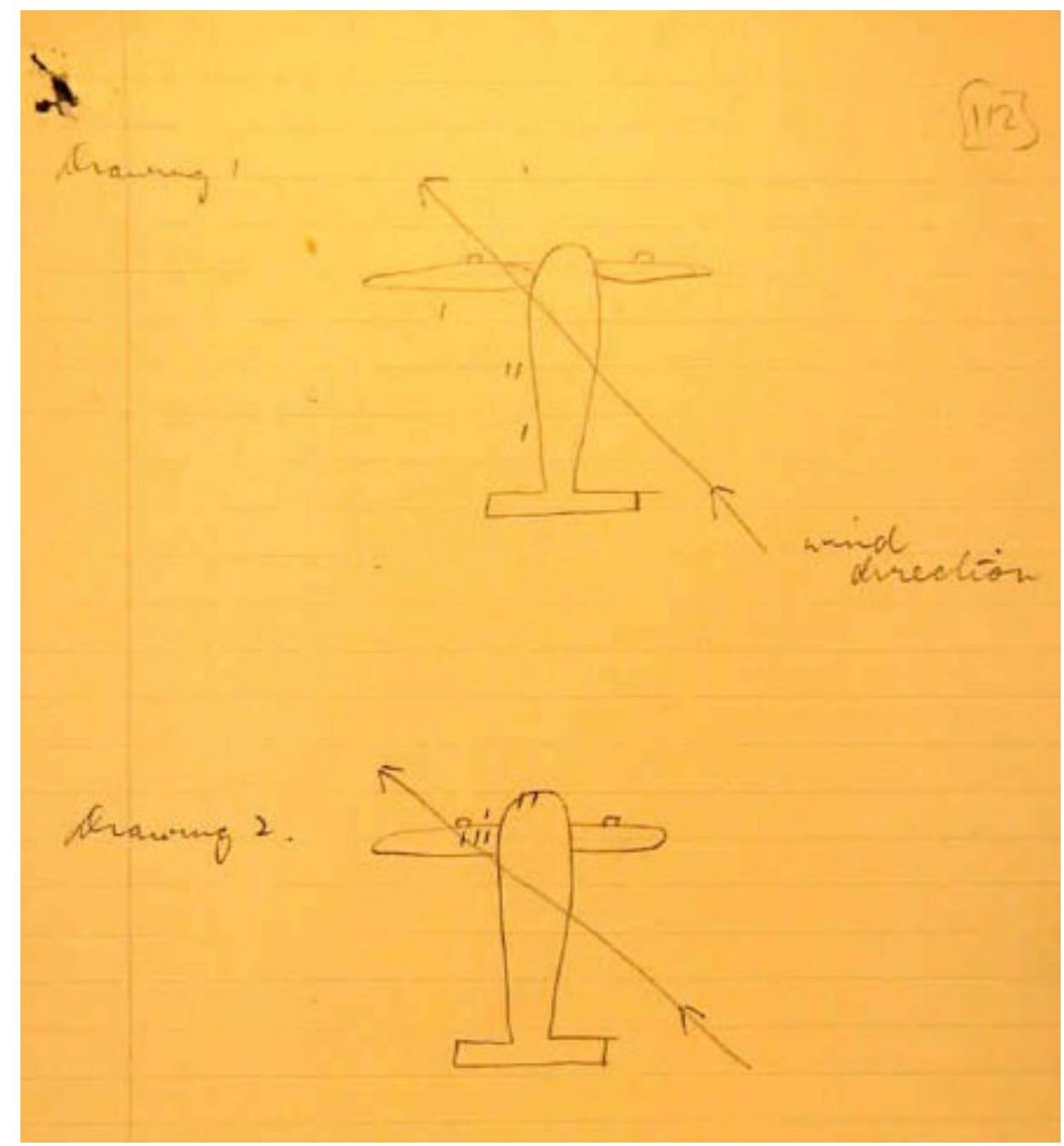

Flying Officer Wilson sketches where he thought bodies were

(Commonwealth Police file P8903, NAA: A1378)

Station Officer Maloney's typed report is explicit that he had personally taken charge of the situation at the site and 'directed all operations which included the fire, recovery of bodies, covering of same and their subsequent removal to the mortuary'. When his work was completed he advised the RAAF officers present that he and his men would return to the station. Flight Lieutenant Law had come back at 12.07 p.m. and taken charge. A military guard was then posted over the crash. By the time the fire crew reached their base at 12.37 p.m., one hour and 39 minutes had elapsed since they received the call out. 
The next day, as he reflected on the horrific events that were to haunt him for a long time to come, Maloney made a point of drawing attention to the fact that until his team arrived on the scene 'no attempt was made to either fight the fire or remove the occupants of the plane'. This was almost true. Flight Sergeant Smith had deposed to the Coroner that he had 'attempted to extinguish the flames with the extinguisher in the ambulance', playing it on the bodies mostly. 'It wasn't very successful. ${ }^{31}$ Maloney, as his young colleague Kearney remembered, was 'a real old bushman, putting it gently...practical man down to the ground. Hops in and gets things done. ${ }^{32}$ It appeared to him that 'adequate equipment for dealing with such a situation was not available to the R.A.A.F. or, if it was available, no attempt was made to use it either before or after the arrival of the Brigade'. This was not an innocent observation. When Maloney's superior, Percy Douglas, prepared a memorandum to accompany the typed report being forwarded to the Assistant Secretary of the Department of the Interior's Canberra Services Branch he too remarked that it 'would appear that prior to the arrival of the fire engine, under the command of Station Officer Maloney, no fire extinguishing agent was available'.

Douglas added that 'Contrary to press reports all bodies were removed from the burning plane by the Canberra Fire Brigade and without the assistance of anyone.' Douglas could not have known that Flight Sergeant Smith would tell the Service Court the next day, and the Coroner 11 days later, that he had assisted in the removal of the bodies. Sydney Rhodes would also speak to the Coroner's Court on August 26 of helping the RAAF men 'in removing the bodies'. The language was ambiguous. In fact, as Maloney himself said in a statement to Police Constable Leslie Ivey, ambulance officers and RAAF personnel worked with firemen 'in placing the ten bodies in the Ambulance and RAAF Ambulance' - Rhodes presumably gave support in transferring the bodies into the waiting vehicles. The Chief Officer did not comment on an accurate press report that his firemen had to borrow asbestos gloves from the Air Force crash tender before they could lift out the bodies. ${ }^{33}$

The Fire Brigade was not overtly critical of the performance of the RAAF. Maloney had mentioned that the call to the brigade was not a direct one. It had come via the hospital. Perhaps mindful of doubts in some minds that lives might have been saved if rescuers had arrived more promptly, Douglas noted for the record that his men got the call eight minutes after the RAAF said the crash occurred. 'Canberra' was, he said, six miles further from the site of the crash than the aerodrome. The RAAF 'therefore, had 8 minutes and six miles start on a

31 Coroner's Court Inquest Papers, now at NAA: A6079, MO 625.

32 Kearney, interview, 23 July 1977.

33 The Argus, 14 Aug. 1940. 
total run, from Canberra, of 16 miles'. Oddly, the Fire Brigade daily register and occurrence book contained no entry for the time of arrival at the scene; nor did the statements of Maloney and Kearney. ${ }^{34}$

At 55, an AIF Heavy Artilleryman, early president of the Canberra RSL Club, and married to a member of the pioneer Southwell family, Perce Douglas was influential in Territory social and sporting circles. ${ }^{35} \mathrm{He}$ was not looking for credit for his men. Rather he was reminding the public service authorities of complaints and warnings that had been made repeatedly over the previous seven years. In August 1937, he had made recommendations about fire precautions at the aerodrome, explaining:

such crash precautions are provided, not with the idea of using them frequently, but with the knowledge that should a crash occur the Department has at hand up to date equipment which will afford a reasonable measure of success in the attempt to rescue passengers and pilots from which, in an aeroplane crash, is unfortunately but usually, accompanied by dreaded and shocking circumstances [sic].

Subsequent complaints resulted in a flurry of blame-shifting as 'carelessness' was attributed by the aerodrome owners to the occupying RAAF units. As recently as January 1940 Douglas had reiterated his concern that fire-fighting equipment including a 30-gallon chemical engine, a hose reel, and 600 feet of 'best quality hose' were being left out in the open. 'While the... apparatus is left out in the rain and the hot sun, deterioration, far greater than need be, must take place and the gear, small enough as it is to protect such valuable property, will shortly become useless.' Driving the point home, Douglas concluded that it was at the time impossible to purchase new fire hose in Australia. ${ }^{36}$ There is no evidence that these disturbing matters had been rectified eight months later. On 13 July 1940 James Fairbairn had approved provision of $£ 5200$ for 39000 feet of canvas fire hose to be ordered from New York. His successor as Air Minister, Arthur Fadden, authorised a further 32000 feet on September $2 .^{37}$

In his signed witness statement for the Coroner, Maloney said that he assisted in placing four bodies in the ambulance, believing that the other six bodies

\footnotetext{
34 If the firemen had arrived earlier, Jim Kearney might have seen Les McIntyre, a former Queanbeyan rugby league player who had played with a combined Southern Monaro team against Kearney's Canberra two weekends previously (Canberra Times, 27 July 1940).

35 Southwell Family History Society Australia Inc, The Southwell Family in Australia: Pioneers of the Canberra District 1838-2007, 2008, p.X; Lyall L. Gillespie, The Southwell Family: Pioneers of the Canberra District 1838-1988, Southwell Reunion Committee, Canberra, 1988, pp.62-3.

36 Report of Station Officer W. Maloney to Chief Officer, Canberra Fire Brigade, 14 Aug. 1940; Chief Officer to Assistant Secretary, Civil Administration, 9 Aug. 1937, 12 Oct. 1939, to Canberra Services Branch 11 Jan. 1940 and 14 Aug. 1940, copies and transcripts courtesy of Drew McLean, Canberra Fire and Emergency Services Museum.

37 Air Board Agenda 2917, 2985, NAA: A4181, 18.
} 
went in the 'RAAF tenders and ambulances'. When Stephenson and Hynes arrived at the scene, they said, they placed two bodies in their vehicle and drove directly to the morgue. The fire brigade daily-occurrence register had an entry for 1.10 p.m. on August 13 noting the return of the ambulance officers in the No 1 vehicle and their report that they had taken two bodies to the morgue. But Tommy Hynes had corrected this, deleting 'two' and substituting 'three', and adding his initials. The discrepancy does not seem to have been noticed subsequently. Stephenson, an ex-Grenadier Guardsman, had seen and gathered up fragmented bodies on the battlefield; he was perhaps more phlegmatic than his younger partner that day. ${ }^{38}$ Hynes had stumbled over a still-smouldering body at the crash site and he may well still have been in shock. If three had been correct, the total would have been 11, one too many. Sergeant W. H. Galvin, driving the RAAF ambulance, also took four bodies to the morgue. In language providing assurance that nothing untoward had happened on their journeys, both Stephenson and Galvin stated that they did not stop en route and had no accidents. The same assurance was offered by LAC Campbell Sheahan, who had driven a RAAF tender to the crash site and assisted in placing four bodies on the tender and taking them to the morgue.

When word came from the aerodrome that the Air Minister's plane had crashed, Street's secretary (Percy Hayter), Murray Tyrrell (Fairbairn's assistant private secretary), and the Prime Minister's secretary, Corby Tritton, were reported to have driven to Cameron's farm to identify the victims. The speed with which the charred bodies were retrieved and transported to the hospital suggests that only the most cursory examination could have occurred at the scene, if indeed the three ministerial staff arrived there in time. On the morning of August 14, as Bill Maloney was writing his statement for the Coroner, the Canberra Times and other newspapers reported that three ministers (the Treasurer, Percy Spender, the Postmaster-General, Vic Thorby, and the Minister for Supply, Sir Frederick Stewart) had gone to the scene of the crash. According to The Mercury they 'inspected the wreckage'. When they arrived, the Canberra Times said, they saw doctors and Air Force men removing the 'remains' of the victims from 'the head of the burnt wreckage'. 'The remains of some of the victims were unidentifiable', the Times concluded.

Stewart and Thorby had in fact arrived on a commercial flight from Sydney late in the morning, and were joined by Spender who had left the meeting of the Loan Council at which he was presiding. Thorby, as a former Civil Aviation minister, could have had a particular interest in a catastrophe so close to the

38 Yorkshire-born, Stephenson grew up in Cairo where his father was a pharmacist. He returned to England to study medicine but war intervened. Post-war he tried pineapple farming in Queensland before settling in Canberra in 1926 and becoming one of the town's first firemen and ambulancemen (Obituary, Canberra Times, 24 June 1981). 
airport for which he had recently shared ministerial responsibility. He had himself been the survivor of a crash landing. Stewart had been involved in some of Kingsford-Smith's aerial business ventures. It is possible that the three ministers were driven to the scene in time to see Flight Sergeant Smith, fire chief Bill Maloney, and others standing among the wreckage at the front of the aircraft. They might have seen the well-known Canberra doctor Lew Nott, who was briefly at the scene, as well as white-coated ambulance men. ${ }^{39}$

Smith later testified, contrary to Perce Douglas's report, that he had 'helped to remove the bodies'. Senior Constable Brodribb of the Commonwealth Police had written on August 20 that Flying Officer Wilson had 'assisted in the removal of the bodies from the wreckage'. ${ }^{40}$ The precise nature of the 'assistance' or 'help' may not be as significant as the fact, if it were a fact, that ministers might have arrived soon enough to talk to some of those who had been earliest and closest to the crash scene. ${ }^{41}$

\section{Identities}

At the small room that served as the morgue it fell to Dr Duncan Mackellar, medical superintendent of the Canberra hospital, to examine the bodies and determine the cause of death in each case. Mackellar, a Sydney University graduate, was a general practitioner with interests in surgery, radiology, and obstetrics. He had some pathology training but had no claim to expertise in forensic medicine. The Depression had cut short his surgical studies in Edinburgh and he had practised in Wollongong and Portland before being recruited to Canberra at the beginning of 1938. In 1940 he was a captain in the Australian Army Medical Corps Reserve, having been commissioned as an undergraduate into the Sydney University Regiment then known as the Sydney University Scouts. To his intense disappointment he had been rejected for service in the RAAF, perhaps damned by an adverse security report of his youthful flirtation with the ultra-loyalist New Guard, but more likely debarred because, at 34 in 1939, he was six years older than the age limit. ${ }^{42}$

\footnotetext{
39 Tink (Air Disaster, p.180) has the three ministers 'talking to various RAAF types' and being informed that until the plane had struck a log the 'pilot had a good chance of making a crash landing in which all the occupants...might have survived'. The Aug. 14 Canberra Times report quoted has 'flying men' expressing this view but does not say they were speaking to, or within earshot of, ministers.

40 NAA: A1378, P8903.

41 The Herald, 13 Aug. 1940; Canberra Times, 14 Aug, 1940.

42 Dr John Mackellar to $\mathrm{CH}$, (email),10, 18 Feb. 2009. I am grateful to Dr Mackellar who advises that the family name gained its first ' $a$ ' and lower case ' $k$ ' as a result of his emigrant grandfather's admiration for the eminent Australian doctor and politician, Sir Charles Mackellar. For Mackellar's later career in Mooroopna and his pathbreaking work on direct blood transfusion, see Geoffrey Nice, Not Bricks and Mortar and Paint — but People, [?1986], and files with the Historical Society of Mooroopna.
} 
Confronted by the most distressing scene he had ever encountered, Mackellar's first thought was that the bodies, some still emitting vapour, could not be identified. There was even some initial doubt about how many bodies there were. Back at Laverton, Fr Ken Morrison was instructed to prepare to take part in a ceremony at a mass grave. There were doubts about the "possibility of identification'. Morrison recalled working for some time on the assumption that there would be a combined graveside service until he was told there would be individual burials. ${ }^{43}$ As Jim Kearney later commented: 'How the hell they ever identified anybody I wouldn't know really.' ${ }^{44}$ Murray Tyrrell, who remembered having travelled to the hospital, informed Corby Tritton in the Prime Minister's office of the uncertainty. Menzies, said Tritton, had issued an edict: the bodies must be identified. ${ }^{45}$

To assist in the grim task, the Army Minister's private secretary, 'Pip' Hayter, joined Dr Mackellar. Hayter, a Great War survivor, wounded and gassed, was almost a Canberra institution. Unusually among Canberra ministerial staff, he had a working wife. The Hayters had no children and, as Pip's assistant Garry Armstrong remembered, 'they had a few bob more than some of their contemporaries'. After a preliminary visit around noon, Hayter returned to the morgue in the evening. His attention was directed to six of the bodies. The first was Frank Thornthwaite, for whom he had given up his place on the flight. Identifiable by military uniform on 'a portion of the body' and a key chain and keys in a pocket of the uniform, Thornthwaite was said to have carried a pipe, tobacco pouch, and matchbox, together with a pocket knife. Later a cigarette case with the initials 'F. T.' and the date '3/2/20' was found. ${ }^{46}$

Hayter knew both Thornthwaite and Brudenell White well. The CGS's 'general appearance and features' helped to identify White; but he was definitely recognisable by the cross-sword-and-baton badge found embedded in a chest that before that morning would have had visible scars. The insignia was worn only by general officers on the shoulder strap of their coat and jacket. White's pipe and the silver ring that he always wore on the little finger of his left hand - a gift from his beloved youngest brother Eustace, who had died after falling from a horse 42 years earlier - were not found. ${ }^{47}$ The gold signet ring that Street wore, well known to Hayter, allowed Mackellar to identify the Army Minister. An upper denture plate was also unique to Street. Gullett was the only member of the party known to have sets of both upper and lower dentures. Fairbairn

\footnotetext{
43 Msgnr K. R. Morrison to CH, 6 June 1983.

44 Kearney, interview, 23 July 1977.

45 In another version of these events Tyrrell recalled for Lord Casey going with Tritton to the morgue to try to identify the bodies: 'a fairly hopeless task. There was little left to argue about' (NAA: M1129 WHITE/C B). 46 NAA: A1378, P8903; MO 625 A6079 44 (Inquest). In an amplified statement sworn for the Coroner, Hayter substituted the less graphically confronting 'portion of uniform' for 'portion of the body'.

47 Bean, Two Men I Knew, p.81.
} 
had distinctive wartime injuries. With these identifications already made, Elford's 'general appearance and build' — he was, Mackellar said, about the same stature as Fairbairn - were enough to confirm that his was the remaining body not in uniform.

Hayter could aver that he had been in daily contact with Brudenell White and Thornthwaite for the last five months, and with Street over nearly two years. There could be confidence in his identifications. He also knew Elford and Gullett well. He would tell the Coroner that he had identified the bodies 'in company with Dr Mackellar'. He had, he said, 'looked over the bodies' in the morning and returned in the evening when he 'identified' them. In a statement to the Coroner, Hayter was explicit about seeing the dental plate being removed from Street's mouth by Mackellar. He also said he 'recognised' Elford by his general appearance and build. But on all of the others the wording of Hayter's statement indicates how he 'identified' them by certain physical features or personal items which were shown to him or whose presence was confirmed by the doctor. He would tell the Coroner that a part of a khaki uniform and keys in the pocket served to distinguish Thornthwaite. ${ }^{48}$ Mackellar himself testified that 'Mr. Hayter came to the morgue and told me certain things about the deceased and together we identified the bodies.'

Mackellar's testimony to the Coroner also left some doubt as to what Hayter actually saw. 'Mr Hayter told me a ring would be found on Mr Street's finger. A ring was found on Mr Street's finger. I recognise the ring produced.' From a statement he prepared for the Commonwealth Police it seems doubtful that Hayter looked closely at the bodies:

I identified the body of Sir Henry Gullett because of the general appearance and build of Sir Henry Gullett and I was informed by the Medical Officer that his body had a double set of dentures.

I identified the body of the Honourable J. V. Fairbairn because I was informed by the Medical Officer that this particular body showed injuries of long standing to each arm and, in particular, to the right arm.

I identified the body of Mr. R. E. Elford because I was informed by the Medical Officer that this body had only one testicle and because of his general build. ${ }^{49}$

Mackellar, probably unaware of Hayter's war record with the 23rd Infantry Battalion, had perhaps tried to spare the former regimental quartermaster sergeant sights that would distress even battle-hardened servicemen and pathologists.

48 Courier-Mail, 27 Aug. 1940.

49 Inquest testimony: NAA: A6079, MO 625; unsigned statement by P. Hayter, Commonwealth Police file P8903, NAA: A1378, 4/95. Italics added. 
When Mackellar himself, still nauseous and understandably shaken by the appalling nature of what he had seen, came to write up a summary report for the Police a week after the accident he seems to have forgotten some of what he had been told. 'A larger body [than the one he had determined was Street's] with evidence of a war wound in the left shoulder', he said, distinguished Fairbairn from the others. More strangely, he referred to the ministerial private secretary who had assisted him in the morgue as 'Mr Tritton'. Someone quietly amended the Commonwealth Police file copies: Fairbairn's right shoulder (it should have been elbow) not the left; 'Mr Hayter' not 'Mr Tritton', the Prime Minister's private secretary. ${ }^{50}$ The possibility that Corby Tritton was in fact present may account for Mackellar's confusion. Certainly Tritton was well informed, recalling years later the injury, the result of a motor bike accident, that uniquely marked his friend Elford. ${ }^{51}$

When it came to determining the identities of the RAAF officers and men, Group Captain D. E. L. Wilson, who had been flown from Sydney by A. B. 'Tich' McFarlane, took responsibility. Flying Officer McFarlane and his crew in Hudson A16-57 had scrambled at Richmond at 1.00 p.m., picked up Wilson at Mascot, and taken off for the capital 20 minutes later, arriving at 2.30 p.m. As the senior commander nearest to Canberra, Douglas 'Del' Wilson, accompanied by Squadron Leader Sturt de Burgh Griffith, was assigned to liaise between government departments and the Air Board. ${ }^{52}$ Pilot, crew, and passengers had little time to think about the circumstances that brought them urgently together in an aircraft similar to the one that had just inexplicably crashed. McFarlane recorded in his log book: 'Bob Hitchcock spun in in A16/97 with a stack of politicians on board.' In retrospect, McFarlane felt that, with about 100 hours in Hudsons, he would not have considered himself suitable for the flight that Hitchcock had captained. He recalled learning that his own approach to land in Canberra, after a low circuit to get a better look at the nearby accident site, was 'watched in fear by the locals'. ${ }^{53}$ McFarlane took practically the same course as A16-97 had in the morning; but, as J. V. Power told the Service Court, 'the one in the afternoon was flying higher this was a remark made by spectators at my office'.

At the morgue, Group Captain Wilson proceeded by elimination. He was to admit to the Coroner that he knew none of the men personally. Identity discs were found but not with the bodies. However, Crosdale and Palmer's dress

\footnotetext{
50 D. G. Mackellar, 'Identification of Bodies recovered from Aeroplane Crash Near Duntroon 13/8/40', Commonwealth Police file P8903, NAA: A1378, 4/97; cf his inquest testimony NAA: A6079, MO 625.

51 N. C. Tritton, interview, 7 June 1977. According to Sir Edwin Hicks (interview, 18 Sept 1980), then a Department of Air officer, it was Fairbairn who was identified by the fact that he was known to have only one testicle.

52 EFTS Mascot to Sec. Prime Minister's Dept, telegram, 13 Aug. 1940, NAA: A461, 700/1/392.

53 McFarlane, interview, 19 April 1978; logbook 13 Aug. 1940.
} 
indicated that they were not officers. Crosdale would have been at the rear of the aircraft in a seat by the door; he was the least burnt and mutilated. Of the two pilots, Wilson attested that he identified Wiesener as 'the younger of the two bodies'. 'Hitchcock was identified by reason of the fact that it was the only further body awaiting identification.' The men at the front of the plane had borne the full impact of the crash and the flames.

Wilson's claim to be able to distinguish between Hitchcock and Wiesener because Wiesener was younger strains credibility. 'Wiesener is 28 and Hitchcock 38', Wilson said. Wiesener was in fact 18 months older than Hitchcock. Maybe Wilson took height as a proxy for age. If he did, then his identifications would certainly have been wrong. At 6' $1 / 2 "$, Wiesener was $63 / 4$ inches taller than the senior man. The one surviving photograph of a somewhat cherubic Wiesener in 1940 suggests that in life he looked significantly younger than the more careworn and balding Hitchcock. In any case, as fireman Jim Kearney recalled the horrific scene, 'there wouldn't have been any wrinkles on those bodies, that's for sure'. But Wilson was clearly there to make positive identifications without delay. Accuracy was a secondary consideration. When he presented his evidence to the inquest, the Coroner asked him no questions. ${ }^{54}$

\section{Cause of death}

After examining each of the bodies Dr Mackellar pronounced that it would 'be fairly safe to assume that all ten men were killed when the plane hit the ground'. All the men, he said, had fractured skulls as 'the immediate cause of death.' 'I am of the opinion that the men were killed before the plane was burnt.' On the day of the crash, 'Tich' McFarlane had met the local Air Force doctor at the scene 'wandering around with a jam tin and a fork. When I asked him what he was doing... he looked at me as if to say "You bloody fool what do you think I am doing?" He was picking up fingers, toes, and bits and pieces... gruesome sight.' Standing back to look at the still-smoking wreckage McFarlane remarked on how terrible it would have been to be burnt to death. The doctor corrected him: 'These people weren't burnt to death. They were all dead when they hit the ground - hit the ground with a great thump. They would have had broken backs, broken necks, thump like that, look at the chairs, broken, sagging. None of them would have burned to death.' This, of course, was a conclusion at variance with Jack Butt's belief that he had seen struggling survivors a few hours earlier, and with several newspaper reports the next day. Whatever the

54 NAA: A6079, MO 625. Tink (Air Disaster, p.11) quotes Wilson's plainly erroneous identification of the two pilots without comment. He says that Gullett's identity was confirmed by his gold cigarette case, actually found later, whereas his double set of dentures was conclusive. 
truth about the deaths, modern forensic pathology suggests that it was more likely the subsequent inferno than the impact that caused all of the skulls to be fractured..$^{55}$

Acting Coroner 'Colonel' John Goodwin (he had been made an honorary Lieutenant Colonel on his retirement from the militia in 1920) accepted the postmortem findings. In the state of medical knowledge at the time, it was unlikely that any further examination could have conclusively determined whether the men had died on impact. This was, in any case, the kindest conclusion that could be reached. Moreover, it was consistent with the fact that almost as soon as it hit the ground, as the first RAAF investigators on the scene noticed, the aeroplane had come to a sudden stop against a large box log. As 'Tich' McFarlane had deduced, the plane had fallen into the ground in an almost flat horizontal attitude and slid forward no more than 30 yards.

Sadly for the families of the victims, some newspapers had already headlined, as did the Canberra Times on August 14, 'Ten Persons Burnt to Death.' The Launceston Examiner the same day had referred to 'officials who examined the wreckage after the flames died down' saying that it was 'the explosion' after the crash that killed the occupants. The Argus even said that officials who examined the wreckage were certain that the aircraft 'was very little damaged in landing, and that had the fire not occurred the occupants would have escaped'. These reports lend credence to the story of ex-AIF Lance Corporal Jack Butt and his son, axes in hand, being ordered away from the burning aircraft. It is possible that an anguished Butt himself could have spoken to journalists at the scene. Duncan Cameron's friend might have been mistaken about what he saw. Men still alive for moments after the crash might have sustained fatal injuries. But, whatever the now unknowable truth, an official consensus soon emerged about the deaths. Making belated amends for its insensitivity two weeks earlier, the Canberra daily led its story on the Coroner's findings on August 27 with a triple-decker headline: 'AIR VICTIMS KILLED BY FATAL CRASH DIED BEFORE MACHINE CAUGHT FIRE CORONIAL INQUIRY INTO CANBERRA DISASTER.' ${ }^{56}$

Colonel Goodwin, 74-year-old retired Commonwealth Surveyor-General and Director of Lands, and now chairman of the Federal Capital Territory Advisory Council, had begun the inquest in the tiny Canberra court 'house' in one of the dining rooms of the old Acton Hotel on the morning of August 14. On the previous evening he had been out to inspect the wrecked aircraft. Goodwin had

55 I am grateful to Professor Jo Duflou (email 28 March 2012), Chief Forensic Pathologist, Clinical Professor, University of Sydney, for advice on the effect of extreme heat on human bodies. Tink (Air Disaster, p.178) follows the Coroner, concluding that all 10 men 'died instantly'; but at pp.191-2 he points out that a fractured skull 'is not necessarily fatal'.

56 Canberra Times, The Examiner, The Argus, 14 Aug. 1940; Chronicle (Adelaide), 29 Aug. 1940: 'Victims Were Not Burnt Alive: WERE DEAD WHEN FIRE STARTED'. 
been a special magistrate in the Court of Petty Sessions in Canberra since 1930 and was experienced in coronial duties. As Charles Daley recalled, Goodwin was 'less experienced and alert' than his Advisory Council colleagues; but 'he had nevertheless a tenacious side to his personality'. ${ }^{57}$ As a member of the Canberra Community Hospital Board he was also one of the men to whom Dr Mackellar - who 'seemed to be afraid of the Board' - reported.$^{58}$ There were three RAAF officers, the chief of police (Colonel Jones), two reporters, and court attendants present in the court. Harry Jones, being there in his capacity as the Capital Territory's police chief, could keep his other roles as director of the Commonwealth Investigation Branch and the Secret Defence Security Intelligence Bureau unadvertised. But if issues affecting security were to arise he would want to be the first to know. His meticulously presented claim for reimbursement of private car expenses records that he had been out to the scene of the crash and later to the aerodrome the previous afternoon and returned to the aerodrome the following day. ${ }^{59}$ Goodwin was to be assisted by J. M. Mills of the Commonwealth Crown Solicitor's Office. As the officials who had identified the civilian bodies were said to have already departed to Melbourne and Sydney on government business, evidence was taken only about the identification of the Service personnel. In the afternoon, Group Captain Wilson was reported to have gone out to the crash site to examine the wreckage. According to the Herald he was securing evidence for an inquiry by the Air Accidents Investigation Committee 'which may be held in Melbourne'.

When the inquest resumed on August 26, Mills questioned people who saw A1697's last moments in the air, presented evidence connecting specific exhibits with individuals who had perished, and led the evidence of identification for the three ministers and Dick Elford. The proceedings, carried out in accordance with the Capital Territory Coroners Ordinance 1932 and the New South Wales Coroners Act 1912, were expeditious. As the bodies had already been released for burial, and no evidence was taken as to the pilot's health immediately before the crash, Goodwin clearly had ruled out the possibility of a medical condition contributing to the pilot's loss of control of the aircraft. In so doing he was ignoring the working principle of the doyen of Australian coroners, Dr A. A. Palmer of Sydney, who counselled never to infer from the circumstances

57 Charles Daley, As I Recall, p.49. Canberra had no magistrates until 1949. Special magistrates like Goodwin dealt with undefended cases; defended cases were heard by visiting magistrates from Queanbeyan and Goulburn (Susan Mary Woolcock Withycombe, Ethos and Ethics: A History of the Law Society of the Australian Capital Territory 1933-1993, Canberra, 1993, p.13). For Goodwin as 'a sort of father-figure to the city', Jim Gibbney, Canberra 1913-1953, AGPS, Canberra, 1988. p.80.

58 A. J. Proust (ed.), History of Medicine in Canberra and Queanbeyanand their hospitals, Brolga Press, Gundaroo, 1994, p.53 (observation of Dr Lew Nott, medical supt 1929-34, 1940-49); Jack Taylor, 'Goodwin, John Thomas Hill (1865-1950)', Ritchie and Cunneen (eds), Australian Dictionary of Biography, vol. 14, pp.293-4.

59 'Use of Private Car on Official Business', Aug. 1940, Lieutenant Colonel H. E. Jones (Personal file), NAA: A367, C17200. 
in which a body was found that death was due to those circumstances. ${ }^{60}$ The idea of the pilot 'collapsing' was, as Hitchcock's fellow flight commander, Jack Ryland, would later say, 'very improbable' but not impossible. ${ }^{61}$

All 13 eye-witnesses were examined between 10.55 a.m. and 2.40 p.m. with a break of an hour and 25 minutes for lunch. Flight Sergeant Smith was on the stand for 23 minutes; Dudley Lalor for 15 minutes; Sydney Rhodes for 13. Since the viewings in the morgue, additional items had been found, mostly by an administrative and special-duties officer at Canberra Station HQ, Flying Officer Stanley Willmott, a 1914-18 artillery, RFC, and RAF veteran, who had seen more carnage than most men at Canberra aerodrome. 'Pathetic personal belongings of the victims', blackened, charred, half-melted, 'littered' a table in the court house. ${ }^{62}$ They confirmed the presence in the plane of White (his nine-year-old monogrammed hair brushes), Fairbairn (his engraved gold pocket watch and gold rail pass on a gold chain), Thornthwaite (a cigarette case marked 'F. T. 3/2/20'). Another gold cigarette case was recognisably one presented to Gullett by staff of the Ministry of Information exactly two months earlier on June 14. The engraved back of Elford's watch was enough to satisfy the Coroner that he too had died in the aircraft. Dr Mackellar was shown and verified the items that he had seen in the morgue.

Had Mackellar or Colonel Goodwin paused to reflect on the assembled 47 exhibits they might have been struck by the poignant assembly of five pocket timepieces and four wrist watches - silenced reminders of the social gulf that separated in life the 10 men united in death. Percy Hayter restated how he was able to identify the six civilian victims. Having determined the identity of the men and the cause of their deaths, the Coroner's task was complete. Mills had advised Goodwin that coronial jurisdiction started at the time of death. What caused the plane to fall was a matter for another tribunal. These were dubious contentions. However, Mills evidently felt free to say that 'there were no suspicious circumstances'. The Coroner was more cautious. 'There is no evidence', he concluded, 'to determine the cause of the accident.' ${ }^{63}$

60 J. B. Cleland, 'Inquests and Experiences in the Coroner's Court', Medical Journal of Australia, vol. II No. 18, 9 Nov. 1940, p.435. In the UK and US, post-mortem examinations or autopsies after transport accidents were not routine until the late 1950s (Peter J. Stevens, Fatal Civil Aircraft Accidents: Their Medical and Pathological Investigation, John Wright \& Sons, Bristol, 1970, pp.2-3; Col. Claude K. Leeper, 'The Development of Aviation Pathology and the Joint Committee on Aviation Pathology', in William J. Reals et. al., eds, Medical Investigation of Aviation Accidents, College of American Pathologists, Chicago, 1968, p.72).

61 Air Force Court of Inquiry, transcript of evidence, 27 Aug. 1940, p.24 (NAA: A705, 32/10/2729).

62 Northern Standard (Darwin), 27 Aug. 1940.

63 'Inquisition before a Coroner Sitting Alone', 26 Aug. 1940, Canberra Coroner's Court Papers, and in NAA: A6079, MO 625; Canberra Times, 27 Aug. 1940. Tink (Air Disaster, p.191) says: 'It appears that in accepting Mills' argument about the commencement of his jurisdiction...Goodwin ignored all the evidence he had heard which suggested that some of the victims might have survived the initial impact.' In fact, whatever he might have read in the newspapers, no evidence of this kind was put to the Coroner. 
None of those affected by the crash were to forget where they were when they first heard about it. Or rather, as is the way with human memory, recollections evolved. Roland Wilson, then Commonwealth Statistician and Economic Adviser to the Treasurer, remembered 44 years later that he was at a Premiers' Conference in Canberra at 11.00 a.m. when someone came in and spoke quietly to the Prime Minister who quickly made the news known to all of those present. ${ }^{64}$ Wilson was right to remember being present at a meeting with the state premiers that day. The Loan Council had been in session for several days. But it was not the Prime Minister at his side but the Treasurer, Percy Spender, who was president of the Council. ${ }^{65}$

Was there a fear that secret papers or security keys might have fallen into inappropriate hands? As late as January 1941, enquiries were being made about two keys issued to Jim Fairbairn facilitating after-hours access to Victoria Barracks. A similar set held by Street had been returned, as had the keys to his Melbourne and Canberra safes. Officers of the Prime Minister's department were said to be searching through the wreckage for 'valuable documents'. No one could say what had been taken on board. Newspapers reported that files and secret documents had been destroyed in the flames. Officials were quick to call on the widows of ministers, Thornthwaite, and Elford to retrieve papers that had been in their husbands' possession. But there seems to have been no urgency about returning a bundle of partly burnt papers recovered from the scene. The Commonwealth Police passed the six typewritten sheets in an envelope to the Defence Secretariat in Canberra on October 10, whence they were forwarded to Army headquarters. Evidently the papers had remained in police safekeeping along with personal items like house keys, badges, cigarette cases, hair brushes, scissors, coins, and watches, most of which had been found at the scene by Flying Officer Willmott. ${ }^{66}$ All these were returned to the relevant next of kin or executors at the same time. It was not until November 19 that a letter from Olive Hitchcock to the Prime Minister drew attention to Mrs Palmer's wish to know of any of her husband's belongings, specifically the rosary beads he had been wearing. ${ }^{67}$ The beads and an attached St Christopher medal had indeed been found. MPs' gold passes were sent back to the Department of the Interior.

While the coronial inquest was adjourned after its first sitting, official protocols of condolence and funeral preparation were being set in motion and messages about the memorial service were being despatched to the bereaved families.

64 Sir Roland Wilson, interview, 28 March 1984. Wilson had inherited what remained of the aeroplane's duraluminum propeller from his friend the Commissioner for Patents, who had retrieved it from the Deakin tip and had been cutting off pieces and melting them down in his workshop.

65 Canberra Times, 14 Aug. 1940, p.5.

66 NAA: A1378, 4/168,181,190,197. Other items were found by Cpl Victor Walpole, F/O Wilson, and Flt Sgt Smith (NAA: A6079, MO 625).

67 NAA: A461, 700/1/392. 
In Canberra and Melbourne there was urgent confabulation about what must happen next. For the Air Force there was some satisfaction that the Coroner had been plainly intent on a rapid and tidy inquest. Not for him or for them the embarrassment of the inquest at Windsor in January into the crash of an Avro Anson into the Richmond Golf Links resulting in the deaths of Flight Lieutenant Arthur Moorehouse Watkins, Flight Lieutenant Hugh Horner, two accompanying flying officers, and a leading aircraftsman. The Windsor court house had been the scene of an inquisition of RAAF witnesses by relatives of the deceased. 'King' Cole's No. 2 Group HQ had been instructed by the Air Board that, although it was not considered necessary to have counsel to represent the Service, there should be a 'responsible senior officer in touch with facts of the case to watch Service interests and ensure that Coroner exercises powers under National Security Regulations and otherwise to prevent publication in the Press of any matters... which are considered contrary to public policy to have published'. But, to the horror of Cole's superiors, the Windsor and Richmond Gazette had carried a full report of the proceedings; and the national press seized on the story of laxity in engine checks, deficiencies in record keeping, alleged shortage of mechanics, and over-working of personnel. ${ }^{68}$

There was little comfort for the RAAF in being told that the legal officer sent to Windsor to watch the Service's interests reported that every technical allegation made against the Air Force was refuted, that all the Sydney newspaper reports were misleading, and the Daily Telegraph 'appeared to be deliberately so'. Following the inquest, a confidential investigation at No. 1 Group by Group Captain Henry Wrigley had substantiated that there was 'serious laxity in the application of the maintenance system', the captains of the aircraft and the officer in charge of the flight having neglected the supervision for which they were responsible. The father of the dead pilot, knowing nothing of the adverse findings on his son, pressed his local MP, Sir Frederick Stewart (Minister for Supply and Development), for answers to unanswered questions. But it was not until May 1940 that a bulky file containing the Court of Inquiry proceedings and an explanation of what looked like a dismissive draft reply to the bereaved father - 'answers to several of the points reflect adversely on his late son, therefore the less said the better' — had found its way to an impatient Minister for Air's desk. Jim Fairbairn's evasiveness about allegations of lax maintenance had meanwhile brought him a rebuke from one of the fathers. 'Mr Fairbairn

68 Parents had themselves testified to the Coroner to rebut allegations that their pilot sons had been drinking the night before the crash. Hearsay evidence was led that the captain of the aircraft had complained that maintenance of his machine was being compromised because the number of mechanics in the squadron had been reduced from 15 to six. To the relief of harried RAAF officers, after a day of angry outbursts and conflicting testimony the Coroner had thought better of prolonging his inquiry into what 'does appear to be some laxity in the manner in which the planes were serviced before flight' (Windsor and Richmond Gazette, 26 Jan. 1940). 
would be doing an injustice to the cause of aviation generally and particularly to the interests of the hundreds of young men now training if he showed a reluctance to examine carefully all evidence relating to fatalities in the RAAF.'

It was symptomatic of the confusion and apprehension in Service headquarters over this episode that the Court of Inquiry file had been mislaid for two months, wrongly attached to a related file on coronial inquiries. Confusion was further compounded by the preparation of a letter for the Air Minister's signature referring to the Service Court of Inquiry as an 'Air Court of Inquiry'.$^{69}$ These muddles could no doubt be eliminated. When the victims were not household names the press would in due course lose interest. But a judicial probe into the accident to A16-97 would be a major national news story no matter how carefully it was shaped and monitored.

69 Sydney Morning Herald, 20, 22 Jan. 1940. A Court of Inquiry held in the last two weeks of December had blamed this otherwise inexplicable accident during a celestial navigation exercise on the Venturi-driven instruments not settling down before the aircraft entered cloud, thus giving the pilot a false horizon ('Flying Accident to Anson Aircraft N 4887...', NAA: A705, 32/10/2386). 



\section{Extinguishers}

Extinguishing the inferno of a crashed aircraft was never easy and often impossible. Even with enough men, equipment, water, and flame retardant it would be a daunting confrontation for experienced professionals. For the Canberra firemen and RAAF airmen attending A16-97 in Duncan Cameron's paddock there was no chance that they could repel the unyielding flames. The horror of what assailed their senses would keep them awake that night and bring disturbance to their sleep long into the future. For those charged with guarding the site and searching among the twisted wreckage and charred grass for fragments of past lives there were scattered cues to reflection. Here in burnt cloth, shattered watches, warped cufflinks, fractured dentures, a tangled rosary, and yards of wind-strewn parachute silk, was evidence of God's indifference to distinctions of rank and status. There was no discrimination in death between rich and poor, old and young, men of all faiths and of none. What did it mean? What in Divine Providence had decreed an end in one terrifying moment to 10 lives, in this way, in this place, at this time?

Questions and doubts about a loving Creator would afflict bereaved families and friends for years to come. As Thornton Wilder had meditated in his 1927 novella The Bridge of San Luis Rey: why had God settled upon that person and upon that day for His demonstration of wisdom? The kindly Archbishop of Melbourne had consolation to offer, but no explanation. He wrote to Audrey Elford:

It is very difficult to give an answer to the question of why this accident happened. I can only pass on to you my belief that the Love of God is with His children whatever may happen to us. Brave men are always prepared to take risks in the discharge of their duty, and if they meet with danger or even death, God's love for them is unchanged. That Divine Love meets them upon the other side of the grave, and in their Heavenly Father's keeping all is well with them whether in this life or in the life to come. ${ }^{1}$

The clamouring mysteries of life and death on a fatal flight might in time be quieted by pastoral compassion and habits of worship. But preventing the molten metal and embers of A16-97 from igniting a flash fire of innuendo, probing, and devastating criticism was a challenge that brooked no delay. Frequent as they had been in the last decade, aviation accidents remained headline news. Not always on the front page as the war progressed, but often alongside the

1 Abp F. W. Head to Mrs R. E. Elford, 19 Aug. 1940, Elford MSS. 
main political stories. They sold newspapers and drew cinema audiences. ${ }^{2}$ Press photographers jostled to get pictures, sometimes like a Daily Telegraph man in May 1939, running afoul of Air Force guards and prompting complaints of assault from Frank Packer and the Australian Journalists' Association to the Prime Minister. ${ }^{3}$ As RAAF pilot training and operations gathered momentum in 1940, the increasing frequency of crashes and enquiries from the censors prompted a policy clarification from the Air Board to the Director of Staff Duties at the beginning of May: statements about accidents were not to be issued to the press unless the occupants were killed or seriously injured. ${ }^{4}$

In the days after the crash of A16-97 hundreds of curious local residents flocked to Duncan Cameron's property. They were kept at bay by guards with fixed bayonets. Thousands more saw press photographs, and Cinesound and Movietone newsreel footage of the broken and incinerated aircraft and commentary on the gravity of the nation's loss. For the RAAF, therefore, as for all air forces around the world, the urgent need to understand what had caused a calamitous accident was accompanied by acute concern about a possible loss in public confidence.

There was a repertoire of protocol and technique on which shocked authorities could draw. The Air Board had turned its mind to the procedures in place for investigating Air Force accidents in the week following Robert Menzies' declaration in September 1939 that Australia was at war. Conscious of a recent history of embarrassing revelations and jurisdictional squabbles, the Board was determined to set a simplified course for the future. Up to four separate inquiries could occur in peacetime: '(a) Air Force Court of Inquiry (Judicial); (b) Inquiry by Air Accidents Investigation Committee; (c) Service (or internal) Court of Inquiry; (d) Coroner's Inquiry.' Under King's Regulations for the Royal Air Force, incorporated in RAAF Orders, a Court of Inquiry was to be held into wartime accidents 'in the field' that involved 'any injury to persons or damage to property (including aircraft) unless the Commanding Officer is satisfied that the cause of the accident is free from doubt, or that the holding of an inquiry would serve no useful purpose.'

\footnotetext{
2 Leigh Edmonds, 'How Australians were made airminded', Continuum: The Australian Journal of Media \& Culture, vol. 7, no. 1, 1993.

3 NAA: A461, V314/1/1. The Minister for Defence (Geoff Street) detailed an agreement reached in Sydney on 15 May 1939 with newspaper proprietors and the Australian Journalists' Association regarding photographs of air crashes. In future, photographers would get in touch with the officer in charge. If photographers arrived before the officer, the photographs would be submitted before publication to an RAAF officer, who would be sent to the newspaper office (Townsville Daily Bulletin, 18 May 1939).

4 NAA: A705, 32/10/2536. Publication of crash photographs was banned in Feb. 1941 (NAA: A2676, 819).
} 

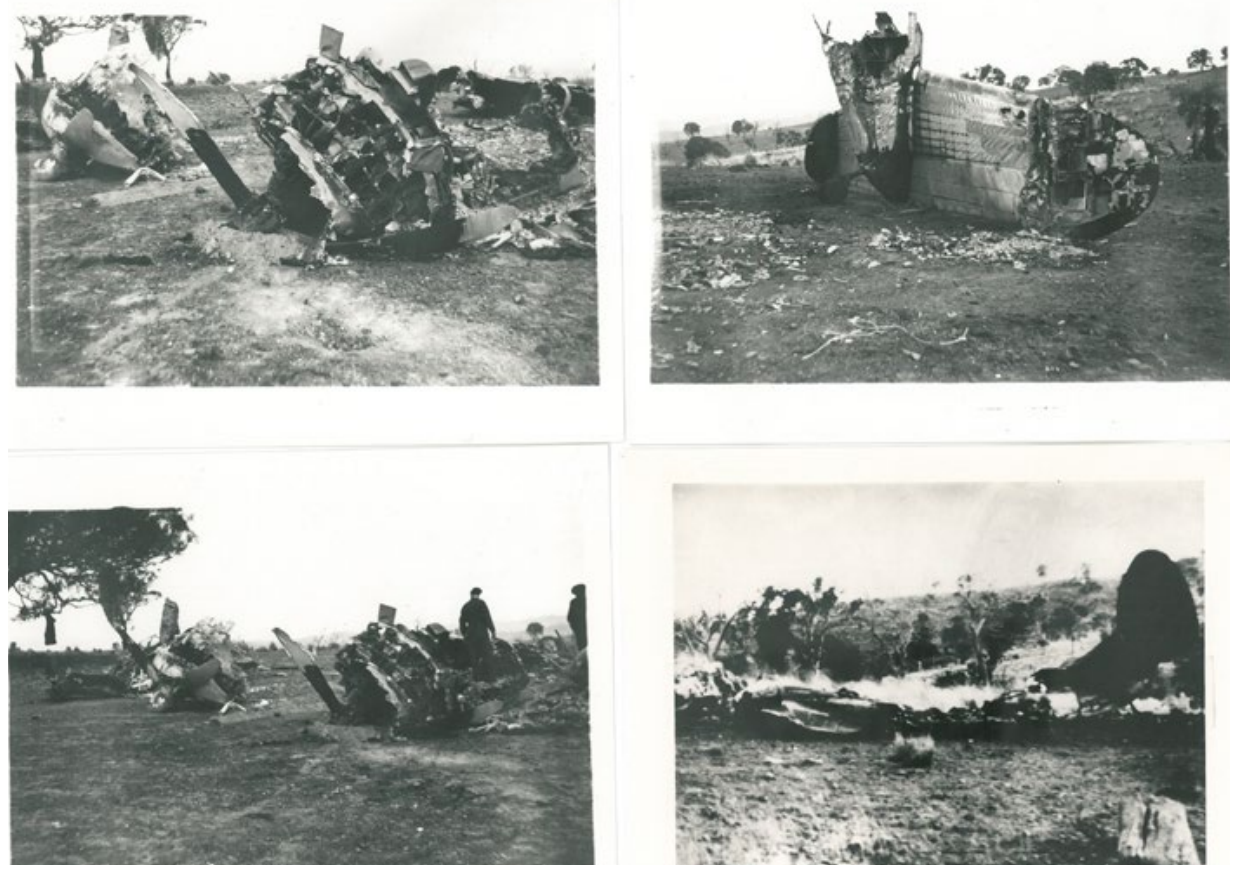

\section{A16-97 awaiting removal from Cameron's farm}

(Photos by Frank Jefferies, courtesy of the RAAF Museum and Frank and Helen Struc)

The Air Board had urged that the internal Service Courts of Inquiry should be held in accordance with King's Regulations and that judicial inquiries and Air Accident Investigation Committee Inquiries should be discontinued. This appears to have been the policy followed over the next 11 months. (In the case of the Air Accidents Investigation Committee the Secretary of the Air Board had already advised that, as it was now constituted under the Air Navigation Regulations which did not apply to the Air Force, the AAIC was 'considered to lack jurisdiction in air-force accidents.' $)^{5}$ There was a further recommendation. If coronial inquiries were still to be held, the censor should be instructed that no reference to them should be permitted in the press. Wiser heads prevailed. As ministers scarred by years of newspaper scrutiny well understood, nothing would foster suspicion and discontent more than blatant attempts to suppress information about catastrophic events. 


\section{Announcements}

Just six weeks before the Canberra crash the RAAF had appointed its first Director of Public Relations. Sir Keith Murdoch, Director-General of Information since late in May, had recommended that each of the three fighting services as well as the munitions and supply departments should have public relations directorates. The War Cabinet had concurred. The RAAF's public relations operation, approved in detail by the Minister for Air, was mandated to assist with recruiting as well as 'inform and educate' the general public, and manage contact with the press and radio stations. Fairbairn also sought to head off 'hasty criticism' in Canberra with a weekly bulletin of 'publishable' RAAF activities for parliamentarians. Dick Elford's friend Archer Kyffin Thomas, the chief of staff at the Melbourne Herald, was chosen to lead the directorate in Melbourne, and issued the first decisions on procedures after a meeting of the Air Minister, Air Board, and Directors late in June. ${ }^{6}$ But Thomas was not in good health and the Herald's Reg Leonard, a UAP volunteer publicist and a protégé of Keith Murdoch's, with 16 years newspaper experience though still only 33, had taken up the RAAF post in July. As luck would have it, Leonard was away in Tasmania on the day of the crash, and 'unable to be involved in dealing with Press inquiries and related matters...I was stranded there for a couple of days and was more or less "out of the action" during the crisis.. ${ }^{7}$ Standing in at first for Leonard was his deputy Wilfred Bailey Tart, Sir Earle Page's son-in-law. Wilf Tart, as Press Relations Officer, would have been responsible for issuing a statement, in accordance with recently confirmed practice, about the accident and the names of those who died. ${ }^{8}$ But on the day after the crash, by the time information about action the RAAF was taking was ready for release, Leonard was there to authorise it.

The Department of Air announced on Wednesday, August 14 that two inquiries were under way. First was an investigation by the Inspectorate of Air Accidents, 'an organisation set up in the Department of Air to provide a speedy means of investigating R.A.A.F. aircraft accidents and forced landings, in order to determine the cause and prevent recurrences'. The Inspector 'and staff' had left for Canberra on Tuesday. When they had finished their work a report would be submitted to the Chief of the Air Staff 'outlining as far as can be gauged the cause of the accident and any underlying circumstances which may have contributed directly or indirectly to it'. The phrase about 'underlying

6 NAA: AA1966/5/226, A705, 168/1/166; The Advertiser, 19 June 1940.

7 R. B. Leonard to CH, 22 May 1978; Gillison, Royal Australian Air Force 1939-1942, p.103; Lyons MSS NAA: M2270 24 for Leonard's assistance in the 1937 election campaign. Leonard was on the last leg of a visit to state capitals to set up relations with RAAF stations and the press (NAA: A705, 168/1/168 Part 1). 8 Acting Sec. Air Board to Director Staff Duties, 'Aircraft Accidents and Press Notices', 5 May 1940, NAA: A705, 32/10/2536. 
circumstances' was drawn directly from an Air Board order (N391) issued just 33 days earlier. Without actually saying so, the press release implied that this investigation would be little more than a preliminary assessment. But it could possibly rule out some feared explanations. Newly sworn-in Minister for Air, Arthur Fadden, told the press that the Inspectorate would report to him as well as to the Chief of the Air Staff. ${ }^{9}$

The first concern of the government was to assure the public that the disaster was not the work of enemy saboteurs. It was barely six months previously, when the first Australian Hudson test flight had been held at Richmond, that over-zealous censors had prohibited publication of details of the aircraft's performance. Precisely what secrets might have been divulged was not clear for, as Aircraft magazine pointed out, 'by the expenditure of a few pence at a well-stocked local bookstall any school boy can work out their top speed and cruising range' ${ }^{10}$ Recognising the truth of this, Jim Fairbairn tacitly approved a proposal in July that John Harrison, just beginning work at the Public Relations Directorate, should prepare an illustrated article on Hudsons for distribution to newspapers. ${ }^{11}$

Ineffectual as restrictions were in relation to an aircraft that was essentially similar to one that had been in service around the world for several years, there were more justified fears about loose talk. Air Force personnel could mostly be relied upon to respect the order issued late in June not to 'make any communication, directly or indirectly', to the press without the Minister's authorisation. ${ }^{12}$ Nevertheless, it would have been no surprise to discover that the Hudson's passenger list on August 13 had not been confidential. Far more secret information had escaped from loose lips. Squadron Leader Paddy Heffernan had reported just over a month earlier that news of No. 8 Squadron's planned move to Singapore had leaked from Air Force Headquarters and 'people associated with Government positions' within a week of the decision being taken. An officer of Heffernan's No. 8 Squadron en route to Canberra had heard of the proposed departure and the destination while pausing for refreshment at the 'Niagara' café in Gundagai. When the squadron arrived at Alice Springs on August 5 they were greeted warmly by a local population supposedly uninformed about where they were going. ${ }^{13}$

\footnotetext{
9 The Mercury, 15 Aug. 1940.

10 Aircraft, vol. 18 (6), 1 March 1940, p.15.

11 NAA: A705, 168/1/168 Part 1.

12 NAA: AA1966/5/226.

13 CO RAAF Station, Canberra to Secretary, Air Board, 4 July 1940, secret, Al196, 36/501/111; Vincent, The RAAF Hudson Story Book One, p.38. Contrast the 'Gilbertian' prohibition on the Canberra aerodrome ground attendant answering telephone enquiries, even from his departmental head, about whether the mail plane had arrived because the RAAF used the same landing ground (Canberra Times, 5 Feb. 1940).
} 
The possibility of sabotage was on many minds. In the previous week the Australian press had reported that the director of the United States Federal Bureau of Investigation had announced the discovery of acts of sabotage, including the placing of emery dust in aircraft engines and 'destructive metal in naval motive power...Every one of these heinous things,' J. Edgar Hoover had warned dramatically, 'has been done by persons shielded by innocent but subversive forces. ${ }^{14}$ It was only a couple of months since the New South Wales Deputy Premier, the Country Party's Michael Bruxner, had attacked the Commonwealth government for being slow to recognise the dangers of subversion from both communist and fascist groups. The Prime Minister had been obliged to mount a public defence without being able to reveal all that had been done, necessarily without publicity. ${ }^{15}$

Military guards had been supplied to Essendon aerodrome and the associated aeradio station shortly after war was declared. Menzies had written to state premiers noting that sabotage was thought to be the cause of the destruction of a hangar and aircraft at Broken Hill, and requesting that they assist by providing protection at aeradio transmission stations and aerodromes where aircraft of commercial or training value were housed. ${ }^{16}$ The correspondence was secret. By late November RAAF guards were preventing cars from entering Canberra aerodrome, to the immediate discomfort of the Prime Minister himself, his wife, and Sir Harry Gullett who were compelled to walk several hundred yards to the landing ground to catch a Friday morning flight to Melbourne. ${ }^{17}$

Some newspapers, in ignorance of much that had been done to increase security around the country, reported fears that the 'RAAF bomber' with its prominent passengers might have been sabotaged. The better-informed Daily Telegraph said there was no such suspicion. They had perhaps been briefed off the record on the three sets of instructions RAAF stations had received within the previous four months on 'the question of special security and anti-sabotage methods'. Sentries were doubled (20 men were on guard at Laverton during non-working hours). Hangars, usually containing six aircraft, were fully lit as well as locked at night.

If security had not been breached, could the aircraft have been carrying too much weight? Departmental officials were quick to deny fears that the plane

\footnotetext{
14 Canberra Times, 7 Aug. 1940.

15 Don Aitkin, The Colonel: a Political Biography of Sir Michael Bruxner, Australian National University Press, Canberra, 1969, pp.239-40. Bruxner had discussed security and intelligence with Menzies and Lt Gen. Squires in July 1939 (Squires diary, 21 July 1939, Australian Defence Force Academy [UNSW@ADFA] Library, MS 184 folder 2).

16 Prime Minister to Premier of Victoria, n.d. [13 September 1939], Premier's Office Secret Papers 18891944, 1939/78, Public Record Office of Victoria, VPRS 1172.

17 Sydney Morning Herald, 25 Nov. 1939.
} 
was overloaded. ${ }^{18}$ The press were enjoined not to identify the type of aircraft, though the Canberra Times and Western Mail had already done so, and it was readily recognisable from photographs and newsreels of the wreckage. The Mercury left even less to the imagination by putting a photograph of 'an RAAF bomber in flight' across six columns of its front page on August 14.

The absurdity of the censorship was pointed out by the Cairns Post, reporting on August 24 that the Commonwealth Gazette had mentioned that the aircraft was a Hudson. The inadvertent revelation was made in a notification of the appointment of RAAF 'assessors' to assist an announced open inquiry into the accident. Among the thousands of people for whom this was not news, Jim Fairbairn's grieving widow Peggy had wondered aloud to family and friends about sabotage. Of those reliant on other sources of information, at least one psychic was moved to write to the Prime Minister about a clairaudient revelation that 'The landing controls were tampered with', followed by a clairvoyant view of 'a man in white overalls kneeling under the machine doing something with his right hand...I am also told for you to question the sentry or watchman on duty.' $^{19}$

Since the signing of the Nazi-Soviet non-aggression pact, subversion could be suspected from more than one direction. The security services had long been watchful of communists, Nazi and fascist sympathisers, and those with Japanese connections. Years later some contemporaries remembered speculation that the pilot Bob Hitchcock might have been a fifth columnist. Members of the Wiesener family, whose grandfather had been naturalised in 1876, recalled feeling that they might be under suspicion because of their German origins. Unfounded though they were, these were predictable responses to a shocking and inexplicable event. They could not be completely ignored. But they were unlikely to deflect those responsible for investigating the tragedy from their proper focus on more likely explanations. It was not as if aircraft accidents were a rare phenomenon.

In addition to the rapid deployment of the Inspectorate of Air Accidents, the press were advised, a Service Court of Inquiry had been constituted 'under Air Force regulations'. The purpose of the Service Court would be 'to inquire into and to report upon the circumstances surrounding the accident'. It would make a 'thorough review of all relevant factors' and submit recommendations to the Air Board 'to avoid any similar occurrence in the future'. Anticipating some possible puzzlement about the overlapping roles of the two processes now in train, the statement concluded: 'The ultimate aim of the two investigating

18 Air Force Court of Inquiry, evidence of S/Ldr A. D. Carey, 27 Aug. 1940, NAA: A705, 32/10/2729; Daily Telegraph, 14 Aug.1940.

19 Geoffrey Fairbairn, interview, 10 Oct. 1978; I. Harry to Prime Minister, 18 Aug. 1940, NAA: A461, AM314/1/1. 
bodies is the same, but they work entirely independently.' ${ }^{20}$ It was presumably thought that confusion might be compounded if an attempt were made to correct reports in many newspapers linking Group Captain D. E. L. Wilson and two other officers examining the wreckage on the afternoon of August 13 with the superseded Air Accidents Investigation Committee.

\section{'A complicated one to operate'}

While the machinery of investigation was being mobilised at Southern Area headquarters in 10 Irving Road Toorak, in Sydney the moment was being seized to advance 'King' Cole's agenda for the training of Hudson pilots. Four days after the crash, a conference of station commanders, commanders of squadrons equipped with Hudsons, and other staff concerned, was convened at Central Area HQ in Edgecliff. Air Commodore Cole reported immediately to the Secretary of the Air Board that it was agreed that:

since the Lockheed type was a complicated one to operate, had a wing loading of ten pounds per square foot more than any other type in the Service, and the supply was limited, the question of their successful operation would require pilots with the following attributes:

a. Above average flying ability as shown by graduation course and subsequent experience.

b. To be of a reliable type, and

c. To have had at least 500 hours solo by day and by night.

Cole had already argued that previous postings to squadrons with Hudsons had included people who did not meet these standards. He reiterated that many of the present postings of flying ranks were 'below average in their flying course, weak in instrument flying, and have as little as 45 hours solo experience'. In many cases, Cole said, individuals had none of the requisite attributes; 'and their present demeanour would suggest that it will take a considerable period to achieve all - in the interim they would be dangerous first pilots on the type'. The remedy, rejected four weeks earlier, was immediate switching of postings with officers of 'known ability' replacing those of the 'lower category'. Ten men - seven flying officers and three pilot officers - were named. And Cole concluded with a 'recommended flow' scheme by which the optimal conversion of first pilots could be achieved. ${ }^{21}$

20 NAA: A9845, 319/22.

21 NAA: A705, 208/1/1533. 
Cole's persistence, opportunistic as it was, is understandable in the context of the RAAF's recent history. Never noted for his tact, his personal assertiveness also owed something to the diminishing of his influence resulting from the supersession of his friend Air Commodore Williams. ${ }^{22}$ Concern about accidents had been a perennial preoccupation of the Air Board and Defence ministers through the 1920s and 1930s. After a spate of misadventures involving Hawker Demons, the RAF's Inspector-General, Air Marshal Sir Edward Ellington, had reported to the Australian government in July 1938 that the training of both RAAF pilots and their instructors was deficient. Ellington's observations about accidents had led ineluctably to a more wide-ranging review. His secret criticisms, extending to the responsibility of the Air Board, provided grounds and a rationale, if not an unanswerable case, for changes at the top. The government, seizing on the Ellington critique, was happy to look as though it was doing something. In vain did the Air Board 'emphatically contest' Ellington's flawed accident analysis. Someone had to take the blame. Unmoved by Air Board rebuttals of Ellington's conclusions, and stiffened in his resolve by a hostile press campaign casting the affair as a triumph for a pro-English school of thought, the Prime Minister had pronounced that 'the main responsibility' for shortcomings rested with the Chief of the Air Staff, Richard Williams. Noting that further accidents 'indicated the persistence of underlying causes', the government sidelined Williams, whose determined recommendation of American aircraft for the RAAF had cost him the support of Menzies and Casey. Williams was replaced with his perennial rival Jimmy Goble. ${ }^{23}$ Goble had been away with the RAF for two years to January 1938. He adroitly disclaimed responsibility for the unsatisfactory situation highlighted by Ellington. Within a year, Goble in turn had overplayed his hand, been moved aside, and succeeded by an RAF officer, Sir Charles Burnett.

As we have seen, Air Chief Marshal Burnett, not Menzies' first choice, owed his appointment to an uncharacteristic episode of insubordination by Fairbairn. Burnett had developed a good relationship with his minister. Much as he would have preferred Dicky Williams in the post, Fairbairn was pragmatic. He realised that the Scottish Air Marshal had a grasp and vigour, despite recurring ill-health, that had been good for the Air Force. On 4 July 1940 Cabinet had endorsed Fairbairn's recommendation that the CAS's appointment should be extended for

22 Chris Coulthard-Clark, McNamara VC: a hero's dilemma, Air Power Studies Centre, Fairbairn ACT, 1997, p.82; Knight, These Things Happened, p.383.

23 Report of Marshal of the Royal Air Force Sir Edward L. Ellington...on the Royal Australian Air Force together with the Comments of the Air Board and the Civil Aviation Board and the Decisions and Observations of the Commonwealth Government, [Jan. 1939]; 'War Mates Rally To Aid Of Williams', Sunday Sun and Guardian, 16 Oct. 1938, 'Innocent Aussie Taking Blame For Errors', Truth, 15 Oct. 1938, cuttings in Williams MSS, RAAF Museum. 
another year. ${ }^{24}$ Burnett had been determined to prove that he was worthy of the Minister's trust. Growing evidence of problems with Hudsons as they came into service was an embarrassment that could not be concealed from his political masters. On June 13, information about four accidents had been circulated to Area commands at his behest. Aiming to prevent similar occurrences and to impress on unit commanders and other officers the need for close supervision of training and maintenance, 'Dad' Bladin provided brief details of each incident. A pilot had landed with his tail wheel unlocked; another had attempted to climb at too slow a speed after take-off; a third had stalled back to the ground because he failed to remove hoar frost; and the fourth had lost power in both engines as tank drain cocks had not been opened to discharge water that condensed inside the tank. ${ }^{25}$

These were not trivial incidents. One of them was fatal. And too many people knew about them. At a meeting of the War Cabinet in Melbourne on July 23 the matter was raised. 'Arising from rumours of recent crashes of Hudson aircraft, the Chief of the Air Staff said that he would include in his report in future reference to any serious losses that might occur.' ${ }^{26}$ The wording was curious. The crashes were not just rumoured. They had actually happened. It was rumours about unexplained crashes that presumably were creating anxiety. The next day Bladin, writing on behalf of the Deputy Chief of the Air Staff, advised appropriate colleagues that the minister wanted the Weekly Statement to include the number of aircraft that had been written off. ${ }^{27}$

Aware that his predecessor but one, the luckless Williams, had been held accountable for unacceptable losses of pilots and aircraft, Burnett had already pressed George Jones for action as Director of Training. In his second month in the job Burnett realised that he did not know what system was being used to investigate and analyse accidents. 'I wish a proper record of flying accidents kept and analysed so that periodic instructions can be sent out for the benefit of the Flying Training Schools and others.' From a hustle of review and recommendations it emerged that the preliminary accident report form and subsequent analysis based on an American format were about to be replaced with a process 'more in keeping with the R.A.F. system'. Fresh instructions about accident reporting were promulgated in mid-May. ${ }^{28}$ At first Jones, now a Group Captain, tried to develop a better appreciation of what was really

\footnotetext{
24 'Extension of Appointment of Chief of the Air Staff', War Cabinet Minute 392, 3 July 1940, NAA: A5954, $804 / 1$.

25 NAA: A705, 32/10/2478.

26 'Extract from War Cabinet Minutes, 23rd July 1940', NAA: A5954, 331/1.

27 NAA: A1196, 37/501/14.

28 Since March 1938 considerable effort had been devoted to revising form E/E/24 for reporting technical and training matters arising from aircraft 'casualties'. As late as April 1940 forms amended in Nov. 1939 had not been distributed (NAA: A705, 32/10/1950). It had been determined in August 1937 that messages reporting aircraft casualties should be in plain language, not code or cypher (NAA: A705, 32/10/1764).
} 
happening. A statistical analysis was to be prepared each month showing the numbers of accidents, their causes, the penalties imposed, and the remedies adopted. Instructors and pupils were required to sight the reports. Burnett had personally corrected the text of the order and a covering letter, expunging some ill-considered words that were 'most dangerous to give to Pilots. To say we allow aircraft to be flown that are dangerous to fly owing to age will not foster confidence with the Pilot or his relatives. ${ }^{29}$

In a further endeavour to at least do something about recurring collisions, Jones 'cooked up a scheme'. In the absence of better suggestions, he remembered, 'I originally decided to put a big red sticker on the instrument board of every aeroplane: Avoid collisions. Look out for other aircraft.' When the order to print the notices crossed the desk of 'Johnnie' Coleman, the Secretary of the Air Board and Air Council and the first Assistant Secretary of the Department of Air, counselled more customary public service language: 'Wouldn't it be better to say: In accordance with regulations so and so you are required to keep a sharp look-out?' Jones recalled that he prevailed, notwithstanding that Coleman's 'sharp look-out' was quoted from the Air Board Order on 'Flying Instruction Approaching and Landing', issued at the end of April 1940. ${ }^{30}$

It was one thing to issue orders, but as the Director of Operations and Intelligence would comment on 'recent accidents' in July: 'in the end it is the vigilance of the flight or squadron commander and the efficiency of the unit training which determine whether pilots apply the orders issued'. ${ }^{31}$ And on the morning of August 13, Jones's bureaucratic victory over someone not known to throw his weight around shrivelled into insignificance. It was a time when the organisation and its senior men would be put to a test unlike anything they had hitherto encountered.

\section{Accident investigation}

Viewed from a distance of over 70 years, the reactions of the Air Force and government are remarkable for their speed and effectiveness. On the day of the crash, RAAF procedure entailed the prompt completion of a one-page 'Preliminary report (external) of flying accident or forced landing'. Procedure was followed, presumably on receipt of a signal from Canberra to the duty officer at headquarters. The form was completed and submitted as required to the Secretary, Department of Air. However, the next day it was replaced by a

29 CAS [Chief of Air Staff] to AMP (DT), 28 Feb. 1940, NAA: A707, 32/10/2478.

30 AM Sir George Jones, interview, 14 Sept. 1977. In From Private to Air Marshal: The Autobiography of Air Marshal Sir George Jones, p.67, the intervention of Coleman is omitted; NAA: AA 1997/635; A705, 32/10/2476.

31 NAA: A705, 208/1/1549. 
second version bearing the annotation 'This cancels preliminary report 39 dated 13/8/40.' The second version on file is also numbered 39. The original does not appear to survive in the National Archives. Nor is there an explanation of why it was thought necessary to replace it. ${ }^{32}$

It would be fruitless to speculate on why another report would have been substituted for the original. But it may be doubted that it was normal practice to do so. ${ }^{33}$ The 'preliminary' report, submitted by the Director of Training (DoT) and bearing the signature of the DoT, George Jones, provided cryptic details. 'Nature of Accident: Spun into ground.' 'Probable cause: Obscure.' Reflecting the recent concern to understand and if possible reduce accidents, the printed circulation list was headed by the Minister for Air, then the Chief of the Air Staff, the Air Member for Organisation and Equipment, the Air Member for Personnel, the Secretary of the Air Board, and the Director of Medical Services (Air). The Assistant Secretary of the Air Board added his own initials. ${ }^{34}$ A typed addition to the names printed on the circulation list was 'Gp Captain Murphy'.

Arthur W. Murphy, already at 49 a veteran RAAF flyer who had begun in the Australian Flying Corps as a technical warrant officer, had been appointed Inspector of Aircraft Accidents only two months earlier. As a Wing Commander immediately before this, he had commanded the No. 1 Aircraft Depot at Laverton. After wartime service with the Royal Flying Corps and Australian Flying Corps which earned him a DFC, 'Spud' Murphy had made his mark in 1919 as the sergeant mechanic accompanying his old Melbourne High School friend Captain Harry Wrigley on an epochal trans-continental survey flight from Point Cook to Darwin. His technical background as well as his long flying experience had made him a logical choice to lead accident investigations. ${ }^{35}$ In December 1937, when controversy erupted over a spate of what the Defence Department suggested should be called 'mishaps' - including the death of Pilot Officer J. F. Fallon, the son of a Labor MP - Murphy had been appointed by the Air Board with Group Captain W. H. Anderson and Wing Commander E. C. Wackett as a special committee to 'investigate the troubles experienced recently with Demon aircraft fitted with Rolls Royce "Kestrel" engines' . ${ }^{36}$ Jack Graham, who had been called from the RAAF's legal office into a personnel role early in

\footnotetext{
32 There does not appear to be a revised form E/E 24 relating to Al6-97.

33 I have not seen a similar note on any of hundreds of other reports in this period.

34 'Lockheed Hudson A16 [Accidents Part 2]', NAA: A9845, 135/27. The form is annotated with references to other files on which copies were presumably placed: 32/10/2824, 32/10/2729, 32/10/2733.

35 Alan Fraser, 'Murphy, Arthur William (1891-1963)', Nairn and Serle (eds), Australian Dictionary of Biography, vol. 10, p.633 does not mention the Air Accident Inspectorate. In 1936 Murphy had been part of a mission overseas to advise on aircraft suitable for production in Australia, and was involved in the decision to produce the Beaufort and the establishment of the Commonwealth Aircraft Factory. Murphy's wartime exploits in Egypt, Palestine, Syria and Arabia earned him a place, 'one of the immortals by proxy', in the index of T. E. Lawrence's Seven Pillars of Wisdom (Stanley Brogden, Sky Diggers: A Tribute to the R.A.A.F., Whitcombe \& Tombs, Melbourne, 1944, p.14).

36 'Accidents to Hawker Demon Aircraft 7/12/1937', Secret Confidential, NAA: A5954, 869/10.
} 
1940, remembered Murphy as 'a hard bitten character' ${ }^{37}$ He would be expected to work quickly and report candidly. He had known and served with Richard Williams since the very earliest days of the AFC. There were few men in the senior ranks of the permanent Service whom Murphy did not know personally. Charles Burnett, like Williams before him, reposed considerable trust in him.

The Inspectorate was the creation of the Chief of the Air Staff. At a staff conference on 18 June 1940, Burnett had been surprised to discover that the Director of Training, not the Director of Operations and Intelligence, was responsible for Courts of Inquiry. ${ }^{38}$ Impatient at the delay in forwarding findings about a Hudson that had force-landed after both engines cut out, he directed that proceedings of Courts should reach headquarters more quickly. His temper was not improved when the Director of Technical Services revealed that the Hudson had been imperilled because the daily inspection had not been properly carried out and water had not been drained from the petrol tanks. ${ }^{39}$ Plainly mistrustful of the adequacy of existing arrangements, Burnett had set his own machinery in motion. The Service was notified of the existence of Murphy's unit and its functions in a temporary order issued on July 11. The unit had no statutory basis but action was in train to establish it formally and confer its functions and powers by regulation under the National Security Act.

Burnett's initiative paralleled a change to the more formal practice. The Air Accidents Investigation Committee, whose jurisdiction over RAAF accidents had been queried a year earlier, was abolished as from 7 August 1940. It had taken some nine months to draw up the Air Navigation regulations necessary to put into effect the Cabinet decision to abolish the Air Accidents Committee - thereby saving $£ 600$ a year as well as the time of senior officers who were members - and to establish Air Courts of Inquiry. ${ }^{40}$ Under statutory rule No. 155 of 1940 the new Courts of Inquiry would ensure due process and the representation of RAAF interests. But Burnett wanted advice without delay, irrespective of process. In fact, the dual system of investigation was the outcome of a struggle for control that had erupted 18 months earlier.

Early in 1939 the Acting Director-General of Civil Aviation, Maurice Mehaffey, in collaboration with the Crown Solicitor, Harry Fred Whitlam, had begun to prepare a bill for the creation of Air Courts of Inquiry constituted on similar lines to the traditional Marine Courts of Inquiry. Civil Aviation Minister Vic Thorby

\footnotetext{
37 GpCpt. J. E. Graham, interview, 11 May 1978.

38 Although lines were sometimes crossed, responsibility for investigating accidents lay with the Director of Training 'because the majority of accidents are due to the pilot's error and the D.T. being responsible for flying training is in the best position to prevent their recurrence' (S/Ldr J. M. McCauley D.T. to AVM H. R. Nicholl A.M.P., 19 March 1937, NAA: A705, 32/10/1704).

39 Report of Staff Conferences Nos 39, 40, 18 and 25 June 1940, NAA: AA1977/635.

40 H. E. Holt (A/g Minister for Civil Aviation), 'Air Courts of Inquiry', Cabinet Agenda 244, approved 30 Nov. 1939, NAA: A461, V314/1/1.
} 
had referred the proposal to the Defence Minister, Geoff Street, for advice on 20 February 1939. Street passed it to the Air Board. Alarmed by the prospect of intrusion into Service affairs, the Board scurried to defend its autonomy. Within four days Air Commodore Williams had made it clear that he agreed with his subordinates that 'in the first instance they should try to remain outside the jurisdiction of the proposed Air Court of Inquiry'. 'If unsuccessful,' the fallback position was that 'they should limit it to fatal accidents only and that the assessors be Air Force officers.' Meanwhile Air Commodore Goble, four days from formally taking over from Williams as Chief of the Air Staff, 'directed that no reference be made to the Air Accidents Investigation Committee at present'.

The Air Board's case was developed in a minute to the Secretary of the Department of Civil Aviation on February 24. With the provocative caveat, 'on the assumption that the Government has already decided to establish an Air Court of Inquiry', they accepted that the proposals of the Director-General of Civil Aviation were 'satisfactory so far as civil aviation is concerned'. But there the agreement ended:

As for Air Force accidents, these are now investigated by a Service Court of Inquiry, as it is in the vital interest of the Board, and the Royal Australian Air Force as a whole, to discover causes. Irrespective of what other Courts or Committees may be charged to investigate Air Force accidents, this internal Court of Inquiry must still be held, and the Board feels that such a Court, conducted by qualified officers of experience, is the most satisfactory means of investigating Air Force accidents.

The argument then shifted to another level.

The Government, on the advice of the Air Board, has consistently refused to agree to allow Air Force accidents to be investigated at 'open' enquiries, and it is considered that this policy should continue. The Air Force is a fighting Service dependent mainly on the morale of its pilots for its efficiency in flying, and it is considered that the publicity connected with open investigations would have a most harmful effect on the morale of the young pilot or cadet pupil.

The conclusion embodied the outgoing Chief of the Air Staff's position: Air Force accidents should not come under the jurisdiction of the proposed new Air Courts of Inquiry. Just as accidents involving naval vessels were excluded from Marine Courts of Inquiry so should RAAF accidents be subject only to Service inquiries.

If the Air Board thought that was the end of the matter they were in for a shock. When the Defence Minister saw their advice he recognised the political danger at once: 'I cannot agree that public opinion would be satisfied with the 
investigation of Air Force accidents by R.A.A.F. Courts of Inquiry only.' Street had been unimpressed by the RAAF response to a forced landing on King Island on 11 September 1938. The Court of Inquiry was belated and 'the facts were only elucidated promptly by reference to the Air Accidents Committee'. Geoff Street laid down the policy that was to be followed:

R.A.A.F. Courts of Inquiry can still operate for Service purposes, but Air Force accidents should be dealt with by the Air Court of Inquiry, and an Air Force officer added as an additional assessor in these cases. Rules can be laid down for dealing with accidents in camera where important Service considerations are involved, or the Court can use its discretion.

Lest it be thought that he was surrendering any Defence prerogatives, Street added an oral assurance, noted on the file the same day: as far as Air Force accidents were concerned any powers to be exercised by 'the Minister' under the new Act or regulations should be vested in the Minister for Defence, not the Minister for Civil Aviation. ${ }^{41}$

\section{Burnett's inspectorate}

With the appointment of a Minister for Air late in 1939, Geoff Street's role in relation to Air Force aircraft accidents had passed to his friend Jim Fairbairn. The new minister brought another dose of common sense to the developing regulatory regime. He successfully urged the deletion of a draft clause mandating a Court of Inquiry whenever there was loss of life or serious injury. There would, he said, be cases where there was some obvious cause that would not warrant bringing in a judge and assessors. It would be far better that the minister should have discretion to decide if an investigation was in the public interest, or if it was desirable because the department was unable to certify the cause of an accident or had not 'correctly explained' it. More worrying for civil aviation officials was an entirely new recommendation, accepted by Cabinet on 29 May 1940, that would enable any officer authorised by the Director-General to investigate any accident or forced landing that had not previously been referred to an Air Court of Inquiry, and to summon witnesses to give evidence on oath or affirmation. ${ }^{42}$

Although not directly affected by these changes, Sir Charles Burnett was alert to the fact that his minister not only knew a lot about flying but had strong views about the government's accountability to a potentially fractious electorate.

41 NAA: A705 108/2/189; A432, 39/442.

42 NAA: A461, F114/1/1. Fairbairn's submission, 8 May 1940, took further proposals brought to Cabinet in his absence by Holt, Cabinet Agenda 244, 'Air Courts of Inquiry', NAA: A2697, roll 2. 
Burnett had realised that if he was to keep ahead of political curiosity and concern, and of inquiries he could not control, it was essential to have his own 'quick and expert' source of information. His first thought had been to bring in an outsider, independent of the RAAF hierarchy, as 'Inspector of Air Accidents'. Advice on suitable men from A. B. Corbett, Director-General of the Department of Civil Aviation and his deputy E. C. Johnston, led to an overture to Qantas for the services of their chief engineer, Arthur Baird. Qantas managing director Hudson Fysh, communicating directly with his old friend Jim Fairbairn, made it clear that Baird could not be spared. ${ }^{43}$ No other available 'outside' man met Burnett's requirements. He therefore settled on Wing Commander Murphy, who was recommended by Air Commodore Anderson over the objection of Air Marshal Williams who thought Murphy would be 'pulling a far greater weight' in command of the Aircraft Depot. Murphy was instructed that he would operate directly under the CAS's orders 'or those of the Deputy Chief of the Air Staff, and you will be responsible solely to me, through the Deputy Chief of the Air Staff' - the arrangement demonstrating the unique position of trust and authority now enjoyed by Bill Bostock. The Inspectorate's remit covered all Air Force aircraft accidents and forced landings. Its brief was to ascertain the cause of an accident and recommend suitable preventative action for the future. An unadvertised occasional extra dimension of their mission was to take a good look at station administration, aircraft maintenance, and flying orders, especially in new Elementary and Service Flying Schools manned by comparatively inexperienced COs, chief flying instructors, instructors, and ground personnel. Murphy thus ran a de facto unofficial organisational investigation team for the Chief of the Air Staff. ${ }^{44}$

Burnett's Inspectorate, a rather grand name for what at the time was a four-man operation - the 'staff' mentioned by the departmental press release was one legal officer, a clerk, and a pilot - was despatched to Canberra in the afternoon of August 13. ${ }^{45}$ Murphy's initials on the 'preliminary' form are undated but he would certainly have known of its unenlightening contents before he left. He had already that morning heard of another accident that might ordinarily have demanded his attention. A Hudson of No. 23 Squadron based at Archerfield had disappeared the day before on a navigation exercise out to sea. Three pilots and

\footnotetext{
43 'Air Accidents - Investigation of', NAA: A705, 32/1/45 Part 1. In March 1943, the DCAS was advised that 'the file covering the formation and policy of the Inspectorate... was lost towards the end of $1941^{\prime}$ and the Inspectorate had been operating for 18 months without terms of reference. The file was identified and released for the first time on 17 May 2013.

44 Sir Harry Winneke, interview, 18 Jan. 1979; 'CAS - Inspectorate of Aircraft Accidents — Policy', NAA: A705, 32/1/45 PART 2. The establishment of the Inspectorate was belatedly announced in a press release in Fairbairn's name on 8 Aug. 1940 but Gillison (Royal Australian Air Force 1939-1942, p.96) was mistaken in saying that it was 'set up to make confidential reports to the Minister'.

45 Two fitters on the establishment of No. 1 Aircraft Depot were to be placed at the disposal of the Inspectorate 'as and when required' (NAA: A705, 231/9/462).
} 
three other men were missing. ${ }^{46}$ In the absence of physical evidence there was no immediate call for the Inspectorate's presence in Queensland. So Murphy and his associate, Squadron Leader Harry Winneke, the able young Melbourne barrister originally attached to the RAAF legal section, scrambled for Canberra. Harry Winneke's flying experience was limited. He was not a pilot. He was not there to be an aviation expert but to use his forensic skills to elicit information from witnesses. He had enjoyed the benefit of kindly instruction from 'Air Force fellows...they'd take me down to Point Cook and those places and explain the theory of flight to me, take me up in the air and put me through the controls and show me how the aircraft worked' ${ }^{47}$

Winneke was no stranger to aircraft accidents. In November and December 1938 he had represented Associated Airlines Pty Ltd during the Air Accidents Investigation Committee's inquiry into the Kyeema crash. That had been a significant learning experience. As the inquiry report noted: 'The accident in question involved a greater loss of life than any other aircraft accident which has ever occurred in Australia and one of the most serious in the history of regular air transport throughout the world. ${ }^{48}$ It was not just the 15 men and three women who perished, but the enormous publicity surrounding the most prominent of them, the greatly respected federal MP Charles Hawker, that made the Kyeema accident so notable. A separate inquiry headed by Robert Lawson, the Chief Engineer of the Postmaster General's Department, had revealed the administration of civil aviation to be dysfunctional. Sweeping organisational reforms were recommended and implemented: too late to save the lives of the Kyeema's passengers and crew. Too late, also, for the peace of mind of Jim Fairbairn and Geoff Street, the distressed political colleagues and friends of Charles Hawker, who blamed the bungling and procrastination of the Civil Aviation Board for the failure to install and test radio beacons that might have prevented the crash. ${ }^{49}$

In mid-1939 Winneke had been counsel assisting with RAAF accident inquiries run by Justice H. B. Piper. ${ }^{50}$ He was thus familiar with the new Air Court of Inquiry process. With Piper he had been taken on familiarisation flights in Ansons, given basic instruction in the theory of flight, and even flown alongside the pilot in a dual-control aircraft. His forceful leading of evidence on the Riverstone crash of A4-32 and the Port Philip Bay crash of A4-11 suggested that the pilots, not the machines, were at fault. He had struck a chord at RAAF headquarters. Very early in the war he was asked by Group Captain

\footnotetext{
46 'Lockheed Hudson Al6 [Accidents Part 1]', NAA: A9845, 134.

47 Sir Harry Winneke, interview, 18 Jan. 1979.

48 'Department of Defence Air Accidents Investigation Committee, Report on...Fatal Accident to the Douglas D. C. 2 Aircraft VH-UYC “Kyeema”...', Melbourne, 5 Dec. 1938, p.1, enclosed in Australian Archives Accession MP 1353/3, 'Civil Aviation confidential report on Kyeema crash, 1938'.

49 For the 'minefield of bureaucratic delays', see Macarthur Job, Disaster in the Dandenongs: the Kyeema airliner tragedy, Sierra Publishing \& Mount Dandenong Historical Society, 2008, pp.48-55.

50 NAA: A705, 32/10/2387.
} 
Bill Bostock, then Deputy Chief of the Air Staff, to join up to handle courts of inquiry, courts martial, and various other personnel matters that were the anticipated consequence of a rapidly expanding Service. He had been posted to the Inspectorate of Air Accidents in mid-June 1940. ${ }^{51}$

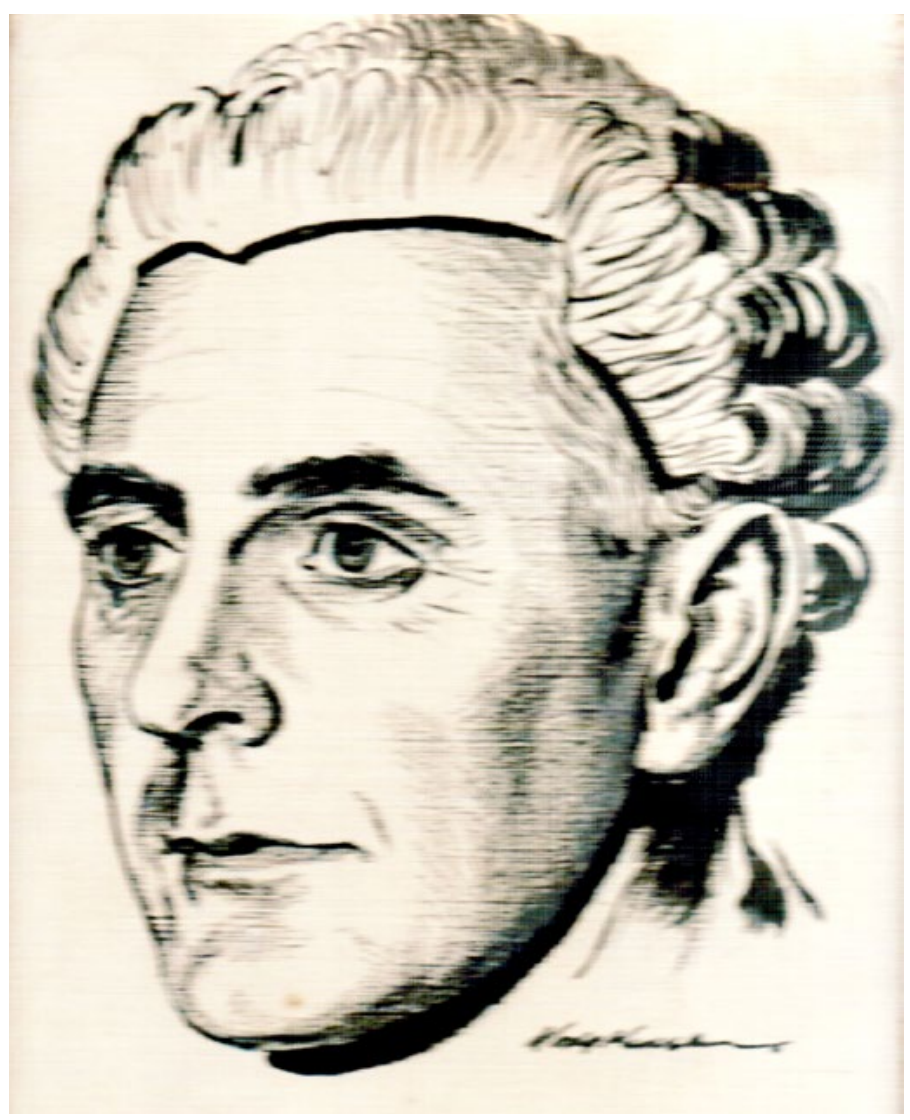

\section{Harry Winneke, advocate and accident investigator}

(Sketch attributed to Roy Hodgkinson, courtesy of Heather Winneke) ${ }^{52}$

The Air Member for Personnel had pleaded in vain that Winneke be retained in his legal role but Burnett's incontrovertible argument was that he would work smoothly with Murphy 'who, I fancy, is sometimes a little difficult in producing his meaning on paper'. ${ }^{53}$ In August, the Accident Inspectorate was on 24-hour standby, with their own aircraft, Dick Casey's four-seater Percival P10 Vega Gull Six, now impressed and repaired for Service use. Complete with Casey's

51 Robert Coleman, Above Renown: The Biography of Sir Henry Winneke, Macmillan \& Herald \& Weekly Times, Melbourne, 1988, pp.93, 98-9, for a different version of Bostock's approach to Winneke.

52 The image is attributed to Roy Hodgkinson in Robert Coleman's biography of Winneke but on close inspection the signature is indistinct.

53 NAA: A705, 32/1/45 Part 1. 
customised soft-leather upholstery, it was a luxury ride 'more like flying in a saloon car than in an aeroplane. One can even carry on a reasonable conversation while in flight.' They had their own pilot, an RFC and commercial flyer, Frank Neale. Neale had been recalled to duty at Laverton as a flying officer, later promoted squadron leader in charge of the Communication Flight, a small fleet of light aircraft formed at Laverton in November 1939 and available to move Air Officers Commanding Groups or Areas and their staffs. ${ }^{54}$ It was into this unit that the private planes of both Casey and Fairbairn had been collected. ${ }^{55}$ The crash in Canberra was to be the Inspectorate's most sensitive assignment; and the CAS needed answers rapidly.

\section{The Service looks after its own}

Murphy and Winneke were not to have the field to themselves. Independently of the Air Force, Commonwealth Police detectives and uniformed officers were already interviewing witnesses and preparing statements for the Coroner. The Inspectorate was also raced to the scene and to the witnesses by the members of a specially constituted Service Court of Inquiry. Under Air Force Regulations such a Service Court could be assembled by the Air Board or, in the carefully chosen words of the Secretary of the Board, Mel Langslow, 'other appropriate air-force authority'. As Langslow advised the new Minister for Air, the Country Party's Arthur Fadden, two days after the crash, it was not superseded by the new Inspectorate; and when assembled 'may still function in the normal way and even investigate the same accident'. What Langslow did not say was that Burnett's Inspectorate took precedence in access to the wreckage. As the Air Board Order had put it on July 11: 'A court of inquiry shall not... without the permission of the Inspectorate, interfere with, for purposes of inspection or examination, any aircraft involved in an accident concerning which the Inspectorate has been directed to report.' If there were to be a Service Court of Inquiry inspection or examination, it would 'normally take place concurrently with that conducted by the Inspectorate, but the Inspectorate may grant such permission subject to such conditions as it thinks fit' ${ }^{56}$

\footnotetext{
54 Edward P. Wixted, The North-West Aerial Frontier 1919-1934, Boolarong Publications, Brisbane, 1985, pp.196-7 for Neale, 'one of the great aerial achievers of Australian history'. Neale had ferried Fairbairn from Mt Elephant to Laverton in Vega Gull A32-1 on 3 June 1940 (NAA: A11094, 5/6/Air Part B.).

55 Sandy Johnstone diary, 20 March 1940, Air Vice-Marshal Sandy Johnstone, Enemy in the Sky: My 1940 Diary, William Kimber, London, 1976, p.36; AFCO 15-16/1939, NAA: A7674, 1/30; Sir Harry Winneke, interview, 18 Jan. 1979. Maie Casey recorded 'Gull goes', diary, 15 Jan. 1940, Lady Casey MSS, NLA MS 1840/13. A second Vega Gull had been impressed from the Queensland pastoralist and aviation enthusiast J. W. F. Collins shortly before he was commissioned into the RAAF in March 1940 (NAA: A705, 9/23/163/10).

56 ABO N391/1940, 11 July 1940, NAA: AA1977 635.
} 
The Air Board did not need ministerial approval to set up a Service Court. Unlike the less formal procedure of Murphy and Winneke, a Service Court had unfettered authority to call and examine Air Force personnel. It could also invite, though not compel, civil witnesses. ${ }^{57}$ Within hours of news of the crash reaching Melbourne, Group Captain U. E. Ewart, Senior Administrative Staff Officer, Southern Area, had signed off on the appointment of a three-person Court of Inquiry. The president was to be Wing Commander L. V. Lachal, a 36-year-old career officer lately returned from the United Kingdom where he had been CO of No. 10 Squadron, and currently working alongside Ulex Ewart at Headquarters Southern Area in Toorak. ${ }^{58}$ The other members were Squadron Leader Frederick Ivor Stevens on engineer duties at No. 1 Service Flying Training School, and Pilot Officer George A. Pape, who was 'marched in' to join the law staff attached to Southern Area HQ on August 5 after completing a month's course for administrative and special-duties officers. Thirty-seven years old, unmarried, and living at home with his father, in applying for a commission Pape had modestly noted ' 13 years as a barrister with a reasonably good practice'.$^{59}$ His presence was, as Lachal would recall, a 'very happy coincidence'. The team was to submit 'proceedings in triplicate...not later than MONDAY, 19 ${ }^{\text {th }}$ August, 1940' ${ }^{60}$

Leon Lachal, a Xavier College boy, had risen in 14 years from cadet to squadron commander and senior headquarters staff appointments. He had experience of courts of inquiry. He was trusted and understood the urgency. Honest, pleasant, and well-liked, 'Old Stump' (he was about $6 \mathrm{ft}$ 3in, the RAAF photographer, John Harrison, remembered) was not a man to make waves. 'He was a sound fellow,' his chief, Harry Wrigley, recalled, 'he had a pretty wide flying experience, and he had a fund of common sense. ${ }^{61}$ But he had not flown Hudsons. Fred Stevens, a CAF officer aged 37 called to serve at HQ in 1939, was fully alert to the implications of the crash for the flying training task to which he had been posted at Point Cook. He had been a sergeant pilot and had been Lachal's flying instructor. ${ }^{62}$ Pape, whose service in the Melbourne University Regiment had

57 Minute, Secretary, Air Board to Minister, 'Investigation of Accidents Affecting Air-Force Aircraft', 15 Aug. 1940, NAA: A705, 32/10/2733. A concerned Mel Langslow had written to the Secretary of the AttorneyGeneral's Department on Aug. 21 suggesting that the draft Inspectorate of Air Accidents Regulations would need amendment as they would have prohibited the Air Court of Inquiry approved by the government. A-G's had been sent the draft on July 10; on Nov. 4 the Air Department was advised that their enactment was in hand as 'an urgent matter'. The Statutory Rules were finally agreed in May 1941 (NAA: A705, 32/1/45 Part 1). 58 HQ Southern Area had been No. 1 Group HQ until renamed in March 1940 and transferred from 425 St Kilda Road to the old Creswick family mansion 'Yarrien' which was scheduled for demolition, its five acres to be sub-divided into 19 home sites (NAA: Al1334, 2/1/1/Air; The Argus, 26 Aug. 1939). The RAAF was not permitted to use the name 'Yarrien' during its tenancy (NAA: A705, 4/4/164).

59 NAA: A9300, PAPE GA.

60 Sir George Pape and ACdre L. V. Lachal, interview, 14 Sept. 1977; Convening Order, GpCpt U. E. Ewart to WCdr L. V. Lachal, 13 Aug. 1940, NAA: A705, 32/10/2733.

61 John Harrison to CH, 25 July 1978; AVM H. N. Wrigley, interview, [1977].

62 NAA: A9300, STEVENS FI. 
overlapped that of Lieutenant Robert Menzies, had been one of Menzies' last pupils at the bar. Like Menzies, he practised from Selborne Chambers; he needed no advice about the Prime Minister's temperament and impatience with brains that moved more slowly than his own. By the end of the day, five interviews had been taken at Essendon, and another four at Laverton. Two days later, flown in a Hudson piloted by Bob Hitchcock's fellow flight commander Jack Ryland with Wilbur Wackett as 2nd pilot, the team was in a chilly Canberra and Queanbeyan where they took sworn statements from 13 witnesses. With language tightened up - and no hint, for example, that one interview had taken place out in a paddock among the farmer's cows - Pape could bring coherence to what might otherwise have been stumbling narratives. Flight Lieutenant Ryland, who was formally 'in attendance' throughout the interviews, was the twenty-fourth and last witness. By Saturday August 17 the four men were back in Melbourne. Pape, who had to collect the final signatures on the witness statements, had been the last to get aboard the aircraft in Canberra as its engines were warming up. The Service Court report, drafted by Pape, was completed on Sunday.

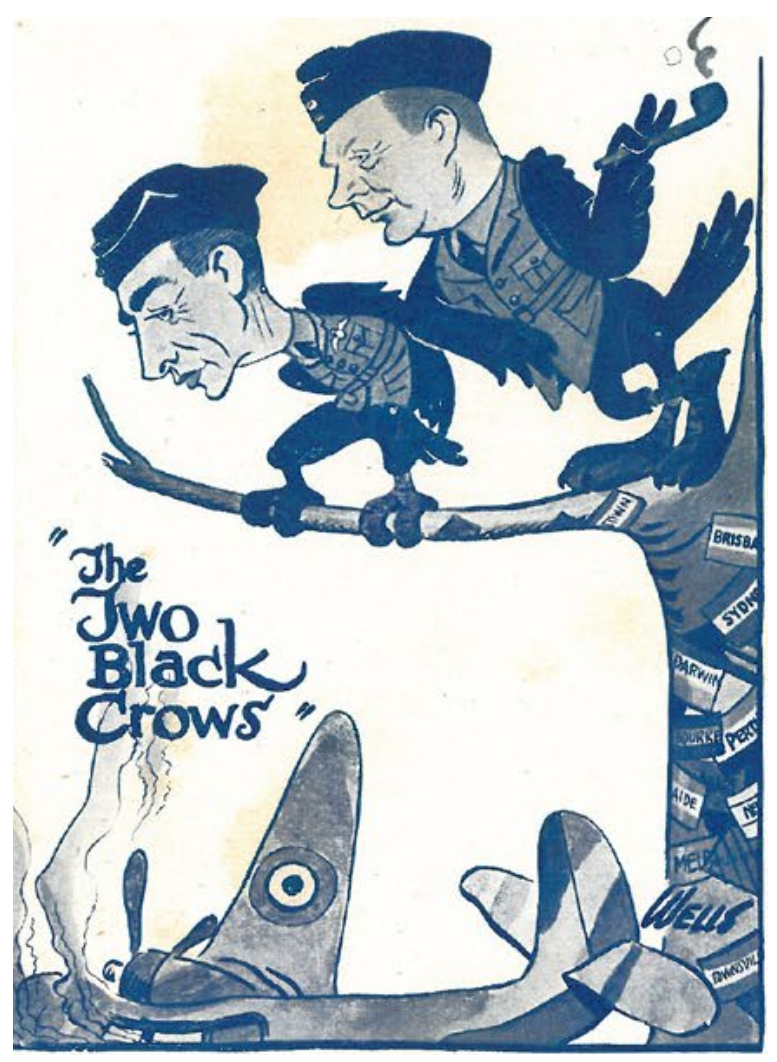

The Accident Inspectorate: Murphy and Winneke about to swoop

(Courtesy of Sir Harry Winneke) 
Murphy and Winneke had already finished their own work. Watching them at dusk on August 13 examining the wreckage, a reporter saw that the dead tree upon which the plane was virtually impaled, burned fiercely, throwing a red glow over the scarred hillside' ${ }^{63}$ The inspectors had spoken to 15 witnesses in Canberra and Queanbeyan by the time they submitted their report on August 16. Although the report of the Inspector of Air Accidents went formally to the Chief of the Air Staff, within hours a copy was despatched by Winneke to the Secretary of the Air Department for the information of the new minister.

Four days before the accident, the day after the Inspectorate's existence was publicly announced, Fairbairn had sent a minute to the CAS, routed via the Secretary of the Air Department, saying that he wanted to be sent copies of all reports from Murphy. Softening any implication of mistrust, Fairbairn pointed out that the Air Accidents Investigation Committee had reported on RAAF accidents to the Defence Minister and latterly to the Minister for Air. ${ }^{64}$ Burnett may well have had preliminary advice as early as the afternoon or evening of the crash, having arrived in Canberra that day to stay at Government House accompanied by his personal assistant, Flying Officer N. B. Palmer. In a 'Most Secret' minute, Mel Langslow advised Arthur Fadden that what he had submitted was 'for your personal information'. With characteristic caution Langslow wrote:

This report is submitted in accordance with the approved procedure but, in view of the fact that the Government has decided to constitute the Air Force Court of Inquiry to investigate this accident, it is considered that the contents of this report should not be disclosed at this stage.

The last three words were added by hand. Earlier in the day, with no formal advice of what the two concurrent Service investigations would report, Cabinet had agreed to set up an Air Force Court of Inquiry. It was to be an open judicial inquiry of the kind the Air Board had unsuccessfully argued against the previous year. What Artie Fadden now learned was to set the tone for all that followed. Murphy concluded that the 'immediate cause' of the crash was a stall. He thought that the height of Canberra aerodrome, some 2000 feet above sea level, and a heavier load than the pilot was accustomed to, 'may have been factors contributing to cause the stall'. But 'the first pilot's attention' had been drawn to these matters on the afternoon before the crash. The aircraft itself was 'completely serviceable'. He had made a 'close inspection' of what was left at the site. The remains of the starboard wing showed the flaps to be down to within nine inches of the total travel of the ramp. The throttles appeared to be to the

63 Sun News-Pictorial, 14 Aug.1940.

64 Three months later Langslow was tersely reminding the CAS that 'the directions of a previous Minister that a copy of all reports... was to be forwarded to the Minister as issued, are not being complied with' (NAA: A705, 32/1/45 Part 1). 
rear. The throttle of the port carburettor was partly open. The elevator tabs were 'slightly up', three-eighths of an inch above the elevator's trailing edge. The starboard aileron tab was in the neutral position. The surviving elevator and rudder 'worked quite freely'.

Nothing that Murphy noticed in the wreckage indicated a failure of the aircraft. He did not repeat in his report what he seems to have incautiously conveyed to reporters near the wreckage on August 13: that the collision of the aircraft with a fallen log and the subsequent conflagration had caused most if not all of the deaths. As the Launceston Examiner story put it the next day: 'if it had not been for the fire most of them could have been extricated from the 'plane without serious injury'. What credence could be given to Murphy's conclusions? In the opinion of L. P. Coombes, who had arrived in January 1939 from the British aircraft establishment at Farnborough to create the CSIR Aeronautical Research Laboratories (ARL), Murphy was 'a sound practical engineer with long workshop and maintenance experience'. ${ }^{65} \mathrm{He}$ was certainly no mechanical forensic pathologist. 'Tich' McFarlane was less kind: 'Nice enough bloke - he wouldn't know which was the flying end of a Hudson. ${ }^{66}$ But, in the absence of a more thorough investigation, his advice on the causes of the crash was as good as the Chief of the Air Staff could hope to get. The ARL itself was not yet sufficiently established and equipped to have undertaken any engineering tests.

In the circumstances, Murphy had 'no option but to attribute the stall to an error of judgment on the part of the pilot'. Whether the baldly listed technical detail in the Inspectorate report would have been comprehensible to Fadden or any other non-flying minister must be doubted. Burnett, who was in Canberra for the August 13 Cabinet meeting and did not return to Melbourne until the next day, would have been relieved. ${ }^{67}$ What they would all have assimilated was the unequivocal conclusion that the responsibility lay with the pilot. The last thing that Murphy would have wanted to present to the Chief of the Air Staff, still less to the Air Minister or Prime Minister, was a suggestion of mechanical fault symptomatic of careless maintenance, poor construction, or design flaw.

While it might be thought that there was an unseemly haste about Murphy's activities and those of Lachal's Court, the rapid interviewing of those who had first-hand testimony to offer ensured that there was little time for details to be forgotten or memories to be conflated or corrupted. Among the Service witnesses from RAAF Station Canberra to whom Murphy and Winneke had spoken were Pilot Officer R. R. H. Winter (duty officer, Survey Flight), Flying Officer Ronald C. Wilson (Station Equipment Officer), Flight Sergeant Clifford Linton Smith 
(storekeeper), and Corporal Mortimer G. Ewing (fitter IIa).$^{68}$ All four had also been interviewed by the Lachal group. So too was ACl Henry F. House, the mess steward at No. 2 School of Technical Training, who had told them he saw the aircraft's nose dip and the machine commence to turn in a spinning position above the height of the hills on the eastern side of the aerodrome. House had not seen the plane hit the ground but when he saw an eruption of flames he hastened to tell the mess chief, Warrant Officer Jordan. Corporal Harold Unitt, also of No. 2 S.T.T., did not give evidence to Lachal's team. Murphy did not mention that he had never flown a Hudson. His knowledge of its construction, functioning, and performance was limited. Nor did he take evidence from anyone who was familiar with the aircraft.

\section{The Ryland factor}

Lachal and his associates might have had informal conversations with Murphy. Pape and Winneke were friends and regular golfing companions. However, there is no evidence of any co-operation between the two investigating teams. Certainly the Service Court did not take evidence on the record about what could be inferred from the wreckage. They did have the time to talk to ground crew at Laverton to establish that required maintenance and checking had been done. But they sought no independent professional advice. If the range of expertise enlisted by the Service Court was limited there was perhaps an even more serious concern about its procedure. To understand the flying characteristics of the Hudson better, they had contemplated calling 34-year-old Squadron Leader Dallas Scott who had been given command of No. 7 Squadron late in June 1940. Scott, a Melbourne Grammar boy and Public Schools boxing champion, had briefly been Bob Hitchcock's flight commander in No. 21 Squadron in 1937. While awaiting the arrival of his own squadron's Hudsons, he had been assisting No. 2 Squadron with their conversions. One of the Air Force's most experienced Hudson pilots, Scott had flown Sir Charles Burnett in May in a week-long tour of inspection of Darwin, Townsville, Archerfield, Richmond, Cootamundra, and Wagga. He had subsequently been attached to No. 1 Squadron at Sembawang to help with their Hudson conversions. ${ }^{69}$ Lachal was evidently unaware that Scott

68 The haste with which the report was compiled is reflected in a number of minor errors such as the listing of P/O R. H.[sic] H. Winter. Winter's three forenames, Richard Raymond Henry, also defeated Lachal's team who listed him as R. M. H. Winter.

69 No. 1 Squadron Operations Record Book, NAA: A9186, 1/178. For the confused decision-making around the formation of No. 7 Squadron, and the arrival of its first two Hudsons on Aug. 12: Kevin Gogler, We Never Disappoint: A History of 7 Squadron RAAF 1940-1945, Air Power Development Centre, Canberra, 2012, pp.1-6. 
was out of the country and would not return to Australia until August 18. With Scott absent, the Service Court was to rely for technical advice on the behaviour of the aircraft on Jack Ryland, with whom they had travelled to Canberra. ${ }^{70}$

Ryland was without doubt exceptionally able. David Campbell, converted by him to the Hudson in the weeks after the crash, thought he was an 'extraordinarily good officer and pilot...there was no better instructor than him' ${ }^{71}$ However, in the rush to get things done, no one seems to have been troubled by the conflict of interest Ryland faced. He would unavoidably be giving advice relevant to the adequacy of his own training and evaluation of Bob Hitchcock. Murphy and Winneke had seen a copy of Hitchcock's conversion course certificate, signed by Ryland and Squadron Leader Freddie Thomas. But they did not report having spoken to either man. Nevertheless, Murphy and Winneke wrote that Hitchcock's Squadron Commander assessed him as 'above average as a pilot and a sound experienced pilot'. His instructor on the conversion course (Ryland was not named) assessed him as 'a very sound pilot, slightly above average on HUDSONS'.

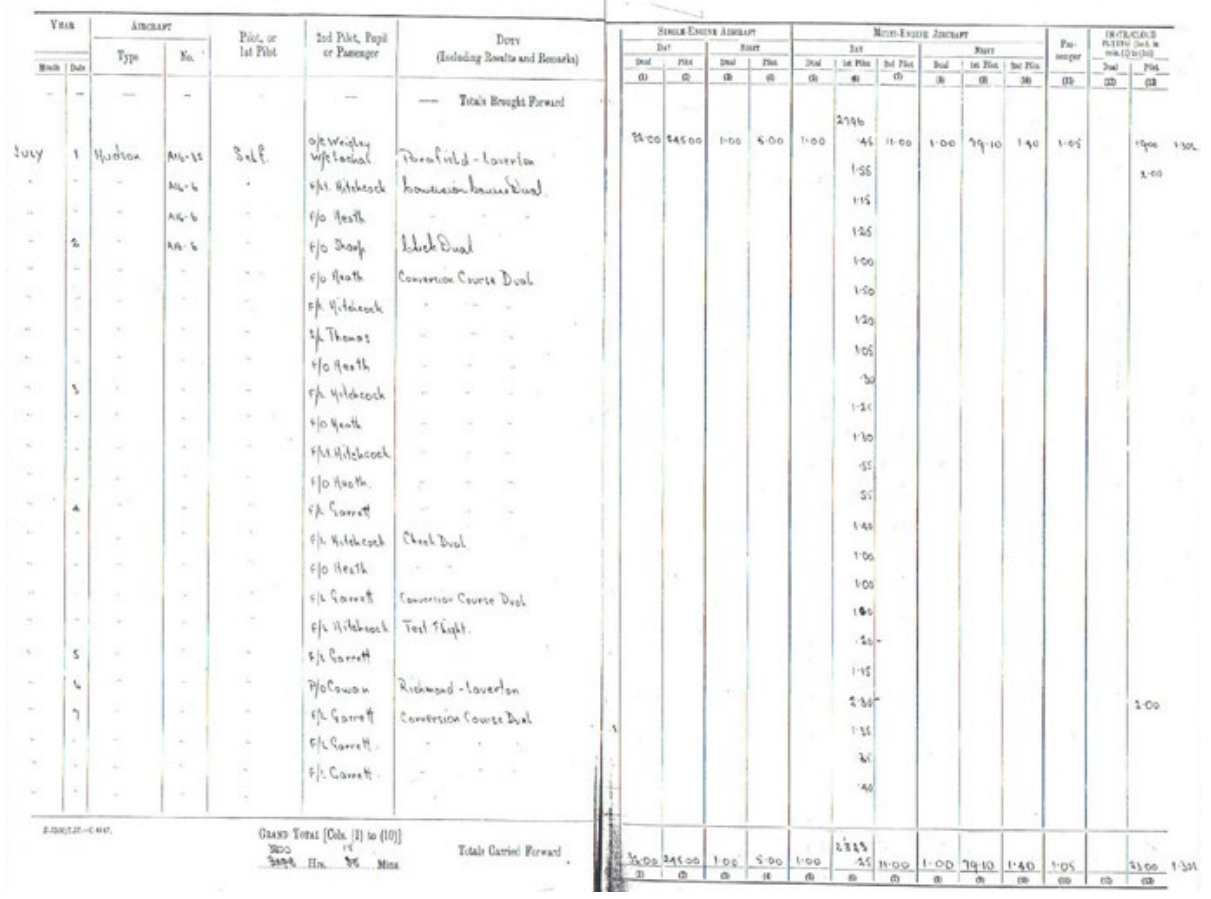

Jack Ryland records a week of Hudson conversion courses at No. 2 Squadron (F/Lt Ryland's flying log book, Ryland MSS NLA MS 5020)

70 Service Court of Inquiry, Notes on suggested witnesses to be called, undated [13 Aug. 1940?], NAA: A9845, 318/48; E. R. (Bon) Hall, Glory in Chaos: The RAAF in the Far East in 1940-42, Sembawang Association, West Coburg, 1989, pp.4, 11

71 Campbell, telephone interview, 24 May 1978. 
Jack Ryland recounted for the Service Court the details of the conversion course for his pupil Hitchcock between June 26 and July 21: 19 hours 15 minutes dual and check dual, 49 hours 10 minutes solo practice. Had Hitchcock been given instruction in full-load flying? Yes. He had taken off at full permissible takeoff load of $18500 \mathrm{lbs}$, flown until sufficient fuel had been burned to reduce the load to $17500 \mathrm{lbs}$ (maximum permissible landing weight), and carried out 'three or four landings'. Was Flight Lieutenant Hitchcock instructed in the stalling characteristics of 'Hudson type' aircraft? Yes, and both before and after solo he was made to demonstrate these characteristics 'to ensure that he fully understood them'. Was he instructed in the stalling characteristics with full load? No, Ryland did not consider that the stalling characteristics would be 'vastly different' with full load to what they were when he instructed in them and demonstrated them.

The Court then turned to the possible need to alter the disposition of the load during flight as petrol was consumed. Ryland here was careful to give a conditional ' $\mathrm{No}^{\prime}$ - if the aircraft was loaded correctly in the first place and if the tanks were operated in the correct sequence 'which I taught to Flight Lieutenant Hitchcock and which is shown on a label in front of the fuel cock'. What then, Lachal and Stevens asked, do we know about the characteristics of the aircraft with the load disposed in different manners? Had any tests been done? Yes, Ryland in company with Dallas Scott, had tried two unusual loads: the first had the pilot in the correct position, four people in the navigator's compartment, and nobody in the cabin; the second had four people and ballast in the ballast compartment and only the pilot in the cockpit with no people forward of the pilot. 'As far as I can remember,' Ryland went on:

in the first case, one complete turn of the trimming tab maintained the aircraft in normal flight and in the second case one complete turn of the trimming tab similarly trimmed off tail heaviness. Otherwise the aircraft was quite normal except for a slight vertical hunting in the second instance. This vertical hunting was in no way dangerous and could be easily controlled by the pilot. I do not think that the Hudson reacted in a manner different to any other type of aircraft which I have flown under similar conditions.

Satisfied with this explanation, the Court then asked which of the four main types of stall with Hudsons was the most sudden: (1) gear up, power on (2) gear up, power off (3) gear down, power on (4) gear down, power off? It was (3): gear down, power on.

There remained the question of whether Hitchcock had landed on Canberra aerodrome before the fatal crash (and implicitly whether local conditions might have contributed to the accident). In fact both Ryland and Hitchcock had flown 
in on the same day on an earlier occasion. The wind had been blowing from the same direction as on August 13; so the approach was similar, and Ryland 'experienced no difficulty'. He would later tell the Air Court of Inquiry that he had watched Hitchcock execute a perfect landing. ${ }^{72}$ But had Hitchcock practised landings with various flap settings? The Court was assured that he had done so on many occasions and that it was normal practice to vary flap settings according to the wind.

In their report, completed the day after the final testimony had been taken, Pape, Lachal and Stevens noted that they had 'co-opted the services of Flight Lieutenant J. P. Ryland...in order to have available his knowledge when witnesses were being questioned' ${ }^{73}$ There is no direct reference in the transcripts to any intervention he might have made. But it is difficult to believe that Ryland's contribution was limited to the recorded testimony. Having sat through the proceedings, there was only one piece of evidence which he openly and strongly rejected. In an obviously pre-arranged final question, it was put to him that he had heard it said that the aircraft did a complete roll and a change of direction as it was coming in to land at a height of about 500 feet above the ground. 'Do you consider this possible? Definitely no. ${ }^{74}$

Ryland was brought in as a witness to attest to Hitchcock's competence as a pilot. It might reasonably have been supposed that his own judgment as an instructor could have been put in question if there were doubts about Hitchcock's ability to handle the Hudson. Yet not only did Ryland testify, the last person to do so, he was co-opted as 'an experienced "Hudson" "Captain" and Instructor', in effect an expert assessor. There is no reason to suppose that Ryland's testimony was anything other than candid. But, in relying on his professional advice some of it, one might suppose, given off the record - the Court was rendered vulnerable to the possibility that Service witnesses might be shielded or deflected rather than stringently examined.

If Ryland were to find reason to attribute blame to the aircraft itself, its construction, maintenance, or performance, he would by implication be leading Lachal's inquiry to a finding that would at least in part exonerate the pilot. He took pains to say that the aircraft presented no problems to a competent pilot. In conveying to Lachal, Pape, and Stevens his assessment of Hitchcock as a 'slightly better than average' Hudson pilot, Ryland was setting up a question to which there was no easy answer. How could a very sound, better-than-average pilot, in a machine with no discernible mechanical faults or severe flying peculiarities, in good weather, be responsible for this shocking accident? The evidence of

72 Testimony of S/Ldr J. P. Ryland, Service Court of Inquiry, 17 Aug. 1940, NAA: A705, 32/10/2729; $32 / 10 / 2733$.

73 'Statement by the Court', Service Court of Inquiry, 18 Aug. 1940, NAA: A705, 32/10/2729; 32/10/2733.

74 Ryland testimony, Service Court of Inquiry, 17 Aug. 1940, NAA: A705, 32/10/2729; 32/10/2733. 
Squadron Leader Thomas implicitly posed the same question: 'What was your personal assessment of Flight Lieutenant Hitchcock as a pilot? I consider Flight Lieutenant Hitchcock was slightly above average as a pilot, his instrument flying was good and he was a steady and thorough type.'

Here was a puzzle that Lachal was ill-equipped to solve. Geoff Hartnell, then the navigation officer in Group Captain Bladin's Directorate of Operations and Intelligence, recalled Lachal at headquarters as 'professionally absolutely unimpressive', a judgment confirmed when he served under him later in the war. It did not help Lachal that he had no direct knowledge of Hudsons. ${ }^{75}$ But George Pape, no pilot but a smart lawyer, was shrewd enough to realise the value to the Service and the government of a finding that even a well-trained and competent pilot might make an unforeseeable error of judgement. The contemporary record bears the stamp of Pape's command of language and logic. And as Lachal ruefully remembered, 'George, from the legal aspect, gave me a kick in the pants a few times... and said "He didn't say that, he didn't say that" and so on. ${ }^{76}$

The members of the Service Court were troubled that they had not been able to ascertain the all-up weight of Hudson A16-97 when it left Essendon. Taking their cue from Ryland, they did not think the distribution of the load in any way contributed to the accident. They did, however, recommend that squadrons equipped with modern multi-engined aircraft be issued with a weight sheet summary for the type of aircraft and with Librascope 'balance computors [sic]' for calculating an aircraft's centre of gravity and total weight and enable the load to be correctly disposed. And pilots of multi-engined aircraft should, they said, be given as much full-load practice as possible.

Led by Pape, who crafted the words, the Court was confident enough in its understanding to pronounce a finding that the crash was 'due to the aircraft stalling when approaching the aerodrome to land' with its landing gear and flaps lowered. What then was the cause of the stall? It was:

...probably due to the power approach being made at too low an altitude and the pilot realizing that he would not be able to clear an intervening hill easing the nose of the aircraft up to such a position that it stalled.

A contributing factor to this may have been the existence of high hills on the western side of the aerodrome. These would give a false horizon.

The accident was due to an error of judgment on the part of the pilot.

75 AVM G. C. Hartnell, interview, 11 April 1978.

76 Sir George Pape and ACdre L. V. Lachal, interview, 14 Sept. 1977. 
The evidence of civilian eye-witnesses on the last moments of A16-97's flight had informed the Service Court's analysis. But their observations were interpreted through the professional eyes of Ryland. Whatever those on the ground thought they saw, it would be understood within the framework of possibility and probability that Ryland elaborated for his Air Force colleagues.

The Service Court of Inquiry met its deadline. Forwarded from Southern Area to the Director of Training, its proceedings and report had been digested by George Jones and circulated to the most senior headquarters officers within five days. Jones was uneasy. His initial reaction on hearing of the crash had been to say that its cause was 'obscure'. Presented with a formal finding that the accident was 'due to an error of judgment on the part of the pilot', he was disinclined to accept it. 'I feel that this is going too far', he told the Air Member for Personnel and his directorate colleagues:

There appears to me to be insufficient evidence to arrive at any definite finding as to the cause of the accident. I cannot believe that a pilot of HITCHCOCK's experience would stall the aircraft under the circumstances which apparently existed. I have experimented with the Hudson under similar circumstances, except as regards load, and find that the aircraft would give ample warning of an approach of a stall.

The capitalisation of Hitchcock might have looked like a subtle hint for some readers. But it was common practice in RAAF documents to capitalise surnames. This time, however, Jones seems to have been suggesting something he could not put into words. 'Dad' Bladin, Director of Operations and Intelligence, returned Jones's minute on August 27 with a courteous but emphatic declaration: 'The evidence points to a stall which after all is the result of a pilot's error of judgment.' Before placing the documents on file Jones added a final enigmatic rebuttal: 'I agree, but I doubt whether this was a pilot's error of judgment.'77 And in a later accident summary under the heading 'Criticism by Director of Training' he simply referred to the Court of Inquiry's finding that the accident was caused by the pilot's error of judgment. Jones expressed no doubt and offered no alternative explanation. But he might have had in mind the acerbic observation of the long-serving editor of The Aeroplane published nearly nine years before this event in a three-part essay on 'Errors of Judgment'. The phrase was most useful, Charles Grey wrote, because it covered everything 'from a genuine error in calculation by a thoroughly competent person all the way down to an act which in the common tongue, would be described as just plain damned foolishness' ${ }^{78}$

77 GpCpt. G. Jones, D. T., Minute, 24 Aug. 1940, note by GpCpt. F. M. Bladin, D. O. I., 27 Aug. 1940, and undated note by Jones, NAA: A705, 32/10/2733. The file was secret.

78 NAA: A705, 32/10/2478; C. G. G., 'On Errors of Judgment - 1', The Aeroplane, XLI, 11 Nov. 1931. For Grey's subsequent logical dissection of 'errors of judgment', see Proceedings of the Royal Aeronautical Society, vol. XXXVI, no. 251, Feb. 1932, p.105. 
For those outside official circles who studied aviation accidents, the concept of pilot error was an inexhaustible theme. The respected American expert Harry Armstrong, head of the Physiology Research Laboratory of the Air Corps, returned to it repeatedly. To him much of what was concluded by official inquiries was simplistic and self-serving. There were only four explanations of a crash that could be considered valid, he said in 1938:

If it was shown that a pilot was not mentally or physically fit, then the flight surgeon who is charged with his care is at fault and the accident should be charged to 'doctor's error.' If it can be shown that the pilot was lacking in flying technique or experience then the accident should be charged to 'employment manager's error.' If it can be shown that any of his equipment failed then the accident should be charged to 'material failure.' Finally if it can be shown that the accident was due to a multiplicity of duties which might cause him to forget, to make an erroneous calculation, or to overlook a fact which would have been obvious under less trying conditions then the accident should be charged to 'airplane designer's error. ${ }^{.79}$

Troubled, but uninstructed in these subtleties, Jones ventured his own simple explanation of the crash of A16-97. It was possible, he suggested, that too low an approach could have been a contributory cause. All units had previously had their attention drawn to this error, 'an undesirable outcome of the use of powered approaches'. He proposed to write a special letter to units reiterating this concern. But for the moment he would have to keep his ideas to himself. For now, although the victims of the crash were interred, and the Service was returning to an equilibrium that had been disturbed by a fortnight of introspection and stifled suspicion, there was yet another inquiry in motion.

79 Harry G. Armstrong, 'The Influence of Aviation Medicine on Aircraft Design and Operation', Journal of the Aeronautical Sciences, vol. 5, 1937-8. p.196. 


\section{Obsequies}

Understanding the crash was an imperative for the Air Force. The government also had to be seen to be committed to doing all that could be done to advance the quest for explanations. What had happened in Canberra was shocking and bewildering. The tragedy of 13 August 1940 was national. But first it was personal, intimate. For families and friends whose loved ones had been lost in horrific circumstances the grief was natural and intense. No one could predict exactly when and how it would find expression, how long it would last. It was properly private. Yet there was an indistinct boundary between what could and should be kept from the public gaze and the national recognition and mourning that enveloped the personal loss. Burial or cremation were family decisions. But in a disaster of this magnitude somehow they had to be harmonised with the ceremonial events that were prescribed by custom or created for the occasion. For the public, an opportunity to pay tribute, and to perform rituals of eulogy, thanksgiving, and memorial, required planning and organisation. It was all done in a day.

On the morning of August 14, The Argus leader writer, who had lost a former colleague in the crash, wrote of the 'fearful swath cut by Death':

...a reverent sense of fitness and spontaneous feeling alike demand that the community shall pause in its daily round to express sympathy with the bereaved relatives, with the Federal Ministry, with the Royal Australian Air Force, and with the Australian Army in the loss of their loved ones, their loyal colleagues, and their efficient servants.

In Service protocol, distinctions of rank, status, and religion were finely drawn, in death as in life. For the three Cabinet ministers, the Army and Air Force officers, and Dick Elford there was to be a combined memorial service in St Paul's Cathedral, Melbourne at 11.45 a.m. on August 15. Services would be held simultaneously at St Andrew's Cathedral in Sydney and St John's Church in Canberra. The Anglican Archbishop of Melbourne would give the address at St Paul's. Dick Wiesener, a member of the Homebush-Strathfield Congregational Church, was to be embraced among the Church of England group. So too were Dick Elford whose parents were Christian Scientists and Bob Hitchcock, a member of the Church of Christ. ${ }^{1}$ All of the bodies were to be brought overnight by special train, leaving from Canberra at 7.30 p.m., to Princes Bridge station opposite the cathedral. ${ }^{2}$ Passing through Seymour, the train would slow down

1 'Feeling references were made to the death of Bro. R. Hitchcock' at the following Sunday service at the Hampton church where he had once worshipped (Australian Christian, 21 Aug. 1940).

2 The Age wrongly reported on Aug. 15 that the bodies had been flown to Melbourne. Other papers thought that only nine bodies were going to Melbourne. 
for a guard of honour from Puckapunyal to pay tribute. Troops along the length of the Princes Bridge platform would present arms, with officers coming to the salute. Eight of the caskets were then to be carried across Flinders Street by bearer parties flanked by a guard of honour. Three officers and 50 other ranks of 12 Garrison Battalion and five RAAF officers and 100 other ranks would make up the guard. A full muffled peal of bells, a tribute reserved for the nation's greatest citizens, would be rung at 11.00 a.m.

For the Roman Catholic airmen, Jack Palmer and Charlie Crosdale, there were other arrangements to be made. There had been some anxieties, especially among Sheila Palmer's brothers and the rest of the Curtain clan, that their Catholic faith would not be acknowledged in a memorial service in an Anglican cathedral. They would not have forgotten the controversy that had continued since 1938 when the Victorian branch of the Returned Sailors and Soldiers Imperial League of Australia (RSSILA), in a gesture of inclusiveness to Catholics and Jews in particular, had introduced a non-denominational ANZAC Day service of songs and silent prayer at the Shrine of Remembrance. Archbishop Head as well as the senior Presbyterian and Methodist chaplains had protested and declined to attend the 'civic' ceremony. Generals Brudenell White and Smyth, following the lead of the most senior Australian General, Chauvel, unhappy at the abandonment of the traditional Anglican service, had refused to lead the march to the Shrine in 1938; and, like the church leaders, they were again absent in April 1939 and 1940. Congregational and Baptist spokesmen regretted the RSSILA's decision but left attendance to the conscience of individual ministers. ${ }^{3}$

Catholic fears were allayed when it was announced that a special requiem mass had been arranged by Archbishop Mannix at St Patrick's Cathedral for the day after the state funeral, 'as an expression of the general sympathy of the Catholic community'. It was agreed that the caskets of Corporal Palmer and Aircraftman Crosdale would be taken directly from the train by an Air Force party to St Patrick's, thence to Sleight's Funeral Parlors in St Kilda Road. An Air Force tender would take Palmer's casket to St Patrick's where it was placed on a catafalque in front of the high altar. There, in the presence of Sheila Palmer, her parentsin-law, siblings and other relatives, prayers were read by Father Ken Morrison,

3 With Catholic students expected to listen to the broadcast service, the state Education Department had suggested the replacement of the 'Protestant' hymns 'O God Our Help' and 'Abide With Me' with 'Australia, Land of Ours' and 'Land of Hope and Glory' (Mark Lyons, Legacy: The first fifty years, Legacy Co-ordinating Council \& Lothian Publishing, Melbourne, 1978, p.68). Peter S. Sadler, The Paladin: A Life of Major-General Sir John Gellibrand, Oxford UP, Melbourne, 2000, pp.241-2; The Argus, 24 Feb., 23, 25 April 1940. Smyth's absence in 1938 was attributed to ill-health. The 1937 march had been marred by a wrangle over the selection of Major-General Senator Brand over the heads of three more senior generals after White, Smyth, and Gellibrand had all declined (Cairns Post, 19 April 1937). Chauvel said that 'the Jews wanted to cut everything Christian out of the service' (Lord Wakehurst diary, 24 April 1938, Wakehurst Papers, ML MSS 6347 1 5). 'The service as drawn up meets with the unqualified approval of Rabbi Danglow only!' (F. E. Dixon to the editor, The Herald, 12 April 1938, copy, Menzies MSS, NLA 4936, 579/2). 
the padre at Laverton. The funeral mass, deferred to the next day because of the Feast of the Assumption, was celebrated by Father Morrison, and attended by Palmer's parents, sister, and brothers Max and Laurie, as well as five brothersin-law, the Tasmanian Deputy Premier, the influential Victorian ALP executive member and Curtain family friend, Councillor Arthur Calwell, and unnamed RAAF officers and airmen. An RAAF guard of honour, 20 NCOs and men and five officers, lined the path from the gateway to the cathedral entrance. Father Morrison also conducted the funeral service at the old Melbourne General Cemetery.

Following telephone consultation with Rita Crosdale and her husband's parents, it was decided that Charlie Crosdale's remains would be returned directly to the Hunter Valley. The news that Crosdale's body would be taken home via Newcastle was conveyed to his widow's parents by railway officers who intercepted them en route to Melbourne to be with their daughter and new grandchild. Ben and Mary Ling had responded to an eight-word telegram from their daughter the day before: 'Charles killed. Baby son born. Come at once.' Keith Murdoch's Melbourne Sun News Pictorial had published the message. Even the details of the changed travel arrangements were reported in the press - no aircraftman had ever been paid such attention in death or in life. Crosdale's casket was taken by car from West Maitland railway station to his parents' home in Paxton, 27 miles further; after a requiem mass at St Joseph's Catholic Hall in Cessnock, he was buried in Ellalong cemetery. Contingents from the RAAF seaplane base at Rathmines and the AIF at Gretna were present along with the RAAF band. Rowley James MHR and the NSW Premier's private secretary had accompanied the casket most of the way, James detouring nine miles to his own home town, Kurri Kurri. Federal ministers, who had hurried to Melbourne the day before, were represented by the Cessnock Postmaster. Business houses in Cessnock closed for five minutes at four o' clock on August 16 to coincide with the funeral ceremony. The rest of the community showed their respects at a Sunday night memorial service at St John's Church of England. The next morning the Prime Minister gave instructions that the Commonwealth was to meet the costs of travel from Melbourne to Cessnock of Crosdale's widow, her parents, and her infant son.

The Adjutant-General, Major General Victor Stantke, appointed only two weeks earlier, was responsible for arranging the state funeral. He had previously managed the funeral procession for Joe Lyons in Sydney and the transfer of the late Prime Minister's coffin to a naval destroyer for return to Tasmania. Stantke had received preliminary advice by telegram from Duntroon just after 4.30 p.m. on the day of the crash from the Secretary of the Prime Minister's Department that there might be a service in King's Hall at Parliament House on Wednesday and at St Paul's Cathedral in Melbourne the next day. Colonel 
R. C. Prisk, Director of Personal Services, was sent immediately to Canberra to liaise with officials there. Stantke and his staff were bombarded with queries, requests, and suggestions, not least from RAAF headquarters. Duties were to be shared and co-ordinated. The military worked with E. C. Rigby, the lay canon of St Paul's, on requirements at the cathedral. By the next day Lieutenant Colonel R. E. Pascoe, Assistant Chief Marshal, signed and distributed 180 copies of a five-page summary of the arrangements for special trains, guards of honour, bearer parties, troops to line the streets, vehicles for the conveyance of caskets, formation of the corteges, floral cars, mourners' cars, routes to be taken, an artillery salute, and a motor ambulance to be held on call at Victoria Barracks. Dress was prescribed: 'All ranks - No. 4 Service Dress Drill Order.' Officers would wear Service Dress (cloth), cap, jacket, breeches, field boots or leggings, Sam Browne belts without shoulder strap, mourning band, gloves, ribands but not medals. 'Armlets and spurs will not be worn. Swords and canes will not be carried.' ${ }^{4}$

Geoff Street and Frank Thornthwaite, intimate friends for 25 years, neighbours at Derrinallum, were to make their last journey together. After the half-hour service was over they were to be brought out first and carried back across Flinders Street to Princes Bridge station then placed on a train for Lismore, 106 miles to the west. A large official party, led by the Prime Minister and including Cabinet colleagues, senior public servants, and Army officers, would accompany the coffins on the special train. After a procession to the Presbyterian church a mile from the Lismore railway station, a funeral service would be led by the Rev. E. A. Forbes. Hundreds of returned servicemen formed a guard of honour at the cemetery. Former comrades filed past the graves casting poppies over the coffins. $^{5}$

Normally, The Argus had reported, a general's coffin would be carried on a gun carriage with a cortege of four battalions of infantry, and a cavalry escort led by the general's charger. On this occasion the arrangements were to be much simpler. Brudenell White would, in due course, follow Street and Thornthwaite in the leading motor hearse en route to Buangor accompanied by a police escort. As White's casket was placed on its conveyance outside the cathedral, a flag signal from high on a parapet would be given to begin an artillery salute, 17 minute guns fired by a saluting battery in the nearby Domain. ${ }^{6}$ Then would come Gullett, Fairbairn, Hitchcock, Wiesener, and Elford, each in turn, followed

4 'Funeral Arrangements - Air Accident Canberra, involving Ministers, Military Officers and others on 13 Aug 1940', NAA: MP508/1, 76/701/78.

5 Camperdown Chronicle, 17 Aug. 1940.

6 For the scene viewed from a bedroom window at Young and Jackson's Hotel by one of Brudenell White's family friends: Bethia Foott Ogden, Ethel and the Governors' General: A biography of Ethel Anderson (18831958) and Brigadier-General A. T. Anderson (1868-1949), Rainforest Publishing, Paddington (NSW), 1992, pp.191-2. 
by a floral coach and chief mourners' car. The whole procession would turn south along St Kilda Road, travelling between some 1800 men from Navy, Army, and Air Force units standing in single rank on both sides from Batman Avenue.

As each cortege reached a designated turn-off point it would form up with its own funeral party. Wiesener's casket, which would be returning to Sydney by train, would be taken in the interim to Sleight's Funeral Parlors. The others would pause at Victoria Barracks; and then would be driven under RAAF direction to Springvale Cemetery — Elford, Gullett, and Fairbairn for cremation (a costly option as fuel prices had risen), Hitchcock for burial. ${ }^{7}$ At the Spring Vale Necropolis, a Masonic service was conducted for Hitchcock by the secretary of the Verdon Lodge. Among the pall bearers were two young Flying Officers, B. M. Palmer and Stanley Prowd, who had been under Hitchcock's tutelage, Bob Dalkin, and their squadron commander Fred Thomas. ${ }^{8}$

The Prime Minister, better acquainted with Presbyterian than Anglican forms, had asked Archbishop Head to 'personally' conduct the service. In the event, the Precentor, the Rev. H. O. Hole, read the burial service; Bishop Charles Riley from Bendigo, chaplain of the $10^{\text {th }}$ Light Horse 1918-19, read the lesson; and the Archbishop gave the address. The anthem was the consoling chorus 'How Lovely is Thy Dwelling Place' from Brahms' German Requiem. (The order of service acknowledged the composer but omitted the title with its reminder of the enemy nation.) The 'Dead March' from Handel's Saul provided the traditional ending. National radio stations broadcast the service and reported on the processions to and from the cathedral. There were few serious hitches. Invitational telegrams from the Prime Minister went out on the afternoon of August 14 noting that the service would be at 11.45 a.m. the next day, not 2.00 p.m. as had been announced in the press. Sir George Fairbairn missed the service for his nephew because the telegram arrived after he had already left to visit his property. The Wiesener family name was misspelled in the order of service. Lieutenant General Miles of Eastern Command, Major General Sturdee of the $8^{\text {th }}$ Division, and Major General Richardson of the $1^{\text {st }}$ Cavalry Division (Brudenell White's associate in the secretive patriotic defence of the realm a decade before), all of whom had travelled from Sydney, were left off the Army list of attendees provided to the press. The next day, the Deputy AdjutantGeneral wrote to newspaper chiefs of staff asking that the generals' travel from Sydney to attend be mentioned.

Meanwhile, a panicky morning telegram from Frank Strahan, Secretary of the Prime Minister's Department, exposed fears that important personages arriving

7 Cremation cost approximately $£$ 7.7.0, double the cost of burial. RSSAILA diaries advised that members were eligible for a reduction to £4.4.0 (Sir Thomas White, diary 1940, T. W. White MSS, NLA MS9148, Box 1; Jessie Hennessy, Springvale Botanical Cemetery to CH, [email], 19 Jan. 2010).

8 F/O Stanley Prowd was killed in a test flight accident in August 1941. 
by plane at Essendon might not get tickets assuring their passage through the barriers around the cathedral. 'Not received until too late', noted Stantke, a man of few words, most of them blunt and direct. He did not have to deal with the complaint to the Prime Minister from the Netherlands Consul-General that, after negotiating their way through barricades and chain fences, he and his Chinese colleague were forced to sit in one of the last rows of chairs rather than on the consular bench. After the cathedral service and processions were over, Stantke joined the party that accompanied White to Buangor for what was meant to be a very private burial. 'Presumed a great deal', General Lavarack's ADC recorded. Lavarack, never inhibited in expressing his opinions, had a simple explanation for Stantke's presumption: 'He's a Bosch.'

Unaware of this annoyance to a former Chief of the General Staff, the Prime Minister had written before the day was out to the new Minister for the Army commending Stantke's customary 'great courtesy and efficiency'. Menzies went on to add that the 'parades of Troops at the various places between Canberra and Melbourne, and in Melbourne, and the military bearing of those taking part therein, were the subject of gratifying comment'. Members of units of the Citizen Military Forces who were detailed for duty had cost the Army £145.1.3 in pay and fares. ${ }^{10}$ As far as the Chief Finance Officer (Military) was concerned, the expenditure was incurred in connection with the funerals of Lieutenant General Sir Brudenell White and Lieutenant Colonel Frank Thornthwaite. The others, it seems, were incidental beneficiaries. When the other costs of the funerals and memorial services, including a service in St Paul's Cathedral in London attended by 22 relatives as well as dignitaries, were calculated, the Treasury's final tally was £1434.17.2.

As invoices were collated and bills paid, missing flags tracked down, and thankyou letters despatched, there were a few remaining glitches and aggravations to be dealt with. The Department of Supply and Development fielded complaints from the Queanbeyan undertaker, M. H. O'Rourke, and Melbourne's B. Matthews Pty Ltd that their contracts to arrange funerals for Defence personnel had not been honoured. The Prime Minister's Department, acting in ignorance of these arrangements, had authorised the Department of the Army to engage A. A. Sleight in Melbourne and Masons of Queanbeyan. The quick-thinking head of the Prime Minister's Department maintained that, as the Commonwealth had decided on a state funeral for all of the men, the contracts did not apply. Unappeased, the contractors niggled for months over whether the inclusion of

9 Curtis Wilson's diary, 15 Aug. 1940, A. B. Lodge Papers, UNSW@ADFA, MS 164, Box 4 folder 10; Warren Perry, 'Lieutenant General Henry Douglas Wynter: An Officer of the Australian Staff Corps', The Victorian Historical Magazine, vol. 43, no. 2, May 1972, p.852.

10 NAA: MP508/1, 76/701/80. 
RAAF personnel in the state funeral was a breach of the exhaustively detailed contract which in Matthews' case had been signed to run for four years from 1 July $1940 .^{11}$

'The ceremonies were carried out satisfactorily despite much tension in the upper echelons', recalled the then Group Captain Joe Hewitt who, as RAAF Director of Personal Services, was closely involved. Hewitt, possibly the ablest of his generation in the Air Force, ${ }^{12}$ had himself presided late in 1938 over a politically sensitive Committee of Inquiry after the crash of an Anson and the loss of five lives. Tasked now by the Chief of the Air Staff to keep him informed on how the funeral arrangements were progressing, he was careful not to mention anything that would reflect badly on his colleagues. With attention focused on the procession of vehicles leaving the cathedral, no-one had noticed that 22 of the 30 cars that had conveyed passengers from Spencer Street were retained for hours after they were needed. Sir Charles Burnett was not told of the disarray at Laverton when it was realised that many of the airmen directed to attend the funerals were still awaiting the issue of complete uniforms. ${ }^{13}$ Dick Elford's friend from Geelong Grammar, the porter Tom Judd, was among those rushed through the store to make up the deficiencies but he still had to borrow someone else's trousers. The men from Laverton had been divided into Catholic and Protestant groups, but the Catholic contingent was so small it had to be reinforced with unsuspecting Protestants. ${ }^{14}$ The Anglican Judd found himself attending mass at St Patrick's rather than paying his respects to the Geelong Grammarians, Elford and Fairbairn. ${ }^{15}$

Air Vice-Marshal Hewitt was to write years later:

The disaster seemed to make each and every one of us experience a sense of blame. Just why should such a thing happen!

Burnett obviously felt the loss of Fairbairn and perhaps, too, a sense of failure since a major reason for his being CAS was to cut down the aircraft accident rate in the RAAF. He was really hot on this problem

11 Army papers relating to funeral arrangements and condolence messages from service units were gathered in NAA: MP 508, 76/701/78. The Prime Minister's Department file including the Service funeral contract conditions for Tasmania, South Australia, and Victoria is at NAA: A461, 700/1/392.

12 He was so regarded by ACM Sir Frederick Scherger (interview, 2 Sept. 1978).

13 Before the war, uniforms had been manufactured by the Commonwealth Government Clothing Factory; but it had been unable to keep up with demand and civilian contractors had not yet made up the shortage (NAA: A705, 39/8/188).

14 'I had 230 Catholics between Laverton \& Point Cook in 1939 out of a total of $1300 \ldots$ We were very heavily represented in clerical \& medical musterings etc. but lacking in trade musterings' (Msgnr K. Morrison to $\mathrm{CH}_{\text {, }}$ 6 June 1983).

15 Judd, Fifty Years, pp.112-3. 
and despite the growth rate of the RAAF under war conditions he had certainly been successful in the circumstances - never failing to see that appropriate disciplinary action was taken.

Burnett, as we have seen, owed his appointment in Australia to an almost accidental meeting with Fairbairn when it seemed that his career was almost over. He had enjoyed notably amicable relations with his minister. Whatever hint may have reached Burnett that Fairbairn might have been in part at least the author of his own fatal misfortune, Joe Hewitt 'sensed in him after this terrible accident an irritability on his part for Australians and things Australian'. The senior commanders on whom Burnett relied had let him down. ${ }^{16}$

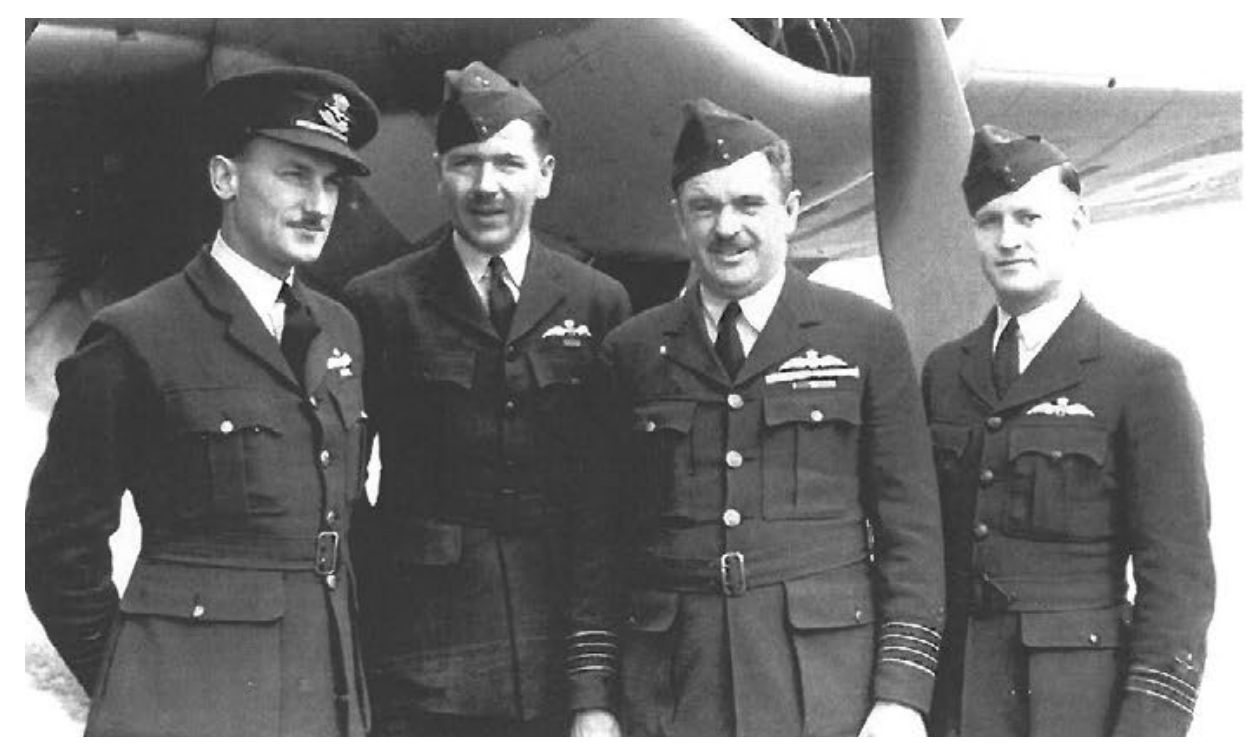

WCdr Joe Hewitt, S/Ldr Fred Thomas, GpCpt Ray Brownell, and unidentified S/Ldr at Laverton, October 1940

(Courtesy of Rob Thomas)

Their lives having been celebrated, their bodies at rest, private mourning for the victims would continue long after the short season of public homage ended. Three days after the state funeral, The Argus and the Canberra Times reported, many people were visiting the crematorium in the hope of seeing the urns of Gullett, Fairbairn, and Elford. As the ashes were kept in steel containers in a room to which only family members were permitted access, the pilgrimages were

16 AVM J. E. Hewitt, 'Diary for my daughter Pt II', Sept. 1939-Dec. 1948, p.6, Hewitt MSS, Australian War Memorial. The published version of this document omits some passages and reduces Burnett's 'sense of failure' to 'disappointment' (Hewitt, Adversity in Success, pp.4-5, 161-2). 
in vain. As the tide of grief receded, the routines of government and Service life resumed. The Prime Minister would replace his lost Cabinet colleagues and install a new Army chief under the formal authority of the Governor-General.

For the RAAF personnel, being 'struck off the strength' required a series of 17 signatures. Designated authorities had to certify the absence of liabilities to the barracks, mess, canteen, recreation club, technical library, medical and dental, base library, tool store, pay clerk, benevolent fund, stores officer, O.C Flight, Squadron Commander, and education officer. The accounting officer and the adjutant signed off 'final clearing action', completing the 'clearance certificate', form E/A. 32. Then, just in case any of the officers or men from No. 2 Squadron had died owing money to their fellows, station 'routine orders' on the day of the funeral invited anyone with a claim to submit it in writing to the president of the Committee of Adjustment by noon on August 18. The Committee of Adjustment was also responsible for making inventories of each man's 'personal and private' effects and Service clothing, assembling death certificates and information about the beneficiaries of any wills, and gathering statutory declarations to authenticate the validity of spouse claims. For men who had been issued with equipment, 'deficiencies' in toolkits had to be listed. However defective its flying training or pilot selection might be, the Service's adherence to its administrative procedures and paperwork was unimpeachable. A cohort of ex-RFC, RAF, and RAAF officers had been recruited and given a course of training to relieve officers in full flying practice from such administrative chores and other ground duties; and a whole new 'Administrative and Special Duties Branch' had been created in the CAF to embrace essential non-flying tasks. ${ }^{17}$

In the face of tragedy there was something about the assignments and responsibilities laid down in Service manuals and routine orders that assuaged the pain. Fatalities were always and inevitably distressing. Yet they had become commonplace enough in the RAAF for there to be protocols in place to cover the contingent consequences. Wrecked machines would be written off and replaced. Within a few days, new pilots would arrive to take the place of those who were lost. Personal effects would be dispersed to next-of-kin. Shared memories would begin to fade as fresh challenges and adventures obtruded. Pilot Officer Keith Eddison, who 'used to have a good bit of fun' with Hitchcock, probably reflected the sentiments of many young men in No. 2 Squadron, when he wrote to his mother:

I managed to escape the funeral even though I was tempted with seat tickets at St Paul's. I've been O.C. wreaths \& general chucker out about 
the place. You've absolutely no idea the upheaval it caused here for a day or two but thank heaven it's all over now \& forgotten. By the way I lent my cap to put on the bod [sic] so you may see it in the pictures. ${ }^{18}$

Insouciant as some might affect to be, puzzles about a crash that had killed friends and work mates would linger, debated inconclusively. But in this unique case the ill-informed and desultory speculation of the officers' mess would soon be overshadowed by intimations that in the upper echelons of the Service and the government there were deep concerns. There was surely more to be said about the causes of a most calamitous event. 'A pretty poor show that,' as Eddison wrote on August 16, '\& nobody knows just what happened yet.' When comrades in uniform died in company with some of the nation's most famous men, serious questions had to be asked and answered by those in authority. 


\section{Part 4 Understanding}





\section{Inquiry and investigation}

Whatever might be learned from the inquiries set in train by the Air Force, the Prime Minister and the members of his Cabinet knew that a nation prompted by an inquisitive press would want answers that internal and secret investigations could not give. Hugh Dash, reporting from the crash scene for the Daily Telegraph, had learned that a coronial inquest would be the 'only public inquiry'. 'Only an open inquiry will satisfy the public', the Telegraph said on August 14, 'because of the number of accidents to the type of machine in which the Ministers flew from Melbourne.' Here was a signal that the Telegraph knew more than it was saying about the RAAF's new Hudsons and the difficulties their pilots had experienced with them. A day into his new ministerial role, Arthur Fadden had enough sense of self-preservation to let it be known to the press that he would be seeking Cabinet approval of the action to be taken. ${ }^{1}$

What could the government do to give reassurance to an anxious and disturbed public? The Secretary of the Department of Air hurriedly prepared a briefing paper to explain the options. When there was a fatal accident involving an RAAF aircraft, a Service Court of Inquiry was 'invariably convened', Mel Langslow pointed out on August 15. Since the Inspectorate of Air Accidents had been established in June 1940 its two-man team also had a duty 'to make a first-hand investigation of any accident or forced landing when directed by the Chief of the Air Staff and to make a personal report to him'. As ministers well understood, these inquiries were established and conducted within the RAAF. They were already in motion before the Cabinet had considered what should be done.

A moment's reflection would have brought the realisation that those who undertook the RAAF inquiries, competent as it may be supposed they would be, might have been personally acquainted with the officers and airmen whose deaths they were examining. The Air Force investigators could bring to their inquiries knowledge acquired from their own observations, as well as impressions conveyed by fellow officers. They might be willing and capable of keeping open minds. But there was a further possible concern. Officers selected by their superiors, subject to Service discipline and rules, naturally having regard for their own careers, could be portrayed by sceptical reporters and informed aviation commentators as lacking independence. The point had been made in Parliament nearly four years earlier by a school contemporary of Jim Fairbairn, the United Country Party leader in the Senate, Charles Hardy. The charismatic Hardy, former leader of the secessionist Riverina Movement, had deemed it 'anomalous' and 'inadvisable' that Defence Department officers who

1 The Argus, 15 Aug. 1940. 
were members of the Air Accidents Investigation Committee (AAIC) should be allowed to 'determine the cause' of accidents for which Defence Department officers might have been responsible. ${ }^{2} \mathrm{Had}$ he been conscious of the extent to which the AAIC relied on work done by departmental officials other than those on the Committee, Hardy might well have been even more perturbed.

What else could be done? It had been the very concern about perceptions that had prompted the proposal to Prime Minister Stanley Bruce 13 years previously to create the Air Accidents Investigation Committee: the tendency for press and public to suspect that an Inquiry by the Service interested 'is not as full, farreaching and searching as is necessary in such cases'. ${ }^{3}$ Until less than a week before Al6-97 crashed, the AAIC, established by powers conferred by the Air Navigation Act No. 50 of 1920, might have been mandated to investigate the Hudson accident. At least so it was thought by those who had not followed the intricacies by which the Committee's civil and military aviation roles had recently been separated. The Committee consisted of an independent chairman with engineering qualifications and two (originally four) aircraft and flying experts appointed by the Minister of Defence. It was required to furnish reports on all accidents involving injury to personnel or damage to aircraft, and all forced landings. The Committee would seek to determine the cause of an accident, and recommend action to prevent a recurrence. It had rights of access to any aircraft establishment and could examine any aircraft, equipment, or process in that establishment. Evidence presented was to be kept confidential. Reports of all Air Force accidents were made to the Air Board. Other reports were made to the Controller of Civil Aviation.

Perennial criticism from aero clubs and aviation companies about the secrecy and alleged unfairness of AAIC proceedings had been brushed aside by successive Defence Ministers. The Committee even resolved in 1934 that in the interests of both aviation and the public, no reports on accidents would be submitted for insertion in the press'. But more widespread public disquiet about aviation safety in the late 1930s produced a shift in policy. The creation of a Department of Civil Aviation had led to the separation of responsibilities for investigating RAAF and civil accidents. The Committee was replaced by Air Courts of Inquiry. ${ }^{4}$ Such Courts were to be established under the authority of the Governor-General, with jurisdiction to make inquiry into air accidents referred by the Minister. Jim Fairbairn had been keen to retain ministerial control but was in Canada at the end of November 1939 when Cabinet decided in relation to civil aviation that causes of accidents or forced landings were to be

$2 C P D$, Senate, 26 Nov. 1936, p.2378; Hardy died in an aircraft accident in August 1941.

3 Minister of Defence (Sir T. W. Glasgow) to Prime Minister, 12 May 1927, NAA: A461, F314/1/1; Dept of Defence, Air Board, Air Accidents Investigation Committee, NAA: A664/1 415/402/120. For continuing doubts about the expertise and independence of the committee, see NAA: MP187/1.

4 The Courts of Inquiry were established under Statutory Rule No. 40 of May 1939 amended as No. 155 of 1940. 
referred to the Court of Inquiry, 'unless the Minister certifies that the matter is too trivial so to do; provided, however, that the Minister should not be entitled so to certify in the event of death or serious injury without a direction from the Governor-General' . ${ }^{5}$

The new Courts had characteristics in common with the Air Navigation (Enquiry Committee) Regulations drafted in 1929 by Attorney-General Latham. When a baffled and angry public made it imperative to investigate the forced landing of Kingsford-Smith's Southern Cross and the tragic fate of Bob Hitchcock and Keith Anderson, the government had decided that a smaller inquiry body with greater powers than the AAIC was needed. ${ }^{6}$ But to create the appearance of independence, the new regime established late in 1939 went too far in yielding political control. Jim Fairbairn applied his mind to the matter and came back to Cabinet in May 1940. Cabinet agreed with him that the Court of Inquiry should have jurisdiction only when the minister referred an accident to it. Similarly, under the revised Air Force Courts of Inquiry regulations, the Minister for Air could refer a Service accident to a Court constituted by a Justice or Judge of any federal or state court or court of a territory appointed by the GovernorGeneral. As with civil accidents there was no obligation to set up such a Court of Inquiry. It was a matter for ministerial decision. Once appointed, however, the presumption of judicial independence provided the assurance that neither the government nor the Air Force could determine the result.

With this background fresh in his mind, Mel Langslow reminded ministers that the new inquiries were 'to be held in open court'. The Court itself would have the discretion to hold the hearing 'or any part of the hearing...in camera'. Langslow proffered no advice. However, the government could not ignore the newly established process for independent inquiry. As The Mercury reported on August 15, 'a section of the Federal Cabinet and probably an overwhelming majority of the members of the Federal Parliament believe that the inquiry should be public'. The government's decision was noted by the Prime Minister at the foot of the submission: 'Cabinet approves of open enquiry by Air Force Court of Inquiry.' Murray Tyrrell, now assistant private secretary to Arthur Fadden, conveyed these precise words to the Secretary of the Air Department on August 16. ${ }^{7}$

5 'Air Courts of Inquiry', Cabinet Agenda 244, NAA: A461, V314/1/1.

6 'Summary of Events in Connection with Flights of "Southern Cross" and "Kookaburra"', NAA: MP274,

4 21/1/846 Pt 5.

7 NAA: A461, F314/1/1; A705, 32/10/2729. 


\section{Justice Piper's tune}

Legislation to establish the Air Courts of Inquiry was being drafted early in 1939. But when an Avro Anson crashed at Riverstone in New South Wales, and another went down into Port Phillip Bay, a fresh eruption of public consternation about the safety of RAAF operations prompted an urgent political response. The first parliamentary questions addressed to Robert Menzies as Prime Minister in April 1939, and to his new Minister for Defence, Geoff Street, were about these accidents. John Curtin asked if the Prime Minister would direct the Minister to ensure that an open inquiry would be held by a High Court Justice. The Prime Minister announced on 5 May 1939 that legislation to create a 'Federal Air Court' would be presented to Parliament 'in a week or two'. Menzies did not know that the current draft bill was replete with anomalies and ambiguities. Not the least of these - resulting from the failure of the Civil Aviation Department to pass on to the Attorney-General's Department the views of the Minister for Defence - was that it actually made no specific provision for the investigation of accidents to Air Force aircraft. Realising that a new Act could not be ready within Menzies' time frame, Geoff Street immediately instructed the Defence Department to prepare 'Special Draft Regulations' under the Defence Act to 'constitute a Committee of Enquiry'. Street's idea was that the 'Court of Enquiry' - the language and the spelling were not yet settled - would not be restricted to the recent Avro Anson crashes but would have 'general application'.

In anticipation of a new regime coming into effect, Judge Harold Bayard Piper, an Adelaide barrister and vice-president of the Liberal and Country League who had joined the Court of Conciliation and Arbitration in early 1938, was appointed to undertake investigation of air accidents as a temporary justice of the Supreme Court of the ACT until the end of November 1939. ${ }^{8}$ It had at first been thought, too optimistically as it turned out, that a High Court judge might be available. But by mid-May, Menzies had to admit that after discussion with the Minister for Defence he was 'agreeable to the inquiry being conducted by a judge, if one can be obtained for the purpose, or, failing that, a magistrate'. Temporary appointment to the ACT Supreme Court was necessary for Court of

8 P. A. Selth, ‘Piper, Harold Bayard (1894-1953), Ritchie and Langmore (eds), Australian Dictionary of Biography, vol. 16, p.6. 
Conciliation and Arbitration judges because theirs was not regarded as a proper court. ${ }^{9}$ Ex-AIF Gunner Piper, the default selection, held the first Air Force Courts of Inquiry under hastily devised procedures later that month. ${ }^{10}$

Three days after the funeral services, Artie Fadden told reporters that 'Bay' Piper would probably preside over the open inquiry announced by the Prime Minister. ${ }^{11}$ A draft Executive Council minute paper on August 20 requested the Governor-General to establish a Court of Inquiry and appoint 'His Honour Harold Bayard Piper' to constitute the Court. But Piper's name is struck out and 'The Hon. Charles John Lowe' is inserted by hand. What might have been overlooked was that both Piper, and his Conciliation and Arbitration Court colleague the Deputy President, former Senator, Major General E. A. DrakeBrockman, whose family connection and acquaintance with senior RAAF officers made him the first choice in 1939, could only sit on the Supreme Court bench if another of the judges was on leave. The Governor-General had to certify that for the period of the appointment he was satisfied that the judge was 'unable to act'. ${ }^{12}$ That had been possible when the ailing 71-year-old Judge Lionel Lukin, a 'crusted Conservative' in Jack Lang's words, was absent on sick leave the previous year; but at two days' notice it would have been difficult to contrive to create a vacancy. The fact was, however, that Piper was unavailable, being already engaged in the Full Court hearing of the 1940 Basic Wage Inquiry. ${ }^{13}$

The substitution of Justice Charles Lowe of the Victorian Supreme Court for Judge Piper might in any case not have been a belated change of mind, at least not by the departmental and Service chiefs. Piper's previous work had been thorough and meticulous. Perhaps too meticulous - 'a painstaking chap', Harry

9 NAA: A432, 39/486; Sec., Air Board to AMP, 5 May and 10 May 1939; Sec. Dept of Air to Sec., Air Board, 5 May 1939, copies, NAA: A705, 108/2/189; 'Appointment of Acting Supreme Court Judges ACT', NAA: A432, 1942/733. 10 The (Adelaide) Mail, 8 Jan. 1938, had wrongly said that Piper on the Arbitration Court bench would have the status of a High Court Judge. When it seemed that Piper might not be free, it was reported that his Arbitration Court colleague Edmund Drake-Brockman would be appointed. An Executive Council minute naming him was prepared and hastily amended. The disarray of the government was reflected in the press with stories that Drake-Brockman was to be added to the Air Accidents Investigation Committee (NAA: A432, 1939/19; The West Australian, 10 May 1939). The Advertiser, 17, 18 May 1939, for clarification of government intentions and Piper's appointment to the two Anson inquiries.

11 Sydney Morning Herald, 19 Aug. 1940. It is possible as Tink says (Air Disaster, p.205) that Cabinet resolved that Piper should conduct the Inquiry, though more likely that they just assumed he would.

12 A similar stipulation was suggested when Piper took leave of absence as Chief Justice of the Arbitration Court in 1946 (NAA: A2153, PIPER H B).

13 At the time of Piper's appointment Lukin had not sat in the Arbitration Court jurisdiction for several years, being preoccupied with bankruptcy cases and Supreme Court work in the Federal Capital Terrritory (The Mercury, 8 Jan. 1938). The Basic Wage Inquiry sat on Aug. 5-8, 12-15, 20-22, 1940 and was then interrupted by the illness of Beeby CJ (Sheehan's Bulletin of Proceedings in the Commonwealth Arbitration Court, vol. 14, 1940, Noel Butlin Archives Centre, ANU, NBAC E217). 
Wrigley recalled. ${ }^{14}$ Sitting with Piper as an assessor with Squadron Leader Allan Walters, Wrigley had seen the examination of witnesses in relation to the crash in fog of Anson A4-11. The thoughtful Wrigley and the 'fiery' Wally Walters, a brilliant flying instructor whose recent RAF Staff College evaluation noted that he reasoned by instinct rather than logic and was an 'indifferent and somewhat incoherent speaker', made an odd combination. ${ }^{15}$ Neither could have been comforted by Piper's rigorous questioning of Service witnesses and his observation that 'there appears to be a difference of opinion amongst superior officers as to whether during the period of instruction at Laverton it is necessary for pilots to fly in actual cloud'.

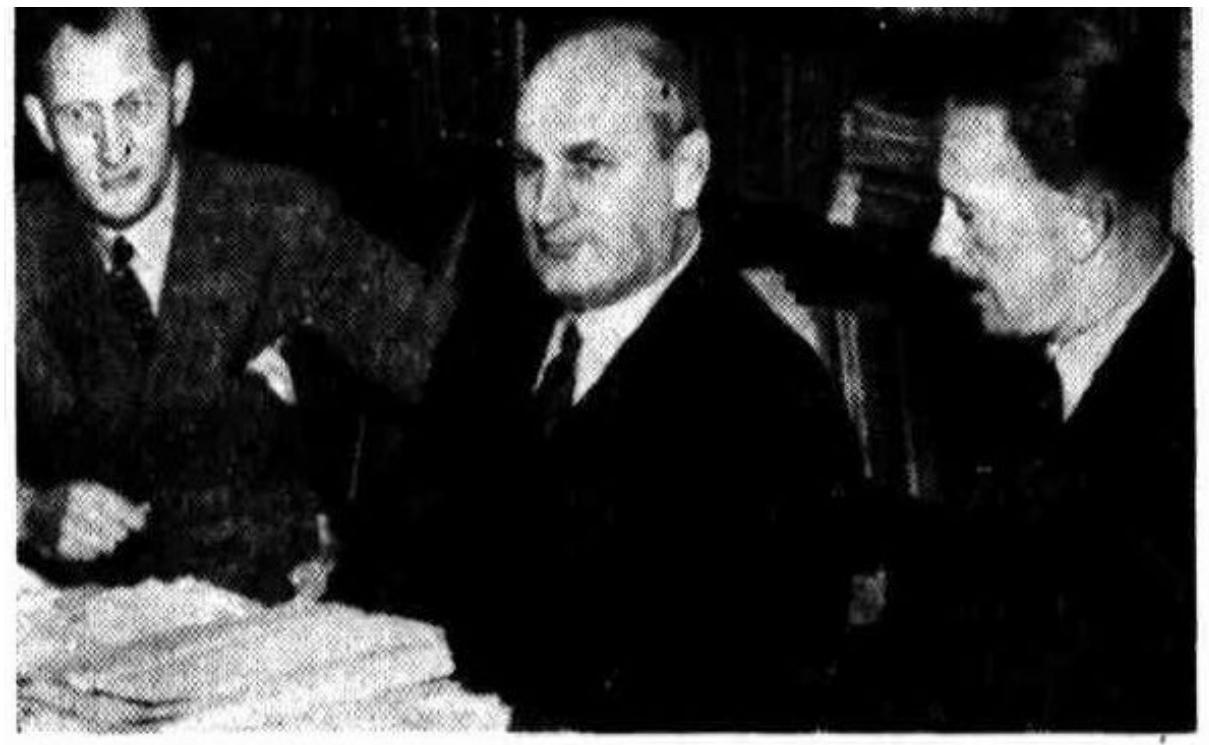

\section{THE NEWLY-CONSTITUTED AIR FORCE COURT OF ENQUIRY which held its first sitting in the Arbitration Court, Melbourne, recently. Above are members of the court. From left: Group Captain Wrigley, Judge Piper and Squadren Leader Walters.}

\section{Piper's Court}

(Border Watch [Mount Gambier], 3 June 1939)

14 AVM H. N. Wrigley, interview [1978]. To my chagrin I cannot recall, and can find no note of, what Wrigley told me about Piper off the record, with the tape recorder switched off. Piper's penchant for off-thecuff remarks from the bench could also have been a worry e.g. The Advertiser, 17 May 1939. In welcoming him to the Bench, Attorney-General Menzies had spoken of his 'integrity, ability and reputation for strong commonsense and strong vigilant judgment' (Piper MSS, NLA MSAcc06/057 Box 1).

15 NAA: A12372, O312. AVM Walters' personality appraisal in 1937 does not appear to have impeded his career progression. Clive Caldwell, who served under him in No. 1 Fighter Wing, thought him 'a first class officer and an excellent chap'. The US Air Force Gen. George C. Kenney remembered a 'big, red-faced, and jolly' Walters; promotion to ACdre followed Walters' unwise disclosure that as a GpCpt. he had been combat flying and shot down a Zero (Hayes, Angry Skies, p.100; Watson, Killer Caldwell, pp.147-8; George C. Kenney, General Kenney Reports: A Personal History of the Pacific War, Duell, Sloan and Pearce, New York, 1949, p.33). For Walters' landing mishap in a Gypsy Moth in 1932, see NAA: A9845, 73/10. 
In his inquiry into the fatal crash of another Anson, A4-32, on 28 April 1939, Piper had drawn attention to training matters which he had not had time to investigate. The question he had been asked to consider was whether trainees were 'reasonably capable of carrying out the duties and responsibilities which they are required to perform'. After reviewing the training of the pilot of A432, he added pointedly: 'It is not within my province to express an opinion as to whether, under this practice, the pilot, on this amount of training and experience should be entrusted with a valuable machine carrying a crew of three besides himself.' He went on to qualify this judgement: 'mishaps and accidents are rare'. And if it was good enough for the RAF, which it was, 'it must be considered...that the pilots are reasonably capable of carrying out ordinary peace-time operations under normal flying conditions'. But what about abnormal situations?: '...under the present system the pilots get the knowledge but it is doubtful whether they get sufficient practical experience to ensure speedy and instinctive action in some cases of emergency' ${ }^{16}$

A finding of this kind, unwelcome as it was to the RAAF, would be potentially much more damaging in a public report on the most shocking air disaster in Australian history. In a summary prepared for the Prime Minister's information, Piper's most troubling ruminations had not been mentioned. ${ }^{17} \mathrm{He}$ had confined his report to the relationship between training and the specific accident he was charged with investigating. He and the assessors would, he said, 'willingly make further inquiry' and submit a further report if asked. They were not.

Piper had himself brought the government's attention to the drawbacks and pitfalls of the kind of inquiry with which he had been entrusted. In a letter to Sir George Knowles, the Commonwealth Solicitor-General, on the day he sent his reports to the Governor-General, he explained:

In the report re the Port Phillip accident I have referred to the difficulties I experienced in obtaining complete evidence from Laverton. This was to some extent [italicised words were added by hand to replace the typed 'largely'] due to the fact that the evidence was not privileged and could therefore be used in any other place or proceedings. Some officers were therefore on the defensive and not being represented by Counsel were obviously not sure of their position. I could of course have taken their evidence in camera but this would have been very undesirable.

I would suggest that consideration be given, if the Court should have to sit again in the future, to the possibility and desirability of making some provision for prohibiting the evidence being used in any other

16 'Air Force Court of Inquiry - Avro Anson A4-32 crash on 28th April 1939', NAA: A9845 317/15-16, 19.

17 NAA: A461, V314/1/1. 
sphere. Apart from the position of officers concerned, it may be a matter of some importance to the Government if civil claims were to be made for damage done to private property by a crash.

In my covering letter to His Excellency I have referred to the fact that my comments on the syllabus and training are based on normal conditions of training and not the exigencies of war. ${ }^{18}$

On the most significant training matters raised by Piper the files reveal a sequence of evasion and buck-passing that plainly did not impress the principal officers of the Department of Air. Geoff Street as Minister for Defence had asked for the comments of the Air Board. But as late as March 1940 nothing more than what 'Johnnie' Coleman minuted as 'a most sketchy reply to the Minister's request' had been received. By then Piper's report had passed through the hands of the Prime Minister (who, as Attorney-General, had appointed him to the Arbitration Court), and Harold Holt, as Acting Minister for Air. It had been 'noted' by Jim Fairbairn almost as soon as he arrived at his desk on returning from England. Fairbairn had himself expressed a desire for Air Board comments on 'the questions of a training, technical, etc. character, specifically raised' in Piper's two reports. It had already been decided that air cadets would receive some training before they left Point Cook in Ansons or 'some similar type of machine' ${ }^{19}$ Flight Lieutenant Dixie Chapman, Deputy Director of Training, was quick to inform his superiors that instrument flying was to be included in the conversion course syllabus and 'a far more extensive \& comprehensive syllabus has been prepared for conversion of pilots to Hudson aircraft'. But the Director of Training, George Jones, referring to the use of the Link Trainer as well as 'a certain amount of the experience in actual cloud flying', cautiously drew the Secretary of the Air Board's attention to the short duration of the course in wartime. Although files do not always tell the whole story it is notable that, having decided that there was no need to report to the Prime Minister's Department of Defence Co-ordination, the Air Board does not appear even to have reported to its own minister. The file was quietly 'put away' on 16 July $1940 . .^{20}$

If inconvenient facts could be pigeon-holed, inhibitions caused by fear of selfincrimination could be removed by amending the regulations. The necessary change was drafted in October 1939 but stalled while the Attorney-General's and Defence Departments punctiliously consulted each other over wording. It was finally made in a statutory rule (No. 165) signed by UAP Senator Herbert

18 H. B. Piper to Sir George Knowles, 2 Oct. 1939, NAA: A432, 39/486. Piper had commented in his report that 'certain officers were obviously not sure of their position when giving evidence and this led at times to some confusion in their answers and to their adopting a somewhat defensive attitude which was entirely unnecessary but understandable' (NAA: A705, 32/10/2387).

19 Courier-Mail, 8 June 1939.

20 NAA: A705, 32/10/2387; A461, V314/1/1 
Collett, Vice President of the Executive Council, a week after the Canberra crash. The new Minister for Air had been briefed urgently the day before. In language that had sat on a file for 12 months, Arthur Fadden was advised that witnesses might not be 'altogether ingenuous, especially if they feel that the Inquiry is being used as a "fishing expedition" as a prelude to civil or criminal (including court-martial) proceedings' ${ }^{21}$ It does not seem to have been noticed that, if the Governor-General were to issue a commission by Letters Patent, witnesses would have been protected under Section 6DD of the Royal Commissions Act 1902-1933.

Other dangers to the Air Force could be minimised by writing the terms of reference far more tightly than the ones that Geoff Street as Defence Minister had endorsed in great haste for Piper. But, for a beleaguered government with a general election due in not more than two months, a senior judicial figure was needed to deflect potential harm. This was not the time for the kind of specious objection raised on an earlier occasion by 'Johnnie' Coleman, then Secretary of the Air Board, that 'it is difficult to see how a judge of the High Court or any other court could be more qualified to judge the cause of an aircraft accident than the Coroner'. ${ }^{22}$

Arthur Fadden, as the rapidly installed Minister of State for Air, made the press statement accompanying the proclamation of the inquiry on 20 August 1940. The Governor-General had that same day received the Prime Minister's recommendation that the House of Representatives be dissolved and a general election held on September 21. It was the day after Wing Commander Leon Lachal's Service Court of Inquiry had reported. The Coroner's inquest had not yet been completed. Technically, setting up the Air Court of Inquiry was separate from referring a particular accident to it. The reference from Fadden requested that the Court 'with all possible expedition, inquire into, and report to His Excellency the Governor-General concerning the accident and the cause or causes thereof' ${ }^{23}$ Fadden was unavoidably the formal authority but the file on the constitution and terms of reference of the new inquiry bore the unmistakeable fingerprints of the Service hierarchy.

There was a salient contested element in the task remitted to the Inquiry. It was to look for the 'cause or causes' - it was not assumed that there was a single cause. But even more important was a word that did not appear in the Commonwealth of Australia Gazette on August 21. 'It will be noted,' the Secretary of the Air Board had advised the Minister on the nineteenth, 'that in the Reference the Court is asked to inquire into the immediate cause or causes of the accident.'

21 'Air Force Courts of Inquiry — Regulations', NAA: A705, 108/2/189; A432, 39/442.

22 'Accidents Involving Hawker Demon Aircraft of the Royal Australian Air Force', Notes for the Minister, 10 Feb. 1938, NAA: A5954, 869/10. Much of this memo, including this sentence, was copied from a minute by the Chief of the Air Staff, 7 Jan. 1938, NAA: A5954, 869/8.

23 NAA: A9845, 319/37. 
The Chief of the Air Staff had sensed the danger inherent in a draft prepared by the Attorney-General's Department after a telephone conversation between Mel Langslow and Jim Fairbairn's friend Gilbert Castieau, Assistant Secretary of the Attorney-General's Department.

The draft proclamation from Castieau invited a report 'concerning the circumstances connected with, and the probable cause or causes of that accident'. Burnett corrected the phrasing in his own hand, deleting the 'circumstances connected' and inserting the qualifying word 'immediate'. ${ }^{24}$ The proposed restriction of the Inquiry's scope to 'immediate cause or causes' was clearly designed to minimise the potential for embarrassing discoveries and revelations. For the Chief of the Air Staff there was to be no trawling back through previous months and years of policy and performance, omissions and mistakes that might prove to be relevant to an understanding of the fate of A16-97, its crew and passengers.

By directing attention to the word 'immediate' had Mel Langslow intended to offer reassurance to the Minister or to undo the Air Force's self-serving restriction on an Inquiry they could not control? Arthur Fadden, with an instinct for due process and conflict of interest, asked the Attorney-General's Department to re-draft the terms of reference. Fadden's signed copy was returned to the department by his acting private secretary, Murray Tyrrell. Faint pencil underlining of the changed wording — 'immediate' had gone — showed that its import was understood. Whatever Langslow's motive had been, the outcome was alarming for anyone in the RAAF who understood the ways of inquisitive judges and zealous counsel.

\section{Assembling the court}

The reasons for the choice of Charles Lowe to lead the Inquiry can only be surmised. Even if a judicial berth could be found for him, Edmund DrakeBrockman was unavailable, having stepped down from the Arbitration Court in November 1939 to become an active Major General. The policy file created to deal with Lowe's appointment, which passed between the Secretary of the Air Board and the Attorney-General's Department between 17 and 23 August 1940, was destroyed some time after $1960 .^{25}$ The Victorian judiciary was known in later years to be averse to undertaking royal commissions and inquiries. But,

\footnotetext{
24 NAA: A705, 32/10/2729 for Burnett's pencilled amendments, the advice to Fadden, and Gazette reference; A9845, 319/37; A705, 32/10/2387. Lowe's surviving papers in the Victorian Supreme Court Library contain no relevant material.

25 NAA: A2408, 108/2. The subject registration booklet for Air Department correspondence records the creation on 17 Aug. 1940 of the file 'Establishment of the Court and appointment of Judge to constitute', and the file's movement and destruction.
} 
doubtless realising that this was no ordinary matter, the Chief Justice of the Victorian Supreme Court and the Premier, Albert Dunstan, consented to make Lowe available. ${ }^{26}$ Before his elevation to the bench in 1927 Lowe had enjoyed a strong practice in common and criminal law. He had never taken silk but was the recognised leader of the County Court Bar. Concealed beneath 'a grave and courtly demeanour', Lowe was known for a sense of humour, 'at times impish in its unexpectedness'. He had crossed swords and laughed uproariously with the young junior, Robert Menzies, a fellow tenant of Selborne Chambers. ${ }^{27} \mathrm{~A}$ member of the Melbourne and Australian Clubs, and the Royal Melbourne Golf Club, he had long moved in the same professional and social circles as the Prime Minister. They sat together on the council of Melbourne University. He had served on the council of Trinity College. They were both likely to be found taking summer holidays in picturesque Macedon, where the Menzies family had their own retreat and the Lowes would stay at the exclusive Golf House.

Menzies knew that Lowe would bring detachment and a keen mind to the task. He would also have a broader appreciation of the government's sensitivities. There might be scepticism in aviation circles generally and the RAAF in particular about the ability of a 59-year-old judge who had never been in an aeroplane to add anything of value to their understanding of the crash. However, Lowe could be relied upon to listen carefully to the evidence of those who supposedly knew what they were talking about. And he was quick to win over some of the doubters by taking to the air himself with the court registrar and the two RAAF assessors appointed to assist him; he would see, hear, and feel a Hudson and its crew at work. On the morning of August 27, with Squadron Leader Freddie Thomas at the controls of Hudson A16-78, he was treated to a 30-minute demonstration flight in sight of the granite peaks of the You Yangs near Lara, north of Geelong, the world so familiar to Jim Fairbairn, Geoff Street, and Frank Thornthwaite. $^{28}$

For the vital role of counsel assisting the Inquiry the logical man on grounds of experience would have been Harry Winneke, incidentally a friend both of the Lowe family and the Prime Minister. It was 'understood', according to press reports, that Winneke would be appointed. ${ }^{29}$ But he was now in uniform,

\footnotetext{
26 'Air Force Court of Inquiry to Investigate the Aircraft Accident Near Canberra on 13/8/40', AttorneyGeneral's Department File, NAA: A432, 1940/729.

27 'John Minogue', in Dow (ed.), More Memories of Melbourne University, p.47; F Maxwell Bradshaw, Selborne Chambers Memories, Butterworths, Sydney, 1962, pp.54-8; Sir Robert Gordon Menzies, The Measure of the Years, Cassell, London, 1970, pp.255-6.

28 F. W. Thomas, flying log book, 27 Aug. 1940, Thomas MSS, courtesy of Rob Thomas; Sydney Morning Herald, 28 Aug. 1940. Tink, Air Disaster, (p.209), following the paraphrase in Newman Rosenthal, Sir Charles Lowe, A Biographical Memoir, Robertson \& Mullens, Melbourne, 1968, p.99, makes the flight 30 minutes. Thomas would recall that he demonstrated a stall to Lowe (Frank Cranston, 'Note of Telephone Conversation with Group Captain Sir Frederick Thomas Sunday November 11, $19904.55 \mathrm{pm}$ to 5.20pm', courtesy of Rob Thomas).
}

29 The West Australian, 17 Aug. 1940. 
and his involvement in the Inspectorate of Air Accidents would in any case disqualify him. Having already participated in one inquiry into the accident, Squadron Leader Winneke could not be seen as independent. Nor could he easily be spared from his other duties. Someone from outside the Air Force had to be found: someone who would have the confidence of both Justice Lowe and the government. Fred Gamble, a friend and former pupil of the Prime Minister at the Bar, and counsel assisting the Air Accidents Investigation Committee inquiry into the Kyeema accident, would have been an obvious choice. But he was now on the verge of embarking for overseas service as a major in the 2nd AIF. The answer was a slightly older Law School contemporary of the Prime Minister's from Melbourne University, a fellow Presbyterian and Freemason, Arthur Dean.

Unlike Menzies, a conspicuous figure on the wartime Parkville university campus, Dean had postponed his entry into the legal profession to enlist in the Army in 1915. He had served in the ranks on the Western Front, earned a commission, was wounded and gassed. In 1933 he had co-authored a history of the AIF 7th Battalion. ${ }^{30}$ He was now a leading junior at the Victorian Bar with a practice in equity and industrial property, and the acknowledged authority on the law relating to estate agents, auctioneers, and hire purchase. He had continued through the 1930s in the Reserve of Officers, rising to the rank of Lieutenant Colonel. In 1940 he was the 3rd Division's legal officer. Arthur Dean and Menzies had seen each other at close quarters over 20 years. Dean had the highest admiration for Menzies' forensic skills and advocacy. He had fought with him and against him. ${ }^{31}$ He was also well acquainted with Charles Lowe, whose learning, extraordinary memory, courtesy, judicial temperament, and home tennis court he knew at first hand. He was to describe Lowe 28 years later as 'a simple and straightforward character with no complications... a practical minded lawyer' ${ }^{\prime 2}$ In later years, Air Marshal Sir Richard Williams, who professed never to understand why judges were appointed to inquire into aircraft accidents, was to say that counsel assisting 'without any real knowledge' made their own decision about who was to blame and then set out to prove it. ${ }^{33}$ But, whatever premature conclusion Dean might have been tempted to formulate, he would not be left uninstructed for long.

30 Arthur Dean \& Eric W. Gutteridge, The Seventh Battalion AIF: resume of activities of the Seventh Battalion in the Great War - 1914-1918, Melbourne, 1933, reprint with amendments 1986. The authors had paid tribute to their CO, Pompey Elliott: 'Outspoken, impulsive, straight as a ruled line, intensely headstrong...a dour fighter, brave to a fault...' (p.7).

31 Dean was a signatory of a testimonial to Menzies by scores of eminent civic leaders, businessmen, and barristers re-affirming on 7 Aug. 1941 their 'complete confidence' in his leadership (Menzies MSS NLA MS 4936/40/23). He had not signed a similar circular in June 1940 (Wright MSS, NLA MS 8119, Series 6/1).

32 R. L. Sharwood, 'Dean, Sir Arthur (1893-1970)', Ritchie and Cunneen (eds), Australian Dictionary of Biography, vol. 13, pp.599-600; Sir Arthur Dean, A Multitude of Counsellors, F. W. Cheshire, Melbourne, 1968, pp.220-4; Sir Arthur Dean, 'Pillar of Justice', The Age, 1 June 1968; Ursula Whiteside to CH, 14 March 2010.

33 Williams, These Are Facts, p.350. 


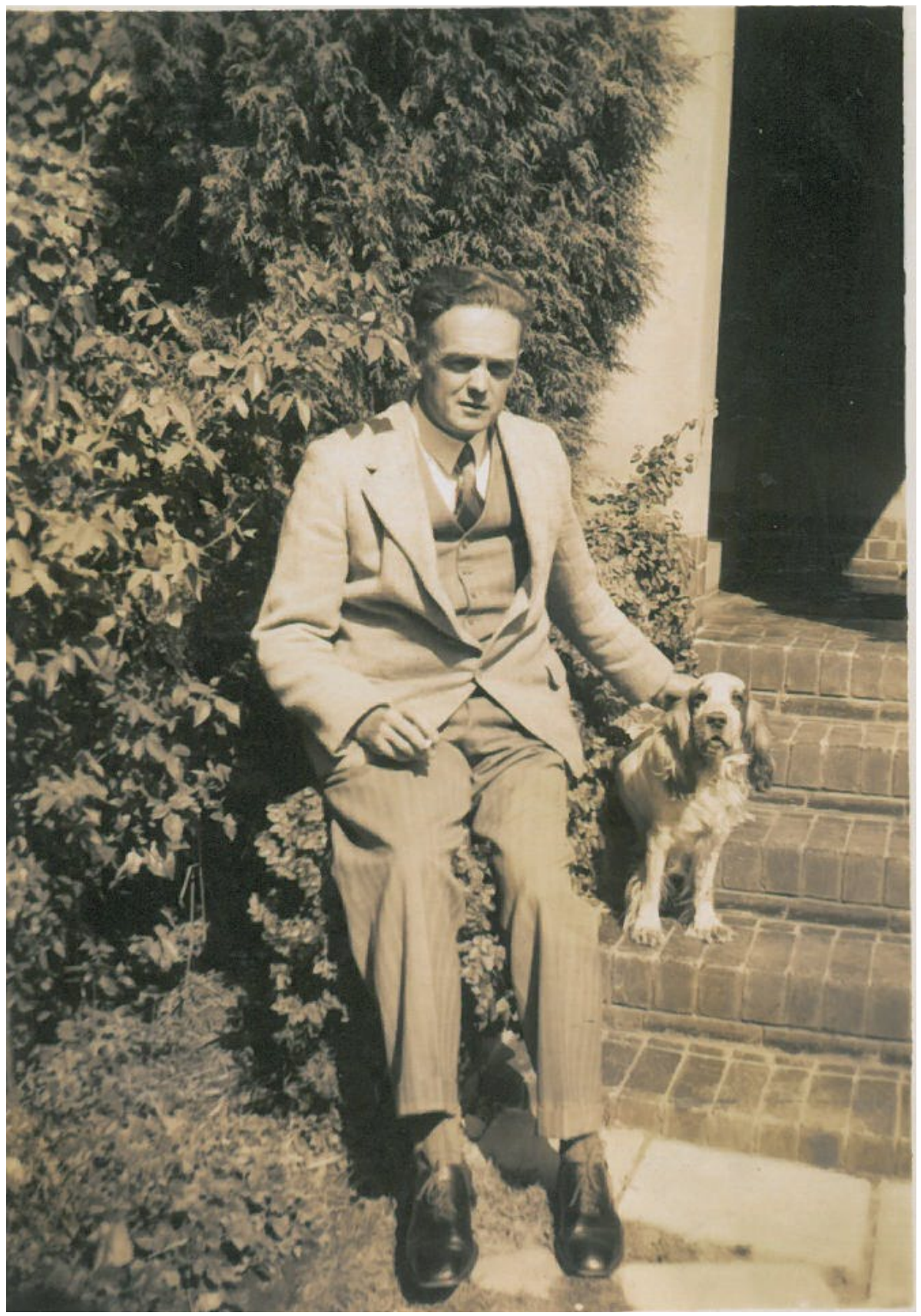

\section{Arthur Dean at home}

(Courtesy of Ursula Whiteside) 
Even before Dean was briefed by the Crown Solicitor, Fred Whitlam, two assessors to 'assist and advise' the Court had been chosen and announced. Wing Commander (temporary Group Captain) D. E. L. Wilson had been, like his contemporaries Ulex Ewart and 'Dad' Bladin, an Army lieutenant when he joined Lester Brain, Joe Hewitt, and others in the first group of a dozen men to go through the RAAF's new flying course in 1923. Douglas 'Del' Wilson, Service number 16, had later graduated from the RAF Staff College, and commanded the RAAF station at Richmond 1939-40 before becoming Senior Administrative Staff officer at RAAF Central Area Headquarters in Sydney. ${ }^{34}$ 'He has had long experience in Service squadrons', the press release noted. His experience as a vigorous court-martial prosecutor in 1936, reassuring as it perhaps was to his superiors, was not mentioned. Nor his confident exposition of theories to explain the crash of the Anson A4-32 to Judge Piper in June 1939. ${ }^{35}$ Wilson had been seen making a 'minute examination of the wreckage' the day after the crash in Canberra. Attention would not be drawn to this. Or to his role in identifying bodies at the Canberra morgue on August 13, or his testimony to the Coroner the next day. The Victoria Barracks and Toorak hierarchy, especially his close friend the Director of Operations and Intelligence, 'Dad' Bladin, (the oldest of his group at Duntroon), needed no briefing on his record. ${ }^{36}$

Wilson's companion was to be 33-year-old Squadron Leader (temporary Wing Commander) A. G. Carr AFC. Tony Carr was Director of Staff Duties at Air Force Headquarters, Melbourne. He was a rising star, like Paddy Heffernan and Val Hancock a Duntrooner taught to fly by Ray Garrett, and as experienced a Hudson pilot as could be found. He had only recently relinquished command of No. 1 Squadron, equipped with Hudsons since April. The appointment of Wilson and Carr on the recommendation of the Air Board gave reassurance that the legal minds would have reliable professional guidance. But in case it might be thought that they could unduly influence the outcome of the Inquiry their role was explained for the press: 'The duties of assessors in the Court will be similar to those performed by assessors in the long established Marine Courts of Inquiry, and like the latter, these officers have no power of adjudication.' As Air Marshal Williams was to lament, assessors 'could not submit a minority report even if they considered the finding of the Court was wrong' ${ }^{37}$ What noone appears to have remembered was the advice about the selection of assessors given by the Secretary of the Air Board to the Air Member for Personnel the previous year: '...consideration should be given to whether they have been

\footnotetext{
34 NAA: A9300, WILSON DEL.

35 The West Australian, 23 June 1939.

36 F. M. Bladin, Typescript Memoir, 1953, AWM: MSS 886. For Bladin's sobriquet 'Dad', see J. E. Hewitt, The Black One, Langate Publishing, South Yarra, 1984, p.101.

37 'Draft Press Statement', 'telephoned to Pte Sec to Min at Canberra 1715 hrs 20/8/40', NAA: A705, 32/10/2729/72.; Williams, These Are Facts, p.350.
} 
connected directly with the particular inquiry, e.g. if they have been witnesses at the air-force court of inquiry or members of such court or otherwise directly interested in the accident' ${ }^{38}$

These implicit criteria should have given pause to anyone who knew of Wilson's roles in Canberra immediately after the accident.

With Lowe, Dean, Wilson, and Carr appointed, on August 20 the Deputy Chief of the Air Staff, Air Commodore Bill Bostock, who was orchestrating proceedings, passed the accident inquiry file to the RAAF's principal legal officer, Wing Commander F. F. Knight. Fred Knight, another Victorian barrister, veteran of Gallipoli and the Western Front, was asked for his 'comments and any necessary advice'. Knight at once recognised the danger inherent in the reference the Court had been given. There were crucial procedural elements that Anderson, Bostock, Burnett, and others had missed. Another job needed to be done, one that the RAAF high command should be anxious to ensure would be done by someone they could trust. If there was going to be an independent judge and an independent counsel and assessors assisting him, it was essential that the Air Board had someone in the room to represent their interests. Knight had learned this lesson when Justice Piper had roamed freely and mused over embarrassing issues the previous year. 'It is considered advisable', Knight warned, 'to take action to avoid the recurrence of certain unfortunate incidents which took place during the hearing before the previous court in 1939.' In that case the Service was not represented by counsel:

Neither the assessors, nor any technical representative of the Service saw counsel assisting court before the hearing. The result was that at the outset and whilst evidence of a somewhat damaging nature was given, counsel was left without the technical assistance essential to enable him effectively to cross-examine the witnesses.

Knight's version of events in 1939 was tendentious. The truth was not that there had been no meeting between the assessors and counsel before proceedings began. Rather, that meeting had not afforded an opportunity to talk privately to counsel assisting; it had occurred in the presence of the judge, and officers of the Deputy Crown Solicitor's office and the Air Board. ${ }^{39}$ The situation was, Knight noted, retrieved before the Court convened for a second time to inquire into the accident to Anson A4-11 but not before 'considerable damage had been done to the Service in the eyes of the public'. Determined that this should not happen again, Knight laid out the course that needed to be taken. In a minute to the Air Member for Personnel on August 20, seen first by the Director of Personal Services, Joe Hewitt, he recommended:

38 'Assessors for Special Courts of Inquiry into Aircraft Accidents', 10 May 1939, NAA: A705, 108/2/189.

39 Sec., Air Board to Sec., Dept of Defence, 'Air Force Court of Inquiry - Accident to Anson A4-11 on 2.3.39', NAA: A705, 108/2/189. 
(a) that counsel be briefed to represent the Air Board, or, if this is not agreed to, that a legal officer be detailed to do so. It is recognised that Squadron Leader WINNEKE may not be available, and if that be so Pilot Officer PAPE is suggested. He is a member of the Service Court of Inquiry on this accident;

(b) that a General Duties Branch officer, preferably with experience of Hudsons, be detailed to assist counsel assisting the court, if counsel so desires;

(c) that all assistance be offered to counsel assisting the court by this Department, and that the services of Squadron Leader WINNEKE be made available to him, if he so desires. This suggestion is made because in this way counsel could be advised of the witnesses who might be called, and the order in which it is advisable to call them;

(d) that, where possible, all service witnesses, be instructed to confer with a service legal officer before giving evidence, if the service is not represented before the court;

(e) that the assessors confer with Section L. 1 with respect to the exclusion from the press, etc. of secret and confidential matter arising before the court. $^{40}$

Knight's message was not lost on his superiors. Known as the 'Legal Eagle', for over a decade he had lectured and examined cadets as well as officers seeking promotion to squadron leader. He had served frequently as Judge Advocate in courts-martial. Called up in December 1939, he had helped steer the Air Force Act through Parliament. ${ }^{41}$ He was a respected and trusted advisor. Educated at Melbourne Grammar and Trinity College at Melbourne University, Knight had been in the Service part-time since 1926 and was promoted Wing Commander in 1934. The son of a prominent pastoralist, stockbroker, and philanthropist, and cousin of Otway Falkiner of the famous Boonoke merino stud, he moved familiarly in Melbourne club land and was a valuable link between the Bar and the Air Force. His closest Service friends were 'King' Cole, Harry Cobby, Allan Walters, Doug Candy, and Jack Graham, who was his legal assistant before being called up in 1939.

40 Sec., Air Board to Sec. Dept of Defence, 30 May 1939, NAA: A705, 108/2/189; WCdr F. F. Knight to Air Member for Personnel (through Director of Personnel [sic] Services), minute, 20 Aug. 1940, NAA: A705, $32 / 10 / 2729 / 85$.

41 The provision of the legislation purporting to apply British rules and regulations via a general regulationmaking power was 'probably invalid' (Neil Preston, 'The Development of Defence Force Disciplinary Law 1901-1985: An Outline', Work-in-Progress Seminar, Research School of Social Sciences, ANU, 29 Nov. 1988). 
Knight openly displayed his political sympathies, scrutineering at elections for the UAP deputy leader, Jack Latham. ${ }^{42}$ With his barrister friend Ned Herring, he had played his part in the Victorian secret army organisation of the previous decade, and was a close friend of Geoff Street's cousin, Jack Scott, now in counter-intelligence. ${ }^{43}$ His recommendation of counsel to represent the Air Force went up to the Deputy Chief of the Air Staff. Bostock was careful not to reveal too much of his own hand. He was adept at pleasing his chief, as his promotion to Air Commodore, vaulting over the heads of seven more senior officers (Anderson, Harrison, Cole, De La Rue, Wrigley, McNamara, and Lukis), had marked two months earlier. ${ }^{44}$ He endorsed Knight's advice and passed the file to the CAS. Sir Charles Burnett agreed and sent the papers back to the Air Member for Personnel (AMP) and the Secretary of the Department.

'A. M. P. will I presume take necessary action', Burnett wrote. 'Mucker' Anderson knew better than the British CAS about the relevant lines of authority. He took the opportunity to nominate someone for the task in a minute to the Secretary on August 23:

Action to request that counsel be briefed to represent the Air Board must be taken by the Secretary. I recommend Mr J. B. Tait, of the Victorian Bar, who is a man of high standing in his profession and was a pilot in the last war. If the request for counsel to represent the Air Board is refused, Section L.1 will supply a legal officer.

Why there might be a refusal, and who might refuse, was not clear. The nomination of Jim Tait was shrewd. As an Australian Flying Corps Lieutenant in No. 3 Squadron he was an old comrade both of Anderson and Harry Wrigley. He was one of only three men ever to read with the formidable High Court judge, Owen Dixon, Menzies being another. Would there be political resistance to the appointment of outside counsel? Would the engagement of so well-regarded a barrister suggest that the RAAF felt it needed exceptionally able protection? That had not been the thought 31 months earlier when both the then Minister for Defence and the Attorney-General had approved of the department being represented in the politically sensitive inquest into the death of Flying Officer Jack Fallon, a Labor MP's son. Attorney-General Menzies had then 'directed that the best available counsel should be secured'. ${ }^{45}$ This time, as Anderson

\footnotetext{
42 Knight, These Things Happened, pp.285-327; F. F. Knight, History of the Australian Club, Melbourne, vol. II 1932-1965, [1971]. Knight does not mention that he was a contemporary of R. G. Menzies in the Melbourne University Law School and Melbourne University Rifles.

43 Robert Darroch's diary, 12 March 1985, reporting conversation with Ernest Whiting. For Darroch's quest to identify Scott with D. H. Lawrence's Jack Callcott in Kangaroo, see D. H. Lawrence in Australia, Macmillan, Sth Melbourne, 1981, and www.cybersydney.com.au/dhl/thesislb.htm.

44 In his own words, Bostock had 'made his mark very quickly' with Burnett. ('Why Bostock?', ts draft article, Heritage Collections, Queensland State Library, Acc. 4349).

45 'Accidents involving Hawker Demon Aircraft of the Royal Australian Air Force', NAA: A5954, 869/8.
} 
noted the next day, there was 'further discussion', after which 'it was agreed to provide one of our own legal officers rather than brief outside counsel, \& this is being arranged. CAS concurred.' Given that George Pape had already assisted Lachal, it might have been predicted that he would be assigned. There was in any case no-one else. ${ }^{46}$

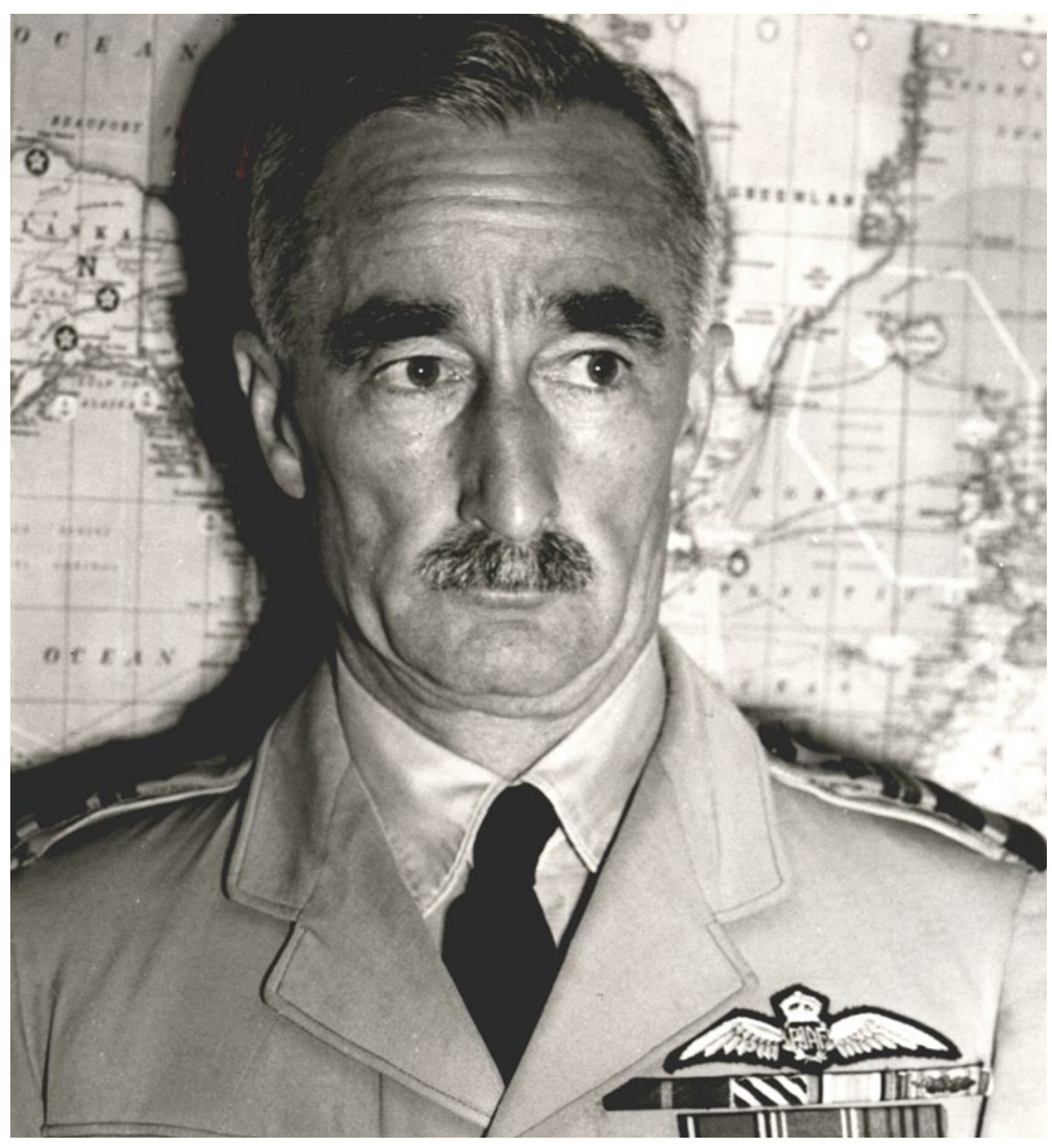

'Mucker' Anderson: 'immersed in the minutiae of administration'

(Courtesy of the RAAF Museum) 


\section{Bostock's precautions}

The Air Force hierarchy had mobilised for damage control. A week later, on the day the Inquiry was due to start, Pape received his riding instructions. The directive came down from the Deputy Chief of the Air Staff to the Air Member for Personnel with a copy to Fred Knight. Whereas Knight had urged that the RAAF not be left without protection before the court, Bostock now set out a comprehensive strategy to ensure that anything that might conceivably be embarrassing was shielded from view. Bostock had for some time been alert to criticism, including letters reaching the Air Minister, of 'the administration of senior officers and of equipment by personnel in units'. The Air Member for Personnel had taken the matter up with Area commands 'in an endeavour to improve morale generally'. There had been concern, too, about a 'large percentage increase in forced landings'. In secret conclave it was admitted that the cause was 'principally the lack of close supervision by Flight and Squadron Commanders'. Poorly executed aerobatics and incomplete knowledge of the characteristics of particular engines were blamed. Now Bostock might have taken as his text the advice of the Secretary of the Air Board to the Minister of Defence on an earlier politically fraught occasion: 'it has not been the practice in the past to enter into any discussion with the press or public on the technical causes of air accidents, otherwise ill-informed criticism and comments cannot be avoided' ${ }^{47}$

In 1937 Jim Fairbairn had been a strong defender of secret inquiries: 'I believe that aviation would benefit to the greatest extent if the evidence were given in camera...the rights of the public are protected by means of coronial investigations. ${ }^{48}$ Those senior officials familiar with the Piper inquiries that followed would have known that, on the advice of the assessor, Group Captain Harry Wrigley, the proceedings in camera in Melbourne were closely held. Only three transcripts were made. Defence Minister Geoff Street, distinctly peeved, noted that 'advice should have been given to the Judge for a copy of such evidence to be made available to the Minister'. Street directed that in future he was to be sent any evidence taken in camera. ${ }^{49}$ What Street could not have known was that the Solicitor-General, the recently knighted Sir George Knowles, had privately recommended that Piper keep his inquiry papers in the

\footnotetext{
47 'Report of Staff Conference No. 35..', 21 May 1940, NAA: AA1977/635; 'Accidents to Bomber Squadron on Training Flight', minute, 6 Dec. 1937, NAA: A5954, 869/10.

48 Uncorrected proof of Debate in House of Representatives, 8 Dec. 1937, NAA: A5954, 869/8.

49 Minute by Street, 8 Sept. 1939, on Sec., Air Board to Sec. Dept of Defence, 14 Aug. 1939, NAA: A705, $108 / 2 / 189$.
} 
offices of the Arbitration Court in Sydney and Melbourne. If he had to rely on support staff from the Air Department he could at least keep the files secure under his own control. ${ }^{50}$

Air Commodore Bostock knew what he was doing. As station commander at Richmond in the mid-1930s he had used his press contacts to avert 'unjustified but nevertheless distasteful publicity when individual members of the Service, suffering under the emergency "cuts", were anxious to rush into print with all sorts of grievances' ${ }^{51}$ In June 1939, as Director of Operations and Intelligence he had belatedly been assigned to assist counsel to Piper's Air Court of Inquiry in Melbourne. It was his activity at that time - providing the Court with a secret document explaining why all Ansons not fitted with Sperry instruments had been grounded after a crash into Port Phillip Bay — that Fred Knight had hinted at when he spoke of the situation being retrieved. Bostock's ostensible brief then was to assist in gathering 'requisite information' relating to the 'adequacy of training of air-force personnel'. Alert to the potential for the independence of the proceedings to be undermined, Geoff Street had approved the arrangement but insisted that "the officer should not "sit in" as a member of the Court but be available to give advice when required' ${ }^{52}$ Such a passive role minimised the influence that could be brought to bear on the scrupulous Harry Winneke. And, when Piper's two assessors found him unbiddable, the judge's subsequent damning queries and faint praise brought no joy to the RAAF's upper echelon.

Bostock was determined that nothing like this would happen again. Arthur Fadden had let it be known that before Cabinet met to decide on the form of a possible public inquiry he would seek the views of the Air Board on technical evidence that might prove useful to the enemy. ${ }^{53}$ On such matters a new and inexpert minister would be foolhardy not to follow the advice he received. Taken at its face, Bostock's minute on August 27 amounted to a brazen order to subvert the 'open inquiry' authorised by the Cabinet. 'As the terms of reference are wide in their scope,' he pointed out, 'it is inevitable that evidence may be required which must not be made available to the Press or Public.'

It is therefore considered necessary that the officer appearing for the Air Board should request that evidence on the following matters should be taken in camera:

Maintenance of Aircraft:

50 Knowles to Piper, 22 June 1939, NAA: A432, 486 of 1939. Knowles had a personal source on RAAF flying safety, his son, Air Cadet Lindsay Knowles (later F/Lt, killed in action Nov. 1941).

51 Bostock to Norman Ellison, 16 Aug. 1940, Ellison MSS NLA MS 1882 2/22.

52 The Mercury, 10 June 1939; Sec., Air Board to Sec., Dept of Defence, 31 May 1939, annotated by Street, 1 June 1939, NAA: A705, 108/2/189.

53 Townsville Daily Bulletin, 15 Aug. 1940. 
Standards reached by maintenance personnel.

Maintenance equipment available.

Security of aircraft storage:

Whether aircraft are housed in hangars or in the open.

Disposition of aircraft on the aerodrome.

System and numbers of guards available.

Training of Pilots:

Methods and time spent.

Adverse comment on general standard.

Adverse comment on standard of pilots of the particular aircraft.

Armament and Wireless Equipment:

No indication of armament or details of wireless equipment should be given.

Adverse comment on crew members.

General Equipment:

No indication should be given as to lack of equipment. ${ }^{54}$

Taking care not to divulge matters that would jeopardise security was of course entirely proper. When opening his inquiry in Melbourne in May 1939 Judge Piper had said 'It was the wish of the Court to preserve any state secrets. He would ask witnesses not to divulge openly details of defence importance.' If necessary the Court would sit in camera (as it did for a period at Winneke's request) or confidential matter would not be taken in evidence. There were already stipulations in place that prohibited disclosure of the mark of the engine; all internal construction, armament, and equipment of the aircraft; as well as performance, range, or estimated speeds. ${ }^{55}$ However, all this was not enough for Bostock. Adverse comment on crew members unable to defend themselves might justifiably be kept confidential. But to endeavour to hide criticisms of

54 DCAS (ACdre W. D. Bostock) to AMP (ACdre W. H. Anderson), 27 Aug. 1940, copy, to L.1. (WCdr F. F. Knight) passed to P/O G. Pape, NAA: A705, 32/10/2729/38. Anderson prefixed 'any' to each 'Adverse comment'.

55 The Argus, Courier-Mail, 26 May 1939; 'Disclosure of Information Regarding Aircraft and Engines', AFCO 3/1939, NAA: A7674, 1/5. 
pilot training, shortages of equipment, or maintenance standards could be seen as self-serving - or would have been if the contents of the document had been made public.

Bostock's list of areas for in camera evidence was as good a guide as could be assembled to the RAAF's fears about the flaws and weaknesses that might be exposed. The Deputy Chief of the Air Staff could scarcely have forgotten, for example, that it was less than four months since the Air Board issued orders promulgating a new policy on 'approaching and landing'. The introduction of 'modern high wing-loaded, flapped monoplanes' had made 'the old accepted methods of approaching and landing both difficult and unnecessary'. Four pages of detailed advice followed on the 'modern technique' that was henceforth to be imparted. ${ }^{56}$ Bostock knew only too well how hard it was proving to replace 'old accepted methods' with 'modern technique'. Well aware of how narrowly he had himself escaped a share of the blame for the spate of accidents a few years earlier, he now took a perilous step across the line of propriety.

The Secretary of the Department of Air was not sent a copy of Bostock's advice to the court until August 28. Extraordinary as it may seem, the Service members of the Air Board had gone behind the back of the Department and the Minister. Alerted by the transcript of evidence typed and delivered to his office each day, the departmental Secretary, Mel Langslow, sent a brusque request late on August 27 to the Chief of the Air Staff, invoking the Minister's name:

C. A. S.

It is understood that at the opening of the sittings of the Air Force Court of Inquiry, which is investigating the aircraft accident at Canberra on 13th August, 1940, a document was handed to the judge 'by order of the Deputy Chief of the Air Staff' relating to the evidence which should be heard in camera.

Would you please forward for the information of the Minister a copy of the document which was handed to the judge.

ML

Secretary

A typed message, conveying a request that could very easily have been made personally or by telephone, signalled displeasure and an implicit rebuke, on the record. ${ }^{57}$

56 'Flying Instruction - Approaching and Landing', 26 April 1940, ABO N196/40, NAA: AA 1977/635.

57 'Proceedings of Court of Inquiry - Flying Accidents, Master Copy, Vol. 1', NAA: A98451, 318/39. 
Precise as always for the file, when the document arrived Langslow noted: 'Copy of statement handed to Court by Deputy Chief of Air Staff.' But, as Langslow already knew, the statement by the Deputy Chief of Air Staff had not been handed to the court by Bostock himself. The distinction is important, and was not a syntactical error. When George Pape had received his copy of the Deputy Chief of the Air Staff's minute he knew what was meant by 'For your information \& attention. ${ }^{58}$ He could rely on Lowe to seek guidance from counsel assisting about when to exercise the power to direct that evidence should be given in camera. A word to Arthur Dean would ensure that he would have the opportunity to advise what should be kept from the public. And so it proved.

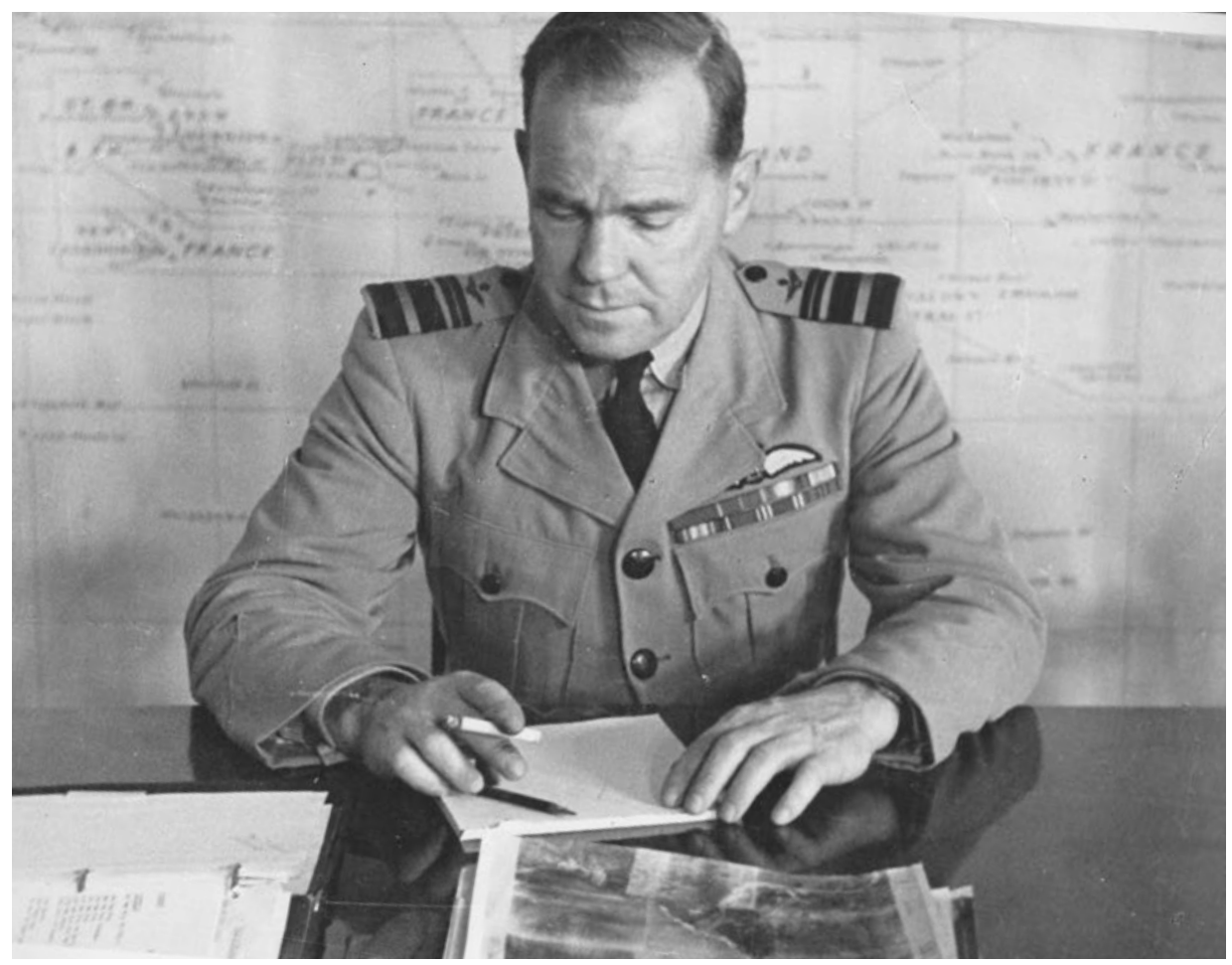

\section{Bill Bostock, orchestrator of proceedings}

(Courtesy of Geoff Bostock)

Dean in his opening remarks referred to evidence from Service personnel 'of a character that should not be published'. Lowe asked him to indicate when such evidence was about to be led. Dean then opened the door for Pape:

MR. DEAN: I will do that to the Court and, if there is any evidence that my friend Mr. Pape thinks should not be made public, and which I 
Ten Journeys to Cameron's Farm

should not so describe, I feel sure that he will no doubt give Your Honor [sic] a similar indication. It is not necessary to indicate the reasons that exist for this course to be followed.

THE COURT: No, they are obvious. In a time like this, evidence of this nature, which is of a technical character, should be made subject to that protection.

MR. DEAN: Exactly.

Whether or not Justice Lowe realised it, he had walked into a trap. He had assumed that the evidence that needed to be protected was 'of a technical character'. This was of course true in part. But, as Dean and Pape led him forward, the net tightened. Dean explained that he was first going to call Air Force personnel from Laverton whose evidence should be taken in camera. There was, however, no reason he believed, as 'at present advised', why persons from Essendon or observers from Canberra need be heard in camera. As the first witness was about to be sworn, Lowe sought confirmation from Pape that the evidence from Laverton personnel was of a nature that ought not be disclosed in public. Yes it was, Pape responded, seizing his chance:

...furthermore, it may perhaps assist Your Honor in dealing with this matter if I hand you [a] copy of an instruction from the Deputy-Chief of the Air Staff which has been supplied to me. Your Honor will see the particular type of matter which it is felt should not be elicited in public.

With Bostock's 'instruction' in his hands, Lowe heard Pape continue for about 20 seconds, repeating his agreement about the way to deal with the witnesses from Laverton, Essendon, and Canberra. Having had barely enough time to scan the 'instruction', the judge made the commitment that guaranteed the secrecy Bostock wanted: 'I propose to follow, at any rate at the outset, the suggestion that has been made, and to direct that evidence which involves matters under the headings handed to me by Mr. Pape shall be taken in camera.'

Lowe clearly had insufficient time to assimilate the document Pape put in his hands. He had already agreed in principle to the exclusion of what he thought would be matters of a 'technical character'. Now he acquiesced in the placing of a cloak over everything that had not been observed on August 13 by civilian witnesses. Such was to be the 'open inquiry' that the Cabinet had approved. Pape, entitled to an extra blue cotton band on his sleeves denoting his promotion 
to acting flight lieutenant with effect from August 26, had done his work well. ${ }^{59}$ Unintentionally perhaps, the 37-year-old barrister had also provided plausible deniability to the government.

Just in time for the next morning's newspapers, Arthur Fadden issued a statement. 'Commenting on the fact that the Court had met in camera for the greater part of yesterday's hearing,' The Argus reported on August 28, the Air Minister said, 'the interpretation of the terms of reference was a matter for the judge. The aim of the Ministry was a comprehensive inquiry into the cause or causes of the accident consistent with protection of the war effort.' What Fadden never knew was the Air Force's fall-back position if the judge declined to close the Court when 'matters of a secret nature' were about to be raised: 'Failing the agreement of the judge it is suggested that the assessor seek the adjournment of the court to enable the Minister to decide whether the proceedings should be held in camera. ${ }^{60}$

The government had insulated itself from Lowe's inquiry. There was no need for anyone to articulate the obvious truth that the Air Force interest in limiting unhelpful revelations was itself a bulwark against political embarrassment for an embattled Prime Minister.

\footnotetext{
59 All quotations from the Inquiry transcript copy in NAA: A705, 32/10/2729 where Pape is addressed as ' $M r^{\prime}$ throughout, and sometimes described as Pilot Officer. Pape's promotion: HQ Southern Area Personal Occurrence Reports, 2/1940, NAA: A10605, 48/2; NAA: A9300, PAPE GA shows P/O 1 July 1940, F/O 1 Jan. 1941, F/Lt 20 July 1941.

60 'Assessors for Special Courts of Inquiry into Aircraft Accidents', 10 May 1939, NAA: A705, 108/2/189. The Secretary of the Air Board, following the Defence Minister's lead, had argued: 'It is essential that there should be a provision empowering the Minister to certify that in the public interest it is desirable that any particular inquiry be held in camera.'
} 



\section{Expert witnesses?}

Charles Lowe had been preoccupied. He had dispensed justice to a procession of innocent men and minor miscreants over the weeks following the Canberra disaster. Judgement on a civil suit involving Sir Brudenell White's Trustees, Executors, and Agency Co. had been followed by cases of false pretences and alleged larceny of a bicycle. On Monday, August 26, Justice Lowe had sat in the Criminal Court while a Grand Jury - Victoria's first in 15 years and one of only half a dozen called in the state's history — was sworn to deliberate on the case of three police constables charged with perjury. Fourteen prosecution witnesses were also sworn. The 23 jurors were instructed by the judge on the role of a Grand Jury and the law of perjury. After five hours of deliberation behind locked and guarded doors, a 'True Bill' was returned against the constables. ${ }^{1}$ Thus, with just an evening to prepare, Lowe could turn his mind to a very different task. Here, knowledge of statute, case law, and sentencing precedent would be of no service. He had neither theory nor practical experience to guide him. With no technical background, he must rely on the RAAF assessors to alert him to issues, clarify and reconcile conflicting testimony. He had no tentative answers, and would struggle even to formulate meaningful questions to the parade of witnesses who had been summoned.

Lowe had the assistance of Arthur Dean of counsel ('30 guineas on Brief, 5 guineas Conference, with refreshers of 20 guineas for Melbourne and 27 guineas for attendance at Canberra'); James Aloysius Davoren of the Air Department, appointed by the Attorney-General as registrar; and a team of four shorthand writers from the parliamentary reporting staff. Two aircraft models, a large panoramic photographic mosaic, and a map of the area around the crash scene and Canberra aerodrome - 'the Australian Capital Territory Landing Ground', as the Coroner had described it - had been assembled. ${ }^{2}$ On accepting the appointment, Lowe had indicated to the Crown Solicitor that he would open the Inquiry on Tuesday, August 27 'and proceed without interruption until the completion of the Melbourne evidence'. He aimed to travel to Canberra on Wednesday night (vouchers for train travel for himself and his associate had been supplied), begin sittings on Thursday, and again proceed without interruption until all the evidence had been taken. Canberra and Queanbeyan witnesses were served summonses on August 26 to appear at the Supreme Court

\footnotetext{
1 The Argus, 27 Aug. 1940.

2 The mosaic appears to be one compiled in May 1940 and now to be found in the NLA aerial photography collection. The map (Air Court of Inquiry Exhibit No. 9) is the 'Federal Territory feature map' published by the Dept of Home Affairs now catalogued in NLA: MAP G8981.P6 and viewable online. The Coroner's Inquest had another copy of the map, similarly marked; this map, of which I obtained a photograph 35 years ago, now seems to have disappeared.
} 
at 10.30 a.m. on Thursday, August 29. Lowe hoped to complete the Inquiry by the end of the week and 'immediately set about the preparation of my report'. It was a brisk timetable. ${ }^{3}$

It had been envisaged by the drafters of the Air Court regime that the evidence collected and the findings of a Service Court of Inquiry would be available to counsel assisting the Air Court. Counsel could then determine whether the evidence on all relevant points was complete or whether the Service Court needed to be re-opened to clear up any remaining questions. The intended procedure was that the Service Court (referred to as the 'ordinary court of inquiry' by the officials) 'will be used solely for the purpose of enabling the Minister to determine whether or not the Court should be held'. The expectation was that the 'ordinary' Court's proceedings would be used to prepare 'the statement of the case and notes to enable the Court to obtain a complete outline of the subject matter of the inquiry'. Apart from this limited purpose, the proceedings of a Service Court 'should not be available to the Court, witnesses, etc., during the inquiry'. ${ }^{4}$

No-one had contemplated a situation in which the government would decide to hold an Air Court of Inquiry before a Service Court had completed its work. But, as it turned out, the members of the Service Court had signed their report on August 18. The Coroner had also issued his findings on August 26, a day before the Air Court opened in No. 2 High Court. A copy of the record of the Coroner's Court was despatched immediately from Canberra to the Deputy Crown Solicitor's office in Melbourne; it could have reached the registrar of the Air Court in time to be read before the Court re-convened in Canberra on August 29. It appears that Arthur Dean quickly assimilated the Service Court documents. He submitted a list of topics on which he would require additional evidence: the aircraft's design, construction, assembly, maintenance, and flying record; arrangements for guarding the aircraft; load calculation; and crucially:

Some expert opinion by the most qualified person available as to

(i) deductions as to cause of crash, to be deduced from accounts of eyewitnesses;

(ii) what are most likely reasons for crash, and why?

Dean had been told that Flight Lieutenant Ryland and Squadron Leader Dallas Scott were the suggested experts. But there was doubt about Scott's availability, and the possibility was raised that Squadron Leader Freddie Thomas and Pilot

3 Deputy Crown Solicitor (F. F. Clausen) to Crown Solicitor (Sir George Knowles), 28 Aug. 1940; Charles Lowe to Knowles [23 Aug. 1940], NAA: A432, 85 1940/729/25-6.

4 'Special Court of Inquiry (Investigation of Aircraft Accidents) Air Force Regulations, Part XVI, Notes on Procedure of the Court', 19 May 1939, NAA: A705, 108/2/189. 
Officer Raymond Winter might be called in his stead. ${ }^{5}$ Dean asked that Ryland, Scott (if available), Thomas, and 'any other witnesses' who might be able to give evidence on the cause of the crash would see him on Monday afternoon, the day before the Court convened. ${ }^{6}$ Wing Commander Fred Knight co-ordinated the Air Board response. Scott and Ryland, he said, were on 'an extremely important operational flight' and it was impossible to say when they would return, 'if at all'. Scott was about to fly the Chief of the Air Staff and was not expected to return before Thursday or Friday the following week. But the advice about Ryland was misleading. He was engaged on August 26 and 27 on taking Flight Lieutenant F. B. Chapman of the RAAF Reserve through a Hudson conversion course. ${ }^{7}$ It was obvious from Knight's letter to Dean that great reliance was going to be placed on Freddie Thomas's performance in the Court. Pilot Officer Ray Winter was not considered a satisfactory expert witness because of his 'limited experience'. But Wing Commander Colin MacKenzie Henry, Director of Technical Services, was suggested as an alternative.

Lowe and Dean had planned to finish hearing the Melbourne witnesses by lunchtime on Wednesday, August 28. They did not expect any dramatic revelations. In his 'opening of the facts' in the case on August 27, Dean summarised what had been observed and determined about A16-97's last flight and the crash. ${ }^{8}$ As a result of the destruction of the greater part of the aircraft, he said, 'it is impossible to reconstruct any definite cause of the accident'. The pilot, Dean said, was 'trained, competent and experienced', familiar with the aircraft type and with Canberra aerodrome. 'In all the circumstances, it is impossible to state accurately what led to the trouble.' With the slenderest of hints about a matter that could possibly prove embarrassing, Dean concluded that the aircraft took off from Essendon with its full load 'with the crew properly on it, without any difficulty whatever'.

Commenting on the appearance of the crashed plane itself, Dean noted, as the Inspector of Aircraft Accidents, Wing Commander Murphy, had reported, that the wing flaps remained more or less intact; they were extended almost to the full extent, and appeared to have operated together. Informed by this observation from the official accident investigator, Lowe could reasonably expect that what would be elicited from the Laverton ground crew would be straightforward if unilluminating. But he had not counted on the effect of the evidence to be presented in camera by ACl Les Roffey, the 22-year-old flight rigger of No. 2 Squadron's A Flight, who had inspected A16-97 at Laverton on the morning

\footnotetext{
5 There was no mention of the other most experienced Hudson pilot, F/Lt Alec Barlow, who had been attached to No. 7 Squadron at Laverton since Aug. 5.

6 NAA: MP401/1, CL12774; A432, 1940/729.

7 F/Lt J. P. Ryland, Flying Log Book, 26-7 Aug. 1940, Ryland MSS, NLA MS5020 Box 1.

8 Unless otherwise indicated, information and quotations from proceedings of the Air Court of Inquiry are from the transcript found at NAA: A705, 32/10/2729.
} 
of the fatal flight. Group Captain Wilson, who seemed to have a theory, had asked the fitter, Corporal Jim Davey, at the end of his testimony on August 27: 'Could you give us any indication of under what circumstances one flap would be caused to come down while the other flap remained in position?' Davey, more expert on the airframe than the hydraulics, had ventured that a wire would have to break or a pin shear, 'which is very unlikely'. He added that a rigger would be more qualified to speak. Flight Lieutenant Ryland, who had been listening to proceedings, was asked the same question. He said it would be impossible in a Hudson deliberately to lower one flap without the other being lowered as well. To the related question, if one flap were down and one up would that put the aircraft on its back, Ryland had no answer. But he was in no doubt that 'nothing I can think of' would cause a Hudson to go on its back. Pressed by Acting Flight Lieutenant George Pape, Ryland said he was not qualified to say under what circumstances one flap might be lowered while the other did not move. Echoing Corporal Davey, he advised that a rigger would be more qualified to answer. It would, he agreed with Pape, have to be a 'defect in the system of working the controls'.

Thus attention turned to Les Roffey. Roffey, too ill in hospital with influenza to appear on Tuesday, was thought to be the man best able to explain the working of the flaps. He had testified briefly to the Service Court on August 13 that he checked the pilot's controls that morning and found them 'serviceable'. That had been the first time he had ever touched A16-97. Brought in from his sick bed, Roffey elaborated for the benefit of civilian counsel and the judge, that he had 'pumped down' the flaps - lowered them by hand pump. He had gone under the bomb doors and satisfied himself that the flaps were all right, then back into the cockpit to close the bomb doors and raise the flaps. He had found 'no defect of any kind' in any of the controls: ailerons, elevators, and rudders as well as flaps. He had stayed by the aircraft while the fitters warmed up the motors and lowered the bomb doors and flaps with the power pump.

Initially questioned by Arthur Dean, Roffey was then cross-examined by George Pape on behalf of the Air Force. Possibly primed by the assessors, Pape asked the question that no-one else had been able to answer: under which conditions might one flap be lowered while the other remained in position? 'More than likely,' Roffey said, 'it would mean a broken wire.' He had of course checked the wires and found no indication of weakness in the wires controlling the flaps. He conceded that it was possible that there might be a weakness in part of the wire that was concealed in a sleeve; but, even if he could not see it, he said, he would feel it, knowing that the tension was not right. At this moment 'Del' Wilson intervened with a series of increasingly technical questions about the linkages between the flaps and the pilot's control in the cabin - the hydraulic jack, the sleeve and swage joints by which cables were attached to each other. Had Roffey 
ever known of a case where a wire had pulled out slightly from the sleeve joint? 'I have never actually seen it, but I believe there was one such incident in the squadron... and the whole squadron had to dissemble [sic] those sleeves and inspect those joints.'

Having heard of an occasion in which all the Hudson aircraft of No. 2 Squadron needed to be inspected, Wilson seemed convinced that he was on to something significant:

If both flaps were down, as we will assume from the evidence which will probably be obtained from Canberra, and the pilot had reason to take his flaps up again; in other words, if he were going round to make another approach, and one of those cables was loose and had pulled out, would I be right in saying that one flap would be down and the other flap up and the flap indicator in the pilot's cabin indicating that the flaps had both come up?

— I am afraid I do not know exactly where the indicator reading comes from.

There was nothing more Roffey could offer the Court other than an opinion:

Would you say it is possible - I think you have said it is possible that if both flaps were down and the pilot endeavoured to bring them up, and this cable were broken, it is possible for one flap to come up and other flap to remain down?

- Yes.

Wilson did not mention that he had personally examined the wreckage on the day of the crash and had seen for himself what there was left to see of the flaps. He asked no questions of the next two airman witnesses - Corporal Dines, the instrument maker, and ACl Bardwell, the electrician - who described their inspections and conclusions that they found nothing amiss. But he returned to flaps when Corporal Mortimer Ewing, trained as a rigger and now a fitter with 2A Survey Flight, took the stand. All of the Service witnesses from Laverton had been examined in camera to this point. But at 11.05 a.m. the proceedings were resumed in public to hear evidence about events at Essendon. When the last of the Essendon witnesses had been heard, Corporal Ewing was called. He had asked to give his testimony in Melbourne although he was stationed at Canberra. Whether by accident or design the Court remained open to the public and the press.

Ewing was questioned in detail about his observation of the aircraft as it flew over Canberra aerodrome and then descended. However, Wilson's interest was elsewhere. He wanted Ewing to explain to 'His Honor' what a swage joint was, 
and then say whether it would be regarded as a serious defect if the wire started pulling away from the cylinder which surrounded it. 'It could be.' What if it pulled away one-quarter of an inch, would it be likely to pull away the whole distance? 'Once it broke the joint it would be absolutely useless.' There was to be nothing more from Ewing on this subject. And Dean had no more evidence to offer in Melbourne. But Wilson now had the ear of Lowe, who invited him to indicate 'a class of evidence which he thinks may be useful, and which it may be possible to obtain here'. What we want, Wilson said, is 'technical evidence which will show the effect on a Lockheed aircraft when the cable connecting the flap hydraulic gear comes apart'. Lowe put the request to Dean in his own words:

...the point involved is whether where such an event as that happens you may have one flap which will operate and the other will not. I desire to have the information, so far as it can be got, as to what would be the effect on the behaviour of the plane in such an event.

\section{Flap puzzles}

Lowe wanted answers before he left for Canberra. He had heard Ryland talk at length in the morning about tests he had carried out with Freddie Thomas on the aircraft's stalling proclivities. ${ }^{9}$ But Ryland could not help with the 'remote contingency', as Wilson had put it, of one flap up and the other down. Flight Sergeant McGowan, the A Flight senior NCO, was in court. He was a rigger - one of the first to spend time at Richmond with Ryland and the Lockheed team - but could not be expected to answer complicated questions about what the plane might do in flight. At 12.20 p.m. therefore Dean was on notice to produce an expert witness when the Court was due to resume in just under two hours. Wilson suggested that Air Force Headquarters might be able to supply the evidence required. Headquarters, in the person of 27-year-old Squadron Leader Ernie Hey, could help. Hey, who had completed a two-year 'long engineering' course with the RAF, was the staff officer in charge of airframes in the Directorate of Technical Services. His superior, Wing Commander Colin Henry, who had preceded him on the RAF course, had no hesitation in nominating him. Summoned to explain how the flaps worked, Hey gathered a manual and drawings, and was driven at speed to face the waiting Court. Arriving breathless, and admonished for being late, he was sworn in, and a 40-minute grilling began. The Court was closed to the public.

9 Ryland with Thomas alongside in A16-34 spent 55 minutes on stall tests on August 20 (Ryland, Flying Log Book, 20 Aug.1940, Ryland MSS, NLA MS5020 Box 1). 
Asked at the outset whether he had any knowledge of the design and construction of Lockheed Hudson bombers, Hey answered cautiously, 'Some — very little as yet.' Undeterred by Hey's next qualified response - he could speak only 'generally' as to the means by which flaps on the wings of Hudsons were raised and lowered - Dean and then Lowe pushed on. To each query the young engineering officer gave careful answers, providing a little more detail but consistent with Corporal Roffey, until he too came to the limit of his knowledge. He did not know if there was an indicator for each of the flaps. But, as Wilson immediately pointed out, it was immaterial because:

one flap being down and the other flap up would cause such a movement of the aircraft that it would dive down very very suddenly, and the pilot would only have, perhaps, two or three seconds to make any correction that was necessary. He would be still thinking of what was wrong rather than looking at his flap indicator to see whether that was the cause of the aircraft behaving abnormally.

Hey agreed. Then, to Hey's surprise, Wilson opened up another line of enquiry. Wilson had heard Corporal Ewing say that he had seen the aircraft at one point on its back. Ewing had shown with the aid of models what he thought he saw. Wilson now tried to connect this observation to the position of the flaps. If one flap was fully down and the other fully up, would that cause the aircraft to turn on its back? Not necessarily. Would it be liable to do that? It would depend on the difference in stalling speeds with flaps up or down. Hey explained how it would be possible for one mainplane (wing) to be near stalling speed while the other was not. But Wilson evinced little interest in the question of stalling. What he wanted to know was whether the aircraft would have turned on its back. Again Hey disappointed him: 'I cannot say.' Eventually Hey would agree that with one flap up and the other down it would be possible for the aircraft to partially roll while continuing in the same direction.

In what felt more and more like an interrogation, Hey remained cool. He would not be rushed. The Court transcript omits a frosty exchange that occurred when he took a little time to respond to what he characterised many years later as 'badgering'. 'Answer my question! .... I'm thinking. When I've finished I'll answer you. ${ }^{10}$ When Wilson switched to questions about swaging he was again frustrated. Asked to describe how swaging was done, Hey told him he 'could not answer that accurately'. Determined, Wilson demanded first that the process be described 'generally'. There followed a dialogue about swaging, clamping, and sweating (using solder), leading to the conclusion Wilson seemed to be seeking:

10 AVM E. Hey, interview, [20] Aug. 1977. 
Would you say when the wire has been disturbed in its position, pulled out even slightly, that that is a dangerous fitting from the point of view of aircraft; that it is liable, in other words, to pull out?

— On Air Force standards, yes; but it might still be strong enough.

Has it come to your notice at any time that that has happened?

- Not officially.

Lowe's interest was aroused by the revelation that something that an RAAF Group Captain was indicating might be 'dangerous' had not been the subject of an official report. Wilson then asked specifically if any wire had been pulled out of a swaged joint 'to a certain extent'. Yes, Hey said, but he could not say which wire. 'Would you consider that good engineering practice - that type of joint?' Hey was reluctant, even in camera, to be drawn into an implicit criticism of RAAF practice. 'I do not think it is for me to say.'

As the afternoon wore on, the exchanges between Wilson and Hey, who had missed his lunch, became increasingly testy. Providing his opinion about the merits of swaging to an insistent interlocutor, Hey said that it was not as good as splicing 'used in the R.A.F., and normally used under British specifications'. Then, given an opportunity by both Lowe and Dean to add to what he had said about flaps, he was resolute: 'only if there is anything else you want me to say'. Well then, Dean asked: did he know if there was anyone in the Service who had a more precise knowledge of the operation of the flaps in the Hudson bombers? An exasperated Hey responded: 'To get precise knowledge you would require blue prints and technical books on the subject. I could do that myself. I have a blue print here at the moment, but I doubt whether anyone would understand it.' Hey began to unfold the drawings he had brought, at which Lowe, sensing that Hey was right about the Court's capacity to grasp the technicalities, held up his hands in submission. Dean then took a different tack. Did Hey know of anyone who had 'practical working knowledge...from a constructional point of view' who could give evidence on the working of the flaps?' 'If you ask me questions I will give the evidence,' Hey retorted.

Lowe was intent on doing his best to make sense of what he had been hearing. If the stalling speed would differ depending on whether the flaps were up or down, how, he asked, would one ascertain the stalling speed? Answer: by practical flying experience. Could Hey estimate stalling speeds? The actual stalling speed - which would differ from the theoretical — could best be given by pilots. Wilson came back to the puzzle over what he now called a 'half turnover' of the aircraft. At full power you could turn the machine in a roll without losing height, he opined. But how much height might be lost when coming in to land with a small amount of power, and the wing coming down and the aircraft 
then turning entirely on its back? Hey could not say: 'there would be too many factors involved'. Appreciating the unwillingness of Wilson, the senior RAAF officer present, to accept how little was known, and realising that he was the best informed person in the room, Hey chanced his arm:

I feel it would be rather difficult to find anybody to give that information, because that is a manoeuvre which is an extraordinary one so far as this aircraft is concerned. In no circumstances would it be put on its back; it is not the type of aircraft for that...In my opinion this machine would not have turned on its back at that height.

Asked by Lowe if he could give reasons for this opinion, Hey explained that, assuming the flaps were up and the mainplane stalled, the machine would have a tendency to roll in the direction of the stalled wing. But, in rolling, the aircraft would also sideslip, and the air pressure on the keel surface would cause the machine to turn in the direction of the stalled wing: the machine would probably go into a spiral glide. Again Wilson pushed the scenario of one flap up and one down, and neither wing in a stalled position. In that position would the machine turn on its back? 'No, Sir.' The extra lift given by the wing with the flap down could be partially corrected by the aileron on the un-stalled wing. Hey reiterated that in his opinion the circumstances outlined by Wilson would not cause the machine to roll on to its back.

A bewildered Lowe sought clarification: 'Do I take it from you, Squadron Leader, that before any roll of the machine on to its back could take place there must have been a stalling of the machine?' 'No, Sir. There must have been force to cause it to roll, which may be other than the forces produced by stalling.' Could Hey suggest any other possible cause which would cause it to roll? By this time Hey was almost at the end of his tether: 'No, Sir, because I am not suggesting that it did roll.' Troubled by the conflict of Hey's advice with the eye-witness testimony of Corporal Ewing, Lowe asked if Hey had read or heard Ewing's evidence. 'Not fully.' At which Lowe then read out what Ewing had said and asked if it conveyed anything to the expert witness about the cause of the crash. The question was broad. The answer was unequivocal: 'It does not suggest any cause that I can put forward.' To the narrower question of whether he thought at some stage one flap was up and the other down, the answer was an emphatic 'No. Sir.'

Lowe pressed on. Could Hey think of any cause for the port mainplane slowly to dip, without losing height, and then after four or five seconds slowly turn completely over on its back? Not at the height the witness had indicated - 500 feet off the ground. Ryland had said as much the previous day. At a loss about how to gain further elucidation, Lowe tried one last open question. Did Ewing's description 'induce you to make any comment at all?' Hey was not to be drawn. 
But he offered a glimmer of hope: a pilot could comment on the possibility of these evolutions occurring at that height. Wilson knew that no RAAF pilot had ever done it. He made one last plea to the engineering officer who had given him no comfort: 'You have no theory to advance as to why that machine went on to its back? 'No.' 'Would you say it is improbable that such a thing did happen?' 'I have already stated that in my opinion I did not consider it could have rolled on its back.' That being the case, Lowe concluded and Hey concurred, Ewing's account must have been 'inaccurate observation'. The Court having 'exhausted its questions on this subject', the judge looked hopefully to counsel representing the RAAF. George Pape could not assist. Lowe turned one more time to Hey to ask if there was any officer who could express an opinion on whether Ewing had given 'possibly an accurate account or certainly an inaccurate account'. Even now he was to be disappointed. No, Hey told him, opinions vary, and his own was 'just a theoretical opinion which I have formed'. It was, he concluded, a matter of a theoretical opinion against the statement of an eye-witness who probably, 'in all truth, considers that is what he saw'.

Hey did not volunteer the information that, just over four years earlier, he had been one of Hitchcock's advanced-flying instructors. Nor did he offer his opinion that the Point Cook training was so strict that it was implausible that Hitchcock would have stalled the Hudson.

\section{'Obscure reasons'}

The Court adjourned at 2.55 p.m. and Lowe's entourage set off at 6.30 p.m. on the Sydney train from Spencer Street Station. They would complete the journey to Canberra at 8.00 a.m., travelling by car from Goulburn. Before the Court opened at the Patent Office Building at 10.55 a.m. the judge, the two assessors, and counsel drove out to inspect the crash scene. Less than 20 hours after they had finished their proceedings in Melbourne 'Del' Wilson, now armed with a length of cable, would resume his quest to verify Corporal Ewing's description of the aircraft on its back. In questioning Ryland the day before, he had reflected that until then there had been 'no evidence at all as to how this thing might have happened'. That being so, it was necessary to look for 'obscure reasons'. To the first witness, Pilot Officer Winter, who had described his view of the aircraft 500 feet from the ground, he asked: 'You saw no suggestion of it turning on its back?' 'No.' Not satisfied with Winter's answer, Wilson asked if it could have happened without Winter seeing it. 'Not from the position I was in, unless it happened later.' 'After it passed from your view?' The most that Winter would concede was 'Possibly, I could not say.' Nor could he say definitely where Corporal Ewing was standing. However, when told that Ewing was near the OC's former office, he said that would not be far from where he was. Asked to 
indicate their relative positions on Exhibit 9, the map of the district, Winter helpfully pointed out that, given the scale of the drawing (20 chains to an inch), the same position would do for both. A chain was 66 feet. The two men were about 20 to 30 feet apart. The map being therefore of no help, Lowe stipulated that their angle of vision would be the same. ${ }^{11}$

Flying Officer Ronald Wilson could add nothing; he had watched the aircraft for only a few seconds and noticed nothing unusual apart from a slight wobble that he later concluded might have been a trick of the sun. The fact that Wilson had been in the Service for only eight months, and was an accountant not a pilot, was not mentioned. ${ }^{12}$

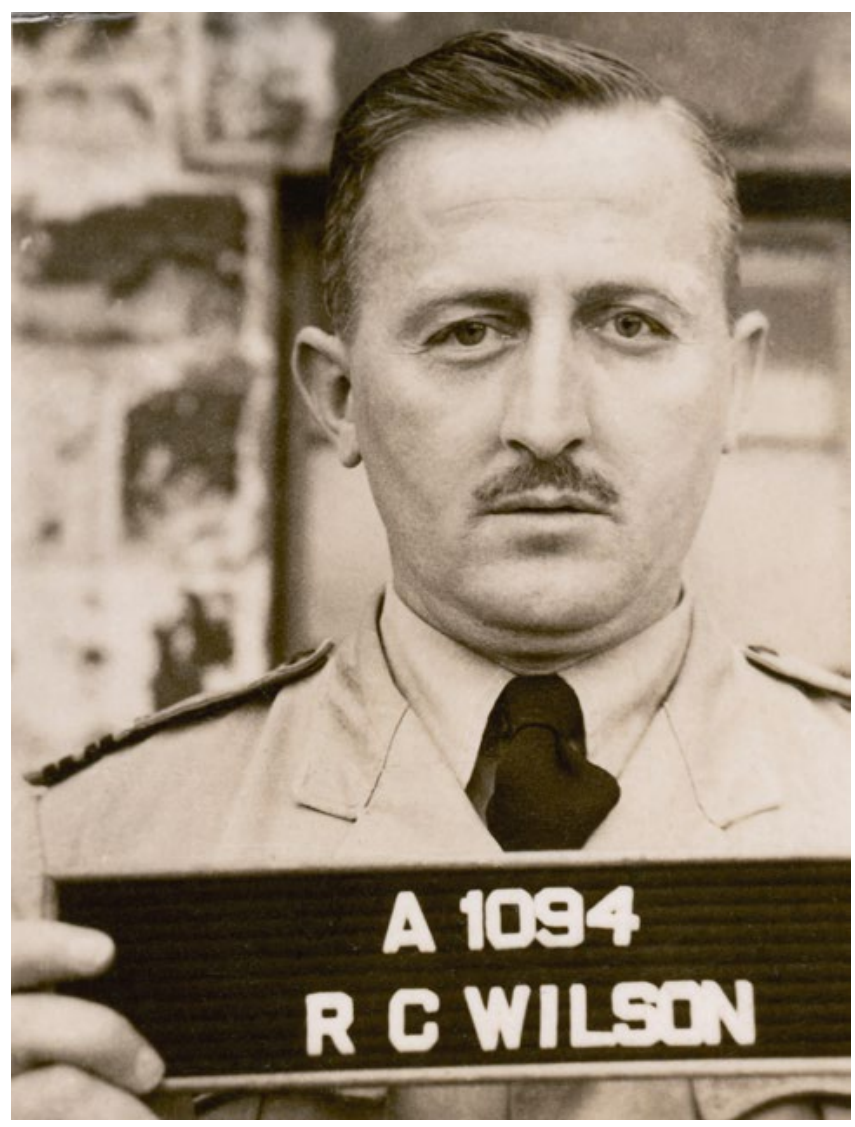

F/O Ronald Wilson: 31 years old, new to the Air Force, claimed to be the first man at the crash scene

(National Archives of Australia: NAA A9300 WILSON RC)

11 The map was $75 \times 105 \mathrm{~cm}$. Scale 1:15,840.

12 NAA: A9300, WILSON RC. 
Standing at the end of the aerodrome, Flight Sergeant Smith saw more. He had seen the aircraft make a 'complete roll' after which the port wing dropped. With a model in hand, Smith showed how he was facing east, the machine came across his line of vision travelling north, and he could see the flap down on the port wing. One after another Dean, Lowe, and Wilson, dissected Smith's memory. Had he discussed his observations with Ewing? No, he had not even met Ewing until after he had been interviewed by Murphy. It was his independent recollection, and he was not mistaken. It was not, as some 'flying men' had suggested to him, that the aircraft had tilted slightly as it came in. It definitely made 'a complete roll'. He was satisfied that 'momentarily' the machine was on its back with its wheels up. Although others thought they saw the aircraft coming towards them, he was sure that it was practically at right angles to him. From where he was standing it would, he conceded, be difficult to say whether the machine was slightly on the turn or was flying straight and level to the north. He had watched other aircraft coming in since the accident, and now thought it was possible that it could have been 'slightly on the turn in preparation for landing'. He had never seen a similar machine do a similar manoeuvre, or seen another aircraft on its back.

Having finished with Smith, the Court swore in Sydney Rhodes, the senior aerodrome attendant. Rhodes, now repeating his story officially for the fifth time, had lost sight of the aircraft briefly when the hangar came between them. But he was sure he had seen it gradually descending, with under-carriage down, in a normal gliding motion as it came towards the last hill. Then, he remembered, he had exclaimed to someone standing nearby: 'Good Lord! This 'plane has lost considerable height.' In answer to Wing Commander Carr's leading question, he was explicit that he had not noticed a sudden drop of the aircraft's nose. Losing sight of the Hudson as it was coming across the nearest hill, he was uncertain initially if it had cleared the hill. 'Sometimes a camouflaged 'plane will come over the crest of that hill and be obscured for a few moments in the shadows of the trees, especially if there are any clouds.' Asked what interval there had been between losing sight of the aircraft and hearing the crash, Rhodes said he could not have taken more than three or four steps. He had not realised where Arthur Dean was heading.

Would it not have been ten or fifteen seconds?

- Oh no.

But you did say that at the Service inquiry - that it took ten or fifteen seconds between the time it disappeared and the time when you heard it crash?

— That would not be so. 
Why did you say that?

- I have thought it all over since, and ten or fifteen seconds is a long time for that sort of thing to happen.

In revising your evidence, or in thinking it over since, have you had to reconsider any other parts of it?

- No.

But in that part of it you do think that you were wrong?

- I must have been wrong. I feel now that it could not have been that long.

Dean had followed the lead of Lowe in subtly undermining Rhodes's credibility. Lowe had earlier sought reassurance that the aerodrome attendant's recollections had not been influenced as a result of subsequent conversations with others who had been alongside him. Rhodes admitted he had talked to others - 'it would naturally be discussed by those who saw it' — but denied that they had caused him to change his mind. Henry House, who was next to be questioned, had also spoken to others before he made a statement on August 14. He was not sure who they were other than that they were 'flying officials from Melbourne'. Having established that House had only been in the Service six weeks, had not seen a wing dip nor seen the plane turn or roll with the nose up, the Court excused him.

The memory of Dudley Lalor, whose graphic accounts had been published in the immediate aftermath of the crash, was next subjected to fine-grained scrutiny. A sceptical 'Del' Wilson elicited the admission that, from the moment he saw the Hudson through his windscreen, Lalor continued to drive for a quarter of a mile down a slope without taking his eyes off the aircraft. Dean helpfully drew out the fact that Lalor was driving on 'a good wide open road' with no other traffic. There was no special reason to be watching the plane, Lalor said, until he observed that it was 'so low that it might strike the hill in front'. When he saw the wing dip he drew his friend's attention to it. 'What did you say to your friend? - I could not say...' Grasping for a version more suitable for the courtroom than those he had given to the press, he added: 'I may have said, "Goodness Jack, look at this 'plane" or something similar.' Tilyard, who followed Lalor, confirming that his boss told him to 'Notice that 'plane, how it is carrying on', said he saw the aircraft about 200 feet above coming down towards the ground 'spiral like'.

What more could be said about the flaps? At the crash site, Winter had seen on the starboard wing that they were 'flapped about 80 per cent' — the rollers had travelled about $1 \frac{1}{2}$ or 2 inches. It was not possible to say anything with certainty 
about the flaps on the destroyed port wing. And he could not say whether the flaps had been down when he was looking at the aircraft on approach. Nor could the civilian aerodrome manager Rhodes, who thought he would have seen them if they had been lowered when the aircraft flew around the aerodrome. The oil company manager Vest, the garage mechanic O'Brien, the railways clerk Power, and the market gardener Southwell, did not know if the flap extensions were down. And there the puzzles about flaps, and the aircraft possibly rolling over on to its back, were abandoned. Dean had no more evidence to offer. Pape had no evidence to advance on behalf of the Air Force.

Wilson's widely reported cable queries had shown only how little was known about the design and construction of the Hudson. His tenacious pursuit of a theory that could not be proved appears consistent with Jack Graham's memory of him as 'a most peculiar bloke, most erratic fellow... he was quite unpredictable'. Joe Hewitt, who knew Wilson well, described him as an introvert. 'He was,' Hewitt remembered, 'a violinist of some ability, and would often lose himself in playing a wealth of classical music.' But, as the Air Court demonstrated, he would not remain in his shell when circumstances permitted his forceful presence. As John Harrison remembered, when Wilson became a POW and senior British officer in Stalag Luft III, someone who had either 'served or suffered' under him remarked: 'God help the Germans.' ${ }^{13}$

With Wilson's inquisition at an end and the last of the witnesses examined, Lowe's main task was about to begin: how to reconcile the conflicts of eyewitness testimony and expert advice, and construct a credible explanation of the tragedy. Without pausing for a moment, he enquired whether counsel assisting proposed to address him 'at this stage'. Dean, exhibiting little enthusiasm, indicated that he was prepared to do so 'if the Court desires'. 'I shall,' Lowe responded, 'require all the assistance I can obtain.' With newspaper reporters poised to take down his words, Dean looked to notes he had evidently prepared overnight, and began a compact summation of the evidence heard in Melbourne.

\section{'An absence of the knowledge of the behaviour of planes'}

Prudently, Dean prefaced his remarks by the admission that 'many aspects of this accident have not been sufficiently established'. Affirming that 'the pilot was a competent and experienced officer and one who has specialised in this

13 GpCpt J. E. Graham, interview, 11 May 1978; John Harrison to CH, 25 July 1978; Hewitt, Adversity in Success, pp.297-8. Wilson was awarded a Czech MC for risking his life in 'fearless and extremely courageous protests to the German officials', saving many Czech POW's lives in Sagan (NAA: A9300, WILSON DEL). 
type of plane', Dean noted that Hitchcock had visited the Canberra aerodrome previously. Lowe interrupted, saying that his recollection (probably from reading Hitchcock's flying log book) was that the pilot had been to the Canberra aerodrome only once before. Dean agreed with Lowe, slightly confusing the issue by saying that Ryland had landed his own plane on that occasion, 'quite successfully'. Then, in an apparent contradiction that suggests that the Court stenographer misheard, he added that 'the pilot', meaning Hitchcock, had been to Canberra the previous week with a load 'similar to that which he had when he took off at Essendon'. This of course was the flight that Bill Heath, not Hitchcock, had captained. Hitchcock and Ryland had both flown from Richmond to Canberra on July 24. It was Hitchcock's only recorded landing there. (The errors were not repeated when Lowe presented his findings.)

Extemporising from then on, and possibly having benefited from some private coaching from Ryland, Dean dealt with 'the manoeuvre described as a flat roll... extremely improbable and difficult to execute'. In determining which accounts were to be accepted, he said, the Court will 'have in mind the evidence given by experienced pilots'. 'What probably happened,' he went on, 'was that those observers who said that they saw the plane on its back saw it with its nose down and turning which would give it the appearance of being on its back.' Lowe agreed that the opinions of 'experienced men' should be a good guide. But he was not ready yet for a conclusion. Would it be convenient to discuss the alternatives - one assuming that the plane did roll and the other that it did not? 'It would be, except', Dean confessed, 'that I find some difficulty owing to an absence of the knowledge of the behaviour of planes.' He reminded the Court that several witnesses had excluded the possibility of a roll but had advanced theories of what might have happened if the aircraft had 'gone to the earth turning as it went'. Thus the way was opened for the RAAF assessors, Wilson and Carr, to furnish the judge with unchallenged advice when he retired to consider his findings.

Lowe had been told, although he acknowledged it was not in evidence, that 'misfortune has overtaken two other aircraft of the same type'. Would it not be possible, he asked, to get the findings of the Service Courts on these two 'incidents'? In one of his rare interventions on behalf of the Air Force, Pape volunteered that the report on the loss of a plane of which no trace was found could not get the Court much further. Stating the obvious about the disappearance over the sea of A16-27, Pape only intensified rather than diverted Lowe's interest. There might, the judge thought, be something in the reports which would have a bearing on some of the 'features disclosed in this case'. If that were so, further investigation would be necessary. Lowe's instinct was 
right. The findings of the A16-27 Service Court would have led him to ask further awkward questions; but the report would not be available in time for him to see it. ${ }^{14}$

The immediate issue was what should be done about the evidence relating to the machine rolling on to its back. Dean was unable to assist further. Asked by Lowe if counsel would like him to reject the evidence, Dean responded that inviting the Court to do so might be presumptuous on his part. Conscious no doubt of the presence of reporters, Lowe said he saw no reason to challenge the honesty of the witnesses, but asked if Dean would like him to reject their evidence as 'inaccurate observation'. That afforded a way out; this was Dean's view of the matter 'for what it is worth'. Pilot Officer Winter's evidence was to be preferred to that of other witnesses, he added. As for Hilton Clothier's story of flames coming over the starboard wing, it was uncorroborated: the fire Clothier saw was 'nothing more than flame coming from the exhaust in a more or less normal manner'. At this point Dean advised the Court that he felt he could not usefully discuss the other witnesses' accounts without having the complete transcript of their evidence. But, with the press as well as Lowe anxious for guidance, he ventured:

Generally speaking the conclusion to be deduced from the evidence is that the 'plane, as it turned from the east towards the Aerodrome, either while it was turning or just afterwards, was, up to that stage, prepared to make a normal landing. Then, for some reason, its left wing descended and kept on descending. The nose eventually started to go down and the 'plane turning over two or three times went to earth nose first.

Before anyone could query Dean's description of the aircraft turning over two or three times, Lowe attempted his own summing up of 'three views' that had been put to him. Flight Lieutenant Ryland, he said, had suggested two: an error of judgment by the pilot and the failure of the engine. In fact, Ryland had never spoken in so many words of an error of judgment by the pilot. The first of the two suggestions he had countenanced was a stall. In Lowe's mind therefore, in the absence of any other acceptable explanation, a stall had become synonymous with an error by the pilot.

The third view, first offered by Group Captain Wilson, was that one of the 'landing flaps' might have been up and the other down, bringing about abnormal pressure creating a 'position of emergency which ultimately resulted in the crash'. Lowe asked if Dean wished to address him in regard to any of these 'alternative theories'. The statement that followed was an extraordinary and revealing departure from what had gone before:

14 NAA: A705, 32/10/2830, and see Chapter 25. 
The Court has committed to it the duty, if it can, of finding the cause of the accident. As I understand the evidence there is nothing to justify the Court in holding that any suggested cause was the actual cause. One might approach the matter by a process of elimination. I suggest that one might very easily omit such a consideration as sabotage or any suggestions that the plane was not airworthy or was overloaded, or the view that some other person than the pilot was piloting the aeroplane.

Dean's last point had never been raised directly in the course of the witness examination. None of the RAAF experts had even hinted that they thought it was possible. However, both Dean and Lowe now took pains to repudiate summarily what Lowe hastened to describe as 'pure speculation'. Hurrying on, Dean gathered his thoughts:

The 'plane itself being airworthy, the pilot being competent, and the day being fine, and no other reason being advanced, the pilot experts say it still might have been due to any one of a number of causes. One witness said a thousand causes.

Counsel was beginning to flounder. Lowe reminded him that the witness (Ryland) had finally selected two causes that were the 'least improbable'. 'On the other hand', Dean rejoined, the possibility of a control wire breaking could not be discounted even though there was nothing to indicate that the wires were not strong and in good order. 'The question is whether we can get out of the realm of speculation and enter certain ground on which the Court can say "This is probably what caused the disaster."'

Dean was emphatic that there was no evidence to be obtained from the wreckage. His next two sentences were crucial:

As to the three causes advanced, the first was that it was a stall, that the pilot miscalculated his speed and that it fell below his proper air speed. That would appear to the layman to be the most feasible explanation.

Squadron Leader Thomas had said that the manner of the descent was consistent with a stall. Both Thomas and Ryland had testified that an engine failure might have caused the 'mishap' but that they thought it unlikely. 'The pilots are obviously most hesitant to suggest that the accident was due to a stall or to loss of air speed.' Ryland in particular had expressed doubts, some of them perhaps off the record. Thomas gave the impression of a man keen to appear more knowledgeable than he was, but unwilling to pin blame directly on one of his own pilots.

Lowe seemed happy to embrace the conclusion that the evidence was, as he interjected himself, 'overwhelmingly against' the failure of an engine. The only 
remaining suggestion, Dean said, was the failure of the flaps in one of the wings. This was a possible theory but there was no evidence of 'any defect or that any of the wires were pulled away'. By process of elimination, Dean was groping for a conclusion:

There being no other theory, the Court is in the position of having to say that it adopts as the most probable cause of the accident, the stalling of the engine, or that it is unable to say what caused the accident...

Here, Dean himself stalled. In his book Air Disaster Canberra, Andrew Tink rightly observes that Dean appeared at this point to be under the 'fundamental misapprehension' that the stall of a plane was like the stall of a motor vehicle. ${ }^{15}$ Only moments earlier Dean had correctly referred to a miscalculation of air speed; and Lowe himself had then rejected the idea of engine failure. But Dean's previous glimpses of understanding now seemed to desert him. Evidently he was troubled that he was not competent to make a judgment that rested on an understanding of technical matters of which until 48 hours earlier he had been entirely ignorant. Lowe, equally ill-equipped, knew that lack of expertise was not going to relieve him of the task he had undertaken. 'The Court which has to determine this matter', he reminded counsel, 'is no more expert than yourself.' Although he had highly expert advice at hand, the value of which he greatly appreciated, 'I have ultimately to accept the responsibility of arriving at a decision.' Still, however, Dean was reluctant to go further. Having regard to the 'assessors of experience' available to the judge it would be 'a waste of time', he said, for counsel to discuss the possibilities surrounding the stalling of the engines. The choice was clear. If Lowe could not say that stalling of the engines caused the accident he would 'probably be forced to the conclusion that it not possible to say what caused the crash'. There was, however, something to be welcomed about the point they had reached. 'All other possibilities have been excluded, and, from the point of the view of the public, that gives some ground for satisfaction.'

So much of the Inquiry had been held beyond the gaze of the public that Dean's final remarks were sure to be seized upon by the reporters present:

Suggestions of sabotage, improper maintenance or inspection, which may have found some foothold in the public mind, have been displaced by the evidence given in this case. I think that the Court can confidently say that there is no reason to suppose that the aeroplane was in any way other than airworthy, or that the pilot was not completely competent to handle the machine. In the final analysis, that means that the Court must determine for itself whether it can say that the accident was due 
to the stalling of the engine, or that it is not able to say what caused the accident, but that various suggested causes can be eliminated, and that while it is impossible to say what was the real cause, the most probable reason was a stalling of the engine.

There, having inadvertently erected an obfuscatory signpost for the judge, Dean rested. 'I am unable to add any further observation which may be of assistance to the court at this stage.' Then, remembering a point he should have made earlier, he directed the Court's attention to Flight Sergeant Smith's testimony that he had seen the port flap down. The evidence showed that it was the starboard flap that was down.

Apart from the lapse into the language of engine stalling, what was most striking about Dean's final summation was the absence of any explicit discussion of pilot error. The Court was directed to the probability of the engines stalling. But both engine and hydraulic failure were ruled out; and there was no other consideration of what might have caused the engines to stall. Dean's confusion could not be disguised. His words a few minutes earlier were crucial. He had in effect provided a gloss on the meaning of a stall - it was the pilot miscalculating his speed. For Charles Lowe there remained the task of reporting what could be 'found' from what he had heard. The Court's findings must be consistent with the balance of the evidence, coherent, logical, and technically credible.

\section{Instruction from Dallas Scott}

Arthur Dean's work was meant to be finished when the Court adjourned. But he was not idle over the next weekend. Some copies of the English magazine The Aeroplane had come to Lowe's attention. They contained details of the crash of a Lockheed 14 in Britain which he felt could not be ignored. Lowe, struggling with the expert testimony he had heard, was perhaps befuddled by Dean's conclusions about engines stalling. He realised that he ought to take advantage of the belated availability of the highly respected Squadron Leader Dallas Scott. Freddie Thomas had been of limited assistance. Ryland had been reluctant to speculate. Of the two assessors, Tony Carr knew the inside of a Hudson but had asked almost no questions. 'Del' Wilson had a lot of questions to which there were few certain answers. Both Ryland and Thomas were now to be brought back for another session during which they would hear Scott put through the same range of questions they had faced the previous week.

The court re-convened at 2.15 p.m. on Tuesday, September 3. Once again, appearing for the RAAF, George Pape had instructions to advise the judge that the safest course would be hear all the evidence in camera. The questions likely to be raised 'cannot properly be answered by pilots without discussing the 
performance of the particular type of aircraft, and the view of the department is that any discussion of the performance of the aircraft is to be deprecated'. Lowe was 'very ready to lend an ear to any suggestion that evidence that may possibly affect the safety of the country should be taken in camera'. Pape assured him that this was the nature of his instructions; accordingly the public were excluded. Once again the judge had been subtly misled. It was the Air Force, not the public servants in the Department of Air, that had given instructions about what should be kept from the public.

Lowe began with some basics. What was the relationship of the Lockheed 14 which had crashed in England to the Lockheed Hudson bomber that had crashed at Canberra? Scott knew from The Aeroplane, which he had read the day before, that the crashed Lockheed 14 was an older type without slotted wings. The circumstances of its accident were different, and he could not see that it would throw any light on the fate of A16-97. Wilson then initiated a discussion of stalling speeds, which led Scott to explain that stalling would depend on the degree of bank and the rate of turn. At 20 to 30 degrees of bank the stipulated speed was 113 knots; this would give a considerable safety margin. Wilson's next question was embarrassing. With flaps down, say 70 per cent flat and 30 degree bank, what would be the stalling speed? Somewhat incredulously, Scott asked: 'During the turn?' The tone of Wilson's subsequent 'Yes?' was captured by the stenographer's question mark. 'It is not our custom to turn the aircraft at all with flaps down', Scott said.

But they do turn aircraft with flaps down. They do turn Lockheeds with the flaps down. It is not your practice here in Victoria?'

- No.

Do you know if it is the practice in N.S.W.?

- Not to my knowledge.

Flummoxed by his own ignorance, Wilson was silent for some time. Lowe and Dean continued with questions about the stalling proclivities of the Hudson, drawing from Scott the unequivocal statement that 'in the ordinary way of handling it' the aircraft was not liable to stall without warning. The only stalls he had experienced had been deliberate. There was nothing to be learned from the very different circumstances of the Richmond accident. But Lowe and Dean were eager to get Scott's opinion of the cause of A16-97's crash on the basis of the Canberra eye-witness evidence. Unfortunately he had not read the complete transcripts. Dean attempted a quick summary: 
Assuming that the machine tilts on its left wing....and quite suddenly it goes into a dive, turning once or twice, to the ground from a height of 400 or 500 feet, can you advance any theories as to why an event of that kind would occur...?

Scott was slow to offer an opinion. Lowe then had the evidence of Pilot Officer Winter read to the witness and invited Scott to suggest 'any cause of what happened...the most probable cause'. If he had hoped for a straightforward answer Dean would be disappointed.

The actual description could cover several contingencies, I would say.

All equally probable, would you think?

- Yes I would say it would be very hard to discriminate between any of them.

What contingency do you suggest? - even such an event as the pilot losing consciousness, the pilot falling forward gently on to the control column and at the same time possibly depressing the left rudder.

You mean as the result of loss of consciousness?

- exactly...

What other contingencies could Scott think of? The possibility that the rudder was in some way applied to the left and the pilot being unable to release it would give a 'banking and turning tendency' coinciding with Winter's description. So too would a jamming of the aileron - 'the lateral control', Scott explained, 'jamming one wing down. If the wing were not able to be brought up there would be a tendency for the aircraft to sideslip to the ground and turn simultaneously.' There was another answer the Court wanted to hear. 'Any others?' Dean asked. 'The possibility of a stall is present.' Seizing on this, Lowe asked whether this meant that the machine was being 'flown with an insufficient safety margin of speed'. It would, if a stall occurred, Scott parried. Lowe pressed: 'it is on that contingency I am putting it to you'. Then, yes, it would 'indicate that the aircraft had become slow'. 


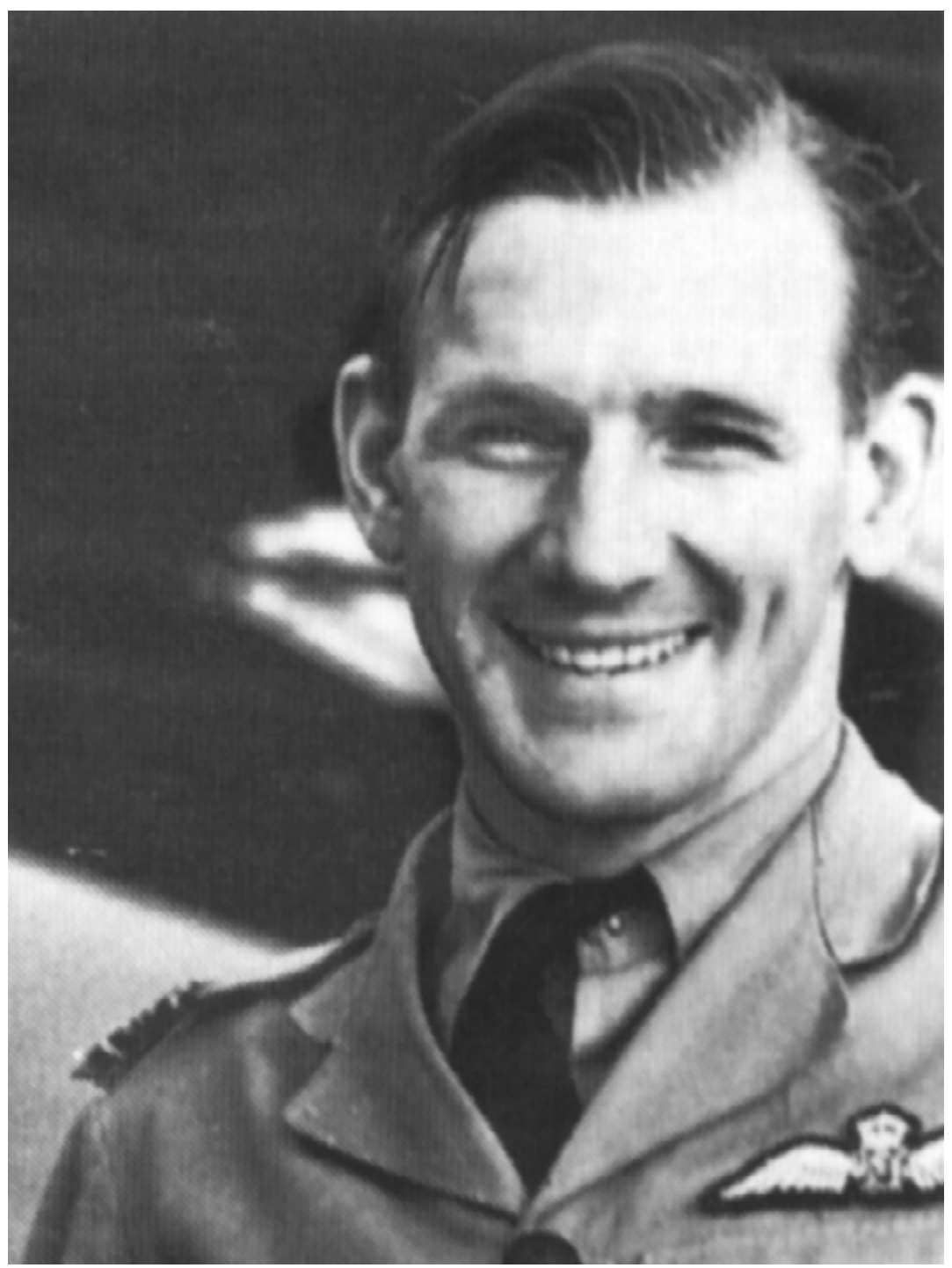

\section{Dallas Scott: no-one in the RAAF knew the Hudson better}

(Courtesy of the Office of Air Force History)

Scott could not deny the logic linking the speed of the aircraft to a stall. But he seemed chary about saying directly that the pilot of A16-97 had erred. In referring to a possible loss of consciousness he was echoing what Ryland had said. At this point Dean stumbled. If the pilot had lost consciousness and was otherwise 'unable to control the machine...I do not think that this has been dealt with yet: is this machine dual controlled?' Some are and some are not, was the best Scott could say. He was unaware if A16-97 had dual controls. Neither Dean nor Lowe remembered that it was already in evidence that the crashed 
aircraft had dual controls. What they did know was that the only person on the Hudson qualified to fly it was Bob Hitchcock. The matter was dropped and the questioning turned to the issue of flames being seen as the aircraft descended. Here Scott seemed sure that whatever might have been seen or heard it was most likely to have been caused by a sudden opening of the throttle causing a backfire through the carburettor intake. There would be a momentary flash of whitish orange flame accompanied by a loud sharp report like a motor car backfire.

From this point the Court could neatly segue to a discussion of stalling. If the motor had suddenly 'opened' resulting in momentarily insufficient fuel supply, a lean mixture, and a resultant backfire, it suggested that the pilot was conscious and trying to get his machine out of trouble. If he found his machine falling to earth it would, Scott said, be a 'natural reaction' to open up his throttle quickly. There followed what amounted to a tutorial on the stalling experiments that Scott had conducted. Much of it reprised what Ryland had already spoken about. Scott described what he had practised at a height of 6000 feet or more. First a gentle stall with the engines fully throttled back and the wheel and flaps fully retracted; it took 400 to 500 feet before the pilot could regain control. Then with flaps and undercarriage retracted and a 'certain amount of engine power applied'; with $300 \mathrm{hp}$ the result was 'rather unpredictable... occasionally it will drop a wing and develop flick characteristics' and lose about 800 to 1000 feet before control was regained. Another possibility was a stall with flaps and wheels extended and engines fully throttled back; the nose would fall straight ahead and there was 'absolutely no tendency to drop a wing', and aileron control was maintained until after the aircraft stalled.

'Del' Wilson now re-joined the conversation. 'Have you never tried to stall the aircraft when the machine is banked?' If the Court did not appreciate the implication of the question, Scott's answer would have alerted the non-flyers: 'I have not stalled through misuse of the controls at all.' Unabashed, Wilson ventured his own answer. In such a case would not the tendency be for the left wing to go down further and the stalling become pronounced? With the caveat that he had not experienced it, Scott agreed that it would. Wilson tried another scenario: what if an aircraft coming in at just above ordinary stalling speed had one wing bumped by an air current that pushed one wing up? In that case, Scott explained, the tendency towards a complete stall would only be 'noticeable' if the aircraft was already almost completely stalled.

Lowe had his own questions. Supposing that the machine was on a straight glide towards the landing ground at 400 or 500 feet, with undercarriage and flaps down, and the machine stalled: 'would there be any possibility whatever of the pilot recovering control?' Again Scott chose his words carefully: '... if the stall had been complete, recovery would be extremely difficult'. Satisfied that 
it was the lack of height that was the critical factor, Lowe turned to 'flaps and slots'. His next question betrayed how little he had understood of the plethora of technical information elicited over the past week. He had read the articles in The Aeroplane and gathered that the editor thought that there should be 'certain safety devices, in the nature of slots and flaps, fitted to the Lockheed 14'. Patiently Scott explained that flaps had always been fitted; it was the absence of slots that was criticised. Wilson then intervened, revealing an astonishing ignorance of the distinguishing characteristics of the RAAF's principal frontline aircraft: 'Has the Lockheed Hudson slotted flaps?' Scott, who was arguably the Service's most knowledgeable Hudson pilot, was careful in the presence of an opinionated superior officer not to sound like a know-it-all. 'The Fowler flap, as I understand it, is a modified form of the slotted flap, inasmuch as there is a gap between the actual flap, which is an aerofoil surface in itself, and the trailing edge of the aircraft.'

With Scott's expertise increasingly evident, Pape now took the opportunity to put to him the troubling observations of Corporal Ewing and Flight Sergeant Smith about the aircraft turning completely on its back at a height of about 500 feet over the place where it ultimately crashed. Was this possible? Not from that height, Scott said: 'A large aircraft travelling at an initially slow speed cannot possibly, in my opinion, be rolled without a very considerable loss of height, running into possibly thousands of feet.' Pape, who had the advantage of participating in the Service Court immediately after the accident, now realised that Scott could provide authoritative advice about flaps as well. Since The Aeroplane articles had been written, Scott said, the Hudson had been fitted with built-in slots, sometimes called the 'letter-box' slot. At Pape's request he gave a short exposition of the difference between Handley Page 'slats' fitted on the leading edge of the main plane at the outboard end, and the Lockheed approach of cutting behind the leading edge slots in the main plane itself. He did not say that one of the reasons why Lockheed, then financially struggling, had developed its own solution was to avoid paying royalties to Handley Page for using their patented technology.

Lowe's understanding was rapidly advancing. Could Scott express an opinion on the respective stalling characteristics of the Lockheed 14 and the Hudson? The Lockheed 14 without slots, which Scott had flown, had different stalling characteristics. So the Hudson could be regarded as a completely airworthy type of aircraft in the hands of a capable pilot? Completely. But what, Tony Carr asked, would happen when you stall the aircraft with the flaps and undercarriage down and some power? Did Carr, who was a Hudson pilot, know the answer? Scott could only tell the Court from hearsay. He had never done it himself. But he thought a stall would be severe. At $300 \mathrm{hp}$ ? He could not be certain. What he could be certain of was that all pilots who flew Hudsons had been through 
a special instructional course lasting a month or so. What kind of experience was desirable for a Hudson pilot? The man with a background on various types, especially twin-engined machines, would be preferable. Was it desirable, before putting a man on a Hudson, that he should necessarily have had any length of experience in other types? Here Scott knew he was on delicate ground:

I think it is desirable. Might I qualify my statement by saying that hours, in themselves, do not form a background of experience, but people who have flown various types under all conditions are the people who can be most relied on to fly a modern aircraft competently.

Knowing how the demand for Hudson pilots was leading to the conversion of relatively inexperienced men, Scott was uncomfortable with a final question from Dean:

Is it possible to indicate whether the man who had about 100 hours flying in general types would be likely to be a competent pilot in all conditions on one of these Hudsons?

- On general types?

I mean your general training types. If he had perhaps 100 hours in the air altogether?

- I would repeat that he could be taught to fly the aircraft perfectly well under favourable conditions.

Scott's qualification - favourable conditions - was a crucial implicit comment on current policy. Although he may not have known of it, what he was saying was an endorsement of the query Justice 'Bay' Piper had raised about training the previous year. Conditions were not always favourable. And there Scott's contribution concluded.

Freddie Thomas was now brought back. He concurred with Scott that there was nothing useful to be learned from the crash reported in The Aeroplane, nor from the Richmond accident. He could say nothing about the comparative safety in the air of the Lockheed 14 and the Hudson. Lowe reminded Thomas that when he was last in the box he had been unwilling to express a definite opinion about the cause of the crash. 'Do you still feel that unwillingness?' 'It is not unwillingness,' Thomas responded, 'I am afraid I just cannot express an opinion at all on the matter.' Scott and Ryland had covered possible causes; 'but definitely to specify one, or even two, is something I would not be prepared to do'. He could add nothing to Scott's explanation of the flame seen over one of the wings. The following exchange teetered on the brink of exploring another possible reason for the crash. 'I suppose you would agree,' Lowe began, that, if Scott was right about the sudden opening of the throttle, 'that would rather definitely 
negative [sic] any idea that the pilot had collapsed though unconsciousness? It would show that he was in control.' 'Yes,' Thomas agreed, with a proviso that went some way to illuminating his unwillingness to reach a conclusion about what had caused the crash, 'he or someone else would have opened the throttle to cause that condition.' Lowe, alert to the mention of 'someone else', once again asked if the machine had dual controls. Yes, Thomas said, 'I was in the aircraft shortly before it took off, and the dual control was fitted.'

Now Dean, seemingly oblivious to the possible implications of this line of questioning, asked: 'If the pilot for some reason became incapable of managing the machine, what time would elapse before anybody else could take over the control of the machine?' Thomas realised that he had gone too far in postulating that 'someone else' could have opened the throttle. 'There was nobody else in the aircraft, in my opinion, who was capable of taking over the duties of the pilot. Wiesener was there only for instructional purposes.' 'He would take no part in the actual piloting of the machine? - None whatever.' There is no evidence that Thomas knew how severely Wiesener's flying performance had been criticised just seven months earlier. But, knowledgeably or not, the commander of No. 2 Squadron spoke no truer word that day.

So, Lowe asked, if a stall occurred at 500 feet, was there any manoeuvre on the pilot's part that could have prevented a crash? No, there was no such action the pilot could have taken. Here Wilson entered once more with his theory of a 'bump' pushing one wing down. If the pilot had attempted to counter this would it cause a spin? If the bump was severe enough, Thomas agreed, you would stall with the wing down. The aircraft would turn. But it would not be a spin; it would be a 'slew'.

Knowing that Thomas led the Hudson squadron in which Hitchcock had been a flight commander, Dean and Lowe sought his views on the preliminary training and conversion of pilots. He was less hesitant than Scott. It was very desirable, he thought, that a pilot about to fly a Hudson should have had experience in twin-engined aircraft, and between 300 and 300 hours flying time. Thomas could not have been surprised that Dean next asked him if his opinion was 'in accordance with the present practice, as you know it'. It had been in some cases but not in others, he acknowledged. Lowe understood the message: 'It is not the universal practice, at any rate?---No. We are having people without any twinengined experience converted.' Wilson, cognisant of the views of 'King' Cole, his chief in Sydney, sensed the danger. Tempted as he might have been to push Cole's agenda of redeploying inexperienced Hudson pilots he gave no hint of the policy argument within the Service. The Court had to understand, he said, that it was necessary 'in expansion' to employ people who had no twin-engined experience. 
I would like to clear your mind on one matter Your Honor. There is no question of all pilots going from the light types directly on to Lockheed Hudsons. There are intermediate and service training types.

(To witness): That is so, is it not?

Thomas was not going to yield: 'Single-engined types.' But Wilson wanted the last word. 'They may be single-engined or double-engined types? - Yes.' Lowe was not taken in. He wanted Thomas's view on the record: 'Do I gather that you think that where it is practicable the advisable course is to bring a man from some other twin-engined plane to the Hudson? - Yes.' 'And that his experience should include something other than fair weather flying?', Dean added. With both Dallas Scott and one of his own flight commanders, Ryland, in the room, men who knew the realities they were facing in converting inadequately prepared pilot officers, Thomas found a compromise formula. 'As Squadron Leader Scott said, there is nothing difficult in teaching men to fly this aircraft, but it is the experience possibly that is the thing that should count in the end.' It was just like swimming, Dean suggested, lifting the tension. Yes, Thomas agreed, the more you swam the better you were, and the more you have flown the better you are.

Finally, the Court re-called Ryland. Lowe reminded him that when he was last in the box, 'I think under some pressure from me', Ryland had offered what he called the two 'least improbable theories' of the crash — engine failure or a stall. Now, given the opportunity to modify or add to what he had said, he added 'structural failure'. Scott had said a jamming of control, either aileron or rudder control. It was possible Ryland, said, that the control of the 'Flattner [sic] tab' may have fractured. ${ }^{16}$ But he was not limiting the possibilities. 'When I say "structural failure" it covers a fairly wide field.' Lowe was hoping for more guidance but Ryland could not help. 'In my own mind I cannot arrive at any conclusion at all for the crash. I just cannot think what may have caused it.' With what was known of A16-97, structural failure was hard to conceive. With what was known of the pilot who was flying the aircraft, he would find it, as Lowe put it, 'very difficult to suppose that he would be flying his craft at such a speed that he did not have sufficient security margin and would have the machine in a condition in which it would be liable to stall.'

There were no more questions. Lowe closed the inquiry at 3.45 p.m. He had 124 pages of testimony to consider.

16 Flettner tab (named after German inventor Anton Flettner): a small hinged device installed on an aircraft control surface to assist the movement of the control surface. (Michael Grossrubatscher, Pilots Reference Guide, p.24). 



\section{Lowe's last word}

To a modern eye one of the most notable aspects of the Air Force Court of Inquiry was the freedom that the RAAF had to guide the proceedings. It did not go unnoticed at the time that the Service had the field to itself. The Court was secretly constrained by the instructions of the Deputy Chief of the Air Staff about what could and could not be asked in public. Counsel assisting had very little time to review the findings of the Service Court and the Inspector of Air Accidents. Just time enough to assimilate the conclusions to which both had come. In the words of Squadron Leader Winneke and Wing Commander Murphy, they had 'no option but to attribute the stall to an error of judgment on the part of the pilot'. It was one of the extraordinary elements of the Air Force Court's proceedings that the notion of 'an error of judgment' by the pilot was never specifically explored. What would have been the nature of such an error of judgment? Arthur Dean had ventured to explain a stall as a consequence of the pilot miscalculating his speed. It seemed that speaking of a stall was in some cases coded language for pilot error. None of the officers who knew Bob Hitchcock gave any credence to such a possibility in their evidence to the Inquiry.

Under the regulations governing Air Force Courts of Inquiry promulgated in May 1939: Any person...the Court considers is or may be aggrieved by the accident, forced landing or inquiry may appear before the Court or be represented before the Court by any barrister or solicitor.' When Justice Piper had investigated the A4-11 Anson crash, a solicitor had been present to represent the relatives of the deceased pilot. For Justice Lowe's Air Court of Inquiry, the 10 widows were given three days' notice by telegram that proceedings would open in Number Two High Court, 450 Law Courts Place, Melbourne, at 2.15 p.m. on August 27. Advice appeared in the Melbourne press that anyone wishing to give evidence should communicate with the registrar at 129 Swanston Street or the Attorney-General's Department in Canberra. However, as F. F. Clausen, the Deputy Crown Solicitor, reported to his chief, Fred Whitlam, at the conclusion of the first two days in Melbourne: 'There was no appearance on behalf of any of the passengers or crew of the aircraft. ${ }^{1}$ Nor is there evidence that any of the families had been advised of their right to be represented. The regulations had envisaged that, if an allegation were to be made against any person affecting his character or reputation, that person should have full opportunity to make his defence. Nothing was said about what opportunity should be given to defend a dead pilot against imputations that his error of judgement caused a fatal crash.

1 Statutory Rules 1939 No. 40, NAA: A432/85 1940/729/43; Sec., Air Board to Mrs R. E. Elford, (telegram), 24 Aug. 1940, Elford MSS; Deputy Crown Solicitor to Crown Solicitor, 28 Aug. 1940, NAA: A432/85, $1940 / 729 / / 21$. 
It was perhaps with the realisation that there was no-one present to represent Bob Hitchcock's interests that neither Lowe nor Dean directly addressed the possibility of pilot error.

In notes on procedure originally prepared for Judge Piper's Court it was laid down that a counsel appointed to assist the Court 'should maintain an entirely neutral attitude and not set himself up as a prosecutor'. He was to see that noone suffered disadvantage by reason of ignorance or incapacity to examine or cross-examine witnesses. With the Court's permission he could call witnesses and put any questions to them 'which appear to him desirable for the purpose of eliciting the truth'. ${ }^{2}$ Arthur Dean appears to have been content to call only on the RAAF officers proposed by the RAAF and the civilian witnesses previously heard by the ACT Coroner and the Service Court. Thus subpoenas were served on nine men, all but one from Queanbeyan, who had already told their stories to the Air Force investigators: Rhodes from Canberra Aerodrome; Vest (manager of the Texas Oil Co.); the farmers Clothier and Southwell; O'Brien, Power, and Tetley from Queanbeyan; and Tilyard and Lalor from the building firm of Simmie and Co. Leading Cook James Mathews of the RAN who was thought by the police to have seen the plane hit the ground was not called. Once again 'one John Cassell', who gave his address as 'Clontarf', Manly, was not asked to testify. John Castle, the Clontarf Beach real estate agent who had been driving with his son in the vicinity when he saw the crash, had driven back to Sydney the same day after speaking to Queanbeyan police. ${ }^{3}$

Reviewing the procession of expert witnesses called to the Inquiry, it is striking that opinion was sought only from within the RAAF. Arthur Dean would have been entitled to call for other witnesses. But it might have been put to him that there was no relevant knowledge or experience outside the Service that could be brought to bear. That had certainly been close to the view of the then Air Commodore Williams when the matter of outside advice was raised in relation to the Demon incidents of late 1937. Apart from the Civil Aviation Branch, as it then was, and the Commonwealth Aircraft Corporation, Williams affirmed 'there are no persons in Australia who can claim to be authorities in aeronautical engineering nor in the operation of service aircraft and the training of service pilots'. ${ }^{4}$

If this had been true a few years earlier, it was questionable whether the same argument could be sustained in 1940. The Vice Chancellor of Sydney University wrote on August 22 to tell the Prime Minister that a new Professor of

\footnotetext{
2 NAA: A705, 108/2/189.

3 'Crash of Ministerial Plane, Majura', Unsigned Note [by Col. H. E. Jones], 13 Aug. 1940, Commonwealth Police file, NAA: A1378, 4/197. No Cassell appears in the 1930 Sands Directory or the 1943 electoral roll in which John and Georgina Castle are listed at Monash Crescent, Clontarf.

4 Chief of the Air Staff to Sec., Air Board, 7 Jan. 1938, NAA: A5954, 869/8.
} 
Aeronautical Engineering, A. V. Stephens, a scientist and a pilot, had arrived in the country two weeks earlier. Somehow it took six days for a copy of the letter to reach the Department of Air. The services of Professor Stephens, later to be used extensively by the RAAF, were not enlisted. ${ }^{5}$ More difficult to defend was the failure to call on the Lockheed personnel still in Australia. It does not seem to have occurred to Dean or Lowe that many of the questions they were asking of RAAF officers and ground crew might usefully have been addressed to the aircraft manufacturer's representatives. Equally, some of the questions that were asked of RAAF pilots, who could not answer them, could more productively have been put to men in the commercial aviation industry who had some knowledge of Lockheed 14s.

There were other areas of expertise that might have been enlisted. If icing was suspected, for example, the Bureau of Meteorology could have advised that cases of ice accretion were common in the winter months over the higher country between Mansfield and Canberra. Hudsons had pitot head heating and a hot-air carburettor system which required timely application. ${ }^{6}$ Even so, Group Captain Claude Browne said when reflecting many years later on the crash, given certain air temperatures and precipitation, Hudsons could ice up very quickly. In this case, though it had been a crisp winter morning, the fair weather conditions allowed icing to be discounted. The conflagration at the crash site would presumably have made it impossible to determine whether there had in fact been significant icing. ${ }^{7}$

In his opening presentation to the Air Court of Inquiry, Arthur Dean had said that the plane was completely destroyed except for 'some very unimportant parts': 'The result of this destruction is that it is impossible to reconstruct any definite cause of the accident. ${ }^{8}$ It had evidently not been thought useful to carry out more than rudimentary structural and mechanical investigations. Nor was there the capacity to do them. The CSIR Aeronautical Research Laboratories, first occupied in April 1940, were not yet sufficiently established and equipped to have undertaken any engineering tests. However, their chief, L. P. Coombes, thought in retrospect that his colleague Henry Wills, head of the ARL structures department, might have contributed usefully to the investigating panels had he been asked. ${ }^{9}$ What is plain was that the Air Force had no desire to prolong and extend the ambit of an inquiry that might well be discomfiting.

5 NAA: A461, AN314/1/1.

6 A pitot tube is a pressure measurement instrument, with heating elements to prevent ice accretion, that acts as an airspeed indicator.

7 'Ice Accretion on Aircraft in Australia', Bureau of Meteorology Bulletin No. 26, 1940, pp.23-6; GpCpt C. D. Browne to $\mathrm{CH}, 15$ May 1978. For RAAF concern in 1939 about wing de-icing and rubber over-shoes for wings: NAA: A705, 9/19/50.

8 'Air Court of Inquiry into loss of Aeroplane at Canberra 13/8/40', Deputy Commonwealth Crown Solicitor's file, NAA: MP401/1 CL12774.

9 L. P. Coombes to CH, 3 April 1982. In 1940 an Australian engineer, Keith Swainger, was the only full-time accident investigator at the Royal Aircraft Establishment, Farnborough (Fred Jones, Air Crash: The Clues in the Wreckage, Robert Hale, London, 1985, p.29). 


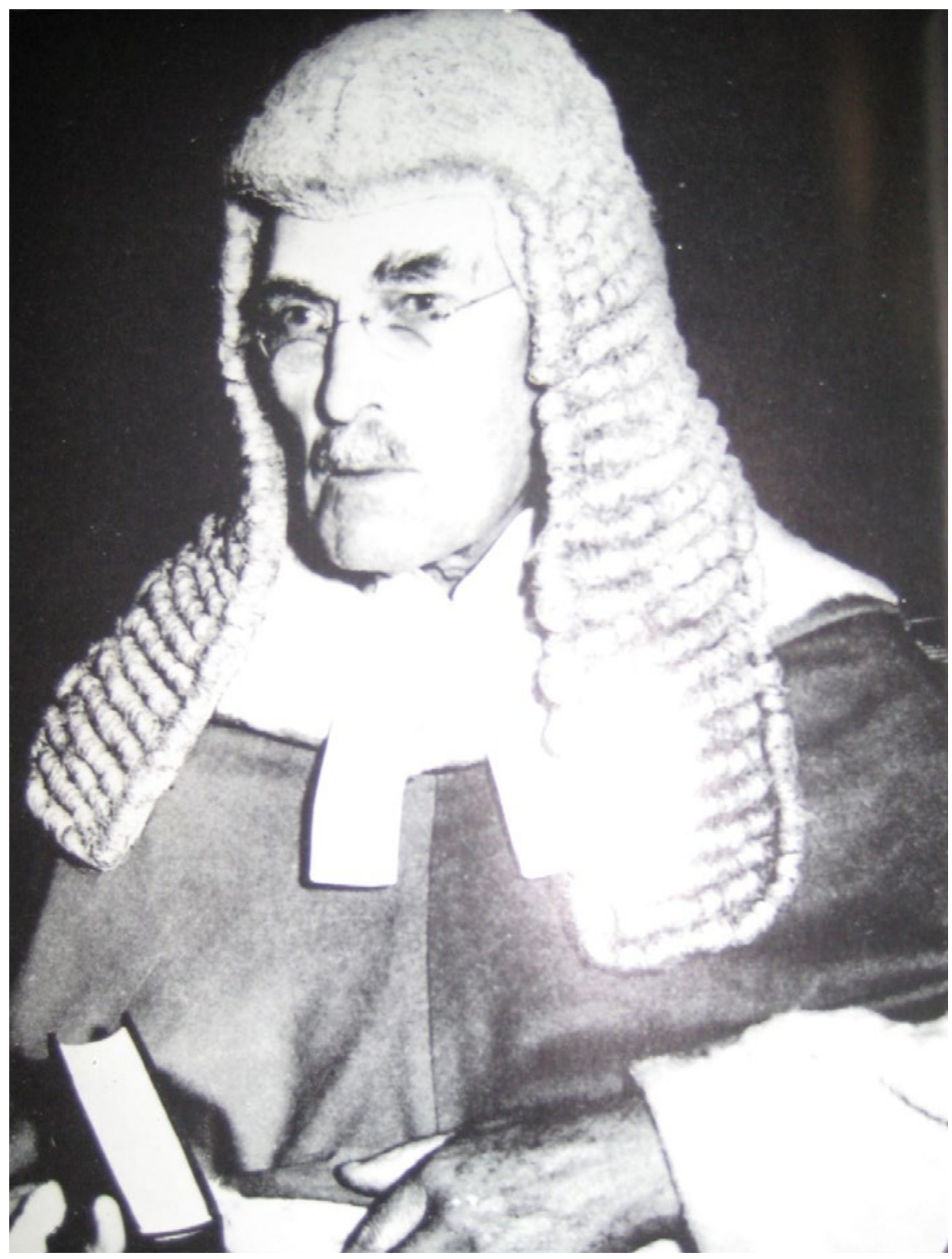

Charles Lowe, 'a grave and courtly demeanour' and judicial detachment

(Newman Rosenthal, Sir Charles Lowe: a biographical memoir, Robertson and Mullins, Melbourne, 1968)

Dean's brief was tight. As counsel assisting, his role was confined to the courtroom and to some preliminary consultation with expert witnesses. If he assisted in any way in the interval between the first adjournment and the additional sitting on September 3 it was not reflected in the fee claim he submitted. Nor was he paid 
for any contribution after Justice Lowe adjourned to write his report. ${ }^{10}$ Dean's work was already done. He received £99.17.0 for his services. From then on the judge would, if he wished, have the benefit of advice from the RAAF assessors. As he was receiving his judicial salary, Lowe himself would be paid no fee no matter how many hours it took him to write the report. As he was resident in Melbourne, there would be no addition to the 12 guineas he was granted at the $£ 4.4 .0$ daily travelling expense rate of a High Court Judge.

\section{‘May it please your Excellency'}

It took Lowe barely two days to complete his findings for submission to the Governor-General. In a preamble he pointed out that the deaths of the men on board meant that there was no direct evidence about the conditions that caused the aircraft to behave as observed. He was therefore prevented from arriving at his conclusions with 'the certainty I should desire'. Before summarising the uncontroversial evidence about the departure of A16-97 from Laverton, its maintenance inspections, and the arrival at Essendon aerodrome, Lowe indicated uncertainty about the way the passengers and crew died. They were, he said, 'killed outright in the crash or the explosion and fire which immediately succeeded it'. The Court had taken no post-mortem evidence. No reference had been made to press reports that suggested the possibility that there might have been survivors of the crash. There was therefore no foundation for the implicit rejection of the Coroner's finding, based on the testimony of Dr Mackellar, of death on impact. But Lowe was right to treat the question as open.

It was four and a half pages into his statement before Lowe began to touch on sensitive matters. Noting that the only evidence of the position taken in the aircraft by any of the passengers related to Dick Elford, the judge then turned to the delay of some 15 minutes before the take-off from Essendon. There were suggestions that the mixture in the port engine might have been too rich or that the pilot was 'not quite ready to go' and signalled some Moth aircraft to take off. No-one, Lowe added, was seen to get out or to enter the aircraft during this delay. The narrative continued with the 'perfect take-off', the record of radiocommunications, the aircraft and its load, and the safeguarding measures which provided assurance that nothing untoward could have happened to it on the ground. The flying experience of Bob Hitchcock was set out. ${ }^{11}$ The 'observations

\footnotetext{
10 NAA: MP401/1 CL12774.

11 Lowe said Hitchcock's 'total flying time was 1,211 hours, 25 minutes, of which 107 hours were in Lockheed types of aircraft'. Tink (Air Disaster, p.150), has the 107 hours 'in Hudsons'. David Vincent's review of Hitchcock's flying log book concludes that Hitchcock's Hudson experience was: '112 hrs 40 mins (2 hrs 55 mins second pilot day, $17 \mathrm{hrs} 55 \mathrm{mins}$ dual day, $89 \mathrm{hrs} 50 \mathrm{mins} 1 \mathrm{st}$ pilot day and $2 \mathrm{hrs} 1 \mathrm{st}$ pilot night) plus there was another 5 hrs 35 mins on Lockheed $14 \mathrm{VH}-\mathrm{ABH}^{\prime}$. (Vincent to $\mathrm{CH}$, email, 30 Aug. 2013.)
} 
at Canberra' were synthesised, with conflicts of evidence acknowledged. The lengthy explanations of stalling, and the experiments conducted by Scott and Ryland, were distilled into two sentences.

Examination of the witnesses, Lowe concluded, had produced four main theories of the cause of the crash: (1) Failure of an engine. (2) Some structural defect such as the fracture of the controlling wire of a wing flap. (3) Collapse of the pilot. (4) Stalling of the aircraft. The first three of these were 'quite unlikely'. Lowe was able to say with confidence that the aircraft was completely airworthy in the hands of a competent pilot; it was adequately maintained and inspected; and no unauthorised person interfered with it. Flight Lieutenant Hitchcock had been 'adequately trained and was a competent pilot and all the evidence before me points to the conclusion that he alone piloted the aircraft on its journey from Essendon to Canberra'.

Had the aircraft rolled on to its back? It was much more probable that it went into a dive or a spin'. Was the aircraft on fire before it crashed? If there was flame coming from the starboard engine it was 'probably to be explained by a sudden opening of the throttle by the pilot causing backfiring through the carburettor intake'. So to the conclusion:

I think the most probable cause was the stalling of the aircraft and consequent loss of control of it by the pilot at a height at which it was beyond his power to recover control. The evidence does not enable me to say whether any special conditions, e.g. disturbance of wind due to the configuration of the hills, was the cause of the stalling.

What Lowe could not say, what Dean had not asked, what none of the professional witnesses had explained, was why A16-97 stalled in the first place. Experts had described the 'how' - the speeds, under-carriage and flap settings. Yet Hitchcock's Service colleagues seemed baffled. They had ruled out various possibilities. They could not understand why the pilot they knew to be wellversed in the Hudson's unique behaviour could have so badly judged his flying speed at so low a height as to go into an irreversible dive or spin. 'Disturbance of wind' might have explained it. But the logic of Lowe's finding was that loss of control was 'consequent' on the stall, not the cause of it. Innate judicial caution would not allow Lowe to go further. He did not echo the conclusion of the Accident Inspectorate investigation and the Service Court. He did not place blame on the pilot for an 'error of judgment'.

'Strictly construed', Lowe continued, his functions ended with the findings he had offered. But he had some observations to add. Not only the accident to A16-97, but the accidents at Richmond and in Britain as well, pointed to the necessity of impressing on Hudson pilots the stalling characteristics of the 
aircraft. Landing grounds should be approached with 'an ample safety factor of speed' to avoid the danger of stalling at an altitude giving only 'the remotest chance of regaining control of the machine'. And especially was this true when an aerodrome was surrounded by hills that might set up air currents affecting a machine's equilibrium and raising the stalling speed. The idea that an upward bump might have caught Bob Hitchcock off guard could not be substantiated. However, Lowe was influenced by the theoretical possibility. He had also taken seriously the concern expressed most forcefully by Squadron Leader Dallas Scott and No. 2 Squadron commander, Freddie Thomas, about relatively inexperienced pilots being converted to Hudsons. 'Where the exigencies of the Service permit', the widest background of experience, including with twinengined types, was advisable. Finally, having heeded Squadron Leader Ernie Hey's reservations about swaged joints on cables, he suggested the advisability of reconsidering the method of attachment. The evidence suggested that the RAF's method was more efficient. ${ }^{12}$

The Judge's findings were signed off on September 5 and delivered with a transcript of proceedings to the Governor-General at Admiralty House in Sydney the next day. On the previous day, the Secretary of the AttorneyGeneral's Department, Sir George Knowles, had passed on the coronial papers - a finding on one page about each of the deceased - to the 'Chief Officer of Police' in the A.C.T., inviting his advice on 'whether in your opinion any further police action in the matter was necessary'. No, Colonel Jones assured him five days later, it was not. ${ }^{13}$ Leaving very few footprints, Jones had satisfied himself that Al6-97 had suffered no untoward interference - at least nothing for which he might bear any responsibility.

Justice Lowe had, as requested, reported 'with all possible expedition'. Lord Gowrie promptly forwarded the documents to the Prime Minister. Then, as ministers dispersed to fight an election, the papers were closely held. Frederick Shedden provided a covering note for Menzies on September 7: 'You will probably wish to pass it on to the Minister for Air.' Two days later, two copies of Lowe's findings were sent to Artie Fadden. Intercepted in Melbourne by the Secretary of the Department of Air, it was another two weeks before the bundle was forwarded to the Minister. Mel Langslow advised Fadden on September 16 that the original report sent to the Governor-General had not yet been received. Now no-one seemed in a hurry. With the election only five days away, Langslow assured the Minister that the details had not been made public. 'It is presumed,' he added, 'that Cabinet will decide the extent to which the findings should be promulgated in the press.' Action would be taken immediately if Cabinet

12 Lowe's conclusions are quoted or paraphrased from the 'Findings' of the Air Court of Inquiry' in NAA: A705, 32/10/2729.

13 NAA: A1378, 148-9. 
required the department to prepare the statement and indicated the 'specific aspects' to be covered. 'Special attention' might be drawn to the findings, Langslow suggested, four sentences which he had marked on one copy together with the riders that Lowe had added. 'These virtually epitomise the findings of the Court.'

Fadden knew that it was not for him or his Department to be 'promulgating' to newspapers on this subject. 'P/Minister will make a Press Statement.' It was not until October 9 that the findings of Lowe's report were presented to the Cabinet and released to newspapers. There was no accompanying statement by the Prime Minister. Knowing that Lowe had reported to the Governor-General, the press generally wrote as though he had presided over a Royal Commission. In fact he was appointed under the authority of Regulation 6 of Air Force Court of Inquiry Regulations rather than the Royal Commissions Act (1902-1933). Noone seems to have thought it necessary to issue a clarification. ${ }^{14}$ The Canberra Times carried the story in 248 words on page two. A month earlier there had been speculation that the most probable reason for the crash was 'a structural defect beyond human control which made the plane unmanageable when the landing gear was brought into operation'. This, the Canberra Times had confidently said, was the theory supported by most experts at the Inquiry. ${ }^{15}$ As they had previously reported the judge's tentative conclusion that there had been no evidence of engine failure or a broken cable, and they were not privy to the RAAF expert testimony taken in camera, the Canberra Times sources had obviously let them down.

For The Argus, it was 878 words on page four. The finding that Bob Hitchcock alone had piloted the aircraft was mentioned but given no prominence; so too was the observation that no-one was seen to enter or leave the aircraft while it sat for an 'unusual' length of time before take-off at Essendon. The Canberra Times report was silent on both points. The Sydney Morning Herald covered the same ground as The Argus in around 650 words, noting in a sub-heading: 'Pilot above average' ${ }^{16}$ After the urgency of the sequence of investigations, culminating in a judicial inquiry intended to allay community concern, the national tragedy of August 13 now commanded fewer column inches than new regulations on investment control and the re-opening of the Burma Road.

\footnotetext{
14 Rosenthal's biography of Lowe, and other works, convey the same misapprehension. The Inquiry had been 'referred' to Lowe by the Minister of State for Air. He was not appointed by Letters Patent issued by the Governor-General although he could have been by virtue of the Royal Commissions Act clause 1B definition of 'Commission' or 'Royal Commission' which included inquiries set up 'in pursuance of this Act or of any other power'. The inquiry is not listed in D. H. Borchardt, Checklist of Royal Commissions, Select Committees of Parliament and Boards of Inquiry, Part 1 Commonwealth of Australia 1900-1950, n.d.

15 Canberra Times, 12 Sept. 1940.

16 Canberra Times, The Argus, Sydney Morning Herald, 10 Oct. 1940. The Examiner, The Mercury, The Advertiser, and the Courier-Mail carried similar reports.
} 
The upper echelons of the RAAF could rest easy. The government had other preoccupations. Having lost his majority, Menzies was attempting first to form a national government and, if that failed, to reconstruct the non-Labor coalition. Reconciliation with Sir Earle Page was the imperative political objective. There was no incentive for anyone in Canberra to draw fresh attention to a catastrophe that had caused so much distress or to publicise deficiencies in Service organisation or performance. The families of the victims might have hoped for more illumination. Charles Lowe had done his best and was understandably dismayed by the resounding silence that greeted his efforts. As Lowe's biographer wrote, he 'never learned of any steps taken by the Royal Australian Air Force following the report... The public could have been informed of possible steps that had not hitherto been taken, and of measures which the department contemplated taking for the future...'

Lowe had a reasonable expectation that some regard might be paid to a Commissioner's findings. His disappointment was as much philosophical as personal. In a democracy, he believed, if a public inquiry was held, 'the enquiring public should be encouraged, and should be provided with satisfactory answers' ${ }^{17}$ On many key technical questions certainty had eluded him. Referring Lowe's findings and riders to the Secretary of the Department of Air for the attention of the Chief of the Air Staff, Artie Fadden asked for comments on the observations made. He would be glad to learn 'what action is proposed should be taken regarding them'. The press was informed that the minister had called for a report. 'Appropriate Air Force officers have been asked to supply information on these points. ${ }^{18}$ The quest for satisfactory answers had begun independently of the Air Force Court and would now continue, along carefully circumscribed lines. The Air Force could get on with its business.

17 Rosenthal, Sir Charles Lowe, pp.101-2.

18 Fadden to Secretary (for C.A.S.), minute, 11 Oct. 1940, NAA: A705, 32/10/2729; The Herald, 12 Oct. 1940. 



\section{Mr Storey's story}

Much about the crash of A16-97 remained inexplicable. As far as the public was concerned, privy only to Justice Lowe's findings, the story was that the 'machine stalled'. Whatever might be suspected, nothing had been said directly to suggest that the pilot had erred. Pilot error could be inferred. It could not be proved. No-one was required to believe that Flight Lieutenant Bob Hitchcock had been inadequately instructed in the dangerous characteristics of the new aircraft he was flying. It would not do for there to be a loss of confidence in the RAAF's selection of prospective Hudson pilots or of its training regime. A more satisfactory deduction for the authorities - a deduction left for the public to make - was that an adequately trained and competent pilot had just made a fatal mistake. There might have been other contributory factors but none could be conclusively confirmed. Thus, how or why such a 'miscalculation' could have been made was left to the imagination.

A delicate path had been constructed for the Air Court of Inquiry. Those whose responsibility it was to advise the Court about Bob Hitchcock's competence had directed attention only to his most recent record. There was no hint of anything other than 'average' or 'above average' performance in the evaluations disclosed. But there was an economy of truth in providing only these assessments. There is no indication that Justice Lowe was made aware of Hitchcock's misadventures as a young pilot officer, or of any later concerns about his flying. It may reasonably be supposed that his superiors judged that Hitchcock's subsequent operational performance demonstrated that he had overcome the crisis of confidence in 1936. Four years on he was a different man. The exacting John Ryland had deemed him 'thoroughly competent...slightly above average' when he converted to Hudsons. 'Not brilliant, but normal' in absorbing instructions. ${ }^{1}$ What none of those who knew Hitchcock's history would want was anything that could have led, as Sir George Jones was to put it years afterwards, to the realisation that there were those who thought 'the man would never have been in the Service but for political influence' ${ }^{2}$

In the absence of other evidence it was legitimate for Lowe to conclude that Hitchcock alone had been in control of Al6-97 from the time it left Essendon to the moment it plunged into the ground in Duncan Cameron's farm. But what if there were other testimony? One man who thought he could throw light on the accident was Herbert J. Storey, Headmaster of the Grenfell Street Trades School in Adelaide. In response to the war's demand for skilled men, the trades school had been designated a Commonwealth Defence Training Centre. It offered Army technical training, RAAF basic training, and training in aircraft

Ryland's testimony, 27 Aug. 1940, Air Court of Inquiry, NAA: A705, 32/10/2729.

2 AM Sir George Jones, interview, 14 Sept. 1977. 
and munitions production. In co-operation with the Adelaide School of Mines, the Trades School had undertaken to train 500 fitters at $£ 15$ per head for a fourmonth course. ${ }^{3}$ Storey's responsibilities took him around the state to Port Pirie, Whyalla, and other country towns. On these trips he would often be flown in RAAF aircraft. On August 31, Storey had written to the Secretary of the Department of Air:

\section{Canberra Air Disaster}

Dear Sir,

I forward for your information, a record of a conversation which took place in my office during a visit to this school by the late Minister for Air, Mr Fairbairn.

I realise of course, that it is not evidence but it may throw some light on the Canberra air crash, perhaps by lending support to evidence at the Court of Enquiry or be of value in some other direction.

Owing to some misunderstanding, Mr Fairbairn arrived at this school some 15 minutes ahead of Air-force officers who were to accompany him on an inspection of the R.A.A.F. activities. The interval was bridged by a quiet chat in my office.

Mr Fairbairn told me something of his trip round Australia. (He was then on the final stage) and we discussed modern service aircraft. I asked him about the Hudson bombers of which I had been reading with interest. Mr Fairbairn stated 'These machines have rather a nasty stalling characteristic. The combined effect of throttling back and dropping the flaps, preparatory to landing, can land you in a whole heap of bother. They are very sensitive, at this stage, to varying air pressures and, from what I have been told, a pilot coming in to land can find himself, suddenly and without warning, in a machine that is no longer air-borne, heading straight for the ground. I don't know much about them yet but, as I will be handing my own machine in when I arrive in Melbourne; you know, we are commandeering all private machines and mine can not be excepted, I will soon know all about them. I will be using a Hudson for my departmental travelling and on every possible occasion I'll practise landings and find out more about this stalling trick. Personally, I think it is only a matter of handling your throttle wisely.'

The conversation closed on the arrival of several R.A.A.F. staff officers and an inspection was then made of this school. 
yours faithfully

\section{H. J Storey \\ H. J. Storey

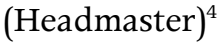

As if to emphasise his sense that he thought he was conveying something important, Storey added at the foot of the letter he had typed with his own hands '/HJS (not dictated)'.

This letter, filed in a bundle of mostly routine departmental correspondence, adjacent to copies of papers relating to the Lowe inquiry, was extraordinary in its implications. There was no trace of Herbert Storey's reported conversation with the late Minister for Air in any of the evidence or conclusions of the Air Force Court of Inquiry. No-one, it seems, contacted him to test his credibility or to see if there was anything further he could contribute. The only discernible response in the files was sent on 9 September 1940:

\section{Dear Sir}

I desire to thank you for your letter of $31^{\text {st }}$ August, 1940, forwarding a record of a conversation which took place in your office during a visit to your school by the late Minister for Air, the Hon. J. V. Fairbairn.

I would inform you that the stalling characteristics of Lockheed Hudson aircraft are well known and pilots are fully instructed in regard thereto, when undergoing conversion courses for this type of aircraft.

A special Air Force Court of Inquiry, presided over by his Honour, Judge Lowe, was constituted to inquire into the accident at Canberra, and the cause or causes thereof. You may be assured that the points brought to notice by you were investigated closely by the Court.

Yours faithfully

$P E C$

(M. C. Langslow),

\section{a SECRETARY}

\footnotetext{
4 Air Force Court of Inquiry under Air Force Courts of Inquiry Regulations into accident to Air Force Hudson Aircraft at Canberra on 13/8/1940 (A16-97)', NAA: A705, 32/10/2729/28-9. Tink, Air Disaster, pp.213, 220, has Fairbairn speak of 'handling your throttles wisely' which would have been true but was not what Storey wrote.

5 The file copy in the Department of Defence Air Services Branch General Correspondence in Melbourne (NAA: A705, 32/10/2729/27) bears the initials of the Assistant Secretary of the Department, (Major) Patrick ('Johnnie') Eugene Coleman. Some years after I discovered Storey's letter and the reply, I told the aviation journalist Frank Cranston about it. In 1990 the Defence Department Air Force Office, under the impression
} 
Both the wording and the timing of the official reply were notable. Storey's letter had been written on a Sunday, four days after Mr Justice Lowe convened his first hearing in Melbourne. The last day of hearings, also in Melbourne, was three days later. The Court had re-convened in the afternoon of Tuesday, September 3, to hear additional evidence 'with regard to the management of the aeroplane'. The departmental response to Storey was dated September 9, four days after Lowe completed his report, with the assistance of the Inquiry registrar, James Davoren. The report was signed and sent to the GovernorGeneral on September 5. If Storey had paid the threepenny surcharge for airmail delivery from Adelaide there would have been time for his letter to be brought to the notice of Arthur Dean, counsel assisting the Inquiry. Time as well for its contents to be intimated to senior officers and ministers before Lowe concluded his work. Even had the letter been carried from Adelaide on The Overland overnight train service it might still have arrived in time to be assimilated by the Inquiry. ${ }^{6}$ In fact the letter was processed by the Defence (RAAF) Central Registry on Monday, September 2. The file on which the letter was eventually placed appears to have been forwarded to the head of the legal branch, Wing Commander Fred Knight, on August 30. From Knight it was sent to 'S A B' (Secretary Air Board) the next day.

It may be surmised that, in the normal course, a clerk from the central registry would have carried the letter to the Air Board Secretary's office and attached it to the file. What might have happened next is a matter of conjecture. The letter bears the pencilled annotation 'S/AB $2 / 9 / 40$ ' in the hand of the registrar of the Inquiry, J. A. Davoren. The file itself was formally in the care of the Secretary of the Air Board from August 31 to October 10. But there is a unique annotation on the file cover. Whereas all other dates of the file's movement are the dates on which it was forwarded, there is an interpolation 'Rec'd 3/9/40' with the initials of the Inquiry registrar. ${ }^{7}$ At that time Davoren was still working with Lowe on drafting the Judge's report.

\footnotetext{
that nobody knew of the correspondence, informed Cranston about it to assist him with an article he was to write on the 50th anniversary of the crash. Cranston's article, 'Spiral dive into Canberra hilltop rocked Australia' (Canberra Times, 12 Aug. 1990), was subsequently referred to in several books including Bennett, Highest Traditions, p.113; Wilson, Anson, Hudson and Sunderland in Australian Service, p.107.

6 Letters for the eastern states could be left at the Adelaide GPO as late as 3.15 p.m. on Saturday or 5.15 p.m. on Sunday (The Advertiser, 31 Aug. 1940, p.14).

7 Secret file covers (e.g. NAA: A705, 231/9/462) contained the instruction: 'Files must not be passed between Branches by hand without transit slips.'
} 


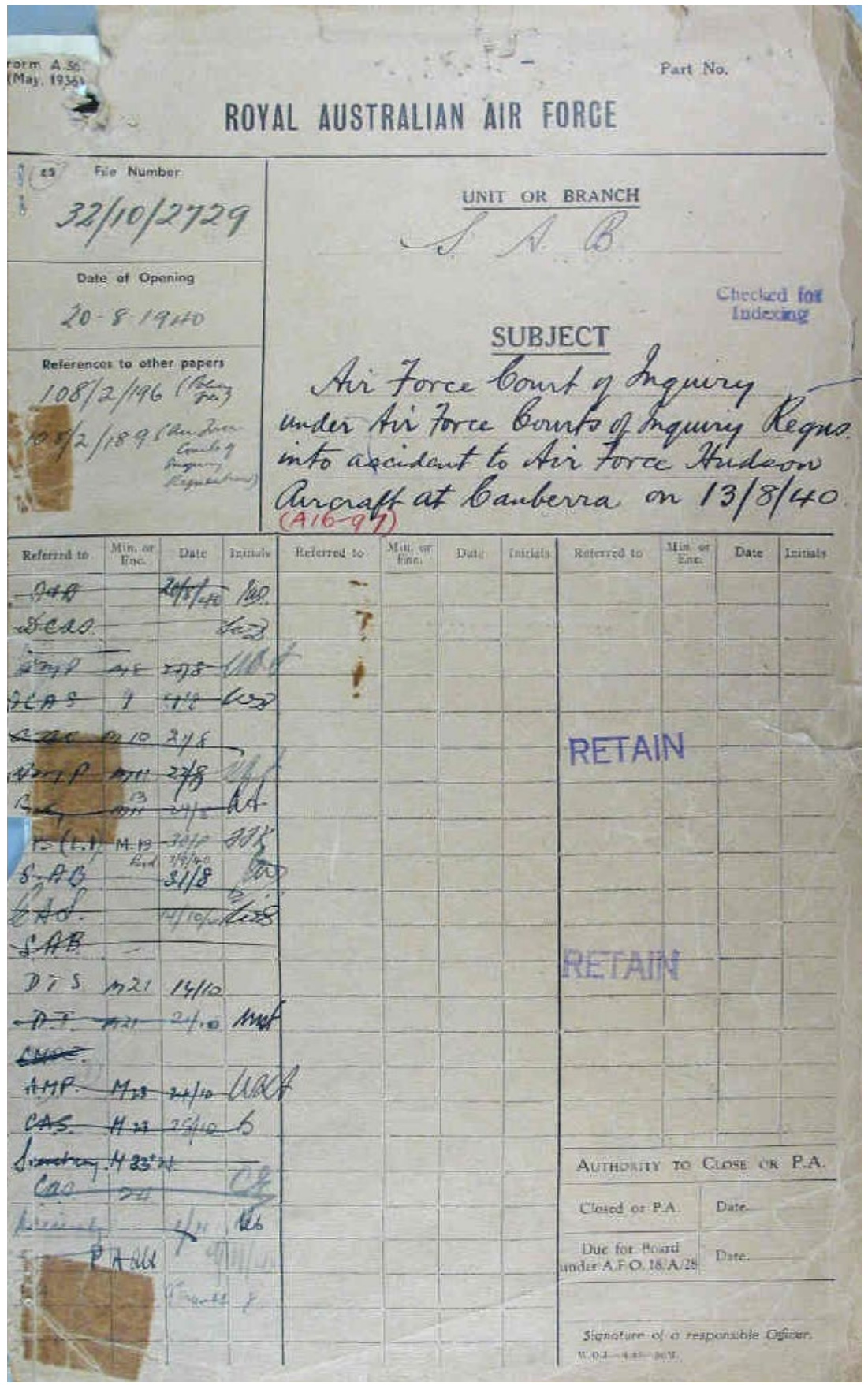

Air Force Court of Inquiry file created by J. A. Davoren, 20 August 1940

(National Archives of Australia: A705, 32/10/2729) 
It may be noted here that in designating the requirements for a 'specially qualified officer to handle all administrative procedures' for Air Force Courts of Inquiry, 'Johnnie' Coleman had stressed that, as the occupant of the position would be representing the department in open court, he should be an officer 'of good personality and bearing'. He would be required to be conversant with 'all Acts, Regulations, Orders, Publications \&c... as one of his functions is to advise the judge regarding these matters' ${ }^{8}$

James Davoren had an intimate knowledge of the relevant legalities. He also faced a stark conflict of duties. When not acting as a registrar, he was a normal member of the Air Board secretariat, understudying the head of the Regulations and Orders sub-section. When Air Force Headquarters had drawn up the duty statement for the third division clerical appointment which he came to hold, they had calculated that some 60 per cent of the time would be allocated to work as registrar. But the balance of the time, subject to the demands of Air Force Courts of Inquiry in all states, would be continuously free for other secretariat duties. ${ }^{9}$ Thus Justice Lowe had a temporary claim to Davoren's services but ultimately he reported to Coleman and through him to Mel Langslow.

With a letter of such extraordinary potency delivered to his desk from the head of his office, what was Davoren to do? What if anything was he told? Was he asked to draft a reply to Storey? If so, was he told what to say? Was he instructed not to pass the letter on to the judge? There are no answers to any of these tantalising questions. Most intriguing of all: why did Davoren make a point of initialling the file the day after he had directed it to the Secretary of the Air Board? It is as if he wanted it on record that the letter had been received in time to be referred to Lowe. It was Davoren who had created the file on August 20. So far as that file can speak further for itself it tells us only that it was next passed to the Chief of the Air Staff on October 14, initialled by the Deputy Chief, Air Commodore Bill Bostock. ${ }^{10}$

Had Herbert Storey written in vain? We cannot know if he had accurately reported the words of the visiting Air Minister. If he had seen the report of the Air Court's proceedings in The Advertiser on August 29 he could not fail to have been struck by a paragraph headed 'Mr Fairbairn's Place in Plane'. Group Captain Wilson, it said, had asked a witness about whether the Minister was sitting next to the pilot before the plane left Essendon. Perhaps Storey's perception of his conversation with Fairbairn had also been coloured by memory of a tiny

8 Sec., Air Board to Sec., Department of Air, 15 Aug. 1939, copy, NAA: A705, 108/2/189.

9 The percentage list of duties was 'one of the most potent weapons available in obtaining a reclassification of salary or position' as the Supervisor of Flying Operations in the Dept of Civil Aviation had learned (Affleck, The Wandering Years, pp.141-3).

10 NAA: A705, 32/10/2729/1. Of course, the file could have been seen by people who did not sign it. Storey's letter is also annotated by Davoren 'File L1 29/8[sic]/40.' 
news item in The Advertiser on May 2 noting that Fairbairn was to receive dual instruction on Wirraways in Canberra in his spare time: 'He will not be satisfied, however, until he can fly solo in any Air Force machine including the latest Hudson bomber.'

Storey was mistaken in thinking that Fairbairn had yet to hand in his own machine. However, as a Broken Hill mining engineer holding a captain's commission in the Royal Australian Engineers since September 1939, he would certainly have understood what Fairbairn was talking about. What none of those who saw Storey's letter might have known is that, while waiting in Adelaide to join the AIF $7^{\text {th }}$ Division, Storey had actually been posted to the RAAF's No. 1 Engineering School in Melbourne. Before he could take up the post he had been poached by the South Australian Superintendent of Technical Education to run the big new trade school.

Air Commodore Harry Wrigley, as AOC Southern Area, was one of those in the upper ranks of the RAAF who knew Storey, and was surprised to discover that he had remained in Adelaide. ${ }^{11}$ If Storey had contacted Wrigley about his conversation with the Minister for Air instead of going through proper channels might the outcome have been different? Having been an assessor for the first of the Air Courts in 1939, Wrigley knew the new procedures; he had taken a personal interest in Bob Hitchcock's career; he had recently commanded the Laverton station; No. 2 Squadron was within his Area Command; the Service Court had been convened by his Senior Administrative Staff Officer. No one in the upper ranks of the RAAF was better placed to assess the credibility of the suspicions raised by Storey's letter. But, if the transmission record is to be trusted, the file was closely held and never came into his hands.

In the event, in classically ambiguous bureaucratic language, Mel Langslow (or 'Johnnie' Coleman) assured his correspondent that 'the points brought to notice by you were investigated closely by the Court'. The points the officials meant were of course the technical questions related to what Fairbairn was said to have described as 'nasty stalling characteristics'. The further point the Department implied was brought to notice was Fairbairn's stated intention 'on every possible occasion' to 'practise landings and find out more about this stalling trick'. What the letter failed to do was confirm that this revelation had been considered by Justice Lowe, or by anyone else. For good reason. The otherwise extensive documentary record shows no witness being called, no evidence being led, that even hinted that the Minister had expressed any interest in the Hudson's behaviour. The transcript of the session of the Court of Inquiry held in camera on September 3 contains no reference to Jim Fairbairn's conversation with the Adelaide trade school principal.

11 The Mail (Adelaide), 7 Dec. 1940; The Advertiser, 31 Jan. 1941, p.16. 
Perhaps the Storey letter simply did not arrive in time for Dean or Lowe to see it before the Inquiry was adjourned. Of course, it is possible that the letter had somehow lain unnoticed in an in-tray. The department might not have been as disingenuous as its response appears to suggest. But, in view of the sensitivity and potential for embarrassment of the air crash investigation, it strains credulity to believe that the letter's significance would not have been immediately appreciated when it was read at Air Force headquarters. Sir Richard Kingsland, a contemporary of Hitchcock, a decorated wartime pilot, and later a high-ranking public servant, was to speak of being 'very surprised that it had been brushed off as casually it was' by the Secretary of the Department of Air. ${ }^{12}$ Even had it arrived too late to be considered by Lowe before he finished writing and transmitting his findings to the Governor-General, all members of the Cabinet as well as the Air Board had been told that the Minister for Air had the discretion to re-open the inquiry. James Davoren would certainly have been aware of this. His immediate superior, Coleman, 'very mild, gentle... a very knowledgeable man', as George Jones recalled him, did not need to be told. Mel Langslow knew the regulatory regime as well if not better than anyone. Having himself unfairly borne the initial brunt of criticism for the financial stringency that delayed the installation of navigational beacons that might have prevented the crash of the Kyeema two years earlier, he could understandably have hesitated to bring down another torrent of controversy on the Air Force and the government.

But Langslow had scrupulously informed ministers and Air Board colleagues from the outset that the Governor-General, 'if requested by the Minister, may reopen and rehear the inquiry or any part thereof, even after the findings and notes of the first hearing have been forwarded to the Governor-General'. ${ }^{13}$ It is hard to avoid the conclusion that a decision had been taken at the highest level to conceal what could be construed as sensational information.

If the Storey letter was not attached to the file before it was received by the Inquiry registrar from Fred Knight on September 3 then Knight, acting most probably under instructions, was responsible for withholding it. Given what we know of the proceedings of the previous weeks, the most likely person to have directed Knight was the Deputy Chief of the Air Staff, Air Commodore Bostock. If the letter was filed, and reached the Inquiry office on September 2, it might

12 Sir Richard Kingsland, interview, 3 April 2007, transcript courtesy Geoff Crane. Kingsland recalled learning of the letter while writing the entry on Mel Langslow for the Australian Dictionary of Biography, vol. 15. Kingsland was Julius Alan 'Dickie' Cohen until he changed his name in 1947, taking his remarried mother's surname.

13 Secretary, Department of Air to Minister, 'Investigation of Accidents Affecting Air-Force Aircraft', minute, 15 Aug. 1940, NAA: A705, 32/10/2729. The paper, annotated by the Prime Minister, notes that Cabinet had approved an open inquiry. 
have been overlooked when Lowe and Davoren returned from Canberra early the next morning. It might even have been overlooked there until after the final session of the Inquiry was over on the third.

Yet there must be lingering suspicion. In developing instructions for registrars of Air Force Courts of Inquiry the Air Board had specifically required that reports of proceedings be furnished daily 'either verbally (personally or per phone) or in writing' ${ }^{14}$ There must therefore have been opportunities each day for the transmission of confidential information. If no such communication had occurred, it may well have been asked thereafter: what public interest would be served by bringing this obscure headmaster's disturbing story into the open? There was no way to determine what had actually happened inside A16-97 as it circled near Canberra. Surely further speculation about what might have been would be unproductive? It could only bring distress to the families of those who died. Better by far to have confined the Court of Inquiry to matters that could more easily be investigated and evaluated.

Is it legitimate to advance these possibilities? No documentary evidence has been discovered to warrant a conclusive finding of improper concealment of information. If Bostock, Knight, Lowe, Dean, Davoren, Langslow, or Coleman kept relevant private records they have not so far been found. But in the nature of things such evidence is unlikely ever to have existed, or to have survived if it had existed. As Air Commodore Bruce Courtney, a junior officer in 1940, has cautioned, even a Court of Inquiry 'should be suspect in a wartime situation - it might well have been necessary to cover up the accident in the general interest' ${ }^{15}$ The fact that Storey's letter itself found its way on to a file at all might be thought remarkable. All the more so when the same file contains evidence of a decision to omit another embarrassing document. In a letter that itself probably was not intended by its author to be filed, Mel Langslow wrote to the Secretary of the Attorney-General's Department about 'the "alarmist" report said to have been spread by an airman mechanic'. This had been 'referred to the Intelligence people to follow up....You may be assured that Mr Simpson's letter will not be placed on an official file'. ${ }^{16}$

\section{Political intervention?}

Those reaching for a conspiratorial explanation of the treatment of Mr Storey's information are inclined to look for political hands at work. With a little imagination some suggestive scenarios can be constructed. It is easy enough to

14 'Air Force Courts of Inquiry — Regulations', NAA: A705, 108/2/189.

15 ACdre E. B. Courtney to CH, 7 April 1978.

16 Langslow to Sir George Knowles, 19 Sept. 1940, copy, NAA: A705, 32/10/2729/24. 
speculate, for example, that words might have passed between the Air Member for Personnel, Bill 'Mucker' Anderson, and his old friend and Melbourne Grammar contemporary, Dick Casey. Anderson was closely involved in selecting the personnel to assist the Air Court. Casey was, of course, in Washington at the time of the crash. But he was only a telephone call away from old colleagues and friends in Canberra and Melbourne. He had learned of the crash from journalists who reported that he was 'inexpressibly shocked and his emotion was evident in his voice'. 'For several seconds he could not speak', according to the Daily Telegraph's' special representative who had telephoned him. The Deputy Chief of the Air Staff, Bill Bostock, who had travelled to London with Casey in 1939, was another potential link at the heart of RAAF headquarters. So too was Alec Barlow, one of the RAAF's most experienced Hudson pilots, attached successively to No. 8 Squadron (Canberra), No. 14 Squadron (Pearce), and No. 7 Squadron at Laverton. ${ }^{17}$ Barlow was the brother-in-law of Maie Casey's secretary, former journalist Pat Jarrett. Jarrett herself had visited the Lockheed factory in April 1940. Whether Casey made any attempt to contact anyone in Australia - or if anyone from the RAAF sought to contact him - is not known. What is known is, as Casey wrote to his friend Jack Latham, that he 'was — \& am - very cast down by the air accident. All my friends. ${ }^{\prime 18}$

Had Casey still been in Australia he would have known of Fairbairn's interest in the problems being experienced with the Hudson. He was endlessly curious about technical matters. When minister in charge of scientific research he had responsibility for the development of plans for an aeronautical research laboratory. He had been closely involved in the discussions and decisions in 1938 to place an order with Lockheed. ${ }^{19}$ Casey's first flying instructor, Fred Scherger, now commanding No. 2 Service Flying School at Wagga, had raced to Canberra on August 13. There he talked first to Peter Looker, Casey's former private secretary now on Menzies' staff. It was little more than two years since Casey had come to Scherger asking 'Am I too old to fly?' He had read so much about flying, Scherger was to recall, that he was concerned about stalling. But he was 'a very good pilot...could always talk flying, could not stop him talking flying' ${ }^{20}$ Scherger's close friend Squadron Leader Paddy Heffernan knew both Fairbairn and Hitchcock well. ${ }^{21}$ Heffernan was out of the country but Scherger's friend from flying training days was Hitchcock's fellow flight commander, Ray Garrett. If Scherger had wanted some background information he was surely capable of getting it.

17 NAA: A9300, Barlow AA.

18 The Argus, Daily Telegraph, 14 Aug. 1940; Audrey Tate, Fair Comment: The Life of Pat Jarrett 1911-1990, MUP, 1996, pp.49-50, 56; Casey to Sir John Latham, 20 Aug. 1940, Latham MSS, NLA MS1009/1/5487.

19 Prime Minister's Department, 'Aviation — Purchase of Lockheed Bombers', Part 1, NAA: A1608, F17/1/2.

20 Scherger, interview, 2 Sept. 1978.

21 For Heffernan and Scherger sharing quarters and hospitality for half a century, see Harry Rayner, Scherger, p.42. 
In Casey's absence there were others to whom the Prime Minister could turn. If he knew that Harry Winneke, a family friend, was a member of the Accident Inspectorate he might have thought to contact him. But more likely to be well informed were Winneke's professional colleague Arthur 'Spud' Murphy and Lawrence 'Wack' Wackett, both of whom Menzies had come to know well on a long sea voyage to England in $1936 .{ }^{22}$ Tempting as it might have been to contact Murphy, the Chief of the Air Staff's principal accident investigator, Menzies' sense of propriety would most likely have inhibited him from intervening in a formal process that was already under way. Nor could he be sure that Murphy would be willing to compromise his own unique relationship with the Chief of the Air Staff. Wackett, focused on his production of Wirraways at Fisherman's Bend, would know nothing first hand. But his son Wilbur was helping to train Hudson pilots at Laverton. There was in any case another alternative, a senior man whom the Prime Minister knew was both knowledgeable and indiscreet.

Menzies had long known Air Commodore 'King' Cole, who was based at Central Area Headquarters at Point Piper in Sydney. Adrian Cole, 'Jimmy' Fairbairn's boyhood friend, was 'very relaxed' off duty, a dedicated club man with a reputation as 'a bit of a playboy'.$^{23} \mathrm{He}$ had taken the risk two months earlier of sending direct to the Prime Minister, 'against regulations and orders', a brief of his own views on Australian air defence and aircraft production. Menzies assured Cole he would treat the communication as confidential and that it would 'prove very valuable to me'. Cole had sent the memorandum to the Chief of the Air Staff but neither he nor Menzies sent it to the Air Minister, Fairbairn. ${ }^{24}$ Would Cole have volunteered information to anyone, let alone the Prime Minister, that would suggest that lives had been put at risk, and had now been lost, because his recommendation four years earlier to terminate Bob Hitchcock had been rejected? The thought might have crossed his mind, but it seems unlikely that Cole would have jeopardised his career by pointing his finger at Hitchcock's protectors, the former Chief of the Air Staff and the then Air Member for Supply, both of them still on the Air Board.

We do not know whether Menzies sought or received information outside the official channels. It is hard to believe that no-one with personal knowledge of Fairbairn's flying habits would have spoken to him after of the crash. But, if they did, no record has survived. Is it likely that he might have intimated that there was to be no investigation of the possibility that Fairbairn had been more than a passenger on A16-97? If he were minded to do so, to whom would he have conveyed his wish? To Sir Charles Burnett, who would be obliged to provide a report on the accident when the War Cabinet met? That might work

22 Wackett, Aircraft Pioneer, p.116.

23 ACM Sir Frederick Scherger, interview with Mel Pratt, 13 Nov. 1973, transcript, NLA TRC 121/52. p.18.

24 Cole to Prime Minister, 25 June 1940; Menzies to Cole, 28 June 1940, Menzies MSS, NLA MS 4936/581/23. 
to contain inquiries by Burnett's RAAF subordinates. But could an independent judicial inquiry be deflected by political influence? What of those who had led the Inquiry that Cabinet had decided upon? As we have seen, Justice Lowe himself, raised to the Supreme Court bench in 1927, moved in the same legal and club circles as the Prime Minister. Arthur Dean had been a contemporary of Menzies at the Victorian bar. Yet there is no evidence of communication with either man by anyone other than those properly participating in the conduct of the Inquiry.

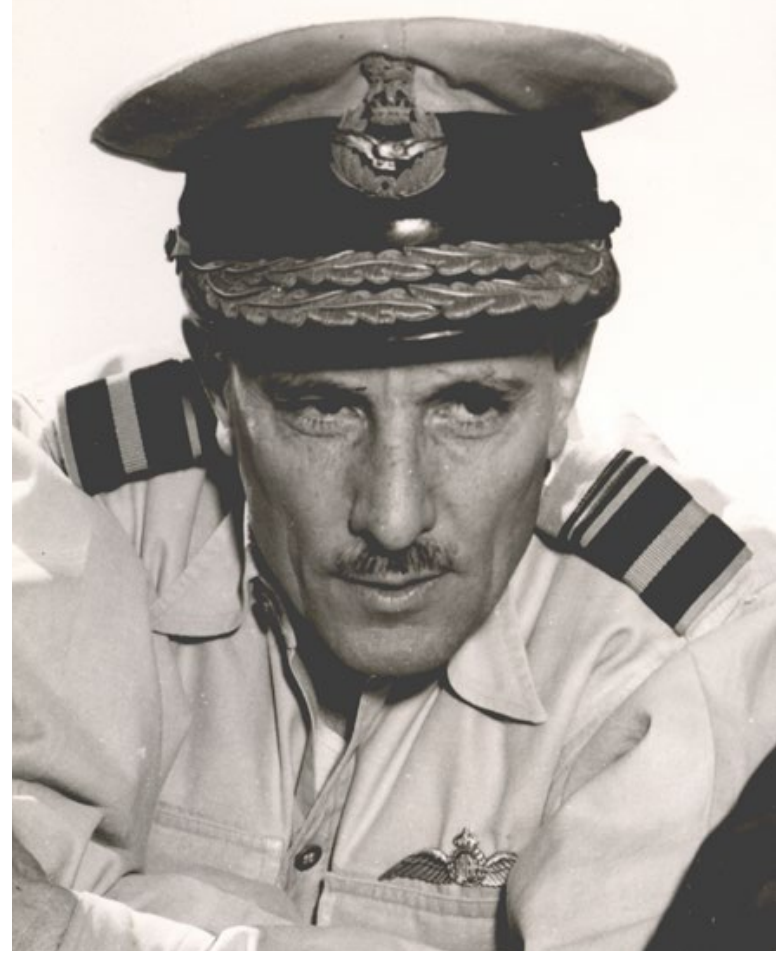
Joe Hewitt, perhaps the most intelligent and reflective officer of his
generation

(Courtesy of the RAAF Museum)

Is it likely that anyone outside the higher echelons of the RAAF would have sought to influence the findings or to hasten the process of a judicial inquiry? The possibility of exposure, if not a disciplined integrity, would weigh against it. Yet there had been no such inhibition a little more than a year earlier when Wing Commander Joe Hewitt had presided over a Service Court of Inquiry into a controversial Anson crash. 
As Hewitt wrote in his memoirs: 'Such a Court of Inquiry requires time and concentration on the problem, but the urgings of Cabinet on the Air Board to determine the cause was passed down the line to me ultimately by telephone calls from the Air Member for Personnel. ${ }^{\prime 25}$ This was precisely the kind of interference - admittedly in this case only a desire to get the matter settled quickly - that had justified the establishment of an independent inquiry system. Even without any inappropriate influence, the appointment of Lowe, and of Dean to assist him, gave the Prime Minister and Cabinet some assurance of sympathetic and discreet handling of what might prove to be awkward discoveries. They could rely as well on the Secretary of the Air Department. As an admittedly jaundiced Sir George Jones was to put it many years afterwards: 'I don't think Langslow would have given any advice other than what he thought was politically acceptable. ${ }^{26}$

\section{'Contrary to all human probability'}

We can trace tendrils of acquaintance, probable relationships of trust. Inferences are possible from what is known. But there is nothing to substantiate doubts about the independence of the Inquiry from direct political interference. We are left with a mystery. The first thing to be noticed is that one possible explanation of the crash that was canvassed with evident discomfort in the Inquiry was indeed that someone other than the trained pilot in command was at the controls of the aircraft. Such a possibility was perhaps so improbable that, without prompting, it might not have occurred to any of those charged with thinking about what had happened. But, as we have seen, the Lowe Inquiry transcript reveals that the possibility had indeed been in the minds of both counsel assisting and Justice Lowe himself. In the closing moments of the hearings on August 29 Arthur Dean had said: 'As I understand the evidence there is nothing to justify the Court in holding that any suggested cause was the actual cause.' By a process of elimination, he said, that:

one might very easily omit such a consideration as sabotage or any suggestion that the plane was not airworthy or was overloaded, or the view that some other person than the pilot was piloting the aeroplane. There is not the slightest evidence to justify the last suggestion. It is contrary to all human probability that a skilled pilot, responsible for the control of the plane, would vacate his seat for anybody else and it is contrary to all human probability that another person knowing the difficulty of piloting a plane of this kind would undertake to do so,

25 Hewitt, The Black One, p.162. The Air Member for Personnel at the time was Air Commodore W. H. Anderson.

26 AM Sir George Jones interview, 14 Sept. 1977. 
particularly in view of the fact that a large number of human lives were involved. Not only is there no evidence to warrant suggestions of that kind but in fact the probabilities are all the other way.

'Contrary to all human probability.' The Judge concurred, somewhat awkwardly if the transcript is to be believed: 'It would be pure speculation to put forward such a theory in the absence of the only evidence which could throw light on that of those who perished in the flames.' The Canberra Times report on August 30 amplified Dean's remarks: no other person 'knowing the course of flying instruction necessary' would be piloting the aircraft. Lowe was made to sound more coherent: 'The theory of another pilot must be pure speculation as the only persons capable of giving evidence on that point were those who had perished.' ${ }^{27}$

In his own publicly released 'Findings', Lowe had explicitly stated that 'the evidence before me points to the conclusion that he [Hitchcock] alone piloted the aircraft on its journey from Essendon to Canberra' ${ }^{28}$ In truth, there was no evidence before the Court on the question of other men possibly piloting the aircraft during the flight. The fact that Pilot Officer Wiesener was not qualified to fly the aircraft was adduced in support of the conclusion that Hitchcock alone had the controls. It would have been a simple deduction from this information to the disturbing realisation that the RAAF had entrusted the safety of three Cabinet ministers and the Chief of the General Staff to just one man. A patriotic, and possibly censored, press did not comment on the hazard implicit in trusting a group so vital to the nation's security to the health and judgment of a single pilot, however competent.

The fact that Arthur Dean had thought it necessary to submit a crushing repudiation of a 'view' and 'suggestion' that had not been presented is telling. Dean and Lowe were rejecting unexpressed 'pure speculation' of which they had obviously heard. The matter had been hinted at when Pilot Officer James Wilson, giving evidence in public on August 28, had been asked about what he had seen on the tarmac at Essendon. Dean asked whether Wilson had seen the passengers enter the aircraft. He had. 'Do you know where they were seated respectively in the machine?' 'No.' A few moments later one of the assessors, Group Captain Wilson (not, as far as can be determined, related to the 38-yearold former car salesman and private flyer, Pilot Officer Wilson), intervened and probed further. He queried why the aircraft might have waited for about 10 minutes after taxiing into position for take-off. This unusually long period

27 Air Force Court of Inquiry, Transcript of Proceedings, 29 Aug. 1940, p.103 (NAA: A705, 32/10/2729). The Canberra Times (30 Aug. 1940) did not have the victims perishing 'in the flames'. This was a curious discrepancy. If Lowe did use the words attributed to him in the transcript he was perhaps revealing that he was unconvinced by the conclusions of Dr Mackellar.

28 Air Force Court of Inquiry No. 1 of 1940, Findings, p.10 (NAA: A705, 32/10/2729). 
had not caught the attention of the Service Court but had been the subject of speculation at Laverton. Herb Plenty, who had undergone instruction by Hitchcock, recalled that when he returned from Sembawang he talked to men from No. 2 Squadron whom he had known before leaving: Bob Dalkin, Wilbur Wackett, and Phil Howson. Plenty recalled their opinions:

Seven or eight minutes at most is all that was required to check the engines, check ignition, set the controls, set the instruments and then away you go. But they were there with the engines idling for 20 to 25 minutes...it seems to indicate, and I would almost bet on it, that Bob Hitchcock was explaining to Fairbairn: 'Now you do it this way, and this is that, and so on, and when you line up I'll watch you, and so on. ${ }^{29}$

The discrepancy between Wilson's contemporary observation of around 10 minutes and the 20 to 25 minutes of Plenty's story 60 years later may not be significant. Howson, Dalkin, and Wackett were not at Essendon when the passengers joined the aircraft. They were talking about what they had heard from others, not what they had seen. The important point about the testimony of Wilson and the control officer Williams was that the aircraft stood for what was thought to be a considerable time, more than normal; and, as they told the Court, the delay was not necessitated by heavy traffic. The Court did not explore one obvious explanation - that the second pilot, who was thought to be in a Hudson cockpit for the first time, was undergoing a briefing on the aircraft.

Pilot Officer Wilson was asked whether he saw any members of the Hudson's crew other than the pilot. He had never actually looked into the aircraft, he said. 'As far as you know, did they leave the aircraft?' Dean asked. Wilson's response was succinct: 'Not Flying-Officer [sic] Wiesener.' By implication, he had seen the other two. There was no recorded reaction to his next recollection of getting the names of the passengers and crew from Hitchcock and then turning and walking away from the aircraft and into the control tower.

The examination of Pilot Officer Wilson in public concluded:

You cannot say whether the Minister for Air was sitting next to the pilot?

- The only person I saw actually in the plane, through the door, was Mr. Elford. I recognised him. He was sitting towards the rear, near the door.

And the pilot did not discuss with you prior to taking off anything about the flying of the aircraft?

29 Plenty, interview with Geoff Crane, 19 April 2007, courtesy Geoff Crane. Plenty had been flying Hudsons operationally for over a year (Herbert C. Plenty, Singapore Slip, Len Books, Canberra, 1990). 
Ten Journeys to Cameron's Farm

- No. ${ }^{30}$

Naturally, you would understand or think that he would be the sole man in charge?

— Quite.

(The witness then withdrew.)

'Del' Wilson was obviously aware, days before Herbert Storey's letter was written, of talk about Fairbairn's disposition to sit up front with the pilot. Wilson asked his question in open court. He pushed for an answer that would justify a denial that anyone other than Hitchcock was at the controls. Whether at the morgue or the air base, Wilson surely had heard the rumours already loose in Canberra. Lowe's conclusion, published without reference to the question and answer from Pilot Officer Wilson, served rather to provoke curiosity than to quell it. The question about the Air Minister 'sitting next to the pilot' had been asked, and reported in the press - albeit buried at the bottom of a column on page five of The Argus, under the sub-heading 'Seating arrangement' in the Sydney Morning Herald, or more directly on page 14 of The Advertiser on August 29 (where Herbert Storey was likely to have seen it) as 'Mr. Fairbairn's Place in Plane'.

It was soon obvious that many people simply did not believe the official finding. At first within the government, the upper reaches of the public service, and the Air Force, and then rippling out by gossip, query, innuendo, and allegation, the idea that Jim Fairbairn was somehow responsible for the crash spread rapidly. In city clubs and what Bob Menzies had called early in 1940 'other congregations of tittle-tattlers' - he had in mind the haunts of a loose-lipped British member of the Air Board - the question continued to be asked. ${ }^{31}$

Spoken in a whisper, or behind a hand, it was rarely alluded to in print, never developed thoroughly as a line of inquiry. Four and five decades later, it lingered as a rumour, occasionally finding its way into books, to be floated lightly into conversation by knowing insiders. For every one who quickly cast the notion aside as improbable, if not unbelievable, there was another who affirmed that it was plausible. The deceased Jack Palmer's brothers-in-law turned over the idea at family gatherings, never quite sure what to believe. ${ }^{32} \mathrm{~A}$ handful of contemporaries are known to have been convinced that it was true.

30 The official transcript differs from some press reports that refer to 'piloting' not 'flying' the aircraft (SMH, The Argus, The Mercury, The Examiner, 29 Aug. 1940). The Canberra Times and Courier-Mail, did not mention this part of the evidence. Some reports had the next question beginning: 'Normally', not 'Naturally'. 31 Sir Geoffrey Whiskard (UK High Commissioner to Australia) to Anthony Eden (Secretary of State for the Dominions), 1 Jan. 1940, PRO: DO 35/100/1 quoted in Norman Ashworth, How Not To Run An Air Force, vol. Two - Documents, Air Power Studies Centre, Canberra, 2000, p.14.

32 John Foley, telephone interview, 25 July 2009. 
Some, like fireman Jim Kearney, even remembered that, at the crash site in the days that followed, RAAF personnel on guard duty were saying that 'Fairbairn was driving the plane and that it wasn't the pilot at all.' Ambulance officer Tom Hynes would tell his family similar stories. ${ }^{33}$ Most troubled of all by the idea was Jim Fairbairn's own son. Geoffrey Fairbairn, on the History staff at The Australian National University, returned again and again to the unresolved question of his father's role in the crash. As one of his students remembered:

Once Geoffrey found out I was a former RAAF pilot, he would frequently ask me whether I thought his father might have been flying the Hudson when it crashed. Geoffrey's seminars were often enlivened by several glasses of wine, and the more he had the more he'd raise the subject. All I could say was that people I knew who'd flown the aircraft told me that the Hudson was unforgiving in the approach and landing configurations, and so it would seem unlikely that the captain would have allowed an uncurrent pilot such as James Fairbairn to have taken the controls, especially during an approach in poor weather. That would satisfy Geoffrey until the next seminar. ${ }^{34}$

\section{‘On every possible occasion I’ll practise landings'}

For a researcher startled in 1978 by the discovery of the file containing the Storey letter the first instinct was to see if Herbert Storey was still alive. After some hundreds of letters and telephone calls to track down other witnesses it was unexpectedly easy to find him. Sadly, the former headmaster and Supervisor of Defence Technical Training was very ill, and his memory fragmentary. But from Unit 8, 45 Princes Road, Kingswood, South Australia, he wrote back to me in his own hand on 15 May 1978:

Right from the beginning I will give you the name of the pilot associated with Mr James Fairbairn. He was Sq. Ldr Walker — familiarly known as 'Black Jack' Walker...

Yes we discussed the Hudsons when I was flying with 'Black Jack.' I recall asking the pilot 'What was the terminal velocity of the Hudson?' The pilot said in reply 'I don't know. Let's find out.' That was enough for me! I never thought I would survive.

33 Kearney, interview, 23 July 1977: 'Shadow of Calamity', Stateline Canberra, ABC broadcast, 22 June 2007, transcript courtesy Geoff Crane.

34 Alan Stephens to CH, (email), 24 April 2009. Ian Hancock, a colleague of Fairbairn's in the ANU School of General Studies history department, had similar memories (email to CH, 12 July 2012). The weather at the Canberra aerodrome on 13 August 1940 was not poor. 
I do know that Mr James Fairbairn had spent some time at Mallala with 'Black Jack' Walker.

There was nothing an ailing Mr Storey could add to what he had told the Secretary of the Department of Air late in August 1940. What could be done independently was to fix the precise context and date of the meeting he had described. It was not difficult to establish that the Minister for Air had indeed visited the school of technical training in Adelaide. Fairbairn, accompanied by a recent addition to the RAAF public relations staff, J. T. Harrison, was on one of the last legs of a trip round the country. His beloved Dragonfly had been requisitioned by the government (and was subsequently sold on for $£ 2300$ to Charles Snook of Airlines [W. A.] Pty Ltd as a replacement for the Airlines DH84 Dragon that had been impressed by the RAAF). ${ }^{35}$ So Fairbairn was attempting a 7000-mile journey in seven and a half flying days in a Percival Q6 Petrel acquired by the Civil Aviation Department in July 1939. The former Civil Aviation Board had belatedly ordered the British twin-engine monoplane to continue the urgent task of flight-testing the network of Lorenz ultra-short wave radio beacons after the Kyeema crash. (Dick Casey, discerning the possibility of a good deal, had bought a similar machine while the Percival company awaited news of the Australian Cabinet's purchase approval. ${ }^{36}$ Comfortably configurable for six or seven passengers, the Q6 was also to be available for carrying the Air Accidents Investigation Committee to accident scenes, and departmental officers for aerodrome inspections. Fairbairn had told Parliament on 6 June 1939: 'The aircraft was not purchased for the transport of Ministers. ${ }^{37}$ Having left Essendon on 21 July 1940 and flown to Sydney, Brisbane, and Darwin, Fairbairn's party had arrived in Adelaide from Perth on Wednesday 31 July 1940. He inspected the Parafield flying training school before going to Storey's school at East Terrace, concluding his day at the recruiting depot. The Adelaide Advertiser reported the Minister's optimism that he would complete his trip within 46 hours, 15 hours ahead of the record set by C. J. Melrose in 1934.

Was it plausible that Fairbairn would have attempted on August 13 to do as Herbert Storey said he had foreshadowed he would a fortnight earlier? Had his interest been increased recently in Darwin by seeing three Hudsons buzzing the town in line abreast to celebrate his visit? Had his travelling companion John Harrison told him of things he had learned on July 25 from Harry Purvis, the doyen of Hudson instructors, while doing air-to-air photography at angles chosen to conceal the absence of rear gun turrets? ${ }^{38}$

35 Brian H. Hernan, Forgotten Flyer: The Story of Charles William Snook and Other Pioneer Aviators of Western Australia, Tangee Publishing, Perth, 2007, p.172; The Advertiser, 9 Aug.1940.

36 Ewer, Wounded Eagle, pp.88-9.

37 Details of the Percival Q6 VH-ABY are at www.airwaysmuseum.com. A similar aircraft of The King's Flight was in use by the C-in-C RAF Bomber Command.

38 John Harrison, 'The last of the "old Bus" pilots dies', Courier-Mail, 18 Sept. 1980. 


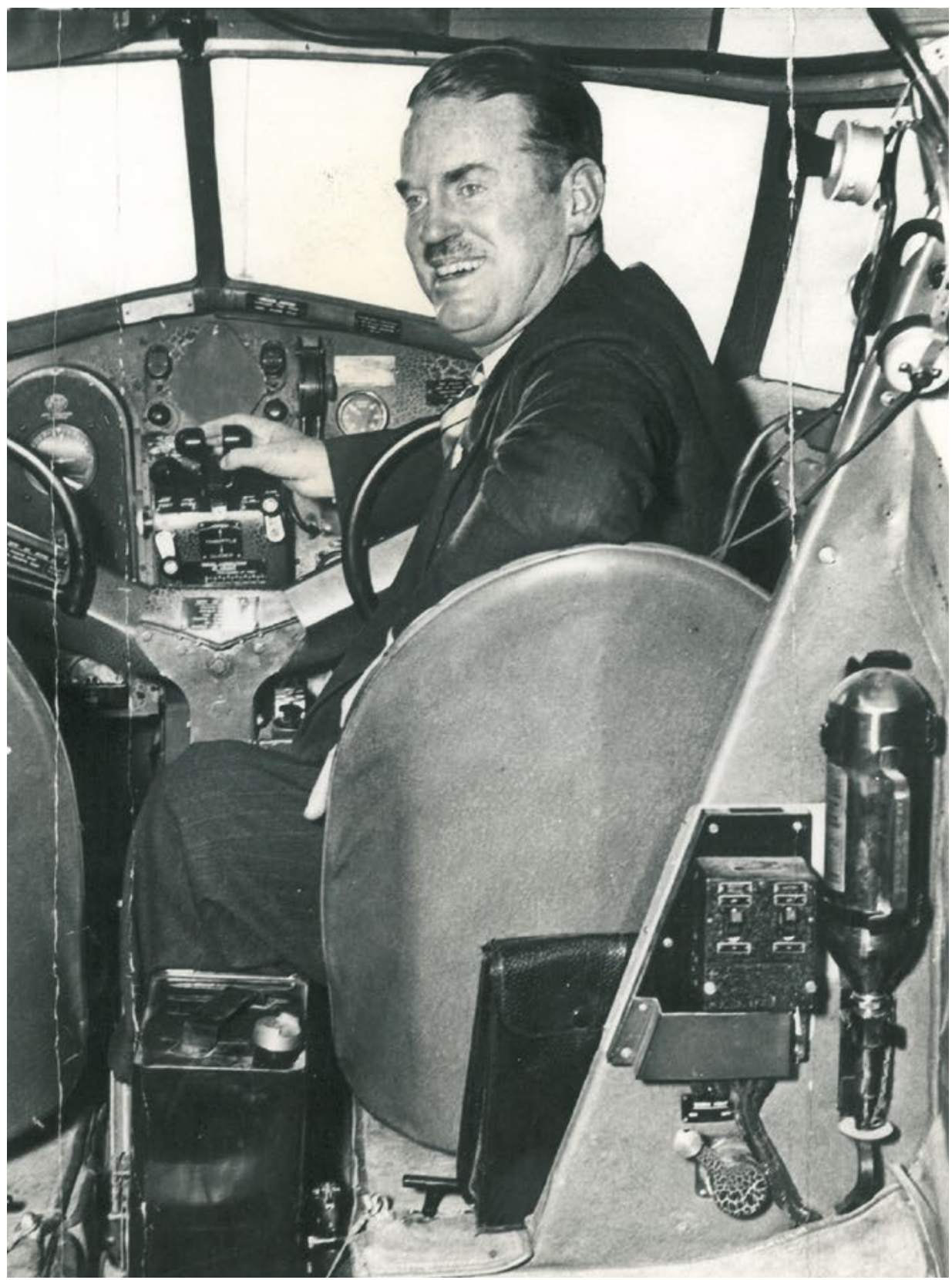

The Minister for Air switches off the 06's motors at the end of his roundAustralia flight

(Courtesy of The Age) 
Perhaps the best source for determining Fairbairn's thoughts and plans would have been the diary which his son affirmed he kept. To Geoffrey Fairbairn's regret, the diary — which he said he had read — was supposedly lost in a fire that destroyed the homestead at Mount Elephant in $1956 .{ }^{39}$

I had asked several contemporaries both before and after coming into possession of Storey's letter what they thought of the rumours about Fairbairn's involvement in the crash. Some extrapolated from first-hand experience. None portrayed the man they knew as having a 'risk-taking nature'.$^{40}$ Geoffrey Fairbairn had flown with his father often enough to be convinced that he was a very cautious pilot. He had heard tales of abandoned flights, including three forced landings in bad weather on one trip from Mt Elephant to Canberra in $1939 .{ }^{41}$ Geoffrey himself recalled an occasion when, much to his irritation and embarrassment, his father turned back only 20 minutes or so from their destination. The 14-year-old, eager to get where he hoped to be, could not see why the expected bad weather should spoil his plans. Conceivably, he admitted, his father might have taken the controls of the Hudson in level flight, but it was most improbable that he would have undertaken a dangerous manoeuvre when an aircraft was close to landing. ${ }^{42}$

Murray Tyrrell's testimony from the perspective of a personal staff member was unequivocal:

That Fairbairn was flying it? It's baloney. It's absolute baloney. Now I flew with Fairbairn not once but repeatedly in at least three different types of aircraft...I used to navigate for him in his private aircraft...Fairbairn was the most cautious of pilots... And if it was bad weather, and we were flying Fairbairn's private aircraft out of Melbourne to Canberra, Fairbairn would just say 'I'm the best turner-backer in the business.' And we'd go back and come by train or by car or some other way.

Now I've known him to take over with the permission of the pilot of the other aircraft he and I had flown in but he never took off and never landed an aircraft.

Reinforcing these observations, Tyrrell emphasised something else he knew. Fairbairn recognised that his injured arm was 'critical in handling an aircraft, and he would no more have attempted to land that Hudson than I would have'. Like Fairbairn's son, Tyrrell was 'not suggesting he mightn't have been at the controls when it was at 9,000 feet'.

39 Geoffrey Fairbairn quoted from his father's diary - presumably from memory — in 'Personal History', Nation, No. 150, 8 Aug. 1964, p.10. He referred in conversation with me to another diary, purportedly written by his father, which he believed to have been fabricated; but he declined to elaborate.

40 Tink, Air Disaster, p.284.

41 Sydney Morning Herald, 6 June 1939. 


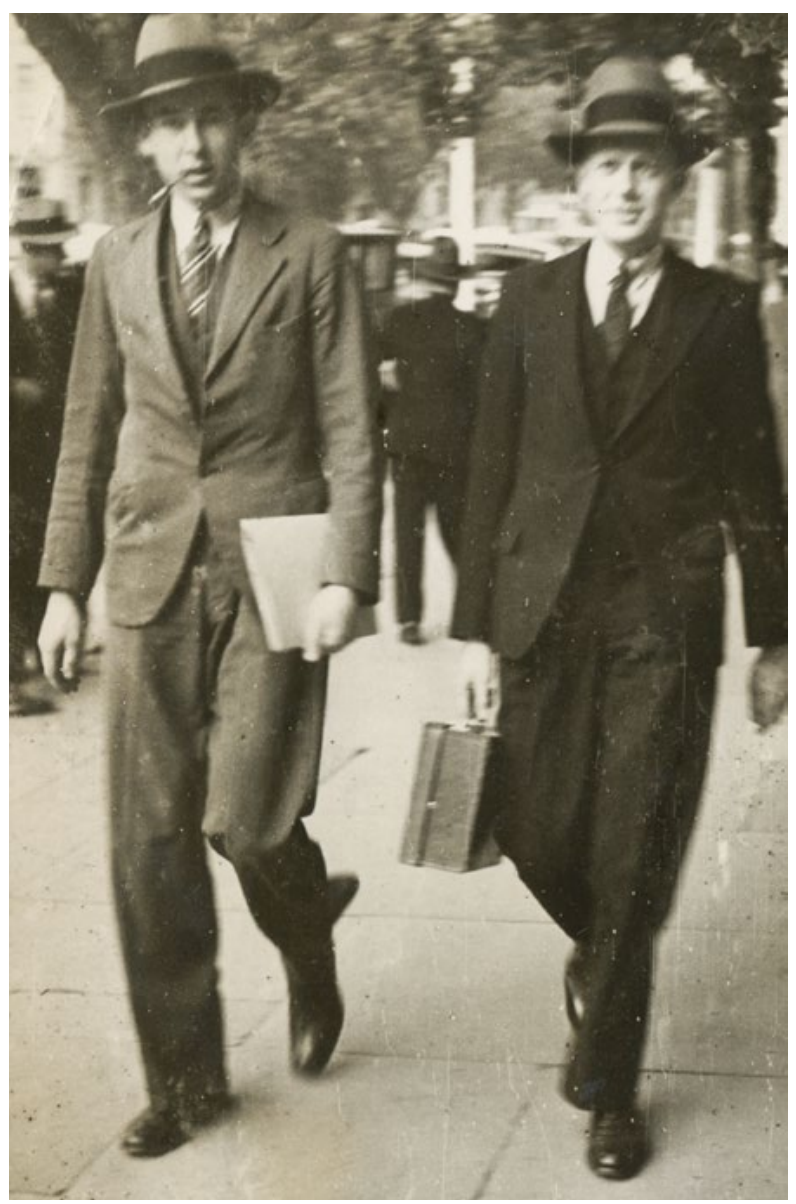

Murray Tyrrell, at left, constantly at Fairbairn's side but never close (Courtesy of Kirsten McCulloch)

Tyrrell's insistence that Fairbairn was 'too sensible, too cautious', was not the evidence of an uncritical admirer. He made no secret of his personal coolness to his Minister in 1940.

'Fairbairn was a very austere detached person. I never got close to him...I could never like Fairbairn.' Tyrrell had been with the Minister on the flight to Canberra in A16-97 piloted by Bill Heath a week before the fatal flight. Although he didn't 'believe for a second' that Fairbairn 'was at the controls when the Lockheed pranged', there is a reluctant hint here, but no more, that he might have seen his chief changing places with Al6-97's second pilot. ${ }^{43}$

43 Sir Murray Tyrrell, interview, 5 April 1977; Tyrrell to Lord Casey, 24 Oct. 1972, NAA: M1129 WHITE/C B. 
Scotty Allan's memory from his days as a senior pilot with Qantas, and as a converted Hudson pilot himself, was clear: 'Jim Fairbairn was not a professional pilot and not up to the standard capable of flying a Lockheed Hudson...' But would he want to see for himself what might happen if the aircraft was put to the test? Sir Edwin Hicks, who saw the Minister for Air at close quarters as a public servant in the new department, had no doubt. Had he been so minded, Fairbairn was a strong enough personality to have insisted on getting his own way in the cockpit. ${ }^{44}$ Scotty Allan said:

I never flew with him acting as pilot but he came into the cockpit of the " $\mathrm{C}$ " class flying boat - Sydney to Darwin on the route to Singapore, where he was interested in methods used for dead reckoning, use of varying winds at different heights.

And would he be content just to watch?

No, I don't think that [he] could have landed a Hudson - that is consistently, but yes, he would try stalling a Hudson but not with me, possibly with some pilot not able to question the wisdom of such a proceeding. ${ }^{45}$

\section{'...some pilot not able to question the wisdom of such a proceeding'}

What troubled many people was less the possibility that the Minister for Air might have taken the controls himself than that he might have persuaded the pilot to execute some ill-advised manoeuvres. In the circumstances, the minimal assessments, 'adequate' and 'competent' would be read by some as a patronisingly coded signal that Hitchcock was the wrong man for the job. There were several clues in Hitchcock's record to what George Jones and others uneasily recognised as danger signs. The first might have been the evidence of the special consideration that had facilitated his acceptance into the service. 'If enlisted by special authority', his enlistment form required that the number and date of the authority be quoted. For those with permission to see the restricted access file the authorisation was clearly visible: 'AS9139d, 18/6/30'. Much more disturbing, had the facts been brought forward, would have been the knowledge that less than five years before the fatal crash his flying had been deemed so poor, and his confidence so eroded, that his commanders at the Richmond station thought he should be separated from the Service. But the paper trail had been efficiently hidden.

44 Sir Edwin Hicks, interview, 18 Sept. 1980

45 G. U. Allan to CH, 16 Aug. 1982. 
What remained was as telling by its silences as by what it said. When the 'RAAF Annual Confidential Report (Officers)' was compiled in June 1939, Hitchcock's evaluation by his immediate superiors was uncritical other than by the resonance of its muted praise and recommendations. Personally he appeared beyond reproach. Was his personal conduct satisfactory? Yes. Were his habits temperate? Yes. Did he always set a correct example to juniors? Yes. Tact in handling men? Average. What then of his technical knowledge? Average. Administrative knowledge? Again average. Power of command, power to impart knowledge, general standard of professional knowledge - all average. But what of his competence? Here the commander of No. 1 Squadron was more appreciative. 'Above average' ability on duties now engaged, Squadron Leader Paddy Heffernan said. And 'above average' in flying duties. Heffernan's 'special remarks' were warm: 'A sound \& reliable officer, who can be trusted to carry out satisfactorily any duty trusted to him. He has shown himself to be well balanced in his judgments.' From the former Chief Flying Instructor at No. 1 Flight Training School this was encouraging. Too encouraging thought the Group Captain in command at Laverton whose remarks were added after Hitchcock had initialled the report. 'Graded a little high...I consider', wrote Harry Wrigley of the 'above average' assessments. ${ }^{46}$ No one knew better than Wrigley the stress Hitchcock had endured in securing his place in the Air Force.

In hindsight, Heffernan's emphasis was different. In 1978, he wrote of Hitchcock as 'a rather stolid type':

Although he flew satisfactorily, I never really felt happy with him...He certainly was not an over-confident pilot and he may not have been a confident pilot. We used to have five pilot gradings, Exceptional, above average, average, below average and poor. I would have placed him in the below average class. ${ }^{47}$

There were, in fact, only four gradings. There was no 'poor' category, except perhaps in the minds of those making the assessments. Heffernan could have forgotten his judgment in 1939, or conceivably been persuaded by Wrigley and by subsequent events that he had been too generous. Gossip about Hitchcock's competence was certainly rife in the spring of 1940. Formal inquiries might distinguish between a man's ability in general and a singular error in judgment. However, the rumour mill soon blurred the distinction. Maybe we were wrong to let an ill-qualified man into the service, one old-hand might say. But, after all, the Service had been trying to do the right thing by the family. And, if an average pilot was responsible for mishandling the aircraft, it could not be the fault of the machine itself, or of those who had been charged with testing

46 NAA: A9300, Hitchcock RE.

47 ACdre P. G. Heffernan to CH, 7 April, 20 July 1978. 
and maintaining it. What was to be gained by speculating on the possibility that a flight lieutenant, nervous and overawed, might have tried a dangerous manoeuvre to please his Minister?

So much might well have been said. So much was said in messes, clubs, and pubs. Among those who had flown with Hitchcock it was not hard to find men who could relate tales that cast doubt on their contemporary's competence. The Roman Catholic chaplain Father Morrison heard after the accident 'doubts expressed as to Bob's ability and the opinion expressed that he was kept on his flying course because of sympathy for his father's death' ${ }^{48}$ Forty-seven years later, Sir Richard Kingsland could say:

I knew Hitchcock and I was on a training course with him in 1935. And when I heard about Hitchcock crashing, this was when I was in England...I just turned around and said to my colleagues 'Hitchcock was just an accident waiting to happen.'

Herb Plenty remembered that he had flown twice with Hitchcock on circuits around Laverton and:

almost from the minute I entered the aircraft and sat up the front, I had the feeling that he was very tentative...he was not fully confident that he knew what he was doing. We had a saying in the Air Force in those days, the aircraft was flying him, he wasn't flying the aircraft.

Plenty had been taken up on June 4 and 19 June 1940 by Hitchcock. The second occasion was Hitchcock's twenty-eighth birthday, a fact he might not have disclosed to the young pilot officer. Plenty was being instructed on the use of flaps in an Anson fitted with dual controls. He later testified that Hitchcock was 'very good as an instructor...sympathetic'. As a gifted flyer who in the 1960s led the Telstars aerobatic team flying dual Vampires from East Sale, Plenty's assessment has to be taken seriously. But hindsight, coloured by knowledge of the events of 13 August 1940 and oft-rehearsed tales in the subsequent decades, must be treated with caution. ${ }^{49}$

So too must be the pejoratively nuanced depiction of events of which there are less prejudicial official accounts. Plenty was with Hitchcock, Pilot Officer James Sutherland, and another crewman in an Anson on 21 May 1940 when Hitchcock had to put the plane down in bad weather on the Melton-Gisborne road near Toolern Vale, northwest of Laverton. They were returning from Albury where

\footnotetext{
48 Msgnr K. Morrison to CH, 6 June 1983.

49 The testimony of Kingsland and Plenty was broadcast in 'Shadow of Calamity', Stateline Canberra, ABC TV, 22 June 2007, and is quoted from a DVD of the program provided by the director and writer Geoff Crane. For Plenty's leadership, see Alan Stephens, Going Solo: The Royal Australian Air Force 1946-1971, AGPS Press, Canberra, 1995, pp.169-70.
} 
they had been searching for an Anson missing with four crew. Landing in fog at 5.30 p.m. the tailplane and airscrew were damaged as the aircraft ran through a fence at the end of a field. Pilot and crew were unhurt. ${ }^{50}$ In Plenty's colourful version 67 years later, Hitchcock 'panicked and put the Anson down in a paddock, wheels down, ran through a fence, avoided some huge rocks, and we walked out of it...not really good judgement, not what they call good airmanship'. ${ }^{51}$ What Plenty did not say was that Hitchcock almost certainly had received no night-flying training at No. 1 FTS; he had not been given any dual night flying training on the twin-engine Anson; and he had been forced to fly too low for the trailing wireless aerial to be used and had therefore received no weather reports. Plenty did indeed walk out of the downed aircraft but it is curious that his presence is not recorded in the official record of the accident.

The Anson that Hitchcock was flying that day (A4-39) was one of the earliest delivered to the RAAF. It had a limited instrument panel and no flaps. With large hills close to the northwest blocking such of the setting sunlight as was coming through the fog, and with last light due at 5.42 p.m., Hitchcock's decision to put the aircraft down in a paddock was prudent. The fact that he was able to fly it back to the base two days later indicates that the damage was minimal. As the late Group Captain John McKenzie concluded after a detailed study of the incident, including an inspection of the terrain and discussion with someone who had been on the scene: 'Had I been in the situation faced by Hitchcock during this flight in foggy conditions at night, with basic instruments and no formal night-flying training, I would have done the same as he did. ${ }^{52}$

Within the RAAF community there has long been another school of thought about Bob Hitchcock's airmanship. Like McKenzie, a former Staff Officer Air Training, not everyone was sure that he was below scratch as a pilot. They were unconvinced that the fault on 13 August 1940 was his. For all his reservations about Hitchcock's ability, Herb Plenty did not believe Hitchcock was in control of A16-97 when it crashed. The alternative view was well expressed by Air Commodore Bruce Courtney, who in 1940 was a flying officer with No. 10 Squadron in England. He knew Bob Hitchcock slightly and thought there was no reason to believe that he was anything other than 'a competent and experienced pilot who should have had no problem with the Hudson':

50 'Preliminary Report (Internal) of Flying Accident or Forced Landing', 1939/40, 184, NAA: A9845, 74/55; Flying Accidents Analysis May 1940, NAA: A705, 32/10/2478. Hitchcock is not among the aircraft crews listed as taking part in the search for Anson A4-4 (NAA: A11094, 241/1/8; 72/1/44).

51 GpCpt. H. C. Plenty, interview with Geoff Crane, 19 April 2007, transcript courtesy Geoff Crane.

52 GpCpt. J. J. McKenzie to Chris Coulthard-Clark, 28 Sept. 1999, made available by Dr Clark. Fifteen days after this incident, Judge Piper elicited the admission in open court that only 38 of the RAAF's 82 Ansons were fitted with Sperry blind-flying instrument panels. WCdr Scherger, Director of Training, then revealed that after 2300 hours flying he had never flown in fog (Cairns Post, 6 June 1939, The Advertiser, 7 June 1939). 
...the hearsay story (which I believe) was that the aircraft was in the hands of Mr Fairbairn at the time of the crash...it is not difficult to imagine that an inexperienced pilot could get into a situation where recovery by the captain could not be achieved in time... it is a reasonable explanation and one which I believe was generally accepted by RAAF pilots. But don't forget that we would want to believe it rather than to accept that any of us could make such an elementary mistake of airmanship. We were a proud lot! $!^{53}$

53 ACdre E. B. Courtney to CH, 7 April 1978. 


\section{Cockpit secrets}

In seeking a path through the conflict of testimony and hypothesis about responsibility for the crash, the formal records of Bob Hitchcock's Service progress are an essential resource. We have seen that he was a slow learner during his initial training. But what seem to be the most relevant official files do not tell the whole story. Whether by accident or deliberate omission, Hitchcock's personal dossier does not contain the evidence that has led some scholars to conclude that a finding of pilot error in August 1940 was most likely to have been correct. The truth was that the records on Hitchcock's personal file omitted the decisive moment when the Service had considered terminating his flying career. The flying log book made available to Justice Lowe had no entries before the beginning of 1938. His friend Rex Taylor was to tell others years later that Hitchcock was 'a frightful pilot and he could not even pass his "ab initio" flying test'. 'This was an exaggeration. So too was George Jones's explanation in hindsight:

Hitchcock was the son of Hitchcock who was lost out in the desert searching for Kingsford Smith. When he got old enough he applied to join the Air Force, but he wasn't very bright, and he would not have been accepted had the selection committee not given a great deal of weight to political influence to get him in. But all throughout his training he was a doubtful case as to whether he should go on or not... he just made the grade and that's all. ${ }^{2}$

Was the Hitchcock of August 1940 the same uncertain pilot of 1935 and 1936 ? That was the assumption of Dickie Cohen (later Sir Richard Kingsland), who had not seen his fellow cadet for four years before his death. It was the experience that the then tyro Herb Plenty said he remembered seven decades later. However, it was not what David Campbell heard when he arrived at No. 2 Squadron to take Dick Wiesener's place. Hitchcock, he understood, was 'a very respected pilot'. Deryck Kingwell's testimony was similar: 'The entire service was shocked by this accident because Bob was not only considered to be a very able pilot but one who was always expected to be "cool" under all circumstances.' Kingwell, who had flown with Hitchcock in a Hudson in late July 1940, was then already recognised as one of the best young pilots in the Service. He was on track to become an outstanding operational battle commander. Thirty-eight years later, a distinguished retired Group Captain, he described his former Laverton mess mate as having 'a very conscientious service outlook'. Hitchcock 'could always be relied upon to give of his best at all times. Because of this attribute he was an excellent pilot and obviously especially chosen for the particular mission.' ${ }^{3}$ 
Ten Journeys to Cameron's Farm

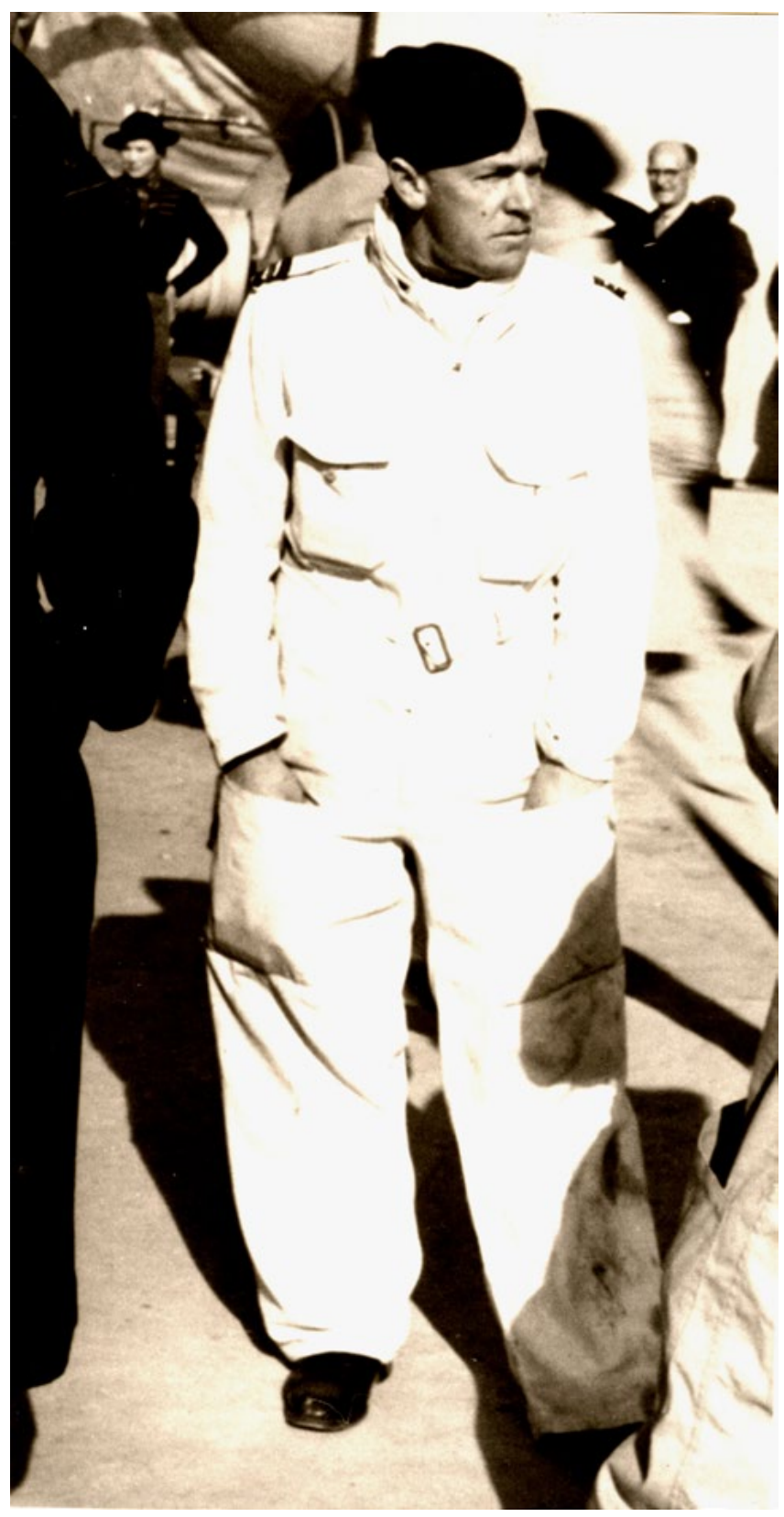

\section{Paddy Heffernan, posted to Sembawang, 5 August 1940}

(Courtesy of the RAAF Museum)

Kingwell spoke of what he remembered and what he had known. He was not on oath but had no obvious reason to colour the truth. He had not been a witness in the 1940 inquiries. At that time he had not been converted to Hudsons. He was not responsible for training Hitchcock, nor did he command him. Others 
who were qualified to offer testimony to successive inquiries were not asked to do so. Some, like Paddy Heffernan, were too far away. Heffernan had arrived in Sembawang near Singapore on August 9. No. 1 Squadron was already there. And the ground personnel of No. 8 Squadron and No. 21 Squadron had left Melbourne in the liner Strathallan on the day of the crash.

Heffernan's absence was unfortunate. ${ }^{4}$ He was one of the RAAF's most experienced and versatile flyers, having undergone a test pilot's course in England and flown 10 different types in a month. He had converted to Hudsons under Alec Barlow, who had taught him that the aircraft could 'bite'. ${ }^{5}$ His written appreciation of Hitchcock's ability in 1939 had been considered generous by Harry Wrigley, but he was uniquely qualified to advise on the credibility of the speculations about Hitchcock and Fairbairn. He had been closely associated with both of them.

In correspondence 38 years later, Heffernan reviewed what he knew about the two men. Hitchcock he said was 'a rather stolid type'. His first thought was that the Hudson's 'flicking characteristic', which he believed to be the most likely cause of the accident, might have caught Hitchcock unawares. But there was more to it than that. His experience with Fairbairn in 1939 was directly relevant:

I knew Fairbairn well and flew with him when I was instructing him on the N.A.16, which was a smaller version of the Wirraway and we used it as a general hack machine for the purpose of keeping in practice on single engine planes. Fairbairn was a good average pilot, but because of the handicap of his useless left arm, I would not let him go solo on the N.A.16 for the following reason, the flaps were wound up and down manually and the control was on the left hand side, the same side as the throttle. On coming into land, the hand was removed from the throttle and placed on the flap control and the flaps then wound down. In the event of a bad landing, the engine was given full power and then the flaps were wound up. In Fairbairn's case, he had to let go the control column with his right hand and then transfer it to the throttle and then to the flaps and in the meantime to hold the control column between his knees. In an emergency, events happened far too quickly for him to do all this with safety, so I refused to send him solo. His private aircraft which he flew solo, did not have flaps, consequently there was no need for his right hand to be flashing round the cockpit. ${ }^{6}$

\footnotetext{
4 RAAF records indicate that Heffernan was in Singapore. For the departures of No. 8 and No. 21 Squadrons see NAA: A1196, 36/501/111 and Gillison, Royal Australian Air Force 1939-1942, p.142. But the Canberra Fire Brigade daily-occurrence register for Aug. 13 notes 'further information may be obtained from Wing Commander Heffernan of R.A.A.F.'

5 Vincent, The RAAF Hudson Story, Book One, p.296.

6 ACdre P. G. Heffernan to CH, 7, 21 April 1978.
} 
It is noticeable that Heffernan said it was the left hand, minus two fingers, that was useless. He might have added that it was Fairbairn's right arm, 'permanently bent by an explosive bullet', that had limited mobility. As readers of the Warrnambool Standard had learned from an article their local state Legislative Assembly member wrote about a visit to Mussolini's Rome in 1933, he had been embarrassed at being able only to 'wave his right arm ineffectively' when attempting to return Fascist salutes. ${ }^{7}$ The implication of Heffernan's story was unmistakeable. Whether he might have wanted to or not, and assuming he understood the controls, Fairbairn would have had great difficulty in effectively controlling a Hudson in anything other than level flight. The later experience of David Campbell in the operation over Rabaul that brought him his DFC illustrates what could happen in a Hudson cockpit when the first pilot could not use his left hand. Shot through the left wrist and minus his little finger, Campbell brought the bullet-riddled A16-130 into land with his right hand on the stick and his only unwounded crew member handling the throttle and flaps. ${ }^{8}$

Would Fairbairn have wanted to try what he could do with his diminished personal capability? Much as he might have wished to feel for himself the temperament of the Hudson, a responsible Minister would be most unlikely to put colleagues, friends, and crew at risk. ${ }^{9}$ This is not to say that such behaviour is inconceivable. As the RAF Dambuster leader, Guy Gibson, testified about the British Air Minister Sir Archibald Sinclair, flying in 1943 as a passenger with some senior RAF officers when Gibson had a new flight engineer:

...the Air Minister jabbed a finger in my back and told me to feather an engine. This was done and he seemed very pleased. Then we feathered another one and he seemed even more pleased.

After we had flown along like this for a few minutes, one of the brass hats came forward and told me to unfeather as they were in a hurry. I gave the order, casually, to the Flight-Engineer. Suddenly, to the horror of both myself and the man with goggles on, looking over my shoulder, the two other engines began to feather themselves. Our new Flight-Engineer had pressed the wrong buttons. It was all right, though, because it didn't take a second to get all four going again. ${ }^{10}$

\footnotetext{
7 J. V. Fairbairn, 'Impressions of a Short Visit to Rome', reproduced from The Standard, 19 April 1933, copy courtesy Mary Browne.

8 Leslie Jillett, Moresby's Few: Being an Account of the Activities of No. 32 Squadron in New Guinea, North Western Courier Publishers, Narrabri, 1945, p.38; David Campbell, Flame and Shadow, UQP, St Lucia, 1976, pp.169-77.

9 Andrew Tink's 'opinion' (Air Disaster, p.175) is that 'Fairbairn had taken control of the Hudson, as he had earlier told Storey he would do, intending to land the plane'; and 'he determined to land the Hudson' (p.284). 10 Guy Gibson, Enemy Coast Ahead - Uncensored: The Real Guy Gibson, Crécy Publishing, Manchester, 2003, p.172.
} 
If Fairbairn had asked to be allowed to sit in the cockpit, what would Hitchcock's response have been? Heffernan's considered conclusion was that Fairbairn 'could have badgered a more junior and therefore more rank conscious pilot into letting him have a go at the controls'. He had in fact 'heard from other pilots that he often asked them to allow him to take over the controls'. What would Hitchcock have done? He might, Heffernan thought, have allowed Fairbairn to sit in the second pilot's seat:

I cannot imagine any pilot in his right mind allowing an inexperienced pilot to attempt a landing on a strange aircraft, whilst flying in the second pilot's seat... Hitchcock could have been placed in an awkward position if Fairbairn had asked him to allow him to take over the controls. He could have been placed in a very tough dilemma. If he said 'No' would he offend a senior Minister, or if he said 'Yes', what latitude would he have given Fairbairn, i.e. would he allow him to fly only in level flight or would he allow him to attempt a landing, knowing that Fairbairn was a reasonably experienced pilot?

Heffernan expressed no doubt about what he would have done himself. It would have been 'Yes' to level flight, 'No' to landing. 'With the throttle controls between the two pilots, Fairbairn would have had to take his right hand off the control column to operate the throttles.' ${ }^{11}$ Hitchcock though 'could have been somewhat over-awed by the importance of Fairbairn's position and allowed his better judgment to be impaired by this thought.' What was more likely was that Fairbairn's very presence in the cockpit could have been distracting.

Heffernan was not alone in pondering the same question. Sir George Jones had not known Hitchcock but he too thought that Hitchcock, indeed any relatively junior officer, was likely to have 'given way to the Minister' ${ }^{12}$ Jones, who had himself started in the Service in the ranks, was perhaps projecting on to Hitchcock his own struggle for acceptance in a socially unfamiliar environment. Sir Richard Kingsland, an exact contemporary of Hitchcock and certainly not a socially inept young officer, is also on record:

Would Hitchcock have allowed Fairbairn to have a go? Oh, you do as you're told! If you have the Minister for Air sitting by you, a pilot of infinitely greater experience than Hitchcock...If he said to me when I was in command of the aircraft 'look, would you let me do this approach and landing?' I'd say 'Yes sir,' because he was a very experienced pilot. Been flying his own aircraft around Australia for a long time. A World War One Pilot...you wouldn't dare... ${ }^{13}$

11 Heffernan to CH, 21 April 1978.

12 AM Sir George Jones, interview, 14 Sept. 1977.

13 Kingsland, interview, 3 April 2007, courtesy Geoff Crane. 
Kingsland of course had not known Fairbairn and had not seen his physical limitations. Nor had he observed anything of Hitchcock's flying after their early training together. Sir George Pape was another who had no first-hand knowledge of Fairbairn and did not know Hitchcock. But reflecting 37 years after the two Inquiries in which he had played a leading role he concluded:

I simply cannot believe that Hitchcock would have allowed anybody to bring this aircraft into land, even assuming that Fairbairn pulled a bit of rank on him on the way up and said 'Do you mind if I take it for a few minutes?' I cannot imagine that when they got into the vicinity of Canberra he just didn't say 'Now look sir, buzz off and get back to your seat.'14

All of those who thought about responsibility for the crash were troubled by the uncertainty and doubts created by the various alternative conclusions. There was no unanimity on the vital questions. But a detached observer could hardly fail to notice that those who were inclined to believe that Hitchcock might have let the Minister take the controls were by implication saying that it was not their former comrade's flying ability that led to the deaths.

\section{In plain sight}

If Herbert Storey's letter, quickly 'put away', filed where it was unlikely to surface, was not the basis of the disturbing idea that Fairbairn might somehow have been responsible for the crash, there were two other possibilities. Fairbairn's concern to know about the Hudson's stalling behaviour could have been discussed with other pilots or political colleagues. It is known that the Air Minister had flown to Canberra with Flying Officer Bill Heath in A16-97 a week before the fatal flight. He had flown in Hudsons at least twice in June. ${ }^{15}$ But his flight with Heath was the first opportunity Fairbairn had after his conversation with Herbert Storey to find out for himself how the Hudson would behave. If he meant what Storey reported him as saying — and the Adelaide headmaster seems to have thought he was listening to more than just idle musings - he might well have tried something while flying with Heath. Knowing that he might be making a number of flights in the coming weeks, he could have used this first one simply to watch and learn. As the accompanying second pilot under instruction was the 6'3" Pilot Officer Keith Eddison, there would have been little room for manoeuvre in the cockpit. If Fairbairn had asked Heath to do anything unusual, no record of his doing so has come to light. No evidence

14 Sir George Pape with ACdre L. V. Lachal, interview, 14 Sept. 1977.

15 Sydney Morning Herald, 21 June 1940. 
of any relevant discussions has emerged. There is not the slightest hint in any of the Inquiry records that anyone thought it might be worthwhile to press Heath for information about his flight with the Minister.

On the contrary. It seems that when Heath was called to give evidence before Justice Lowe his experience with Fairbairn was skated over, in spite of a prompt from his squadron commander moments earlier. Freddie Thomas, testifying as Hitchcock's commanding officer, had been asked if he could name any officers who had flown A16-97. 'Flying Officer Heath, at present in Court, had flown it on the previous occasion.' When was this? What was the trip? Seemingly rattled by Dean's questions, Thomas is reported as saying: 'He carried out a trip of a very similar nature. On the 13th [sic] of the Eighth he had taken the Minister for Air and other passengers from Essendon to Canberra and returned.'

As soon as Thomas had finished his testimony, Heath was sworn and examined. Questioned for just four minutes, Heath spoke of 'five passengers' on his flight to Canberra in A16-97 but he did not say that the Air Minister had been one of them. Nor did he name his other passengers, including Sir Harry Gullett, Murray Tyrrell, and the Clerk of the House of Representatives, Frank Green. Both Lowe and Dean seemed satisfied simply to learn that Heath had noticed nothing abnormal about the machine; that in Dean's words it 'behaved properly'. Heath did not mention that he had also taken A16-97 up the day before his Canberra trip to test its compass and radio. There had been three other junior pilots and two airmen with him on a flight that lasted two hours and 20 minutes. In later years, his sons remember, he would be troubled by the possibility that he had failed to notice something about the aircraft that should have been attended to, something that might have contributed to the fatal crash a week later. ${ }^{16}$

George Pape, understanding full well that his brief was to restrict the ambit of the Inquiry rather than widen it, had no questions for Heath. Perhaps Pape had been quietly warned that Heath's discretion could not be relied upon. ${ }^{17}$ Even if they had not seen Herbert Storey's letter, in a hearing two weeks after the crash it is hard to believe that the rumours about Fairbairn being alongside Hitchcock had not reached Lowe, Dean, or Pape. If anything was likely to deter them from asking about what happened on Heath's flight it was surely the high degree of probability that the Air Minister's curiosity would have led him into the cockpit; and, once there, to have brought him into conversation with the seasoned flying officer at the controls. In his report Lowe referred to Heath's

\footnotetext{
16 W. P. Heath, Flying Log Book, 4, 5 Aug. 1940; Hon. Tony Street, interview, 8 Dec 2009; Daryl Heath, telephone interview, 15 Feb. 2010. After the war Heath would farm on a soldier-settlement block a few miles from the Streets' property at Lismore where his older son Willy and Tony Street would become friends. 17 A confidential report by 'Moth' Eaton in 1945 graded Heath as a 'plodder' on mental alertness, 'slow to appreciate subtle points'. The subjective and idiosyncratic nature of these reports needs to be remembered (NAA: A9300, HEATH WP).
} 
mention of 'five passengers'. But there was no allusion to Squadron Leader Thomas's revelation, during his testimony in camera, that Fairbairn was one of the five. The Minister's presence in a Hudson a week before the fatal crash was to be quietly overlooked. ${ }^{18}$

Valuable as evidence of Fairbairn's behaviour on his penultimate Hudson flight might have been, more telling would have been the discovery at the crash site of his body in a place where no passenger could be expected to be. Here we encounter a conspicuous lack of official interest in pursuing the inevitably distressing facts. 'Del' Wilson alone asked direct questions, almost casually, and only to Pilot Officer Winter:

Have you any remarks to make about the position of the bodies?...From the outside of the aircraft only four bodies were visible in the back of the machine; the others were bunched up together and covered with debris. ${ }^{19}$

I am more concerned with those close to the Pilot. You could not give any information about that?...No; there were a number of bodies together.

After Winter, Flying Officer Ronald Wilson was called and examined briefly. Wilson explained that when he arrived at the scene the fuselage had 'practically finished burning'. Unsolicited, he added, 'I saw one body quite clear where the door of the machine would have been.' Arthur Dean, who had just established that Winter had observed nothing extraordinary when he saw the aircraft in the air, now seized the opportunity to ask if Wilson had seen where the bodies were. He had seen four immediately: in addition to the one where the door would have been, two were about six feet 'in front', and another fell out after a 'mild explosion' ${ }^{20}$ 'You could not identify any of the bodies?' 'No I went to the body by the door but could not recognise it.' Lowe wanted to know what Wilson had meant by 'in front'; did he mean inside the fuselage? No, they were a foot or so outside. Wilson was not asked about the remaining bodies whose location he had marked in a sketch for the Coroner. Flight Sergeant Smith's story differed suggestively. He spoke of seven bodies 'in the nose of the machine', but quickly added that they were 'not in a heap, but spread over the...full fuselage of the machine'. Again, the crucial question was asked in the negative: 'You could not identify any of the bodies?' 'No. There were three near the tail and the other seven were forward.'

18 'Air Force Court of Inquiry...Findings and Transcript of Evidence', 27 Aug. 1940, pp.9, 16, NAA: A705, $32 / 10 / 2729$.

19 Winter had told the Service Court he 'could see about four or five bodies on the portside of the aircraft' (NAA: A705, 32/10/2733).

20 Wilson had signed a statement for the Coroner on Aug. 26 which was originally typed as: 'I didn't see any people or bodies there.' He then inserted and initialled changes so that it read: 'I did see four people or bodies there.' Coroner's Court Inquest Papers, now at NAA: A6079, MO 625. 
The RAAF assessors showed no inclination to extract more information from the Service witnesses or to reconcile what were obviously discrepant observations. Nor did they collate what the Air Force personnel recalled with the unmistakeable and more precise clue that had been in plain sight for two weeks. Fire station chief Bill Maloney, among the first at the scene, had told Senior Constable Brodribb the day after the crash that all 10 bodies were 'packed forward' ${ }^{21}$ This was not strictly true, as Crosdale had been found in the rear. But, more significantly, Maloney testified for the Coroner that there were three bodies in the cockpit. No one questioned this very specific observation. Hitchcock and Wiesener should certainly have been in the cockpit. The unasked questions were: who was the third? And was it possible to say with any degree of certainty where he had been?

That Maloney's observations did not prompt further questions is all the more remarkable in view of a report that had appeared in the Daily Telegraph on August 14. Ten minutes after six bodies had been removed from the wreckage, 'the other four bodies were seen in the forward part of the machine. They were the bodies of the air crew.' Only in one case were the features recognisable, the Telegraph reporter said. It was later established that one member of the crew, Charlie Crosdale, had been at the rear of the aircraft and was most likely to have been the person who released the door and tried to escape at the moment of impact. Palmer, the radio operator, would have been expected to be in his cubicle directly behind the two pilots. His identity disk was found among the ashes. But who was the fourth man in 'the forward part of the machine'?

None of the firemen had been questioned either by Murphy and Winneke or by Lachal and his team. Strictly speaking, there was no reason to suppose that Maloney, Kearney, or their colleagues could contribute anything to an understanding of the causes of the crash. But even the possibility that there could have been a person other than the two pilots in the front of the aircraft ought to have sounded alarm bells. The Director-General of Civil Aviation had subtly signalled this in a teleprinter message to the Secretary of the AttorneyGeneral's Department on August 23. Arthur Corbett had been responding to a telephone call to the Minister's private secretary by Major H. E. Jones, 'the chief investigation officer' of the Commonwealth police. The information, 'furnished for inquest purposes', consisted substantially of the procedure required of commercial aircraft pilots when taking off and landing. Brief details of the actual events at Essendon and A16-97's flight and approach to Canberra were provided. For no declared reason, possibly in response to an unwritten question

21 NAA: A1378, 4/174. 
from Jones, Corbett also inserted this sentence: 'No passenger is allowed to enter the cockpit of a civil aircraft in flight. ${ }^{22}$ This was territory under-explored by the Coroner and the Air Force investigation and Inquiry.

For his part, Justice Lowe quickly appeared satisfied that only those who should have been in the cockpit were there when the aircraft left Essendon. 'Del Wilson' had put a leading question to the Laverton duty pilot: 'You cannot say whether the Minister for Air was sitting next to the pilot?' Pilot Officer J. B. Wilson did not reply directly. The only person he had actually seen in the plane, he said, was Dick Elford, seated towards the rear, near the door. ${ }^{23}$ That being the case there was no requirement that evidence be led to the court concerning relevant Air Force regulations or practice. Confining themselves to the narrowly defined suggestion that someone other than the pilot might have been in control of the aircraft, both Arthur Dean and Charles Lowe ignored what might have been thought of as the 'lesser charges'. Yet, if Maloney was correct in reporting the finding of three bodies in the nose, there were implications that should have prompted questions. The incuriousness of Lowe and Dean is all the more difficult to excuse given that the morning newspapers on August 27 reported Maloney's statement to the Coroner the previous day that 'three were in the nose of the plane'. ${ }^{24}$ At least some of the readers of the Canberra Times, and other newspapers which reported Maloney's testimony, must have known that there should only have been two men in the cockpit.

If there were three bodies in the nose of the crashed aircraft, whose were they? Those who went to the crash and removed the bodies were unanimous in saying that it was impossible to identify any of those they brought out of the wreckage. Flying Officer Wilson, who claimed to be the first person on the scene, told Police Sergeant Ivan Perriman the next day that when he arrived he saw four bodies 'even then not recognisable'. He went on to say 'Each body, as it was removed from the wreckage, was scrutinised by me, but not one was in any way recognisable.' In his own words, rather than the police sergeant's stilted paraphrase, Wilson told Justice Lowe that he had seen four bodies immediately he arrived but could not identify any of them. 'I went to the body by the door but could not recognise it.' Flight Sergeant Clifford Smith stated that, when he reached the scene at the same time as the ambulance, the fire was burning from near the cockpit 'from fittings and personal effects'. It was too hot to approach.

\footnotetext{
22 NAA: A6079, MO625. Although Commonwealth authority over civil aviation had been rejected in a 1937 referendum, a combination of regulations resting on external affairs and trade clauses of the constitution, international conventions, unfettered power in the territories, and complementary legislation by the states had provided an effective national regime by 1938.

23 Lowe Inquiry transcript, p.43. NAA: A705, 32/10/2729.

24 Canberra Times, 27 Aug. 1940.
} 
He saw three bodies, one near the safety door and two towards the port wing where the fuselage was burnt. All were 'burnt beyond recognition'. A fortnight later Smith was questioned by Arthur Dean before Justice Lowe:

In what part of the 'plane were the bodies lying? - One was lying near the exit door at the rear. I cannot say whether it was inside or outside. It could possibly have rolled out afterwards. There were two more bodies about a yard forward and the rest were in the nose of the machine.

Were they all mixed up with the remains of the machine? - They were not in a heap, but spread over the position of the full fuselage of the machine.

Smith could not identify any of the bodies - the three he said were near the tail or the other seven forward. ${ }^{25}$

None of those who were engaged in fighting the flames and retrieving the bodies either knew the occupants or suspected that it might be important to determine who was where at the time they perished. Their accounts of where the bodies were found are replete with inconsistency. Was there anyone else at the scene who could have recognised Jim Fairbairn? As we have seen, the Canberra Times and some other papers had reported that three ministers - Vic Thorby, Fred Stewart, and Percy Spender — had gone out to Duncan Cameron's farm and seen bodies being retrieved from 'the head' of the plane. If any of them had seen something that could not prudently be revealed, there would be good reason for them all to say nothing that could prompt further questions. As it turned out, they were not called to testify by the Coroner, the RAAF inquiries, or Justice Lowe. Maybe they had said that the newspaper story was wrong. But, if any one of them had noticed that three bodies were retrieved from the front of the wreckage, or seen anything to suggest that one of the last bodies to emerge was their colleague Fairbairn, they would be in no rush to broadcast their observations. They might have had nothing to offer to investigators. Whatever they knew or suspected, if they said anything at all, it was unlikely to have remained a secret for long.

Two final clues may be considered. First, there was a barely explicable flaw in the reasoning behind Group Captain Wilson's identifications of the bodies of the two pilots he was shown at the morgue. Theirs were the last two bodies to be identified. And he distinguished them on the basis that one was clearly older than the other, believing erroneously that Hitchcock was 10 years older than Wiesener rather than 18 months younger. The one feature that would have truly distinguished the two was the great difference in their height. Wiesener was nearly seven inches taller than Hitchcock. The question arises therefore: was Wilson actually looking at what remained of the bodies of Hitchcock and Wiesener? Or is it possible that there was confusion between Hitchcock and 
Fairbairn? We know that one body had already been identified as Fairbairn's by Dr Mackellar and Percy Hayter. However, there was a discrepancy between the versions provided by the two men. Hayter, who of course knew what to look for, said that he identified Fairbairn 'because I was informed by the Medical Officer that this particular body showed injuries of long standing to each arm and, in particular, to the right arm'. Mackellar's statement was different. The body he had determined to be Fairbairn's was, he said, larger than Street's and there was evidence of a war wound in the left shoulder. In fact, at five feet ten inches, Street was as tall as Fairbairn though he carried less weight. And Fairbairn's war wound was not in the left shoulder.

From these various inconsistencies an alternative picture emerges. If Hayter did not in fact see all the bodies - and his testimony indicates that he mainly responded to what Mackellar was telling him - his later description was not an eye-witness report but, rather, a statement of what he knew would be accepted as unique identifying marks. In the hurry to complete a horribly confronting task, could Mackellar have incorrectly labelled some of the remains? Wilson understood that he was being asked to distinguish between two pilots, one of whom he would say appeared to be significantly older than the other. In the absence of any portions of uniform with insignia of rank it is understandable that he might conclude that an older one was a man he knew to be the more senior flight lieutenant. But it is at least possible that a plainly older body — if indeed there was anything to suggest the age of the bodies - was that of Fairbairn lying next to Wiesener. If the remains of the three bodies recovered at the same time from the front of the plane were brought together to the morgue and placed there side by side there was evidently potential for confusion. Neither Hayter nor Wilson knew either of the pilots. Wilson might have recognised Fairbairn but he thought that the ministers had been dealt with earlier. Mackellar, told to look for evidence of wartime injury, was vague about what he found. His reference to evidence of a war wound in the left shoulder could not be a description of Fairbairn's shattered right elbow. Whatever he saw, his description is strikingly inconsistent with Hayter's knowledgeable description of what the doctor should have seen. ${ }^{26}$ What is undeniable is that several of the identifications reported to the Coroner can only have been, at best, conjectural. ${ }^{27}$

26 Mackellar signed a statement referring to a war wound in the left shoulder; but in a typed copy in the Commonwealth Police files 'left' is struck out and replaced by 'right' (NAA: A1378, P8903). Tink (Air Disaster, pp.190, 214), notes that 'there was no attempt to question' Inquest witnesses who had seen bodies in the wreckage about whether either of the two bodies marked in the cockpit area in Flying Officer Wilson's drawing had 'an injury to its right arm'. 'With Fairbairn's disabled right arm an obvious identifier, it would have soon been obvious whether or not his body was one of those in the cockpit' (Tink, p.195). Fireman Jim Kearney recalled: 'I don't think any of them had an arm or a leg left' (interview, 23 July 1977).

27 Speaking to an $\mathrm{ABC}$ television reporter at the air disaster memorial site on 13 Aug. 2013 Andrew Tink said that he had not noticed Wilson's error about the ages of the two pilots until it was brought to his attention after the publication of his book. He said the evidence is definitive that mistakes were made in the identification process and concluded that the body identified as Hitchcock's was actually Fairbairn's. He restated this view for a forum at Questacon in Canberra on 14 Aug. 2013 hosted by the ACT Australian Science Communicators and the Australian and New Zealand Forensic Science Society (http://www.abc.net. au/news/2013-08-16/new-questions-raised-over-canberra-air-disaster/4893354?\&section=news). 
To add further doubt, there is the recollection of John Harrison, Fairbairn's companion in the flight around Australia in July 1940. Interviewed by the RAAF historian Chris Coulthard-Clark 50 years later, Harrison is said to have recalled: 'hearing afterwards on 3 or 4 occasions that when police got into the Hudson's wreckage...they found the skeleton of a big man in the pilot's seat'. Harrison went on to say that Fairbairn was 'a big beefy man of 15-16 stone, like the average police constable'. There are several troubling elements here. Police were present when some bodies were removed from the wreckage but they did not get 'into' it. Fairbairn in 1940 was no longer an athletic sportsman but contemporary photographs and film do not make him appear as heavy as Harrison suggested. Harrison admitted that he could not remember when he heard the stories - he was not protecting sources, 'just repeating hearsay current at the time' ${ }^{28}$ If the questionable elaborated detail of the hearsay is discounted, we are left with one challengingly improbable thought: that Fairbairn might not only have been in the cockpit but actually sitting in Hitchcock's seat.

\section{The balance of probabilities}

What can properly be concluded from the surviving evidence? After weighing what is known with what can be inferred and deduced it is possible to reach a view that is at least consistent with the incontrovertible facts. When A16-97 was on its final approach to Canberra aerodrome the captain of the aircraft, Bob Hitchcock, would have been in the pilot's seat on the left of the cockpit. Notwithstanding Harrison's hearsay it is scarcely conceivable that, with the lives of six important passengers in his hands, Hitchcock would have surrendered his seat to Fairbairn or that Fairbairn would have been foolhardy enough to displace him. In the normal course, Dick Wiesener would have been in the secondpilot's seat alongside Hitchcock. Wiesener was taken on the flight in order to familiarise himself with the Hudson; and the appropriate place from which to do that was next to the man in command. In the previous week Hitchcock had gone up in A16-9 with Ryland as first pilot to learn about right-hand-seat flying. The next day, August 8, he had himself instructed several junior members of the squadron on instrument take-offs and right-hand-seat flying. The potential use of the dual controls was fresh in his mind.

28 'Interview with Mr. J. Harrison of 12 Rapanea Street, Rivett ACT...23 Aug. 1990', (notes by Chris Coulthard-Clark, copy from Defence Dept via Ms Selma McLaren and Bronwyn and John Myrtle). 


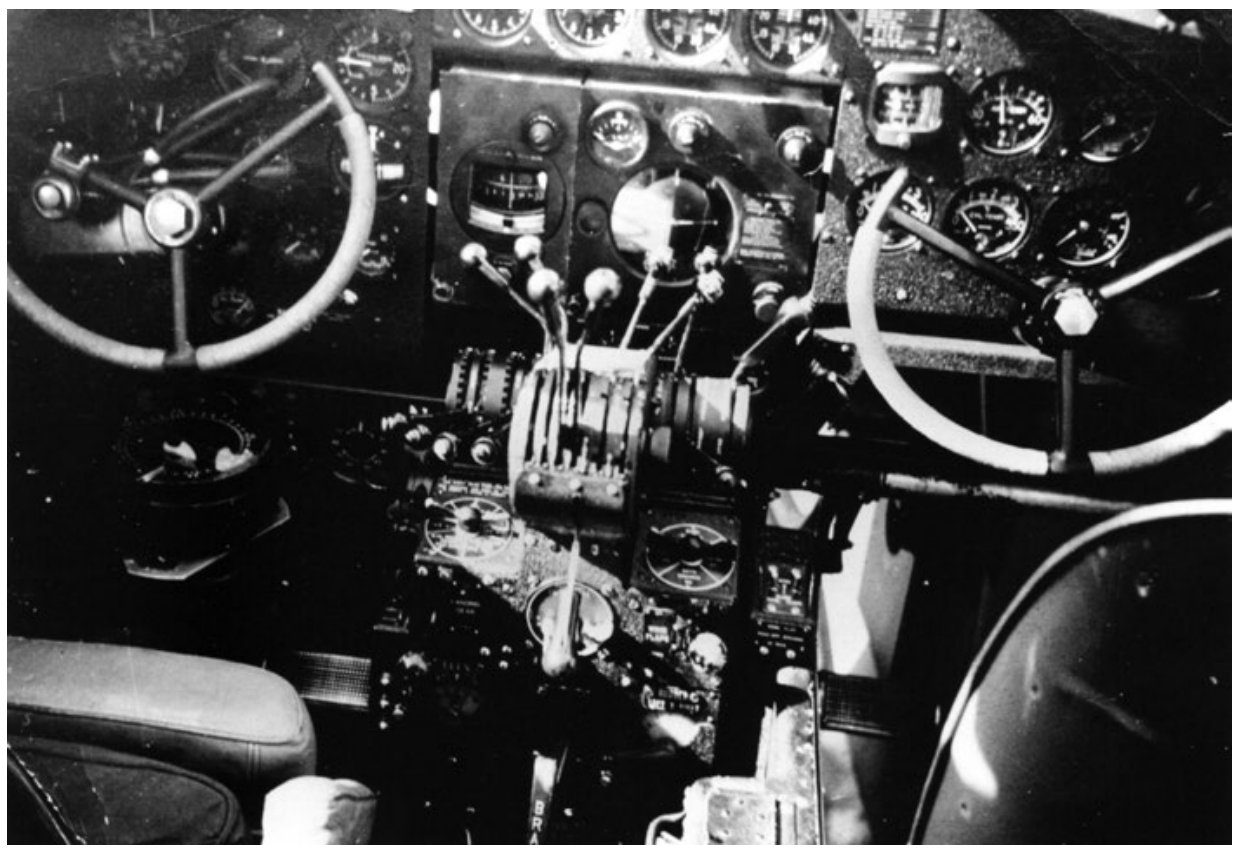

Inside a No. 2 Squadron Hudson cockpit with dual controls

(Courtesy of Murry Lawson via David Vincent)

If Fairbairn were minded to see for himself what happened under certain conditions he might have asked to change places with Wiesener. Or it could have been suggested that Wiesener move forward into the glazed nose of the aircraft. Designed as the navigator or bomb-aimer's station, the glass house in the nose was 'a wonderful grandstand'. It offered, as a British journalist who flew on an operation with Coastal Command the following year described it, a 'clear view in all directions except behind'. ${ }^{29}$ If Wiesener had clambered into the nose before the take-off from Essendon, it would have been impossible for him to return to the second pilot's seat. The companion way would have been obstructed by the dual control; and the second seat would have had to be dismantled. That such a possibility was in the minds of Charles Lowe and Arthur Dean may be inferred from a very carefully worded sentence in the Inquiry Report's narrative of events. Immediately following the point at which the 'unusual' delayed take-off from Essendon is described, it was noted that no explanation had been given although 'several suggestions therefore were made'. Two suggestions are mentioned: that the port engine had taken some time to start, possibly because the mixture was 'a little rich'; and that the pilot was 'not quite ready to go' and signalled some Moth aircraft on the ground to take off.

29 Bernard Gray, War Reporter, Robert Hale, London, 1942, p.178. 
Then, it will be recalled, a new paragraph concludes the section: 'No one was seen to get out of or enter the aircraft during this delay and eventually the plane made a perfect take off and headed towards Canberra. ${ }^{30}$

'Del' Wilson had in fact put it to Assistant Control Officer J. J. Williams: 'Nobody got out of the aircraft there?' The response was carefully qualified: 'No, nobody that I could see. ${ }^{\prime 1}$ There is no evidence that any further effort was devoted to seeking testimony from the many scores of men who might have been able to see the aircraft while it was idling at the eastern boundary of the aerodrome. ${ }^{32}$ But the 10 minutes spent warming the engines out of the wind, and four or five further minutes stationary after turning into the wind, could easily have been thought to be just the amount of time necessary for Wiesener to squeeze past the rudder pedals into the nose. Or to get out of the aircraft via the safety door and then, the aircraft having turned around and concealing him, climb up through the bomb-aimer's window. The window could be partially opened and provided an emergency way out via parachute. A tiny pencilled note in the margin of a minute sheet in the headquarters file on the Air Court of Inquiry shows that the question was being asked: ' $1 / 4 \mathrm{hr}$ delay at Ess ${ }^{\text {nd }}$ Wiesener' ${ }^{33}$

It is difficult to avoid the conclusion that the otherwise unexplained delay makes sense best in the context of Fairbairn's expressed intention to Herbert Storey. The Minister wanted to see for himself; but he and Hitchcock did not need to be told that others might frown on an unauthorised presence in the cockpit. Hitchcock had been practising flying from the second seat. If John Harrison is to be believed, it would have been the right-hand seat where Fairbairn would have chosen to be. In his testimony in 1990 Harrison recalled the Minister's insistence in their round-Australia flight on piloting from the right-hand seat of the Q6. 'This was because Fairbairn liked to have the machine's throttles on his left.' The partially incapacitated flyer required Harrison to navigate from the pilot's seat.

If Fairbairn was sitting in the right-hand seat next to Hitchcock as they approached Canberra, it is possible to construct a plausible scenario that explains an otherwise unlikely lapse of airmanship. It is instructive here to bear in mind the cockpit configuration as described by wartime Hudson pilot Andrew Hendrie:

\footnotetext{
30 'Lockheed Hudson A16 Accidents Part 6 [Air Force Court of Inquiry — Lockheed Hudson A16-97 crash on 13th August 1940] — Master Copy [Volume 1]', NAA: A9845, 318 pp.5-6.

31 NAA: A705, 32/10/2729:The Advertiser, 29 Aug. 1940, reported Wilson's words not as a statement to which assent was sought but as a question: 'Did anybody get out of the plane?' to which the answer was 'No'. 32 P/O Wilson mentioned two possible eye-witnesses: P/O Shiel and 'an Instructor' (NAA: A705, 32/10/2733). 33 John White (AWM) to CH, (email), 25 Aug. 1910; NAA: A705, 32/10/2733. In 'Overnight' with Trevor Chappell, ABC Local Radio, 8 May 2013, Tink said that Hitchcock told Wiesener to go and sit in the main cabin.
} 
There was room below the cockpit instruments on the starboard side for the navigator to pass down into the nose of the aircraft. The location of vital controls such as those for flaps, undercarriage and fuel tank transfer, enabled them to be reached by the navigator or wireless operator if necessary. ${ }^{34}$

We have seen Heffernan's observation about the positioning of the throttles. On a pedestal between the two pilot's seats there were normally three cranks: one trim for the ailerons, one for the rudder, and the one nearest to the pilot for the elevator. With dual controls fitted, there were double sets of rudder pedals and two control columns. At a critical moment, if an adjustment was necessary to the trim of the aircraft, Fairbairn would not have had the knowledge, skill, or possibly even the strength, to do what was required. It was only six weeks since there had been a relevant discussion at Air Force HQ following the fatal crash of Flight Lieutenant Jim Hamilton in A16-58. The air cadet who had died with Hamilton had been there, not as a second pilot but as an 'assistant...to operate auxiliary gear by hand should the emergency have arisen'. Wing Commander Simms, commanding No. 6 Squadron, had suggested that the duty of an assistant could be carried out by 'an intelligent airman'. The essential point was that someone capable needed to be next to the pilot. ${ }^{35}$

Another theory, offered by Dick Wiesener's friend Bob Dalkin, must also be considered. One of the checks for both take-off and landing the Hudson was to ensure that the castered tail wheel was locked to assist in directional stability. It was the second pilot's job to check and advise the pilot 'tail lock OK'. The knob on the lever for the tail wheel was almost identical, and of similar length, to the lever for activating the Sperry automatic pilot. Exactly two months before the crash of A16-97, the Director of Operations and Intelligence ('Dad' Bladin), writing for the CAS, had drawn attention to one of four Hudson accidents when the pilot 'landed with tail wing unlocked and swung' ${ }^{36}$

Someone unfamiliar with the Hudson's controls could have mistaken a raised automatic pilot lever as indicating an unlocked tail wheel. With the throttles half-way back and the pitch of the aircraft well forward, Hitchcock's view of the other controls might have been partly obscured. His attention would in any case have been directed primarily to the ground. If Fairbairn were to tell him that the tail wheel was not locked he might have supposed that the Air Minister had either failed to lock it on take-off or unlocked it when they were in the air.

\footnotetext{
34 Hendrie, Seek and Strike, p.37.

35 NAA: A705, 32/10/2602.

36 'Service Training in Hudson Aircraft', 13 June 1940, NAA: A705, 32/10/2478. An Anson crash with multiple fatalities at Richmond late in 1938 was attributed by the Court of Inquiry to a member of the crew roughly operating the handle that trimmed the elevators, believing it to be the handle for winding down the wheels (Hewitt, The Black One, p.162).
} 
In either case it was something that imperatively had to be fixed. Attempting to correct what looked like a dangerous unlocked tail wheel by depressing the automatic pilot lever would, in Dalkin's opinion, 'have been instantly disastrous, the aeroplane would have just fallen out of the sky' ${ }^{37}$ Whether or not Dalkin was right about the proximate cause, we also have Paddy Heffernan's assessment: "unless I can be assured that the definite cause of the accident was determined, I have a feeling that this "flicking" characteristic, when near the stall, of a Hudson, could have been the basic cause of the accident' ${ }^{38}$

All the official Inquiries adopted the assumption that Hitchcock alone was at the controls as A16-97 approached Canberra. With the exception of Wing Commander Tony Carr, whose recorded contribution as one of Justice Lowe's assessors was meagre, the Inquiry teams were limited in their familiarity with the layout of the Hudson cockpit. They were in ignorance of the manual that would have told them about the critical requirement that the tail wheel be locked, and the second pilot's role in ensuring this was the case. The RAAF officers might perhaps have seen Bladin's June circular referring to an accident caused by an unlocked tail wheel and the need for the 'closest personal supervision' by unit commanders and other officers responsible for training and maintenance 'to ensure thoroughness'. But, among the torrent of communications from headquarters, this admonition might have made little impression on officers with more pressing responsibilities. What is clear from the court transcripts is that those entrusted with inquiring into the causes of the accident were not looking hard for evidence that someone other than the first pilot was at fault. Knowing that Wiesener was new to the Hudson, there could only be embarrassment for the RAAF in exploring possible error by so inexperienced a second pilot with the lives of six important passengers in his hands.

But, as Carr certainly knew, and Murphy and Wilson would have understood, even if Fairbairn had been called upon to do nothing, the very presence of the Air Minister, 'chatting away' as 'Tich' McFarlane speculated, would have been a dangerous distraction for a pilot intent on showing himself to advantage. ${ }^{39}$ Is there anything else to suggest that Hitchcock's normal landing approach might have been compromised? The evidence of the very experienced pilot Ray Winter provides an important clue. Two days after the crash he was questioned closely by the Service Court of Inquiry:

Q. As Duty Pilot, did anything appear abnormal about the circuit and a half that the aircraft did of the aerodrome before the crash?

37 ACdre R. N. Dalkin, interview, 18 April 1978.

38 ACdre P. G. Heffernan to $\mathrm{CH}, 7$ April 1978.

39 A. B. McFarlane, interview, 18 April 1978. 
A. Only the fact that the aircraft came over the aerodrome so high and lost height so very gradually in the circuits. Actually his airmanship seemed to be above average.

The Court did not pursue this point. It evinced no interest in the fact that Hitchcock was making a very gradual descent from a considerable height. Knowing that there was a second pilot under instruction in A16-97 - if not suspecting the presence in the cockpit of the Air Minister - might they not have brought to mind the policy that the height at which a first pilot was to take over for landing from an airman pilot in training on twin-engined aircraft was 2000 feet ${ }^{40}$ However, when the RAAF came to issue its 'Informative Circular Relative to the Accident...', they did emphasise that 'numerous witnesses...practically everyone stated that the aircraft appeared to be flying slower than usual'. What credence could be given to this 'constantly recurring impression'? The fact that a Hudson squadron had been stationed at Canberra for 'some considerable time', and that the two-engined Douglas airliner (similar in size to the Hudson) was landing there twice a day, meant that it deserved 'serious consideration'. What was not divulged was the nature or extent of any serious consideration. Did anyone contemplate why the aircraft might have been flying more slowly than would have been expected? Or why it appeared to have begun its descent so gradually from a greater height than normal? Would it have seemed plausible that the pilot was showing just how close he could go to stalling the aircraft without actually doing so?

The Air Force Court apparently did not seriously consider the testimony of Harry Southwell, who was barely three-quarters of a mile from the scene, that 'as the nose went down the engines appeared to roar'. Southwell (and others) had spoken of the aircraft appearing to roll over on to its back but Jack Ryland and Ernie Hey, in secret evidence, had dismissed the possibility that this could have happened. The civilian witnesses were clearly regarded as unreliable. Hilton Clothier, who was even closer than Southwell, said that it 'may have appeared' that the aircraft was turning on its back. Clothier had also testified to hearing 'a crackle as though it was trying to pick up just before the nose went down'. Questioned closely by the Air Force Court, Clothier re-phrased: it appeared to him as though 'it had been throttled down and then picked up'. It was an acceleration, an increase of noise, rather than a spluttering - the words were suggested by Lowe and Dean. It was at that point that Clothier's credibility crumbled when he insisted, in the face of incredulous cross-examination by Wilson, that he saw flame coming over the top surface of the starboard wing for two or three seconds before the aircraft hit the ground. It was not coming

40 The policy prohibited airman pilots (also known as driver pilots) in training from landing a twin-engined aircraft unless they were thoroughly conversant with flying on one engine, including turns with and against the good engine, and landings with one engine (NAA: A 705, 208/1/1383). 
from the exhaust. 'Was it a big blaze?' Wilson asked. Yes it was. It extended six or seven feet, Clothier told Carr. But to Wilson's final query, 'Was there a streak of flame?', the blaze had shrunk to 'a wisp of reddish flame' for 'only a matter of a fraction of a second'. Other witnesses, asked if they were in a position to see, uniformly said they observed no flames. Yet, evidently troubled by the possibility that the aircraft had been alight before it hit the ground, Lowe asked for Pilot Officer Winter and Flight Sergeant Smith to be recalled: both were clear that they saw neither fire nor smoke.

Asked by Carr if he had heard any sound of an engine backfiring before he saw the flame, Clothier had another attempt at describing what he heard: 'It was like an engine trying to pick up. It may have been a backfire.' With two witnesses concurring that they had heard something like a roar or possibly a backfire, the Court then asked Darcy Vest whether the engines appeared to be functioning normally:

A. Quite normal until it took the spiral dive to the ground and I cannot remember any engines going.

Q. You never heard any sudden burst of engine coming on?

A. No, none whatever.

It had previously been established that Vest was a mile to a mile and a quarter away from the aircraft — considerably further than Southwell and twice as far as Clothier - and that he could not remember hearing the engines. Not all of the subsequent witnesses were asked about a 'crackle' or a surge of engine power. Fred Tetley seems not to have been asked any questions at all after he testified that he saw the aircraft diving towards the ground. 'It appeared to me just before it hit the ground to straighten a little. The aircraft struck the ground and immediately burst into flames but I heard no noise.' Dudley Lalor was next to be asked if the engines of the aeroplane appeared to be 'functioning normally'. 'I could not tell,' he responded, 'as I was in a closed car and could not hear the engines at all.'

Taken together with the relatively shallow angle at which A16-97 hit the ground - 40 or 45 degrees according to some, 60 to 70 degrees to others - there are good reasons for believing that Southwell and Clothier heard what they said they heard. The garage mechanic, O'Brien, also testified that 'As it dived, the motors seemed to make more noise to me; they seemed to rev. faster.' 'They sounded as if they were opening up?' 'Del' Wilson asked. 'Yes.'

What therefore appears to have happened is that Hitchcock did his best to head for a relatively clear patch of ground. As Dudley Lalor had told reporters hours later: 'As the machine neared the ground in its final plunge it seemed to me that 
the pilot made a superhuman effort to right it.' Hitchcock had 'reduced the angle at which it was hurtling to the earth' ${ }^{41} \mathrm{He}$ did what 'Tich' McFarlane would say years later he himself would have done: 'I would have poured the power on and shoved the stick hard forward and, if I had time, scream for somebody to rush up from the back to the front.' As McFarlane would admit, there would not have been time for anyone to move forward. But he would have 'whipped up those flaps, shoved the nose down and pulled the power on'. Would this have worked? 'I probably would have finished up in a molten heap...I might just have made it. $^{\prime 2}$ Irrespective of how Hitchcock came to lose control of the aircraft - about that there can be no definitive answer - his instinct was exactly what it should have been. If he had been another hundred feet or so higher he might have succeeded.

\section{What would Fred Thomas not say?}

What can we conclude? Did Fred Thomas designate Bob Hitchcock to captain A16-97 precisely because he was more likely than any of his peers to acquiesce in a request by the Air Minister to demonstrate the characteristics of the Hudson that were causing concern ${ }^{43}$ If it were Fairbairn's desire to see what the Hudson could do, he might have thought it proper to let the squadron commander know. Even to seek his concurrence. On this question we have testimony from Herb Plenty of a 'little quiet chat' he had with Thomas in the late 1950s by which time the former No. 2 Squadron commander was Lord Mayor of Melbourne. Plenty's view, resting on what Thomas did not say, was that Fairbairn might have been in the captain's seat:

He probably cleared it, with the Chief of the Air Staff maybe. He'd certainly cleared it with Freddie Thomas who was the commanding officer of the squadron. Freddie was quite happy that Fairbairn could have a touch of the controls...

He was a bit evasive, but he didn't say to me that Fairbairn was NOT in the left hand seat. Freddie was very cagey about it, because obviously as commanding officer he felt a certain responsibility...he wouldn't commit himself but he wouldn't say that Fairbairn was not there. ${ }^{44}$

\footnotetext{
41 The West Australian, 14 Aug. 1940.

42 McFarlane, interview, 18 April 1978.

43 At this point, Tink (Air Disaster, pp.172, 176) refers to Hitchcock's 'obedient "old soldier" attitude identified years before by his instructors'. In a photo caption, Tink says Hitchcock was 'described as "an old soldier type" who unquestionably followed orders'. But what the instructors were concerned about was that, after five years in the Service, Hitchcock might lead the younger cadets astray.

44 Plenty, interview with Geoff Crane, 19 April 2007, transcript courtesy Geoff Crane. Tink (Air Disaster, pp.154, 170) speaks of an 'alleged' 'direction' and an 'oral instruction' from Thomas to Hitchcock.
} 
If courtesy dictated that the Minister would ask for approval of his desire to try for himself how the Hudson handled, there remained the issue of nominating a pilot who would be willing to agree. Thomas would have expected some of his flight commanders to be unenthusiastic about obliging the Minister. Bill Heath had been spending almost every day since July 3 putting more than a dozen junior pilots through airmanship training in the newly arrived Hudsons. He had begun teaching them on the same day he finished his own three days of conversion with Jack Ryland in the dual-control A16-6. Had Heath said something to Garrett after the previous week's flight about the Air Minister's curiosity? Did Garrett report illness on August 12 as a convenient way of avoiding what he believed would have been an ill-advised and dangerous demonstration? His log book shows that he did not fly on August 12. But he had flown to Adelaide the previous week with Air Commodore Wrigley, flown patrols over the sea at the weekend, and may have been simply taking a break. Garrett was in fact on duty the next morning and, when news of the crash came, he flew to Adelaide with a crew of four and Frank Jefferies with a load of photographic equipment. ${ }^{45}$

Ryland, though still in his twenties, had been a senior captain and operations manager for Ansett Airways before the war. He was respectful but not overawed by authority. He had flown the Minister to Mascot and back to Laverton via Richmond on June 13 and 14 in Hudsons A16-20 and A16-21. Sir Charles Burnett had accompanied them on the flight up. There is no evidence of what occurred on those flights. However, if Fairbairn had been curious then about the flying characteristics of the aircraft, Ryland would have had the confidence to draw a line beyond which the Minister would not have been permitted to trespass. ${ }^{46}$ Hitchcock, a little less sure of himself, deferential to the urbane flying veteran, would be least likely to be difficult.

What we do know is that the testimony Thomas gave to the Service Court of Inquiry on the day of the crash concluded with this personal assessment of Hitchcock as a pilot: 'I consider Flight Lieutenant Hitchcock was slightly above average as a pilot, his instrument flying was good and he was a steady and thorough type.' Lest there be any suspicion that his opinion was based on hearsay, he added: 'I make the above assessment having flown with this officer.' ${ }^{47}$ This was true as far as it went. Thomas made his judgment on the basis of what he knew first hand. Like others he found Hitchcock quiet and unassuming, a man who rarely took part on mess nights. Conceivably he had heard whispers

\footnotetext{
45 Frank Jefferies, 'The Crash of A16-97 at Canberra 13th August 1940', June 1993, in Bennett, Highest Traditions, p.112.

46 John Gunn, Contested Skies: Trans-Australian Airlines, Australian Airlines 1946-1992, University of Queensland Press, St Lucia, 1999, pp.24, 31.

47 Service Court of Inquiry, p.15, NAA: A705, 32/10/2729. Thomas and Hitchcock had not flown together in Hudsons.
} 
of Hitchcock's crisis of confidence in 1936; perhaps from 'King' Cole, a fellow member of the Naval and Military Club. But, if he had no knowledge of that episode, there was nothing subsequently left in Hitchcock's personal file that would show that Thomas could have seen the documented disposition of the case. $^{48}$

'A steady and thorough type', was the least a commanding officer could say by way of justifying his selection of a subordinate for a flight that ended so tragically. But the words conveyed more. They were the endorsement of a leader who previously had served in No. 21 Squadron with the then Flying Officer Hitchcock, yet barely knew the man who had been one of his flight commanders. Freddie Thomas, ex-Melbourne Grammar, committee member of the Naval and Military Club, was heir to a large family business. Like Dallas Scott, a Melbourne Grammar school captain, or No. 2 Squadron's adjutant, Flying Officer Kenneth Ranger, and the other society flyers from Toorak and South Yarra, he inhabited a different world from the tiny timber cottages of Newport. ${ }^{49}$ Did Thomas know, for example, that Hitchcock was, as his fellow flight commander Ray Garrett said, 'always subject to air sickness and never got over it (on rough days)' ${ }^{50}$ Did he know that the man his friend Jack Graham thought of as 'a pretty cocky bloke' had trained for years to build up his body precisely so that he would not be just another puny working-class lad always looking up to those, like his $5^{\prime} 10 \frac{1}{2}$ " commanding officer, sometimes glowering, born to lead? ${ }^{51}$

Naturally when I began research on this subject three decades ago, I sought to talk to Sir Frederick Thomas, as he had become. His response was circumspect: 'My evidence at the Lowe inquiry covered everything I could possibly tell you... You should understand that I had gone overseas before the transcripts were completed and it so happens that I have never seen the final publication.'

Whether or not he had ever seen the transcripts - they were not published and it is unlikely that he would have done so - Thomas's recollection of the

\footnotetext{
48 In a telephone conversation with the journalist Frank Cranston 50 years after the event Thomas said he was 'unaware of derogatory reports on Hitchcock's personal file' (Cranston, 'Note of Telephone Conversation...1990', Thomas MSS, courtesy of Rob Thomas).

49 Ranger, a 32-year-old WCdr in 1945, was one of seven officers whose request for permission to resign their commissions in protest against 'futile' operations late in the Pacific war led to a Royal Commission under J. V. Barry QC. The story is well told in Alexander, Clive Caldwell, Air Ace. For AVM J. E. Hewitt's recollection of Ranger in 1943 ('the trivialities and innuendoes of a sick man... without operational or air staff experience') see Hewitt's Adversity in Success, pp.85, 109-10.

50 Sir Raymond Garrett to $\mathrm{CH}, 26$ April 1978.

51 GpCpt. J. E. Graham, interview, 11 May 1978; ACdre R. N. Dalkin, interview, 18 April 1978.
} 
timing of his overseas posting was erroneous. He was assigned to 'special duties' at headquarters in April 1941, then posted as a liaison officer to the Dutch Air Force in the Netherlands East Indies from September to November $1941 .^{52}$

What, I asked, did Thomas think of Hitchcock? He was 'a very experienced and capable pilot and for that reason had charge of the special VIP Hudson aircraft'. Finally, he wrote 'the cause of the crash will always remain a mystery'. Then, as if there was something he wanted to say but could not: 'P.S. "Que Sera Sera."' It was much the same enigmatic response that Herb Plenty had received two decades or so earlier. Another decade later Thomas would tell Frank Cranston of the Canberra Times: 'I think I agree with the Air Force finding that it was pilot error. All the evidence pointed that way. ${ }^{53}$ Tony Street also, understandably hoping to learn more about the circumstances of his father's death, was never able to get Thomas to talk about it. What is now remarkable is the discrepancy between the recollections of the weekend pilots - who were inclined to find Hitchcock overconfident - and those like Herb Plenty, then a junior pilot officer signed on for a career, who thought Hitchcock was unsure of himself. If Heffernan's and Wrigley's recollections, and those experienced men who themselves sat with Hitchcock, are to be believed, this was not an overconfident pilot. If he seemed on occasion to be taking risks, was it just as likely because of nerves, maybe even a bout of air sickness, than an impulse to show off? When competently and sympathetically instructed, as he was by Jack Ryland in his Hudson conversion course, he could meet every requirement. With Ryland there was a rapport. Ryland was not one of the society flyers. He was a professional. He had flown for a living, not for recreation. He had, as another junior officer put it, 'no side to him' ${ }^{54}$

It is reasonable to ask: was a nervy pilot, a man who appeared sometimes to take inappropriate risks in the air, the man a responsible squadron commander would assign to fly his own minister and a plane load of very important passengers? Was he the man you could describe a few weeks later as 'a steady and thorough type'? The anonymous testimony of another No. 2 Squadron pilot, 'also a Flight Lieutenant, but far more senior in years and flying experience and an airline pilot pre-war', must be considered here. As paraphrased by the respected aircrash historian Macarthur Job, this pilot had 'accompanied' Hitchcock on a

52 According to Joe Hewitt, Thomas, who finished the war as a Group Captain, was relieved of his command of No. 2 Squadron at the Chief of the Air Staff's insistence after he had 'boobed in operations over Bass Strait'. Memories of the appalling crash that had happened eight months earlier on Thomas's watch would not have been far from the surface. Hewitt was Director of Personal Services in April 1941; I have found no official record to amplify or corroborate his story (Sir Frederick Thomas to CH, 5 Oct. 1979; Air Vice Marshal J. E. Hewitt, 'Diary for my daughter Part II Sept 1939-December 1948', Hewitt MSS, Australian War Memorial NAA: A9300, THOMAS FW 250097). Thomas had ceased signing the squadron's monthly operations reports in February 1940. They were signed by successive adjutants until Frank Headlam arrived as CO in April 1941. Several pages appear to have been removed from the record book in 1940; August, September, and October 1940 are compressed into one page. (Operations Record Book, No. 2 [General Reconnaissance] Squadron, NAA: A9186).

53 Cranston, 'Note of Telephone Conversation...1990', Thomas MSS.

54 David Campbell, interview, 24 May 1978. 
coastal reconnaissance flight in a Hudson 'only days' before the crash. As they came into land at Laverton, Hitchcock's companion was 'appalled at the low airspeed at which Hitchcock was making his turns'. He had 'firmly pointed out that the aircraft was getting much too slow'. Hitchcock 'brushed the advice aside, telling the senior pilot: "Don't panic — it's all right." 55

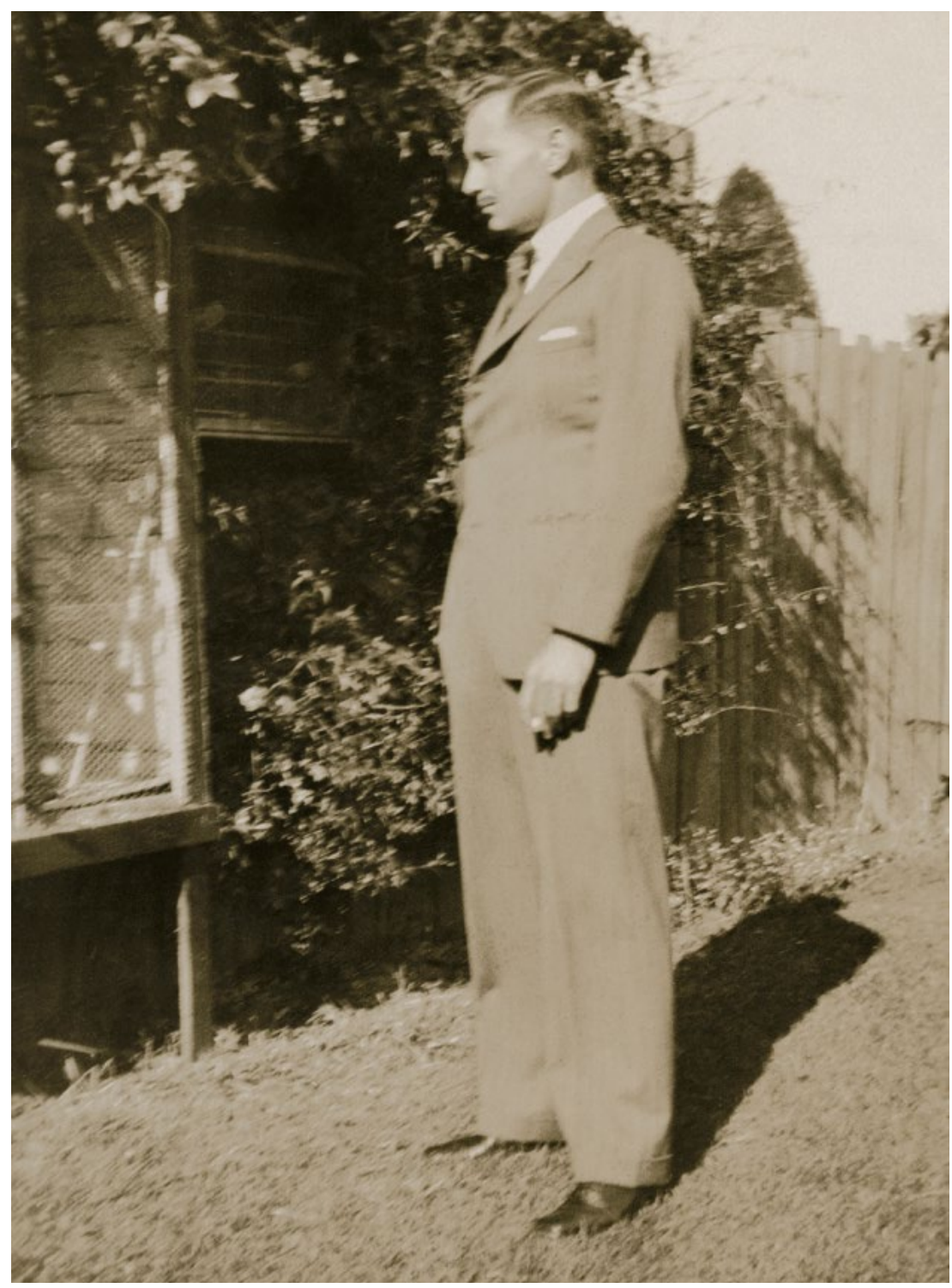

Jack Ryland presents himself in profile for the RAAF personnel file (National Archives of Australia NAA: A9300 RYLAND JP)

55 Macarthur Job, Air Crash, vol. 2, Aerospace Publications, Weston Creek, 1992, pp.16,24. 
The 'well known and distinguished Australian' who provided this information could not have been John Ryland, former managing director of Trans Australia Airlines, who had died in 1973. Ryland had in any case been reluctant even to agree that the aircraft had stalled. It was one theory among many, a 'feasible cause', in the words put to him by Arthur Dean. One 'amongst many other things', no more likely than the 'highly unlikely' possibility of engine failure. When asked at the Air Court of Inquiry if he had ever had to question Hitchcock at all or bring to his notice that he was getting dangerously low in any of his flying or in his approaches to land, he was unequivocal that this was not a fault of Hitchcock's. ${ }^{56}$ In saying this, he was implicitly commenting on the finding of the Service Court that A16-97 had stalled because the power approach was flown too low. There is a hint here that Ryland - like George Jones - was uncomfortable with the conclusion reached by Lachal, Stevens, and Pape that placed the blame for the crash on an error of judgment by Hitchcock.

The only person who fits Job's description is Sir Raymond Garrett. Some 10 years older than Hitchcock, Garrett lived till 1994. He had become a commercial air pilot shortly after graduating from Point Cook in 1926, and had been a member of the Citizen Air Force between 1927 and 1937. Unfortunately, however, neither his own log book nor Hitchcock's bears out the story in Job's book. A week after he arrived at No. 2 Squadron where he had been posted as adjutant, Garrett went up as 'crew' on patrol to Zealey Point with Hitchcock in an Anson. It was not 'days' before the fatal crash but nearly 11 months earlier. ${ }^{57}$ Garrett's name appears in Hitchcock's log book on only one other day before 13 August 1940. It was June 30, 44 days before the crash. Garrett and Hitchcock were alone, not in a Hudson, but again in an Anson flying from Point Cook to Laverton. Hitchcock took the Anson back to Point Cook solo. Then he returned to Laverton with six passengers. And to end the day he took two of the men back to Point Cook in a different Anson. Each flight took 10 minutes. There is no occasion from the beginning of June onwards when Hitchcock is recorded as engaged in coastal reconnaissance. All this is not to deny the possibility that 40 years after the event Garrett genuinely recalled a disturbing incident involving Hitchcock. But, if it happened at all, it did not happen in a Hudson. Nor was it within three months of the fatal crash. ${ }^{58}$

\footnotetext{
56 Ryland's testimony, 27 Aug. 1940, Air Court of Inquiry transcript, NAA: A705, 32/10/2729.

57 Flying Log Book of F/Lt William Raymond Garrett, 18 Sept 1939, photocopy, Garrett MSS, courtesy of Anne Kelly; R. E. Hitchcock's Flying Log Book, 18 Sept. 1939, NAA: A705, 32/10/2729 attachment 1. Job has confirmed that Garrett was his source (telephone, 21 April 2009).

58 Clark cited the alleged episode with the unnamed 'ex-commercial pilot' in an interview 6 Jan. 2008 for the ABC (transcript via Geoff Crane). Tink (Air Disaster, pp.149-50) cites Clark.
} 


\section{Comparisons}

The readiness of so many of his former colleagues not simply to accept an official conclusion that the crash was Bob Hitchcock's fault but to let it be known that they had always had doubts about his ability was deeply hurtful to his widow. Proud of her husband's achievements, knowing the effort it had taken for him to rise through the ranks to officer status and continue to rise, Olive Hitchcock sensed the condescension that he had endured throughout the years since he was commissioned. Even Rex Taylor later expressed his 'understanding and belief' that his friend was 'lacking in the natural aptitudes which could be expected to lead to a really proficient military pilot, in those days' ${ }^{59}$ True as that might have been, the fact was that Taylor's friend had until 12 August 1940 come through flying training, five years of military flying, and conversion to the Anson and Hudson without grievous mishap. In a period when the Air Force was riven by arguments about the causes and remedies for multiple flying accidents Hitchcock had survived.

Any defensible assessment of Hitchcock's Air Force career must be more than a compilation of anecdotes and selected incidents imperfectly if not tendentiously recalled. His ability and performance are best understood when set against the record of his contemporaries. Of the 28 cadets who began the course with him at Point Cook in July 1935, 27 graduated as pilot officers on 16 June 1936. One had been discharged for misconduct. Seven chose the option of joining the RAF. The remaining 20, appointed to four-year short-service commissions on probation from 1 July 1936, were listed in order of seniority:
D. Ashton-Shorter
J. A. Cohen
D. J. Macpherson
A. N. Hick
E. V. Read
W. F. Allshorn
R. F. Wiley
W. J. Keenan
C. T. Hannah
B. G. Braithwaite
N. Ford
J. P. Godsell
E. G. Fyfe
G. J. Quinan
C.A. Houston
J. N. Bell
R. E. Hitchcock
E. J. Eagerty
G. K. Buscombe
T. H. Davies

Having finished in the top half of his class and surmounted the setback at No. 3 Squadron in his probationary year, Hitchcock had gone on to make steady progress. He had proved reliable in his personal life, unlike one classmate who 
had been persuaded to resign in August 1938 for being 'irresponsible in regard to his private affairs' - a man who bounced cheques could not be trusted with the financial responsibilities that accompanied command. ${ }^{60} \mathrm{He}$ had not been 'severely reprimanded' for 'drunkenness' by the Richmond station commander, caught out joyriding, taking girlfriends on unauthorised excursions, alarming the inhabitants of a country town by dive-bombing and barnstorming several feet above the main street, or causing irreparable damage to aircraft by carelessness or bravado. ${ }^{61}$ And, most important, his name did not appear in the summary lists of fatal accidents that so troubled his superiors. He had not been one of the 26 fatalities in 11 RAAF accidents in the five months to 12 August 1940.

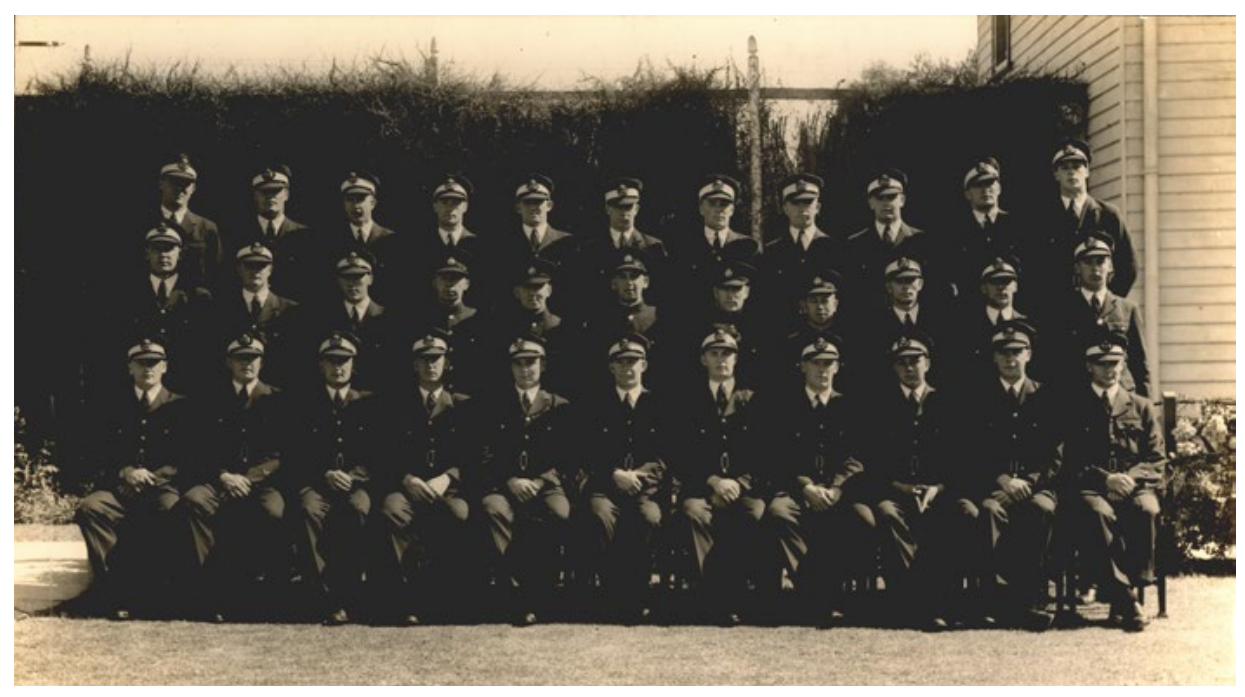

\section{Bob Hitchcock and his peers: 'A' Course July 1935 entry}

(Courtesy of the RAAF Museum)

The contrast with some of his peers is striking. We have seen the sad fates of John Eagerty and Donald Ashton-Shorter. The loss of Charles Houston is another poignant reminder of the thin veil between the flying life of the 1930s and eternity. Like Bob Hitchcock, ACl Houston had been recommended for a cadetship by the CO of No 1 Aircraft Depot. Before enlisting he had been a fitter and turner in the Newport railway workshops. Director of Training George Jones noted at his interview that the young airman dressed oddly, was rather slow and deliberate, and did not seem to have a strong personality. By

60 Air Board Agenda 2239, NAA: A4181, 15.

61 Dickie Cohen's strafing of Corowa made the local newspapers but brought no charge. Earlier he had been fined $£ 5$ for 'disobeying in such a manner as to show wilful defiance of authority a lawful command given personally by his superior officer in the execution of his office', an alleged offence of low flying of which he was guilty on other unobserved occasions but not this one (NAA: A10605, 521/2; Coulthard-Clark, The Third Brother, pp.331-2; Kingsland, Into the Midst, pp.24-6, 39-40). 
contrast, and an illustration of the subjectivity of the character assessments which were routinely recorded at successive stages of an officer's career, another interviewer rated him a strong and pleasing personality. Houston's outstanding educational record at Clifton and Haileybury Colleges, subsequent trade training at Swinburne Technical College, and a year as a sapper, counted in his favour. His enthusiasm for boxing and long-distance running might also have helped to earn him a place in the A course in July 1935. The sole support of his mother, invalid grandmother, and brother, the 23-year-old Pilot Officer Houston died when his D.H. Moth seaplane A7-40 disappeared in Port Phillip Bay in July 1937.

The accident was no secret, though much of what followed was. As members of the armed services were excluded from the benefits of the Commonwealth Employees' Compensation Act, Houston's mother received an ex gratia payment of $£ 100$. The RAAF's proceedings in Houston's case foreshadowed a willingness to conceal inconvenient evidence, a characteristic that was to be exhibited again in August 1940. There was a good precedent for paying Houston's mother, as George Jones pointed out, but the Director of Training's recommendation of $£ 150$ - double the miserly amount suggested by the Finance Member of the Air Board - was rejected. Although other reasons were given, including that her untraceable husband had a legal responsibility to maintain her, it appears likely that the grudging 'act of grace' payment made to Mrs Houston was influenced by facts that were suppressed in the Court of Inquiry into her son's accident. The Chief Commissioner of the Victorian Police had been tipped off that Houston and his companion, Pilot Officer Ernie Yde, had picked up two young women and taken them for a flight just before the crash. The Commissioner passed the information to the Secretary of the Defence Department. After a highlevel conclave at RAAF headquarters a 'request' from the Chief of the Air Staff was conveyed to the President of the Court of Inquiry, Fred Scherger, to make enquiries. Having interviewed one of the girls, Scherger was satisfied that they had nothing to contribute to the investigation and decided to make no reference in the Court to the joyride. What he could not expunge from the official record was the finding of the Air Accidents Investigation Committee that the crash was caused by 'unnecessary low flying' ${ }^{62}$

Inexplicable as some crashes were, even good pilots could never be absolutely sure of the safety of the machines they flew. It was not Joe Godsell's fault, for example, that he had to make a forced landing in his Hawker Demon late in November 1937 - it was a defect, well known in Demons, in the water circulation system. Nor could he be blamed for an accident a week later caused

62 NAA: A705, 53/1/336; MP187, 4/179. It was not long before the 'most popular and most delightful' Yde, had crashed and died in Port Phillip Bay (Gordon Olive and Dennis Newton, The Devil at $6 O^{\prime}$ Clock: An Australian Ace in the Battle of Britain, Australian Military History Publications, Loftus, 2001, pp.5, 36). 
by a tyre puncture.$^{63}$ What all those in authority in the RAAF knew, though sometimes chose to ignore, was that 'efficient' pilots could have accidents. Sometimes equipment could be blamed. But there were other possibilities. The death of Pilot Officer L. R. Sutherland during practice for an air display in April 1938 was one of several examples of highly regarded young pilots - he had been runner-up for the Mannock Cup - making fatal errors of judgment. Lance Sutherland, 'a very sound steady pilot' according to the Air Accidents Investigation Committee, had attempted a slow roll in a Bulldog too close to the ground, realising the impossibility of the manoeuvre too late. ${ }^{64}$

In an earlier tragic incident, it was not the pilot but two spectators at a demonstration of Demons in Swansea, Tasmania, who lost their lives. Nineteenyear-old Geelong Grammar old boy, Pilot Officer Eric Lansell, failed to clear the unmarshalled crowd as he was taking off, and his axle and wheels struck several spectators. Though Lansell was initially charged with manslaughter, the case did not proceed. His offer of resignation in June 1937 was not approved. He resumed his career, by May 1940 commanding the Advanced Training Squadron at Point Cook, and later serving as a squadron leader with No. 30 Squadron, flying Beaufighters in New Guinea, and ending the war as a Wing Commander. ${ }^{65}$

Overweening self-confidence could be as dangerous as timidity. Regular evaluations of competence were no guarantee against lapses of judgment, momentary inattention, surges of emotion, over-tiredness, illness, alcoholic excess, irrational urges to compete with others, to show off, or to prove something to themselves. Bill Allshorn, for example, who would go on to a troubled command of No. 21 and No. 4 Squadrons yet end the war as a Wing Commander with an Air Force Cross, was court-martialled and stripped of three months' seniority in 1936 for crashing into a hill some seven miles beyond the limit imposed at No. 3 Squadron for an airmanship exercise ${ }^{66}$ He was not unique.

Worrisome as Hitchcock's early flying had been, it was no worse than that of his fellow West Australian Hughie Edwards. Edwards had been strongly censured

63 NAA: A5954, 869/1; MP187, 4/184A.

64 NAA: MP187, 4/186. AVM Ernie Hey, an advanced flying instructor in the mid-1930s, reflected four decades later on sword-of-honour winners who killed themselves because of overconfidence (interview [20 Aug. 1977]. Winners in the cadet courses immediately preceding Hitchcock's - E. A Whiteley, A. D. Groom, E. L. Chapman - survived the war. Chapman was not selected for an RAF signals course in 1937 because of 'his lack of willingness to fly', but was later recommended for an engineering course (NAA: A705, 163/1/296). 65 Air Accidents Investigation Committee Report No. 155, NAA: MP116/1; A9300 Lansell E. V.; The Argus, 27 Mar. 1936, 2 Feb. 1943; Coulthard-Clark, The Third Brother, p.333; Russell, Old Geelong Grammarians at War, pp.263-4.

66 NAA: A471, 22488. Allshorn had been awarded four days' C.B. for 'wilful defiance of authority' as a cadet in March 1936. In Sept. 1936 he would write off the airframe of a Moth after striking telephone wires at $200 \mathrm{ft}$, stalling, and falling into the Hawkesbury River during approach for a forced landing (NAA: MP187/3); John Burton, Fortnight of Infamy: The Collapse of Allied Airpower West of Pearl Harbor, Naval Institute Press, Annapolis, 2006, pp.106, 113, 236; S/Ldr W. J. Harper, Report on No. 21 and No. 453 RAAF Squadrons, secret, 14 Jan. 1946, UK National Archives AIR 20/5578. 
for his low-flying exploits during training, including 'bouncing' and narrowly avoiding a train. When he accepted a posting to the RAF, his casual airmanship was soon raising eyebrows. Serving in a Blenheim bomber squadron, he survived a serious accident in Scotland in 1938, 'severely damaged' and permanently paralysed below the right knee. The crash, caused by icing, might have been avoided had he observed that he was flying into cumulonimbus clouds. Edwards was not returned to flying duties until April 1940. He was renowned as a pilot whose landings were frequently hazardous. But his fearless insouciance won friends in high places, and a chestful of decorations, including the V.C., eventually attested to his valour in combat. ${ }^{67}$

To understand the significance of Hitchcock's survival through over a thousand hours of flying, the records of the Air Accidents Investigation Committee (AAIC) are salutary. The 'Accident or Forced Landing' reports fill several volumes between 1935 and 1940. Between 1935 and 1937 alone, the RAAF recorded 219 accidents with nine pilot fatalities. ${ }^{68}$ During the last month of Hitchcock's cadet course the AAIC approved a reprinting of their standard form at $£ 2$ per 1000 copies. An analysis by the Actuarial Society of America published at around the time Hitchcock began his training is instructive. In the United States the annual mortality rate for airline pilots was 25 per 1000; an hour in the air was estimated to be 80 times more dangerous than an hour on the ground. Mortality risk for airmail pilots was 95 times 'normal'. For army and navy pilots it was 170 times. Amateur flyers faced a risk of death 255 times greater than the average man. ${ }^{69}$

For some years before the war, personal accident insurance against aviation accident had been available from major Australian life offices for RAAF officers and other personnel. But generally an extra premium was required, between $£ 5$ and $£ 10$ per $£ 100$ sum assured for coverage of active service overseas. When war came, all the big life offices imposed a restriction on their liability in respect of death on war service outside the country. Unless a premium of £7.10.0 per cent of the sum assured was paid, the liability would not exceed the premiums paid plus interest. A war clause was inserted in new policies that provided for a maximum death benefit of $£ 1000$ plus bonuses. Premiums paid in respect of a sum assured in excess of $£ 1000$ would be refunded plus compound interest calculated at $3 \frac{1}{2}$ per cent. Alert to a gap in the market for RAAF pilots, in April 1940 Bennie S. Cohen \& Son, Lloyd's insurance brokers, of 341 Collins Street, Melbourne, were quoting a premium of $15 /$ - per $£ 100$ for a benefit payable on death for 'period of training limited to 10 weeks'. For six months it was $40 /-$

67 Hoyle, Sir Hughie Edwards, pp.19-20 and passim.

68 S/Ldr J. M. McCauley (DT), 'Analysis of RAAF Flying Accidents', 20 Dec. [1937], NAA: A705 32/10/1915. The AAIC reviewed 96 accidents in 1937, finding 67 of them due to pilot error (J. L. Kepert. Aircraft Accident Investigation at ARL: The First 50 Years, DSTO Australia, 1993, p.10).

69 Unidentified press cutting, ca March 1935, NAA: MP187/1. Modern statisticians would doubtless show the flaws in these risk analyses. 
(£2) per £100. For one year, including training, the premium was '60s \%' or £3 per $£ 100 .^{70}$ These were generous terms offered by the leading Australian firm of Lloyd's brokers, founded by Oswald Benjamin in 1923, specialists in aviation insurance with an office in London's Lombard Street. The AMP, of which Joan Wiesener's uncle was a senior director, was already paying out for airmen who had died in flying accidents; and had recently paid on a policy for Pilot Officer Stanley Thornton, who had disappeared in an operation over Holland in May $1940 .^{71}$

By August 1940, not only had Bob Hitchcock avoided becoming an attrition statistic he had actually progressed in the Service faster than many of those who passed out with him from Point Cook in 1936. He had attained the rank of flight lieutenant in April 1939. His promotion might well have occurred as early as July 1938 had the recommendation of the Air Member for Personnel not been deferred by the Air Board. Flying Officers Read, Hannah, Ford, Fyfe, Buscombe, Macpherson (provisionally, he was undertaking an RAF Signals Course), and Cohen (now qualified as a specialist air navigator) along with Hitchcock eventually went up together, with the approval of the Minister for Defence, Geoff Street. By then another of their number, 'mentally apathetic regarding flying duties', had been terminated. Among Hitchcock's contemporaries still awaiting promotion from flying officer in February 1940 were Norman Hick, Joe Godsell, Geoffrey Quinan, Ralph Wiley, Bill Keenan, John 'Dinger' Bell, Thomas Davies, and Bill Allshorn, the last three having slipped a month behind the rest in seniority, being recommended for temporary promotion from 1 October 1939 rather than 1 September $1939 .^{72}$

Whatever might have been the truth about Bob Hitchcock's flying competence, the incontrovertible fact was that A16-97 was observed to plunge to the ground in a way that Service inquiries concluded was the result of error by the pilot.

\footnotetext{
70 'Personal Accident Insurance Against Accident in Respect of Officers and Other Personnel of the R.A.A.F.', 12 April 1940, ABON 168/1940, NAA: AA1977/635. A Century of Life: The story of the first one hundred years of The National Mutual Life, 1969, pp.78-9; A. C. Gray, Life Insurance in Australia: An Historical and Descriptive Account, McCarron Bird, Melbourne, 1977, p.192; 'Life Assurance Policies and War Risk', Australasian Insurance and Banking Record, 21 Oct. 1939, p.851. Bennie S. Cohen \& Son was later renamed Edward Lumley \& Sons (Rodney Benjamin, Paths to Professionalism: A History of Insurance Broking in Australia, Craftsman Publishing, Melbourne, 1988, pp.96-9, 103, 111).

71 Geoffrey Blainey, A History of the AMP 1848-1998, Allen \& Unwin, Sydney, 1998, p.227: NAA: A705, 32/4/5. 72 Air Board Agenda 2382 NAA A4181, 15 incorrectly lists V. H. Keenan as among those promoted; AMP to Secretary Air Board, [Feb. 1940], NAA: A4181, 17. Bell had been awarded three days' C.B. for disobeying 'a lawful command given by his superior officer' weeks before he graduated (NAA: A10605, 521/3). Among those who survived the war, WCdr Ralph Wiley's 'high sense of duty' and 'good knowledge of the Service' were 'largely offset by having no tact whatever which continually causes him to be unpopular with any officers or airmen with whom he contacts' (Confidential Report, 23 Jan. 1946, NAA: A9300, WILEY RF).
} 


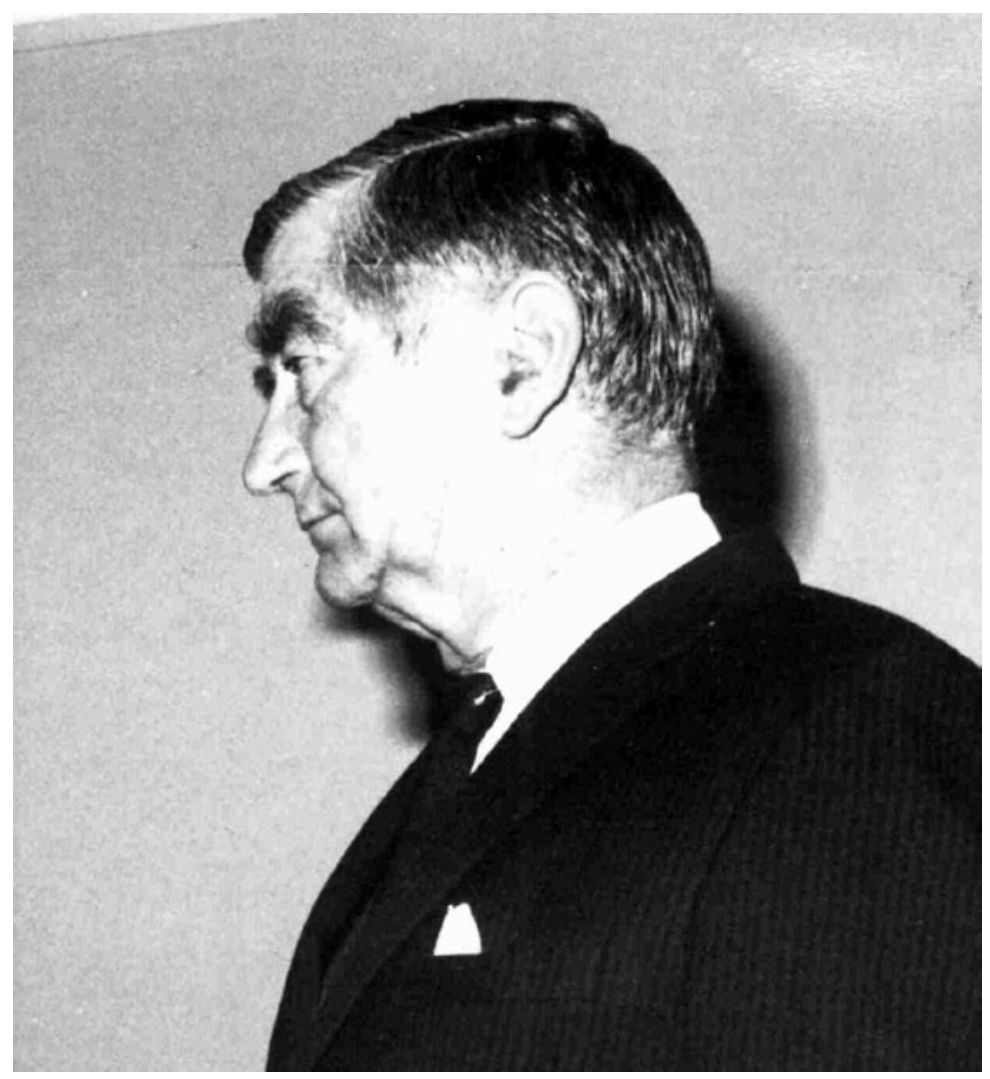

\section{Sir Peter Looker: what did he tell the Prime Minister?}

(Courtesy of Swinburne University of Technology)

Nothing discovered by contemporary investigators would justify a finding that the aircraft itself was defective, although Jack Ryland for one would offer structural failure as a 'very improbable' alternative cause: 'actual breakage of the controls themselves or the wires leading to the control surfaces'. 'Del' Wilson had pushed unsuccessfully for some confirmation that a vital cable could have been broken. It was permissible therefore, and logical, to infer by default that Hitchcock was entirely responsible for the aircraft's stall. Explanations could then be sought in what was known of the pilot's training, aptitude, experience, personality, and state of mind. Expert witnesses testified that the pilot was appropriately trained and experienced. In 1940, RAAF authorities were content to conclude for the record that Bob Hitchcock lost control at a crucial moment and was unable to retrieve the situation. This was a conventional and comfortable explanation. They had no desire to explore why he might have failed to bring in safely an aircraft on which, by the Air Force's standards, he was amply qualified. Nor were they eager to highlight the fact that the accident had occurred to what they knew to be a challenging aircraft. 
The thought that a respected Cabinet minister might somehow have contributed to, if not actually caused, the crash could be relegated to the realm of unsubstantiated speculation. There was no evidence that anyone else was in control of the aircraft. Normally observed cockpit rules and etiquette would exclude such a possibility. Nevertheless, there were doubts. Just two weeks before the fatal crash, John Harrison had completed a trip around the nation with Jim Fairbairn during which Harrison was 'a mixture of deputy private secretary, journalist, navigator, wireless operator, and general dogs-body'. As 'the last person to have sat alongside Jim Fairbairn when he was pilot-incommand', Harrison would admit privately 38 years later 'that dual-control possibility haunts me'. It haunted him all the more as he had been in the queue for a seat in A16-97: 'one of the VIP's needing a seat in that Hudson is a reason why I am alive today'. ${ }^{73}$

Of all the witnesses who have expressed a view about responsibility for the crash, none compels more attention than the man who claimed to have assisted in the identification of the bodies and to have reported directly to the Prime Minister. When I interviewed Sir Peter Looker in March 1976 he was candid about many things but careful about what he chose to reveal. I was talking to Looker about his life as assistant private secretary to Robert Menzies in 1940 and 1941 for the television series on Menzies' life on which I had just embarked. We had been discussing the Prime Minister's travel arrangements between Melbourne and Canberra. The disaster of August 1940 came up without premeditation. 'It was a terrible tragedy. And I had the unenviable experience of having to go across and identify the bodies,' he said. 'It shouldn't have happened'. Was the plane overloaded, I asked? At that stage I knew nothing of the allegations about Fairbairn. 'No, no, somebody was flying the aircraft who shouldn't be flying it.' And then he moved the conversation firmly in another direction. ${ }^{74}$

There was only one somebody it could have been. Thirty-seven years later, I believe Looker was wrong. But it remains an embarrassment that I did not press him then or later to tell me more.

73 John Harrison to CH, 23 June, 25 July 1978.

74 Sir Cecil (Peter) Looker, interview, 25 March 1976. 



\section{Diagnosis and remedies}

No contemporary report places the Prime Minister's assistant private secretary Peter Looker either at the crash scene or the morgue on 13 August 1940. If he accompanied his senior colleague Corby Tritton from the Prime Minister's office, or his friends Percy Hayter or Murray Tyrrell, to view the bodies, his presence was not recorded. Perhaps he went later and separately. In any event, his testimony that 'somebody was flying the aircraft who shouldn't be flying it' is powerful evidence of what was believed at the highest levels of government. No-one could be sure precisely what had happened. But for those in the Air Force with responsibilities for the safety of pilots and their crews it had to be assumed, and be seen to be assumed, that it was one of their own in command at the time of the accident.

Whatever unexpressed doubts simmered in George Jones's mind about who was responsible for a fatal error of judgment on August 13, it was incumbent upon him as the Director of Training to provide trustworthy guidance to other pilots. No matter who had been at fault, the fact was that a new aircraft, some hundreds of which were to be allocated to squadrons, had fallen out of the sky. Many of the most experienced pilots and engineers in the Service had cogitated and debated why this had happened. The sum of their thinking, distilled into systematically presented advice, might save lives in future.

Justice Lowe had reported to the Governor-General on September 5. Fifteen days later, Air Force Confidential Order 79 was issued to draw attention to the stalling characteristics of the Hudson aircraft. There was no gilding the presentation for the Air Court or the public. With flaps down 100 per cent, undercarriage down, and power off, there was, according to Confidential Order 79, nothing to worry about. With power on, it was a different story: 'Very little warning is given. The stall is sudden and the wing drops quickly.' The severity of the stall would depend on the amount of engine power used and the weight of the aircraft: the greater the engine power and weight, the 'more vicious' the stall. If flaps were down 40 per cent, the tail would become heavy. With 40 per cent to 100 per cent flaps down, the nose would become increasingly heavy. But, pilots were assured, this nose and tail heaviness was 'easily controlled.'

There is no difficulty or problem in putting the engine on if undershooting, or if it is necessary to make another circuit. The precautions necessary are to avoid letting the nose rise too soon and to avoid raising the flaps until sufficient speed and height is obtained. There is no difficulty in holding the nose down, and when the flaps are operated, change of trim is easily controlled. 
The danger that could arise in putting the power on was when the aircraft was 'already stalled to a marked degree, without power on, near the ground.' What would happen if the power was put on? The stall would change from a gentle stall without power to a sudden stall with power. It all sounded rather elementary. But, just in case the message was not clear, the point was reiterated: 'The stalling speed with power on is less than that with power off, so that recovery from the stall can be effected by putting the power on provided the nose is definitely put down first.'

Such was the simplified practical advice. On the same day, the Air Board issued generic instructions on 'Powered Approaches in Modern Monoplanes'. A number of accidents had occurred 'both by day and night', because of powered approaches being carried out in 'an incorrect manner'. Referring back to the detailed 'Flying Instruction - Approaching and Landing', distributed in late April, the Air Board reiterated that it should be seen that the engine is used for the purpose of augmenting the pilot's judgment and countering unforeseen difficulties, and not with the object of low flying on considerable power during the approach' ${ }^{2}$

\section{'The moral...always have fair margin above stalling speed'}

For those who wanted a deeper understanding of what had happened on August 13 there was an 'Informative Circular' forwarded on September 28 by F. J. Mulrooney, Secretary of the Air Board, to Air Commodore W. H. Anderson, the Air Member for Personnel. The circumstances of the crash were summarised and 10 possible causes of the stall were examined. ${ }^{3}$ The analysis, 'for the information of pilots', was to be placed in all Unit Confidential Order Books. It was set out in two columns. On the left were listed 'Factors which may have contributed towards causing the aircraft to stall.' In the adjacent column was 'Comment as to the probability or otherwise, of these factors contributing to the stall.'

The first concern was that the aircraft was heavily loaded. The drivers who had brought the passengers to Essendon had estimated the weight of the luggage they carried, producing an average of $47 \mathrm{lbs}$ per passenger. But the pilot of A16-97 had known this, and had previously flown other Hudsons with a full bomb load. In addition, as Bob Hitchcock's log shows, on 22 July 1940 he had taken up Hudson A16-32 with a second pilot and nine other men for 'full load

\footnotetext{
1 'Hudson Aircraft — Stalling Characteristics', A.F.C.O. 79, 20 Sept. 1940, NAA: A7674, 1/119.

2 'Powered Approaches in Modern Monoplanes', ABO N 568/40, 20 Sept. 1940, NAA: AA1977/635.

3 'Informative Circular Relative to the Accident to Hudson A. 16-97 at Canberra on 13th August, 1940', 'Confidential, CD58/40,' n.d., NAA: A705, 32/10/2733.
} 
flying'. The all-up weight of A16-97 as it approached Canberra was assessed as 17500 lbs - heavy, but well below the maximum permissible all-up weight of 18500 lbs.

What, then, if the load was not properly distributed, tending to make the aircraft tail heavy? Here the answer was both factual and hypothetical. The pilot had discussed the trim of this aircraft with another pilot and was warned against placing all the luggage in the rear. 'If the disposition of the load were such as to affect adversely the trim, the pilot could have easily arranged to have the luggage moved during the flight prior to landing.' Could have. But as 'Dad' Bladin, Director of Operations and Intelligence, had commented a month earlier: 'There is little evidence that the pilot worked out his load disposition.' ${ }^{4}$ The Informative Circular concluded less prejudicially: 'nothing is known of how the luggage was actually stowed'.

The Service Court of Inquiry had recommended that a weight sheet summary be issued, and this had quickly been done. As for bad dispositions of load, the Librascope 'balance computor' was the appropriate instrument. The first model had been designed a few years earlier in Burbank California for the Douglas DC-3 and the Lockheed 14, the Hudson's civil precursor. Using it was easy, 'Dad' Bladin had said, but it was for the Director of Equipment to ensure that they were issued to squadrons: 'Can the D. of E. say that a librascope is available in every Hudson unit?' As Bladin would have known, the purchase of five librascopes, one for each station where there were to be Hudsons, had received ministerial approval in September 1939. But there were in fact only three in the country, at Richmond, Darwin, and Pearce, and two with No.1 and No. 8 Squadrons in Singapore. ${ }^{5}$ The instrument could not have been used by Hitchcock and Wiesener in A16-97. What would now become standard practice with a 'centre of gravity calculator' was described by Deryck Kingwell:

Before each flight the location and weight of all sections of the load, including fuel, aircrew, ammunition, guns, bombs, plus anything else placed into the fuselage had to be set on this calculator which gave an indication of the centre of gravity that resulted from that load. Unless the pointer pointed in the green area, the load had to be adjusted either fore or aft until it did so. The calculator also read off the take-off speed, length of take-off run, approach speed and landing speed for that particular load. Movement of load during these phases was very critical and everyone was warned of this feature. ${ }^{6}$

4 Bladin's note, 27 Aug. 1940 on minute by GpCpt. Jones D. T, 24 Aug. 1940, NAA: A705, 32/10/2733.

5 NAA: A705, 32/10/2733. On the Librascope's settings for the Lockheed 14, see The Aeroplane, 23 Feb. 1936, p.240, quoted in Vincent, The RAAF Hudson Story, Book One, p.298; NAA: A4181, vol. 15. For the Librascope and its inventor, Lewis W. Imm, see, http://dcoward.best.vwh.net/analog/libra.htm, and Edward Churchill, 'Automatic Brains', Popular Aviation Magazine, Feb. 1940.

6 ACdre D. W. Kingwell to CH, 18 April 1979. 
If weight and centre of gravity were problematic the fuel tanks also had to be a concern. The petrol in the rear tanks had not been used first. Would it have made a difference if it had? Some people thought so. It was not standard practice to empty the rear tanks first. But in discussion about the trim of the aircraft it had been suggested by another unnamed pilot, probably Jack Ryland, to A1697's pilot (Hitchcock was never named in the document) that to do so would improve the trim for landing.

Then there was the question of the flaps. The starboard flap was found pushed back 'to $80 \%$ of its total travel'. The absence of the last 20 per cent of the travel would have had a significant effect on lift and drag. But no-one could rule out the possibility that the flaps had been pushed back when the aircraft hit the ground. Similarly, the possibility was considered that the engine cooling gills, which had been found open, could have increased the air flow over the flapped section of the wing. Again it was suggested, though some were unpersuaded, that the gills could have been closed until thrown open by the impact.

Experienced observers had consistently reported that the aircraft was flying slower than is usual for similar aircraft. Generally, estimates of the speed of aircraft in the air were thought to be erroneous because of the complex effect on perception of wind, height, and distance. In this event, however, the key RAAF observers were all familiar with the Hudson in flight and their impressions were remarkably uniform. What none of the investigators and headquarters analysts fully appreciated was that it was not just estimates of speed that could be unreliable. It was another two years before RAAF authorities were confronted by irrefutable evidence that the observations of even the most expert of eyewitnesses like Jack Ryland could be seriously defective. The crash of A16-38 at Bairnsdale in full view of a party of senior officers, including Bob Hitchcock's former CO Bob Dalton (now a Group Captain and CO of No. 3 Bombing and Gunnery School), journalists, and Movietone and Cinesound cameramen, was the turning point. As Ryland and Doug Candy, both by then Wing Commanders leading No. 1 Operational Training Unit, conceded, what they and others thought they had seen was irreconcilable. An accurate reconstruction of events was impossible until the Court viewed the Cinesound film of the stricken Hudson aircraft falling to the ground. Some evidence from 'senior and highly trained personnel' was 'completely at variance with the facts' established by the film. The Court of Inquiry therefore recommended:

In future Courts of Inquiry into flying accidents the evidence of eye witnesses be accepted with reservation. While their sincerity is not questioned, events have proved that most experienced officers have been unable to assimilate the true sequence of events and give an accurate description. ${ }^{7}$

7 'Hudson A16-38 - Proceedings of Court of Inquiry re accident to', Oct/Nov. 1942, NAA: A705, 32/14/129; Vincent, The RAAF Hudson Story, Book One, pp.309-12. 
Whether or not human observations could be relied upon, there were ascertainable realities to be considered. Perhaps the fact that the Canberra aerodrome was approximately 2000 feet above sea level could have caused difficulty? It would be necessary to ensure that the angle of the approach was such as to maintain the required air speed: the angle or, as one reader interpolated in the margin of his copy, the power used. It was noted that the pilot had landed at Canberra before, and had specifically discussed this point with another pilot who had landed the same aircraft in Canberra under similar conditions (presumably Flying Officer Bill Heath who had flown up on August 5). By implication, ignorance of the locality could be ruled out. Forgetfulness would have been another matter.

A question had been raised about the possible effect of wind. After a landing scare at No. 14 Squadron in June it had been decided that the effects of wind gradient needed to be explained to all pilots. Over the Canberra hills on August 13 a wind estimated at about 15 miles an hour was blowing. At least one senior officer wondered if the crash was on the lee side of the hill, which could have meant that the aircraft experienced a 'down current'. The expert consensus, however, was that it was probable (not just possible) that the aircraft received an upward 'bump under the starboard wing'. To correct the effects of a bump it would be necessary to use considerable aileron when flying slowly. If aileron were applied there would be additional drag. Eye-witnesses had reported that the port wing had gone down, as it would have if there had been a bump under the starboard wing. The natural reaction of the pilot in these circumstances would have been 'to endeavour to correct this by application of ailerons'.

Finally, it was conjectured, if the port wing had been down 'to a marked degree for quite a period', the aircraft would side-slip, thereby detracting from the effect of the flaps on the lift of the aircraft. It was true that the wing was observed to be down for 'an appreciable time (2-3 seconds)' before dropping further, with the nose going down and the aircraft turning to the left. But, as those who had read some of the eye-witness accounts knew, side-slip had not been noticed.

What could be concluded from this discussion? No single cause could be determined. It was 'possible' that all of the factors mentioned were 'present together at the critical moment, and that their combined effect was to cause the pilot to lose control and the aircraft to stall'. It was 'highly probable' that several of the factors were present and that the cumulative effect could have caused the aircraft 'to stall under adverse conditions, viz., with flaps down and power on.' 'The moral,' as one senior officer wrote at the bottom of the last page, 'always have fair margin above stalling speed (i.e. do not sail too close to it until flattened and within a few feet of ground).' 
The moral was one that would have come as no surprise to anyone who had been converted to the Hudson at Richmond. Wing Commander Lloyd A. 'Smokey' Douglas's considered view was that this was a lesson already learned there. Lloyd Douglas, who was a 21-year-old when he knew Dick Wiesener, believed that the Richmond alumni who had the benefit of both KLM and Lockheed knowledge were the best Hudson pilots in the world. Dallas Scott, who undertook Hudson conversions for No. 2 Squadron while waiting for No. 7 Squadron to receive its own Hudsons, was 'a tremendous bloke' Douglas averred; but he had taught pilots to fly too slowly on approach and take-off. If this were so, it would have been odd in view of Scott's previous experience of Lockheed 14 Super Electras with Guinea Airways. Was Douglas, like so many others who cast their minds back to their adventurous youth, echoing a friendly wartime rivalry between Laverton and Richmond $?^{8}$ Certainly he was too modest to mention that he had himself managed a successful forced landing with wheels up on 30 May 1940 when both engines of Hudson Al6-54 failed 15 miles north of Junee. ${ }^{9}$

'Curly' Brydon, like Dallas Scott a Melbourne Grammar boy, had presented himself for enlistment at the age of 18 years and five months on the day after Britain and France declared war on Germany. By 1944, he was a squadron leader with a DFC and bar. Thinking back to his 550 hours as a captain of Hudsons in No. 6 and No. 1 Squadrons he was also inclined to see the fault less in the machine than in the training of the pilots. He made no exception for those who instructed at Richmond, where he had been posted as a pilot officer in March 1940:

In the early days of conversion the standard instruction from such famous aviators as Swede Parker, Alec Barlow, Pat Hall, Dallas Scott and others was 'Don't apply flap until you are on final'. This probably caused more prangs than saves, specially when turning into the final leg when speed was necessarily low and the aircraft close to the stall. I can remember having a heated argument with a pilot senior to me in Singapore about this. ${ }^{10}$

Neither Douglas nor Brydon may have known that Hitchcock's instructor had been Jack Ryland, familiar as an Ansett Airlines pilot with the Lockheed 12, converted to the Hudson by Swede Parker, but with hundreds of hours since then on the new type.

8 L. A. Douglas, telephone interview, 17 April 1978.

9 'Lockheed Hudson A16 [Accidents Part 1]', NAA: A9845, 134/60.

10 A. H. Brydon to $\mathrm{CH}, 4$ April 1978. Brydon was appraised by his CO WCdr Nicky Barr in 1945 as having 'a tendency to be radical in his outlook, \& occasionally his verbosity outweighs the amount of action required' (NAA: A9300, BRYDON AH). The verbosity may have reflected his brief experience as a radio announcer (Herbert C. Plenty, Singapore Slip, Len Books, Canberra, 1990, p.163). 
What the 'Informative Circular' inadvertently proved to anyone who read it was that Bob Hitchcock had been cautious in preparing for the flight. He had sought advice from at least one of his fellow pilots on matters about which he was uncertain. It was possible that he had not paid sufficient attention to the load and its disposition. But the circular's concluding reference to 'adverse conditions' signalled a subtle rejection of the damning and poorly justified findings of 'pilot error'. Among those who bore responsibility for Hitchcock's steady promotion and progress into positions that tested his ability and temperament were some who were now aware of the likelihood that his control of A16-97 could have been compromised. If there were limits to the public exploration of the truth, at least these senior men of repute could avoid giving professional endorsement to what they knew or strongly suspected to be false.

The circular was distributed across the country to Area Headquarters in Sydney and Melbourne; multiple copies to RAAF stations at Amberley, Archerfield, Richmond, Rathmines, Laverton, Pearce, Darwin, and Canberra, and No. 1 Service Flying Training School at Point Cook; and single copies to every squadron overseas, elementary flying training schools, the Central Flying School, engineering schools, wireless air gunner and bombing and gunnery schools, stores depots, recruiting centres, every directorate, and even the Central War Room. Thereafter it was for instructors, already 'converted' senior pilots, and those just qualified, to teach and learn as best they could.

\section{Politics and Purvis}

While the Air Force was moving to advance understanding of the Hudson and improve flying safety, their political masters were preoccupied with a federal election campaign. The election, held on September 21, resulted in the UAP winning 23 seats and their Country Party coalition partners 13; the ALP won 32 and Lang Labor had four. Two independents held the balance of power. Over the next five weeks, the Prime Minister tried in vain to persuade Labor to join an all-party coalition government. After further upheavals in the Country Party, a refreshed coalition was formed on October 28. Arthur Fadden, now 'Acting Leader' of the Country Party, became Treasurer and was succeeded as Air Minister by John McEwen.

When the well-connected Aircraft magazine came out in November 1940, it commented on the report of what it pointedly called the 'partly public' Lowe inquiry. 'The report is highly satisfactory in that it should end the silly rumors [sic] that followed the accident - rumors of sabotage, and of someone other than the pilot making the approach to land.' Herbert Storey's story, or stories like it from those who had been at the scene of the crash, were already it seems 
common knowledge in the aviation community. Lowe's dismissive comments had the desired effect. It was now legitimate to characterise as 'silly' the notion that anyone other than Bob Hitchcock was responsible for the crash. Noting that not all the evidence was heard in public, Aircraft found it 'particularly interesting' that the report recommended more training for pilots going on to the new machines. 'This is surely an implication that evidence showed some pilots have not had enough experience before being passed out on the type, although in view of the times quoted, this could not have been the case with this particular pilot.'

Aircraft had been beaten to the punch by a more sensational rival, The Air-Log. In its September edition Air-Log had already reported the opinions of unnamed Dutch captains that they considered themselves 'capable of all the answers' on the Lockheed 14 only after 400 hours: 'it amounts almost to criminal negligence for Authority to allow a comparative tyro in the handling of such craft to fly them without an expert supervisor aboard and in the second dickey[seat]'. It was not publicly known that the Director-General of Civil Aviation had provided information for the Inquest that a civil pilot of a large commercial aircraft is required by company regulations to have 3000 hours flying experience and 200 hours as second officer in the type of aircraft before being allowed to take charge as first pilot'. Air-Log took the opportunity to remind readers that, a year earlier, it had championed the invention of a Sydney man, Clive Murray-Waller, the C. M. W. Stall Indicator. 'A stall indicator would probably have saved all', but the device had been rejected by the Air Board as unnecessary. A month later, referring to Lowe's report - 'quiet judicial verbiage almost soft-pedalling in spots' - handed to federal Cabinet on October 9, Air-Log returned to the C. M. W. Stall Indicator. The Air Minister should, they suggested, convene a meeting of technical experts to provide full disclosure of the Air Board's actions. ${ }^{11}$

The Minister had some questions of his own. Artie Fadden had noticed in particular the three 'riders' to Justice Lowe's findings. On October 11, in formally transmitting a copy of Lowe's report and evidence together with the report of the Inspector of Air Accidents, to the Chief of the Air Staff via the Secretary of the Air Board, he asked for comments on Lowe's observations. What action was proposed to be taken about them? Apparently no-one had thought to inform Fadden of the 'Informative Circular' or of other action in train to issue amplified instruction on stalling and recovery for pilots undergoing conversion to Hudsons. Someone did, however, think to leak the Minister's minute to the Herald, where it was reproduced, to the Chief of the Air Staff's gall, 'practically verbatim' ${ }^{12}$

11 Aircraft,19 (2), Nov. 1940, pp.26, 38; NAA: A6079, MO 625; The Air-Log, 2 (6) Sept. 1940, p.7; 2 (7) Oct. 1940, p.5.

12 Report of Staff Conference No. 55, 15 Oct. 1940, NAA: AA1977/635. 
Advice reached the Air Member for Personnel for submission to the CAS, Secretary, and Minister for Air on October 25. Evidently Fadden had touched the nerve Lowe had exposed:

With regard to pilots having the widest possible background of experience before being converted to Hudsons, it is desired to point out that this has always been given careful attention. All pilots who were formerly employed in Civil Aviation on modern multi-engined types of aircraft have, where the exigencies of the Service permit, been employed on aircraft such as the Lockheed Hudson. The problem has been to make the best use of all the pilots available with due regard to the many commitments which the Service now has to face. All Service pilots are now gaining experience at a very rapid rate and special efforts are being made to shield as many operational units as possible from posting action consequent upon the formation of new training schools.

In what was tantamount to an admission that there had been serious shortcomings in the training and posting of Hudson pilots, the briefing disclosed that a 'highly qualified pilot who has had a great deal of experience in modern multi-engined type aircraft has now been appointed to visit all Hudson Units in turn to check the flying of pilots engaged on this type, and to report to this Head-Quarters concerning each individual'. It was intended that this unnamed officer would continue to supervise Hudson flying 'until the Squadron Leaders and the Flight Commanders and all...' The next page of the document is missing from the file. But a handwritten note in the margin identifies the unnamed 'highly qualified

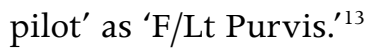

The advice to the Minister was more important for what it apparently did not say than for what it did. Flight Lieutenant Harry Purvis's story epitomised much of what was wrong with the RAAF as it stutteringly came to terms with the massive expansion that wartime demanded. Purvis, born in 1909, was a ticketed mechanical engineer who had been a barnstorming pilot and mechanic with Kingsford-Smith in the early 1930s. He had done geophysical survey work in Western Australia and Queensland in the Southern Cross, operated aerial services in western New South Wales, flown with Cliff Carpenter's Flying Circus, captained Airlines of Australia airmail flights between Sydney, Brisbane, and Cairns, and flown regular passenger services between Sydney and Melbourne, Adelaide and Darwin. Most relevantly, he had been hired by Royal Netherlands Indies Airways (KNILM) in 1939 and trained to their exacting standards to fly the airline's Lockheed 14s. During a year's leave from ANA, he flew the Lockheed 14s regularly from the Dutch East Indies to Darwin and then to Sydney.

13 NAA: A705, 32/10/2729/7. 
The absence of Purvis's name in the briefing note, or of any reference to his experience with the Dutch airline, might be explained as bureaucratic economy of words. Or perhaps it might have been thought that, as far as the Minister was concerned, the identity of the officer and his background were unimportant details. But such was the speculation and questioning of the RAAF's training regime, the Air Board could well have been tempted to preserve Purvis's anonymity. They would not be enthusiastic about an inquisitive minister getting too close to him. The man anointed as the expert best able to remedy detectable deficiencies in every Hudson pilot's capability could reveal some uncomfortable truths. There was a chance that Artie Fadden actually knew Purvis, once an outsider but now inside the Service fold. His departure with Keith Virtue to join KNILM in 1939 had been deplored by the press as 'a sad reflection on the Commonwealth's air development'. If the Minister had occasion to talk to the 'crack pilot' now charged with checking every Hudson pilot in the country, what would he discover?

Harry Purvis had returned to Australia immediately on hearing of the outbreak of war. When he reported to the RAAF Director of Recruiting, Harry Cobby, he learned of the order for 100 Hudsons, the military version of the Lockheed 14s he had been flying. Cobby told him he would be called when he was needed. Six months elapsed. Purvis knew that there was 'reserve and resentment felt by the upper-ranking RAAF officers who had to be converted by civil airline pilots to modern types of aircraft, like the DC-3s (wartime Dakotas) and the Lockheed Hudsons that were just arriving'. But when the Hudsons started to be assembled the RAAF had no choice. In March 1940 Purvis was one of six former civilian pilots called to Richmond. No-one in the RAAF had comparable experience of the new generation of aircraft with variable pitch propellers, super-charged engines, retractable undercarriages, and flaps. With Pat Hall, Alec Barlow and Harold Cook from ANA, Jack Ryland, and Dallas Scott from Guinea Airways, he joined Squadron Leader R. H. 'Bertie' Simms in the team that was to lead the conversions. Each was posted to a different squadron. They put on a display over Sydney and Richmond, and four of them flew to Perth and back in 11 hours 15 minutes, the longest one-day flight in Australia, to demonstrate the value of the new machines.

Purvis was then despatched to Darwin where Bob Hitchcock's former CO, 'Moth' Eaton, had two squadrons under his command. There he trained seven enthusiastic young flying officers and pilot officers before moving on to Perth, where he had a frightening take-off with an inexperienced pilot who stalled at 800 feet:

I was appalled to find myself an unwilling passenger in a pre-dawn take-off...in a Lockheed not equipped with dual controls, with a young pilot... whom I knew could not handle the aircraft under the conditions. 
I'd expressed doubts as to his experience to his squadron commander but was told I was no longer an airline captain, merely a flight lieutenant in the Air Force and must accept decisions.

With a 'very high ranking naval officer' among a full passenger load, an anxious Purvis positioned himself behind the pilot. It was fortunate that he did. As the aircraft plummeted towards the ground he stretched over the pilot's shoulder, seized the control column, and pulled out of the dive just as they clipped the top of a gum tree. So serious a breach of regulations was Purvis's action that he was close to being formally censured for presuming to wrest command from the pilot.

Purvis's difficulties did not end there. As the 'highly qualified' pilot now designated Chief Instructor for Hudsons, he was based at the Central Flying School at Camden with a roving commission covering every squadron:

With memories of the Perth incident and the Canberra disaster still fresh, I drew up and sent to all squadron commanders a syllabus which included blind take-offs, asymmetric (single-engine) flying immediately after take-off, and a general tightening up of training methods. I finally managed to push it through against tremendous resistance. ${ }^{14}$

The RAAF was fortunate in Purvis - 'a solid kind of man whose adrenalin flowed quietly', as one contemporary remembered him. ${ }^{15}$ Things gradually got better as the men whom Purvis, and others like Ryland and Garrett, had trained began to pass on what they knew. Garrett himself was checked by Purvis three weeks after the crash. ${ }^{16}$ Among those who gracefully accepted instruction from Purvis on asymmetric flying was the Qantas pioneer Scotty Allan, who years later was to recall the Hudson's 'tricky qualities'. A particular concern Allan remembered was the general lack of confidence in flying Hudsons after dark. 'A Lockheed pilot was stationed at Richmond N. S. W. and he would not fly it at night.' ${ }^{17}$ Nor at first would Harry Purvis or the brilliant Pat Hall, wisely in Hall's case as it turned out that he was colour blind and had to be restricted to daytime flying. It is notable that Garrett's certification as a first pilot for night flying of Hudsons took effect from the time of the check with Purvis. As the months passed, Purvis himself revisited pilots he had checked. 'Tich' McFarlane, rereading his log book years later, was struck by the number of times that Purvis took him up. McFarlane had originally done 10 hours dual on the Hudson, and he had the 'genius' Pat Hall with him at Richmond. Notwithstanding these

14 Purvis with Priest, Outback Airman, pp.94-101.

15 Balfe, War Without Glory, p.203.

16 Garrett's Flying Log Book, 5 Sept. 1940, Garrett MSS.

17 G. U. Allan to $\mathrm{CH}, 24$ June 1982. A decade after his correspondence with me, Allan evidently told his autobiographical collaborator that the Hudson 'didn't have any tricks' (G. U. Allan with Elizabeth Shearman, Scotty Allan: Australia's Flying Scotsman, Clarion, Balmain, 1992, p.131). 
advantages, he saw Purvis at three-monthly intervals in the year or so he was with No. 6 Squadron. It was evidence, he thought, of the concern and care then being taken by the Service. ${ }^{18}$

The care and concern were warranted. It was not just the Canberra accident that led to it. The unexplained loss at sea of Hudson A16-27, the day before A16-97 went down, had prompted a search to pinpoint administrative failings and people to blame. George Jones had lit the fuse in qualifying the Court of Inquiry's finding that the loss could not be attributed to any 'person or persons now living'. The inquiry, the Director of Training said, had revealed a 'lack of supervision and control' by both the squadron and station commanders at Archerfield. Director of Personal Services Joe Hewitt concurred. DCAS Bill Bostock summarised: 'direct disobedience of orders' (the aircraft was sent over the sea without life jackets for the crew); grave negligence (the aircraft was not equipped with a rubber inflatable boat); unauthorised carriage of supernumerary crew; and lack of initiative by the squadron and base commander when the aircraft was overdue and known to have wireless telegraphy failure. There could of course be no evidence of structural defect or mechanical malfunction. Nor was there any evidence to support the widespread conviction that the accident had been caused by the flap lever being inadvertently knocked into the down position while the aircraft was flying at high speed. As the Service Court drily concluded: 'many of the people who hold this theory do not know exactly where the flap lever is situated in a Hudson, and very few have ever operated it'. Should a guard be erected over the flap lever to prevent this kind of accident? No, they said: 'since modern aircraft, being an inherently complicated and delicate mechanism, must be treated as such, and no amount of fool-proofing can counteract the effects of carelessness or lack of experience' ${ }^{19}$

In the aftermath of A16-97's crash, however, there were further technical matters to be resolved. Rider 3 of the Air Force Court of Inquiry's findings had drawn attention to the method of attaching end fittings to cables. 'Del' Wilson had vigorously pursued the suspicion that the cable controlling the flaps might pull out of its fitting. Ernie Hey had valiantly sought to provide advice. The public had learned that secret evidence had been taken on this point. This was the Director of Technical Services' domain. Group Captain E. C. Wackett had been in North America at the time of the crash on a special assignment to assess what possible equipment of value to the RAAF could be secured as a result of the collapse of France. He returned to Melbourne at the end of September:

18 A. B. McFarlane, interviews, 18, 21 April 1978; Balfe, War Without Glory, pp.207-8 for Pat Hall's briefing No. 36 Squadron in Dec. 1942 to watch out for a power-on stall that 'put Bob Hitchcock in at Canberra'.

19 'Proceedings Court of Inquiry Hudson A16-27 Lost at Sea August 12th 1940' and related minutes, NAA: A705, 32/10/2830. 
The possibility of one flap retracting and the other remaining down, has been examined by the Director of Technical Services who reports that the method of swaging the end fitting to the cable has been carefully investigated by the Air Ministry and approved for the Hudson. It appears that after extensive tests, the method was found to be satisfactory under all conditions, and that in no instance could the cable be made to pull out of the fitting. As the only way in which the flaps could operate independently would be through a cable breaking, it was considered by the officers who investigated the accident that failure in this respect was most improbable.

By the time the response was prepared and approved there was a coalition government in prospect, and another new Minister for Air. Jack McEwen took up his new duties on October 28. The accident file was one of the first to reach his desk. His 'Seen $\mathrm{JMcE}^{\prime}$ was the prudent annotation of a man too canny to indicate he was actually satisfied with what he had read. ${ }^{20}$ The ambitious McEwen was not a minister to be trifled with. Seven weeks later, infuriated at learning of a sequence of events from the press, he demanded from the Chief of the Air Staff an assurance that 'proper provision be made, and effect given to it, for informing me promptly and officially of any serious incidents or operational activities of the R.A.A.F. of an important character'. It had not improved McEwen's temper to be told by the head of the Parliament House switchboard, after a long delay in contacting Air Commodore Anderson, that it was an experience stretching back to Mr Fairbairn's day for it to take as long as an hour to raise Area Headquarters, Sydney'. ${ }^{21}$

\section{Training challenges}

Sturdily constructed, with reliable engines, as David Colquhoun would attest, the Hudson was, 'when one became used to it, a delight to fly'. The trick was to stay alive long enough to become used to it. Bland reports by the Deputy Chief

\footnotetext{
20 Minute by GpCpt. E. C. Wackett, 17 Oct 1940: WCdr L. R. S. Freestone to D.T., 24 Oct. 1940, forwarded by A/g DCAS Bladin to CAS Burnett, thence to Minister, 1 Nov. 1940, NAA: A705, 32/10/1729/5-7; On 30 Nov. 1940 Wackett issued Hudson Instruction No. 10 advising that the efficiency of the swaged ends of the control cables had been investigated and that the blob of solder on the cables that had pre-occupied the Lowe inquiry was to be ignored as an indicator of movement (NAA: A705, 150/4/948); AVM E. C. Wackett to CH, 3 Oct. 1977.

21 NAA: A1196, 60/501/38; AA1977/635. Installation of four additional automatic telephone lines in May had ameliorated delays in the Century Building exchange. But that did nothing to solve the problem of unanswered telephones or the barely credible arrangements at Air Force HQ thrown into relief by a duty staff officer's plaintive comment in Feb. 1940: 'It is pointed out that an up to date list of addresses \& telephone numbers of officers on the staff of Air Force HQ might reasonably be supplied to Duty Staff Officers.' Six weeks later, nothing had been done (NAA: A705, 87/4/813). Eric Windsor, the senior Essendon Air Radio technician, complained to a Court of Inquiry in June 1940 of 'considerable difficulty' always experienced in telephoning Pt Cook and Laverton because of the lines being 'engaged' (NAA: A11094, 72/1/44).
} 
of the Air Staff to the War Cabinet at the end of August 1940 conveyed truthfully that three Hudsons had been written off and three were under repair. But in what appears to have been a breathtakingly risky half-truth Bostock reportedly advised that instruction of pilots for the flying of Lockheed Hudson aircraft was in the hands of civil instructors, who were fully experienced in flying this type of aircraft'. Hard as it might have been for Bostock to admit that the RAAF needed civilian help, it at least displaced some of the responsibility for any training shortcomings. ${ }^{22}$ The shortage of experienced Hudson pilots was not going to be solved in a hurry. The Court of Inquiry into the loss at sea of A16-27 the day before A16-97 crashed would lament that the squadron commander at Archerfield had not undergone a Hudson conversion and was not in a position to exercise any technical supervision over the handling of the aircraft by his junior officers. Moreover, as Squadron Leader Stuart Campbell and his inquiry associates reminded their superiors:

The Press are continually comparing the ability of Service and Air Line pilots, mostly in terms unfavourable to the former. Though their criticisms are frequently of a somewhat hysterical nature, there is one factor usually overlooked, which, if realised, would lend considerable weight to their arguments. This factor is that there is no Commercial Operating Company in the world that would employ, as Captain of a Lockheed Hudson 14, a pilot with only 500 hours flying experience.

George Jones would respond ruefully late in January 1941: 'It has not been possible to select pilots with a minimum of 500 hours' flying before conversion to Hudson aircraft. ${ }^{23}$ Hudsons continued to populate the flying accident tables. ${ }^{24}$ On 7 September 1940, a Hudson from Darwin piloted by Bob Hitchcock's No. 2 Squadron contemporary Jack Sharp, now with No. 13 Squadron, crashed while taking off from Broome aerodrome. The aircraft caught fire and all but the starboard mainplane and tail unit was destroyed. The crew were uninjured. But Sharp was blamed for losing control and was called on to contribute $£ 10$ towards the cost of the loss. 'Inexperience and poor technique' explained why Pilot Officer Graham Gibson of No. 21 Squadron flew heavily into the ground while attempting to land after his first solo on September 19. ${ }^{25}$ An error of judgment by Flight Lieutenant H. A. (Bob) Nicholas accounted for the damage done to A16-10 of No. 13 Squadron at Darwin on New Year's Eve 1940 when it bounced on landing, tipped on its nose, hit the ground and turned through 180 degrees after the starboard wing stalled when the engine power was put on. ${ }^{26}$

\footnotetext{
2 War Cabinet Notes, vol. 2, 28 Aug 1940, NAA: A5954, 729/2; War Cabinet Minutes, 28 Aug. 1940, NAA: A2673. NAA: A705, 32/10/2830.

NAA: A9845, 134,135.

25 'Flying Accidents Analysis of 1940', NAA: A705, 12/10/2478. Gibson, employed as a second pilot until he had more experience, was killed in action in New Britain in Feb. 1942.

26 'Summary of Air Accidents Dec. 1940', NAA: A705, 32/10/3110.
} 
Overseas crashes were also noticed. Six months after the Canberra disaster, an hour after leaving Gander in Newfoundland en route to England, a Hudson bearing Frederick Banting, the co-discoverer of insulin, crash-landed on an icecovered lake. The pilot and Banting survived the crash but Banting died shortly after. He had been on the way to the UK to undertake research on how airmen could best cope with faster and higher flight. ${ }^{27}$ As late as December 1944 there were echoes of the Canberra disaster when eight men died as Al6-68 crashed on landing approach at Richmond. ${ }^{28}$

Meanwhile, the Weekly Report of the Chief of the Air Staff carried summary notes on 'aircraft casualties'. As experience was gathered, additional advice was forthcoming. At the beginning of October 1940 the Air Board disseminated information on flap settings. It had been established that 'although the Lockheed Hudson aircraft is controllable on sudden application of engines, after a bad landing with up to $90 \%$ of flap, there is a considerable nose down change of trim'. It was admitted that at 100 per cent flap setting the pitching moment 'under certain circumstances may become uncontrollable'. The best results were to be obtained with 70 per cent flap setting. This was to be adopted as standard practice. (The RAF had already introduced rubber stop blocks on the guide rail that limited flap travel to 70 per cent. $)^{29}$ During Hudson conversion courses, however, pilots were to be given experience with higher flap settings up to 100 per cent. Such settings might be applicable in an emergency.

What the Hudson required, David Colquhoun later contended, was 'concentration and quick reaction, particularly on take-off when due to its short fuselage a swing could be induced easily'. Colquhoun had heard that the Americans in the Alaskan theatre had lost so many aircraft that they refused to fly them. That was, he believed, one of the reasons why they became available to Australia. ${ }^{30}$ This was a rumour without foundation. But it had become apparent by October 1940 that a 'violent swing' could result from the application of full rudder when brakes were being used during take-off. It was common practice to apply two or three notches of brake during the first part of take-off. The practice was now to be discontinued. What had been observed was that a pilot's head would move when he let off the brake; his attention would be diverted from steering a straight course and the aircraft would be liable to swing. No such problem would normally be expected even in conditions of moderate cross-wind. ${ }^{31}$

\footnotetext{
27 Sholto Watt, I'll Take the High Road: A History of the Beginning of the Atlantic Air Ferry in Wartime, Brunswick Press, Fredericton, 1960, p.114; University of Toronto Magazine, XXIII, 4, 1996, p.17.

28 NAA: A9845, 135. An invaluable history of all RAAF Hudsons compiled by Gordon Birkett is at www. adf-serials.com/2a16.shtml.

29 Vincent, The RAAF Hudson Story, Book One, p.298. It was noted in early 1942 that the rubber stop blocks had been installed in Mk III Hudsons (Vincent, The RAAF Hudson Story, Book Two, p.250).

30 ACdre D. W. Colquhoun to CH, 7 June 1978.

31 ABO N611, 4 Oct. 1940, NAA: AA 1977/635.
} 
Almost all of those who flew Hudsons in 1940 were to recall its troublesome characteristics. Claude Browne was in one of the first groups to fly them. 'They arrived,' he remembered, 'in crates at RAAF Richmond... when I was completing my intermediate course there.' The machines were assembled, flight tested and put into squadron service as soon as 'the then more senior pilots were converted onto them'. Posted to No. 8 Squadron in Canberra, Browne was soon at the controls as a second pilot. Eventually as captain, then as an instructor at No. 1 Operational Training Unit at Bairnsdale and East Sale, he accumulated some 4000 hours on the type. He added to his wartime experience the perspective gained in the mid-1950s as head of the Directorate of Flying Safety: 'Even although only the more/most experienced pilots were posted to convert onto them, the Hudson represented a big step up from its predecessor (the Anson) which was under powered and viceless as regards its handling characteristics.'

The problem with the Hudson, as Browne saw it, was that it had a relatively high wing loading; its handling under asymmetric flight conditions (i.e. with one engine failed) was subject to critical limits. Also, 'it had a rather vicious re-action if stalled under certain conditions of power, load and wheels/flaps up/ down configurations; it could, depending on the circumstances, flick onto its back, or suddenly drop a wing or assume a steep nose down attitude. ${ }^{32}$

What Spud Spurgeon, a Laverton contemporary of Hitchcock's, who went on to No. 8 Squadron in Malaya, was to call 'unpleasant recovery characteristics at low speeds' were widely experienced. ${ }^{33}$ One of those at No. 2 Squadron who took very seriously the injunction about having a fair margin above stalling speed was Neville Hemsworth, a former commercial pilot. David Campbell, who testified that he owed his life to Hemsworth's example of careful flying, nevertheless recalled how he rued being sent into the nose at every landing when Hemsworth was captain. There was a second air-speed indicator in the navigator's perch which could be checked against the one in the cockpit. Campbell was reluctant to inflict this boring and uncomfortable task on others, and did not do so on his own second pilots. ${ }^{34}$

While the challenges of the aeroplane itself were well established, there were other factors at work. Scotty Allan acknowledged a generational problem:

The suggestion that W. W. I. and pilots of the 1920's had difficulty in handling aircraft of the late 1930's is illustrated by Pan American whose system of promotion was based on length of service. Old pilots insisted

32 GpCpt. C. D. Browne to CH, 15 May 1978.

33 ACdre C. H. Spurgeon, telephone interview, 16 Nov. 1982.

34 David Campbell, interview, 24 May 1978. 
on their rights to fly the new aircraft with dire results. There were of course exceptions, but many pilots were quite unable to apply new techniques or even to recognise that new techniques were necessary. ${ }^{35}$

'By a strange turn of events,' Harry Purvis was to write, 'I found myself having to check my old instructor, Scotty Allan, on asymmetric flying. He quickly put me at my ease and also indicated he approved the tighter training.' With 9591 hours prior to enlisting on 4 September 1940, Allan had nothing to prove. ${ }^{36}$ Whatever the understanding or potential ability of individual pilots, it would not necessarily compensate for insufficient and inadequate training. Flying a Hudson was similar in many respects to flying an Anson, except in the 'full flap' 'power on' condition. As Air Commodore Derek Cuming, later to be the RAAF's Chief Test Pilot and, in Sir Fred Scherger's view, one of the six best pilots in the world, recalled: 'In this condition of flight the aircraft could give a sharp wing drop at the stall and unless immediate correction was made it could roll nearly inverted.' The prospect of this happening 'did frighten some pilots'. And at less than 1000 feet a crash would be inevitable.

'It must be borne in mind,' Air Commodore Cuming cautioned in retrospect, 'that in 1940, with the exception of a few, most pilots were very inexperienced in flying by the time they were put in charge of an aircraft such as the Hudson.' In his own case, his total flying experience was 182 hours as pilot in charge and 250 hours as second pilot or navigator in various types of aircraft. Cuming, who had been posted to No. 2 Squadron for three weeks in June/July 1940, acknowledged that he had the advantage of instruction from Sam Balmer and Harry Purvis while flying with No. 13 Squadron in Darwin. ${ }^{37}$ Not everyone had been so lucky. As 'Spud' Spurgeon put it, the practice of making flight commanders responsible for supervising the conversion of their own pilots was 'hazardous'. With few exceptions in August 1940 'real instructors did not then exist'. When he was posted to Singapore the week before the Canberra disaster his first pilot had 20 hours in the Hudson; he, as second pilot, had nine and a half hours. ${ }^{38}$ The situation was not greatly improved four months later when the Training Directorate pronounced after another (non-fatal) Hudson landing accident that: 'Conversion courses should always be given by the most experienced pilot available, if necessary by the Squadron Commander himself, particularly in the case of Hudson aircraft. ${ }^{39}$

35 G. U. Allan to $\mathrm{CH}, 24$ Nov. 1982,

36 Allan with Shearman, Scotty Allan, pp.130-2.

37 ACdre D. R. Cuming to CH, 17 April 1978; NAA: A12372, R/33012/P; ACM Sir F. Scherger, interview, 2 Sept. 1978; Vincent, The RAAF Hudson Story, Book One, p.300; Grantham, The 13 Squadron Story, for Purvis and J. R. Balmer and Al6-8 with dual controls.

38 Spurgeon, telephone interview, 16 Nov. 1982.

39 'Flying Accidents Analysis of 1940', NAA: A705, 12/10/2478. 
Sir Norman Brearley, for whom Hitchcock's father had worked, made no secret of what he thought of RAAF pilots. In 1940 he was commanding No. 5 Flying Training School: 'My main reaction to the Hudson air crash was in the report of the enquiry. This stated that the pilot was an average R.A.A.F. pilot. To me this meant that he was much below the standard that I would employ.' ${ }^{40}$

There is no doubt that the pressure to produce pilots placed unprecedented strain on the capacity of the RAAF. In May 1940 a large percentage increase in forced landings was attributed to lack of close supervision by flight and squadron commanders. Incomplete knowledge of the engine characteristics of particular types was one cause. The Director of Training was charged with reviewing syllabuses and recommending limits on the range of aerobatics to be taught and practised. ${ }^{41}$ The stretching sinews of the training establishment were exposed in a sequence of confidential orders in the months after the Canberra disaster. Less than four weeks had passed when a pilot and two pupils were killed in the crash of an Anson near Wagga. It was determined that the aircraft had become uncontrollable and broken up in a vertical dive after the instructor had indulged in a display of aerobatics, half-rolls, which he had promised to execute before going up. The pilot had ignored repeated warnings about overconfidence, 'and his sense of discipline was not sufficiently developed to prevent a serious breach of orders'. The official reaction was a departure from the usual impersonal tone of the confidential orders:

The bad effect on the Service due to loss of life and loss of aircraft which arose directly out of these shortcomings need not be stressed. A daring spirit is entirely commendable provided it is used in action against the enemy, but it must be accompanied by sufficient commonsense, loyalty to the Service and discipline generally to prevent such a waste of the limited resources available to the Service. ${ }^{42}$

There was sensitivity about the extent to which the 'daring spirit' might be insufficiently tempered by discipline in individual squadrons. There was an echo here of the reaction to the Ellington report in 1938. 'I can remember numerous occasions,' the gallant AFC pilot and VC winner Frank McNamara had told Dicky Williams, 'when many of us used to wonder whether we were sometimes not too severe in punishing some of these high-spirited lads by sending them up for court-martial, fining them a proportion of the cost of damage to aircraft, etc. ${ }^{43}$ Others might fairly have wondered whether there was not too much chummy tolerance of poor technique and ill-disciplined bravado. The fact was

\footnotetext{
40 Sir Norman Brearley to $\mathrm{CH}, 30$ March 1982.

41 Chief of Air Staff Conference No. 35, 21 May 1940, NAA: AA1977/635.

42 'Flying Discipline', A.F.C.O. 77/40 NAA: A7674, 1/118.

43 GpCpt. F. H McNamara to AVM R. Williams, 7 Oct. 1938, Williams to McNamara, 26 Oct. 1938, copy, Williams MSS, RAAF Museum.
} 
that 'over-keenness' to show 'daring and/or efficiency' was endemic; even when an injunction to improve flying discipline was being circulated in May 1940 it was acknowledged by 'Mucker' Anderson that 'this spirit has its value'. ${ }^{44}$

\section{The necessary data}

On 10 September 1940, Sir Charles Burnett told the War Cabinet that he would 'shortly submit statistics showing the comparison of the ratio of casualties... since the war with the pre-war period'. This apparently spontaneous offer caught his principal subordinate unawares. 'Have you the nec ${ }^{\mathrm{y}}$. data for this?' the Deputy Chief of the Air Staff asked the Director of Training before remembering that protocol dictated the request should go via George Jones's superior, the Air Member for Personnel. As it happened, at the CAS's direct request, 25-year-old Squadron Leader Joshua McDonald in Jones's directorate had prepared a day earlier a 'summary of fatal accidents' - 14 fatal accidents, with 40 people killed in the previous six months. There was also a table for the same period showing the number of fatal and non-fatal accidents per hours flown by each aircraft type. The numbers suggested that the Hudson was the most likely aircraft to be involved in fatal accidents and the least likely to be in non-fatal accidents. But no attempt was made to assess the meaning or significance of the data. ${ }^{45}$

The War Cabinet continued to gnaw at the accident rate. The CAS told them - not for the first time - about his Inspector of Air Accidents, appointed before the Canberra crash, and the legal officer to assist 'in the interrogation of the persons concerned and witnesses'. Trainees were not being pushed on too quickly in their preliminary training, Burnett said. The 'fullest possible use' was being made of efficient civil pilots. The trouble was that the accidents were occurring at the stage in the trainees' careers when they had 'commenced to gain that degree of experience which easily led to over-confidence'. Fines were being imposed in cases of negligence. ${ }^{46}$

The more comprehensive information sought by Burnett was provided on October 10. In the 12 months before the war, there had been 39672 hours flown and four 'fatal accidents'. In 'non-fatal' accidents, nine aircraft had been totally lost, 20 needed more than a month to be repaired, and 83 more had suffered

\footnotetext{
44 NAA: A705, 231/8/7 Pt 1. 'Members of a club are disinclined to criticise each other professionally, and it seems probable that a causal relationship existed between that comfortable atmosphere and the RAAF's disturbing accident record' (Alan Stephens, The Royal Australian Air Force, [The Centenary History of Defence vol. II], Oxford UP, South Melbourne, 2001, p.37).

45 WCdr McDonald, newly appointed CO of No. 13 Squadron at Laha, Ambon, in Dec. 1941, stalled his Hudson at 400 feet, spun into water and was killed (NAA: A9300, McDONALD JR; Johnston, Whispering Death, pp.110-1).

46 War Cabinet Notes, vol. 2, 2 Oct. 1940, NAA: A5954, 729/2.
} 
minor damage. In the 12 months of war, 93864 hours had been flown; there were 11 fatal accidents. Twenty aircraft were lost in non-fatal accidents, 36 were out of action for more than a month, and another 274 made serviceable within a month. The tabulated data were in due course submitted to the War Cabinet over the signature of R. G. Menzies in his capacity as Minister for Defence Coordination. ${ }^{47}$

No doubt to the relief of RAAF headquarters the information compiled by Jones's staff was simply noted by ministers. No-one seems to have noticed or been concerned that the figures of 'casualties' provided to ministers were of aircraft in which men were killed rather than the number of fatalities. But the whole subject of accidents and casualties would continue to be sensitive. Nerves were exposed in an extraordinary eruption of paper warfare in the Air Board in November 1940. It began as what purported to be a reduction of unnecessary reporting of minor accidents. From the beginning of November it was proposed that the customary signal and forwarding of form E/E 24 should only be continued for 'major accidents'. The new policy defined major accidents as any that involved injury, breaches of flying discipline, or carelessness. It also included any occasion when the aircraft could not be made serviceable within four days. An incident that did not meet these criteria could be included in a monthly return to be collated for statistical analysis.

When he saw the minute accompanying the suggested order, the DCAS Bill Bostock immediately picked the flaw. Reports were in effect to be censored before they had been seen by the Inspectorate of Air Accidents. But, as Bostock well understood, one of the most important functions of the IAA was to inform the Chief of the Air Staff, by personal investigation, of the state of flying discipline and maintenance at units in which accidents occurred. An accident might have a negligible outcome but still be symptomatic of a serious problem. The existing system should continue, he concluded. Risking the wrath of his superiors, the Director of Training, George Jones, replied that commanding officers must be considered reliable to decide what was a minor accident. Bostock smartly pushed the issue up to the CAS. He could be confident of the Chief's response. 'I am afraid,' Charles Burnett noted:

that the ability of officers commanding units is in doubt in some cases, and we cannot afford to lessen up, in any way, the supervision.

Over the last two months the average over the months is one accident a day, and I do not think that will congest our lines of communication. I therefore wish that the old order should stand for the present. ${ }^{48}$

47 War Cabinet Minutes, 10 Sept. 1940, NAA: A2673, 359; NAA A1196, 37/501/14; Sec., Dept of Defence Co-ordination to Sec., Dept of Air, secret, 4 Oct. 1940, NAA: A705, 231/8/7 Pt 1.

48 'Reporting of Flying Accidents AFO's 10/D/21 and 18/E/1', NAA: A705, 32/10/2240. 


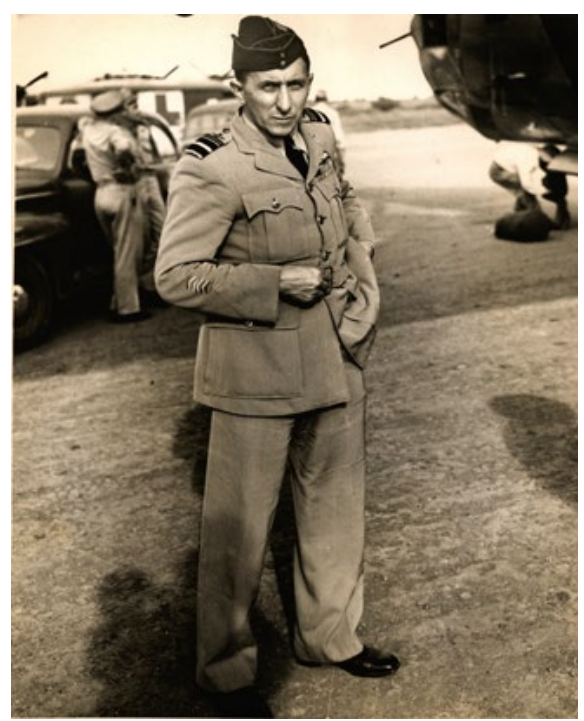

George Jones: always looking for ways of reducing the accident rate (Courtesy of the RAAF Museum)

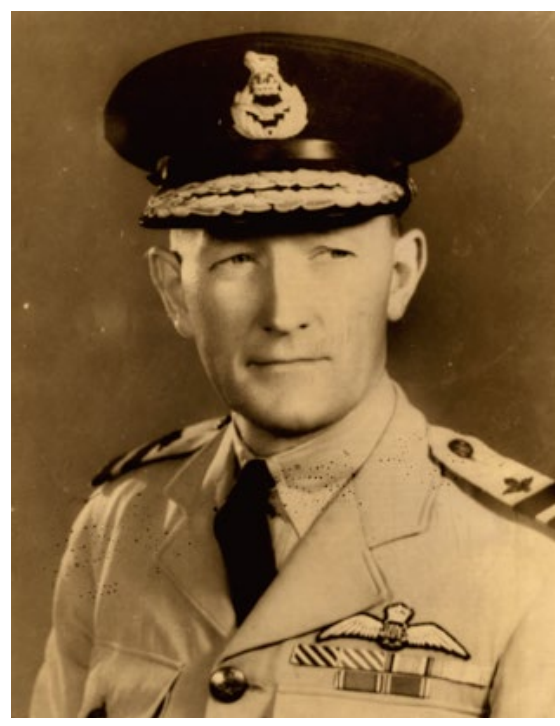

Harry Wrigley: urged the 'elimination of reckless pilots and pupils' (Courtesy of the RAAF Museum)

Burnett was struggling to construct a coherent policy. No sooner had he called into question the ability of some unit commanders, he was insisting in December that squadron commanders were immediately to review the flying ability of all pilots under their command. Below-average pilots were to be given every opportunity to gain flying experience 'preferably with the minimum crew compatible with the duty to be carried out, under the strict supervision 
of the flight commander'. For new pilots special attention was to be given to supervising their conversion course; they should have 'ample solo flying experience before carrying a $\mathrm{crew}^{\prime}{ }^{49}$

Trying to prevent accidents by inexperienced pilots was only a partial solution. Men who should have known better were also a big part of the problem. So worrisome were ongoing breaches of flying discipline that stringent action was demanded. The number of accidents attributed to 'flying indiscipline' had reached such proportions early in 1941 that the CAS conferred with Bostock, Murphy, Knight, Winneke, and Reg Leonard - the Air Member for Personnel and the Director of Training being noteworthy absentees — on means of preventing breaches. A confidential order followed, calling for increased severity of sentences in 'flagrant cases'; 'punishment must be deterrent, as well as corrective'. 'It must be borne in mind,' the new AMP Harry Wrigley wrote, 'that, although there is a shortage of pilots, the efficiency of the Service may be increased by the elimination of reckless pilots and pupils who endanger the lives of themselves and others and hazard the safety of their aircraft.'

Paddy Heffernan, enjoined by George Jones 'to take any measures to keep the accident rate down' at the newly opened No. 4 Service Flying Training School, instituted his own draconian punishment: wrongdoers in Geraldton, careless or disobedient, would be fined 14 days' pay. But this was local practice not a Service policy. For court-martial offences, it was decided to publish the charge and sentence. Publicising the fate of miscreants would serve the additional purpose, valuable to both the higher command and the government, of deflecting perceptions that the fault lay in the equipment or the training regime. ${ }^{50}$

Official anxiety about public perceptions was matched by a growing realisation that pupil pilots themselves were arriving at Service Flying Training Schools 'impressed with the idea that certain types of Service aircraft are difficult and dangerous to fly'. The Hudson was implied but not named. What had emerged was that these impressions emanated from instructors at the Elementary Flying Schools, 'invariably' men who had never flown the types they were talking about. The 'misleading and inaccurate statements' were lowering morale and detrimentally affecting pupils' flying. Commanding officers were enjoined to put a stop to dissemination of false information by personnel in their units. And, doubtless in the hope that their efforts would not actually foster the fear they were meant to diminish, the order was to be brought to the notice of squadron and flight commanders 'but not to personnel holding lesser appointments' ${ }^{51}$

49 'Prevention of Flying Accidents by Inexperienced Pilots', A.B.O. N.817, 6 Dec. 1940, NAA: A705, 32/10/2943, in A705, 231/8/7/ Pt 1.

50 P. G. Heffernan in Stand-To, Oct-Dec. 1966; A.F.C.O. 4,5,/41, NAA: A7674, 1/170-1, 209; A705, 231/8/7 Pt 1.

51 'Adverse Criticism of Service Aircraft', A.F.C.O., 2/41, 16 Jan. 1941, NAA: A7674, 1/206-7. 
Restriction of what was to be said outside the walls of central and area headquarters reflected another acute outbreak of blame-shifting between the Directors of Training and Technical Services. On reading the report of his Accident Inspectorate in January 1941, the Chief of the Air Staff seized on Group Captain Murphy's analysis indicating that nearly 19 per cent of accidents the previous month were attributable to 'equipment' and 'maintenance'. The number of preventable accidents is still too high, Burnett minuted. Ellis Wackett put up a provocative defence of maintenance standards. 'My general impression after going into these statistics fairly carefully,' he wrote, 'is that many of the accidents seem to be due to failure on the part of the pilot to carry out simple elementary acts such as turning on the petrol cock.'

Better instruction rather than disciplinary action, appears the only course likely to improve this position. Whilst I deprecate spreading rumours, yet I feel that I should state that I learned, with great surprise, during the last few days that certain pilots who were just about to finish their flying course (on Ansons) in their Advanced Training Squadron of a S.F.T.S. did not even know that the engine in an Anson is a Cheetah. If this indicates the amount of material information that these pilots are receiving apart from actually handling the aeroplane's controls, then it is not surprising that they fail to turn on a petrol cock as they are probably not at all clear that the aeroplane requires petrol to remain in the air.

George Jones, as Director of Training, was quick to reply that you didn't need to know the name of an engine to understand how it worked. But he acknowledged that the 58 per cent of accidents designated by the Accident Inspectorate as 'personal' and 'training' occurred through disobedience of orders or poor flying techniques.

Disciplinary action was invariably taken when pilots had transgressed. But 'poor flying technique' was, he argued, 'brought about mainly through the rate at which we are expanding'. He had been making the same point since the beginning of 1940. Instructors with very little experience were being used. Sending Central Flying School Instructors to detect weak instructors was helping to improve standards. But it was not enough: 'the more we force the pace the greater will be our accident rate'.$^{52}$

52 'Summary of Air Accidents Dec. 1940', NAA: A705, 32/10/3110. Vincent, The RAAF Hudson Story Book One, Ch. 5 summarises Hudson training to 1945. 


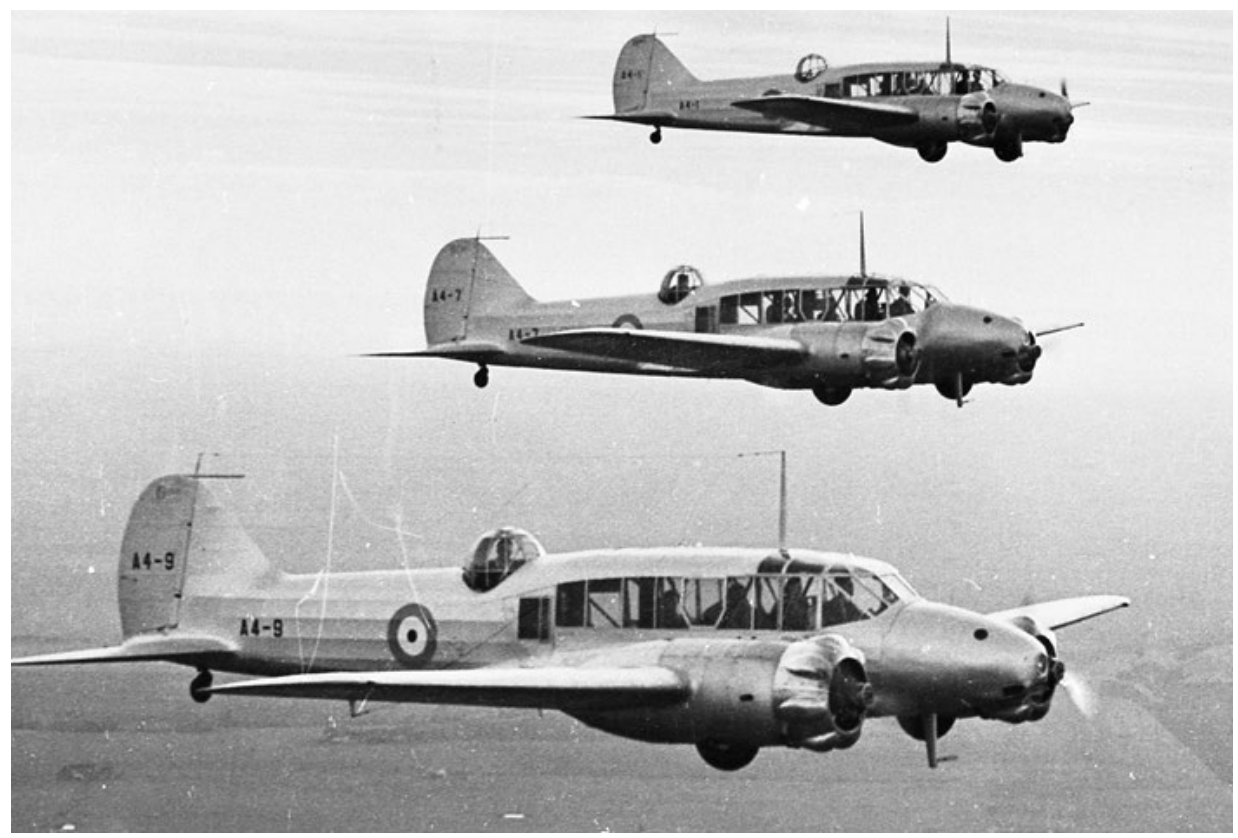

\section{Bob Hitchcock successfully flew these 3 Ansons and 14 others}

(Courtesy of Bob Livingstone)

Jones might have been right about the ineluctable rise in accidents. But it did nothing to alleviate Burnett's 'grave concern'. All detected offences should result in punishment, he insisted, 'whether resulting in injury or damage or not...I should like to feel assured that offenders have acted in full knowledge of the serious consequences likely to ensue to them, and in wilful defiance of their commanding officer, officers, and instructors.' The Chief of the Air Staff and his advisers realised that threats were not enough. They knew that they were attempting to change a culture that was deeply engrained. In addition to a letter addressed to commanding officers of all units, Burnett took it upon himself to prepare a statement for distribution throughout the Service. It was to be read to all trainees at the end of their courses at Initial Training Schools and at the beginning of their subsequent elementary and service flying courses. In all other units it was to be 'brought to the notice of all flying personnel'.

Six paragraphs of persuasion distilled Burnett's argument. First was an appeal to logic. Flying orders were the result of 'the combined wisdom of persons with years of experience in all the varied aspects of flying and common sense alone dictates that they are not to be disregarded because of the inclinations, or conceit, of some particular individual'. Then came an ethical proposition: 'No person has in time of peace, let alone in time of war, the right to kill or injure himself, much less...to cause death or injury to others.' Then shame. Other people's lives and health were entrusted to pilots: 'any pilot who betrays that trust through 
breach of orders is not fit to take his place in the pilot's seat'. Patriotism was next. A member of the Service who caused 'wanton destruction' was hindering the war effort 'just as effectively and in some cases more effectively, than the enemy agent or saboteur'. Service pride followed. It was up to everyone to ensure that the good name of the RAAF was not sullied: 'Low flying and other breaches of discipline which cause loss damage and grief to civilians must eventually lower the prestige of the Service in the eyes of the community.' Finally there was the prospect of retribution. Men had already been fined and imprisoned. They had been stopped from obtaining a commission. But flagrant breaches were still occurring. There was no alternative, Burnett concluded, but to make the punishments increasingly severe, including discharge from the Service, publicised throughout the Service and in the press. ${ }^{53}$

Evidently at their wits' end to prevent low aerobatics and unauthorised low flying, RAAF headquarters came up with another idea a couple of months later. It was issued over the signature of George Jones as Director of Training for the Air Member for Personnel. The gravity of the present national emergency, Jones announced, demanded 'every effort to conserve both aircraft and personnel'. Therefore it was proposed to introduce an honour system:

Commanding officers are to interview each of their pilots, explain the urgent necessity for conserving both themselves and their aircraft, and request each pilot individually to give his word of honour not intentionally to break any flying regulation, order or instruction.

If any pilot was not prepared to give his word, the matter was to be referred immediately to Headquarters. What Jones had not expected was that some COs might require signed undertakings rather than a quiet 'verbal assurance'. Nor that a cantankerous officer with nothing to lose might conscientiously decline. At 40, Dr Clyde Cornwall Fenton OBE, with 2600 hours in light aircraft as the celebrated pioneer of the Northern Territory Aerial Medical Service, was now a general duties flying officer at No. 3 Elementary Flying Training School. Fenton envisaged a number of occasions when the letter if not the spirit of regulations might be broken so as 'not to retard instruction unduly'. While expressing his dismay at an attitude 'unexpected in an officer of Flying Officer Fenton's standing', Jones realised that a conciliatory course was called for. $\mathrm{He}$ might have known that 10 years earlier Fenton had resigned an RAF commission over a disagreement about regulations. In a memorandum copied to Southern Area headquarters, Jones stressed that the intention had always been 'to make obedience to flying orders and regulations a personal matter between the pilots and their commanding officers and to impress on the minds of all pilots that intentional disobedience of orders is a dishonourable thing'. There would 
always be borderline cases: 'the test is the intention underlying the act...any reasonable variation of flying orders applied intelligently and in a co-operative spirit should never be regarded as evidence of the intention to break an order'. All ended well and Fenton finished the war as a squadron leader still recognised by his commanding officers as a man of fixed opinions with 'a tendency to go his own way'. ${ }^{54}$

For the wartime RAAF, flying accidents would continue to be an intractable concern. The inquiries into the crash of A16-97 had unintentionally revealed how little was yet understood about why some accidents occurred. The focus continued on trying to determine whether a pilot was at fault. In April 1941, a new system was introduced in which an entry was to be made in a pilot's log book in relation to any accident for which he was considered 'blameworthy'. The assessment would refer to (a) inexperience (b) error of judgment (c) carelessness (d) gross carelessness (e) disobedience. Entries in categories (a) and (b) would be in black ink; the others in red. There was a further taxonomy of 'accident causes' which would be classified as 'taxying', taking off, overshooting, heavy landing, faulty cockpit drill, air collision, forced landing (lost, fuel exhausted, etc.), low aerobatics, and unauthorised low flying. Even if a breach of flying discipline did not result in an accident, the same procedure would be followed in the hope of reducing accidents for which pilots were to blame - and all 'without loss of initiative or enterprise'. As it had occurred to the Air Member for Personnel that putting pilots in fear of red ink might have adverse consequences in some circumstances, the system was not to apply in cases of flights in 'operational missions'. These were omitted 'in order to foster the present high standard of self-reliance and initiative'.

Bemusing as all this might be, the AMP concluded that each pilot who had a 'clean' log book would be afforded 'a sense of pride additional to that in his own positive war service, that no fault of his has detracted from the war effort of the Nation as a whole'. Here were well-intentioned men at the pinnacle of a burgeoning organisation floundering for insight into the behaviour and motivation of thousands of new volunteer subordinates. They were overwhelmed by a sea of anonymity where just two years earlier they had known by name every pilot in their fraternity. ${ }^{55}$

54 NAA: A9300, FENTON CC; Brian Reid, 'Fenton, Clyde Cornwall (1901-1982)', Langmore (ed.), Australian Dictionary of Biography, vol.17, p.382; Neil Follett, 'Oswald Watt Medal Dr. Clyde Cornwall Fenton 1937', Aviation Heritage, vol.42, no.3 Sept. 2011, pp.107-8; N. M. Parnell, 'Trials and Tribulations in the Top End', Aviation Heritage, vol.43, no.1, March 2012, pp.30-6.

55 By 1943 a punch-card system for analysing aircraft accident data allocated percentages to fourteen categories of cause. Six related to personnel (error of judgement, poor technique, disobedience of orders, carelessness or negligence, errors of supervisory personnel, errors of other personnel); three to material (structural, power plant, and instrument failure); and five miscellaneous (weather, darkness, airport or terrain, other, obscure). Lockheed Hudson A16 [Accidents Part 3], NAA: A9845, 136. For thinking six decades later, see A Guide for the Conduct of Investigations into ADF Aviation Safety Occurrences Classed as Incidents or Serious Incidents, Dec. 2003. 


\section{Better understanding}

Harry Wrigley's endorsement of eliminating 'reckless pilots and pupils' was one solution. Something could also be done about what was going into the minds of trainee pilots. And, as George Jones would clarify a month later, pupils 'should never be punished where accidents result solely from lack of ability' ${ }^{56}$ However, no-one doubted that it would be better if candidates who might prove a danger to others as well as themselves could be screened out before they were accepted into the Service. Good pilots were a scarce resource in wartime. Interviews, references, physical requirements, and police checks would weed out some obviously unsuitable applicants. Beyond that there was some primitive science. In 1932 an attempt had been made by the RAAF to assist aircrew selection by correlating reaction times to the ability to learn to fly. It would be some years before it was realised that rapid reactions might lead to speedy execution of bad decisions.

In striving to improve the selection of men for flying training, as well as to understand what had gone wrong when crashes did occur, attention turned belatedly to research on the character, temperament, and personality of pilots. In explaining accidents, pilot error was the residual explanatory category when no mechanical fault, environmental calamity, or physical infirmity could be found. But what if it were possible reliably to identify candidates who were less likely to be successful in the air and exclude them before they became a hazard to themselves and others?

In the United States, where aviation medicine was already an expanding specialty, it was recognised, in the words of the leading authorities, that those qualities which determine the probable success or failure of a candidate for flying training have not as yet been accurately defined' ${ }^{57}$ The RAAF did not pay close attention to American developments, depending rather on liaison with the RAF for exchanges of medical officers and advice on medical matters. In Britain as well as Australia there had been an almost exclusive reliance on subjective assessments of the personal characteristics of potential recruits. The value of professional inquiry into the psychology and physiology of pilots had been neglected. Giving evidence to one of the 1939 Courts of Inquiry, Wing Commander John McCauley, CO of the cadet wing, disclosed:

56 The documents quoted in the preceding seven paragraphs are all in NAA: A705, 231/8/7 Pt 1.

57 Harry G. Armstrong, Principles and Practice of Aviation Medicine, Williams \& Wilkins Co., Baltimore, 1943 (1st ed. 1939), p.147. Armstrong p.440: 'pilot error accounts for about 50 per cent of all accidents'. 
Although trainees were selected only after personal interviews in which an effort was made to judge their ability to stand up to stress, an average of 15 to 20 trainees were found toward the end of the dual-flying stage not to have shown natural aptitude for flying.

It was his responsibility to determine whether they were up to the standard but the Air Board decided whether they were to be given further training or dismissed. ${ }^{58}$

A frustrated British authority, F. C. Bartlett, Professor of Experimental Psychology at Cambridge University, had surveyed 'Psychology and the Royal Air Force' in 1937. Speaking of the period when Bob Hitchcock was a cadet in training, Bartlett pointed out that 20 per cent of candidates for RAF shortservice commissions who passed the initial medical examination had to be rejected after a period of preliminary instruction. Steps were being taken to assess intelligence and motor co-ordination, but there were more profound problems that awaited systematic research. Having studied instructors' reports Bartlett noted that in some cases 'all the necessary capabilities are present, but something prevents them from coming into operation under certain conditions':

A man has everything necessary in the way of natural fitness and acquired skill, but when he is confronted by unusual conditions, in a moment of stress, through unusual susceptibility to fatigue, when the tempo of his reactions must be radically changed, or for a variety of other reasons, his inherent ability and skill seem to desert him. Failure of this kind may be merely incidental to a stage of training. But it may also be persistent, inescapable, a part of a man's temperament or character.

In Germany at around the same time authorities were beginning to talk about how medical officers could help in developing a better understanding of 'errors of judgment'. The Australian CAS had brought to his desk a synopsis of an article urging 'psycho-analytical treatment' of the pilot to 'throw light on his mental worries' ${ }^{59}$ The objective would be to discriminate between cases of what in everyday language might be described as a nervous breakdown and others that were better characterised as over-compensation for an inferiority complex. But, as the Psychiatric Section of the Victorian Branch of the British Medical Association observed in mid-1940, Australian authorities were giving no lead

58 The Argus, 8 June 1939. In a paper for the Institute of Engineers Aeronautical Branch in November 1932 S/Ldr Bostock said that on average about 3 per cent of applicants were considered suitable for selection for an Air Force flying course; of those selected, approximately 20 per cent were discarded during the first three months as 'unlikely to become efficient Air Force pilots' (Ellison MSS NLA MS 1882 7/215).

59 H. V. Diringshofen, 'The Special Duties of a Medical Officer Attached to a Squadron', Luftwer, 5 (8), Aug. 1938, pp.324-6, Extract from Scientific and Technical Press, Oct. 1938, Williams MSS, RAAF Museum. For the role of psychologists in German Army and RAF officer selection, see John James, The Paladins: A Social History of the RAF up to the outbreak of World War II, Macdonald, London, 1990, pp.200-2. 
to those with special knowledge of psychiatry and psychotherapy about how they might best serve. ${ }^{60}$ The psychiatric professionals might have guessed the sceptical concern expressed by Victor Hurley, the Director-General of Medical Services, to the Air Force's principal legal officer Fred Knight that psychiatrists 'would make life difficult for those trying to enforce discipline'. ${ }^{61}$

Old ways were ingrained. The president of the RAF's Central Medical Board, Group Captain Raymond Ryan, who was appointed early in 1940 to organise a medical service for the Royal Canadian Air Force, encapsulated conventional attitudes in an address to the Canadian Medical Association in June 1940:

\begin{abstract}
A hard and fast rule cannot be laid down, but those with successes in team games are preferable to those of the solitary type - the full back at rugby and hockey, or the stroke of a crew, are selected for their stability and reliability. It is not prejudice but experience which prompts the statement that the man whose only hobby is stamp-collecting or music more frequently breaks down than his more versatile brother... While a man's hobbies alone should not militate against his acceptance, one has a certain suspicion about him, as his type frequently develops an anxiety state. ${ }^{62}$
\end{abstract}

Little wonder that sharper minds would say that authorities were generally agreed that 'the pilot's nervous and emotional stability is of prime importance, while...the existing tests for its estimation are inadequate and actually misleading in some cases' ${ }^{63}$ Change was coming, slowly. In Britain Professor Bartlett had been heeded. ${ }^{64}$ From early 1940 the RAF Aviation Candidate Selection Board had begun to use a battery of 12 aptitude tests developed by the Cambridge Psychological Laboratory to assist in discriminating between potential fighter

\footnotetext{
60 H. Selby Link to the Editor, 12 June 1940, Medical Journal of Australia, I, 26, 29 June 1940, pp.912-3.

61 Knight, These Things Happened, p.344.

62 GpCpt. R. W. Ryan, 'Medical Aspects of the Air Force', Canadian Medical Association Journal, vol. 43, 1940, p.317.

63 M. R. Harrower-Erickson, 'Psychological Factors in Aviation', Canadian Medical Association Journal, vol. 44, 1941, p.350; Lt Cmdr R. Barry Bigelow, 'The Evaluation of Aptitude for Flight Training: The Rorschach Method as a Possible Aid', Journal of Aviation Medicine, vol.11, 1940, pp.202-9.

64 Bartlett argued in secret notes in late 1940 that it was time to think of flying accidents 'less as a problem of training than as one of the lapses which even the most highly trained skill [sic] are likely to suffer' (NAA: A705, 43/1/674).
} 
and bomber pilots. ${ }^{65}$ In Melbourne an RAAF Medical Training Unit had been established, and was followed near the end of 1940 by the creation of a Flying Personnel Research Committee personally chaired by the Director-General of Medical Services. However, even the limited insights into aptitude and 'defects of personality' that the committee and its network of researchers developed would come a decade too late to benefit Bob Hitchcock and his fellow cadets from the class that graduated in $1936 .{ }^{66}$

In considering the question of accidents, Frederic Bartlett had observed that it was usual to think in terms of 'accident proneness'. An accident-prone person would have more accidents than others of similar background in comparable circumstances. 'It is clear,' he pronounced, 'that no "accident-prone individual" could possibly go very far as a flying officer.' Yet this was precisely what some of his contemporaries maintained was what had happened to Bob Hitchcock. If it were true, was it simply a triumph of hope over experience? Did the sense of obligation to his family outweigh what could be thought to be remediable lapses? Or had some fundamental problems been overlooked? Bartlett's list of 'outstanding significant temperamental qualities' might well have been assembled with Hitchcock in mind:

impetuosity or caution; suggestibility or contrariness; capacity to move rapidly from one type of adjustment to a different one; ability to translate what has been learned in one medium into a different medium... power to remain cool-headed and steady whenever the normal tempo of reactions is radically altered; sociability.

On all of these criteria a shrewd assessor might have had doubts about Bob Hitchcock. But an undeniable truth had to be confronted. In spite of any shortcomings he might have had in the qualities deemed essential for a good pilot, Hitchcock had survived five years of regular flying and his career in

65 The USAAF would also soon adopt an 'adaptability rating for military aeronautics aptitude' (Louis Hopewell Bauer, ed. Henry A. Christian, Aviation Medicine, Oxford University Press, New York, 1943, pp.568-9). For later US developments: Roy R. Grinker and John P. Spiegel, Men Under Stress, Blakiston, Philadelphia, 1945. For Bartlett's research program and conclusions on the continuing inadequacy of accident investigation reports: D. Russell Davis, Pilot Error: Some Laboratory Experiments, HMSO, London, 1948. On RAF scepticism about the pre-selection testing regime and the development of alternative approaches, see $\mathrm{T}$. M. Gibson and M. H Harrison, Into Thin Air: A History of Aviation Medicine in the RAF, Robert Hale, London, 1984, pp.238-54; Philip E. Vernon and John B. Parry, Personnel Selection in the British Forces, Uni. of London Press, 1949, pp.67-82; R. N. Ironside and I. R. C. Batchelor, Aviation Neuro-Psychiatry, E. \& S. Livingstone, Edinburgh, 1945; Psychological Disorders in Flying Personnel of the Royal Air Force investigated during the war 1939-1945, Air Ministry Air Publication 3139, HMSO, London, 1947; Mark K. Wells, Courage and Air Warfare: The Allied Aircrew Experience in the Second World War, Frank Cass, London, 1995.

66 AVM E. A. Daley, 'Aviation Medicine Progress in Australia over Twenty-Five Years', Journal of Aviation Medicine, vol.25, Oct. 1954, pp.451-6; 'Flying Personnel Research Committee - Medical aspects of aircraft crashes', NAA: A705, 43/1/674; Allan S. Walker, Medical Services of the R.A.N. and R.A.A.F., Australian War Memorial, Canberra, 1961, pp.324-5; D. P. Mellor, The Role of Science and Industry, Australian War Memorial, 1958, pp.186-7. 
the Service had prospered. For the four years from 1935, when he began his training, to 1938 there had been 18 fatal Air Force accidents with 26 deaths (two of them a civilian mother and daughter). Another nine men were seriously injured. ${ }^{67}$ If earlier fears about his flying had persisted, it would have been possible at any time to assign him to station or headquarters duties to which minimal risk attached. From the outbreak of war onwards there were many more posts in administration, recruiting, and flying instruction than men to fill them. Instead, Hitchcock had been one of the first to be put in charge of the Air Force's newest and most demanding aircraft, and to be given the task of guiding less experienced men as they joined his squadron. No one who graduated with him in July 1936 had passed him in seniority. Somehow it was overlooked by many that while he ascended a dangerous competitive ladder 10 per cent of his contemporaries had fallen by the wayside.

There was of course an explanation for Hitchcock's longevity in the Service. As the Air Board had pointed out in 1938 in its refutation of Sir Edward Ellington's conclusions about RAAF accident rates, of the 12 cases he examined eight had involved pilots with less than two years' experience, and two were cadets under instruction. The probability of fatal accidents clearly shrank with each year of experience. ${ }^{68}$ What no-one in the upper ranks of the RAAF wanted to say in the spring of 1940 was that the man they held responsible for the crash that killed their own Minister as well as nine other men was in fact one of their better pilots.

67 Mark Lax, 'The Impact of Technology and Command on No 1 Squadron Operations 1915-1958', MA Hons thesis, University College of University of New South Wales, 1995, pp.91-4.

68 'Report of Marshal of the Royal Air Force Sir Edward L. Ellington...on the Royal Australian Air Force together with the Comments of the Air Board and the Civil Aviation Board and the Decisions and Observations of the Commonwealth Government' [Jan. 1939], p.16. 

Part 5 Reflection 



\section{6. 'That terrible hour'}

Three Cabinet Ministers and the Chief of the General Staff killed. Six others dead, flight crew and staff. A terrible inexplicable accident. A story so shocking and sensational galvanised the press. There was a scramble for photographs. Cinesound and Movietone newsreel cameramen sped to the scene. Eyewitnesses, people who were happy to tell of what they had seen, would be questioned repeatedly over the next few days by official investigators as well as journalists. Others in demand by the newspapers were those whose good fortune it had been to choose to travel to Canberra another way for the meeting on August 13. No major accident story was complete without expressions of relief and thanksgiving from those who might have been victims.

After the radio stations, the Tuesday afternoon papers had the news out first. They were wrong to report, as 'The Hand of Fate', that Sir Henry Gullett had planned to fly up with Jim Fairbairn in his own plane but that both men changed their minds at the last moment so that they could travel with Sir Brudenell White. ${ }^{1}$ It was closer to the mark to say that the Minister for Customs, Senator George McLeay, was to have travelled by the ill-fated plane, as a 'special representative' of the Melbourne Herald reported on the afternoon of the crash. Geoffrey Street had telephoned McLeay on Monday asking if he would like to join him on the flight to Canberra. McLeay declined the invitation, the reporter was told, because he had planned a long conference on the train with his departmental head, the Controller-General of Customs. Not quite true. The meeting, according to the Minister's private secretary, Bob Willoughby, had been with some 'motor car people' on the way up to Albury. McLeay had kept his options open until the afternoon, deciding finally not to take up the offer. The prospect of a post-prandial brandy and cigar in the parlor car might have tipped the balance. Before Willoughby could call Dick Elford to tell him that the seats were not required, Fairbairn himself rang to ask whether McLeay still wanted them. Fairbairn was relieved to find that they would be free because 'we're taking Brudenell White up with us'. ${ }^{2}$ McLeay was to be one of Fairbairn's pallbearers on August 15.

The Assistant Treasurer, Arthur Fadden, one of the first to hear the news at Parliament House, had also been invited by Fairbairn to join the party, but was already booked on the train. By the time the Herald appeared on Melbourne's streets, Fadden was acting Minister for Air. The Canberra Times explained the next day that it was 'inconvenient to cancel the seat'. Fadden later recalled that he had been asked by Fairbairn to give up his seat for Elford so that Elford could

1 Advocate (Burnie), 14 Aug. 1940.

2 J. R. Willoughby, interview, 18 Oct. 1977. 
stay in Melbourne on the night of August 12 to celebrate the first anniversary of his wedding. Like many of Fadden's autobiographical memories it was a good story marred only by its comprehensive inaccuracy: the Elfords had been married in November 1931. ${ }^{3}$ No other high-profile escapes were reported. Some fateful decisions rested on personal preferences; some on unavoidable alternative arrangements. But for others a different element played its part.

For one very important person who most certainly could have had a seat, there was no hint in the press of the events that led to his absence from the flight. On the afternoon of Monday, 12 August 1940, Murray Tyrrell, the Minister for Air's messenger, assistant to his private secretary, was in his office at Victoria Barracks on St Kilda Road, Melbourne. An unenthusiastic Tyrrell had been chosen to join Fairbairn's official staff in July 1939. Until then Tyrrell's acquaintance with federal politics had been limited. He had been ruled out of order at an election meeting in East Malvern for the neophyte UAP candidate Harold Holt when asking 'socialistic questions he couldn't answer'. Then, as a 17-year-old he had been dislodged from a soapbox outside a baby health centre in Caulfield and frogmarched home by a police sergeant - his offence being to draw a bigger crowd than Harry Gullett, who was speaking at the markets across the road. Tyrrell was an unabashed socialist but had learned not to let his political convictions contaminate his public service life. He had been personally interviewed for the job with the Minister by A. B. Corbett, the Director-General of the new Department of Civil Aviation. Arthur Corbett had known of him previously in the central office of the Postmaster-General's Department. His quixotic brief from Corbett was to 'make sure that Fairbairn doesn't do anything I wouldn't approve'.

Among Tyrrell's newer duties was allocating spare seats on RAAF flights arranged for the Air Minister. ${ }^{4}$ As the time for his chief to return to Canberra grew closer, he had an eventful few days. Fairbairn himself, his close friend Street, and Tyrrell's immediate superior, Elford, were all issuing invitations to join the flight. Some ministers temporised. Others declined. Nothing was settled until it was known who had opted for a Monday night rail journey and the train had actually departed. Meanwhile, those who minded the mighty could exert such influence as their seniority gave them. Naturally, if the Prime Minister wanted a seat on a flight, he took precedence over others in the queue or already allotted a place. Knowing that the new Hudson offered superior

\footnotetext{
3 Sir Arthur Fadden, They called me Artie, Jacaranda Press, Milton, Q, 1969, p.43. Fadden's false memory of Elford's supposed first wedding anniversary is quoted by Tink (Air Disaster, p.163), who omits 'first' but does not notice the wrong month as well as the nearly nine years since the Elford wedding.

4 'VIP', though not yet coined in 1940, is believed to have been the creation of a British officer responsible for organising wartime flights for 'very important personages' whose safety might be preserved by anonymity. For R. G. Casey on a Vip [sic] flight taking the controls of an RAAF Sunderland, a type he had never flown: Army News (Darwin), 31 July 1944.
} 
speed and more comfortable seating than the planes previously used, the Prime Minister's assistant private secretary Peter Looker thought it sensible to reserve two berths on the flight. He himself disliked nights on the train, often sleepless. What happened next was recalled by Looker:

Dick Elford, Jim Fairbairn's private secretary...came along to me and said 'how are you going back to Canberra? Are you going back tonight?' And I said 'Yes we are, blast it all we're going and we're going to sit up all night.' He said 'Well look, why don't you come up with us in the morning?' And I said 'How are you going?' And he said, 'Well the minister is going to fly up again in a RAAF plane, a Lockheed Hudson, and why don't you come with us?' I said 'that is an excellent idea... what time are you leaving?' He said 'Well we're leaving I think at about eight o'clock or half past eight...' So I said, 'Well that's fine...would you tell the minister...that the P.M. and I would like to come up too.' So he said 'Sure I will.'

By this time the P. M. had gone home to 10 Howard St Kew. I rang him through, and I said 'Look instead of going by train tonight' — this was about four o' clock on Sunday [sic] afternoon - 'the Minister for Air is flying up tomorrow morning in a RAAF plane. I've suggested that he reserve two seats for you and I.' I got the full blast: 'We will go by train!' So I said 'Alright.' So I had to ring up Dick Elford and say: 'Look, cancel it, the old man won't agree, we're going up by train. ${ }^{5}$

Why did Menzies blast Looker for arranging to fly to Canberra? As a minister and Prime Minister he flew when he had to. Alfred Stirling, one of his last legal pupils and his first private secretary in Canberra, recalled that Menzies had done some private flying with Sir Chester Manifold when both were in the Victorian Parliament. On the Attorney-General's European trip in 1938 he noted that Bob and Pattie Menzies flew in separate planes. When Stirling, by then working with Stanley Bruce in London, joined them on a visit to Holland and Germany, it seemed that Menzies sensed that it was the fastidious bachelor Stirling's first flight. He murmured reassuring words that it would be alright. ${ }^{6}$

Sympathetic as he could be to a nervous flyer like Stirling, Menzies' sentiment was not based on any particular knowledge of aircraft. The Prime Minister's lack of curiosity about aviation matters was confirmed by Lawrence Coombes of the CSIR Aeronautical Research Laboratory at Fisherman's Bend. On a visit to CSIR in 1939 Menzies called briefly at the Division of Aeronautics after a

5 Sir Cecil ('Peter') Looker, interview, 25 March 1976. Looker had told the story in similar words to Alan Hodgart in 1975 (NLA Oral TRC 370). The incident is referred to in Michael McKernan, The Strength of a Nation, Allen \& Unwin, Sydney, 2008, pp.96-7.

6 Alfred Stirling, interview, 14 May 1976. 
morning with the Division of Industrial Chemistry. He met Coombes and three or four of the senior staff and left showing 'no interest in aeronautical research or aircraft manufacture'. If he was aware that Coombes was a decorated wartime RAF ace with 15 confirmed victories, and a former member of a 'joy-ride outfit' with Charles Kingsford-Smith, he did not show it. ${ }^{7}$

From the public record there was nothing to indicate that Menzies was reluctant to fly. In February 1939, he was booked, with Jack McEwen, George McLeay, Hattil Foll and their wives, Dick Casey and Vic Thorby, on an Australian National Airways flight from Launceston to Melbourne after a Cabinet meeting in Hobart and a brief tour of the Tasmanian northwest coast. ${ }^{8}$ In July 1939 he travelled by air from Sydney to Melbourne and then spent 10 days on a tour of South and Western Australia. Five months later, he flew by airliner from Melbourne to Sydney to attend a farewell dinner to Bertram 'Tubby' Stevens, the ex-Premier of New South Wales. In April 1940 he had even ventured to join Geoff Street in a flight from Canberra to Melbourne piloted by Jim Fairbairn. Fairbairn had landed the plane on a makeshift landing ground at Seymour to enable Street to visit the Puckapunyal Army camp. ${ }^{9}$ It was perhaps Fairbairn's last flight in the Dragonfly before handing it in for government use. An Argus photographer was there to capture the moment with the Prime Minister in the cockpit with the pilot.

Menzies flew on other occasions. But the truth was that he never liked flying. ${ }^{10}$ His Cabinet colleague Tom White had enjoyed a pleasant flight to Canberra with him one morning in September 1937 and could not resist retailing to his wife 'The legal gentleman informed me that his feet were very cold - apparently chronic since $1914 !^{\prime 11}$ Nothing illustrates Menzies' aversion better than a memorable incident early in 1940 recalled by his assistant private secretary. At the last moment one Friday afternoon, Menzies decided that he wanted to go with his wife by train from Canberra to Melbourne for the weekend. Despite the best efforts of his staff, including a personal appeal by Peter Looker to the NSW Railways Commissioner T. J. Hartigan, there were no seats - all had been commandeered by the Services. No carriage could be added. It would have required a second engine and extra coal that would not be approved because of a fuel conservation policy caused by the miners' strike. What happened next is best told in Looker's own words:

7 L. P. Coombes to CH, 7 May 1982; 'Research Head Arrives', Aircraft, vol. 18 (6), 1 March 1939, p.7; C. B. Schedvin, Shaping Science and Industry: A History of Australia's Council for Scientific and Industrial Research, 1926-49, Allen \& Unwin, Sydney, 1987, pp.195-201.

8 'Cabinet Meetings in Tasmania', NAA: A461, AC4/1/3.

9 Sydney Morning Herald, 13 Dec. 1939; The Argus, 13 April 1940.

10 Menzies' flight to Melbourne from Canberra, The Advertiser, 11 May 1940; Looker, interview, 25 March 1976.

11 T. W. White to Vera White, 13 Sept. 1937, T. W. White MSS, NLA MS9148/2/2. 
I rang up what was then Australian National Airways - they used to run DC-3s from Canberra to Melbourne - and told them the problem and I said would you have three seats available tomorrow morning? And they said, yes certainly, we'll make them available for you. So I thought I had shown a lot of initiative and I walked into the P.M.'s office about five or half past five, told him the story, that there were no seats on the train and we'd fly down in the morning and we'd get there just about the same time as if we'd sat up all night.

Well, at that he let fly. He thumped the table and he said: 'Look, I am Prime Minister of this country. Do you mean to tell me that I cannot have a seat on that train tonight?' And I said, 'well that's what I have been told, and there's nothing I can do about it, and nothing that the Chief Commissioner of Railways in New South Wales can do about it, and after all we'll get down the same time and we'll be able to sleep tonight.' Of course he loathed air flying, he loathed flying... And he oh he really tore strips off me. ${ }^{12}$

Once more having lambasted his young staff member for trying to get him to fly when it was not essential, Menzies arrived in Canberra early on the morning of August 13. 'It was a bright and sunny day, and I was at work,' he remembered. 'A knock came on my door, and somebody walked in. There had been a dreadful air crash, almost within sight of my windows.' Murray Tyrrell, who had also come up by train - having bribed a railway porter with 10 shillings for seats for himself and Pip Hayter - brought the news to the Prime Minister. ${ }^{13}$ Tyrrell had accompanied his minister with Harry Gullett and others to Canberra in A16-97 the previous week. ${ }^{14}$ Shaken by the realisation of how close he himself had come to being one of those in the fallen plane, he told Menzies: 'I suspected they had [all] died in the crash. I didn't know. I rang him immediately I knew there was a crash, went and saw him in his office in Parliament House and said I was going out to check at...Canberra airport.'

Menzies was stunned. 'Just absolutely stunned,' Tyrrell recalled. The young assistant private secretary knew nothing of the abortive attempt by Elford and Looker to get the Prime Minister on to the aircraft the previous afternoon. Menzies himself said nothing about it. Looker too kept his counsel, realising at once that nothing good could come of such a revelation. Fifteen hours earlier he

\footnotetext{
12 Looker, interview, 25 March 1976. On broader questions of transport co-ordination, an official postwar report concluded: 'the railway systems did not altogether willingly accept the surrender of any of their normal functions to the Commonwealth' (G. J. Christopherson, A Difficult Relationship: Defence and Civilian Transport Industry Relations since 1945, Defence Fellowship Paper, Melbourne, 1991, p.69).

13 N. D. Tanswell, 'Forgotten Memorial', triad, No. 18, Winter 1980, p.19.

14 Flying Log Book, W. P. Heath, 5 Aug. 1940, Heath MSS.
} 
had been 'growling like mad' with George McLeay's secretary Bob Willoughby about 'having to travel by train while others were lucky enough to get a plane trip up' ${ }^{15}$ Tyrrell was grasping at wisps of hope as he told Menzies:

'I can't be certain.' What happened was that I hadn't heard the plane go over, you see. By this time I was already at Parliament House. So was Hayter. And I rang the control tower... And the control tower said 'No it hasn't arrived yet.' And then he added almost like an afterthought, he said 'But there's a kite just gone into the hill about two miles away and I've sent an ambulance.' I said 'What sort of kite?' He said 'Oh, I think it was a RAAF Hudson.' I said 'You bloody fool, send four ambulances. There are thirteen or fourteen people on board.' He said 'Well, it's too late' or words to that effect, 'it's burning. ${ }^{16}$ And it was.

The distress of the Prime Minister was palpable to all who saw him that day. He had not been to the scene of the accident. 'He immediately drove out to Government House to interview the Governor-General on urgent constitutional questions,' the Canberra Times reported the next morning. There were three ministerial appointments to be made and a Chief of the General Staff to replace. Speaking briefly to reporters on the afternoon of the crash he 'was deeply distressed at the tragedy and made no effort to conceal his emotion'. 'Mr Menzies Overcome', the Barrier Miner headlined. 'To me,' he said, 'it is a most grievous personal loss.' The death of his three Cabinet colleagues 'does not bear thinking about'. Menzies was seen to be 'on the point of a breakdown on several occasions'. After a few sentences he broke off his statement, pausing for more than 10 seconds, and 'brushing his hand distractedly across his forehead: "I am afraid I am not able to talk about it very much. It is a cruel blow."'17 Tyrrell remembered the initial reaction of a man not quite in a state of shock but "more than upset to talk rationally about anything' ${ }^{18}$

Menzies was to describe the event in his memoirs, Afternoon Light, published 27 years later:

Gullett was dead; Street was dead; Fairbairn was dead; the most scholarly and technically talented soldier in Australian history, Sir Brudenell White, whom I had recalled from retirement to be Chief of the General Staff, was dead. And dead with them were other younger men whom I knew, and for whom I had an affection.

15 J. R. Willoughby, interview, 18 Oct. 1977.

16 Tyrrell told the story with slight variations to Lord Casey, 24 Oct. 1972 (NAA: M1129 WHITE/C B).

17 Sydney Morning Herald, The Examiner, The West Australian, 14 Aug. 1940.

18 Sir Murray Tyrrell, interview, 5 April 1977. 
This was a dreadful calamity, for my three colleagues were my close and loyal friends; each of them had a place not only in my Cabinet, but in my heart. I shall never forget that terrible hour; I felt that for me the end of the world had come. ${ }^{19}$

Late that night, among the messages of condolence despatched to the bereaved families, two telegrams to Audrey Elford were lodged for morning delivery. At 11.47 p.m. officials on behalf of the Commonwealth government conveyed deepest sympathy over the Prime Minister's signature for the 'tragic loss that you and all of us have suffered'. Three minutes later an obviously more personal message followed: 'My wife and I are deeply distressed at today's tragic disaster. We share to the depth your sorrow and grief...R G Menzies. ${ }^{20}$

The next day, when he rose in the House of Representatives, the Prime Minister's emotion could not be concealed. He had woken to news that German planes had for the third day in succession launched wave after wave of attacks on England. What would soon be known as the Battle of Britain was under way. ${ }^{21}$ Whatever Menzies knew and feared about the war above the clouds over the southeast of Britain, it was the previous day's tragedy in Canberra that gripped his mind. If he believed what he read in the morning papers, his friends had been burnt to death: 'had the fire not occurred the occupants would have survived', The Argus reported. The Canberra Times 'had learned' that he had not known until the crash was reported that the ministerial party was travelling by air. At least one person in the Prime Minister's office knew this to be false. Peter Looker was well aware that Jim Fairbairn was going to be aboard, even if he had not been told the names of the others. 'I tried to speak about them,' Menzies wrote, '... It was difficult for me, and for all of us. In the whole history of government in Australia, this was the most devastating tragedy.' Menzies had not been one to let the world see what was in his heart. 'It was only in my later years that the feelings in me would occasionally break through,' he admitted in retirement. Although, he said, he had 'always had a lot of emotion in me, I learned to distrust its public expression' ${ }^{22}$

On this occasion, there was genuine grief and little artifice. This was a man deeply distressed. The extent of the disturbance to his equanimity is glimpsed in the confusion he conveyed in Parliament about the widows of Frank Thornthwaite and Geoff Street. They were sisters, he said. The Canberra Times had said this that morning. A reporter had perhaps heard someone say they were like sisters. But Menzies should have known that they were cousins. The next day at St

19 Sir Robert Gordon Menzies, Afternoon Light, Some Memories of Men and Events, Cassell, London, 1967, p.18.

20 Both telegrams were lodged at 10.50 p.m. Elford MSS. Punctuation added.

21 On Aug. 13 a vigilant censorship had prohibited publication of a photograph of bombed London buildings (NAA: A11666, 136).

22 Menzies, Afternoon Light, p.11. 
Paul's, reporters noticed that he was 'weary and haggard'.$^{23}$ Nearly 30 years later he wrote of the three Cabinet colleagues: 'I still mourn for them and carry them in my memory.' The intensity of the feelings Menzies expressed, both in 1940 and 1967, is unique. He spoke publicly of no-one else so movingly: 'on that dreadful day I was sad beyond the powers of description; some of my greatest friends were gone'.

When I first read the eulogies and lament in Afternoon Light the revelation of anguish seemed out of character for a man who habitually hid his own sentiments. The questions I began to ask myself were the germ of the idea that impelled me to write this book. Was Menzies simply exhibiting the mixture of relief and guilt so often felt by those who might so easily have been among those who perished? Or was it something more? Did he ask, like Thornton Wilder's Brother Juniper who had seen the bridge of San Luis Rey snap and precipitate five men and women to their deaths in the valley below: 'Why did it happen to these people?' Did he know of the possibility that the pilot's control of the aircraft might have been compromised by Jim Fairbairn? If others were canvassing that disconcerting idea, could it have been kept from him? There is no evidence to confirm that Menzies was by then informed of the rumours that would soon be reverberating in parliamentary corridors and at dinner tables around the nation. But it seems at least a plausible inference that the stories had reached him. And, if they did, the question that he could scarcely avoid asking himself was: would Fairbairn have restrained his curiosity if the Prime Minister had been among the passengers? Were all those deaths the result of his own insistence on travelling by train? Had his aversion to flying caused 10 other men to die? The questions could be asked. There could be no certain answers.

The public mask of Robert Menzies was rarely dropped. Four years before the crash he had mused about the 'paradoxical fact' that people are so 'inaccessible even in the most crowded places'. 'We guard ourselves against the prying eyes of others;' he wrote, 'we sometimes laugh when we are sad, and assume an air of modest gloom when we are elated, not out of perversity,' he added, 'but because we have been taught to believe that to wear our hearts on our sleeves is to forget the lessons of a self-controlled, not to say sophisticated civilisation.' ${ }^{24}$ The 'sophisticated civilisation' that Menzies inhabited was one in which appearance and perception were never less important than reality. To exhibit emotion, except by calculation, would be to reveal vulnerability. But, if political exigency demanded self-control, detachment from superfluous information ensured that a leader could remain focused on the decisions that mattered.

23 Sun News-Pictorial, 16 Aug. 1940.

24 Robert G. Menzies, 'Foreword', Ambrose Pratt, Sydney Myer: a Biography, Quartet, Melbourne, 1978, p.vii. The foreword was written in 1936 but the book was not published for another 42 years. 
Like many successful barristers Menzies was admired for his rapid assimilation of the essentials of a brief. The technique that served him well at the Bar had become instinctual by the time he was a minister. The British businessman Larry Hartnett had observed Menzies closely in attempting to persuade him to support the development of an Australian aeroplane manufacturing capability: 'He wants to know all the things that seem pertinent to the case but he doesn't want to dig at all deep. And Bob had no leanings towards what I call practical matters or the technical aspects of a subject. ${ }^{25}$

When he came to write almost three decades later about the events of August 1940, Menzies portrayed only the harmony and trust he had enjoyed with the colleagues he had lost in the crash. He had a political history to tell, with a message for the next generation about the comradeship and loyalty he had enjoyed. Neither the story nor his dignity in retirement was to be diminished by reviving forgotten witticisms or cruelties, extempore or premeditated. Thus there was no place in his memoirs for observations about Gullett's 'whingeing' voice (which Percy Spender was sure the Prime Minister had found irritating). There would be no repetition of disparaging remarks about Western District wives. No recollection of Fairbairn's defiant appointment of Sir Charles Burnett or of his occasionally wanting performance. 'These were all men of character, capable of being difficult, but never capable of disloyalty.' ${ }^{26}$

In Parliament on 14 August 1940 Menzies had naturally spoken of all of those who died - first of Brudenell White, whose abilities were outstanding, a man of 'lofty character and a gracious personality'. Then of Frank Thornthwaite, 'a gifted and popular officer'. He had described the 50-year-old Thornthwaite to reporters the previous afternoon as 'one of the ablest of the younger army officers' ${ }^{27}$ And of Dick Elford, 'a young man greatly admired by all honorable members who had come into contact with him...on the threshold of what, no doubt, would have been a distinguished, as it was certainly an honorable, career'. The four RAAF personnel, 'men of skill... on the threshold of life', were acknowledged. But they were not mentioned by name. There was a collective tribute to the three Cabinet ministers who 'had their greatest attributes in common'. In a voice 'charged with emotion', the Sydney Morning Herald recorded, the Prime Minister praised them all: 'men of courage and untouched honour, fired by a burning loyalty and enlightened by ability and experience'. Each, Menzies said, had 'a genius for friendship. They were rare men.' Harry Gullett's life was 'an epic of honourable achievement'. His mind was 'studious

25 Sir Laurence Hartnett's recollections, recorded 16 Sept. 1977.

26 Menzies, Afternoon Light, p.18.

27 The Examiner, 14 Aug. 1940. According to the Barrier Miner the Prime Minister had paid tribute to Thornthwaite as 'one of our ageless younger officers'. 
and reflective...penetrative and inquiring'. His political work was done with 'the disinterested zeal of a crusader. Henry Gullett could give and take hard knocks.'

But when the fight was over, even his opponents saw only the greyhaired, studious-looking man with the quick smile, the tender human charm, the capacity for giving a friendship so understanding and so moving that I can hardly bear to speak of it.

Of Jim Fairbairn there was a measured appreciation of 'immense, though undemonstrative, personal courage...unmatched energy and ability' in performing 'the stupendous task of Minister for Air':

His mind and character were strong, and he displayed an unusual combination of cheerful fellowship with, perhaps, a hint of Scottish dourness. He was slow to speech, but, once engaged, he was gifted in exposition and resolute in advocacy of what he believed to be true.

The deepest feelings emerged for Geoff Street whose principal pallbearer he was to be the next day. Street had brought to the heavy tasks of the Minister for the Army 'a mind informed by study and experience and sustained by a modest but courageous heart'.

He had a great simplicity which made him the friend of all of us; each of us can say, as I now do, 'He was my friend, faithful and just to $\mathrm{me}^{\prime} .^{28}$ In a period of immense personal strain and trial, his steady loyalty meant more to me than I can hope to say. To him the business of government, and, in particular, the business of conducting the administration of war, was a grave personal responsibility. He abhorred flamboyancy and display. But those of us who knew him so well will for long remember those things about him that many may not have realised - his scholarship, his gentleness of spirit, his quiet gaiety and wit, his memories and his love of the great game of cricket, whose standards were his, his honesty of mind. ${ }^{29}$

Jim Fairbairn, though charming, hardworking, and politically reliable, had never really been close to Menzies. Gullett's hospitality was a welcome escape from the cares of office; but he was not an intimate. Street, whose enthusiasm for cricket exceeded even Menzies' own, was as Percy Spender observed, 'keenerminded', and a more sought-after companion. But, whatever the loss of these three colleagues had meant personally, it had a vital political dimension for the Prime Minister in the winter of 1940. Gullett's status in the party and links with the press made him a useful ally, notwithstanding his age and poor health.

28 William Shakespeare, Julius Caesar, act 3, sc. 2 (Marc Anthony on Julius Caesar).

$29 C P D$, House of Representatives, vol. 164, 14 Aug, 1940, pp.373-5, 378-9. 
Street, an invaluable source of guidance to Menzies about the senior ranks of the military, was popular and effective in Parliament and on the platform. ${ }^{30}$ Both of them, with Fairbairn, were key members of a Cabinet that had an unavoidable general election date with the nation in less than three months. Newspapers were already forecasting a September 21 poll. ${ }^{31}$

\section{A heaven-sent opportunity?}

No one was more conscious of the impending election than the men who ran and financed the UAP party machine. Within hours of the crash, Telford Simpson of the Consultative Council had written to Menzies with breathtaking indelicacy of a 'rather heaven sent' opportunity to launch a new party. There were three ministerial vacancies. If 'men of better standing' were willing to come forward to support a 'Win the War' party, the Prime Minister 'could select a better ministry'.32 Although it was not made public until August 27, Sir Frederick Stewart had offered in June to step down from the Cabinet and vacate his seat in Parliament. ${ }^{33}$ Among the men of 'better standing' was the former NSW premier Bertram Stevens, whose Canberra ambitions were widely touted. News was published on August 16 that Menzies had sent an urgent telegram asking Stevens to come to Melbourne. ${ }^{34}$ Simpson pressed his case three days later, pointing out that the NSW branch of the UAP was in disarray and independent candidates 'backed up by large financial resources' threatened to emerge. Menzies did not rise to the bait.

Buying time, Menzies reshuffled the existing ministry, leaving the House of Representatives back-bench unchanged and promoting two UAP senators. His South Australian friend Phil McBride became Army Minister; and the respected 72-year-old West Australian Herbert Collett, a decorated AIF infantry Colonel, was given Gullett's portfolios. Artie Fadden added Air and Civil Aviation to his existing Ministry of Supply and Development and role as Minister without Portfolio assisting the Treasurer. As the three deceased colleagues all held Victorian seats, it was obvious that if the government were returned at the forthcoming election there would be Victorian additions to the ministry. On August 20 the Prime Minister announced the election date of September 21. The next day's Sydney Morning Herald and Daily Telegraph rebuked him for missing the chance to form a new patriotic party and reinforce his ministry with 'big

\footnotetext{
30 Sir Percy Spender, interview, 16 Aug. 1977.

31 Tink contends (www.abc.net.au/unleashed/4686146.html): 'Rather than hold three by-elections, Menzies decided to bring the general election forward.' A September election date was already settled: there was never any prospect that three by-elections would be held.

32 Telford Simpson to Menzies, 13 Aug. 1940, Menzies MSS, NLA MS 4936/40/23.

33 Canberra Times, 28 Aug. 1940.

34 Sydney Morning Herald, 16 Aug. 1940.
} 
men'. The Argus joined the chorus on August 24, regretting in an editorial the missed opportunity of welcoming the Victorian Country Party Premier Albert Dunstan's willingness to stand for the seat of Flinders. Evidently in a fragile state, Menzies dictated a mournful letter to Hugh McClure Smith, the editor of the Herald. The letter was quoted by Menzies' biographer Allan Martin from a copy in the Menzies family papers. In eight elections over 12 years 'every campaign has been abhorrent to $\mathrm{me}^{\prime}$, the Prime Minister lamented:

I have waded through the sewer of personal abuse, but I have so far emerged. I have never expected that high office would be handed to me on a plate without pains and without trouble, and, quite frankly, I don't see why anyone else should expect it...It is indeed ironical to think that the Government's danger of defeat - a defeat which might have tragic results for Australia - does not come from its opponents but from the destructive activities of a relatively small group of men who have failed to realize that if the people are persuaded that this Government is a bad one they will certainly instal [sic] another government which will not be made up of angels of light but of Curtin, Ward, Brennan and Company. That result will not so much be bad for me or my party as ruinous for Australia. I tell you quite honestly that my own defeat would, as such, leave me cheerful. As Prime Minister I have sweated day and night, under recurrent difficulties and disappointments, and sometimes disloyalties. I have gone on in spite of it all, doing my indifferent best, sniped at and loftily admonished by every leading newspaper except the Melbourne 'Age' until I sometimes curse the day I entered politics.

On reading the typed version Menzies thought better of the reference to The Age and deleted it. ${ }^{35}$ Revealing that he was not himself, he left in an argument that he must have known was not quite true: that it was constitutionally impossible to bring unelected men into the Cabinet - forgetting, it would seem, Section 64 of the Constitution envisaging that "no Minister of State shall hold office for a longer period than three months unless he is or becomes a senator or a member of the House of Representatives'. Had he chosen to do so, the Prime Minister could have responded to the call to bring in new men from outside the Parliament in the knowledge that they could stand for election within a month. The point was no secret; it had been made by the press. Nevertheless, Menzies thought better than to throw in his hand with Telford Simpson and his henchman Bert Horsfield of whose joint 'disloyalties' earlier in the year he had been warned. 
Menzies narrowly survived the ensuing election. He contemplated another appeal to the electorate if he could not conjure a workable majority. ${ }^{36}$ Choosing to rely on the support of two Independents in the House of Representatives, he brought back into the government Harold Holt from service as a gunner in the AIF, reinstated close ally Eric Harrison who had twice stood down to make way for Country Party members, and gave the last place to his father-in-law, Senator John Leckie. Though lacking the weight of Fairbairn, Street, and Gullett the three replacements were, it seemed safe to assume, men on whom he could rely. The men on whom ultimately he could not rely were rebellious UAP backbenchers. A year later, after his return from an extended period in Britain, and a Cabinet re-shuffle, 'dissension, discontent and personal animosities' abounded. ${ }^{37}$ Labor would not join a national government. With his own party support crumbling and the Country Party resurgent, a dispirited Menzies stepped down. He was succeeded by Arthur Fadden. In retrospect he would say that he did not believe his 'rejection and, as I felt it at the time, my humiliation, would have happened if those three men had lived... ${ }^{38}$

\section{'A hole in the fabric of government'}

Many historians have been inclined to agree with Menzies' political analysis. The Official Historian Paul Hasluck's judgment cannot be disputed: 'The loss of any one of these men alone would have weakened the Ministry and Parliament. The loss of the three together tore a hole in the fabric of government. ${ }^{39}$ In his book, Air Disaster Canberra, Andrew Tink goes further, arguing that the eventual fall of the coalition government, and the accession of John Curtin and Labor, would not have occurred if Harry Gullett had not died. Gullett's seat was lost in the 1940 general election to an Independent, Arthur Coles, who eventually voted the government down. However, in the realm of counter-factual thinking many conclusions are possible. The overwhelming facts about Menzies' 'humiliation' were that he had led the UAP to a disastrous election result, and that he had antagonised the press and too many of his own party. ${ }^{40}$ Even had Fairbairn, Street, and Gullett lived, there is no certainty that they would have supported him wholeheartedly in a divided party room in $1941 .{ }^{41}$ Moreover, the vote of one

\footnotetext{
36 F. H. Wright to Capt. J. R. Patrick, 4 Oct. 1940, copy, Wright MSS, NLA MS8119 Series 2 Box 15.

37 Percy Spender quoted in Hazlehurst, Menzies Observed, p.242.

38 Menzies, Afternoon Light, p.18.

39 Hasluck, The Government and the People 1939-1941, p.244.

40 For Keith Murdoch's preference for Labor in 1941 and belief that Menzies' unpopularity around the country doomed him, see S. Ricketson to Murdoch, 5 Feb. 1943, copy; Ricketson to W. S Robinson, 1 Dec. 1941, copy, for the 'sniping campaign' and 'vendetta' of The Argus and Sydney Morning Herald, Wright MSS, NLA MS 8119 Series 6/1.

41 There is little evidence to sustain Tink's notion (e.g. Sydney Morning Herald, 23 May 2013) that Gullett, Street, and Fairbairn constituted a kind of political Praetorian Guard for Menzies.
} 
or two Independents in Parliament would never have been crucial if so many men had not previously lost their seats and so many others deserted him. The carnage when A16-97 plummeted into Cameron's paddock was truly a dreadful calamity; but it was not 'the plane crash that destroyed a government' ${ }^{42}$

What is undeniable is the intense emotion Menzies exhibited about the deaths of his colleagues. Kenneth Menzies, the Prime Minister's older son, 18 years old in August 1940, would tell of how his father was devastated. 'Not only were they his friends, but from the point of view of the war machine, they were the key Cabinet members.' The testimony of the ABC television producer Geoff Crane provides further insight:

I have chatted with Heather Henderson, Sir Robert's daughter, on a number of occasions through work. She was eleven at the time of the accident and was at boarding school in Melbourne at the time...She recently told me her mother mentioned that within Sir Robert there was a tangible personal change in him after the crash. ${ }^{43}$

Murray Tyrrell, though very young and junior at the time, was a shrewd political observer with an attentive ear. 'Half your job was to...feed your minister with whatever information you picked up.' The secretaries and assistant secretaries and other staff used to play table tennis in the basement of Parliament House. 'You all talked and said "Hey, have you heard this?" and then I'd go back and tell Dick Elford.' Tyrrell was friendly with Peter Looker, who was courting the stenographer in Fairbairn's office, his future wife Jean Withington. Through Looker he was privy to the moods and attitudes of Menzies. 'I don't think he was particularly close to those three,' Tyrrell was to say, 'I think they were close to him. And that is a different matter.' What Tyrrell recognised in retrospect, with all the percipience of a Canberran with decades as Official Secretary and counsellor to successive Governors-General, was the political nature of the support that Menzies was receiving. His party leadership had been close fought. The nation was at war. 'I think they were looking for leadership and Menzies provided it and I think they stuck with him. ${ }^{\prime 4}$ But there could be no certainty about how long the leadership compass would continue to point in the same direction.

Distressed though he was, Menzies had another duty to perform. He must return to Melbourne and lead the mourners at the service in St Paul's Cathedral. If there were public doubts about the safety of the RAAF's Hudson aircraft, seeing the Prime Minister flying to Melbourne for the funeral would have been

42 Tink, Air Disaster, p.280. Tink went further in a broadcast on 8 May 2013, saying that, if the crash had not occurred, he had little doubt that Menzies would have won the 1940 election ('Overnight' with Trevor Chappell, ABC Local Radio).

43 John Lahey, 'The day Sir Robert committed a nation to war', Canberra Times, 28 Aug. 1989; Geoff Crane to $\mathrm{CH}$, (email), 16 July 2007.

44 Tyrrell interview, 7 April 1977. 
a good way to dispel them. One of No. 2 Squadron's most experienced Hudson pilots would be entrusted with the responsibility of captaining such a flight. Ray Garrett recalled that he was that man. At 39 he had flown for 13 years with the CAF and the Larkin Aircraft Company in the Northern Territory before the war. The first civilian flying instructor with the CAF, Garrett was, he said, 'the only qualified instructor in the Squadron though Ryland did a lot of desk instruction'. This was to depreciate Jack Ryland's undoubted greater expertise at the time. Still, what Garrett clearly remembered was being detailed to collect Menzies and several colleagues from Canberra.

A flight to Melbourne in an aircraft identical to the one that lay wrecked on Duncan Cameron's farm, would have given the Prime Minister the time and the ambience in which to reflect on the 'terrible hour' that had passed two days earlier. He could see, hear, and feel the world as Harry Gullett, Geoff Street, Brudenell White, Frank Thornthwaite, and Dick Elford did in their last untroubled minutes. And exactly as he must have suspected Jim Fairbairn did. Indeed Garrett remembered, 'he was in the $2^{\text {nd }}$ pilot's seat part of the trip' ${ }^{45}$ Vivid as the recollection was - and much as I wanted to believe it - Garrett's memory had betrayed him. He did not fly Menzies that day, or any other day in the next six weeks. The Prime Minister, along with the Governor-General and other ministers and officials travelled to Melbourne on the same train that bore the coffins from Canberra. The first minister reported as taking to the air after the deaths of his colleagues was Sir Frederick Stewart who returned from Melbourne to Sydney on Saturday August 17. ${ }^{46}$

Did Menzies blame himself for the fate of A16-97 and its crew and passengers on 13 August 1940? It is hard not to wonder whether the enduring sentiment expressed in his memoirs went beyond sadness and regret at the loss of their companionship and political support. His brain was agile enough to rebut insidious doubt. If Jim Fairbairn had behaved rashly surely it was not his fault? What he could certainly do was try to minimise the likelihood of such a calamity befalling so many national leaders in the future. Immediately after the crash there was considerable criticism of the government for allowing so many important men to travel together. ${ }^{47}$ It was widely believed that Cabinet had decided that in future no more than two ministers should fly together. But this would have been an impossible requirement. In fact, as the Canberra Times and other papers had reported on August 15, it had been agreed that air travel would be limited to the smallest possible parties. A spokesman said that a hard and fast rule could not be laid down but: 'Members of the Cabinet will continue

45 Sir Raymond Garrett to CH, 26 April and 2 Nov. 1978.

46 The Argus, 19 Aug. 1940.

47 Sydney Morning Herald, editorial, 14 Aug. 1940. 
to use air transport frequently, as their work demands the utmost mobility at times. However, they will not travel more than one or two at a time except when it is unavoidable.'

Two months later, perturbed citizens were drawing attention to the fact that four ministers had flown together to a meeting. About the same time, returning in a commercial airline DC-3 from reporting on electoral campaigning in Tasmania, Dick Elford's old Argus colleague Harold Cox, then with the Sun, found himself sitting next to the Prime Minister:

As we came into land the motors were suddenly switched on again and we climbed and did a second circuit. I noticed Menzies lying back, apparently quite asleep except that his hand was on the armrest of the seat and I noticed the knuckles white and the fingers tensed and I said 'Well, we're doing a second circuit too Prime Minister!' Menzies looked at me... ${ }^{48}$

\section{Remembering}

If Menzies could not forget the 'terrible hour', many others were determined that the nation should remember. Arthur Fadden endorsed a suggestion that an aerodrome in Victoria be named after Jim Fairbairn. John Curtin had proposed within months of the tragedy that the design of Canberra should incorporate a memorial garden where simple stone obelisks mounted with plaques would commemorate the nation's great men - there the three ministerial victims would find a place amid explorers, educationists, road and railway builders, trade union pioneers. Although Curtin compared his idea with Westminster Abbey and Washington's Arlington National Cemetery there was no mention of either famous generals or other servicemen who might have shared their fate. ${ }^{49}$ The Labor leader's idea was not taken up.

At the time of the coronial inquiry the site of the crash had been marked by the surveyor of the Department of the Interior, L. C. A. Hope, with a cement peg. Later, Cameron's paddock had become part of the field-firing and manoeuvre area of the Royal Military College, Duntroon. ${ }^{50}$ Relatives of Sir Brudenell White eventually suggested to Senator Annabelle Rankin that a memorial might be erected. Senator Rankin visited the site of the crash with Jo Gullett M.P., accompanied by departmental officers. If other relatives concerned approved the idea, it was reported in March 1952, then the Minister for the Interior, W. S. Kent Hughes, an old comrade of Fairbairn and Street from their Young

48 The Argus, 31 Oct. 1940; Harold Cox, interview with Mel Pratt, 6 April 1973, transcript, NLA TRC 121/43, pp.14-15.

49 Sydney Morning Herald, 23 Aug. 1940, The Argus, 12 Oct. 1940.

50 Rural block 602 DP 554. 
Nationalist days, would submit the proposal to the National Memorials Committee. Provision would also be made for a plaque at Fairbairn aerodrome hangars.

The National Memorials Committee was suspended in 1952 because of the workload of its chairman, the Prime Minister. It did not meet again for 23 years. ${ }^{51}$ The National Capital Planning and Development Committee was alerted informally to the proposal and recorded the opinion that 'psychologically it would be inappropriate to erect a cairn at the site of the crash, or any plaque at the airport relating to the crash other than possible naming of the airport as Fairbairn'. The committee felt that 'the memory of Sir Brudenall [sic] White might be recorded at the Australian War Memorial; and the parliamentarians concerned by an appropriate tablet at Parliament House'. The other six victims were not considered. In the event, Brudenell White was commemorated by his family with a plaque and Shrine of Remembrance in St John's Church, Reid. The Wiesener family would have Dick honoured along with four other members of the congregation in a pair of stained-glass windows at the Homebush-Strathfield Congregational Church. ${ }^{52}$

On official recognition of all 10 men, wiser heads prevailed. Agreement having been secured from the next-of-kin, a 'simple memorial cairn' was approved. In late 1955 the Department of Works submitted a sketch plan and drawing of a rectangular cairn in local stone with a metal plaque. The concept was priced at $£ 250$ in April 1958. The plan did not proceed. As the Australian Heritage Database enigmatically states, between April and August 1958 'a change in proposal occurred'. On 7 August 1958, a two-metre-wide granite monolith was removed from the site of the Ainslie Rex Hotel to the site of the disaster. Supported by two smaller stones, and embedded in concrete, it became what is known as the Air Disaster Memorial. The plaque named the 10 men who 'while serving their country lost their lives on this spot'. The cairn was dedicated by the Prime Minister at a private ceremony on 12 August 1960. ${ }^{53}$ Doubts were subsequently expressed about whether the 'spot' in Kowen Forest, Fairbairn Pine Plantation, off

\footnotetext{
51 National Memorials Committee Agenda: meeting, April 1975, Archives ACT.

52 Built in 1884, the Homebush-Strathfield Congregational Church, corner Albert Road and Homebush Road Strathfield, is now the Sydney Korean Parish.

53 The Minister for the Interior and Works, Allen Fairhall, announced in Sept. 1958 that the cairn had been erected. Menzies, hearing of it on the radio, expressed his astonishment that he had been 'disregarded in a very offensive fashion'. No relatives were informed and no ceremony was held. The P.M's private secretary told Fairhall: 'Mr Menzies does not consider it necessary that an official unveiling ceremony should now be held.' Eighteen months later H. J. Manning of the Dept of the Interior, who had written an article about the crash, suggested to the Prime Minister that a ceremony of remembrance be held at the site on the twentieth anniversary of the disaster. Menzies now agreed. Families were given nine days' notice in a letter that avoided actually inviting them: 'PM wants all notified of the event \& told they would be welcome if they could come.' Bob Hitchcock learned by telegram on Aug. 11 and drove to Canberra overnight on the twelfth. Charlie Crosdale's widow was too ill to attend and her son, unemployed like her, could not afford the trip. Jack Palmer's widow chose not to go. According to the official file neither she nor her brother Laurie could be located (NAA: A463, 1960/3940).
} 
Pialligo Avenue, Oaks Estate, was correctly located. Half a century later several versions of the plaque had been stolen or vandalised. The site of the memorial was off-limits because of its proximity to a military rifle range. The current plaque was in storage. Early in 2013, yet another replacement plaque bore witness to community indifference and repeated acts of vandalism. ${ }^{54}$

While the public memorial of an accident never adequately explained was damaged and eventually rendered inaccessible, almost all of the sources from which the official story of the accident could be told remained secure. The records of the Service Court of Inquiry, the Air Force Court of Inquiry, and other secret files, lay quietly undisturbed in the Australian Archives until 16 years later a curious historian and a succession of pertinacious research assistants began to prise them open.

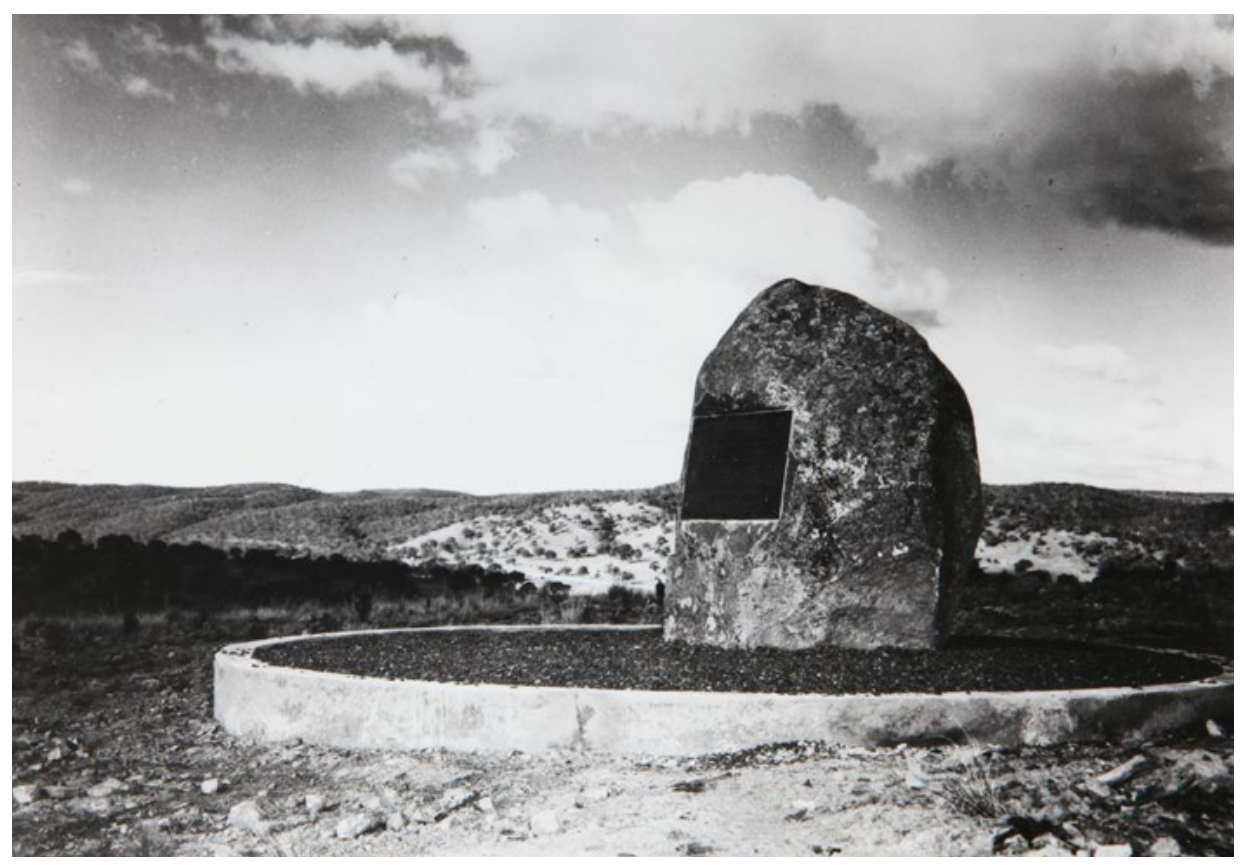

\section{The cairn}

(Courtesy of the Australian News and Information Bureau)

54 Australian Heritage Database, Place ID, 18801, Place File No. 8/01/000/0419. I am grateful to Mark Dawson and Elizabeth Estberg for information and references about the cairn: Department of the Interior file PC 40/11/0 NAA: A3032, ACT Archives. In 1996, Selma McLaren noted in a Heritage Study Proposal that the isolated and neglected site was in an area where 4WD vehicles raced on forest trails; it had been attacked by vandals; random fires had occurred and cult ceremonies and rituals held nearby; there had been assaults and allegedly a murder in the vicinity (File courtesy of John Myrtle). Tink (Air Disaster, opp. p.103) for a photograph of the 'pitted and dented' plaque. On 13 Aug. 2013 Andew Tink and Estelle Blackburn brought together family members of the victims for a ceremony to mark enhancements to the memorial and its environs (Canberra Times, 14 Aug. 2013). 


\section{Aftermath}

'Both the Prime Minister and Mrs Menzies were deeply shocked by the tragedy,' the Sydney Morning Herald reported on 14 August 1940. 'They were friendly with all the passengers in the plane and their families and Mr Menzies could not conceal his grief.' Haunting as the crash may have proved for Robert Menzies, its impact on him could not compare with the searing sorrow of those who, without warning, lost husbands, fathers, brothers, and children. It was not until October 10 that the newspapers reported Justice Lowe's findings. The news was no longer on the front pages but the healing of time had barely begun. For some of the widows, grief would soften into enduring sadness. To others, bitterness would cling, fuelled by resentment at the perceived injustices that followed.

Audrey Elford, aware of Peggy Fairbairn's flirtation with her husband, nevertheless sent a letter of sympathy and flowers to the widow of the Air Minister. There was no reciprocal gesture, not even a reply. The slight, for thus it was interpreted, rankled for decades. As Dick Elford had risen in the last year of his life as a young man of promise, and the boys had begun to go to school, Audrey too had emerged from the domestic shadows. On 13 August 1940 she had been invited to a lunch party with Evelyn Casey, Dick Casey's widowed mother. At an adjoining table she heard someone talking about a crash in Canberra that morning. She was assured that her husband had not been involved but she knew otherwise. In a faint, she was taken upstairs to Mrs Casey's room. Two hours later, Sir Earle Page's daughter and her husband Bill Tart from the RAAF public relations office arrived to convey the news that Dick was among the victims.

To Audrey's shock was added the realisation of how much she had relied on Dick's official private secretary's salary of $£ 508$ a year and a supplementary allowance of $£ 36$ as liaison officer between the Minister and the Departments of Air and Civil Aviation. As the widow of a ministerial staff member, Audrey had no entitlement to a Service pension. 'I still get furious,' she admitted, 'when I hear rumours that the Government gave me $£ 80$ 000.' She recalled receiving $£ 350$ in Commonwealth Employees' compensation and £250 in securities initially yielding 2 $\frac{1}{4}$ per cent for each of her boys. ${ }^{1}$ Her solicitor, Geoffrey Cohen, did his best on her behalf. But they encountered Menzies at his most insensitive. Invited to talk to the Prime Minister at his Victoria Barracks office, Audrey was reminded that she was a civilian widow with no claim on the government.

1 In fact, £200 for each of the boys was placed in trust, administered by a departmental official, until $31 / 4$ per cent Treasury bonds were passed over in full and final settlement in 1954. Treasury rejected a proposal that the total amount of compensation be supplemented by Audrey and a sum of $£ 1000$ be invested in higherearning securities recommended by Ian Potter (NAA: 705, 300/1/9). 
The Treasurer Arthur Fadden had advised against granting a pension as recommended by the Department of Air: 'dependants of other victims of the same disaster are probably not so well provided for as Mrs Elford'. Ironically, Fadden as Minister for Air had previously proposed a widow's pension of $£ 117$ a year plus 5/- per week per child, only to meet the classic objection to 'establishing a new principle' from the then Treasurer Percy Spender.

Audrey Elford was spared the humiliating bureaucratic calculations of her total assets of approximately $£ 3000$, including the proceeds of insurance policies valued at $£ 1600$ after probate duties and expenses, Dick's bank deposit funds of $£ 46$, and her own 'private means' ( $£ 700$ in Commonwealth bonds, $£ 20$ in Argus shares and an average of $£ 1$ a week in trust income). But she would never forget the long cigar on which Menzies drew while telling her he could not create a precedent of granting a pension to a non-Service widow: she was young and could go out to work to support her two sons and send them to a good state school. Thirty-seven years later she was to recall with shame that she blurted in response: 'my children were not born to go to a state school'.

What made the apparent indifference of Menzies so hurtful was that the government subsequently decided that dependants of Commonwealth officers killed while travelling by air on official duty should receive a $£ 1000$ insurance payment. But the decision was not to apply retrospectively. With the pain of loss and grievance intermingled, Audrey would carry long afterwards the belief that Menzies had even objected to the erection of a memorial to the crash victims. ${ }^{2}$

Possibly prompted by the Prime Minister, the Air Department offered Audrey a job eight weeks after Dick's death. It was too soon. Her family was in turmoil. Six days after the Canberra crash, her 30-year-old brother Geoff, a clerk, who had enlisted in June 1940, was discharged as a gunner. The support he might have given was short-lived as he re-enlisted at the beginning of October. Less than a fortnight after his brother-in-law's death, another potential family supporter, Audrey's younger brother, Maxwell (known as Bill), a poultry farmer and orchardist, had enlisted in the Army. Dick's sister, Barbara Elford, who had married a Corowa farmer, Roy Pearce, in 1937, lived far away. ${ }^{3}$ Audrey's mother, Alice, would in time move to Melbourne and live in an adjoining apartment to her daughter and grandchildren.

\footnotetext{
2 NAA: M2606, 23 for 'bias against the P.M.' in 1961 for not having done more for her; undated press cutting (ca 1992), Elford MSS.

3 Max Basham served in the ranks till the end of the war, when he was discharged as a trooper in the 9th Division Cavalry. After the war he worked for a while with the Olympic Tyre company before moving to Perth. Geoffrey Basham ended the war as a captain in the Infantry Corps after serving as a liaison officer at General MacArthur's headquarters. After the war he would own and operate a soft drink factory, become a hotel licensee, and eventually senior partner in a jam and pickle business. For the Basham brothers' war service see, http:// www.ww2roll.gov.au. Barbara Pearce had three children, owned and managed rural properties with her husband whom she outlived by several decades, and died aged 98 in 2006.
} 
Crushed by anxiety, Audrey had lost heart, finally giving up her Air Force job after fainting into a waste paper basket. She tried again, this time in postal censorship, but it was not a happy situation. Unwell, and in reduced circumstances, having moved into a two-room flat, Audrey had approached the new Labor government for assistance. The War Cabinet, on the recommendation of the Advisory War Council, approved an ex gratia payment of £250. A month later the War Cabinet revisited the matter and doubled the additional payment. It might have been more. ${ }^{4}$ But Archie Elford, scrupulous to the last, had included in a statement of his daughter-in-law's income and assets the $£ 4$ a week he had been giving her as well as her one-tenth share of the trustee sale of a recently deceased aunt's property in South Australia.

A year later, determined to be independent, Audrey worked briefly with the American Red Cross arranging accommodation for Marines on leave. The weekly subvention from Archie Elford was discontinued after four years, his own retirement income - he would die aged 94 in 1972 - not keeping pace with inflation. In 1944 she married a divorced Canadian-born airman, Bill Belfield. In poor health, her private life was troubled. The marriage ended three years later, after which she reverted to her previous married name. ${ }^{5}$ After the war Audrey worked in a real estate office for two years, then moved to the Royal Children's Hospital Auxiliary as Organising Secretary. Later, she worked for Don Chipp organising billets for the 1956 Olympic Games. She bought, refurbished, and sold old houses; and for a while ran a guest house. Her resolve to maintain her social position was strikingly visible in a white carpet, defiantly resisting the trampling of her boys and their friends, and a marvel to relatives visiting the home. The twins were her pride. If she could not have the life that she had hoped to share with Dick, she would do all she could for the young men who were his legacy to her. Particularly galling therefore were unsubstantiated stories in later years that Peggy Fairbairn had paid for the education of Dick Elford's sons at Geelong Grammar. ${ }^{6}$

In accordance with compensation regulations in force for the RAAF since 1930, Olive Hitchcock was awarded £750, of which £50 was to be held in trust for her son until he was 21 . Under the Superannuation Act, as the widow of a Permanent Air Force officer she was entitled to a pension per annum of $£ 169$ plus $£ 13$ for a child. It was not until October 1946 that it occurred to anyone in authority that an amendment to the Repatriation Act in December 1941 'would

\footnotetext{
4 NAA: A2676, 2172.

5 Married in 1944 to William Ewart Belfield, a Winnepeg-born, London-educated, pre-war building contractor, Audrey Elford resumed her former married name by deed poll after her divorce three years later. Belfield, then a flight rigger, had been seriously injured late in 1941 when caught in a roller moving a Fairey Battle crate at Point Cook (NAA: A705, 15 163/91/148; MT 522/1; A9301, 13041).

6 Audrey Elford, interview, 27 June 1977; Audrey Elford to CH, 30 June 1977, 11 Nov. 1978; NAA: A2676, 2172. For Audrey Elford's final years see the memoirs of her daughter-in-law: Jennifer Laycock Elford, the snow girl story: A Story about Survival and Revival, Wodonga, 2011.
} 
entitle the widow to consideration for War Pension'. A pension of £5.9.0 a fortnight was duly granted with an additional £1.15.0 a fortnight for her 'first child', backdated to the end of June 1945. ${ }^{7}$ Money had not been uppermost in Olive's mind. Knowing that the inscribed American Conklin pen-and-pencil set Bob had been carrying in his pocket, her precious gift to him, had not been found, she had hoped for 'just some little things belonging to my husband or some part of the plane, to forward to the Perth Museum to be placed alongside his father's'. For a few weeks after the crash she had moved to Glen Iris, five minutes' walk from Sheila Palmer, on whose behalf she wrote in November to the Prime Minister enquiring about the rosary beads Jack Palmer had with him when he died. Palmer's blue mittens, balaclava, and two scarves had already been returned along with sundry kit and uniform items.

Olive was inconsolable for months. It was not just being forgotten by inert and indifferent bureaucrats. Or even, four months after Bob's death, having to ask for the government's assurance that his funeral expenses would be met before the bank would allow her to operate her husband's savings account. ${ }^{8}$ The enduring trauma was the way in which she learned of her beloved Bob's death. The Prime Minister's office had let it be known that a ban had been imposed on the publication and broadcasting of the news until the relatives of the victims had been informed.

Mrs Menzies...played an important part in arrangements to break the news as gently as possible to relatives of the dead men, all of whom were married. She telephoned from the Lodge at Canberra to friends and acquaintances in Melbourne who were also acquainted with the families of many of the men in the plane, and they were thus spared the shock of receiving the news as a bald announcement. ${ }^{9}$

Not everyone was spared. According to several newspapers on August 14, Bob's mother, uninformed, had a presentiment of the tragedy. She was assisting at an RAAF camp-comforts canteen in Perth, it was said, and became so disturbed at 'an entertainment' that she left before the show ended. ${ }^{10}$ No newspaper reported what Bob Hitchcock's friend Rex Taylor heard. On the morning of August 13 Olive had an appointment at the hairdresser's.

Immediately following the accident, broad details were announced over the national, and some commercial, radio stations and the names of the passengers along with those of the aircrew were read out...at

7 NAA: A705, 300/1/9; A705, 166/17/1565; A705, 42/2/180.

8 NAA; A461, 700/1/392.

9 The Examiner, 14 Aug. 1940.

10 The West Australian, Barrier Miner, 14 Aug. 1940. 
that precise moment Olive was sitting in the Salon and heard the radio reference to her husband's name. It was a shocking experience for her, and one which would haunt her for the rest of her life.

Resolved to devote herself to the careful nurturing of her child Robert Jr, over the next decade and more she raised him into 'a fine youth and caring son'. Her nieces remembered her as a gifted dressmaker who made 'exquisite gowns, beaded and embroidered...the house was always full of rolls and rolls of materials, beads, furs, embroidery'. Young Robert became an enthusiastic member of the Air Training Corps. He was, as Rex Taylor saw, 'a source of great, but brief pleasure' in his mother's otherwise sad and grieving life. A daughter, Kaye, who became close to Bob, as he too came to be known, was the legacy of a casual encounter after the war ended. Anonymous phone calls and letters suggesting that her husband had been a fifth columnist who premeditated the crash had tormented Olive. As the years passed, distressing rumour and innuendo, defamatory of Bob's character and Service reputation, was never entirely extinguished. Olive's mother died in 1956. Wilfred Beecroft, who had sold his farm and moved with his wife to St Kilda to live with his daughter and grandchildren, died of cancer two years later. Olive moved to Springvale and nursed her father there through his final illness. Increasingly reclusive and paranoid, believing at times that she was being followed, she fell into recurring bouts of deep depression that was unrelieved by multiple electro-convulsive therapy sessions. Returning home one afternoon in July 1959, Robert discovered the body of his 47-year-old mother alone in the house. His 13-year-old half-sister Kaye had earlier found the doors and windows locked and was told to walk to an aunt's house several miles away. After numerous failed attempts, Olive had at last succeeded in escaping the misery that had engulfed her. ${ }^{11}$

For Robert's uncles, Les and Harry Hitchcock, there would be frequent reminders in the years ahead of the older brother they had lost. They had both, as they were promised, followed him into the Air Force. Harry entered as an aircraft mechanic, and in August 1940 was at Flemington as a sergeant instructor on air frames. He was commissioned as a technical officer in November 1943 and became the engineer officer of the Elementary Flying School at Benalla. Later he came under the wing of Rex Taylor, becoming his assistant engineer at No. 2 Training Group, Wagga. After the war, promoted to Wing Commander, he was head of RAAF motor transport engineering. For some years Harry assumed responsibility for his orphaned nephew's welfare. After the war, Les returned to work with West Australian Newspapers where he had been apprenticed as a

11 Joan Richardson to CH, 5 Oct. 2009; ACdre C. R. Taylor to CH, 25 Sept., 26 Oct. 1983; Fleta Page, 'Tragic bond lingers for air-crash families', Canberra Times, 14 Aug. 2013. Kaye Hitchcock, as she was known, would spend three happy months with Don and Claire Beecroft before being placed in the care of a father she had barely known. Four years of abuse ended with his death in a car accident (Kaye Greene, telephone interview, 29 Aug. 2013). 
compositor. He had been boarding an RAAF tender to catch the train at Perth en route for Point Cook when news of the Canberra crash came through the Pearce station communications centre. Bob Hitchcock's protégé Len Bacon, by then a flying officer, organised the cancellation of the travel orders so that Les could remain to comfort his mother. As early as 1943 when he joined No. 13 Squadron in Canberra preparing for duty in New Guinea and Borneo, a fellow senior NCO had shown him the then secret Air Court of Inquiry file.

In his later years Les proved a proud custodian of his older brother's memory. Their father had been 37 years and six months old when he perished in the Tanami. Their mother died 23 years later, aged just 62. Separated in life they were at last reunited. In 1929 Violet had arranged that she would be interred with her husband. Henry Smith Hitchcock's granite and marble headstone bears the additional inscription: 'Also his wife Violet Elizabeth born 21-3-1890 died 5-6-1952.'

The government ban on releasing news of the crash until the relatives were informed was well meant. But some families had proved harder to reach than those of the more distinguished passengers. Like Audrey Elford, Joan Wiesener - not one of the Prime Minister's circle - would learn of her husband's death in traumatic circumstances. Her daughter-in-law Diney Wiesener heard the story many years later from Joan's mother, Gertrude Beale:

Joan Wiesener was at the dentist in Macquarie Street when the dentist received a telephone call from her home telling him what had happened. The dentist then told Joan that her family had called and that she had to go straight home. She was about 6 months pregnant with Richard but he sent her off by herself. In the street she saw the newspaper billboards for the latest editions, announcing the accident and she knew what had happened.

Seventy years later, the family remained baffled and outraged. 'How she ever managed to get home, I will never know,' Diney Wiesener said. 'Why could that dentist not have called a taxi, and when it arrived, not seen her into it himself?'12 Joan's third child, born four months after her husband's death, was given his father's names, Richard Frederick. (His older brother's forenames were reversed and he became Antony Richard, known as 'Tony'.) Her husband's friend Ray Purves, later to rise to the commanding heights of the economy as Sir Raymond Purves CBE, chairman of Clyde Industries, became the guardian of her three young children. A congenital deformity of the feet had thwarted Purves' earnest effort in 1939 to enlist with Dick in the Air Force. He was to become a brilliant entrepreneurial financial adviser and mentor to members of the Wiesener family, many of whom became shareholders in Clyde Engineering. 
As a widow of a war appointee with dependent children, Joan was entitled to a pension of around three pounds a week. Like Dick's previous emoluments of $£ 427$ a year, the Service pension was not critical to her wellbeing. Her father Ronald had sold his interest in the Beale family company. Her parents now lived close by and ensured that she lacked for nothing. The children had a nurse. When the boys were old enough, they went as boarders to the King's School, Parramatta, their entry facilitated by the pastoralist Eric Hill. Richard left school at 16, learned accountancy, and completed his education at Columbia University before going on to a spectacularly successful and controversial career in business finance. While still a teenager he had met and would soon marry Diana ('Diney') Hipsley, daughter of his father's contemporary at Shore, Richard Burton Hipsley.

Margot Abbey Wiesener went to Frensham in Mittagong. She would grace the social pages while hinting at her career with a charm bracelet in the form of a tiny gold typewriter with a seed pearl-studded keyboard. ${ }^{13}$ In 1962, aged 24 and immediately after his headline-making divorce, she married the journalist Charles Buttrose, then an Australian Broadcasting Commission executive. Buttrose, whose secretary she had been, was 30 years her senior and father of four, including the precocious journalist Ita, and Will who was to become a notable banker. ${ }^{14}$ Joan's brother-in-law Brian Wiesener, just 15 when his brother died, completed his Leaving Certificate at Sydney Church of England Grammar School in 1942, and signed on to the Air Training Corps as a cadet two and a half years after the accident. Studying accountancy at the Metropolitan Business College, he worked as a junior audit clerk until on 14 August 1943, two years and a day after his brother perished, he enlisted in the RAAF as an ACl. In due course he became a sergeant pilot and served in New Guinea and in training units until demobilised and discharged in November 1945. After the war, he worked with Ray Purves before becoming a stockbroker with Ord Minnett. ${ }^{15}$

A total of 47 exhibits had been used to assist in identifying the victims of the accident for the Coroner. Not one of the personal items recovered from the crash site belonged to Dick Wiesener. Thus, when it came to convincing the NSW Probate Registrar that her husband was in fact dead, Joan Wiesener's solicitors had a problem. They had noted newspaper reports that the bodies were unrecognisable. Fortunately, the Coroner's finding and a photostat of the record of the identification of Wiesener by Group Captain Wilson sufficed. Perhaps they might have added conclusively a copy of the condolence message from the King. In any event, no one in the Registrar's office was in a position to question the basis, flawed as it almost certainly was, of 'Del' Wilson's determination.

13 Australian Women's Weekly, 26 October 1960.

14 Charles Buttrose, Words \& Music, Angus \& Robertson Publishers, London, 1984, pp.80-3.

15 James Murray, Phoenix to the World: The Story of Clyde Industries and Sir Raymond Purves, CBE, Playright Publishing, Sydney, 1992, pp.52-70; B. W. Wiesener, Personal File, NAA: A9301, 2002/05049050; J. R. Gorham and C. J. L. Hewett (eds), The Torch Bearers: War Service of Shore Old Boys 1939-1999, Shore Sydney Church of England Grammar School, North Sydney, 1999, p.595. 
A few months later Inez Thornthwaite, her husband's sole executrix, encountered the same problem with the NSW Probate authorities. Her incredulous solicitor explained to the Canberra Coroner:

The Registrar has refused to grant the probate until we can give evidence that her late husband was actually in the plane. We have pointed out that Colonel Thornthwaite's death was practically a matter of public knowledge, and have produced to him an official certificate of his death, but this will not satisfy him. He wants some evidence that Colonel Thornthwaite actually entered the plane at the time of the accident. ${ }^{16}$

Eventually common sense prevailed.

Inez Thornthwaite, who had turned 44 on the day the Lowe Inquiry began, was a woman of conviction and independent spirit. She was not going to be enfeebled by adversity. Her husband's headstone at Lismore cemetery would bear the blithesome inscription 'The luck of the game'. After receiving two fortnightly pension payments of $£ 4.9 .0$ she had promptly advised departmental officials that she had no wish to apply for a pension. She had substantial assets and no children to support. Her mother died six weeks after Frank Thornthwaite's fatal crash. Her parents-in-law as well as her own parents were dead, as were her husband's sister and two brothers. Liberated from family responsibilities, she continued her active role in the local Red Cross Society, the Country Women's Association, and Australian Comforts Fund. Scarcely a charity appeal went unheeded. ${ }^{17}$ Calamities like the bushfires in January 1944 that destroyed six of her station employees' cottages were surmounted with equanimity and an open swipe at a Premier's unfounded boast of 'gratifying' progress in rehabilitating burnt out areas. ${ }^{18}$ As the war went on she did not hide her opinions about the proper relations between government and people:

I am getting very tired of our present Government 'asking' various sections of the community to do certain things. The wharf labourers were 'asked' to return to work. The coalminers are frequently 'asked' to resume production. We are fighting 2 nations who do not 'ask' their populations to do certain things for the good of their country. Nothing will bring home our very serious position to some members of this community but strong action and enforcement of regulations which will ensure equal sacrifice by all to the war effort. ${ }^{19}$

16 Correspondence Feb., March, and May 1941 re proof of death, NAA: A6079/T1 and A432, 1940/764.

17 The Argus, 8 Nov. 1940; Camperdown Chronicle, 4 Jan. 1941, 20 Jan. 1942.

18 The Argus, 31 May 1944.

19 The Argus, 6 May 1943. She was rebuked the next day by another correspondent for what 'seems quite the wrong attitude to any democratic-minded person'. 
After the war, Inez spent 18 months in Britain, returning 'filled with admiration at the efficiency of all public services...but, above all, at the quiet determination with which the whole nation has gone to work, in spite of the maze of forms, regulations, and controls, to get the country back on to its feet ${ }^{\prime} .^{20}$ In 1947 , the Closer Settlement Board resumed 'Larra' and the homestead block of 1375 acres was sold. ${ }^{21}$ Having moved to Ocean Grove, and taken a flat in Alcaston House in 1950, Inez lived on until 1992, an intermittent but memorable presence in the lives of her cousins and their children to whom she was known as 'Dook', after a comic-book character whose straight-legged walk reminded them of hers. Living with a companion helper, and never afflicted by financial concerns, she inspired a bemused affection. As one of her contemporaries said in earshot of an awed member of the next generation: 'I don't suppose she has ever had to turn down her own bed.'

Once the Director of Staff Duties had confirmed for the Director of Personal Services that both Colonel Thornthwaite and General White were on duty when they were killed, the Army could determine its liability to pay compensation. Brudenell White had been appointed to his position directly by the Cabinet, with a salary inclusive of allowances other than travelling allowances of $£ 2000$ a year. The Army had no formal record of the appointment but, as a Citizen Force officer called back for full-time duty, it was eventually determined that he was a 'Member of the Forces' covered by Section 45 AT of the Australian Soldiers' Repatriation Act of 1940. His widow and 19-year-old student daughter, Rosemary, were dependants. Lady White was entitled to a share of the pension her husband was receiving before he was recalled to duty. A war pension of $£ 6$ a fortnight was approved to be paid in quarterly instalments. ${ }^{22}$

Proud of their husband and father, close to him as they had been, the Whites were devastated. Almost half a century later, his daughter Rosemary Derham would write:

The horror of his death haunted us, although we did not say so. He felt pain so much and to have been burned to death is unspeakable. Of course they told us that the impact killed them all and we pray that is what happened but we can never know.

For me, his anguish lives on. ${ }^{23}$

\footnotetext{
20 The Argus, 6 Nov. 1948.

21 Historic Homesteads of Australia, vol. two, Australian Council of National Trusts, Cassell, North Melbourne, 1976, p.267.

22 'War Pension benefit for families of Late General Sir C. B. B. White and Late Col. F Thornthwaite', NAA; MP508, 66/701/27.

23 Derham, The Silence Ruse, p. 269.
} 


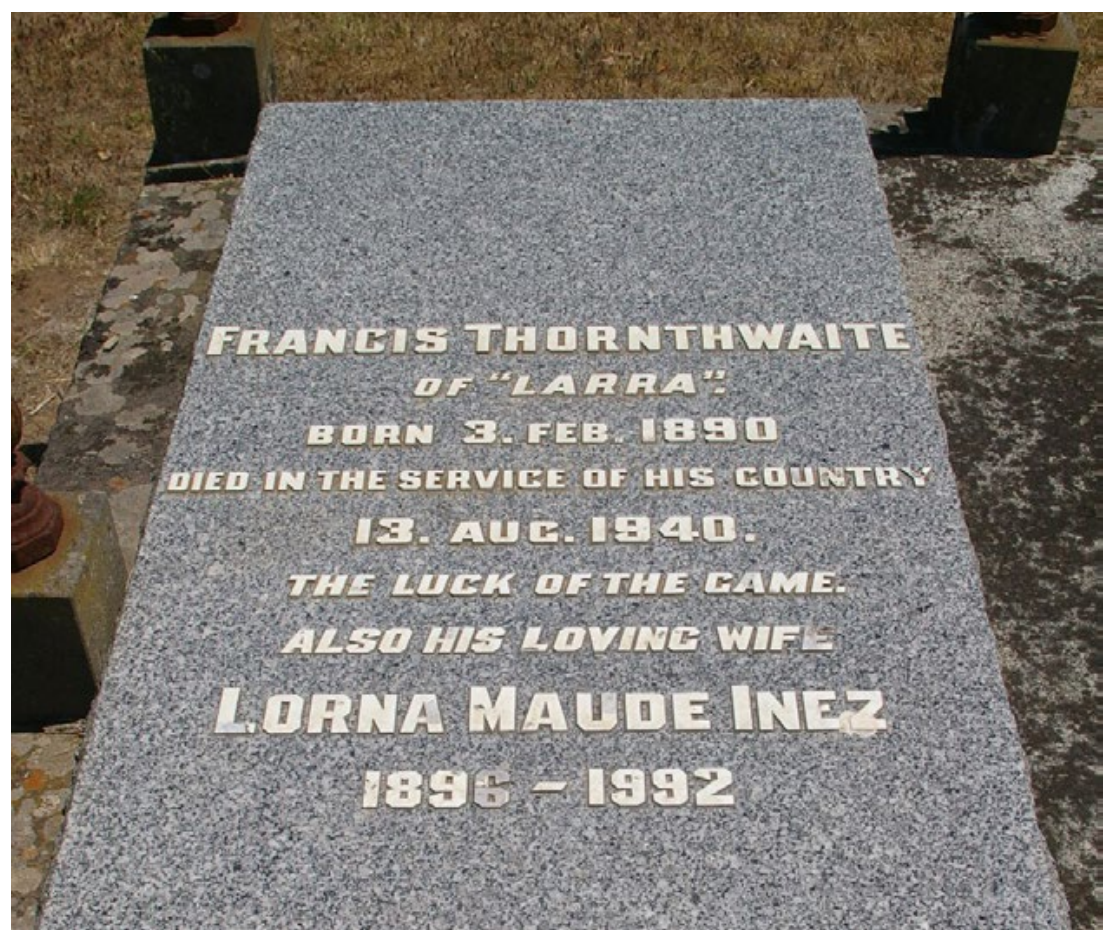

\section{Francis and Inez Thornthwaite, together after half a century}

(Courtesy of Carol Judkins)

The anguish for some had a tincture of guilt as well as sorrow. For young Geoffrey Fairbairn at Geelong Grammar, taken under the wing of the 26-year-old history master Manning Clark, there was no hiding the distress and confusion. With so much to live up to, his mother confided to the headmaster Dr Darling, it would be difficult for her son. She confessed that there was nothing she could say or do that was any help. Manning Clark had arrived in Melbourne to take up his teaching appointment three days before the Canberra tragedy. When he looked around his class a month later he noticed 'one face with pleading eyes...It was the look of a boy telling anyone with eyes to see: don't tell me there is any answer to my pain.' 'I remember,' Clark wrote in an obituary, 'showing him in 1941 at a time when the wound from his father's death still hurt — it was to hurt him all his life - the remark by Ivan in The Brothers Karamazov: "I want to be there when everyone suddenly understands what it has all been for."' ${ }^{24}$ What Geoffrey, who was for many years an academic colleague of Clark at The Australian National University, made of this, if indeed it happened, is not recorded.

24 Manning Clark, The Quest for Grace, Penguin Books, Ringwood, 1991, p.123; Manning Clark, 'Geoffrey Fairbairn - a conscience for "old" Australia', The Weekend Australian, 13-14 Sept. 1980, p.4. 
Canberra aerodrome, named 'Fairbairn' in February 1941, would be a reminder to the end of Geoffrey Fairbairn's days of 10 horrible deaths and the possibility that his father was somehow to blame for them. The erection of the two-metrehigh memorial cairn at the crash site and the memorial service there in August 1960 would accentuate, not assuage, the doubts. So, too, the renaming in 1962 of Headquarters RAAF Canberra as Headquarters RAAF Fairbairn. Even three decades after the crash it was evident that, in the language of the day, he had not found closure. For Geoffrey, and even more for his sister, Angela, who had been especially devoted to her father, young adulthood and later life were also to be indelibly marked by the absence of their mother.

Peggy Fairbairn had been bequeathed an annuity of two-thirds of the net annual income of her husband's trust fund (valued at over $£ 78800$ in Victoria as well as assets in Queensland and New South Wales). Understandably, she found her life 'quite empty' without Jim. She was an inveterate socialite, not made for reclusive widowhood. ${ }^{25}$ The family property came under the stewardship of her brother-in-law, Osborne. Knowing that her annuity would be halved if she were to wed again, in 1952 she married a British naval officer Commander Kenneth Kemble, 'an English charmer' as a niece remembered, and moved to England.$^{26}$ There she slipped into an accent so foreign to Australian ears that her daughter was to say she would need a course at the Berlitz School of Languages to understand her. Infrequent as her visits were to be (Angela's daughter, Mary, was to see her gregarious grandmother only three times), the family could rely on her for lively companionship on the occasions when she did re-join them.

To those of different temperament, wealth, and status there was conventional consolation, aid to tide them over, but limited prospects. Like Olive Hitchcock, Audrey Elford, and Joan Wiesener, Sheila Palmer was to be told of her husband's death hours after thousands already knew. As her son John Foley learned:

Sheila was unaware of the Canberra air disaster in the morning though there were Herald posters announcing it in the city as she went outside for a sandwich for lunch. Fortunately she ran into her brother Frank who took her to a café where they were able to sit down as he told her.

Sheila Palmer's sorrow, compounded by a dispute over the funeral service, was profound. Unusually for Catholic couples, after 15 months of marriage she and Jack had not been blessed with a child. During his service Jack, like all airmen members of the Permanent Air Force, had contributed to a compulsory superannuation fund at rates determined by his age and salary. An ACl fitter

25 Peggy Fairbairn to J. R. Darling, n.d., Geelong Grammar School Archives, A-F 1940, A-L 1941; Last will of James Valentine Fairbairn, and codicil, 13 April 1934, Public Record Office Victoria, VPRS 7591/P/2, 1121, 318/135; The Argus, 5 Dec. 1940.

26 Alethea Russell to $\mathrm{CH}$, (email), 22 Jan. 2009. 
would pay around 11 shillings a fortnight. With no children, Sheila Palmer could expect to receive a pension of $£ 65$ a year for the rest of her life. There would be a compensation payment of $£ 750$. It was little enough but she would have the support of her large family, and from 1942 she would be eligible for the new Commonwealth government's widow's pension as well.

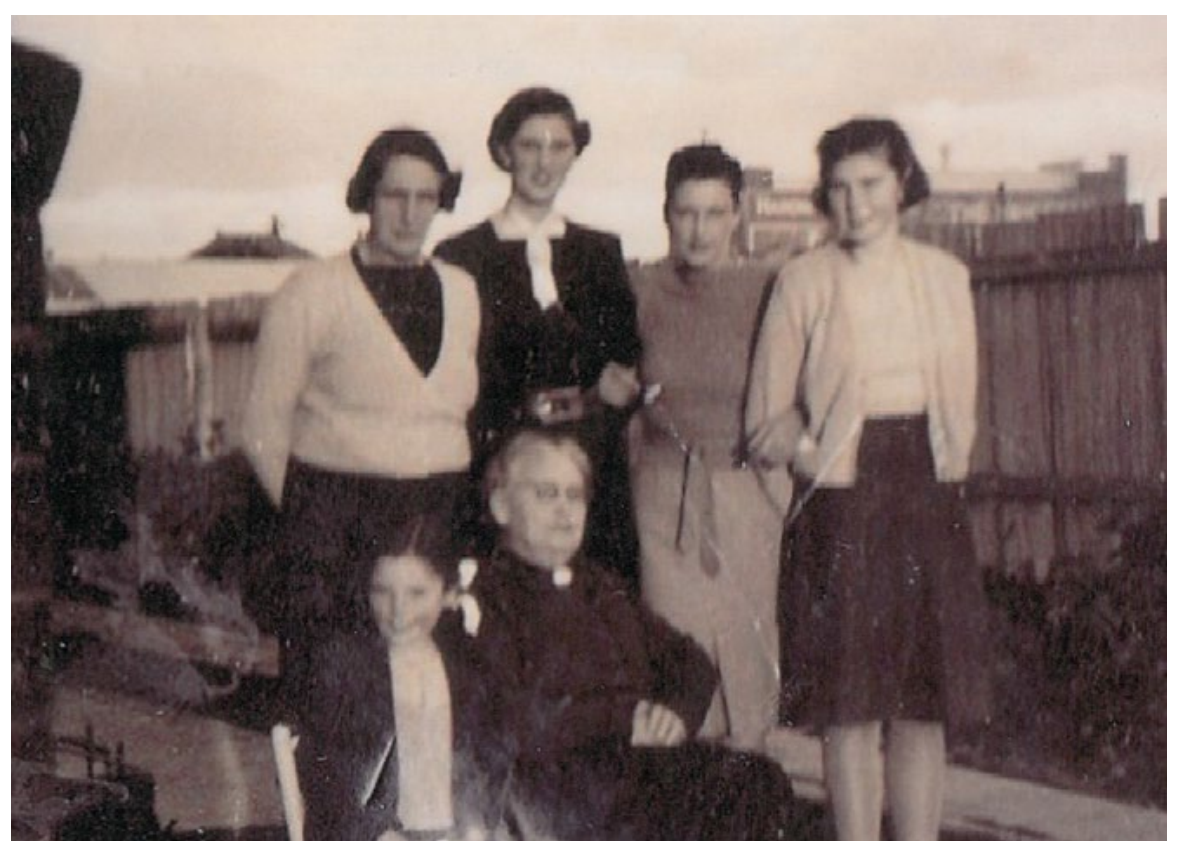

Sheila Palmer, the widow, tall among her sisters, nieces, and 'Grandma Curtain'

(Courtesy of Pat Snowball)

In 1944 she remarried. Her husband, Denis Foley, had emigrated from a small family farm in County Cork in 1935 after a falling out with his father and oldest brother. In his mid-twenties, with some experience of horse training, he found mostly labouring work where he could in outback Queensland and Western Australia and latterly in Johnny Connell's hotel on the corner of Flinders Lane and Elizabeth Street. Foley sang in the choir at St Mary's, East St Kilda; devoted to both Catholic faith and culture, he met Sheila not at church but at the races.

After the war Denis Foley and his wife, like four of Sheila's brothers, were put into a pub as managers by the patriarch of their generation, Cyril Curtain. Prosperous from his expanding legal practice, Cyril had become a hotel broker and eventually owner of a string of suburban and country public houses. The Curtain brothers would remain a sustaining force in their sister's life. Sheila's son, John, born late in 1944, looked up to them as role models. Jack Palmer's mother also remained close to Sheila. 'I well remember my mother taking 
me to meet Jack Palmer's mother when my father was at work', John Foley recalled, 'Mrs Palmer was a kindly gentle woman and she and my mother got on extremely well.' As the years went by, it was evident that Sheila's first great love was proving a disturbing presence to her second husband. 'My mother had many photographs of her time with Jack,' her son remembered, and 'many plans for the memorial which she approved. However this was a source of some friction with my father and these records have been lost.' Sheila Foley, a lifelong smoker, died of lung cancer aged 62 in $1974 .{ }^{27}$

Rita Crosdale was receiving £4.4.0. a fortnight at the time of her husband's death. As the authorities quickly noted, the payments would continue until 'the pension conditions are settled'. She could expect a pension of £109.4.0 a year to be supplemented by an additional pound a fortnight for her newborn son until he reached the age of 16. As Charlie's was a war appointment, no compensation was payable. ${ }^{28}$ But her special situation called forth special assistance. Monsignor Ken Morrison, then Laverton's Catholic chaplain, recalled the hours and days that followed the accident: 'A.C.l Crosdale's wife was in the Queen Victoria Hospital Melbourne, expecting a child when the crash occurred. I was sent off immediately to see about informing her. I discussed the matter with a woman doctor... and questioned whether it was wise to tell her.'

Believing that it was agreed that Rita Crosdale be shielded, the priest entrusted the hospital with keeping reporters and newspapers away. On his return to break the news the next day, he 'found other counsels had prevailed and she had been informed'.

Father Morrison, who had never met Charlie Crosdale, joined with Mary Daly of the Catholic Welfare Association in seeing to his widow's needs. Mrs Daly provided a christening robe for the baby. After the baptism in Footscray she and Father Morrison saw Rita off by train to Newcastle. The men at Laverton had a 'whip round' on the next pay day and several hundred pounds was entrusted to Morrison. The men knew that two years earlier the RAAF Airmen's Benevolent Fund - a voluntary contribution scheme managed by the airmen themselves - had ceased paying cash grants to cover hardship while compensation and superannuation payments were being processed. The fund had run out of money, partly as a result of the series of accidents in 1938 that had so perturbed Sir Edward Ellington. The Defence Minister had approved instead a scheme that paid approximately the airman's rate of fortnightly pay up to a total of $£ 50$. The amount was to be treated as an advance against whatever compensation - not more than three years' pay at the time of death - was eventually received. ${ }^{29}$ It

27 John Foley, biographical notes on Sheila Curtain, 23 July 2009, and Denis Foley [2009].

28 NAA: A705, 300/1/9.

29 Sec. Air Board to Sec. [Dept of Defence?], 31 Aug. 1938; Note by H. C. Thorby, 28 Oct. 1938, NAA: A705, 42/2/212; 'Compensation - Regulations,' NAA: A705, 42/2/180; Crosdale C. J. A9301, NAA: A9301, 6673. 
was helpful but not nearly enough. Morrison established a trust account with the money raised by Crosdale's workmates and assigned the administration to a local priest in Cessnock. ${ }^{30}$

Two other Crosdale boys who were old enough to serve, Francis and Fred, joined the Army and went to Egypt and New Guinea. Doug 'Tiger' Crosdale, who had wanted Charlie to send him aeroplane photographs to show his Air League friends, became a career soldier, serving in Japan, Korea, and Vietnam, mostly as an instructor, before retiring as a captain. Twelve years after her husband's death, Charlie Crosdale's widow married a local builder, James Marshall, with whom she was to have two children. Rita's second husband predeceased her and she married a third time. The family's tribulations had not ended with Charlie's death. Rita would write to the Prime Minister in 1960: 'I have had three nervous breakdowns in four years. I have never been the same since I received the shock from my late husband's death. ${ }^{31}$ Her son, Gary, born on the day his father was killed, was stricken with multiple sclerosis. Charlie's youngest brother Barry died, aged 35, leaving two children and a pregnant wife. A fireman, Barry had part-time work on his day off removing rubbish from local factories. One day, he had emptied his load but the back lid of the truck would not close. A piece of cardboard was jamming it. He pulled it away and the lid guillotined him. Tragedy followed tragedy. Another brother was burned to death in a house fire at the age of 40 . He had been alone. His wife was a nurse working the night shift; his children were staying with relatives. Sidney, the oldest brother, who had served as a mechanic with the Air Force in New Guinea, died of liver cancer at 58. In the annals of family misfortune, the Crosdales were perhaps the most sorely afflicted of those who lost a loved one in August 1940.

Gyp Street had been determined from the beginning of the war to once again 'do her bit'. She had gone down to Lismore, she said to an interviewer, to buy a sheep dog and learn to milk:

I am a countrywoman and the countrywoman's place is on her property... If she is able to assist in men's work she had much better stay there. I have kept station books and helped in boundary riding and sheep mustering. Most of these things I have done for fun. Now I will do them in earnest... Some may even learn to drive tractors, and a few may even be capable of driving teams should the necessity arise.

As it turned out, it was her daughter, Tim, who mastered milking as well as joining her mother for hours in the saddle and exhausting days in the yards. ${ }^{32}$ At home with Tim, who had turned 11 just two days earlier, Gyp was prostrate

30 Msgnr K. Morrison to CH, 14 Oct. 1982.

31 R. Marshall to Prime Minister, [8?] Aug. 1960, NAA: A463, 1960/3940.

32 Woman, 24 June 1940. 
on learning of her husband's death. Her son Tony, called to the headmaster's office at Melbourne Grammar to be given the news by the chaplain, was taken back to Lara by Gwenda Manifold to be with his mother. The family did not attend the service in St Paul's. Unusually for a man so well organised, Geoff Street had not made a will and it was necessary for his widow to seek letters of administration, a process that ran on into $1941 .{ }^{33}$ Her brother Clive Currie, recalled from the AIF, was entrusted with running the family estate as well as 'Gala', his own adjoining property. In due course Gyp saw her son Tony through Melbourne Grammar into the Royal Australian Navy in 1945-6 before he returned on Clive Currie's death to take up farming at Eildon. Eventually, persuaded by Ford Guthrie and Chettie Manifold that it was his duty, Tony Street followed his father into federal politics. He was well-liked and respected in Canberra and held a succession of Cabinet posts in Malcolm Fraser's coalition government, serving finally as Minister for Foreign Affairs 1980-83. Like his father, he was an enthusiastic cricketer, golfer, and flyer. Daughter Tim, like her mother a free spirit, fine horsewoman, golfer, and tennis player, married Gregor Gillespie and settled to a life on the land at Berry Bank, 10 miles down the road from the family property 'Eildon' at Lismore.

Among the large military presence at Geoff Street's funeral, Major W. J. R. Scott was observed to be representing the Army Minister's parents who were in Sydney. Jack Scott was Street's cousin. He was serving in intelligence at Melbourne's Victoria Barracks in August 1940 and was sent down to 'Eildon' to retrieve all of the official papers that the Army Minister had taken home. Gyp Street had met Scott in London during the first war. He had been in love with her then before she married. But she had not seen him again for over 20 years. Their friendship was to be rekindled after 1945. Childless and recently divorced for the second time, Scott had spent years in Japanese captivity after his 'Gull' force battalion was captured in Ambon. Sadly his reputation never recovered from his alleged too-easy compliance with his captors. He had told Gyp that what had kept him going during his years of internment had been the thought of her. Touched, sorry for him, and feeling an obligation to respond to his proclaimed devotion, Gyp married Scott in 1948. A man of some mystery in his middle years, and shunned by many of his former wartime comrades, Scott would struggle with his demons until his death eight years later. ${ }^{34}$

For Dick Elford's parents the pain of his loss could not be masked by the emotional reticence of the many letters they had to write: 'We were very proud of Dick and felt sure that he had a great future before him,' his father wrote to

33 Street left personal property in Victoria valued at £639.14.10. (The Argus, 15 Jan. 1941).

34 Scott had been divorced in 1926 and on 8 February 1930 had married a widow, Andree Adelaide Oatley, née Kaeppel. After their divorce in 1948, on May 5 he married Gyp Street. He died in Adelaide in November 1956. I am grateful to Mrs 'Tim' Gillespie for information about her mother and Scott (telephone interview, 31 Jan. 2010). 
Sir John Latham. 'Every one has been most kind in trying to soften the blow as much as possible by bearing tribute to the high regard in which Dick was held.' They appreciated the references the Prime Minister and other ministers made to him in the House of Representatives. Mackenzie King, the Prime Minister of Canada, had taken the trouble to send a message to Audrey Elford saying that he had seen quite a lot of Dick in Canada and had formed a very high opinion of him and had thought that he had a great future ahead of him'. ${ }^{35}$ The Geelong Grammar School magazine commended 'a particularly loyal old boy' who had been on the committee of the Old Geelong Grammarians' Association since 1929.

Although Archie Elford was to tell Dr Darling that the family could not afford the fees, junior school places were found in 1946 for the twins. Hugh left after three years, his mother having been encouraged by the headmaster to guide him towards a non-academic path. His later life of service in employment, accommodation and advocacy associations for people with disabilities was acknowledged with an OAM. David, who was to have a distinguished career as a mechanical engineer and inventor, stayed at the school until 1951. He won a Commonwealth scholarship for university study but thought it unreasonable to his mother to take it. In search of a 'career without a degree' he was introduced to several of his grandfather's business friends before finding a berth in an engineering firm. After many years of design innovation and business success while struggling with gender disphoria, he eventually emerged as the vivacious Dianne Boddy, whose husband Harold had been a contemporary of her father's at Geelong Grammar. ${ }^{36}$

What Audrey Elford and her parents-in-law knew was that Dick had been longing to be set free from his civilian employment so that he could join the Air Force. His heart was set on becoming a combat flyer as his boss once had been, like the flamboyant, ever mischievous young men who were rapidly rising to prominence in the RAAF. The Rev. J. H. Allen, the Geelong Grammar chaplain, had read the burial service for both Fairbairn and Elford at the Springvale cemetery. But in a final loving gesture, the family decided to release Dick's ashes from the air over the city. Freddie Thomas and Bob Dalkin of No. 2 Squadron, with a crew dressed in their best blues, took a Hudson up over the coast on the eastern side of Port Philip Bay. Dalkin was given the task of dispersing the contents of the urn. All those aboard the aeroplane learned something that day about the airflow over the fuselage of a Hudson. ${ }^{37}$

As for the remains of Lockheed Hudson A16-97, their destiny was written on RAAF form E/E.88, 'Record Card Airframes, Aero Engines and Mechanical

35 A. S. Elford to Latham, 24 Aug. 1940, Latham MSS, NLA MS 1009/54/5489.

36 Dianne Boddy to $\mathrm{CH}$, (email), 9,10 Jan. 2011. Hugh Elford's adult years are part of the snow girl story, the memoir by his wife, Jennifer Laycock Elford.

37 ACdre R. N. Dalkin, interview, 18 April 1978. 
Transport'. The Air Member for Organisation and Equipment approved their 'conversion to components' on 27 August 1940. Not much was reusable. The Service Court of Inquiry had concluded: 'Aircraft completely burnt with exception of portion of starboard mainplane, tail plane, stabilizers and rudder.' The unserviceable residue was dumped at the Canberra tip, then in the inner suburb of Reid. At least one propeller found its way there, to be discovered and retrieved by a fossicking Commonwealth Commissioner of Patents, Harold Wilmot. A metallurgist, Wilmot was interested in the properties of the propeller's new material, duraluminum, a blend of aluminium, copper, and magnesium. From Wilmot one blade of the propeller was eventually passed on together with his home forge to his senior public service colleague Sir Roland Wilson of the Treasury. Wilson would fill idle retirement moments by fashioning ashtrays and toys from molten slices of the metal. Sixty-seven years after the crash, the last blade was the centrepiece of a small display cabinet in the National Museum of Australia. ${ }^{38}$ In addition to whatever else could be salvaged, the Twin Row Wasp engines, 2845L (port) and 2853R (starboard), were 'converted'. The Service Court of Inquiry had recorded that the engines were 'completely burnt and of no further use except possibly for instruction'. But they had not allowed for the resourcefulness of the mechanics. The fate of the Wasps was to furnish replacement parts for their surviving but worn or damaged siblings. ${ }^{39}$

\section{Those who remained}

Of Bob Hitchcock's fellow cadets, the stories of some of those who survived after 13 August 1940 tell us what might have been for him. Flight Lieutenant Johnny Bell was to be the first RAAF pilot who died on active service, killed while attempting a daring rescue of General De Gaulle's family from northern Brittany in June $1940 .{ }^{40}$ Squadron Leader Norman Hick survived until his No. 10 Squadron Sunderland crashed on landing at Pembroke Dock, Milford Haven in June 1941. ${ }^{41}$ Don Macpherson, whose distinguished pass in June 1936 was

\footnotetext{
38 Sir Roland Wilson, interview with Cameron Hazlehurst and Colin Forster, 28 March 1984; David Wardle, notes of interview with Sir Roland Wilson, [8] Jan. 1990, National Museum of Australia, File 90/11, courtesy Daniel Oakman.

39 'Proceedings of Court of Inquiry-Flying Accidents, Master Copy, Vol. 1', NAA: A98451, 318/30; Aircraft status card: Lockheed Hudson A16-97, NAA: A10297, BLOCK 84/180. From early 1941 log books of airframes and aero engines converted, written off, or assumed to be total losses, were no longer held at Air Force HQ but retained by units for a year and then submitted for disposal (NAA: A705, 87/4/815). A16-97's log books and history sheets were with the Director of Engineering until late Oct. 1940 and then returned to Southern Area. Disposal action was initiated by RAAF Station Canberra in Jan. 1941 (NAA: A2408, 1 87/4/808; 334/1/1 [3053], A705, 32/10/2733).

40 The story has recently been told in: Alan Hall, Four men and the walrus: the secret mission to rescue Madam Charles De Gaulle \& family by the first two Royal Australian Air Force members to have ever died in action together with two British Defence members, [Downard Crescent, Victoria], [2014].

41 NAA: A9300, HICK AN; NAA: 705, 163/36/86.
} 
a harbinger of future success, became the first commanding officer of the Point Cook Signals School; a Wing Commander aged 28, Macpherson died when the MV Melbourne Star was sunk in the Atlantic in 1943. Bob's friend Wing Commander Bill Keenan DFC commanded No. 13 Squadron during the war and retired as an honorary Group Captain in 1960. ${ }^{42}$ By late 1941 Bill Allshorn was CO of No. 21 Squadron in Malaya but was relieved 'on account of unsatisfactory leadership in connection with air operations'. He would go on to command No. 4 Squadron and No. 5 EFTS and end the war as a Wing Commander. Eric V. Read had survived a crash in bad weather in December 1936 which saw him unable to fly for nine months; he ended the war as a Wing Commander AFC. Squadron Leader G. J. Quinan, promoted temporary flight lieutenant in February 1940 (with effect from 1 September 1939), commanded the Australian Army Cooperation Squadron in 1941 and was senior instructor in the new Army Air Cooperation School in 1942; he transferred to the CAF Reserve at his own request in February 1945 after leading both No. 4 and No. 5 Squadrons in New Guinea. ${ }^{43}$ Ted Fyfe commanded No. 21 Squadron, was awarded a DSO, and retired as a Group Captain CBE in 1969 after a series of senior staff appointments. ${ }^{44}$

In a massively expanded air force, there were operational and administrative posts for all of the pre-war generation who survived. Gerry Buscombe, for example, was promoted squadron leader and, 16 days after Bob Hitchcock's death, given command of the new No. 7 Elementary Flying Training School in Tasmania. Three years later Eric Lansell, now a Wing Commander, took over 7 EFTS. He had previously commanded the Armament Training Station at Laverton. Early in 1945 Wing Commander Norman 'Phil' Ford was appointed to head the Central Flying School at Point Cook. Air Marshal Sir Colin Hannah would rise through operational and administrative posts during the war, reach the pinnacle of the RAAF in 1970 as Chief of the Air Staff, retire early, and

\footnotetext{
42 KEENAN, William James NAA: A12372 R/342/H,P. Keenan's DFC citation referred to his 'conspicuous leadership and ability' but his postwar career stalled with 'below average' assessments of his 'inexpressive personality'.

43 NAA: A9300, QUINAN GJ.

44 FYFE, Edwin Glen NAA: A12372 R/340/H,P.
} 
then serve a controversial term as Governor of Queensland. ${ }^{45}$ After several years in the RAF, Dickie Cohen returned to Australia with a DFC and a glowing reputation; aged 27, he was promoted Group Captain in 1943, and held a series of senior training and HQ posts before beginning a public service career as Richard Kingsland in 1947. He became Secretary of the Departments of the Interior, Repatriation and Veterans' Affairs. Knighted in 1978, he was appointed an Officer (AO) of the Order of Australia in 1989. He died in August 2012, the last of Hitchcock's cadet contemporaries. ${ }^{46}$

\section{A fatal decision?}

In August 1940, 25-year-old Sergeant Jo Gullett of the AIF was attending a British Army tactical school in Cairo. He learned of his father's death from the senior officer of the school, before receiving a cable from his mother who had been in Sydney, returning from a holiday in Queensland with her daughter Sue. He returned briefly to Australia, finding his mother like the other widows in great shock 'accentuated... by the unavoidably public nature of the church services and funerals'. Assured that his father's farm was in the hands of a capable neighbour, and confident that his mother 'always kept a firm hand in her affairs', he set his face again to the war. 'I was sad to leave my mother and sister in the large house, but at least they were comfortable among friends. It did not occur to anyone that I should not return to the battalion. ${ }^{47}$

45 Five airmen also graduated as Temporary Sergeant Pilots in July 1936: Lou Lohse, after nine years in the Permanent RAAF enrolled in the Air Force Reserve in 1938 and was appointed by ANA as an instructor, captained DC-2s and DC-3s, joined BCPA, re-joined the RAAF, and was discharged as a F/Lt (NAA: A9301/2, A9300, 2002/05090488; see also the No. 22 Squadron Association web site). Kenneth Berry, mustered on enlistment as a W/T operator, graduated third with a distinguished pass, was discharged to the Reserve in 1937 on appointment to Qantas; he returned as an F/O in Sept. 1939, was promoted F/Lt 1943, served briefly with No. 36 Squadron in Merauke before resuming civil occupation in 1945 (NAA: A9301, A9301/2, A9300, 2002). Reginald Peverell, formerly a PMG telephone mechanic and RCA instrument adjuster, then a RAAF $\mathrm{W} / \mathrm{T}$ operator mechanic, was discharged in 1937 'at own request, on payment of $£ 240 \mathrm{~s} 0 \mathrm{~d}^{\prime}$ after barely passing the 'ab initio' seaplane training course; enrolled in the Reserve while a Qantas First Officer, he died after a motor accident in 1938 (NAA: A9301, 2002/04901212). Cliff Tuttleby DFC AFM, commissioned in June 1941, served with Nos 7, 8 and 100 Squadrons in Beaufort bomber operations over New Guinea 1942-3, No. 24 Squadron in B24 Liberators over Morotai, North Moluccas 1944-45; RAAF 'mutiny' New Guinea 1943; discharged as F/Lt 1947 (NAA: A9300, TUTTLEBY CE; Recorded interview with Fred Morton, 1980, Imperial War Museum 9670). Douglas Edwin Morgan, enlisted in 1933 after a year in CAF, experienced in motor and general engineering, served at No.1 A.D. with Hitchcock; a warrant officer and flying instructor by 1938, he was posted to the General Reconnaissance School in April 1940; commissioned in 1942, promoted F/Lt (temp.) 1944; Milne Bay with No. 33 Squadron 1943-44; transferred to Reserve Aug. 1945 (NAA: A9300, A9301 2002). 46 Deborah Cornwall, 'Short straw, long straw: a deadly decision', Sydney Morning Herald, 18 June 1990; NAA: A705, 163/23/53 (Bell); NAA: A9300, MACPHERSON DJ; Vincent, The RAAF Hudson Story Book One, p.377 (Allshorn); Anne Twomey, The Chameleon Crown: The Queen and her Australian Governors, Federation Press, Sydney, 2006, pp.62-8, 161-76 (Hannah); John Farqhuarson, 'Boys Own adventures in wartime and sterling public service', The Age, 29 Aug. 2012 (Cohen/Kingsland).

47 Gullett, Good Company, pp.132-3. 
Though their wealth was modest - Gullett's real and personal estate was sworn at $£ 13265$ - Penny Gullett and her children had been well provided for through her mother's will. She would not need her husband's gold railway pass, which as the widow of a minister who had served for three years, she was entitled to keep. ${ }^{48}$ In time, however, Orchard Cottage would prove too big and expensive to keep up. Staff were almost impossible to find. She moved into a flat in South Yarra. As Jo moved on with other Australian forces from North Africa to New Guinea, Melbourne was swamped by American troops. Jo's sister Sue, like many impressionable young Australian women, was swept off her feet by an American officer, an assistant military attaché at the American legation, and went as a war bride to the United States. The marriage did not last. She remarried in 1948 to a British oil company executive, Paul Hackforth-Jones. ${ }^{49}$

A daughter departed, and anxious not to lose her son as well as her husband, Penny Gullett contrived to get Jo the UAP pre-selection for his father's old seat of Henty for the 1943 election. To his relief, he was defeated by the sitting Independent, Arthur Coles. Major Gullett, as he had become, would not return to New Guinea but was posted to England to serve with the British Army. Returning from the war an infantry company commander with an $\mathrm{MC}$, and rare personal experiences for an Australian officer of D-Day and the battle of Normandy, he was easily elected to the House of Representatives when Arthur Coles chose not to run again in 1946. Jo was not a natural parliamentarian. Although he became Chief Whip for the Menzies government, he was never completely comfortable with the sacrifice of independence that party politics demanded. As the Prime Minister reflected on learning of Gullett's retirement, he had been 'rather ready to reconcile the office of Government Whip with that of chief Government critic'.$^{50}$ After a term as Ambassador to Greece he returned to farming at 'Lambrigg' on the Murrumbidgee.

Jo Gullett was to publish two acclaimed autobiographical works - a war memoir and a fine evocation of his early life with an admiring but believable portrait of his father. ${ }^{51}$ Convivial, plainspoken, a vivid writer and raconteur, Jo had a good 'drinking friend', Group Captain Dixie Chapman. They met regularly in the Naval and Military Club in Melbourne. Chapman, a career officer with a farming background, had served with mixed success through the war and postwar period, earning by his own admission 'a somewhat dubious erstwhile reputation as a drinker'. He had been commissioned as a pilot officer in 1935 after instruction on Wapitis by Eric Douglas who, with Charles Eaton, had

\footnotetext{
48 The Argus, 16 Aug. 1940.

49 Their daughter, Penne Hackforth-Jones, would enjoy a successful career as an actress and biographer of her great-grandmother, Barbara Baynton. Her death was announced in May 2013.

50 Menzies to Heather Henderson, 31 Oct. 1955, Heather Henderson (ed.), Letters to my Daughter: Robert Menzies, letters, 1955-1975, Pier 9, Millers Point, NSW, 2011, p.14.

51 Not as a Duty Only: an infantryman's war, MUP, 1976.
} 
buried Bob Hitchcock's father in the Tanami. He was a flying instructor at Point Cook the following year. Promoted rapidly, he was a flight lieutenant by 1938, and in July 1939 became Deputy Director of Training at RAAF headquarters. On 1 June 1940 he was made a squadron leader though he was not appointed to a squadron until the end of the year. ${ }^{52}$

One afternoon at the club, the conversation turned to Jo Gullett's father and the events of August 1940. Chapman had an extraordinary tale. About a fortnight before the crash, he said, he had taken Bob Hitchcock for his annual flying test. Coming in to land Hitchcock had lost flying speed. Chapman told him to 'give it a gun' and go round again. The same thing happened. Chapman took over the controls himself. Alarmed by what he had seen, Chapman failed the No.2 Squadron flight commander. Hitchcock, he ruled, was not to captain again until he had sorted out his problem. Hitchcock appealed against the suspension. Then, Chapman said, the Minister for Air personally overrode the decision. ${ }^{53}$

The story was startling. Nothing that would confirm it emerged from the archives. Could it possibly have been true? Why would Chapman, holding a headquarters post, have been taking Hitchcock's flying test, normally the task of a senior officer at Laverton? Could the story be verified? The first and most obvious question is whether Hitchcock was due for a test at the time Chapman indicated. To that question the answer would seem to be 'yes'. He had been put through his paces for the 'RAAF Annual Confidential Report (Officers)' in June 1939. Unfortunately, the documents presented to the inquiries in 1940, and files released later to scholars, contain no such report (Form P/P. 29) by Hitchcock's CO for 1940. If a flying test had not been taken it was also probably overdue. Hitchcock had been at No. 2 Squadron for over a year. Possibly, because of the heavy training and operational demands of the first year of war the annual assessment due in June had been deferred. ${ }^{54}$ But if a flying test had been taken where was the report?

Was there anything else to lend credence to Chapman's story? Could he be placed at Laverton at the right time? The logical place to look was Hitchcock's flying log book. There, in Hitchcock's own hand, we find an entry for Thursday, 25 July 1940 with several unusual names. Hitchcock had taken Hudson No. 54 for an hour and a half. The stated 'duty' was 'Cloud flying \& compass swing.' There were three other people with him. None had flown with him in recent months. They were not pupils under his command. Under the heading ' $2{ }^{\text {nd }}$ Pilot, Pupil or Passenger' are three names: 'Hilder Chapman F/L Kingwell.' It was an

\footnotetext{
52 CHAPMAN, Dixie Robison, NAA: A12372 R/335/P.

53 H. B. Gullett, telephone interview, 19 July 1978; interview, 7 Aug 1978.

54 I have not noticed a report written in 1940 in any other personnel files. There is a gap in the reports on F/Lt then S/Ldr Frank Headlam between one signed in June 1939 and another for the period March 1940 to Feb. 1941 (NAA: A12372, R/331/P). S/Ldr K. Parsons had a report from Dec. 1939 to Feb. 1941 (NAA: A12372, R/337/P).
} 
extraordinary group. Brett Hilder was a 29-year-old former merchant marine officer with an Extra Master's ticket, who had been called up from the naval reserve into the RAN at the beginning of the war. Appalled at the lowly status he was given and the exiguous pay he was receiving, Hilder effectively absconded from the Navy and offered his services to the RAAF. After passing a navigation instructors' conversion course with 'special distinction' he was happily received into the RAAF fold on secondment on 13 May 1940. 'Although I knew nothing about Air Navigation itself, my knowledge of navigation generally was possibly superior to that of anyone else in Australia.' His navigation expertise, such as it was, being at a premium in the Air Force he was now assisting at Point Cook as a navigation reconnaissance instructor, temporary flight lieutenant, with special knowledge of naval co-operation. ${ }^{55}$

Flight Lieutenant Deryck Kingwell's assignment at the time was leading the instructional work on the navigation reconnaissance course. Among his pupils were Dick Wiesener, Bob Dalkin, Bill White, and Peter Fowler. The presence of Kingwell and Hilder in Al6-54 suggests that Hitchcock was being given some pointers to assist him in his own work with the young officers in his flight whom he was familiarising with the Hudson. Compass swinging - calculating the compensation required to adjust for deviations caused by the proximity of metal objects, magnetic fields, and electrical equipment, including radios - was normally done on the ground. But, as it was the Hudson's undercarriage that was causing problems with the pilots' compasses, the calculations had to be done in the air. Kingwell was with Hitchcock again two days later in a different aircraft for compass swinging and preparation of the deviation card for A16-80. ${ }^{56}$

And 'Chapman'? In a photograph of officers of No. 2 Squadron taken by the squadron photographer Frank Jefferies late in August 1940, sitting in the front row between Flight Lieutenants Neville Hemsworth and Ray Garrett is a 'Chapman' ${ }^{57}$ However, this Chapman appears from his uniform to be a flight lieutenant, and was in fact F. B. Chapman of the RAAF Reserve who was posted to the squadron on August 17 and began his Hudson conversion course with

55 For the tale of Brett Hilder's self-initiated conversion from the Navy to the Air Force, see his Navigator in the South Seas, pp.81-5.

56 'Navigation Facilities Hudson Aircraft', NAA: A705, 9/19/144; F. W. Wood and P. M. McGregor, Magnetic survey of compass swinging site, R.A.A.F. airfield, Laverton, Victoria, Bureau of Mineral Resources, Geology and Geophysics, Canberra, 1953.

57 Bennett, Highest Traditions, p.112. Bennett does not date the photograph; but it cannot be earlier than 26 August 1940 when Hemsworth joined the squadron. 
Jack Ryland two days later. ${ }^{58}$ Of Squadron Leader Dixie Chapman there is no sign. Service records throw no light on his possible role at Laverton in those weeks. ${ }^{59}$

The story as Jo Gullett recalled it is impossible to verify. Was Chapman conflating several episodes? Remembering perhaps something that had happened at Point Cook in 1936 when he was a flight commander and flying instructor? Or a flight in August 1939 when Hitchcock was undergoing dual instruction with him in an NA33. Though it is possible, this seems unlikely. In the latter case, Hitchcock was in the air twice more the same day, three times the day after, and again twice three days on. Chapman does not appear to have been with him again at this time during which his airmanship was being assessed ${ }^{60}$ Whatever truth there was in Dixie Chapman's recollections, there is no evidence to suggest that Hitchcock's flying was significantly interrupted in the weeks after he went up with him, together with Hilder and Kingwell, on Thursday July 25. Hitchcock's logbook tendered to the Service Court of Inquiry shows him doing instrument flying, cloud flying, photography, local night flying, and flight formation with various crews on an almost daily basis from July 27 to August 11. It is inconceivable that so serious a matter as a recommendation to suspend a flight commander's right to captain an aircraft could have been written up, endorsed, forwarded to a higher authority, and overruled in the space of a day.

Did Jo Gullett misunderstand what his companion said? Could Chapman have embellished his story? He had a reputation in later years for a 'wingeing attitude re his career' (Val Hancock) and exaggerating 'situations and circumstances' (Colin Hannah). ${ }^{61}$ But surely this was too poignant a subject of which to speak lightly to the son of a man who perished. Could it have been that on that July 25 flight Chapman, then Deputy Director of Training, had been so concerned about what he saw that he spoke of it to No. 2 Squadron's CO? Did he urge some dramatic action to improve Hitchcock's performance? Did Freddie Thomas, knowing of the degree of political protection that Hitchcock had enjoyed, decide there was no point in taking the matter further? Thomas would, after all, have had the comfort of knowing that Ryland, a tough instructor, had certified Hitchcock as competent to fly the Hudson. Everyone knew that the Hudson could be tricky to handle. One imperfect episode was hardly a justification for blighting a man's career.

\footnotetext{
58 NAA: A9300, CHAPMAN FB; Flying Log Book of J. P. Ryland, Aug.-Sept. 1940, Ryland Papers, NLA MS 5020 Box 1. I am grateful to Martin James, Senior Historical Officer, Office of Air Force History, for help with this identification (email, 6 March 2008).

59 Apart from normal routine duties, as Deputy Director of Training Chapman 'engaged in the formulation of the Empire Air Training Scheme plan as applicable to the R.A.A.F, examining civilian flying training schools... and flight testing civilian flying instructors' (CHAPMAN Dixie Robison, NAA: A12372 R/335/H).

60 R. E. Hitchcock, Flying Log Book, NAA: A705, 32/10/2729 Attachment 1.

61 NAA: A12372 R/335/H.
} 
If official records that would illuminate Chapman's story ever existed it is easy to imagine why they might have been purposely mislaid. Like so many elements of the story of A16-97 we are left with uncertainty. Some of that uncertainty was undoubtedly deliberately created. The fate of the 10 men whose journeys ended in Duncan Cameron's farm was poorly explained in 1940. The rush to conclusion suited the Air Force. It was politically convenient. For the children and grandchildren of the victims, for their surviving friends and comrades, for all who still seek answers to questions that should have been asked long ago, the truth about Bob Hitchcock's last flight remains elusive.

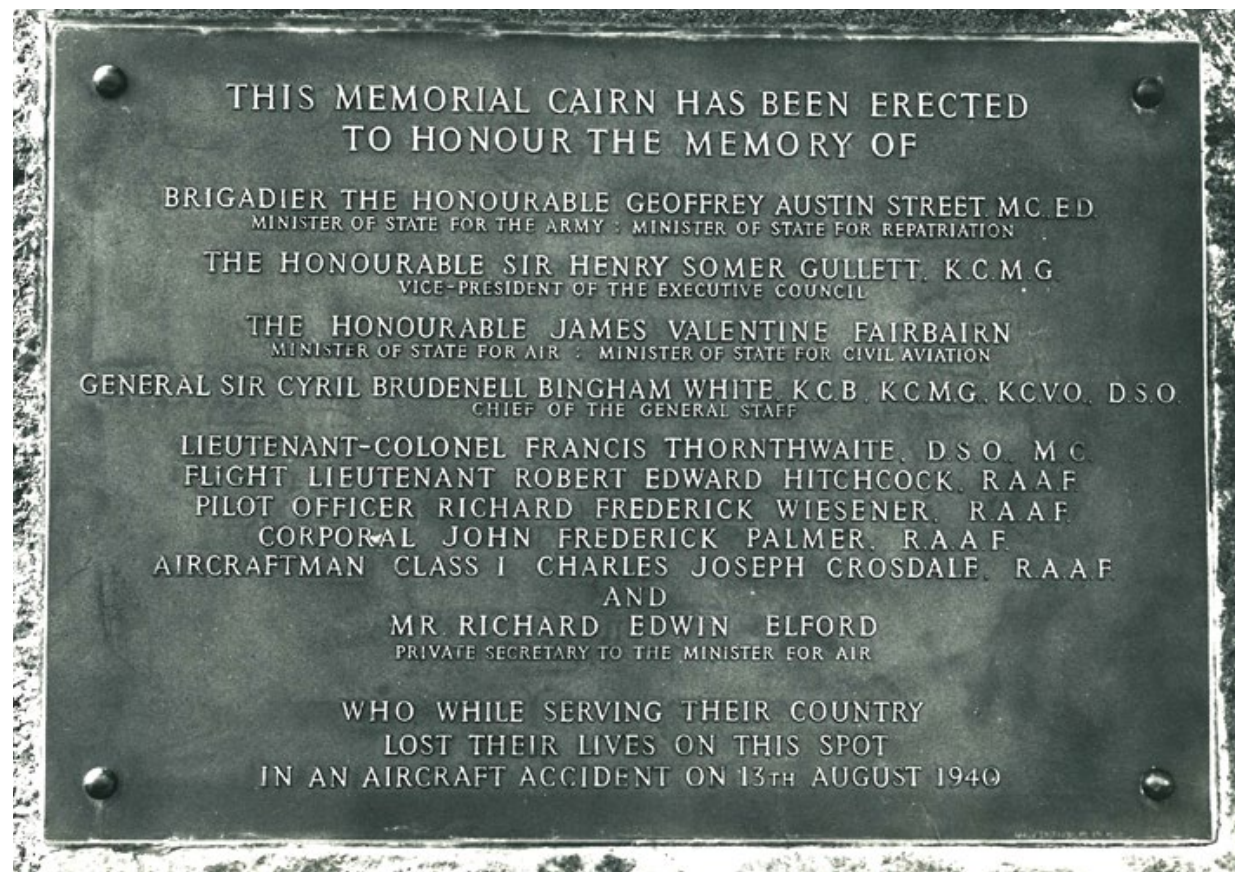

\section{Plaque on the cairn}

(Australian News and Information Bureau) 


\section{Sources and acknowledgements}

Scholars writing about recent history - the past that is within living memory — do not and should not believe everything they are told. Nor for that matter everything they read. They should be sceptical about motives, alert to faulty recall, and watchful for undeclared jealousies and enmities.

Some of my professional colleagues may cavil at reliance on some of the evidence deployed in this book, particularly the quotation of conversations recalled after 40 , 50, or, in some cases, more than 60 years. I am happy to acknowledge the likelihood that the remembered words might in many cases differ from those that were actually spoken long ago. This could diminish the reliability of some testimony. But one thing should be clear. Unlike some earlier accounts of the events and characters critical to the story I have told, the conclusions reached are not based on a bare handful of affirmations or allegations. Where there is conflicting testimony of roughly equivalent probability, it is all presented. As so much of the story turns on perceptions of personality and judgments of ability, it seems to me that the lesser evil is to let people speak for themselves wherever possible. If there is reason to doubt the essence of what they say then that is indicated. Vigilant readers will see a number of occasions where I have discounted or discarded testimony that cannot be true.

The research on which this book is based began in 1976. All of the documentary and newspaper sources on which I have drawn are cited in the footnotes. I follow therefore the precept of my late colleague and friend Allan Martin in his biography of Sir Robert Menzies: 'it would be tedious, not to say pretentious, to list them in detail here'. The many people who responded to my enquiries with interviews, written recollections, telephone calls, and other informal conversations are also acknowledged in the footnote references. Sadly most of them have not lived to see the work completed. But their contributions testify to the unique value of the memories of men and women 'who were there'. I am very conscious of the gaps that might have been filled had my research been more persistent and more thorough. If I knew then what I know now... Yet I am deeply indebted to those who shared with me their observations of old friends, family, and comrades; explained technical matters that were beyond my ken; identified locations, and recounted experiences, routine, exhilarating, emotional, painful, even traumatic. To all of them, for this and in many cases for most enjoyable hospitality and patient encouragement, I offer a candid account which I hope will not disappoint. Of those few who did not help, though they could have done so, or were economical with the truth, only they can have known how much better the book might have been. 
I owe particular gratitude to a number of people who were especially close to those who lost their lives in Duncan Cameron's farm on 13 August 1940 and who shared their memories and provided access to family papers and photographs: James Fairbairn's children, Geoffrey Fairbairn and Angela Mercer, their friend Virginia 'Bardie' Mercer (née Grimwade), his nieces Alethea Russell and Gillian Gubbins, and his grandchildren Mary Browne and Tim Mercer; Geoffrey Street's son Tony Street, his wife Ricky, his daughter 'Tim' Gillespie, and nephew David Sydney Burnand, and his friend Sir Rutherford Guthrie; Dick Elford's widow Audrey Elford, her twins Dianne Boddy and Hugh Elford (whose rescue of papers consigned to an incinerator by his Aunt Barbara ensured that some vital family history was not lost), Hugh's wife, Jenny, and Audrey Elford's granddaughter, Wendy Elford, and great-niece Annie Basham; Sir Henry Gullett's son, Jo Gullett, and grandson, Peter Gullett, and Kate Gullett; Frank Thornthwaite's widow, Inez Thornthwaite; Dick Wiesener's widow, Joan Wiesener, his daughter Margot Buttrose, his son Richard Wiesener and Richard's wife Diana, and granddaughter Anna Hyles; the family of Charlie Crosdale, especially his sister, Alice McDonald, brother Norman and Jan Crosdale, Janette Crosdale, and Charlie's nieces Michelle Lake and Jeannette Turner; the family and friends of Jack Palmer, especially Sheila Palmer's son John Foley, her brother Ron Curtain and niece Pat Snowball who supplied important photographs; Bob Hitchcock's son Robert Hitchcock, his nephew Ian Hitchcock, and his brother Les Hitchcock; Bob Hitchcock's friends Les Lingwood and Rex Taylor, and May Lingwood; members of Olive Hitchcock's family, especially her daughter Kaye Greene, cousin Beryl Noske, her niece Joan Richardson (née Beecroft), and Helen Gregg (née Hoskings); Sir Charles Manifold's daughter, Mary Schlicht. Mark Derham granted me access and permission to quote from the indispensable diaries of his grandfather, Sir Brudenell White, furnished family photographs, and generously made a press cutting collection available on CDRom as well as an insightful biographical essay.

Many academic colleagues and other writers have been kind enough to share information with me and guide me to sources: John McCarthy, Sid Ingham, Steve Dyer, Rob Darroch, Jeffrey Davis, Katherine Dunbabin, Andrew Moore, Janet Butler, Alan Fewster, Jon Chittleborough, Alan Gregory, John Lack, John Poynter, Jock Given, Clem Lloyd, Robin Sharwood, Peter Gronn, Robert Coleman, David Maunders, David Merrett, Matthew Ricketson, Stephen Gower, Nick Lambert, Nicholas Black, Peter Fearon, Tony Cunneen, Jeffrey Grey, Mike Gibson, Joyce Batty, Kim Torney, Peter Dennis, David Sissons, Kosmas Tsokhas, Hank Nelson, Philip Selth, Jo Duflou, Kevin O'Reilly, Bronwyn and John Myrtle, Laurence Maher, and Marc Dierikx. I have learned much from Macarthur Job's pioneering publications on Australian aviation accidents, and have had the benefit of conversation with him. It is impossible to over-emphasise how much I have been instructed by the justly acclaimed compendium of brief lives in 
the Australian Dictionary of Biography. And I am glad also to acknowledge Peter Helson's important thesis (now published) on Sir George Jones; and the excellent Wikipedia contributions on RAAF officers by Ian Rose.

The first instalment of David Vincent's indefatigable research on RAAF Hudsons appeared two decades after I started exhuming the relevant archives. His second volume, part of which he generously showed me in draft, completes an incomparable resource. I am indebted to him as well for a thoughtful exchange of views on some key points and for several important photographs. Mark Lax brought the special understanding of an officer of 'Air Rank' as well as a scholar to answering the questions of a newcomer to RAAF history; he transferred a valuable interview with Paddy Heffernan from tape to CD, and his vigilant reading of much of the manuscript saved me from many errors and inconsistencies. Neither he nor anyone else can be blamed for the remaining blemishes.

As will be evident from the notes, I have drawn information from the published work of countless scholars and dedicated explorers of family, institutional, military, and aviation history. I salute their achievements, both celebrated and unsung. It was a relief to find the incisive commentaries of an official historian, Alan Stephens, notably his contribution on the RAAF to the Australian Centenary History of Defence, resonating with what I was concerned might be my own prejudices. Earlier work by Chris Clark on RAAF history, especially his study of inter-war developments, The Third Brother, has been an invaluable foundation on which to proceed. Clark and his colleagues Greg Gilbert, Steve Allan, and Martin James in the Office of Air Force History in the Air Power Development Centre, and Kerry Hodge in the Department of Veterans' Affairs, have been patient and unfailingly thorough in responding to queries and guiding me to official sources I might otherwise not have located. John Bennett's published history of No. 2 Squadron and Master's thesis on No. 3 Squadron answered important questions and prompted others. H. J. Manning's 'Air Disaster at Canberra' (Stand-To, Jan-Feb. 1962), though occasionally astray, was an important early account, based in part on information supplied to A. W. Bazley three years earlier by A. B. 'Tich' McFarlane, then Secretary of the Department of Air (NAA: A705, 32/10/2733).

Andrew Tink's book, Air Disaster Canberra: the plane crash that destroyed a government, came to hand on 3 April 2013, seven months after the MS of this book was despatched to publishers. An early synopsis of my proposed work had been sent to several publishers between September 2008 and March 2009. My tentative conclusions were foreshadowed in 'Evidence, deduction, and inference: Lockheed Hudson A16-97 and the men who died in it on 13 August 1940', a paper presented to a seminar at the ANU Humanities Research Centre, 25 September 2009. Draft chapters of the book were circulated to colleagues 
from March 2011 onwards. Dr Tink's interpretations differ from mine on a number of significant issues and I have drawn attention to his published and broadcast views at appropriate places in the text and in footnotes.

Both in the original research phase and in more recent work I have been greatly aided by librarians and archivists, genealogists, booksellers, film-makers, and other writers who have shared information and ideas. John Taylor and Ray Walls enlightened me on the parents and extended family of Bob Hitchcock's wife, Olive Beecroft. Estelle Blackburn furnished timely contact details for descendants of the Crosdale and Hitchcock families. I have cause also to be grateful to the volunteers who sustain the work of the Williamstown Historical Society (Jane Ridley, Brian Haynes), Essendon Historical Society (Lenore Frost), Ku-ring-gai Historical Society (Jennifer Harvey), Maryborough-Midlands Historical Society (Margaret Walkley), Camperdown \& District Historical Society (Maree Belyea, Ray Watson), Derrinallum \& Lismore Community Association History Group (Avon Buchholz, Margaret Nixon), Western Australia Scout Museum (Fay Hall), Australian Association of Time Table Collectors (Geoff Lambert, Victor Isaacs), Horticultural Society of Canberra (Merylyn Condon), Royal Victorian Aero Club (Rex Hobson), NSW Presbyterian Church Archives (Daryl Lightfoot), Australian Racing Museum (Elizabeth Brown), and several independently maintained websites including the Lockheed file (Ron Cuskelly), and OzatWar (Peter Dunn).

Ian Mackersey generously sent me transcripts of his interviews with Barley and Lyle Hitchcock. Bob Landt made available diaries and unpublished memoirs of Joyce Batty, including notes of her conversation with Les Hitchcock. Pedr Davis kindly lent me his own files gathered during the writing of his books on the Kookaburra (with Dick Smith) and Charles Kingsford-Smith. Moya Sharp of Outback Family History searched sources for the West Australian background of the Hitchcock family. Geoff Crane of the ABC in Canberra copied his valuable short film on the crash for me, lent transcripts of interviews, and reminded me of a number of sources I had neglected. Jonathan Persse helped to check details of David Campbell's RAAF career. Bernard Malloy of Antique Goodies in Auckland sent pictures from rare illustrated volumes on the Orient line ships Orvieto and Osterley. Penny Olsen and her digital camera made possible the inclusion of a portrait of Justice Charles Lowe. Bridget McDonnell and Jennifer Phipps helped with the provenance and dating of Loudon Sainthill's portrait of Peggy Fairbairn.

Bob Livingstone furnished tantalising photographs of Anson aircraft which might have had Bob Hitchcock at the controls. Phil Vabre and Geoff Goodall instructed me on the history of Jim Fairbairn's aircraft and guided me to other pictorial collections; and John Hopton responded generously. Gordon Birkett and Brendan Cowan welcomed me to the resources of ADF-Serials. Brian Hernan provided photographs of Jim Fairbairn's Dragonfly VH-ADG. For photographs 
and recollections of life at Mount Elephant, I am grateful to Fay Stokie-Ryan, the granddaughter of James Fairbairn's station manager. Loftus Dun copied Henry Darwen's account of the fatal crash of Donald Ashton-Shorter. Joan Priest gave helpful leads. Peter Lowe and Sue Thompson helped me in the search, sadly unavailing, for relevant papers of their grandfather, Sir Charles Lowe. So too Bill, Geoff, and David Bostock searched through family papers still in their possession with the happier result that Geoff provided a selection of pictures of their father. Carol Judkins responded instantly to a request for copies of her photographs of the Lismore cemetery headstones of Frank, Inez, and William Currie Thornthwaite. Edna Byrne related her own childhood memories and the startling crash site story of her father, Jack Butt; her son, Graham Byrne kindly scanned a photograph of his grandfather. John McIntyre recalled the eyewitness account of the crash scene given by his father, Les McIntyre. Raphael Clothier, Bert Vest, and Max Hill shared their own memories and stories of the Clothier, Southwell, and Vest families. And Ann and David Brech's quest for the story (www.sealikeglass.com) of Bob Hitchcock's Point Cook contemporary, Robbie Watson, was the belatedly discovered source of information about the careers of the seven graduates of the 1935-36 cadet cohort who joined the RAF.

Michael Collins Persse and Melissa Campbell have furnished essential material from the archives of Geelong Grammar School. For other Australian schools, I have received valuable information from Alison Field (Trinity Grammar School), Diana Winyard (Meriden School), Thomas Gunn (Launceston Grammar School), Pauline Atkins (Coburg High School Historical Group), Welwyn Petersen, Kate Riseley (Shore), Margaret Mason-Cox (The Hutchins School), Col Lannan (Geelong College), Rebecca Gabriel (St Peter's College, Adelaide), and Gordon Cooper (Sydney Grammar School).

Long before the task was simplified by integrated computer catalogues and the internet, members of the Inter-Library Loans Unit at The Australian National University, especially Graeme Morriss, were untiring in the pursuit of rare published works. Thirty years ago Jenny Stokes, Thea Exley, and Joy Wheatley in Canberra and Margaret Chambers in Melbourne scoured the Australian Archives, as they were then known, for record series that might yield material I might otherwise have overlooked. Together with Richard Somerelle and Major C. A. W. Chant in the Defence Department, they arranged access to a number of files that had previously been closed. More recently, at ANU's Noel Butlin Archives Centre, Pennie Pemberton, Margaret Avard, and Sarah Lethbridge directed me to the minute books and other records of the Australasian Steamship Owners' Federation which helped provide background on the social and business connections of the Elford family.

Like many students of modern Australian history I am deeply indebted to the National Archives of Australia, the National Library of Australia, and the 
Australian War Memorial. The sustained assistance of staff in each of these institutions has been critical to this project. I thank them all and, in particular, at the National Archives in Canberra and Melbourne: Jenny Stokes, Carolyn Connor, Kerri Ward, Bill Edwards, Leslie Weatherall, Brendan Fenton, Pauline Maly, Karan Oberoi, Nancy Taylor, Laura Shannon, Diana Nguyen, Diep Nguyen, Molly ApThomas, Luke McKay, Carey Garvie, Tim Mifsud, Pat Kuhn, and Sarah Hall-Kearins; at the National Library Marie-Louise Ayres, Robyn Holmes, Kylie Scroope, Andrew Sergeant, Matthew Stuckings, Karen Johnson, Sharon Cullinan, Alison Weir, Claire Cruickshank, Lena Fox, and Lucy Nuttall; at the War Memorial Michael Piggott, Geoff McKeown, Jeremy Richter, Alyssa Phabmixay, Margaret Lewis, Jennie Norberry, Andrew Currey, Penny Hyde, John White, Paul Taylor, David McGill, Lauren Hewitt, Sue Ducker, Melissa Cadden, and Antoni Rudnicki. To Stewart Shannon at the National Film \& Sound Archive and Glenn Eley of Cinesound Movietone Productions I owe the opportunity to examine and copy Cinesound Review No. 459 compiled in August 1940.

I also received exemplary aid from the Maitland City Library (Peter Woodley), Cessnock City Council (Simon Eade), Northern Territory Library (Louise Paynter and Margret Curry), Geelong Heritage Centre (Cheryl Timbury), Corangamite Shire (Leah Haworth), State Library of New South Wales (Arthur Easton), State Records Authority of New South Wales (Emily Hanna), Russell Fox Library, ACT Coroner's Office (H. Tazewell), ACT Law Court \& Tribunal Administration (Victor Rodziewicz, Michael Edwards), ACT Planning \& Land Authority (Sharon Priestly), ACT Archives (Elizabeth Estberg, Mark Dawson), State Library of Queensland Heritage Collections (Simon Farley), National Museum of Australia (Daniel Oakman), National Portrait Gallery (Trish Kevin), State Library of Victoria (Lucy Shedden), Royal Historical Society of Victoria (Gerardine Horgan), Geelong Gallery (Veronica Filmer), Stonnington History Centre (Ellen Porter), Canberra Fire and Emergency Services Museum (Drew McLean), University of Melbourne Archives (Jason Benjamin, Katie Wood, Jane Beattie), RAAF Museum (Monica Walsh), University of NSW-Australian Defence Force Academy Library Special Collections (Wilgha Edwards, Tobie Garrick), Swinburne University of Technology (Nyssa Parkes), Waverley Library (Kimberly O'Sullivan Steward), Royal Australasian College of Physicians History of Medicine Library (Liz Rouse), Tamar Visitor Centre (Heidi Smith, Christine Phillips), State Library of Tasmania \& Tasmanian Archive and Heritage Office (Caitlin Sutton), Murdoch University Library (Margaret Bruce), Churches of Christ in Western Australia (Don Parker), Warragul Church of Christ (Judy Farmer), Burwood Library, NSW (Kasia Malicka), Freemasons Victoria (Tony Morris), Geraldton Family History Society (Melody Cartwright), Lockheed Aircraft (Australia) Pty Ltd (G. M. Gipple), the Melbourne Club (Ronda Blyth), Manly Library (John MacRitchie), Battye Library (Steve Howell), ACT Heritage 
Library (Antoinette Buchanan), Local Studies Library, Queanbeyan City Council (Judy Becker), Skipton and District Historical Society (Janet Walsh), Terang Library (Margaret McIntosh), Springvale Botanical Cemetery (Jessie Hennessy), Anglican Church of Australia General Synod Archives (Joanne Burgess), The Canberra Times (Megan O'Doherty, Fleta Page), and the Victorian Supreme Court Library (James Butler).

From the United Kingdom I was aided by the Bodleian Library, Oxford (Helen Langley), Medway Archives and Local Studies Centre (Alison Cable), the Royal Air Force Museum Hendon (Peter Elliott), the First Aid Nursing YeomanryPrincess Royal's Volunteer Corps (Lt Liz Weston), the British Red Cross Museum and Archives (Sarah Cox); and from Geneva the International Committee of the Red Cross Archives (Magali Chahlaoui-Girod).

In exploring the British background of Dick Elford and his forebears I was provided with far more information than I could have discovered on my own, or could reasonably have expected any archivist or genealogist to supply. I record my thanks to Michael Riordan (St John's College, Oxford), Robin Darwall-Smith (Magdalen College, Oxford), Deborah O'Brien (Devon Online Parish Clerk Coordinator), Amy Collins (Oxfordshire County Council), Peter Rowe (Cirencester Grammar School), Dorothy Gorsuch (Coopers' and Coborn School), and Christine Brown (Wolverhampton Archives \& Local Studies). Liz Winney (elford@onename.org) has been an unfailing support. Of Dick Elford's Australian friends, Balcombe Griffiths and Edgar Holt were particularly helpful.

Without the aid and guidance of many former Servicemen, aviators, and their families I could not have hoped to recapture the atmosphere of the RAAF of the 1930s and the first year of the conflict that was beginning to be called the Second World War. All those who helped are acknowledged in footnotes. But it would be wrong not to accord special mention to those who were exceptionally responsive to a historian they knew was exploring an unfamiliar world. With apologies that space is insufficient to include their decorations and final rank (and apologies as well for not adopting in the text the RAAF convention of capitalising abbreviations of rank e.g. GPCPT for GpCpt), and in no particular order: Paddy Heffernan, Ernie Hey, Sir George Jones, John Graham, Deryck Kingwell, Leon Lachal, G. U. 'Scotty' Allan, Sir Frederick Scherger, Sir Norman Brearley, Rex Taylor, Claude Browne, Sir John McCauley, David Colquhoun, Geoff Hartnell, Sir Raymond Garrett, Bruce Courtney, Ivon Black and Derek 'Jell' Cuming, all of whom graciously answered questions that became more sensible under their tutelage. Harry Wrigley provided crucial information about Bob Hitchcock (and his son Ron Wrigley kindly facilitated access to diaries held in the RAAF Museum, and to his own Box Brownie photographs). Kym Bonython trustingly lent me his rare film of Hudsons in flight ('Guardians of the Trade Routes') and spoke to me about his No. 2 Squadron contemporaries. John 
Harrison sent personal memories and unique photographs, and traced others who could help. The invaluable pictures taken at Laverton and Canberra by Frank Jefferies were found and copied for me by his daughter and son-in-law, Helen and Paul Struc. Wendy Coultas did the same for pictures in the collection of her father Jack McNally. Unfortunately, Harry Kuehne's No. 2 Squadron ground crew photos, kindly sent by his daughter-in-law Judy, arrived too late for inclusion.

'Tich' McFarlane, Bob Dalkin, and Geoff Hartnell not only talked to me at length but made available flying log books and personal correspondence. Anne Kelly kindly allowed me to see a photocopy of the log books of her father Sir Raymond Garrett, the originals of which are in the RAAF Museum at Point Cook, as well as letters, articles, and photographs, and her own compilation of stories from his taped recollections. Charles Eaton sent me draft chapters from his planned biography of his father, 'Moth' Eaton; provided a cornucopia of photographs; and introduced me to Sally Douglas who most helpfully sent transcripts of her father Eric's diary, log, excerpts from RAAF reports, and photographs of the Kookaburra, Bobby Hitchcock, and Keith Anderson in 1929. At very short notice Rob Thomas retrieved and digitised an important letter, photographs, and extracts from the flying log book of his father Sir Fred Thomas. Extracts from Bill Heath's log book were copied for me by his son Daryl Heath. Bill White's nephew, Geoffrey White, guided me through the important collection of letters and photographs which he has assembled. Charles Eaton, Daryl Heath, and Geoffrey White were valuable sources of family information. The Rev. Bill Gilmour and Msgnr Ken Morrison contributed the unique perspectives of RAAF chaplains. I learned much about the legal fraternity and their relationship with the Air Force in conversation with Sir George Pape, Sir Harry Winneke, and Sir Arthur Dean's daughter, Ursula Whiteside. Heather Winneke kindly found and scanned pictures of her father-in-law Sir Harry Winneke. Sir Murray Tyrrell's daughter and grand-daughter, Leonie and Kirsten McCulloch, allowed me to select from an enviably ample digitised family album. The life of Dr Duncan Mackellar was illuminated by information furnished by his son, Dr John Mackellar. L. P. Coombes recalled early days at the Aeronautical Research Laboratory. Ron Duffield, a vastly experienced civil airline pilot, gave me incisive commentary on the training and experience of RAAF pilots. Margaret Lodge, to whom scholars are indebted for the deposit of her father General Ernest Squires' diaries at ADFA, brought to life his period as Chief of the General Staff.

The ghastly task of fighting the fire and retrieving the bodies from Al6-97 was recalled by Bill Maloney and Jim Kearney.

The research for this book began over 37 years ago. At first it was carried on concurrently with a project on the life of Sir Robert Menzies which culminated in the publication of Menzies Observed in 1979. It grew out of, and in the end 
displaced, what was intended as a study of the Menzies wartime premiership. I am grateful to Alan Bateman and the Hon. Humphrey Fisher of the Australian Broadcasting Commission (as it then was) for the original impetus, and access to film and sound archives; and to the Australian War Memorial for a grant which enabled me to assemble much of the material on the wartime political environment which underpinned the relevant chapters of Menzies Observed as well as the political background and narrative in this book. The award of a fellowship by the Australian Prime Ministers Centre gave me the opportunity to deepen my understanding of Robert Menzies' emergence as Prime Minister in 1939. Among those who instructed me on the Lyons and Menzies governments, and public service and political life between the two world wars, I am deeply indebted to Dame Enid Lyons, Sir Chester and Lady Manifold, Lady White, Sir Murray Tyrrell, Sir Peter Looker, Sir Keith Waller, Sir Laurence McIntyre, Sir Roland Wilson, Sir Percy Spender, J. R. Willoughby, K. R. Ingram, Garry Armstrong, Colin Moodie, Sam Landau, Corbett Tritton, Hattil Foll, Sir John McEwen, Sir Laurence Hartnett, Charles Meeking, Sir Albert Chadwick, F. T. Hill, Sir Reginald Leonard, Sir Richard Randall, Sir Edwin Hicks, and Alfred Stirling.

A series of public service and academic appointments as well as private business commitments, deflected me from the work until 2006 when I was invited to an Adjunct Professorship in the Humanities Research Centre at The Australian National University. This beneficent privilege was all the more welcome as the original research had been undertaken when I held a fellowship in the History Department in the ANU's Research School of Social Sciences. At that time I had the benefit of assistance from several able and resourceful people, notably Jan Brazier, Marion Stell, Carol Flanagan, Jeannette Horrocks, Brenda Willcox, Ann Millar, Anthea Bundock, and Pam Crichton; and I must acknowledge my appreciation of the rather puzzled forbearance of supportive academic colleagues, especially Barry Smith and Allan Martin. More recently, the enthusiastic interest of Ian Donaldson, Paul Pickering, and Christine Wallace inspired me to get on with putting into my laptop that which had long been in my mind; and Ian Hancock has brought his unrivalled knowledge of twentiethcentury conservative politics to reviewing draft chapters, saving me from an abundance of infelicity and solecism, and convincing me of the worth of the project.

Because of the sensitive nature of some of the information uncovered in the 1970s and 1980s it seemed appropriate to defer completion and publication until the passage of time reduced the potential for offence or embarrassment. I am conscious that even now some of what is recounted here may dismay some readers. There are things they might feel were better left unsaid. In each case where I have thought there was potential for upset or hurtful speculation 
I have sought counsel from wise friends. None of them of course bears any responsibility for the outcome. All of the research and correspondence files for the project will be deposited in the National Library of Australia.

In preparing the manuscript for publication I have had the reassuringly professional assistance of Duncan Beard and his team at the ANU E Press (Nausica Pinar, Beth Battrick, and Lorena Kanellopoulos). John Owen skilfully transformed a neat but poorly formatted WORD document, patiently explaining that copy-edited and re-formatted pages that looked a mess to me were exactly what was required. Thankfully he was right. It was a further relief to learn of a grant from the ANU Publications Subsidy Committee to assist in off-setting the copy-editing costs. Christine Fernon at the National Centre of Biography came to my rescue when assembling pictures into a single file threatened to defeat me.

At a time when I questioned whether the subject warranted the effort that it was demanding, Alan and Clara Bateman gave the kind of credible reassurance that only trusted friends can give. Mary Cunnane, the esteemed literary agent I found just in time, has been a fount of encouragement and wisdom. Melanie Nolan's championing of a book that had daunted others came at a critical moment. Kayleen Hazlehurst - sustaining companion in travail, sensitive critic, profound source of strength — has always believed. 